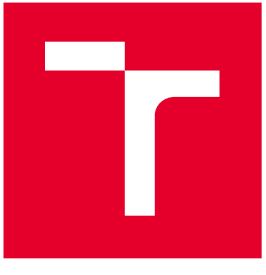

VYSOKÉ UČENÍ

TECHNICKÉ

V BRNĚ

\title{
TECHNIKA ANALOGOVÝCH OBVODŮ
}

prof. Ing. Kamil Vrba, CSc.

prof. Ing. Jiř́i Mišurec, CSc.

Vydání elektronické knihy podpořila Fakulta elektrotechniky a komunikačních technologií a Ústř̌ední knihovna VUT v Brně. Kniha je vydána zdarma a otevřeně pod veřejnou licencí Creative Commons - Uved’te původ 4.0 Mezinárodní (CC BY 4.0). 
Autoři: prof. Ing. Kamil Vrba, CSc., prof. Ing. Jiří Mišurec, CSc.

Název: Technika analogových obvodů

Vydání: 1. vydání

Druh: e-kniha

Rok a měsíc vydání: 2020/12

Počet stran: 423

Náklad: e-publikace pod veřejnou licencí CC BY 4.0

Vědní obor: Elektrotechnika, elektronika, audio inženýrství, mikroelektronika, telekomunikace, analogová technika

Vydavatel: Vysoké učení technické v Brně, Nakladatelství VUTIUM ISBN: 978-80-214-5901-4

DOI: $10.13164 /$ book.circuits.analog

Lektoři: prof. Ing. Tomáš Dostál, DrSc., prof. Ing. Ivan Baroňák, PhD.

\begin{abstract}
ANOTACE: Elektronická publikace představuje otevřený př́stup $\mathrm{k}$ vědeckým poznatkům $\mathrm{z}$ oblasti analogové obvodové techniky. Jsou vysvětleny návrhové postupy základních bloků integrovaných analogových obvodů s bipolárními a unipolárními tranzistory až po koncepční řešení základních typů operačních zesilovačů. Podstatná část publikace je pak zaměřena na využití operačních zesilovačů v lineárních a nelineárních či parametrických aplikacích. V publikaci je prezentována celá řada původních zapojení z oblasti elektronicky přepínatelných zesilovačů, elektronických střídačů a operačních usměrňovačů, která autoři mají patentována. Patentovaná zapojení byla již uvolněna $\mathrm{k}$ bezplatnému použití.
\end{abstract}

Autoři děkuji za technickou a odbornou pomoc při zpracování knihy těmto kolegům: prof. Ing. J. Kotonovi, PhD.; Ing. P. Hanákovi, PhD.; Ing. O. Sládokovi; H. Lukešové a J. Hoškové. 


\section{Obsah}

1 TEORETICKÉ POZNATKY .............................................................................

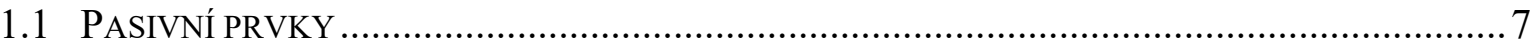

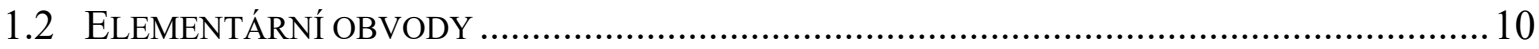

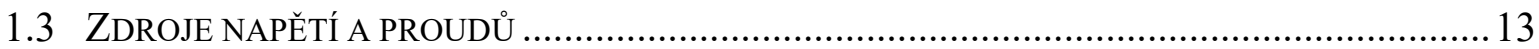

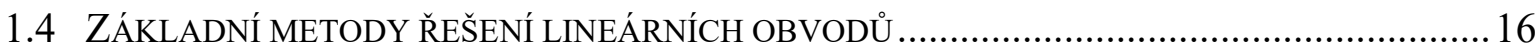

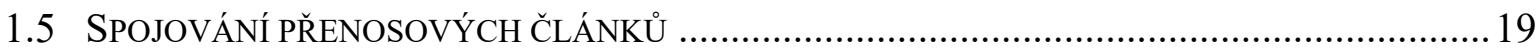

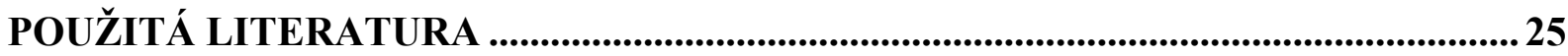

2 ZÁKLADNÍ STAVEBNÍ JEDNOTKY ANALOGOVÝCH OBVODŮ.................... 26

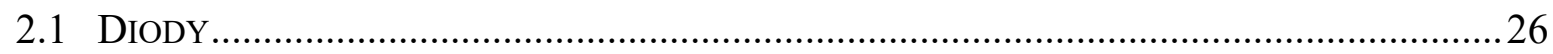

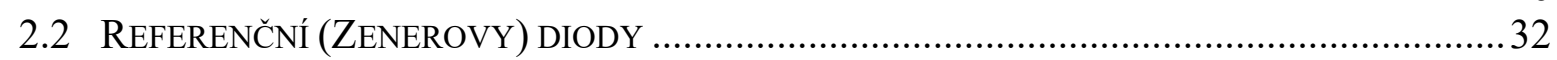

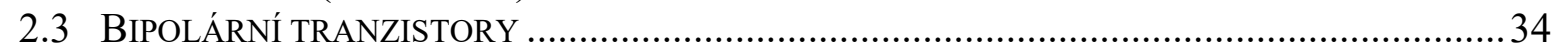

2.3.1 Základní zapojeni tranzistoru ............................................................. 41

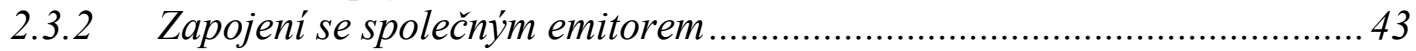

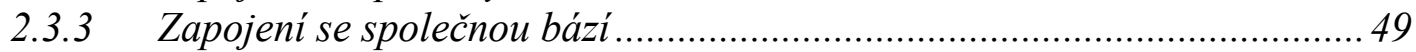

2.3.4 Emitorový sledovač - zapojeni se společným kolektorem .........................50

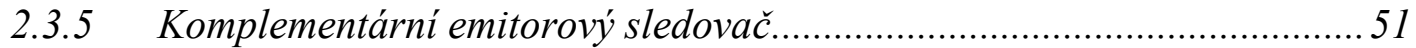

2.3.6 Tranzistor jako zdroj referenčního napětí ................................................ 57

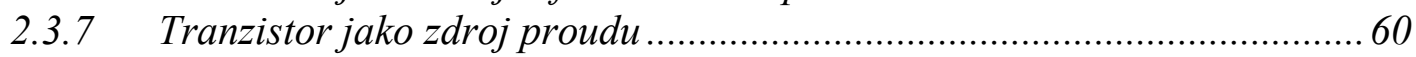

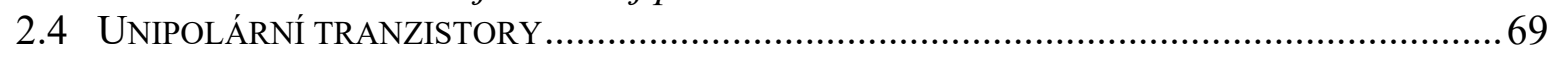

2.4.1 Základní zapojení unipolárních tranzistori̊ .......................................... 75

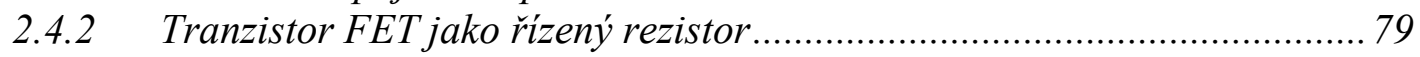

2.4.3 Tranzistor FET jako zdroj proudu ................................................... 80

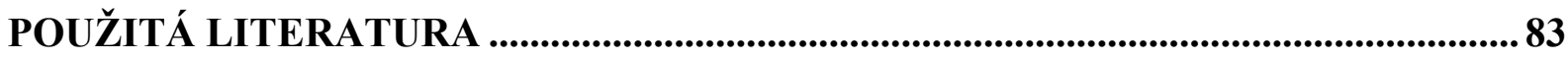

3 VNITŘNÍ STRUKTURA OPERAČNÍCH ZESILOVAČŮ ........................................... 84

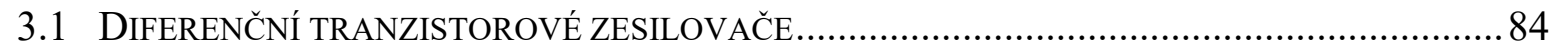

3.1.1 Diferenční zesilovače s bipolárními tranzistory ................................... 84

3.1.2 Diferenční zesilovače s unipolárními tranzistory ...................................89

3.1.3 Diferenční zesilovač s aktivní zátěži i..................................................... 91

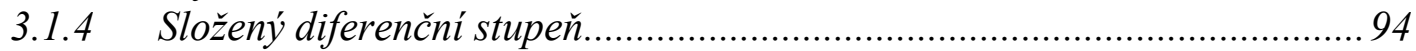

3.1.5 Kaskódové zapojení diferenčního zesilovače..........................................99

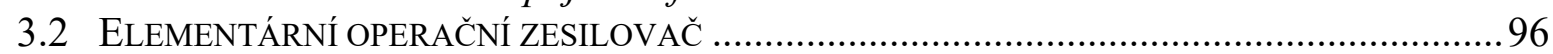

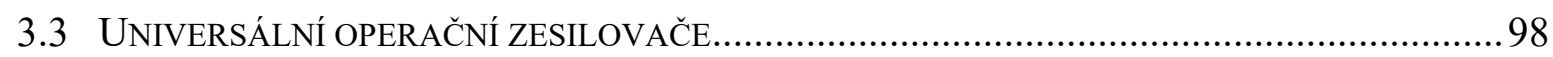

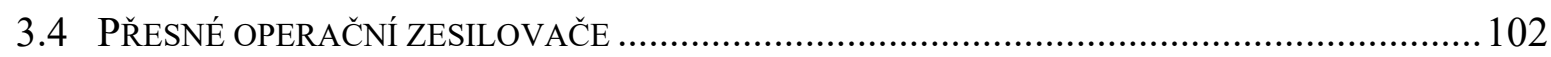

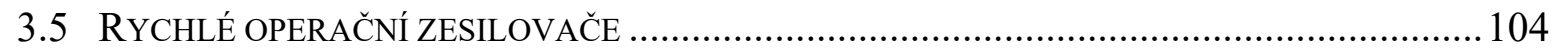

POUŽITÁ LITERATURA …........................................................................................ 106

4 INVERTUJÍCÍ A NEINVERTUJÍCÍ ZESILOVAČ .................................................. 107

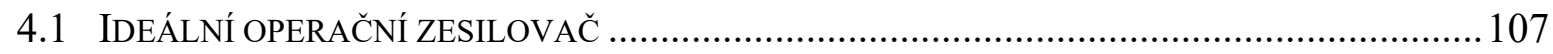

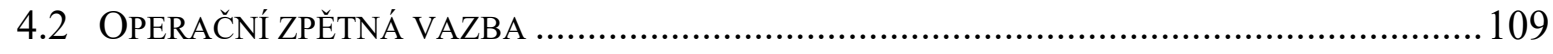

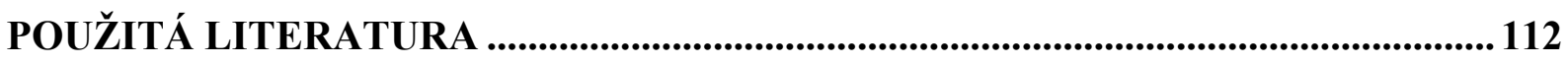

5 PARAMETRY OPERAČNÍCH ZESILOVAČŮ ....................................................... 113

5.1 PARAMETRY A CHARAKTERISTIKY OPERAČNÍCH ZESILOVAČŮ ….............................. 113

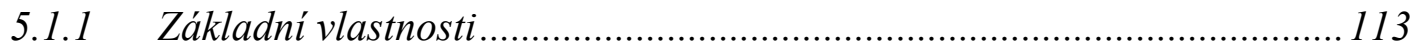

5.1.2 Diferenčni vstupni odpor, souhlasné vstupni odpory, výstupni odpor ....116 
5.1.3 Napětový a proudový ofset, vstupni klidové proudy, drift .................. 118

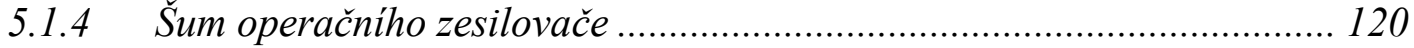

5.1.5 Kmitočtová charakteristika .............................................................. 121

5.1.6 Dynamické vlastnosti operačního zesilovače ........................................ 125

5.2 VLIV REÁLNÝCH PARAMETRŮ OPERAČNÍHO ZESILOVAČE NA ZÁKLADNÍ ZAPOJENÍ...... 127

5.2.1 Vliv konečného zesílení a jeho závislosti na kmitočtu ............................ 128

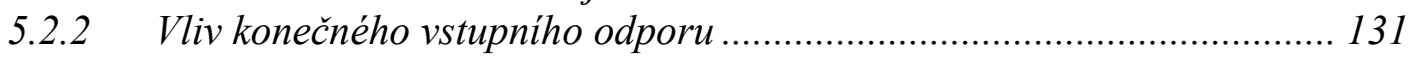

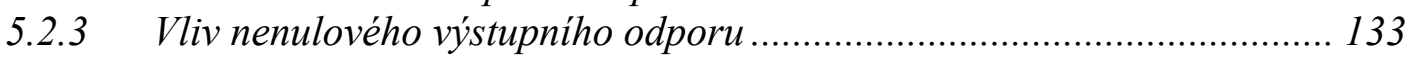

5.2.4 Vliv klidových vstupních proudio a jejich kompenzace.......................... 136

5.2.5 Vliv napét'ového ofsetu a jeho kompenzace........................................ 138

5.2.6 Vliv souhlasného napètí na základním zapojení ................................. 140

POUŽITÁ LITERATURA...........................................................................................142

6 LINEÁRNÍ OBVODY S OPERAČNÍMI ZESILOVAČI ............................................143

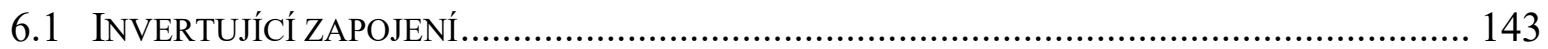

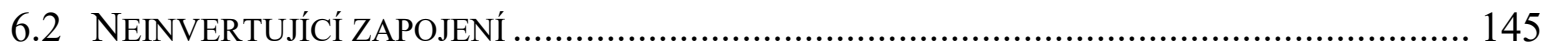

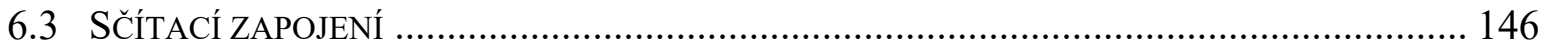

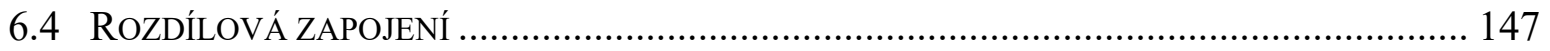

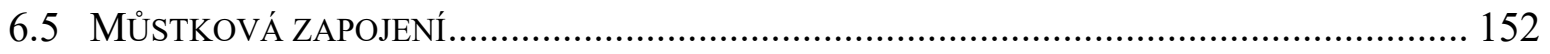

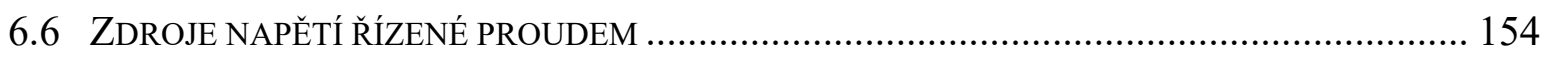

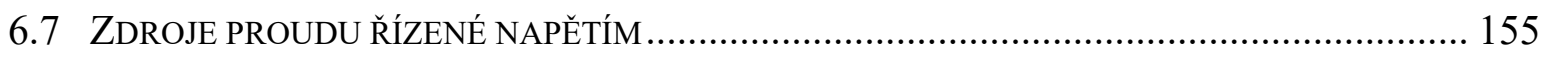

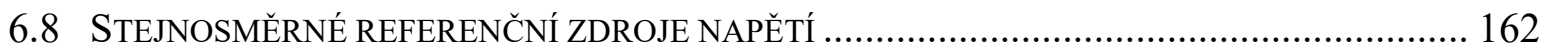

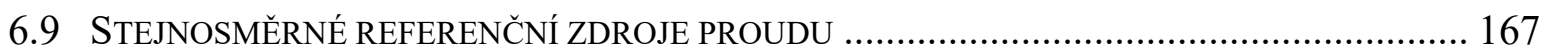

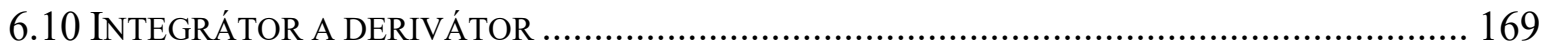

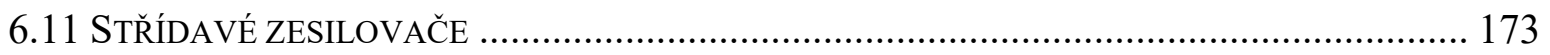

POUŽITÁ LITERATURA .........................................................................................175

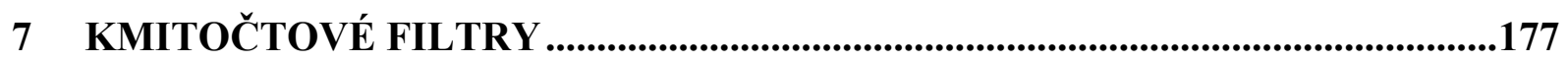

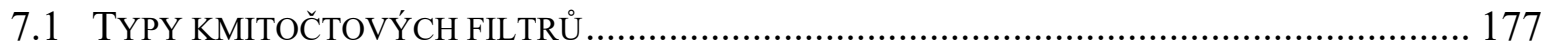

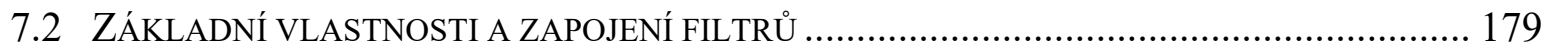

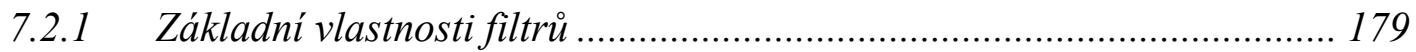

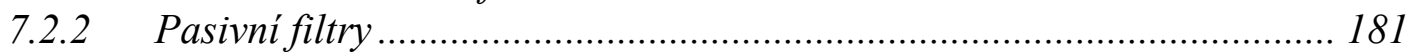

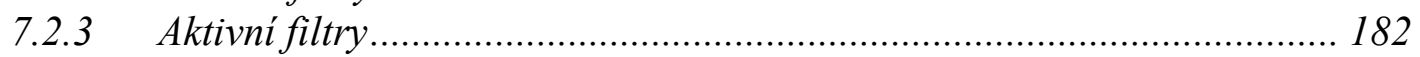

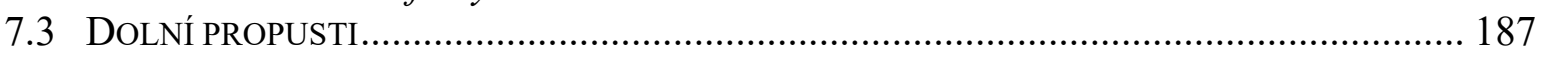

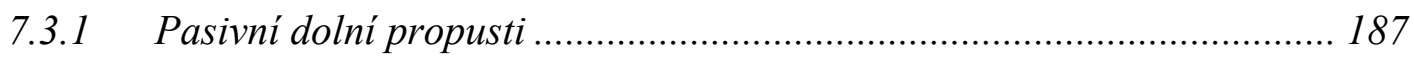

7.3.2 Aproximace prenosové funkce dolní propusti ..................................... 192

7.3.3 Aktivni dolni propusti ............................................................... 203

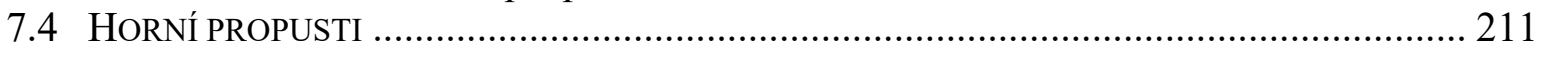

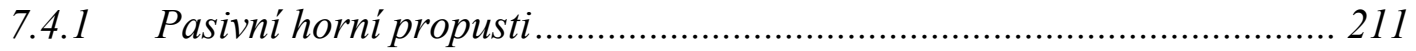

7.4.2 Transformace dolní propusti na horni propust.................................. 214

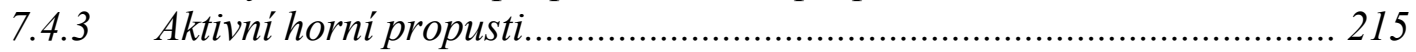

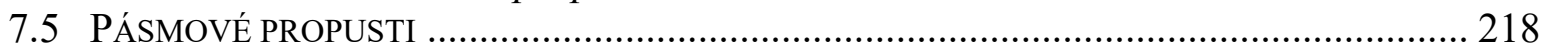

7.5.1 Základní vlastnosti pásmových propustí .......................................... 218

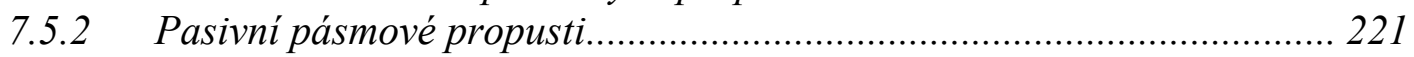

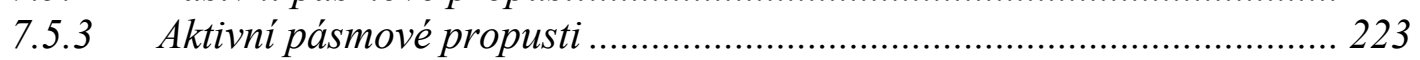

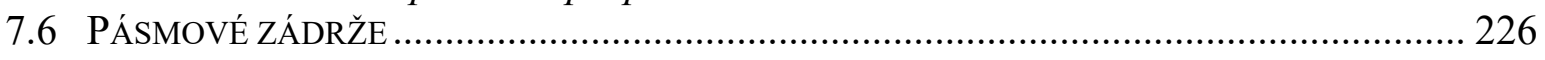

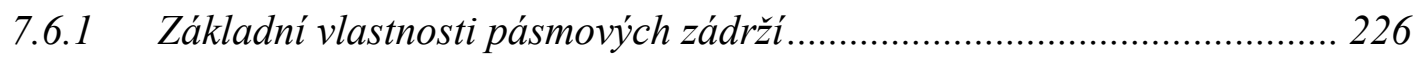

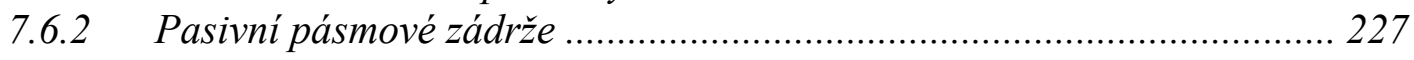

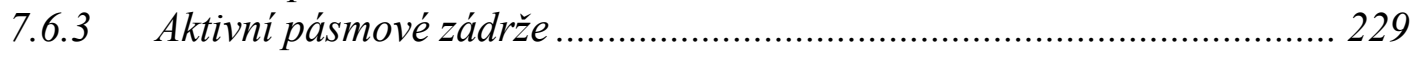

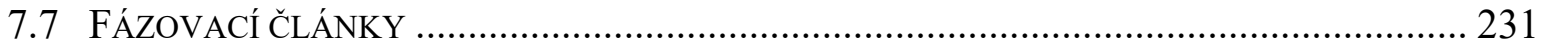


7.7.1 Přenosová funkce fázovacího článku.................................................221

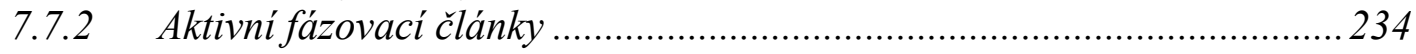

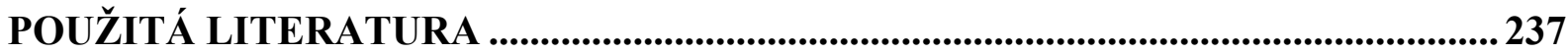

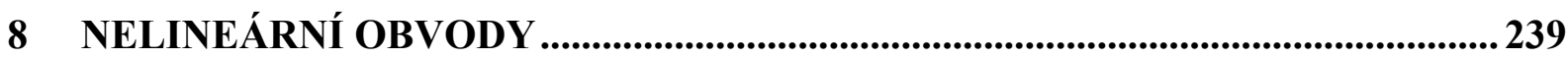

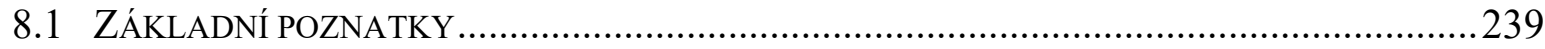

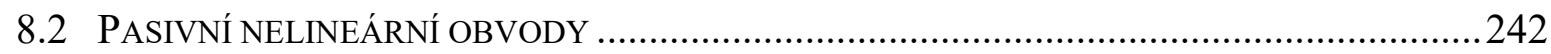

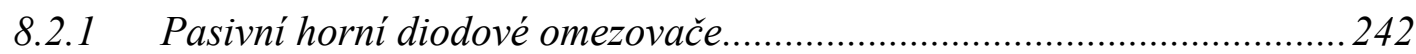

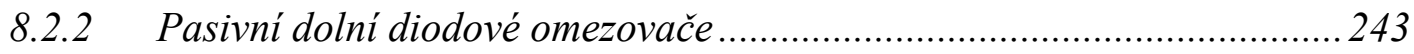

8.2.3 Pasivní oboustranné diodové omezovače …...........................................2 244

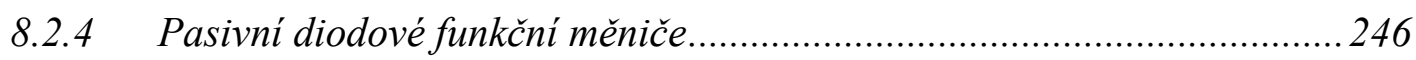

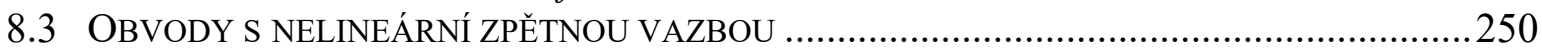

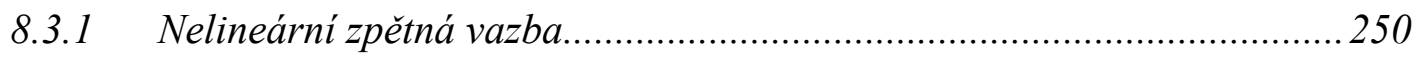

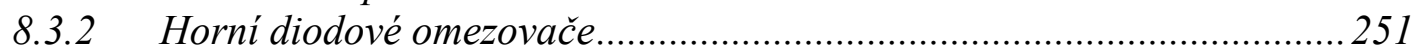

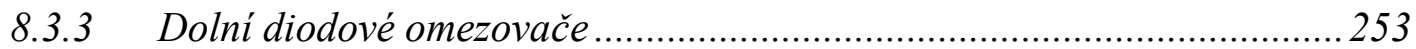

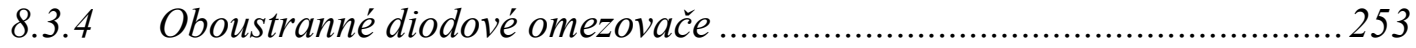

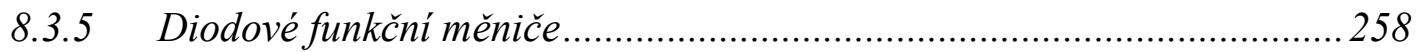

8.3.6 Logaritmické a exponenciální prevodníky ..............................................2262

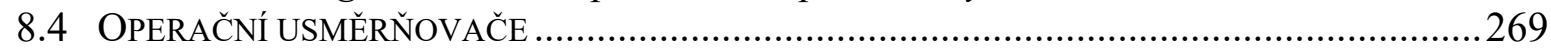

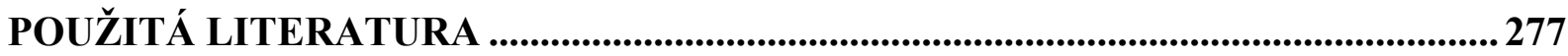

9 OBVODY S ELEKTRONICKÝMI SPÍNAČI ..................................................278

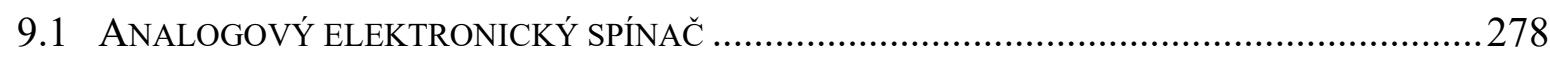

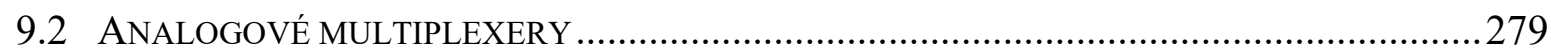

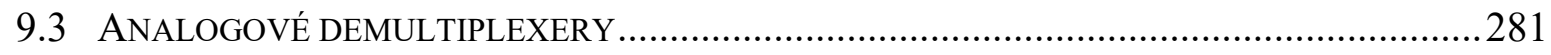

9.4 ZESILOVAČE S ELEKTRONICKY PŘEPÍNANÝM ZESÍLENÍM ...........................................228

9.4.1 Invertující zesilovače s přepínatelným zesílením.................................2282

9.4.2 Neinvertujicí zesilovače s prepínatelným zesílením...............................283

9.4.3 Zesilovače s prepínatelným zesílením pro náročnější aplikace............... 285

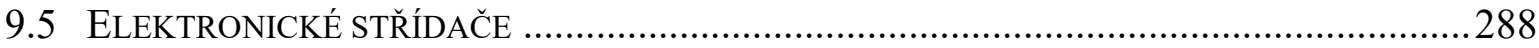

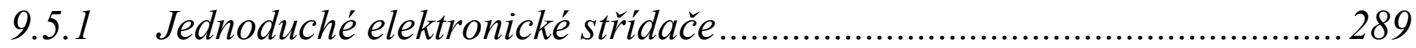

9.5.2 Přesné elektronické střídače ................................................................290

9.5.3 Střidače s velkým vstupním odporem................................................292

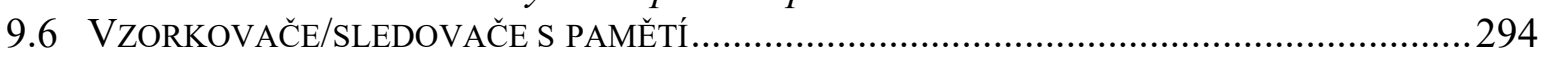

9.6.1 Princip vzorkovače/sledovače s pamětí................................................294

9.6.2 Vzorkovače/sledovače s pamètí bez zpětné vazby...................................295

9.6.3 Vzorkovače/sledovače s pamětí se zpětnou vazbou ................................296

POUŽITÁ LITERATURA .........................................................................................299

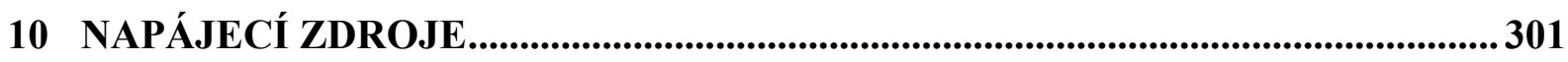

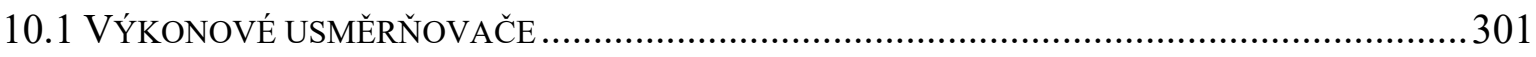

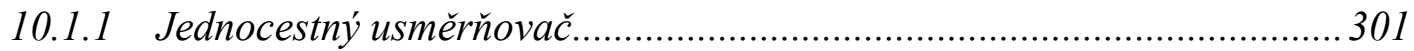

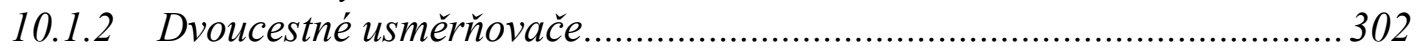

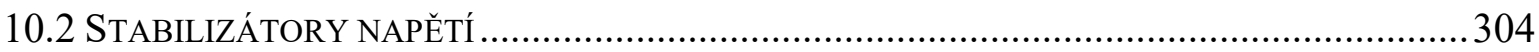

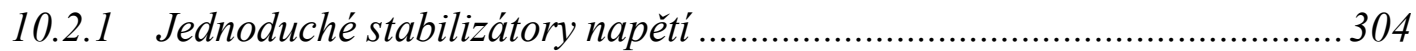

10.2.2 Stabilizátory se zesilovačem regulační odchylky ....................................305

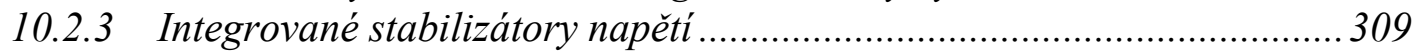

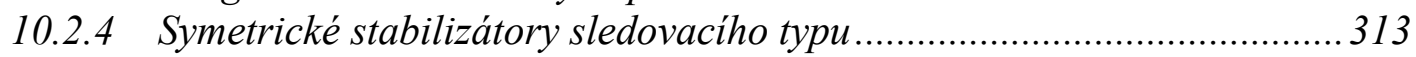

10.2.5 Stabilizátory s malým úbytkem napětí .............................................. 315 
10.2.6 Jiné druhy stabilizovaných zdrojů................................................ 317

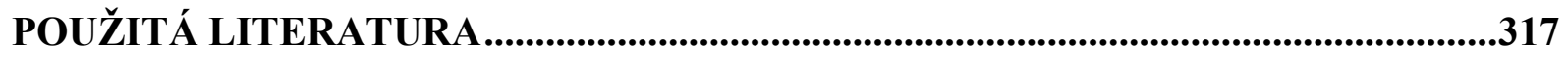

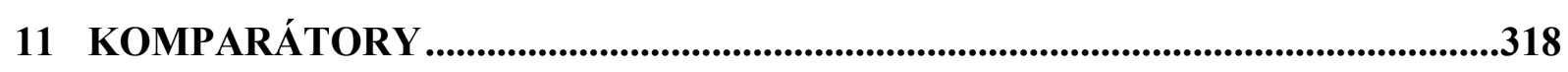

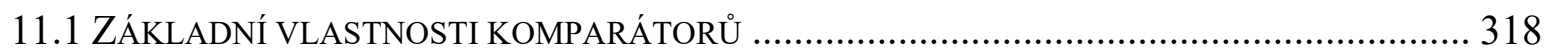

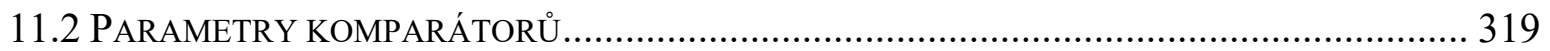

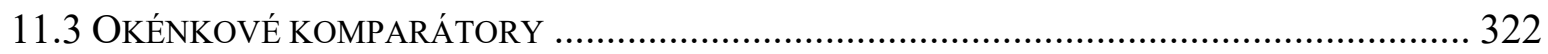

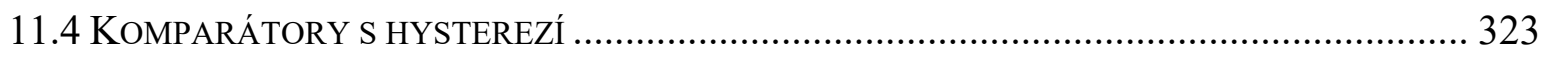

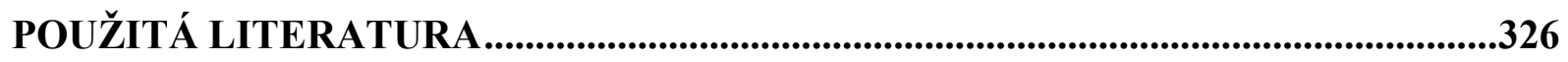

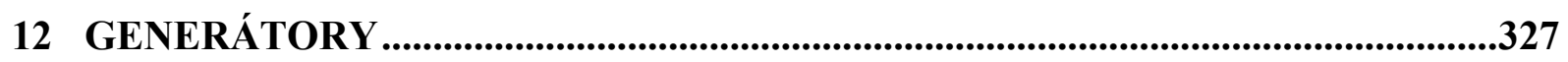

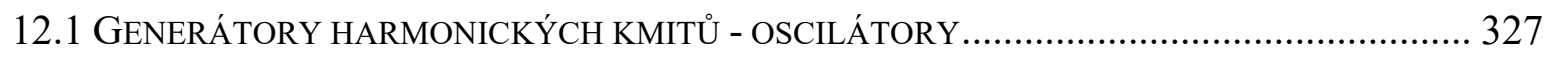

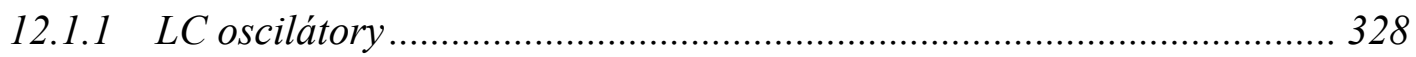

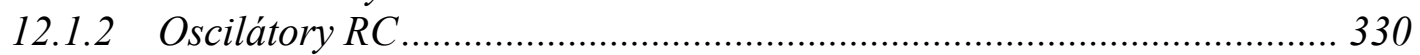

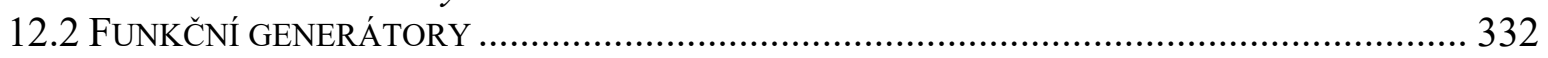

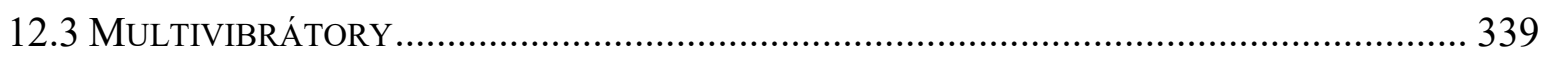

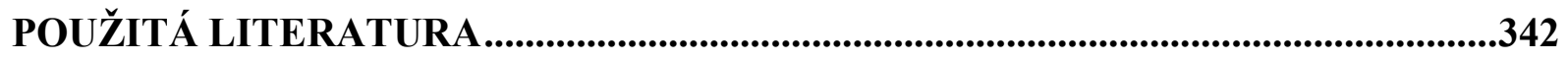

13 APLIKAČNÍ PRAVIDLA PRO ANALOGOVÉ INTEGROVANÉ OBVODY ......343

13.1 APLIKAČNÍ PRAVIDLA PRO OPERAČNÍ ZESILOVAČE ................................................ 343

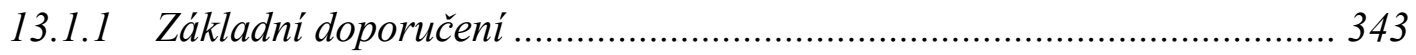

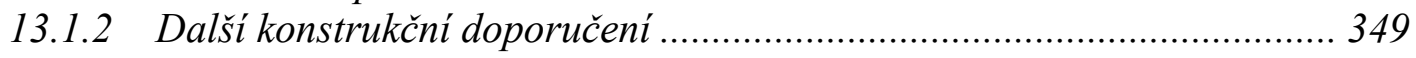

13.1.3 Požadavky na napájecí zdroje .............................................................. 352

13.2 APLIKAČNÍ PRAVIDLA PRO VZORKOVAČE A SLEDOVAČE S PAMĚTÍ ............................... 364

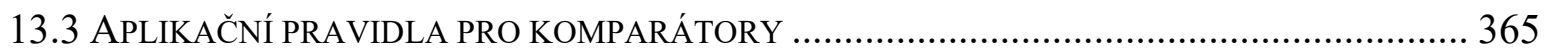

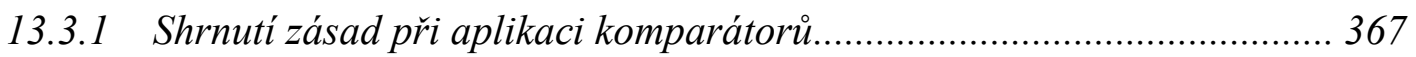

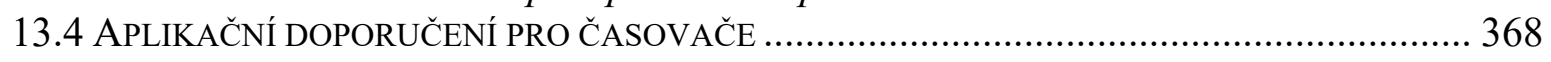

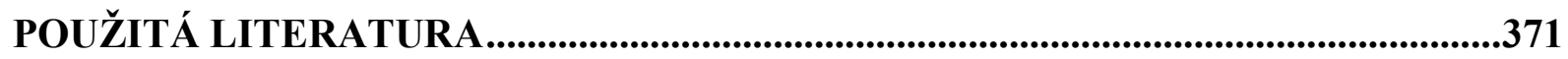

14 POČÍTAČOVÁ ANALÝZA ANALOGOVÝCH OBVODŮ ................................372

14.1 ÚVOD DO POČÍTAČOVÉ ANALÝZY ANALOGOVÝCH OBVODU゚ ...................................... 372

14.1.1 Základní vlastnosti simulačního nástroje Micro-Cap ........................... 373

14.1.2 Instalace programu Micro-Cap 12 ................................................ 375

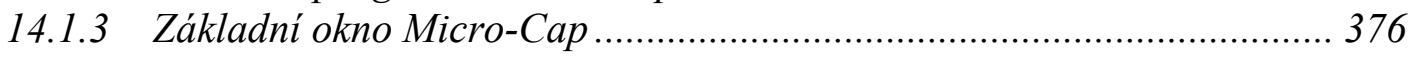

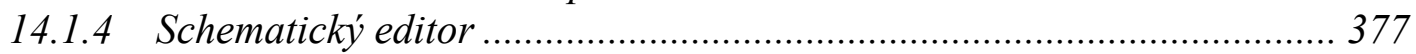

14.1.5 Základní obvodové prvky a jejich parametry..................................... 378

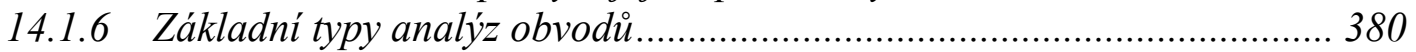

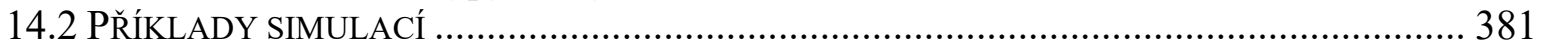

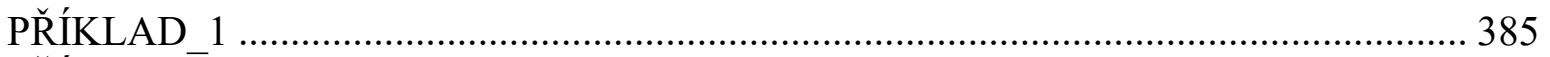

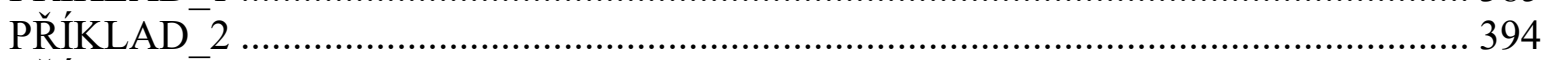

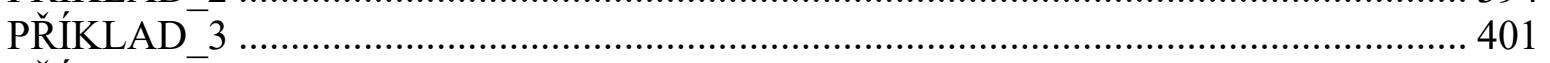

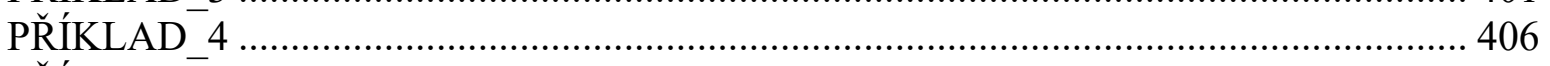

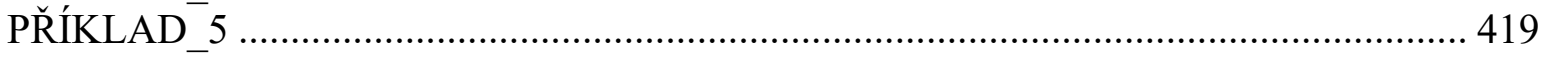

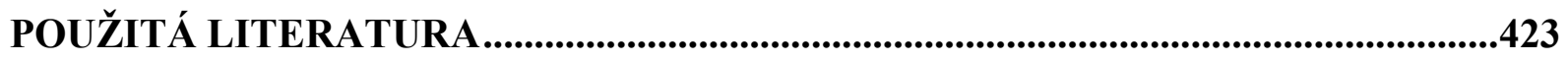




\section{Teoretické poznatky}

Abychom předešli nejasnostem, zopakujeme vlastnosti základních obvodových prvků, dohodnuté způsoby značení napětí a proudů, zapojení některých elementárních lineárních obvodů a základní metody řešení lineárních analogových obvodů.

\subsection{Pasivní prvky}

Rezistor. Parametrem rezistoru $R$ je odpor $R$, resp. vodivost $G=1 / R$. Schématická značka rezistoru je uvedena na Obr. 1.1a. Mezi napětím a proudem platí Ohmův zákon $u(t)=R i(t)$, či zjednodušeně

$$
u=R i
$$

resp.

$$
i=\frac{u}{R}=G u
$$

Kapacitor. Parametrem kapacitoru $\mathrm{C}$ je kapacita $C$. Mezi napětím a proudem kapacitoru (viz Obr. 1.1b) platí

$$
i(t)=C \frac{\mathrm{d} u(t)}{\mathrm{d} t}
$$

resp.

$$
u(t)=u(0)+\frac{1}{C} \int_{0}^{t} i(t) \mathrm{d} t,
$$

kde $u(0)$ značí výchozí nabití kapacitoru v okamžiku $t=0$.

Induktor. Parametrem induktoru $\mathrm{L}$ je indukčnost $L$. Mezi napětím a proudem induktoru (viz Obr. 1.1c) platí

$$
u(t)=L \frac{\mathrm{d} i(t)}{\mathrm{d} t}
$$

resp.

$$
i(t)=i(0)+\frac{1}{L} \int_{0}^{t} u(t) \mathrm{d} t
$$

kde proud $i(0)$ značí proud induktorem $\mathrm{v}$ čase $t=0$.

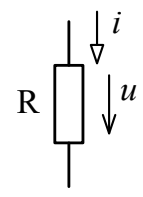

a

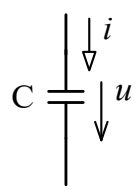

b

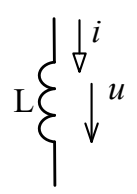

C 
Impedance. Při řešení lineárních obvodů se často místo s časovými průběhy napětí a proudů pracuje s komplexním napětím $\bar{U}=|\bar{U}| \mathrm{e}^{\mathrm{j} \varphi_{\mathrm{U}}}=U \mathrm{e}^{\mathrm{j} \varphi_{\mathrm{U}}}, \operatorname{kde}|\bar{U}|=U$ značí modul komplexního čísla a $\varphi_{\mathrm{U}}$ jeho argument či fázové natočení a $\mathrm{s}$ komplexním proudem $\bar{I}=|\bar{I}| \mathrm{e}^{\mathrm{j} \varphi_{1}}=I \mathrm{e}^{\mathrm{j} \varphi_{1}}$, kde podobně $|\bar{I}|=I$ značí jeho modul a $\varphi_{\mathrm{I}}$ argument. Impedance je definována vztahem

$$
\bar{Z}=\frac{\bar{U}}{\bar{I}}=\frac{U \mathrm{e}^{\mathrm{j} \varphi_{U}}}{I \mathrm{e}^{\mathrm{j} \varphi_{\mathrm{I}}}}=\frac{U}{I} \mathrm{e}^{\mathrm{j}\left(\varphi_{\mathrm{U}}-\varphi_{\mathrm{I}}\right)}=Z \mathrm{e}^{\mathrm{j} \varphi}
$$

kde $\varphi=\varphi_{\mathrm{U}}-\varphi_{\mathrm{I}}$ značí fázové natočení mezi napětím a proudem. Značení proudu a napětí na impedanci je zřejmé z Obr. 1.2 a.

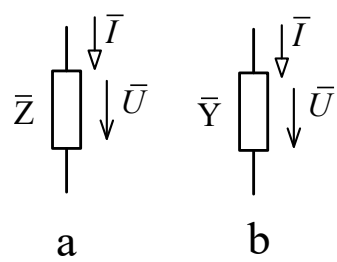

Obr. 1.2: Schematická značka impedance a admitance

Rezistor má impedanci $\bar{Z}_{\mathrm{R}}=R$. Kapacitor je popsán impedancí

$$
\bar{Z}_{\mathrm{C}}=\frac{1}{\mathrm{j} \omega C}=\frac{1}{\bar{p} C}
$$

kde $\omega$ značí úhlový kmitočet $\omega=2 \pi f$ (zde $f$ značí kmitočet resp. frekvenci v Hz) a $\bar{p}$ pak komplexní proměnnou $\bar{p}=\sigma+\mathrm{j} \omega$ (obvykle $\sigma=0$ ). Induktor je popsán impedancí

$$
\bar{Z}_{\mathrm{L}}=\mathrm{j} \omega L=\bar{p} L \text {. }
$$

Admitance. $\mathrm{Z}$ podobných důvodů se zavádí i komplexní admitance

$$
\bar{Y}=\frac{\bar{I}}{\bar{U}}=\frac{1}{\bar{Z}} \text {. }
$$

Schematická značka admitance a značení proudů je naznačena na Obr. 1.2b. Admitance rezistoru je $\bar{Y}_{\mathrm{R}}=1 / R=G$, admitance kapacitoru

$$
\bar{Y}_{\mathrm{C}}=\mathrm{j} \omega C=\bar{p} C
$$

a induktoru

$$
\bar{Y}_{\mathrm{L}}=\frac{1}{\mathrm{j} \omega L}=\frac{1}{\bar{p} L} .
$$

Sériové a paralelní spojení pasivních prvků. Nejčastější spojení dvou rezistorů jsou uvedena na Obr. 1.3. Výsledný odpor sériového spojení rezistorů (Obr. 1.3a) je

$$
R_{\mathrm{S}}=R_{1}+R_{2}
$$


a paralelního spojení (Obr. 1.3b)

$$
R_{\mathrm{P}}=R_{1} \| R_{2}=\frac{R_{1} R_{2}}{R_{1}+R_{2}} .
$$

Pro výsledný odpor paralelního spojení rezistorů se velmi často používá zjednodušeně označení $R_{1} \| R_{2}$. Při sériovém spojení většího počtu rezistorů (Obr. $\left.1.3 \mathrm{c}\right)$ se pak užívá pro vyjádření výsledného odporu zjednodušené značení $\mathrm{R}_{1}\left\|\mathrm{R}_{2}\right\| \mathrm{R}_{3}$.

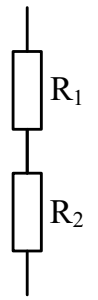

a

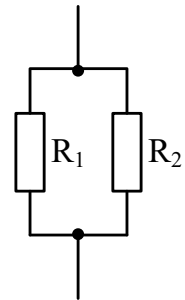

b

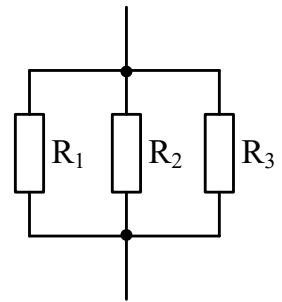

$\mathrm{c}$

Obr. 1.3: Sériové a paralelní spojení rezistorů

V př́padě sériové spojení kapacitorů (Obr. 1.4a) je výsledná kapacita

$$
C_{\mathrm{S}}=\frac{C_{1} C_{2}}{C_{1}+C_{2}}
$$

a v případě paralelního spojení (Obr. 1.4b)

$$
C_{\mathrm{P}}=C_{1} \| C_{2}=C_{1}+C_{2} .
$$

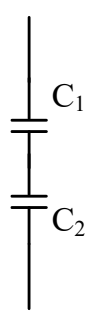

a

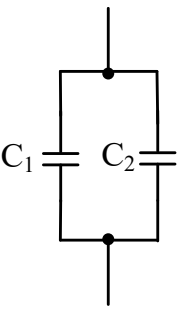

b

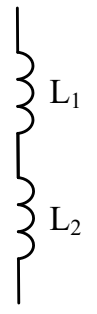

c

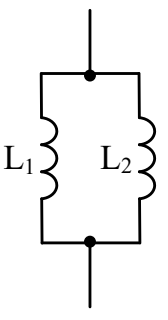

d

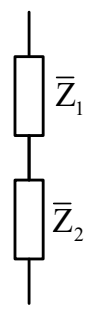

e

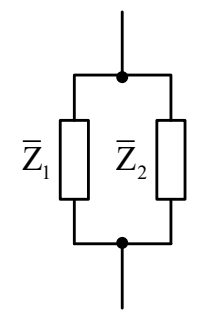

f

Obr. 1.4: Sériové a paralelní spojení kapacitorů, induktorů a impedancí

Spojíme-li dva induktory do série, indukčnost se ve výsledku zvětší podle vztahu

$$
L_{\mathrm{S}}=L_{1}+L_{2},
$$

ale cívky nesmí mít společný magnetický tok, resp. nesmí mít vzájemnou indukčnost. Při paralelním spojení induktorů se výsledná indukčnost sníží

$$
L_{\mathrm{P}}=\frac{L_{1} L_{2}}{L_{1}+L_{2}} .
$$


Obecně pak sériové spojení (viz Obr. 1.4e) dvou impedancí $\bar{Z}_{1}=1 / \bar{Y}_{1}$ a $\bar{Z}_{2}=1 / \bar{Y}_{2}$ bude mít výslednou impedanci

$$
\bar{Z}_{\mathrm{S}}=\bar{Z}_{1}+\bar{Z}_{2}
$$

a pro př́pad paralelního spojení

$$
\bar{Z}_{\mathrm{P}}=\bar{Z}_{1} \| \bar{Z}_{2}=\frac{1}{\bar{Y}_{1}+\bar{Y}_{2}}=\frac{\bar{Z}_{1} \bar{Z}_{2}}{\bar{Z}_{1}+\bar{Z}_{2}}
$$

\subsection{Elementární obvody}

Rezistorový dělič napětí. Pokud bude dělič napětí na Obr. 1.5a nezatížený ( $\left.i_{Z}=0\right)$, teče oběma rezistory proud $i=u_{1} /\left(R_{1}+R_{2}\right)$. Tento proud vyvolá na rezistoru $R_{2}$ napětí $u_{2}=i R_{2}=u_{1} R_{2} /\left(R_{1}+R_{2}\right)$. Napět'ový přenos nezatíženého děliče

$$
K_{\mathrm{U}}=\frac{u_{2}}{u_{1}}=\frac{R_{2}}{R_{1}+R_{2}} .
$$

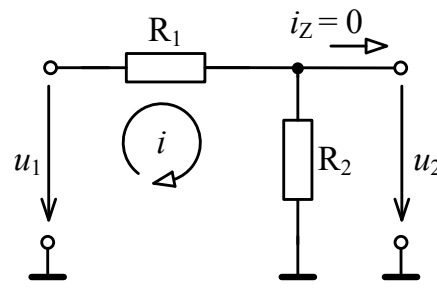

a

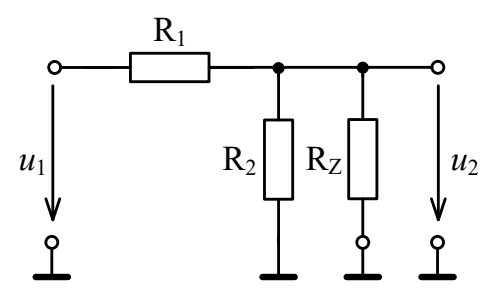

$\mathrm{b}$

Obr. 1.5: Rezistorový dělič napětí: a) nezatížený, b) zatížený

Bude-li odporový dělič zatížen zátěží $\mathrm{R}_{Z}$ (viz Obr. 1.5b), tj. například vstupním odporem následujícího zařízení, bude $\mathrm{R}_{2} \| \mathrm{R}_{\mathrm{Z}}$ a proto

$$
K_{\mathrm{U}}=\frac{R_{2} \| R_{\mathrm{Z}}}{R_{1}+R_{2} \| R_{\mathrm{Z}}} .
$$

Impedanční dělič napětí. Výsledek (1-21) pro rezistorový dělič můžeme zobecnit i pro nezatížený impedanční dělič na Obr. 1.6a

$$
\bar{K}_{\mathrm{U}}=\frac{\bar{Z}_{2}}{\bar{Z}_{1}+\bar{Z}_{2}} .
$$

Přenos kapacitního děliče na Obr. 1.6b pak bude mít podle rov (1-23) hodnotu 


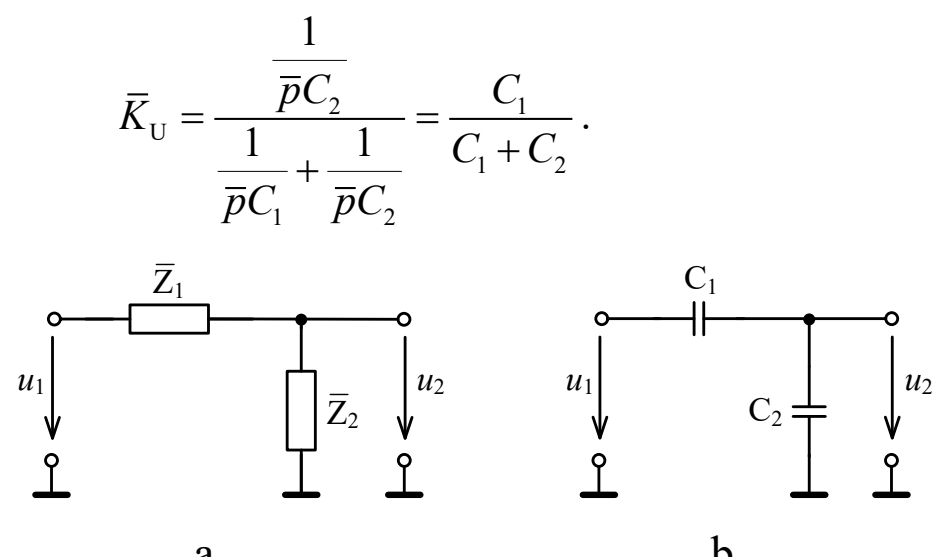

Obr. 1.6: a) Impedanční dělič, b) kapacitní dělič

Rezistorový dèlič proudu je nakreslen na Obr. 1.7. Proud $i$ vyvolá na paralelní kombinaci $\mathrm{R}_{1} \| \mathrm{R}_{2}$ napětí $u=i R_{1} \| R_{2}$. Rezistorem $\mathrm{R}_{1}$ pak teče proud

$$
i_{1}=\frac{u}{R_{1}}=i \frac{R_{1} \| R_{2}}{R_{1}}=i \frac{R_{2}}{R_{1}+R_{2}} .
$$

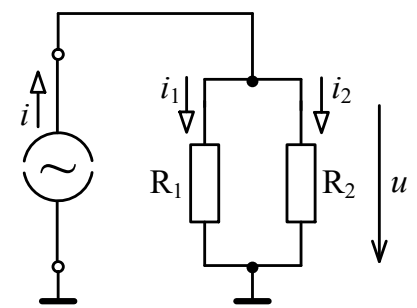

Obr. 1.7: Rezistorový dělič proudu

a proud rezistorem $R_{2}$

$$
i_{2}=\frac{u}{R_{2}}=i \frac{R_{1} \| R_{2}}{R_{2}}=i \frac{R_{1}}{R_{1}+R_{2}} .
$$

Proudy tekoucí děličem proudu pak budou v poměru

$$
\frac{i_{1}}{i_{2}}=\frac{R_{2}}{R_{1}} .
$$

Rezonanční obvod (kmitavý okruh) vznikne sériovým nebo paralelním spojením kapacitoru a induktoru (viz. Obr. 1.8). V případě sériového rezonančního obvodu (Obr. 1.8a) je jeho impedance

$$
\bar{Z}=\bar{p} L+\frac{1}{\bar{p} C}=\mathrm{j} \omega L+\frac{1}{\mathrm{j} \omega C}=\mathrm{j}\left(\omega L-\frac{1}{\omega C}\right)=\mathrm{j}\left(X_{\mathrm{L}}-X_{\mathrm{C}}\right) .
$$

Ta bude nulová při kmitočtu $\omega_{0}, \mathrm{když} \omega_{0} L-1 / \omega_{0} C=0$, resp. $\omega_{0} L=1 / \omega_{0} C$ kdy reaktance induktoru i kapacitoru budou shodné $X_{\mathrm{L}}=X_{\mathrm{C}}$. 
Pro admitanci paralelního rezonančního obvodu (Obr. 1.8b) můžeme psát

$$
\bar{Y}=\bar{p} C+\frac{1}{\bar{p} L}=\mathrm{j} \omega C+\frac{1}{\mathrm{j} \omega L}=\mathrm{j}\left(\omega C-\frac{1}{\omega L}\right)=\mathrm{j}\left(\frac{1}{X_{\mathrm{C}}}-\frac{1}{X_{\mathrm{L}}}\right) .
$$

Tato admitance bude nulová při kmitočtu $\omega_{0}$, když $\omega_{0} C=1 / \omega_{0} L$, resp. $\omega_{0} L=1 / \omega_{0} C$ kdy reaktance induktoru i kapacitoru budou shodné $X_{\mathrm{L}}=X_{\mathrm{C}}$.

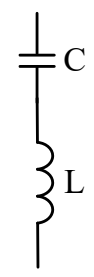

a

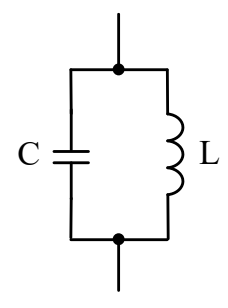

b

Obr. 1.8: Ideální rezonanční obvod: a) sériový, b) paralelní

Odtud pro oba př́pady můžeme stanovit pro úhlový rezonanční kmitočet tzv. Thompsonův vztah

$$
\omega_{0}=\frac{1}{\sqrt{L C}}
$$

resp. pro rezonanční kmitočet $f_{0}=\omega_{0} / 2 \pi$ vztah

$$
f_{0}=\frac{1}{2 \pi \sqrt{L C}} \text {. }
$$

Při tomto kmitočtu bude impedance sériového obvodu $\bar{Z}\left(\omega_{0}\right)=0$ a admitance paralelního obvodu $\bar{Y}\left(\omega_{0}\right)=0$.

Ztrátový rezonanční obvod (tlumený kmitavý okruh). V reálním př́padě cívka induktoru vykazuje ztrátový odpor a podobně ztrátový odpor vykazuje i kondenzátor. Všechny ztrátové odpory v obvodu lze vyjádřit odporem v sérii nebo paralelně $\mathrm{k}$ ideálnímu rezonančnímu obvodu (viz Obr. 1.9). V prí́padě sériového zapojení (Obr. 1.9a) je impedance

$$
\bar{Z}=R+\bar{p} L+\frac{1}{\bar{p} C}
$$

a pro př́ipad paralelního zapojení (

Obr. 1.9b) je admitance

$$
Y=G+\bar{p} C+\frac{1}{\bar{p} L}
$$

Při kmitočtu $\omega_{0}=1 / \sqrt{L C}$ bude nyní impedance sériového obvodu $\bar{Z}\left(\omega_{0}\right)=R$ a admitance paralelního obvodu $\bar{Y}\left(\omega_{0}\right)=G=1 / R$. V obou prrípadech tedy bude impedance při rezonanci $\bar{Z}\left(\omega_{0}\right)=R$. 
Poměr energie uchované v magnetickém poli induktoru ke ztrátám v obvodu při rezonančním kmitočtu vyjadřuje činitel jakosti

$$
Q=\frac{X_{\mathrm{L}}}{R}=\frac{\omega_{0} L}{R}=\frac{1}{R} \sqrt{\frac{L}{C}} .
$$

Obdobně můžeme činitel jakosti vyjádřit i jako poměr energie uchované v elektrickém poli kapacitoru ke ztrátám v obvodu při rezonančním kmitočtu

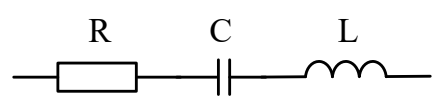

$\mathrm{a}$

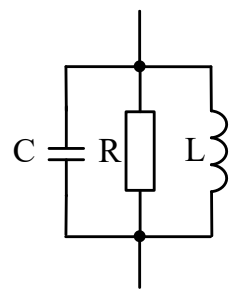

$\mathrm{b}$

Obr. 1.9: Ztrátový rezonanční obvod: a) sériový, b) paralelní

$$
Q=\frac{X_{\mathrm{C}}}{R}=\frac{1}{\omega_{0} C R}=\frac{1}{R} \sqrt{\frac{L}{C}} .
$$

Činitel jakosti rezonančního okruhu $Q$ je definován vždy při rezonančním kmitočtu $\omega_{0}$.

\subsection{Zdroje napětí a proudů}

Ideální zdroj napětí. Ideální zdroj napětí dodává trvale konstantní napětí bez ohledu na odebíraný proud. Pro zdroje stejnosměrného (ss) napětí se užívají schematické značky uvedené na Obr. 1.10a. Napět'ová šipka směřuje vždy od vyššího potenciálu k nižšímu a proto se většinou vyznačení polarity vypouští (znaménka + a -). Pokud je obvod napájen ze zdroje ss napětí, schématická značka zdroje se obvykle nekreslí a použije se zjednodušené značení nakreslené na Obr. 1.10b.
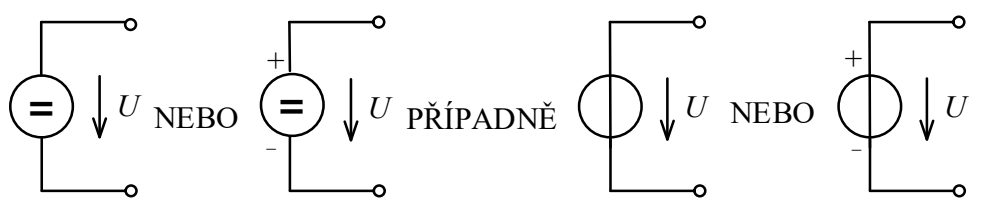

a
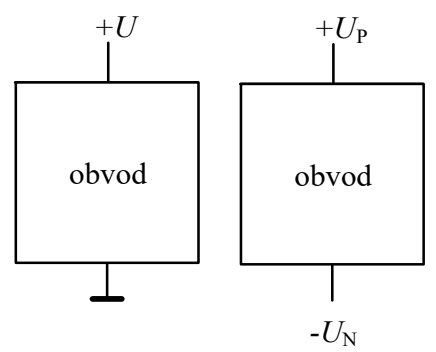

b

Obr. 1.10: a) Zdroje stejnosměrného napětí, b) zjednodušené značení ss napájecích zdrojů

Vždy se předpokládá, že napětí je vztaženo ke společné svorce a to i tehdy, když společná svorka není vyznačena. Zde poznamenejme, že společná svorka může být na libovolném 
potenciálu (např. $200 \mathrm{~V}$ ). Speciálním případem je pak zemní svorka, která je připojena na potenciál $0 \mathrm{~V}$.

Užívané schématické značky stř́idavého zdroje napětí jsou naznačeny na Obr. 1.11a. Pro přesnost je třeba uvést, že takto vyznačený zdroj může mimo střídavé složky zahrnovat i ss složku. Velmi často se ale také užívá zjednodušené značení uvedené na Obr. 1.11b. Napětí jsou vždy vztažena ke společné svorce i když tato není vyznačena.

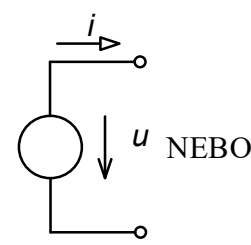

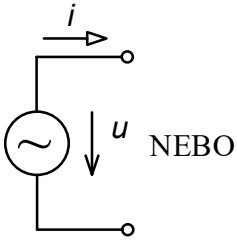

a

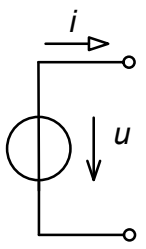

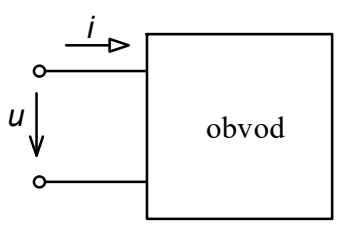

$\mathrm{b}$

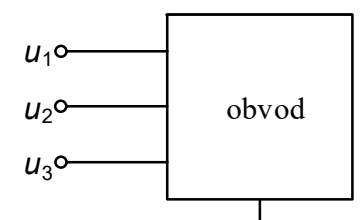

b

Obr. 1.11: a) Zdroj střídavého napětí, b) zjednodušené značení střídavých zdrojů napětí

Ideální zdroj proudu. Ideální zdroj proudu dodává trvale proud $i$ bez ohledu na napětí $u$ na jeho svorkách.

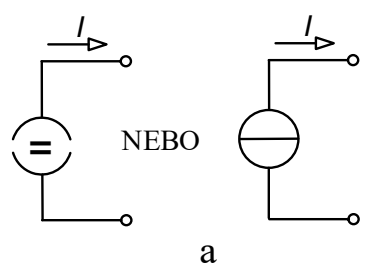

$\mathrm{a}$
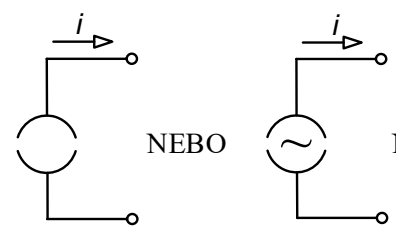

NEBO

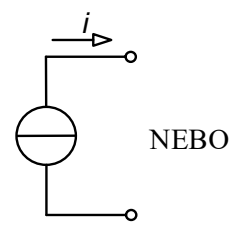

b

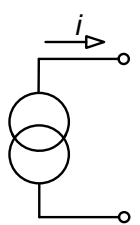

Obr. 1.12: a) Zdroj stejnosměrného proudu, b) zdroj stř́idavého proudu

Pro stejnosměrný zdroj proudu se užívají značky na Obr. 1.12a, pro střídavý pak značky na Obr. 1.12b. Poznamenejme, že v literatuře lze nalézt i jiné alternativní značky zdrojů proudu. V př́padě střídavého zdroje proudu může zdroj zahrnovat mimo strrídavé složky i stejnosměrnou složku proudu.

\section{Spojování zdrojů napětí a proudu.}

Napětové zdroje lze spojovat pouze do série (viz Obr. 1.13a). Výsledné napětí je pak dáno součtem napětí jednotlivých zdrojů $u=u_{1}+u_{2}+U$.

Proudové zdroje se spojují pouze paralelně (viz Obr. 1.13b). Výstupní proud je pak určen součtem všech dílčích zdrojů proudu $i=i_{1}+i_{2}+I$. 

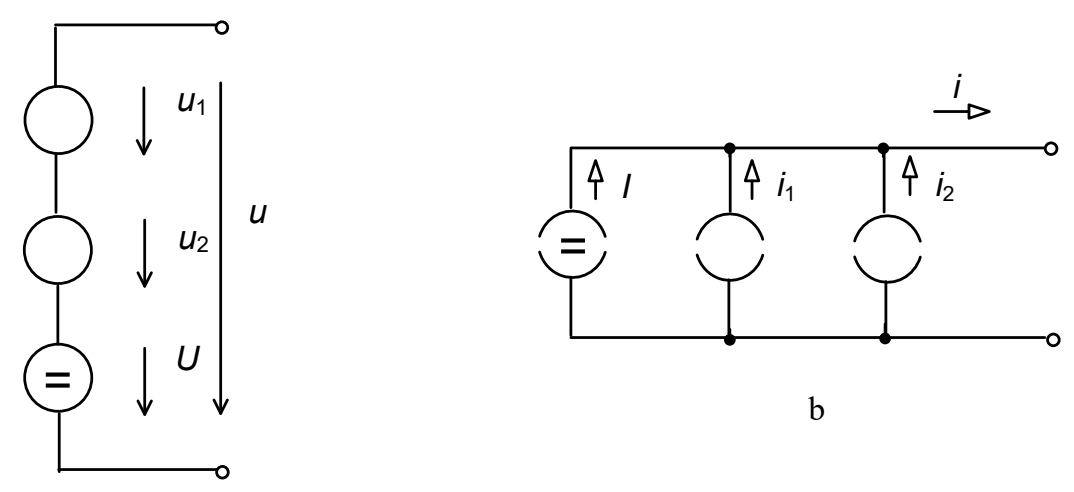

a

Obr. 1.13: a) Napětové zdroje lze spojovat pouze do série, b) proudové zdroje se spojují pouze paralelně

Reálné zdroje napětí a proudu. Skutečný zdroj napětí vykazuje při zvětšování odběru proudu resp. při zvětšování zatížení takovéhoto zdroje pokles napětí na svorkách. Tento jev budeme brát $\mathrm{v}$ úvahu zavedením zdroje napětí (viz Obr. 1.14a) o vnitřním napětí $u_{0}$ a vnitřním odporu $R_{0}$ nebo obecně o vnitřní impedanci $\bar{Z}_{0}$. Jeho svorkové napětí $u$ je pak dáno vztahem

$$
u=u_{0}-R_{0} i \text {. }
$$

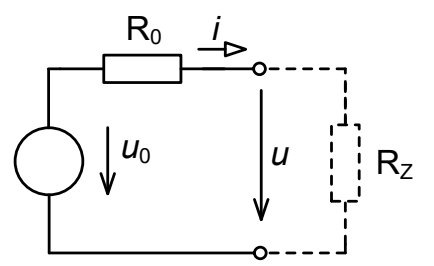

a

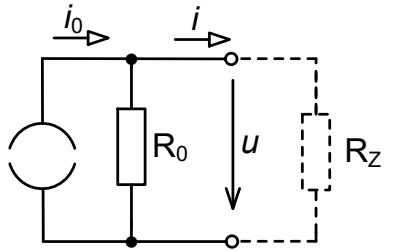

b

Obr. 1.14: a) Reálný zdroj napětí, b) reálný zdroj proudu

Čím bude vnitřní odpor $R_{0}$ menší, tím méně bude výstupní napětí záviset na proudu do zátěže. Pro $R_{0} \rightarrow 0$ získáme zdroj blížící se ideálnímu zdroji napětí. Zdroj napětí s malým vnitřním odporem $R_{0}<1 \Omega$ je někdy také označován jako „tvrdý $\boldsymbol{z} \boldsymbol{d r o j}$ “ napětí a vyznačuje se tím, že na jeho svorkách je trvale napětí $u$ bez ohledu na velikost proudu $i$ tekoucího do zátěže resp. bez ohledu na velikost zátěže připojené k takovémuto zdroji napětí.

Skutečný zdroj proudu vykazuje vnitřní odpor obvykle $1 \mathrm{M} \Omega$ až $10 \mathrm{M} \Omega$. Model reálného zdroje proudu je nakreslen na Obr. $1.14 \mathrm{~b}$ a obsahuje vnitřní zdroj proudu $i_{0}$ a vnitřní odpor $R_{0}$ (resp. obecně vnitřní impedanci $\bar{Z}_{0}$ ). Jeho výstupní proud je pak dán vztahem

$$
i=i_{0}-\frac{u}{R_{0}}
$$

Č́m bude vnitřní odpor $R_{0}$ větší, tím méně bude výstupní proud záviset na napětí $u$. Pro $R_{0} \rightarrow \infty$ se bude zdroj blížit ideálnímu zdroji proudu. 


\subsection{Základní metody řešení lineárních obvodů}

Kirchoffův zákon o proudech. První Kirchoffův zákon říká, že součet všech proudů tekoucích do uzlu rovná se nule. Přitom proud označený šipkou směřující do uzlu se považuje za kladný a proud označený šipkou směřující od uzlu se považuje za záporný.

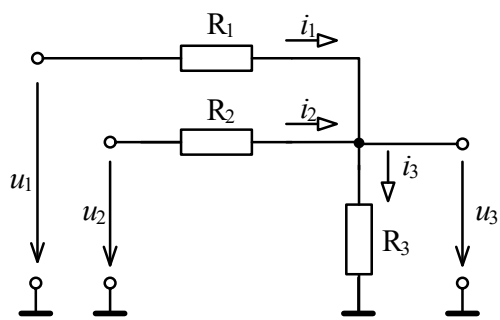

a

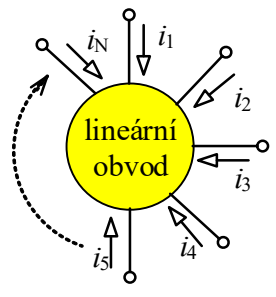

b

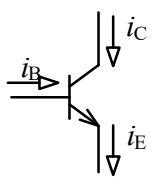

C

Obr. 1.15: a) Kirchoffův zákon o proudech, b) zobecněný Kirchoffův zákon o proudech, c) př́klad použití zobecněného zákona

Využití tohoto zákona ukážeme při řešení obvodu nakresleného na Obr. 1.15a, kdy záměrem je vypočítat výstupní napětí $u_{3}$. Podle pravidla o proudech tekoucích do uzlu dostáváme

$$
i_{1}+i_{2}-i_{3}=0 .
$$

Podle Ohmova zákona pro jednotlivé proudy platí

$$
\begin{gathered}
i_{1}=\frac{u_{1}-u_{3}}{R_{1}}, \\
i_{1}=\frac{u_{2}-u_{3}}{R_{2}}, \\
i_{3}=\frac{u_{3}}{R_{3}} .
\end{gathered}
$$

Dosazením těchto proudů do rov.(1-38) dostaneme

$$
\frac{u_{1}-u_{3}}{R_{1}}+\frac{u_{2}-u_{3}}{R_{2}}-\frac{u_{3}}{R_{3}}=0
$$

Odtud vyčíslíme výstupní napětí obvodu

$$
u_{3}=\frac{u_{1} R_{2} R_{3}+u_{2} R_{1} R_{3}}{R_{1} R_{2}+R_{1} R_{3}+R_{2} R_{3}} .
$$

Kirchoffův zákon o proudech můžeme použít i pro zobecněný obvodový uzel (Obr. $1.15 \mathrm{~b})$, kdy pro součet proudů tekoucích do zobecněného uzlu platí $\sum_{n=1}^{N} i_{n}=0$, pro $n=1,2, \ldots$, $N$. Tento zobecněný zákon můžeme použít např. pro popis proudů bipolárního tranzistoru pracujícího v lineární oblasti $(\mathrm{Obr} .1 .15 \mathrm{c})$, kdy pro proudy platí $i_{\mathrm{E}}=i_{\mathrm{B}}+i_{\mathrm{C}}$. 
Kirchoffưv zákon o napětích. Druhý Kirchoffův zákon říká, že součet všech napětí ve smyčce je roven nule. Přitom za kladná se považují napětí jejichž směr šipek je souhlasně se zvoleným směrem proudu $i$ ve smyčce. Napětí s opačnými šipkami se uvažují jako záporná.

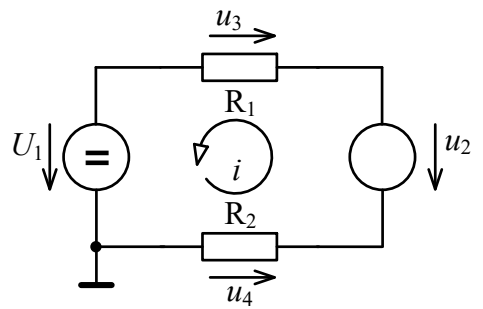

Obr. 1.16: Př́iklad použití Kirchoffova zákona o napětích

Podle tohoto zákona bude v obvodu nakresleném na Obr. 1.16 platit

$$
U_{1}+u_{4}-u_{2}-u_{3}=0
$$

Metoda superpozice platí v lineárních obvodech a říká, že celková odezva vyvolaná všemi zdroji najednou je rovna součtu odezev vyvolaných jednotlivými zdroji. Pokud obvod obsahuje zdroje napětí i proudu, postupujeme tak, že zkratujeme všechny zdroje napětí až na jeden a všechny zdroje proudu rozpojíme. Postupně takto zjistíme účinek jednotlivých zdrojů napětí. Následně zkratujeme všechny zdroje napětí a rozpojíme všechny zdroje proudu až na jeden. Postupně pak zjistíme účinky jednotlivých zdrojů proudu. Na závěr všechny jednotlivé dílčí výsledky sečteme.

Řešení metodou superpozice ukážeme na obvodu nakresleném na Obr. 1.17. Předpokládejme nejprve, že bude rozpojen zdroj proudu, tj. $I_{0}=0$ a pak podle Ohmova zákona platí

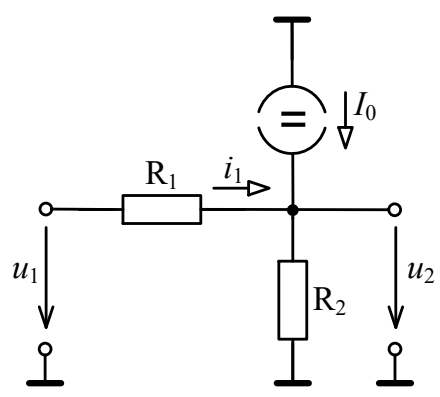

Obr. 1.17: Př́iklad použití metody superpozice

$$
i_{1}=\frac{u_{1}}{R_{1}+R_{2}}
$$

a tedy

$$
u_{2}^{\prime}=i_{1} R_{2}=\frac{R_{2}}{R_{1}+R_{2}} u_{1} .
$$

V dalším kroku zkratujeme zdroj napětí, tj. $u_{1}=0$ a pak 


$$
u_{2}^{\prime \prime}=I_{0} \cdot R_{1} \| R_{2}=I_{0} \frac{R_{1} R_{2}}{R_{1}+R_{2}}
$$

Dílčí výsledky sečteme

$$
u_{2}=u_{2}^{\prime}+u_{2}^{\prime \prime}=\frac{R_{2}}{R_{1}+R_{2}} u_{1}+I_{0} \frac{R_{1} R_{2}}{R_{1}+R_{2}}=\frac{R_{2}}{R_{1}+R_{1}}\left(u_{1}+I_{0} R_{1}\right) .
$$

Metoda ekvivalentního zdroje napěti - Théveninův teorém. Libovolně složitý lineární aktivní obvod, ve kterém působí zdroj o vnitřním napětí $u$ v nebo vnitřním proudu $i_{\mathrm{V}}$, můžeme nahradit ekvivalentním zdrojem napětí (Obr. 1.18). Ten obsahuje jeden ideální zdroj napětí o vnitřním napětí $u_{0}$ a jednu impedanci $\bar{Z}_{0} \mathrm{v}$ sérii $\mathrm{s}$ ním. Ekvivalentní vnitřní napětí $u_{0}$ se rovná výstupnímu napětí nahrazovaného obvodu naprázdno (tj. bez uvažování zátěže mezi výstupními svorkami). Ekvivalentní vnitřní impedance $\bar{Z}_{0}$ se rovná impedanci mezi výstupními svorkami při $u_{\mathrm{V}}=0$, resp. $i_{\mathrm{V}}=0$. Ekvivalentní vnitřní impedance bývá často označována jednoduše jako výstupní impedance.

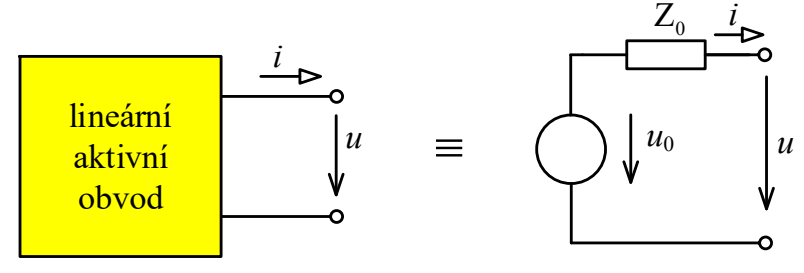

Obr. 1.18: Lineární aktivní obvod a jemu ekvivalentní zdroj napětí

Poznamenejme ještě, že je-li ve složitém lineárním aktivním obvodu obsaženo několik nezávislých zdrojů napětí $u_{\mathrm{V} n}$ či několik nezávislých zdrojů proudu $i_{\mathrm{V} m}$, použije se ke stanovení ekvivalentního zdroje princip superpozice.

Využití Théveninova teorému ukážeme na při stanovení ekvivalentního obvodu napět'ového děliče na Obr. 1.19. Poznamenejme, že i kdyby byl dělič zatížen, ekvivalentní obvod zátěž nezahrnuje.

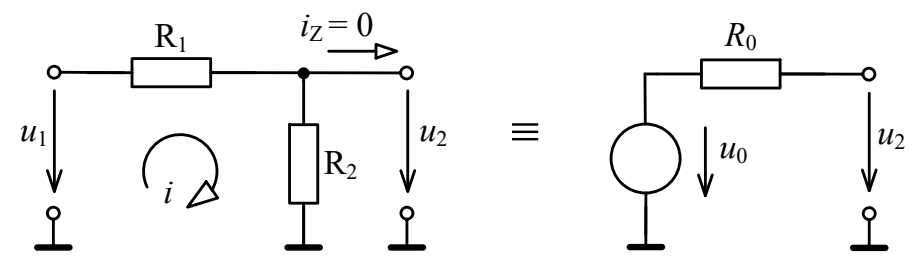

Obr. 1.19: Určení ekvivalentního zdroje napětí pro případ napětového děliče napětí

Ekvivalentní vnitřní napětí určíme jako výstupní napětí nezatíženého děliče

$$
u_{0}=u_{20}=i R_{2}=\frac{R_{2}}{R_{1}+R_{2}} u_{1} \text {. }
$$

Ekvivalentní vnitřní impedanci resp. v daném případě vnitřní či výstupní odpor určíme při zkratovaných vstupních svorkách, tj. pro $u_{1}=0$

$$
R_{0}=R_{1} \| R_{2}=\frac{R_{1} R_{2}}{R_{1}+R_{2}}
$$


Metoda ekvivalentního zdroje proudu - Nortonův teorém. Libovolně složitý lineární aktivní obvod, ve kterém působí zdroj o vnitřním napětí $u_{\mathrm{V}}$ nebo vnitřním proudu $i_{\mathrm{V}}$, můžeme nahradit ekvivalentním zdrojem proudu (Obr. 1.20) o vnitřním proudu $i_{0}$ a paralelně $\mathrm{k}$ němu připojenou vnitřní impedanci $\bar{Z}_{0}$. Ekvivalentní vnitřní proud $i_{0}$ se rovná výstupnímu proudu nakrátko (tzn. při zkratovaných svorkách) a ekvivalentní vnitřní impedance $\bar{Z}_{0}$ se rovná impedanci mezi výstupními svorkami při $u \mathrm{~V}=0$ resp. $i_{\mathrm{V}}=0$.

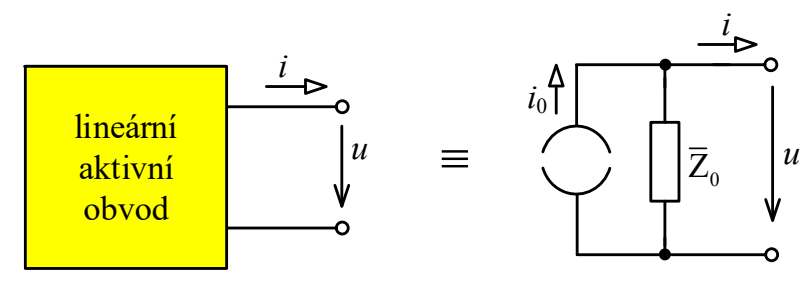

Obr. 1.20: Lineární aktivní obvod a jemu odpovídající ekvivalentní zdroj proudu

Př́klad využití Nortonova teorému ukážeme při stanovení ekvivalentního obvodu proudového děliče na Obr. 1.21. Při zkratovaných výstupních svorkách určíme tzv. proud nakrátko. Nejprve ovšem určíme napětí $u$, které vznikne v př́padě zkratovaných výstupních svorek na $\mathrm{R}_{1} \| \mathrm{R}_{2}$

$$
u=i_{1} R_{1} \| R_{2}=i_{1} \frac{R_{1} R_{2}}{R_{1}+R_{2}} .
$$

Potom při zkratovaných výstupních svorkách určíme ekvivalentní proud
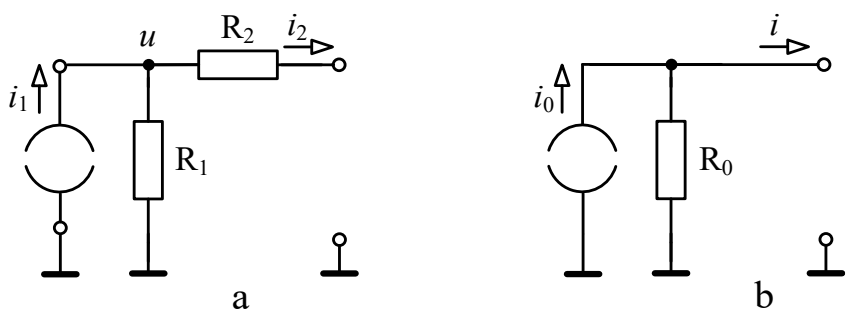

Obr. 1.21: Určení ekvivalentního zdroje proudu pro případ děliče proudu

$$
i_{0}=i_{2 \mathrm{~K}} \frac{u}{R_{2}}=\frac{R_{1}}{R_{1}+R_{2}} i_{1}
$$

Ekvivalentní vnitřní impedanci resp. $\mathrm{v}$ daném př́ípadě vnitřní či výstupní odpor určíme při $i_{1}=0$, tzn. pro odpojený zdroj proudu

$$
R_{0}=R_{1}+R_{2}
$$

\subsection{Spojování přenosových článků}

Přenosový článek je charakterizován jednou vstupní a jednou výstupní branou, resp. dvěma vstupními a dvěma výstupními svorkami (Obr. 1.22). Vlastnosti přenosového článku většinou popisujeme napět'ovým přenosem 


$$
\bar{A}_{\mathrm{U}}=\frac{\bar{U}_{2}}{\bar{U}_{1}} .
$$

nebo proudovým přenosem

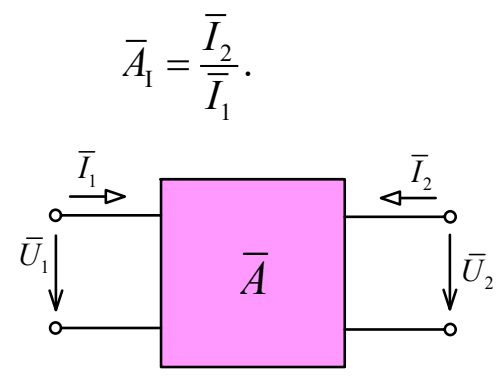

Obr. 1.22: Přenosový článek

V prŕípadě proudového přenosu je třeba poznamenat, že i když existuje mezinárodní úmluva, že obě napětí přenosového článku se vztahují ke společnému vodiči (zemi) a oba proudy tečou dovnitř přenosového článku, můžeme se často setkat s př́ípady, že proud $\bar{I}_{2}$ má opačný směr šipky a výsledný proudový přenos má z tohoto důvodu opačné znaménko.

$\mathrm{V}$ dalším budou uvedena jen ta spojení přenosových článků, která budeme potřebovat pro další výklad. Zájemce o všechny typy spojení přenosových článků odkazujeme na odbornou literaturu.

Kaskádní zapojení přenosových článků. U kaskádního zapojení přenosových článků jsou výstupní svorky prvního článku přímo spojeny se vstupními svorkami druhého článku (viz Obr. 1.23). Pokud vstupní impedance druhého článku s přenosem $\bar{A}_{2}$ bude mít vstupní impedanci daleko větší než je výstupní impedance prvního článku $\bar{Z}_{\mathrm{i} 2} \gg \bar{Z}_{\mathrm{o} 1}$ (obvykle dostačuje $\bar{Z}_{\mathrm{i} 2}>100 \bar{Z}_{\mathrm{o} 1}$ ), bude pro výsledný přenos platit

$$
\bar{A}=\bar{A}_{1} \bar{A}_{2}
$$

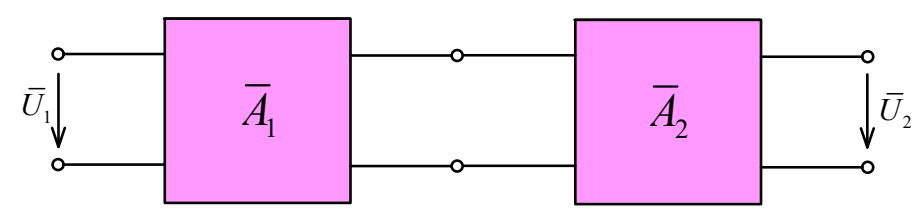

Obr. 1.23: Kaskádní zapojení přenosových článků

Vstupní impedance takovéhoto spojení bude dána vstupní impedancí prvního článku $\bar{Z}_{\mathrm{i} 1} \mathrm{a}$ výstupní impedance pak výstupní impedancí druhého článku $Z_{\mathrm{o} 2}$.

Zpětnovazební zapojení přenosových článků. Zpětnovazební spojení přenosových článků, kdy prostřednictvím zpětné vazby záměrně přivádíme část výstupního signálů zpět na vstup, ovlivňuje prakticky všechny vlastnosti výsledného obvodu. Princip zpětnovazebního spojení přenosových článků je zřejmý z blokového schématu na Obr. 1.24. 


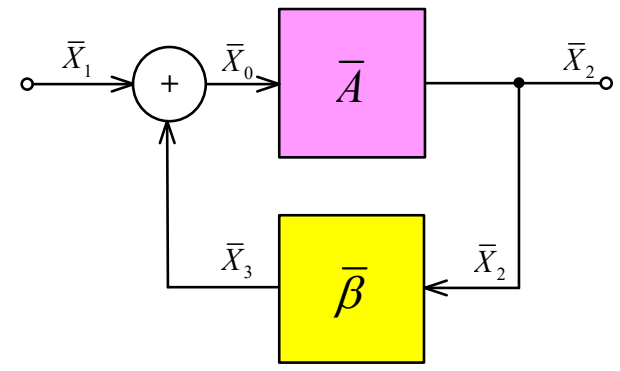

Obr. 1.24: Zpětnovazební zapojení přenosových článků

Označme přenos v př́mém směru

$$
\bar{A}=\frac{\bar{X}_{2}}{\bar{X}_{0}}
$$

a přenos zpětné vazby (také někdy tzv. zpětnovazební činitel)

$$
\bar{\beta}=\frac{\bar{X}_{3}}{\bar{X}_{2}} .
$$

Přenos celého systému bude

$$
\bar{K}=\frac{\bar{X}_{2}}{\bar{X}_{1}}=\frac{\bar{A}}{1-\bar{\beta} \bar{A}}
$$

Podle typu zpětné vazby mohou být veličiny $\bar{X}_{0}, \bar{X}_{1}, \bar{X}_{2}$ a $\bar{X}_{3}$ napětí nebo proudy. Rovnice (1-59) bývá označována jako Blackův vztah či Blackův vzorec vyjadřující vliv zpětné vazby na zesílení zesilovače.

Součin $\bar{\beta} \bar{A}$ bývá často označován jako přenos otevřené smyčky, tzn. přenos kaskádního spojení článků, při rozpojené zpětné vazbě. Pokud bude přenos otevřené smyčky $0<\bar{\beta} \bar{A}<1$ půjde o kladnou zpětnou vazbu, která bude zvyšovat celkové zesílení $\bar{K}>\bar{A}$. Bude-li splněna podmínka $\bar{\beta} \bar{A}=1$, vzniknou oscilace a $\bar{K} \rightarrow \infty$. Pokud $\bar{\beta} \bar{A}<0$, půjde o zápornou zpětnou vazbu, která snižuje zesílení $\bar{K}<\bar{A}$.

Zpětná vazba se cíleně využivá ke zlepšení vlastností výsledného obvodu jako např. ke zvýšení vstupního odporu, ke snížení výstupního odporu, k definování výsledných přenosových vlastností obvodu pomocí zpětnovazební sítě, nebo k potlačení nelineárního zkreslení. Poznamenejme však, že v některých případech může být zpětná vazba nežádoucí a výrazně zhoršovat vlastnosti obvodu. 

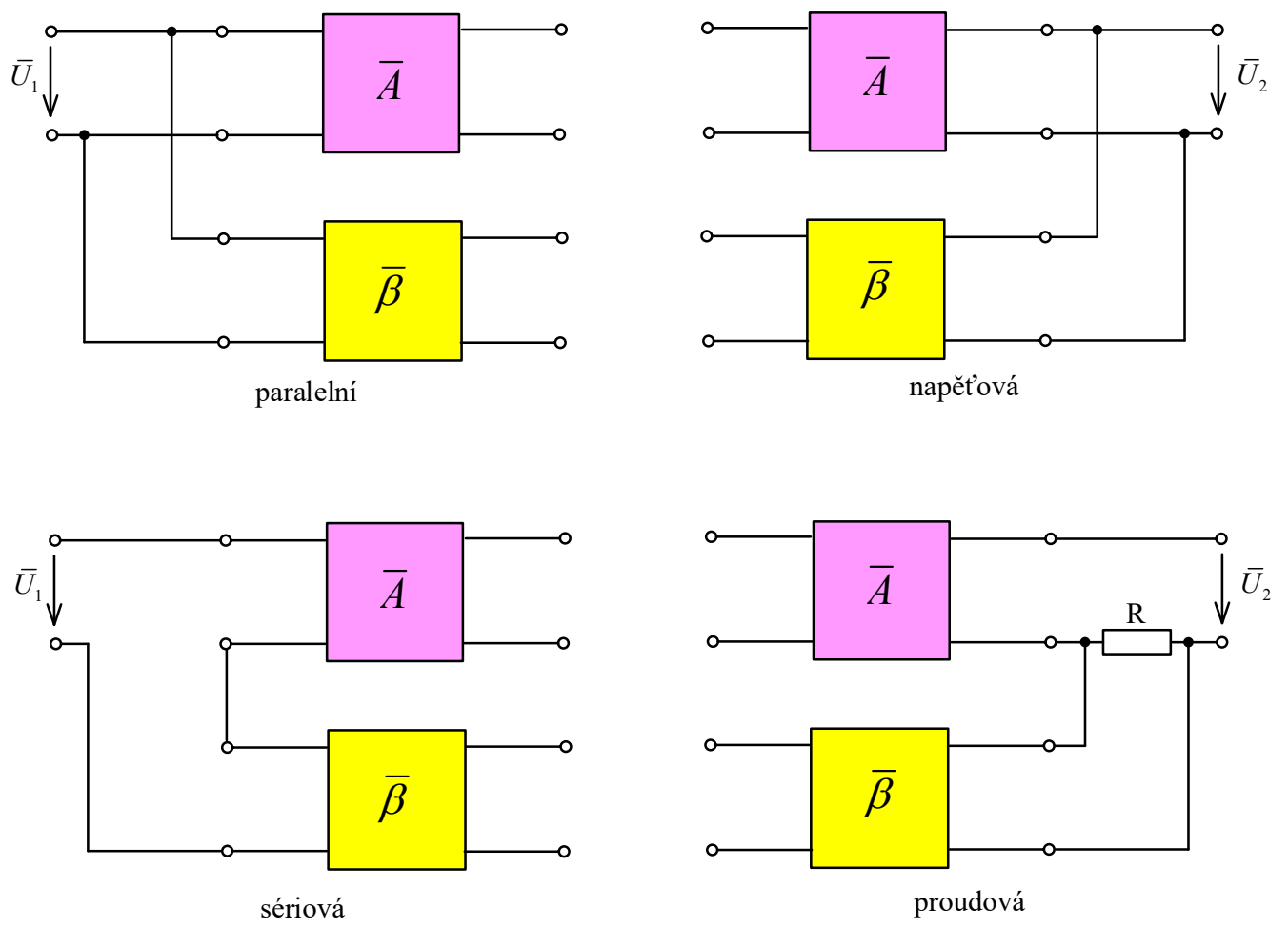

Obr. 1.25: Typy zpětných vazeb

Jednotlivé typy zpětných vazeb lze členit podle několika možných hledisek (viz Obr. 1.25):

a) podle vlivu na zesílení se rozlišuje

- kladná zpětná vazba, kdy se zpětnovazební signál sčitá s původním vstupním signálem,

- záporná zpětná vazba, kdy se zpětnovazební signál odečitá od původního vstupního signálu,

b) podle způsobu přivedení zpětnovazebního signálu na vstup zesilovače se rozlišuje

- paralelní zpětná vazba, kdy zpětnovazební signál působí paralelně s původním vstupním signálem,

- sériová zpětná vazba, kdy zpětnovazební signálů působí v sérii s původním vstupním signálem,

c) podle způsobu odběru zpětnovazebního signálu $\mathrm{z}$ výstupu zesilovače se rozlišuje

- napětová zpětná vazba, kdy zpětnovazební signál je odvozen z výstupního napětí zesilovače

- proudová zpětná vazba, kdy zpětnovazební signál je úměrný výstupním proudu zesilovače, který teče zátěží a snímá se na rezistoru R.

$\mathrm{V}$ dalším jsou shrnuty vlastnosti nejčastěji uživaných zpětných vazeb.

Sériová napětová zpětná vazba. Při sériové napětové vazbě se část výstupního napětí zesilovače přenese zpět přs zpětnovazební článek tak, že výstupní napětí zpětnovazebního článku působí v sérii se vstupním napětím (viz Obr. 1.26). Je-li původní napětové zesílení zesilovače bez zpětné vazby $\bar{A}=\bar{U}_{2} / \bar{U}_{0}$, kde $\bar{U}_{0}$ a $\bar{U}_{2}$ jsou původní vstupní a výstupní napětí 


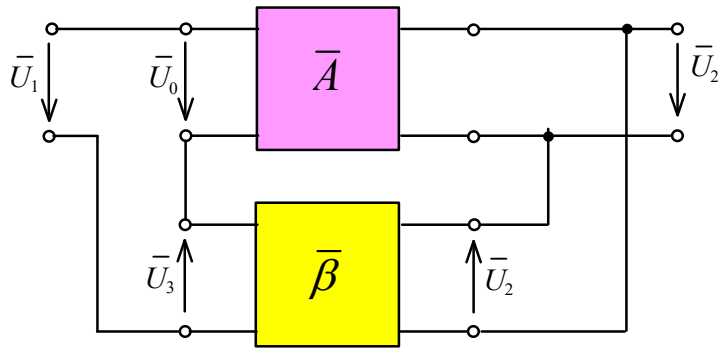

Obr. 1.26 : Sériová napětová zpětná vazba

a zpětnovazební činitel $\bar{\beta}=\bar{U}_{3} / \bar{U}_{2}$, pak po zavedení sériové zpětné vazby platí pro nové vstupní napětí $\bar{U}_{1}=\bar{U}_{0}-U_{3}$. Protože $\bar{U}_{0}=\bar{U}_{2} / A$ a $\bar{U}_{3}=\bar{U}_{2} \bar{\beta}$ bude napětový přenos zpětnovazební soustavy

$$
\bar{K}=\frac{\bar{U}_{2}}{\bar{U}_{1}}=\frac{\bar{U}_{2}}{\bar{U}_{0}-U_{3}}=\frac{\bar{U}_{2}}{\bar{U}_{2} / \bar{A}-\bar{U}_{2} \bar{\beta}}=\frac{A}{1-\bar{\beta} \bar{A}} .
$$

$\mathrm{V}$ př́padě, že bude přenos zesilovače nebo zpětnovazebního článku záporný, půjde o zápornou zpětnou vazbu $(\bar{\beta} \bar{A}<0)$. Výsledný vztah lze upravit do tvaru

$$
\bar{K}=\frac{1}{1 / \bar{A}-\bar{\beta}},
$$

ze kterého je zřejmé, že pokud bude zesílení tak velké, že lze psát, $\bar{A} \approx \infty$, bude $\bar{K} \approx-1 / \bar{\beta}$, což znamená, že zesílení zavazbeného zesilovače není vůbec určeno parametry zesilovače, ale závisí pouze na vlastnostech zpětné vazby.

Sériová záporná napětová zpětná vazba zvyšuje vstupní impedanci

$$
\bar{Z}_{\mathrm{vst}}=\bar{Z}_{\mathrm{i}}(1-\bar{\beta} \bar{A})
$$

a výstupní impedanci snižuje

$$
\bar{Z}_{\text {vysst }}=\frac{\bar{Z}_{0}}{1-\bar{\beta} \bar{A}}
$$

Bude-li zpětnovazební článek jen rezistorový a nebudeme-li uvažovat kmitočtové závislosti parametrů zesilovače, bude jednoduše

$$
R_{\mathrm{vst}}=R_{\mathrm{i}}(1-\beta A),
$$

a

$$
R_{\text {vyst }}=\frac{R_{0}}{1-\beta A} .
$$

Paralelni napětová zpětná vazba. Paralelní spojení dvou přenosových článků je naznačeno na Obr. 1.27. Je charakterizováno tím, že část výstupního napětí zesilovače s přenosem $\bar{A}$ se přes zpětnovazební článek s př̀nosem $\bar{\beta}$ přenese zpět na vstup a to paralelně s původním vstupním napětím. 


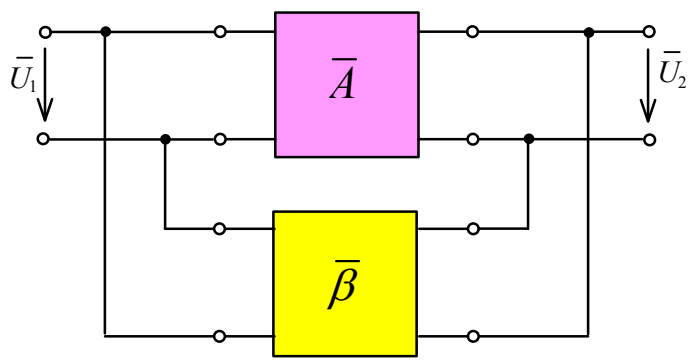

Obr. 1.27: Paralelní napět'ová zpětná vazba

Důsledky zpětné vazby na celkový přenos obvodu popisuje rov. (1-59). Paralelní napětová záporná zpětná vazba snižuje vstupní impedanci obvodu

$$
\bar{Z}_{\mathrm{vst}}=\frac{\bar{Z}_{\mathrm{i}}}{1-\bar{\beta} \bar{A}} .
$$

kde $\bar{Z}_{\mathrm{i}}$ značí vstupní impedanci samotného zesilovače. Podobným způsobem se snižuje i výstupní impedance

$$
\bar{Z}_{\text {výst }}=\frac{\overline{Z_{0}}}{1-\bar{\beta} \bar{A}} .
$$

kde $\bar{Z}_{0}$ značí výstupní impedanci zesilovače bez zpětné vazby. Pokud bude zpětnovazební článek čistě rezistorový a nebudeme uvažovat kmitočtové závislosti zesilovače, bude jednoduše

$$
R_{\mathrm{vst}}=\frac{R_{\mathrm{i}}}{1-\beta A}
$$

a

$$
R_{\mathrm{vyst}}=\frac{R_{0}}{1-\beta A},
$$

kde $R_{\mathrm{i}}$ značí vstupní odpor a $R_{0}$ výstupní odpor zesilovače bez zpětné vazby.

Kladná zpětná vazba, oscilační podmínky. Zpětnovazební zapojení s kladnou zpětnou vazbou se používá zejména ke generování kmitů, kdy musí být splněny tzv. oscilační podmínky. Oscilační podmínky vysvětlíme na základě blokového schématu na Obr. 1.28. Oscilátor sestává ze zesilovače s přenosem $\bar{A}=\bar{U}_{2} / \bar{U}_{1}$ a ze zpětnovazebního článku, jehož přenos je $\bar{\beta}=\bar{U}_{3} / \bar{U}_{2}$. Přenos otevřené smyčky pak

$$
\bar{U}_{3} / \bar{U}_{1}=\bar{A} \bar{\beta}
$$

Základní podmínkou vzniku kmitů při uzavřené smyčce zpětné vazby je v uvažovaném případě rovnost

$$
\bar{U}_{1}=\bar{U}_{3}=\bar{U}_{1} \bar{A} \bar{\beta}
$$




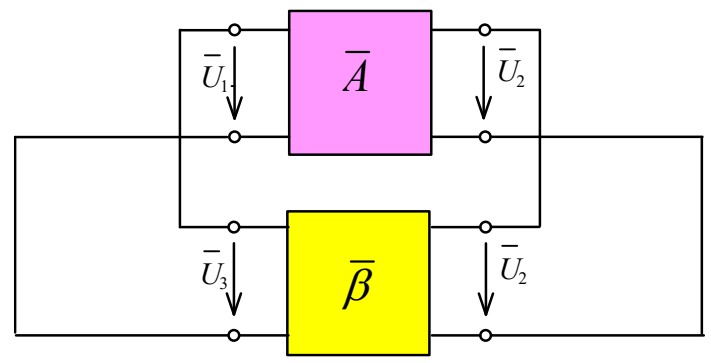

Obr. 1.28: Blokové schéma oscilátoru

V obvodu tedy vzniknou ustálené kmity, pokud bude splněna podmínka

$$
\bar{A} \bar{\beta}=1 \text {. }
$$

Vyjádř́me-li komplexní veličiny vexponenciálním tvaru $\bar{A}=A \mathrm{e}^{\mathrm{j} \varphi_{\AA}} \mathrm{a} \quad \bar{\beta}=\beta \mathrm{e}^{\mathrm{j} \varphi_{\beta}}$, můžeme vyslovit dvě podmínky pro vznik kmitů

$$
\begin{gathered}
A \cdot \beta=1, \\
\varphi_{\mathrm{A}}+\varphi_{\beta}=n 2 \pi, \quad(n=0, \pm 1, \ldots, \pm N) .
\end{gathered}
$$

První z nich je tzv. modulová podmínka, která říká, že celkový přenos otevřené smyčky oscilátoru musí být roven jedné. Druhá rovnice je argumentová podmínka, z níž vyplývá, že celkové fázové posunutí ve smyčce zpětné vazby musí být celistvým násobkem $2 \pi$, resp. celistvým násobkem $360^{\circ}$.

\section{Použitá literatura}

[1] BRANČÍIK, L. Elektrotechnika 1. VUTIUM: Vysoké učení technické v Brně, 2004, 135 s. ISBN 80-214-2607-1.

[2] BRANČÍK, L. Elektrotechnika 1. FEKT VUT v Brně, 2004, 160 s. E-text TEE102.

[3] VALSA, J., SEDLÁČEK, J. Teoretická elektrotechnika I. Nakladatelství VUTIUM, VUT Brno, Brno 1998.

[4] VALSA, J., SEDLÁČEK, J. Teoretická elektrotechnika II. Nakladatelství VUTIUM, VUT Brno, Brno 2002.

[5] ČAJKA, J., KVASIL, J. Teorie lineárních obvodů. SNTL, Alfa Praha, 1979.

[6] MAYER, D. Úvod do teorie elektrických obvodů SNTL-ALFA Praha, 1978.

[7] MIKULEC, M., HAVLÍČEK, V. Základy teorie elektrických obvodů 1., ČVUT Praha, 1999.

[8] MIKULEC, M., HAVLÍČEK, V. Základy teorie elektrických obvodů 2., ČVUT Praha, 1998.

[9] IRWIN, J. D. Basic Engineering Circuits Analysis Macmillan Publishing Company, New Youk, 1987. 


\section{Základní stavební jednotky analogových obvodů}

Diskrétní i integrované analogové obvody jsou vytvořeny z pasivních a aktivních obvodových prvků. Některé klasické obvodové prvky, např. induktory a transformátory neumíme prostředky mikroelektroniky realizovat, a proto je $\mathrm{v}$ integrované podobě nepoužíváme. Naopak integrované struktury nám dávají proti klasickým postupům některé nové možnosti (např. tranzistor s několika emitory apod.). V celku je však možno říci, že analogové obvody jsou až na malé výjimky vytvořeny $z$ omezené množiny poměrně jednoduchých stavebních jednotek, mezi nimiž převažují zdroje napětí, zdroje proudu, tranzistorové zesilovače, komplementární a kvazikomplementární výkonové zesilovače třídy B a některé další obvody. Při zpracování této tématické oblasti byla použita lit. [1] až [13].

\subsection{Diody}

Statické vlastnosti diody

Dioda je nelineární prvek, jehož odpor závisí na směru a velikosti proudu, který jím protéká. Činnost diody plně popisuje její ampérvoltová charakteriskika $i_{\mathrm{D}}\left(u_{\mathrm{D}}\right)$, viz např. [1]. Typická charakteristika polovodičové diody je uvedena na Obr. 2.1a. Proud $i_{\mathrm{D}}$ prudce roste již při relativně malém kladném napětí $u_{\mathrm{D}}$ a to po překročení tzv. prahového napětí $U_{\mathrm{P}}$. Tento proud však nesmí překročit maximální proud $I_{\mathrm{DM}}$. Při překročení maximálního proudu může totiž dojít $\mathrm{k}$ přehřátí diody a $\mathrm{k}$ jejímu zničení. Z Obr. 2.1a je vidět, že proud v závěrném směru je $\mathrm{v}$ širokém rozmezí napětí téměř zanedbatelný. Avšak při dosažení tzv. maximálního závěrného napětí $U_{\mathrm{DM}}$, začne proud v závěrném směru prudce narůstat. Běžné diody nemohou v této oblasti pracovat, protože dochází k lokálnímu přehřátí a ke zničení diody. Maximální závěrné napětí je dáno konstrukcí diody a je obvykle v rozmezí $10 \mathrm{~V}$ až $10 \mathrm{kV}$.

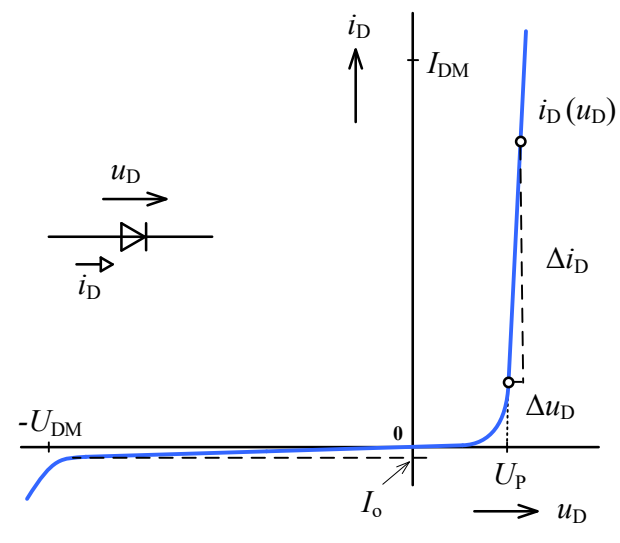

a

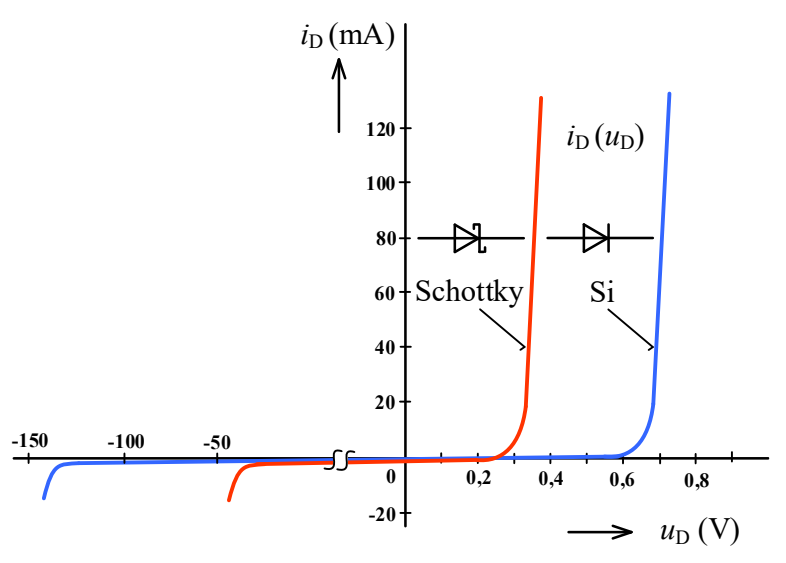

b

Obr. 2.1: a) Typická charakteristika diody, b) charakteristika křemíkové a Schottkyho diody

Prahové napětí diody $U_{\mathrm{P}}$ se určí jako průsečík prodloužení strmé části charakteristiky $i_{\mathrm{D}}\left(u_{\mathrm{D}}\right) \mathrm{s}$ vodorovnou osou. Často se však nahrazuje napětím, které na diodě vznikne při proudu $i_{\mathrm{D}} \approx 0,1 I_{\mathrm{DM}}$. Odpor v propustném směru je dán diferenčním vnitřním odporem $r_{\mathrm{D}} \approx \Delta u_{\mathrm{D}} / \Delta i_{\mathrm{D}} \mathrm{a}$ 
je obvykle z rozmezí 100 až $1000 \Omega$. Typické průběhy ampérových charakteristik malovýkonových signálových diod jsou uvedeny na Obr. 2.1b. U Schottkyho diod se prahové napětí pohybuje $\mathrm{v}$ rozmezí hodnot 0,2 až $0,5 \mathrm{~V}$ (typicky $0,4 \mathrm{~V}$ ) a u křemíkových diod v rozmezí 0,5 až $0,8 \mathrm{~V}$ (typicky $0,6 \mathrm{~V}$ ).

V prvním přiblížení můžeme na diodu pohlížet jako na ideální ventil (Obr. 2.2a). Pokud je anoda ideální diody proti katodě kladná $\left(u_{\mathrm{D}}>0\right)$, je dioda pólována v propustném směru a má odpor v propustném směru $r_{\mathrm{D}}=0$. Naopak je-li anoda diody proti katodě záporná $\left(u_{\mathrm{D}}<0\right)$, je dioda pólována $v$ závěrném směru a vykazuje odpor v závěrném směru $r_{Z}=\infty$. Při změně polarity napětí $u_{\mathrm{D}}$ přcechází ideální dioda ze stavu propustného do stavu závěrného okamžitě, bez jakéhokoliv zpoždění. Skutečné diody se vlastnostem ideální diody bohužel jen přibližují.

Při posuzování vlastností diody je proto často účelné nahradit skutečnou fyzikální diodu sériovou kombinací ideální diody, zdroje prahového napětí $U_{\mathrm{P}}$ a rezistoru s odporem $\mathrm{v}$ propustném směru $r_{\mathrm{P}}$. Linearisovaný model diody je naznačen na Obr. 2.2b.

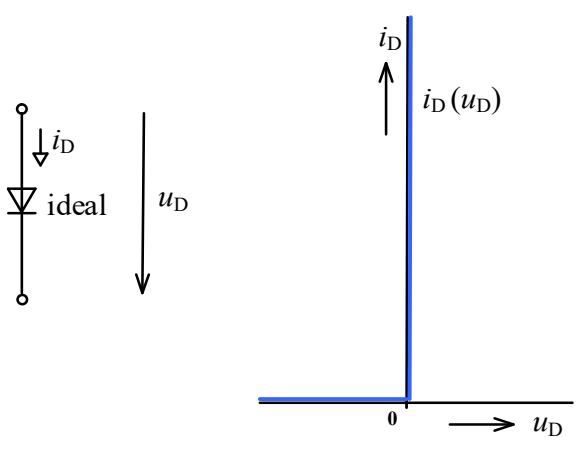

a
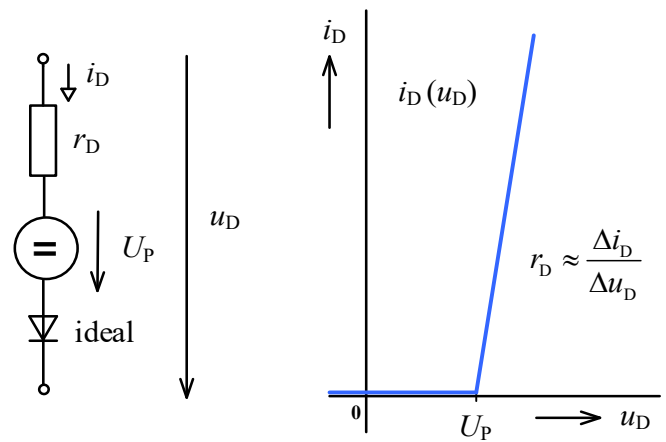

b

Obr. 2.2: a) Ideální dioda, b) linearisovaný model diody

Velmi přesný model polovodičové diody je možno vytvořit aproximací ampérvoltové charakteristiky posunutou exponenciální funkcí [2]

$$
i_{\mathrm{D}}=I_{0}\left(\exp \frac{u_{\mathrm{D}}}{m U_{\mathrm{T}}}-1\right)
$$

kde $I_{0}$ je nasycený teoreticky odvozený proud, tekoucí diodou v závěrném směru (viz Obr. 2.1a), $m$ konstanta z rozmezí 1 až 2 závisející na typu diod, $U_{\mathrm{T}}$ teplotní napětí $U_{\mathrm{T}}=k T / q$, kde $k$ je Boltzmanova konstanta $1,38 \cdot 10^{-23} \mathrm{~J} / \mathrm{K}, T$ je teplota $\mathrm{v}$ Kelvinech, $q$ pak značí náboj elektronu $1,60 \cdot 10^{-19} \mathrm{C}$. Při pokojové teplotě

$$
U_{\mathrm{T}}=\frac{k T}{q}=\frac{1,38 \cdot 10^{-23} \mathrm{~J} / \mathrm{K} \cdot 296 \mathrm{~K}}{1,60 \cdot 10^{-19} \mathrm{C}} \doteq 25,5 \mathrm{mV} .
$$

Obvykle je konstanta $m=1$ a protože pro napětí $u_{\mathrm{D}}>100 \mathrm{mV}$ převládá $\mathrm{v}$ rov. (2-1) exponenciální člen, můžeme ampérvoltovou charakteristiku diody přibližně popsat výrazem

$$
i_{\mathrm{D}} \approx I_{0} \exp \frac{u_{\mathrm{D}}}{U_{\mathrm{T}}} \quad\left(\text { pro } u_{\mathrm{D}}>100 \mathrm{mV}\right) .
$$


Pro úplnost je třeba poznamenat, že rov. (2-1) resp. rov. (2-3) vystihují charakteristiku skutečné diody pouze $\mathrm{v}$ propustném směru a platí pro neprríliš velké proudy. Přitom však popisují chování diody pólované v propustném směru velmi přesně v rozmezí několika dekád proudu. Že je tomu skutečně tak, můžeme např. posoudit $\mathrm{z}$ ampérvoltové charakteristiky křemíkové diody, která je v semilogaritmickém znázornění uvedena na Obr. 2.3. V lineární části semilogaritmického zobrazení může být propustně pólovaná dioda přesně popsána exponenciální funkcí.

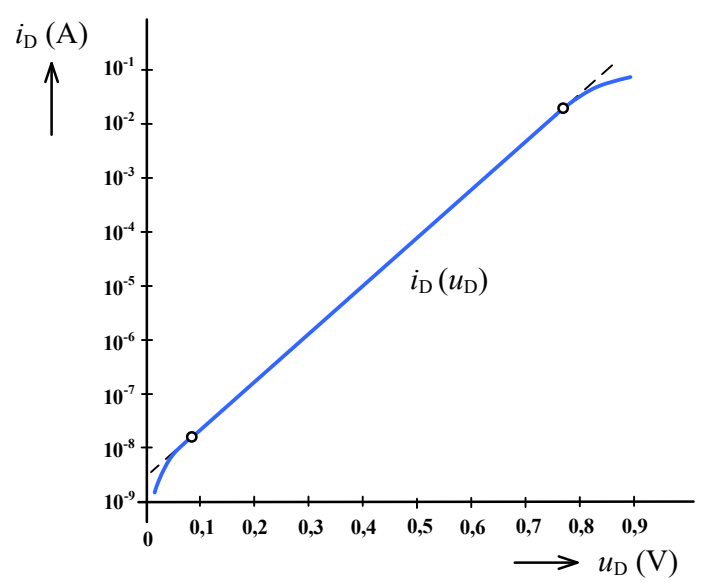

Obr. 2.3: Ampérvoltová charakteristika křemíkové diody v semilogaritmickém znázornění

Pomocí rov. (2-3) můžeme snadno vyvodit, že napětí na propustně pólované diodě se změní o $U_{\mathrm{T}} \ln 10 \approx 60 \mathrm{mV}$ při zvětšení proudu desetkrát. Protože teplotní napětí $U_{\mathrm{T}}$ a navíc $\mathrm{i}$ proud $I_{0}$ závisí na teplotě, bude napětí na propustně pólované diodě při konstantním proudu záviset také na teplotě. Tato závislost je obvykle definována teplotním činitelem

$$
\frac{\Delta u_{\mathrm{D}}}{\Delta T} \approx-2 \mathrm{mV} / \mathrm{K}=-2 \mathrm{mV} /{ }^{\circ} \mathrm{C} \text { (při } i_{\mathrm{D}}=\text { konst), }
$$

nebo poměrným teplotním činitelem

$$
\frac{\Delta u_{\mathrm{D}}}{\Delta T u_{\mathrm{D}}} \approx-3 \cdot 10^{-3} / \mathrm{K}=-3 \cdot 10^{-3} /{ }^{\circ} \mathrm{C} \text { (při } i_{\mathrm{D}}=\text { konst). }
$$

\section{Dynamické vlastnosti diody}

Zotavovací procesy při přechodu diody z propustné oblasti do nepropustné a naopak určují dynamické vlastnosti diody. Nejvíce se uplatňuje závěrná zotavovací doba $t_{\text {rr }}$ (reverse recovery time), která určuje dobu přechodu diody z otevřeného směru do stavu uzavřeného. 


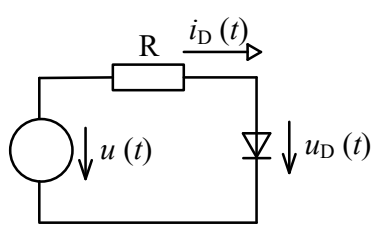

a

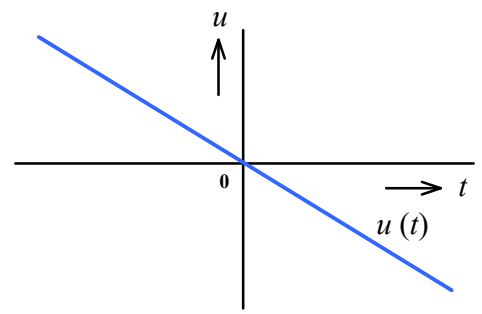

b

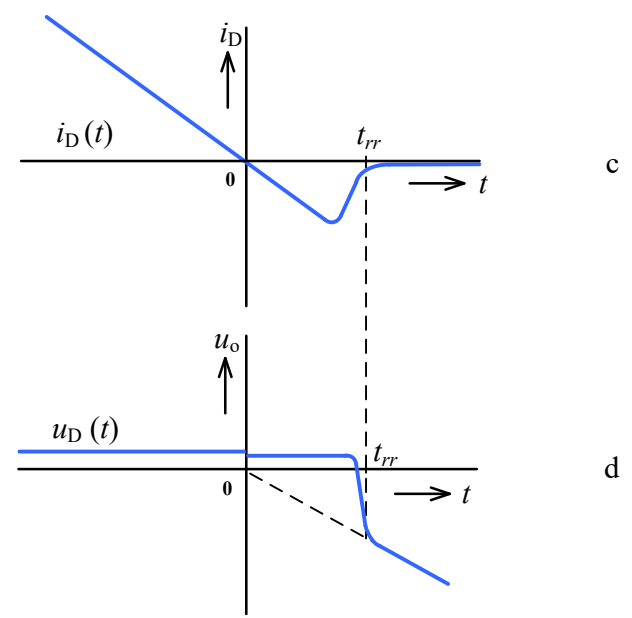

Obr. 2.4: Chování diody při přechodu do závěrného směru

Pokud se bude u obvodu s diodou na Obr. 2.4a měnit v čase napětí $u(t)$ a v okamžiku $t=0$ změní svou polaritu (viz Obr. 2.4b), dalo by se u diody očekávat, že proud diodou poklesne na nulu, resp. na malý závěrný proud. Avšak dioda, která byla předtím otevřena, má dvě vrstvy polovodiče (tvořící usměrňující přechod PN) plné volných menšinových nosičů elektrického náboje. Pro tyto menšinové nosiče je i při obrácení proudu přechod průchodný. Proto krátce po změně smyslu proudu prochází diodou mnohem větší závěrný proud (Obr. $2.4 \mathrm{c})$ než později v ustáleném stavu a teprve po vyčerpání nahromaděných nosičů v okamžiku $t_{\mathrm{rr}}$ se zmenší na velikost, odpovídající statické charakteristice. Přitom se napětí na diodě mění podle Obr. $2.4 \mathrm{~d}$, kdy se dioda po dobu $t_{\mathrm{rr}}$ jeví jako zdroj přibližně konstantní napětí o velikosti málo menší než je napětí na otevřené diodě. Teprve po odčerpání většiny volných nosičů se na diodě objeví rychle závěrné napětí. U klasických malovýkonových diod s přechodem $\mathrm{PN}$ má závěrná zotavovací doba hodnotu od 3 ns do 100 ns. U výkonových diod pak doba zotavení dosahuje až jednotek mikrosekund.

Schottkyho diody potřebují daleko kratší dobu pro přechod do závěrného směru. Tyto diody mají přechod kov-polovodič. Nahromadění náboje v přechodu tohoto typu je zanedbatelné, protože nemá žádnou oblast pro hromadění minoritních nosičů. Schottkyho diody proto téměř nepotřebují žádný čas na zotavení. Závěrná zotavovací doba pro Schottkyho malovýkonové diody je snížena na hodnoty kolem 100 ps, u výkonových Schottkyho diod může být až desítky nanosekund.

Dynamické vlastnosti diody zejména na vyšších kmitočtech také popisuje kapacita diody $C_{\mathrm{D}}$. Rozhodující složkou je kapacita závěrné vrstvy přechodu PN (tzv. bariérová kapacita), která je nelineární funkcí napětí na přechodu. Závěrně pólovaným napětím se kapacita zmenšuje, při propustné polaritě se zvětšuje. Růst kapacity však platí jen do propustně pólovaného napětí asi 0,2 až $0,3 \mathrm{~V}$, protože při vyšším napětí se uplatní přemostění kapacity propustně pólovaným přechodem diody. Stačí proto uvažovat pouze kapacitu v závěrném směru. Kmitočtově tato kapacita prakticky závislá není. 
Dioda jako zdroj malého napětí

Dioda se jako jednosměrný ventil obvykle užívá pro usměrnění stř́idavých signálů. Její nejjednodušší aplikací však je, použít propustně pólovanou diodu jako stabilizovaný zdroj malého napětí $U_{\mathrm{D}} \approx U_{\mathrm{P}} \approx 0,6 \mathrm{~V}$. Základní uspořádání takovéhoto zdroje je nakresleno na Obr. 2.5a, b. V prvém případě (Obr. 2.5a) je pro nastavení pracovního proudu diodou použit zdroj napětí a rezistor. $\mathrm{V}$ integrovaných obvodech, kdy se jako dioda využívá přechod báze-emitor tranzistoru, se pracovní bod obvykle nastavuje zdrojem konstantního proudu (Obr. 2.5b).

Nebude-li obvod na Obr. 2.5a zatížen $\left(i_{\mathrm{D}} \approx 0\right)$ bude diodou téct proud

$$
i_{\mathrm{D}}=\frac{U_{\mathrm{N}}-U_{\mathrm{D}}}{R} \approx \frac{U_{\mathrm{N}}-0,6}{R} .
$$

Odtud můžeme stanovit odpor rezistoru

$$
R \approx \frac{U_{\mathrm{N}}-0,6}{i_{\mathrm{D}}} .
$$

Proud diodou, který určuje pracovní bod na charakteristice $i_{\mathrm{D}}\left(u_{\mathrm{D}}\right)$, volíme tak, aby pracovní bod byl dostatečně daleko za kolenem charakteristiky, obvykle v rozmezí 5 až $10 \mathrm{~mA}$. Ve většině případů však takovýto zdroj pracuje se zátěži $R_{Z}$ a pak musíme počítat i s proudem do zátěže $i_{Z}$. Potom

$$
R=\frac{U_{\mathrm{N}}-0,6}{i_{\mathrm{R}}}=\frac{U_{\mathrm{N}}-0,6}{i_{\mathrm{D}}+i_{\mathrm{Z}}} .
$$

Musíme pak ovšem vždy zkontrolovat, co se stane při př́ipadném odpojení zátěže $R_{Z}$, protože veškerý proud $i_{\mathrm{R}}=i_{\mathrm{D}}+i_{\mathrm{Z}}$ poteče $\mathrm{v}$ tom prrípadě diodou a mohl by být překročen maximální proud diodou $I_{\mathrm{DM}}$.

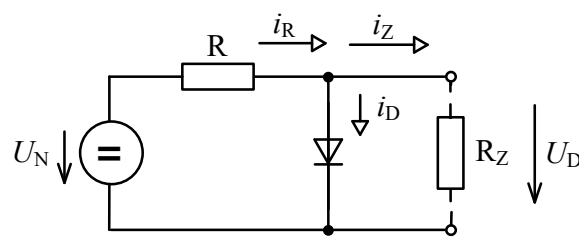

a

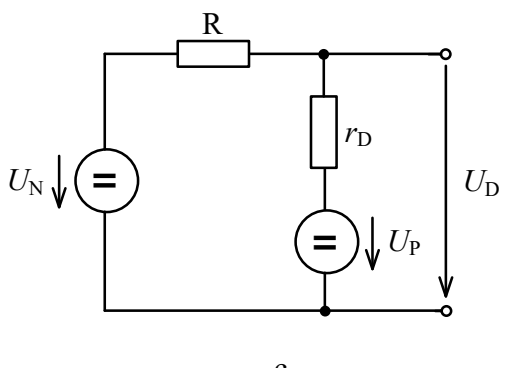

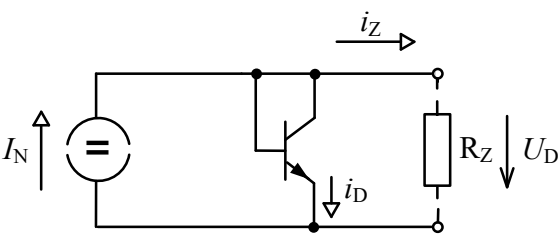

b

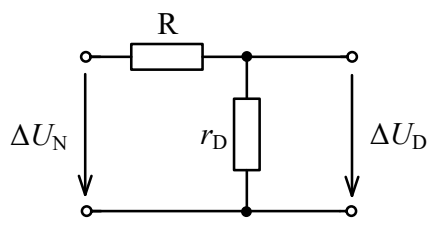

d

Obr. 2.5: Stabilizovaný zdroj malého napětí s diodou: a) napájený ze zdroje napětí, b) ze zdroje proudu, c) náhradní model, d) náhradní model pro střídavé změny 
V př́ípadě napájení se zdroje proudu (viz Obr. 2.5b) je situace obdobná. Zdroj proudu musí dodat pro napájení obvodu proud $I_{\mathrm{N}}=i_{\mathrm{D}}+i_{\mathrm{Z}}$. Pracovní proud tekoucí diodou se volí stejně jako v předchozím případě 5 až $10 \mathrm{~mA}$.

Výstupní resp vnitřní odpor zdroje napětí s diodou určíme $\mathrm{z}$ náhradního modelu nakresleného na Obr. 2.5c. Po zkratování zdrojů $U_{\mathrm{N}}$ a $U_{\mathrm{P}}$ můžeme určit výstupní odpor takovéhoto zdroje $R_{\text {výst }}=R \| r_{\mathrm{D}} \approx r_{\mathrm{D}}$.

Stabilizační účinek zdroje se definuje činitelem stabilizace, který určuje, do jaké míry se na výstupu zdroje potlačí zvlnění vstupního napájecího napětí $\Delta U_{\mathrm{N}}$. Z modelu pro strídavé změny na Obr. 2.5d určíme snadno

$$
\Delta U_{\mathrm{D}}=\frac{r_{\mathrm{D}}}{r_{\mathrm{D}}+R} \Delta U_{\mathrm{N}} \approx \frac{r_{\mathrm{D}}}{R} \Delta U_{\mathrm{N}}\left(\text { pro } r_{\mathrm{D}} \ll R\right) .
$$

Činitel stabilizace pak

$$
S=\frac{\Delta U_{\mathrm{N}}}{\Delta U_{\mathrm{D}}} \approx \frac{R}{r_{\mathrm{D}}} .
$$

U zdroje malého napětí s diodou bývá činitel stabilizace typicky $S \approx 100$.

Někdy se pro hodnocení stabilizačního účinku užívá činitel zvlnění

$$
P=\frac{1}{S}=\frac{\Delta U_{\mathrm{D}}}{\Delta U_{\mathrm{N}}} \approx \frac{r_{\mathrm{D}}}{R}
$$

Typická hodnota činitele zvlnění pro tento typ stabilizovaného zdroje je $P \approx 0,01$.

Vyšší napětí se získá řazením diod do série (viz Obr. 2.6). To je však v některých případech nevýhodné, protože jsou do série zapojeny i jejich diferenční vnitřní odpory, což zhorší stabilizační účinek zdroje. Proto se někdy pro napětí z rozmezí 1,5 až $2,4 \mathrm{~V}$ užívají LED diody, kdy červená má $U_{\mathrm{P}} \approx 1,6$ až $1,8 \mathrm{~V}$, oranžová $U_{\mathrm{P}} \approx 2,0$ až $2,2 \mathrm{~V}$, žlutá $U_{\mathrm{P}} \approx 2,0$ až $2,2 \mathrm{~V}$, zelená $U_{\mathrm{P}} \approx 2,2$ až $2,4 \mathrm{~V}$ při proudu diodou 10 až $20 \mathrm{~mA}$. Samožrejmě toto řešení není př́íhodné pro integraci.

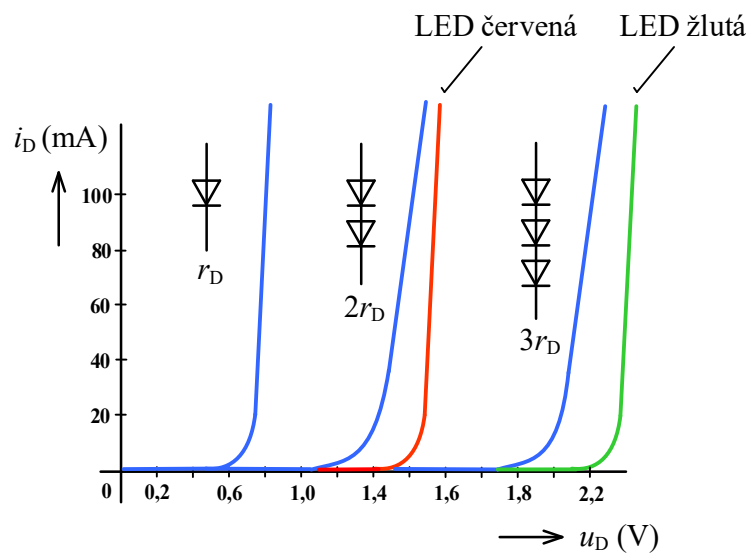

Obr. 2.6: Zvýšení výstupního napětí zdroje s diodou řazením diod do série, nebo použitím diod LED 


\subsection{Referenční (Zenerovy) diody}

U obyčejných diod dochází při př̀kročení určitého závěrného napětí k prudkému nárůstu proudu v závěrném směru. Tohoto jevu se právě využívá u referenčních napětových diod. Často bývají označovány jako Zenerovy diody, i když tento název nezahrnuje všechny druhy referenčních diod. Typická ampérvoltová charakteristika takovéto diody je naznačena na Obr. 2.7, [1]. Napětí, při kterém dochází v závěrném směru k prudkému nárůstu proudu se označuje jako Zenerovo napětí $U_{Z}$. Proud diodou v závěrném směru nesmí překročit maximální proud $I_{\text {ZDM}}$, jinak dojde k jejímu zničení.

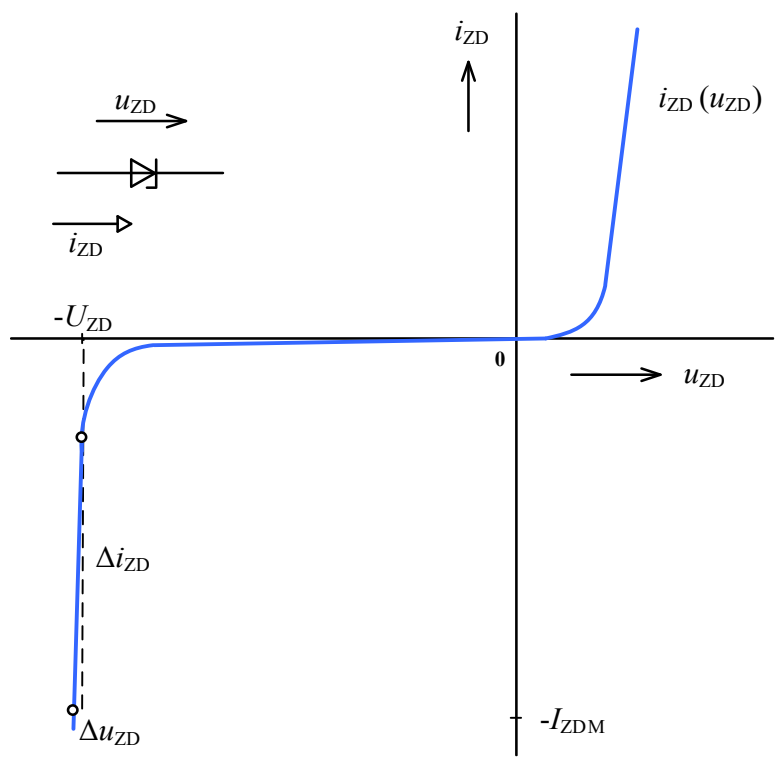

Obr. 2.7: Ampérvoltová charakteristika Zenerovy diody

Pro realizaci referenčních diod se užívají dva principy. Při referenčních napětích pod $5,7 \mathrm{~V}$ převládá tunelový jev, tzv. Zenerův průraz, při vyšších napětích pak průrazový jev (lavinový průraz v důsledku nárazové ionizace). Zenerovo napětí bývá v rozmezí 3 až $20 \mathrm{~V}$, v některých případech až $200 \mathrm{~V}$. Prahové napětí (v propustném směru) má obvykle hodnotu 0,6 $\mathrm{V}$, stejně jako u křemíkové diody. V integrovaných strukturách se jako referenční prvek používá často přechod $\mathrm{BE}$ tranzistoru, provozovaný $\mathrm{v}$ závěrném směru. $\mathrm{V}$ tomto př́padě typicky $U_{\mathrm{Z}} \approx 7 \mathrm{~V}$.

Zenerovy diody se užívají jako stabilizační prvky ve zdrojích referenčního či stabilizovaného napětí. Využívá se toho, že při velké změně proudu $\Delta i_{\text {ZD }}$ (viz Obr. 2.7) dojde pouze k malé změně napětí $\Delta u_{\mathrm{ZD}}$. Stabilizační účinek je tím lepší, čím je charakteristika diody $\mathrm{v}$ pracovní oblasti strmější, resp. čím menší je diferenční vnitřní odpor $r_{\mathrm{ZD}} \approx \Delta u_{\mathrm{ZD}} / \Delta i_{\mathrm{ZD}}$. Nejmenší diferenční odpor $3 \Omega$ až $10 \Omega$ mívají referenční diody s $U_{Z} \approx 8 \mathrm{~V}$; pro nižší napětí se diferenční odpor postupně zvětšuje. Proto se stabilizační účinek při malých referenčních napětí $U_{\mathrm{Z}}$ projevuje s menší účinností.

Teplotní činitel referenčních diod závisí na referenčním napětí. Při referenčních napětích pod 5,7 V, kdy se využívá Zenerův průraz, je teplotní činitel záporný, nad 5,7 V, když je využit lavinový průraz, je teplotní činitel kladný. Využíváme-li průraz přechodu EB tranzistoru 
$\left(U_{\mathrm{ZD}} \approx 7 \mathrm{~V}\right)$, je teplotní činitel $\Delta U_{\mathrm{ZD}} / \Delta T \mathrm{~V}$ rozmezí asi $+2 \mathrm{mV} / \mathrm{K}$ až $+4 \mathrm{mV} / \mathrm{K}$ a tedy odpovídající poměrný činitel $+2,9 \cdot 10^{-4} / \mathrm{K}$ až $+5,7 \cdot 10^{-4} / \mathrm{K}$.

\section{Zenerova dioda jako zdroj referenčního napětí}

Nejčastěji se Zenerova dioda používá jako jednoduchý stabilizovaný zdroj referenčního napětí. Zapojení takovéhoto zdroje je uvedeno na Obr. $2.8 \mathrm{a}$, kdy pro nastavení pracovního proudu diodou se použije napájecí zdroj a rezistor. V integrovaných obvodech, kde se Zenerova dioda obvykle nahrazuje závěrně provozovaným přechodem báze - emitor tranzistoru, se spíše využívá pro nastavení pracovního proudu zdroj konstantního proudu (Obr. 2.8b).

$\mathrm{V}$ př́ípadě zapojení referenčního zdroje podle Obr. 2.8a poteče rezistorem R proud

$$
i_{\mathrm{R}}=\frac{U_{\mathrm{N}}-U_{\mathrm{ZD}}}{R},
$$

kde $i_{\mathrm{R}}=i_{\mathrm{ZD}}+i_{\mathrm{Z}}$. Odpor rezistoru proti musí mít hodnotu

$$
R=\frac{U_{\mathrm{N}}-U_{\mathrm{ZD}}}{i_{\mathrm{R}}}=\frac{U_{\mathrm{N}}-U_{\mathrm{ZD}}}{i_{\mathrm{ZD}}+i_{\mathrm{Z}}}
$$

Pracovní proud diodou se volí tak, aby pracovní bod byl umístěn dostatečně za kolenem charakteristiky Zenerovy diody provozované v závěrném směru, obvykle volíme 5 až $20 \mathrm{~mA}$. Pro prrípad odpojení zátěže $R_{\mathrm{Z}}$, kdy veškerý proud teče Zenerovou diodou, se nesmí nikdy překročit maximální povolený proud v závěrném směru $I_{\mathrm{ZDM}}$.

Vnitřní resp. výstupní odpor ekvivalentního zdroje napětí určíme z náhradního schématu na Obr. 2.8c, kdy je zřejmé, že po zkratování zdrojů napětí bude výstupní odpor $R_{\mathrm{výst}}=R \| r_{\mathrm{ZD}} \approx r_{\mathrm{ZD}}$.

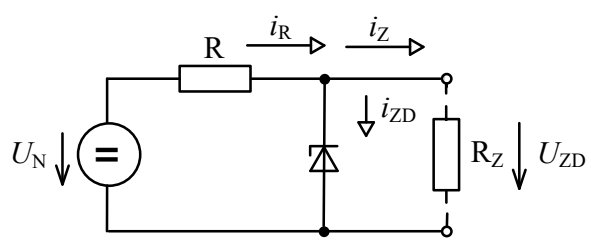

a

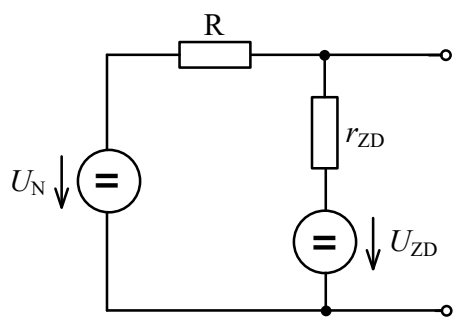

c

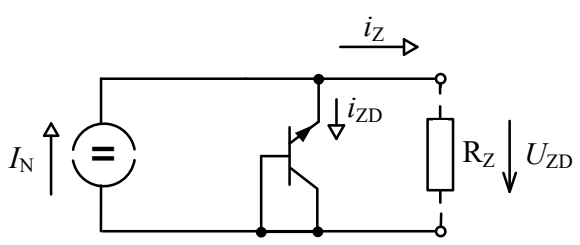

$\mathrm{b}$

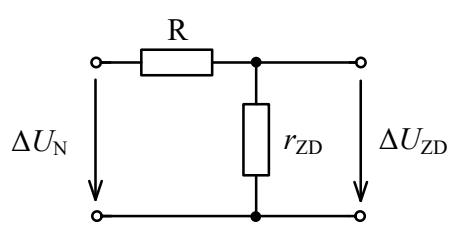

$\mathrm{d}$

Obr. 2.8: Stabilizovaný zdroj napětí se Zenerovou diodou: a) napájený ze zdroje napětí, b) ze zdroje proudu, c) náhradní model, d) náhradní model pro střídavé změny 
Činitel stabilizace zdroje se Zenerovou diodou bude (viz Obr. 2.8d)

$$
S=\frac{\Delta U_{\mathrm{N}}}{\Delta U_{\mathrm{ZD}}}=\frac{R+r_{\mathrm{ZD}}}{r_{\mathrm{ZD}}} \approx \frac{R}{r_{\mathrm{ZD}}} .
$$

Typická hodnota činitele stabilizace bývá v rozmezí 100 až 300. Podobně činitel zvlnění

$$
P=\frac{1}{S}=\frac{\Delta U_{\mathrm{ZD}}}{\Delta U_{\mathrm{N}}}=\frac{r_{\mathrm{ZD}}}{R+r_{\mathrm{ZD}}} \approx \frac{r_{\mathrm{ZD}}}{R} .
$$

Ten mívá hodnoty v rozmezí $3 \cdot 10^{-3}$ až $1 \cdot 10^{-2}$.

\section{Teplotně kompenzovaný zdroj se Zenerovou diodou}

Pokud do série se Zenerovou diodou s kladným teplotním činitelem připojíme propustně pólovanou diodu se záporným teplotním činitelem dojde ke vzájemné kompenzaci teplotních vlivů. Schéma zapojení takovéhoto zdroje je nakresleno na Obr. 2.9. Pokud napětí na diodách v pracovním bodě označíme $U_{\mathrm{ZD}}$ a $U_{\mathrm{D}}$, bude pro výstupní napětí platit

$$
U_{0}=U_{\mathrm{ZD}}+U_{\mathrm{D}}
$$

a teplotní závislost výstupního napětí pak

$$
\frac{\Delta U_{0}}{\Delta T}=\frac{\Delta U_{\mathrm{ZD}}}{\Delta T}+\frac{\Delta U_{\mathrm{D}}}{\Delta T} .
$$

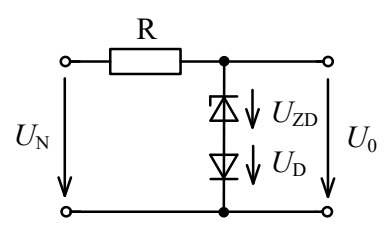

Obr. 2.9: Teplotně kompenzovaný zdroj se Zenerovou diodou

Použijeme-li jako Zenerovu diodu závěrně provozovaný přechod $\mathrm{BE}$ tranzistoru $\mathrm{s} U_{\mathrm{ZD}}=$ $7 \mathrm{~V}$, bude její teplotní činitel $\Delta U_{\mathrm{ZD}} / \Delta T \approx+3 \mathrm{mV} /{ }^{\circ} \mathrm{C}$. Křemíková dioda má jako obvykle napětí $U_{\mathrm{D}} \approx U_{\mathrm{P}} \approx 0,6 \mathrm{~V}$ a teplotní činitel $\Delta U_{\mathrm{D}} / \Delta T=-2 \mathrm{mV} /{ }^{\circ} \mathrm{C}$. Teplotně kompenzovaný zdroj pak bude mít výstupní napětí $U_{0} \approx U_{\mathrm{ZD}}+U_{\mathrm{D}}=7,6 \mathrm{~V}$ a teplotní činitel $\Delta U_{0} / \Delta T \approx+1 \mathrm{mV} /{ }^{\circ} \mathrm{C}$.

\subsection{Bipolární tranzistory}

V prvním přiblížení můžeme na bipolární tranzistor pohlížet jako na dvě opačně pólované diody, které mají jednu vrstvu polovodiče typu N nebo P společnou. Vývod spojený s touto společnou vrstvou nazýváme báze B. Další dva vývody nazýváme emitor $\mathrm{E}$ a kolektor $\mathrm{C}$. Schématické značky a odpovídající diodové náhradní obvody pro tranzistor typu NPN a PNP jsou uvedeny na Obr. 2.10, [3]. Přestože diodový náhradní obvod je jen velmi hrubým modelem tranzistoru (viz Obr. 2.10a, c), umožňuje posoudit, který přechod má být polarizován v propustném směru a který ve směru závěrném. V obvyklých provozních podmínkách 
tranzistoru jako zesilovače je přechod mezi bází a emitorem provozován v propustném směru a stejně jako u propustně pólované diody je na něm napětí $0,6 \mathrm{~V}$. Přechod mezi bází a kolektorem

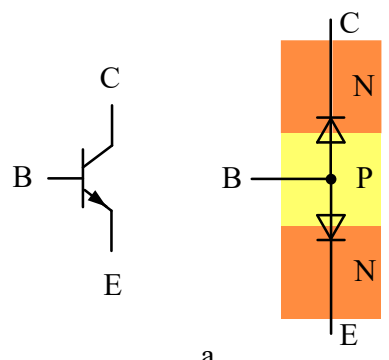

a

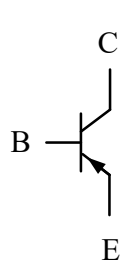

$\mathrm{E}$

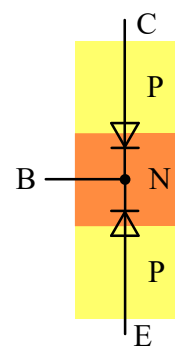

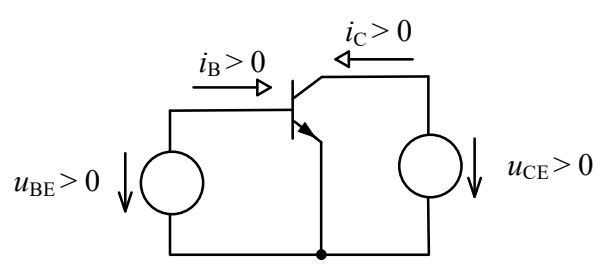

b

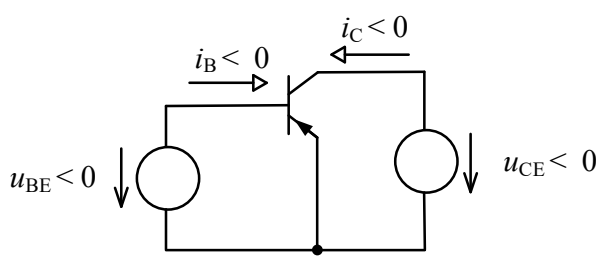

d

Obr. 2.10: a) Tranzistor typu NPN a jeho diodový model, b) obvyklý způsob připojení zdrojů k tranzistoru typu NPN, c) tranzistor typu PNP a jeho diodový model, d) obvyklý způsob připojení zdrojů k tranzistoru typu PNP

musí být provozován $\mathrm{v}$ závěrném směru. $\mathrm{Z}$ těchto důvodů zdroje napětí musí být zapojeny tak, jak je to pro tranzistor NPN naznačeno na Obr. 2.10b, resp. pro tranzistor PNP na Obr. 2.10d.

V dalším budeme pracovat zejména s NPN tranzistory, protože $\mathrm{v}$ ekvivalentních obvodech s PNP tranzistory se jen zamění polarita napětí i proudi̊. Pro rychlé určení přibližných vlastností tranzistorových obvodů budeme používat zjednodušené metody, které jsou vhodné pro prvotní výpočty a návrh. Tento způsob poskytuje výsledky s dostačující přesností, přitom vyžaduje znalosti minimálního počtu parametrů tranzistoru a velmi usnadňuje výpočet. Ve většině príípadů vystačíme s proudovým zesilovacím činitelem $\beta$ nebo se strmostí tranzistoru $g_{\mathrm{m}}$. Který z těchto parametrů se použije, závisí obvykle na konkrétní aplikaci tranzistoru. Použije se ten, který usnadní řešení obvodu. Při podrobnějším zkoumání vlastností obvodů pak budeme používat vstupní odpor $r_{\mathrm{BE}}$ a výstupní odpor $r_{\mathrm{CE}}$ tranzistoru.

\section{Proudový zesilovací činitel}

Diferenciální proudový zesilovací činitel, někdy také proudový zisk tranzistoru lze určit $\mathrm{z}$ přenosové charakteristiky $i_{\mathrm{C}}\left(i_{\mathrm{B}}\right)$. Z charakteristiky na Obr. $2.11 \mathrm{a}$ je zřejmé, že malá změna vstupního proudu $i_{\mathrm{B}}$ vyvolá velkou změnu kolektorového proudu $i_{\mathrm{C}}$. Charakteristika závisí na napětí $u_{\mathrm{CE}}$ jen velmi málo (čárkovaný průběh). Proto proudový zesilovací činitel $\beta$ popisuje vlastnosti tranzistoru $v$ širokém rozmezí změn napětí mezi kolektorem a emitorem. Mírné zvyšování proudového zesilovacího činitele $\beta$ v závislosti na napětí $u_{\mathrm{CE}}$ se nazývá Earlyho jev či efekt. 


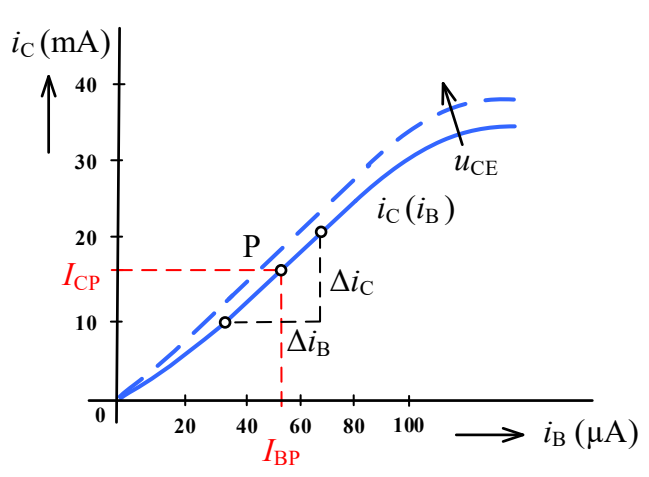

a

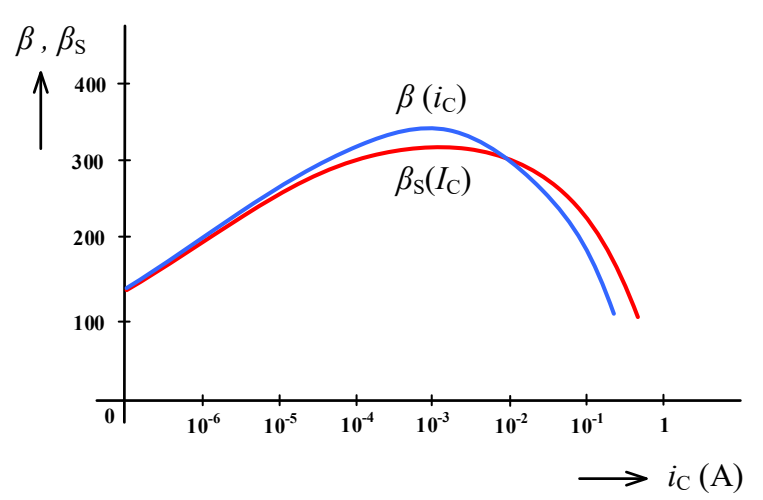

b

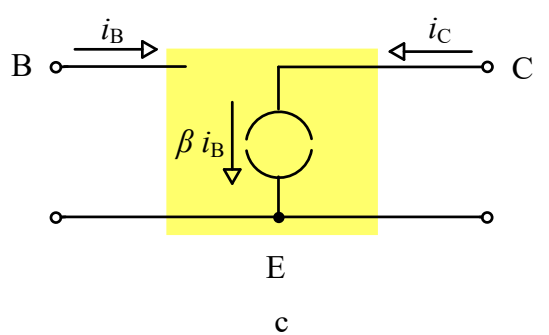

Obr. 2.11: a) Přenosová charakteristika, b) závislost statického a dynamického proudového zesilovacího činitele na kolektorovém proudu pro malovýkonové tranzistory, c) tranzistor jako zdroj proudu ř́zený proudem

Diferenciální proudový zesilovací činitel v pracovním bodě $\mathrm{P}$ je definován pro malé signálové změny vztahem

$$
\beta \equiv h_{21 \mathrm{E}}=\left.\frac{\partial i_{\mathrm{C}}}{\partial i_{\mathrm{B}}} \approx \frac{\Delta i_{\mathrm{C}}}{\Delta i_{\mathrm{B}}}\right|_{u_{\mathrm{CE}}=\text { konst }} .
$$

Mírné zvyšování $\beta$ v závislosti na $u_{\mathrm{CE}}$ se nazývá Earlyho jev či efekt (čárkovaná charakteristika na Obr. 2.11a). V katalogových listech je proudový zesilovací činitel často uváděn jako hybridní parametr $h_{21 \mathrm{E}} \mathrm{V}$ zapojení se společným emitorem.

Typicky je proudový zesilovací činitel pro malovýkonové tranzistory v rozmezí $\beta=100$ až 400 a závisí na proudu $i_{\mathrm{C}}$ (viz Obr. 2.11b). V určité oblasti, přibližně do $50 \mathrm{~mA}$, je však jej možno považovat za přibližně konstantní, obvykle se uvažuje $\beta=100$. Při větších proudech se pak proudový zesilovací činitel rychle snižuje a pro výkonové tranzistory je např. $\beta=20$.

Někdy se uvádí statický proudový zesilovací činitel $\beta_{\mathrm{S}}=I_{\mathrm{C}} / I_{\mathrm{B}}$. Také tento činitel závisí na kolektorovém proudu. Protože hodnota dynamického a statického proudového zesilovacího činitele není prŕliš odlišná, obě veličiny se často ztotožňují.

Protože charakteristika $i_{\mathrm{C}}\left(i_{\mathrm{B}}\right)$ je v okolí pracovního bodu $\mathrm{P}$ téměř lineární, můžeme vztah (2-15) rozšiřit i na velké signálové změny a pak $\beta \approx i_{\mathrm{C}} / i_{\mathrm{B}}$. Na základě uvedených vlastností a popisu tranzistoru pomocí proudového zesilovacího činitele můžeme vyvodit úplně nejjednodušší náhradní model nakreslený na Obr. 2.11c. Na tranzistor totiž můžeme pohlížet v okolí pracovního bodu jako na zdroj proudu $i_{\mathrm{C}}$ ř́zený proudem $i_{\mathrm{B}}$. 


\section{Strmost tranzistoru}

$\mathrm{Na}$ tranzistor můžeme také nahlížet tak, že malá změna vstupního napětí $u_{\mathrm{BE}}$ vyvolá velkou změnu kolektorového proudu $i_{\mathrm{C}}$. To je vidět z přenosové charakteristiky $i_{\mathrm{C}}\left(u_{\mathrm{BE}}\right)$ naznačené na Obr. 2.12a. Na napětí $u_{\mathrm{CE}}$ není charakteristika $i_{\mathrm{C}}\left(u_{\mathrm{BE}}\right)$ př́liš závislá (čárkovaný průběh).

Strmost tranzistoru, někdy také transkonduktace $g_{\mathrm{m}}$, je pro malé signálové změny definována vztahem

$$
g_{\mathrm{m}}=\left.\frac{\partial i_{\mathrm{C}}}{\partial u_{\mathrm{BE}}} \approx \frac{\Delta i_{\mathrm{C}}}{\Delta u_{\mathrm{BE}}}\right|_{u_{\mathrm{CE}}=\text { konst }} .
$$

Strmost tranzistoru můžeme určit také analyticky. Přenosovou charakteristiku tranzistoru je možno, podobně jako v príípadě diody, aproximovat exponenciální funkcí

$$
i_{\mathrm{C}} \approx I_{\mathrm{CS}} e^{u_{\mathrm{BE}} / U_{\mathrm{T}}}-1 \text {, }
$$

ve které značí ICS zpětný saturační proud a UT teplotní napětí (pro pokojovou teplotu $U_{\mathrm{T}} \approx$ $25,5 \mathrm{mV})$. Graficky je tato závislost vynesena v semilogaritmickém zobrazení na Obr. 2.12b. Pro hodnoty $u_{\mathrm{BE}}>0,1 \mathrm{~V}$ převládá $\mathrm{v}$ rovnici exponenciální člen a proto

$$
i_{\mathrm{C}} \approx I_{\mathrm{CS}} \mathrm{e}^{u_{\mathrm{BE}} / U_{\mathrm{T}}} .
$$

Ve většině případů však můžeme na tranzistor pohlížet jako na lineární zesilovač. Je to možné za předpokladu, že klidový pracovní bod tranzistoru je umístěn v lineární části

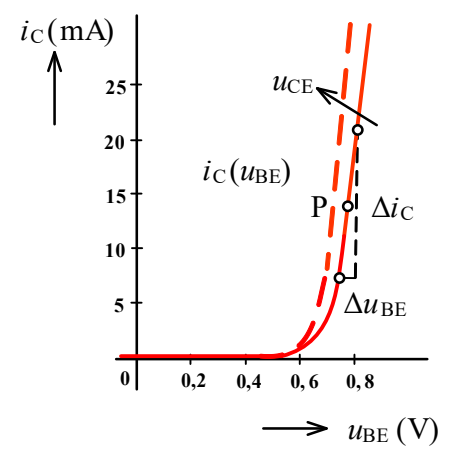

a

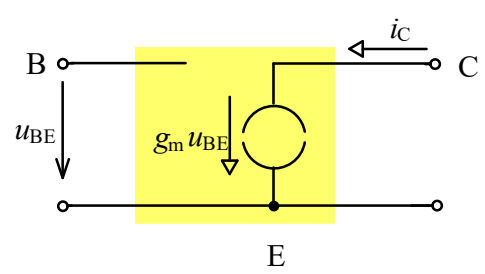

c

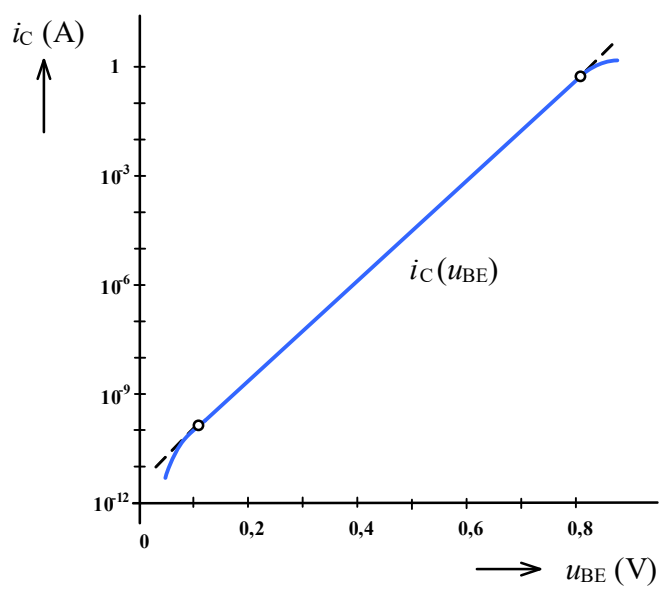

b

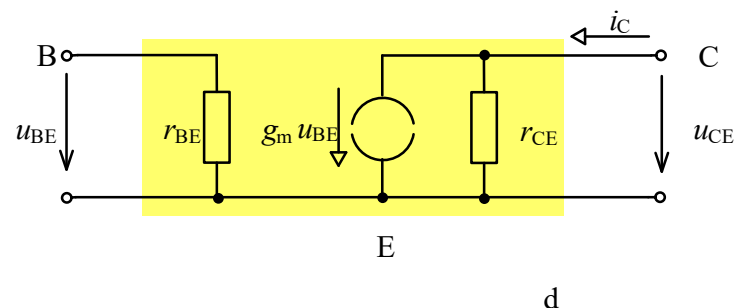

d

Obr. 2.12: a) Přenosová charakteristika, b) přenosová charakteristika v semilogaritmickém zobrazení, c) model tranzistoru jako zdroj proudu řízený napětím, d) náhradní model tranzistoru 
charakteristiky a že tranzistor je buzen malým signálem, při kterém se ještě nemohou nelineární vlastnosti tranzistoru uplatnit. Při výpočtu obvodu se pak charakteristika nahrazuje tečnou resp. strmostí v pracovním bodě

$$
g_{\mathrm{m}}=\frac{\partial i_{\mathrm{C}}}{\partial u_{\mathrm{BE}}} \approx \frac{\partial}{\partial u_{\mathrm{BE}}} I_{\mathrm{CS}} \mathrm{e}^{u_{\mathrm{BE}} / U_{\mathrm{T}}}=\frac{1}{U_{\mathrm{T}}} I_{\mathrm{CS}} \mathrm{e}^{u_{\mathrm{BE}} / U_{\mathrm{T}}}=\frac{i_{\mathrm{C}}}{U_{\mathrm{T}}} \approx \frac{i_{\mathrm{C}}}{25,5 \cdot 10^{-3}} \approx 40 i_{\mathrm{C}} / 1 \mathrm{~V} .
$$

Je zřejmé, že strmost je přímo úměrná kolektorovému proudu a nezávisí na individuálních vlastnostech použitého tranzistoru. Proto pro určení strmosti není nutné provádět žádné měření, nebo hledání v katalogovém listě. Strmost je dána kolektorovým proudem, který určuje polohu pracovního bodu na charakteristice $i_{\mathrm{C}}\left(u_{\mathrm{BE}}\right)$. Protože tato charakteristika je v okolí pracovního bodu lineární, můžeme vztah (2-16) rozšířit i pro velké signálové změny a pak $g_{\mathrm{m}}=i_{\mathrm{C}} u_{\mathrm{BE}}$. Tranzistor lze proto nahradit $\mathrm{v}$ nejjednodušším prriblížení zdrojem proudu $i_{\mathrm{C}}$ řízeným napětím $u_{\mathrm{BE}}$ (viz Obr. 2.12c).

\section{Náhradní model tranzistoru}

Přesnější náhradní model tranzistoru pro malé stř́ídavé změny signálu zahrnuje vstupní odpor $r_{\mathrm{BE}}$ mezi bází a emitorem a výstupní odpor $r_{\mathrm{CE}}$ mezi kolektorem a emitorem. Náhradní model tranzistoru zahrnující vstupní a výstupní odpor pro př́ípad, že tranzistor je respektován zdrojem proudu řízeným vstupním napětím $u_{\mathrm{BE}}$ je nakreslen na Obr. 2.12d.

\section{Vstupní odpor}

Protože vstupní proud tranzistoru není nulový, chová se tranzistor z hlediska zdroje vstupního napětí jako zátěž. Vstupní odpor tranzistoru se charakterizuje diferenciálním vstupním odporem

$$
r_{\mathrm{BE}}=\left.\frac{\partial u_{\mathrm{BE}}}{\partial i_{\mathrm{B}}} \approx \frac{\Delta u_{\mathrm{BE}}}{\Delta i_{\mathrm{B}}}\right|_{u_{\mathrm{CE}}=\text { konst }} .
$$

Odpor lze určit ze vstupní charakteristiky $i_{\mathrm{B}}\left(u_{\mathrm{BE}}\right)$ uvedené na Obr. 2.13a. Charakteristika závisí na $u_{\mathrm{CE}}$ jen nepatrně a proto není tato závislost ani vyznačena. Obvykle se dá hodnota vstupního odporu nalézt v katalogovém listu, typicky bývá z rozmezí $r_{\mathrm{BE}}=5 \mathrm{k} \Omega$ až $10 \mathrm{k} \Omega$. Můžeme jej také určit ze znalosti proudového zesilovacího činitele $\beta$ a strmosti tranzistoru $g_{\mathrm{m}}$

$$
r_{\mathrm{BE}}=\frac{\partial u_{\mathrm{BE}}}{\partial i_{\mathrm{B}}}=\frac{\partial u_{\mathrm{BE}}}{\frac{\partial i_{\mathrm{C}}}{\beta}}=\frac{\beta}{\frac{\partial i_{\mathrm{C}}}{\partial u_{\mathrm{BE}}}}=\frac{\beta}{g_{\mathrm{m}}} .
$$

V náhradním obvodu na Obr. 2.12a representuje odpor $r_{\mathrm{BE}}$ vstupní odpor mezi bází a emitorem. 


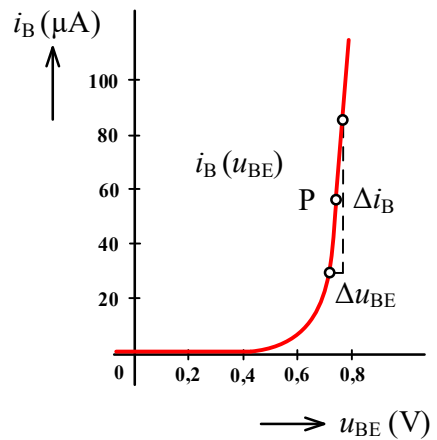

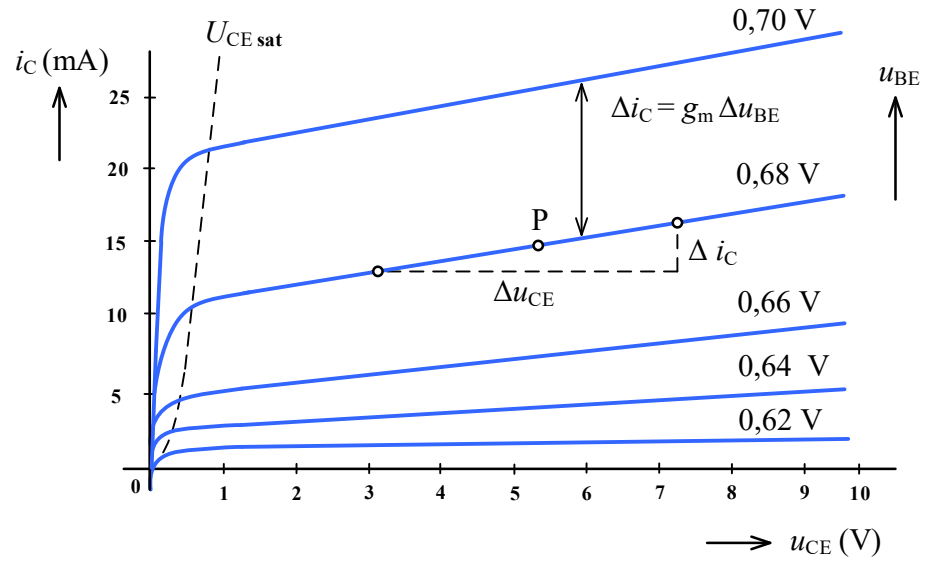

b

Obr. 2.13: a) Vstupní charakteristika, b) výstupní charakteristika tranzistoru

\section{Výstupní odpor}

Systém výstupních charakteristik tranzistoru je uveden na Obr. 2.13b. Jde o závislost výstupního proudu $i_{\mathrm{C}}$ na výstupním napětí $u_{\mathrm{CE}}$, přičemž parametrem je vstupní napětí $u_{\mathrm{BE}}$. Typickou vlastností tranzistoru je, že po dosažení určitého napětí $u_{\mathrm{CE}}$ se kolektorový proud mění jen málo. Napětí, při kterém dochází ke zlomu výstupní charakteristiky, se nazývá saturační napětí $U_{\mathrm{CE} \text { sat }}$ (čárkovaná křivka na Obr. 2.13b). Pokud má tranzistor pracovat jako zesilovač, musí být napětí $u_{\mathrm{CE}}>U_{\mathrm{CE} \text { sat }}$ Saturační napětí je typicky z rozmezí 0,2 až $0,4 \mathrm{~V}$, $\mathrm{v}$ některých př́padech až $1 \mathrm{~V}$.

Závislost kolektorového proudu na napětí mezi kolektorem a emitorem je charakterizována diferenciálním výstupním odporem

$$
r_{\mathrm{CE}}=\left.\frac{\partial u_{\mathrm{CE}}}{\partial i_{\mathrm{C}}} \approx \frac{\Delta u_{\mathrm{CE}}}{\Delta i_{\mathrm{C}}}\right|_{u_{\mathrm{BE}}=\text { konst }} .
$$

Z Obr. $2.13 b$ je vidět, že se zvětšováním kolektorového proudu se odpor zmenšuje tak, jak se zvětšuje strmost charakteristiky. S dostatečnou přesností platí

$$
r_{\mathrm{CE}}=\frac{U_{\mathrm{E}}}{i_{\mathrm{C}}}
$$

kde $U_{\mathrm{E}}$ je tzv. Earlyho napětí (viz Obr. 2.14). Toto napětí je možno určit změřením strmosti charakteristiky a následně určit průsečík čárkované přímky s vodorovnou osou. Pak již není obtížné stanovit hodnotu $r_{\mathrm{CE}}$ pro libovolný kolektorový proud. Pro tranzistory PNP leží napětí $U_{\mathrm{E}} \mathrm{V}$ rozmezí 40 až $150 \mathrm{~V}$ a pro tranzistory NPN v rozmezí 80 až $200 \mathrm{~V}$. Typicky je výstupní odpor tranzistoru z rozmezí $r_{\mathrm{CE}} \approx 50 \mathrm{k} \Omega$ až $100 \mathrm{k} \Omega$. 


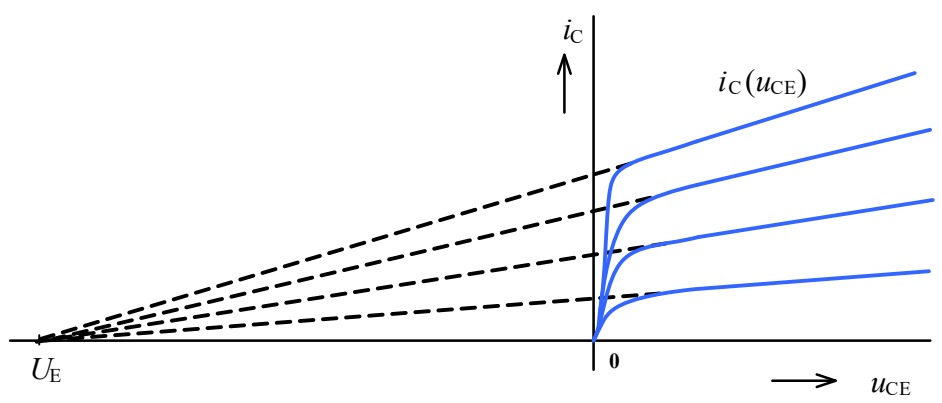

Obr. 2.14: K určení Earlyho napětí

\section{Dalši parametry tranzistoru}

Závislost vstupní charakteristiky $i_{\mathrm{B}}\left(u_{\mathrm{BE}}\right)$ na napětí $u_{\mathrm{CE}}$ je jen nepatrná, takže není ani na Obr. 2.13a zakreslena, protože křivky by téměř splývaly. Bylo by však možné nakreslit celou sít' charakteristik $i_{\mathrm{B}}\left(u_{\mathrm{BE}}\right)$ s parametrem $u_{\mathrm{CE}}$. Lze pak definovat tzv. zpětnou strmost

$$
g_{\mathrm{mr}}=\left.\frac{\partial i_{\mathrm{B}}}{\partial u_{\mathrm{CE}}} \approx \frac{\Delta i_{\mathrm{B}}}{\Delta u_{\mathrm{CE}}}\right|_{u_{\mathrm{BE}}=\text { konst }} .
$$

Hodnoty zpětné strmosti jsou většinou tak malé, že se zpětná strmost běžně neuvažuje.

Podobně lze definovat zpětný napětový přenos

$$
A_{\mathrm{r}}=\left.\frac{\partial u_{\mathrm{BE}}}{\partial u_{\mathrm{CE}}} \approx \frac{\Delta u_{\mathrm{BE}}}{\Delta u_{\mathrm{CE}}}\right|_{i_{\mathrm{B}}=\text { konst }} .
$$

Pro malé kolektorové proudy je činitel napětové zpětné vazby kladný, pro velké proudy záporný. Jeho absolutní hodnota nepřevyšuje hodnotu $\left|A_{\mathrm{r}}\right| \approx 1 \cdot 10^{-4}$ až $5 \cdot 10^{-4}$. Proto se vliv této zpětné vazby zanedbává. Avšak při zpracování signálů s vysokým kmitočtem je třeba zpětný přenos uvažovat. Oba výše uvedené parametry mezi sebou souvisí, lze odvodit, že $A_{\mathrm{r}}=-g_{\mathrm{mr}} r_{\mathrm{BE}}$.

Závěrem ještě uved’me vzájemné souvislosti s jinými parametry tranzistoru, které jsou často uváděny jako katalogové údaje:

$$
\begin{aligned}
& \beta=h_{21 \mathrm{E}}, \\
& g_{\mathrm{m}}=y_{21 \mathrm{E}}=h_{21 \mathrm{E}} / h_{11 \mathrm{E}}=\beta / r_{\mathrm{BE}}, \\
& r_{\mathrm{BE}}=1 / y_{11 \mathrm{E}}=h_{11 \mathrm{E}}, \\
& r_{\mathrm{CE}}=1 / y_{22 \mathrm{E}} \approx 1 / h_{22 \mathrm{E}}, \\
& g_{\mathrm{mr}}=y_{12 \mathrm{E}}=-h_{12 \mathrm{E}} / h_{11 \mathrm{E}}, \\
& A_{\mathrm{r}}=y_{12 \mathrm{E}} / y_{11 \mathrm{E}}=h_{12 \mathrm{E}} .
\end{aligned}
$$

V předchozím značí parametr $y$ přenosovou vodivost a $h$ hybridní parametr. Někdy je pro hybridní parametry užito i jiné značení $h_{\mathrm{FE}} \equiv h_{21 \mathrm{E}}, h_{\mathrm{IE}} \equiv h_{11 \mathrm{E}}, h_{\mathrm{OE}} \equiv h_{22 \mathrm{E}} a h_{\mathrm{RE}} \equiv h_{12 \mathrm{E}}$. 


\section{Darlingtonovo zapojeni tranzistorů}

V některých případech je hodnota proudového zesilovacího činitele nedostačující. Jde zejména o př́ípady, kdy proud do báze tranzistoru má být velmi nízký, aby tímto proudem nebyl zatěžován předchozí zesilovací stupeň, anebo v případě výkonových tranzistorů, které mají obvykle malý proudový zesilovací činitel, např. jen $\beta \approx 20$. V těchto př́padech je možné užít tzv. Darlingtonovo zapojení tranzistorů (Obr. 2.15a). Darlingtonovu dvojici je možné považovat za jediný tranzistor s vývody $\mathrm{B}_{\mathrm{D}}, \mathrm{E}_{\mathrm{D}}$ a $\mathrm{C}_{\mathrm{D}}$, jehož proudový zesilovací činitel $\beta_{\mathrm{D}} \approx \beta_{1}$ $\beta_{2}$. Vstupní odpor Darlingtonovy dvojice $r_{\mathrm{BED}} \approx 2 r_{\mathrm{BE} 1}$ a výstupní odpor $r_{\mathrm{CED}} \approx 2 r_{\mathrm{CE} 2} / 3$. Mezi bází a emitorem bude nyní napětí $u_{\mathrm{BED}} \approx u_{\mathrm{BE} 1}+u_{\mathrm{BE} 2} \approx 1,2 \mathrm{~V}$.

Aby se tranzistor $\mathrm{T}_{2}$ rychleji zavíral, často se paralelně $\mathrm{k}$ jeho přechodu $\mathrm{BE}$ zapojuje rezistor R. Když se totiž zavře tranzistor $T_{1}$, není jak odvést náboj z báze tranzistoru $T_{2} a$ tranzistor $\mathrm{T}_{2}$ by zůstal po dobu samovolné rekombinace nábojů stále otevřen. Př́iliš malý odpor rezistoru ale zmenší proudový zesilovací činitel Darlingtonovy dvojice, protože proudový zesilovací činitel $\beta_{\mathrm{D}} \approx \beta_{1} \beta_{2} R /\left(r_{\mathrm{BE} 2}+R\right)$. Z těchto důvodů by měl odpor rezistoru splňovat podmínku $R>r_{\mathrm{BE} 2}$. Proto se menší hodnota odporu použije především tehdy, když Darlingtonova dvojice zpracovává rychlé signálové změny nebo pracuje ve spínacím režimu.

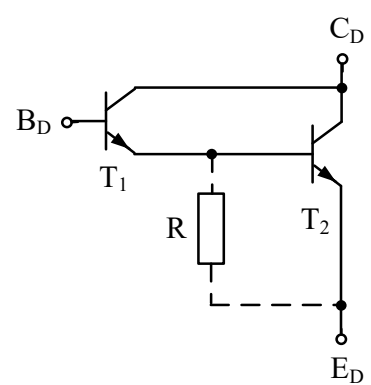

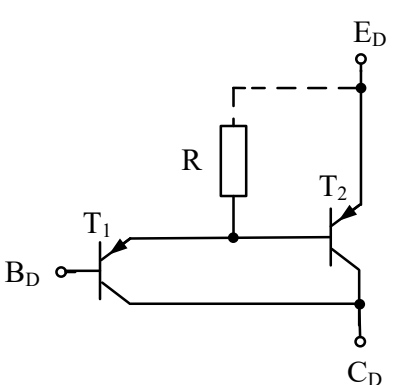

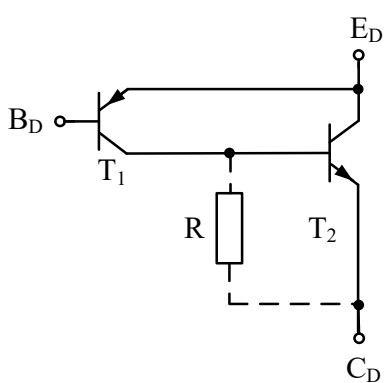

Obr. 2.15: a) Darlingtonovo zapojení, b) komplementární Darlingtonovo zapojení, c) kvazikomplementární zapojení

Komplementární zapojení Darlingtonovy dvojice s tranzistory PNP je uvedeno na Obr. 2.15b. Vlastnosti jsou obdobné. Často se však užívá tzv. kvazikomplementární Darlingtonovo zapojení na Obr. $2.15 \mathrm{c}$ a to $\mathrm{v}$ př́padech, kdy $\mathrm{z}$ výkonového tranzistoru NPN se tímto uspořádáním realizuje výkonový tranzistor typu PNP. Realizace výkonového tranzistoru NPN je vintegrovaném obvodu totiž snažší než výkonového tranzistoru PNP. Vlastnosti kvazikomplementárního zapojení jsou popsány vztahy $\beta_{\mathrm{D}} \approx \beta_{1} \beta_{2}, r_{\mathrm{BED}} \approx r_{\mathrm{BE} 1}, r_{\mathrm{CED}} \approx r_{\mathrm{CE} 2} / 2$. $\mathrm{V}$ tomto prŕípadě ale $u_{\mathrm{BED}} \approx u_{\mathrm{BE} 1} \approx-0,6 \mathrm{~V}$.

\subsubsection{Základní zapojení tranzistoru}

Jsou známa tři základní zapojení tranzistoru. Zapojení jsou nakreslena na Obr. 2.16. V každém obvodu je mimo napájecího napětí $U_{\mathrm{N}}$ zařazen ss zdroj napětí $U_{\mathrm{B}}$, který musí mít takovou polaritu a velikost, aby byl přechod báze-emitor otevřen, tzn. aby $u_{\mathrm{BE}} \approx 0,6 \mathrm{až} 0,65 \mathrm{~V}$ a tranzistorem tekl proud přibližně miliampéry. Stejnosměrné napětí $U_{\mathrm{B}}$ je bud' již předem přidáno $\mathrm{k}$ budicímu stř́́davému signálu $\mathrm{v}$ předchozím stupni, anebo se vhodným způsobem 
přidává $\mathrm{k}$ budicímu signálu až $\mathrm{v}$ obvodu tranzistorového stupně (viz kapitola nastavení pracovního bodu). To proto, že zdroj plovoucího (neuzemněného) napětí $U_{\mathrm{B}}$ by se obtížně realizoval.

O jaké konkrétně jde zapojení tranzistoru se nejlépe posuzuje z náhradních schémat pro stř́́davé signály, která jsou také uvedena pro všechny tři př́ípady na Obr. 2.16. Obvody se odlišují tím, zda je ke společnému bodu vstupní a výstupní části připojen emitor, báze, či kolektor. Podle toho je označujeme jako:

- zapojení se společným emitorem, zkrácené zapojení SE (Obr. 2.16a),

- zapojení se společnou bází, zkrácené zapojení SB (Obr. 2.16b),

- zapojení se společným kolektorem, zkrácené zapojení SC (Obr. 2.16c).
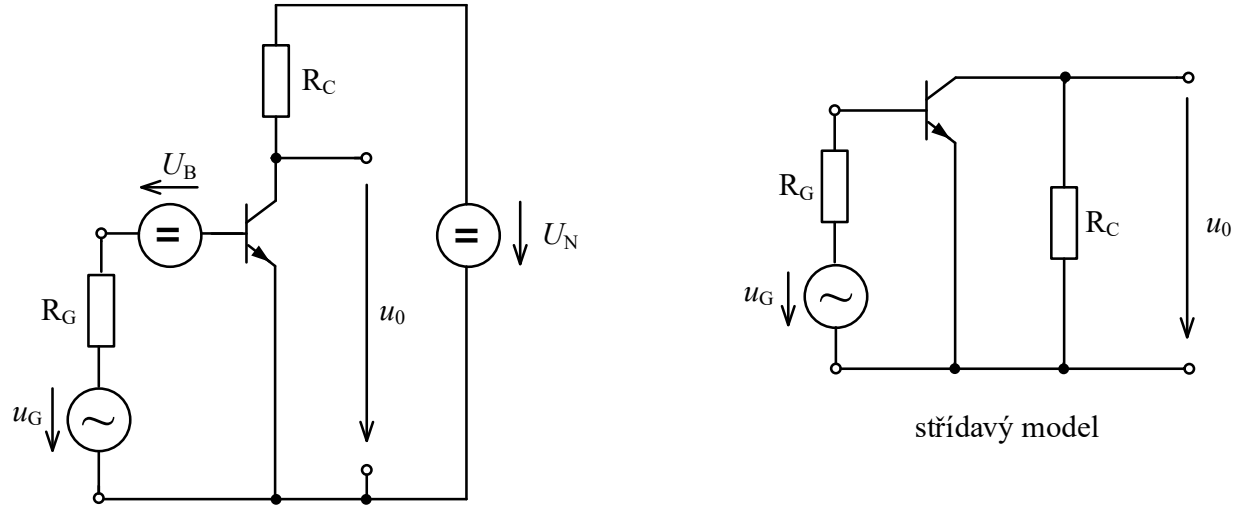

zapojení se společným emitorem

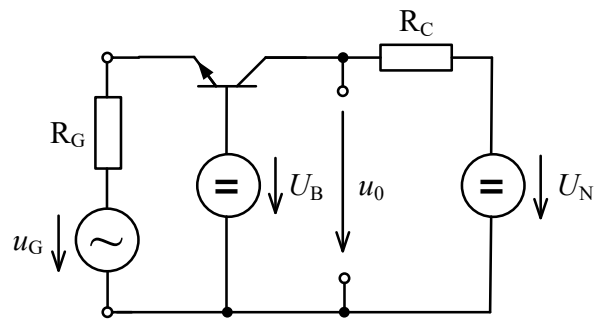

zapojení se společnou bází

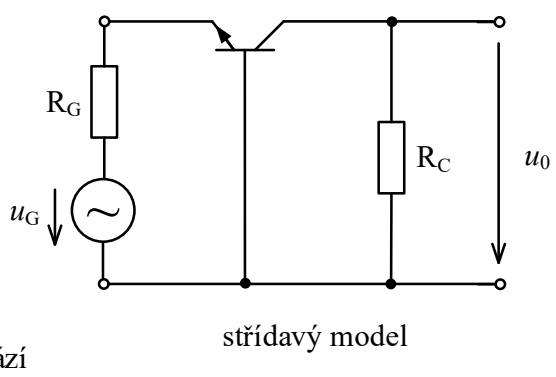

b
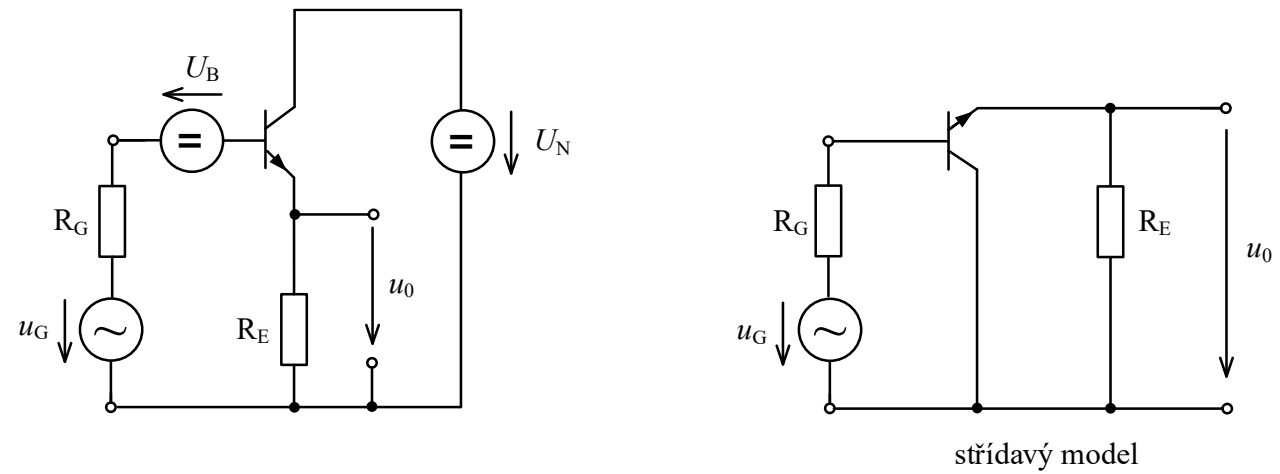

zapojení se společným kolektorem

c

Obr. 2.16: Třri základní zapojení tranzistoru a jejich náhradní schémata pro stř́idavé signály 
Zapojení se od sebe odlišují tím, jaké vykazují zesílení napětí, zda signál invertují, či jaký je jejich vstupní a výstupní odpor.

\subsubsection{Zapojení se společným emitorem}

Aby tranzistor pracoval v nenasyceném stavu jako lineární zesilovač, budeme i v dalších prrípadech předpokládat, že vstupní napětí $u_{\mathrm{G}}$ obsahuje mimo střídavé složky i stejnosměrnou složku, která nastavuje pracovní bod tranzistoru tak, že kolektorový proud má ve všech uvažovaných prípadech pro jednoduchost $1 \mathrm{~mA}$. Způsoby nastavení pracovního bodu budou uvedeny později. Zapojení se společným emitorem (SE) je nakresleno na Obr. 2.17a. Jestliže zvětšíme vstupní napětí o malou hodnotu $\Delta u_{1} \equiv \Delta u_{\mathrm{BE}}$, pak se proud tekoucí kolektorem zvětší (viz Obr. 2.12a). Protože výstupní charakteristiky (Obr. 2.13b) jsou přibližně vodorovné, můžeme zjednodušeně předpokládat, že proud $i_{\mathrm{C}}$ závisí pouze na $u_{\mathrm{BE}}$ a na $u_{\mathrm{CE}}$ nezávisí. Pokud pro popis tranzistoru použijeme $g_{\mathrm{m}}$, kolektorový proud vzroste o hodnotu

$$
\Delta i_{\mathrm{C}} \approx g_{\mathrm{m}} \Delta u_{\mathrm{BE}}=g_{\mathrm{m}} \Delta u_{1}
$$
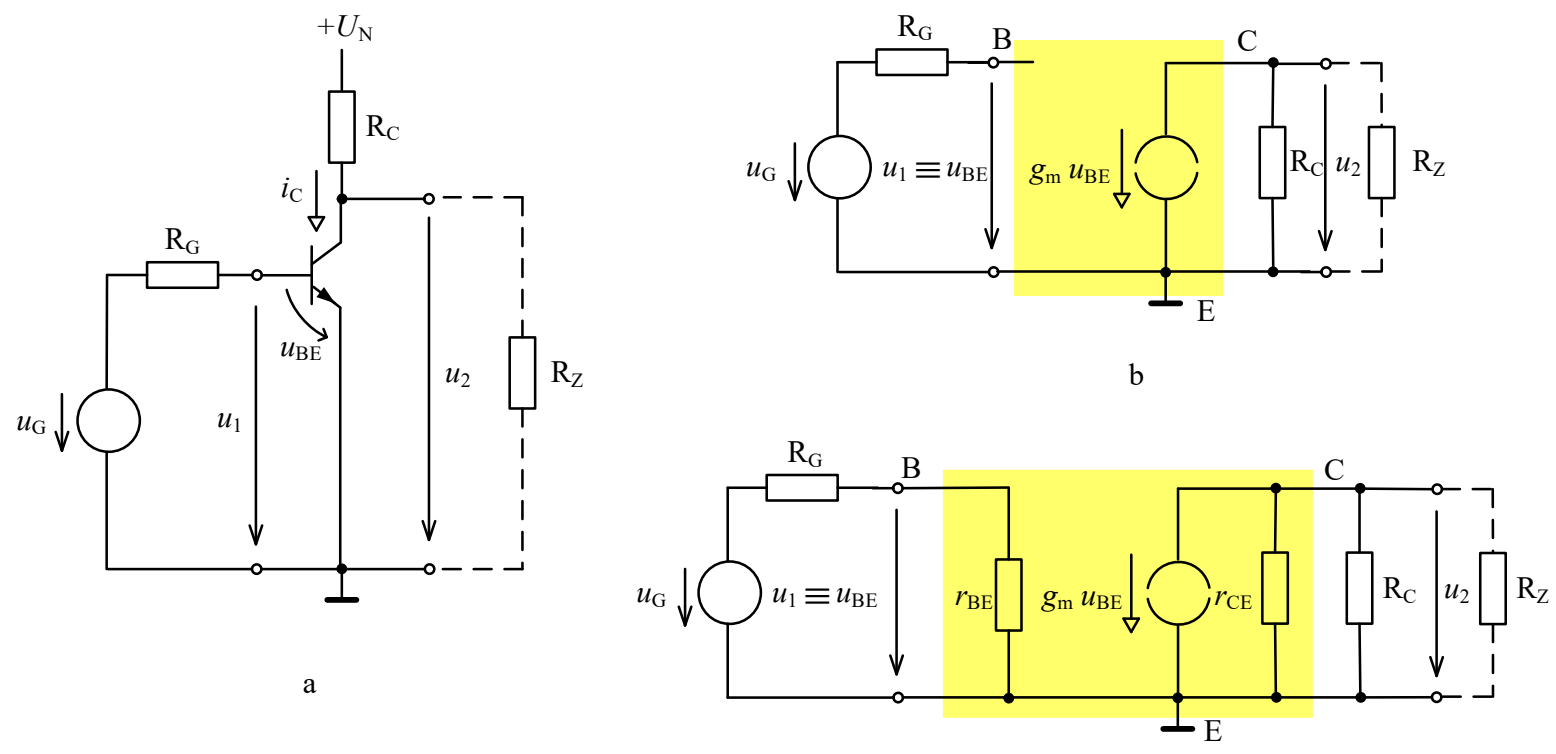

Obr. 2.17: Zapojení se společným emitorem a jeho modely pro střídavé signály

Zvětšení kolektorového proudu způsobí zvětšení úbytku napětí na kolektorovém rezistoru $\mathrm{R}_{\mathrm{C}} \mathrm{a}$ o stejnou hodnotu poklesne výstupní napětí

$$
\Delta u_{2}=-\Delta i_{\mathrm{C}} R_{\mathrm{C}} \approx-g_{\mathrm{m}} R_{\mathrm{C}} \Delta u_{1} .
$$


Napětové zesílení, resp. obecně napětový přenos tranzistoru v zapojení SE

$$
A_{\mathrm{U}}=\frac{\Delta u_{2}}{\Delta u_{1}}=-g_{\mathrm{m}} R_{\mathrm{C}}
$$

Z výsledku je zřejmé, že zapojení se společným kolektorem vstupní napětí zesílí a invertuje, resp. natočí fázi výstupního napětí vůči vstupnímu o $180^{\circ}$.

Př́́kladně pro nastavený pracovní bod $i_{\mathrm{C}}=1 \mathrm{~mA}$ bude podle rov. (2-19) strmost $g_{\mathrm{m}} \approx 40 i_{\mathrm{C}}=40 \mathrm{~mA} / \mathrm{V}$. Bude-li $R_{\mathrm{C}}=4,7 \mathrm{k} \Omega$, bude napětové zesílení $A_{\mathrm{U}}=-188$.

Ke stejnému výsledku se dopracujeme, když použijeme pro malosignálové stř́davé změny zjednodušený model tranzistoru na Obr. 2.17b. Stejnosměrný napájecí zdroj $+U_{\mathrm{N}}$ je pro střídavé signály nahrazen zkratem. Řízený zdroj proudu vyvolá na rezistoru $\mathrm{R}_{\mathrm{C}}$ napětí

$$
u_{2} \approx-g_{\mathrm{m}} u_{\mathrm{BE}} R_{\mathrm{C}}=-g_{\mathrm{m}} u_{1} R_{\mathrm{C}}
$$

Napětové zesílení proto $A_{\mathrm{U}}=u_{2} / u_{1} \approx-g_{\mathrm{m}} R_{\mathrm{C}}$.

Pro přesnější určení vlastností musíme použít přesnější model tranzistoru uvedený na Obr. 2.12d. Stř́davý model zesilovače v zapojení se společným emitorem je pak nakreslen na Obr. 2.17c. Je zřejmé, že řízený zdroj proudu dodává nyní proud do paralelního spojení rezistorů $R_{\mathrm{C}} \| r_{\mathrm{CE}}$. Proto

$$
u_{2}=-g_{\mathrm{m}} u_{\mathrm{BE}}\left(R_{\mathrm{C}} \| r_{\mathrm{CE}}\right)=-g_{\mathrm{m}} u_{1}\left(R_{\mathrm{C}} \| r_{\mathrm{CE}}\right)
$$

a napětové zesílení

$$
A_{\mathrm{U}}=\frac{u_{2}}{u_{1}}=-g_{\mathrm{m}}\left(R_{\mathrm{C}} \| r_{\mathrm{CE}}\right)
$$

Výsledek se však př́liš neodlišuje. Bude-li stejně jako v předchozím př́ípadě $g_{\mathrm{m}} \approx 40 \mathrm{~mA} / \mathrm{V}$, $R_{\mathrm{C}}=4,7 \mathrm{k} \Omega$ a $r_{\mathrm{CE}} \approx 100 \mathrm{k} \Omega$, bude zesílení $A_{\mathrm{U}}=-180$. S dobrou přibližností proto lze pro první orientační výpočty zesílení používat zjednodušený vztah (2-28). Toto zesílení bývá označováno jako zesílení zesilovače bez zátěže $\left(R_{\mathrm{Z}} \approx \infty\right)$. Pokud bychom započítali zátěž, což může být např. vstupní odpor následujícího stupně, pak zátěž sníží zesílení na hodnotu $A_{\mathrm{U}}=-g_{\mathrm{m}}\left(R_{\mathrm{C}}\left\|r_{\mathrm{CE}}\right\| R_{\mathrm{Z}}\right)$. Bude-li např̀. zátěž $R_{\mathrm{Z}}=10 \mathrm{k} \Omega$, sníží se zesílením na hodnotu $A_{\mathrm{U}}=-124$.

Vstupní odpor zesilovače v zapojení SE podle náhradního zapojení na Obr. 2.17c bude $R_{\mathrm{vst}} \approx r_{\mathrm{BE}}$ a pokud přihlédneme k rov. (2-21) můžeme psát

$$
R_{\mathrm{vst}} \approx r_{\mathrm{BE}}=\frac{\beta}{g_{\mathrm{m}}} \approx \frac{\beta}{40 i_{\mathrm{C}}} .
$$

Např. pro $i_{\mathrm{C}}=1 \mathrm{~mA}, \beta=300$ bude $R_{\mathrm{vst}} \approx 7,5 \mathrm{k} \Omega$.

Výstupní odpor určíme z náhradního modelu jako obvykle, tzn. pro zkratované zdroje napětí a rozpojené zdroje proudu

$$
R_{\text {výst }}=R_{\mathrm{C}} \| r_{\mathrm{CE}} \approx R_{\mathrm{C}} \text {. }
$$

Např. pro $R_{\mathrm{C}}=4,7 \mathrm{k} \Omega, r_{\mathrm{CE}} \approx 100 \mathrm{k} \Omega$, bude $R_{\mathrm{výst}} \approx 4,5 \mathrm{k} \Omega$. 
Aby zesilovač s tranzistorem v zapojení SE na Obr. 2.17a pracoval bez zkreslení zesilovaného signálu, mohou být, pro zkreslení výstupního signálu menší než $1 \%$, změny vstupního napětí maximálně $\Delta u_{1} \approx 1 \mathrm{mV}$. Pokud bude zesílení $A_{\mathrm{U}}=200$, bylo by napětí na výstupu pouze $\Delta u_{2} \approx 200 \mathrm{mV}$. Proto se zavádí záporná zpětná vazba, která sice zmenší zesílení, ale potlačí vliv nelinearity charakteristiky $i_{\mathrm{C}}\left(u_{\mathrm{BE}}\right)$. Výstupní napětí pak může být větší.

\section{Zapojeni SE s proudovou zpětnou vazbou}

V tranzistorovém zesilovači na Obr. 2.18a je zavedena proudová záporná zpětná vazba pomocí rezistoru $\mathrm{R}_{\mathrm{E}}$. Pokud se vstupní napětí $u_{1}$ zvětší, zvětší se i kolektorový proud $i_{\mathrm{C}}$. Protože $i_{\mathrm{E}} \approx i_{\mathrm{C}}$, zvětší se i úbytek napětí na rezistoru $\mathrm{R}_{\mathrm{E}}, u_{\mathrm{RE}}=i_{\mathrm{E}} R_{\mathrm{E}} \approx i_{\mathrm{C}} R_{\mathrm{E}}$. Toto napětí působí proti vstupnímu napětí tranzistoru, protože $u_{\mathrm{BE}}=u_{1}-u_{\mathrm{RE}}$ a tím zmenšuje jeho zesílení. Protože tento děj je vyvolán proudem tekoucím emitorovým odporem, označuje se jako záporná proudová zpětná vazba.

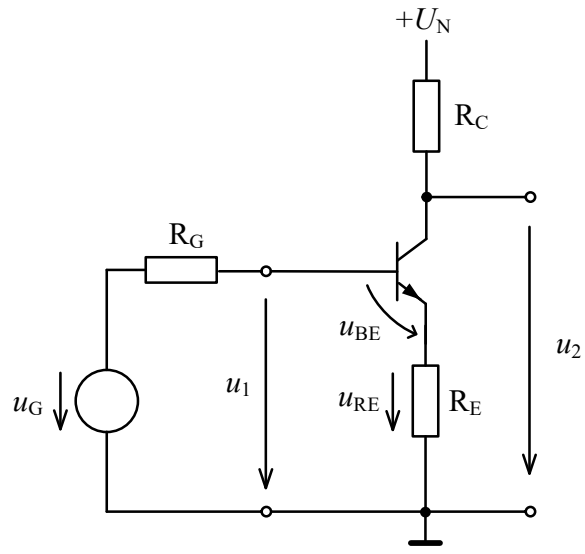

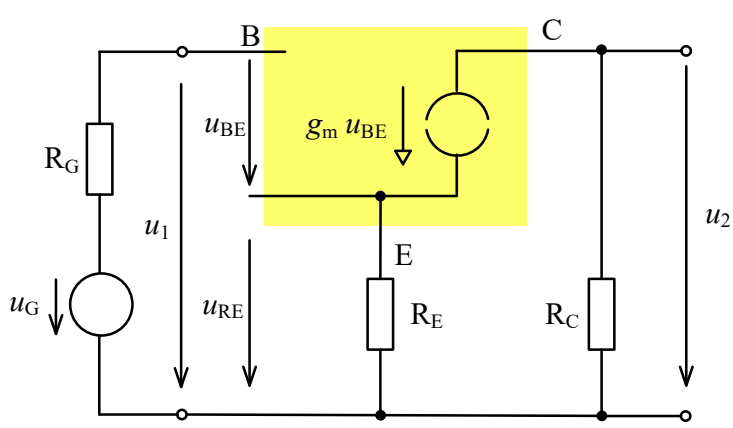

b

Obr. 2.18: a) Zapojení SE s proudovou zpětnou vazbou, b) náhradní model pro malé stř́idavé signály

Napětové zesílení pro střídavé signály určíme pomocí zjednodušeného náhradního modelu na Obr. 2.18b. Protože $u_{\mathrm{RE}} \approx g_{\mathrm{m}} u_{\mathrm{BE}} R_{\mathrm{E}}$, můžeme určit vstupní napětí

$$
u_{1}=u_{\mathrm{BE}}+u_{\mathrm{RE}} \approx u_{\mathrm{BE}}\left(1+g_{\mathrm{m}} R_{\mathrm{E}}\right)
$$

a odtud vstupní napětí

$$
u_{\mathrm{BE}} \approx \frac{u_{1}}{1+g_{\mathrm{m}} R_{\mathrm{E}}} .
$$

Výstupní napětí zesilovače

$$
u_{2} \approx-g_{\mathrm{m}} u_{\mathrm{BE}} R_{\mathrm{C}}=-\frac{g_{\mathrm{m}} R_{\mathrm{C}}}{1+g_{\mathrm{m}} R_{\mathrm{E}}} u_{1} .
$$

Odtud napět’ové zesílení

$$
A_{\mathrm{U}}=\frac{u_{2}}{u_{1}} \approx-\frac{R_{\mathrm{C}}}{R_{\mathrm{E}}+\frac{1}{g_{\mathrm{m}}}} \approx-\frac{R_{\mathrm{C}}}{R_{\mathrm{E}}} .
$$


Při užití přesnějšího modelu je pak možné, za předpokladu $r_{\mathrm{CE}} \gg R_{\mathrm{C}}$, určit vstupní odpor $R_{\mathrm{vst}} \approx r_{\mathrm{BE}}+\beta R_{\mathrm{E}}=r_{\mathrm{BE}}\left(1+g_{\mathrm{m}} R_{\mathrm{E}}\right)$ a výstupní odpor $R_{\mathrm{výst}} \approx R_{\mathrm{C}}$.

\section{Zapojení SE s napětovou zpětnou vazbou}

Druhá varianta záporné zpětné vazby je nakreslena na Obr. 2.19a. Část výstupního napětí je přes dělič $R_{1}, R_{2}$ přivedena paralelně na vstup tranzistoru. Protože zapojení SE signál invertuje, působí toto napětí proti vstupnímu napětí. Jde tedy o zápornou paralelní napět'ovou zpětnou vazbu.

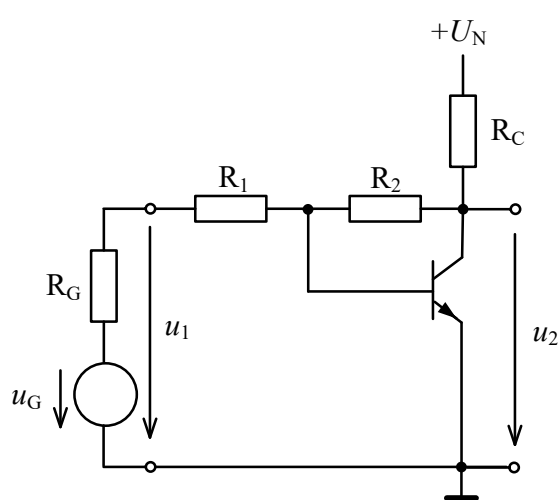

a

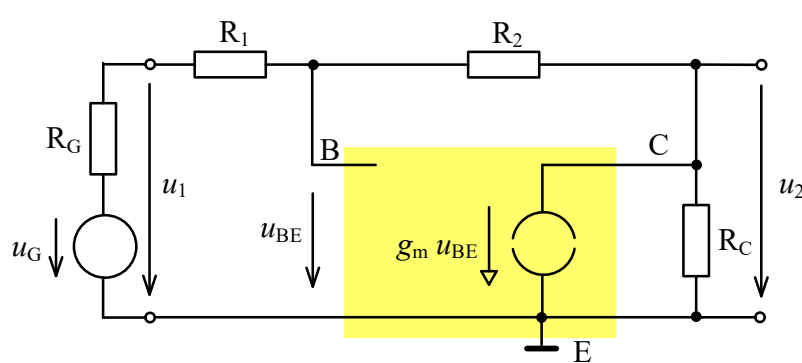

b

Obr. 2.19: Zapojení SE s napětovou zpětnou vazbou a jeho model pro stř́ídavé signály

Pro malé signálové změny můžeme nakreslit zjednodušený model na Obr. 2.19b. Rezistorový dělič $\mathrm{R}_{1}, \mathrm{R}_{2}$ je na jednom konci napájen napětím $u_{1}$, na druhém pak napětím $u_{2}$. Napětí na výstupu děliče, tj. napětí mezi rezistory $\mathrm{R}_{1}$ a $\mathrm{R}_{2}$, můžeme určit metodou superpozice

$$
u_{\mathrm{BE}}=\frac{R_{2}}{R_{1}+R_{2}} u_{1}+\frac{R_{1}}{R_{1}+R_{2}} u_{2} .
$$

Protože $u_{2} \approx-g_{\mathrm{m}} u_{\mathrm{BE}} R_{\mathrm{C}}$, můžeme po dosazení za $u_{\mathrm{BE}} \mathrm{z}$ rov. (2-36) vyčíslit napět’ový přenos

$$
A_{\mathrm{U}}=\frac{u_{2}}{u_{1}} \approx-\frac{R_{2}}{R_{1}+\frac{R_{1}+R_{2}}{g_{\mathrm{m}} R_{\mathrm{C}}}} \approx-\frac{R_{2}}{R_{1}} .
$$

$Z$ podrobnější analýzy s přesnějším modelem tranzistoru vyplývá, že odpor $R_{2}$ by měl být větší než $R_{\mathrm{C}}$, ale odpor $R_{2}$ nesmí být o mnoho větší než $r_{\mathrm{BE}}$. Důsledkem je kompromis $R_{2} \approx R_{\mathrm{C}} \approx r_{\mathrm{BE}}$.

Vstupní odpor

$$
R_{\mathrm{vst}} \approx R_{1}
$$

a výstupní odpor

$$
R_{\text {výst }} \approx \frac{1}{g_{\mathrm{m}}}\left(\frac{R_{2}}{r_{\mathrm{BE}}}+\frac{R_{2}}{R_{1}}+1\right) .
$$

Výstupní odpor, díky záporné napět’ové zpětné vazbě bude, ve srovnání se zapojením bez zpětné vazby, snížen. 


\section{Nastavení pracovního bodu tranzistoru}

Dříve uvedené vztahy platí pro malé změny signálu kolem pracovního bodu $\mathrm{P}$ určeného proudem $I_{\mathrm{CP}}$ a napětím $U_{\mathrm{BEP}}$, resp. $I_{\mathrm{CP}}$ a $U_{\mathrm{CEP}}$. V podstatě lze pro nastavení pracovního bodu použít zdroj $U_{\mathrm{B}}$ zařazený do přívodu báze tak, jak je to ukázáno na Obr. 2.16a. Zdroj by bohužel musel být plovoucí, tedy neuzemněný. Realizace takovéhoto zdroje by však byla neekonomická. Proto se užívají uzemněné zdroje a budicí signál se na vstup zesilovače přivede tzv. stř́davou vazbou.

Při stř́idavé vazbě je zesilovač, nebo zesilovací stupeň připojen na zdroj signálu přes oddělovací kapacitor $\mathrm{C}_{1}$ a zátěž je připojena přes další oddělovací kapacitor $\mathrm{C}_{2}$ (viz Obr. 2.20). Pak je možné stejnosměrně nastavit pracovní bod tranzistoru nezávisle na budicím zdroji a na zátěži. Ve vícestupňovém stř́davém zesilovači pak mohou být pracovní body nastaveny pro každý stupeň samostatně. Kapacitor $\mathrm{C}_{1}$ tvoří společně se vstupním odporem zesilovače horní propust. Podobně kapacitor $\mathrm{C}_{2}$ společně se vstupním odporem následujícího stupně, resp. obecně se zátěží, představují další horní propust. Mezní kmitočty horních propustí musí být navrženy tak, aby filtry propustily celé kmitočtové pásmo zpracovaných signálů.

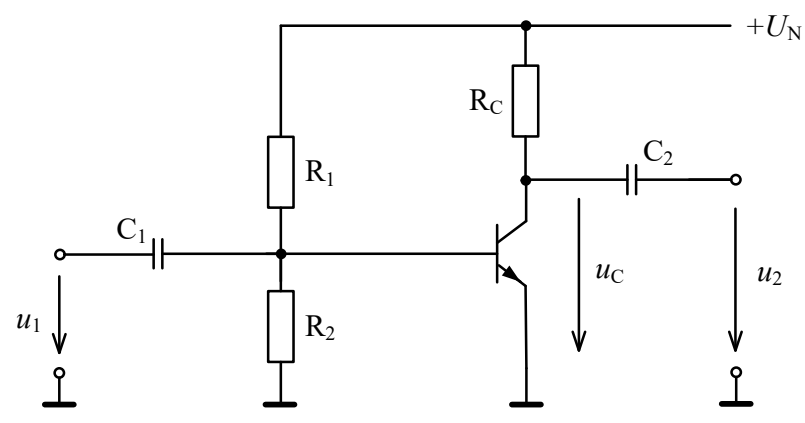

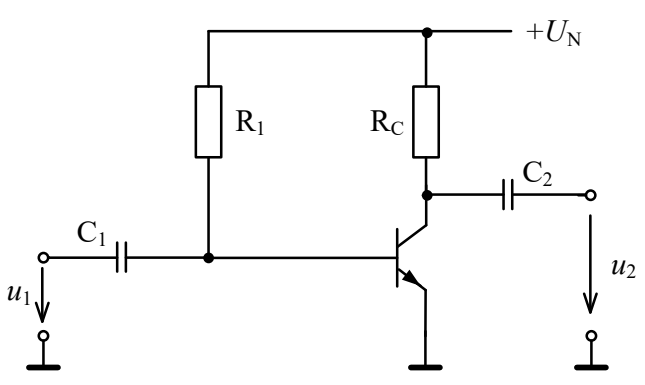

b

Obr. 2.20: Nastavení pracovního bodu se střídavou vazbou: a) pomocí děliče, b) pomocí proudu do báze

\section{Nastavení pracovního bodu pomocí děliče}

$\mathrm{Na}$ Obr. 2.20a je pro nastavení pracovního bodu tranzistoru použit dělič $\mathrm{R}_{1}, \mathrm{R}_{2}$. Dělič je navržen tak, aby na bázi tranzistoru nastavil napětí pracovního bodu $U_{\mathrm{BEP}}=U_{\mathrm{N}} R_{2} /\left(R_{2}+R_{1}\right)$ a to přibližně na hodnotu $U_{\mathrm{BEP}} \approx 0,6 \mathrm{~V}$. Nastavení pracovního bodu děličem však není příliš praktické. Z přenosové charakteristiky $i_{\mathrm{C}}\left(u_{\mathrm{BE}}\right)$ na Obr. $2.12 \mathrm{a}$ je vidět, že nevelká odchylka napětí $U_{\mathrm{BEP}}$ způsobí velkou změnu proudu $I_{\mathrm{CP}}$. Velký rozptyl parametrů tranzistorů pak vyžaduje, aby pro individuální nastavení pracovního bodu byl dělič regulovatelný.

Největší problémy ale činí teplotní závislost napětí $u_{\mathrm{BE}}$, které se mění v závislosti na změně teploty $\Delta T$ o hodnotu $\Delta u_{\mathrm{BE}} / \Delta T=-2 \mathrm{mV} /{ }^{\circ} \mathrm{C}$. Bude-li zesílení obvodu $A_{\mathrm{U}} \approx-200$, přenese se tato změna na kolektor tranzistoru zesílena $\Delta u_{\mathrm{C}} / \Delta T=A_{\mathrm{U}} \cdot \Delta u_{\mathrm{BE}} / \Delta T=0,4 \mathrm{~V} /{ }^{\circ} \mathrm{C}$. Při změně teploty o $\Delta T=20^{\circ} \mathrm{C}$, bude ss změna kolektorového napětí činit $\Delta u_{\mathrm{C}} \approx 8 \mathrm{~V}$. To je však nepř́ípustně velká změna pracovního bodu. $Z$ výše uvedených důvodů se toto zapojení př́liš neužívá. 
Nastavení pracovního bodu proudem do báze

Vliv teplotních změn $u_{\mathrm{BE}}$ můžeme eliminovat nastavením pracovního bodu proudem do báze (Obr. 2.20b). Zdroj poudu je realizován zdrojem napětí $U_{\mathrm{N}}$ a velkým odporem rezistoru $\mathrm{R}_{1}$. Při návrhu vyjdeme z požadavku na kolektorový proud pracovního bodu $I_{\mathrm{CP}}$. Do báze musí téct proud $I_{\mathrm{BP}} \approx I_{\mathrm{CP}} / \beta$. Rezistor $\mathrm{R}_{1}$ proto musí mít odpor

$$
R_{1}=\frac{U_{\mathrm{N}}-U_{\mathrm{BEP}}}{I_{\mathrm{BP}}} \approx \beta \frac{U_{\mathrm{N}}-U_{\mathrm{BEP}}}{I_{\mathrm{CP}}} .
$$

Obvykle je napájecí napětí $U_{\mathrm{N}} \gg U_{\mathrm{BEP}}$ a proto

$$
R_{1} \approx \beta \frac{U_{\mathrm{N}}}{I_{\mathrm{CP}}} .
$$

Odtud je také zřejmé, že změna $U_{\mathrm{BEP}}$ nastavení pracovního bodu $I_{\mathrm{CP}} \approx \beta U_{\mathrm{N}} / R_{1}$ př́iliš neovlivní. $Z$ velké míry je ze stejného důvodu také potlačen vliv teplotních změn napětí $u_{\mathrm{BE}}$.

I když teplotní vliv je daleko menší než v př́ípadě nastavení pracovního bodu, velký rozptyl proudových zesilovacích činitelů vyžaduje nahrazení rezistoru $\mathrm{R}_{1}$ potenciometrickým trimrem. Proto se toto uspořádání také nepoužívá často.

\section{Stabilizace pracovního bodu pomocí ss proudové zpětné vazby}

Z rozboru zapojení, kdy se pro nastavení pracovního bodu užívá rezistorový dělič (Obr. 2.20a) je zřejmé, že teplotní změny napětí $u_{\mathrm{BE}}$ jsou na výstupu zesilovače zesíleny. Protože teplotní změny jsou pomalé, stačí redukovat zesílení pro ss signály. Toho se dá docílit kmitočtově závislou zápornou zpětnou vazbou, která bude účinná pro ss signály a pro signály s kmitočtem nižším, než jsou kmitočty užitečného pásma. Tento princip teplotní stabilizace pracovního bodu pomocí ss proudové záporné zpětné vazby je použit v zapojení na Obr. 2.21a.

Pro ss signály a nízké kmitočty vykazuje kapacitor $\mathrm{C}_{\mathrm{E}}$ velkou impedanci a nemusíme ho uvažovat. Zesílení bude pro pomalé změny dáno vztahem (2-35), tj. $A_{\mathrm{U}}=-R_{\mathrm{C}} / R_{\mathrm{E}}$. Pokud např. zvolíme $R_{\mathrm{C}}=R_{\mathrm{E}}$, bude $A_{\mathrm{U}}=-1$ a změny $u_{\mathrm{BE}}$ s teplotou nebudou zesilovány. Změna pracovního bodu $\mathrm{s}$ teplotou tedy bude nepatrná. Pro stř́́davé signály vykazuje kapacitor $\mathrm{C}_{\mathrm{E}}$ malou impedanci a na vysokých kmitočtech jej můžeme nahradit zkratem. Zesilovač v tom př́padě vykazuje plné zesílení, tj. $A_{\mathrm{U}}=-g_{\mathrm{m}} R_{\mathrm{C}}$ (viz rov. (2-28)).

Pokud použijeme symetrické napájení zesilovače, můžeme dělič $\mathrm{R}_{1}, \mathrm{R}_{2}$ vypustit (Obr. 2.21b). Stejnosměrně pak musíme odpor rezistoru $\mathrm{R}_{\mathrm{E}}$ dimenzovat tak, aby bez buzení vstupu, tj. pro $u_{1}=0$, byl emitor na potenciálu $U_{\mathrm{BEP}} \approx-0,6 \mathrm{~V}$.

Vliv kapacitoru $\mathrm{C}_{\mathrm{E}}$ na činnost obvodu je zřejmý z Obr. 2.21c, kde je nakreslena charakteristika $z(f) \approx 20 \log \left|A_{\mathrm{U}}(f)\right|$. Protože se celý popsaný děj odehrává na velmi nízkých kmitočtech je obvykle nutno kapacitor $\mathrm{C}_{\mathrm{E}}$ volit elektrolytický. Pokud se užije zapojení se symetrickým napájením je zapotřebí polaritu elektrolytického kapacitoru zaměnit (Obr. 2.21b). 

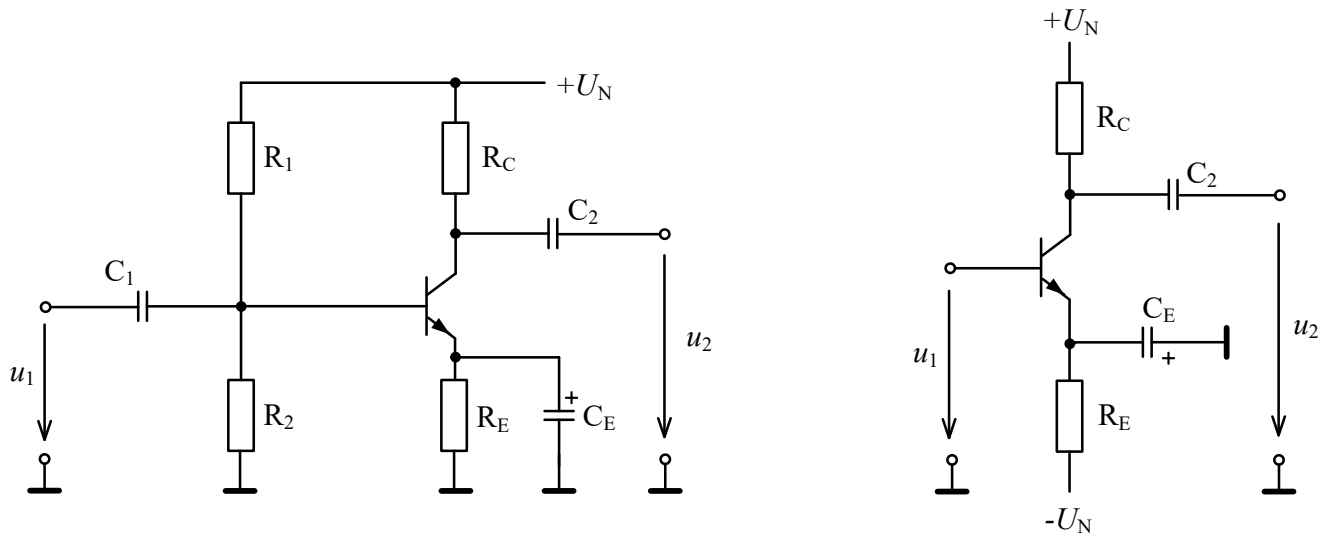

$\mathrm{b}$

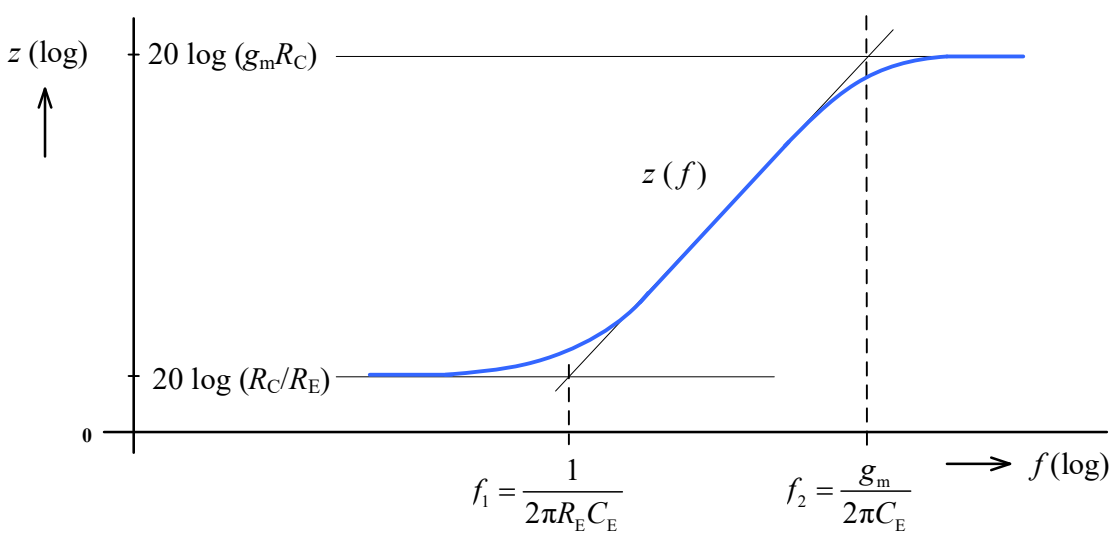

$\mathrm{c}$

Obr. 2.21: a) Stabilizace pracovního bodu pomocí ss zpětné vazby, b) zjednodušení při symetrickém napájení, c) kmitočtová charakteristika

\subsubsection{Zapojení se společnou bází}

Zapojení tranzistoru se společnou bází (SB) je uvedeno na Obr. 2.22a. Ze srovnání se zapojením se společným emitorem na Obr. 2.17a plyne, že budicí zdroj $u_{\mathrm{G}}$ je i zde zapojen ve stejné proudové smyčce, tj. do série s přechodem $\mathrm{BE}$, nyní ale $u_{\mathrm{BE}}=-u_{1}$. Zjednodušený náhradní model pro malé signálové změny je pak nakreslen na Obr. 2.22b. Řízený zdroj proudu dodává proud pouze do rezistoru $\mathrm{R}_{\mathrm{C}}$ a proto $u_{2} \approx-g_{\mathrm{m}} u_{\mathrm{BE}} R_{\mathrm{C}}=g_{\mathrm{m}} u_{1} R_{\mathrm{C}}$. Zesilovač má $\mathrm{v}$ tomto př́ípadě neinvertující charakter a $A_{\mathrm{U}} \approx g_{\mathrm{m}} R_{\mathrm{C}}$.
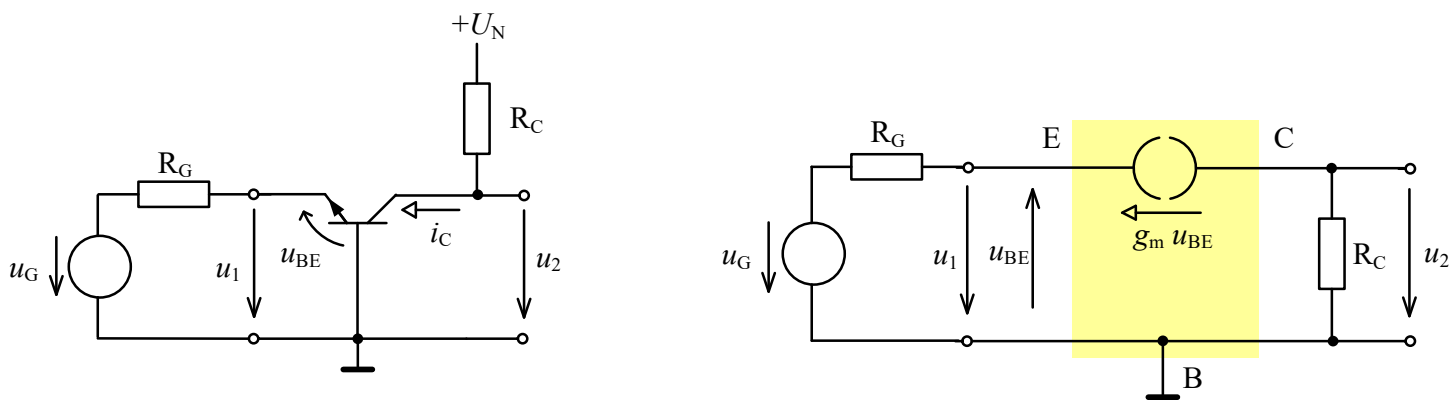

Obr. 2.22: Zapojení se společnou bází a jeho model pro stř́idavé signály 
Pokud se použije přesnější model tranzistoru, lze stanovit vstupní odpor $R_{\mathrm{vst}} \approx 1 / g_{\mathrm{m}} \mathrm{a}$ výstupní odpor $R_{\text {výst }} \approx R_{\mathrm{C}}$, pro $r_{\mathrm{CE}} \gg R_{\mathrm{C}}$. Vstupní odpor obvodu je velmi nízký, např. při proudu $i_{\mathrm{C}}=1 \mathrm{~mA}, \mathrm{kdy} g_{\mathrm{m}} \approx 40 \cdot 10^{-3} \mathrm{~A} / \mathrm{V}$, bude $R_{\mathrm{vst}}$ pouze $25 \Omega$. Z tohoto důvodu se zapojení běžně v nf technice neužívá, ale u rychlejších či širokopásmových zesilovačů má velké využití pro potlačení Millerova jevu v tzv. kaskodovém zapojení tranzistorů.

\section{Kaskodové zapojení}

Použití zapojení se společným emitorem omezuje na vysokých kmitočtech tzv. Millerův jev. Parazitní kapacita $C_{\mathrm{BC}}$ (viz Obr. 2.23a) se totiž jeví na vstupu tranzistoru v zapojení SE jako daleko větší Millerova kapacita $C_{\mathrm{M}}=\left(1-A_{\mathrm{U}}\right) C_{\mathrm{BC}}, A_{\mathrm{U}}<0$. Tato kapacita tvoří společně $\mathrm{s}$ vnitřním odporem $R_{\mathrm{G}}$ budicího zdroje dolní kmitočtovou propust (Obr. 2.23b), která může omezit kmitočtové pásmo zpracovaného signálu. Např. pro $C_{\mathrm{BC}}=5 \mathrm{pF}, R_{\mathrm{G}}=1 \mathrm{k} \Omega, A_{\mathrm{U}}=-200$, bude $C_{\mathrm{M}} \approx 1 \mathrm{nF}$ a k omezení kmitočtového pásma začne docházet již od kmitočtu $f_{\mathrm{m}}=1 / 2 \pi R_{\mathrm{G}} C_{\mathrm{M}} \approx 160 \mathrm{kHz}$.

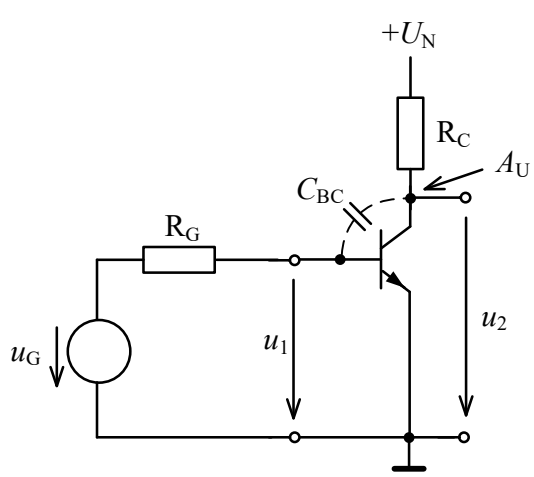

a

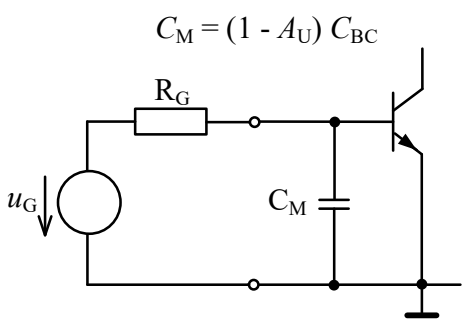

b

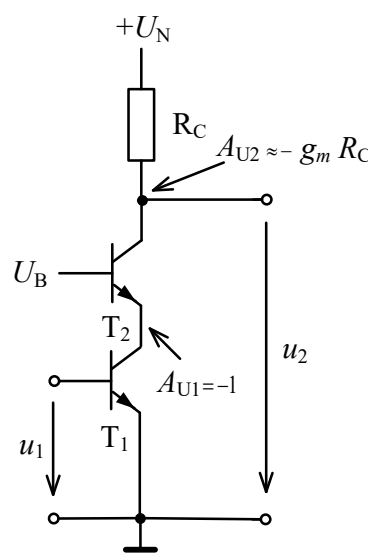

Obr. 2.23: a) Vliv parazitní kapacity na zapojení SE, b) k vysvětlení Millerova jevu, c) kaskódové zapojení

Tento jev potlačuje kaskódové zapojení tranzistorů na Obr. 2.23c. Tranzistor $\mathrm{T}_{1} \mathrm{zde}$ pracuje $\mathrm{v}$ zapojení $\mathrm{SE}$ a tranzistor $\mathrm{T}_{2} \mathrm{v}$ zapojení $\mathrm{SB}$. V kolektoru tranzistoru $\mathrm{T}_{1}$ je zde místo kolektorového odporu použit vstupní odpor zapojení $\mathrm{SB}$, který má hodnotu $R_{\mathrm{vst}} \approx 1 / g_{\mathrm{m}}$. Proto bude zesílení signálu na kolektoru $\mathrm{T}_{1}$ jednotkové $A_{\mathrm{U} 1}=-g_{\mathrm{m}} R_{\mathrm{vst}}=-g_{\mathrm{m}} / g_{\mathrm{m}}=-1$ a Millerův efekt se prakticky neuplatní. Napět’ové zesílení kaskódového zesilovače na kolektoru $\mathrm{T}_{2}$ zůstává stejné $A_{\mathrm{U} 2} \approx-g_{\mathrm{m}} R_{\mathrm{C}}$.

\subsubsection{Emitorový sledovač - zapojení se společným kolektorem}

Pokud ke vstupnímu napětí emitorového sledovače (Obr. 2.24) bude přidáno takové ss napětí, aby se přechod $\mathrm{BE}$ otevřel a bylo na něm ss napětí $u_{\mathrm{BE}} \approx 0,6 \mathrm{~V}$, potom $u_{2}=u_{1}-u_{\mathrm{BE}}=$ $=u_{1}-0,6$. Jestliže se zvětší vstupní napětí o $\Delta u_{1}$, zvětší se kolektorový a tedy i emitorový proud a na rezistoru $R_{\mathrm{E}}$ se zvětší napětí. Zanedbáme-li nepatrné změny napětí $u_{\mathrm{BE}}$ při zvětšování 
kolektorového proudu, bude výstupní napětí přímo sledovat změny vstupního napětí $\Delta u_{2} \approx \Delta u_{1}$ a přenos emitorového sledovače $A_{\mathrm{U}}=\Delta u_{2} / \Delta u_{1} \approx 1$.

Přesnější výsledek získáme ze zjednodušeného náhradního modelu pro stř́idavé signály na Obr. 2.24b. Proud $\mathrm{z}$ rrízeného zdroje proudu teče pouze rezistorem $\mathrm{R}_{\mathrm{E}}$ a proto na něm vznikne napětí $u_{2} \approx g_{\mathrm{m}} u_{\mathrm{BE}} R_{\mathrm{E}}$, přičemž $u_{\mathrm{BE}}=u_{1}-u_{2}$. Po dosazení za $u_{\mathrm{BE}}$ můžeme pro přenos napětí odvodit vztah

$$
A_{\mathrm{U}} \approx \frac{g_{\mathrm{m}} R_{\mathrm{E}}}{g_{\mathrm{m}} R_{\mathrm{E}}+1} \approx 1, \text { pro } g_{\mathrm{m}} R_{\mathrm{E}} \gg 1
$$

Pro stanovení vstupního a výstupního odporu je nutno použít přesnější model tranzistoru. Pro vstupní odpor emitorového sledovače pak platí $R_{\mathrm{vst}} \approx r_{\mathrm{BE}}+\beta R_{\mathrm{E}} \approx \beta R_{\mathrm{E}}$. Typicky mívá vstupní odpor hodnotu $R_{\mathrm{vst}} \approx 1 \mathrm{M} \Omega$ a více. Pro výstupní odpor lze odvodit $R_{\mathrm{výst}} \approx R_{\mathrm{E}} \|\left(1 / g_{\mathrm{m}}\right)$ obvykle $R_{\text {výst }} \approx 25 \Omega$.

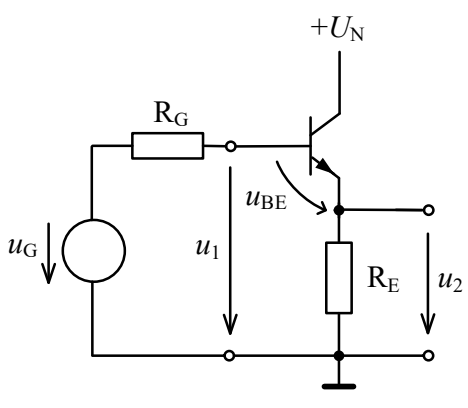

a

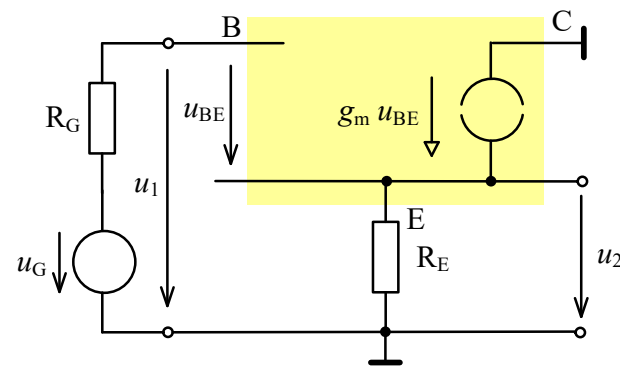

b

Obr. 2.24: Emitorový sledovač a jeho model pro stř́idavé změny signálu

Je zřejmé, že emitorový sledovač je vhodné používat k impedančnímu oddělení jednotlivých stupňů: předřazený stupeň zatěžuje málo, kdežto z hlediska následujícího stupně se chová jako „tvrdý“ zdroj napětí. Často se ale také emitorový sledovač užívá v koncových zesilovacích stupních jako zesilovač výkonu.

Pro nastavení pracovního bodu emitorového sledovače se v integrovaných obvodech často na místě rezistoru $R_{E}$ použije zdroj konstantního proudu. To má příznivé účinky i na další parametry sledovače. Jeho přenos se pak bude s větší přesností blížit jedné a vstupní odpor sledovače se ještě dále zvýší.

\subsubsection{Komplementární emitorový sledovač}

Výstupní odpor tranzistorových zesilovacích stupňů je obecně velmi vysoký a proto musí být zátěž oddělena od vlastního zesilovacího stupně tak, aby zátěž neovlivňovala jeho zesílení. Současně musí takový koncový oddělovací stupeň být schopen dodat do zátěže dostatečný proud resp. obecně výkon. K tomu se právě dá využít emitorový sledovač, který, přestože nezesiluje napětí, zesiluje proud a tedy i výkon. Při téměř stejných napětích na vstupu a na výstupu sledovače $\left(A_{\mathrm{U}} \approx 1\right)$ procházejí totiž vstupním obvodem proudy řádu desetin miliampérů, kdežto výstupem proudy řádu desítek miliampérů. Proto bývá emitorový sledovač také někdy označován jako zesilovač výkonu popř. proudový posilovač. 
Princip činnosti emitorového sledovače byl probrán v předchozí kapitole. Zde uvedeme některé doplňkové informace při jeho užití jako koncového oddělovacího stupně či zesilovače výkonu [1]. Protože se obvykle preferuje symetrické napájení, kdy bez buzení bude na výstupu nulové napětí, budeme v dalším uvažovat symetrické napájení (Obr. 2.25a).

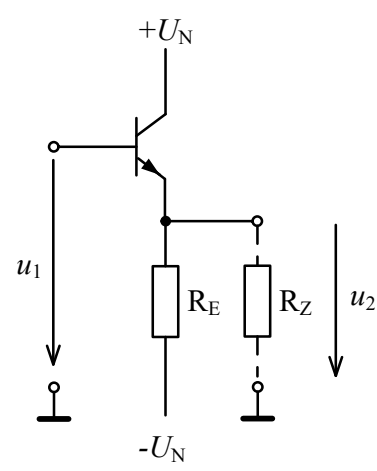

a

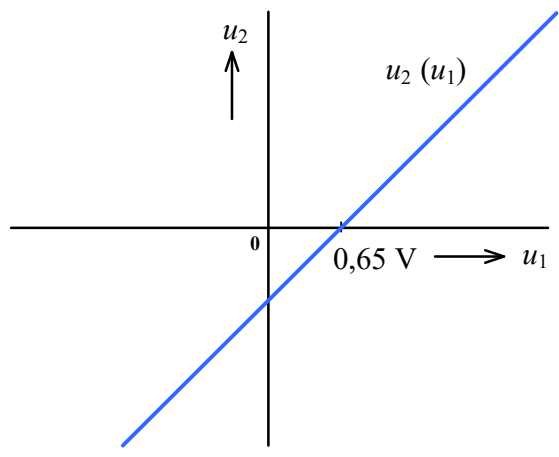

b

Obr. 2.25: Symetrický napájený emitorový sledovač ve tř́́dě A a jeho převodní charakteristika

Aby emitorový sledovač zpracoval kladné i záporné změny vstupního napětí $u_{1}$ bez zkreslení, volí se pracovní bod doprostřed aktivní oblasti. Potom však tranzistorem i rezistorem $\mathrm{R}_{\mathrm{E}}$ teče trvale klidový proud $I_{\mathrm{CP}}$ nastavující pracovní bod a to tak velký, aby pro největší změnu $\Delta i_{\mathrm{C}}$ vyvolanou změnou $\Delta u_{1}$ platilo $\left|I_{\mathrm{CP}}\right|-\left|\Delta i_{\mathrm{C}}\right|>0$. Zesilovač pak pracuje tzv. třídě A a jeho převodní charakteristika je lineární (Obr. 2.25b). Má-li emitorový sledovač dodávat do zátěže $\mathrm{R}_{\mathrm{Z}}$ proud resp. výkon, bude činnost ve třídě $\mathrm{A}$ energeticky nevýhodná, protože $\mathrm{z}$ napájecích zdrojů se bude trvale i bez buzení odebírat příkon $U_{\mathrm{N}} I_{\mathrm{CP}}$.

\section{Komplementární emitorový sledovač ve tř́dě $B$}

Účinnost emitorového sledovače lze zvýšit, zmenšíme-li jeho klidový př́íkon i za cenu nelineárního zkreslení signálu tak, že rezistor $\mathrm{R}_{\mathrm{E}}$ nahradíme komplementárním tranzistorem (Obr. 2.26a). Při kladném vstupním napětí pracuje tranzistor $\mathrm{T}_{1}$ jako emitorový sledovač, dodává proud do zátěže a tranzistor $\mathrm{T}_{2}$ je zavřen. Při záporném vstupním napětí je tomu naopak. Tranzistory tak pracují stř́ídavě podle polarity vstupního signálu. Pokud bude obvod bez buzení, budou oba tranzistory uzavřeny. Aby se jeden nebo druhý tranzistor otevřel, je zapotřebí překonat napětí $\pm 0,6 \mathrm{~V}$. Takový režim se označuje jako dvoutaktní režim ve třídě $\mathrm{B}$. 


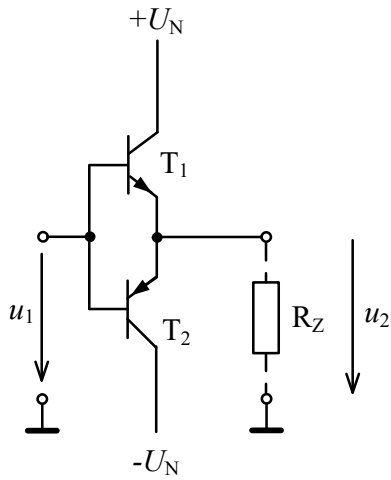

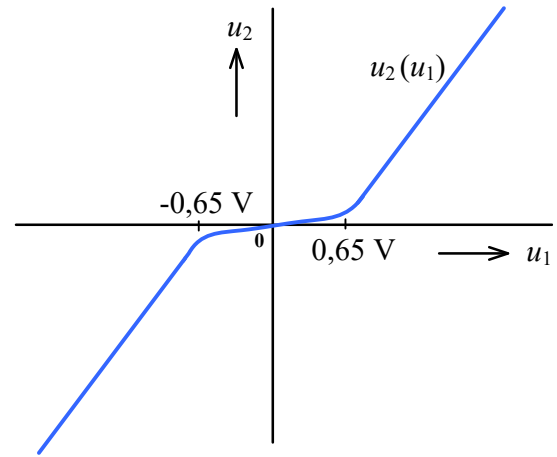

b

Obr. 2.26: Komplementární emitorový sledovač ve třídě B a jeho převodní charakteristika

Přechodové zesílení převodní charakteristiky (Obr. 2.26b) způsobuje nelineární zkreslení signálu a proto se jej snažíme potlačit (viz dále).

\section{Komplementární emitorový sledovač ve třídě $A B$}

Menší nelineární zkreslení vykazuje zapojení komplementárního emitorového sledovače pracujícího ve třídě $\mathrm{AB}$ na Obr. 2.27a. Předpětí $U_{\mathrm{P} 1}$ a $U_{\mathrm{P} 2}$ jsou nastavena tak, aby způsobila otevření tranzistorů již při malém zvýšení či snížení napětí vstupního napětí $u_{1}$ od nuly. Napětí zdrojů $U_{\mathrm{P} 1}$ a $U_{\mathrm{P} 2}$ tedy musí být o něco menší než $0,6 \mathrm{~V}$. Převodní charakteristika pak bude vykazovat daleko menší přechodové zkreslení (Obr. 2.27b). Takovýto režim se nazývá dvoutaktní režim $\mathrm{AB}$.

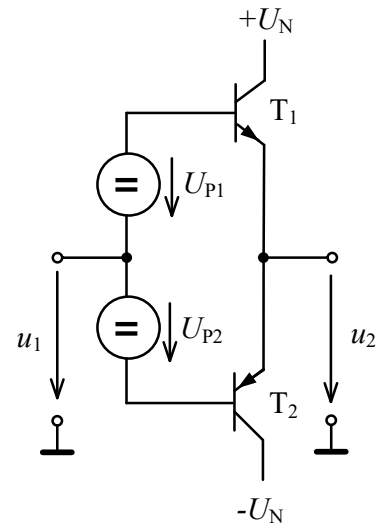

a

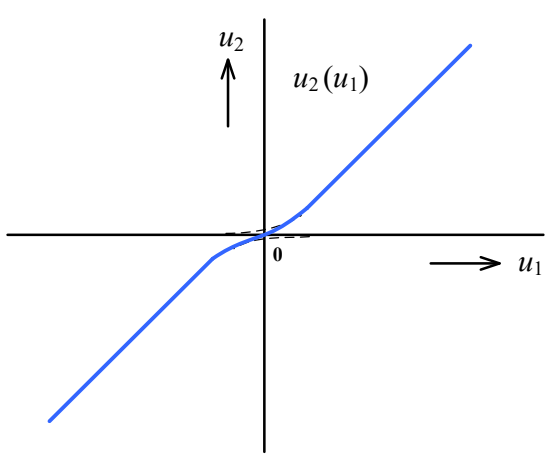

b

Obr. 2.27: Komplementární emitorový sledovač ve třídě $\mathrm{AB}$ a jeho převodní charakteristika

Velkým problémem koncového stupně je nutnost udržet klidový proud tranzistorů $\mathrm{v}$ širokém rozmezí teplot. Se zvýšením teploty tranzistoru se klidový proud totiž zvyšuje. To způsobí další zvýšení teploty, což ve svém důsledku vede k teplotnímu zničení tranzistoru. Tento efekt se označuje jako tepelná kladná zpětná vazba. Pro potlačení tohoto jevu se do cesty výstupnímu proudu tranzistorů zařazují rezistory $\mathrm{R}_{1}$ a $\mathrm{R}_{2}$, které realizují zápornou proudovou 
zpětnou vazbu (Obr. 2.28a). Pokud se proud rezistorem zvýší, zvýší na něm úbytek napětí, ten
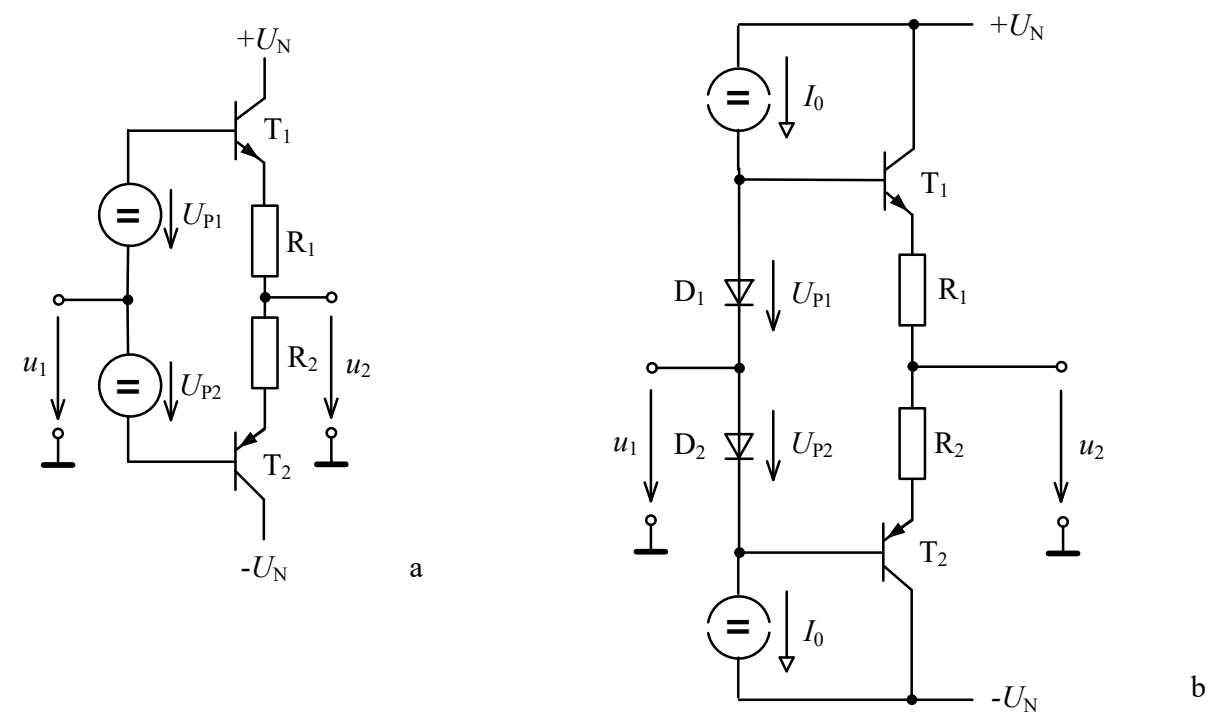

Obr. 2.28: a) Potlačení kladné tepelné zpětné vazby, b) nastavení režimu AB pomocí diod

způsobí snížení napětí BE tranzistoru a ten se začne zavírat. Účinnost této zpětné vazby se zvětšuje $s$ růstem odporů těchto rezistorů. Rezistory $R_{1}$ a $R_{2}$ jsou však zařazeny v sérii zátěži $\mathrm{R}_{\mathrm{Z}}$ a snižují výkon dodaný do zátěže. Proto se odpor rezistorů volí daleko menší, než je povolený odpor zátěže. Většinou rezistory $\mathrm{R}_{1}$ a $\mathrm{R}_{2}$ mají odpor 15 až $50 \Omega$. Jak bude ukázáno později, může být tento problém elegantně vyřešen při použití Darlingtonova zapojení i jiným způsobem.

Př́klad konkrétní realizace komplementárního emitorového sledovače ve třídě $A B$ je uveden na Obr. 2.28b. Zdroje proudu nastavují pracovní body diod $\mathrm{D}_{1}$ a $\mathrm{D}_{2}$ tak, aby na nich vzniklo napětí $U_{\mathrm{P} 1}=U_{\mathrm{P} 2} \approx 0,6 \mathrm{~V}$. Při tomto napětí přes tranzistory $\mathrm{T}_{1}$ a $\mathrm{T}_{2}$ poteče při $u_{1}=0$ jen nevelký proud.

Př́liš malý odpor zátěže, nebo zkrat na výstupu koncového stupně, může přetížit koncové tranzistory a zničit je. Proto se používají obvody pro omezení výstupního proudu koncového stupně. Nejčastěji užívané zapojení elektronických pojistek je uvedeno na Obr. 2.29. Tranzistor $\mathrm{T}_{3}$ se otevře, jestliže napětí na rezistoru $\mathrm{R}_{1}$ převýší napětí $0,6 \mathrm{~V}$. Další zvyšování kolektorového proudu tranzistoru $\mathrm{T}_{1}$ bude omezeno, protože napětí $u_{\mathrm{CE} 3}$ otevřeného tranzistoru $\mathrm{T}_{3}$ bude menší než $0,5 \mathrm{~V}$ a tranzistor $\mathrm{T}_{1}$ se proto začne zavírat. Pro druhou polaritu výstupního proudu bude činnost elektronické pojistky $\mathrm{s}$ tranzistorem $\mathrm{T}_{4}$ obdobná. Maximální hodnota výstupního proudu bude omezena na hodnotu $I_{\mathrm{Z} \text { max }} \approx 0,6 \mathrm{~V} / R_{1}$ resp. pro druhou polaritu $I_{\mathrm{Z} \text { max }} \approx-$ $0,6 \mathrm{~V} / R_{2}$.

Jiný způsob získání předpětí pro tranzistory $\mathrm{T}_{1}$ a $\mathrm{T}_{2}$ pro potlačení přechodového zkreslení je ukázán na Obr. 2.30. Tranzistoru $\mathrm{T}_{1}$ je předřazen komplementární emitorový sledovač $\mathrm{s}$ tranzistorem $\mathrm{T}_{3}$. Pro zvýšení vstupního odporu má tento emitorový sledovač místo emitorového rezistoru zdroj konstantního proudu $I_{0}$. Úbytky napětí na přechodech BE se u obou tranzistorů $\mathrm{T}_{1}$ a $\mathrm{T}_{3}$ kompenzují, takže malé zvýšení $u_{1}$ nad $0 \mathrm{~V}$ způsobí otevření tranzistoru $\mathrm{T}_{1}$. 
Pro záporné napětí $u_{1}$ je situace $\mathrm{s}$ tranzistory $\mathrm{T}_{2}$ a $\mathrm{T}_{4}$ obdobná. Zapojení bývá označováno jako dvojstupňový komplementární emitorový sledovač.

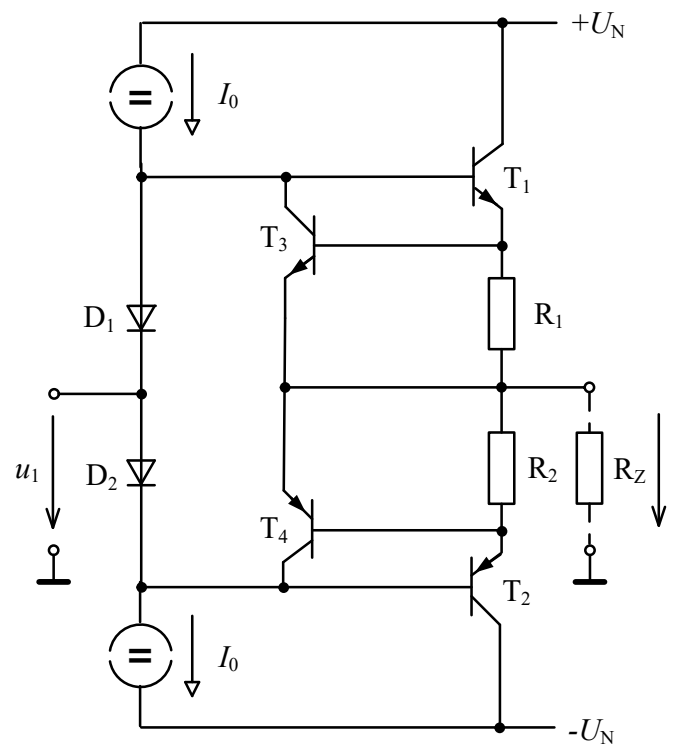

Obr. 2.29: Příklad řešení elektronických pojistek

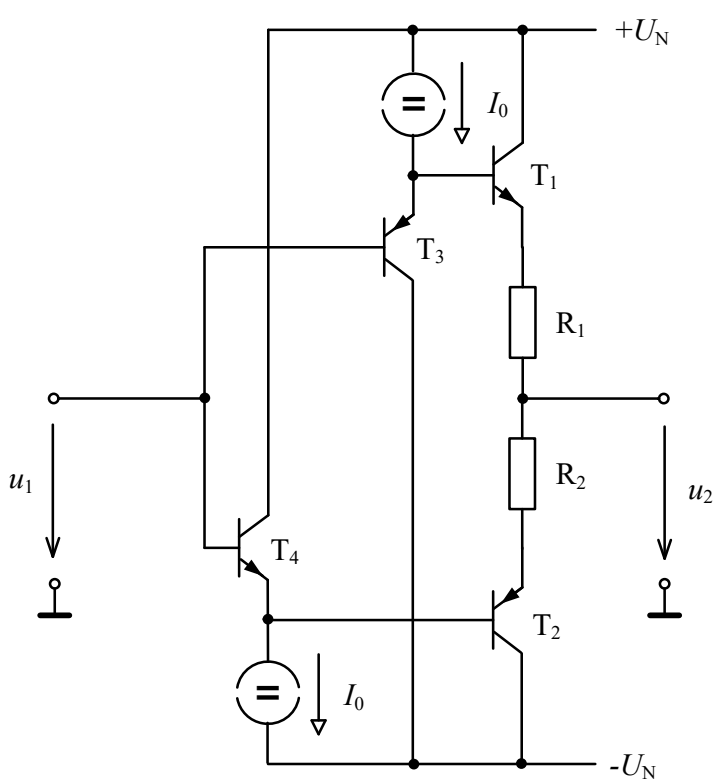

Obr. 2.30: Dvojstupňový komplementární emitorový sledovač

Přechodové zkreslení je možné potlačit i pomocí jediného zdroje předpětí tak, jak je to ukázáno na principiálně na Obr. 2.31a. Napětí $U_{\mathrm{P} 3}$ musí být nyní o trochu menší, než je součet napětí $\mathrm{BE}$ u obou tranzistorů tj. $U_{\mathrm{P} 3} \approx 2 \cdot 0,6 \mathrm{~V}=1,2 \mathrm{~V}$. Př́k lad takového řešení je uveden na Obr. 2.31b. Zdroj předpětí je realizován tzv. „násobičem $u_{\mathrm{BE}}$ “ $\mathrm{s}$ tranzistorem $\mathrm{T}_{3}$ a rezistory $\mathrm{R}_{3}$, $\mathrm{R}_{4}$. Návrh „násobiče $u_{\mathrm{BE}}$ “ bude ukázán později, zde pouze bez odvození

$$
U_{\mathrm{P} 3} \approx u_{\mathrm{BE}}\left(1+R_{3} / R_{4}\right)=0,6 \cdot\left(1+R_{3} / R_{4}\right) \text {. }
$$

Pokud má být na výstupu bez buzení $0 \mathrm{~V}$, musí mít vstupní napětí ss složku $-0,6 \mathrm{~V}$.
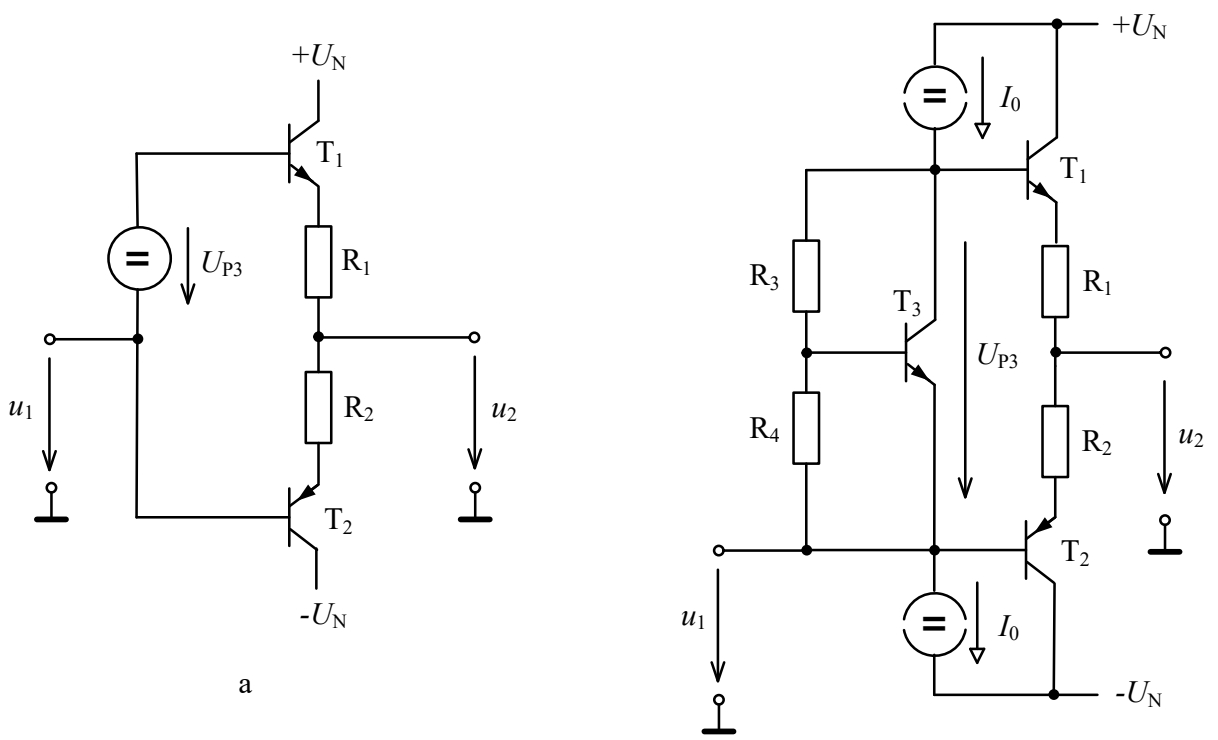

Obr. 2.31: Nastavení režimu AB pomocí: a) jednoho zdroje napětí, b) „násobiče $u_{\mathrm{BE}}$ ““ 


\section{Proudový posilovač}

U předchozích zapojení může být proud dodávaný do zátěže několik desítek miliampérů. Při požadavku na větší výstupní proud je nutno použít výkonové tranzistory, které jsou schopny do zátěže dodat proudy až několik ampérů. Protože ale takové tranzistory mají malý proudový zesilovací činitel a tedy do jejich bází tekou velké proudy, které by přetížily předchozí zesilovací stupeň, je nutno použít Darlingtonovo zapojení tranzistorů. Komplementární uspořádání emitorového sledovače s Darlingtonovými dvojicemi tranzistorů je Obr. 2.32a.

Aby zapojení pracovalo ve trrídě $\mathrm{AB}$, je nutno vykompenzovat napětí na čtyřech přechodech BE. To je možné splnit, definujeme-li pracovní body pouze pro tranzistory $\mathrm{T}_{1} \mathrm{a}_{3}$, které při větších proudech do bází výkonových tranzistorů budou mít napětí $U_{\mathrm{BEP}} \approx 0,7 \mathrm{~V}$.

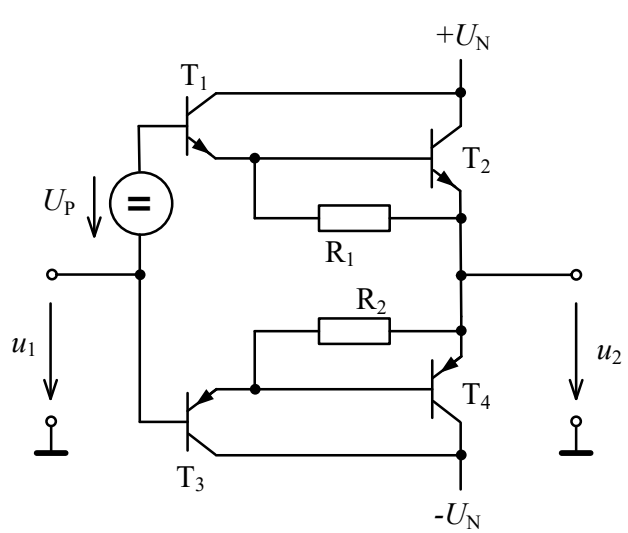

$\mathrm{a}$

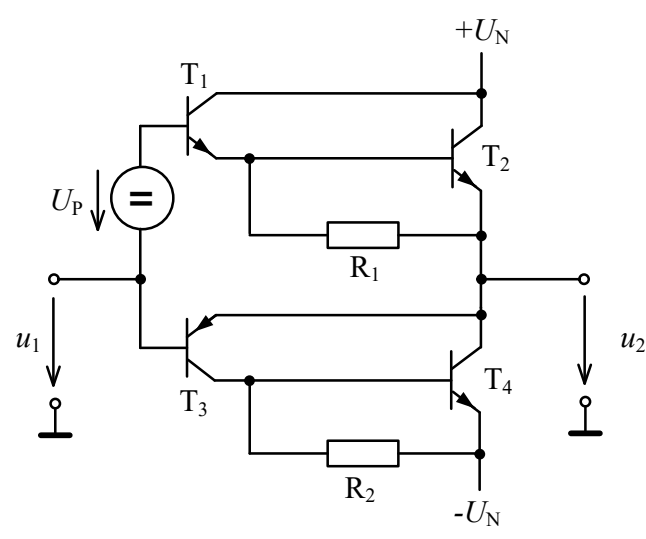

b

Obr. 2.32: Proudový posilovač: a) komplementární Darlingtonovo zapojení, b) kvazikomplementární Darlingtonovo zapojení

Potom se tranzistory $\mathrm{T}_{2}$ a $\mathrm{T}_{4}$ budou otvírat až při velkých proudech do zátěže. $\mathrm{S}$ tímto záměrem nastavíme napětí $U_{\mathrm{P}}$ tak, aby úbytky na rezistorech $\mathrm{R}_{1}, \mathrm{R}_{2}$ byly kolem $0,4 \mathrm{~V}$. Proto

$$
U_{\mathrm{P}} \approx 2(0,4 \mathrm{~V}+0,7 \mathrm{~V})=2,2 \mathrm{~V}
$$

a budicí napětí $u_{1}$ pak musí obsahovat ss složku $-1,1 \mathrm{~V}$. Pokud bude obvod bez buzení, budou výkonové tranzistory $\mathrm{T}_{2}$ a $\mathrm{T}_{4}$ zavřeny. Proto při malém proudu do zátěže budou dodávat tento proud prŕmo do výstupu tranzistory $\mathrm{T}_{1}$ nebo $\mathrm{T}_{3}$ přes rezistory $\mathrm{R}_{1}$ nebo $\mathrm{R}_{2}$. Pokud proud do zátěže zvětší úbytek napětí na $\mathrm{R}_{1}$ nebo $\mathrm{R}_{2}$ na hodnotu $0,7 \mathrm{~V}$, otevře se tranzistor $\mathrm{T}_{2}$ nebo $\mathrm{T}_{4}$ a proud do zátěže je pak dodáván těmito výkonovými tranzistory. Podle požadovaného proudu do zátěže bývá odpor rezistorů $\mathrm{R}_{1}$ a $\mathrm{R}_{2}$ obvykle v rozmezí 10 až $50 \Omega$.

Pokud by se tranzistory $\mathrm{T}_{2}$ a $\mathrm{T}_{4}$ přehřívaly a vznikla kladná tepelná vazba, která by mohla tranzistory zničit, bude tento stav doprovázen zvyšováním proudu do bází $T_{2}$ a $T_{4}$. $Z$ tohoto důvodu poteče většina emitorového proudu tranzistorů $\mathrm{T}_{1}$ a $\mathrm{T}_{3}$ do báze výstupních tranzistorů, proud rezistorem $R_{1}$, resp. $R_{2}$ bude menší a menší bude i úbytek napětí na rezistoru $R_{1}$ nebo $R_{2}$, což způsobí uzavření koncových tranzistorů.

Rezistory $\mathrm{R}_{1}$ a $\mathrm{R}_{2}$ současně slouží pro odvod náboje $\mathrm{z}$ bází výstupních tranzistorů. Čím budou tyto odpory menší, tím rychleji se budou výstupní tranzistory zavírat. Je to důležité v těch př́padech, kdy při změně polarity $u_{1}$ se jeden tranzistor otevře, zatímco druhý ještě není zavřen. 
V tom př́padě by přes oba koncové tranzistory tekl příčný proud, jehož důsledkem by byl tzv. sekundární průraz, kdy dojde k protavení přechodu, což ve svém důsledku znamená nevratný zkrat mezi emitorem a kolektorem.

Někdy je zapotřebí v koncovém stupni použít výkonové tranzistory jednoho typu. To proto, že realizace výkového tranzistoru NPN, je při integraci obvodu snažší, než realizace výkonového tranzistoru PNP. V tom př́padě použijeme kvazikomplementární Darlingtonovo zapojení tranzistorů (Obr. 2.32b). Podobně jako v předchozím obvodu úbytek napětí na rezistorech $\mathrm{R}_{1}, \mathrm{R}_{2}$ musí být bez buzení přibližně $0,4 \mathrm{~V}$. Předpětí $U_{\mathrm{P}}$ nyní bude mít hodnotu $U_{\mathrm{P}} \approx 0,4 \mathrm{~V}+2 \cdot 0,7 \mathrm{~V}=1,8 \mathrm{~V}$. Budicí napětí $u_{1}$ musí nyní obsahovat ss složku $-0,7 \mathrm{~V}$. Klidový proud přes tranzistor $T_{3}$ a rezistor $R_{2}$ teče $k$ zápornému napájecímu zdroji. Zvolíme-li $R_{1}=R_{2}$, bude lom přechodové charakteristiky při napětí $\pm 0,4 \mathrm{~V}$. Stejně jako $\mathrm{v}$ předchozím př́padě slouží rezistory $R_{1}$ a $R_{2}$ současně $k$ rychlejšímu obvodu náboje $z$ báze tranzistorů $T_{2}, T_{4}$ a tím se urychlí rozpojení těchto výkonových tranzistorů.

\subsubsection{Tranzistor jako zdroj referenčního napětí}

V integrovaných obvodech se jako zdroj malého napětí místo diody používá přechod BE tranzistoru. Technologicky je totiž snažší vyrobit tranzistor společně s dalšími tranzistory a v propojovací vrstvě jej zapojit jako diodu. Obvykle se použije přechod BE v propustném směru (Obr. 2.33a). Přechod $\mathrm{CB}$ se jako dioda nepoužívá. Vlastnosti přechodu $\mathrm{BE}$ provozovaném v propustném směru jsou shodné jako u křemíkové diody, tj. $u_{\mathrm{BE}} \approx 0,6 \mathrm{~V}$ až $0,7 \mathrm{~V}, \Delta u_{\mathrm{BE}} / \Delta T \approx-2 \mathrm{mV} /{ }^{\circ} \mathrm{C}$.

Přechod BE provozovaný v závěrném směru se chová jako Zenerova dioda (Obr. 2.34b) s napětím $u_{\mathrm{EB}} \approx 7 \mathrm{~V}$ a $\Delta u_{\mathrm{EB}} / \Delta T \approx+3 \mathrm{mV} /{ }^{\circ} \mathrm{C}$. Pro úplnost ještě poznamenejme, že v poslední uvedené variantě tranzistoru zapojeného jako Zenerova dioda vykazuje přechod $\mathrm{CB}$ provozovaný v závěrném směru Zenerovo napětí $u_{\mathrm{CB}}=20$ až $300 \mathrm{~V}$ a tedy při napětí $7 \mathrm{~V}$ se tento přechod neotevře. Pokud je zapotřebí vyšší napětí, řadí se prvky v sérii $(O b r .2 .33 \mathrm{c}, \mathrm{d})$. $\mathrm{V}$ př́padě užití přechodů EB tranzistorů jako dvou Zenerových diod platí obdobně, že přechod $\mathrm{CB}$ provozovaný $\mathrm{v}$ závěrném směru má napětí $u_{\mathrm{CB}}>2 u_{\mathrm{EB}}$ a přechod $\mathrm{CB}$ se proto neotevře. 

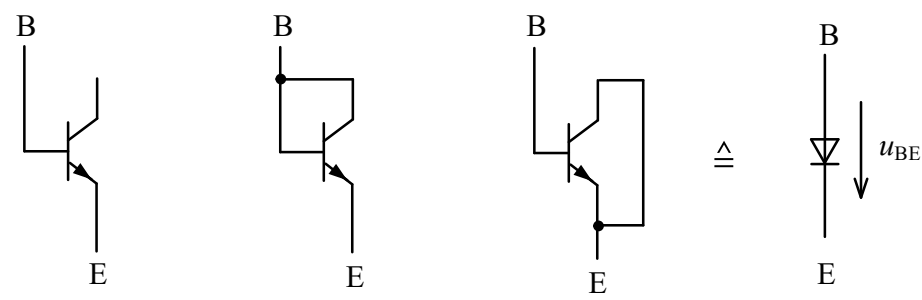

a
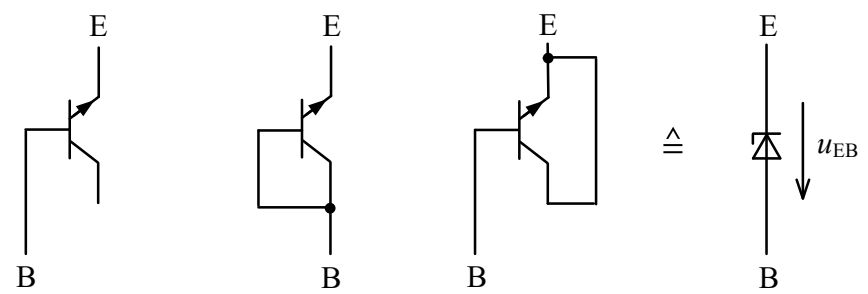

$\mathrm{b}$
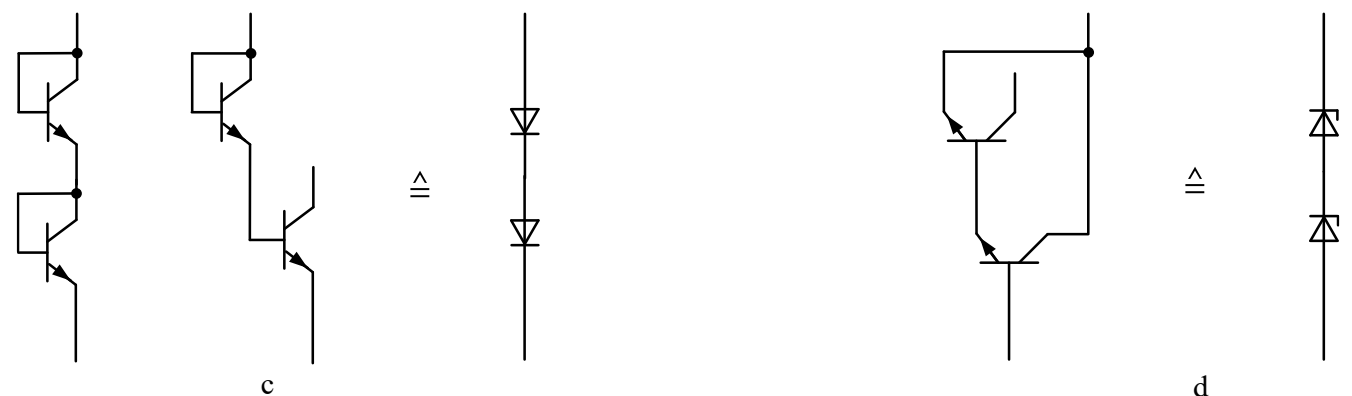

d

Obr. 2.33: Tranzistor zapojený jako: a) dioda, b) Zenerova dioda, c) d) řazení přechodů v sérii

Uvedené teplotní závislosti používaných referenčních prvků jsou mnohdy pro praktická použití nepř́ípustně velké. $\mathrm{V}$ takových případech využíváme obvykle možnosti kompenzovat kladný teplotní činitel přechodu BE provozovaném v závěrném směru záporným teplotním činitelem přechodu BE pracující v propustném směru (Obr. 2.34a). Někdy se ke stejnému účelu použije tranzistor se dvěma emitory (Obr. 2.34b). V tomto př́padě je jeden $\mathrm{z}$ přechodů $\mathrm{BE}$ využíván v závěrném směru a pracuje jako referenční dioda, druhý pracuje v propustném směru. Nežádoucí tranzistorové jevy se dají potlačit volbou dostatečné vzdálenosti mezi oblastmi emitorů a použitím rezistoru $\mathrm{R}_{\mathrm{B}} \mathrm{v}$ prrívodu báze $\left(R_{\mathrm{B}} \approx 1 \mathrm{k} \Omega\right)$. Výstupní napětí v obou př́padech

$$
U_{\mathrm{R}}=u_{\mathrm{BE}}+u_{\mathrm{EB}}
$$

má teplotní činitel

$$
\Delta U_{\mathrm{R}} / \Delta T=\Delta u_{\mathrm{BE}} / \Delta T+\Delta u_{\mathrm{EB}} / \Delta T .
$$

Při $u_{\mathrm{EB}}=7 \mathrm{~V}, \Delta u_{\mathrm{EB}} / \Delta T=+3 \mathrm{mV} /{ }^{\circ} \mathrm{C}$ a $u_{\mathrm{BE}}=0,6 \mathrm{~V}, \Delta u_{\mathrm{EB}} / \Delta T=-2 \mathrm{mV} /{ }^{\circ} \mathrm{C}$ je tedy referenční napětí $U_{\mathrm{R}}=7,6 \mathrm{~V}$ a má teplotní činitel $\Delta U_{\mathrm{R}} / \Delta T=+1 \mathrm{mV} /{ }^{\circ} \mathrm{C}$.

Velmi přesné referenční napětí se dá nastavit tzv. „násobičem $u_{\mathrm{BE}}$ “ zapojeným podle Obr. 2.35a. Pokud bude proud $i_{\mathrm{B}}$ daleko menší než proud děličem $\mathrm{R}_{1}, \mathrm{R}_{2}$, můžeme dělič řešit jako nezatížený 


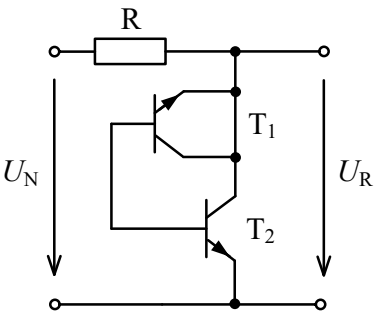

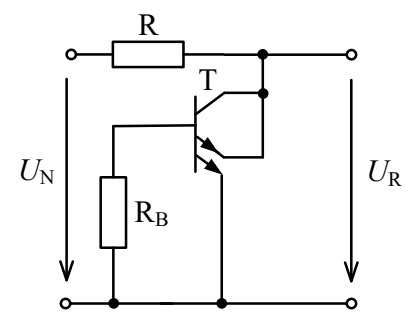

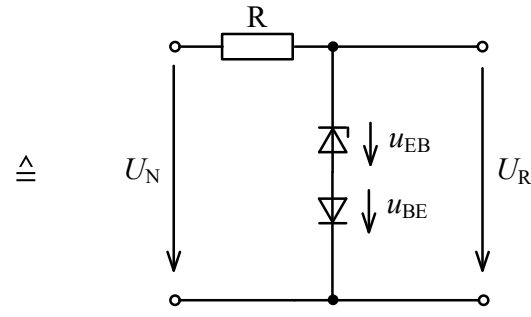

Obr. 2.34: Referenční zdroje napětí s teplotní kompenzací

$$
u_{\mathrm{BE}} \approx \frac{R_{2}}{R_{1}+R_{2}} u_{\mathrm{CE}}
$$

Odtud pro $u_{\mathrm{CE}}$ dostaneme

$$
u_{\mathrm{CE}} \approx\left(1+\frac{R_{1}}{R_{2}}\right) u_{\mathrm{BE}}
$$

Zapojení tedy umožňuje násobit napětí $u_{\mathrm{BE}} \approx 0,6 \mathrm{~V}$ činitelem $\left(1+R_{1} / R_{2}\right)$. To znamená, že se takto dá násobit i teplotní činitel $\Delta u_{\mathrm{BE}} / \Delta T$ př̌echodu mezi bází a emitorem použitého tranzistoru.

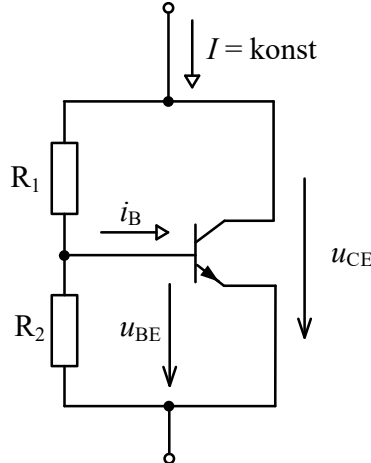

a

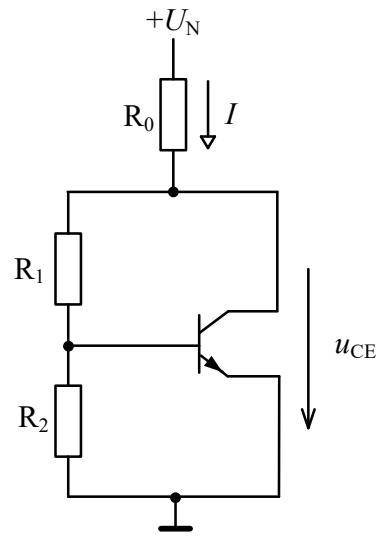

c

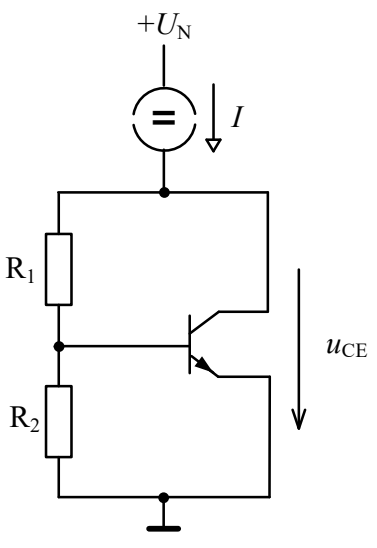

b

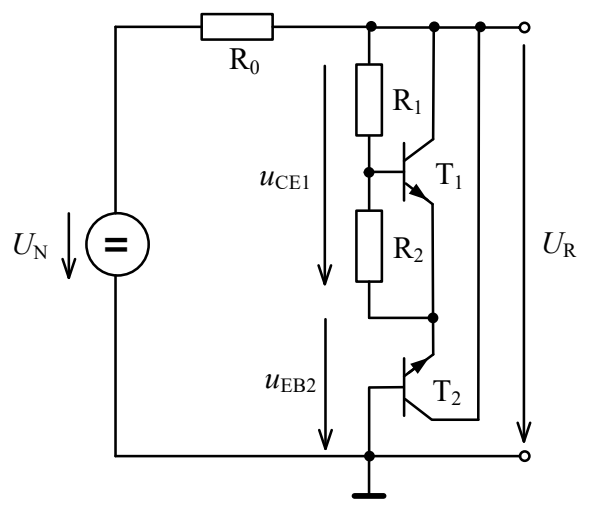

d

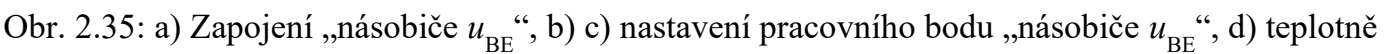
kompenzovaný zdroj s ,násobičem $u_{\mathrm{BE}}$ “ 
V případě napájení ze zdroje napětí (Obr. 2.35b), musí rezistorem $\mathrm{R}_{0}$ téct proud pro nastavení pracovního bodu $I=\left(U_{\mathrm{N}}-u_{\mathrm{CE}}\right) / R_{0}$. V integrovaných obvodech se pro nastavení pracovního bodu obvykle používá zdroj proudu (Obr. 2.35c). Pro nastavení pracovního bodu se obvykle volí $I \approx 1 \mathrm{~mA}$ až $5 \mathrm{~mA}$.

Zapojíme-li takovýto „násobič $u_{\mathrm{BE}}$ “ do série se Zenerovou diodou (viz Obr. 2.35d) bude výstupní napětí $U_{\mathrm{R}}=u_{\mathrm{CE} 1}+u_{\mathrm{EB} 2}, \mathrm{tj}$.

$$
U_{\mathrm{R}}=\left(1+\frac{R_{1}}{R_{2}}\right) u_{\mathrm{BE} 1}+u_{\mathrm{EB} 2}
$$

Teplotní závislost takového obvodu pak bude

$$
\frac{\Delta U_{\mathrm{R}}}{\Delta T}=\left(1+\frac{R_{1}}{R_{2}}\right) \frac{\Delta u_{\mathrm{BE} 1}}{\Delta T}+\frac{\Delta u_{\mathrm{EB} 2}}{\Delta T} .
$$

Protože činitel $\Delta u_{\mathrm{BE} 1} / \Delta T$ je záporný a $\Delta u_{\mathrm{EB} 2} / \Delta T$ kladný, lze vhodnou volbou poměru $R_{1} / R_{2}$ docílit úplné teplotní kompenzace. Pokud má být teplotní činitel $\Delta U_{\mathrm{R}} / \Delta T=0$, musí platit

$$
\frac{R_{1}}{R_{2}}=-\frac{\Delta u_{\mathrm{EB} 2} / \Delta T}{\Delta u_{\mathrm{BE} 1} / \Delta T}-1
$$

S typickými hodnotami $u_{\mathrm{EB} 2}=7 \mathrm{~V}, \Delta u_{\mathrm{EB} 2} / \Delta T=+3 \mathrm{~m} \mathrm{~V} /{ }^{\circ} \mathrm{C}, u_{\mathrm{BE} 1}=0,6 \mathrm{~V}, \Delta u_{\mathrm{BE} 1}$ / $\Delta T=-2 \mathrm{mV} /{ }^{\circ} \mathrm{C}$ dostaneme $R_{1} / R_{2}=0,5$. Takto stabilizované referenční napětí má pak velikost $U_{\mathrm{R}} \approx 7,9 \mathrm{~V}$. Aby byl proud děličem $\mathrm{R}_{1}, \mathrm{R}_{2}$ daleko větší než proud do báze $\mathrm{T}_{1}$, volí se obvykle $R_{1}=105 \Omega$ a $R_{2}=210 \Omega$.

\subsubsection{Tranzistor jako zdroj proudu}

Tranzistory jako zdroj konstantního proudu je většinou užíván v integrovaných obvodech pro nastavení pracovního bodu tranzistoru. Používá se také v proudových zrcadlech, které kopírují vstupní proud, nebo jej zesílí či zeslabí. Obecně tak pracují jako zdroj proudu řízený proudem. Pokud je proudové zrcadlo buzeno konstantním proudem, lze jej také využít jako zdroj konstantního proudu. Zdroje konstantního proudu i proudová zrcadla se pak dají s výhodou aplikovat jako tzv. aktivní zátěž tranzistorových zesilovacích stupňů.

\section{Tranzistorový zdroj konstantního proudu}

Jako zdroj proudu se dá použít tranzistor v zapojení se společným emitorem (Obr. 2.36a), když využijeme jako výstupní veličinu kolektorový proud. Kolektorový proud je totiž téměř konstantní bez ohledu na velikost zátěže $R_{Z}$, resp. nezávisí na úbytku napětí na zátěži. Je to zřejmé z výstupní charakteristiky $i_{\mathrm{C}}\left(u_{\mathrm{CE}}\right)$ na Obr. $2.36 \mathrm{~b}$, protože $i_{\mathrm{C}}$ závisí na $u_{\mathrm{CE}}$ jen nepatrně, jelikož charakteristiky jsou téměř vodorovné. Tato vlastnost je navíc podpořena zavedením záporné zpětné vazby pomocí rezistoru $R_{\mathrm{E}}$. 


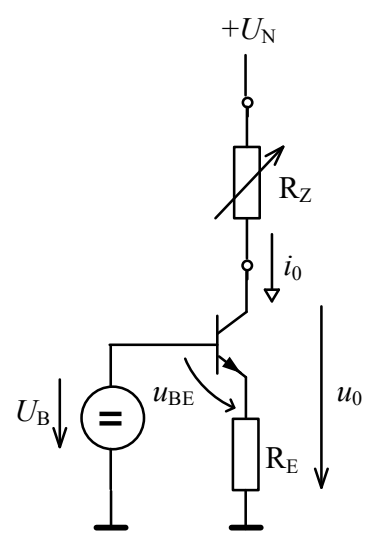

a

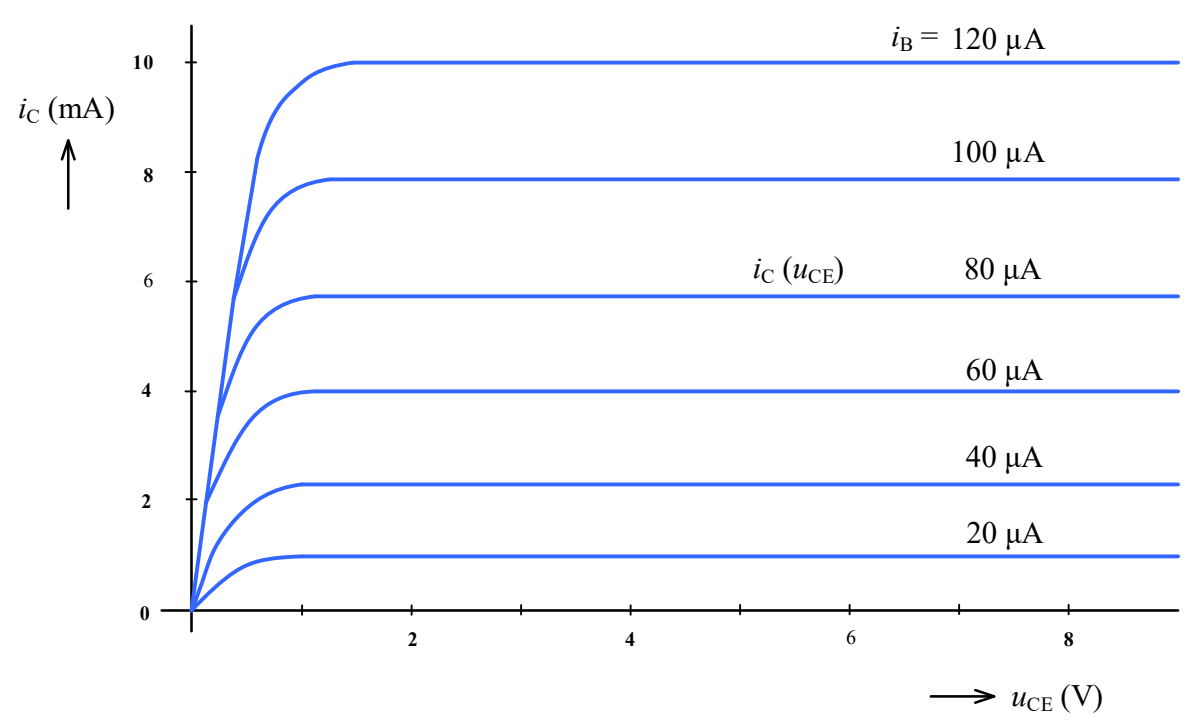

b

Obr. 2.36: a) Základní zapojení zdroje proudu s tranzistorem, b) výstupní charakteristiky tranzistoru

Zanedbáváme-li proud do báze tranzistoru (Obr. 2.36a), bude

$$
i_{0}=i_{\mathrm{C}} \approx i_{\mathrm{E}}=\frac{U_{\mathrm{B}}-u_{\mathrm{BE}}}{R_{\mathrm{E}}} \approx \frac{U_{\mathrm{B}}-0,6}{R_{\mathrm{E}}} .
$$

Statický vnitřní odpor zdroje proudu $U_{\mathrm{CE}} / I_{\mathrm{C}}$ je malý, typicky jen několik kiloohmů.

Diferenciální vnitřní odpor pro malé střídavé změny je ale značně velký. Diferenciální vnitřní odpor můžeme stanovit s využitím modelu tranzistoru pro stř́davé změny

$$
r_{0}=\left.\frac{\partial u_{0}}{\partial i_{0}}\right|_{U_{\mathrm{B}}=\text { konst }} \approx r_{\mathrm{CE}}\left(1+\frac{\beta R_{\mathrm{E}}}{R_{\mathrm{E}}+r_{\mathrm{BE}}}\right)=r_{\mathrm{CE}}\left(1+g_{\mathrm{m}} \frac{r_{\mathrm{BE}} R_{\mathrm{E}}}{R_{\mathrm{E}}+r_{\mathrm{BE}}}\right) .
$$

$\mathrm{Z}$ diskuse rovnice vyplývá, že pro $R_{\mathrm{E}}=0$ bude výstupní odpor pouze $r_{0} \approx r_{\mathrm{CE}}$ a pro $R_{\mathrm{E}} \gg r_{\mathrm{BE}}$ bude naopak nejvyšší $r_{0} \approx \beta r_{\mathrm{CE}}=g_{\mathrm{m}} r_{\mathrm{BE}} r_{\mathrm{CE}}$. Bohužel již při odporu $R_{\mathrm{E}}=10 \mathrm{k} \Omega$, by vzniklo na takovém rezistoru při proudu $1 \mathrm{~mA}$ napětí $10 \mathrm{~V}$. To ovšem omezuje možný úbytek napětí na zátěži $R_{\mathrm{Z}}$. Proto se obvykle volí kompromis $R_{\mathrm{E}} \approx 100 \Omega$ až $1 \mathrm{k} \Omega$. Vnitřní diferenciální odpor zdroje proudu proto bývá typicky z rozmezí hodnot $r_{0} \approx 100 \mathrm{k} \Omega$ až $1 \mathrm{M} \Omega$.

\section{Jednoduché zdroje konstantního proudu}

Dvě zapojení jednoduchých proudových zdrojů používaná při diskrétní realizaci obvodů jsou uvedena na Obr. 2.37a, b. Pokud u zdroje proudu nakresleném na Obr. 2.37a zvolíme proud děličem $i_{\mathrm{D}} \gg i_{\mathrm{B}}$, můžeme dělič $\mathrm{R}_{1}, \mathrm{R}_{2}$ řešit jako nezatížený, tj. $u \approx U_{\mathrm{N}} R_{2} /\left(R_{1}+R_{2}\right)$. Výstupní proud pak

$$
i_{0}=i_{\mathrm{C}} \approx i_{\mathrm{E}}=\frac{u_{\mathrm{RE}}}{R_{\mathrm{E}}}=\frac{u-u_{\mathrm{BE}}}{R_{\mathrm{E}}}=\frac{1}{R_{\mathrm{E}}}\left(\frac{R_{2}}{R_{1}+R_{2}} U_{\mathrm{N}}-u_{\mathrm{BE}}\right), \text { kde } u_{\mathrm{BE}} \approx 0,6 \mathrm{~V} .
$$

Výstupní proud bude závislý na teplotě, protože $u_{\mathrm{BE}}$ závisí na teplotě. Z rov. (2-52) pro teplotní změny výstupního proudu vyplývá 


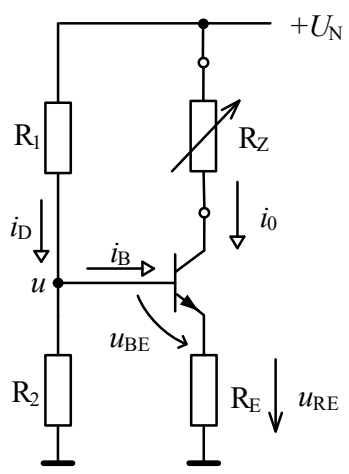

a

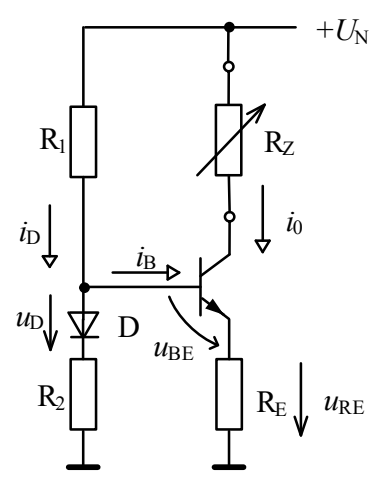

b

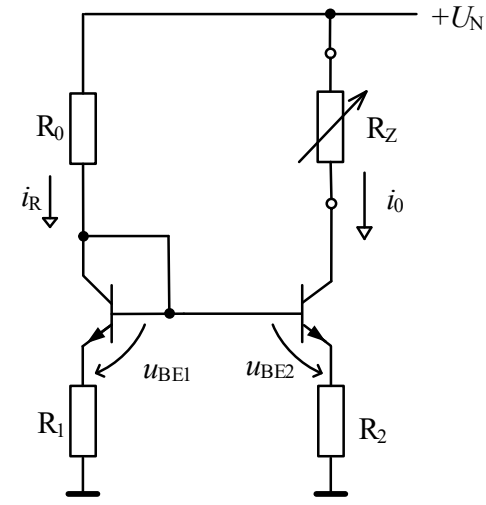

Obr. 2.37: Jednoduché zdroje konstantního proudu: a) b) pro diskrétní realizaci, c) pro integraci

$$
\frac{\Delta i_{0}}{\Delta T}=-\frac{1}{R_{\mathrm{E}}} \frac{\Delta u_{\mathrm{BE}}}{\Delta T} \approx \frac{2 \mathrm{mV} /{ }^{\circ} \mathrm{C}}{R_{\mathrm{E}}} .
$$

Citlivost na teplotu lze snižovat zvyšováním odporu rezistoru $R_{E}$.

V zapojení na Obr. $2.37 \mathrm{~b}$ je teplotní závislost redukována kompenzací $u_{\mathrm{BE}}$ napětím na diodě $u_{\mathrm{D}} \approx u_{\mathrm{BE}}$. Budeme-li opět předpokládat, že proud děličem $i_{\mathrm{D}} \gg i_{\mathrm{B}}$, bude

$$
i_{\mathrm{D}} \approx \frac{U_{\mathrm{N}}-u_{\mathrm{D}}}{R_{1}+R_{2}}
$$

Protože $i_{\mathrm{E}} \approx i_{\mathrm{C}}=i_{0}$, bude platit $i_{\mathrm{D}} R_{2} \approx i_{0} R_{\mathrm{E}}$ a odtud výstupní proud

$$
i_{0} \approx \frac{R_{2}}{R_{\mathrm{E}}} i_{\mathrm{D}} \approx \frac{1}{R_{\mathrm{E}}} \frac{R_{2}}{R_{1}+R_{2}}\left(U_{\mathrm{N}}-u_{\mathrm{D}}\right)
$$

V tomto případě bude teplotní závislost výstupního proudu

$$
\frac{\Delta i_{0}}{\Delta T} \approx-\frac{1}{R_{\mathrm{E}}} \frac{R_{2}}{R_{1}+R_{2}} \frac{\Delta u_{\mathrm{D}}}{\Delta T} \approx \frac{1}{R_{\mathrm{E}}} \frac{R_{2}}{R_{1}+R_{2}} \cdot 2 \mathrm{mV} /{ }^{\circ} \mathrm{C} .
$$

Teplotní činitel bude nyní navíc redukován dělícím poměrem rezistorového děliče $\mathrm{R}_{1}, \mathrm{R}_{2}$.

V integrovaných obvodech se obvykle ve zdroji konstantního proudu k teplotní kompenzaci používá tranzistor zapojený jako dioda (Obr. 2.37c). Budeme předpokládat, že oba tranzistory jsou shodné, tj mají $u_{\mathrm{BE} 1} \approx u_{\mathrm{BE} 2}=0,6 \mathrm{~V}$. Pokud zanedbáváme proudy do bází tranzistorů bude

$$
i_{\mathrm{R}} \approx \frac{U_{\mathrm{N}}-u_{\mathrm{BE} 1}}{R_{0}+R_{1}} .
$$

Protože $u_{\mathrm{BE} 1} \approx u_{\mathrm{BE} 2}$, bude $i_{\mathrm{R}} R_{1} \approx i_{0} R_{2}$ a můžeme odtud stanovit výstupní proud

$$
i_{0} \approx \frac{R_{1}}{R_{2}} i_{\mathrm{R}} \approx \frac{R_{1}}{R_{2}} \frac{U_{\mathrm{N}}-u_{\mathrm{BE} 1}}{R_{0}+R_{1}},
$$


Obvykle $R_{1}=R_{2}$ a pak

$$
i_{0} \approx \frac{U_{\mathrm{N}}-u_{\mathrm{BE} 1}}{R_{0}+R_{1}} \approx \frac{U_{\mathrm{N}}-0,6}{R_{0}+R_{1}} .
$$

\section{Jednoduché Widlarovo proudové zrcadlo}

Zdroj proudu na Obr. 2.37c ve své podstatě představuje proudový opakovač, kdy výstupní proud $i_{0}$ zrcadlí vstupní proud $i_{\mathrm{R}}$. Pokud $\mathrm{v}$ integrovaném obvodě budou tranzistory $\mathrm{T}_{1}$ a $\mathrm{T}_{2}$ úplně shodné, lze rezistory v emitorech tranzistorů vypustit (Obr. 2.38a). Zapojení bývá v literatuře označováno jako Widlarovo proudové zrcadlo.

Při shodnosti tranzistorů bude $u_{\mathrm{BE} 1} \approx u_{\mathrm{BE} 2}, i_{\mathrm{B} 1} \approx i_{\mathrm{B} 2}=i_{\mathrm{B}}, \beta_{1}=\beta_{1}=\beta$. Vstupní proud $i_{1}$ $=i_{\mathrm{C} 1}+2 i_{\mathrm{B}}$ a protože $i_{\mathrm{C} 1} \approx \beta i_{\mathrm{B}}$ bude $i_{1} \approx \beta i_{\mathrm{B}}+2 i_{\mathrm{B}}=i_{\mathrm{B}}(\beta+2)$. Protože $i_{2} \approx \beta i_{\mathrm{B}}$, resp. $i_{\mathrm{B}} \approx i_{2} / \beta$ bude pro vstupní proud platit

$$
i_{1} \approx \frac{\beta+2}{\beta} i_{2}
$$

Odtud již můžeme vyčíslit proudový přenos zrcadla

$$
K_{\mathrm{I}}=\frac{i_{2}}{i_{1}} \approx \frac{\beta}{\beta+2} \approx 1 .
$$

Č́m větší bude proudový zesilovací činitel $\beta$, tím lépe se bude proudový přenos tohoto opakovače blížit jedné. Např. při $\beta=100$ bude $K_{\mathrm{I}} \approx 0,98$, tedy asi o $2 \%$ menší než požadovaný přenos $K_{\mathrm{I}}=1$.

Diferenciální výstupní odpor bude podle rov. (2-51) v tomto př́ípadě $r_{0} \approx r_{\mathrm{CE}} \approx 100 \mathrm{k} \Omega$. Stále je to však př́znivá hodnota, protože proud $1 \mathrm{~mA}$ by na statickém odporu $100 \mathrm{k} \Omega$ vyvolal napětí $100 \mathrm{~V}$. Rozdílné napětí $u_{\mathrm{CE} 1}=0,6 \mathrm{~V}$ a $u_{\mathrm{CE} 2}=2$ až $20 \mathrm{~V}$ může způsobit chybu přenosu až $20 \%$. Proudový zesilovací činitel tranzistoru $\mathrm{T}_{2}$ se totiž v závislosti na rostoucím $u_{\mathrm{CE} 2}$ zvětšuje (tzv. Earlyho efekt) a tím roste jeho kolektorový proud (viz přenosová charakteristika tranzistoru na Obr. 2.11a). K omezení této chyby se do emitorů tranzistorů zařazují rezistory $\mathrm{R}_{1}$ a $\mathrm{R}_{2}$ pracující jako záporná proudová zpětná vazba stejně jako to bylo u zapojení na Obr. 2.37c. Typicky se volí tyto rezistory 50 až $200 \Omega$.

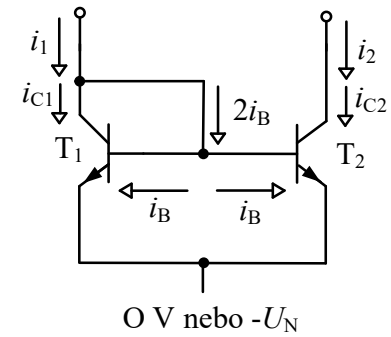

a

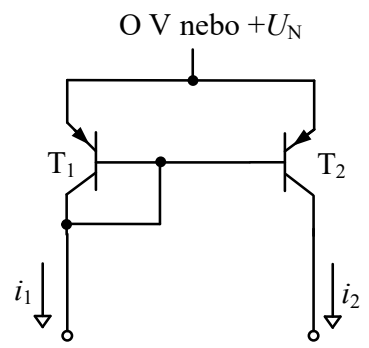

$\mathrm{b}$

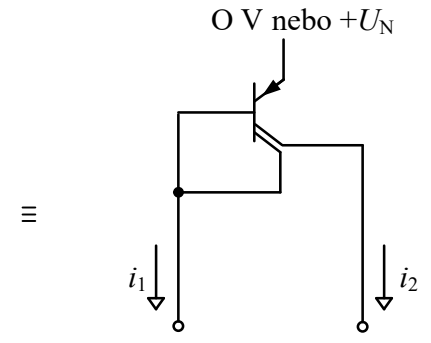

c

Obr. 2.38: a) Widlarovo proudové zrcadlo, b) komplementární zapojení, c) integrované komplementární proudové zrcadlo s tranzistorem se dvěma kolektory 
Proudové zrcadlo je možné realizovat i v komplementární podobě s tranzistory PNP (viz Obr. 2.38b). Uspořádání komplementárního proudového zrcadla vhodné k integraci, kdy jsou dva tranzistory PNP s př́mo spojenými bázemi a emitory nahrazeny jediným tranzistorem se dvěma kolektory, je pak naznačeno na Obr. 2.38c.

Proudová zrcadla ve funkci zdroje konstantního proudu se užívají jednak pro nastavení stejnosměrných pracovních proudů tranzistorů, ale také jako tzv. aktivní zátěž tranzistorových zesilovacích stupňủ pro zvětšení jejich zesílení. Příklad nastavení pracovního bodu emitorového zesilovače je na Obr. 2.39a. Čím větší bude odpor $R_{\mathrm{E}}$, tím více se bude přenos blížit jedné a vstupní odpor bude větší. Avšak při $R_{\mathrm{E}}=100 \mathrm{k} \Omega$ a $I_{\mathrm{CP}}=1 \mathrm{~mA}$ by na něm vznik1 úbytek napětí $100 \mathrm{~V}$. Pokud rezistor $\mathrm{R}_{\mathrm{E}}$ nahradíme zdrojem proudu s proudovým zrcadlem, kterým se nastaví ss proud $I_{\mathrm{CP}} \approx I_{\mathrm{E}} \approx I_{\mathrm{R}} \approx\left(U_{\mathrm{N}}-0,6 \mathrm{~V}\right) / R=1 \mathrm{~mA}$; bude odpor $R_{\mathrm{E}}$ pro střídavé signály nahrazen dynamickým vnitřním odporem zdroje proudu $r_{0} \approx r_{\mathrm{CE}} \approx 100 \mathrm{k} \Omega$. $\mathrm{Z}$ podobných důvodů se zdroj konstantního proudu s proudovým zrcadlem užije u zesilovače v zapojení SE jako tzv. aktivní zátěž (Obr. 2.39b). Zdroj proudu nastaví tranzistorem $\mathrm{T}_{1}$ požadovaný klidový ss proud $I_{\mathrm{CP}} \approx I_{\mathrm{R}} \approx\left(U_{\mathrm{N}}-0,6 \mathrm{~V}\right) / R=1 \mathrm{~mA}$, ale jeho vnitřní dynamický odpor pro střídavé signály bude $r_{0} \approx r_{\mathrm{CE}} \approx 100 \mathrm{k} \Omega$, takže zesílení $A_{\mathrm{U}} \approx-g_{\mathrm{m} 1} r_{\mathrm{CE}}$ bude větší.

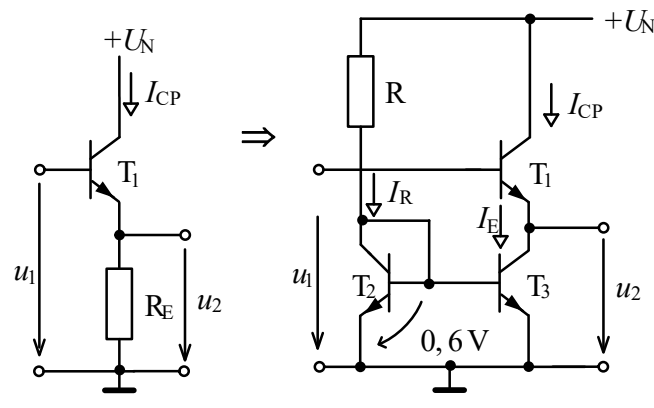

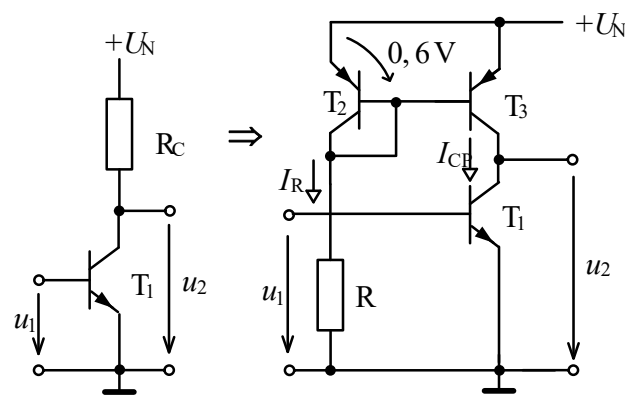

b

Obr. 2.39: a) Nastavení pracovního bodu emitorového sledovače, b) zesilovač v zapojení SE s aktivní zátěží

\section{Proudové zrcadlo s redukcí proudu do bází tranzistorů}

Malý proudový zesilovací činitel $\beta$ tranzistorů má nepř́znivý vliv na proudový přenos jednoduchého proudového zrcadla. Způsobuje to proud tekoucí do spojených bází tranzistorů. Zlepšení vlastností je možné přidáním třetího tranzistoru $\mathrm{T}_{3}$, který bude dodávat proud spojeným bázím tranzistorů $\mathrm{T}_{1}$ a $\mathrm{T}_{2}$ (viz Obr. 2.40a).

Budeme-li předpokládat shodné vlastnosti všech tranzistorů $\beta_{1}=\beta_{2}=\beta_{3}=\beta$, bude $i_{\mathrm{B} 1} \approx i_{\mathrm{B} 2}=i_{\mathrm{B}}$. Pro vstupní proud proudového zrcadla platí $i_{1}=i_{\mathrm{C} 1}+i_{\mathrm{B} 3}$, přičemž

$$
i_{\mathrm{C} 1} \approx \beta i_{\mathrm{B}} \text { a } i_{\mathrm{B} 3} \approx i_{\mathrm{E} 3} /(\beta+1)=2 i_{\mathrm{B}} /(\beta+1) .
$$

Odtud

$$
i_{1} \approx \beta i_{\mathrm{B}}+\frac{2}{\beta+1} i_{\mathrm{B}}=i_{\mathrm{B}}\left(\beta+\frac{2}{\beta+1}\right)
$$




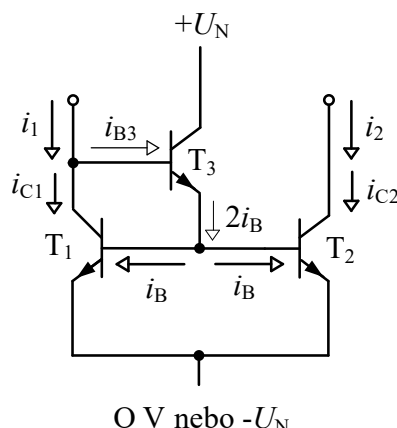

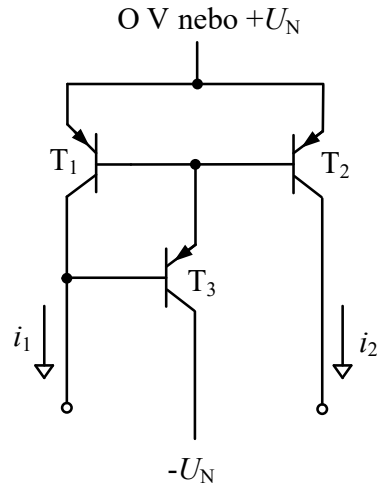

b

Obr. 2.40: Proudové zrcadlo s redukcí proudu do bází tranzistorů: a) NPN, b) PNP

Protože $i_{\mathrm{B}} \approx i_{2} / \beta$, bude

$$
i_{1} \approx \frac{i_{2}}{\beta}\left(\beta+\frac{2}{\beta+1}\right) .
$$

Odtud již můžeme určit proudový přenos

$$
K_{\mathrm{I}}=\frac{i_{2}}{i_{1}} \approx \frac{\beta}{\beta+\frac{2}{\beta+1}}=\frac{\beta^{2}+\beta}{\beta^{2}+\beta+2} \approx 1 .
$$

Pro $\beta \approx 100$ bude $K_{\mathrm{I}} \approx 0,9998$, tzn. chyba přenosu bude jen $0,02 \%$. Vnitřní odpor zdroje bude stejně jako $\mathrm{v}$ předchozím případě $r_{0} \approx r_{\mathrm{CE} 2} \approx 100 \mathrm{k} \Omega$.

Earlyho efekt se zde uplatní podobně jako $\mathrm{v}$ předchozím př́ípadě. Napětí $u_{\mathrm{CE} 1} \approx u_{\mathrm{BE} 1}+$ $u_{\mathrm{BE} 3} \approx 2 u_{\mathrm{BE}} \approx 1,2 \mathrm{~V}$, ale $u_{\mathrm{CE} 2}=2 \mathrm{~V}$ až $20 \mathrm{~V}$. Proto se většinou do emitorů tranzistorů $\mathrm{T}_{1}$ a $\mathrm{T}_{2}$ zařazují rezistory 50 až $200 \Omega$, které tento jev částečně omezí.

Komplementární řešení proudového zrcadla s kompenzací proudů do bází tranzistorů $\mathrm{T}_{1}$ a $\mathrm{T}_{2}$ je nakresleno na (Obr. 2.40b).

\section{Zpětnovazební Wilsonovo zrcadlo}

Dokonalejší Wilsonovo zrcadlo je zapojeno podle Obr. 2.41a. Zdokonalení spočívá $\mathrm{v}$ použití smyčky paralelní proudové zpětné vazby, $\mathrm{v}$ níž emitorový proud tranzistoru $\mathrm{T}_{3}$ působí přes proudový opakovač s tranzistory $T_{1}$ a $T_{2}$ zpětně na proud ve vstupní smyčce opakovače. Díky tomu vykazuje několikanásobně větší vnitřní odpor než předchozí uspořádání. Předpokládejme opět, že tranzistory $\mathrm{T}_{1}, \mathrm{~T}_{2}$ a $\mathrm{T}_{3}$ jsou shodné a tedy $\beta_{1}=\beta_{2}=\beta_{3}=\beta$.

Vstupní proud jednoduchého proudového zrcadla $\mathrm{s}_{1}$ a $\mathrm{T}_{2}$ je

$$
i_{3}=i_{2}+i_{\mathrm{B}}=i_{2}+\frac{i_{2}}{\beta}=i_{2} \frac{\beta+1}{\beta}
$$




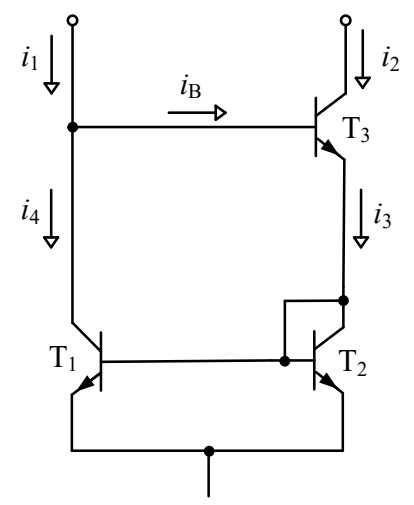

O V nebo $-U_{\mathrm{N}}$

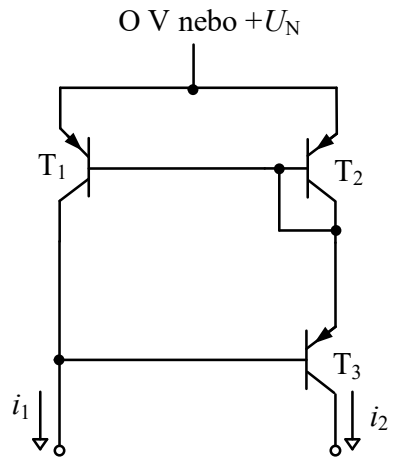

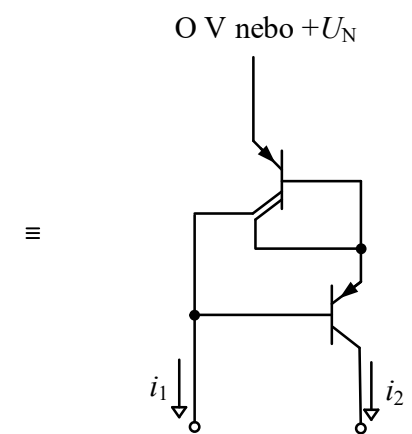

Obr. 2.41: a) Wilsonovo proudové zrcadlo, b) komplementární zapojení, c) integrované proudově zrcadlo $\mathrm{s}$ tranzistorem se dvěma kolektory

Jeho výstupní proud určíme s využitím výsledku (2-60) a (2-65)

$$
i_{4} \approx \frac{\beta}{\beta+2} i_{3}=\frac{\beta+1}{\beta+2} i_{2} \text {. }
$$

Protože

$$
i_{1}=i_{4}+i_{\mathrm{B}} \approx \frac{\beta+1}{\beta+2} i_{2}+\frac{i_{2}}{\beta}=\frac{\beta^{2}+2 \beta+2}{\beta^{2}+2 \beta} i_{2},
$$

můžeme pro proudový přenos Wilsonova zpětnovazebního proudového zrcadla psát

$$
K_{\mathrm{I}}=\frac{i_{2}}{i_{1}} \approx \frac{\beta^{2}+2 \beta}{\beta^{2}+2 \beta+2} \approx 1 .
$$

Výsledek je podobný jako v př́ípadě proudového zrcadla s redukcí proudu do bází tranzistorů, viz rov. (2-64).

Výhodou Wilsonova zapojení je zejména vysoký vnitřní odpor $r_{0} \approx \beta r_{\mathrm{CE} 3} / 2$. Bude-li např. $\beta \approx 100$ a $r_{\mathrm{CE} 3} \approx 100 \mathrm{k} \Omega$, bude vnitřní odpor kolem $5 \mathrm{M} \Omega$. Earlyho efekt, kdy se proudový zesilovací činitel $\beta$ zvyšuje v závislosti na napětí $u_{\mathrm{CE}}$, se nyní uplatní v daleko menší míře, protože $u_{\mathrm{CE} 1}=u_{\mathrm{BE} 3}+u_{\mathrm{BE} 1} \approx 0,6+0,6=1,2 \mathrm{~V}$ a $u_{\mathrm{CE} 2}=u_{\mathrm{BE} 2} \approx 0,6 \mathrm{~V}$.

Přidáním čtvrtého tranzistoru $\mathrm{k}$ Wilsonovu proudovému zrcadlu (viz Obr. 2.42a) získáme modifikované či zlepšené Wilsonovo zrcadlo. Zlepšení přesnosti vstupního a výstupního proudu se dosahuje vyrovnáním napětí kolektoru $\mathrm{T}_{1}$ a $\mathrm{T}_{2}$ na $u_{\mathrm{BE}}=0,6 \mathrm{~V}$. Nyní totiž bude $u_{\mathrm{CE} 1}=u_{\mathrm{BE} 2}+u_{\mathrm{BE} 3}-u_{\mathrm{BE} 4} \approx 0,6 \mathrm{~V}$ a $u_{\mathrm{CE} 2}=u_{\mathrm{BE} 2} \approx 0,6 \mathrm{~V}$. 


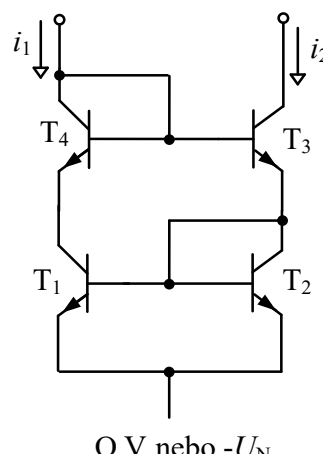

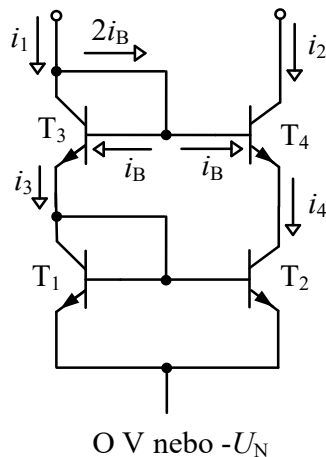

b

Obr. 2.42: a) Zlepšené Wilsonovo proudové zrcadlo, b) kaskódové zapojení proudového zrcadla

\section{Kaskódové zapojení proudového zrcadla}

Jinou cestou, jak zvýšit vnitřní odpor je spojení dvou jednoduchých proudových zrcadel do série (viz Obr. 2.42b). Analogicky jako kaskódové zapojení tranzistoru se nazývá kaskódové proudové zrcadlo. Pro určení proudového přenosu využijeme výsledek (2-60) pro jednoduché Widlarovo zrcadlo

$$
i_{3} \approx \frac{\beta+2}{\beta} i_{4}
$$

kde

$$
i_{3}=i_{\mathrm{B}}+i_{\mathrm{C} 3}=i_{\mathrm{B}}+i_{1}-2 i_{\mathrm{B}}=i_{1}-i_{\mathrm{B}}=i_{1}-\frac{i_{2}}{\beta} .
$$

a podobně

$$
i_{4}=i_{\mathrm{B}}+i_{2}=\frac{i_{2}}{\beta}+i_{2}=\frac{\beta+1}{\beta} i_{2} .
$$

Po dosazení do vztahu (2-69) za $i_{3}$ a $i_{4}$

$$
i_{1}-\frac{i_{2}}{\beta}=\frac{\beta+2}{\beta+1} i_{2}
$$

dostaneme

$$
i_{1}=\left(\frac{\beta+2}{\beta+1}+\frac{1}{\beta}\right) i_{2} .
$$

Proudový přenos pak

$$
K_{\mathrm{I}}=\frac{i_{2}}{i_{1}} \approx \frac{\beta^{2}+2 \beta}{\beta^{2}+2 \beta+2} .
$$

Vnitřní diferenciální odpor kaskódového proudového zrcadla $r_{0} \approx \beta r_{\mathrm{CE} 4} \approx 10 \mathrm{M} \Omega$. 
Proudové zrcadlo s přenosem jiným než jednotkovým

Možnost vytvoření proudového zrcadla u něhož je $K_{\mathrm{I}} \neq 1$, nám dává použití emitorových rezistorů s rozdílnými odpory v obvodu proudového zrcadla podle Obr. 2.43a. Má-li být $i_{2}<i_{1}$ je nutno volit $R_{1}<R_{2}$, jestliže $i_{2}>i_{1}$ bude naopak $R_{1}>R_{2}$. Bude-li splněna podmínka $1+R_{1} / R_{2} \ll \beta$, bude pro proudový přenos přibližně platit $K_{\mathrm{I}} \approx R_{1} / R_{2}$.

V krajním př́ípadě rezistor s menším odporem úplně vypustíme. Řešení pak není úplně jednoduché, protože vlastnosti tranzistoru je nutno modelovat exponenciální funkcí. Zapojením proudového zrcadla podle Obr. $2.43 \mathrm{~b}$ lze realizovat proudový přenos pro $K_{\mathrm{I}} \epsilon\langle 0,01 \mathrm{až} 1\rangle$. Zapojením podle Obr. $2.43 \mathrm{c}$ se bez potíží dá realizovat proudový přenos $K_{\mathrm{I}} \epsilon\langle 1$ až 100$\rangle$.

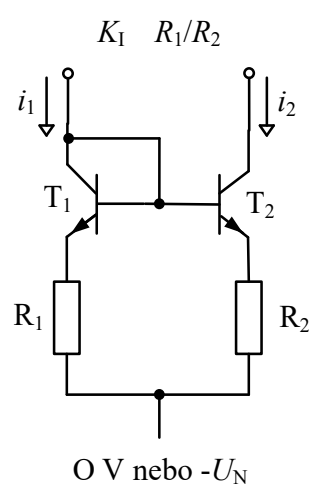

a

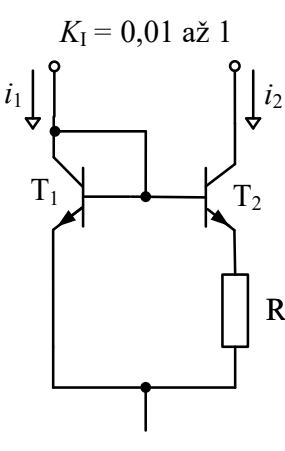

$\mathrm{O} \mathrm{V}$ nebo $-U_{\mathrm{N}}$

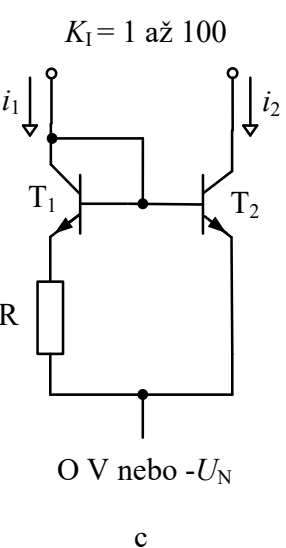

$\mathrm{c}$

Obr. 2.43: Proudová zrcadla s přenosem jiným než jedna

\section{Vicevýstupové proudové zrcadlo}

Vícevýstupová proudová zrcadla se používají jako zdroje konstantního proudu pro nastavení pracovních proudů tranzistorových zesilovacích stupňů a také jako aktivní zátěže diferenčních tranzistorových zesilovačů. Přednostně se využívá zapojení proudového zrcadla $\mathrm{s}$ redukcí proudu do bází tranzistorů (viz Obr. 2.44a), protože tranzistor $\mathrm{T}_{3}$ dodává proud do spojených bází ostatních tranzistorů. Poměrem rezistorů $R_{1} / R_{2}, R_{1} / R_{3}, \ldots$ se nastaví požadované výstupní proudy $i_{21}, i_{22}, \ldots$. Zdroje konstantního proudu s vícevýstupovým proudovým zrcadlem jsou typicky určeny pro integrované analogové obvody.

\section{Proudový invertor}

V některých aplikacích požadujeme, aby proudové zrcadlo současně proud invertovalo. Př́klad zapojení proudového invertoru (obraceče) je uvedeno na Obr. 2.44b. Jde v podstatě o aplikaci základního zapojení proudového opakovače nakresleného na Obr. 2.38a a jeho komplementární varianty na Obr. 2.38 b. Pro výstupní proud platí $i_{2} \approx-i_{1}$.

Další podrobnosti a analýzy vlastností proudových zrcadel lze dohledat v publikacích J. Widlara [4], [5], nebo v lit. [3] a [12]. 


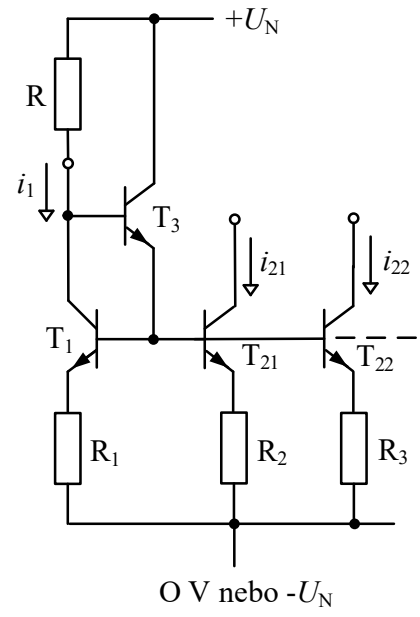

a

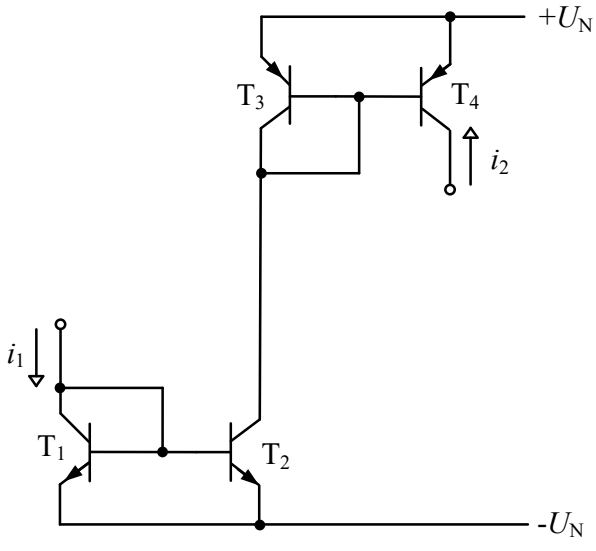

b

Obr. 2.44: a) Vícevýstupové proudové zrcadlo, b) proudový invertor

\subsection{Unipolární tranzistory}

U unipolárních tranzistorů se vodivost polovodičového kanálu ovlivňuje čistě elektrickým polem, tzn. bezproudově, pomocí napětí přivedeného na řídicí elektrodu. $Z$ tohoto důvodu jsou označovány jako tranzistory řízené elektrickým polem a používá se pro ně zkratka FET (field effect transistor). V podstatě rozlišujeme dvě kategorie tranzistorů řízených elektrickým polem, a to tranzistor s izolovaným hradlem, též MOSFET (metal oxide semiconductor FET) nebo také IGFET (insulated gate FET), kde kovová řídicí elektroda (hradlo) je izolována od kanálu tenkou vrstvou oxidu křemičitého a dále tranzistor s přechodovým hradlem, též JFET (junction FET), kde se vodivost kanálu mění pomocí přechodu PN. Oba druhy se dále rozlišují typem vodivosti většinových nosičů v kanále a to na tranzistory FET s kanálem N nebo P.

Celkem existuje šest základních typů tranzistorů řízených polem [3]. Jejich vlastnosti jsou přehledně uvedeny na obrázcích Obr. 2.45 až Obr. 2.47. Všechny typy tranzistorů FET mají tři vývody a to G (gate) - řídicí elektroda popř. hradlo, D (drain) - kolektor popř. nora (přesněji řečeno proudová nora) a $S$ (source) - emitor popř. zdroj. Vodivost kanálu mezi kolektorem D a emitorem S se ovlivňuje rrídicí elektrodou G. Řídicím napětím je napětí $u_{\mathrm{GS}}$. Většina tranzistorů řízených polem vykazuje symetrii, tzn. že jejich vlastnosti se nezmění, jestliže se elektrody D a S zamění.

U tranzistorů s izolovaným hradlem MOSFET je řídicí elektroda oddělena od kanálu DS tenkou izolační vrstvou $\mathrm{SiO}_{2}$. Při tomto řešení tranzistoru neteče proud do řídicí elektrody pro libovolnou polaritu napětí $u_{\mathrm{GS}}$ na řídicí elektrodě. U tranzistorů s přechodovým hradlem JFET je rrídicí elektroda oddělena od kanálu DS polovodičovým přechodem PN nebo NP. Napětí $u_{\mathrm{GS}}$ musí mít proto takovou polaritu, aby dioda, představovaná přechodem řídicí elektroda - kanál, byla zavřena a izolovala řídicí elektrodu od kanálu. Při opačné polaritě se přechod otevírá, ale v této oblasti se tranzistor JFET neprovozuje. Reálné proudy, které tečou do rrídicích elektrod MOSFET tranzistorů jsou od $1 \mathrm{fA}$ do $1 \mathrm{pA}$ a u tranzistorů JFET jsou tisíckrát větší, tj. $1 \mathrm{pA}$ až $1 \mathrm{nA}$.

Analogicky jako se dělí bipolární tranzistory na PNP a NPN tranzistory se unipolární tranzistory MOSFET a JFET dělí na tranzistory s kanálem $\mathrm{P}$ a s kanálem $\mathrm{N}$. U tranzistorů s 

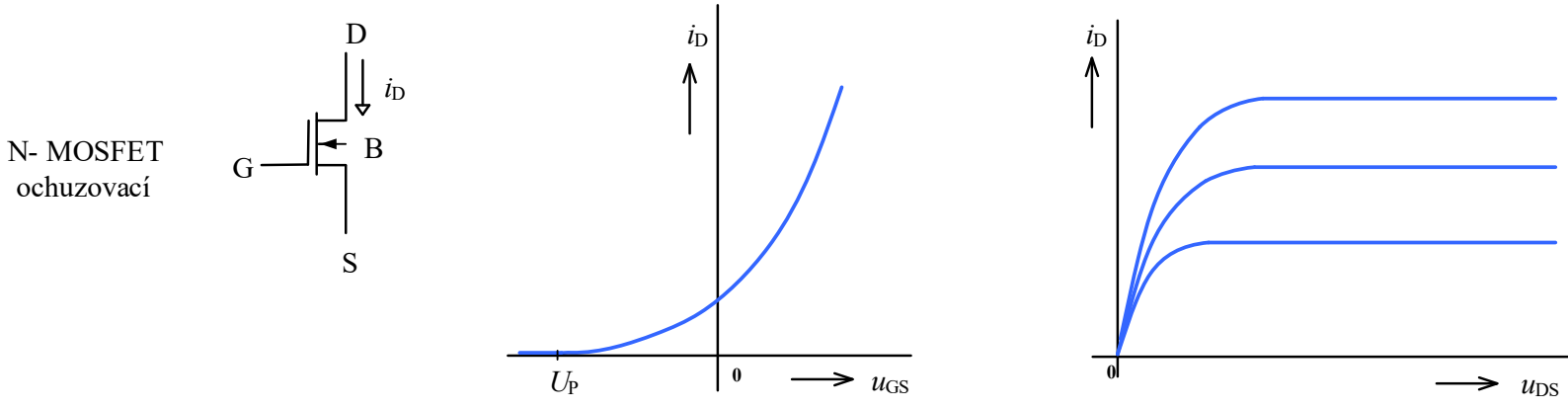

a
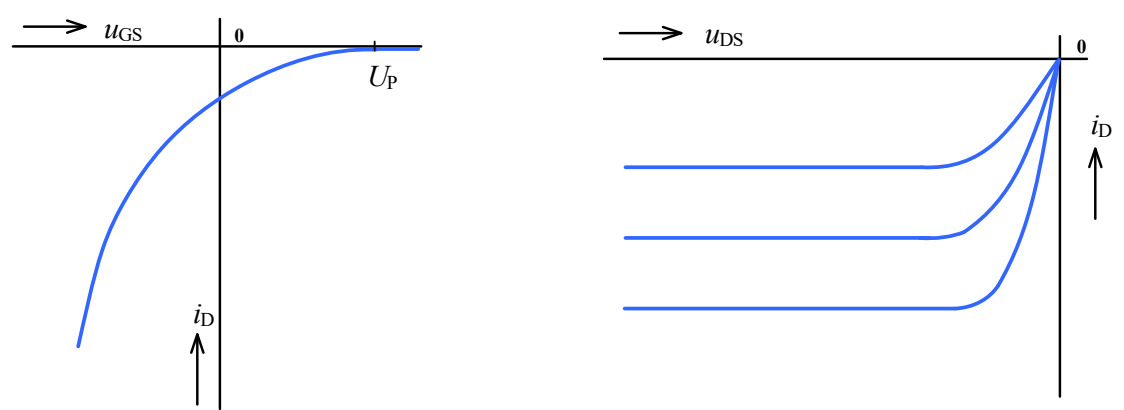

$\mathrm{b}$

Obr. 2.45: Tranzistory MOSFET ochuzovacího typu: a) s kanálem N, b) s kanálem P

N- MOSFET

obohacovací

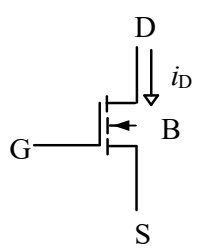
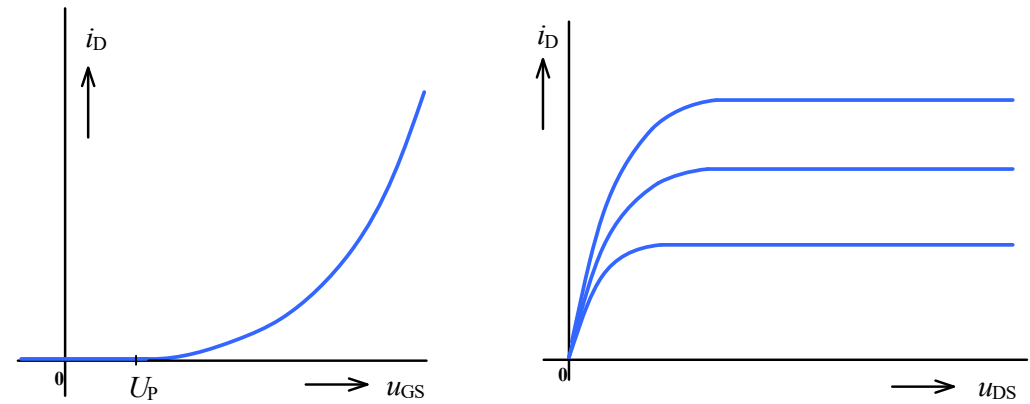

a
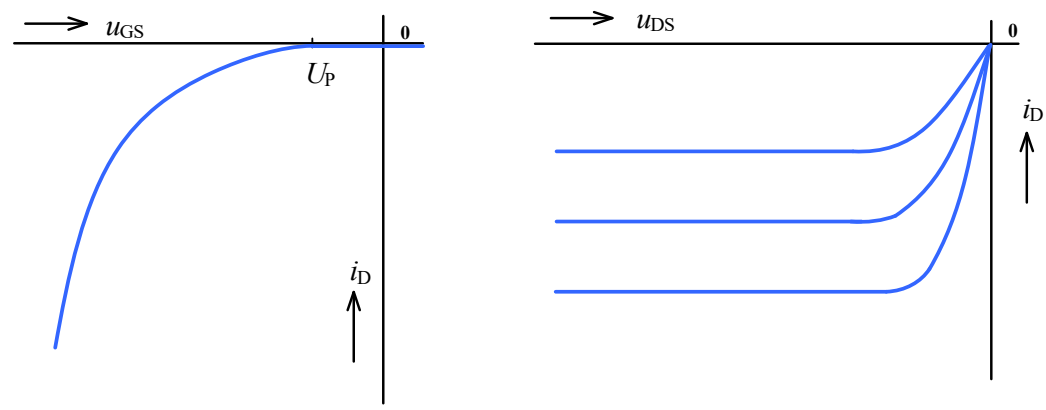

$\mathrm{b}$

Obr. 2.46: Tranzistory MOSFET obohacovacího typu: a) s kanálem N, b) s kanálem P 
N-JFET
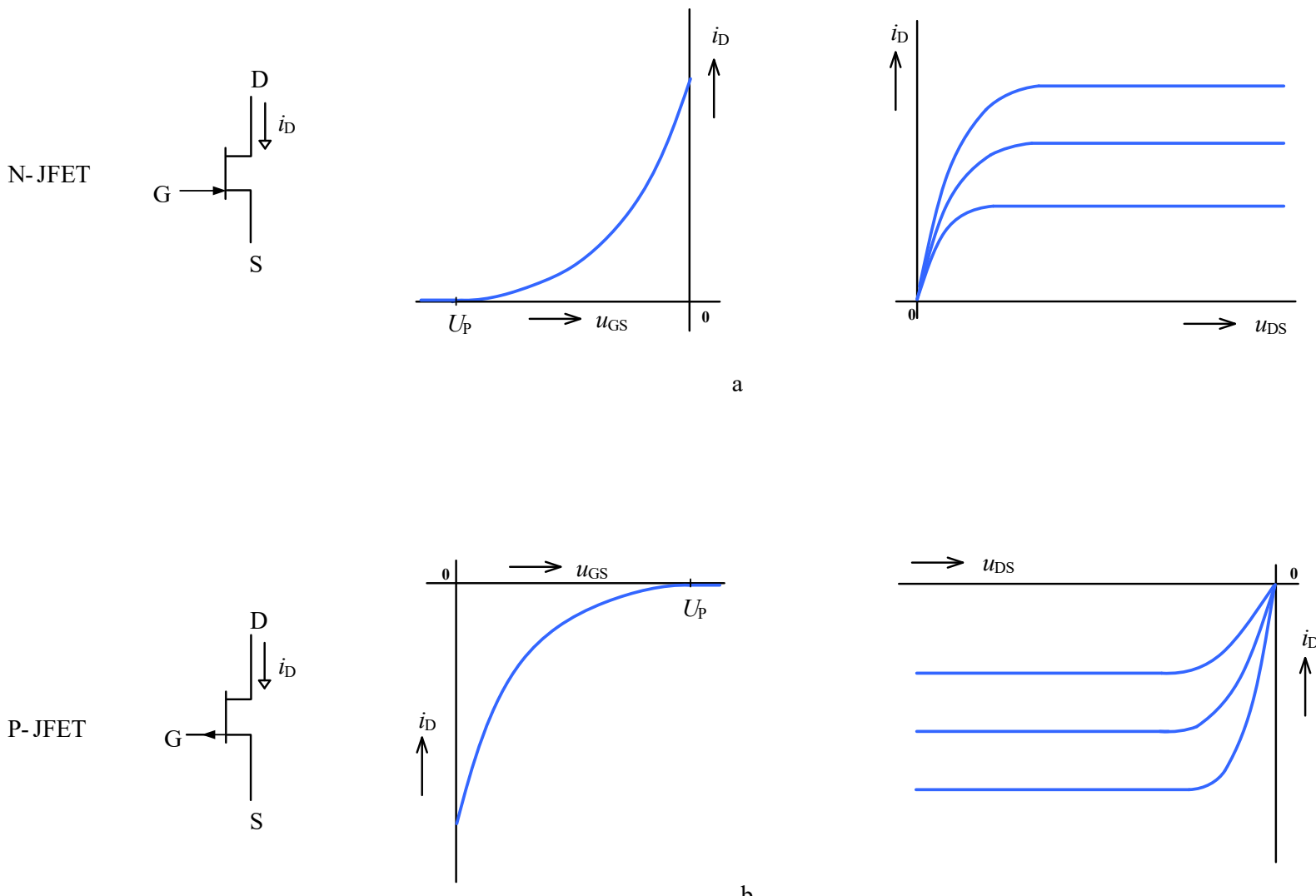

$\mathrm{b}$

Obr. 2.47: Tranzistory JFET: a) s kanálem N, b) s kanálem P

kanálem $\mathrm{N}$ je proud iD kanálem tím menší, čím nižší bude potenciál řídicí elektrody, tj. čím bude napětí uGS menší. U tranzistorů s kanálem $P$ je to opačně.

Dále se tranzistory MOSFET člení podle toho, zda je kanál při nulovém napětí mezi hradlem a emitorem vodivý či nevodivý. U tzv. ochuzovacího typu tranzistoru MOSFET (Obr. $2.45)$ je kanál při uGS $=0$ vodivý. Jeho vodivost lze zvětšovat nebo zmenšovat podle přivedené polarity a velikosti napětí mezi hradlem a emitorem. U obohacovacího typu tranzistoru MOSFET (Obr. 2.46) je kanál při uGS = 0 nevodivý. Vodivý kanál se vytvoří teprve přivedením napětí vhodné polarity mezi hradlo a emitor. Poznamenejme, že přes tranzistory JFET (Obr. 2.47) teče při napětí uGS $=0$ kanálem největší proud.

Integrované tranzistory FET, které jsou vyrobeny současně s jinými polovodičovými prvky na společném substrátu, mají ještě čtvrtý vývod označený B (bulk - podložka či substrát). Pomocí této elektrody, podobně jako v př́ípadě hradla, je možno řídit vodivost kanálu, avšak tato elektroda je od vlastního kanálu oddělena pouze přechodem PN. Obvykle se řízení prostřednictví substrátu neužívá a pak se vývod B spojuje s emitorem, nebo se př́ipojí na takový potenciál, aby přechod PN mezi substrátem a kanálem zůstal zavřen. Tento vývod u diskrétních tranzistorů FET také existuje, ale není vyveden vně tranzistoru a je uvnitř tranzistoru spojen s emitorem S.

$\mathrm{V}$ dalším budou probírány tranzistory s kanálem $\mathrm{N}$ a tranzistory s kanálem $\mathrm{P}$ pouze tehdy, když k tomu bude důvod. Záměna obvodů $\mathrm{s}$ tranzistory s kanálem $\mathrm{N}$ na obvody $\mathrm{s}$ tranzistory kanálem $\mathrm{P}$ je možná, pokud zaměníme polaritu napětí a proudů $\mathrm{v}$ obvodu. 


\section{Strmost tranzistoru rízeného polem}

Protože vodivost kanálu DS se řídí téměř bezproudově čistě elektrickým polem, bude proud $i_{\mathrm{G}}$ tekoucí do řídicí elektrody zanedbatelně malý a proto se u tranzistorů FET proudový zesilovací činitel $\partial i_{\mathrm{D}} / \partial i_{\mathrm{G}}$ neužívá. Pro popis vlastností tranzistorů FET se výhradně užíá strmost $g_{\mathrm{m}}$, kterou můžeme určit z přenosové charakteristiky $i_{\mathrm{D}}\left(u_{\mathrm{GS}}\right)$. Na Obr. 2.48 jsou nakresleny přenosové charakteristiky tranzistorů FET $\mathrm{s}$ kanálem $\mathrm{N}$ pro tranzistory MOSFET ochuzovacího i obohacovacího typu a pro tranzistor JFET, [3]. Z charakteristik je zřejmé, že závisejí na napětí $u_{\mathrm{DS}}$ jen velice málo (čárkované průběhy). S přenosové charakteristiky určíme snadno strmost tranzistoru ř́zeného polem

$$
g_{\mathrm{m}}=\left.\frac{\partial i_{\mathrm{D}}}{\partial u_{\mathrm{GS}}} \approx \frac{\Delta i_{\mathrm{D}}}{\Delta u_{\mathrm{GS}}}\right|_{u_{\mathrm{DS}}=\text { konst }} .
$$

Napětí při kterém je kolektorový proud $i_{\mathrm{D}}$ minimální se nazývá prahové napětí $U_{\mathrm{P}}$. Pro napětí $u_{\mathrm{GS}}>U_{\mathrm{P}}$ je možno přenosovou charakteristiku aproximovat funkcí

$$
i_{\mathrm{D}}=I_{\mathrm{D} 0}\left(1-\frac{u_{\mathrm{GS}}}{U_{\mathrm{P}}}\right)^{2},
$$

kde $I_{\mathrm{D} 0}$ u tranzistorů JFET značí kolektorový proud při $u_{\mathrm{GS}}=0$. U tranzistorů JFET je proud $I_{\mathrm{D} 0}$ současně proudem mezním, protože při kladných napětích $u_{\mathrm{GS}}$ vzrůstá proud tekoucí do řídicí elektrody. Pro tranzistory MOSFET ochuzovacího typu se proud $I_{\mathrm{D} 0}$ určí při $u_{\mathrm{GS}}=\left|U_{\mathrm{P}}\right|$, resp. pro MOSFET obohacovacího typu se proud $I_{\mathrm{D} 0}$ určí při $u_{\mathrm{GS}}=2 U_{\mathrm{P}}$.

Uvážíme-li, že proud $i_{\mathrm{D}}$ je charakterizován vztahem (2-76) bude strmost dána jeho derivací

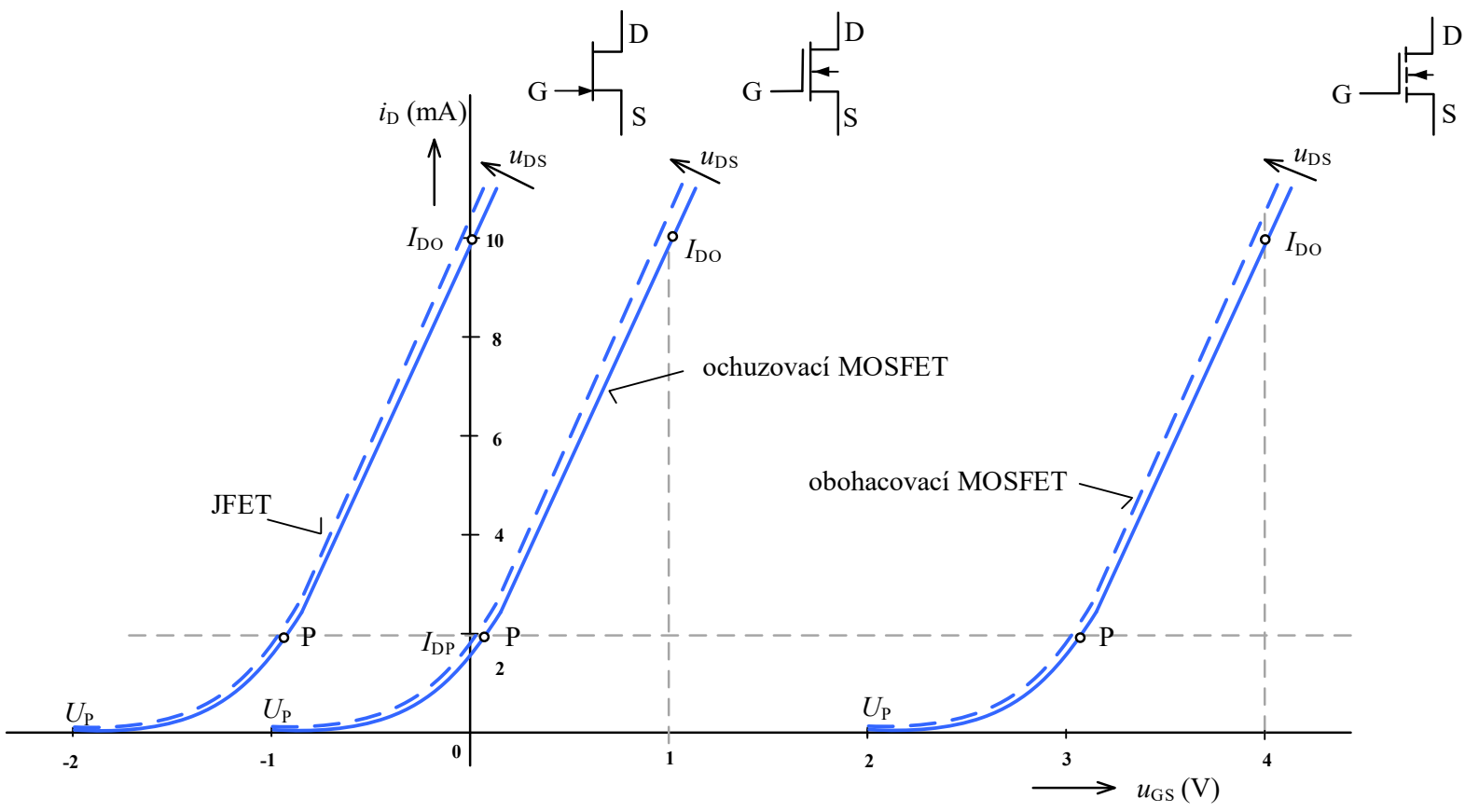

Obr. 2.48: Přenosové charakteristiky tranzistorů FET s kanálem N 


$$
g_{\mathrm{m}}=\frac{\partial i_{\mathrm{D}}}{\partial u_{\mathrm{GS}}}=-\frac{2}{U_{\mathrm{P}}} I_{\mathrm{D} 0}\left(1-\frac{u_{\mathrm{GS}}}{U_{\mathrm{P}}}\right) .
$$

Protože podle rov. (2-76) také platí

$$
1-\frac{u_{\mathrm{GS}}}{U_{\mathrm{P}}}=\sqrt{\frac{i_{\mathrm{D}}}{I_{\mathrm{D} 0}}},
$$

bude strmost tranzistoru dána vztahem

$$
g_{\mathrm{m}}=-\frac{2}{U_{\mathrm{P}}} \sqrt{i_{\mathrm{D}} I_{\mathrm{D} 0}}
$$

Takto určená strmost platí pro JFET a MOSFET ochuzovacího typu, které mají $U_{\mathrm{P}}<0$. Aby vztah platil i pro MOSFET obohacovacího typu, který má $U_{\mathrm{P}}>0$, musíme vztah zobecnit

$$
g_{\mathrm{m}}=\frac{2}{\left|U_{\mathrm{P}}\right|} \sqrt{i_{\mathrm{D}} I_{\mathrm{D} 0}}
$$

Známe-li $U_{\mathrm{P}}$ a $I_{\mathrm{D} 0}$, můžeme podle rovnice (2-80) určit strmost $g_{\mathrm{m}}$ při proudu $i_{\mathrm{D}}$. Zajímavá je strmost při $i_{\mathrm{D}}=I_{\mathrm{D} 0}$, kdy strmost dosahuje maxima

$$
\max g_{\mathrm{m}}=\frac{2 I_{\mathrm{D} 0}}{\left|U_{\mathrm{P}}\right|} \text {. }
$$

Typicky pro $I_{\mathrm{D} 0}=1$ až $50 \mathrm{~mA}$ a $\left|U_{\mathrm{P}}\right|=0,5$ až 50 bude strmost maximálně $g_{\mathrm{m}}=2$ až $20 \mathrm{~mA} / \mathrm{V}$. Strmost FET je tedy podstatně menší než u bipolárního tranzistoru, kdy již při $1 \mathrm{~mA}$ je strmost bipolárního tranzistoru $g_{\mathrm{m}} \approx 40 i_{\mathrm{C}} / 1 \mathrm{~V}=40 \mathrm{~mA} / \mathrm{V}$.

\section{Vstupní odpor tranzistoru řízeného polem}

Protože vstupní proud do řídicí elektrody je téměř nulový je vstupní diferenciální odpor

$$
r_{\mathrm{GS}}=\left.\frac{\partial u_{\mathrm{GS}}}{\partial i_{\mathrm{G}}} \approx \frac{\Delta u_{\mathrm{GS}}}{\Delta i_{\mathrm{G}}}\right|_{u_{\mathrm{DS}}=\text { konst }} .
$$

tak velký, že se běžně předpokládá $r_{\mathrm{GS}} \approx \infty$. Vstupní odpor je v případě tranzistorů MOSFET běžně $r_{\mathrm{GS}} \approx 10^{13}$ až $10^{15} \Omega$ a v případě tranzistorů JFET pak $r_{\mathrm{GS}} \approx 10^{10}$ až $10^{13} \Omega$.

\section{Výstupní odpor tranzistoru řizeného polem}

Na Obr. 2.49 je uvedena soustava výstupních charakteristik tranzistoru ř́zeného polem $i_{\mathrm{D}}\left(u_{\mathrm{DS}}\right)$, přičemž napětí $u_{\mathrm{GS}}$ je zde parametrem. Charakteristiky mají obdobný průběh pro všechny typy tranzistorů řízených polem. Pro malé hodnoty $u_{\mathrm{DS}}$ proud $i_{\mathrm{D}}$ narůstá přibližně úměrně s napětím $u_{\mathrm{DS}}$. V této oblasti se tranzistor řízený polem chová jako rezistor, jehož odpor lze rrídit napětím $u_{\mathrm{GS}}$. Proto se oblast vyznačená křivkou $U_{\mathrm{DS}}=u_{\mathrm{GS}}-U_{\mathrm{P}}$ nazývá odporová oblast. Nad touto křivkou závisí proud pouze na napětí $u_{\mathrm{GS}}$ a jen neznatelně na napětí $u_{\mathrm{DS}}$. Tranzistor se nachází v tzv. oblasti saturace. Poznamenejme však v této souvislosti, že označení saturační oblast, které je obvykle uváděno v literatuře, není nejšt’astnější, protože saturace má zde úplně jiný význam, než je tomu u bipolárních tranzistorů. 


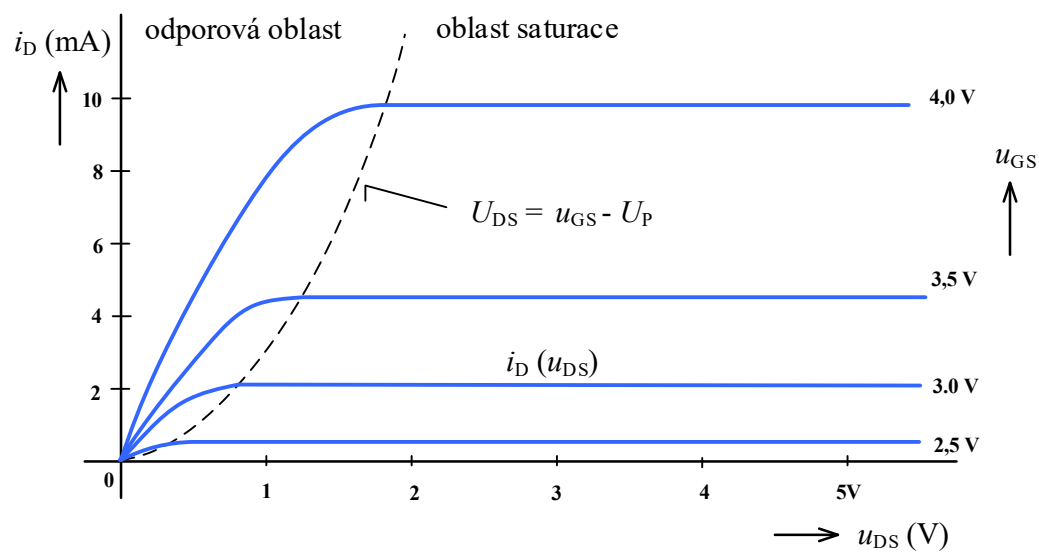

Obr. 2.49: Výstupní charakteristiky tranzistoru FET

Zbytková závislost proudu $i_{\mathrm{D}}$ na napětí $u_{\mathrm{DS}}$ je charakterizována výstupním diferenciálním odporem

$$
r_{\mathrm{DS}}=\left.\frac{\partial u_{\mathrm{DS}}}{\partial i_{\mathrm{D}}} \approx \frac{\Delta u_{\mathrm{DS}}}{\Delta i_{\mathrm{D}}}\right|_{u_{\mathrm{GS}}=\text { konst. }} .
$$

Většinou se ale výstupní odpor určí ze znalosti Earlyho napětí

$$
r_{\mathrm{DS}} \approx \frac{U_{\mathrm{E}}}{i_{\mathrm{D}}} .
$$

Pro tranzistory MOSFET je Earlyho napětí $U_{\mathrm{E}}=20$ až $100 \mathrm{~V}$ a pro tranzistory JFET pak $U_{\mathrm{E}}$ $\approx 30$ až $200 \mathrm{~V}$. Typicky má výstupní odpor tranzistoru FET hodnotu $r_{\mathrm{DS}}=10 \mathrm{k} \Omega$ až $100 \mathrm{k} \Omega$.

Protože Earlyho efekt je u tranzistorů FET způsoben jevem nazývaným modulace délky kanálu, je místo Earlyho napětí často uváděn parametr modulace délky kanálu

$$
\lambda=\frac{1}{U_{\mathrm{E}}} .
$$

Pro tranzistory MOSFET je $\lambda \approx 10 \cdot 10^{-3}$ až $50 \cdot 10^{-3} \mathrm{~V}^{-1}$ a pro tranzistory JFET je $\lambda \approx 5$. $10^{-3}$ až $30 \cdot 10^{-3} \mathrm{~V}^{-1}$.

\section{Náhradní model tranzistoru FET}

Protože výstupní diferenciální odpor je u tranzistorů FET většinou podstatně menší než tomu bylo u bipolárních tranzistorů, nelze ani pro orientační určení vlastností použít zjednodušený model, kdy tranzistor by byl nahrazen jen zdrojem proudu řízený napětím. $\mathrm{Na}$ druhé straně, vstupní diferenciální odpor tranzistorů FET není nutné uvažovat ani v přesnějším modelu, protože $r_{\mathrm{GS}} \approx \infty$. Model tranzistoru řízeného polem pro malé střídavé změny signálu je uveden na Obr. 2.50 . 


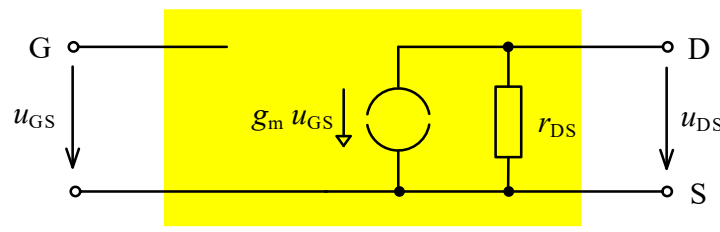

Obr. 2.50: Náhradní model tranzistoru ř́zeného polem

Napětový zesilovací činitel

V některých př́padech se u tranzistorů řízených polem užívá jako parametr tzv. zesilovací činitel

$$
\mu=-\frac{\partial u_{\mathrm{DS}}}{\partial u_{\mathrm{GS}}}=-\frac{\partial u_{\mathrm{DS}}}{\partial u_{\mathrm{GS}}} \frac{\partial i_{\mathrm{D}}}{\partial i_{\mathrm{D}}}=-\frac{\partial i_{\mathrm{D}}}{\partial u_{\mathrm{GS}}} \frac{\partial u_{\mathrm{DS}}}{\partial i_{\mathrm{D}}}=-g_{\mathrm{m}} r_{\mathrm{DS}} .
$$

\subsubsection{Základní zapojení unipolárních tranzistorů}

Podobně jako u bipolárních tranzistorů v závislosti na tom, který vývod tranzistoru je připojen ke společnému bodu vstupní a výstupní části obvodu, se rozlišují tři zapojení: se společným emitorem, se společným kolektorem a se společnou řídicí elektrodou.

Pro analýzu vlastností základních zapojení s tranzistory FET můžeme použít výsledky získané $\mathrm{v}$ předchozí kapitole pro bipolární tranzistory. Z porovnání charakteristik a parametrů pro malé signály je nutné zaměnit jednotlivé veličiny takto:

- proudy: $i_{\mathrm{B}} \rightarrow i_{\mathrm{G}} \approx 0, i_{\mathrm{C}} \rightarrow i_{\mathrm{D}}, i_{\mathrm{E}} \rightarrow i_{\mathrm{S}}$;

- napětí: $u_{\mathrm{BE}} \rightarrow u_{\mathrm{GS}}, u_{\mathrm{CE}} \rightarrow u_{\mathrm{DS}}$;

- parametry $g_{\mathrm{m}} \rightarrow g_{\mathrm{m}}, g_{\mathrm{mr}} \rightarrow g_{\mathrm{mr}} \approx 0, r_{\mathrm{BE}} \rightarrow r_{\mathrm{GS}} \approx \infty, r_{\mathrm{CE}} \rightarrow r_{\mathrm{DS}}, \beta \rightarrow g_{\mathrm{m}} r_{\mathrm{GS}} \approx \infty$.

\section{Zapojení se společným emitorem}

Zapojení tranzistoru FET se společným emitorem je uvedeno na Obr. 2.51. Zdroj $u_{\mathrm{G}}$ musí obsahovat ss složku pro nastavení pracovního bodu na převodní charakteristice $i_{\mathrm{D}}\left(u_{\mathrm{DS}}\right)$. Řešení je obdobné jako s bipolárním tranzistorem, ale $r_{\mathrm{CE}}$ nyní nelze zanedbat. Proto použijeme výsledky (2-30) až (2-32), kde nahradíme $r_{\mathrm{CE}} \rightarrow r_{\mathrm{DS}}, r_{\mathrm{BE}} \rightarrow r_{\mathrm{GS}} \simeq \infty, R_{\mathrm{C}} \rightarrow R_{\mathrm{D}}$. Potom napětové zesílení bude

$$
A_{\mathrm{U}}=-g_{\mathrm{m}}\left(R_{\mathrm{D}} \| r_{\mathrm{DS}}\right)
$$

vstupní odpor

$$
R_{\mathrm{vst}} \approx r_{\mathrm{GS}} \approx \infty
$$

a výstupní odpor

$$
R_{\text {vyst }} \approx R_{\mathrm{D}} \| r_{\mathrm{DS}} .
$$




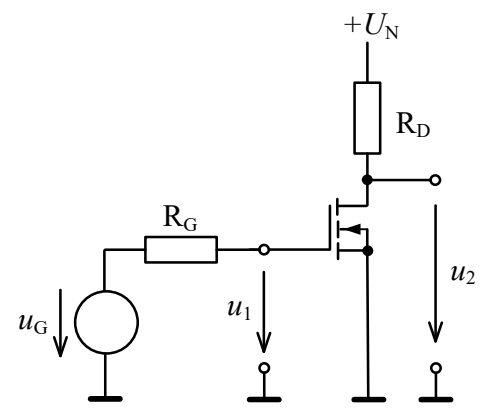

Obr. 2.51: Zapojení se společným emitorem

Např́. při $i_{\mathrm{D}} \approx 1 \mathrm{~mA}$ je strmost tranzistoru FET $g_{\mathrm{m}} \approx 5 \mathrm{~mA} / \mathrm{V}$ a pro $R_{\mathrm{D}}=4,7 \mathrm{k} \Omega, r_{\mathrm{DS}} \approx 10$ $\mathrm{k} \Omega$, bude $A_{\mathrm{U}} \approx 16$, tj. o rrád méně než s bipolárním tranzistorem, který při $i_{\mathrm{C}} \approx 1 \mathrm{~mA}$ má strmost $g_{\mathrm{m}} \approx 40 \mathrm{~mA} / \mathrm{V}$ a $r_{\mathrm{BE}} \approx 100 \mathrm{k} \Omega$. Obecně platí, že napětové zesílení je přibližně desetkrát menší než u zapojení se společným emitorem s bipolárním tranzistorem. Je to způsobeno jednak malou strmostí tranzistorů FET a relativně malým výstupním odporem $r_{\mathrm{DS}}$. Velkou výhodou je ale téměř nekonečný vstupní odpor. V neposlední řadě v rozhodnutí, zda použít bipolární tranzistor nebo tranzistor FET, hraje roli cena, která je u integrovaných obvodů realizovaných bipolární technologií až čtyřikrát vyšší.

\section{Zapojení se společným emitorem a proudovou zpětnou vazbou}

Na Obr. 2.52a je nakresleno zapojení tranzistoru FET se společným emitorem a zápornou proudovou zpětnou vazbou realizovanou pomocí rezistoru $\mathrm{R}_{\mathrm{S}}$. Podobně jako napět'ový přenos s bipolárním tranzistorem (viz rov. (2-35)) bude

$$
A_{\mathrm{U}} \approx-\frac{R_{\mathrm{D}}}{R_{\mathrm{S}}+\frac{1}{g_{\mathrm{m}}}} .
$$

Vstupní odpor zapojení $R_{\mathrm{vst}} \approx \infty$ a výstupní odpor $R_{\mathrm{výst}} \approx R_{\mathrm{D}}$.

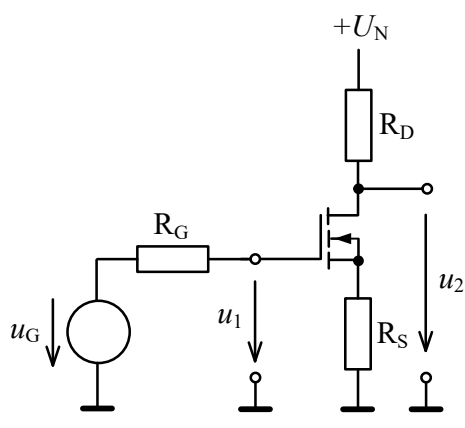

$\mathrm{a}$

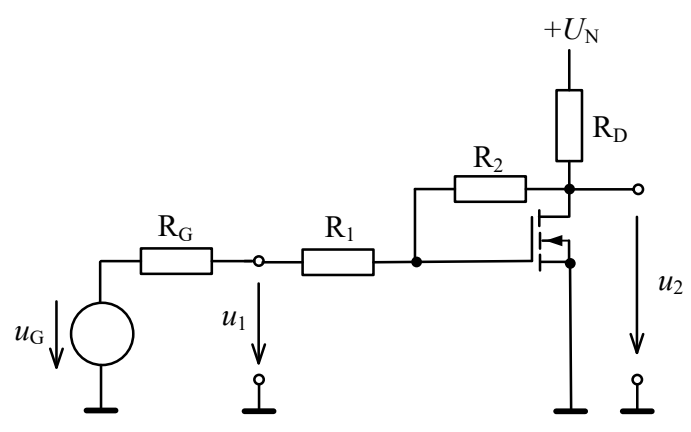

$\mathrm{b}$

Obr. 2.52: Zapojení se společným emitorem: a) s proudovou zpětnou vazbou, b) s napětovou zpětnou vazbou 
Zapojení se společným emitorem a napětovou zpětnou vazbou

Obdobně jako u bipolárního tranzistoru je na Obr. 2.52b realizována záporná zpětná vazba u zapojení tranzistoru FET se společným emitorem. Použijeme-li výsledek (2-37) pro bipolární tranzistor bude $\mathrm{v}$ tomto případě pro napět'ový přenos platit

$$
A_{\mathrm{U}} \approx-\frac{R_{2}}{R_{1}+\frac{R_{1}+R_{2}}{g_{\mathrm{m}} R_{\mathrm{D}}}} .
$$

Vstupní odpor bude přibližně $R_{\mathrm{vst}} \approx R_{1}$ a výstupní odpor $R_{\mathrm{vyst}} \approx\left(1+R_{2} / R_{1}\right) / g_{\mathrm{m}}$.

\section{Emitorový sledovač - zapojeni se společným kolektorem}

Zapojení emitorového sledovače s tranzistorem FET (viz Obr. 2.53) se vyznačuje téměř nekonečným vstupním odporem. Napět’ový přenos můžeme analogicky odvodit s využitím vztahu (2-42)

$$
A_{\mathrm{U}} \approx \frac{g_{\mathrm{m}} R_{\mathrm{S}}}{g_{\mathrm{m}} R_{\mathrm{S}}+1}
$$

vstupní odpor $R_{\mathrm{vst}} \approx \infty$, výstupní odpor $R_{\mathrm{výst}} \approx R_{\mathrm{S}} \|\left(1 / g_{\mathrm{m}}\right)$.

Typické hodnoty napětového přenosu a výstupního odporu ukážeme pro ilustraci na prŕkladu. Při strmosti tranzistoru $g_{\mathrm{m}} \approx 5 \mathrm{~mA} / \mathrm{V}$ a odporu $R_{\mathrm{S}}=1 \mathrm{k} \Omega$, bude $A_{\mathrm{U}} \approx 0,83$ a $R_{\text {výst }} \approx 167 \Omega$.

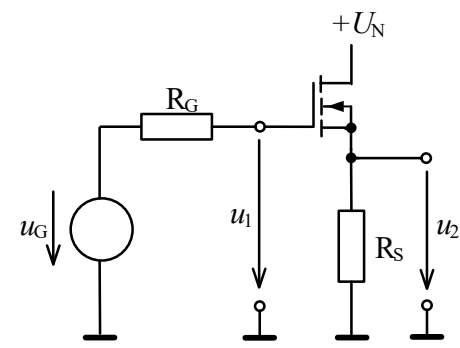

Obr. 2.53: Emitorový sledovač - zapojení se společným kolektorem

\section{Nastavení pracovního bodu}

Jestliže má být tranzistor FET provozován jako zesilovač, je nutno nejprve nastavit proudem $I_{\mathrm{DP}}$ a napětím $U_{\mathrm{GSP}}$, resp. $I_{\mathrm{DP}}$ a $U_{\mathrm{DSP}}$ jeho pracovní bod P a kolem tohoto pracovního bodu tranzistor budit malým střídavým signálem. $\mathrm{V}$ tom případě může být charakteristika nahrazena tečnou $\mathrm{v}$ pracovním bodě a tranzistor se bude chovat skutečně jako lineární zesilovač.

Pracovní bod tranzistoru je určen vnějšími obvody. Pokud má tranzistor pracovat jako lineární zesilovač, musí se pracovní bod nacházet v saturační oblasti výstupních charakteristik $i_{\mathrm{D}}\left(u_{\mathrm{DS}}\right)$. Na Obr. 2.54 je ukázána požadovaná polarita napětí a proudů pro všech šest základních typů tranzistorů FET.

Pokud budou mít tranzistory FET s kanálem $\mathrm{N}$ charakteristiky $i_{\mathrm{D}}\left(u_{\mathrm{DS}}\right)$ nakreslené na Obr. 2.48 a požadujeme proud pracovního bodu $I_{\mathrm{DP}}=2 \mathrm{~mA}$, musíme vnějšími obvody nastavit $U_{\mathrm{GSP}}=U_{\mathrm{P}}+1,1 \mathrm{~V}$. Pro tranzistory s kanálem $\mathrm{P}$ má prahové napětí $U_{\mathrm{P}}$ opačné znaménko a pro pracovní proud $I_{\mathrm{DP}}=-2 \mathrm{~mA}$ musíme nastavit $U_{\mathrm{GSP}}=U_{\mathrm{P}}-1,1 \mathrm{~V}$. 

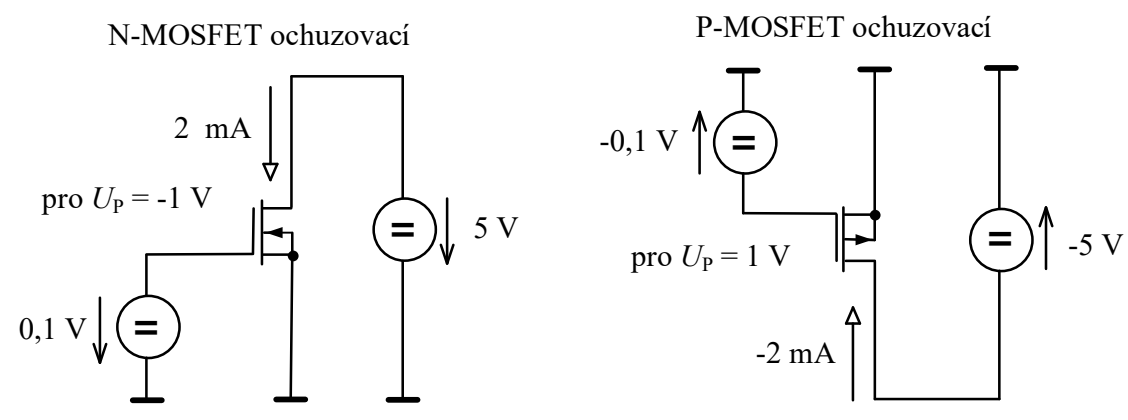

N-MOSFET obohacovací

P-MOSFET obohacovací
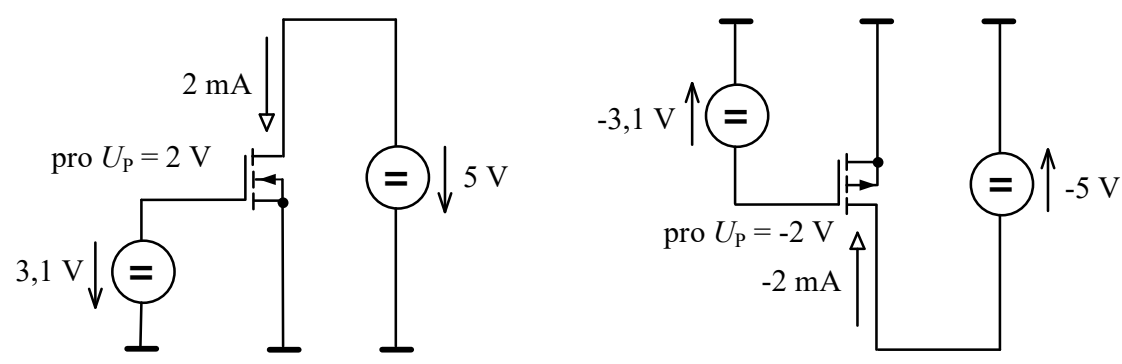

N-JFET
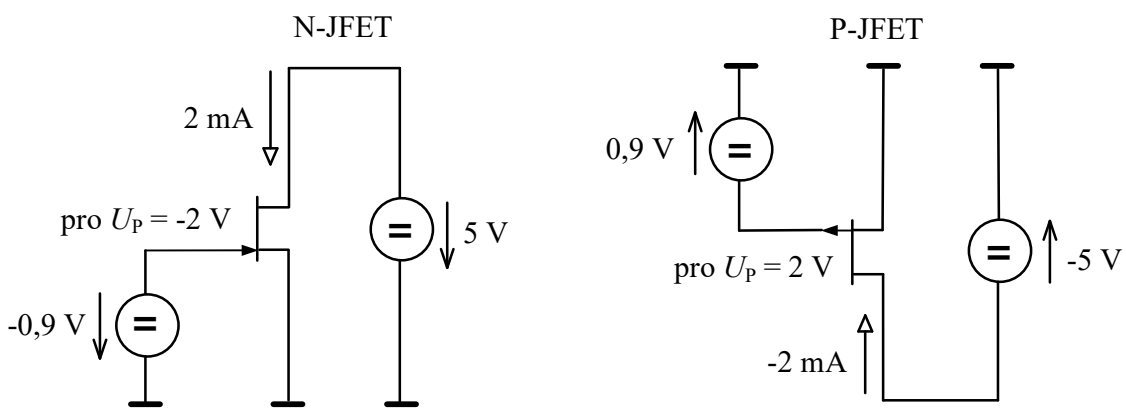

Obr. 2.54: Požadovaná polarita napětí a proudů pro šest základních typů tranzistorů FET

Jako př́íklad uvedeme nastavení pracovního bodu zesilovače se střídavou vazbou na Obr. 2.55a. Zesilovač je na zdroj signálu připojen přes tzv. vazební či oddělovací kapacitor $\mathrm{C}_{1}$ a podobně zátěž je oddělena kapacitorem $\mathrm{C}_{2}$. Pak lze stejnosměrně nastavit pracovní bod tranzistoru nezávisle na budicím zdroji a na zátěži. Kapacitor $\mathrm{C}_{1}$ tvoří se vstupním odporem zesilovače $R_{1}$ $\| R_{2}$ horní propust a podobně kapacitor $\mathrm{C}_{2}$ tvoří horní propust se vstupním odporem následujícího stupně. Mezní kmitočty horních propustí musí být navrženy tak, aby tyto filtry propustily celé pásmo kmitočtů zpracovaného signálu. $Z$ tohoto důvodu jsou obvykle kapacity vazebních kapacitorů velké a je nutno použít elektrolytické kondenzátory.

Současně je v obvodu použita stabilizace pracovního bodu pomocí kmitočtově závislé proudové zpětné vazby na $\mathrm{R}_{\mathrm{S}} \| \mathrm{C}_{\mathrm{S}}$. Pro stejnosměrné či pomalé změny pracovního bodu $\mathrm{s}$ teplotou, kdy kapacitor $\mathrm{C}_{\mathrm{S}}$ vykazuje velkou impedanci, bude zesílení malé (viz rov. (2-90)). Pro střídavé signály, kdy impedance $\mathrm{C}_{\mathrm{S}}$ bude malá, bude zesílení zesilovače velké (viz rov. (2-87)).

Tímto způsobem nastavení pracovního bodu se ovšem ztratila výhoda téměř nekonečného vstupního odporu zesilovače, protože ten se v zapojení podle Obr. 2.55a sníží v oblasti 
pracovních kmitočtů pouze na hodnotu $R_{1} \| R_{2}$. Zlepšené vlastnosti, pokud se týká vstupního odporu, vykazuje uspořádání střídavého zesilovače na Obr. 2.55b. Na řídicí elektrodě bude ss napětí dané děličem $R_{1}, R_{2}$, protože úbytek napětí na rezistoru $R_{3}$ je díky malému proudu do řídicí elektrody zanedbatelný. Pro střídavé signály je zavedena speciální stř́ídavá zpětná vazba nazývaná „bootstrap“, která zvyšuje vstupní odpor. Napětí z emitoru tranzistoru, které je přibližně stejné jako na řídicí elektrodě, je na vyšších kmitočtech přivedeno přes kapacitor $\mathrm{C}_{3}$ zpět pod rezistor $\mathrm{R}_{3}$, takže rezistor $\mathrm{R}_{3}$ má na obou koncích přibližně stejné střídavé napětí a vstupní odpor je pak přibližně $R_{\mathrm{vst}} \approx R_{3}\left(1+g_{\mathrm{m}} R_{\mathrm{S}}\right)$.

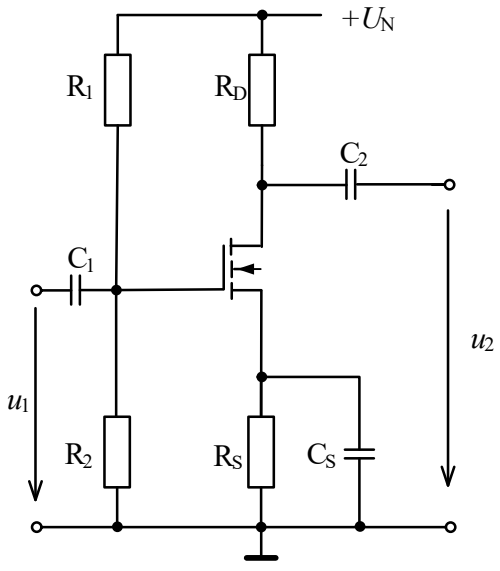

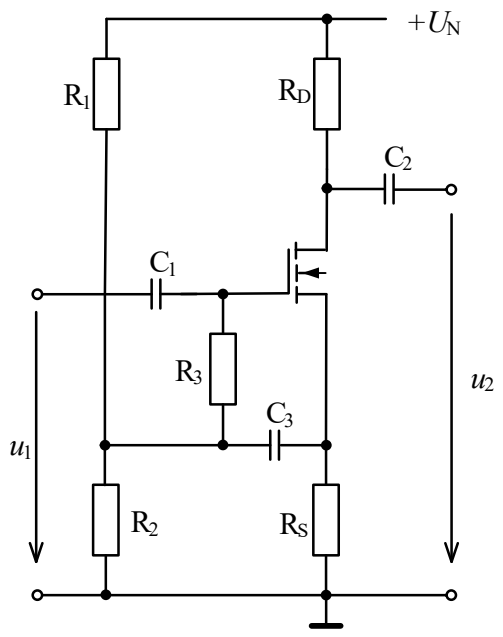

$\mathrm{b}$

Obr. 2.55: a) Nastavení pracovního bodu střídavého zesilovače, b) zvýšení vstupního odporu technikou ,bootstrap“

U vícestupňových zesilovačů obvykle není možné nastavovat pracovní body samostatně u každého zesilovacího stupně a je proto nutná ss vazba mezi jednotlivými stupni. Při ss napětové vazbě, která se nazývá také přímá nebo galvanická vazba, je zesilovač připojen přímo na zdroj signálu a zátěž. Ss napětí na vstupu a na výstupu zesilovače proto musí být přizpůsobeno ss napětí zdroje signálu a následujícího zesilovacího stupně. Stejný závěr platí i pro integrované zesilovače, protože není možno volit libovolně velké hodnoty kapacit vazebních kapacitorů a externí kapacitory nejsou povoleny. Ve vícestupňových zesilovačích se ss vazba často kombinuje se zpětnou vazbou přes všechny zesilovací stupně tak, aby se dosáhlo definovaného a teplotně stabilního pracovního bodu.

\subsubsection{Tranzistor FET jako ř́zený rezistor}

Ze soustavy výstupních charakteristik $i_{\mathrm{D}}\left(u_{\mathrm{DS}}\right)$ tranzistoru ř́zeného polem na Obr. $2.49 \mathrm{je}$ vidět, že ampérvoltová charakteristika $\mathrm{v}$ tzv. odporové oblasti je při malých napětích $u_{\mathrm{DS}}$ obdobná jako u rezistoru, jehož odpor $R_{\mathrm{DS}}$ lze měnit v širokém rozmezí napětím $u_{\mathrm{GS}}$. Tento jev 

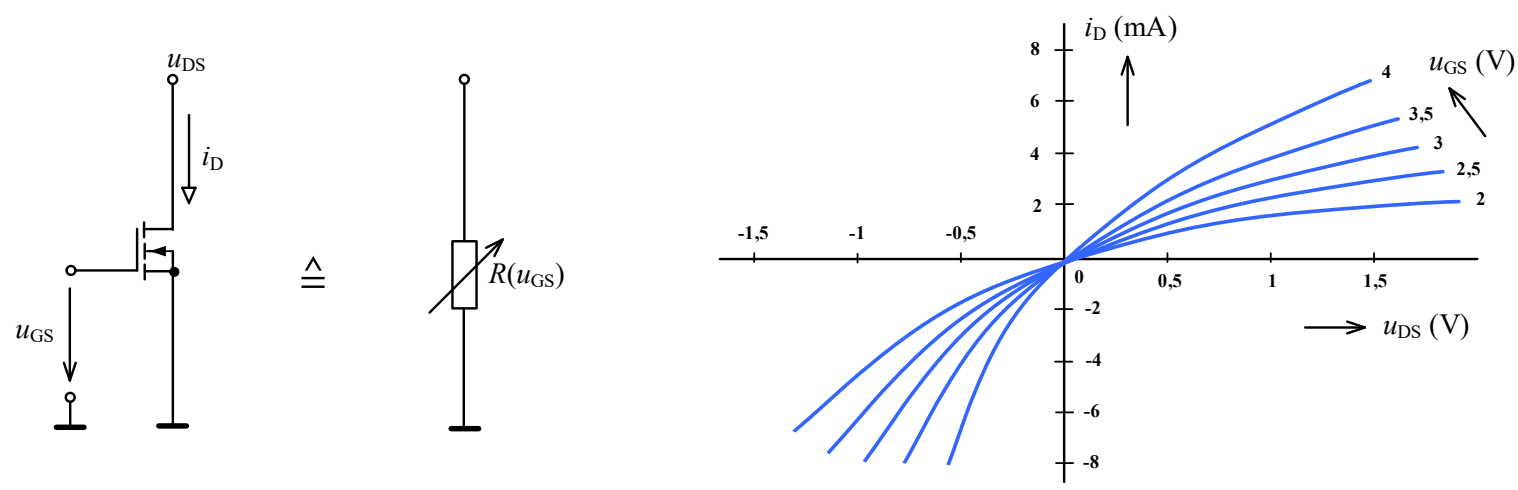

a
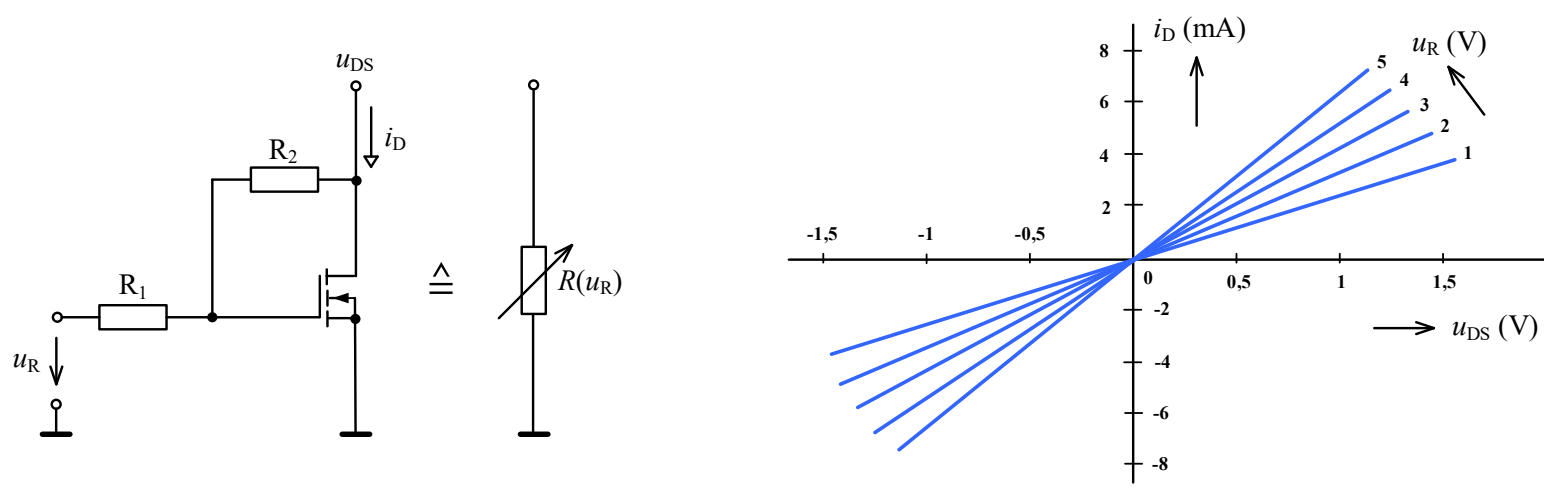

$\mathrm{b}$

Obr. 2.56: a) Tranzistor FET jako řízený rezistor, b) linearizace ampérvoltových charakteristik

je v okolí počátku charakteristik detailně zobrazen na Obr. 2.56a. U malovýkonových tranzistorů FET lze odpor $R_{\mathrm{DS}}$ řídit v rozmezí od 50 do $500 \Omega$. Z Obr. 2.57a je však také zřejmé, že při větších hodnotách $u_{\mathrm{DS}}$ je takovýto rezistor již značně nelineární.

Aby došlo $\mathrm{k}$ linearizaci charakteristik, zavádí se část napětí $u_{\mathrm{DS}}$ zpět na řídicí elektrodu (viz Obr. 2.56b), [1]. Se zvětšováním napětí $u_{\mathrm{DS}}$ roste pak také napětí $u_{\mathrm{GS}}$ a částečně se tak kompenzuje změna hodnoty $R_{\mathrm{DS}} \mathrm{v}$ závislosti na napětí $u_{\mathrm{DS}}$. Jestliže bude napětí $u_{\mathrm{DS}}$ záporné, bude se díky obvodu linearizace zmenšovat i napětí $u_{\mathrm{GS}}$. $Z$ tohoto důvodu dojde k linearizaci charakteristik i ve třetím kvadrantu. Optimální linearizace se dosáhne při $R_{1} \approx R_{2} \gg R_{\mathrm{DS}}$, obvykle se volí $R_{1}=R_{2} \approx 1 \mathrm{M} \Omega$. Odchylka od lineární charakteristiky pro $\left|u_{\mathrm{DS}}\right| \leq 1 \mathrm{~V}$ pak nepřevýší $1 \%$.

\subsubsection{Tranzistor FET jako zdroj proudu}

\section{Zdroj konstantního proudu s tranzistorem FET}

Podobně jako u bipolárního tranzistoru je soustava výstupních charakteristik v oblasti saturace téměř vodorovná. $V$ této oblasti je kolektorový proud $i_{\mathrm{D}}$ téměř nezávislý na napětí $u_{\mathrm{DS}}$. Tato vlastnost je $\mathrm{v}$ zapojení zdroje proudu na Obr. $2.57 \mathrm{a}$ ještě podpořena zavedením záporné proudové zpětné vazby pomocí rezistoru $R_{S}$. U zdroje proudu s bipolárním tranzistorem byl 
návrh jednoduchý, protože $u_{\mathrm{BE}} \approx 0,7 \mathrm{~V}$. V tomto př́ípadě musíme ale napětí $u_{\mathrm{GS}}$ určit $\mathrm{z}$ rov. (2-76), ze které lze odvodit výraz

$$
u_{\mathrm{GS}}=U_{\mathrm{P}}\left(1-\sqrt{i_{\mathrm{D}} / I_{\mathrm{D} 0}}\right) .
$$

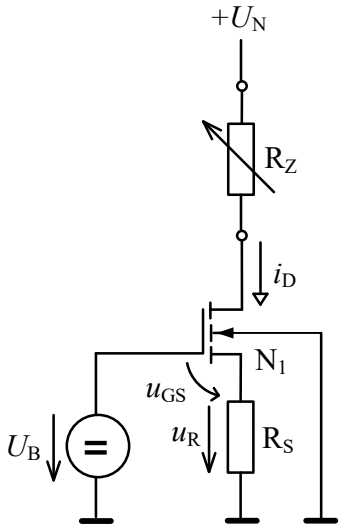

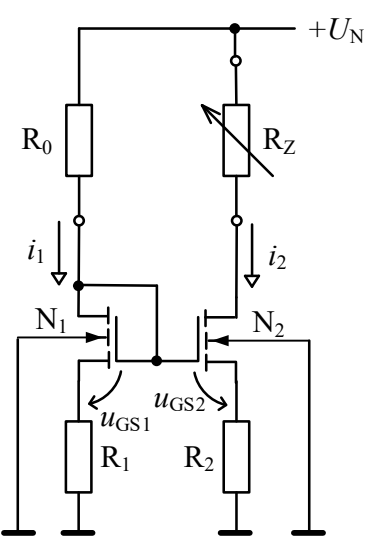

b

Obr. 2.57: a) Zdroj konstantního proudu, b) zdroj konstantního proudu s proudovým zrcadlem

Proud $i_{\mathrm{D}}$ tekoucí zátěží je pak určen odporem rezistoru $\mathrm{R}_{\mathrm{S}}$, jehož hodnotu pro požadovaný proud zátěží $i_{\mathrm{D}}$ určíme pomocí vztahu

$$
R_{\mathrm{S}}=\frac{U_{\mathrm{B}}-u_{\mathrm{GS}}}{i_{\mathrm{D}}}=\frac{U_{\mathrm{B}}-U_{\mathrm{P}}\left(1-\sqrt{i_{\mathrm{D}} / I_{\mathrm{D} 0}}\right)}{i_{\mathrm{D}}} .
$$

Zdroj konstantního proudu s proudovým zrcadlem podle Obr. $2.57 \mathrm{~b}$ se užívá pro nastavení pracovního bodu integrovaných tranzistorových zesilovačů, nebo také jako jejich tzv. aktivní zátěž. Bude-li $R_{1}=R_{2}$, bude napětí $u_{\mathrm{GS} 1}=u_{\mathrm{GS} 2}$ a protože proudy do řídicích elektrod tranzistorů jsou zanedbatelné, s velkou přesností pro proudy v obvodu platí

$$
i_{2} \approx i_{1}=\frac{U_{\mathrm{N}}-u_{\mathrm{GS} 1}}{R_{0}+R_{1}} .
$$

\section{Proudová zrcadla s tranzistory FET}

Princip proudového zrcadla je obdobný jako u bipolárních tranzistorů. Obdoba Widlarova jednoduchého proudového zrcadla s tranzistory FET je uvedena na Obr. 2.58. Proudový přenos zrcadla se v prŕípadě tranzistorů FET nejsnáze vyjadřuje poměrem šířky $W$ a délky $L$ kanálu tranzistorů

$$
K_{\mathrm{I}}=\frac{i_{2}}{i_{1}} \approx \frac{W_{2} / L_{2}}{W_{1} / L_{1}}
$$

Diferenciální výstupní resp. vnitřní odpor proudového zrcadla $r_{\mathrm{V}} \approx r_{\mathrm{DS} 2} \approx 50 \mathrm{k} \Omega$ až $100 \mathrm{k} \Omega$. 


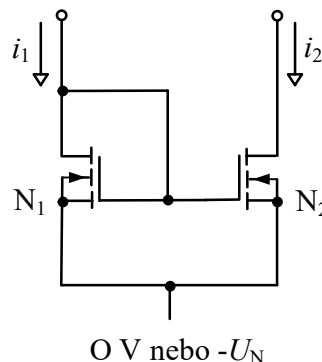

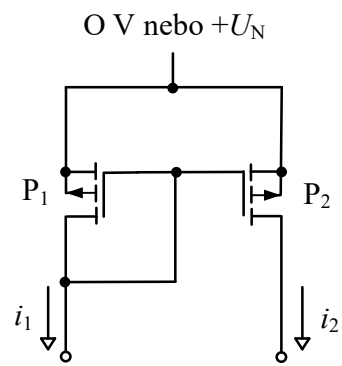

$\mathrm{b}$

Obr. 2.58: Jednoduché Widlarovo proudové zrcadlo s tranzistory: a) NMOS, b) PMOS

Zapojení proudového zrcadla s redukcí proudu do řídicích elektrod obdobně jako je to u zrcadla s bipolárními tranzistory nemá pro MOS technologii význam, protože proudy do řídicích elektrod jsou zanedbatelné. Zpětnovazební zapojení Wilsonova proudového zrcadla s unipolárními tranzistory se ale užívá, protože vykazuje daleko větší vnitřní odpor, než jednoduché proudové zrcadlo. Zapojení s MOSFET tranzistory s kanálem $\mathrm{P}$ a s kanálem $\mathrm{N}$ je uvedeno na Obr. 2.59. Další podrobnosti k proudovým zrcadlům s tranzistory FET lze dohledat v publikacích [1], [7], [13].

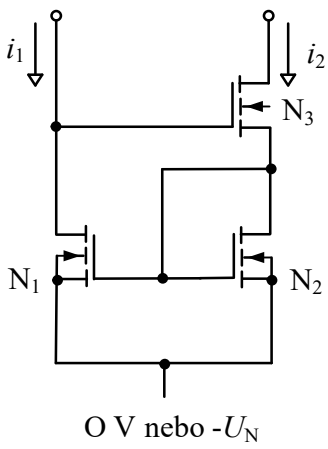

a

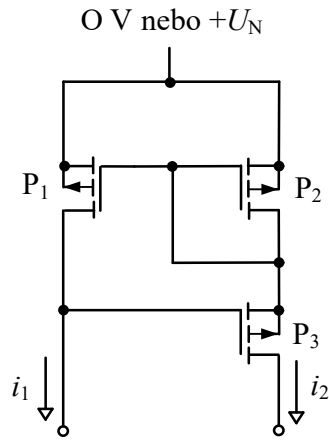

b

Obr. 2.59: Zpětnovazební Wilsonovo proudové zrcadlo s tranzistory: a) NMOS, b) PMOS 


\section{Použitá literatura}

[1] TIETZE, U.; SCHENK, CH. Electronic Circuits. Design and Applications. Springer Verlag, Berlin 1991. ISBN 3-540-50608-X

[2] KOUŘIL, F.; VRBA, K. Teorie nelineárních a parametrických obvodů. SNTL, Praha 1981

[3] TIETZE, U.; SCHENK, CH.; GAMM, E. Electronic Circuits. Hand book for Design and Applications. 2nd edition, Springer - Verlag, Berlin 2008. ISBN 978-3-54000429-5

[4] WIDLAR, R. J. "Some Circuit Design Techniques for Linear Integrated Circuits", IEEE Transactions on Circuit Theory, vol. CT-12, Dec 1965, pp. 586-590

[5] WIDLAR, R. J. "Design Techniques for Monolithic Operational Amplifiers", IEEE Journal of Solid-State Circuits, vol. SC-4, 1969, pp. 184-191

[6] ALAMI, M.; FABRE, A.; BOUHDADA, A. "Second generation current conveyors with enhanced input resistance", Int. J. Electronics, 1999, Vol. 86, No.4, pp.405-412

[7] AKIYA, M.; NAKASHIMA, S., "High-Precission MOS Current Mirror", IEE Proceedings, Pt. I., vol.131, 1984, pp. 170-175

[8] WILSON, G. R. "A Monolithic Junction FET-npn Operational Amplifier", IEEE Journal of Solid-State Circuits, vol. SC-3, Dec 1968, pp. 341-348

[9] SÄCKINGER, E.; GUGGENBÜHL, W. A high-swing, high-impedance MOS cascode circuit. IEEE J. of Solid-State Circuits, vol. SC-25, 1990, pp. 289-298

[10] EITAKE, I.; YUKIHIRO, K.; AKIRA, H.; KEITARO, S. "A Novel Low-Voltage Cascode Current Mirror Without Bias Curcuits", Theory and its Aplications (NOLTA'98), Crans-Montana, Switzerland, Sept. 14-17, 1998, pp.413-416

[11] VRBA, K.; VRBA, K. jun. Technika analogových obvodů a systémů. Skriptum, 4. vydání. Ediční středisko VUT Brno,1989

[12] VRBA, K.; BUCHMAIER, P. Vlastnosti bipolárních proudových zrcadel. www.elektrorevue.cz, 1999

[13] VRBA, K.; BUCHMAIER, P. Proudová zrcadla s unipolárními tranzistory. www.elektrorevue.cz, 2000

[14] SODAGAR, A. M. Analysis of bipolar and CMOS amplifiers. CRC Press, New York, 2007, ISBN 1-4200-4644-6

[15] BAKER, R.J.; LI, H.W.; BOUYCE, D.E. CMOS circuit design, layout and simulation. Wiley - IEEE Press, New York, 1998, ISBN 0-7803-3416-7 


\section{Vnitřní struktura operačních zesilovačů}

Zesilování signálů tvoří nesporně nejrozsáhlejší a nejdůležitější oblast využití elektronických obvodů zpracovávajících analogové signály. V posledních desetiletích se díky zvládnutí technologie mikroelektronických obvodů masově rozš́iríilo používání hotově postavených tzv. operačních zesilovačů. To umožnilo osvojit si nový, systémový př́stup k navrhování elektronických obvodů či soustav. Vlastní návrh zesilovače ustupuje do pozadí (omezuje se v podstatě jen na výběr vhodného typu operačního zesilovače) a hlavní důraz je přenesen na návrh zpětnovazební sítě připojené k zesilovači, která určuje pracovní charakteristiky celého takto vytvořeného elektronického obvodu. Přesto však je nutné alespoň zběžně znát vnitřní strukturu operačních zesilovačů, abychom mohli vybrat operační zesilovač požadovaných vlastností, resp. využít všech jeho schopností. Znalost struktury operačního zesilovače je dokonce nezbytná $\mathrm{v}$ těch prŕípadech, kdy užíváme zesilovač v netradičních aplikacích.

Nejobvykleji používané operační zesilovače mají diferenční (rozdílový) vstup a jednoduše zakončený výstup. Diferenční vstup umožňuje širší výběr zpětnovazebních zapojení než jednoduchý (zpravidla invertující) vstup zesilovače. Výstupní napětí diferenčního operačního zesilovače pak závisí pouze na rozdílu mezi napětími přivedenými na dvě vstupní svorky.

Další podrobnosti k vnitřním strukturám operačních zesilovačů lze dohledat v publikacích [1] až [9].

\subsection{Diferenční tranzistorové zesilovače}

Významným stavebním prvkem operačních zesilovačů je tranzistorový diferenční zesilovač, který v důsledku své symetrické stavby umožňuje výrazně kompenzovat vlivy teplotních změn parametrů tranzistorů. Tranzistorový diferenční zesilovač získáme obvykle spojením dvou tranzistorových zesilovačů pracujících v zapojení se společným emitorem.

\subsubsection{Diferenční zesilovače s bipolárními tranzistory}

Diferenční zesilovač s diferenčním výstupem

Základní zapojení diferenčního zesilovače s tranzistory NPN je uvedeno na Obr. 3.1a, na Obr. 3.1b je pak uvedena komplementární varianta s tranzistory PNP. Obvykle se diferenční stupeň provozuje s kladným a záporným napájením, které je obvykle (ale ne nutně) symetrické, jak je uvedeno na Obr. 3.1. Pak je totiž možné zesilovač budit přímo střídavým signálem bez nutnosti přidávat ss složku pro nastavení pracovního bodu tranzistorů. Zdroj proudu $2 I_{0}$ nastavuje pracovní proudy tranzistorů $\mathrm{T}_{1} \mathrm{a} \mathrm{T}_{2}$. Nebude-li diferenční stupeň buzen, rozdělí se podle Kirchlofova zákona proud ze zdroje proudu na polovinu a každý tranzistorem proto poteče proud $I_{0}$. 


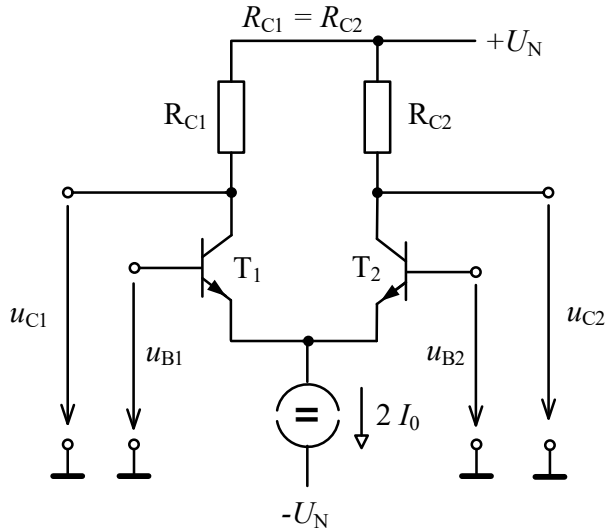

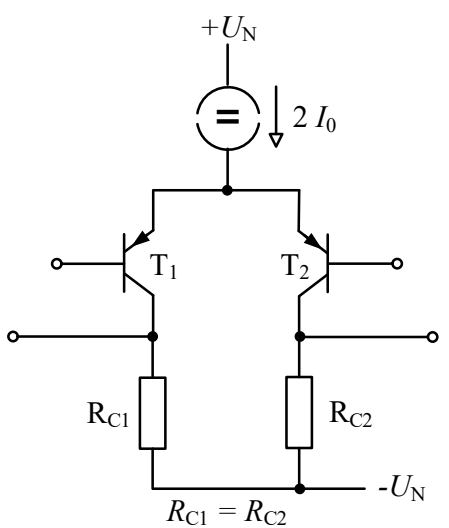

b

Obr. 3.1: a) Diferenční tranzistorový zesilovač, b) komplementární varianta

Vstupní napětí diferenčního stupně $u_{\mathrm{B} 1}$ a $u_{\mathrm{B} 2}$ (viz Obr. 3.12a) můžeme nahradit souhlasným napětím $u_{\mathrm{CM}}$ a diferenčním napětím $u_{\mathrm{D}}$, [1]. Souhlasné napětí na vstupu diferenčního stupně bude

$$
u_{\mathrm{CM}}=\frac{u_{\mathrm{B} 1}+u_{\mathrm{B} 2}}{2}
$$

a diferenční napětí

$$
u_{\mathrm{D}}=u_{\mathrm{B} 1}-u_{\mathrm{B} 2} .
$$

Potom

$$
u_{\mathrm{B} 1}=u_{\mathrm{CM}}+\frac{u_{\mathrm{D}}}{2}, u_{\mathrm{B} 2}=u_{\mathrm{CM}}-\frac{u_{\mathrm{D}}}{2} .
$$

Z rovnice (3-3) vyplývá, že buzení diferenčního stupně lze nahradit dvěma zdroji, každý $\mathrm{s}$ napětím $u_{\mathrm{D}} / 2$ a jedním společným zdrojem souhlasného napětí $u_{\mathrm{CM}}$. Na Obr. $3.2 \mathrm{~b}$ je ukázána

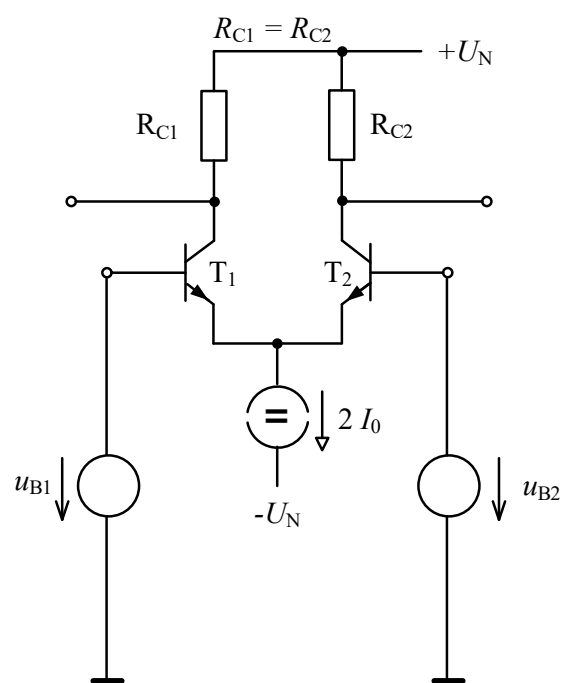

a

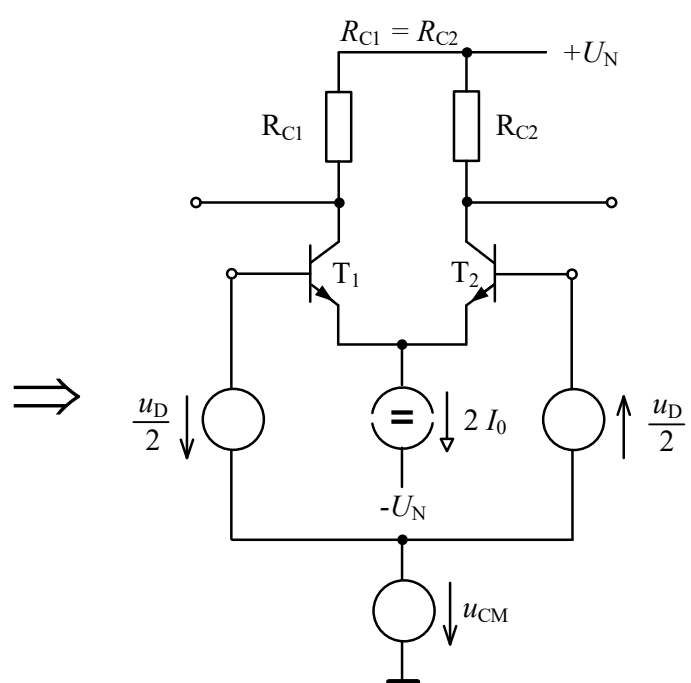

$\mathrm{b}$

Obr. 3.2: Náhrada vstupních napětí $u_{\mathrm{B} 1}$ a $u_{\mathrm{B} 2}$ souhlasným napětím $u_{\mathrm{CM}}$ a diferenčním napětím $u_{\mathrm{D}}$ 
náhrada vstupních napětí $u_{\mathrm{B} 1}$ a $u_{\mathrm{B} 2}$ pomocí souhlasného napětí $u_{\mathrm{CM}}$ a diferenčního napětí $u_{\mathrm{D}}$.

Napětové a proudové poměry $v$ diferenčním zesilovači jsou podrobně uvedeny na Obr. 3.3a. Jak bylo již řečeno, bude-li diferenční stupeň bez buzení, tj. budou-li obě vstupní napětí $u_{\mathrm{B} 1}=u_{\mathrm{B} 2}=0$, rozdělí se proud $2 I_{0} \mathrm{v}$ důsledku symetrie rovnoměrně mezi oba tranzistory $i_{\mathrm{E} 1}=i_{\mathrm{E} 2}=I_{0}$. Zanedbáváme-li proudy tekoucí do bází tranzistorů, bude $i_{\mathrm{C} 1}=i_{\mathrm{C} 2}$ $=I_{0}$. Pokud budou mít rezistory v kolektorech tranzistorů shodný odpor, $R_{\mathrm{C} 1}=R_{\mathrm{C} 2}=R_{\mathrm{C}}$ bude

$$
u_{\mathrm{C} 1} \approx U_{\mathrm{N}}-I_{0} R_{\mathrm{C}}, u_{\mathrm{C} 2} \approx U_{\mathrm{N}}-I_{0} R_{\mathrm{C}}
$$

a proto $u_{\mathrm{C} 1} \approx u_{\mathrm{C} 2}$.

Tyto poměry budou $\mathrm{v}$ diferenčním zesilovači zachovány i pro $u_{\mathrm{B} 1}=u_{\mathrm{B} 2}=u_{\mathrm{CM}}$, pokud zůstane $u_{\mathrm{D}}=0$. Proud ze zdroje konstantního proudu se totiž i nyní rovnoměrně rozdělí mezi oba tranzistory. Pro souhlasné vstupní napětí bude rozdíl výstupních napětí stále nulový $u_{0}=u_{\mathrm{C} 1}-u_{\mathrm{C} 2} \approx 0$. Proto zesílení souhlasného signálu

$$
A_{\mathrm{CM}}=\left.\frac{\partial u_{0}}{\partial u_{\mathrm{CM}}} \approx \frac{\Delta u_{0}}{\Delta u_{\mathrm{CM}}}\right|_{u_{\mathrm{D}}=0}
$$

bude teoreticky nulové $A_{\mathrm{CM}} \approx 0$. Ve skutečnosti bude mírně záporné v rozmezí $A_{\mathrm{CM}} \approx-10^{-}$ 4 až $-10^{-2}$. Je to způsobeno konečným vnitřním odporem $r_{\mathrm{V}}$ zdroje konstantního proudu, protože $A_{\mathrm{CM}} \approx-R_{\mathrm{C}} / 2 r_{\mathrm{V}},[2]$.

To, že zapojení nereaguje na souhlasné buzení, je velmi významnou vlastností diferenčního uspořádání. Protože tranzistory jsou obvykle vyrobeny stejnou technologií, mají stejné rozměry a dobrou tepelnou vazbu (jsou na jednom čipu), působí teplotní změny $u_{\mathrm{BE} 1}$ a $u_{\mathrm{BE} 2}$ na diferenční stupeň stejně jako buzení souhlasným signálem a proto se jejich teplotní změny $\mathrm{v}$ diferenčním stupni neuplatní. $Z$ tohoto důvodu se diferenční stupeň užíá i v př́ípadech, kdy je zapotřebí zesilovat nikoli rozdíl napětí, ale pouze vstupní napětí vztažené k zemi. V tom případě je jeden ze vstupů diferenčního zesilovače uzemněn.

Pokud budeme diferenční zesilovač budit diferenčním napětím $u_{\mathrm{D}}=u_{\mathrm{B} 1}-u_{\mathrm{B} 2}$, pak pro $u_{\mathrm{B} 1}>u_{\mathrm{B} 2}$ se změní rozdělení proudů takto: $i_{\mathrm{C} 1}$ se zvětší a $i_{\mathrm{C} 2}$ se zmenší. Jejich součet však

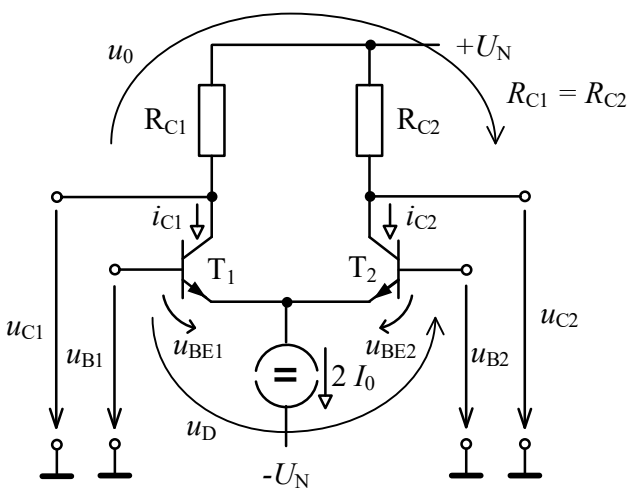

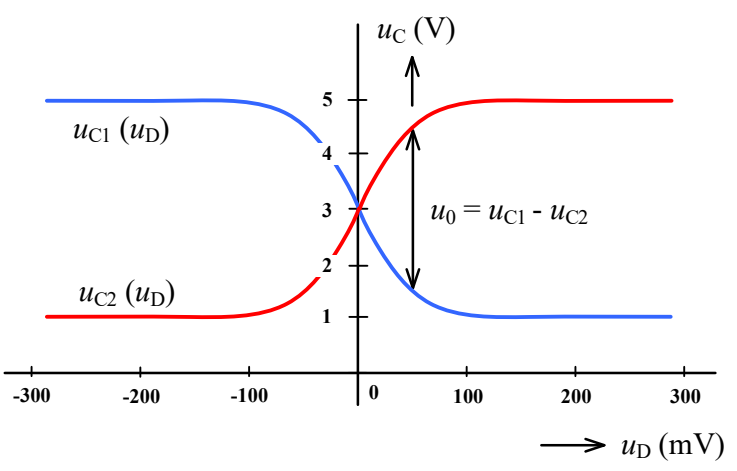

b

Obr. 3.3: a) Napět'ové a proudové poměry v diferenčním zesilovači, b) převodní charakteristiky 
bude stále $2 I_{0}$ a proto $\Delta i_{\mathrm{C} 1}=-\Delta i_{\mathrm{C} 2}$. Napětí $u_{\mathrm{C} 1}$ se přitom sníží a $u_{\mathrm{C} 2}$ se zvýší. Na diferenčním výstupu bude diferenční napětí $u_{0}=u_{\mathrm{C} 1}-u_{\mathrm{C} 2}$. Můžeme tedy definovat diferenční zesílení

$$
A_{\mathrm{D}}=\left.\frac{\partial u_{0}}{\partial u_{\mathrm{D}}} \approx \frac{\Delta u_{0}}{\Delta u_{\mathrm{D}}}\right|_{u_{\mathrm{CM}}=\text { konst }} .
$$

Hodnota diferenčního zesílení je záporná a je z rozmezí $A_{\mathrm{D}} \approx-50$ až -100 pokud jsou $\mathrm{v}$ kolektorech tranzistorů rezistory $\mathrm{R}_{\mathrm{C}}$ tak, jako je tomu u zapojení na Obr. 3.3a. Pokud kolektorové rezistory nahradíme zdroji konstantního proudu, můžeme mít diferenční zesílení hodnoty v rozmezí $A_{\mathrm{D}} \approx-500$ až -1000 .

Poměr diferenčního zesílení a souhlasného zesílení se nazývá činitel potlačení souhlasného signálu CMRR (common-mode rejestion ratio)

$$
C M M R=\frac{A_{\mathrm{D}}}{A_{\mathrm{CM}}} .
$$

$\mathrm{V}$ ideálním př́padě $A_{\mathrm{CM}} \approx 0$ a pak $C M M R=\infty$. Ve skutečnosti je $C M M R$ z rozmezí v $10^{3}$ až $10^{5} \mathrm{v}$ závislosti na vnitřním odporu zdroje konstantního proudu.

Při analýze zesilovacích vlastností diferenčního zesilovače vyjdeme ze situace, kdy diferenční vstupní napětí $u_{\mathrm{D}}=u_{\mathrm{B} 1}-u_{\mathrm{B} 2}$ se změní o $\Delta u_{\mathrm{D}}=\Delta u_{\mathrm{B} 1}-\Delta u_{\mathrm{B} 2}$. Prostudujeme př́pad symetrického buzení, kdy kladné změně napětí $u_{\mathrm{B} 1}$ odpovídá stejně velká záporná změna napětí $u_{\mathrm{B} 2}$, tj. $\Delta u_{\mathrm{B} 1}=-\Delta u_{\mathrm{B} 2}=\Delta u_{\mathrm{D}} / 2$. Při takové změně vstupních napětí zůstane z důvodu symetrie obvodu potenciál obou spojených emitorů beze změny, a proto můžeme na oba tranzistory pohlížet jako na tranzistory pracující v zapojení se společným emitorem.

Tranzistor $\mathrm{T}_{1}$ je $\mathrm{v}$ tomto případě buzen polovinou diferenčního vstupního napětí $\Delta u_{\mathrm{BE} 1}=\Delta u_{\mathrm{D}} / 2$, tzn. $\Delta u_{\mathrm{D}}=2 \Delta u_{\mathrm{BE} 1}$ a zesílení diferenčního napětí na jednoduchý výstup tranzistoru $\mathrm{T}_{1}$ (vztažený vůči zemi) bude

$$
A_{\mathrm{D} 1} \approx \frac{\Delta u_{\mathrm{C} 1}}{\Delta u_{\mathrm{D}}}=\frac{\Delta u_{\mathrm{C} 1}}{2 \Delta u_{\mathrm{BE} 1}} \approx-\frac{g_{\mathrm{m}}\left(R_{\mathrm{C}} \| r_{\mathrm{CE}}\right)}{2} \approx-\frac{g_{\mathrm{m}} R_{\mathrm{C}}}{2} .
$$

Podobně tranzistor $\mathrm{T}_{2}$ realizuje zesílení druhé poloviny diferenčního napětí, ale s opačným znaménkem $\Delta u_{\mathrm{BE} 2}=-\Delta u_{\mathrm{D}} / 2$ a tedy $\Delta u_{\mathrm{D}}=-2 \Delta u_{\mathrm{BE} 2}$. Zesílení diferenčního napětí na jednoduchý výstup $\mathrm{T}_{2}$ proto

$$
A_{\mathrm{D} 2} \approx \frac{\Delta u_{\mathrm{C} 2}}{\Delta u_{\mathrm{D}}}=\frac{\Delta u_{\mathrm{C} 2}}{-2 \Delta u_{\mathrm{BE} 2}} \approx \frac{g_{\mathrm{m}}\left(R_{\mathrm{C}} \| r_{\mathrm{CE}}\right)}{2} \approx \frac{g_{\mathrm{m}} R_{\mathrm{C}}}{2} .
$$

Poznámka: V obou předchozích rovnicích musíme uvažovat strmost, že odpovídající klidovému proudu $I_{0}$ protékajícímu tranzistory $\mathrm{T}_{1} \mathrm{i} \mathrm{T}_{2}$, proto $g_{\mathrm{m}} \approx 40 I_{0} / 1 \mathrm{~V}$.

Diferenční výstupní napětí $u_{0}$ diferenčního zesilovače je dáno rozdílem obou výstupních napětí $u_{0}=u_{\mathrm{C} 1}-u_{\mathrm{C} 2}$. Proto bude zesílení z diferenčního vstupu na diferenční výstup dáno vztahem 


$$
A_{\mathrm{D}} \approx \frac{\Delta u_{0}}{\Delta u_{\mathrm{D}}}=\frac{\Delta u_{\mathrm{C} 1}-\Delta u_{\mathrm{C} 2}}{\Delta u_{\mathrm{D}}}=\frac{\Delta u_{\mathrm{C} 1}}{\Delta u_{\mathrm{D}}}-\frac{\Delta u_{\mathrm{C} 2}}{\Delta u_{\mathrm{D}}}=A_{\mathrm{D} 1}-A_{\mathrm{D} 2}=-g_{\mathrm{m}}\left(R_{\mathrm{C}} \| r_{\mathrm{CE}}\right) \approx-g_{\mathrm{m}} R_{\mathrm{C}} .
$$

Diferenční vstupní odpor (vstupní odpor pro symetrické buzení) diferenčního zesilovače je zřejmě dán součtem vstupních odporů obou jednoduchých zesilovačů pracujících v zapojení se společným emitorem. Můžeme proto využít výsledek $R_{\mathrm{vst}} \approx r_{\mathrm{BE}}$ odvozený pro zapojení se společným emitorem. Potom vstupní diferenční odpor

$$
R_{\mathrm{i}}=R_{\mathrm{vst} 1}+R_{\mathrm{vst} 2} \approx 2 r_{\mathrm{BE}} .
$$

Také výstupní odpor každého výstupu vůči společnému vodiči je stejný jako u zesilovacího stupně s tranzistorem v zapojení se společným emitorem $R_{\text {výst }} \approx R_{\mathrm{C}} \| r_{\mathrm{CE}}$. U diferenčního (symetrického) výstupu se uplatní oba tyto odpory, takže jeho výstupní diferenční odpor

$$
R_{0}=R_{\text {výst1 }}+R_{\text {výst2 }} \approx 2\left(R_{\mathrm{C}} \| r_{\mathrm{CE}}\right) .
$$

V předchozím byly zkoumány přenosové vlastnosti diferenčního stupně pro malé signálové změny v lineární části př̀evodní charakteristiky. Chování pro velké signály vystihují převodní charakteristiky $u_{\mathrm{C} 1}\left(u_{\mathrm{D}}\right)$ a $u_{\mathrm{C} 2}\left(u_{\mathrm{D}}\right)$ na Obr. 3.3b, [10]. Byly získány pro $U_{\mathrm{N}}=5 \mathrm{~V}, R_{\mathrm{C}}=20 \mathrm{k} \Omega$ a $I_{0}=100 \mu \mathrm{A}$ jako u funkce diferenčního napětí $u_{\mathrm{D}}$.

Aktivní část charakteristik, kdy se diferenční zesilovač chová jako zesilovač, je v oblasti $u_{\mathrm{D}} \approx \pm 125 \mathrm{mV}$. Pro vyšší vstupní napětí pak dochází k přetížení diferenčního stupně. $\mathrm{V}$ tomto př́ípadě poteče většina proudu ze zdroje konstantního proudu (téměř $99 \%$ ) jen jedním z tranzistorů. Např. pro $u_{\mathrm{D}}>125 \mathrm{mV}$ je tranzistor $\mathrm{T}_{2}$ nevodivý a na jeho výstupu bude maximální napětí $u_{\mathrm{C} 2} \approx U_{\mathrm{N}}=5 \mathrm{~V}$. Tranzistorem $\mathrm{T}_{1} \mathrm{v}$ tomto prrípadě teče veškerý proud ze zdroje konstantního proudu $2 I_{0}$ a na jeho výstupu bude napětí

$$
u_{\mathrm{C} 1}=U_{\mathrm{N}}-2 I_{0} R_{\mathrm{C}}=5-2 \cdot 100 \cdot 10^{-6} \cdot 20 \cdot 10^{3}=1 \mathrm{~V} .
$$

Pro $u_{\mathrm{D}}<125 \mathrm{mV}$ tomu bude naopak.

Je vidět, že převodní charakteristiky na Obr. 3.3b jsou lineární pouze v okolí počátku charakteristik, jinak je průběh značně nelineární. Pokud si dáme požadavek, aby zkreslení výstupního signálu nebylo větší než $1 \%$, lze odvodit, že vstupní diferenční napětí nesmí přesáhnout $u_{\text {Dmax }} \approx 18 \mathrm{mV}$. Z rov. (3-10) pak vyplývá, že maximální výstupní napětí diferenčního stupně může být $u_{0 \max }=-u_{\text {Dmax }} g_{\mathrm{m}} R_{\mathrm{C}}=-u_{\mathrm{Dmax}} 40 I_{0} \cdot R_{\mathrm{C}}$. Pro $I_{0}=100 \mu \mathrm{A}$ a $R_{\mathrm{C}}$ $=20 \mathrm{k} \Omega$ bude $u_{0 \max }=-1,4 \mathrm{~V}$. To je, ve srovnání se zapojením se společným emitorem, kdy při stejných požadavcích na zkreslení může být maximální výstupní napětí pouze $0,2 \mathrm{~V}$, daleko prŕiznivější výsledek.

\section{Diferenční zesilovač s nesymetrickým výstupem}

Diferenční zesilovač může pracovat i s nesymetrickým výstupem (Obr. 3.4). Rezistor $\mathrm{v}$ kolektoru tranzistoru $\mathrm{T}_{1}$ může pak mít nulový odpor. Na činnosti obvodu se prakticky nic nezmění, proud $2 I_{0}$ se přerozdělí mezi tranzistory stejně jako v předchozím. Zesílení diferenčního vstupního napětí bude dáno rovnicí (3-9). Tento obvod se užívá při konverzi diferenčního signálu na jednoduchý výstup vztažený k zemnímu potenciálu. 
Pokud ještě uzemníme bázi tranzistoru $\mathrm{T}_{2}$, bude obvod pracovat $\mathrm{s}$ nesymetricky buzeným vstupem a nesymetrickým výstupem. Napět'ové zesílení pak $A_{\mathrm{U}} \approx g_{\mathrm{m}} R_{\mathrm{C}}$. V obou případech se teplotní změny napětí $u_{\mathrm{BE}}$ navzájem vykompenzují.

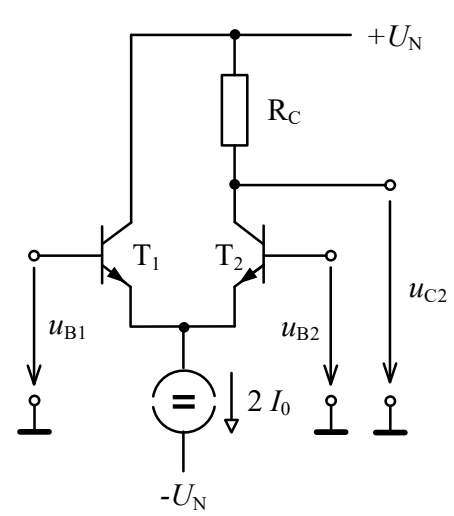

Obr. 3.4: Diferenční zesilovač s nesymetrickým výstupem

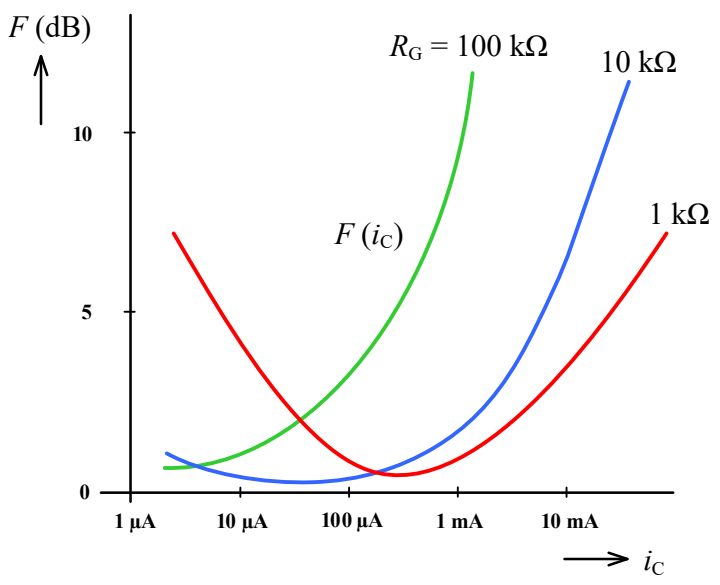

Obr. 3.5: Typická závislost šumového čísla na kolektorovém proudu

\section{Volba pracovního bodu}

Protože diferenční zesilovač je obvykle na vstupu zesilovacího řetězce, bude jeho šum dále zesilován. Šumové vlastnosti tranzistorů se obvykle vyjadřují pomocí šumového čísla v závislosti na hodnotě vnitřního odporu $R_{\mathrm{G}}$ zdroje budicího napětí [1]. Přitom vlastní tranzistor se uvažuje jako bezšumový. Šumové číslo $F$ udává hodnotu, jakou je nutné násobit šumový výkon $\mathrm{v}$ rezistoru $R_{\mathrm{G}}$ tak, abychom na výstupu bezšumového tranzistoru získali stejný výkon šumu jako v reálném obvodu. Šumové číslo tranzistoru silně závisí na kolektorovém proudu a na vnitřním odporu zdroje signálu $R_{\mathrm{G}}$ (viz Obr. 3.5). Je zřejmé, že lze nalézt takový kolektorový proud, kdy je šum tranzistoru nejmenší. Obvykle se proto pracovní body tranzistorů $\mathrm{T}_{1} \mathrm{a} \mathrm{T}_{2} \mathrm{v}$ diferenčním stupni volí $I_{0} \approx 100 \mu \mathrm{A}$. Klidové proudy do bází tranzistorů pak budou přívětivě nízké kolem $1 \mu \mathrm{A}$. Na druhou stranu se ale diferenční zesilovač nemůže z tohoto důvodu zatěžovat př́iliš velkými výstupními proudy tekoucími do vstupu dalšího zesilovacího stupně. Proto bývají mezi vstupní diferenční stupeň a následující zesilovací stupeň vloženy oddělovací emitorové sledovače, nebo má následující stupeň na vstupu tranzistory v Darlingtonově uspořádání.

\subsubsection{Diferenční zesilovače s unipolárními tranzistory}

Diferenční zesilovač s diferenčním výstupem

V mnoha případech je požadován diferenční zesilovač s vysokým vstupním odporem. V principu by bylo možné na místě tranzistorů v bipolárním diferenčním stupni použít Darlingtonových dvojic tranzistorů. Daleko lepších výsledků, pokud se týká vstupního odporu, šiřky kmitočtového pásma i šumových vlastností, se dá dosáhnout při použití unipolárních tranzistorů [1]. 
Typické zapojení diferenčního zesilovače s tranzistory MOSFET s kanálem N je uvedeno na Obr. 3.6a. Substrát B (bulk) se připojí obvykle na potenciál $-U_{\mathrm{N}}$ tak, aby byl přechod PN mezi substrátem a kanálem uzavřen. Na Obr. 3.6b je pak komplementární varianta $\mathrm{s}$ tranzistory MOSFET $\mathrm{s}$ kanálem $\mathrm{P}$. V tomto př́ipadě se substrát $\mathrm{B}$ připojí na $+U_{\mathrm{N}}$.

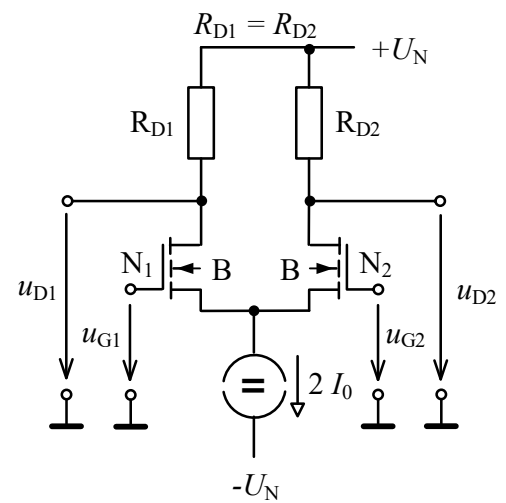

a

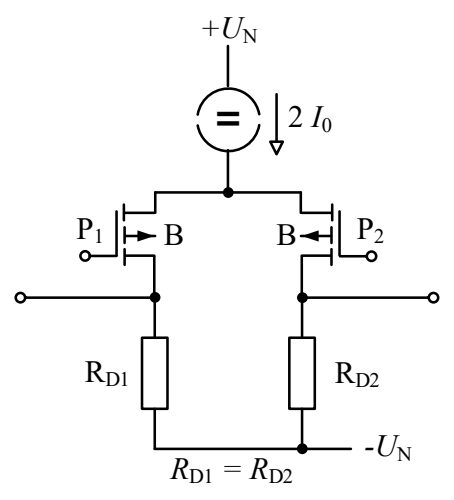

b

Obr. 3.6: Diferenční zesilovač s tranzistory MOSFET: a) s kanálem N, b) s kanálem P

Pro určení vlastností zapojení je možno použít vztahy odvozené v předchozí kapitole, ale v tomto prrípadě již nelze zanedbat výstupní odpor $r_{\mathrm{DS}}$. Zde diferenční vstupní napětí $u_{\mathrm{D}}=u_{\mathrm{G} 1}-u_{\mathrm{G} 2}$ a diferenční výstupní napětí $u_{0}=u_{\mathrm{D} 1}-u_{\mathrm{D} 2}$. Opět předpokládáme $R_{\mathrm{D} 1}$ $=R_{\mathrm{D} 2}=R_{\mathrm{D}}$. Zesílení souhlasného napětí $u_{\mathrm{CM}}=\left(u_{\mathrm{G} 1}+u_{\mathrm{G} 2}\right) / 2$ bude i zde přibližně nulové

$$
A_{\mathrm{CM}} \approx \frac{\Delta u_{0}}{\Delta u_{\mathrm{CM}}} \approx 0
$$

Diferenční zesílení

$$
A_{\mathrm{D}} \approx \frac{\Delta u_{0}}{\Delta u_{\mathrm{D}}} \approx-g_{\mathrm{m}}\left(R_{\mathrm{D}} \| r_{\mathrm{DS}}\right)
$$

Pokud využijeme výstupy nesymetricky, tj. vztažené k zemnímu potenciálu, bude

$$
\begin{gathered}
A_{\mathrm{D} 1}=\frac{\Delta u_{\mathrm{D} 1}}{\Delta u_{\mathrm{D}}}=-g_{\mathrm{m}}\left(R_{\mathrm{D}} \| r_{\mathrm{DS}}\right) / 2, \\
A_{\mathrm{D} 2}=\frac{\Delta u_{\mathrm{D} 2}}{\Delta u_{\mathrm{D}}}=g_{\mathrm{m}}\left(R_{\mathrm{D} 2} \| r_{\mathrm{DS}}\right) / 2 .
\end{gathered}
$$

Protože diferenční vstupní odpor $r_{\mathrm{GS}} \approx \infty$, bude i vstupní odpor mezi diferenčními vstupy $R_{\mathrm{i}} \approx \infty$. Výstupní odpor mezi diferenčními výstupy je $R_{0} \approx 2\left(R_{\mathrm{D}} \| r_{\mathrm{DS}}\right)$.

\section{Nastavení pracovního bodu}

Na rozdíl od bipolárních tranzistorů převodní charakteristika diferenčního zesilovače $\mathrm{s}$ unipolárními tranzistory $u_{0}\left(u_{\mathrm{D}}\right)$ závisí v režimu velkých signálů na nastavení pracovního proudu $I_{0}$ (viz Obr. 3.7a). Je vidět, že proud $I_{0}$ určuje využitelnou oblast vstupního 
diferenčního napětí. Např. pro $I_{0}=0,01 I_{\mathrm{D} 0}$ je využitelná oblast vstupního napětí $u_{\mathrm{D}} \approx \pm$ $0,8 \mathrm{~V}$, kdežto pro $I_{0}=I_{\mathrm{D} 0}$ může být vstupní napětí jen z rozmezí $u_{\mathrm{D}} \approx \pm 0,2 \mathrm{~V}$. Zesílení diferenčního zesilovače, které je dáno strmostí charakteristiky v okolí počátku, je ale při

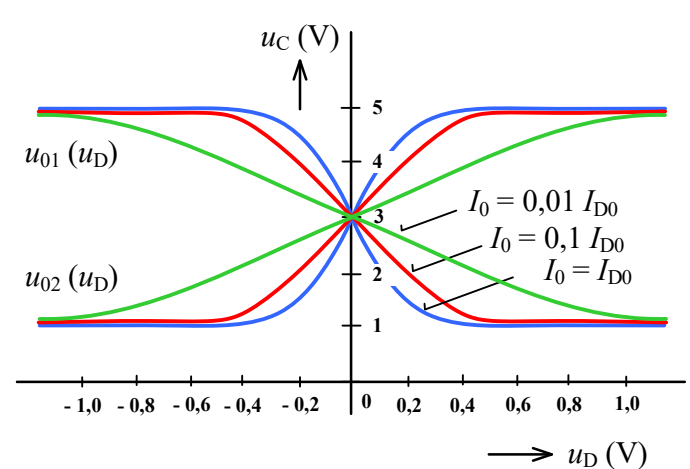

a

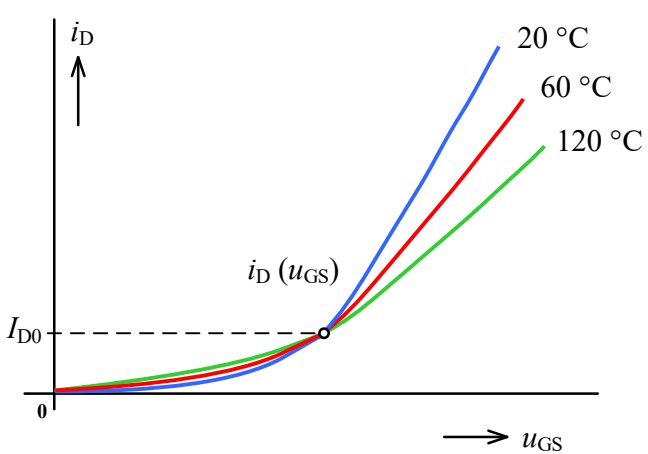

b

Obr. 3.7: a) Závislost převodních charakteristik diferenčního zesilovače pracovního bodu, b) závislost přenosové charakteristiky tranzistoru FET na teplotě

$I_{0}=I_{\mathrm{D} 0}$ největší. Při volbě pracovního bodu musíme proto zohlednit, zda diferenční stupeň bude na počátku zesilovacího řetězce, kdy vstupní napětí budou malá, nebo bude v zesilovacím řetězci zpracovávat vstupní signály s větším rozkmitem.

Nastavení klidových proudů tekoucích diferenčním stupněm se u bipolárních tranzistorů řídí požadavkem na malý šum tranzistorů, který silně závisí na hodnotě kolektorových proudů. Tranzistory FET takovou vlastnost většinou nevykazují. Volba pracovního se v př́ípadě tranzistorů FET řídí teplotním činitelem napětí mezi řídicí elektrodou a emitorem tranzistoru. Je to dáno, tím, že teplotní koeficient napětí mezi řídicí elektrodou a emitorem $u_{\mathrm{GS}}$ silně závisí na kolektorovém proudu $i_{\mathrm{D}}$. Jak je vidět z Obr. $3.7 \mathrm{~b}$, při malých proudech je tento koeficient záporný a při velkých naopak kladný. Z průsečíku charakteristik lze ale nalézt proud $I_{\mathrm{D} 0}$, kdy je teplotní koeficient nulový, Pokud tedy diferenční stupeň bude na vstupu zesilovacího řetězce, kdy je požadováno velké zesílení a malé změny vlastností $\mathrm{s}$ teplotou, volíme proud pracovního bodu právě $I_{\mathrm{D} 0}$.

\subsubsection{Diferenční zesilovač s aktivní zátěží}

\section{Diferenční zesilovač s aktivní zátěži a diferenčním výstupem}

Snaha o co největší zesílení diferenčního zesilovače vede na zvyšování odporů rezistorů $\mathrm{R}_{\mathrm{C} 1}$ a $\mathrm{R}_{\mathrm{C} 2}$, resp. $\mathrm{v}$ prrípadě diferenčního zesilovače $\mathrm{s}$ tranzistory $\mathrm{FET}$ odporu rezistorů $R_{\mathrm{D} 1}$ a $R_{\mathrm{D} 2}$. Na rezistoru s velkým odporem by však vznik1 již při nastavení pracovního bodu relativně malým proudem př́liš velký úbytek napětí. To by vedlo k požadavku na zvýšení napájecího napětí $U_{\mathrm{N}}$. Navíc rezistory s velkým odporem zabírají na integrovaném obvodu velkou plochu a proto nejsou žádoucí. Takový rezistor se proto nahrazuje zdrojem konstantního proudu, který dodá patřičný proud $I_{0}$, ale pro strídavé signály bude vykazovat vysoký vnitřní diferenční odpor $r_{\mathrm{V}}$. 
V diferenčním zesilovači na Obr. 3.8a jsou použity místo kolektorových odporů dva zdroje konstantního proudu $I_{0}$. První je tvořen rezistorem $\mathrm{R}_{0}$ a komplementárním proudovým zrcadlem $\mathrm{s}$ tranzistory $\mathrm{T}_{3}$ a $\mathrm{T}_{4}$. Proud, který proudové zrcadlo dodává do zátěže představované tranzistorem $\mathrm{T}_{1}$, je určen vztahem $I_{0} \approx\left(2 U_{\mathrm{N}}-u_{\mathrm{BE} 3}\right) / R_{0} \approx\left(2 U_{\mathrm{N}}-0,6\right) / R_{0}$.

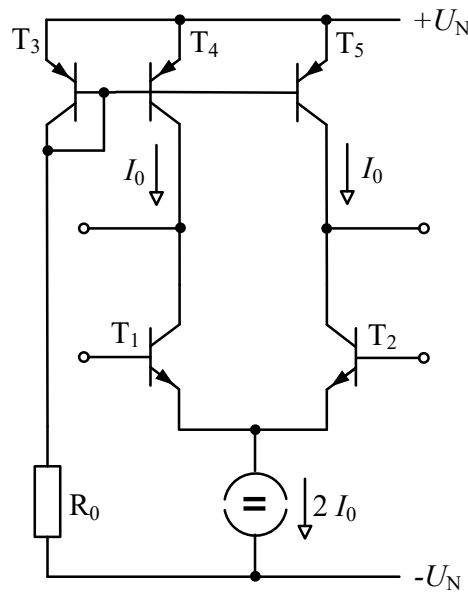

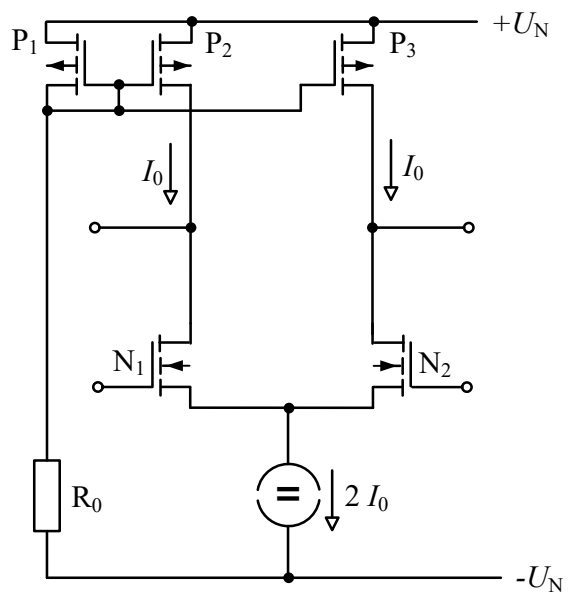

b

Obr. 3.8: Diferenční zesilovač s aktivní zátěží a diferenčním výstupem: a) s bipolárními tranzistory, b) s tranzistory MOSFET

Protože do kolektoru $\mathrm{T}_{2}$ musí být dodáván tentýž proud $I_{0}$, je ř́dicí napětí báze $\mathrm{T}_{5}$ navázáno taktéž na bázi tranzistoru $\mathrm{T}_{3}$. Druhý zdroj konstantního proudu je proto tvořen rezistorem $\mathrm{R}_{0}$ a proudovým zrcadlem $\mathrm{s}$ tranzistory $\mathrm{T}_{3}$ a $\mathrm{T}_{5}$. Zátěž v kolektorech tranzistorů $\mathrm{T}_{1}$ a $\mathrm{T}_{2}$ pro

střídavé signály nyní představují diferenciální vnitřní odpory proudových zrcadel $r_{\mathrm{V} 4} \approx r_{\mathrm{V} 5} \approx 100 \mathrm{k} \Omega$. Poznamenejme, že pokud by byl v kolektoru tranzistoru rezistor s odporem $R_{\mathrm{C}}=100 \mathrm{k} \Omega$, pak by na takovémto rezistoru při proudu $1 \mathrm{~mA}$ vznikl úbytek napětí $100 \mathrm{~V}$.

$\mathrm{Na}$ Obr. 3.8b je nakresleno alternativní zapojení diferenčního stupně s tranzistory MOSFET. Pokud jsou tranzistory $\mathrm{N}_{1}$ a $\mathrm{N}_{2}$ vlastního diferenčního stupně s kanálem $\mathrm{N}$, musí být logicky zdroje konstantního proudu s tranzistory s kanálem $\mathrm{P}$. V prŕípadě tranzistoru MOSFET se musí substrát (bulk) vždy ošetřit tak, aby se izolační přechod PN mezi substrátem a vlastním kanálem zavřel. $V$ případě tranzistorů $\mathrm{N}_{1}$ a $\mathrm{N}_{2}$ se proto substrát připojí na napětí $-U_{\mathrm{N}}$ a v př́padě tranzistorů $\mathrm{P}_{1}, \mathrm{P}_{2}$ a $\mathrm{P}_{3}$ na napětí $+U_{\mathrm{N}}$. Většinou se toto připojení pro zjednodušení ve schématech nezakresluje.

\section{Diferenční zesilovač s aktivní zátěži a nesymetrickým výstupem}

Jestliže je to vyžadováno, můžeme diferenční stupeň provozovat s nesymetrickým jednoduchým výstupem vztaženým k zemnímu potenciálu stejně jako je tomu na Obr. 3.4. Nejlepši řešení, které v konkrétních aplikacích převládá, je uvedeno na Obr. 3.6. V tomto př́padě je zdroj proudu nahrazen proudovým zrcadlem, které proud z chybějícího výstupu zrcadlí na nesymetrický výstup. Proudový přenos proudového zrcadla musí být $K_{\mathrm{I}}=1$, resp. 
v praxi $K_{\mathrm{I}} \approx 1$. Do zátěže (viz Obr. 3.9a) poteče proud $i_{0}=i_{\mathrm{C} 2}-i_{\mathrm{C} 4}$. Protože proudové zrcadlo zopakuje proud $i_{\mathrm{C} 1}$ na svém výstupu $i_{\mathrm{C} 4} \approx i_{\mathrm{C} 1}$, poteče do zátěže proud

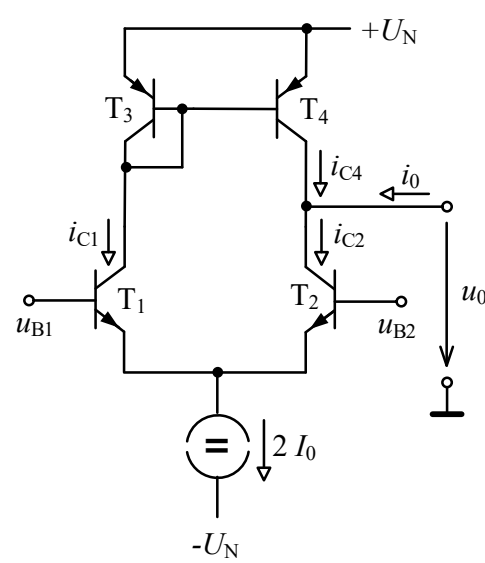

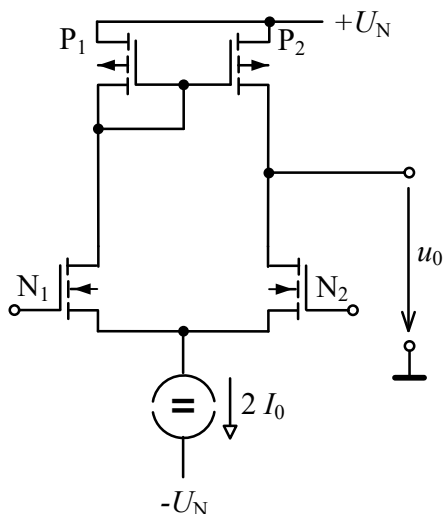

b

Obr. 3.9: Diferenční zesilovač s aktivní zátěží a nesymetrickým výstupem: a) s bipolárními tranzistory, b) s tranzistory MOSFET

$$
i_{0}=i_{\mathrm{C} 2}-i_{\mathrm{C} 1} .
$$

Pokud bude diferenční stupeň bez buzení, tzn. $u_{\mathrm{D}}=0$, nepoteče do výstupu žádný proud, protože $i_{0}=i_{\mathrm{C} 2}-i_{\mathrm{C} 1}=I_{0}-I_{0}=0$. Při symetrickém buzení, kdy kladné změně napětí $\Delta u_{\mathrm{B} 1}=\Delta u_{\mathrm{D}} / 2$ odpovídá stejně velká záporná změna $\Delta u_{\mathrm{B} 2}=-\Delta u_{\mathrm{D}} / 2$, dojde k rozvážení proudových poměrů a tranzistorem $\mathrm{T}_{1}$ poteče nyní proud $i_{\mathrm{C} 1}=I_{0}+\Delta i_{\mathrm{C} 1}$ a tranzistorem $\mathrm{T}_{2}$ proud $i_{\mathrm{C} 2}=I_{0}-\Delta i_{\mathrm{C} 2}$. Do výstupu proto poteče proud $i_{0}=i_{\mathrm{C} 2}-i_{\mathrm{C} 1}=-\Delta i_{\mathrm{C} 2}-\Delta i_{\mathrm{C} 1}$. Pokud tranzistory $\mathrm{T}_{1}$ a $\mathrm{T}_{2}$ budou mít shodné vlastnosti bude $i_{\mathrm{C} 1} \approx \Delta i_{\mathrm{C} 2}$ a proud do zátěže se změní o hodnotu $\Delta i_{0}=-2 \Delta i_{\mathrm{C} 2}$. Protože tranzistor $\mathrm{T}_{2}$ pracuje $\mathrm{v}$ zapojení se společným emitorem, jeho kolektorový proud vzroste jak známo o hodnotu $\Delta i_{\mathrm{C} 2} \approx g_{\mathrm{m}} \Delta u_{\mathrm{B} 2}=-g_{\mathrm{m}} \Delta u_{\mathrm{D}} / 2$ a proud se změní o $\Delta i_{0}=-2 \Delta i_{\mathrm{C} 2} \approx g_{\mathrm{m}} \Delta u_{\mathrm{D}}$. Na nesymetrické napětí se převede tato změna výstupního proudu na zátěži $r_{0} \approx r_{\mathrm{CE} 2} \| r_{\mathrm{CE} 4}$, která je tvořena paralelní kombinací výstupního diferenčního odporu $r_{\mathrm{CE} 2}$ zesilovače s tranzistorem $\mathrm{T}_{2}$ a vnitřního diferenčního odporu proudového zrcadla $r_{\mathrm{CE} 4}$

$$
\Delta u_{0}=-\Delta i_{0} r_{0} \approx-g_{\mathrm{m}} \Delta u_{\mathrm{D}}\left(r_{\mathrm{CE} 2} \| r_{\mathrm{CE} 4}\right) .
$$

Zesílení diferenčního napětí na jednoduchý výstup $\mathrm{T}_{2}$ proto bude

$$
A_{\mathrm{D} 2} \approx \frac{\Delta u_{0}}{\Delta u_{\mathrm{D}}} \approx-g_{\mathrm{m}}\left(r_{\mathrm{CE} 2} \| r_{\mathrm{CE} 4}\right)
$$

Zátěž zpravidla tvoří i vstupní odpor následujícího stupně. Aby bylo výsledné napět'ové zesílení co největší, bývá většinou jako další stupeň zařazen emitorový sledovač, který vykazuje vysoký vstupní odpor $R_{\mathrm{vst}} \gg r_{\mathrm{CE} 2} \| r_{\mathrm{CE} 4}$. 
Variantní řešení s tranzistory MOSFET je nakresleno na Obr. 3.9b.

\subsubsection{Složený diferenční stupeň}

Diferenční stupeň na Obr. 3.10a je typický pro tzv. druhou generaci operačních zesilovačů. Vlastní diferenční stupeň je realizován tranzistory $\mathrm{T}_{3} \mathrm{a} \mathrm{T}_{4} \mathrm{~V}$ zapojení se společnou bází [3]. Zdroj proudu $I_{0}$ nastavuje jejich pracovní body. Předřazené tranzistory $\mathrm{T}_{1}$ a $\mathrm{T}_{2} \mathrm{j}$ sou zapojeny jako emitorové sledovače. Uvedené řešení odstraňuje problémy s malým proudovým zesilovacím činitelem použitých NPN tranzistorů a současně se tím zvětší povolené diferenční a souhlasné napětí.

Skutečná realizace diferenčního stupně musí potlačit závislost pracovních kolektorových proudů tranzistorů $\mathrm{T}_{3}$ a $\mathrm{T}_{4}$ na výrobním rozptylu strmosti použitých PNP tranzistorů. Proto jsou pracovní proudy diferenčního zesilovače stabilizovány zpětnovazební smyčkou uzavřenou přes proudové zrcadlo $\mathrm{T}_{7}, \mathrm{~T}_{8}$ (viz Obr. 3.10b). Protože výstup diferenčního zesilovače je v tomto př́ípadě nesymetrický, je jako aktivní zátěž použito proudové zrcadlo $\mathrm{T}_{5}, \mathrm{~T}_{6}$.
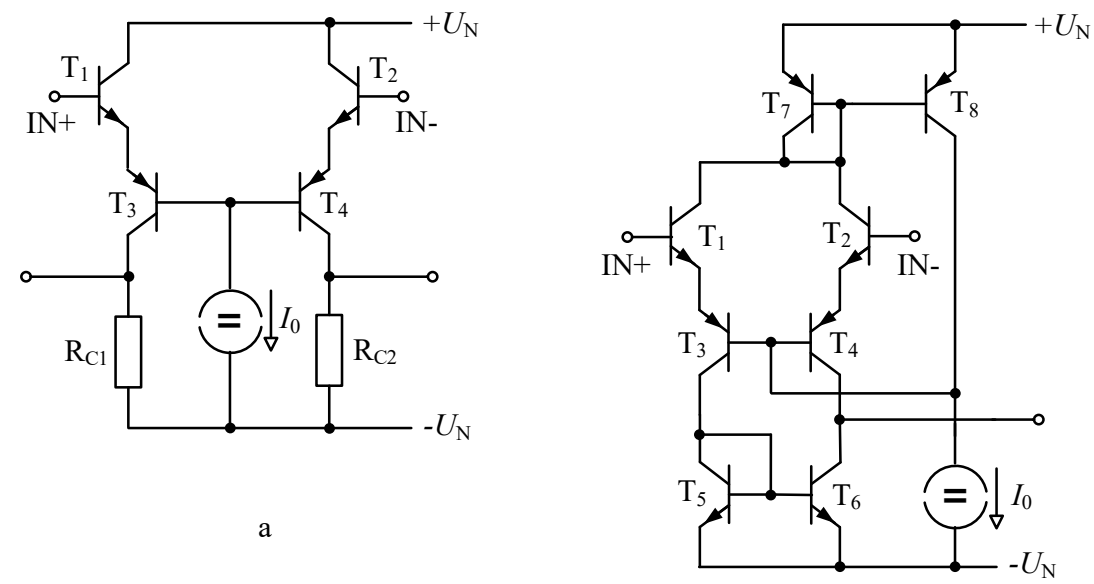

b

Obr. 3.10: a) Složený diferenční stupeň, b) stabilizace pracovních proudů

\subsubsection{Kaskódové zapojení diferenčního zesilovače}

Kaskódový diferenční zesilovačs diferenčním výstupem

Jak již bylo konstatováno, diferenční zesilovač obvykle sestává ze symetrického spojení tranzistorů v zapojení se společným emitorem. Proto se u zapojení uplatňuje taktéž Millerův jev, kdy se parazitní kapacity $C_{\mathrm{BE}}$ jeví na vstupech diferenčního zesilovače daleko větší, což způsobuje zmenšení šiřřky kmitočtového pásma zpracovaných signálů. Pro odvrácení Millerova efektu se obě větve diferenčního stupně nahradí kaskódovým zapojením tranzistoru tak, jako je to naznačeno na Obr. 3.11a. Pomocné napětí $U_{\mathrm{B}}$ musí splňovat podmínku

$$
U_{\mathrm{B}}>U_{\mathrm{CEsat}}+u_{\mathrm{BE}} \approx 0,8 \mathrm{až} 1 \mathrm{~V} \text {. }
$$

Pak tranzistory $\mathrm{T}_{1}$ a $\mathrm{T}_{2}$ budou pracovat v normálním aktivním režimu. 


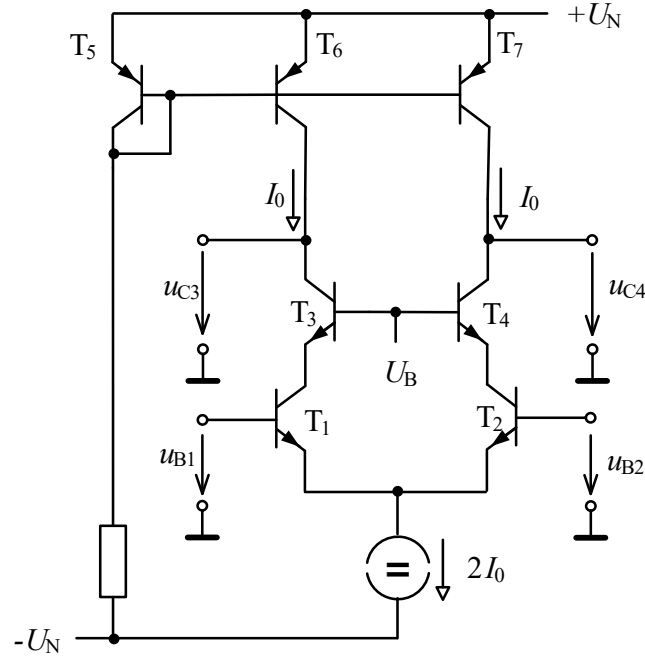

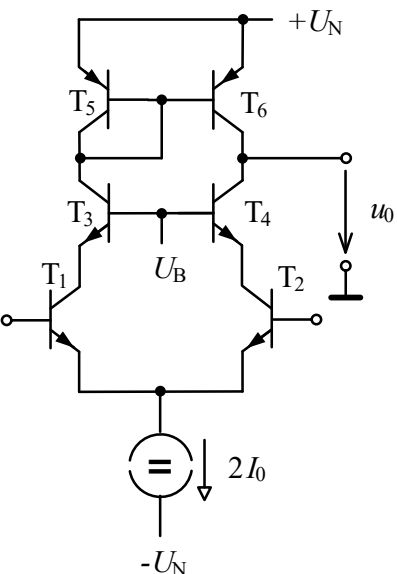

$\mathrm{b}$

Obr. 3.11: Kaskódové zapojení diferenčního zesilovače s aktivní zátěží: a) s diferenčním výstupem, b) s nesymetrickým výstupem

V zapojení na Obr. 3.11a jsou použity zdroje konstantního proudu $I_{0}$ jako aktivní zátěže pro získání většího diferenčního zesílení. Pokud je cílem pouze zvýšení šiřky pásma, používají se jako zdroje proudu jednoduchá proudová zrcadla. Vyšší diferenční zesílení je však často stejně důležité jako větší šiřka kmitočtového pásma, Pak je nutno pro konstrukci zdrojů konstantního proudu, použít kvalitnější proudová zrcadla, která vykazují vysoký vnitřní odpor.

\section{Kaskódový diferenční zesilovač s nesymetrickým výstupem}

Diferenční kaskódový zesilovač můžeme použít i s nesymetrickým výstupem, kdy se s výhodou jako aktivní zátěž použije proudové zrcadlo podobně jako tomu bylo v zapojení na Obr. 3.9a. Zapojení kaskódového diferenčního zesilovače s nesymetrickým výstupem je naznačeno na Obr. 3.11b. Pokud je současně se zvětšením šířky pásma, které zajišt’uje zapojení se společnou bází s tranzistory $\mathrm{T}_{3}$ a $\mathrm{T}_{4}$, požadováno i zvětšení zesílení, je nutno použít lepší proudová zrcadla s vyšším vnitřním odporem.

\section{Diferenční zesilovač s kombinovanou kaskodou}

Diferenční zesilovač s kombinovanou kaskodou (differential amplifier with folder cascode) je složen $z$ diferenčního zesilovače s tranzistory NPN v zapojení se společným kolektorem (Obr. 3.12a) a komplementárního diferenčního zesilovače v zapojení se společnou bází s tranzistory PNP (Obr. 3.12b). Výsledné zapojení diferenčního zesilovače s kombinovanou kaskodou je uvedeno na Obr. 3.12c. Millerův jev se zde opět neuplatní, protože napět'ové zesílení do kolektorů tranzistoru $\mathrm{T}_{1}$ a $\mathrm{T}_{2}$ bude, díky tomu, že tranzistory $\mathrm{T}_{3}$ a $\mathrm{T}_{4}$ jsou zapojeny se společnou bází, jednotkové. Aby se docílilo dostatečné zesílení, bývají kolektorové rezistory $\mathrm{R}_{\mathrm{C} 1}$ a $\mathrm{R}_{\mathrm{C} 2}$ nahrazeny zdroji konstantního proudu $I_{0}$. Pokud je požadován přechod na nesymetrický výstup, kolektorové rezistory se nahradí vhodným typem proudového zrcadla. 


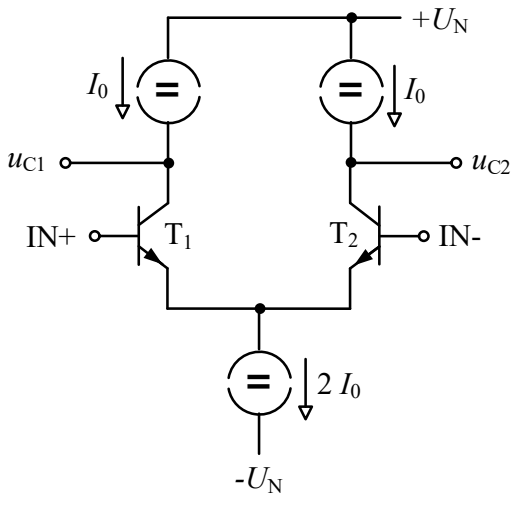

$\mathrm{a}$

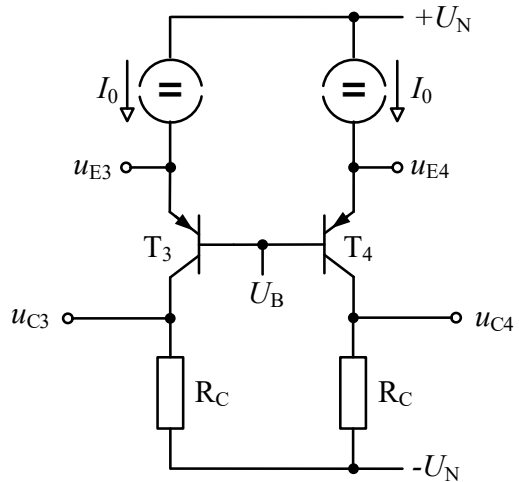

$\mathrm{b}$

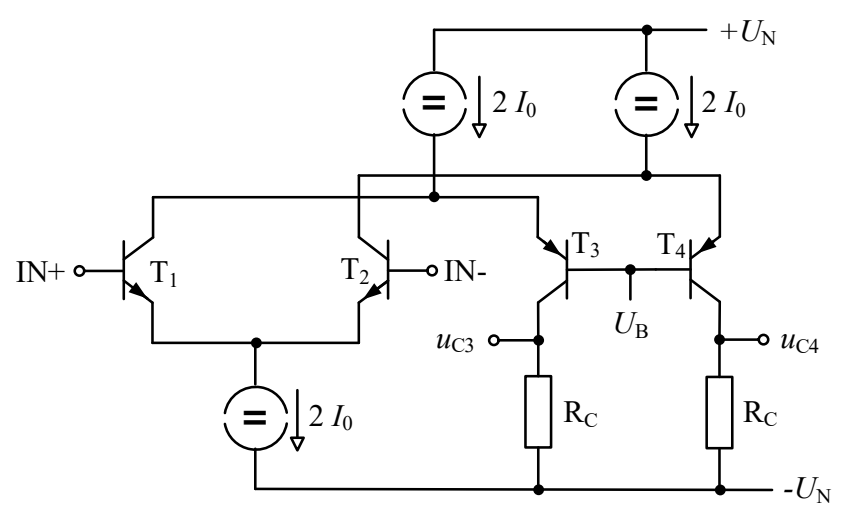

c

Obr. 3.12: a) Diferenční zesilovač v zapojení SE, b) diferenční zesilovač v zapojení SB, c) diferenční zesilovač s kombinovanou kaskódou

Protože první diferenční stupeň je s tranzistory PNP a druhý s tranzistory NPN, mají napájecí zdroje druhého stupně opačnou polaritu. Proto je možné udržet dynamický rozkmit napětí $\mathrm{i}$ obou stupňů téměř $\mathrm{v}$ plném rozsahu napájecích napětí. U předchozích uspořádání diferenčních kaskódových stupňů (Obr. 3.11) vložení tranzistorů zapojených se společnou bází totiž způsobuje posun stejnosměrné složky napětí na výstupu celého diferenčního stupně směrem ke kladnému napájecímu napětí $+U_{\mathrm{N}}$, nebo v př́padě komplementárního řešení směrem k zápornému napájecímu napětí $-U_{\mathrm{N}}$. To jednostranně limituje dynamický rozkmit zpracovaného signálu.

\subsection{Elementární operační zesilovač}

Ideové uspořádání elementárního diferenčního operačního zesilovače je uvedeno na Obr. 3.13a. Aby na výstupu operačního zesilovače nebyla nežádoucí stejnosměrná složka, je použit symetrický napájecí zdroj. Ve vstupním diferenčním tranzistorovém zesilovači je použit pro nastavení pracovního bodu tranzistorů $\mathrm{T}_{1}$ a $\mathrm{T}_{2}$ zdroj konstantního proudu $2 I_{0}$. Výstup z diferenčního stupně je nesymetrický a je vztažen k zápornému napájecímu napětí - $U_{\mathrm{N}}$, které z hlediska stř́ídavých signálů můžeme považovat za zemní potenciál. 


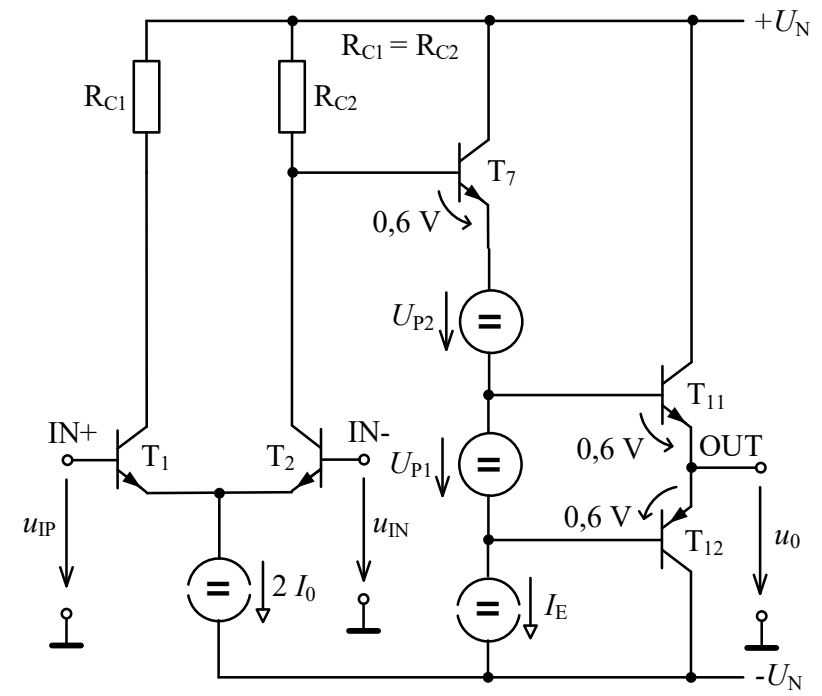

a

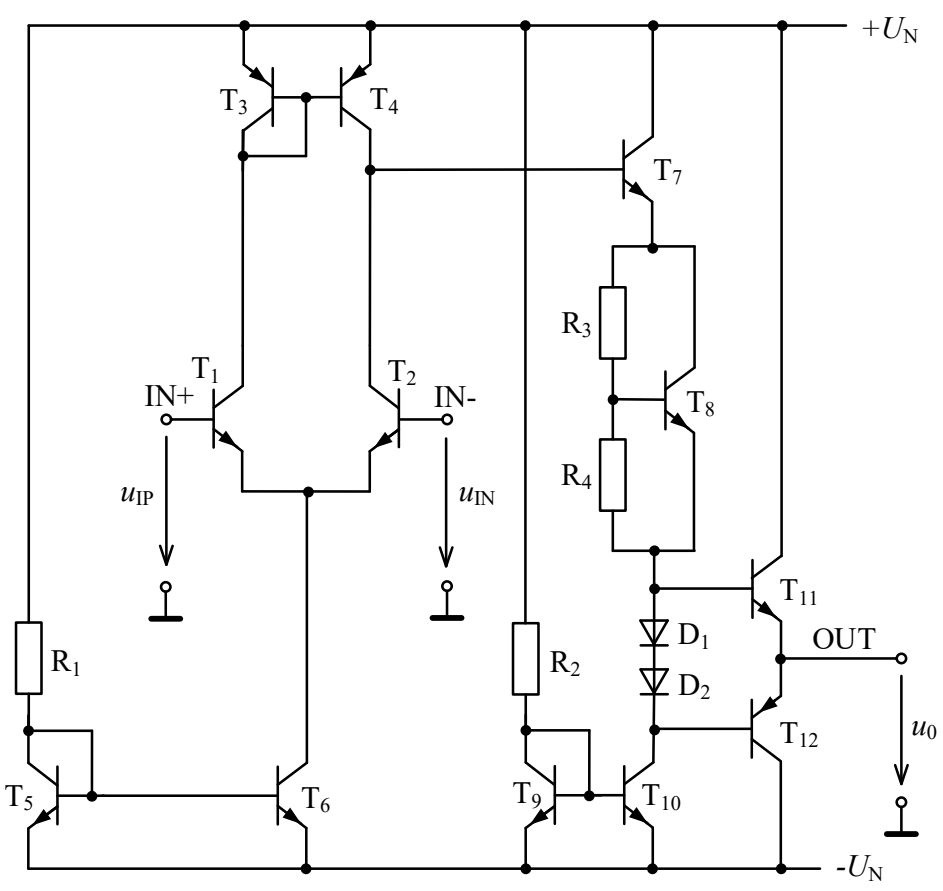

b

Obr. 3.13: a) Koncepce elementárního operačního zesilovače, b) př́klad řešení jednoduchého operačního zesilovače

Protože tranzistory $\mathrm{T}_{1}$ a $\mathrm{T}_{2}$ by měly $\mathrm{z}$ důvodu nižšího šumu pracovat $\mathrm{s}$ malými kolektorovými proudy $I_{0}$, je pro oddělení následujícího stupně použit emitorový sledovač $\mathrm{s}$ tranzistorem $\mathrm{T}_{7}$. Aby emitorový sledovač vykazoval co největší vstupní odpor je v jeho emitoru místo rezistoru zapojen zdroj konstantního proudu $I_{\mathrm{E}}$. Koncový stupeň je tvořen komplementární dvojicí emitorových sledovačů pracujících ve třídě $\mathrm{AB}$ (tranzistory $\mathrm{T}_{11} \mathrm{a}$ $\mathrm{T}_{12}$ ). Pro zmenšení přechodového zkreslení koncového emitorového sledovače je zapojen zdroj pomocného napětí $U_{\mathrm{P} 1}=2 \cdot 0,6 \mathrm{~V}=1,2 \mathrm{~V}$. Převodní charakteristika celého uspořádání 
pak bude hladká i v oblasti velmi malých napětí. Pokud budou oba vstupy operačního zesilovače uzemněny $u_{\mathrm{IP}}=u_{\mathrm{IN}}=0$, měl by operační zesilovač při symetrickém napájení vykazovat na výstupu také nulové napětí $u_{0}=0$. K tomu slouží zdroj posuvného napětí $U_{\mathrm{P} 2}$, který posune ss úrovně tak, aby výstupní napětí bylo nulové.

Př́klad konkrétního uspořádání elementárního operačního zesilovače je uveden na Obr. 3.13b. Diferenční tranzistorový zesilovač $\mathrm{T}_{1}, \mathrm{~T}_{2}$ je napájen ze zdroje konstantního proudu s rezistorem $\mathrm{R}_{1}$ a proudovým zrcadlem $\mathrm{T}_{5}, \mathrm{~T}_{6}$. Protože výstup z diferenčního stupně je nesymetrický, je jako aktivní zátěž použito proudové zrcadlo $s$ tranzistory $T_{3}$ a $T_{4}$. Emitorový sledovač $\mathrm{s}$ tranzistorem $\mathrm{T}_{7}$ má pracovní bod nastaven ze zdroje konstantního proudu $\mathrm{s} \mathrm{T}_{9}, \mathrm{~T}_{10}$ a $\mathrm{R}_{2}$. Tento proud současně určuje proud tekoucí diodami $\mathrm{D}_{1}, \mathrm{D}_{2}$ a „násobičem $u_{\mathrm{BE}}$ “ $\mathrm{s}$ tranzistorem $\mathrm{T}_{8}$. Koncový stupeň je tvořen komplementárním emitorovým sledovačem s tranzistory $\mathrm{T}_{11}$ a $\mathrm{T}_{12}$. Diody mezi bázemi těchto tranzistorů jsou trvale otevřeny a je na nich napětí $1,2 \mathrm{~V}$. Zajišt'ují vodivý stav obou tranzistorů $\mathrm{T}_{11}$ a $\mathrm{T}_{12}$ v okolí průchodu výstupního napětí nulou. Tranzistor $T_{8}$ je společně s rezistory $R_{3} a R_{4}$ zapojen jako „násobič $u_{\mathrm{BE}}$ “ a slouží k posunutí ss úrovní tak, aby celý zesilovač měl bez buzení na výstupu nulové stejnosměrné napětí.

Dvě nejvýraznější části každého operačního zesilovače tvoří první (vstupní) stupeň a poslední (koncový, výkonový) stupeň. Jejich vazba může být bezprostřední tak, jak je tomu u elementárního operačního zesilovače uvedeného na Obr. 3.13, nebo přes další zesilovací mezistupně.

Vstupní zesilovací stupeň je nejkritičtější částí každého operačního zesilovače, místem kde se střetávají vzájemně protichůdné konstrukční požadavky na přesnost, rychlost, vysoký vstupní odpor, malé vstupní proudy a také co nejmenší šum. Přímo určuje všechny vstupní parametry a spoluurčuje řadu přenosových i výstupních parametrů.

Vlastnosti dvou velkých skupin operačních zesilovačů pak určuje volba zesilovacího prvku - bipolárního nebo unipolárního tranzistoru.

Bipolární operační zesilovač se vyznačují dobrou až výbornou stabilitou napět'ového ofsetu, průměrnými někdy až př́liš velkými vstupními proudy, průměrnými až malými vstupními odpory. Díky velké strmosti bipolárních tranzistorů se dá dosáhnout dostatečně velkého diferenčního zesílení pomocí jen několika málo zesilovacích stupňů. Jejich nevýhodou ale je až čtyřikrát vyšší cena výrobní technologie.

Unipolární operační zesilovače se pak vyznačují malými vstupními proudy a velkými vstupními odpory za cenu horší stability napětového ofsetu. Nezávislost vstupních klidových proudů na pracovních kolektorových proudech vstupní dvojice tranzistorů umožňuje vystupňovat dynamické parametry vstupního diferenčního zesilovače bez podstatného zhoršení přesnosti. Nevýhodou je obecně malá strmost tranzistorů řízených polem, která omezuje dosažitelnou hodnotu celkového diferenčního zesílení.

\subsection{Universální operační zesilovače}

První generace operačních zesilovačů byly vyvinuty pro universální použití. Autorem jednoho z prvních zapojení integrovaného operačního zesilovače byl Robert. J. Widlar, průkopník v obvodové technice, v technologii i aplikacích. Jeho monolitický operační zesilovač svými vlastnostmi, nízkou cenou a milionovými sériemi způsobil zvrat v technice analogových 
obvodů, kdy návrh vlastního zesilovače byl potlačen do pozadí a návrh se soustředí na připojené zpětnovazební obvody.

\section{Operační zesilovač typové rady 741}

Největší rozširrení doznal operační zesilovač pro všeobecné užití typového čísla 741 tzv. druhé generace [3], [9], který je v modernizované verzi stále ve výrobním programu řady světových firem. Obvykle vykazuje ss zesílení $A_{0}>200 \mathrm{~V} / \mathrm{mV}=200000$, vstupní diferenční odpor $R_{\mathrm{i}}>300 \mathrm{k} \Omega$, výstupní odpor $R_{0} \approx 75 \Omega$, rychlost přeběhu $V_{\mathrm{P}} \approx 0,5 \mathrm{~V} / \mu \mathrm{s}$, tranzitní kmitočet $f_{\mathrm{T}} \approx 1 \mathrm{MHz}$.

Jeho první publikované schéma autora Roberta J. Widlara doznalo mnoho obměn; jedna z nich je naznačena na Obr. 3.14. Zesilovač má dvoustupňové uspořádání. Vstupní diferenční stupeň je tvořen složeným zapojením emitorových sledovačů $\mathrm{s} \mathrm{T}_{1}$ a $\mathrm{T}_{2}$ a diferenčního stupně $\mathrm{T}_{3}, \mathrm{~T}_{4} \mathrm{v}$ zapojení se společnou bází (viz základní uspořádání na Obr. 3.10a). Protože výstup tohoto diferenčního zesilovače je nesymetrický, je jako aktivní zátěž použito proudové zrcadlo $\mathrm{T}_{5}, \mathrm{~T}_{6} \mathrm{~s}$ kompenzací proudů do bází tranzistorů pomocí tranzistoru $\mathrm{T}_{7}$. Mírným rozvážením proudů $\mathrm{v}$ proudovém zrcadle pomocí potenciometrického trimru $\mathrm{P}_{1}$ je možno snadno provést kompenzaci napětového ofsetu operačního zesilovače a tímto nastavit na výstupu celého zesilovače nulové ss napětí.

Klidové pracovní proudy diferenčního stupně určuje zdroj proudu $I_{1}$ s proudovým zrcadlem $\mathrm{T}_{10}$ a $\mathrm{T}_{11}$, které dodává proud do spojených bází $\mathrm{T}_{3}$ a $\mathrm{T}_{4}$. Pracovní proudy tranzistorů $\mathrm{T}_{3}$ a $\mathrm{T}_{4}$, resp. i $\mathrm{T}_{1}$ a $\mathrm{T}_{2}$ jsou stabilizovány zpětnovazební smyčkou přes proudové zrcadlo $\mathrm{T}_{8}$, $\mathrm{T}_{9}$. Pokud začne narůstat proud oběma větvemi, bude narůstat i výstupní proud proudového zrcadla $\mathrm{T}_{8}, \mathrm{~T}_{9}$, což způsobí snížení proudu do spojených bází $\mathrm{T}_{3}, \mathrm{~T}_{4}$. To proto že součet kolektorového proudu $\mathrm{T}_{9}$ a spojených bází $\mathrm{T}_{3}, \mathrm{~T}_{4}$ musí být vždy roven $I_{1}$.

Proud $I_{1} \approx 20 \mu \mathrm{A}$ je definován proudovým zrcadlem $\mathrm{s} \mathrm{T}_{10}$ a $\mathrm{T}_{11}$, které má rezistorem $\mathrm{R}_{4}$ nastaven proudový přenos na hodnotu $K_{\mathrm{I}} \approx 0,06$. Řídícím proudem proudového zrcadla $\mathrm{T}_{10}$, $\mathrm{T}_{11}$ je přitom proud tekoucí rezistorem $\mathrm{R}_{5}$, jehož hodnota je

$$
I_{2} \approx\left(2 U_{\mathrm{N}}-u_{\mathrm{BE} 12}-u_{\mathrm{BE} 11}\right) / R_{5} \approx\left(2 U_{\mathrm{N}}-1,2 \mathrm{~V}\right) / R_{5} \approx 0,3 \mathrm{~mA}
$$

při napájení ze zdroje $\pm 15 \mathrm{~V}$. Proudové zrcadlo $\mathrm{T}_{8}, \mathrm{~T}_{9}$ snímá proud tekoucí diferenčním stupněm a pokud tento začne růst, sníží proud do bází $\mathrm{T}_{3}, \mathrm{~T}_{4}$ a tím stabilizuje nastavené pracovní body diferenčního stupně.

Druhý zesilovací stupeň je tvořen Darlingtonovou dvojicí tranzistorů $\mathrm{T}_{17}, \mathrm{~T}_{18} \mathrm{v}$ zapojení se společným emitorem. Aby se $\mathrm{T}_{18}$ rychleji zavíral, urychluje se odvod náboje z přechodu PN pomocí rezistoru $\mathrm{R}_{12}$. Darlingtonova dvojice má jako aktivní zátěž použit zdroj konstantního proudu s proudovým zrcadlem $\mathrm{T}_{12}, \mathrm{~T}_{13}$. To zrcadlí proud $I_{2}$ tekoucí rezistorem $\mathrm{R}_{5}$ a proto je klidový pracovní bod Darlingtonovy dvojice nastaven na 0,3 mA. Kapacitor $\mathrm{C}_{1}$ koriguje kmitočtovou charakteristiku tak, aby operační zesilovač měl tzv. standardní průběh kmitočtové charakteristiky. Operační zesilovač tak bude stabilní pro jakoukoliv rezistorovou zpětnou vazbu. 


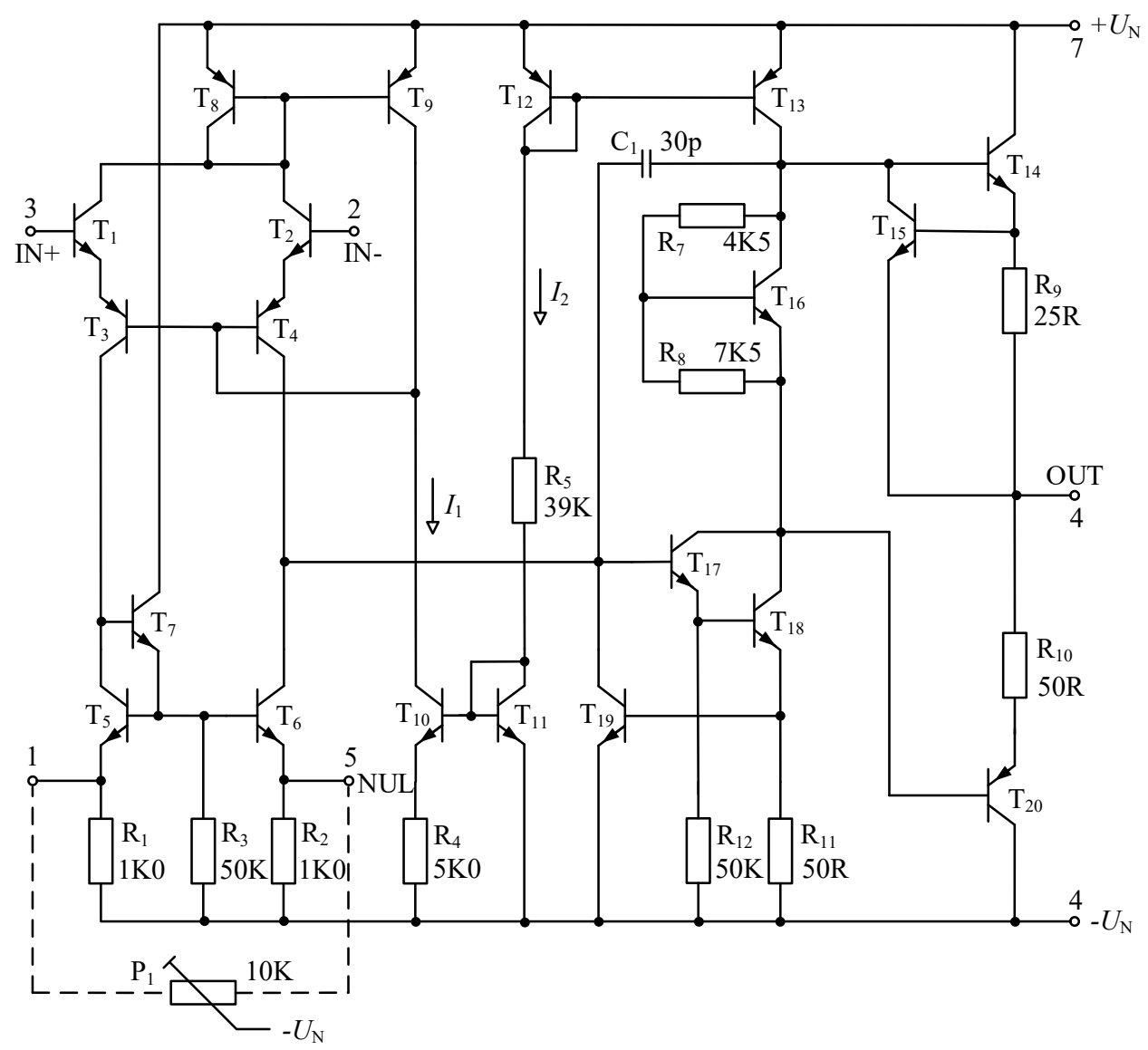

Obr. 3.14: Vnitřní struktura universálního operačního zesilovače typového čísla 741

Klidový proud tekoucí Darlingtonovou dvojicí současně určuje pracovní bod „násobiče $u_{\mathrm{BE}}$ “ $\mathrm{s}$ tranzistorem $\mathrm{T}_{16}$ a rezistory $\mathrm{R}_{7}, \mathrm{R}_{8}$. Násobič má nastaveno napětí $u_{\mathrm{CE} 16} \approx\left(1+\mathrm{R}_{7} / \mathrm{R}_{8}\right) u_{\mathrm{BE} 16} \approx(1+4,5 / 7,5) 0,6 \approx 1 \mathrm{~V}$. Toto napětí eliminuje přechodového zkreslení komplementárního emitorového sledovače $\mathrm{s} \quad \mathrm{T}_{14}, \mathrm{~T}_{20}$. Rezistory $\mathrm{R}_{9}, \mathrm{R}_{10}$ v koncovém stupni slouží k potlačení tzv. kladné tepelné zpětné vazby, kdy s teplotou narůstá kolektorový proud, což může vést až k tepelnému zničení koncových tranzistorů. Rezistor $\mathrm{R}_{9}$ slouží také jako snímací rezistor pro elektronickou pojistku s tranzistorem $\mathrm{T}_{15}$, který omezuje maximální výstupní proud a chrání tak tranzistor $\mathrm{T}_{14}$ před přetížením. Ochrana tranzistoru $T_{20}$ před přetížením je řešena jinak. Pokud poteče tranzistorem $T_{20}$ př́liš velký proud zvýší se i jeho bázový proud. Ten následně zvýší proud tranzistorem $\mathrm{T}_{18}$ a to způsobí zvýšení napětí na snímacím rezistoru $\mathrm{R}_{11}$. Tranzistor $\mathrm{T}_{19}$ se začne otvírat, proud do báze tranzistoru $\mathrm{T}_{17}$ se zmenší a Darlingtonova dvojice se začne zavírat.

\section{Universální Bi-FETový operační zesilovač}

Bi-FETové operační zesilovače kombinují výhodné vlastnosti unipolárních tranzistorů s bipolárními tranzistory. Zjednodušené schéma operačního zesilovače tohoto typu je uvedeno na Obr. 3.15. Díky použitým tranzistorům, JFET na vstupu zesilovacího řetězce je vstupní odpor operačního zesilovače vysoký. Bipolární tranzistory pak zajišt’ují $\mathrm{v}$ důsledku větší strmosti $g_{\mathrm{m}}$ dostatečné zesílení. Operační zesilovače tohoto typu jsou 
určeny pro všeobecné užití, obvykle mají ss zesílení $A_{0}>200 \mathrm{~V} / \mathrm{mV}=200000$, vstupní diferenciální odpor $R_{\mathrm{i}}>10^{12} \Omega$, rychlost přeběhu $V_{\mathrm{P}} \approx 7 \mathrm{~V} / \mu \mathrm{s}$, tranzitní kmitočet $f_{\mathrm{T}} \approx 2,5 \mathrm{MHz}$.

První zesilovací stupeň tvoří diferenční zesilovač $\mathrm{s}$ diferenčním výstupem $\mathrm{s}$ tranzistory JFET $\mathrm{T}_{1}$ a $\mathrm{T}_{2}$. Zesilovač má aktivní zátěže realizované zdroji konstantního proudu $I_{0}$. Tyto proudy se dají mírně rozvážit pomocí tranzistorů $\mathrm{T}_{3}, \mathrm{~T}_{4}$ a vnějšího potenciometrického trimru $\mathrm{P}_{1}$. Tímto způsobem se kompenzuje napětový ofset operačního zesilovače, tzn. potenciometrickým trimrem $\mathrm{P}_{1}$ se dá na výstupu operačního zesilovače nastavit nulové ss napětí. Druhý zesilovací stupeň je realizován bipolárními tranzistory $\mathrm{T}_{6}$ a $\mathrm{T}_{7}$. Kapacitory $\mathrm{C}_{1}$ a $\mathrm{C}_{2}$ slouží ke korekci kmitočtové charakteristiky celého zesilovače.

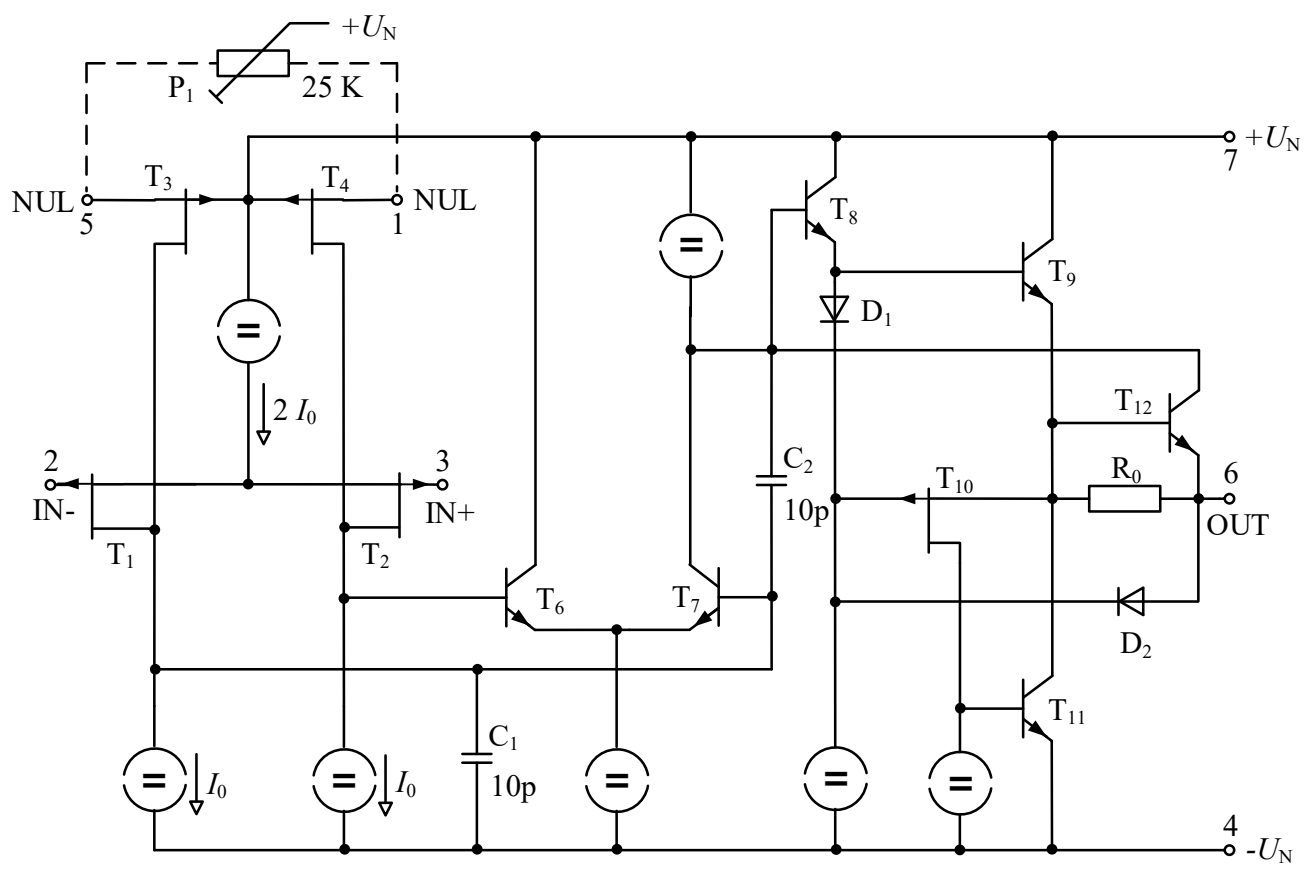

Obr. 3.15: Zjednodušené zapojení univerzálního Bi-FETového operačního zesilovače

Aby nebyl druhý zesilovací stupeň zatěžován, je za něj zařazen emitorový sledovač $\mathrm{s}$ tranzistorem $\mathrm{T}_{8}$, který má po zvýšení svého vstupního odporu místo rezistoru $\mathrm{v}$ emitoru vložen zdroj konstantního proudu. Dioda $\mathrm{D}_{1}$ slouží jako zdroj napětí $0,6 \mathrm{~V}$ pro potlačení nelineárního zkreslení koncového stupně. Koncový stupeň je koncipován jako dvojčinný emitorový sledovač pracující ve třídě $A B$. Je tvořen tranzistorem $T_{9} a$ kvazikomplementárním zapojením tranzistorů $\mathrm{T}_{10}$ a $\mathrm{T}_{11}$. Protože tranzistor $\mathrm{T}_{9}$ se začíná otvírat při napětí $u_{\mathrm{BE} 9} \approx 0,6 \mathrm{~V}$, ale kvazikomplementární zapojení $\mathrm{T}_{10}$ a $\mathrm{T}_{11}$, které nahrazuje komplementární tranzistor, se otevírá již při nulovém napětí na řídicí elektrodě $\mathrm{T}_{10}$, dostačuje pro potlačení přechodového zkreslení jen úbytek $0,6 \mathrm{~V}$ na diodě $\mathrm{D}_{1}$.

Elektronická pojistka, která ochraňuje tranzistor $\mathrm{T}_{9}$ před zničením velkým proudem do zátěže, je tvořena rezistorem $\mathrm{R}_{0}$ a tranzistorem $\mathrm{T}_{12}$. Pokud bude proud do zátěže tak 
velký, že úbytek na rezistoru $\mathrm{R}_{0}$ se bude blížit $0,6 \mathrm{~V}$, začne se tranzistor $\mathrm{T}_{12}$ otevírat a odebírat proud tekoucí do báze $\mathrm{T}_{8}$, což způsobí uzavření tranzistoru $\mathrm{T}_{8} \mathrm{i} \mathrm{T}_{9}$. Pokud do zátěže poteče prŕliš velký proud opačně polarity, zvýší se napětí na rezistoru $\mathrm{R}_{0}$ tak, že se dioda $\mathrm{D}_{2}$ otevře a omezí proud kvazikomplementární dvojice $\mathrm{T}_{10}, \mathrm{~T}_{11}$.

\section{Universální CMOS operační zesilovač}

Universální operační zesilovač na Obr. 3.16 (viz lit. [1]) je koncipován tak, aby mohl být napájen asymetricky jen jediným napájecím napětím (single-supply). Zapojení je zjednodušeno o pomocné obvody, které př́íhodně nastavují ss úrovně v zesilovači podle použitého napájecího napětí. Operační zesilovač je vyroben technologií CMOS (Complementary MOS), která umožňuje v jednom technologickém procesu vyrobit komplementární a symetrické páry tranzistorů MOS typu $\mathrm{P}$ a $\mathrm{N}$.

Tranzistory MOSFET $\mathrm{P}_{1}$ a $\mathrm{P}_{2} \mathrm{~s}$ kanálem $\mathrm{P}$ tvoří diferenční zesilovač. Jeho aktivní zátěž představuje proudové zrcadlo s tranzistory $\mathrm{N}_{1}$ a $\mathrm{N}_{2} \mathrm{~s}$ kanálem $\mathrm{N}$. Druhý zesilovací stupeň s tranzistorem $\mathrm{N}_{3}$ je $\mathrm{v}$ zapojení se společným emitorem, který má jako aktivní zátěž zapojen zdroj konstantního proudu $I_{2}$. Tranzistor $\mathrm{N}_{5}$ koncového stupně je zapojen jako emitorový sledovač. Rozdíl oproti jiným koncovým stupňům je v zapojení tranzistoru $\mathrm{N}_{4}$. Ten není zapojen jako komplementární emitorový sledovač, ale pracuje v zapojení se společným emitorem stejně jako tranzistor $\mathrm{N}_{3}$. Tranzistory $\mathrm{N}_{4}$ a $\mathrm{N}_{5}$ jsou buzeny inversně, což umožňuje, aby tranzistor $\mathrm{N}_{4}$ byl vodivý a snížil výstupní napětí na $0 \mathrm{~V}$ v př́padě, kdy tranzistor $\mathrm{N}_{5}$ bude nevodivý. Článek $\mathrm{R}_{1}, \mathrm{C}_{1}$ slouží ke korekci kmitočtové charakteristiky zesilovače. Substrát (bulk) tranzistorů s kanálem $\mathrm{P}$ je připojen na napájecí napětí $+U_{\mathrm{N}}$, substrát všech tranzistorů s kanálem $\mathrm{N}$ je pak připojen na zem.

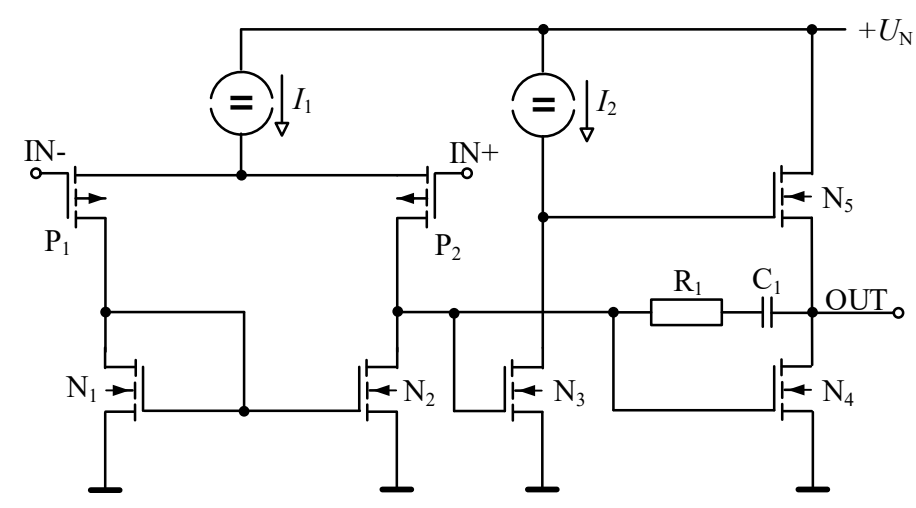

Obr. 3.16: Zjednodušené zapojení universálního CMOS operačního zesilovače s asymetrickým napájením

\subsection{Přesné operační zesilovače}

Přesné operační zesilovače (precision, ultraprecision op amp) se vyznačují velkým zesílením, malým napět'ovým ofsetem, malým driftem a nízkým šumem. Obvykle jsou řešeny třístupňovou koncepcí [10]. Ss zesílení má většinou hodnotu $A_{0} \approx 1000$ až $5000 \mathrm{~V} / \mathrm{mV}=10^{10}$ až $5 \cdot 10^{6}$, napět'ový ofset bývá $25 \mu \mathrm{V}$ až $1 \mathrm{mV}$ max. Velký počet zesilovacích stupňů, které 


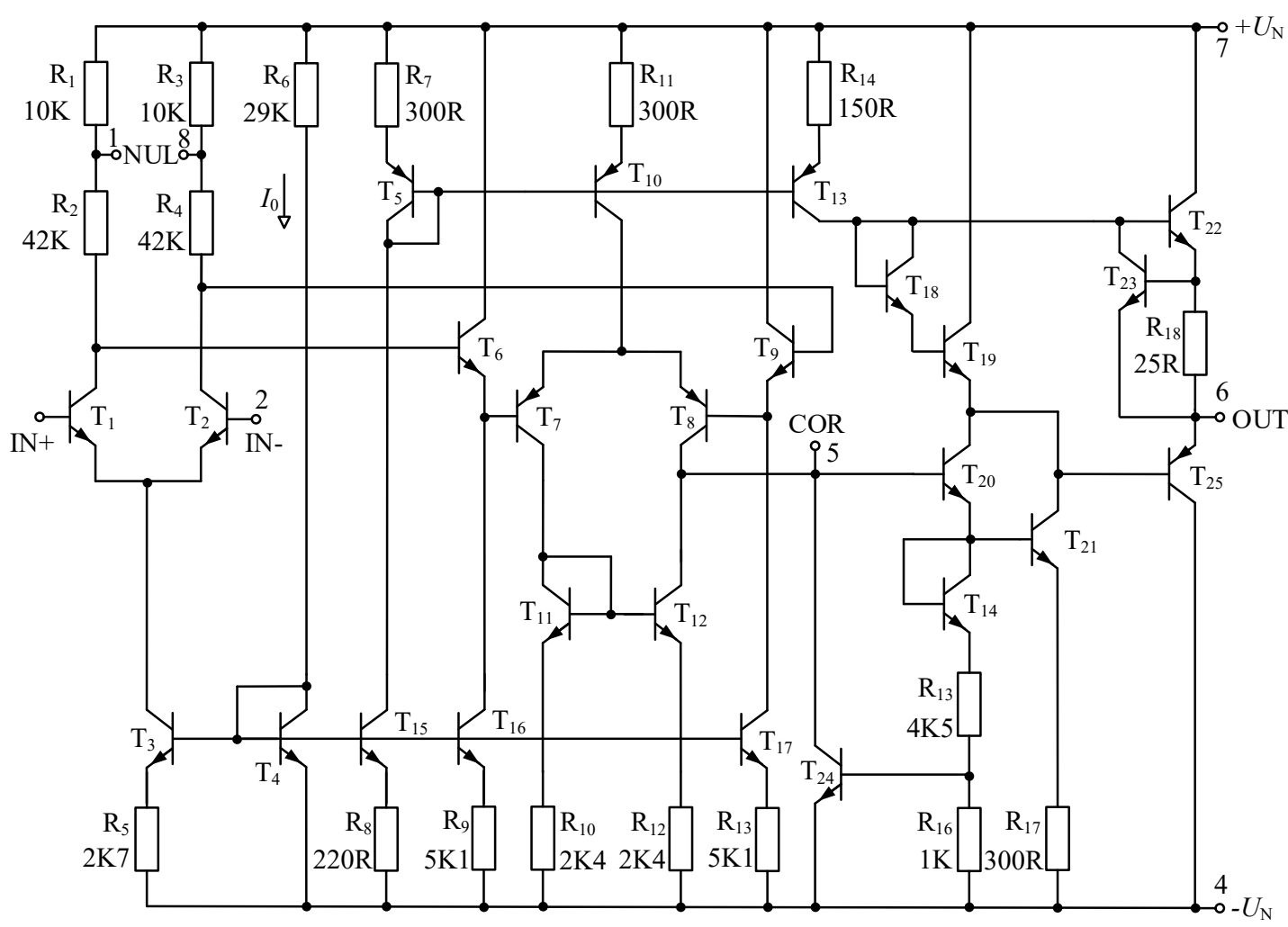

Obr. 3.17: Příklad zapojení přesného operačního zesilovače

vykazují větší počet parazitních kapacit, však způsobuje snížení tranzitního kmitočtu na hodnotu $f_{\mathrm{T}} \approx 300$ až $600 \mathrm{kHz}$. Ze stejného důvodu mají tyto zesilovače nižší rychlost přeběhu $V_{\mathrm{P}} \approx 0,1 \mathrm{~V} / \mu \mathrm{s}$.

Př́klad takovéhoto typu operačního zesilovače je uveden na Obr. 3.17. Všechny zdroje konstantního proudu mají proud odvozen pomocí proudových zrcadel z proudu, který teče rezistorem $\mathrm{R}_{6}$. Tento proud má velikost $I_{0} \approx\left(2 U_{\mathrm{N}}-u_{\mathrm{BE} 4}\right) / R_{6} \approx(2 \cdot 15-0,6) / 29 \cdot 10^{3} \approx 1 \mathrm{~mA}$. Proudové zrcadlo $\mathrm{T}_{3}$ a $\mathrm{T}_{4}$ nastavuje pracovní body tranzistorů diferenčního stupně $\mathrm{T}_{1}$ a $\mathrm{T}_{2}$. Proudové zrcadlo $\mathrm{T}_{4}$ a $\mathrm{T}_{16}$ slouží jako zdroj konstantního proudu pro nastavení pracovního proudu emitorového sledovače s tranzistorem $\mathrm{T}_{6}$. Podobně je napájen i emitorový sledovač $\mathrm{s}$ tranzistorem $\mathrm{T}_{9}$, jehož pracovní bod nastavuje proudové zrcadlo $\mathrm{s}_{4}$ a $\mathrm{T}_{17}$. Proudový inventor s proudovým zrcadlem $\mathrm{T}_{4}, \mathrm{~T}_{15}$ a komplementárním proudovým zrcadlem $\mathrm{T}_{5}, \mathrm{~T}_{10}$ nastavuje klidové proudy tranzistorů komplementárního diferenčního stupně $\mathrm{T}_{7}$ a $\mathrm{T}_{8}$. Proudové zrcadlo $\mathrm{T}_{5}$ a $\mathrm{T}_{13}$ tvoří zdroj konstantního proudu pro nastavení pracovního bodu zesilovače s Darlingtonovou dvojicí $\mathrm{T}_{20}, \mathrm{~T}_{21}$.

Vstupní diferenční stupeň s tranzistory $T_{1}, T_{2}$ pracuje do rezistorové zátěže $R_{1}+R_{2} a$ $\mathrm{R}_{3}+\mathrm{R}_{4}$. Proudy $\mathrm{v}$ kolektorech tranzistorů lze mírně rozvážit připojením potenciometrického trimru mezi svorky označené NUL po připojení běžce potenciometru na kladné napájecí napětí. Tímto způsobem lze vynulovat na výstupu ss chybové napětí způsobené napětovým ofsetem.

Druhý diferenční stupeň je tvořen komplementárním diferenčním zesilovačem $\mathrm{T}_{7}, \mathrm{~T}_{8}$, který má místo rezistorů v kolektorech tranzistorů jako aktivní zátěž proudové zrcadlo $\mathrm{s} \mathrm{T}_{11}, \mathrm{~T}_{12}$. 
Protože první diferenční stupeň z důvodu nízkého šumu pracuje jen s velmi malými proudy a nemůžeme ho proto př́liš zatěžovat, jsou před druhý diferenční stupeň předřazeny dva emitorové sledovače $\mathrm{s}$ tranzistory $\mathrm{T}_{6}, \mathrm{~T}_{9}$, které místo emitorových odporů mají zdroje konstantního proudu $\mathrm{s} \mathrm{T}_{3}, \mathrm{~T}_{16}$ a s $\mathrm{T}_{3}, \mathrm{~T}_{17}$.

Třetí zesilovací stupeň je zapojen jako zesilovač v zapojení se společným emitorem $\mathrm{s}$ Darlingtonovou dvojicí $\mathrm{T}_{20}, \mathrm{~T}_{21}$. Zesilovač má v kolektoru jako aktivní zátěž zdroj konstantního proudu s proudovým zrcadlem $\mathrm{T}_{5}, \mathrm{~T}_{13}$. Tento proud současně otevře přechody $\mathrm{BE}$ tranzistorů $\mathrm{T}_{18}$ a $\mathrm{T}_{19}$ tak, že na nich vznikne úbytek $1,2 \mathrm{~V}$.

Koncový komplementární sledovač je realizován tranzistory $\mathrm{T}_{22}$ a $\mathrm{T}_{25}$. Díky tomu, že jejich báze jsou navzájem ss posunuty o $1,2 \mathrm{~V}$, bude přechodové zkreslení eliminováno. Aby se tranzistor $\mathrm{T}_{22}$ nezničil velkým proudem do zátěže, je instalována elektrická pojistka s rezistorem $\mathrm{R}_{18}$ a tranzistorem $\mathrm{T}_{23}$. Tranzistor $\mathrm{T}_{25}$ je proti velkému proudu ze zátěže chráněn pojistkou $\mathrm{s}$ rezistorem $\mathrm{R}_{16}$ a tranzistorem $\mathrm{T}_{24}$. Pokud bude při záporném výstupním napětí $\mathrm{OZ}$ prétížen a ze zátěže by do $T_{25}$ tekl prŕiliš velký proud, zvětší se i proud tekoucí z báze $T_{25}$, který se přidá $\mathrm{k}$ pracovnímu kolektorovému proudu $\mathrm{T}_{20} \mathrm{~V}$ emitoru $\mathrm{T}_{20}$ poteče proto větší proud než za běžného provozu a na $\mathrm{R}_{16}$ se zvýší napětí, které otevře $\mathrm{T}_{24}$. Proud do báze $\mathrm{T}_{20}$ se následně sníží a $\mathrm{T}_{20} \mathrm{se}$ začne zavírat.

\subsection{Rychlé operační zesilovače}

Rychlé, nebo někdy také širokopásmové operační zesilovače, se vyznačují velkou šiřkou kmitočtového pásma. Jejich tranzitní kmitočet bývá z rozmezí $f_{\mathrm{T}} \approx 50 \mathrm{MHz}$ až 1,3 $\mathrm{GHz}$ a rychlost přeběhu je v rozmezí $V_{\mathrm{P}} \approx 100$ až $350 \mathrm{~V} / \mu \mathrm{s}$. Konstrukčně jde o jednostupňové zesilovače a proto je jejich ss zesílení nízké $A_{0} \approx 1000$. Aby operační zesilovač vykazoval na vstupu jen malé parazitní kapacity, je pro rychlý operační zesilovač typické použití kaskódového řešení diferenčního stupně (viz kap.3.1.5). Nejčastěji se používá zapojení diferenčního zesilovače s kombinovanou kaskodou z Obr. 3.12c.

Koncepční řešení rychlého operačního zesilovače je uvedeno na Obr. 3.18a. Tranzistory $\mathrm{T}_{1}$ a $\mathrm{T}_{2}$ jsou v diferenčním zapojení. Pro potlačení Millerovy kapacity jsou na ně kaskódově navázány komplementární tranzistory $\mathrm{T}_{3}$ a $\mathrm{T}_{4} \mathrm{v}$ zapojení se společnou bází. Tranzistory $\mathrm{T}_{3}$ a $\mathrm{T}_{4}$ mají pracovní bod nastaven pomocí napětí na spojených bázích

$$
U_{\mathrm{B}} \approx U_{\mathrm{N}}-u_{\mathrm{D} 1}-u_{\mathrm{D} 2} \approx U_{\mathrm{N}}-1,2 \mathrm{~V} \text {. }
$$

Aby se docílilo velkého zesílení $\mathrm{v}$ jediném zesilovacím stupni, jsou kolektorové rezistory tranzistorů $\mathrm{T}_{3}$ a $\mathrm{T}_{4}$ nahrazeny kaskódovým řešením proudového zrcadla s tranzistory $\mathrm{T}_{11}$ až $\mathrm{T}_{14}$. Výstup z kombinovaného kaskódového diferenčního zesilovače je nesymetrický. Aby byl jeho výstup oddělen od zátěže, je pro oddělení použit napětový sledovač s jednotkovým přenosem.

Podrobnější schéma zapojení rychlého operačního zesilovače je uvedeno na Obr. 3.18b. Diferenční zesilovač s kombinovanou kaskodou tvoří tranzistory $T_{1}$ až $T_{4}$. Kaskódové zapojení proudového zrcadla s tranzistory $\mathrm{T}_{11}$ až $\mathrm{T}_{14}$ představují aktivní zátěž diferenčního stupně. Proudy pro nastavení pracovních bodů tranzistorů diferenčního zesilovače s kombinovanou kaskodou jsou odvozeny od proudu $I_{1}=\left(2 U_{\mathrm{N}}-3 u_{\mathrm{BE}}\right) / R_{1} \approx\left(2 U_{\mathrm{N}}\right.$ $-1,8 \mathrm{~V}) / R_{1}$ 
pomocí vícestupňového proudového zrcadla $T_{7}, T_{8}$ a $T_{9}$ a proudového zrcadla $T_{5}, T_{6}$.
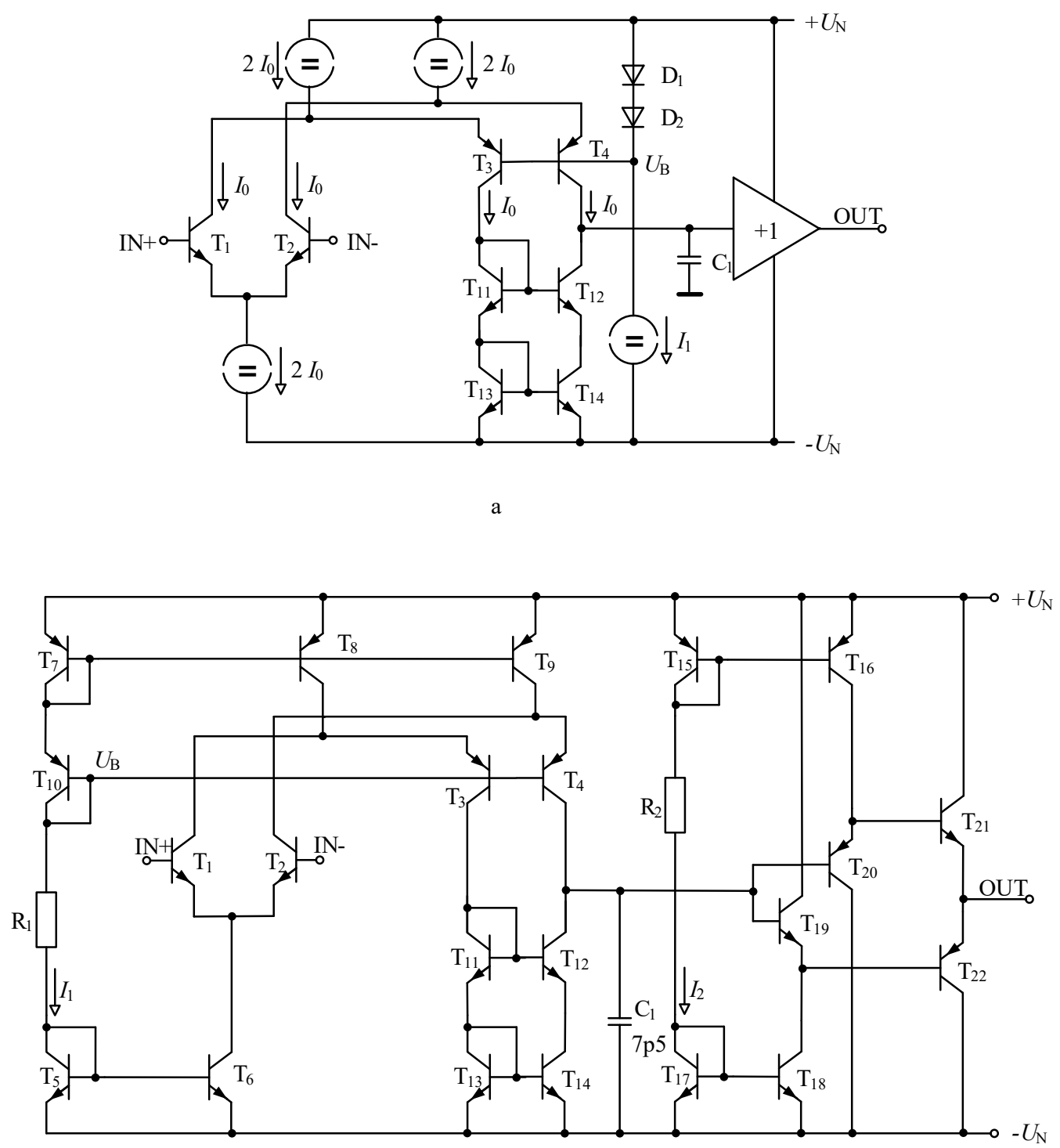

b

Obr. 3.18: a) Koncepce rychlého (širokopásmového) operačního zesilovače, b) príílad řešení

Tranzistory $\mathrm{T}_{19}$ až $\mathrm{T}_{22}$ jsou zapojeny jako tzv. dvojstupňový komplementární emitorový sledovač. Emitorový sledovač $\mathrm{s}$ tranzistorem $\mathrm{T}_{21}$ má předřazen komplementární emitorový sledovač $\mathrm{s}$ tranzistorem $\mathrm{T}_{20}$. Podobně je emitorovému sledovači s tranzistorem $\mathrm{T}_{22}$ předřazen emitorový sledovač $\mathrm{s}$ tranzistorem $\mathrm{T}_{19}$. Napětí $u_{\mathrm{BE}}$ tranzistorů $\mathrm{T}_{20}, \mathrm{~T}_{21}$ a podobně i tranzistorů $\mathrm{T}_{19}, \mathrm{~T}_{22}$ se vzájemně kompenzují a přechodové zkreslení se neuplatní. Proud $I_{2}=\left(2 U_{\mathrm{N}}-2 u_{\mathrm{BE}}\right) / R_{2} \approx\left(2 U_{\mathrm{N}}-1,2 \mathrm{~V}\right) / R_{2}$ se zrcadlí proudovým zrcadlem $\mathrm{T}_{17}, \mathrm{~T}_{18}$ a určuje pracovní bod emitorového sledovače $\mathrm{T}_{19}$. Podobně je komplementárním proudovým zrcadlem $\mathrm{T}_{15}, \mathrm{~T}_{16}$ určen pracovní bod emitorového sledovače $\mathrm{T}_{20}$. Úbytky na přechodech 
BE tranzistorů $\mathrm{T}_{7}$ a $\mathrm{T}_{10}$ vytvářejí přepětí $U_{\mathrm{B}}=2 U_{\mathrm{N}}-2 u_{\mathrm{BE}} \approx 2 U_{\mathrm{N}}-1,2 \mathrm{~V}$. Kapacitor $\mathrm{C}_{1}$ slouží ke korekci kmitočtové charakteristiky.

\section{Použitá literatura}

[1] TIETZE, U.; SCHENK, CH.; GAMM, E. Electronic Circuits. Hand book for Design and Applications. 2nd edition, Springer - Verlag, Berlin 2008. ISBN 978-3-54000429-5

[2] TIETZE, U.; SCHENK, CH. Electronic Circuits. Design and Applications. Springer Verlag, Berlin 1991. ISBN 3-540-50608-X

[3] DOSTÁL, J. Operační zesilovače. BEN, Praha 2005

[4] DOSTÁL, J. Operational Amplifiers. Elsevier, Amsterdam 1981

[5] ROBERGE, J. K. Operational Amplifiers. J. Wiley, New Your, London, Sydney, Toronto 1975

[6] SEDRA, A. S.; SMITH, K. C. Microelectronics Circuits. Oxford University Press, New York, 2010

[7] WILSON, G. R. "A Monolithic Junction FET-npn Operational Amplifier", IEEE Journal of Solid-State Circuits, vol. SC-3, Dec 1968, pp. 341-348

[8] SÄCKINGER, E.; GUGGENBÜHL, W. A high-swing, high-impedance MOS cascode circuit. IEEE J. of Solid-State Circuits, vol. SC-25, 1990, pp. 289-298

[9] HUIJSING, J.H. Operational Amplifiers - Theory and Desing. Kluwer Academic Publishers, Boston 2001

[10] VRBA, K.; VRBA, K. jun. Technika analogových obvodů a systémů. Skriptum, 4. vydání. Ediční středisko VUT Brno,1989

[11] VRBA, K.; VRBA, K. jun. Technika analogových obvodů a systémů - sbírka př́kladů. Skriptum, 3. vydání. Ediční středisko VUT Brno,1989

[12] KOTON, J.; HERENCSÁR, N.; VRBA, K. Analogová technika. Elektronické skriptum, FEKT VUT v Brně, 2011

[13] SODAGAR, A. M. Analysis of bipolar and CMOS amplifiers. CRC Press, New York, 2007, ISBN 1-4200-4644-6

[14] BAKER, R.J.; LI, H.W.; BOUYCE, D.E. CMOS circuit design, layout and simulation. Wiley - IEEE Press, New York, 1998, ISBN 0-7803-3416-7 


\section{Invertující a neinvertující zesilovač}

\subsection{Ideální operační zesilovač}

Schematická značka operačního zesilovače. Z předchozí kapitoly pojednávající o struktuře operačních zesilovačů lze vyvodit, že operační zesilovač je stejnosměrný zesilovač s velkým zesílením. Přívlastkem stejnosměrný se zde rozumí rozšíření spektra zpracovaných signálů k nulovému kmitočtu (ke stejnosměrným signálům), nikoli tedy horní omezení dynamických vlastností zesilovače.

Pro operační zesilovač s diferenčním vstupem se užívá symbolická značka uvedená na Obr. 4.1a. Tři ze čtyř znázorněných signálových vývodů představují tři svorky skutečného operačního zesilovače a nazývají se ve smyslu předchozí kapitoly invertující (záporný) vstup, neinvertující (kladný) vstup a výstup. Čtvrtou signálovou svorku představuje společný vodič, který je obvykle spojen s nulovým potenciálem, tj. se zemí. Společný vodič resp. zem tvoří referenční bod pro zbývající trri signálové svorky a tedy obě vstupní napětí $u_{\mathrm{N}}, u_{\mathrm{P}}$ a výstupní napětí $u_{0}$ jsou vztažena $\mathrm{k}$ tomuto bodu.

V literatuře bývá často propojení schématické značky operačního zesilovače se společným vodičem vypuštěno Obr. $4.1 \mathrm{~b}$ a mlčky se předpokládá, že propojení je realizováno nepřímo přes napájecí zdroje. Z hlediska analýzy obvodů s operačním zesilovačem je však nutno toto propojení se zemí vždy uvažovat. Zem může být skutečná jako na Obr. 4.1c, pak ovšem budou všechny svorky stejnosměrně posunuty o $U_{\mathrm{P}} / 2$. I když se někdy tento způsob napájení používá, činí značné problémy při vlastních aplikacích operačního zesilovače. Lépe je napájet operační zesilovač ze symetrických napájecích zdrojů (viz Obr. 4.1d) a napětí svorek vztahovat $\mathrm{k}$ pomyslné zemi, která je tvořena středem mezi oběma napájecími zdroji. Při symetrickém napájení $\left(U_{\mathrm{P}}=U_{\mathrm{N}}\right)$ budou svorky operačního zesilovače stejnosměrně na potenciálu zemní svorky.

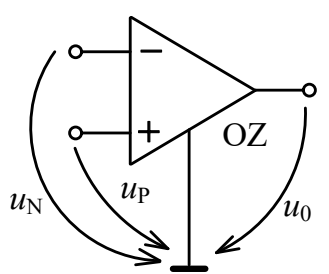

a

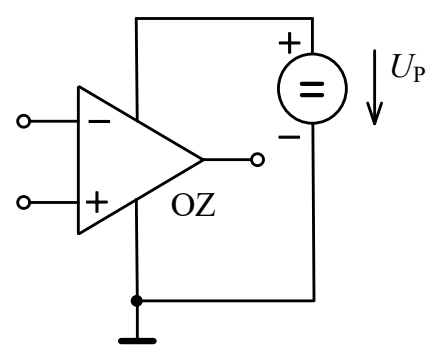

C

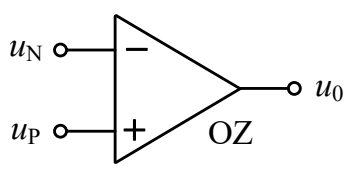

$\mathrm{b}$

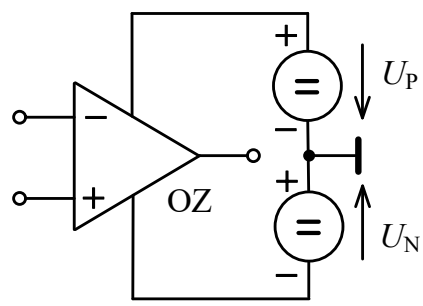

d

Obr. 4.1: a) Schematická značka operačního zesilovače, b) zjednodušená značka, c) přímé spojení operačního zesilovače se zemí, d) nepř́mé spojení operačního zesilovače se zemí přes napájecí obvody 
Vedle signálových a napájecích svorek má operační zesilovač podle potřeby ještě další vývody určené např. pro připojení korekčních prvků, prvků pro nulování napětové nesymetrie apod.

\section{Ideální operační zesilovač}

Při elementárních úvahách o vlastnostech zpětnovazební obvodů s operačními zesilovači se jeví jako účelné zavést ideální operační zesilovač. Zavedení ideálního operačního zesilovače umožňuje rychlou a přehlednou analýzu obvodů s operačním zesilovačem zapojeným v síti zpětné vazby a výsledky analýzy vyhovují s dostatečnou přesností obvykle i pro reálné obvody.

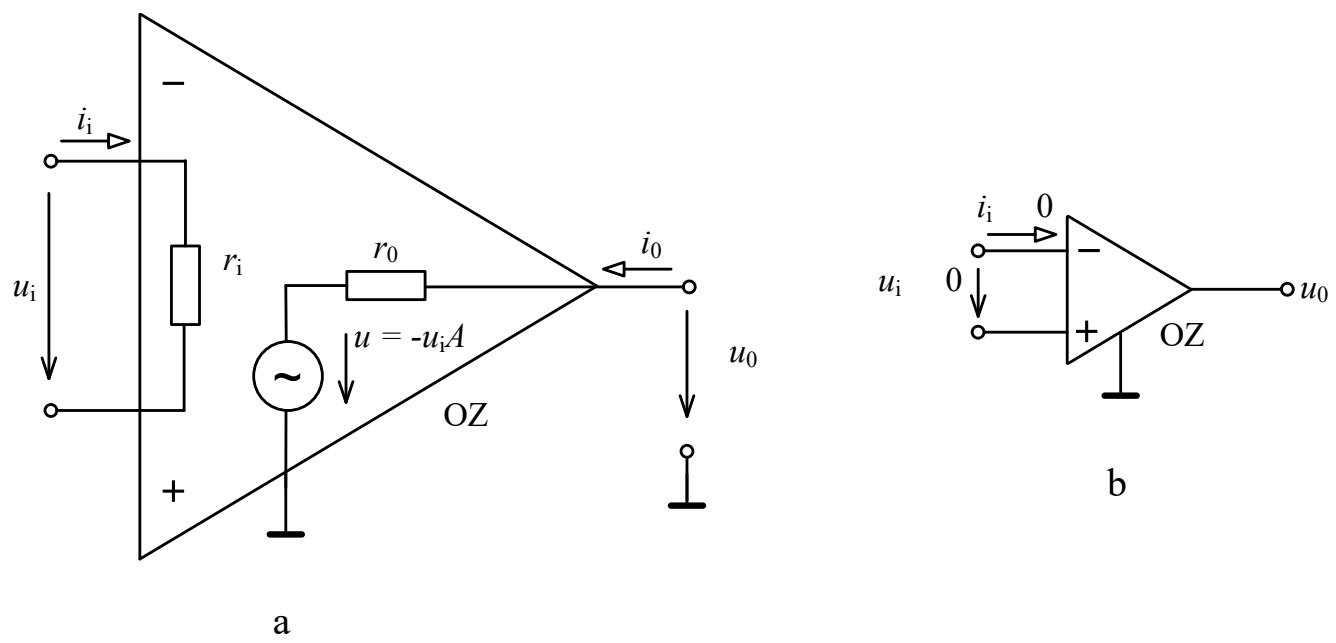

Obr. 4.2: a) Zjednodušený model reálného OZ, b) ideální operační zesilovač

Reálný operační zesilovač si v prvním přiblížení můžeme představit jako diferenční zesilovač napětí s velkým napětovým zesílením $A$, s velkým odporem mezi diferenčními vstupy $r_{\mathrm{i}}$ a s malým výstupním odporem $r_{\mathrm{o}}$ (viz Obr. 4.2a). U ideálního operačního zesilovače se předpokládá, že má nekonečné zesílení napětí a to bez ohledu na kmitočet. Vzhledem $\mathrm{k}$ tomu, že operační zesilovač je vždy zapojen v síti záporné zpětné vazby, nemá v této souvislosti smysl zabývat se otázkou vstupního či výstupního odporu ideálního operačního zesilovače. Nekonečné zesílení ideálního operačního zesilovače totiž jejich vliv zcela potlačí. Pro jednoznačnost se však obvykle uvažuje ideální operační zesilovač jako zesilovač s nekonečným zesílením $A \approx \infty$, s nekonečným vstupním odporem $r_{\mathrm{i}} \approx \infty$ a nulovým výstupním odporem $r_{\mathrm{o}} \approx$ 0. Předpokládá se dále, že ideální operační zesilovač, jehož schematická značka je na Obr. 4.2b, nemá žádné jiné nežádoucí vlastnosti. Reálné operační zesilovače ale takové nežádoucí vlastnosti vykazují a při podrobnější analýze je musíme vždy uvažovat. Bude o nich řeč později.

Obvody s operačními zesilovači je možno řešit celou řadou metod. Je možné používat maticové metody anebo řešení pomocí grafư signálových toků, jindy je vhodnější použít modelu nulorového. Pro naše účely bude ve většině prŕípadů postačovat přibližné řešení, předpokládající užití ideálního operačního zesilovače. Při tomto způsobu řešení se předpokládá, že zesílení operačního zesilovače je téměř nekonečné, a tedy že pro libovolné konečné výstupní napětí je diferenční vstupní napětí nulové, $u_{\mathrm{i}} \approx 0$. V důsledku nekonečného vstupního odporu pak můžeme předkládat, že vstupní proud je také přibližně nulový, $i_{\mathrm{i}} \approx 0$. 


\subsection{Operační zpětná vazba}

Samotný operační zesilovač (OZ) je jen částí výsledného zařízení, i když zpravidla částí nejdůležitější. Požadované vlastnosti se získají zavedením záporné zpětné vazby pomocí zpětnovazební sítě připojené ke vstupní a výstupní svorce zesilovače. Způsob zavedení zpětné vazby se mnohdy označuje jako „operační zpětná vazba“. Jde o historické značení mající původ $\mathrm{v}$ analogových počítačích, kde se tímto způsobem realizovaly matematické operace násobení konstantou, sčítání, integrace, derivace aj.

U diferenčního operačního zesilovače známe dvě základní možnosti uspořádání rezistorové zpětné vazby. Zapojení jsou uváděna pod označením invertující a neinvertující zapojení operačního zesilovače, popř. zkráceně invertující a neinvertující zesilovač.

\section{Invertující zesilovač}

Invertující zapojení operačního zesilovače je naznačeno na Obr. 4.3a. Pro invertující zesilovač bude pro uzel S platit Kirchhoffův zákon o proudech, $i_{1}=i_{2}+i_{\mathrm{i}}$, a protože proud do invertující vstupní svorky je zanedbatelný $i_{\mathrm{i}} \approx 0$, bude jednoduše $i_{2} \approx i_{1}$. Při činnosti obvodu se nastaví potenciál uzlu $\mathrm{S} v$ důsledku záporné zpětné vazby přibližně na potenciál neinvertující vstupní svorky, tj. v tomto př́padě na potenciál společného vodiče (země) tak, aby byla splněna podmínka $u_{\mathrm{i}} \approx 0$. Pro proudy invertujícího zesilovače pak platí

$$
i_{1} \approx \frac{u_{1}}{R_{1}}, \quad i_{2} \approx-\frac{u_{2}}{R_{2}}
$$

Protože $i_{1} \approx i_{2}$, bude jeho výstupní napětí popsáno vztahem

$$
u_{2}=-\frac{R_{2}}{R_{1}} u_{1}=A_{\mathrm{U}} u_{1}
$$

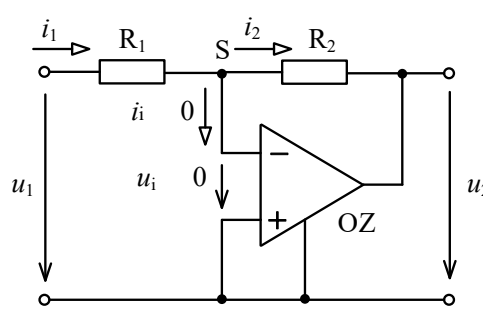

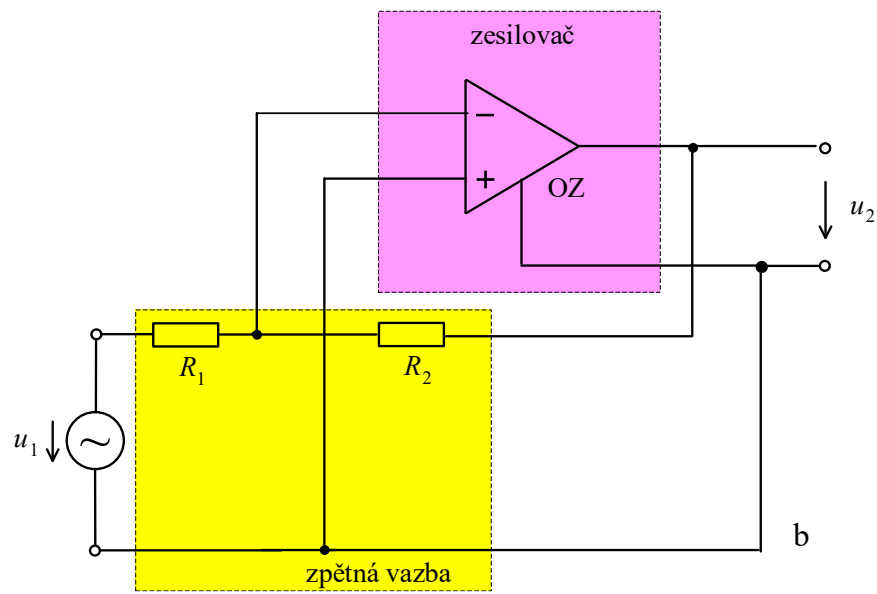

Obr. 4.3: Invertující zesilovač: a) invertující zapojení operačního zesilovače, b) k vysvětlení paralelní záporné zpětné vazby,

Pro pochopení typu zpětné vazby využijeme uspořádání invertujícího zapojení na Obr. $4.3 b$, kde je blokově vyznačen zesilovač a př́islušný zpětnovazební obvod. Podle způsobu přivedení zpětnovazebního signálu na vstup zesilovače jde o paralelní zpětnou vazbu, protože 
část výstupního napětí je přes dělič $\mathrm{R}_{1}, \mathrm{R}_{2}$ přivedena paralelně na vstup operačního zesilovače. Protože operační zesilovač signál invertuje, působí toto napětí proti vstupnímu napětí a proto jde o zápornou zpětnou vazbu. Zpětnovazební signál se odebírá z napětového výstupu zesilovače a tudíž jde o napětovou zpětnou vazbu. Invertující zesilovač tedy využívá paralelní napětovou zápornou zpětnou vazbu.

Prozkoumejme ještě podrobně vlastnosti uzlu $\mathrm{S}$ u invertujícího zapojení na Obr. 4.3a. U invertujícího zapojení operační zesilovač udržuje potenciál uzlu S na potenciálu země a proto je také obvykle tento bod označován jako „virtuální zem“ nebo „virtuální nula“ operačního zesilovače. Jestliže do tohoto uzlu bude připojeno několik vstupních větví nebo několik zpětnovazebních větví, bude podle Kirchoffova zákona o proudech součet proudů tekoucích vstupními větvemi roven součtu proudů tekoucích větvemi zpětnovazebními. $Z$ tohoto důvodu se invertující vstupní svorka OZ často nazývá „sčítací bod“" operačního zesilovače.

Protože u invertujícího zesilovače je uzel S na nulovém potenciálu $\left(u_{\mathrm{i}} \approx 0\right)$, bude vstupní proud $i_{1}$ určen pouze vstupním napětím $u_{1}$ a odporem rezistoru $\mathrm{R}_{1}$ a tedy vstupní odpor invertujícího zesilovače $R_{\mathrm{vst}} \approx R_{1}$. V této souvislosti poznamenejme, že nebude-li zdroj vstupního signálu ideální, tzn. bude vykazovat vnitřní odpor, je nutno tento vnitřní odpor započítat do odporu rezistoru $R_{1}$ a je také třeba př́slušným způsobem upravit i rov (4-2).

Díky použití záporné zpětné vazby, která jak známo snižuje výstupní odpor jakéhokoliv zesilovače, můžeme pro př́pad ideálního $\mathrm{OZ}$ předpokládat výstupní odpor invertujícího zapojení $R_{\text {výst }} \approx 0$. I v př́ípadě, že použijeme reálný $\mathrm{OZ}$, můžeme počítat $\mathrm{s}$ tím, že prakticky vždy $R_{\text {výst }}<1 \Omega$ a tedy výstup invertujícího zapojení se chová jako tzv. „tvrdý zdroj“ napětí, tzn. že ani po připojení zátěže k výstupním svorkám zesilovače se jeho výstupní napětí nezmění a bude dáno rov (4-2).

\section{Neinvertující zesilovač}

Obvyklé schéma zapojení neinvertujícího zesilovače je nakresleno na Obr. 4.4a. V př́padě neinvertujícího zapojení operačního zesilovače je část výstupního napětí $z$ rezistorového děliče přivedena $v$ sérii ke vstupu operačního zesilovače (viz Obr. 4.4b). Protože i zde operační zesilovač signál invertuje, jde o sériovou zápornou zpětnou vazbu.

Za stejných zjednodušených předpokladů $u_{\mathrm{i}} \approx 0, i_{\mathrm{i}} \approx 0$, řešíme i neinvertující zesilovač. Protože $i_{\mathrm{i}} \approx 0$, můžeme napětí $u$ přivedené na invertující vstup OZ určit jako výstupní napětí nezatíženého rezistorového děliče

$$
u \approx \frac{R_{1}}{R_{1}+R_{2}} u_{2}
$$

Operační zesilovač si díky činnosti zpětné vazby udržuje na diferenčním vstupu napětí $u_{\mathrm{i}} \approx 0$, takže $u \approx u_{1}$ a výstupní napětí

$$
u_{2} \approx\left(1+\frac{R_{2}}{R_{1}}\right) u_{1}=A_{\mathrm{U}} u_{1}
$$




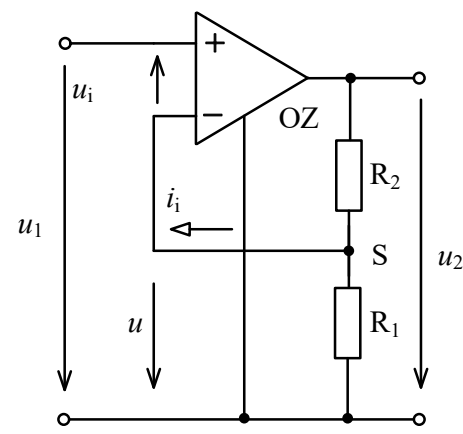

a

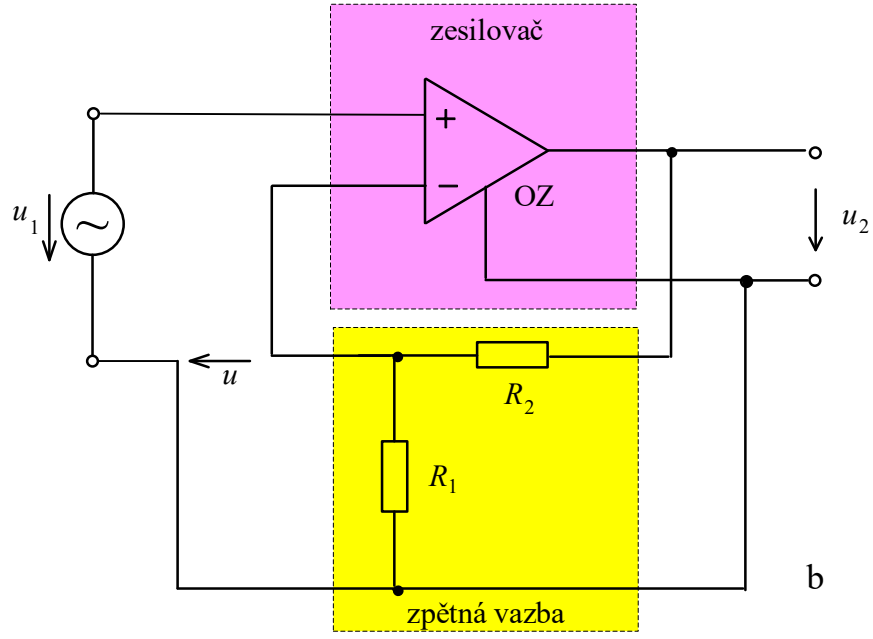

Obr. 4.4: Neinvertující zesilovač: a) neinvertující zapojení operačního zesilovače, b) k vysvětlení sériově záporné zpětné vazby,

kde $A_{\mathrm{U}}=1+R_{2} / R_{1}$ značí napět'ové zesílení neinvertujícího zesilovače.

U neinvertujícího zapojení se uzel S nachází přibližně na potenciálu neinvertující vstupní svorky, tzn. že se v tomto bodě udržuje napětí přibližně rovné napětí vstupnímu. Protože proud tekoucí do invertující vstupní svorky OZ je zanedbatelný $\left(i_{i} \approx 0\right)$, bude i zde podle Kirchoffova zákona o proudech platit, že součet proudů tekoucích do tohoto uzlu je nulový a můžeme i v tomto prrípadě invertující vstup $\mathrm{OZ}$ označit za „sčítací bod“. V tomto př́ípadě ovšem uzel S není na „virtuální nule“.

Neivertující zesilovač s ideálním operačním zesilovačem neodebírá proud ze zdroje vstupního signálu a proto se vstupní odpor tohoto uspořádání jeví jako nekonečný $R_{\mathrm{vst}} \approx \infty$. I v prrípadě, že vstupní odpor $r_{\mathrm{i}}$ mezi diferenčními vstupními svorkami nebude u skutečného operačního zesilovače nekonečný (viz Obr. 4.5), tak díky tomu, že na obou vstupech OZ se udržuje téměř stejné napětí, poteče tímto odporem zanedbatelný proud a můžeme počítat $\mathrm{s}$ tím, že prakticky vždy $R_{\text {vst }}>10^{6} \Omega$ až $10^{12} \Omega$. Je to díky tomu, že sériová záporná zpětná vazba vstupní odpor obvodu zvyšuje.

Výstupní odpor neinvertujícího zapojení je při uvažování ideálního operačního zesilovače nulový $R_{\text {výst }} \approx 0$ a zesilovač můžeme považovat za ideální zdroj napětí. Záporná zpětná vazba zajistí tuto vlastnost i v případě, že výstupní odpor reálného OZ je nenulový a tedy můžeme počítat s tím, že neinvertující zesilovač se chová prakticky vždycky jako „tvrdý $\boldsymbol{z} \boldsymbol{d r o j}$ “ napětí $\mathrm{s} R_{\text {výst }}<1 \Omega$. 


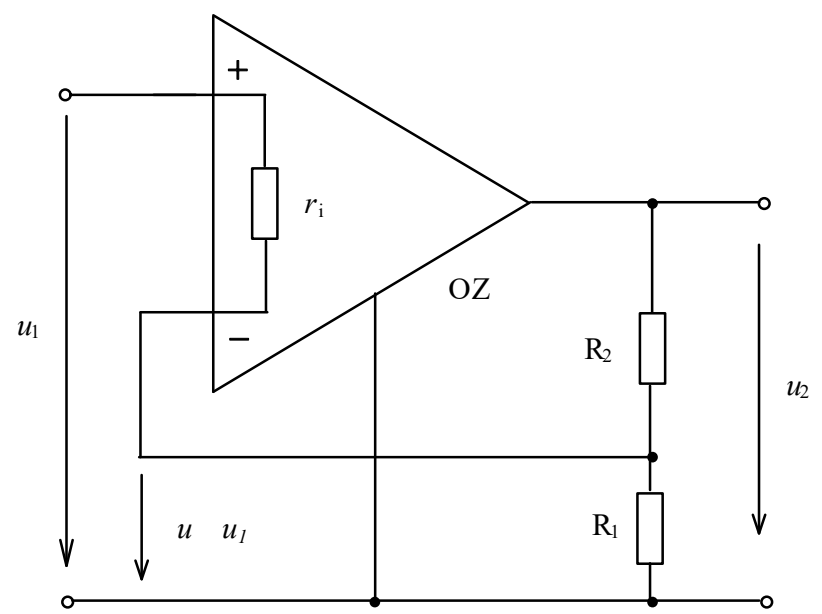

Obr. 4.5: K vysvětlení vysokého vstupního odporu neinvertujícího zesilovače

Ostatní zapojení operačních zesilovačů (mimo obvodů s kladnou zpětnou vazbou) jsou téměř vždy rozšiřrením nebo modifikací těchto dvou základních způsobů uspořádání operační zpětné vazby. Další aplikační možnosti získáme, nahradíme-li odporové lineární prvky ve vstupní větvi nebo zpětnovazební větvi, nebo v obou větvích operační zpětné vazby, prvky kmitočtově závislými nebo prvky nelineárními.

Závěrem této stati je možno konstatovat, že přenosové vlastnosti v ideálním případě nezávisí na vlastnostech operačního zesilovače, ale pouze na parametrech prvků jeho operační zpětnovazební sítě. Vlastnosti operačních zesilovačů vyráběných v současnosti se v určitých směrech přibližují ideálnímu zesilovači a hlavním omezujícím činitelem v běžných aplikacích se pak stává přesnost s jakou je možno vybrat prvky operační zpětnovazební sítě. Využívámeli však operační zesilovač až na mezi jeho parametrů je třeba sáhnout k podrobnější analýze a uvažovat reálné vlastnosti operačního zesilovače.

\section{Použitá literatura}

[1] GRAME, J. G. Designing with Operational Amplifiers - Applications Alternatives. New York, McGraw-Hill Book Company, 1977

[2] TIETZE, U.; SCHENK, CH.; GAMM, E. Electronic Circuits. Hand book for Design and Applications. 2nd edition, Springer - Verlag, Berlin 2008. ISBN 978-3-54000429-5

[3] TIETZE, U.; SCHENK, CH. Electronic Circuits. Design and Applications. Springer Verlag, Berlin 1991. ISBN 3-540-50608-X

[4] DOSTÁL, J. Operační zesilovače. BEN, Praha 2005

[5] DOSTÁL, J. Operational Amplifiers. Elsevier, Amsterdam 1981

[6] VRBA, K.; VRBA, K. jun. Technika analogových obvodů a systémů. Skriptum, 4. vydání. Ediční středisko VUT Brno,1989

[7] VRBA, K.; VRBA, K. jun. Technika analogových obvodů a systémů - sbírka prríkladů. Skriptum, 3. vydání. Ediční středisko VUT Brno,1989

[8] CLAYTON, G.B. Operational Amplifier. London, Butterworth Co 1971

[9] HUIJSING, J.H. Operational Amplifiers - Theory and Desing. Kluwer Academic Publishers, Boston 200 


\section{Parametry operačních zesilovačů}

\subsection{Parametry a charakteristiky operačních zesilovačů}

Konkrétní operační zesilovače se svými vlastnostmi liší od ideálního operačního zesilovače. Pro popis těchto vlastností použiváme různých provozních charakteristik a parametrů.

\subsubsection{Základní vlastnosti}

Převodní charakteristika

Charakteristickou přenosovou vlastností operačního zesilovače je jeho velká citlivost k rozdílu obou vstupních napětí $u_{\mathrm{i}}=u_{\mathrm{N}}-u_{\mathrm{P}}$, tzn. že operační zesilovač vzhledem k velkému zesílení reaguje již na velmi nepatrné odchylky diferenčního napětí $u_{\mathrm{i}}$ od nuly.

Průběh typické převodní charakteristiky operačního zesilovače bez zpětné vazby $u_{\mathrm{o}}\left(u_{\mathrm{i}}\right)$ je uveden na Obr. 5.1. Charakteristika vykazuje vedle střední aktivní oblasti, které se využívá pro zesilování, ještě dvě oblasti nasycení, ve kterých je vstupní napětí $u_{\mathrm{o}}$ blízké napájecímu napětí $\pm U_{\mathrm{N}}$. Napětí se označuje jako saturační napětí $U_{\mathrm{o} \text { sat}}$.
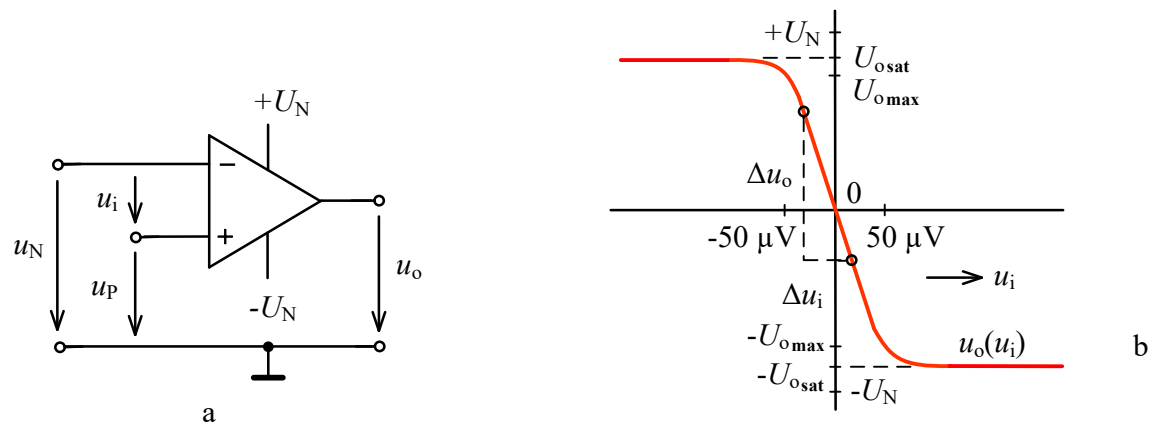

Obr. 5.1: Diferenční operační zesilovač a jeho převodní charakteristika

\section{Diferenční zesílení}

Diferenční zesílení operačního zesilovače je dáno strmostí převodní charakteristiky v její lineární oblasti

$$
A=-\Delta u_{\mathrm{o}} / u_{\mathrm{i}}
$$

Jde o zesílení samotného operačního zesilovače bez zpětné vazby. Často bývá označováno jako stejnosměrné (ss) zesílení operačního zesilovače a v katalogových listech je uváděna jeho absolutní hodnota $|A|$. 
Souhlasné vstupní napětí operačního zesilovače je dáno aritmetickým průměrem vstupního napětí $u_{\mathrm{P}}$ a $u_{\mathrm{N}}$

$$
u_{\mathrm{CM}}=\left(u_{\mathrm{P}}+u_{\mathrm{N}}\right) / 2 .
$$

Při rovnosti obou vstupních napětí, $u_{\mathrm{P}}=u_{\mathrm{N}}$, je zřejmě vstupní diferenční napětí nulové, tj. $u_{\mathrm{i}}=0$ a výstupní napětí by mělo být také nulové, $u_{\mathrm{o}}=0$. Avšak u reálných diferenčních operačních zesilovačů je i při $u_{\mathrm{i}}=0$ výstupní napětí funkcí souhlasného vstupního napětí. Typický průběh přenosové charakteristiky $u_{\mathrm{o}}\left(u_{\mathrm{CM}}\right)$ je nakreslen na Obr. 5.2. Také tato přenosová charakteristika má aktivní oblast, předcházející na obou stranách v oblasti nasycení. Je z ní možno odvodit souhlasné zesílení

$$
A_{\mathrm{CM}}=\Delta u_{\mathrm{o}} / \Delta u_{\mathrm{CM}} .
$$

Někdy bývá označováno jako souhlasné potlačení CMR (common-mode rejection).

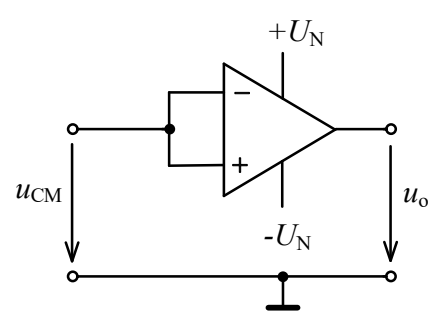

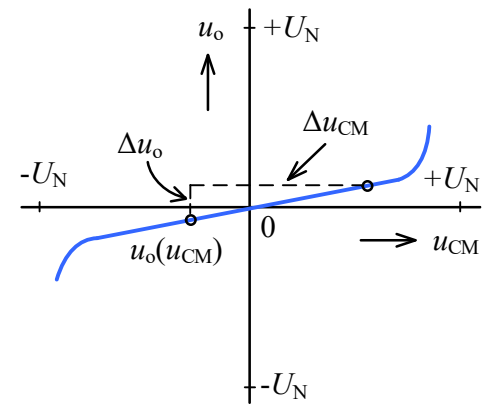

b

Obr. 5.2: Vliv souhlasného napětí na operační zesilovač

\section{Činitel potlačení souhlasného napětí}

Činitel potlačení souhlasného napětí CMMR (common-mode rejection ratio) charakterizuje do jaké míry je potlačen vliv souhlasného napětí $u_{\mathrm{CM}}$. Je definován jako poměr diferenčního zesílení $A$ a souhlasného zesílení $A_{\mathrm{CM}}$

$$
G=A / A_{\mathrm{CM}} .
$$

Obvykle se v katalogových listech uvádí v decibelech

$$
C M M R=20 \log \left(A / A_{\mathrm{CM}}\right) .
$$

Běžně je činitel potlačení 60 až $100 \mathrm{~dB}$, u vysoce kvalitních zesilovačů pak až $130 \mathrm{~dB}$.

\section{Maximální diferenční vstupní napětí}

Ve většině př́ípadů je napětí mezi diferenčními vstupními svorkami operačního zesilovače vlivem připojené operační zpětnovazební sítě udržováno na velice malé hodnotě. V některých aplikacích nebo při poruše ve zpětnovazební síti může však napětí dosáhnout značné hodnoty. Pak musíme zajistit, aby napětí nepřekročilo tzv. maximální diferenční vstupní napětí, protože by mohlo dojít k trvalému poškození operačního zesilovače. Ochrana diferenčního vstupu se obvykle realizuje dvěma antiparalelně zapojenými diodami, které omezí 
diferenční napětí na $\pm 0,6 \mathrm{~V}$. Řada moderních operačních zesilovačů je proti vstupnímu přetížení vnitřně chráněna a nemusíme se tímto problémem většinou zabývat.

\section{Maximální souhlasné vstupní napětí}

Maximální, popř. jmenovité souhlasné vstupní napětí $U_{\mathrm{CM}}$ je maximální hodnota souhlasného napětí, kdy operační zesilovač pracuje ještě v lineární oblasti. Má-li být operační zesilovač použit v podmínkách, kdy by mohlo nadměrné souhlasné napětí způsobit poškození zesilovače, je vhodné chránit vstup operačního zesilovače pomocí napětového omezovače se Zenerovou diodou. Lze však vybrat typy operačních zesilovačů, které mají maximální souhlasné napětí určeno použitým napájecím napětím operačního zesilovače $\pm U_{\mathrm{N}}$.

\section{Maximální výstupní napětí}

Klasické operační zesilovače jsou obvykle konstruovány tak, aby při napájení ze symetrického zdroje $\pm 15 \mathrm{~V}$ a při plném zatížení byly schopny dodat výstupní napětí s rozkmitem $U_{\mathrm{o} \text { max }}$ minimálně $\pm 10 \mathrm{~V}$ při maximální zátěži operačního zesilovače. Maximální, popř. jmenovité výstupní napětí $U_{\mathrm{o} \text { max }}$ je největší hodnota výstupního napětí, které může být dosaženo bez zkreslení výstupního signálu vlivem saturace operačního zesilovače (viz Obr. 5.1b). Hodnota maximálního výstupního napětí závisí na tom, do jaké zátěže operační zesilovač pracuje (obvykle se uvažuje maximální výstupní proud) a jaké je napájecí napětí zesilovače. Maximální rozkmit výstupního napětí je běžně uváděn v katalozích a neměl by být překročen. Pokud je zapotřebí větší rozkmit výstupního napětí nad $\pm 30 \mathrm{~V}$, doplní se vnější posilovač napětí (voltage booster).

U klasického operačního zesilovače je rozkmit výstupního napětí vždy o 2 V menší než je kladné či záporné napětí (viz Obr. 5.3a). Pokud budeme klasický operační zesilovač napájet

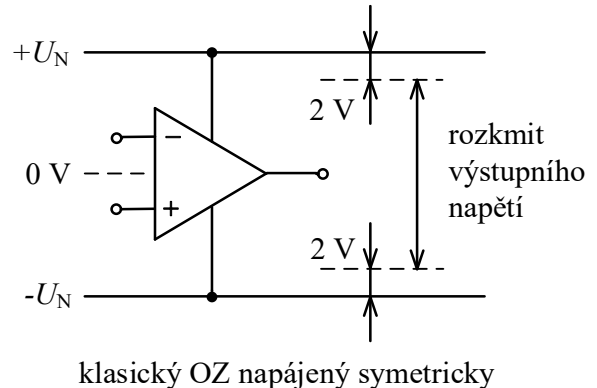

a

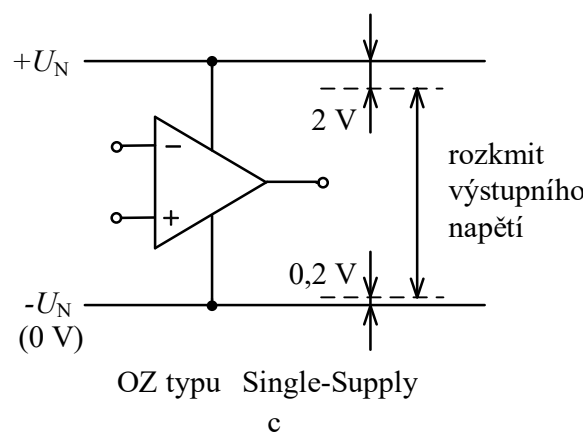

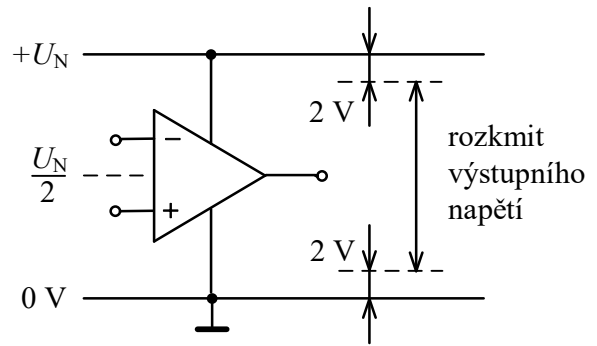

klasický OZ napájený asymetricky

$\mathrm{b}$

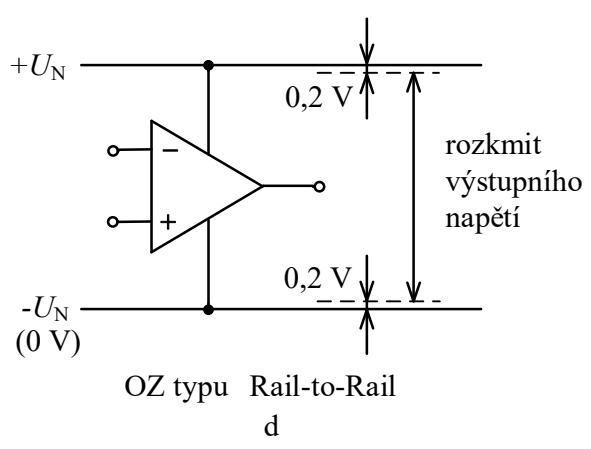

Obr. 5.3: Rozkmit výstupního napětí: a) klasický OZ napájený symetricky, b) klasický OZ napájen asymetricky, c) OZ s jediným napájecím zdrojem, d) OZ s plným rozkmitem 
asymetricky, nap̌r. uzemníme záporný napájecí přívod (viz Obr. 5.3b), bude tato vlastnost omezovat možnosti použití zejména při nízkém napájecím napětí. Budeme-li např. takovýto zesilovač napájet $\mathrm{z}$ jednoho zdroje $+5 \mathrm{~V}$, na výstupu zesilovače bude maximální rozkmit stř́́davého signálu $1 \mathrm{~V}$. Takovýto zesilovač proto funguje nejlépe při symetrickém napájecím napětí.

Poněkud lepší vlastnosti pokud se týká rozkmitu výstupního napětí vykazují speciální zesilovače konstruované pro jediné napájecí napětí (Single-Supply) a zesilovače s plným rozkmitem dosahujícím téměř napájecí napětí (Rail-to rail), [1]. Tyto dva typy zesilovačů jsou určeny zejména pro bateriové př́stroje, kdy by klasické zesilovače kladly na bateriové napájení vysoké nároky co do počtu bateriových článků.

Operační zesilovače určené pro jediné napájecí napětí (Single-Supply) lze napájet jak jedním zdrojem, tak i symetrickým napájecím zdrojem. Mají větší rozkmit napětí výstupního napětí než klasické operační zesilovače (viz Obr. 5.3c). Jejich záporný rozkmit se může blížit k $-U_{\mathrm{N}}$ (nebo k zemnímu potenciálu) v rozmezí 100 až $500 \mathrm{mV}$. Od kladného napájecího napětí

$+U_{\mathrm{N}}$ však musí být dodržen odstup $2 \mathrm{~V}$, stejně jako u klasického operačního zesilovače.

U operačních zesilovačů s plným rozkmitem výstupního napětí (Rail-to-Rail) se rozkmit výstupního napětí může přiblížit až $\mathrm{k}$ jeho napájecím napětím $+U_{\mathrm{N}} \mathrm{a}-U_{\mathrm{N}}$, často $\mathrm{v}$ rozmezí 10 až $100 \mathrm{mV}$ od jeho kladného či záporného napájecího napětí (viz Obr. 5.3d). Poznamenejme, že $-U_{\mathrm{N}}$ nemusí znamenat záporné napájecí napětí, ale může to být zemní potenciál.

\section{Maximální výstupní proud}

Běžné operační zesilovače jsou schopny dodat do zátěže obvykle proud $\pm 2 \mathrm{~mA}$ až $\pm 5 \mathrm{~mA}$. Maximální, popř. jmenovitý výstupní proud $I_{\mathrm{o} \text { max }}$ je největší hodnota výstupního proudu, kdy operační zesilovač pracuje ještě v lineární oblasti, tj. platí lineární parametry udané v katalogu. Koncové tranzistory operačních zesilovačů jsou obvykle chráněny před uničením velkým výstupním proudem elektronickými pojistkami. Pokud je zapotřebí větší výstupní proud operačního zesilovače, doplní se zesilovač vnějším posilovačem proudu (current booster). To proto, že posilovač je zdrojem tepla a mohlo by dojít k velkým teplotním změnám parametrů vlastního zesilovače.

Napájecí proud

Napájecí proud značí proud $I_{\mathrm{N}}^{+} \approx I_{\mathrm{N}}^{-}$tekoucí do napájecích svorek nezatíženého operačního zesilovače. U běžných operačních zesilovačů je napájecí proud 2 až $3 \mathrm{~mA}$ a to jak z kladného, tak i ze záporného napájecího zdroje. Odběr napájecího proudu se však zvyšuje o proud do připojené zátěže.

\subsubsection{Diferenční vstupní odpor, souhlasné vstupní odpory, výstupní odpor}

U ideálního operačního zesilovače předpokládáme nekonečný odpor mezi diferenčními vstupy, nekonečný odpor jednotlivých vstupů vůči společnému vodiči a nulový výstupní odpor. U skutečného operačního zesilovače musíme tyto vlastnosti brát v úvahu. V náhradním modelu na Obr. 5.4a se tyto vlastnosti reálného operačního zesilovače uvažují. 


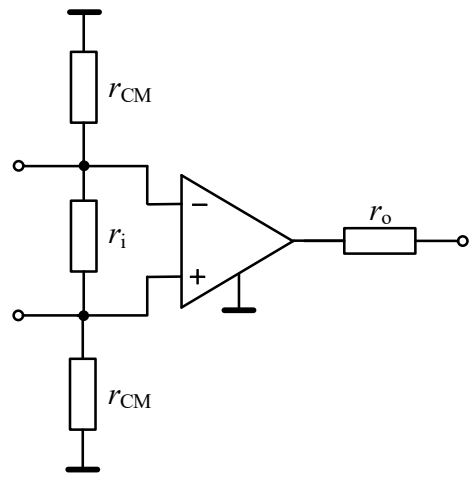

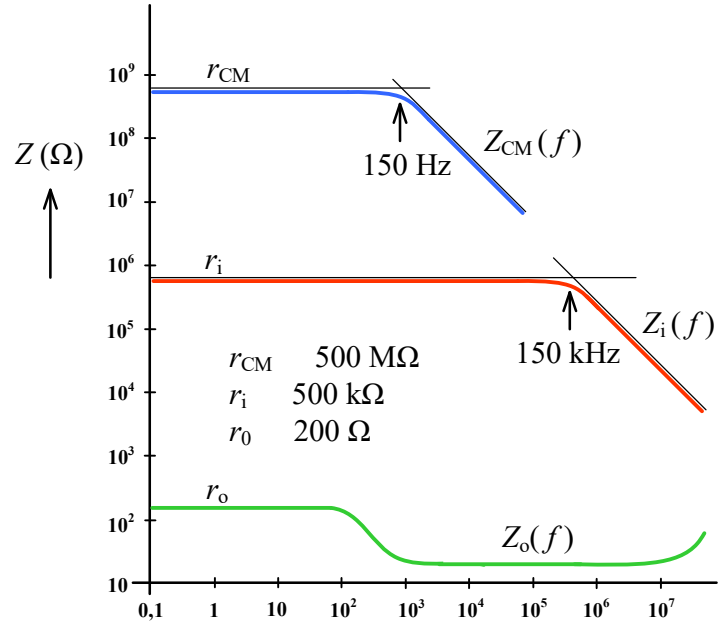

$f(\mathrm{~Hz})$

Obr. 5.4: a) Náhradní schéma operačního zesilovače při uvažování vstupního odporu, souhlasných odporů a výstupního odporu, b) typické průběhy vstupních a výstupních impedancí universálního bipolárního zesilovače

\section{Diferenční vstupní odpor}

Odpor mezi diferenčními vstupními svorkami operačního zesilovače se definuje jako dynamický odpor pro velmi malé změny $r_{\mathrm{i}} \approx \Delta u_{\mathrm{i}} / \Delta i_{\mathrm{i}}$. U operačních zesilovačů s bipolárními tranzistory na vstupu má diferenční vstupní odpor velikost $500 \mathrm{k} \Omega$ až několik megaohmů, u zesilovačů s unipolárními tranzistory na vstupu až $10^{9} \mathrm{k} \Omega$.

Ve skutečnosti má vstupní odpor impedanční charakter a je kmitočtově závislý. Typický průběh modulu diferenční vstupní impedance operačního zesilovače v závislosti na kmitočtu je $Z_{\mathrm{i}}(f)$ uveden na Obr. 5.4b. Vstupní impedance má obecně kapacitní charakter s ekvivalentní diferenční vstupní kapacitou $C_{\mathrm{i}}$ připojenou paralelně $\mathrm{k} r_{\mathrm{i}}$. Pokles impedance nastane při kmitočtu $1 / 2 \pi r_{\mathrm{i}} C_{\mathrm{i}}$. V katalogových listech se uvádí údaj o vstupní impedanci obvykle ve tvaru $r_{\mathrm{i}} \| C_{\mathrm{i}}$, např. $1 \mathrm{M} \Omega \| 3 \mathrm{pF}$.

\section{Souhlasné vstupni odpory}

Odpory jednotlivých vstupů operačního zesilovače vůči společnému vodiči se samostatně neuvádí, protože jsou přibližně stejné. Uvádí se souhlasný vstupní odpor $r_{\mathrm{CM}}$, který se určí jako dvojnásobek dynamického odporu mezi oběma zkratem spojenými vstupními svorkami vůči společnému vodiči (zemi). Jeho řádová hodnota je u zesilovačů s bipolárními vstupními tranzistory $10^{9} \Omega$, u zesilovačů s unipolárními vstupními tranzistory $10^{4} \Omega$.

Souhlasný vstupní odpor má taktéž impedanční charakter, [2]. Z průběhu modulu souhlasné vstupní impedance $Z_{\mathrm{CM}}(f)$ na Obr. $5.4 \mathrm{~b}$ je vidět, že velký souhlasný vstupní odpor $r_{\mathrm{CM}}$ je již na poměrně nízkých kmitočtech degradován reaktancí paralelní souhlasné vstupní kapacity $C_{\mathrm{CM}}$. Pokles impedance se začne projevovat při kmitočtech nad $1 / 2 \pi r_{\mathrm{CM}} C_{\mathrm{CM}}$.

Protože souhlasné vstupní odpory jsou až o několik řádů větší než hodnota diferenčního vstupního odporu, obvykle se jejich vliv na činnost obvodů s operačním zesilovačem neuvažuje. 


\section{Výstupní odpor}

Výstupní odpor $r_{\mathrm{o}}$ operačního zesilovače je dynamický odpor, jevící se mezi výstupní svorkou operačního zesilovače a společným vodičem. Jeho velikost bývá 50 až $250 \Omega$. Výstupní odpor operačního zesilovače zapojeného ve zpětnovazební síti je ale v důsledku silné záporné zpětné vazby mnohonásobně menší (obvykle $<1 \Omega$ ).

Pro průběh modulu výstupní impedance $Z_{\mathrm{o}}(f)$ je příznačný přechod mezi větší stejnosměrnou a menší vysokofrekvenční hodnotou (viz Obr. 5.4b), způsobený korekčními kapacitory koncového stupně. Závěrečný induktivní nárůst impedance, způsobený mezním kmitočtem koncových tranzistorů, už obvykle leží mimo aktivní kmitočtové pásmo operačního zesilovače.

\subsubsection{Napět’ový a proudový ofset, vstupní klidové proudy, drift}

\section{Napětový ofset}

Napětí $U_{\mathrm{IO}}$, které je nutno přivést na vstup operačního zesilovače (pracujícího bez buzení), aby na jeho výstupu bylo napětí nulové, $u_{\mathrm{o}}=0$, se nazývá napětový ofset, resp. napětové nesymetrie vstupů. Tento jev vzniká v důsledku elektrické nesymetrie operačního zesilovače, především jeho vstupních obvodů. Jeho vliv modelujeme tak, že do některého ze vstupních převodů ideálního operačního zesilovače vřadíme zdroj napětí $U_{\mathrm{IO}}$ (viz Obr. 5.5). Ofset u universálních operačních zesilovačů mívá velikost až několik milivoltů. U operačních zesilovačů s ultranízkým ofsetem pak $25 \mu \mathrm{V}$ a méně.

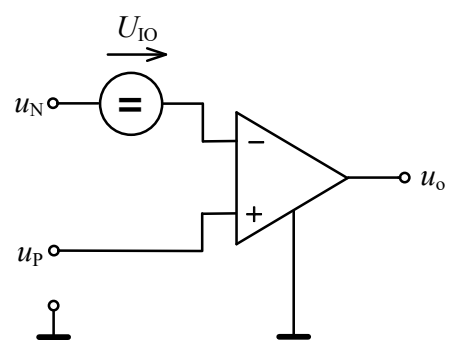

Obr. 5.5: Napět'ový ofset operačního zesilovače

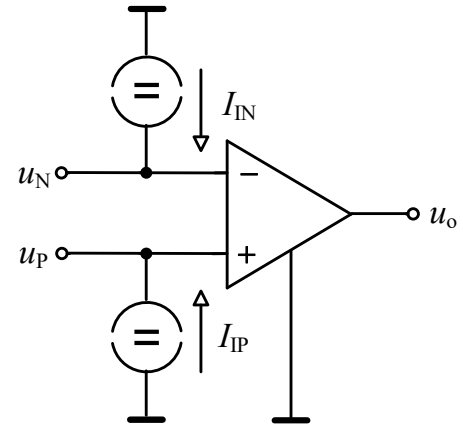

Obr. 5.6: Vstupní klidové proudy

Nejčastěji se ofset nuluje pomocí potenciometrického trimru připojeného k pomocným svorkám, kterým se vyvolá rozvážení vnitřní struktury obvodu operačního zesilovače, což má za následek vykompenzování ofsetu.

Poznamenejme, že řada výrobců nabízí operační zesilovače s potlačeným ofsetem, kdy k seřízení dochází již při výrobě. Samozřejmě se to projeví na ceně takového zesilovače. Odpadne však pracné nastavování obvodů při hromadné výrobě př́strojů. Ve strídavých aplikacích např. pro zpracování audiosignálů je kompenzace napět'ové nesymetrie zbytečná, protože chybová ss složka na výstupu zesilovače se eliminuje použitím tzv. oddělovacích kapacitorů. Operační zesilovače určené pro zpracování audiosignálů většinou ani pomocné svorky pro nulování ofsetu nemají vyvedeny. 
Reálné operační zesilovače se vyznačují tím, že nejsou buzeny bezproudově, ale že do obou jejich vstupních svorek tekou proudy (v podstatě proudy báze resp. řídicích elektrod vstupních tranzistorů). Jejich střední hodnotu $I_{\mathrm{N}}=\left(I_{\mathrm{IN}}+I_{\mathrm{IP}}\right)$ označujeme jako vstupní klidový proud. Tento proud má u bipolárních operačních zesilovačů řádově velikost $10 \mathrm{nA}$ až $1 \mu \mathrm{A}$, u zesilovačů majících na vstupu tranzistory řízené polem pak pod $1 \mathrm{nA}$. Jejich prítomnost modelujeme tak, že do obou př́vodů ideálního operačního zesilovače připojíme zdroje proudu $I_{\text {IN }}$ a $I_{\text {IP }}$ (viz Obr. 5.6). Účinek vstupních proudů lze zásahem do operační sítě zesilovače obvykle navzájem vykompenzovat. Poznamenejme, že vstupní klidové proudy operačních zesilovačů s unipolárními tranzistory jsou tak malé, že se obvykle ani jejich účinek na konkrétní zapojení neuvažuje a kompenzace se neprovádí.

\section{Proudový ofset}

Při nulovém výstupním napětí (a přibližně nulovém napětí obou vstupních svorek vůči společnému vodiči) jsou proudy tekoucí do vstupních svorek reálného operačního zesilovače navzájem různé. Jejich rozdíl $I_{\mathrm{IO}}=\left|I_{\mathrm{IP}}-I_{\mathrm{IN}}\right|$ se označuje jako proudový ofset, popř. proudová nesymetrie vstupů. Př́čina je tatáž jako u napět'ové nesymetrie vstupů, tzn. elektrická nesymetrie obvodů operačního zesilovače. Oba př́ípady se od sebe liší pouze způsobem napájení vstupních svorek zesilovače. V prvním př́ípadě šlo o napětové napájení, v druhém prrípadě o napájení vstupů proudem.

Proudová nesymetrie $I_{\mathrm{IO}}$ bývá značně menší než klidový vstupní proud. Její velikost se pohybuje u bipolárních vstupních tranzistorů v rozmezí od jednotek nanoampérů do několika set nanoampérů. V prvním přiblížení proto stačí eliminovat nežádoucí vliv obou vstupních proudů $I_{\mathrm{IP}}$ a $I_{\mathrm{IN}}$ a teprve potom se zabývat vlivem proudového ofsetu $I_{\mathrm{IO}}$, jehož účinek se již dá obvykle eliminovat prostředky použitými pro kompenzaci napětového ofsetu.

\section{Drift}

Celkově lze říci, že vliv napětového či proudového ofsetu a vstupních klidových proudů lze vnějším zásahem do operačního zesilovače nebo do operační zpětnovazební sítě vykompensovat. Hodnota těchto parametrů však není stálá, ale mění se - mluvíme o driftu, resp. o ujíždění parametrů operačního zesilovače. Příčiny driftu jsou různé, např. teplotní změny parametrů jednotlivých prvků operačního zesilovače, nestabilita napájecích zdrojů, stárnutí obvodových prvků, nedokonalost izolace apod. Poznámka: Náhodné změny výstupního napětí, které nejsou ve vztahu se vstupním signálem, nazýváme šum. Drift je šum na nejnižších kmitočtech.

Teplotní drift představuje největší potíže v řadě aplikací. Vzniká v důsledku teplotních závislostí jak aktivních tak i pasivních prvků. Teplotní drift bývá vyjádřen teplotními koeficienty vstupního klidového proudu a vstupních nesymetrií $\Delta I_{\mathrm{I}} / \Delta T, \Delta I_{\mathrm{IO}} / \Delta T, \Delta U_{\mathrm{IO}} / \Delta T$. Tyto koeficienty jsou obvykle definovány jako průměrné hodnoty v určeném teplotním rozsahu, které se získávají jako rozdíl vstupních klidových proudů resp. rozdíl nesymetrií při mezních pracovních teplotách. Protože závislosti $I_{\mathrm{I}}(T), I_{\mathrm{IO}}(T)$ jsou značně nelineární (změny ujíždění jsou v oblasti mezních teplot daleko větší než v okolí standardní teploty), je takto stanovený údaj o jejich směrnici sporný a proto se často udávají jen zaručené maximální hodnoty obou proudů $I_{\mathrm{I}}$ a $I_{\mathrm{IO}}$ při standardní teplotě a při mezních pracovních teplotách.

Dosud uvažované teplotní změny se týkaly operačního zesilovače jako celku. Mnohem větší vliv ale mohou mít i poměrně malé teplotní diference mezi jeho kritickými částmi, způsobené cizími tepelnými zdroji i vlastním ohřevem (po zapnutí napájení, po změnách zátěže, 
po zahlcení vstupu) projevující se porušením vnitřní teplotní kompenzace diferenčních zesilovacích stupňů nebo vznikem termoelektrických napětí.

Kolísání napájení je druhou podstatnou př́íčinou změn těchto parametrů. Citlivost na změny napájení $U_{\mathrm{N}}$ se udává podobně jako u teplotních změn koeficienty $\Delta I_{\mathrm{I}} / \Delta U_{\mathrm{N}}, \Delta I_{\mathrm{IO}} / \Delta U_{\mathrm{N}}$, $\Delta U_{\mathrm{IO}} / \Delta U_{\mathrm{N}}$. Koeficient $\Delta U_{\mathrm{IO}} / \Delta U_{\mathrm{N}}$ je koeficient bezrozměrový (udávaný $\mathrm{v} \mu \mathrm{V} / \mathrm{V}$ ) a analogicky $\mathrm{k}$ potlačení souhlasného napětí bývá někdy uváděn $\mathrm{v}$ převráceném poměru jako potlačení vlivu napájecího napětí $\Delta U_{\mathrm{N}} / \Delta U_{\mathrm{IO}}$ a udáván $\mathrm{v}$ decibelech. Všeobecně lze konstatovat, že v porovnání s jinými elektronickými obvody při uvážení dosahované přesnosti je operační zesilovač na změny svého napájecího napětí málo citlivý. Stabilita napájecího zdroje $1 \%$ až 10 \% je dostačující, pokud napájecí zdroj neslouží zároveň jako referenční zdroj operační sítě.

Samovolná časová změna parametrů operačního zesilovače, způsobená dlouhodobým stárnutím, je nevratná. $Z$ tohoto důvodu údaje v katalozích bud' nejsou uváděny vủbec, nebo je udána typická hodnota zjištěná na ověřovacím souboru zesilovačů. Analogicky k předchozím koeficientům se používají údaje o změně vstupního klidového proudu $\Delta I_{\mathrm{I}} / \Delta t$, vstupního proudového ofsetu $\Delta I_{\mathrm{IO}} / \Delta t$ a vstupního napětového ofsetu $\Delta U_{\mathrm{IO}} / \Delta t$ vztažené na interval dne, měsíce nebo roku.

\subsection{4 Šum operačního zesilovače}

V aplikacích zpracovávajících malé signály, můžeme hrát důležitou roli vlastní šum operačního zesilovače. Šum si můžeme modelovat efektivní hodnotou vstupního šumového napětí $U_{\mathrm{N}}\left(\right.$ zde $\mathrm{N}$ značí Noise = šum) a vstupních šumových proudů $I_{\mathrm{NP}}, I_{\mathrm{NN}}$ (viz Obr. 5.7). Vzhledem ke statistické povaze šumu se obvykle uvádí pouze společný údaj $I_{\mathrm{N}} \mathrm{s}$ významem $I_{\mathrm{NP}}$ nebo $I_{\mathrm{NN}}$. Šumové zdroje se obvykle charakterizují efektivní hodnotou nebo spektrální hustotou. Spektrální hustota vstupního šumového napětí a vstupního šumového proudu poskytuje nejúplnější informace o vlastnostech zesilovače. Je diferenciálním vyjádřením závislosti efektivních hodnot $U_{\mathrm{N}}, I_{\mathrm{N}}$ na sledovaném oboru kmitočtů $f$. Často je definována prostřednictvím spektrální hustoty šumového výkonu, úměrného druhé mocnině efektivní hodnoty $U_{\mathrm{N}}^{2}, I_{\mathrm{N}}^{2}$

$$
U_{\mathrm{Nd}}^{2}=\frac{\mathrm{d} U_{\mathrm{N}}^{2}}{\mathrm{~d} f}, \quad I_{\mathrm{Nd}}^{2}=\frac{\mathrm{d} I_{\mathrm{N}}^{2}}{\mathrm{~d} f} .
$$

Rozměr spektrální hustoty šumového výkonu $U_{\mathrm{Nd}}^{2}$ a $I_{\mathrm{Nd}}^{2} \mathrm{je} \mathrm{V}^{2} / \mathrm{Hz} \mathrm{a} \mathrm{A}^{2} / \mathrm{Hz}$. Rozměr spektrálních hustot šumu $U_{\mathrm{Nd}}, I_{\mathrm{Nd}} \mathrm{je} \mathrm{V} / \sqrt{\mathrm{Hz}}$ a A $/ \sqrt{\mathrm{Hz}}$. Někteří výrobci uvádějí průběhy spektrálních hustot šumového výkonu $U_{\mathrm{Nd}}^{2}(f)$ a $I_{\mathrm{Nd}}^{2}(f)$, většinou se však udává průběh spektrálních hustot šumu $U_{\mathrm{Nd}}(f)$ a $I_{\mathrm{Nd}}(f)$. Není důležité, který průběh je znám, protože oba způsoby vyjádření sdělují tutéž informaci. Je důležité si pouze povšimnout, o kterou veličinu se jedná.

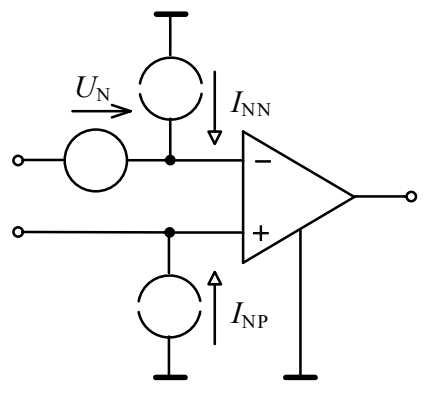

Obr. 5.7: Náhradní šumový model operačního zesilovače 
Znalost kmitočtového průběhu spektrálních hustot $U_{\mathrm{Nd}}(f)$ a $I_{\mathrm{Nd}}(f)$ ve tvaru analytického výrazu, grafu nebo alespoň několika diskrétních hodnot umožňuje stanovení efektivního šumu ve sledovaném kmitočtovém pásmu $f_{1}$ až $f_{2}$ analytickou nebo numerickou integrací a následným odmocněním

$$
U_{\mathrm{N}}=\sqrt{\int_{f_{1}}^{f_{2}} U_{\mathrm{Nd}}^{2}(f) \mathrm{d} f}, \quad I_{\mathrm{N}}=\sqrt{\int_{f_{1}}^{f_{2}} I_{\mathrm{Nd}}^{2}(f) \mathrm{d} f} .
$$

Většinou se však průběhy spektrálních hustot $U_{\mathrm{Nd}}(f)$ a $I_{\mathrm{Nd}}(f)$ použijí přímo pro porovnání jednotlivých typů operačních zesilovačů a výběr vhodného typu (viz Obr. 5.8), [1].

Od vlastního šumu operačního zesilovače, který jsme dosud uvažovali, odlišujeme tzv. vnesený šum, který je vyvolán vnějšími prríčinami, jako např. šumem a zvlněním napájecích zdrojů, kapacitní a induktivní vazbou ze sít'ového rozvodu, z prresyceného transformátoru, z rozhlasových vysílačů a z jiskřících kontaktů, povrchovými svody na deskách plošných spojů a nežádoucími úbytky napětí $v$ rozvodu společného vodiče. V tomto př́ípadě jde pak o charakteristiku operační sítě $\mathrm{v}$ daném rušivém prostředí. Tento vnesený šum může být až o několik řádů vyšší než vlastní šum operačního zesilovače. Proto je zapotřebí se při konstrukci nízkošumového zesilovače věnovat nejen výběru nízkošumového zesilovače, ale i sofistikovanému návrhu při vlastní realizaci.

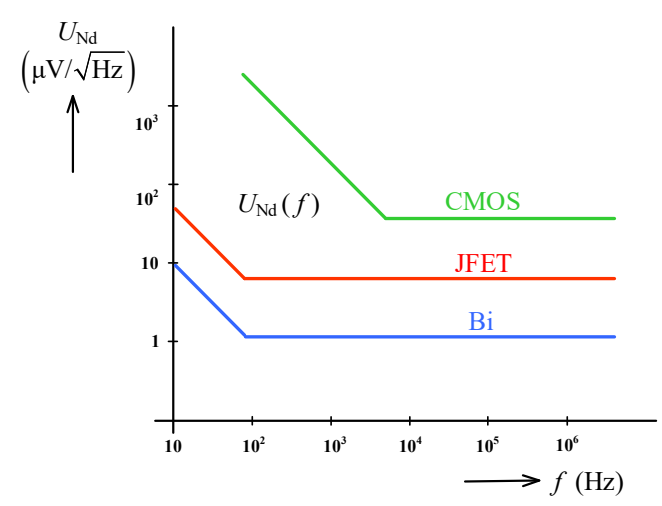

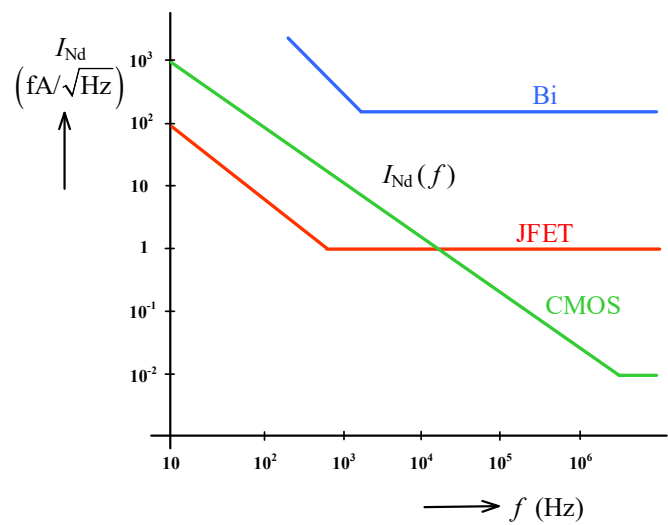

b

Obr. 5.8: Porovnání napět'ového a proudového šumu nízkošumových operačních zesilovačů

\subsubsection{Kmitočtová charakteristika}

Doposud jsme uvažovali jen stejnosměrné zesílení operačního zesilovače $A$. Při zesílení signálů se širokým kmitočtovým spektrem však musíme brát v úvahu, že činitel zesílení operačního zesilovače $\bar{A}=A \mathrm{e}^{j \varphi}$ má komplexní charakter a bude kmitočtově nezávislý $\bar{A}(f)$ $=A(f) \mathrm{e}^{j \varphi}, \operatorname{kde} A=\bmod \bar{A}$ je modul činitele zesílení operačního zesilovače a $\varphi$ je jeho fáze resp. argument $\varphi=\arg \bar{A}$.

Řada aplikací pracuje se šířkou pásma pouze několik stovek hertzů a zdálo by se tedy, že není tř̌eba komplexní charakter zesílení uvažovat. Přesto je velmi důležité znát průběh kmitočtových charakteristik v celém kmitočtovém rozsahu. To proto, že pokles zesílení se zvyšujícím se kmitočtem je vždy doprovázen změnou fáze výstupního napětí, a proto se u obvodů se zápornou zpětnou vazbou může při vyšších kmitočtech záporná zpětná vazba změnit 
v kladnou, což má za následek převýšení na modulové kmitočtové charakteristice uzavřené zpětnovazební smyčky nebo dokonce vznik vysokofrekvenčních oscilací.

Výrobci operačních zesilovačů uvádějí v katalogových listech obvykle kmitočtové charakteristiky a to nejčastěji modulovou charakteristiku $A(f)$, méně často jí odpovídající fázovou charakteristiku $\varphi(f)$. Modul $A(f)$ je obvykle vyjádřen v decibelech jako zisk

$$
z(f)=20 \log A(f) .
$$

Závislosti $z(f)$ a $\varphi(f)$ kreslíme s výhodou v semilogaritmickém znázornění (s logaritmickou stupnicí kmitočtu) jako tzv. Bodeův diagram. Bodeův diagram universálního operačního zesilovače s tzv. standardním průběhem kmitočtové charakteristiky (bez zpětné vazby) je nakreslen na Obr. 5.9a. Pro takový zesilovač je typické, že zisk od mezního kmitočtu $f_{0}$ klesá rychlostí $20 \mathrm{~dB} /$ dek a další lom charakteristiky na $40 \mathrm{~dB} / \mathrm{dek}$ je až pod osou $0 \mathrm{~dB}$. Pak bude zesilovač stabilní pro všechny druhy rezistorové zpětné vazby. Průsečík charakteristiky $z(f)$ s osou $0 \mathrm{~dB}$ se označuje jako tranzitní kmitočet $f_{\mathrm{T}}$.
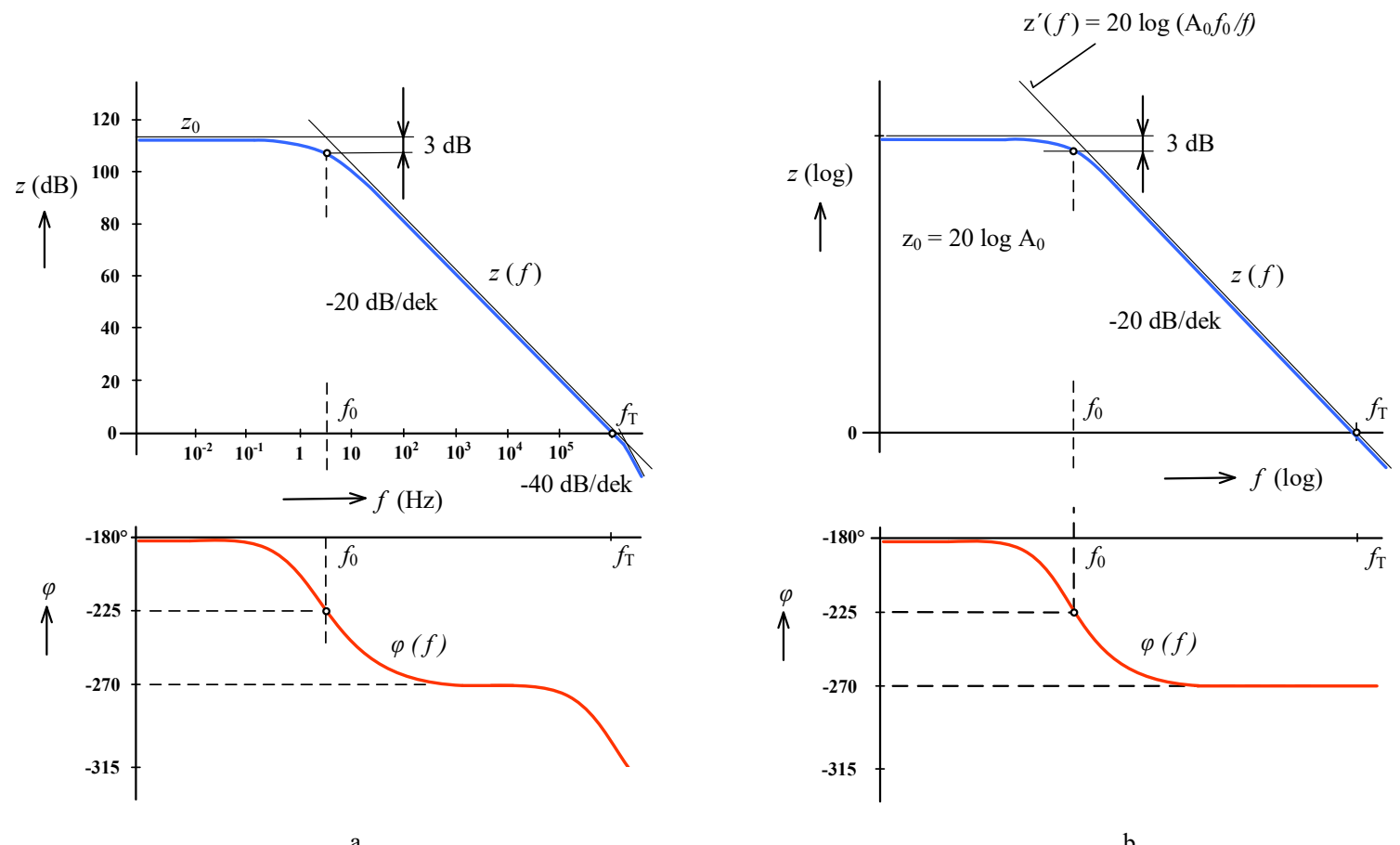

Obr. 5.9: a) Bodeho diagram tj. kmitočtová charakteristika zisku a fázová charakteristika universálního operačního zesilovače, b) Bodeův diagram zesilovače s tzv. standardní kmitočtovou charakteristikou

\section{Standardní kmitočtová charakteristika}

$\mathrm{Z}$ důvodů zabezpečení potřebné stability zesilovače zapojeného v síti zpětné vazby musí u operačního zesilovače s univerzální použitelností odpovídat kmitočtová závislost diferenčního zesílení kmitočtové charakteristice dolní propusti prvního řádu. Operační zesilovače, které vykazují takovýto průběh se označují jako zesilovače se standardním průběhem kmitočtové charakteristiky, [3].

Pokud vezmeme v úvahu invertující charakter operačního zesilovače bude

$$
\bar{A}(f)=-\frac{A_{0}}{1+\mathrm{j} f / f_{0}} .
$$


Zde je $A_{0}$ zesílení operačního zesilovače při velmi nízkých kmitočtech a $f_{0}$ horní mezní kmitočet, charakterizovaný poklesem zesílení o $3 \mathrm{~dB}$. Závislosti (1-9) odpovídá modulová a argumentová charakteristika

$$
A(f)=\frac{A_{0}}{\sqrt{1+\left(f / f_{0}\right)^{2}}}, \quad \varphi(f)=-180-\operatorname{arctg}\left(f / f_{0}\right) .
$$

resp. pokud zesílení vyjádříme v decibelech jako zisk

$$
z(f)=20 \log \frac{A_{0}}{\sqrt{1+\left(f / f_{0}\right)^{2}}}, \quad \varphi(f)=-180^{\circ}-\operatorname{arctg}\left(f / f_{0}\right) .
$$

Pro standardní kmitočtové charakteristiky je typické, že zisk při nízkých kmitočtech se asymptoticky blíží ke konstantě $z_{0}=20 \log A_{0}$, kdežto při vysokých kmitočtech je křivka závislosti $z(f)$ asymptotická k prímce $z^{\prime}(f)=20 \log \left(A_{0} f_{0} / f\right)$ (viz Obr. 5.9b). Obě asymptoty se protínají při kmitočtu $f=f_{0}$ a zde (podle rovnice (5-10)) je právě $A\left(f_{0}\right)=A_{0} / \sqrt{2}$. V Bodeově diagramu tomu odpovídá pokles charakteristiky $z(f)$ o $3 \mathrm{~dB}$. Vysokofrekvenční asymptota $z^{\prime}(f)$ v tomto znázornění klesá se sklonem $20 \mathrm{~dB}$ na 1 dekádu kmitočtu ( $\left.-20 \mathrm{~dB} / \mathrm{dek}\right)$.

Průběh argumentové charakteristiky $\varphi(f)$ (Obr. 5.9b) má charakteristický bod při $f=f_{0}$. Při tomto kmitočtu má totiž podle rov. (5-9) reálná a imaginární část zesílení $\bar{A}(f)$ stejnou velikost, a proto dochází k př́davnému fázovému posunutí právě o $-45^{\circ}$, tj. $\varphi\left(f_{0}\right)=-180^{\circ}-45^{\circ}=-225^{\circ}$. Při kmitočtech $f \gg f_{0}$ dochází k př́ídavnému fázovému posunutí blízkému $-90^{\circ}$, argumentová charakteristika se proto asymptoticky blíží konstantě $\varphi=-180^{\circ}-90^{\circ}=-270^{\circ}$. Tuto hodnotu však zesilovač se standardní kmitočtovou charakteristikou nikdy nepřekročí. Zesilovač s takovou charakteristikou je pak stabilní pro všechny rezistorové zpětnovazební sítě, protože fázové natočení zesilovače nikdy nepřesáhne $-270^{\circ}$ a zpětná vazba se nikdy nemůže stát kladnou, pro kterou je zapotřebí fázové natočení $-360^{\circ}$.

Tranzitní kmitočet $f_{\mathrm{T}}$, kdy bude zesílení $A\left(f_{\mathrm{T}}\right)=1$, resp. zisk $z\left(f_{\mathrm{T}}\right)=0 \mathrm{~dB}$, můžeme určit $\mathrm{z}$ rov. (5-10), když levou stranu rovnice pro $A(f)$ položíme rovnu jedné

$$
f_{\mathrm{T}} \approx A_{0} f_{0} .
$$

Tranzitní kmitočet $f_{\mathrm{T}}$ operačního zesilovače je tedy dán součinem ss zesílení $A_{0}$ a šiřky pásma $f_{0}$. Tranzitní kmitočet bývá často také uváděn jako šírka pásma pro jednotkové zesílení a označuje se zkratkou $G B W$ (gain-bandwidth, unity gain bandwidth), přičemž $G B W \equiv f_{\mathrm{T}}$.

Korekce kmitočtové charakteristiky

Jak už bylo řečeno, většina operačních zesilovačů má interně korigovánu kmitočtovou charakteristiku tak, že na vysokých kmitočtech klesá rychlostí $20 \mathrm{~dB} /$ dek a její lom na 40 $\mathrm{dB} /$ dek je až pod osou $0 \mathrm{~dB}$. V nabídce výrobců však stále existuje řada operačních zesilovačů s tzv. rychlým poklesem kmitočtové charakteristiky. Př́klad charakteristiky operačního zesilovače s rychlým poklesem kmitočtové charakteristiky je uveden na Obr. 5.10a.

U těchto zesilovačů se uplatní v oblasti mezi mezním kmitočtem $f_{0}$ a tranzitním kmitočtem $f_{\mathrm{T}}$ ještě další kmitočty lomu charakteristiky, která má při znázornění v Bodeově diagramu při kmitočtu $f_{\mathrm{T}}$ mnohem větší zápornou strmost než $20 \mathrm{~dB} / \mathrm{dek}$, u standardní charakteristiky. To je způsobeno tím, že ve snaze rozšiřic šířku pásma zesilovače je mezní 
kmitočet $f_{0}$ posunut směrem $\mathrm{k}$ vyšším kmitočtům a na vytvoření charakteristiky se podílejí ještě mezní kmitočty dalších zesilovacích stupňů operačního zesilovače. Jestliže charakteristika klesá v oblasti nad druhým lomovým kmitočtem rychlostí $20 \mathrm{~dB} / \mathrm{dek}$, klesá v oblasti mezního kmitočtu rychlostí $40 \mathrm{~dB} / \mathrm{dek}$. Operační zesilovač s rychlým poklesem kmitočtové charakteristiky nemusí již být při použití rezistorové zpětnovazební sítě vždy stabilní. Pro určení stability zpětnovazebního obvodu existuje tzv. Bodeho pravidlo stability, které je pro rezistorové sítě velmi jednoduché, [4]. Vyneseme kmitočtovou charakteristiku zisku samotného operačního zesilovače bez zpětné vazby $z(f)$. Do grafu pak vyneseme charakteristiku $z_{\beta}$ $(f)=20 \log (1 / \beta)$, přičemž zde $\beta$ značí tzv. zpětnovazební činitel. Ten udává, jaká část výstupního napětí se dostane na vstup operačního zesilovače při rozpojené smyčce zpětné vazby. V př́ípadě invertujícího zesilovače (viz Obr. 5.10b) bude zpětnovazební činitel $\beta=$ $R_{1} /\left(R_{1}+R_{2}\right)$ a do grafu tedy vyneseme charakteristiku $z_{\beta}(f)=20 \log (1 / \beta)=20 \log \left(1+R_{2} / R_{1}\right)$. Pokud bude přibližování charakteristiky samotného operačního zesilovače $z(f)$ a zpětnovazebního činitele $z_{\beta}(f)$ rychlostí $20 \mathrm{~dB} / \mathrm{dek}$, bude obvod stabilní. Pokud se ale obě charakteristiky budou blížit rychlostí $40 \mathrm{~dB} / \mathrm{dek}$ bude obvod na mezi stability a většinou se rozkmitá.
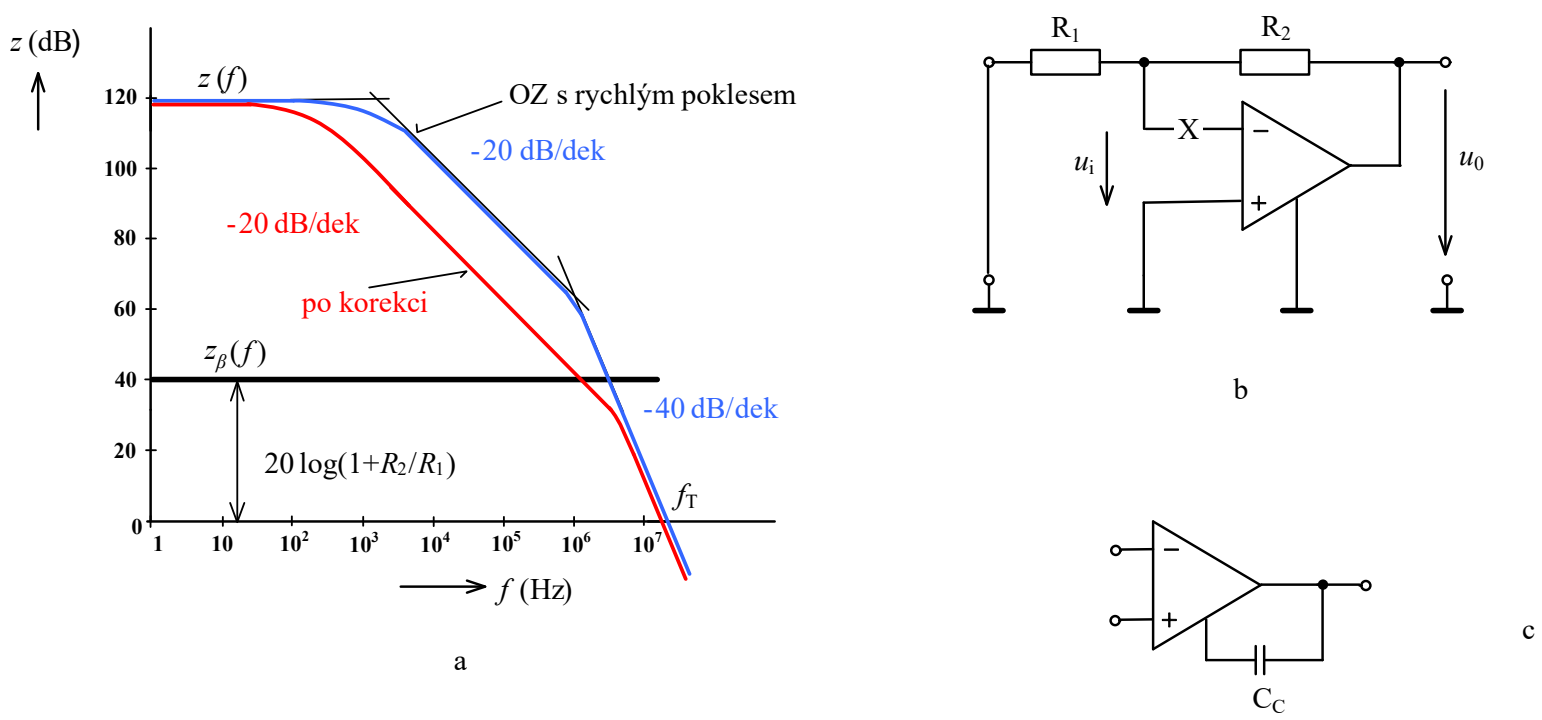

Obr. 5.10: a) Průběh kmitočtové charakteristiky před korekcí a po korekci, b) k určení zpětnovazebního činitele, c) připojení korekčního kapacitoru

Při použití operačního zesilovače s rychlým poklesem přenosové charakteristiky je proto někdy nutné korigovat kmitočtovou charakteristiku v závislosti na nastaveném zpětnovazebním zesílení tak, aby se předešlo rozkmitání obvodu na vysokých kmitočtech. Takovéto zesilovače mají obvykle vyvedeny pomocné svorky, kam se připojují prvky pro korekci kmitočtové charakteristiky. Korekční prvky jako např. kapacitor (viz Obr. 5.10c), nebo sériová kombinace $\mathrm{RC}$, se připojí k příslušným vývodům zesilovače pokud možno krátkými spoji. Doporučenou kapacitu korekčního kapacitoru udává výrobce vždy pro určité zesílení nastavené zpětnovazební síti tak, aby rychlost přibližování charakteristiky $z_{\beta}(f)$ a korigované kmitočtové charakteristiky operačního zesilovače byla $20 \mathrm{~dB} / \mathrm{dek}$.

V př́padě operačních zesilovačů se standardním průběhem kmitočtové charakteristiky je korekce kmitočtové charakteristiky provedena interně a nemusíme se tímto problémem 
zabývat. V tom př́padě výrobce uvádí, že operační zesilovač je stabilní i pro jednotkové zesílení.

\subsubsection{Dynamické vlastnosti operačního zesilovače}

Dynamické vlastnosti se obvykle udávají nikoli pro samotný operační zesilovač, ale pro operační zesilovač doplněný jednoduchou zpětnovazební sítí, s níž tvoří např. neinvertující zesilovač s jednotkovým přenosem, tzv. napět'ový sledovač (viz Obr. 5.11a). Dynamické chování operačních zesilovačů při malých a velkých signálech je odlišné. Zesilovače obecně nereagují na velké signálové změny tak rychle, jak by to odpovídalo charakteristikám zjištěným pro malé signály, protože obvodové kapacitory, zejména parazitní kapacity tranzistorů vlastního operačního zesilovače mohou být nabíjeny jen tak rychle, jak to jejich napájecí obvody dovolí. Tento jev je obvykle charakterizován rychlostí přeběhu $S_{\mathrm{R}}$ (slew rate), vyjádřenou ve $\mathrm{V} / \mu$ s a definovanou jako maximální rychlost změny výstupního napětí, které může zesilovač dosáhnout při velké skokové změně. Někteří výrobci vyjadřují tento jev dobou čela $t_{\mathrm{C}}$ pro jednotkový skok vstupního napětí. Na Obr. $5.11 \mathrm{~b}$ je naznačena přechodová charakteristika napětového sledovače, [3]. Z tohoto obrázku je zřejmá definice doby čela a též je možné určit vzájemnou souvislost mezi rychlostí přeběhu $S_{\mathrm{R}}$ a dobou čela $t_{\mathrm{C}}$

$$
S_{\mathrm{R}} \approx \frac{0,8 U_{\text {omax }}}{t_{\mathrm{C}}}
$$

V tomto vztahu $U_{\text {omax }}$ značí povolené maximální, resp. jmenovité výstupní napětí zesilovače.

Doba ustálení $t_{\mathrm{s}}$ operačního zesilovače zapojeného jako napět'ový sledovač je doba potřebná na ustálení výstupního napětí v předepsaném tolerančním pásmu kolem ustálené hodnoty $U_{\mathrm{o} \max }$ po skokovém vybuzení (viz Obr. 5.11c). Standardní rozmezí tolerančního pásma je $0,01 \%$, nebo $0,1 \%$, zřídka $1 \%$. Poznamenejme ještě, že zákmity a šiř́ka tolerančního pásma na Obr. 5.11 jsou pro názornost nakresleny přehnaně zvětšené. 


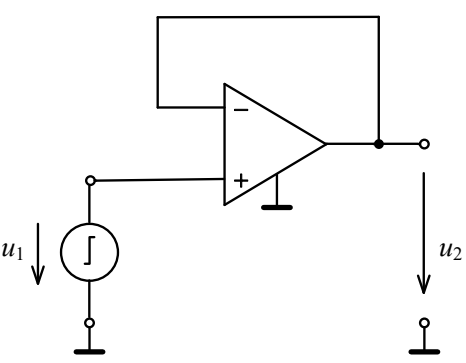

a

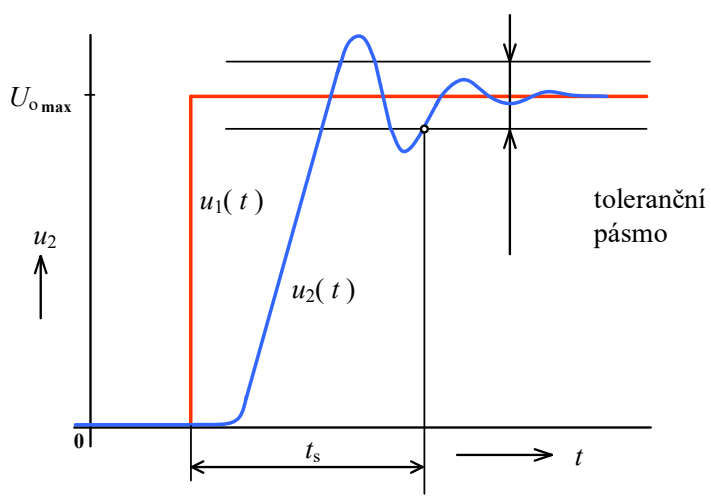

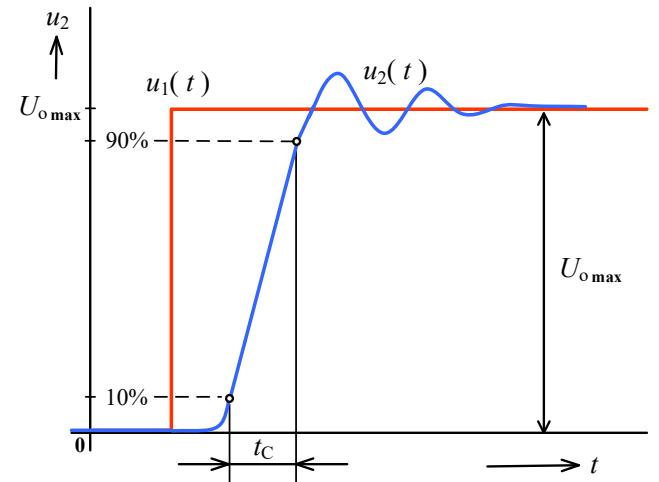

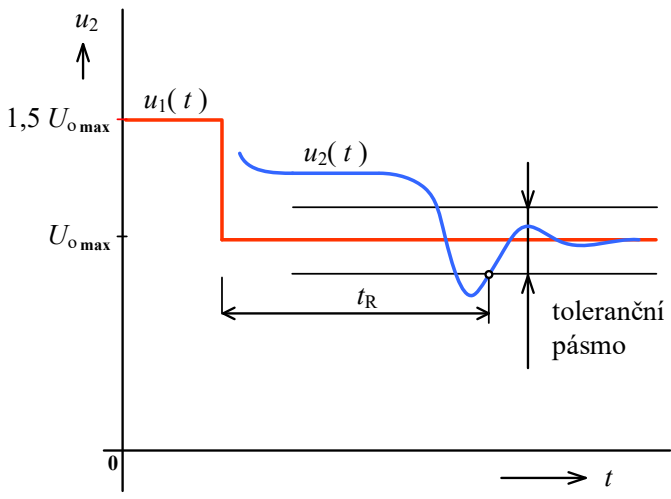

d

Obr. 5.11: a) Operační zesilovač zapojený jako napětový sledovač, b) jeho přechodová charakteristika,

c) doba ustálení, d) doba zotavení

Doba zotaveni $t_{\mathrm{R}}$ operačního zesilovače zapojeného jako napět'ový sledovač je doba potřebná $\mathrm{k}$ ustálení výstupního napětí $\mathrm{v}$ tolerančním pásmu kolem ustálené hodnoty po definovaném $50 \%$ přebuzení napět'ového sledovače vstupním napětím $1,5 U_{\mathrm{o} \text { max }}$ a následujícím přechodu do normálního režimu s výstupním napětím $U_{\mathrm{o} \text { max }}$ (viz Obr. 5.11d). Doba zotavení může být i několikanásobně delší, než doba ustálení. Za provoz by proto nikdy nemělo dojít k přebuzení operačního zesilovače.

\section{Mezní výkonový kmitočet}

Neschopnost výstupního napětí zesilovače reagovat rychleji než konečnou rychlostí může vést ke zkreslení harmonického signálu, jehož kmitočet je v propustném pásmu zesilovače. Všechny zesilované signály, které by měly mít na výstupu operačního zesilovače některé části průběhu strmější, než odpovídá rychlosti přeběhu, budou totiž nutně zkresleny. Při zesilování harmonického signálu nízkých kmitočtů můžeme plně využívat dovoleného rozkmitu výstupního napětí a pracovat s amplitudou $U_{\mathrm{o} \text { max }} 12 \mathrm{~V}$ až $13 \mathrm{~V}$ (při napájecím napětí $\pm 15 \mathrm{~V}$ ). Při zvyšování kmitočtu však musíme dbát na to, aby výstupní harmonický signál neměl absolutní strmost větší než $S_{\mathrm{R}}$. U harmonického signálu $u_{\mathrm{o}}(t)=U_{\mathrm{o}} \sin 2 \pi f t$ je jeho okamžitá strmost dána derivací 


$$
\frac{\mathrm{d} u_{\mathrm{o}}(t)}{\mathrm{d} t}=2 \pi f U_{\mathrm{o}} \cos 2 \pi f t .
$$

Největší strmost harmonického signálu je při průchodu nulou

$$
\frac{\mathrm{d} u_{\mathrm{o}}(0)}{\mathrm{dt}}=2 \pi f U_{\mathrm{o}} .
$$

Pokud bude $S_{\mathrm{R}} \geqq 2 \pi f U_{\mathrm{o}}$, rychlost přeběhu se neuplatní, [4]. Překročíme-li tento kmitočet, dostaneme situaci nakreslenou na Obr. 5.12a. Jestliže si dáme požadavek, aby se chyba vlivem rychlosti přeběhu neuplatnila, musíme od určitého kmitočtu zmenšovat amplitudu výstupního napětí $U_{\mathrm{o}}$ (resp. jí odpovídající amplitudu vstupního napětí). Kmitočet, do kterého můžeme pracovat s plnými rozkmitem výstupního napětí určíme z povoleného maximálního výstupního napětí $U_{\mathrm{o} \text { max }}$

$$
f_{\mathrm{P}}=\frac{S_{\mathrm{R}}}{2 \pi U_{\text {omax }}} .
$$

V katalogových listech je tento údaj uváděn pod názvem výkonový kmitočet $f_{\mathrm{P}}$, protože představuje mezní kmitočet, do kterého je možný plný rozkmit výstupního napětí operačního zesilovače. Nad tímto kmitočtem je nutno zmenšit amplitudu výstupního harmonického napětí nepř́mo úměrně pracovnímu kmitočtu $f$ podle vztahu $U_{\mathrm{o}}=S_{\mathrm{R}} / 2 \pi f$ (viz Obr. $5.12 \mathrm{~b}$ ).

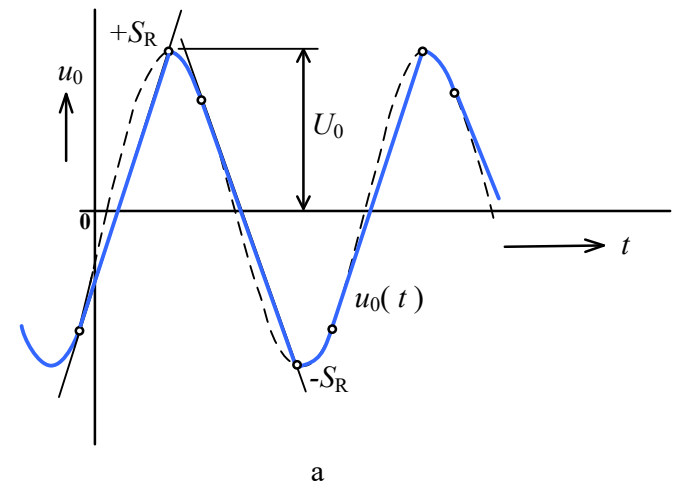

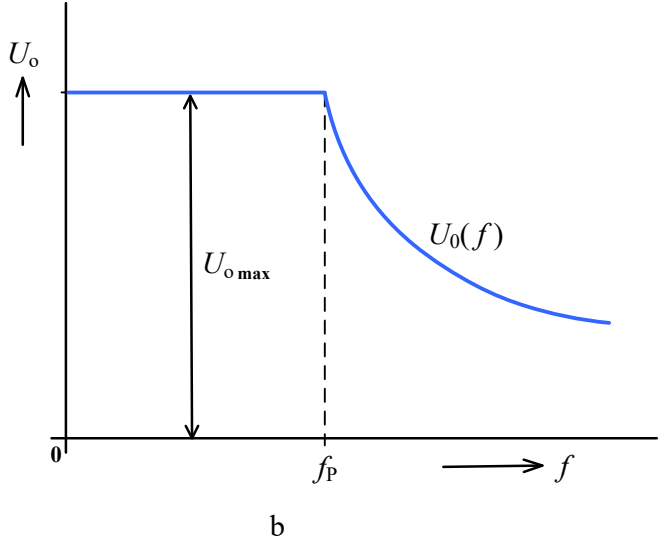

$\mathrm{b}$

Obr. 5.12: a) Zkreslení výstupního napětí vlivem konečné rychlosti, b) závislost maximálního povoleného výstupního napětí na kmitočtu

\subsection{Vliv reálných parametrů operačního zesilovače na základní zapojení}

Význam parametrů operačního zesilovače spočívá $\mathrm{v}$ tom, že nám v podstatě určuje dosažitelnou přesnost zpětnovazebních obvodů s operačním zesilovačem. V předchozím jsme odvodili výrazy pro dvě základní uspořádání operační zpětné vazby při použití ideálního operačního zesilovače, tj. pro invertující a neinvertující zapojení zesilovače. S těmito výrazy budeme porovnávat vlastnosti zapojení při uvažování jednotlivých parametrů operačního zesilovače. Většinou budeme analyzovat invertující zapojení operačního zesilovače, ale v př́ípadě odlišných výsledků i zapojení neinvertující. Na základě uvedených výsledků pak můžeme poznatky aplikovat i na další zpětnovazební zapojení operačního zesilovače. 


\subsubsection{Vliv konečného zesílení a jeho závislosti na kmitočtu}

\section{Vliv konečného zesílení}

Prozkoumáme nejprve vliv konečného zesílení operačního zesilovače $A$ na invertující zapojení, přičemž budeme uvažovat, že všechny ostatní vlastnosti zesilovače jsou ideální, tj. zesilovač má nekonečnou šířku kmitočtového pásma, nekonečný vstupní a nulový výstupní odpor apod., [4]. Při uvažování konečného zesílení již nebude vstupní napětí operačního zesilovače nulové a mezi diferenčními svorkami zesilovače bude malé napětí $u_{\mathrm{i}}$ (viz Obr. 5.13). Toto napětí si můžeme představit jako vstupní chybové napětí reprezentující chybu způsobenou vlivem nedokonalosti zesilovače.

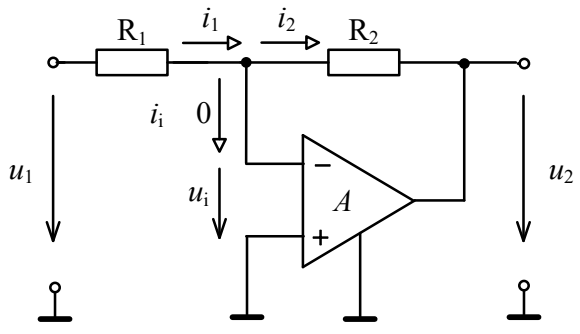

Obr. 5.13: Invertující zapojení operačního zesilovače při uvažování konečného zesílení

Uvažujeme-li nekonečný vstupní odpor operačního zesilovače, bude $i_{1} \approx i_{2}$, tj.

$$
\frac{u_{1}-u_{\mathrm{i}}}{R_{1}} \approx \frac{u_{\mathrm{i}}-u_{2}}{R_{2}} \text {. }
$$

Dosadíme-li za $u_{\mathrm{i}}=-u_{2} / A$ (operační zesilovač vstupní napětí $u_{\mathrm{i}}$ invertuje) dostaneme po úpravě

$$
A_{\mathrm{U}}=\frac{u_{2}}{u_{1}} \approx-\frac{R_{2}}{R_{1}} \frac{1}{1+\frac{R_{1}+R_{2}}{R_{1}} \frac{1}{A}}=-\frac{R_{2}}{R_{1}} \frac{1}{1+\frac{1}{\beta A}} .
$$

Přitom jsme, stejně jako před tím, označili zpětnovazební činitel $\beta=R_{1} /\left(R_{1}+R_{2}\right)$, který definuje jaká část výstupního napětí se dostane na vstup operačního zesilovače při rozpojení zpětnovazební smyčky. Pokud bude zesílení invertujícího zesilovače požadováno jednotkové, tj. $R_{1}=R_{2}$ a zesílení operačního zesilovače $A=200000$, bude $A_{\mathrm{U}}=0,99999$. Chyba bude vzhledem k tolerancím odporů rezistorů $\mathrm{R}_{1}$ a $\mathrm{R}_{2}$ zanedbatelná. Aby bylo zesílení zesilovače určeno pouze zpětnovazebními prvky, je tedy nutno vybrat operační zesilovač s velkým ss zesílením bez zpětné vazby. Poznamenejme však, že zesílení operačního zesilovače $\mathrm{s}$ kmitočtem rychle klesá a výsledky na vyšších kmitočtech nebudou již tak příznivé.

Skutečná důležitost zesílení rozpojené smyčky zpětné vazby spočívá v jeho účinku na jiné vlastnosti zesilovače při zavedení zpětné vazby, jako např. na stabilitu zesilovače se zpětnou vazbou, výstupní odpor se zpětnou vazbou, šířku pásma při uzavřené smyčce zpětné vazby atd. Bude o nich řeč později.

\section{Vliv omezené šǐrky kmitočtového pásma}

Kmitočtová závislost zesílení operačního zesilovače bez zpětné vazby má samozřejmě vliv na kmitočtovou charakteristiku zpětnovazebních obvodů s operačním zesilovačem. Jak už bylo řečeno, musíme $\mathrm{z}$ obecného hlediska uvažovat komplexní zesílení operačního zesilovače $\bar{A}=A \mathrm{e}^{\mathrm{j} \varphi}$ a při rozboru invertujícího zapojení pracovat s komplexními veličinami 
(viz Obr. 5.14) Zde $\bar{U}_{1}$ značí komplexní amplitudu vstupního napětí, $\bar{U}_{2}$ komplexní amplitudu výstupního napětí a $\bar{A}=\bar{U}_{2} / \bar{U}_{\mathrm{i}}$ komplexní zesílení operačního zesilovače bez zpětné vazby. Zde podotýkáme, že argument komplexního zesílení $\bar{A}$ v sobě zahrnuje invertující charakter operačního zesilovače, [5].

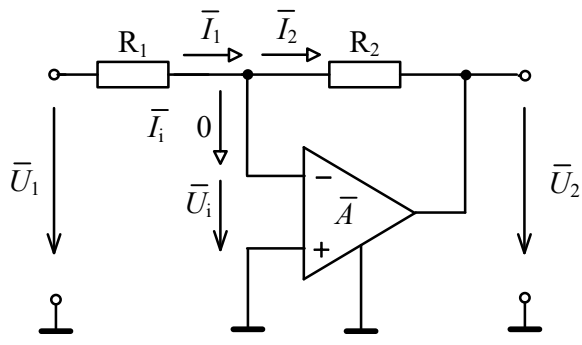

Obr. 5.14: Invertující zapojení při uvažování komplexních veličin

Pro proudy v obvodu i zde platí $\bar{I}_{1} \approx \bar{I}_{2}$ a tedy

$$
\frac{\bar{U}_{1}-\bar{U}_{\mathrm{i}}}{R_{1}} \approx \frac{\bar{U}_{\mathrm{i}}-\bar{U}_{2}}{R_{2}} \text {. }
$$

Po dosazení za $\bar{U}_{\mathrm{i}}=\bar{U}_{2} / \bar{A}$ bude komplexní zesílení invertujícího zesilovače

$$
\bar{A}_{\mathrm{U}} \approx-\frac{R_{2}}{R_{1}} \frac{1}{1-\left(1+\frac{R_{2}}{R_{1}}\right) \frac{1}{\bar{A}}}=-\frac{R_{2}}{R_{1}} \frac{1}{1-\frac{1}{\beta \bar{A}}} .
$$

Vyšetříme nyní jakou kmitočtovou charakteristiku bude mít invertujcí zesilovač, použijeme-li k jeho stavbě operační zesilovač se standardní kmitočtovou charakteristikou. K tomu dosadíme za $\bar{A}=\bar{A}(f)$ z rov. (5-9) do rov. (5-20) a dostaneme

$$
\bar{A}_{\mathrm{U}}(f) \approx-\frac{R_{2}}{R_{1}} \frac{1}{1+\frac{1+\mathrm{j} f / f_{\mathrm{o}}}{\beta A_{\mathrm{o}}}}=-\frac{R_{2}}{R_{1}} \frac{1}{1+\frac{1}{\beta A_{\mathrm{o}}}+\mathrm{j} \frac{f}{\beta A_{\mathrm{o}} f_{\mathrm{o}}}} .
$$

Pokud bude $\beta A_{\mathrm{o}} \gg 1$, lze vztah zjednodušit

$$
\bar{A}(f) \approx-\frac{R_{2}}{R_{1}} \frac{1}{1+\mathrm{j} \frac{f}{\beta A_{\mathrm{o}} f_{\mathrm{o}}}} .
$$

Reálná a imaginární část jmenovatele zlomku se sobě rovnají při kmitočtu

$$
f_{\mathrm{o}}^{\prime} \approx \beta A_{\mathrm{o}} f_{\mathrm{o}} .
$$

Vztah (5-22) pro komplexní zesílení pak můžeme zapsat ve tvaru

$$
\bar{A}_{\mathrm{U}}(f) \approx-\frac{R_{2}}{R_{1}} \frac{1}{1+\mathrm{j} f / f_{\mathrm{o}}^{\prime}} .
$$

Tomu odpovídá modulová charakteristika 


$$
A_{\mathrm{U}}(f) \approx \frac{R_{2}}{R_{1}} \frac{1}{\sqrt{1+\left(f / f_{\mathrm{o}}^{\prime}\right)^{2}}}, \text { resp. } z_{\mathrm{U}}(f) \approx 20 \log \left(\frac{R_{2}}{R_{1}} \frac{1}{\sqrt{1+\left(f / f_{\mathrm{o}}^{\prime}\right)^{2}}}\right) .
$$

Při kmitočtu $f_{\mathrm{o}}^{\prime}$ bude mít modulová charakteristika hodnotu $A_{\mathrm{U}}\left(f_{\mathrm{o}}^{\prime}\right)=R_{2} / \sqrt{2} R_{1}$, resp. zisk $z_{\mathrm{U}}\left(f_{\mathrm{o}}^{\prime}\right)$ při tomto kmitočtu poklesne o $3 \mathrm{~dB}$. Př́slušná fázová charakteristika je popsána rovnicí

$$
\varphi_{\mathrm{U}}(f)=-180^{\circ}-\operatorname{arctg}\left(f / f_{\mathrm{o}}^{\prime}\right)
$$

kde fázové posunutí $-180^{\circ}$ odpovídá invertujícímu charakteru zesílení.

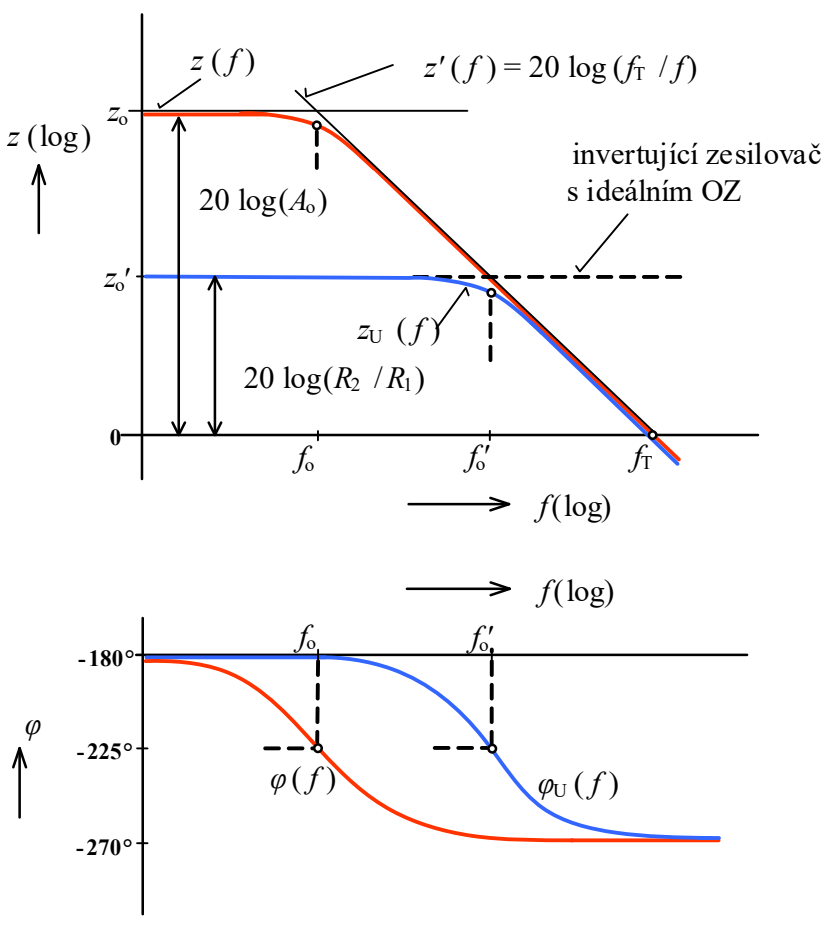

Obr. 5.15: Charakteristiky invertujícího zesilovače v Bodeho diagramu

Kmitočtová charakteristika invertující zesilovače je zakreslena do Bodeho diagramu na Obr. 5.15. Je vidět, že invertující zesilovač bude mít opět standardní průběh kmitočtové charakteristiky, avšak s vyšším mezním kmitočtem $f_{\mathrm{o}}{ }^{\prime}=\beta A_{\mathrm{o}} f_{\mathrm{o}}=\beta f_{\mathrm{T}}$. V diagramu je zakreslena charakteristika $z(f)=20 \log A(f)$ operačního zesilovače bez zpětné vazby. Modulová charakteristika invertujícího zesilovače s ideálním zesilovačem je nakreslena čárkovanou př́mkou, rovnoběžnou s osou kmitočtu, a to ve vzdálenosti $z_{\mathrm{o}}^{\prime}=20 \log \left(R_{2} / R_{1}\right)$ od ní. Tato přímka protíná charakteristiku $z(f)$ při kmitočtu $f_{\mathrm{o}}^{\prime}$, který je mezním kmitočtem invertujícího zesilovače $\mathrm{v}$ prŕpadě, že je pro jeho stavbu použito reálného operačního zesilovače $\mathrm{s}$ charakteristikou $z(f)$. Invertující zesilovač má pak kmitočtovou charakteristiku $z_{\mathrm{U}}(f)$, která v oblasti $f \ll f_{\mathrm{o}}^{\prime}$ prakticky vzato splývá s charakteristikou zesilovače s ideálním operačním zesilovačem. Při kmitočtu $f_{\mathrm{o}}^{\prime} \approx \beta f_{\mathrm{T}}$ vykazuje charakteristika $z_{\mathrm{U}}(f)$ pokles o $3 \mathrm{~dB}$, při vyšších kmitočtech se pak přimyká $\mathrm{k}$ charakteristice $z(f)$ samotného operačního zesilovače a při 
$f \gg f_{\mathrm{o}}^{\prime} \quad$ má strmost $-20 \mathrm{~dB} / \mathrm{dek}$. Také argumentová charakteristika $\varphi_{\mathrm{U}}(f)$ je posunuta vůči charakteristice $\varphi(f)$ směrem k vyšším kmitočtům podél osy kmitočtu.

\subsubsection{Vliv konečného vstupního odporu}

Prozkoumáme vliv vstupního diferenčního odporu $r_{\mathrm{i}}$ na základní zapojení. Vliv souhlasných vstupních odporů $r_{\mathrm{CM}}$ nebudeme uvažovat, protože tyto odpory jsou obvykle o několik řádů větší než diferenční vstupní odpor a př́iliš se proto neuplatní. Náhradní schémata dvou základních zapojení operačního zesilovače při uvažování diferenčního vstupního odporu jsou uvedena na Obr. 5.16. Máme-li dostat reálné výsledky, musíme zahrnout do počtu i konečné zesílení operačního zesilovače $A$. Pokud bychom totiž uvažovali, že operační zesilovač má nekonečné zesílení, vliv diferenčního odporu by se neprojevil.

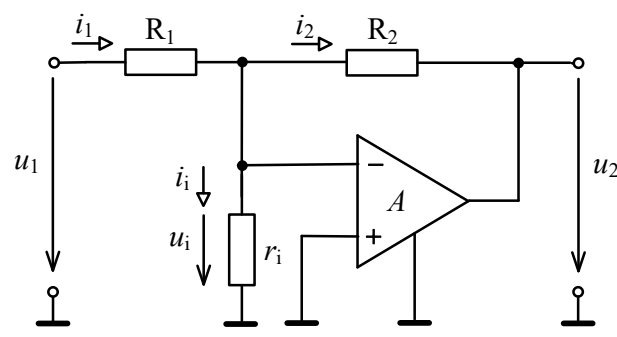

a

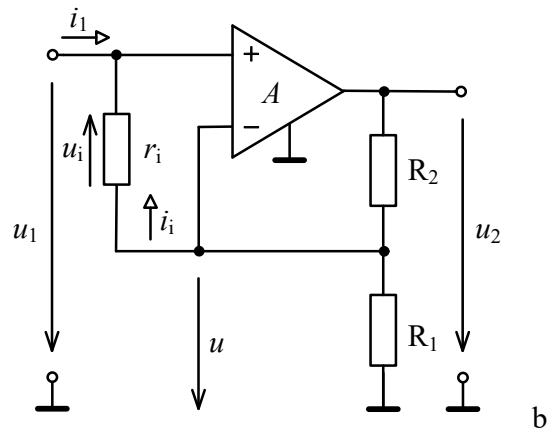

Obr. 5.16: Invertující a neinvertující zesilovač při uvažování diferenčního vstupního odporu

Vliv vstupního odporu na zesílení zesilovače

Pro proudy invertujícího zapojení (Obr. 5.16a) můžeme psát $i_{1}=i_{1}+i_{2}$, tzn.

$$
\frac{u_{1}-u_{\mathrm{i}}}{R_{1}}=\frac{u_{\mathrm{i}}}{r_{\mathrm{i}}}+\frac{u_{\mathrm{i}}-u_{2}}{R_{2}} .
$$

Dosadíme-li za $u_{\mathrm{i}}=-u_{2} / A$, pak můžeme po úpravách stanovit výstupní napětí

$$
u_{2}=-\frac{R_{2}}{R_{1}} \frac{1}{1+\frac{1}{\beta A}+\frac{R_{2}}{A r_{\mathrm{i}}}} u_{1} \text {. }
$$

Obdobný vztah můžeme odvodit i pro neinvertující zapojení na Obr. 5.16b.

Porovnáme-li tento výsledek se vztahem (5-18) odvozeným za předpokladu konečného zesílení, vidíme, že je vhodné volit odpor zpětnovazebního rezistoru $R_{2} \ll A r_{\mathrm{i}}$. Pak je totiž možno vliv konečného vstupního odporu operačního zesilovače zanedbat vůči chybě způsobené konečným zesílením. Stejné závěry platí i pro neinvertující zesilovač.

\section{Vstupní odpor invertující zesilovače}

Vstupní odpor invertující zesilovače je v modelu podle Obr. 5.16a dán vztahem 


$$
R_{\mathrm{vst}}=\frac{u_{1}}{i_{1}}=\frac{i_{1} R_{1}+u_{\mathrm{i}}}{i_{1}}=R_{1}+\frac{u_{\mathrm{i}}}{i_{1}}
$$

Pro proudy tekoucí v obvodu podle Kirchhofova zákona platí

$$
i_{1}=i_{2}+i_{\mathrm{i}}=\frac{u_{\mathrm{i}}-u_{2}}{R_{2}}+\frac{u_{\mathrm{i}}}{r_{\mathrm{i}}}
$$

Dosadíme-li za $u_{2}=-A u_{\mathrm{i}}$, dostaneme

$$
i_{1}=\frac{u_{\mathrm{i}}+A u_{\mathrm{i}}}{R_{2}}+\frac{u_{\mathrm{i}}}{r_{\mathrm{i}}}=\left(\frac{1+A}{R_{2}}+\frac{1}{r_{\mathrm{i}}}\right) u_{\mathrm{i}} .
$$

Po dosazení za $i_{1}$ do rov. (5-29) bude

$$
R_{\mathrm{vst}}=R_{1}+\frac{1}{\frac{1+A}{R_{2}}+\frac{1}{r_{\mathrm{i}}}} .
$$

Pokud bude $A \gg 1$, můžeme ve vztahu zanedbat 1 vůči $A$ a potom

$$
R_{\mathrm{vst}} \approx R_{1}+\frac{1}{\frac{A}{R_{2}}+\frac{1}{r_{\mathrm{i}}}}=R_{1}+\frac{\frac{1}{A}}{\frac{1}{R_{2}}+\frac{1}{A r_{\mathrm{i}}}} .
$$

Hodnota zlomku $1 / A r_{\mathrm{i}} \ll 1 / R_{2}$ a proto lze přibližně pro vstupní odpor psát

$$
R_{\mathrm{vst}} \approx R_{1}+\frac{R_{2}}{A}
$$

Z výsledků je zřejmé, že vstupní diferenční odpor operačního zesilovače ovlivní vstupní odpor invertujícího zesilovače jen zanedbatelně, dominantní vliv na jeho hodnotu má především zesílení operačního zesilovače bez zpětné vazby. Použijeme-li operační zesilovač s dostatečně velkým zesílením, bude vstupní odpor invertujícího zesilovače $R_{\mathrm{vst}} \approx R_{1}$.

\section{Vstupní odpor neinvertujicího zesilovače}

Vstupní odpor neinvertujícího zesilovače odvodíme s využitím modelu na Obr. 5.16b. Abychom získali reálné výsledky uvažujeme i zde nejen vstupní diferenční odpor $r_{\mathrm{i}}$, ale i konečné zesílení $A$ a proto $u_{2}=-A u_{\mathrm{i}}$. Nejprve určíme výstupní napětí u zpětnovazebního děliče $R_{2}$ a $R_{1}$, dělič řššíme jako nezatížený

$$
u \approx \frac{R_{1}}{R_{1}+R_{2}} u_{2}=-\frac{R_{1}}{R_{1}+R_{2}} A u_{\mathrm{i}} .
$$

Pro napětí v obvodu pak platí

$$
u_{1}=u-u_{\mathrm{i}}=-\left(\frac{R_{1}}{R_{1}+R_{2}} A+1\right) u_{\mathrm{i}} \approx-\frac{R_{1}}{R_{1}+R_{2}} A u_{\mathrm{i}}
$$

a dále 


$$
i_{1}=-i_{\mathrm{i}}=\frac{u_{\mathrm{i}}}{r_{\mathrm{i}}}
$$

Z rovnic (5-36) a (5-37) již můžeme stanovit vstupní odpor neinvetujícího zesilovače

$$
R_{\mathrm{vst}}=\frac{u_{1}}{i_{1}} \approx \frac{-\frac{R_{1}}{R_{1}+R_{2}} A u_{\mathrm{i}}}{-\frac{u_{\mathrm{i}}}{r_{\mathrm{i}}}}=\frac{R_{1}}{R_{1}+R_{2}} A r_{\mathrm{i}}=\beta A r_{\mathrm{i}} .
$$

Z výsledku je zrejmé, že na vysokém vstupním odporu neinvertujícho zesilovače se podílí hodnota zesílení a hodnota vstupního odporu operačního zesilovače stejnou měrou a že tvrzení o téměř nekonečném vstupním odporu neinvertujícho zesilovače je pravdivé.

\subsubsection{Vliv nenulového výstupního odporu}

Vliv výstupního odporu na zesílení invertujícího zesilovače

Abychom získali reálné výsledky, musíme uvažovat nejen dynamický výstupní odpor operačního zesilovače $r_{0}$, ale i jeho konečné zesílení $A$. V tomto př́padě předpokládáme, že diferenční vstupní odpor je nekonečný a v důsledku toho bude vstupní proud operačního zesilovače $i_{\mathrm{i}} \approx 0$. Tyto předpoklady jsou respektovány ve schématu invertujícího zesilovače na Obr. 5.17.

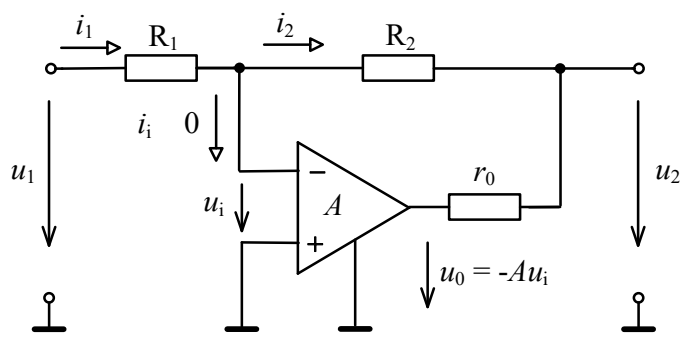

Obr. 5.17: K určení vlivu výstupního odporu na zesílení invertujícího zapojení

Nejprve stanovíme diferenční vstupní napětí operačního zesilovače a to z rovnosti proudů tekoucích rezistory $R_{2}$ a $r_{0}$

$$
\frac{u_{2}-u_{0}}{r_{0}}=\frac{u_{\mathrm{i}}-u_{2}}{R_{2}}
$$

Po dosazení $u_{0}=-A u_{\mathrm{i}}$ lze vyčíslit diferenční vstupní napětí

$$
u_{\mathrm{i}}=\frac{r_{\mathrm{o}}+R_{2}}{r_{\mathrm{o}}-A R_{2}} u_{2}
$$

$\mathrm{Z}$ přibližné rovnosti vstupního a zpětnovazebního proudu $i_{1} \approx i_{2}, \mathrm{tj}$.

$$
\frac{u_{1}-u_{\mathrm{i}}}{R_{1}} \approx \frac{u_{\mathrm{i}}-u_{2}}{R_{2}}
$$

určíme výstupní napětí 


$$
u_{2} \approx-\frac{R_{2}}{R_{1}} u_{1}+\frac{R_{1}+R_{2}}{R_{1}} u_{\mathrm{i}}=-\frac{R_{2}}{R_{1}} u_{1}+\frac{u_{\mathrm{i}}}{\beta}
$$

a po dosazení za $u_{\mathrm{i}} \mathrm{z}$ rov. (5-40) dostaneme

$$
u_{2} \approx-\frac{R_{2}}{R_{1}} \frac{1}{1+\frac{1}{\beta A} \frac{R_{2}+r_{\mathrm{o}}}{R_{2}-r_{\mathrm{o}} / A}} u_{1} \approx-\frac{R_{2}}{R_{1}} \frac{1}{1+\frac{1}{\beta A}\left(1+\frac{r_{\mathrm{o}}}{R_{2}}\right)} u_{1} .
$$

Srovnáme-li výsledek se vztahem (5-18), který byl odvozen při uvažování konečného zesílení, vidíme, že musíme volit $R_{2} \gg r_{0}$. Vliv konečného výstupního odporu se pak téměř neuplatní a chyba závisí pouze na konečném zesílení operačního zesilovače. Obdobný poznatek můžeme získat rozborem neinvertujícího zesilovače.

Z předchozích analýz vyplývá, že odpor zpětnovazebního rezistoru $R_{2}$ musí, jak v prrípadě invertujícího, tak i neinvertujícího zapojení operačního zesilovače vyhovovat podmínce

$$
A r_{\mathrm{i}} \gg R_{2} \gg r_{\mathrm{o}} \text {. }
$$

Jako nejvhodnější se ukazuje volit odpor zpětnovazebního rezistoru z oblasti $5 \mathrm{k} \Omega$ až $100 \mathrm{k} \Omega$. Kvalitní rezistory těchto hodnot odporu mají malé parazitní kapacity, které dávají i při započtení ostatních kapacit v obvodu přiměřeně malé časové konstanty. Ve většině aplikací se použivají SMD rezistory s kovovou vrstvou a malým teplotním součinitelem odporu.

\section{Výstupní odpor invertujícího zesilovače}

Způsob určení výstupního resp. vnitřního odporu ukážeme na elementárním případě libovolného lineárního obvodu nakresleného na Obr. 5.18a. Nejprve určíme výstupní napětí obvodu naprázdno. Protože rezistorem $R_{\mathrm{o}}$ neteče $\mathrm{v}$ tomto př́padě žádný proud a nevznikne na něm proto úbytek napětí, bude výstupní napětí naprázdno $u_{20}=u_{0}$. Pak určíme proud při výstupu nakrátko (viz Obr. 5.18b). V tomto př́ípadě bude na rezistoru $\mathrm{R}_{\mathrm{o}}$ napětí $u_{\mathrm{o}}$ a proud $i_{2 \mathrm{~K}}=u_{\mathrm{o}} / R_{\mathrm{o}}$. Výstupní odpor takového obvodu potom $R_{\text {výst }}=u_{20} / i_{\text {ZK }}=u_{\mathrm{o}} / u_{\mathrm{o}} / R_{\mathrm{o}}=R_{\mathrm{o}}$.

Pro potřebu určení výstupního odporu invertujícího zapojení jsou tyto dva stavy obvodu vyznačeny na Obr. 5.18.c,d. Jestliže bude výstup obvodu naprázdno (viz Obr. 5.18c), můžeme využít výsledek (5-43), který pro $r_{\mathrm{o}} \ll R_{2}$ ještě zjednodušíme

$$
u_{20} \approx-\frac{R_{2}}{R_{1}} \frac{1}{1+\frac{1}{\beta A}} u_{1} \text {. }
$$

Pokud bude výstup invertujícího zesilovače nakrátko (viz Obr. 5.18d), bude proud nakrátko mít velikost

$$
i_{2 \mathrm{~K}}=i_{2}+i_{0}=\frac{u_{\mathrm{i}}}{R_{2}}+\frac{u_{\mathrm{o}}}{r_{\mathrm{o}}} .
$$

Protože $u_{\mathrm{o}}=-u_{\mathrm{i}} A$, bude

$$
i_{2 \mathrm{~K}}=\frac{u_{\mathrm{i}}}{R_{2}}-\frac{u_{\mathrm{i}} A}{r_{\mathrm{o}}}=\left(\frac{1}{R_{2}}-\frac{A}{r_{\mathrm{o}}}\right) u_{\mathrm{i}} .
$$




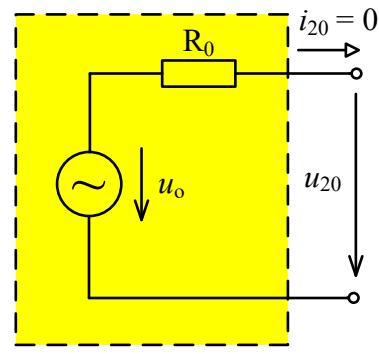

a

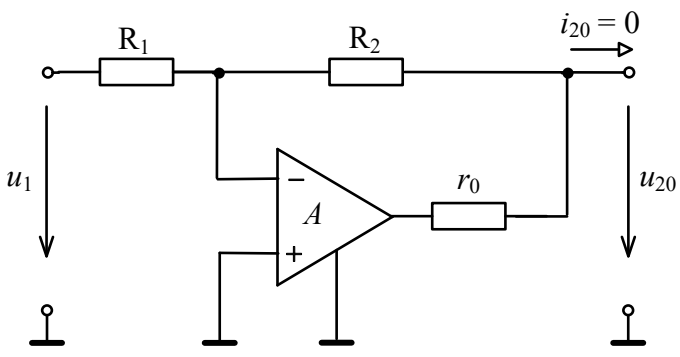

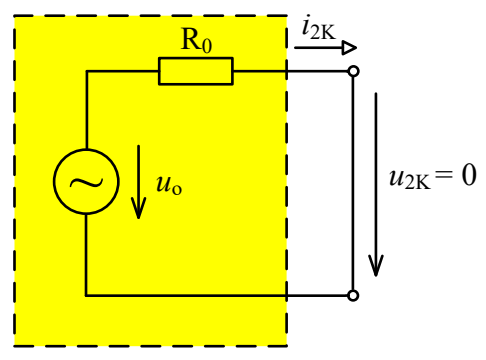

b

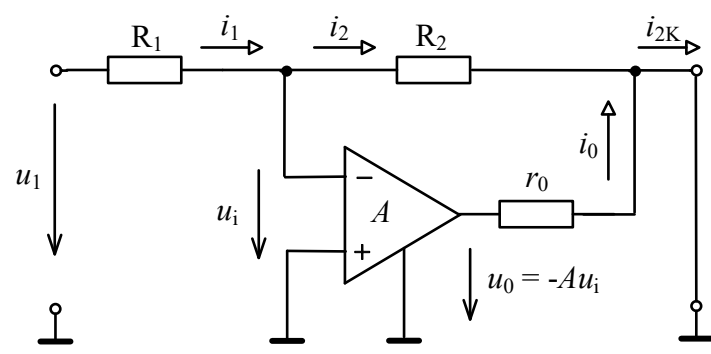

d

Obr. 5.18: K určení výstupního odporu: a) c) napětí naprázdno, b) d) proud nakrátko

Předpokládáme-li opět $A$ velké a $R_{2} \gg r_{0}$, bude přibližně

$$
i_{2 \mathrm{~K}} \approx-\frac{A}{r_{\mathrm{o}}} u_{\mathrm{i}} .
$$

Napětí na diferenčním vstupu operačního zesilovače určíme z rovnosti $i_{1}=i_{2}, \mathrm{tj}$. z rovnosti

$$
\frac{u_{1}-u_{\mathrm{i}}}{R_{1}}=\frac{u_{\mathrm{i}}}{R_{2}}
$$

Odtud vyčíslíme

$$
u_{\mathrm{i}}=\frac{R_{2}}{R_{1}+R_{2}} u_{1}
$$

a dosadíme-li do rov. (5-48), bude proud nakrátko

$$
i_{2 \mathrm{~K}} \approx-\frac{R_{2}}{R_{1}+R_{2}} \frac{A}{r_{\mathrm{o}}} u_{1}=-\frac{R_{2}}{R_{1}} \frac{\beta A}{r_{\mathrm{o}}} u_{1} .
$$

Výstupní odpor invertujícího zapojení potom

$$
R_{\text {výst }}=\frac{u_{20}}{i_{2 \mathrm{~K}}} \approx \frac{\frac{1}{1+\frac{1}{\beta A}}}{\frac{\beta A}{r_{\mathrm{o}}}}=\frac{r_{\mathrm{o}}}{\beta A+1} \approx \frac{r_{\mathrm{o}}}{\beta A} .
$$

Shodný výsledek lze vypočítat i pro neinvertující zapojení. 
Výstupní odpor každého zpětnovazebního zapojení operačního zesilovače se zápornou zpětnou vazbou bude mít proto výstupní odpor řádově desítky $\mathrm{m} \Omega$. S rezervou tedy můžeme tvrdit, že výstupní odpor zesilovače se zápornou zpětnou vazbou $R_{\text {výst }}<1 \Omega$ a zesilovač se bude chovat jako tzv. „tvrdý“ zdroj napětí. Za „tvrdý“ zdroj napětí považujeme přitom takový zdroj, u kterého po připojení zátěže neklesne jeho výstupní napětí v důsledku úbytku napětí na jeho výstupním odporu.

\subsubsection{Vliv klidových vstupních proudů a jejich kompenzace}

\section{Účinky vstupních klidových proudi̊}

Prozkoumáme vliv vstupních klidových proudů na invertující zapojení. V př́padě invertujícího zesilovače se uplatní pouze vstupní klidový proud $I_{\mathrm{IN}}$ tekoucí do invertující vstupní svorky operačního zesilovače (Obr. 5.19a). Tento proud vyvolá na výstupu zapojení při zkratovaných vstupních svorkách chybové napětí

$$
u_{2} \approx I_{\text {IN }} R_{2} .
$$

Odpor rezistoru $\mathrm{R}_{1}$ výsledek neovlivní, protože oba konce tohoto odporu jsou na nulovém potenciálu, jeden na zemním potenciálu a druhý na „virtuální“" nule. Chybové napětí může být tak velké, že ho nejde prostředky běžně užívanými pro nulování napět'ového ofsetu vykompenzovat a je nutno užít jiný způsob kompenzace.
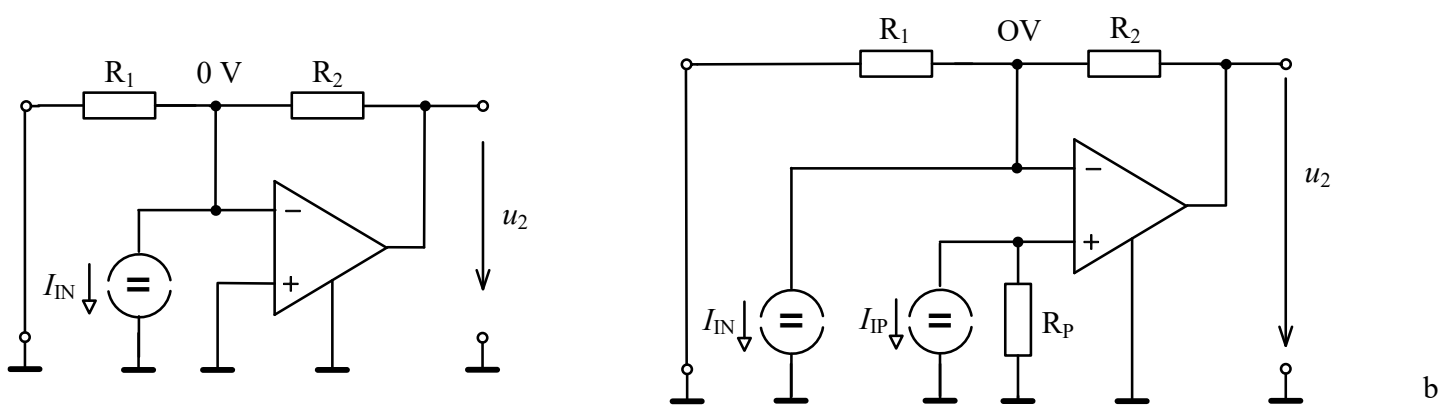

Obr. 5.19: K určení vlivu vstupních klidových proudů

\section{Kompenzace vstupnich klidových proudi̊}

Pro kompenzaci účinku vstupního proudu $I_{\mathrm{IN}}$ je využívá proud $I_{\mathrm{IP}}$ tekoucí do neinvertujícího vstupu operačního zesilovače. Do př́vodu k neinvertujícímu vstupu se vloží rezistor $R_{\mathrm{P}}$ (viz Obr. 5.19b), jehož odpor se navrhne tak, aby se účinky obou vstupních klidových proudů vykompenzovaly. Výstupní napětí modelu invertujícího zapojení na Obr. $5.19 \mathrm{~b}$ vyřešíme napr. metodou superposice

$$
u_{2} \approx I_{\mathrm{IN}} R_{2}-I_{\mathrm{IP}} R_{\mathrm{P}}\left(1+\frac{R_{2}}{R_{1}}\right) .
$$

Aby výstupní napětí obvodu při zkratovaných vstupních svorkách bylo nulové, musí platit 


$$
I_{\mathrm{IP}} R_{\mathrm{P}}\left(1+\frac{R_{2}}{R_{1}}\right)=I_{\mathrm{IN}} R_{2}
$$

resp.

$$
R_{\mathrm{P}}=\frac{I_{\mathrm{IN}}}{I_{\mathrm{IP}}} \frac{R_{1} R_{2}}{R_{1}+R_{2}}
$$

Protože $I_{\mathrm{IN}} \approx I_{\mathrm{IP}}$, bude pro odpor rezistoru $R_{\mathrm{P}}$ platit

$$
R_{\mathrm{P}} \approx \frac{R_{1} R_{2}}{R_{1}+R_{2}}=R_{1} \| R_{2}
$$

Dimenzujeme-li odpor rezistoru $R_{\mathrm{P}}$ takto, bude chybové výstupní napětí invertujícího zesilovače při nulovém vstupním napětí podle rov. (5-54) sníženo na hodnotu

$$
u_{2} \approx\left(I_{\mathrm{IN}}-I_{\mathrm{IP}}\right) R_{2}=I_{\mathrm{IO}} R_{2},
$$

kde $I_{\mathrm{IO}}$ značí hodnotu proudového ofsetu, resp. proudové nesymetrie. Zbytkové chybové napětí $I_{\mathrm{IO}} R_{2}$ se již snadno vykompenzuje prostředky používanými pro nulování napět'ového ofsetu.

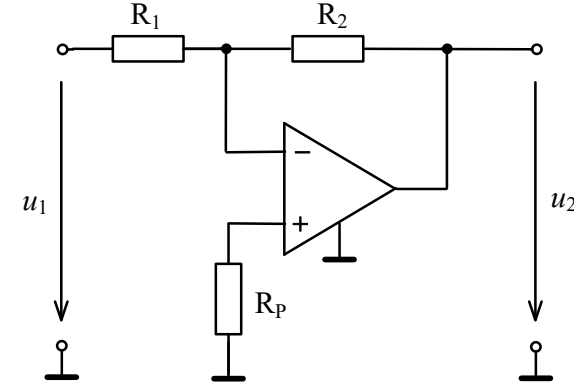

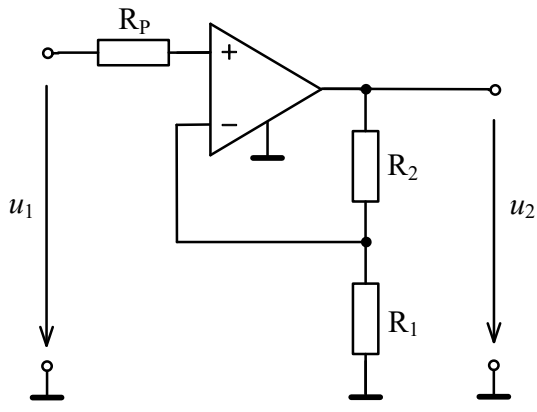

b

Obr. 5.20: Kompenzace vstupních klidových proudů u bipolárních operačních zesilovačů: a) pro invertující zesilovač, b) pro neinvertující zesilovač

Způsob kompenzace vstupních klidových proudů $\mathrm{u}$ invertujícího a neinvertujícího zesilovače je nakreslen na Obr. 5.20. V obou př́ípadech se volí $R_{\mathrm{P}} \approx R_{1} \| R_{2}$. V př́padě neinvertujícího zesilovače se však vychází z předpokladu, že neinvertující zesilovač je buzen z ideálního zdroje napětí. Jestliže tomu tak není, musíme při kompenzaci vstupního klidového proudu brát $\mathrm{v}$ úvahu i vnitřní odpor $R$ tohoto zdroje, protože pak $R_{\mathrm{P}} \approx R_{1} \| R_{2}-R$. Může dokonce nastat př́ípad, že odpor $R_{\mathrm{P}}$ vyjde záporný; stane-li se to, přesuneme rezistor $R_{\mathrm{P}}$ do prŕvodu k invertujícímu vstupu a jeho odpor dimenzujeme tak, aby $R_{\mathrm{P}} \approx R-R_{1} \| R_{2}$.

Kompenzace vstupních klidových proudů se provádí pouze u bipolárních operačních zesilovačů. U operačních zesilovačů s unipolárními tranzistory, kdy proudy do řídicích elektrod jsou zanedbatelné, by takovýto rezistor byl zbytečně drahý a šumící. 


\subsubsection{Vliv napět'ového ofsetu a jeho kompenzace}

\section{Vliv napětového ofsetu}

Účinek napět'ového ofsetu modelujeme tak, že do některého vstupního přívodu ideálního operačního zesilovače vřadíme zdroj napětí $U_{\mathrm{IO}}$. Tato okolnost je respektována v náhradních obvodech základních zapojení na Obr. 5.21. Protože $u_{\mathrm{i}} \approx 0$, můžeme v obou př́padech zdroje $U_{\text {IO }}$ formálně přesunout do přívodu k neinvertujícímu vstupu. Bez buzení (vstupní svorky obvodů zkratovány) dostaneme na výstupu chybové napětí

$$
u_{2} \approx\left(1+\frac{R_{2}}{R_{1}}\right) U_{\mathrm{IO}} .
$$

Při velkých hodnotách poměru odporů $R_{2} / R_{1}$ se může toto chybové napětí pohybovat v oblasti až kolem $1 \mathrm{~V}$. Pak je nutné vliv napět'ového ofsetu vykompenzovat.

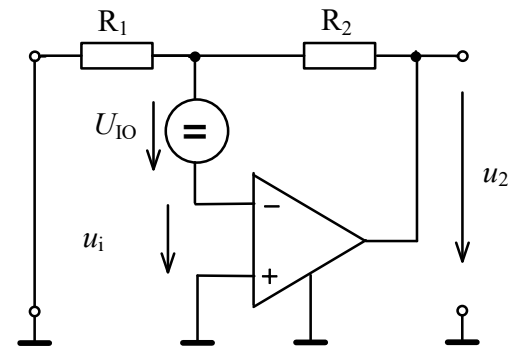

a

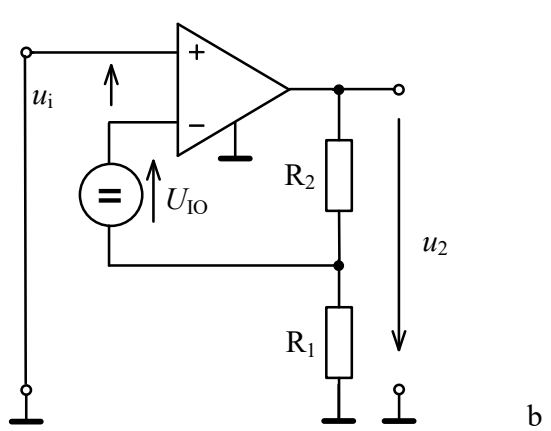

$\mathrm{b}$

Obr. 5.21: K určení vlivu napětového ofsetu na základním zapojení

\section{Kompenzace napětového ofsetu}

Nejjednodušší způsob je vynulovat napět'ový ofset pomocí potenciometrického trimru, který se připojí k pomocným svorkám operačního zesilovače (viz Obr. 5.22). Konkrétní zapojení potenciometrického trimru se řídí doporučením výrobce. U některých typů operačních zesilvoačů se běžec potenciometrického trimtu připojuje na $+U_{\mathrm{N}}$ u jiných na $-U_{\mathrm{N}}(\mathrm{Obr} .5 .22 \mathrm{a}$, b). Je to dáno vnitřní konstrukcí operačního zesilovače. $V$ př́ípadě kompenzace napět'ového ofsetu rozdílového zesilovače s rozdílovým výstupem (Obr. 5.22c) je nutno vývody pro připojení potenciometrického trimru obou operačních zesilovačů propojit do křiže a použít společný potenciometrický trimr.

Protože potenciometrický trimr je připojen v blízkosti vstupních obvodů operačního zesilovače je vynulování ofsetu velmi citlivé na nastavení potenciometrického trimru. Jednootáčkový trimr vyhoví přibližně do hodnoty zpětnovazebního zesílení $A_{\mathrm{U}} \leqq 5$. Pro vyšší zesílení nutno použít potenciometrické trimry víceotáčkové.

Nejlepší, ale samozřejmě nejdražší řešení, je vybrat typ operačního zesilovače, který má nastaven ofset již při výrobě a napětový ofset je tedy tak malý, že jej není nutno nulovat. Při sériové výrobě se ale tímto způsobem ušetrrí značné prostředky na oživení a seřizení přistroje. 


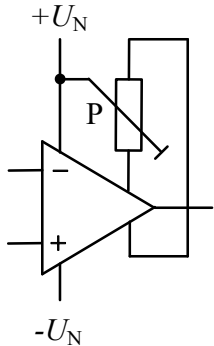

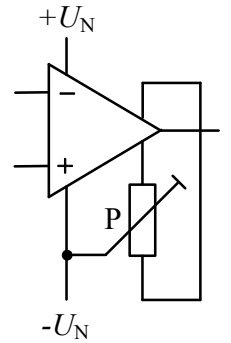

b

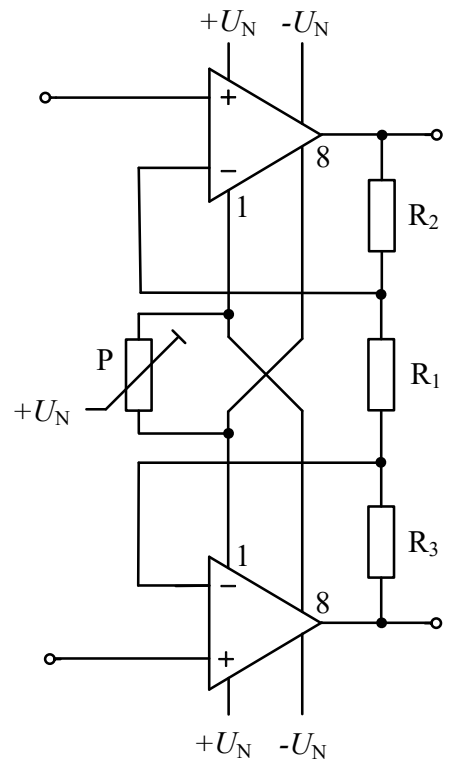

Obr. 5.22: Nulování ofsetu pomocí potenciometrického trimru připojeného k pomocným svorkám

V případech, kdy výrobce operačních zesilovačů nevyvede pomocné svorky a kompenzace napětového ofsetu je potřebná, je nutné využít některý z principů uvedených na Obr. 5.23. V př́ípadě invertujícího zapojení (Obr. 5.23a) bude mít obvod bez buzení na výstupu napětí
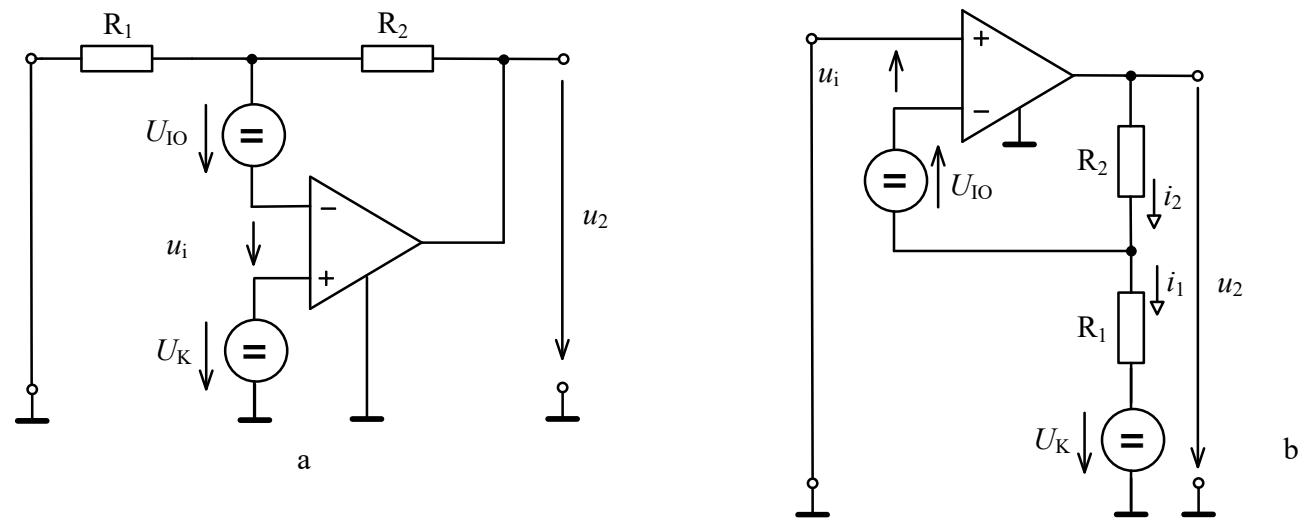

Obr. 5.23: Způsob kompenzace napětového ofsetu u základních zapojení

$$
u_{2} \approx\left(1+\frac{R_{2}}{R_{1}}\right)\left(U_{\mathrm{IO}}+U_{\mathrm{K}}\right) .
$$

Napět'ový ofset bude vykompenzován pro $U_{\mathrm{K}}=-U_{\mathrm{IO}}$.

Podobně můžeme odvodit pro výstupní napětí neinvertujícího zesilovače na Obr. 5.23b

$$
u_{2} \approx\left(1+\frac{R_{2}}{R_{1}}\right) U_{\mathrm{IO}}-\frac{R_{2}}{R_{1}} U_{\mathrm{K}} .
$$

Chybové výstupní napětí způsobené napět’ovým ofsetem bude nulové, když 


$$
U_{\mathrm{K}} \approx\left(1+\frac{R_{1}}{R_{2}}\right) U_{\mathrm{IO}} .
$$

Protože výrobci uvádějí velikost napětového ofsetu ve tvaru $\pm U_{\mathrm{IO}}$, musí být kompenzační napětí regulovatelné v rozmezí $\pm U_{\mathrm{K}}$.

Př́iklady osvědčených řešení vnějších obvodů pro nulování napětového ofsetu jsou uvedeny na Obr. 5.24. Rezistory zakreslené čárkovaně pro kompenzaci vstupních klidových proudů se využívají jen v případě bipolárních operačních zesilovačù.

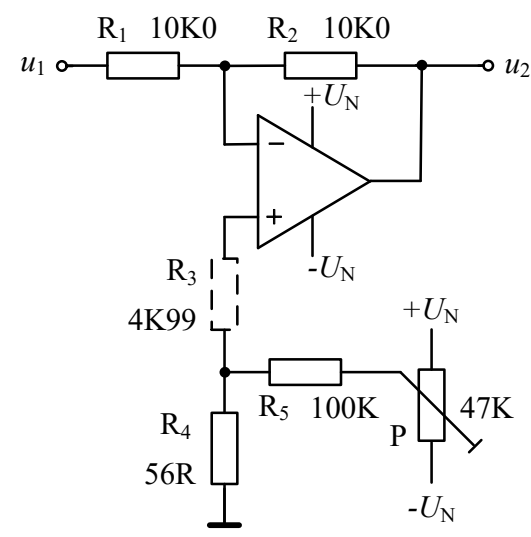

a

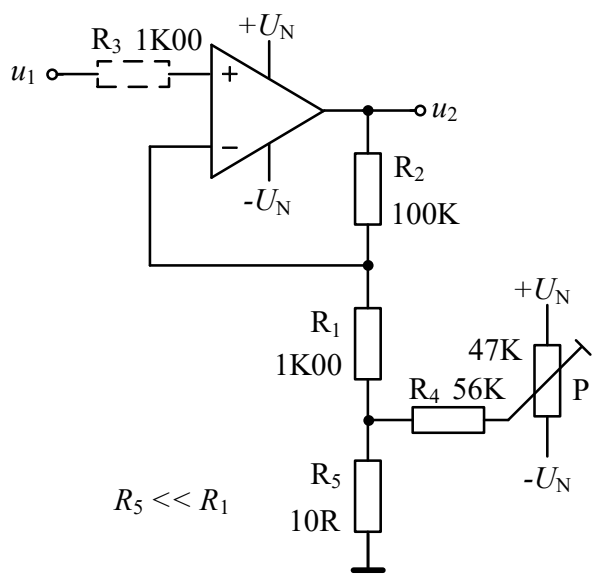

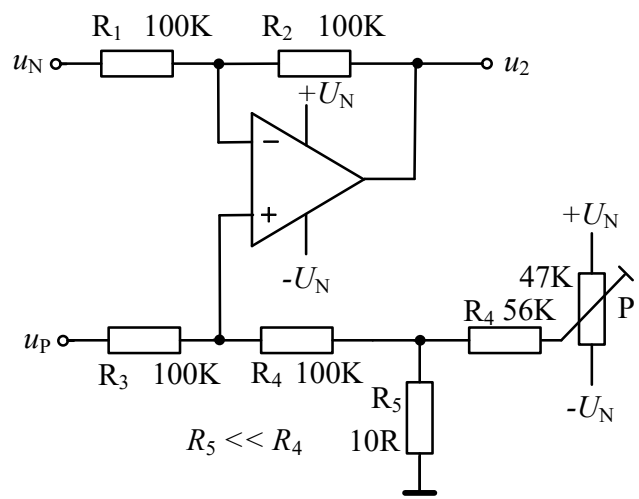

b

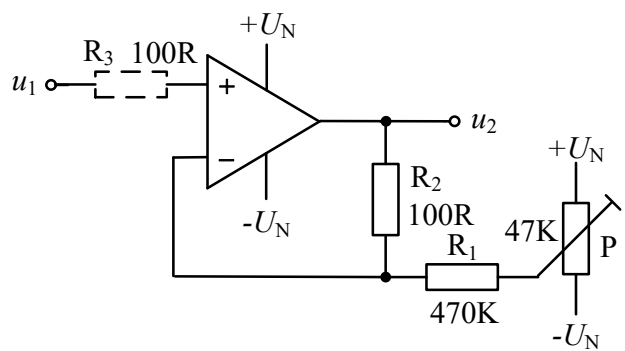

d

Obr. 5.24: Doporučená zapojení pro nulování napět’ového ofsetu: a) invertující zesilovač, b) rozdílový zesilovač, c) neinvertující zesilovač, d) napět’ový sledovač

\subsubsection{Vliv souhlasného napětí na základním zapojení}

$Z$ definice diferenčního zesílení operačního zesilovače $A=-\Delta u_{0} / \Delta u_{\text {i }}$ a souhlasného zesílení $A_{\mathrm{CM}}=\Delta u_{\mathrm{o}} / \Delta u_{\mathrm{CM}}$ vyplývá pro změnu výstupního napětí operačního zesilovače

$$
\Delta u_{\mathrm{o}}=-A \Delta u_{\mathrm{i}}+A_{\mathrm{CM}} \Delta u_{\mathrm{CM}} .
$$

Protože přenosové charakteristiky jsou v pracovní oblasti lineární (viz Obr. 5.1b, Obr. 5.2b), můžeme rov.(5-62) aplikovat i pro velké změny signálu 


$$
u_{\mathrm{o}}=-A u_{\mathrm{i}}+A_{\mathrm{CM}} u_{\mathrm{CM}} \cdot
$$

Souhlasné zesílení zde nahradíme častěji užívaným činitelem potlačení souhlasného napětí $G=$ $A / A_{\mathrm{CM}}$ Pak

$$
u_{\mathrm{o}}=-A u_{\mathrm{i}}+\frac{A}{G} u_{\mathrm{CM}}
$$

Na vstupu operačního zesilovače pak bude napětí

$$
u_{\mathrm{i}}=-\frac{u_{\mathrm{o}}}{A}+\frac{u_{\mathrm{CM}}}{G} .
$$

Tato skutečnost je podchycena v modelu invertujícího i neinvertujícího zesilovače na Obr. 5.25.
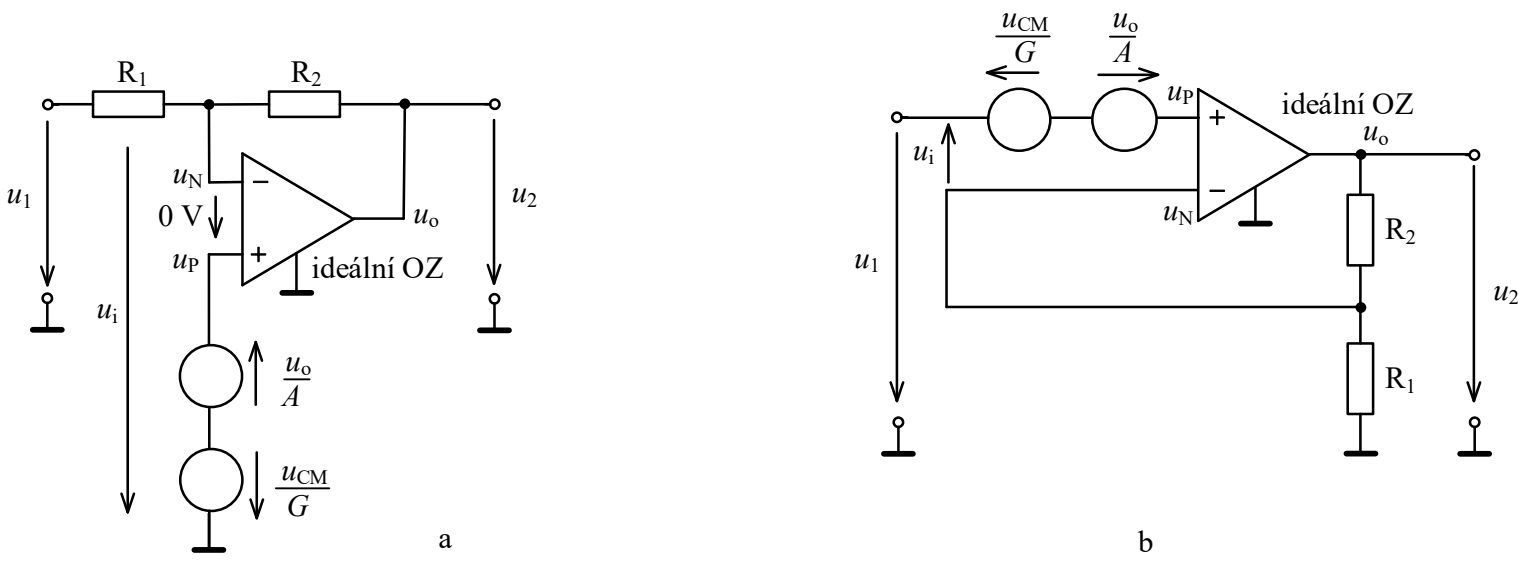

Obr. 5.25: Vliv konečného zesílení a nenulového činitele potlačení souhlasného napětí: a) u invertujícího zesilovače, b) u neinvertujícího zesilovače

Vliv souhlasného napětí na invertujicí zesilovač

Pro invertující zapojení (Obr. 5.25a) můžeme vyčíslit výstupní napětí např. metodou superposice

$$
u_{2}=-\frac{R_{2}}{R_{1}} u_{1}-\frac{u_{\mathrm{o}}}{A}\left(1+\frac{R_{2}}{R_{1}}\right)+\frac{u_{\mathrm{CM}}}{G}\left(1+\frac{R_{2}}{R_{1}}\right) .
$$

$\mathrm{U}$ invertujícího uspořádání bude mít souhlasné napětí hodnotu $u_{\mathrm{CM}}=\left(u_{\mathrm{N}}+u_{\mathrm{P}}\right) / 2=u_{\mathrm{i}}$. Pokud stejně jako $\mathrm{v}$ předchozím zavedeme zpětnovazební činitel $\beta=R_{1} /\left(R_{1}+R_{2}\right)$ a vezmeme v úvahu, že $u_{\mathrm{o}}=u_{2}$, bude

$$
u_{2}=-\frac{R_{2}}{R_{1}} u_{1}-\frac{u_{2}}{\beta A}+\frac{u_{\mathrm{i}}}{\beta G} .
$$

Odtud již můžeme vyčíslit výstupní napětí

$$
u_{2}=-\frac{R_{2}}{R_{1}} \frac{1}{1+\frac{1}{\beta A}} u_{1}+\frac{1}{\beta G\left(1+\frac{1}{\beta A}\right)} u_{\mathrm{i}} .
$$


Protože chybové napětí $u_{\mathrm{i}} \ll u_{1}$, můžeme druhý člen v rovnici zanedbat a pak

$$
u_{2} \approx-\frac{R_{2}}{R_{1}} \frac{1}{1+\frac{1}{\beta A}} u_{1} .
$$

Po porovnání s rov. (5-18) je zřejmé, že v prrípadě invertujícího zesilovače jeho přenos ovlivní jen konečné zesílení operačního zesilovače a souhlasné napětí operačního zesilovače nemá na činnost invertujícího zapojení prakticky vliv. Je to dáno tím, že oba vstupy operačního zesilovače jsou přibližně na nulovém potenciálu a souhlasné napětí je tedy téměř nulové.

Vliv souhlasného napětí na neinvertující zesilovač

$\mathrm{V}$ př́padě neinvertujícího zesilovače bude situace odlišná. Protože $u_{\mathrm{i}} \ll u_{1}$, bude $u_{\mathrm{P}} \approx u_{\mathrm{N}} \approx u_{1} \mathrm{a}$ souhlasné napětí proto $u_{\mathrm{CM}}=\left(u_{\mathrm{N}}+u_{\mathrm{P}}\right) / 2 \approx u_{1}$. Podobně jako v přechozím vyčíslíme výstupní napětí náhradního modelu neinvertujícího zesilovače z Obr. 5.25b

$$
u_{2}=\left(1+\frac{R_{2}}{R_{1}}\right)\left(u_{1}+\frac{u_{\mathrm{CM}}}{G}-\frac{u_{\mathrm{o}}}{A}\right) .
$$

Dosadíme-li za $u_{\mathrm{CM}}=u_{1}$ a $u_{\mathrm{o}}=u_{2}$, můžeme vyčíslit výstupní napětí

$$
u_{2}=\left(1+\frac{R_{2}}{R_{1}}\right) \frac{1}{1+\frac{1}{\beta A}} u_{1}+\frac{1}{\beta G\left(1+\frac{1}{\beta A}\right)} u_{1} \text {. }
$$

Přitom jsme opět označili $\beta=R_{1} /\left(R_{1}+R_{2}\right)$. Z poslední rovnice je zřejmé, že její druhý člen, který vyjadřuje účinek souhlasného napětí, již nelze zanedbat.

Závěrem lze konstatovat, že prvním kritériem, zda použít invertující či neinvertující zesilovač je vysoký vstupní odpor neinvertujícího zapojení. Hned druhým kritériem pro rozhodnutí zda použít neinvertující zesilovač je však jeho citlivost na souhlasném napětí. Tato citlivost u obvodů založených na principu invertujícího zapojení neexistuje. Jejich nevýhodou je ale relativně nízký vstupní odpor.

\section{Použitá literatura}

[1] TIETZE, U.; SCHENK, CH.; GAMM, E. Electronic Circuits. Hand book for Design and Applications. 2nd edition, Springer - Verlag, Berlin 2008. ISBN 978-3-540-00429-5

[2] DOSTÁL, J. Operační zesilovače. BEN, Praha 2005

[3] DOSTÁL, J. Operational Amplifiers. Elsevier, Amsterdam 1981

[4] CLAYTON, G.B. Operational Amplifier. London, Butterworth Co 1971

[5] VRBA, K.; VRBA, K. jun. Technika analogových obvodů a systémů - sbírka prííkladů. Skriptum, 3. vydání. Ediční středisko VUT Brno,1989 


\section{Lineární obvody s operačními zesilovači}

Operační zesilovač byl původně vyvinut pro potřeby analogových počítačů, kde se využíval jako stavební prvek různých analogových počítacích obvodů. Analogové obvody, které řeší základní matematické operace jako sčítání, odčítání, násobení či dělení konstantou a jejich modifikace tvoří i dnes základ pro většinu přístrojových aplikací operačních zesilovačů.

Při analýze obvodů s operačními zesilovači budeme uvažovat použití ideálního operačního zesilovače, protože vlastnosti reálných obvodů se při použití kvalitních operačních zesilovačů př́liš neodlišují od ideálních. Budeme tedy předpokládat, že zesílení operačního zesilovače je nekonečné, a tedy že pro libovolné konečné výstupní napětí je vstupní napětí nulové, $u_{\mathrm{i}} \approx 0 ; \mathrm{v}$ důsledku toho můžeme předpokládat, že je i vstupní proud nulový $i_{\mathrm{i}} \approx 0$. Pro úplnost budeme také u ideálního operačního zesilovače předpokládat, že vstupní odpor mezi diferenčními vstupy je nekonečný $R_{\mathrm{i}} \rightarrow \infty$ a výstupní odpor je nulový $R_{0} \approx 0$.

\subsection{Invertující zapojení}

Invertujicí zesilovač. Základní uspořádání invertujícího zapojení operačního zesilovače je uvedeno na Obr. 6.1. Zavedeme-li obvyklá zjednodušení, tj. $u_{\mathrm{i}} \approx 0, i_{\mathrm{i}} \approx 0$, bude se invertující vstup operačního zesilovače nacházet na tzv. „virtuální nule“ a bude jednoduše platit $i_{1} \approx u_{1} / R_{1}$, $i_{2} \approx-u_{2} / R_{2}$. Protože $i_{1} \approx i_{2}$, bude

$$
u_{2} \approx-\frac{R_{2}}{R_{1}} u_{1}=A_{U} u_{1},
$$

kde $A_{\mathrm{u}}=-R_{2} / R_{1}$ značí napětové zesílení či napět’ový přenos invertujícího zesilovače.

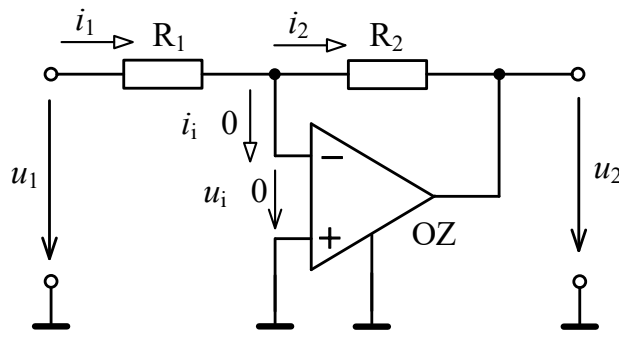

a

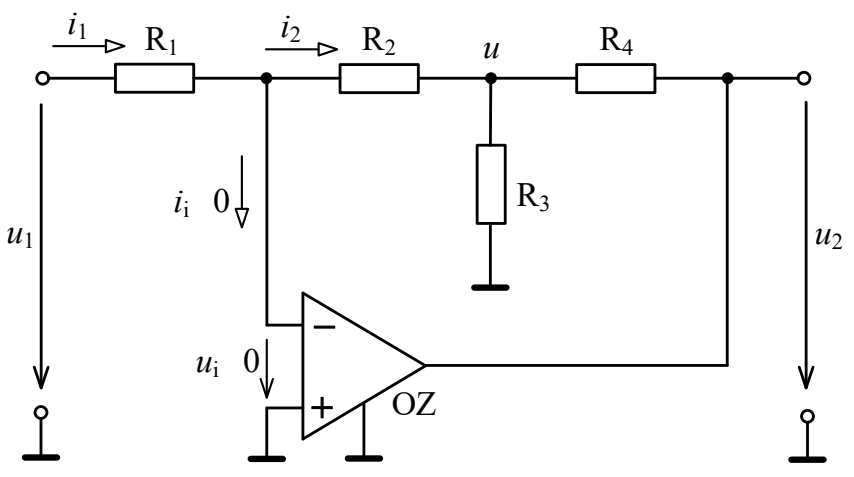

b

Obr. 6.1: a) Invertující zesilovač, b) zapojení invertujícího zesilovače pro velké zesílení

Vliv souhlasného napětí se u tohoto uspořádání neuplatní, protože oba vstupy operačního zesilovače jsou přibližně na nulovém potenciálu. Vstupní odpor obvodu $R_{\mathrm{vst}} \approx R_{1}$, výstupní odpor $R_{\mathrm{výst}} \approx 0$ (zesilovač se chová jako „tvrdý“ zdroj napětí). Ze vztahu (6-1) je zřejmé, že nastavené zesílení obvodu závisí především na poměru odporů $R_{2} / R_{1}$. Proto je nutno věnovat velkou pozornost výběru rezistorů zpětnovazební sítě. Dobré přesnosti se dosáhne při použití rezistorů s kovovou vrstvou. Jejich elektrické parametry se v uvažovaných frekvenčních rozsazích prakticky nemění a vykazují malý vzájemný rozptyl. Některé typy mají i dostatečně malý teplotní koeficient. 
Požadujeme-li velké zesílení, kdy by bylo nutno volit odpor zpětnovazebního rezistoru $\mathrm{R}_{2}$ větší než $1 \mathrm{M} \Omega$, je možno nahradit zpětnovazební rezistor článkem T sestaveným z rezistorů s menším odporem. Zapojení je uvedeno na Obr. 6.1b. Uved'me jeho zjednodušenou analýzu. Protože rezistor $\mathrm{R}_{2}$ je připojen $\mathrm{k}$ „virtuální zemi““ operačního zesilovače, bude jednoduše

$$
u \approx \frac{R_{2} \| R_{3}}{R_{4}+R_{2} \| R_{3}} u_{2}
$$

přičemž $R_{2} \| R_{3}$ značí paralelní kombinaci těchto rezistorů $R_{2} \| R_{3}=R_{2} R_{3} /\left(R_{2}+R_{3}\right)$. Protože $i_{1} \approx$ $\approx i_{2}$ a tedy $u_{1} / R_{1} \approx-u / R_{2}$, bude po dosazení za $u$ z rov.(6-2) platit

$$
u_{2} \approx-\frac{R_{2}}{R_{1}}\left(\frac{R_{4}}{R_{2} \| R_{3}}+1\right) u_{1} .
$$

Zvolíme-li $R_{2}>>R_{3}$, bude jednoduše

$$
u_{2} \approx-\frac{R_{2}}{R_{1}}\left(\frac{R_{4}}{R_{3}}+1\right) u_{1} .
$$

Realizace velkého odporu článkem $T$ je však provázena závažným nedostatkem a to zvětšením nesymetrie a šumu zesilovače. Odpor rezistoru $\mathrm{R}_{2}$ se proto doporučuje volit co největší. Článek $\mathrm{T}$ je použitelný jen u operačních zesilovačů s malým vstupním zbytkovým napětím; šumové vlastnosti se však stejně zhorší.

Řizení zesíleni invertujícího zesilovače. Pokud chceme řídit či dostavit zesílení invertujícího zesilovače, můžeme rezistor $R_{1}$ nebo $R_{2}$ nahradit potenciometrem či potenciometrickým trimrem. Při náhradě je však zapotřebí postupovat uvážlivě. Pokud budeme měnit odpor rezistoru $\mathrm{R}_{1}$, bude řízení zesílení nelineární a při změně zesílení se bude měnit $\mathrm{i}$ vstupní odpor zesilovače. Lépe je tedy nahradit potenciometrem rezistor $\mathrm{R}_{2}$ (viz Obr. 6.2a), kdy ř́zení bude lineární vzhledem k otáčení či posunutí potenciometru

$$
u_{2} \approx-\frac{x R_{\mathrm{P}}}{R_{1}} u_{1},
$$

přičemž jsme označili $x \in(0 ; 1)$ úhel natočení či polohu nastavení potenciometru. Vstupní odpor obvodu zůstává konstantní, $R_{\mathrm{vst}} \approx R_{1}$. Abychom se vyhnuli zvýšení šumu a náchylnosti zesilovače ke kmitání, nesmíme nikdy běžec potenciometru připojit k invertujícímu vstupu operačního zesilovače, ale vždy k výstupní svorce zesilovače.

Pokud chceme pouze dostavit zesílení, nahradí se část rezistoru $\mathrm{R}_{2}$ potenciometrickým trimrem (Obr. 6.2b). Protože potenciometrický trimr může zhoršit šumové i teplotní vlastnosti obvodu volíme jeho odpor podstatně menší, než je odpor rezistoru $R_{2}$. Stejně jako v předchozím př́ípadě zapojíme běžec potenciometru vždy $\mathrm{k}$ výstupu zesilovače.

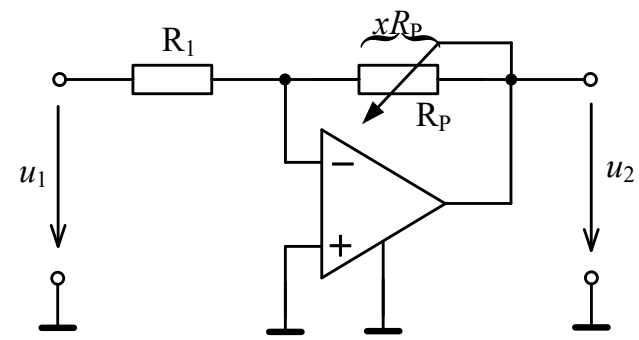

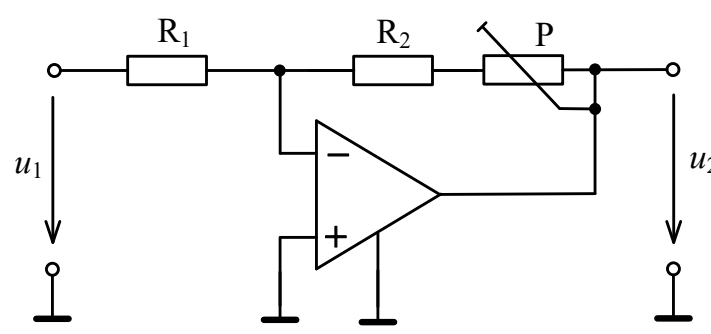

b

Obr. 6.2: a) Lineární řízení zesílení invertujícího zesilovače, b) dostavení zesílení 


\subsection{Neinvertující zapojení}

Rozdílový vstup operačního zesilovače umožňuje vstupní signál přivádět na neinvertující vstup, přičemž zpětná vazba je vedena $\mathrm{z}$ výstupu zesilovače na invertující vstup. Jde o sériovou zápornou zpětnou vazbu typu „bootstrap“, kdy zpětnovazební signál je v sérii se vstupním signálem a působí proti němu. To způsobuje, že vstupní odpor je mnohokrát větší než samotný diferenční vstupní odpor operačního zesilovače. Uvedené vlastnosti jsou ve shodě s teorií zpětné vazby, podle níž paralelní záporná zpětná vazby zmenšuje vstupní impedanci a sériová záporná zpětná vazba vstupní impedanci zvětšuje. U neinvertujících zapojení se však v plné míře uplatňuje vliv nedokonalého potlačení souhlasného napětí a musí se také věnovat pozornost tomu, aby nebylo překročeno jmenovité souhlasné napětí.

Neinvertující zesilovač. Zapojení neinvertujícího zesilovače je uvedeno na Obr. 6.3a. Protože proudy tekoucí oběma rezistory jsou stejné $\left(i_{\mathrm{i}} \approx 0\right)$ je výstupní napětí nezatíženého děliče

$$
u \approx \frac{R_{1}}{R_{1}+R_{2}} u_{2}
$$

Operační zesilovač si udržuje prostřednictvím zpětné vazby napětí mezi diferenčními vstupy přibližně nulové napětí $u_{\mathrm{i}} \approx 0$ a tedy $u \approx u_{1}$. Potom

$$
u_{2} \approx\left(1+\frac{R_{2}}{R_{1}}\right) u_{1}=A_{\mathrm{U}} u_{1},
$$

prričemž jsme označili $A_{\mathrm{U}}=1+R_{2} / R_{1}$ napět'ové zesílení resp. napět'ový přenos neinvertujícího zesilovače.

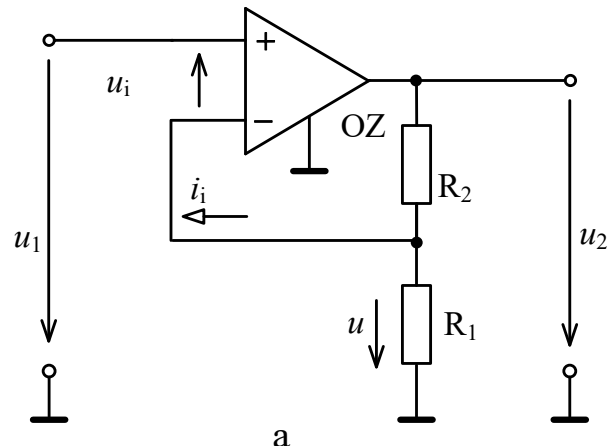

a

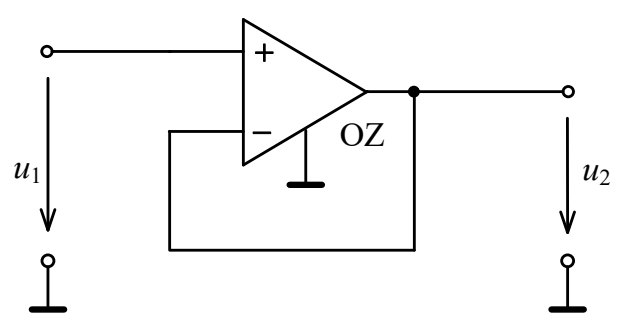

$\mathrm{b}$

Obr. 6.3: a) Neinvertující zesilovač, b) neivertující zesilovač s jednotkovým zesílením, tzv. impedanční transformátor

Hlavní rozdíl mezi invertujícím a neinvertujícím zapojením operačního zesilovače je ve vstupním odporu, který určuje zatížení zdroje signálu $u_{1}$. Neinvertující zesilovač s ideálním operačním zesilovačem neodebírá proud ze zdroje signálu, a proto můžeme v podstatě uvažovat, že má nekonečný vstupní odpor $R_{\text {vst }} \approx \infty$, resp. obecně má nekonečnou vstupní impedanci. Je nutno poznamenat, že i když impedance mezi diferenčními vstupy reálného operačního zesilovače bude konečná, velmi velké zesílení operačního zesilovače zaručuje, že vstupní impedance neinvertujícího zesilovače se bude blížit nekonečnu. Další rozdíl ve srovnání s invertujícím zapojením je skutečnost, že u neinvertujícího zapojení se plně uplatní vliv souhlasného napětí, protože oba vstupy operačního zesilovače se nacházejí přibližně na souhlasném potenciálu $u_{1}$.

Požadujeme-li, aby neinvertující zesilovač měl jednotkové zesílení, je možno volit $R_{1}=\infty, R_{2}=0$; schematicky je tento př́pad vyznačen na Obr. 6.3b. Obvod se užívá jako 
oddělovací zesilovač či napět’ový sledovač resp. jako impedanční transformátor. To protože má jednotkový přenos a že se vyznačuje velmi velkou vstupní a velmi malou výstupní impedancí. Napětový drift je poloviční než u invertujícího zapojení s týmž operačním zesilovačem.

Řizení zesílení neinvertujicího zesilovače. Základní uspořádání vhodné pro řízení zesílení pomocí potenciometru je uvedeno na Obr. 6.4a. Řešení je za použití rov. (6-7) pro neinvertující zesilovač jednoduché

$$
u_{2} \approx\left(1+\frac{x R_{\mathrm{P}}}{R_{1}}\right) u_{1},
$$

přičemž jsme opět označili $\mathrm{x} \in(0 ; 1)$ polohu běžce potenciometru.

Pokud požadujeme pouze dostavovat zesílení neinvertujícího zesilovače, použijeme uspořádání uvedené na Obr. $6.4 \mathrm{~b}$. V obou případech musíme opět věnovat pozornost tomu, kam připojíme běžec potenciometru či potenciometrického trimru, protože připojení $\mathrm{k}$ invertujícímu vstupu OZ může způsobit zhoršení šumových vlastností nebo vést i k rozkmitání zesilovače. $V$ případě zapojení pro dostavení zesílení (Obr. 6.4b) je pak vhodné volit odpor potenciometrického trimru podstatně menší než je odpor $R_{2}$. Potenciometrické trimry mají totiž většinou vyšší šum a horší teplotní vlastnosti než rezistory.

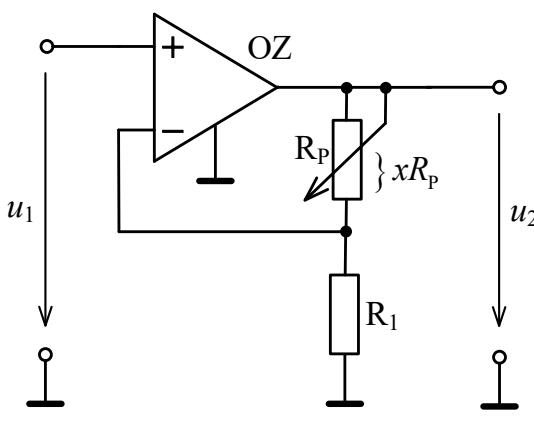

a

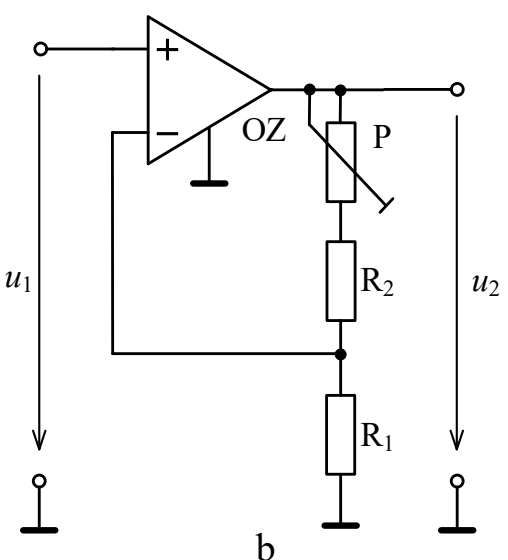

$\mathrm{b}$

Obr. 6.4: a) Rízení zesílení neivertujícího zesilovače, b) dostavení zesílení

\subsection{Sčítací zapojení}

Invertující sčitací zesilovač. Jestliže místo jediného rezistoru je $\mathrm{k}$ uzlu S připojeno několik rezistorů $\mathrm{R}_{11}, \mathrm{R}_{12}, \ldots, \mathrm{R}_{1 N}$ (viz Obr. 6.5), pak za předpokladu, že operační zesilovač je ideální, pro proudy v obvodu podle Kirchhoffova zákona platí

$$
i_{2} \approx i_{11}+i_{12}+\ldots+i_{1 N}=\sum_{n=1}^{N} i_{1 n}
$$

kde $i_{1 n} \approx u_{1 n} / R_{1 n}$, pro $n=1$ až $N$ a $i_{2} \approx-u_{2} / R_{2}$. Z tohoto důvodu se obvod nazývá sčítací zesilovač a uzel $\mathrm{S}$ je často označován jako „sčítací bod“. Poznamenejme, že tento bod se i v tomto př́padě nachází na „virtuální nule“ $\left(u_{i} \approx 0\right)$. Výstupní napětí invertujícího sčítacího zesilovače pak 
$u_{2} \approx-R_{2} \sum_{n=1}^{N} \frac{u_{1 n}}{R_{1 n}}$

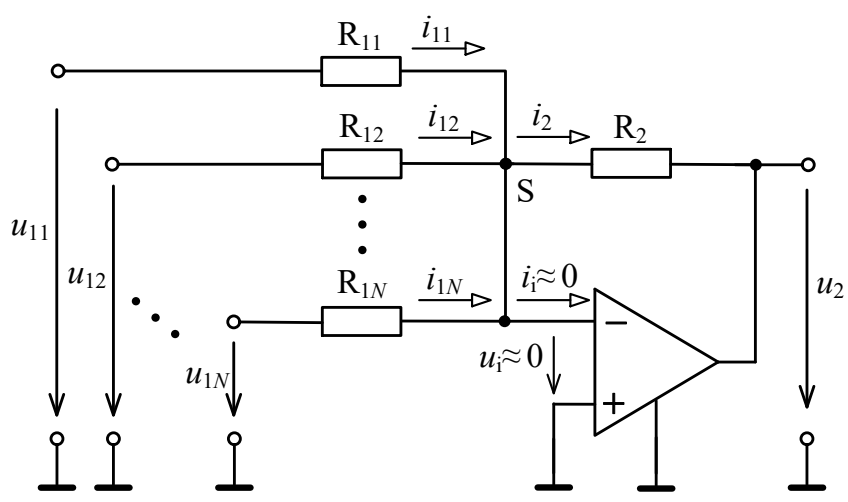

Obr. 6.5: Invertující sčítací zesilovač

Poznámka: Stejné pravidlo pro sčítací bod platí i z hlediska zpětné vazby - jestliže je zpětná vazba zaváděna několika zpětnovazebními cestami, je součet jednotlivých proudů $\mathrm{v}$ těchto cestách roven součtu vstupních proudů.

Ukážeme zde i jiný způsob řešení sčítacího zesilovače z Obr. 6.5. Protože jde o lineární obvod, můžeme použít metodu superpozice, kdy spočítáme postupně účinek jednotlivých vstupních napětí, kdy ostatní vstupní napětí jsou nulová. Přitom využijeme výsledku (6-11) pro výstupní napětí invertujícího zesilovače

$$
\begin{gathered}
u_{2}^{\prime} \approx-\frac{R_{2}}{R_{11}} u_{11}, \\
u_{2}^{\prime \prime} \approx-\frac{R_{2}}{R_{12}} u_{12}, \\
\cdot \\
\cdot \\
\cdot \\
\cdot \\
u_{2}^{(N)} \approx-\frac{R_{2}}{R_{1 N}} u_{1 N} .
\end{gathered}
$$

Dílčí výsledky pak sečteme

$$
u_{2} \approx-R_{2}\left(\frac{u_{11}}{R_{11}}+\frac{u_{12}}{R_{12}}+\cdots+\frac{u_{1 N}}{R_{1 N}}\right)=-R_{2} \sum_{n=1}^{N} \frac{u_{1 n}}{R_{1 n}} .
$$

\subsection{Rozdílová zapojení}

Rozdilový zesilovač. Diferenční vstup operačního zesilovače umožňuje, aby vstupní signály byly přivedeny současně na obě vstupní svorky. Na tomto principu pracuje rozdílový zesilovač naznačený na Obr. 6.6. Analýza obvodu pomocí metody superpozice je následující. 


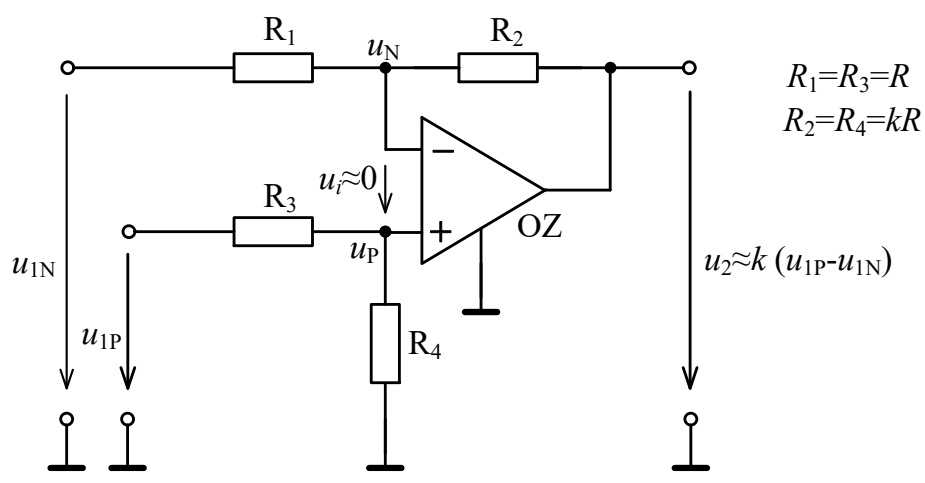

Obr. 6.6: Rozdílový zesilovač

Bude-li $u_{1 \mathrm{P}}=0$, a protože do neivertujícího vstupu $\mathrm{OZ}$ teče jen zanedbatelný proud, který na paralelní kombinaci $R_{3} \| R_{4}$ nevyvolá téměř žádné napětí, bude $u_{\mathrm{P}} \approx 0$. Zapojení se pak pro tento případ chová jako invertující zesilovač a tedy

$$
u_{2}^{\prime} \approx-\frac{R_{2}}{R_{1}} u_{1 N} .
$$

Bude-li $u_{1 \mathrm{~N}}=0$, bude se zapojení chovat jako neinvertující zesilovač, který má na vstupu předřazen odporový dělič $R_{3}, R_{4}$. Protože neinvertující zapojení vykazuje téměř nekonečný vstupní odpor, počítáme tento dělič jako nezatížený

$$
u_{\mathrm{P}} \approx \frac{R_{4}}{R_{3}+R_{4}} u_{1 \mathrm{P}} .
$$

Výstupní napětí pak

$$
u_{2}^{\prime} \approx\left(1+\frac{R_{2}}{R_{1}}\right) u_{\mathrm{P}} \approx \frac{R_{4}}{R_{3}+R_{4}}\left(1+\frac{R_{2}}{R_{1}}\right) u_{1 \mathrm{P}} .
$$

Dílčí výsledky (6-13) a (6-14) pak sečteme

$$
u_{2} \approx \frac{R_{4}}{R_{3}+R_{4}}\left(1+\frac{R_{2}}{R_{1}}\right) u_{1 \mathrm{P}}-\frac{R_{2}}{R_{1}} u_{1 \mathrm{~N}} .
$$

Zvolíme-li $R_{1}=R_{3}=R$ a $R_{2}=R 4=k R$, je činnost rozdílového zesilovače popsána vztahem

$$
u_{2} \approx k\left(u_{1 \mathrm{P}}-u_{1 \mathrm{~N}}\right) \text {, }
$$

kde $k$ značí přenos rozdílového zesilovače. Bude-li $R_{1}=R_{2}=R_{3}=R_{4}=R$, bude jednoduše

$$
u_{2} \approx u_{1 \mathrm{P}}-u_{1 \mathrm{~N}} .
$$

Vstupní odpory jednotlivých vstupů rozdílového zesilovače zapojeného dle Obr. 6.6 jsou odlišné: $R_{\mathrm{vstN}} \approx R_{1}, R_{\mathrm{vstP}} \approx R_{3}+R_{4}$. Vliv souhlasného napětí se u tohoto rozdílového zapojení uplatní částečně, protože oba vstupy operačního zesilovače se nacházejí na souhlasném napětí $u_{\mathrm{P}} \approx u_{\mathrm{N}} \approx u_{1 \mathrm{P}} R_{4} /\left(R_{3}+R_{4}\right)$.

Rozdílová zapojení se dvěma operačními zesilovači. Činnost rozdílového zesilovače uvedeného na Obr. 6.6 je, jak bylo již řečeno, omezena nežádoucím vlivem souhlasného napětí. 


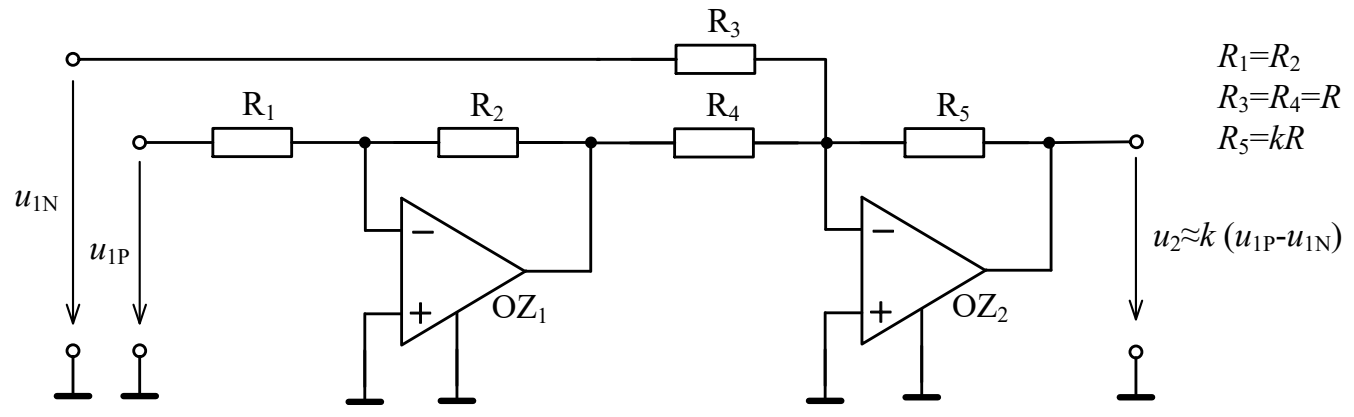

Obr. 6.7: Rozdílový zesilovač, u kterého se neuplatňuje vliv souhlasného napětí

Obvod naznačený na Obr. 6.7 využívá k vytvoření rozdílu vstupních napětí dvou invertujících zapojení OZ [2]. Tímto způsobem je vliv souhlasného napětí vyloučen, protože u invertujícího zapojení $\mathrm{OZ}$ se souhlasné napětí neuplatní. Určitou nevýhodou je relativně malý vstupní odpor, který je u negativního vstupu roven $R_{3}$ a u positivního vstupu $R_{1}$. Obvod řešíme metodou superpozice. Pro $u_{1 \mathrm{P}}=0$ dostáváme

$$
u_{2}^{\prime} \approx-\frac{R_{5}}{R_{3}} u_{1 \mathrm{~N}}
$$

Bude-li $u_{1 \mathrm{~N}}=0$, bude se zapojení chovat jako dva invertující zesilovače v kaskádě a jejich přenosy se budou násobit

$$
u_{2}^{\prime \prime} \approx \frac{R_{2}}{R_{1}} \frac{R_{5}}{R_{4}} u_{1 \mathrm{P}}
$$

Výstupní napětí pak po sečtení dílčích výsledků (6-18) a (6-19) je dáno vztahem

$$
u_{2} \approx \frac{R_{2}}{R_{1}} \frac{R_{5}}{R_{4}} u_{1 \mathrm{P}}-\frac{R_{5}}{R_{3}} u_{1 \mathrm{~N}}
$$

Zvolíme-li $R_{1}=R_{2}, R_{3}=R_{4}=R$ a $R_{5}=k R$, bude jednoduše

$$
u_{2} \approx k\left(u_{1 \mathrm{P}}-u_{1 \mathrm{~N}}\right) \text {. }
$$

Pokud rozšíríme počet vstupů zesilovače $\mathrm{OZ}_{1}$ nebo $\mathrm{OZ}_{2}$ obdobně jako je tomu u sčítacího zesilovače na Obr. 6.5 , můžeme současně sčítat či odčítat větší počet vstupních napětí.

Na Obr. 6.8 je uvedeno schéma rozdílového zesilovače, který k získání velkého vstupního odporu využívá dvou neinvertujících zesilovačů. Předpokládáme-li dle metody superpozice, že $u_{1 \mathrm{~N}}=0$, bude $u_{3} \approx 0$ a OZ 2 se chová jako neinvertující zesilovač

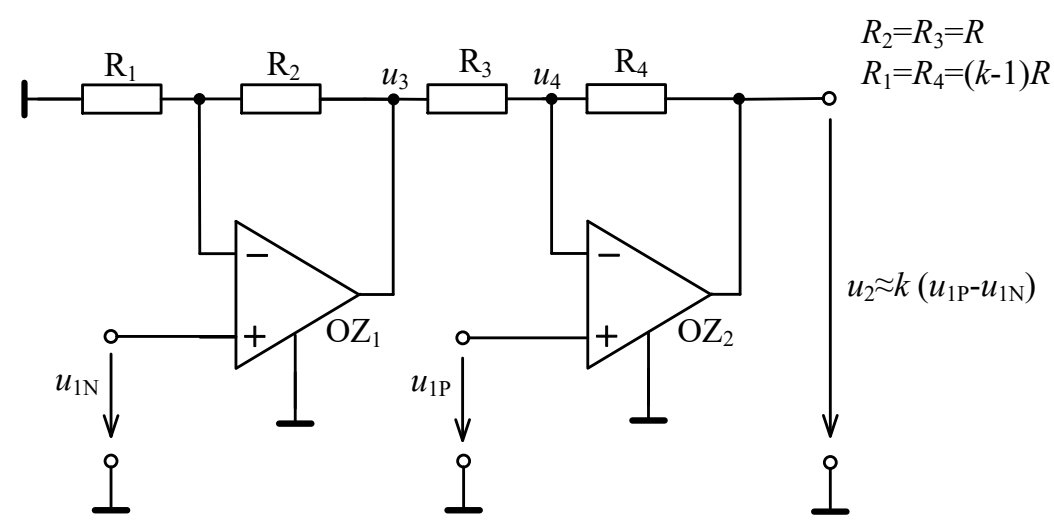

Obr. 6.8: Rozdílový zesilovač s velkým vstupním odporem 


$$
u_{2}^{\prime} \approx\left(1+\frac{R_{4}}{R_{3}}\right) u_{1 \mathrm{P}}
$$

Pro př́pad $u_{1 \mathrm{P}}=0$, budou oba zesilovače zařazeny kaskádně a to $\mathrm{OZ}_{1}$ jako neinvertující zesilovač a $\mathrm{OZ}_{2}$ jako invertující zesilovač. Dílčí přenosy kaskádně řazených zesilovačů se budou $\mathrm{v}$ tomto př́padě násobit

$$
u_{2}^{\prime \prime} \approx-\frac{R_{4}}{R_{3}}\left(1+\frac{R_{2}}{R_{1}}\right) u_{1 \mathrm{~N}} .
$$

Sečtením dílčích výsledků (6-22) a (6-23) dostáváme

$$
u_{2} \approx\left(1+\frac{R_{4}}{R_{3}}\right) u_{1 \mathrm{P}}-\frac{R_{4}}{R_{3}}\left(1+\frac{R_{2}}{R_{1}}\right) u_{1 \mathrm{~N}} .
$$

Zvolíme-li $R_{2}=R_{3}=R$ a $R_{1}=R_{4}=(k-1) R$, bude zřejmě $u_{2} \approx k\left(u_{1 \mathrm{P}}-u_{1 \mathrm{~N}}\right)$. Protože zapojení využívá dvou neinvertujících zesilovačů, bude zapojení stejně jako každé neivertující zapojení citlivé na souhlasná napětí.

Př́strojový rozdílový zesilovač. Požadujeme-li měnit zesílení rozdílového zesilovače $\mathrm{s}$ velkým vstupním odporem uvedeného na Obr. 6.8 , je nutno měnit jak odpor rezistoru $\mathrm{R}_{1}$, tak i odpor rezistoru $\mathrm{R}_{4}$. Navíc se u tohoto rozdílového zesilovače, jak bylo již řečeno, uplatňuje vliv souhlasného napětí. Z tohoto hlediska je výhodnější zapojení naznačené na Obr. 6.9. U tohoto uspořádání lze zesílení nastavit změnou odporu jediného rezistoru $\mathrm{R}_{1}$ a vliv souhlasného napětí je u tohoto zapojení výrazně potlačen, protože zesilovače $\mathrm{OZ}_{1}$ a $\mathrm{OZ}_{2}$ jsou zapojeny jako diferenční zesilovač s diferenčním výstupem, za který je zapojen rozdílový zesilovač $\mathrm{s} \mathrm{OZ}_{3}$.

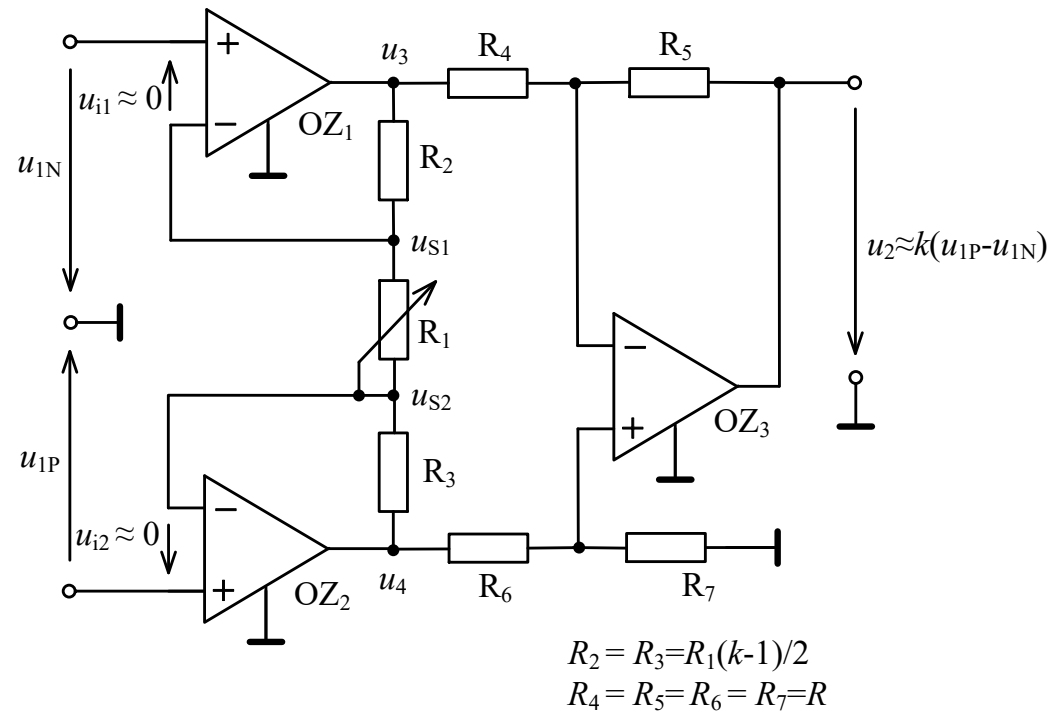

Obr. 6.9: Přístrojový rozdílový zesilovač

Pro odvození činnosti použijeme metodu superpozice. Nejprve budeme předpokládat $u_{1 \mathrm{~N}}=0$ a tedy i $u_{\mathrm{S} 1}=0$. Operační zesilovač $\mathrm{OZ}_{1}$ se bude chovat jako invertující zesilovač, který má na vstupu napětí $u_{\mathrm{S} 2} \approx u_{1 \mathrm{P}}$ a tedy 


$$
u_{3}^{\prime} \approx-\frac{R_{2}}{R_{1}} u_{1 \mathrm{P}}
$$

Operační zesilovač OZ2 se bude současně chovat jako neinvertující zesilovač

$$
u_{4}^{\prime} \approx\left(1+\frac{R_{3}}{R_{1}}\right) u_{1 \mathrm{P}}
$$

Dále předpokládejme, že $u_{1 \mathrm{P}}=0$ a tedy $u_{\mathrm{S} 2} \approx 0$. Nyní se bude $\mathrm{OZ}_{1}$ chovat jako neinvertující zesilovač a

$$
u_{3}^{\prime \prime} \approx\left(1+\frac{R_{2}}{R_{1}}\right) u_{1 \mathrm{~N}} .
$$

Současně se $\mathrm{OZ}_{2}$ chová jako invertující zesilovač, který má na vstupu napětí $u_{\mathrm{S} 1} \approx u_{1 \mathrm{~N}}$ a tedy

$$
u_{4}^{\prime \prime} \approx-\frac{R_{3}}{R_{1}} u_{1 \mathrm{~N}}
$$

Dílčí výsledky sečteme a tak získáme napětí, která jsou přivedena na vstupy rozdílového zesilovače s $\mathrm{OZ}_{3}$

$$
\begin{aligned}
& u_{3} \approx\left(1+\frac{R_{2}}{R_{1}}\right) u_{1 \mathrm{~N}}-\frac{R_{2}}{R_{1}} u_{1 \mathrm{P}}, \\
& u_{4} \approx\left(1+\frac{R_{3}}{R_{1}}\right) u_{1 \mathrm{P}}-\frac{R_{3}}{R_{1}} u_{1 \mathrm{~N}},
\end{aligned}
$$

Aby se vliv souhlasného napětí na $\mathrm{OZ}_{3}$ uplatnil co nejméně, je nutné volit přenos rozdílového zesilovače $\mathrm{s} \mathrm{OZ}_{3}$ jednotkový, tj. $R_{4}=R_{5}=R_{6}=R_{7}=R$. Pak

$$
u_{2} \approx u_{4}-u_{3}=\left(1+\frac{R_{3}}{R_{1}}\right) u_{1 \mathrm{P}}-\frac{R_{3}}{R_{1}} u_{1 \mathrm{~N}}-\left(1+\frac{R_{2}}{R_{1}}\right) u_{1 \mathrm{~N}}+\frac{R_{2}}{R_{1}} u_{1 \mathrm{P}}=\left(1+\frac{R_{2}}{R_{1}}+\frac{R_{3}}{R_{1}}\right)\left(u_{1 \mathrm{P}}-u_{1 \mathrm{~N}}\right) .
$$

Zvolíme-li $R_{2}=R_{3}=R_{1}(k-1) / 2$, bude

$$
u_{2} \approx k\left(u_{1 \mathrm{P}}-u_{1 \mathrm{~N}}\right) .
$$

Protože vstupní stupeň je složen ze dvou navzájem vázaných neinvertujících zesilovačů, které tvoří diferenční stupeň s diferenčním výstupem má celý obvod pro souhlasná napětí jednotkové zesílení, pro napětí rozdílová má však zesílení $k$. Vstupní stupeň složený se dvou samostatných neinvertujících zesilovačů by zesiloval stejně jak souhlasná napětí, tak i napětí rozdílová.

Uvedené uspořádání se třemi operačními zesilovači je tak výhodné, že ho ve svém výrobním programu má téměř každý výrobce lineárních integrovaných obvodů. Rezistor $\mathrm{R}_{1} \mathrm{se}$ dá bud' připojit $\mathrm{k}$ vnějším svorkám integrovaného obvodu, nebo je uvnitř integrovaného obvodu připravena sada rezistorů, které se připojují zkratováním vnějších svorek a tak určují výsledné zesílení obvodu. 


\subsection{Můstková zapojení}

Můstková zapojení se většinou používají v tenzometrických snímačích pro měření ohybu či průhybu materiálu, pro měření tlaku či tahu. Součástí odporového můstku je odporový tenzometr, což je pasivní odporové čidlo nalepené na povrchu součásti (páskové tenzometry) nebo pevně spojené $s$ měřeným tělesem (napřr. tenzometry pro váhy), které převádí mechanickou deformaci na změnu elektrického odporu. Můstková zapojení jsou samozřejmě použitelná i pro jiné aplikace, např. pro měření teploty, kdy se použije teplotní odporové čidlo.

Diferenční operační zesilovač je možno různými způsoby aplikovat při zesilování výstupního napětí z vyvážených rezistorových můstků. Volba vhodného uspořádání závisí na konkrétní aplikaci. Při výběru zapojení se řídíme následujícími kritérii: zdroj napájecího napětí můstku je nebo není přímo spojen se společným vodičem (zemí), měřený rezistor je nebo není přímo spojen se společným vodičem, požaduje se nebo nepožaduje lineární závislost výstupního napětí na změnách odporu měřeného rezistoru jak pro velké tak i pro malé změny odporu.

\section{Můstkové zapojení s jedním operačním zesilovačem}

U zapojení nakresleného na Obr. 6.10 jde vlastně o použití základního uspořádání rozdílového zesilovače z Obr. 6.6, u kterého jsou oba vstupy propojeny a připojeny na zdroj napětí $U$. Můžeme proto využít výsledku dle rov. (6-15), kdy $u_{1 \mathrm{P}}=u_{1 \mathrm{~N}}=U$, tzn.

$$
u_{2} \approx \frac{R_{4}}{R_{3}+R_{4}}\left(1+\frac{R_{2}}{R_{1}}\right) U-\frac{R_{2}}{R_{1}} U=\frac{R_{1} R_{4}-R_{2} R_{3}}{R_{1}\left(R_{3}+R_{4}\right)} U .
$$

Jsou dvě možnosti použití tohoto můstkového zapojení:

a) Zvolme $R_{1}=R, R_{3}=R_{4}=R_{0}$ a měřený tenzometr necht' má odpor $R_{2}=R+\Delta R$, kde $R$ je odpor tenzometru při výchozím mechanickém zatížení a $\Delta R$ přírůstek odporu tenzometru při zatížení.

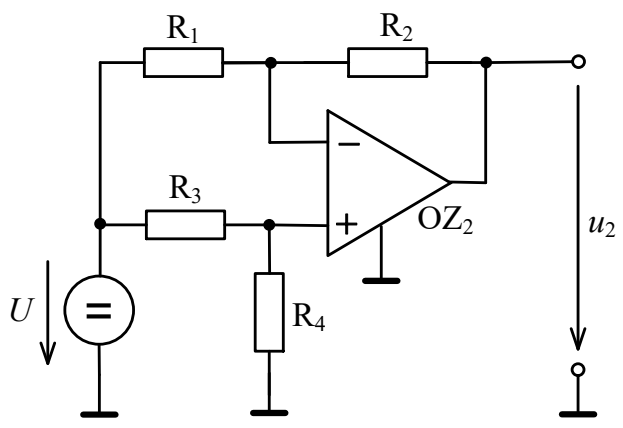

Obr. 6.10: Můstkové zapojení s napájecím zdrojem spojeným se společným vodičem

Zavedeme-li poměrnou změnu odporu tenzometru $\delta=\Delta R / R$, můžeme pro odpor tenzometru psát $R_{2}=R(1+\delta)$. Dosadíme-li tyto hodnoty do výrazu pro výstupní napětí, dostaneme 


$$
u_{2} \approx \frac{U}{2} \delta
$$

Obvod tedy dává výstupní napětí př́mo úměrné rozdílu $\Delta R$ odporu způsobeného mechanickým zatížením tenzometru a normálu při výchozím zatížení. Linearita je zajištěna i pro velké odchylky odporu tenzometru od normálu. Obvod nezesiluje a pro zvýšení citlivosti je nutno připojit další zesilovač. Měřený tenzometr není přímo spojen se společným vodičem. Nevýhodou zapojení tenzometru na pozici rezistoru $R_{2}$ je skutečnost, že jeden konec tenzometru je připojen k invertujícímu vstupu OZ, což může vést při dlouhých přívodech ke zhoršení šumových vlastností obvodu nebo dokonce k jeho rozkmitání.

b) Požadujeme-li, aby jeden konec tenzometru byl spojen se společným vodičem (zemí) a má-li se usnadnit jeho napájení velkým proudem, umístíme ho do druhé větve můstku na pozici rezistoru $\mathrm{R}_{4}$. Volíme $R_{3}=R, R_{1}=R_{2}=R_{0}$ a $R_{4}=R(1+\delta)$. Vstupní napětí pak je

$$
u_{2} \approx U \frac{\delta}{\delta+2}, \quad \text { popř. } u_{2} \approx \frac{U}{2} \delta \text { pro } \delta \ll 2 .
$$

Vstupní napětí je přímo úměrné odchylce jen pro malé odchylky odporu měřeného rezistoru $(\delta<<2)$.

V obou uvažovaných př́padech nesmí být překročeno jmenovité souhlasné napětí operačního zesilovače.

\section{Můstkové zapojení s přistrojovým rozdillovým zesilovačem}

Nejjednodušší cesta je použít k zesilování výstupního napětí rezistorového můstku př́strojový rozdílový zesilovač se třemi operačními zesilovači, diskutovaný v předchozím textu (Obr. 6.9). Uspořádání takového můstku s tenzometrickým prvkem je uvedeno na Obr. 6.11. Tenzometr je na pozici rezistoru $R_{3}, \mathrm{tj} . R_{3}=R+\Delta R$. Činnost můstku, pokud zvolíme $R_{1}=R_{2}=$ $R_{4}=R$, popisují tyto rovnice:

$$
u_{\mathrm{P}}=\frac{U}{2} ; \quad u_{\mathrm{N}}=U \frac{R}{2 R+\Delta R} ;
$$

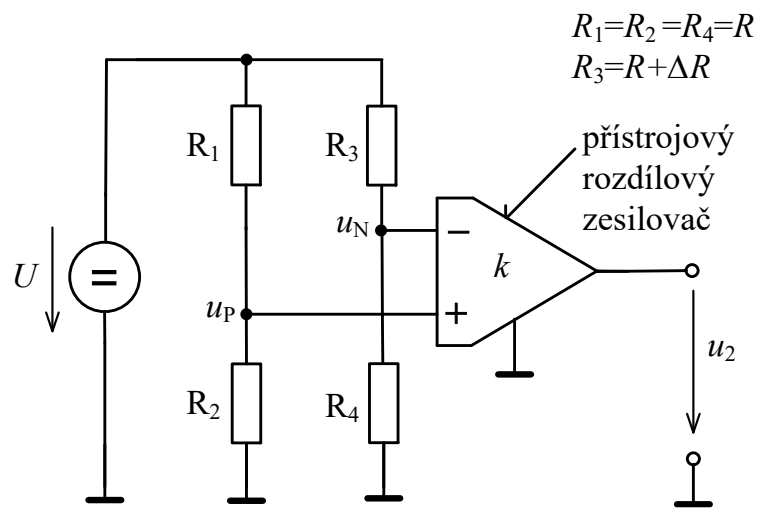

Obr. 6.11: Můstkové zapojení s přístrojovým rozdílovým zesilovačem

$$
u_{\mathrm{P}}-u_{\mathrm{N}}=\frac{U}{2} \frac{\delta}{2+\delta}
$$


Přičemž jsme opět označili poměrnou změnu odporu tenzometru $\delta=\Delta R / R$. Zesiluje-li př́strojový rozdílový zesilovač $k$-krát, bude výstupní napětí

$$
u_{2} \approx k\left(u_{\mathrm{P}}-u_{\mathrm{N}}\right)=\frac{k U}{2} \frac{\delta}{2+\delta}
$$

Jestliže $\delta<<2$, pak jednoduše

$$
u_{2} \approx k U \frac{\delta}{4} .
$$

Výstupní napětí je lineární funkcí změny odporu tenzometru pouze pro velmi malé změny. Jestliže je nutné sledovat větší změny, musíme používat přsesnou rovnici (6-38), př́ípadně je možno provést linearizaci převodní charakteristiky v následujících obvodech. Určitou nevýhodou tohoto uspořádání může být poněkud vyšší cena přístrojového zesilovače ve srovnání s cenou jediného operačního zesilovače použitého v zapojení na Obr. 6.10.

\subsection{Zdroje napětí řízené proudem}

Stavebním prvkem použitelným v mnoha zařízeních je převodník proudu na napětí, resp. zdroj napětí řízený proudem. Použití operačního zesilovače v této aplikaci je velmi snadné. Obvod uvedený na Obr. 6.12a konstrukčně vychází z invertujícího zapojení zesilovače, u kterého je vynechán vstupní zpětnovazební rezistor. Je to jednoduchá, ale velice vhodná metoda pro měření proudu prakticky vzato bez úbytku napětí. Výstupní napětí je př́mo úměrné vstupnímu proudu. Proud tekoucí k invertujícímu vstupu operačního zesilovače vyvolá stejný proud tekoucí zpětnovazebním rezistorem $\mathrm{R}$ a výstupní napětí proto

$$
u_{2} \approx-i_{1} R \text {. }
$$

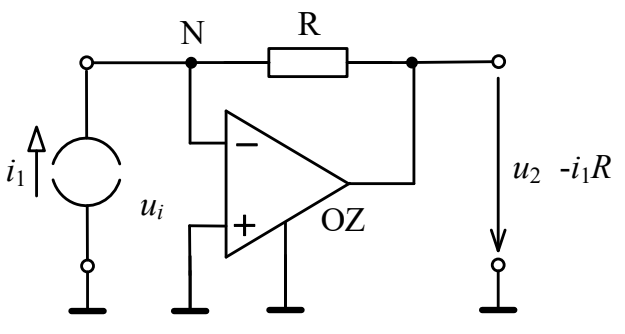

$\mathrm{a}$

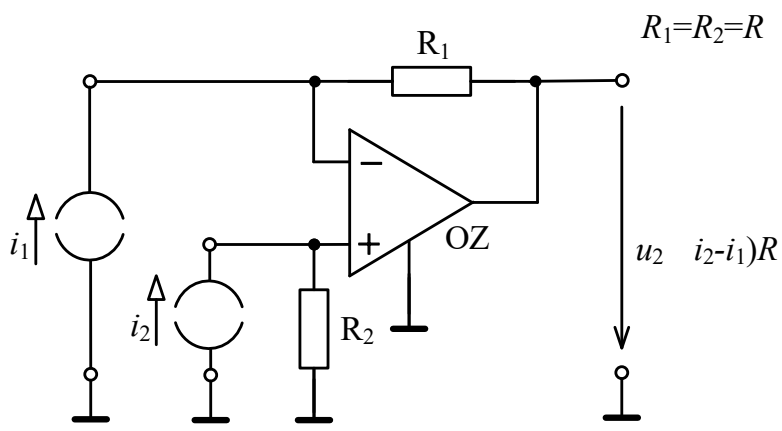

b

Obr. 6.12: a) Převodník proudu na napětí, b) měření rozdílu dvou proudů

Použijeme-li vhodný zesilovač s tranzistory řízenými polem na vstupu, můžeme tímto obvodem měřit i proudy extrémně malé. Výhodou je, že mezi vstupními svorkami tohoto převodníku proudu na napětí vznikne jen nepatrný úbytek napětí $u_{\mathrm{i}}$ (řádově milivolty). Proto se uzel N označuje někdy jako tzv. ,proudová nora“. Obvod se často užívá jako nulový indikátor. Ke zvýšení citlivosti obvodu v oblasti nuly se pak lineární rezistor často nahrazuje rezistorem nelineárním. 
Rozdílové uspořádání převodníku proudu na napětí se užívá k získání napětí, které je prŕmo úměrné rozdílu mezi proudy. Př́klad takového uspořádání je naznačen na Obr. 6.12b. Obvod řešíme metodou superpozice: a) předpokládejme $i_{2}=0$, pak stejně jako v př́padě obvodu na Obr. $6.12 \mathrm{a}$ bude $u_{2}^{\prime} \approx-i_{1} R_{1} ; \mathrm{b}$ ) bude-li $i_{1}=0$, vyvolá proud $i_{2}$ na odporu $\mathrm{R}_{2}$ napětí $i_{2} \mathrm{R}_{2}$ a protože $\mathrm{OZ}$ je nyní zapojen jako neinvertující zesilovač $\mathrm{s}$ jednotkovým přenosem, bude na výstupu napětí $u_{2}^{\prime \prime} \approx i_{2} R_{2}$. Bude-li $R_{1}=R_{2}=R$, pak po sečtení dílčích výsledků pro výstupní napětí dostaneme

$$
u_{2} \approx\left(i_{2}-i_{1}\right) R
$$

\subsection{Zdroje proudu ř́zzené napětím}

Při návrhu elektronických zařízení často využíváme jako stavební prvek zdroj proudu řízený napětím. Řízený zdroj proudu nachází aplikace při zkoumání vlastností prvků při buzení různými proudy, nebo pro nastavení vhodného pracovního bodu. Nap̌r. při měření odporu je použití zdroje proudu výhodnější než použití zdroje napětí, protože se při měření neuplatňuje vliv přechodových odporů. Řizený zdroj proudu může být využit také jako programovatelný zdroj proudu při proměřování charakteristik tranzistoru. Řadu aplikací mají zdroje proudu také v číslicově analogových převodnících.

Přesné zdroje proudu s tranzistory. Na Obr. 6.13a je naznačeno zapojení řízeného zdroje proudu, které využívá operačního zesilovače ke zlepšení vlastností klasického zdroje proudu s tranzistorem. Zesilovač se stoprocentní zápornou zpětnou vazbou zaručuje, že napětí $u$ na emitorovém rezistoru $\mathrm{R}$ se $\mathrm{s}$ dobrou přibližností rovná vstupnímu napětí $u_{1}$ a proto

$$
i_{\mathrm{E}} \approx \frac{u}{R} \approx \frac{u_{1}}{R}
$$

Protože $i_{\mathrm{E}}=i_{\mathrm{C}}+i_{\mathrm{B}}$ a $i_{\mathrm{B}}=i_{\mathrm{C}} / \beta$, bude jako obvykle $i_{\mathrm{E}}=i_{\mathrm{C}}\left(1+\frac{1}{\beta}\right)$ a po dosazení do vztahu (6-42) můžeme určit proud zátěží $R_{Z}$

$$
i_{\mathrm{C}} \approx \frac{u_{1}}{R} \frac{1}{1+1 / \beta} \approx \frac{u_{1}}{R} \text { pro } u_{1}>0 .
$$

Pokud potřebujeme připojit zátěž $\mathrm{R}_{\mathrm{Z}}$ jedním koncem k zápornému napájecímu napětí, musíme použít komplementární tranzistor - viz Obr. $6.13 \mathrm{~b}$. Obvod je pro $u_{1}<0$ popsán stejnou rovnicí (6-43).

Pro některé přesné účely může být na závadu, že výstupní proud $i_{\mathrm{C}}$ zdroje proudu je menší než proud $i_{\mathrm{E}}$ tekoucí emitorovým odporem. Poměrná chyba, která tím vzniká, činí $1 / \beta,(z d e)$

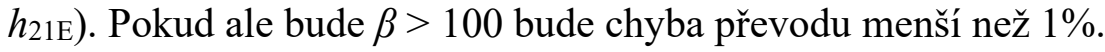




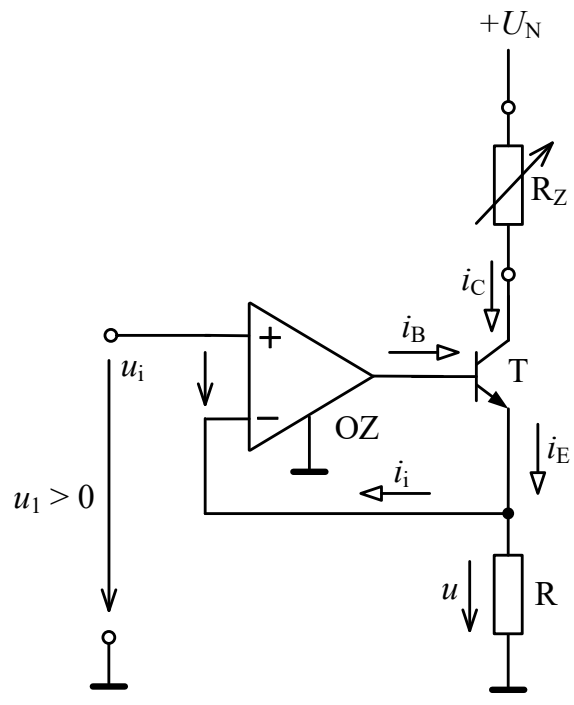

a

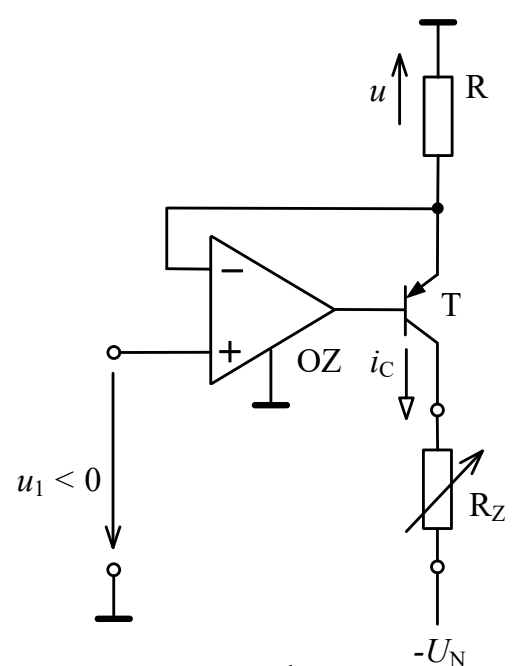

$\mathrm{b}$

Obr. 6.13: a) Ř́zený zdroj proudu s tranzistorem, b) řízený zdroj proudu s komplementárním tranzistorem

Situaci podstatně zlepší použití dvojice tranzistorů v Darlingtonově zapojení s celkovým proudovým zesilovacím činitelem $\beta=\beta_{1} \beta_{2}$. Takto se omezí velikost chyby způsobené rozdílností proudů emitoru a kolektoru na zlomky promile. Přŕklad takového uspořádání je naznačen na Obr. 6.14.

Ještě lepších výsledků lze dosáhnout s tranzistorem řízeným polem (viz Obr. 6.15). Proud tekoucí do rrídící elektrody je zanedbatelný vůči ostatním proudům $\mathrm{v}$ obvodu, $i_{\mathrm{G}} \approx 0$ a tedy

$$
i_{\mathrm{D}} \approx i_{\mathrm{S}} \approx \frac{u}{R} \approx \frac{u_{1}}{R} \quad \text { pro } \quad u_{1}>0
$$

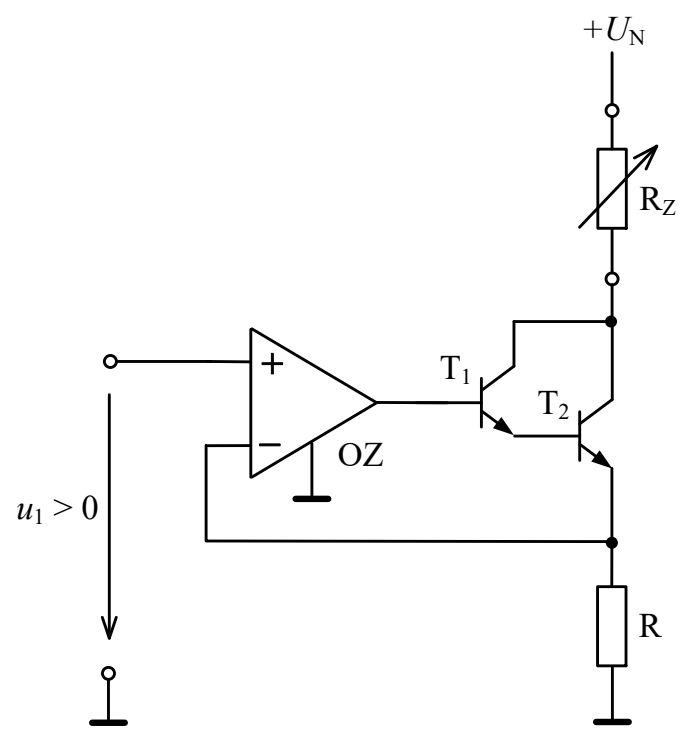

Obr. 6.14: Ř́zený zdroj proudu s Darlingtonovou dvojicí tranzistorů 


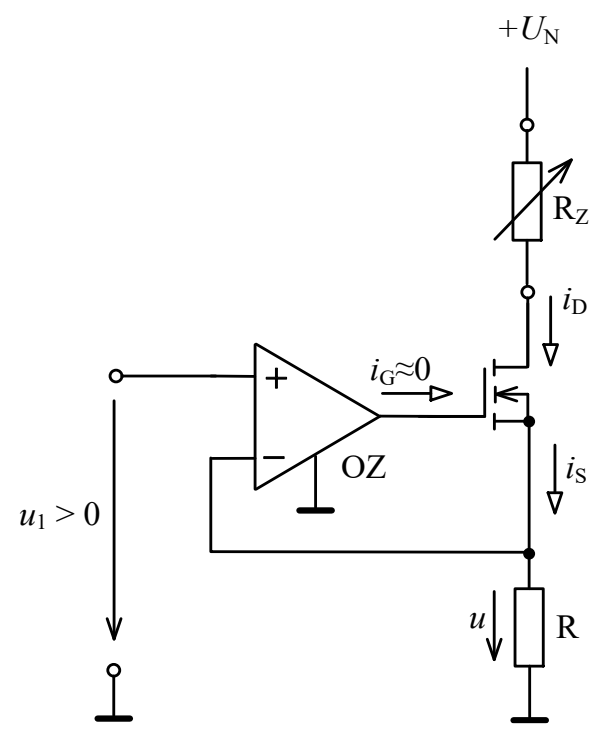

Obr. 6.15: Řízený zdroj proudu s tranzistorem řízeným polem

Výhodou všech těchto zapojení je skutečnost, že oproti jednoduchým zdrojům s tranzistory nezávisí proud zátěží na napětí $u_{\mathrm{BE}}$ nebo $u_{\mathrm{GS}}$ a tato napětí nemusí být ani přesně nastavena. Předřazený $\mathrm{OZ}$ si totiž toto napětí automaticky vždy dostaví na požadovanou hodnotu. Určitou nevýhodou těchto zdrojů proudu je skutečnost, že jeden konec zátěže Rz musí být připojen na napájecí napětí.

$\check{R} a d a$ proudových zdrojů pro prevodníky $D / A$. Pro některé typy číslicově analogových převodníků je zapotřebí řada váhových zdrojů proudu. Jako př́klad uvedeme řadu proudových zdrojů zapojených podle Obr. 6.16. Tranzistory $\mathrm{T}_{1}$ až $\mathrm{T}_{4}$ dodávají na výstup proudy, jež jsou po řadě v poměru $1: 2: 4: 8$. Aby úbytek napětí $u_{\mathrm{BE}}$ byl u všech tranzistorů shodný při různých kolektorových proudech má každý tranzistor počet emitorů resp. plochu přechodu báze - emitor odpovídající poměrné velikosti proudu jím dodávaného, tzn. plochy přechodu báze-emitor budou v poměru A : 2A : 4A : 8A. Vlastnosti obvodu jsou zlepšeny proudovou zpětnou vazbou, využívající emitorových rezistorů $\mathrm{R}_{1}$ a $\mathrm{R}_{4}$, jejichž odpory jsou odstupňovány nepřímo úměrně protékajícím proudům. Řídicí napětí pro všechny čtyři proudové zdroje je dodáváno operačním zesilovačem, $v$ jehož zpětnovazební síti je zařazen pátý proudový zdroj uvažované řady, který má stejné elektrické vlastnosti jako zdroj s tranzistorem $T_{3}$ a kterým teče proud $4 I$. Vzhledem $\mathrm{k}$ tomu, že tranzistor $\mathrm{T}_{0} \mathrm{z}$ hlediska zavedení zpětné vazby signál invertuje, jsou vstupní svorky operačního zesilovače zaměněny. Protože u operačního zesilovače předpokládáme, že pracuje $\mathrm{s}$ přibližně nulovým vstupním napětím a přibližně nulovým vstupním proudem, bude v obvodu zpětnovazební sítě platit $I_{\mathrm{R}} \approx 4 I$ a tedy

$$
I \approx I_{\mathrm{R}} / 4 \approx U_{\mathrm{R}} / 4 R_{\mathrm{R}} \text {. }
$$




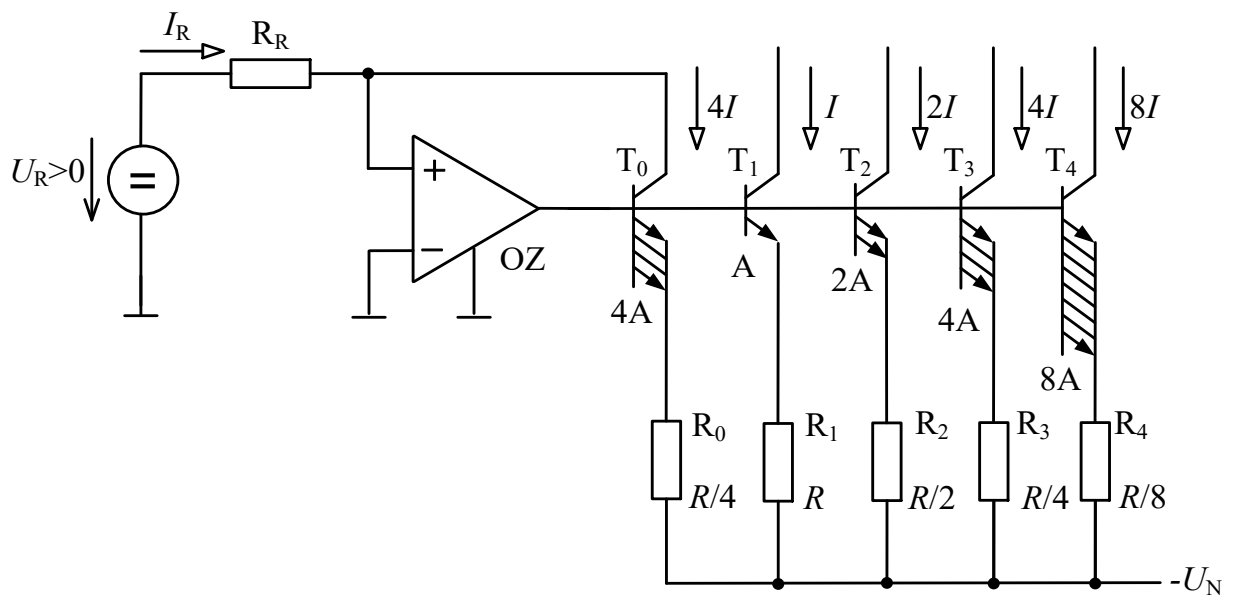

Obr. 6.16: Řada proudových zdrojů pro převodníky D/A

Výhodou obvodu je, že je málo citlivý na teplotní změny. To proto, že vliv teploty je u všech použitých tranzistorů $\mathrm{T}_{0}$ až $\mathrm{T}_{4}$ prakticky vzato stejný, takže zpětná vazba, která řídí otvírání či přivírání tranzistoru $\mathrm{T}_{0}$ zasáhne vždy současně i u ostatních tranzistorů.

Řizené zdroje proudu pro neuzemněnou zátěž. Na Obr. 6.17 je naznačen jednoduchý převodník napětí na proud. Převodník využívá vlastností invertujícího zapojení operačního zesilovače. Předpokládáme-li, že se vlastnosti operačního zesilovače blíží ideálním, je proud tekoucí zátěží př́mo úměrný vstupnímu napětí

$$
i_{\mathrm{Z}} \approx i \approx \frac{u}{R}
$$

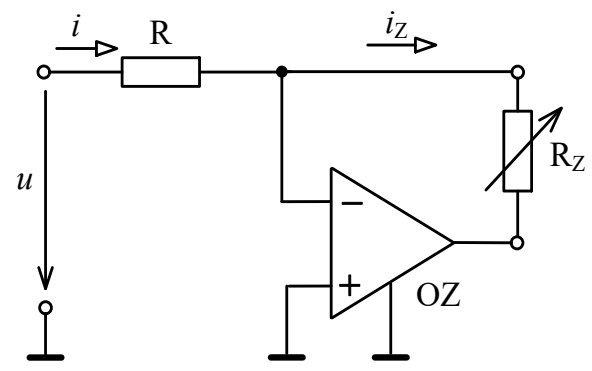

Obr. 6.17: Invertující zapojení jako zdroj proudu

Výhodou zapojení je skutečnost, že vychází z invertujícího uspořádání a tedy se neuplatní vliv souhlasného napětí. Nevýhodou je, že vyžaduje, aby zdroj vstupního napětí byl schopen dodávat proud tekoucí zátěží. Také je nevýhodné, že jeden konec zátěže je připojen k invertujícímu vstupu $\mathrm{OZ}$, což při dlouhých př́ívodech může vést ke zhoršení šumu nebo i k nestabilitě obvodu.

Na Obr. 6.18 je uvedeno zapojení řízeného zdroje proudu, které využívá vlastností neinvertujícího zapojení operačního zesilovače. Pro proud tekoucí do zátěže platí stejně jako $\mathrm{v}$ předchozím

$$
i_{\mathrm{Z}} \approx i \approx \frac{u}{R}
$$




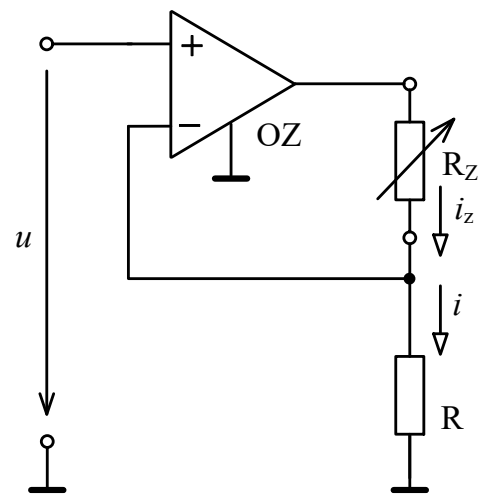

Obr. 6.18: Neinvertující zapojení jako zdroj proudu

U tohoto zapojení je proud tekoucí do zátěže dodáván z operačního zesilovače. Není obvykle problém doplnit operační zesilovač tzv. proudovým posilovačem, který pak dodá potřebný výstupní proud. Přesnost obvodu je však omezena souhlasným napětím stejně jako je tomu u neinvertujícího zapojení. Obdobně jako v předchozím př́padě je nevýhodné, že jeden konec zátěže je připojen k citlivému invertujícímu vstupu OZ.

Invertující uspořádání převodníku, které nemá nevýhody předchozích dvou uspořádání je nakresleno na Obr. 6.19. Protože pracuje na principu invertujícího zesilovače, souhlasné napětí OZ se neuplatní. Zátěž není přímo připojena k invertující svorce OZ. Proud do zátěže je dodáván z výstupu OZ, který je možno v př́padě nutnosti doplnit proudovým posilovačem. Předpokládáme-li, že v ideálním př́ípadě je napětí mezi diferenčními vstupy nulové, bude napětí na rezistorech $\mathrm{R}_{2}$ a $\mathrm{R}_{3}$ stejné $i_{2} R_{2} \approx i_{3} R_{3}$, a tedy

$$
i_{3} \approx i_{2} R_{2} / R_{3}
$$

přičemž

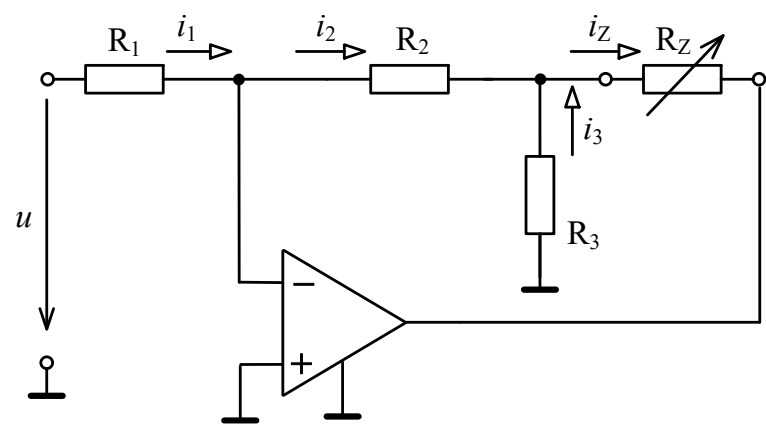

Obr. 6.19: Invertující uspořádání řízeného zdroje proudu

$$
i_{2} \approx i_{1} \approx u / R_{1} \text {. }
$$

Proud zátěží má pak velikost

$$
i_{\mathrm{Z}}=i_{2}+i_{3} \approx i_{1}\left(1+\frac{R_{2}}{R_{3}}\right)=\frac{u}{R_{1}}\left(1+\frac{R_{2}}{R_{3}}\right) .
$$

Hodnota proudu $i_{1}$ je $\mathrm{v}$ tomto př́padě zesílena činitelem $1+R_{2} / R_{3}$, takže zdroj vstupního napětí $u_{1}$ není zatěžován celým proudem do zátěže $\mathrm{R}_{\mathrm{z}}$. 
Řizené zdroje proudu pro uzemněnou zátěž. U všech předchozích zapojení nebylo možno uzemnit zátěž. Mnohdy však potřebujeme dodávat proud uzemněné zátěži. Příklad zdroje, který to umožňuje, je nakreslen na Obr. 6.20. Pro proudy v obvodu platí

$$
\frac{u_{\mathrm{N}}}{R_{3}} \approx \frac{u_{0}-u_{\mathrm{N}}}{R_{4}}
$$

a

$$
\frac{u_{1}-u_{\mathrm{P}}}{R_{1}} \approx \frac{u_{\mathrm{P}}-u_{\mathrm{Z}}}{R_{2}}
$$

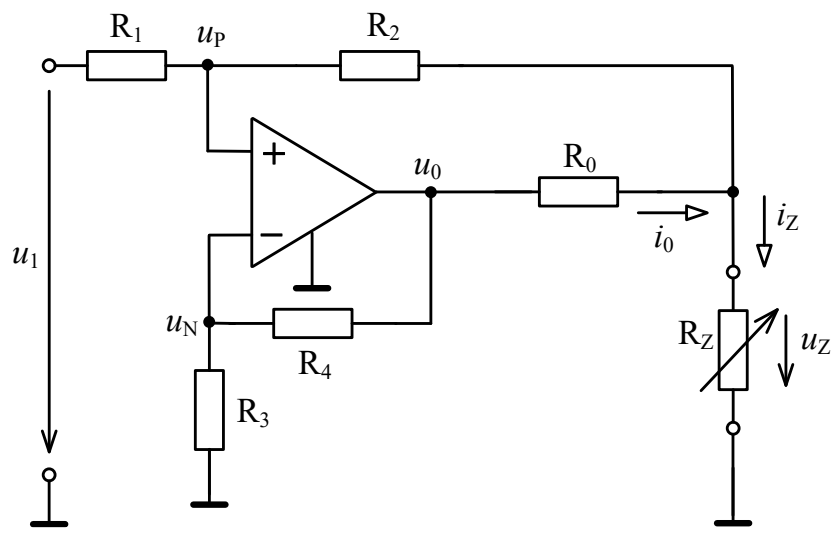

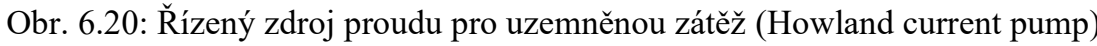

Zvolíme-li $R_{1}=R_{3}=R$ a $R_{2}=R_{4}=k R$ můžeme z rovnice (6-51) stanovit napětí

$$
u_{\mathrm{N}} \approx \frac{u_{0}}{k+1}
$$

a z rovnice (6-52) pak napětí

$$
u_{\mathrm{P}} \approx \frac{k u_{1}+u_{\mathrm{Z}}}{k+1}
$$

$\mathrm{Z}$ rovnosti $u_{\mathrm{N}} \approx u_{\mathrm{P}}$ můžeme nyní stanovit napětí na rezistoru $\mathrm{R}_{0}$

$$
u_{0}-u_{\mathrm{Z}} \approx k u_{1} \text {. }
$$

Bude-li $R_{0}<<R_{2}$, resp. $R_{0}<<k R$, můžeme proud rezistorem $\mathrm{R}_{2}$ zanedbat a potom

$$
i_{\mathrm{Z}} \approx i_{0} \approx \frac{u_{0}-u_{\mathrm{Z}}}{R_{0}} \approx k \frac{u_{1}}{R_{0}} \text {. }
$$

Aby maximální hodnota zátěže $R_{Z}$ nebyla limitována napětím na této zátěži, volí se úbytek napětí na rezistoru $R_{0}$ kolem $1 \mathrm{~V}$. Např. pro zdroj proudu 1 A by se volil odpor $R_{0}=1 \Omega$.

Jak bylo již řečeno, výhodou zapojení řízeného zdroje proudu na Obr. 6.20 je uzemněná zátěž a skutečnost, že proud je dodáván do zátěže z výstupu operačního zesilovače, který je možno doplnit proudovým posilovačem. U velmi přesných aplikací však může být na závadu citlivost tohoto zapojení na souhlasné napětí OZ.

Zapojení řízeného zdroje proudu se dvěma operačními zesilovači, u kterého se neuplatňuje vliv souhlasného napětí OZ je uvedeno na Obr. 6.21. Zapojení se užívá ve velmi přesných aplikacích, kdy požadujeme, aby proud byl dodáván do uzemněné zátěže. 


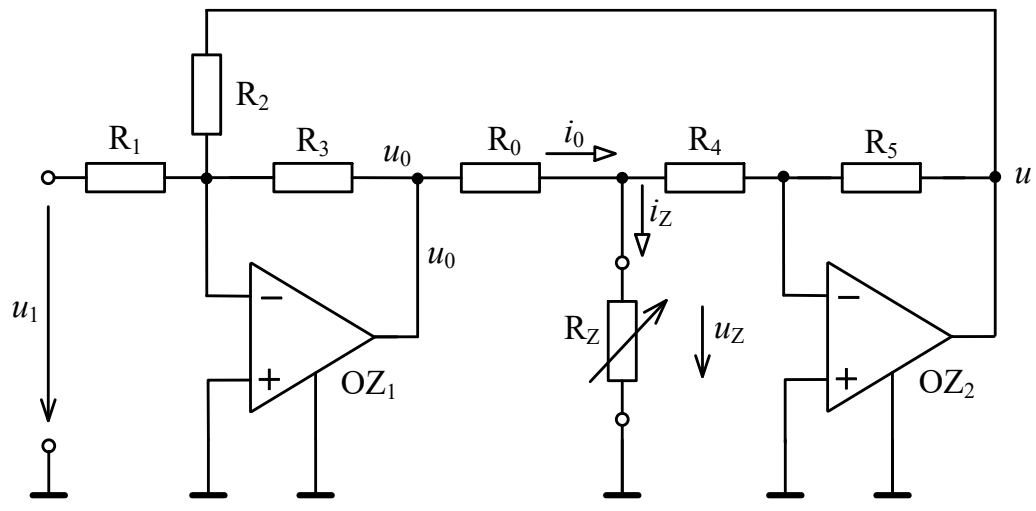

Obr. 6.21: Zapojení řizeného zdroje proudu, u kterého se neuplatňuje vliv souhlasného napětí

Operační zesilovač $\mathrm{OZ}_{1}$ je zapojen jako invertující sčítací zesilovač a proto

$$
u_{0} \approx-\frac{R_{3}}{R_{1}} u_{1}-\frac{R_{3}}{R_{2}} u \text {. }
$$

$\mathrm{Na}$ výstupu invertujícího zesilovače s $\mathrm{OZ}_{2}$ bude napětí

$$
u \approx-\frac{R_{5}}{R_{4}} u_{\mathrm{Z}}
$$

a po dosazení za $u$ do rovnice (6-56) bude

$$
u_{0} \approx-\frac{R_{3}}{R_{1}} u_{1}+\frac{R_{3}}{R_{2}} \frac{R_{5}}{R_{4}} u_{\mathrm{Z}} .
$$

Zvolíme-li $R_{1}=R_{2}=R_{5}=R$ a $R_{3}=R_{4}=k R$ můžeme z předchozí rovnice vyčíslit napětí na rezistoru $R_{0}$

$$
u_{0}-u_{\mathrm{Z}} \approx-k u_{1} \text {. }
$$

Bude-li $R_{0}<<R_{4}$ resp. $R_{0}<<k R$, můžeme proud rezistorem $\mathrm{R}_{4}$ zanedbat a

$$
i_{\mathrm{Z}} \approx i_{0} \approx \frac{u_{0}-u_{\mathrm{Z}}}{R_{0}} \approx-k \frac{u_{1}}{R_{0}} .
$$

V některých případech požadujeme, aby výstupní proud byl řízen rozdílem dvou napětí. To nám umožňuje zapojení na Obr. 6.22. Předpokládejme $R_{1}=R_{3}=R, R_{2}=R_{4}=k R$. Potom pro proudy v obvodu platí

$$
\begin{aligned}
& \frac{u_{1}-u_{\mathrm{N}}}{R} \approx \frac{u_{\mathrm{N}}-u_{0}}{k R} \\
& \frac{u_{2}-u_{\mathrm{P}}}{R} \approx \frac{u_{\mathrm{P}}-u_{Z}}{k R} .
\end{aligned}
$$




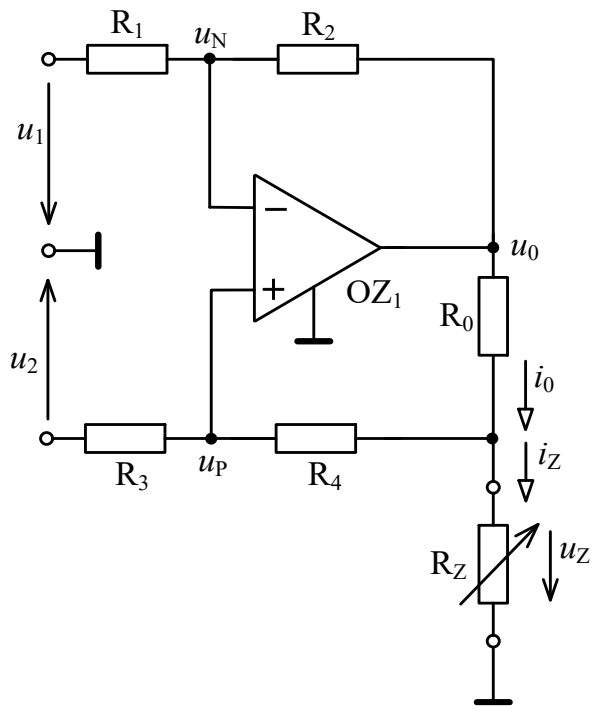

Obr. 6.22: Diferenční zapojení řízeného zdroje proudu

Z rovnice (6-62) vyčíslíme

$$
u_{\mathrm{N}} \approx \frac{k u_{1}+u_{0}}{k+1}
$$

a obdobně z rov. (6-63) dostáváme

$$
u_{\mathrm{P}} \approx \frac{k u_{2}+u_{\mathrm{Z}}}{k+1}
$$

$\mathrm{Z}$ rovnosti $u_{\mathrm{N}} \approx u_{\mathrm{P}}$ vypočítáme napětí $u_{0}-u_{\mathrm{Z}}$ na rezistoru $\mathrm{R}_{0}$

$$
u_{0}-u_{\mathrm{Z}} \approx k\left(u_{2}-u_{1}\right) \text {. }
$$

Zvolíme-li $R_{0}<<R_{4}$, resp. $R_{0}<<k R$, můžeme proud rezistorem $\mathrm{R}_{4}$ zanedbat a pro výstupní proud bude platit

$$
i_{\mathrm{Z}} \approx i_{0} \approx \frac{u_{0}-u_{\mathrm{Z}}}{R_{0}} \approx k \frac{u_{2}-u_{1}}{R_{0}}
$$

I v tomto př́padě odpor rezistoru $\mathrm{R}_{0}$ volíme tak, aby na něm za provozu nevznikl prŕliš velký úbytek napětí. Obvykle dostačuje, aby na rezistoru $\mathrm{R}_{0}$ bylo napětí kolem $1 \mathrm{~V}$ při maximálním proudu do zátěže.

\subsection{Stejnosměrné referenční zdroje napětí}

Ve stejnosměrných referenčních zdrojích se využívají bud' přímo základní zapojení operačního zesilovače, nebo jeho modifikace. Při aplikaci se vychází z výhodných vlastností zpětnovazebních zapojení OZ, které umožňují zatěžovat standardní referenční zdroj napětí (např. teplotně kompenzovanou referenční diodu) minimálním či konstantním odběrem, dále se využívá malého výstupního odporu operačního zesilovače se zavedenou zápornou zpětnou vazbou, který dovoluje zatížit výsledný referenční zdroj proudem řádu mA i více.

Referenční zdroje s podpovrchovou referenční diodou. Základní uspořádání referenčního zdroje je uvedeno na Obr. 6.23 . 


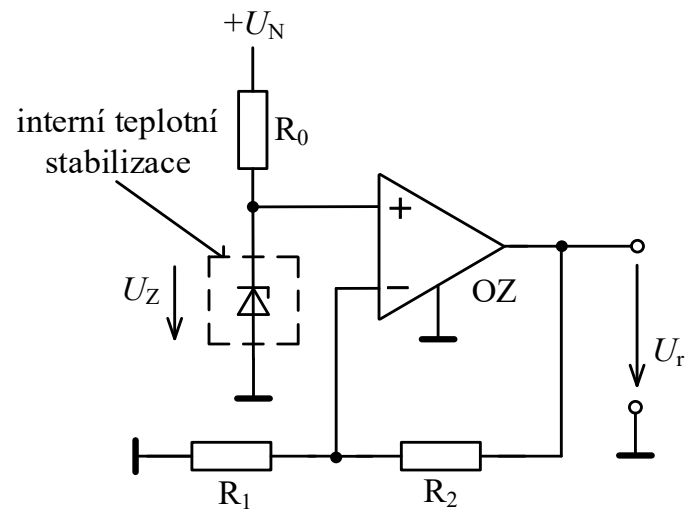

a

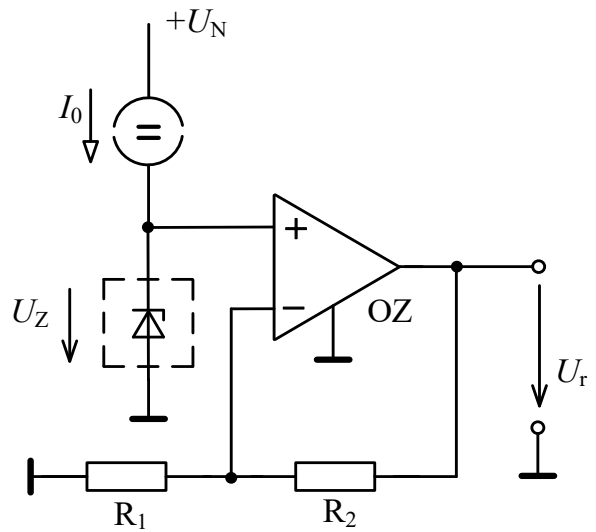

$\mathrm{b}$

Obr. 6.23: ̌̌ešení ss referenčního zdroje s podpovrchovou referenční diodou pro $U_{\mathrm{R}} \geq U_{\mathrm{Z}}$

Pro nastavení pracovního bodu referenční diodou se užije bud' zdroj napětí a rezistor (Obr. 6.23a), nebo v integrovaných obvodech zdroj konstantního proudu (Obr. 6.23b). V obou prrípadech je zřejmé, že referenční dioda není zatěžována výstupním proudem dodávaným do zátěže a dioda má nastaven stále stejný pracovní bod.

Na místě referenčního prvku se obvykle použije podpovrchová referenční dioda s $U_{Z} \approx \approx$ $7,25 \mathrm{~V}$, kdy k průrazu PN přechodu dochází ve větší hloubce polovodiče pod rozhraním křemíkpasivační vrstva. Takováto referenční dioda se vyznačuje výrazně lepší dlouhodobou teplotní stabilitou napětí a o řád menším nízkofrekvenčním šumem, než běžná referenční dioda nebo referenční zdroje využívající princip zakázané šířky pásma v polovodiči (viz dále). Na stejném čipu jsou i teplotní čidla a teplotní regulátor, který udržuje diodu na stabilní teplotě (obvykle $90^{\circ} \mathrm{C}$ ), která je podstatně vyšší než je běžná teplota uvnitř př́istroje. Tím se výrazně potlačí vliv okolní teploty a teplotní ujíždění referenčního napětí je pak o řád menší než u běžné referenční diody. Obvykle se dá docílit teplotní ujiždění $\Delta U_{z} / \Delta T$ lepší než $2 \mu \mathrm{V} /{ }^{\circ} \mathrm{C}$.

Protože pro výstupní napětí obvodů z Obr. 6.23 platí

$$
U_{\mathrm{R}} \approx\left(1+\frac{R_{2}}{R_{1}}\right) U_{\mathrm{Z}}
$$

je zřejmé, že tato uspořádání jsou vhodná pro řešení referenčních zdrojů s napětím $U_{\mathrm{R}} \geq 7,25$ V. Pokud potřebujeme získat napětí nižší, pak se za referenční prvek zařadí odporový dělič s oddělovacím zesilovačem tak, jak je to naznačeno na Obr. 6.24. Potom

$$
U_{\mathrm{R}} \approx \frac{R_{2}}{R_{1}+R_{2}} U_{\mathrm{Z}}
$$

Poznamenejme, že v tomto príípadě je obvod diody zatížen sériovou kombinací $R_{1}$ a $R_{2}$ a aby nedošlo k posunutí pracovního bodu diody, musíme dimenzovat zdroj $I_{0}$ na větší proud

$$
I_{0}=I_{\mathrm{z}}+U_{\mathrm{Z}} /\left(R_{1}+R_{2}\right),
$$

kde Iz značí pracovní proud referenční diody. 


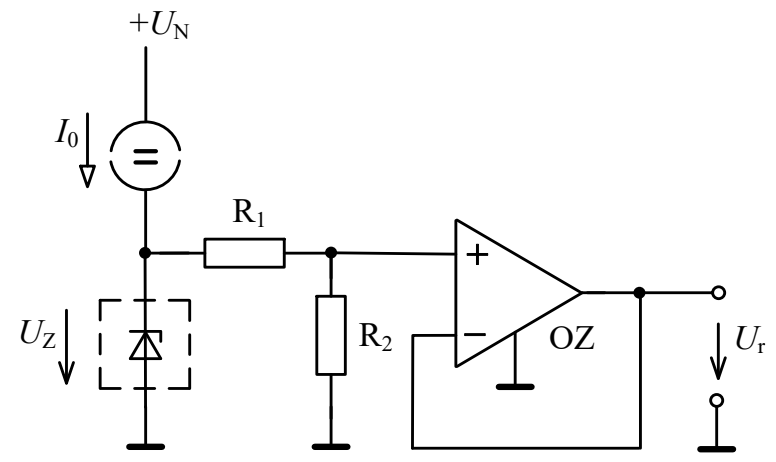

Obr. 6.24: Zapojení ss referenčního zdroje pro $U_{\mathrm{R}}<U_{\mathrm{Z}}$

Pro získání záporného referenčního napětí se pro oddělení referenční diody od zátěže použije invertující zapojení OZ, jak je to naznačeno na Obr. 6.25.

$$
U_{\mathrm{R}} \approx-\frac{R_{2}}{R_{1}} U_{\mathrm{Z}}
$$

Výstupní napětí může být poměrem $R_{2} / R_{1}$ nastaveno na požadovanou hodnotu větší či menší než $-U_{\mathrm{Z}}$.

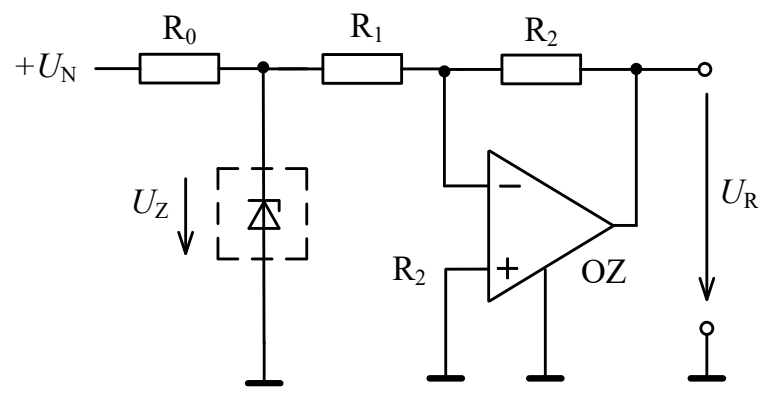

Obr. 6.25: Zapojení ss referenčního zdroje pro získání záporného napětí

Podotkněme pouze, že při určování odporu rezistoru $\mathrm{R}_{0} \mathrm{v}$ zapojení podle Obr. 6.25 musíme počítat s tím, že obvod referenční diody je zatížen rezistorem $\mathrm{R}_{1}$, a proto

$$
R_{0}=\frac{U_{\mathrm{N}}-U_{\mathrm{Z}}}{I_{\mathrm{Z}}+U_{\mathrm{Z}} / R_{1}},
$$

kde $I_{Z}$ Je pracovní proud referenční diody nastavující její pracovní bod.

V případech, kdy výstupní napětí referenčního zdroje má být větší než je napětí na referenční diodě, můžeme docílit vyšších hodnot činitele stabilizace tak, že pracovní bod referenční diody odvodíme nikoliv od napájecího napětí, ale z výstupu samotného referenčního zdroje, jak je to naznačeno na Obr. 6.26. 


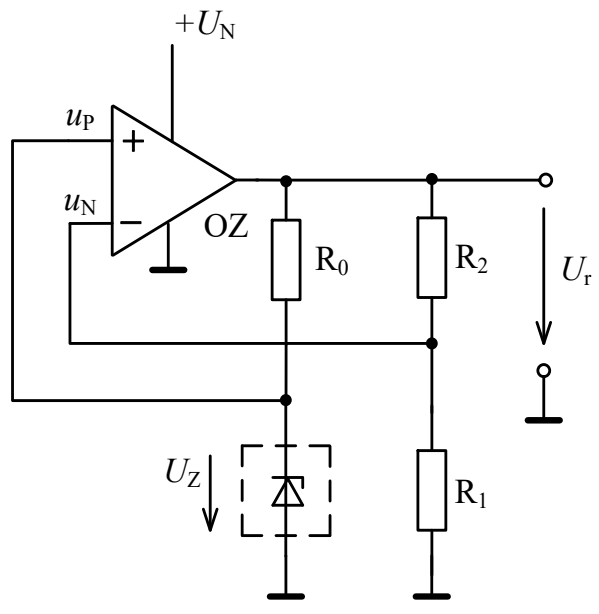

Obr. 6.26: Využití výstupního napětí referenčního zdroje pro nastavení proudu referenčním prvkem

Protože na výstupu referenčního zdroje bude za provozu vždy kladné napětí, není nutné operační zesilovač ani napájet symetricky. Operační zesilovač si bude na diferenčním vstupu udržovat nulové napětí, tj. $u_{\mathrm{P}} \approx u_{\mathrm{N}}$ a tedy

$$
U_{\mathrm{Z}} \approx \frac{R_{1}}{R_{1}+R_{2}} U_{\mathrm{R}}
$$

Proto

$$
U_{\mathrm{R}} \approx\left(1+\frac{R_{2}}{R_{1}}\right) U_{\mathrm{Z}}
$$

Referenční zdroje pracující na principu zakázané šǐrky pásma v polovodiči. Na zcela jiném principu než dosud uvedené zdroje referenčního napětí pracuje zdroj, využívající šířky zakázaného pásma v polovodičích [1]. Je zapojen podle Obr. $6.27 \mathrm{a}$ a nemá nevýhody běžných referenčních diod pracujících v oblasti lavinového průrazu, především jejich velký vlastní šum a poměrně malou dlouhodobou teplotní stálost.
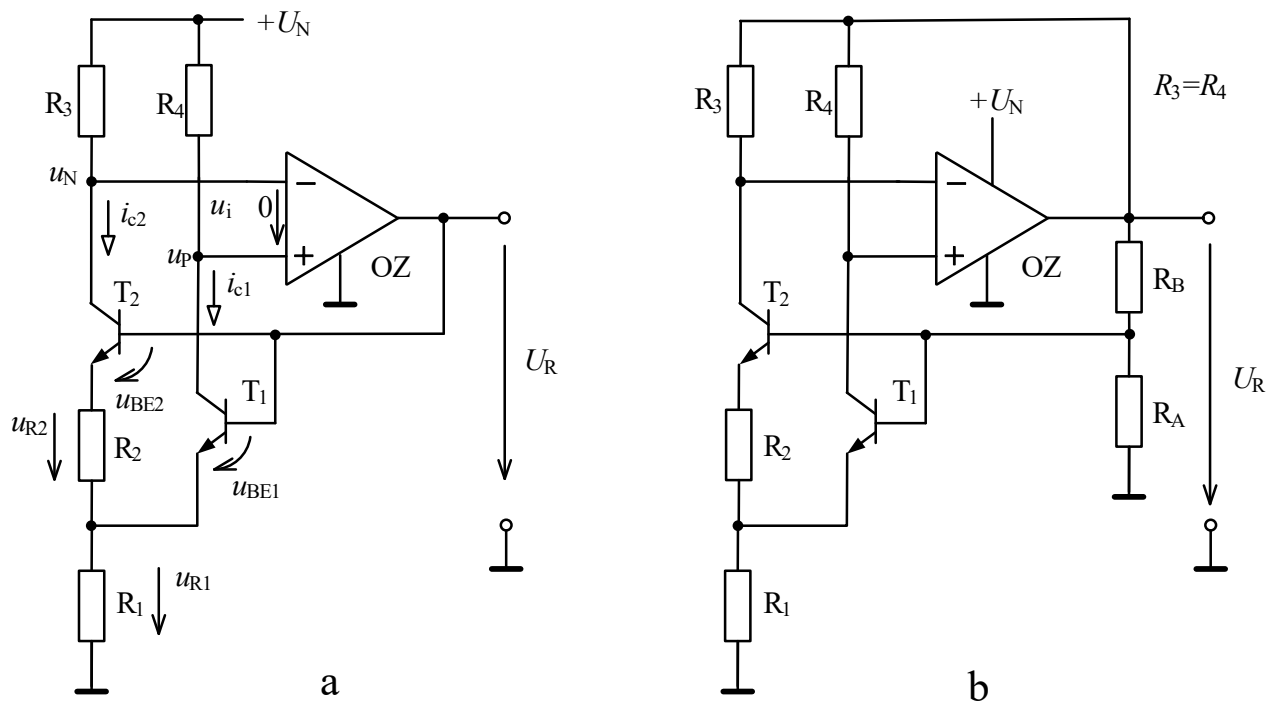

Obr. 6.27: Zdroj referenčního napětí založený na využití šířky zakázaného pásma v polovodiči: a) základní uspořádání, b) zvýšení výstupního napětí 
Odpory rezistorů $\mathrm{R}_{3}$ a $\mathrm{R}_{4}$ jsou shodné, $R_{3}=R_{4}$. Operační zesilovač nastavuje pracovní podmínky $\mathrm{v}$ obvodu s tranzistory $\mathrm{T}_{1}$ a $\mathrm{T}_{2}$ tak, aby na diferenčním vstupu OZ bylo napětí přibližně nulové, tj. aby $R_{3} i_{\mathrm{c} 2} \approx R_{4} i_{\mathrm{c} 1}$. Protože $R_{3}=R_{4}$, je $i_{\mathrm{c} 2} \approx i_{\mathrm{c} 1}$. Kolektorové proudy tranzistorů jsou úměrné ploše přechodu PN a platí pro ně vztahy

$$
\left.\begin{array}{l}
i_{\mathrm{c} 1} \sim A_{1} \mathrm{e}^{u_{\mathrm{BE} 1} / U_{\mathrm{T}}} \\
i_{\mathrm{c} 2} \sim A_{2} \mathrm{e}^{u_{\mathrm{BE} 2} / U_{\mathrm{T}}}
\end{array}\right\}
$$

kde $A_{1}$ a $A_{2}$ značí plochy přechodů PN tranzistorů $\mathrm{T}_{1}$ a $\mathrm{T}_{2}$ a kde $U_{\mathrm{T}}=k \mathrm{~T} / q$ je tzv. teplotní napětí. Protože v obvodu podle Obr. 6.27a je $i_{\mathrm{c} 1} \approx i_{\mathrm{c} 2}$, platí

$$
A_{1} \mathrm{e}^{u_{\mathrm{BE1}} / U_{\mathrm{T}}} \approx A_{2} \mathrm{e}^{u_{\mathrm{BE} 2} / U_{\mathrm{T}}}
$$

Odtud můžeme pro poměr ploch přechodů psát

$$
\frac{A_{2}}{A_{1}} \approx \frac{\mathrm{e}^{u_{\mathrm{BE} 1} / U_{\mathrm{T}}}}{\mathrm{e}^{u_{\mathrm{BE} 2} / U_{\mathrm{T}}}}=\mathrm{e}^{\left(u_{\mathrm{BE} 1}-u_{\mathrm{BE} 2}\right) / U_{\mathrm{T}}},
$$

resp. po zlogaritmování obou stran rovnice

$$
u_{\mathrm{BE} 1}-u_{\mathrm{BE} 2}=U_{\mathrm{T}} \ln \frac{A_{2}}{A_{1}} .
$$

Protože $u_{\mathrm{R} 2}=u_{\mathrm{BE} 1}-u_{\mathrm{BE} 2}$, můžeme s využitím rov. (6-77) psát

$$
u_{\mathrm{R} 2} \approx U_{\mathrm{T}} \ln \frac{A_{2}}{A_{1}} .
$$

Proud tekoucí rezistorem $R_{1}$ je dán součtem emitorových proudů tranzistorů $\mathrm{T}_{1}$ a $\mathrm{T}_{2}$. Protože tyto proudy jsou přibližně stejné, je proud rezistorem $\mathrm{R}_{1}$ přibližně dvojnásobný než proud rezistorem $\mathrm{R}_{2}$. Proto

$$
u_{\mathrm{R} 1} \approx\left(i_{\mathrm{E} 1}+i_{\mathrm{E} 2}\right) R_{1} \approx 2 i_{\mathrm{E} 2} R_{1}=2 \frac{u_{\mathrm{R} 2}}{R_{2}} R_{1} .
$$

Po dosazení z rovnice (6-78) bude

$$
u_{\mathrm{R} 1} \approx 2 \frac{R_{1}}{R_{2}} U_{\mathrm{T}} \ln \frac{A_{2}}{A_{1}}=2 \frac{R_{1}}{R_{2}} \frac{k T}{q} \ln \frac{A_{2}}{A_{1}} .
$$

Tranzistory $T_{1}$ a $T_{2}$ jsou vyrobeny společnou technologií na stejném čipu, avšak $T_{2}$ má obvykle desetkrát větší plochu přechodu $\mathrm{PN}$ mezi emitorem a bází než $\mathrm{T}_{1}, \mathrm{tj} . \mathrm{A}_{2} \approx 10 \mathrm{~A}_{1}$.

Výstupní napětí referenčního zdroje napětí dle Obr. 6.27a bude

$$
U_{\mathrm{R}}=u_{\mathrm{R} 1}+u_{\mathrm{BE} 1} \text {. }
$$

Je zřejmé, že záporný teplotní činitel $-2 \mathrm{mV} /{ }^{\circ} \mathrm{C}$ napětí $u_{\mathrm{BE} 1} \approx 0,6 \mathrm{~V}$ můžeme vykompenzovat teplotním činitelem $+2 \mathrm{mV} /{ }^{\circ} \mathrm{C}$ napětí $u_{\mathrm{R} 1}$ (viz rov.(6-80)). Lze dokázat, že teplotní činitel takovéhoto zdroje napětí je právě roven nule, když $U_{\mathrm{R}}=\Delta W / q=1,205 \mathrm{~V}$, kde $\Delta W$ je šířka zakázaného pásma pro křemík a $q$ je náboj elektronu. Požadované napětí $\quad u_{\mathrm{R} 1}$ $=U_{\mathrm{R}}-u_{\mathrm{BE} 1} \approx 0,6 \mathrm{~V}$ nastavíme podle rov. (6-80) vhodnou volbou poměru $R_{1} / R_{2}$, př́íp. poměrem $A_{1} / A_{2}$ (obvykle $A_{2} \approx 10 A_{1}$ ).

Je zřejmé, že uvedený referenční zdroj má poměrně malé výstupní napětí kolem $1,2 \mathrm{~V}$. Zapojení lze však jednoduše upravit připojením rezistorového děliče $\mathrm{k}$ výstupu $\mathrm{OZ}$ tak, jak je to naznačeno na Obr. $6.27 \mathrm{~b}$. Vlastnosti tohoto zapojení jsou dále zlepšeny tím, že tranzistory 
jsou napájeny z výstupního napětí samotného referenčního zdroje. Protože na výstupu bude stále kladné napětí, stačí nesymetrické napájení OZ. Pro výstupní napětí pak obdobně jako v př́ípadě zapojení na Obr. 6.26 platí

$$
U_{\mathrm{R}}=1,205 \cdot\left(1+\frac{R_{\mathrm{B}}}{R_{\mathrm{A}}}\right) .
$$

Uvedený princip využívají tzv. třísvorkové integrované referenční zdroje, které mají od výrobce předem nastaveno referenční napětí např. $2,5 \mathrm{~V}, 5 \mathrm{~V}, 10 \mathrm{~V}$. Aplikace těchto referenčních zdrojů je velmi jednoduchá. Pokud dostačuje nastavení výrobce s přesností $\pm 0,5 \%$, je zapojení skutečně tř́svorkové (viz Obr. 6.28a). Doplněním potenciometrického trimru (Obr. 6.28b) lze referenční napětí dostavit, obvykle ale jen v rozmezí $\pm 3 \%$. Pokud potřebujeme získat záporné referenční napětí, doplňuje se za referenční zdroj invertující zesilovač (Obr. 6.28c).

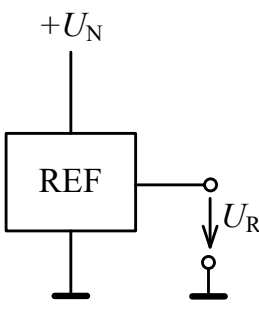

a

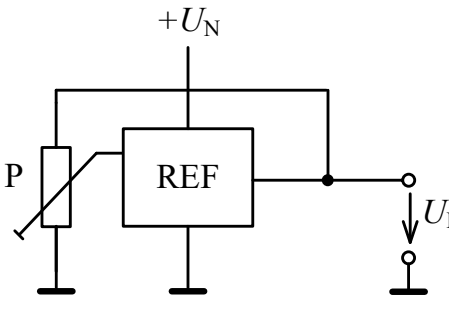

$\mathrm{b}$

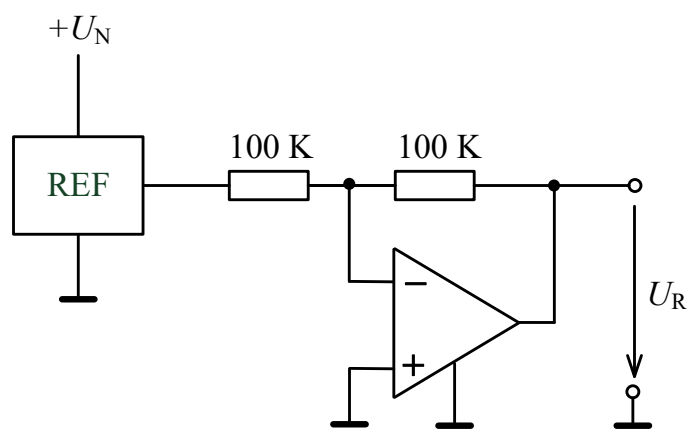

c

Obr. 6.28: Třísvorkový referenční zdroj: a) základní zapojení, b) dostavení výstupního napětí, c) záporné referenční napětí

\subsection{Stejnosměrné referenční zdroje proudu}

Existuje řada zapojení referenčních zdrojů proudu, které se více či méně zdařile pokoušejí eliminovat teplotní ujíždění výstupního proudu. Většinou však takovéto zdroje referenčního proudu nedosahují vlastností referenčních zdrojů napětí. Obvykle se proto využije zdroje referenčního napětí doplněného převodníkem napětí na proud.

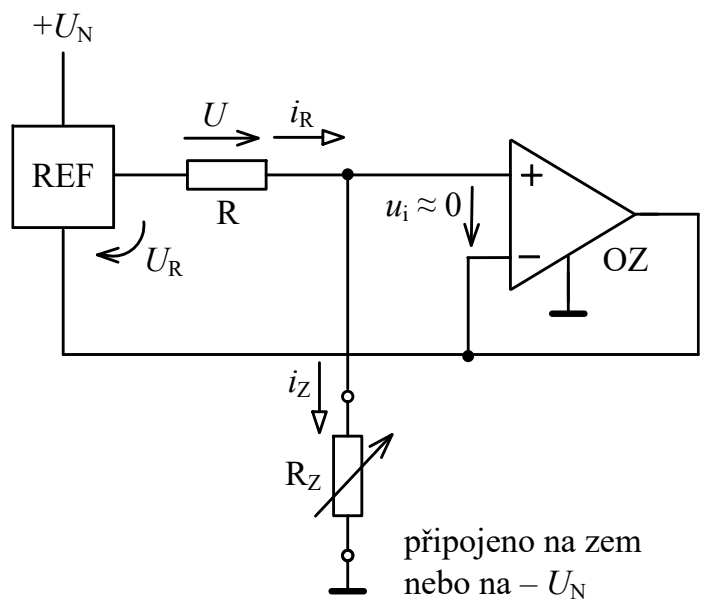

Obr. 6.29: Stejnosměrný zdroj referenčního proudu 
Zapojení referenčního zdroje proudu na Obr. 6.29 využívá tř́svorkový referenční zdroj napětí. Operační zesilovač udržuje mezi diferenčními svorkami nulové napětí a proto $U \approx U_{\mathrm{R}}$. Proud do neinvertující vstupní svorky OZ je zanedbatelný a proto výstupní proud

$$
i_{\mathrm{Z}} \approx i_{\mathrm{R}}=\frac{U}{R} \approx \frac{U_{\mathrm{R}}}{R} \text {. }
$$

Zátěž $\mathrm{R}_{Z}$ může být připojena u tohoto zapojení na zemní potenciál, nebo na záporné napájecí napětí.

Pokud potřebujeme zátěž referenčního zdroje proudu připojit na kladné napájecí napětí, můžeme použít uspořádání na Obr. 6.30. Operační zesilovač udržuje napětí mezi diferenčními svorkami nulové a proto $U \approx U_{\mathrm{R}}$. Pro výstupní proud pak platí

$$
i_{\mathrm{Z}} \approx i_{\mathrm{R}}=\frac{U}{R} \approx \frac{U_{\mathrm{R}}}{R}
$$

Kapacitor $C_{\mathrm{K}}$ zabraňuje rozkmitání obvodu a jeho doručená kapacita je $C_{\mathrm{K}} \geq 1 \mathrm{nF}$.

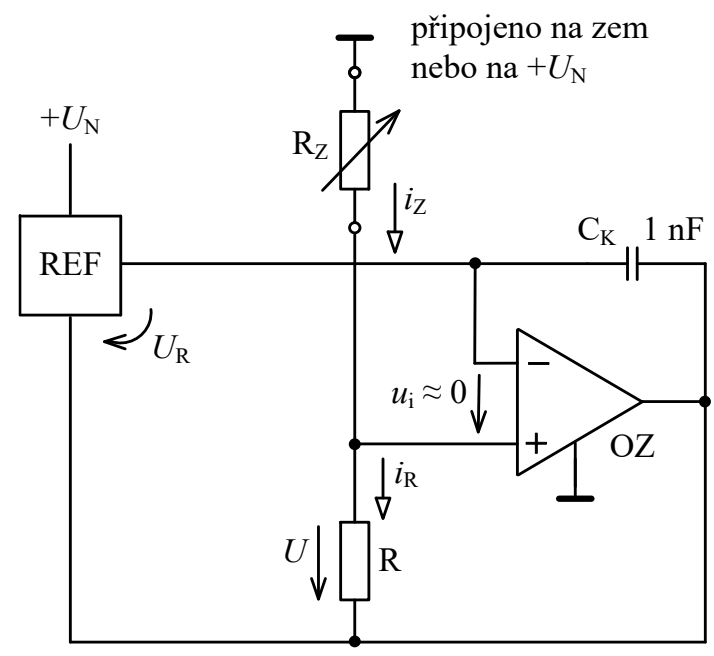

Obr. 6.30: Jiné zapojení stejnosměrného zdroje referenčního proudu

Pokud potřebujeme do zátěže dodat větší proud než je schopen dodat samotný zdroj referenčního napětí či operační zesilovač, použijeme převodník napětí na proud s tranzistorem řízeným polem nebo s Darlingtonovou dvojicí, jak je to naznačeno na Obr. 6.31. Operační zesilovač se snaží mezi diferenčními vstupy udržet nulové napětí a proto $U \approx U_{\mathrm{R}}$. Proud do rrídicí elektrody tranzistoru řízeného polem či do báze Darlingtonovi dvojice je zanedbatelný a proto

$$
i_{\mathrm{Z}} \approx i_{\mathrm{R}} \approx \frac{U}{R} \approx \frac{U_{\mathrm{R}}}{R}
$$




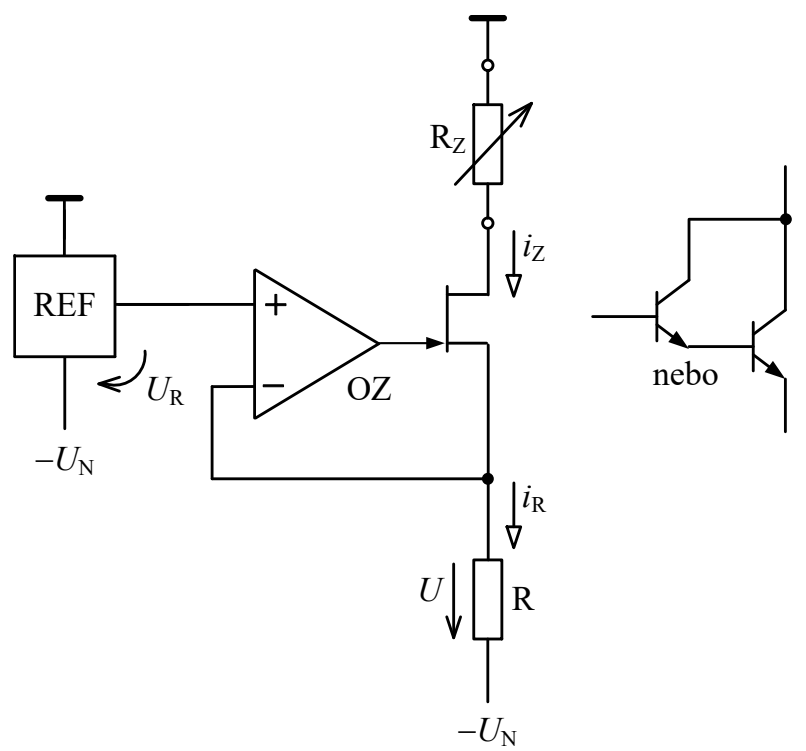

Obr. 6.31: Zapojení referenčního zdroje proudu s tranzistorem řízeným polem

Aby hodnota proudu $i_{z}$ zátěží nebyla omezena napětím na zátěži, je celý systém ss posunut tak, že zdroj referenčního napětí má napájecí svorku připojenu na zem a zemní svorku na $-U_{\mathrm{N}}$ a rezistor $\mathrm{R}$ je připojen nikoliv na zem, ale také na $-U_{\mathrm{N}}$. Skutečnost, že referenční napětí je nyní vztaženo $\mathrm{k}-U_{\mathrm{N}}$ nevadí, protože napětí na rezistoru $\mathrm{R}$ je vztaženo také $\mathrm{k}-U_{\mathrm{N}}$.

\subsection{Integrátor a derivátor}

Použijeme-li ve zpětnovazební síti operačního zesilovače místo rezistorů obvodové prvky, které mají reaktanční charakter, bude přenos obvodu funkcí kmitočtu. Tímto způsobem se dají realizovat téměř dokonalé integrační a derivační obvody.

\section{Integrátor}

Dnes již klasickým obvodem analogové techniky je integrátor s operačním zesilovačem, jehož výstupní napětí je úměrné integrálu vstupního napětí podle času. V analogových výpočetních systémech se užíval především k realizaci matematické operace integrace. Dnes však nalézá integrátor nebo jeho modifikace použití v mnoha dalších obvodech, např. jako stavební blok kmitočtových filtrů.

Základní uspořádání integrátoru je uvedeno na Obr. 6.32a. Podobnost s invertujícím zapojením operačního zesilovače je zřejmá na první pohled; zpětnovazební rezistor je zde nahrazen kapacitorem C. Řešení obvodu je proto obdobné. Rezistorem teče proud $i_{1}(t)=u_{1}(t) / R$ a integračním kapacitorem proud $i_{\mathrm{C}}(t)=C \mathrm{~d} u_{\mathrm{C}}(t) / \mathrm{d} t \approx-C \mathrm{~d} u_{2}(t) / \mathrm{d} t$. Protože $i_{1} \approx i_{\mathrm{C}}, \mathrm{tj}$.

$$
\frac{u_{1}(t)}{R} \approx-C \frac{\mathrm{d} u_{2}(t)}{\mathrm{d} t}
$$

bude 


$$
u_{2}(t) \approx-u_{C}\left(t_{0}\right)-\frac{1}{C R} \int_{t_{0}}^{t_{0}+t} u_{1}(t) \mathrm{d} t .
$$

kde $u_{\mathrm{C}}\left(t_{0}\right)$ značí tzv. integrační konstantu a představuje počáteční nabití kapacitoru $\mathrm{C}$ $\mathrm{v}$ okamžiku $t_{0}$ před zahájením integrace.

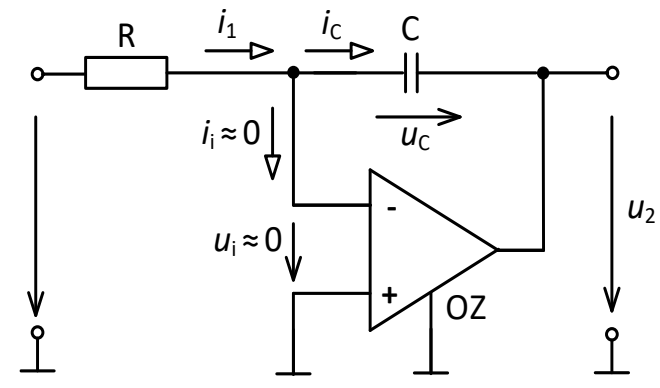

a

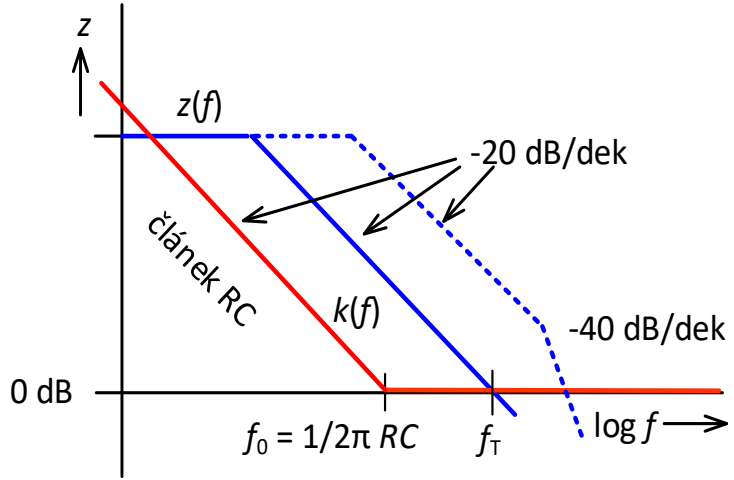

$\mathrm{b}$

Obr. 6.32: a) Integrátor s operačním zesilovačem, b) ke kmitočtové stabilitě integrátoru

Obvykle se před započetím integrace integrační kapacitor vybije na nulu a pak pro $t_{0}=0 \mathrm{je}$ $u_{\mathrm{C}}\left(t_{0}\right)=0$. Výstupní napětí integrátoru potom

$$
u_{2}(t) \approx-\frac{1}{C R} \int_{0}^{t} u_{1}(t) \mathrm{d} t
$$

Časová konstanta $\tau=C R$ je tzv. ,,charakteristický čas““ integrátoru.

Při realizaci integrátoru je nutno věnovat pozornost výběru OZ, protože obvod může být nestabilní. Na Obr. 6.32b je nakreslena charakteristická závislost zisku OZ na kmitočtu $f$, která $\mathrm{v}$ př́ipadě $\mathrm{OZ}$ se standardním poklesem kmitočtové charakteristiky klesá $\mathrm{s}$ rostoucím kmitočtem se sklonem $20 \mathrm{~dB} /$ dek a s tímto sklonem protíná i osu jednotkového zesílení $(0 \mathrm{~dB})$ a v případě OZ s rychlým poklesem kmitočtové charakteristiky protíná osu $0 \mathrm{~dB}$ se sklonem $40 \mathrm{~dB} / \mathrm{dek}$ (vyznačeno čárkovaně). Označíme-li zpětnovazební poměr článku RC při rozpojené smyčce zpětné vazby $\bar{\beta}=R /\left(R+\bar{Z}_{\mathrm{C}}\right)$, bude kmitočtová charakteristika $k(f)=20 \log (1 /|\bar{\beta}|)$ nejprve klesat se sklonem $20 \mathrm{~dB} /$ dek a osu $0 \mathrm{~dB}$ protne při kmitočtu $f_{0}=1 / 2 \pi R C$ a pak bude tato charakteristika sledovat osu $0 \mathrm{~dB}$. Podle Bodeho kritéria stability se musí tato křivka přibližovat ke kmitočtové závislosti zisku OZ rychlostí $20 \mathrm{~dB} / \mathrm{dek}$, což bude splněno pouze v př́padě OZ se standardním poklesem kmitočtové charakteristiky. 


\section{Nastavení počátečních podmínek integrátoru}

V provozu vyvolává vstupní klidový vstupní proud operačního zesilovače a také napětová nesymetrie vstupů trvalé nabíjení integračního kapacitoru i při nulovém vstupním napětí. To znamená, že výstupní napětí integrátoru běžícího bez buzení $\left(u_{1}=0\right)$ ujíždí případně až do oblasti úplného nasycení operačního zesilovače.

Ujíždění (drift) integrátoru může být nastaveno na nulu vhodným nastavením obvodu pro vyvážení nesymetrie operačního zesilovače. Nesymetrie obvodu jsou však ještě teplotně závislé a vykazují také dlouhodobou časovou závislost. To znamená, že postupně dochází k porušení rovnováhy obvodu a ten př́ípadně ujede do některého svého nasyceného stavu. Proto bývá integrátor vybaven prostředky, dovolujícími nastavit nulové počáteční podmínky, a to obvykle těsně před zahájením integrace.

Schéma nakreslené na Obr. 6.33a ukazuje nejobvyklejší metodu nastavení nulových počátečních podmínek. Vynulování integračního kapacitoru $\mathrm{C}$ se provede sepnutím spínače $\mathrm{S}$ (mechanický, elektromechanický nebo elektronický spínač). Rezistor $\mathrm{R}_{2} \mathrm{o}$ malém odporu slouží k omezení vybíjecího proudu kapacitoru a chrání jak spínač tak i kapacitor před zničením. V obvodu je také ukázána metoda kompenzace ujíždění integrátoru. Při rozpojeném spínači a zkratovaném vstupu $\left(u_{1}=0\right)$ se nastaví pomocí potenciometru $\mathrm{P}_{1}$ nulové ujíždění výstupního napětí integrátoru.

Často také potřebujeme nastavit velikost výstupního napětí integrátoru před započetím integrace (tzv. počáteční podmínky) na určitou počáteční hodnotu nebo integraci po určité době ukončit a zapamatovat si výsledek integrace. Princip uspořádání takového obvodu je zřejmý ze schématu uvedeného na Obr. 6.33b. Bude-li spínač $\mathrm{S}_{1}$ rozpojen a spínač $\mathrm{S}_{2}$ sepnut, nastaví se výstupní napětí na hodnotu $u_{2}(0)=-U R_{2} / R_{1}$. Při sepnutém spínači $\mathrm{S}_{1}$ a rozpojeném spínači $\mathrm{S}_{2}$ pak probíhá vlastní integrace a rozpojíme-li po skončení integračního procesu spínač $\mathrm{S}_{1}$, zůstane výsledek integrace zapamatován.

Pro integrátory, které pracují s dlouhými dobami integrování, je třeba užívat operační zesilovače, jejichž klidový vstupní proud a napětová nesymetrie vstupů se mění s teplotou jen málo. Obvykle používáme operační zesilovače osazené na vstupu tranzistory řízenými polem. Jako integrační kapacitory se hodí nejlépe polystyrénové kondenzátory s časově stálou hodnotou kapacity a malou dielektrickou absorbcí. 


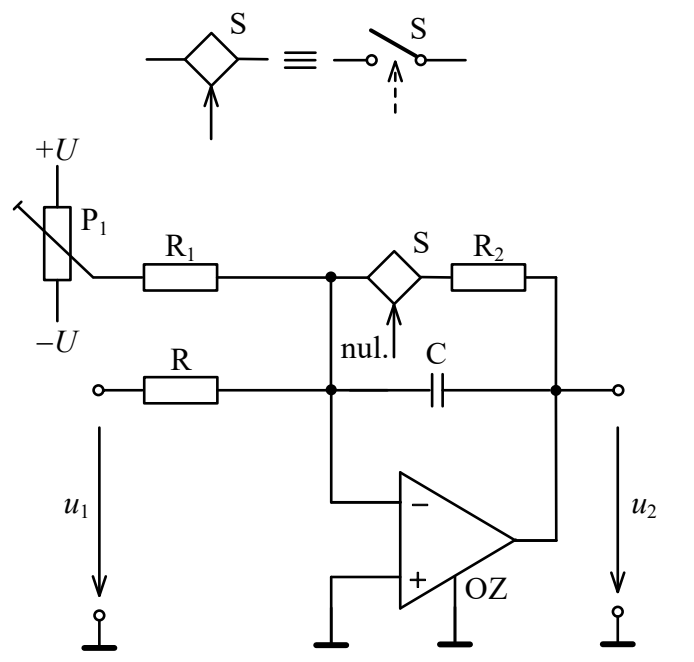

$\mathrm{a}$

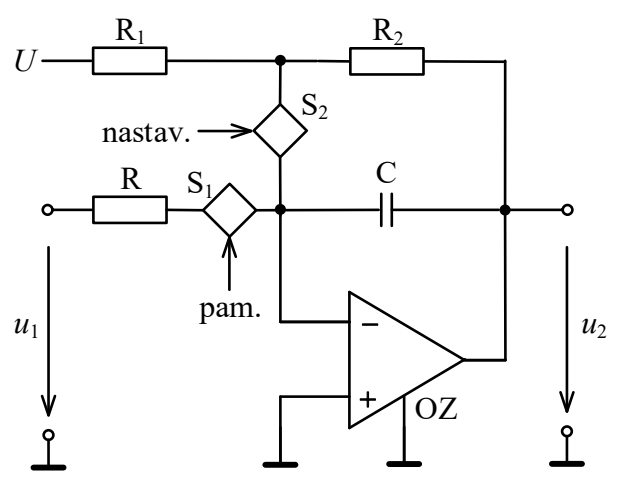

b

Obr. 6.33: a) Nastavení nulových počátečních podmínek a kompenzace ujíždění integrátoru, b) uspořádání integrátoru pro režimy integrace, nastavení, pamatování

\section{Derivátor}

Zaměníme-li pozici rezistoru a kapacitoru u základního zapojení integrátoru, získáme derivační obvod. Jednoduché uspořádání derivátoru s operačním zesilovačem je uvedeno na Obr. 6.34a. Protože $i_{\mathrm{C}} \approx i_{2}$ a $u_{\mathrm{C}} \approx u_{1}$, jsou vlastnosti obvodu vystiženy vztahem

$$
C \frac{\mathrm{d} u_{1}(t)}{\mathrm{d} t} \approx-\frac{u_{2}(t)}{R}
$$

a tedy

$$
u_{2}(t) \approx-C R \frac{\mathrm{d} u_{1}(t)}{\mathrm{d} t}
$$

Tento jednoduchý derivační obvod se nedá v praxi použít proto, že je nestabilní. Na Obr. 6.34b je nakreslena charakteristická závislost zisku operačního zesilovače na kmitočtu $f$, který klesá s rostoucím kmitočtem se sklonem $20 \mathrm{~dB} / \mathrm{dek}$ a s tímto sklonem protíná i osu jednotkového zesílení $(0 \mathrm{~dB})$. Kmitočtová charakteristika zpětnovazební sítě tvořená článkem $\mathrm{RC}$ sleduje osu $0 \mathrm{~dB}$ a od kmitočtu $f_{0}=1 / 2 \pi R C$ roste se sklonem $20 \mathrm{~dB} / \mathrm{dek}$. Rychlost přibližování mezi touto čarou a kmitočtovou charakteristikou operačního zesilovače bez zpětné vazby tedy činí $40 \mathrm{~dB} / \mathrm{dek}$. To vede nutně k nestabilitě jednoduchého derivačního obvodu. V důsledku velkého zesílení na vysokých kmitočtech by se také nepříznivě uplatňoval šum.

Nestabilitě obvodu zabrání a vysokofrekvenční šum pomáhá zmenšit rezistor $\mathrm{R}_{1} \mathrm{v}$ sérii $\mathrm{s}$ kapacitorem $\mathrm{C}$ tak, jak je to uvedeno na Obr. 6.35a. Při kmitočtech nad $f_{1}=1 / 2 \pi R_{1} C$ pracuje derivační obvod jako invertující zesilovač se zesílením $-R / R_{1}$. Z kmitočtových charakteristik na Obr. $6.35 \mathrm{~b}$ je vidět, že obě charakteristiky se v kritické oblasti přibližují pouze rychlostí $20 \mathrm{~dB} / \mathrm{dek}$, což zaručuje stabilitu obvodu. Mezní kmitočet $f_{1}$ je ovšem nutno volit tak, aby byl větší než nejvyšší kmitočty spektra derivovaného signálu. 


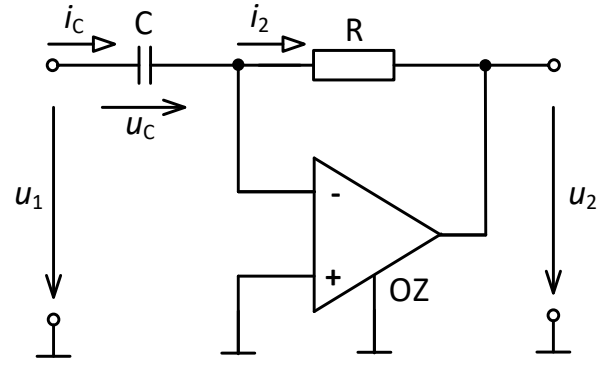

a

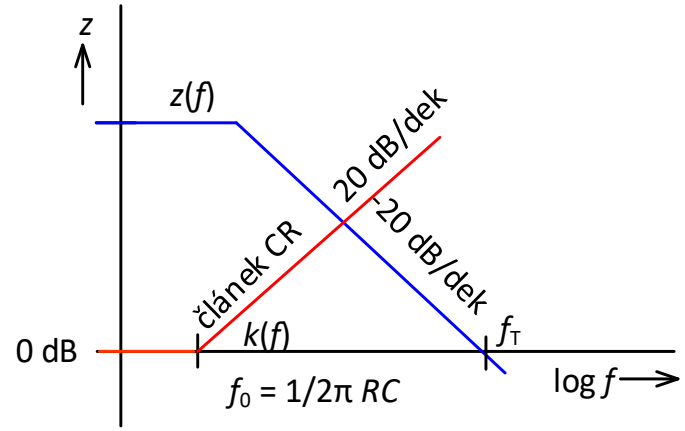

$\mathrm{b}$

Obr. 6.34: a) Derivační obvod s operačním zesilovačem, b) ke kmitočtové stabilitě derivátoru

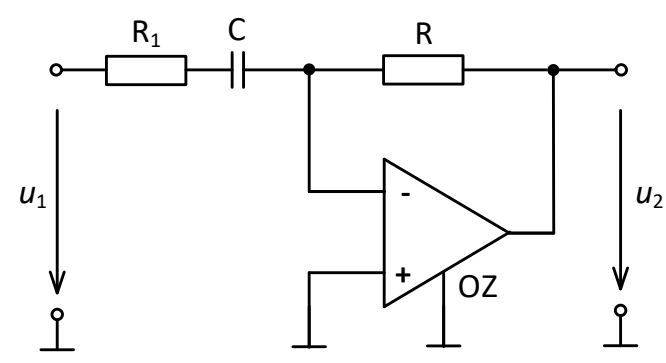

a

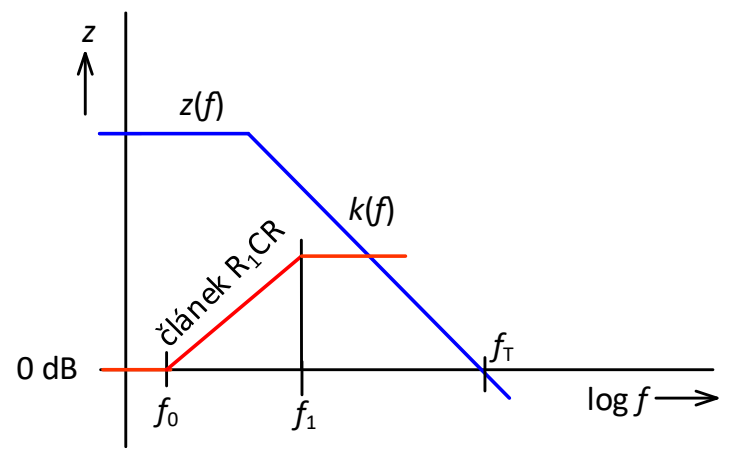

b

Obr. 6.35: Derivační obvod s kmitočtovou korekcí ve zpětnovazební síti operačního zesilovače

\subsection{Stř́ídavé zesilovače}

V praxi se často vyskytují případy, kdy není nutno zesilovat stejnosměrný signál a stačí zesilovat pouze jeho stř́davou složku. Jestliže vložíme do cesty signálu oddělovací (vazební) kapacitory, oddělíme stejnosměrnou složku signálu a bude také podstatně potlačen vliv nesymetrie a ujíždění operačního zesilovače. Tento způsob je také vhodný pro oddělení stejnosměrné složky signálu, jestliže operační zesilovače jsou napájeny pouze z jednoho napájecího zdroje; $v$ tom př́padě jsou totiž jak vstup, tak i výstup operačního zesilovače stejnosměrně posunuty vůči nulovému potenciálu, a to o polovinu napájecího napětí.

Na Obr. 6.36a je uvedeno zapojení klasického invertujícího zesilovače s oddělovacím kapacitorem $\mathrm{C}_{1}$ připojeným $\mathrm{v}$ sérii ke vstupnímu rezistoru $\mathrm{R}_{1}$. Zesílení stř́́davého zesilovače na vyšších kmitočtech je stejně jako u běžného invertujícího zesilovače $-R_{2} / R_{1}$. Přenos se na nízkých kmitočtech zmenšuje, přičemž pokles modulové charakteristiky o $3 \mathrm{~dB}$ nastává při kmitočtu $f_{1}=1 / 2 \pi R_{1} C_{1}$. Na vyšších kmitočtech je činnost obvodu samozřejmě ovlivněna kmitočtovými vlastnostmi samotného operačního zesilovače (viz Obr. 6.36b).

Základem obvodu podle Obr. 6.37a je neinvertující zesilovač, který je doplněn oddělovacími kapacitory $C_{1}, C_{2}$ a rezistorem $R_{3}$. Přenosový článek $C_{1} R_{3}$ slouží k obvyklému oddělení užitečného střídavého zesilovaného signálu od stejnosměrné složky. Pro ss signály vykazuje $\mathrm{C}_{2}$ velkou impedanci a proto je zesílení ss signálů pouze jednotkové. $Z$ tohoto důvodu se napětová nesymetrie (ofset) a ujíždění (drift) OZ uplatní jen málo. Zesílení obvodu na středních kmitočtech je stejné jako u neinvertujícího zesilovače $\left(1+R_{2} / R_{1}\right)$. Modulová 
charakteristika má na nízkých kmitočtech dva body zlomu a to při kmitočtech $f_{1}=1 / 2 \pi R_{1} C_{2}$ a $f_{2}=1 / 2 \pi R_{3} C_{1}$. Na vysokých kmitočtech je pak chování zesilovače ovlivněno omezeným kmitočtovým chováním OZ. Vstupní odpor obvodu je v pracovní oblasti relativně malý. Je to dáno tím, že v oblasti středních kmitočtů, které je obvod schopen zpracovat a při nichž je možno reaktanci kapacitoru $\mathrm{C}_{2}$ pokládat za nulovou, je vstupní odpor zesilovače na Obr. 6.37a dán prakticky jen odporem rezistoru $R_{3}$.

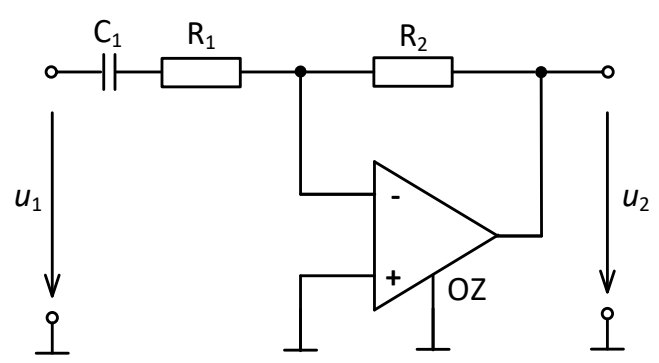

a

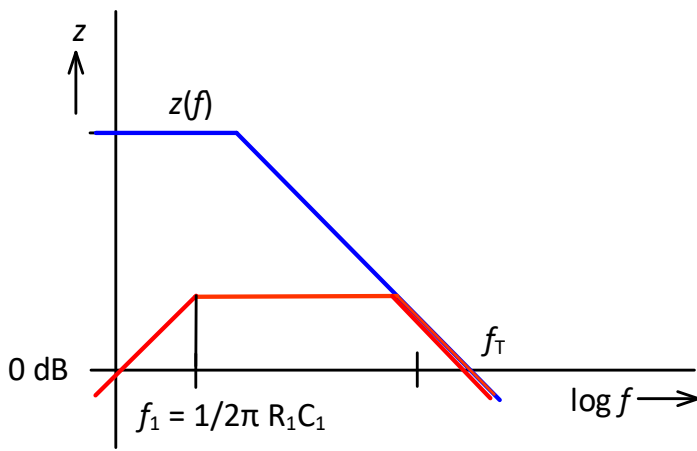

b

Obr. 6.36: a) Invertující střídavý zesilovač, b) jeho kmitočtová charakteristika

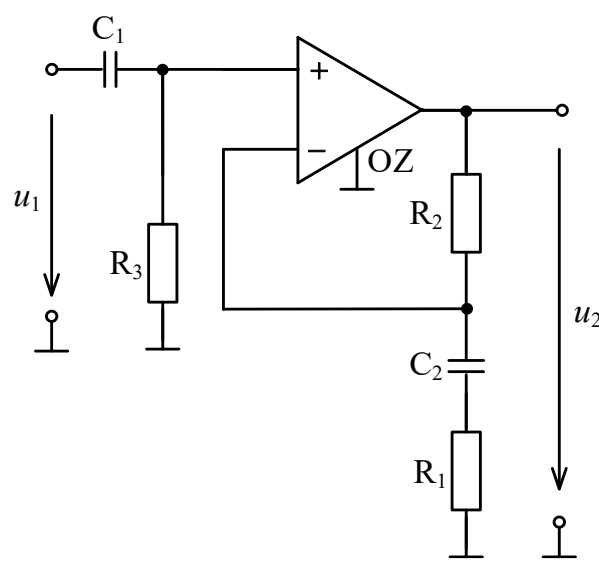

a

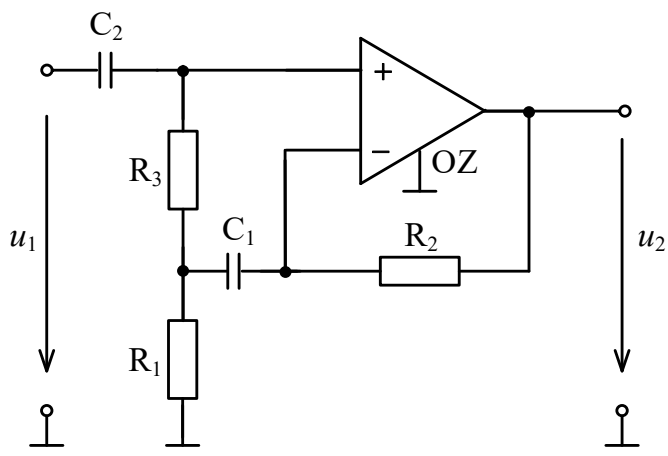

b

Obr. 6.37: a) Neinvertující stř̌́davý zesilovač, b) stř́ídavý zesilovač s velkým vstupním odporem

V zapojení nakresleném na Obr. 6.37b je velký vstupní odpor získán napět’ovou zpětnou vazbou, zaváděnou přes $\mathrm{R}_{2}, \mathrm{C}_{1}$ a $\mathrm{R}_{1} \mathrm{k}$ dolnímu konci rezistoru $\mathrm{R}_{3}$. Dolní konec rezistoru $\mathrm{R}_{3} \mathrm{je}$ $\mathrm{v}$ důsledku toho $\mathrm{v}$ pracovní oblasti středních kmitočtů přibližně na stejném potenciálu jako vstup zesilovače. Z tohoto důvodu se vstupní odpor zesilovače jeví téměř nekonečný. Tato metoda zvětšení vstupního odporu je známa pod názvem „bootstrap“.

Kmitočtové filtry, které patři také do kategorie lineárních odvodi̊, jsou vyčleněny do samostatné kapitoly. 


\section{Použitá literatura}

[1] TIETZE, U.; SCHENK Ch.; GAMM, E. Electronic circuits: handbook for design and application. 2nd ed. New York: Springer-Verlag Berlin Heidelberg, 2008. ISBN 978-3540-00429-5.

[2] TIETZE, U.; SCHENK, Ch. Electronic circuits: design and applications. Berlin: Springer-Verlag, 1991. ISBN 354050608x.

[3] TIETZE, U.; SCHENK, Ch. Halbleiter-Schaltungstechnik. 5. Aufl. Berlin: Springer, 1980. ISBN 3540098488.

[4] TIETZE, U.; SCHENK, Ch. Halbleiter-Schaltungstechnik. 2., neu bearb. und wesentlich erw. Aufl. New York: Springer-Verlag, 1971. ISBN 3540052852.

[5] HUELSMAN, L. P. Active and passive analog filter design: an introduction. New York: McGraw-Hill, c1993. ISBN 0070308608.

[6] Kendall, L. Analog filters. Boston: Kluwer Academic Publishers, 1996. ISBN 0412638401.

[7] KULARATNA, N. Electronic circuit design: from concept to implementation. Boca Raton, FL: CRC Press, c2008. ISBN 9780849376177.

[8] HÁJEK, K.; SEDLÁČEK, J. Kmitočtové filtry. Praha: BEN - technická literatura, 2002. ISBN 8073000237.

[9] GRAEME, J. G. Designing with operational amplifiers: applications alternatives. New York: McGraw-Hill, c1977. ISBN 007023891x.

[10] GRAEME, J. G. Applications of operational amplifiers: third-generation techniques. New York: McGraw-Hill, [1973]. ISBN 0070238901.

[11] GRAEME, J. G.; TOBEY, G. E.; HUELSMAN, L. P. Operational amplifiers: Design and Applications. New York: McGraw-Hill,1971. ISBN 070649170.

[12] HUIJSING, J. H. Operational amplifiers: theory and design. Boston, MA: Kluwer Academic Publishers, c2001. ISBN 0792372840.

[13] STOUT, D.; KAUFAMN, M. Handbook of amplifier circuit design. New York: McGraw-Hill Book Company, 1976. ISBN 007061797x.

[14] CLAYTON, G. B. Operational amplifiers. London: Butterworths, 1971. ISBN 0408702028.

[15] DOSTÁL, J. Operational amplifiers. New York: distribution for the USA, Elsevier/North-Holland, 1981. ISBN 0444417133.

[16] DOSTÁL, J. Operační zesilovače. Praha: BEN - technická literatura, 2005. ISBN 8073000490.

[17] DOSTÁL, J. Analogové a hybridní počítače. Praha: SNTL - Nakladatelství technické literatury, 1971.

[18] DOSTÁL, J. Operační zesilovače. Praha: SNTL - Nakladatelství technické literatury, 1981.

[19] VEDRAL, J.; FISCHER, J. Elektronické obvody pro měřicí techniku. Praha: Vydavatelství ČVUT, 1999. ISBN 8001019500.

[20] NEUMANN, P.; UHLÍŘ, J. Elektronické obvody a funkční bloky 1. Praha: Vydavatelství ČVUT, 1999. ISBN 8001019810.

[21] NEUMANN, P.; UHLÍŘ, J. Elektronické obvody a funkční bloky 2. Praha: Vydavatelství ČVUT, 2001. ISBN 800102394x. 
[22] VRBA, K. Analogová technika. Brno: Vysoké učení technické v Brně, 2012. s. 1202. ISBN: 978-80-214-4458-4.

[23] VRBA, K. Analogová technika - numerická cvičení. Brno: Vysoké učení technické v Brně, 2013. s. 1-82. ISBN: 978-80-214-4727-1.

[24] DOSTÁL, T.; FILKA, M.; SKLENÁŘ, J.; VRBA, K.; VRBA, R. Diplomní semináře telekomunikace. Brno: Vysoké učení technické, 1989.

[25] PUNČOCHÁŘ, J. Operační zesilovače v elektronice. 2. vyd. Praha: BEN - technická literatura, 1996. ISBN 8090198430.

[26] JOHNS, D.; KENNETH, W. M. Analog integrated circuit design. New York: John Wiley, c1997. ISBN 0471144487.

[27] CHEN, W. K. The circuits and filters handbook. 2nd ed. Boca Raton, FL: CRC Press, c2003. ISBN 0849309123.

[28] FRANCO, S. Design with operational amplifiers and analog integrated circuits. 3rd ed. New York: McGraw-Hill, c2002. ISBN 0072320842. 


\section{Kmitočtové filtry}

I když je pravdou, že velká většina informací je zpracovávána v digitální podobě, reálný svět, který nás obklopuje, je analogový a spojité signály je nutné před vlastním převodem do digitální formy nejprve vhodně upravit (např. zesílit, kmitočtové omezit). Také pro potřeby zpětné reprodukce se digitální signály musí převádět zpět do analogové podoby a $\mathrm{v}$ př́padě nutnosti je také následně upravujeme využitím vhodných analogových obvodů. Pro předzpracování (Pre-Processing) nebo po-zpracování (Post-Processing) analogových signálů se využívají především kmitočtové filtry. Jejich úkolem je především výběr určitého kmitočtového pásma zpracovávaného signálu. Např. dolní propust se použivá k omezení kmitočtového spektra při digitalizaci analogového signálu pro zajištění podmínky vzorkování a opět při zpětném převodu k obnovení původního signálu. Pásmové propusti se používají v přijímačích pro výběr kmitočtového pásma požadovaného vysílače. Pásmové zádrže se využívají např. pro potlačení rušivého sít'ového kmitočtu.

Kmitočtové filtry tedy patří do skupiny lineárních obvodů, které požadovaným způsobem mění kmitočtové spektrum procházejícího signálu. Některé kmitočtové složky signálu jsou propuštěny bez či s minimálním útlumem (propustné pásmo filtru) a jiné kmitočtové složky jsou potlačeny (pásmo potlačení, pásmo útlumu či nepropustné pásmo filtru). Zvláštním př́padem kmitočtového filtru je tzv. fázovací článek, který je charakteristický tím, že modul přenosové charakteristiky je konstantní, kdy tedy nedochází ke změně amplitudy jednotlivých harmonických složek zpracovávaného signálu, ale dochází jen k natočení jejich fáze, resp. k časovému zpoždění signálu.

\subsection{Typy kmitočtových filtrů}

Rozdělení kmitočtových filtrů lze provést dle různých hledisek, přičemž primárně se dělí dle způsobu zpracování kmitočtového spektra ([1] až [7]):

- dolní propust (DP, LP - Low-pass) - propouští nižší kmitočty než mezní $f_{\mathrm{m}}$, vyšší potlačuje (Obr. 7.1a),

- $\quad$ horní propust (HP, HP - High-pass) - propouští vyšší kmitočty než mezní $f_{\mathrm{m}}$, nižší potlačuje (Obr. 7.1b),

- $\quad$ pásmová propust (PP, BP - Band-pass) - propouští vybranou část spektra mezi dolním mezím $f_{\mathrm{m} 1}$ a horním mezním kmitočtem $f_{\mathrm{m} 2}$, zbývající potlačuje (Obr. 7.1c),

- $\quad$ pásmová zádrž (PZ, BS - Band-stop) - potlačuje vybranou část spektra mezi dolním mezním $f_{\mathrm{m} 1}$ a horním mezním kmitočtem $f_{\mathrm{m} 2}$, zbývající propouští (Obr. 7.1d),

- $\quad$ fázovací článek (FC, AP - All-pass) - modulová přenosová charakteristika je v celém kmitočtovém pásmu konstantní, ale fázová je kmitočtově závislá.

Zvláštním typem jsou korekční filtry, které slouží pro úpravu kmitočtové charakteristiky zpracovávaného signálu tak, aby celkový přenos soustavy byl konstantní, nebo naopak, aby se zvýraznily či potlačily některé složky kmitočtu. 


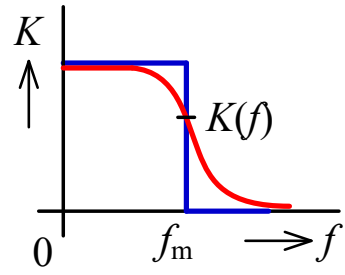

a

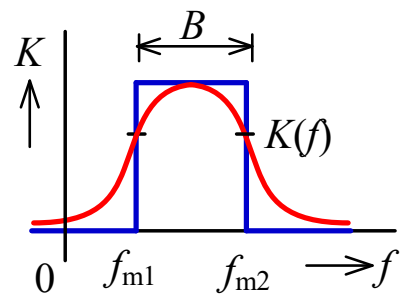

c

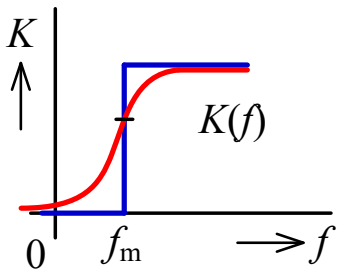

b

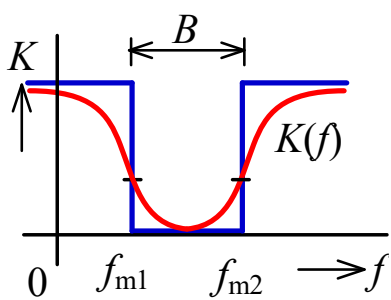

d

Obr. 7.1: Ideální (modré) a skutečné (červené) modulové charakteristiky základních typů kmitočtových filtrů (a) dolní propust (DP), (b) horní propust (HP), (c) pásmová propust (PP), (d) pásmová zádrž (PZ)

Kmitočtové filtry lze také dělit dle způsobu jejich realizace do dvou základních skupin:

- $\quad$ analogové filtry, které se dále člení na:

- pasivní filtry a

- $\quad$ aktivní filtry resp. na filtry s aktivními prvky,

- digitální filtry, které se dále člení na:

- FIR (Finite Impulse Response) filtry s konečnou impulsní odezvou,

- IIR (Infinite Impulse Response) filtry s nekonečnou impulsní odezvou.

Využití číslicových filtrů má svůj význam v okamžiku, kdy použijeme číslicové zpracování signálů a použitý digitální signálový proces disponuje dostatečným výpočetním výkonem.

V případě nutnosti předzpracování signálu před vlastní digitalizací či pro zpracování vysokofrekvenčních signálů, kdy rychlost zpracování v číslicové části by nebyla dostatečná, či slabých a zašuměných signálů je nutné přistoupit $\mathrm{k}$ využití analogových filtrů. $\mathrm{V}$ této oblasti je možné využít propracované a ověřené řešení $\mathrm{v}$ podobě integrovaných filtrů či $\mathrm{v}$ případě specifických požadavků je nutné navrhnout vlastní řešení. Podle požadovaných vlastností kladených na takový analogový filtr je pak možné filtry rozdělit do několika skupin, podle použitých stavebních prvků:

- $\quad$ Pasivní filtry RC - vyznačují se vhodným propojením rezistorů $(\mathrm{R})$ a kapacitorů $(\mathrm{C})$, vynikají svou jednoduchostí a nízkou cenou. Praktické využití mají jen jednoduché struktury filtrů 1. a 2. rádů s nízkým činitelem jakosti $Q$, který je vždy nižší než 0,5 .

- $\quad$ Pasivní filtry RLC - využívají rezistorů, kapacitorů a induktorů (L) a pomocí nich je možné realizovat obecně jakýkoliv typ kmitočtového filtru. Jsou spíše vhodné pro zpracování signálů na vyšších kmitočtech, protože realizace induktorů na nízkých kmitočtech je dosti neefektivní, kdy takové induktory jsou př́lišs rozměrné, nákladné a ztrátové s malým činitelem jakosti. Přesto se lze s nimi setkat, např̀. $\mathrm{v}$ audiotechnice při realizaci pasivních výhybek určených pro reproduktorové soustavy.

- $\quad$ Aktivní filtry RC - umožňují realizovat jakýkoliv typ filtru stejně jako filtry RLC s využitím vhodného aktivního prvku, rezistorů a kapacitorů a to bez nutnosti použít induktory, viz např. [1] až [5], popř. [22] a [24]. Vzhledem k omezeným kmitočtovým 
vlastnostem aktivních prvků se nasazení takto realizovaných kmitočtových filtrů nejčastěji omezuje na kmitočtové pásmo $\mathrm{mHz}$ až stovky $\mathrm{kHz}$, ale vývojem v oblasti mikroelektroniky a návrhem nových typů aktivních prvků se horní hranice použitelnosti těchto kmitočtových filtrů posunula i na desítky až stovky MHz.

- $\quad$ Aktivní filtry SC - jsou obvody využívající principu tzv. spínaných kapacitorů. Jde o modifikaci aktivních RC filtrů, kdy klasické rezistory jsou nahrazeny přepínanými kapacitory, [20], [24], [26], [30]. Hlavní výhodou je možnost poměrně snadného přeladění filtrů změnou přepínací frekvence taktovacích pulsů a poměrně snadné monolitické integrace. Spínací kmitočet musí být 50x až 100x vyšší než mezní kmitočet filtru, což do určité míry minimalizuje možný aliasingový efekt způsobený periodizací spektra zpracovávaného signálu. $\mathrm{Na}$ druhou stranu tato okolnost omezuje šířku pásma zpracovávaných signálů. Velkou výhodou ARC filtrů je skutečnost, že se u těchto obvodů dá dosáhnout menší citlivosti na změnu parametrů použitých kapacitorů.

- Elektromechanické filtry - vycházejí z principu převodu elektrického signálu na mechanický. Podle typu mechanického rezonátoru lze tyto filtry dělit na různé skupiny, kdy nejpoužívanější jsou piezokeramické filtry. Zvláštním typem je krystalový filtr, který lze modelovat složeným rezonančním obvodem s vysokým činitelem jakosti a s vysokou stabilitou rezonančního kmitočtu. Nejčastěji se využívá ve vysoce stabilních oscilátorech, v oblasti realizace kmitočtových filtrů se použivají pro návrh úzkopásmových propustí.

- $\quad$ Filtry s povrchovou akustickou vlnou (PAV) - jsou založeny na principu vyzařování, šírení a fázového, kmitočtově nezávislého skládání povrchových akustických vln. V porovnání s elektromechanickými filtry mohou realizovat širokopásmovější obvody.

- Mikrovlnné filtry - jsou ve své podstatě pasivní RLC filtry, kdy však pro používanou kmitočtovou oblast (nad $300 \mathrm{MHz}$ ) nelze uvažovat pasivní prvky se soustředěnými parametry, ale je nutné pracovat prvky s rozprostřenými parametry.

Možnost nasazení výše zmíněných typů analogových kmitočtových filtrů s ohledem na kmitočtové pásmo použitelnosti je naznačeno přehledně na Obr. 7.2, [8].

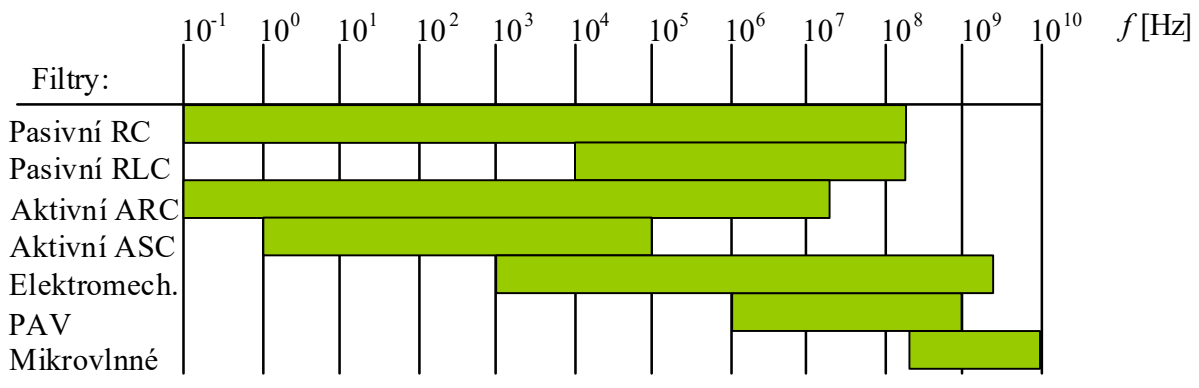

Obr. 7.2: Kmitočtová pásma použitelnosti různých typů analogových kmitočtových filtrů

V této publikaci se omezíme jen na základní informace o pasivních filtrech RC a RLC a o aktivních filtrech RC s operačními zesilovači.

\subsection{Základní vlastnosti a zapojení filtrů}

\subsubsection{Základní vlastnosti filtrů}

Kmitočtový filtr lze chápat jako lineární dvojbran (Obr. 7.3), který z kmitočtového spektra vstupního signálu vyčlení požadovanou část spektra. Obecně je přenos filtru definován jako 
poměr spektrálních funkcí výstupního a vstupního signálu získaných Fourierovou transformací. Protože jde o lineární obvod, můžeme pro potřeby zjednodušeného popisu uvažovat na vstupu pouze harmonický signál

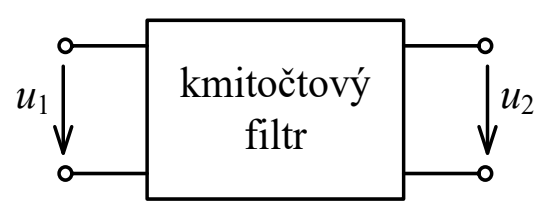

Obr. 7.3: Kmitočtový filtr jako dvojbran

$$
u_{1}(t)=U_{1} \cos \left(\omega t+\varphi_{1}\right)
$$

Na výstupu filtru pak bude výstupní napětí

$$
u_{2}(t)=U_{2} \cos \left(\omega t+\varphi_{2}\right) .
$$

Je zřejmé, že vstupní harmonický signál vyvolá na výstupu filtru opět harmonický signál se stejným úhlovým kmitočtem $\omega$, ale s jinou amplitudou $U_{\mathrm{m} 2}$. V důsledku časového zpoždění signálu procházejícího filtrem dojde navíc k posunu fáze signálu a výstupní signál proto bude mít jinou počáteční fázi $\varphi_{2}$. Při řešení filtrů se obvykle místo časových průběhů pracuje s komplexními veličinami

$$
\bar{U}_{1}(\omega)=U_{1}(\omega) \mathrm{e}^{\mathrm{j} \varphi_{1}(\omega)}, \quad \bar{U}_{2}(\omega)=U_{2}(\omega) \mathrm{e}^{\mathrm{j} \varphi_{2}(\omega)} .
$$

Přenosové vlastnosti kmitočtového filtru jsou pak charakterizovány komplexní přenosovou funkcí

$$
\bar{K}(\omega)=\frac{\bar{U}_{2}(\omega)}{\bar{U}_{1}(\omega)}=\operatorname{Re} \bar{K}(\omega)+\mathrm{j} \operatorname{Im} \bar{K}(\omega)=K(\omega) \mathrm{e}^{\mathrm{j} \varphi(\omega)} .
$$

Kmitočtové vlastnosti filtrů se obvykle popisují pomocí modulové kmitočtové charakteristiky

$$
K(\omega)=\bmod \bar{K}(\omega)=\sqrt{(\operatorname{Re} \bar{K}(\omega))^{2}+(\operatorname{Im} \bar{K}(\omega))^{2}}
$$

a argumentové (fázové) kmitočtové charakteristiky

$$
\varphi(\omega)=\varphi_{2}(\omega)-\varphi_{1}(\omega)=\arg \bar{K}(\omega)=\operatorname{arctg} \frac{\operatorname{Im} \bar{K}(\omega)}{\operatorname{Re} \bar{K}(\omega)} .
$$

Modul přenosu $K(\omega)$ je obecně bezrozměrné číslo. Častěji se však vyjadřuje jako zisk v decibelech

$$
z(\omega)=20 \log K(\omega)
$$

Modulová charakteristika $K(\omega)$, resp. $z(\omega)$ společně s fázovou charakteristikou $\varphi(\omega)$ se označují jako Bodeho diagram.

Protože pro úhlový kmitočet platí $\omega=2 \pi f$, můžeme se setkat také se zápisem přenosové funkce v závislosti na kmitočtu $\bar{K}(f)$, nebo na komplexní proměnné $K(\bar{p})$, kde Laplaceův operátor $\bar{p}=\sigma+\mathrm{j} \omega$ (přičemž pro případ kmitočtových filtrů $\sigma=0$ ).

Obecně lze přenosovou funkci filtru vyjádřit jako racionálně lomenou funkci komplexní proměnné (podíl dvou polynomů) 


$$
K(\bar{p})=\frac{U_{2}(\bar{p})}{U_{1}(\bar{p})}=\frac{b_{0}+b_{1} \bar{p}+b_{2} \bar{p}^{2}+\ldots+b_{m} \bar{p}^{m}}{a_{0}+a_{1} \bar{p}+a_{2} \bar{p}^{2}+\ldots+a_{n} \bar{p}^{n}},
$$

kde řád polynomu čitatele $m$ je menší nebo roven řádu jmenovatele $n$, tj. $m \leq n$. Nejvyšší exponent $n$ komplexní proměnné $\bar{p}$ v polynomu jmenovatele udává řád filtru.

Kmitočtové filtry lze $v$ podstatě řšit dvěma způsoby. V prvém případě jde o tzv. nekaskádní syntézu, kdy všechny dílčí části filtru jsou navzájem provázány. Tento způsob umožňuje minimalizovat počet obvodových prvků, ale klade značné nároky především na stálost jejich parametrů. Také nastavování filtru jako celku bývá obtížné. Proto je zpravidla výhodnější použít druhé možnosti a to kaskádní syntézy, kdy filtr je složen z řady kaskádně zapojených dílčích filtrů (viz Obr. 7.4). Takto uspořádaný filtr má sice větší počet aktivních prvků, avšak nároky na tolerance obvodových prvků jsou nižší. Dílčí filtry se dají obvykle s výhodou navrhnout tak, aby se dílčí filtry navzájem téměř neovlivňovaly. Nastavení dílčích filtrů je pak možné provést zcela samostatně a nezávisle a celý filttr po sestavení z předem seřízených dílčích filtrů není třeba dostavovat. Výsledná přenosová funkce kaskádně řazených dílčích filtrů bude mít přenos

$$
K(\bar{p})=K_{1}(\bar{p}) \cdot K_{2}(\bar{p}) \cdot \ldots \cdot K_{I}(\bar{p})=\prod_{i=1}^{I} K_{i}(\bar{p}),
$$

kde $K_{i}(\bar{p})$ jsou dílčí přenosové funkce nejvýše 2. řádu (výjimečně 3. řádu). Aby se sousedící dílčí filtry neovlivňovaly, je obvykle zapotřebí, aby vstupní impedance následujícího filtru byla alespoň 100 - krát větší než výstupní impedance filtru předchozího.

Problematika syntézy filtrů je velice obsáhlá, a kdybychom ji měli probrat v plné šiři a ze všech hledisek, potřebovali bychom na to samostatnou (nepř́lišs tenkou) knihu. V rámci této publikace se proto zaměříme jen na několik hlavních zásad, kterými se musíme řídit při návrhu filtrů a při jejich realizaci.

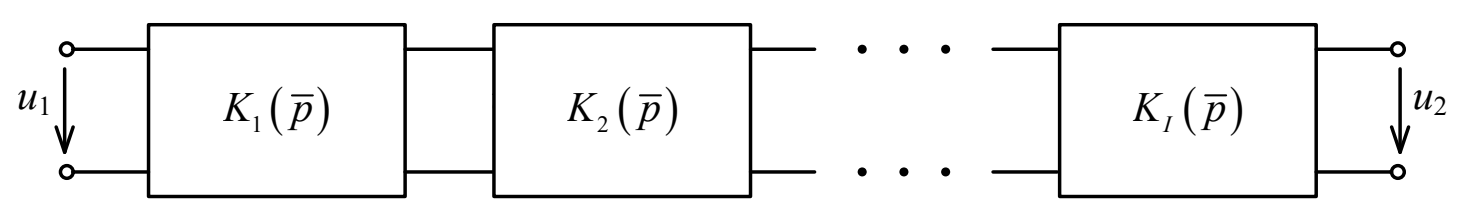

Obr. 7.4: Kaskádní řazení filtrů

\subsubsection{Pasivní filtry}

Základním obvodem řady elementárních filtrů 1. a 2. řádu je většinou impedanční dělič napětí (viz Obr. 7.5a), u kterého je alespoň jedna z impedancí kmitočtově závislá. Přenosová funkce takovéhoto nezatíženého impedančního děliče

$$
K(\bar{p})=\frac{U_{2}(\bar{p})}{U_{1}(\bar{p})}=\frac{\bar{Z}_{2}}{\bar{Z}_{1}+\bar{Z}_{2}},
$$

kde $U_{1}(\bar{p})$ a $U_{2}(\bar{p})$ jsou Laplaceovy obrazy vstupního napětí $u_{1}(t)$ a výstupního napětí $u_{2}(t)$. Připomeňme, že impedance rezistoru $\bar{Z}_{\mathrm{R}}=R$, impedance kapacitoru $\bar{Z}_{\mathrm{C}}=1 / \bar{p} C=1 / \mathrm{j} \omega C$ a impedance induktoru $\bar{Z}_{\mathrm{L}}=\bar{p} L=\mathrm{j} \omega L$. 


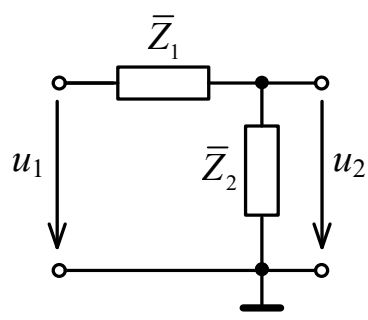

a

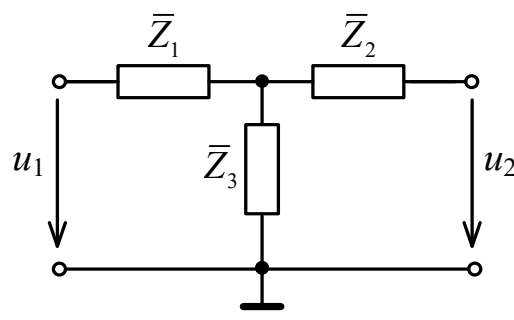

b

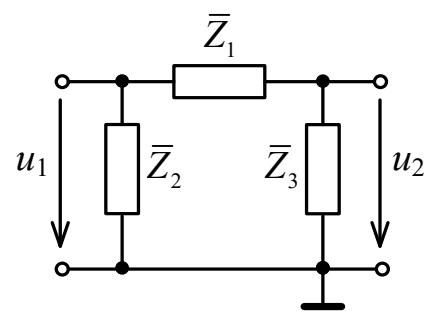

$\mathrm{c}$

Obr. 7.5: Elementární pasivní filtry: a) impedanční dělič, b) T-článek, c) П-článek

Existují samozřejmě i další typy elementárních filtrů jako je např. impedanční $\mathrm{T}$ - článek (Obr. 7.5b) nebo impedanční $\Pi$ - článek (Obr. 7.5c), viz např. [5] a [6]. Těmito filtry se však $\mathrm{v}$ této publikaci zabývat nebudeme.

Pomocí pasivních kmitočtových filtrů je teoreticky možné realizovat libovolný typ filtru. Tyto obvody využívají pouze základní pasivní obvodové prvky, jako jsou rezistory, kapacitory a induktory. Pomocí rezistorů a kapacitorů můžeme sice realizovat některé typy filtrů, nepodaří se nám však dosáhnout vysokou jakost filtru. $\mathrm{K}$ tomu je zapotřebí použít i induktory. Realizace induktorů pro vyšší kmitočty nečiní potíže. Avšak na nízkých kmitočtech jsou zapotřebí induktory s velkou indukčností, které jsou rozměrné, špatně se realizují a vykazují horší elektrické parametry. Proto se pasivní RLC filtry používají většinou jen pro oblast vyšších kmitočtů.

\subsubsection{Aktivní filtry}

Aktivní filtry s operačními zesilovači umožňují realizovat v oblasti nízkých kmitočtů (řádově až do $10 \mathrm{MHz}$ ) filtry bez induktorů. Jak jsme již uvedli, pro sestrojení filtru $n$-tého řádu použijeme jednoduché dílčí aktivní RC filtry 1. nebo 2. řádu. Aby bylo možno jednotlivé dílčí filtry spojovat do kaskády, musí mít velkou vstupní impedanci a malou výstupní impedanci. Obvykle se s výhodou použijí jako výstupní svorky dílčího filtru př́mo výstupní svorky použitého zesilovače, který mívá dostatečně malou výstupní impedanci.

V dalším textu uvedeme několik typických konfigurací aktivních filtrů RC s operačními zesilovači, naznačíme postup jejich návrhu a určení přenosové funkce.

\section{Aktivní filtr s jednoduchou smyčkou zpětné vazby}

Aktivní filtr s jednoduchou smyčkou záporné zpětné vazby je schematicky naznačen na Obr. 7.6. Sestává z operačního zesilovače zapojeného jako invertující zesilovač, který má ve

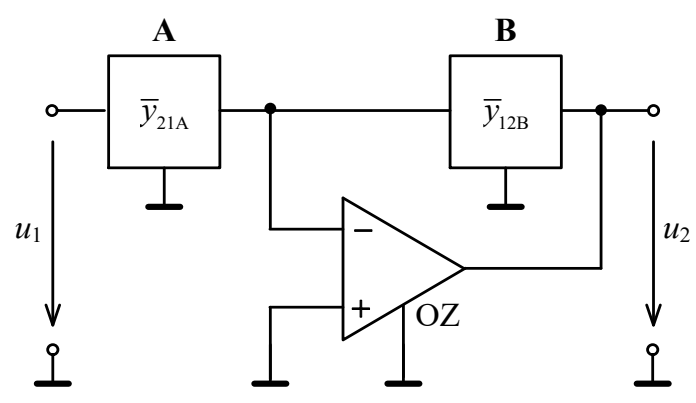


Tab. 7.1: Některé dvojbrany RC a jejich přenosové vodivosti

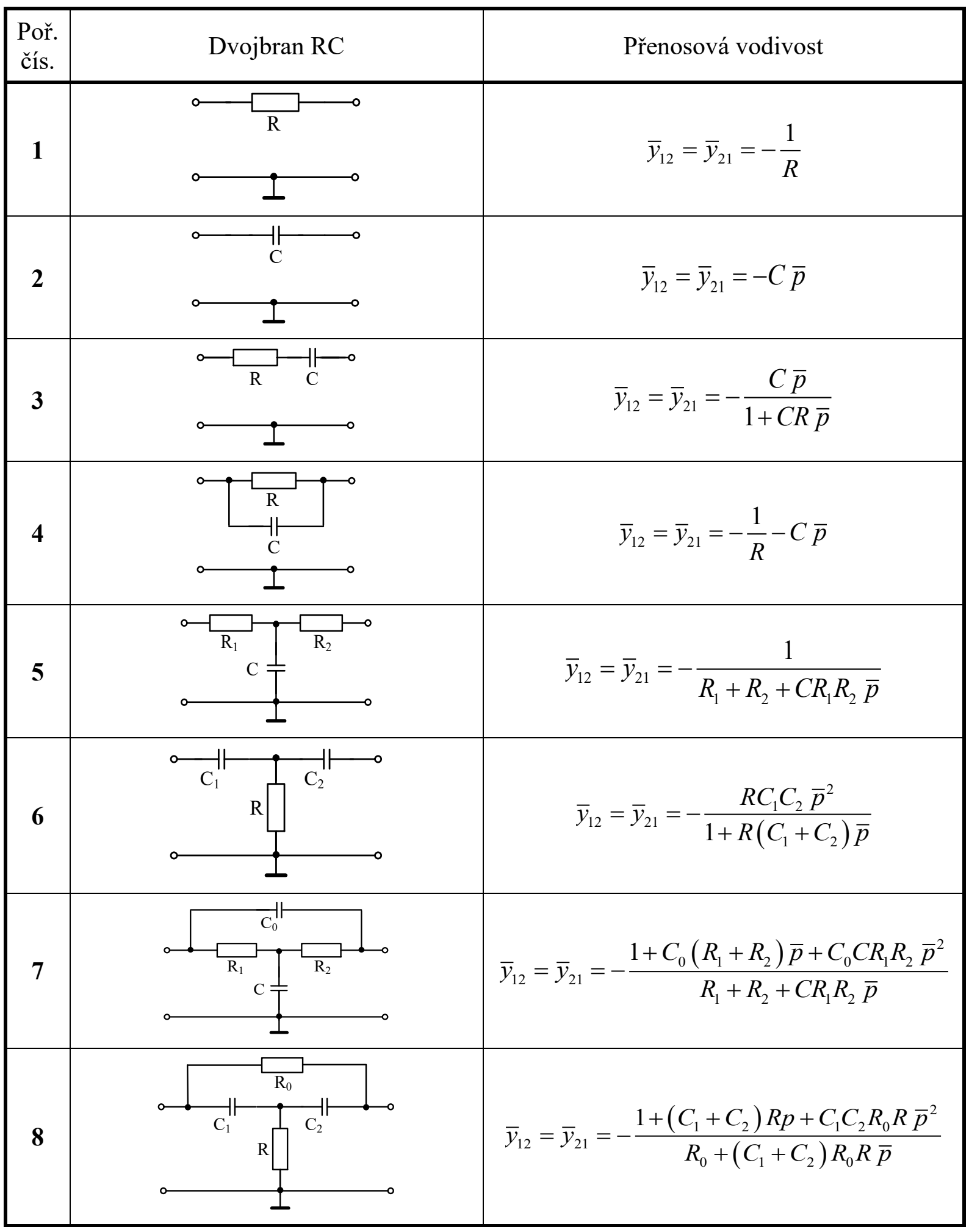

zpětné vazbě zapojeny dva pasivní dvojbrany označené $A$ a $B$. Operační zesilovač si svůj invertující vstup udržuje na virtuální nule a proto lze vlastnosti charakterizovat $\mathrm{v}$ př́ípadě dvojbranu $A$ přenosovou vodivostí $\bar{y}_{21 \mathrm{~A}} \mathrm{v}$ př́mém směru a pro dvojbran $B$ přenosovou vodivostí $\bar{y}_{12 \mathrm{~B}}$ ve zpětném směru. Přenosové vlastnosti jsou pak jednoduše dány vztahem 


$$
K(\bar{p})=-\frac{\bar{y}_{21 \mathrm{~A}}}{\bar{y}_{12 \mathrm{~B}}} .
$$

$\mathrm{K}$ usnadnění práce jsou v Tab. 7.1 nakresleny některé běžné dvojbrany $\mathrm{RC}$, s nimiž se při realizaci aktivních filtrů tohoto typu setkáváme a jsou tam uvedeny i vzorce pro prenosové vodivosti $\bar{y}_{21}$ a $\bar{y}_{12}$. Při vhodném výběru dvojbranů $A$ a $B$ a po dosazení př́slušných přenosových vodivostí do vztahu (7-1) získáme po př́íslušné úpravě zlomku požadovanou funkci $K(\bar{p})$.

\section{Aktivni filtr s rozvětvenou smyčkou zpětné vazby}

U aktivního filtru s rozvětvenou smyčkou zpětné vazby je zpětná vazba u operačního zesilovače realizována několika cestami. Nejužívanější jednoduché uspořádání takového aktivního filttru je nakresleno na Obr. 7.7, např. [11]. Jeho přenosová charakteristika se dá zapsat ve tvaru

$$
K(\bar{p})=-\frac{\bar{Y}_{1} \bar{Y}_{4}}{\bar{Y}_{2} \bar{Y}_{4}+\bar{Y}_{5}\left(\bar{Y}_{1}+\bar{Y}_{2}+\bar{Y}_{3}+\bar{Y}_{4}\right)} .
$$

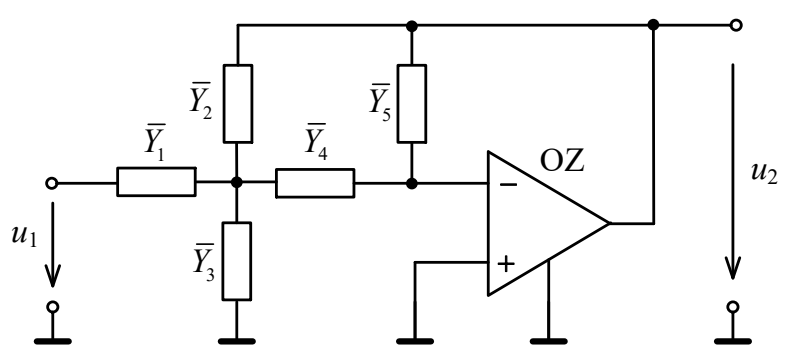

Obr. 7.7: Aktivní filtr s rozvětvenou smyčkou zpětné vazby

Vhodným výběrem dvojpólů, charakterizovaných admitancemi $\bar{Y}_{1}$ až $\bar{Y}_{5}$ je možno realizovat filtr požadovaných vlastností. $\mathrm{V}$ př́ípadě admitance rezistoru dosazujeme $\bar{Y}_{\mathrm{R}}=1 / R=G$, a v př́padě kapacitoru $\bar{Y}_{\mathrm{C}}=\bar{p} C=\mathrm{j} \omega C$. Vhodná kombinace dvojpólů pro různé typy filtrů je přehledně uvedena $\mathrm{v}$ Tab.1.2.

Tab. 7.2: Doporučená volba admitancí pro aktivní filtr s rozvětnou smyčkou zpětné vazby

\begin{tabular}{|c|c|c|c|c|c|}
\hline typ & $\bar{Y}_{1}$ & $\bar{Y}_{2}$ & $\bar{Y}_{3}$ & $\bar{Y}_{4}$ & $\bar{Y}_{5}$ \\
\hline $\mathbf{P P}$ & $\bar{p} C_{1}$ & $G_{1}$ & $G_{3}$ & $G_{2}$ & $\bar{p} C_{2}$ \\
\hline $\mathbf{P P}$ & $G_{1}$ & $\bar{p} C_{1}$ & $G_{2}$ & $\bar{p} C_{2}$ & $G_{3}$ \\
\hline $\mathbf{D P}$ & $G_{1}$ & $G_{2}$ & $\bar{p} C_{1}$ & $G_{3}$ & $\bar{p} C_{2}$ \\
\hline $\mathbf{H P}$ & $\bar{p} C_{1}$ & $\bar{p} C_{2}$ & $G_{1}$ & $\bar{p} C_{3}$ & $G_{2}$ \\
\hline
\end{tabular}




\section{Aktivní filtry se zesilovači s konečným zesílením}

Aktivní filtry se zesilovači s konečným zesílením (viz např. [1], [27], [22]) využívají k dosažení potřebných selektivních vlastností kladné zpětné vazby, avšak tak slabé, že dojde jen k malému odtlumení pasivního obvodu RC ve smyčce zpětné vazby v dané kmitočtové oblasti. V podstatě jde o podobný princip, jaký je využíván u oscilátorů RC. Rozdíl je v tom, že ve smyčce zpětné vazby je sice použit některý z obvyklých selektivních článků RC, avšak upravený tak (obvykle přerušením některého spoje, anebo rozštěpením některého obvodového prvku), aby vznikl trojbran, mající jednu bránu pro vstupní signál, jednu bránu pro zavedení zpětnovazebního signálu a jednu bránu výstupní. Nejužívanější uspořádání je naznačeno na Obr. 7.8a. Zesilovač má konečné zesílení $A_{\mathrm{U}}$. O tom, zda se v obvodu použije neinvertující nebo invertující zesilovač, rozhodují přenosové vlastnosti použitého trojbranu RC. Nejčastěji se uživá neinvertující zesilovač realizovaný diferenčním operačním zesilovačem s př́slušnou zpětnou vazbou (viz Obr. 7.8b). Přenosovou funkci aktivního filtru z Obr. 7.8 můžeme určit ve tvaru

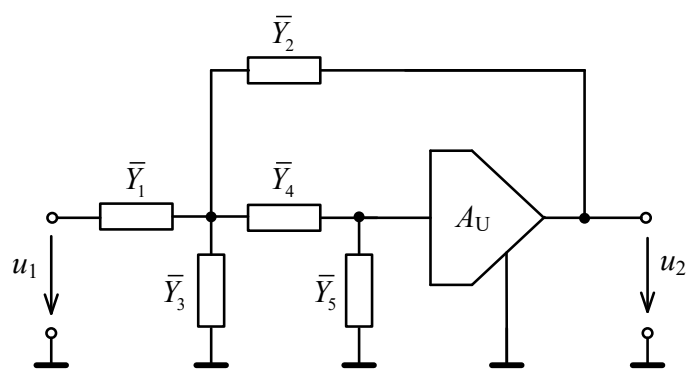

a

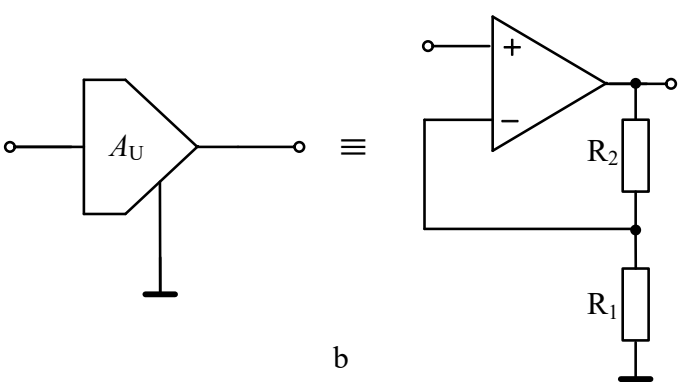

Obr. 7.8: a) Aktivní filtr se zesilovačem s konečným zesílením, b) zesilovač s konečným zesílením $A_{\mathrm{U}} \geq 1$

$$
K(\bar{p})=\frac{A_{U} \bar{Y}_{1} \bar{Y}_{4}}{\bar{Y}_{4}\left(\bar{Y}_{1}+\left(1-A_{U}\right) \bar{Y}_{2}+\bar{Y}_{3}\right)+\bar{Y}_{5}\left(\bar{Y}_{1}+\bar{Y}_{2}+\bar{Y}_{3}+\bar{Y}_{4}\right)}
$$

Doporučená volba admitancí dvojpólů pro různé typy filtrů pro zesílení $A_{\mathrm{U}} \geq 1$ je uvedena v Tab. 1.3.

Tab. 7.3: Doporučená volba admitancí pro aktivní filtr s kladnou zpětnou vazbou

\begin{tabular}{|c|c|c|c|c|c|}
\hline typ & $\bar{Y}_{1}$ & $\bar{Y}_{2}$ & $\bar{Y}_{3}$ & $\bar{Y}_{4}$ & $\bar{Y}_{5}$ \\
\hline DP & $G_{1}$ & $\bar{p} C_{1}$ & 0 & $G_{2}$ & $\bar{p} C_{2}$ \\
\hline PP & $G_{1}$ & $G_{2}$ & $\bar{p} C_{2}$ & $\bar{p} C_{1}$ & $G_{3}$ \\
\hline HP & $\bar{p} C_{1}$ & $G_{1}$ & 0 & $\bar{p} C_{2}$ & $G_{2}$ \\
\hline
\end{tabular}

\section{Aktivní filtry s několika zesilovači}

Rozvoj technologie integrovaných analogových obvodů odsunul mnohá konstrukční omezení do pozadí. Jedním z těchto omezení byl pokud možno co nejmenší počet aktivních prvků. Toto omezení bylo výchozím u všech dosud uvažovaných aktivních filtrů. V současné době se však ukazuje, že nemá smysl minimalizovat počet aktivních prvků. Proto, v př́ípadě, kdy realizace filtru s několika zesilovači může zabezpečit lepší vlastnosti ve srovnání 
$\mathrm{s}$ aktivním filtrem $\mathrm{s}$ jedním zesilovačem, dáme přednost typu s větším počtem zesilovačů. Používá se dvou, nejčastěji však tří až čtyř operačních zesilovačůn, a to podle nároků na přenosovou funkci. Filtry jsou obvykle označovány jako filtry KHN podle začátečních písmen autorů zapojení, Kerwina, Huelsmana a Newcomba. Později byla rozpracována celá řada modifikací těchto filtrů. Zde se omezíme jen na jedno základní zapojení, které několik firem vyrábí v integrované podobě.

Nejčastěji uváděné uspořádání filtru s větším počtem zesilovačů je naznačeno na Obr. 7.9. Podle toho, který výstup využijeme, můžeme obvodem realizovat filtry 2 . ráádu typu dolní propust, horní propust a pásmová propust, [5], [24].

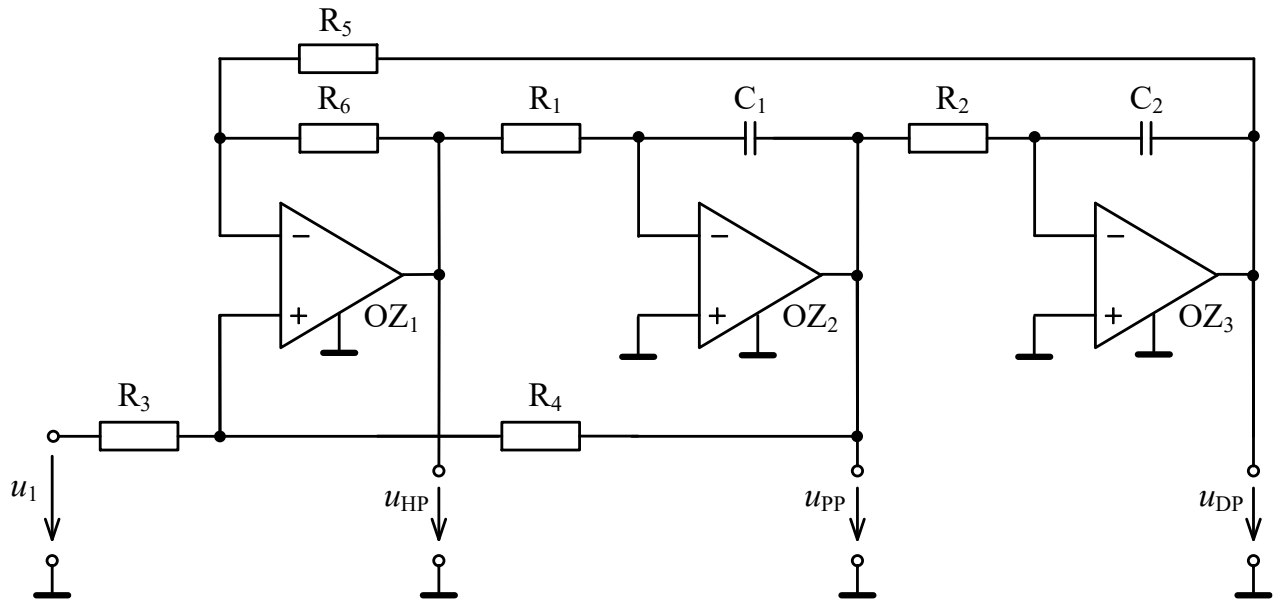

Obr. 7.9: Zapojení filtru s více zesilovači (KHN filtr)

Obvykle je filtr KHN k dispozici jako integrovaný obvod, kdy rezistory $\mathrm{R}_{1}$ a $\mathrm{R}_{2}$ se připojují z vnějšku a $R_{3}=R_{4}=R_{5}=R_{6}=R, C_{1}=C_{2}=C$ jsou součástí integrovaného obvodu. Odpory rezistorů $R_{1}$ a $R_{2}$ a výběr vhodného výstupu pak určuje parametry filtru. funkci

$\mathrm{Z}$ hlediska výstupu $\mathrm{OZ}_{1}$ se obvod chová jako horní propust 2. řádu a má přenosovou

$$
{ }^{\mathrm{HP}} K(\bar{p})=\frac{1}{1+\frac{1}{R_{1} C} \frac{1}{\bar{p}}+\frac{1}{R_{1} R_{2} C^{2}} \frac{1}{\bar{p}^{2}}} .
$$

$\mathrm{Na}$ výstupu $\mathrm{OZ}_{2}$ se obvod chová jako pásmová propust s přenosovou funkcí

$$
{ }^{\mathrm{PP}} K(\bar{p})=-\frac{R_{2} C \bar{p}}{1+R_{2} C \bar{p}+R_{1} R_{2} C^{2} \bar{p}^{2}}
$$

a konečně z hlediska výstupu $\mathrm{OZ}_{3}$ jako dolní propust 2. řádu

$$
{ }^{\mathrm{DP}} K(\bar{p})=\frac{1}{1+R_{2} C \bar{p}+R_{1} R_{2} C^{2} \bar{p}^{2}} .
$$

Velkou výhodou aktivních filtrů s několika zesilovači je skutečnost, že jsou jen velmi málo citlivé na změny tolerancí pasivních prvků. 


\subsection{Dolní propusti}

\subsubsection{Pasivní dolní propusti}

\section{Pasivní dolní propust RC 1. řádu}

Jak již bylo uvedeno, dolní propust je charakteristická tím, že kmitočtové složky nižší než mezní kmitočet jsou filtrem propouštěny s minimálním útlumem a vyšší kmitočtové složky jsou potlačeny. Nejjednodušší dolní propust je možné realizovat strukturou 1. řádu, kdy se filtr skládá $\mathrm{z}$ rezistoru $\mathrm{R}$ a jednoho akumulačního prvku (L nebo C). Častěji se používá kapacitor, protože jeho výroba je jednodušší a méně cenově náročná. Zkráceně takové filtry pak označujeme jako RC filtry.

Na Obr. 7.10 je uvedeno zapojení dolní propusti RC 1. řádu, jejíž napětový přenos lze s přihlédnutím $\mathrm{k}$ rov. (7-10) vyjádřit vztahy

$$
K(\bar{p})=\frac{U_{2}(\bar{p})}{U_{1}(\bar{p})}=\frac{\bar{Z}_{\mathrm{C}}}{\bar{Z}_{\mathrm{R}}+\bar{Z}_{\mathrm{C}}}=\frac{1 / \bar{p} C}{R+1 / \bar{p} C}=\frac{1}{1+\bar{p} R C},
$$

resp.

$$
\bar{K}(\omega)=\frac{\bar{U}_{2}(\omega)}{\bar{U}_{1}(\omega)}=\frac{1 / \mathrm{j} \omega C}{R+1 / \mathrm{j} \omega C}=\frac{1}{1+\mathrm{j} \omega R C} .
$$
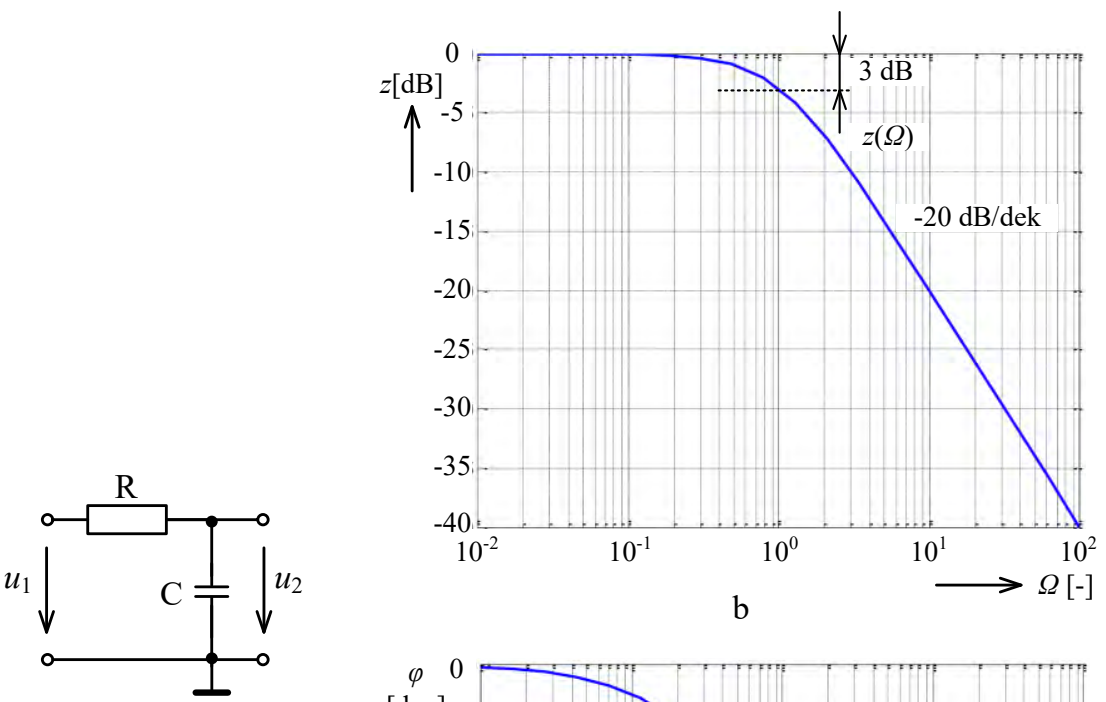

a

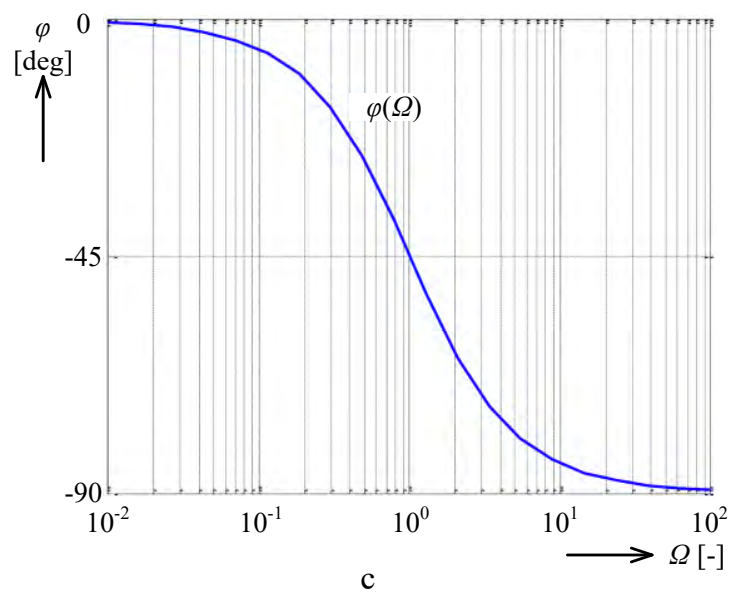

Obr. 7.10: a) Pasivní dolní propust RC 1. řádu a její b) modulová a c) argumentová charakteristika 
Komplexní přenosovou funkci (7-18) rozložíme na reálnou a imaginární část

$$
\bar{K}(\omega)=\frac{1}{1+\mathrm{j} \omega R C} \frac{1-\mathrm{j} \omega R C}{1-\mathrm{j} \omega R C}=\frac{1}{1+\omega^{2} R^{2} C^{2}}-\mathrm{j} \frac{\omega R C}{1+\omega^{2} R^{2} C^{2}}
$$

a odtud již snadno určíme reálnou a imaginární složku přenosové funkce

$$
\operatorname{Re} \bar{K}(\omega)=\frac{1}{1+\omega^{2} R^{2} C^{2}} \quad, \quad \operatorname{Im} \bar{K}(\omega)=-\frac{\omega R C}{1+\omega^{2} R^{2} C^{2}} .
$$

Modulová charakteristika dolní propusti 1. řádu pak

$$
K(\omega)=\bmod \bar{K}(\omega)=\sqrt{(\operatorname{Re} \bar{K}(\omega))^{2}+(\operatorname{Im} \bar{K}(\omega))^{2}}=\frac{1}{\sqrt{1+\omega^{2} R^{2} C^{2}}}
$$

a argumentová charakteristika

$$
\varphi(\omega)=\arg \bar{K}(\omega)=\arctan \frac{\operatorname{Im} \bar{K}(\omega)}{\operatorname{Re} \bar{K}(\omega)}=-\arctan \omega R C .
$$

Pro grafické znázornění v tzv. Bodeově diagramu se modul přenosové funkce vyjadřuje jako zisk dle (7-7), tzn.:

$$
z(\omega)=20 \log K(\omega)=20 \log \frac{1}{\sqrt{1+\omega^{2} R^{2} C^{2}}} .
$$

Ze vztahu (7-23) vyplývá, že na velmi nízkých kmitočtech se modul přenosové funkce asymptoticky bliží hodnotě $0 \mathrm{~dB}$. Naopak na velmi vysokých kmitočtech se modul řídí podle vztahu $z(\omega) \approx 20 \log (1 / \omega R C)$ a je tedy neprímo úměrný kmitočtu. Platí tedy, že zvětšením kmitočtu desetkrát se hodnota modulu sníží o $20 \mathrm{~dB}$. Modul přenosové funkce klesá na vysokých kmitočtech (v nepropustném pásmu) o $20 \mathrm{~dB}$ s každou dekádou kmitočtu.

Mezní kmitočet filtru $\omega_{\mathrm{m}}$ je definován jako kmitočet, při kterém se modul přenosové funkce sníží na hodnotu $1 / \sqrt{2}$, tj. o $3 \mathrm{~dB}$. Tento mezní kmitočet můžeme určit s využitím vztahu (7-21)

$$
K\left(\omega_{\mathrm{m}}\right)=\frac{1}{\sqrt{1+\omega_{\mathrm{m}}^{2} R^{2} C^{2}}}=\frac{1}{\sqrt{2}} .
$$

Řešením této rovnice lze určit mezní kmitočet $\omega_{\mathrm{m}}$ dolní propusti 1. řádu

$$
\omega_{\mathrm{m}}=2 \pi f_{\mathrm{m}}=\frac{1}{R C} \text {, resp. } f_{\mathrm{m}}=\frac{1}{2 \pi R C} .
$$

Fázové natočení výstupního signálu $u_{2}(t)$ vůči vstupnímu signálu $u_{1}(t)$ je při tomto kmitočtu podle $(7-22)-45^{\circ}$.

$\mathrm{Z}$ hlediska obecnějšího přístupu k návrhu filtrů je vhodné komplexní proměnnou $\bar{p}$ $\mathrm{v}$ rov. (7-17) dále normovat vzhledem $\mathrm{k}$ meznímu kmitočtu $\omega_{\mathrm{m}}, \mathrm{tj} .:$

$$
\bar{s}=\frac{\bar{p}}{\omega_{\mathrm{m}}},
$$

kde $\bar{s}$ se označuje jako normovaná komplexní proměnná, kterou lze také vyjádřit jako 


$$
\bar{s}=\frac{\mathrm{j} \omega}{\omega_{\mathrm{m}}}=\frac{\mathrm{j} f}{f_{\mathrm{m}}}=\mathrm{j} \Omega,
$$

Protože mezní kmitočet $\omega_{\mathrm{m}}$ dolní propusti RC z Obr. 7.10a je určen vztahem (7-25), bude $\bar{s}=\bar{p} R C$ a přenosová funkce dolní propusti RC 1 . řádu vyjádřená na v závislosti normované komplexní proměnné $\bar{s}$ bude mít tvar

$$
K(\bar{s})=\frac{1}{1+\bar{s}}, \operatorname{resp} . K(\mathrm{j} \Omega)=\frac{1}{1+\mathrm{j} \Omega} .
$$

Normovaná modulová a argumentová charakteristika bude popsána vztahy

$$
K(\Omega)=\frac{1}{\sqrt{1+\Omega^{2}}}, \text { popř. } z(\Omega)=20 \log \frac{1}{\sqrt{1+\Omega^{2}}}, \varphi(\Omega)=-\operatorname{arctg} \Omega .
$$

Závislost modulu a argumentu přenosové funkce kmitočtového filtru 1. řádu na normovaném kmitočtu jsou uvedeny na Obr. $7.10 \mathrm{~b}, \mathrm{c}$. Z Obr. $7.10 \mathrm{~b}$ je vidět, že při jednotkové hodnotě normovaného úhlového kmitočtu $\Omega$ dochází k poklesu modulu o $3 \mathrm{~dB}$ z hodnoty v pásmu propustnosti (v tomto prŕpadě $0 \mathrm{~dB}$ ). Stejně tak z Obr. $7.10 \mathrm{c}$ je vidět, že při hodnotě normovaného úhlového kmitočtu $\Omega=1$, tedy při kmitočtu vstupního signálu odpovídajícího meznímu kmitočtu $\omega_{\mathrm{m}}$ dochází k fázovému posunu právě $-45^{\circ}$.

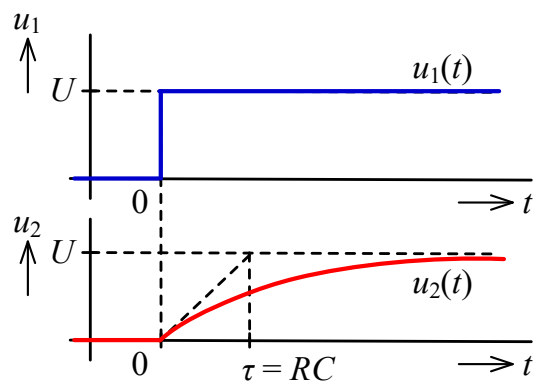

a

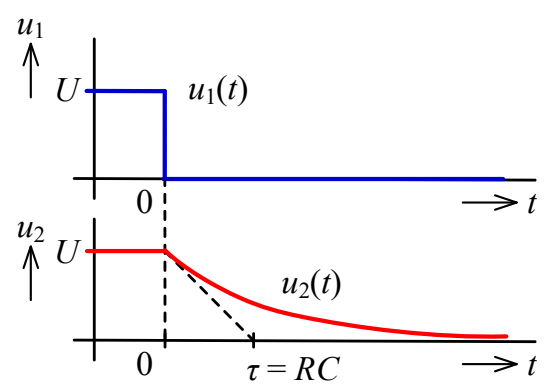

b

Obr. 7.11: Odezva dolní propusti na jednotkový skok (přechodová charakteristika)

Prozkoumáme ještě chování dolní propusti 1. řádu v časové oblasti. Přivedeme-li na vstup skok napětí z nuly na napětí $U$ Obr. 7.11a) nebo naopak z napětí U na nulu (Obr. 7.11b), bude se v prvém př́padě kapacitor nabíjet a výstupní napětí se bude měnit podle vztahu $u_{2}(t)=U\left(1-\mathrm{e}^{-t / R C}\right)$. V druhém př́padě se kapacitor bude exponenciálně vybíjet podle vztahu $u_{2}(t)=U \mathrm{e}^{-t / R C}$. Vlastnosti dolní propusti v časové oblasti charakterizuje časová konstanta $\tau=$ $R C$, která udává dobu, za kterou odezva na jednotkový skok dosáhne hodnoty odlišující se od ustáleného stavu o $1 / \mathrm{e}=1 / 2,718 \doteq 0,37$, tj. o $37 \%$. Dobu ustálení výstupního napětí pro požadovanou přesnost lze přibližně odhadnout z Tab. 7.4.

Tab. 7.4: Doba ustálení výstupního napětí

\begin{tabular}{|c|c|c|c|c|}
\hline Přesnost ustálení & $37 \%$ & $10 \%$ & $1 \%$ & $0,1 \%$ \\
\hline Doba ustálení & $\tau$ & $2,3 \tau$ & $4,6 \tau$ & $6,9 \tau$ \\
\hline
\end{tabular}


V předchozí části bylo ukázáno, že střídavé výstupní napětí je malé ve srovnání se vstupním napětím, pokud pracujeme v oblasti kmitočtů $f \gg>f_{\mathrm{m}}$. Dolní propust pracuje pak jako tzv. pasivní integrační článek

$$
u_{2}(t)=u_{2}(0)+\frac{1}{R C} \int_{0}^{t} u_{1}(t) \mathrm{d} t,
$$

kde integrační konstanta $u_{2}(0)$ představuje nabití kapacitoru $\mathrm{v}$ čase $t=0$.

Jak již bylo naznačeno $\mathrm{v}$ předešlé části, $\mathrm{v}$ př́ípadě požadavku na rychlejší pokles modulové charakteristiky z propustného do nepropustného pásma, je možné zapojit $n$ dolních propustí RC 1. řádu dle Obr. 7.10a do kaskády. Přenosovou funkci takovéto soustavy je pak možné zapsat v obecném tvaru

$$
K(\bar{s})=\frac{1}{\left(1+d_{1} \bar{s}\right)\left(1+d_{2} \bar{s}\right) \ldots\left(1+d_{n} \bar{s}\right)}=\frac{1}{\prod_{i=1}^{n}\left(1+d_{i} \bar{s}\right)},
$$

kde $d_{i}(i=1,2, \ldots n)$ jsou kladné reálné koeficienty. Pokud do hototo vztahu dosadíme $\bar{s}=\mathrm{j} \Omega$ , můžeme odvodit, že pro $\Omega \gg>1$ bude modul přenosové funkce $K(\Omega) \approx 1 / \Omega^{n}$. Přenosová funkce se proto bude asymptoticky blížit k přímce, která klesá se sklonem $n \cdot 20 \mathrm{~dB} / \mathrm{dek}$. Soustava vytvořená kaskádním řazením pasivních dolních propustí s týmž mezním kmitočtem bude mít kritické tlumení (název se týká vlastností přechodové charakteristiky, tj. časového průběhu odezvy na jednotkový skok) a koeficienty $d_{i}$ budou pro všechna $i$ shodné

$$
d=d_{i}=\sqrt{\sqrt[n]{2}-1} .
$$

Jednotlivé dílčí dolní propusti, z nichž je řetězec sestaven, budou mít $(1 / d)$ krát vyšší mezní kmitočet než má celý filtr.

Označení „filttr s kritickým tlumením“ se týká vlastností filtru z pohledu analýzy jeho přechodové charakteristiky, tj. jeho odezvy na jednotkový skok kdy nedochází k překmitu výstupního napětí. Nedostatkem filtru s kritickým tlumením, resp. pasivních RC filtrů je skutečnost, že přechod z propustného do nepropustného pásma není dostatečně ostrý. Z tohoto důvodu jsou pro realizaci výhodnější struktury druhého řádu realizované prostřednictvím RLC prvků.

\section{Pasivní dolní propust RLC 2. řádu}

Jako př́klad pasivní dolní propusti 2. řádu lze uvést zapojení na Obr. 7.11a, např. [19]. Také toto zapojení lze obecně považovat za napětový dělič a přenosovou funkci lze psát ve tvaru

$$
K(\bar{p})=\frac{\bar{Z}_{\mathrm{C}}}{\bar{Z}_{\mathrm{L}}+\bar{Z}_{\mathrm{R}}+\bar{Z}_{\mathrm{C}}}=\frac{1 / \bar{p} C}{\bar{p} L+R+1 / \bar{p} C}=\frac{1}{1+R C \bar{p}+L C \bar{p}^{2}} .
$$

Odpovídající modulová a argumentová charakteristika dolní propusti 2. řádu je uvedena na Obr. $7.12 \mathrm{~b}, \mathrm{c}$. 


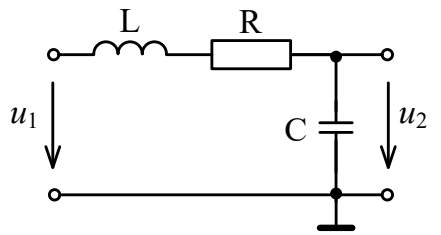

a
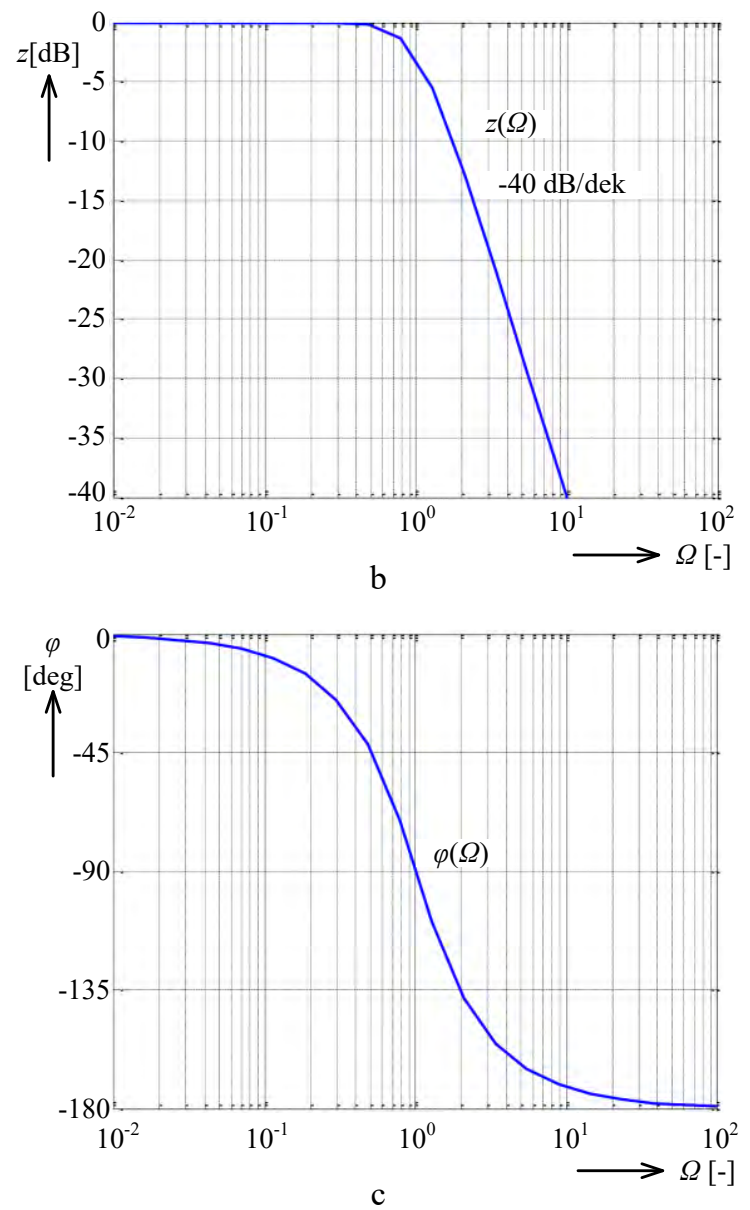

Obr. 7.12: a) Pasivní dolní propust RLC 2. řádu a její b) modulová a c) argumentová charakteristika $(Q=0,707)$

Využitím normované komplexní proměnné $\bar{s}=\bar{p} / \omega_{\mathrm{m}}$ lze (rov.(7-33)) vyjádřit vztahem

$$
K(\bar{s})=\frac{1}{1+\omega_{\mathrm{m}} R C \bar{s}+\omega_{\mathrm{m}}^{2} L C \bar{s}^{2}} .
$$

Zavedením rezonančního kmitočtu $\omega_{0}=1 / \sqrt{L C}$ známého $\mathrm{z}$ teorie rezonančních obvodů jako Thomsonův vztah a činitele jakosti rezonančního RLC obvodu $Q=\omega_{0} L / R=\sqrt{L / C} / R$ lze výraz (7-34) upravit do tvaru

$$
K(\bar{s})=\frac{1}{1+\frac{\omega_{\mathrm{m}}}{\omega_{0} Q} \bar{s}+\frac{\omega_{\mathrm{m}}^{2}}{\omega_{0}^{2}} \bar{s}^{2}} .
$$

Přenosovou funkci dolní propusti 2. řádu (7-34) lze obecně zapsat ve tvaru

$$
K(\bar{s})=\frac{1}{1+a_{1} \bar{s}+b_{1} \bar{s}^{2}},
$$

prričemž koeficienty přenosové funkce

$$
a_{1}=\frac{\omega_{\mathrm{m}}}{\omega_{0} Q}, \quad b_{1}=\frac{\omega_{\mathrm{m}}^{2}}{\omega_{0}^{2}} .
$$


Z koeficientů $a_{1}, b_{1}$ přenosové funkce lze naopak vyjádřit vztah mezi rezonančním kmitočtem $\varpi_{0}$ a mezním kmitočtem $\varpi_{\mathrm{m}}$ filtru, resp. vztah pro činitel jakosti

$$
\omega_{0}=\frac{\omega_{\mathrm{m}}}{\sqrt{b_{1}}}, \quad Q=\frac{\omega_{\mathrm{m}}}{\omega_{0} a_{1}}=\frac{\sqrt{b_{1}}}{a_{1}} .
$$

Tvar modulové i argumentové charakteristiky je silně ovlivněn hodnotou činitele jakosti $Q$, jak je to zřejmé z Obr. 7.13. S rostoucí hodnotou jakosti dochází ke strmějšímu přechodu modulové charakteristiky při přechodu $\mathrm{z}$ propustného do nepropustného pásma. Na druhé straně vyšší jakost filtru způsobuje zvýšení zisku před mezním kmitočtem. Je-li hodnota $Q=1 / \sqrt{2}=0,707$ tak, jako je tomu v př́padě Obr. $7.12 \mathrm{~b}$, pak je modulová charakteristika maximálně plochá.

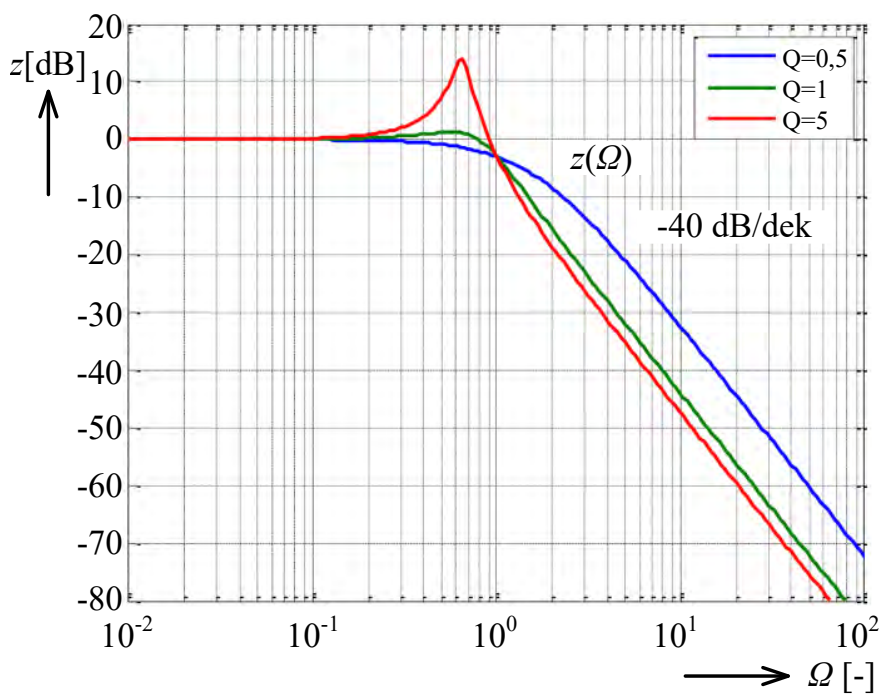

Obr. 7.13: Modulová charakteristika dolní propusti 2. řádu pro různé činitele jakosti $Q$ normovaná vzhledem k meznímu kmitočtu

Pro výpočet hodnot $R$ a $L$ můžeme porovnáním (7-34) a (7-36) získat vztahy

$$
R=\frac{a_{1}}{2 \pi f_{\mathrm{m}} C}, \quad L=\frac{b_{1}}{4 \pi^{2} f_{\mathrm{m}}^{2} C} .
$$

Dolní propust 2. řádu s aproximací přenosové funkce dle Butterworta (viz dále) bude mít koeficienty $a_{1}=1,414$ a $b_{1}=1,000$. Pro mezní kmitočet $f_{\mathrm{m}}=10 \mathrm{~Hz}$ a kapacitu kapacitoru $C=10$ $\mu \mathrm{F}$ dostaneme podle uvedených rovnic $R=2,25 \mathrm{k} \Omega$ a $L=25,3 \mathrm{H}$. Takový filtr by byl prakticky nerealizovatelný z důvodu velké indukčnosti induktoru L. Daleko snadněji lze takovýto filtr realizovat pomocí aktivního filtru s operačním zesilovačem a RC prvky.

\subsubsection{Aproximace přenosové funkce dolní propusti}

Při návrhu kmitočtových filtrů 2. řádu se v řadě př́ípadů pracuje s požadovanou hodnotou činitele jakosti $Q$ a rezonančního kmitočtu $\omega_{0}$. Pro splnění definovaného průběhu přenosové funkce kmitočtových filtrů vyššího řádu je lépe definovat vlastnosti filtru pomocí hodnot koeficientů $a_{i}$ a $b_{i}$ normované přenosové funkce $i$-tého dílčího filtru 2. řádu (viz rov. (7-36))

$$
K_{i}(\bar{s})=\frac{K_{i}}{1+a_{i} \bar{s}+b_{i} \bar{s}^{2}} .
$$


Při kaskádním řazení dílčích filtrů je pak podle rov. (7-9) výsledná přenosová funkce dolní propusti $n$-tého rrádu popsána vztahem

$$
K(\bar{s})=\frac{K_{0}}{\left(1+a_{1} \bar{s}+b_{1} \bar{s}^{2}\right) \ldots\left(1+a_{I} \bar{s}+b_{I} \bar{s}^{2}\right)}=\frac{K_{0}}{\prod_{i=1}^{I}\left(1+a_{i} \bar{s}+b_{i} \bar{s}^{2}\right)},
$$

kde $K_{0}=K_{1} \cdot K_{2} \cdot \ldots \cdot K_{I}$ je přenos v pásmu propustnosti a $a_{i}$ a $b_{i}$ jsou kladné reálné koeficienty $i$-tého filtru 2. řádu, príčemž celkový počet kaskádně řazených filtrů 2. řádu je $I$. Pro lichý řád filtru je koeficient $b_{1}$ roven nule. Jestliže vynásobíme mnohočleny 2 . řádu ve jmenovateli vztahu (7-41) může být přenosová funkce filtru zapsána ve tvaru

$$
K(\bar{s})=\frac{K_{0}}{1+c_{1} \bar{s}+c_{2} \bar{s}^{2} \ldots c_{n} \bar{s}^{n}},
$$

kde $c_{1}, c_{2}, \ldots, c_{n}$ jsou kladné reálné koeficienty. Řád filtru je dán nejvyšším mocnitelem $n=2 I$ normované komplexní proměnné. Řád filtru udává také asymptotu $-n 20 \mathrm{~dB} / \mathrm{dek}=-I 40 \mathrm{~dB} /$ dek, ke které se blíží modulová charakteristika filtru při $\Omega>>1$.

Kmitočtové filtry (pasivní i aktivní) se obvykle navrhují podle zvolené aproximace, kdy nejčastěji se přenosové funkce aproximují dle Butterwortha, Čebyševa, Bessela, př́ípadně i Cauera.

Modulová charakteristika kmitočtového filtru aproximovaná dle Butterwortha je maximálně plochá v propustném pásmu kmitočtů a za mezním kmitočtem vykazuje velmi rychlý pokles modulu přenosu. Přechodová charakteristika (odezva filtru na jednotkový skok) však vykazuje zákmity, kdy s rostoucím řádem filtru jsou tyto zákmity významnější.

Modulová charakteristika filtru s přenosovou funkcí aproximovanou dle Čebyševa za mezním kmitočtem prudce klesá, rychleji, než v případě Butterworthovy aproximace. V pásmu propustnosti však modulová charakteristika není monotonní, ale vykazuje zvlnění s konstantním rozkmitem. Při návrhu filtru lze velikost tohoto zvlnění zvolit. Přestože je přechod z propustného do nepropustného pásma strmější, než v př́ípadě Butterworthovy aproximace, při buzení jednotkovým skokem jsou zákmity podstatně větší.

Optimální přechodovou charakteristiku (odezvu na jednotkový skok) vykazuje filtr $\mathrm{s}$ přenosovou funkcí aproximovanou dle Bessela. Je tomu tak $\mathrm{z}$ toho důvodu, že tato aproximace má konstantní skupinové zpoždění $\tau(\omega)$

$$
\tau(\omega)=-\frac{\mathrm{d} \varphi(\omega)}{\mathrm{d} \omega} \approx h
$$

$\mathrm{v}$ širokém kmitočtovém rozsahu (téměř $\mathrm{v}$ celém pásmu propustnosti). Je-li $h>0$, tj. argumentová charakteristika má rovnoměrně klesající charakter, jsou všechny kmitočtové složky signálu a tedy i celý signál zpožděny o čas $h$ a přechodová charakteristika má optimální průběh bez zákmitů. Pokles modulové charakteristiky filtrů realizovaných dle Besselovy aproximace však má méně strmý pokles z propustného do nepropustného pásma než je tomu u Butterworthovy resp. Čebyševovy aproximace.

Srovnání průběhů modulových charakteristik $z(\Omega)=20 \log \left(K(\Omega) / K_{0}\right)$ nejčastěji používaných aproximací pro dolní propust 4 . řádu společně s RC filtrem s kritickým tlumením (viz rov. (7-31) a (7-32)) je uvedeno na Obr. 7.14a. Na Obr. 7.14b jsou uvedeny př́slušné přechodové charakteristiky dolních propustí 4. řádu pro různé typy aproximací přenosové funkce (zde je čas $t$ normován vzhledem $\mathrm{k} T_{\mathrm{m}}=1 / f_{\mathrm{m}}$ ). Na Obr. $7.14 \mathrm{c}$ jsou pak uvedeny průběhy normovaného skupinového zpoždění $T_{\mathrm{z}}(\Omega)=\tau(\Omega) / T_{\mathrm{m}}$ normovaného taktéž vzhledem $\mathrm{k} T_{\mathrm{m}}$ $=1 / f_{\mathrm{m}}$. 


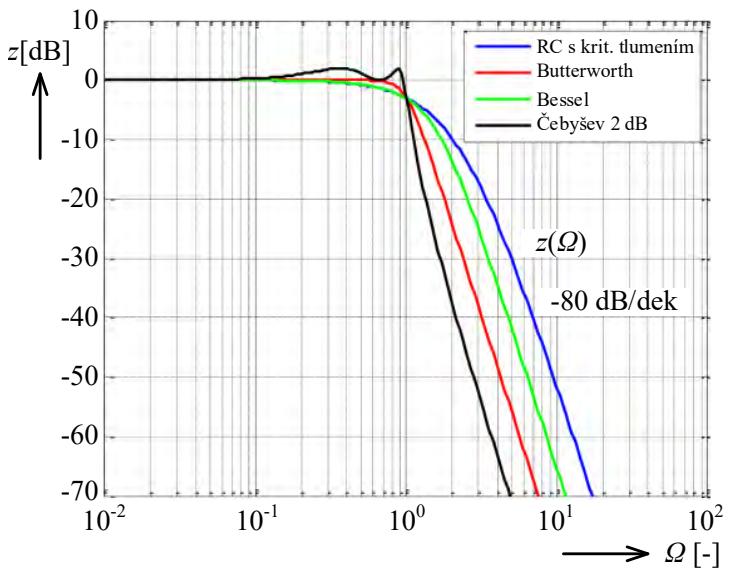

a
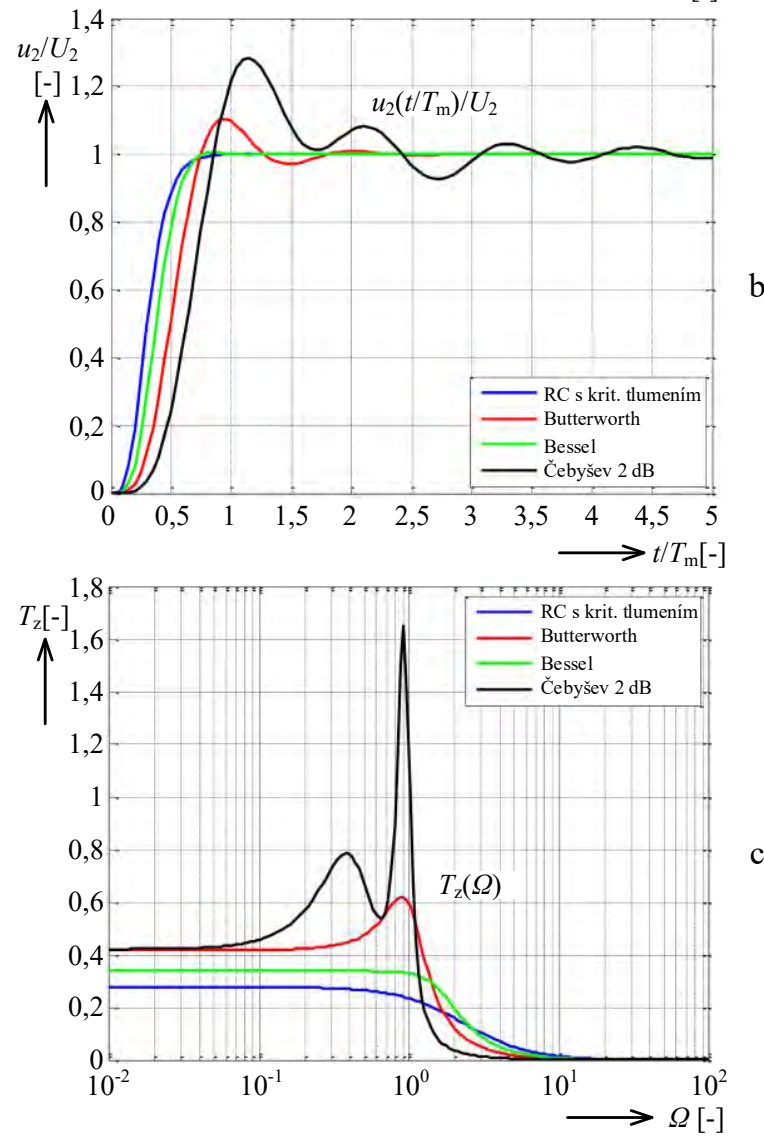

Obr. 7.14: Porovnání vlastností dolních propustí 4. řádu: a) modulové charakteristiky, b) přechodové charakteristiky, c) skupinové zpoždění

Jak bude ukázáno v následující části, změna aproximace při daném řádu filtru spočívá pouze ve volbě jiných hodnot koeficientů $a_{i}$ a $b_{i}$. Využitím stejného výchozího obvodu realizujícího daný typ kmitočtového filtru tak lze realizovat danou aproximaci a to pouze změnou hodnot př́slušných pasivních prvků. Dále jsou blíže popsány nejčastěji využívané typy aproximací a uvedeny hodnoty koeficientů $a_{i}$ a $b_{i}$ určených pro návrh filtrů $n$-tého řádu kaskádní syntézou.

\section{Aproximace přenosové funkce dle Butterwortha}

Jestliže přejdeme z komplexní normované proměnné na normovaný úhlový kmitočet $\bar{s}=\mathrm{j} \Omega$ a využijeme znalosti, že $\mathrm{j}^{2}=-1$, bude podle rov. (7-42) přenos dolní propusti 


$$
\bar{K}(\Omega)=\frac{K_{0}}{\left(1-c_{2} \Omega^{2}+c_{4} \Omega^{4}-\ldots\right)+\mathrm{j}\left(c_{1} \Omega-c_{3} \Omega^{3}+c_{5} \Omega^{5}-\ldots\right)}
$$

Modul přenosové funkce potom

$$
K(\Omega)=\frac{K_{0}}{\sqrt{\left(1-c_{2} \Omega^{2}+c_{4} \Omega^{4}-\ldots\right)^{2}+\left(c_{1} \Omega-c_{3} \Omega^{3}+c_{5} \Omega^{5}-\ldots\right)^{2}}} .
$$

Odtud je vidět, že modul přenosové funkce můžeme obecně určit ve tvaru

$$
K(\Omega)=\frac{K_{0}}{\sqrt{1+d_{2} \Omega^{2}+d_{4} \Omega^{4}+\ldots d_{2 n} \Omega^{2 n}}} .
$$

Je zřejmé, že ve výsledku chybí liché mocniny normovaného úhlového kmitočtu $\Omega$. Pro filtr s přenosovou funkcí aproximovanou dle Butterwortha musí být průběh modulu $K(\Omega)$ v pásmu propustnosti pokud možno konstantní, např. [25]. Aby tento požadavek byl splněn i pro $\Omega<1$, musí průběh modulové charakteristiky záviset pouze na nejvyšší mocnině $\Omega$. Vyplývá to z toho, že nižší mocniny $\Omega$ mají v oblasti $\Omega<1$ větší vliv na výslednou hodnotu rov. (7-46) a také způsobují podstatné zmenšení modulu činitele přenosu. Pak můžeme psát

$$
K(\Omega) \approx \frac{K_{0}}{\sqrt{1+d_{2 n} \Omega^{2 n}}} .
$$

Koeficient $d_{2 n}$ určíme z požadavku, že při kmitočtu $\Omega=1$ se modul přenosové funkce musí snížit o $3 \mathrm{~dB}, \mathrm{tj} . K_{0} / \sqrt{2} \approx K_{0} / \sqrt{1+d_{2 n}}$; odtud plyne, že $d_{2 n}=1$. Modul přenosové funkce dolní propusti aproximovaný dle Butterwortha má pak tvar

$$
K(\Omega) \approx \frac{K_{0}}{\sqrt{1+\Omega^{2 n}}} .
$$

Ve výrazu se vyskytuje pouze nejvyšší mocnina normovaného kmitočtu $\Omega$. Proto se někdy dolní propust s prenosovou funkcí aproximovanou dle Butterwortha nazývá mocninová dolní propust. Vzhledem $\mathrm{k}$ tomu, že modul přenosové charakteristiky je $\mathrm{v}$ propustné části zcela plochý, hovoří se někdy o filtru s maximálně plochou charakteristikou.

$Z$ výše uvedených důvodů jsou v př́padě aproximace dle Butterwortha koeficienty $a_{i}$ a $b_{i}$ $\mathrm{v}$ rov. (7-40) určeny tak, aby koeficienty $d_{2}, d_{4}, \ldots$ mimo koeficientu $d_{2 n}$ u nejvyšší mocniny byly nulové.

Hodnoty koeficienti̊ $a_{i}$ a $b_{i}$ pro Butterworthovu aproximaci jsou pro $n=1, \ldots 10$ uvedeny v Tab.1.5. Kromě těchto koeficientů jsou v Tab 1.5. také uvedeny hodnoty normovaného mezního kmitočtu $f_{\mathrm{m} i} / f_{\mathrm{m}}$ pro každý dílčí článek kaskádní struktury spolu s odpovídající hodnotou činitele jakosti $Q_{i}=\sqrt{b_{i}} / a_{i}$. Znalost $f_{\mathrm{m} i}$ a $Q_{i}$ se zejména hodí při oživování dílčích filtrů.

Normované modulové charakteristiky filtrů $z(\Omega)=20 \log \left(K(\Omega) / K_{0}\right)$ s Butterworthovou aproximací pro různé rády filtru jsou uvedeny na Obr. 7.15. 
Tab. 7.5.:Koeficienty $a_{i}$ a $b_{i}$ přenosové funkce dolní propusti aproximované dle Butterwortha

\begin{tabular}{|c|c|c|c|c|c|}
\hline$n$ & $i$ & $a_{i}$ & $b_{i}$ & $f_{\mathrm{m} i} / f_{\mathrm{m}}$ & $Q_{i}$ \\
\hline 1 & 1 & 1,0000 & 0,0000 & 1,000 & 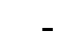 \\
\hline 2 & 1 & 1,4142 & 1,0000 & 1,000 & 0,71 \\
\hline \multirow{2}{*}{3} & 1 & 1,0000 & 0,0000 & 1,000 & \\
\hline & 2 & 1,0000 & 1,0000 & 1,272 & 1,00 \\
\hline \multirow{2}{*}{4} & 1 & 1,8478 & 1,0000 & 0,719 & 0,54 \\
\hline & 2 & 0,7654 & 1,0000 & 1,390 & 1,31 \\
\hline \multirow{3}{*}{5} & 1 & 1,0000 & 0,0000 & 1,000 & - \\
\hline & 2 & 1,6180 & 1,0000 & 0,859 & 0,62 \\
\hline & 3 & 0,6180 & 1,0000 & 1,448 & 1,62 \\
\hline \multirow{3}{*}{6} & 1 & 1,9319 & 1,0000 & 0,676 & 0,52 \\
\hline & 2 & 1,4142 & 1,0000 & 1,000 & 0,71 \\
\hline & 3 & 0,5176 & 1,0000 & 1,479 & 1,93 \\
\hline \multirow{4}{*}{7} & 1 & 1,0000 & 0,0000 & 1,000 & \\
\hline & 2 & 1,8019 & 1,0000 & 0,745 & 0,55 \\
\hline & 3 & 1,2470 & 1,0000 & 1,117 & 0,80 \\
\hline & 4 & 0,4450 & 1,0000 & 1,499 & 2,25 \\
\hline \multirow{4}{*}{8} & 1 & 1,9616 & 1,0000 & 0,661 & 0,51 \\
\hline & 2 & 1,6629 & 1,0000 & 0,829 & 0,60 \\
\hline & 3 & 1,1111 & 1,0000 & 1,206 & 0,90 \\
\hline & 4 & 0,3902 & 1,0000 & 1,512 & 2,56 \\
\hline \multirow{5}{*}{9} & 1 & 1,0000 & 0,0000 & 1,0000 & - \\
\hline & 2 & 1,8794 & 1,0000 & 0,703 & 0,53 \\
\hline & 3 & 1,5321 & 1,0000 & 0,917 & 0,65 \\
\hline & 4 & 1,0000 & 1,0000 & 1,272 & 1,00 \\
\hline & 5 & 0,3473 & 1,0000 & 1,521 & 2,88 \\
\hline \multirow{5}{*}{10} & 1 & 1,9754 & 1,0000 & 0,655 & 0,51 \\
\hline & 2 & 1,7820 & 1,0000 & 0,756 & 0,56 \\
\hline & 3 & 1,4142 & 1,0000 & 1,000 & 0,71 \\
\hline & 4 & 0,9080 & 1,0000 & 1,322 & 1,10 \\
\hline & 5 & 0,3129 & 1,0000 & 1,527 & 3,20 \\
\hline
\end{tabular}

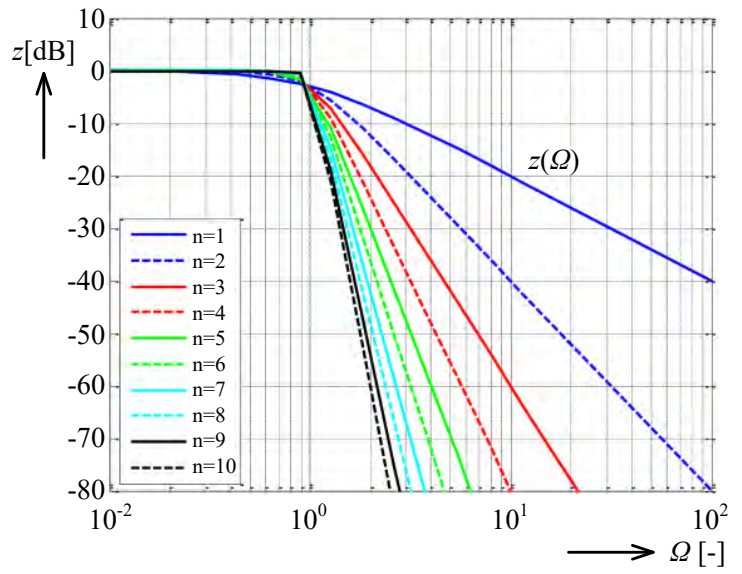

Obr. 7.15: Modulové charakteristiky dolní propusti aproximované dle Butterwortha 


\section{Aproximace přenosové funkce dle Bessela}

Jak již bylo uvedeno, kmitočtové filtry aproximované dle Butterwortha či Čebyševa vykazují významný překmit v př́ípadě přechodové charakteristiky (Obr. 7.14b). Ideální odezva na obdélníkový signál je dosažena u filtrů, které mají kmitočtově nezávislé skupinové zpoždění, tj. lineárně natáčejí fázi v závislosti na kmitočtu. Takové chování vykazují filtry navržené dle Besselovy aproximace, někdy také označované jako Thomsonovy filtry.

Parametry filtru musí být $\mathrm{v}$ tomto př́padě stanoveny tak, aby skupinové zpoždění bylo pro $\Omega<1$ přibližně konstantní a na kmitočtu $\Omega$ pokud možno nezávislé. Jak bylo již uvedeno v (7-40) lze dolní propust 2. ř́a popsat vztahem

$$
K(\bar{s})=\frac{K_{0}}{1+a_{1} \bar{s}+b_{1} \bar{s}^{2}},
$$

resp. po dosazení $\bar{s}=\mathrm{j} \Omega$

$$
\bar{K}(\Omega)=\frac{K_{0}}{1+\mathrm{j} a_{1} \Omega-b_{1} \Omega^{2}}
$$

Z reálné a imaginární složky $\bar{K}(\Omega)$ pak můžeme určit argumentovou charakteristiku

$$
\varphi(\Omega)=\operatorname{arctg} \frac{\operatorname{Im} \bar{K}(\Omega)}{\operatorname{Re} \bar{K}(\Omega)}=-\operatorname{arctg} \frac{a_{1} \Omega}{1-b_{1} \Omega^{2}}
$$

a z ní pak skupinové zpoždění

$$
\tau(\Omega)=-\frac{\mathrm{d} \varphi(\Omega)}{\mathrm{d} \Omega}=\frac{1+b_{1} \Omega^{2}}{1+\left(a_{1}^{2}-2 b_{1}\right) \Omega^{2}+b_{1}^{2} \Omega^{4}} .
$$

Pro $\Omega<<1$ lze člen s nejvyšší mocninou zanedbat a pak přibližně

$$
\tau(\Omega)=\frac{1+b_{1} \Omega^{2}}{1+\left(a_{1}^{2}-2 b_{1}\right) \Omega^{2}} .
$$

Tento vztah nebude záviset na kmitočtu, pokud bude splněna podmínka $b_{1}=a_{1}^{2}-2 b_{1}$, tj. $b_{1}=a_{1}^{2} / 3$.

Výpočet koeficientů $a_{i}$ a $b_{i}$ pro dolní propusti vyšších řádů je samozřejmě složitější. Hodnoty koeficientů Besselovy aproximace $a_{i}$ a $b_{i}$ pro kaskádně realizované dolní propusti vyšších řádů jsou uvedeny $\mathrm{v}$ Tab. 7.6. Normované modulové charakteristiky dolních propustí 1. až 10. řádu $z(\Omega)=20 \log \left(K(\Omega) / K_{0}\right)$ aproximované dle Bessela jsou pak nakresleny $\mathrm{n}$ a Obr. 7.16. Tento typ aproximace se užívá zejména u filtrů určených pro zpracování pravoúhlých signálů nebo signálů vykazujících rychlé změny okamžitých hodnot. 
Tab. 7.6: Koeficienty $a_{i}$ a $b_{i}$ přenosové funkce dolní propusti aproximované dle Bessela

\begin{tabular}{|c|c|c|c|c|c|}
\hline & $i$ & $a_{i}$ & $b_{i}$ & $f_{\mathrm{m} i} /$ & $Q_{i}$ \\
$n$ & & & & $f_{\mathrm{m}}$ & \\
\hline 1 & 1 & 1,0000 & 0,0000 & 1,000 & - \\
\hline 2 & 1 & 1,3617 & 0,6180 & 1,000 & 0,58 \\
\hline \multirow{3}{*}{3} & 1 & 0,7560 & 0,0000 & 1,323 & - \\
& 2 & 0,9996 & 0,4772 & 1,414 & 0,69 \\
\hline \multirow{3}{*}{4} & 1 & 1,3397 & 0,4889 & 0,978 & 0,52 \\
& 2 & 0,7743 & 0,3890 & 1,797 & 0,81 \\
\hline \multirow{5}{*}{5} & 1 & 0,6656 & 0,0000 & 1,502 & - \\
& 2 & 1,1402 & 0,4128 & 1,184 & 0,56 \\
& 3 & 0,6216 & 0,3245 & 2,138 & 0,92 \\
\hline \multirow{4}{*}{6} & 1 & 1,2217 & 0,3887 & 1,063 & 0,51 \\
& 2 & 0,9686 & 0,3505 & 1,431 & 0,61 \\
& 3 & 0,5131 & 0,2756 & 2,447 & 1,02 \\
\hline \multirow{4}{*}{7} & 1 & 0,5937 & 0,0000 & 1,684 & - \\
& 2 & 1,0944 & 0,3395 & 1,207 & 0,53 \\
& 3 & 0,8304 & 0,3011 & 1,695 & 0,66 \\
& 4 & 0,4332 & 0,2381 & 2,731 & 1,13 \\
\hline \multirow{5}{*}{8} & 1 & 1,1112 & 0,3162 & 1,164 & 0,51 \\
& 2 & 0,9754 & 0,2979 & 1,381 & 0,56 \\
& 3 & 0,7202 & 0,2621 & 1,963 & 0,71 \\
& 4 & 0,3728 & 0,2087 & 2,992 & 1,23 \\
\hline \multirow{5}{*}{10} & 1 & 0,5386 & 0,0000 & 1,857 & - \\
& 2 & 1,0244 & 0,2834 & 1,277 & 0,52 \\
& 4 & 0,6320 & 0,2636 & 1,574 & 0,59 \\
& 5 & 0,3257 & 0,2311 & 2,226 & 0,76 \\
& 1 & 1,0215 & 0,2650 & 3,237 & 1,32 \\
\hline & 5 & 0,9393 & 0,2549 & 1,264 & 0,50 \\
& 0,5604 & 0,2883 & 0,1665 & 3,466 & 1,42 \\
\hline
\end{tabular}

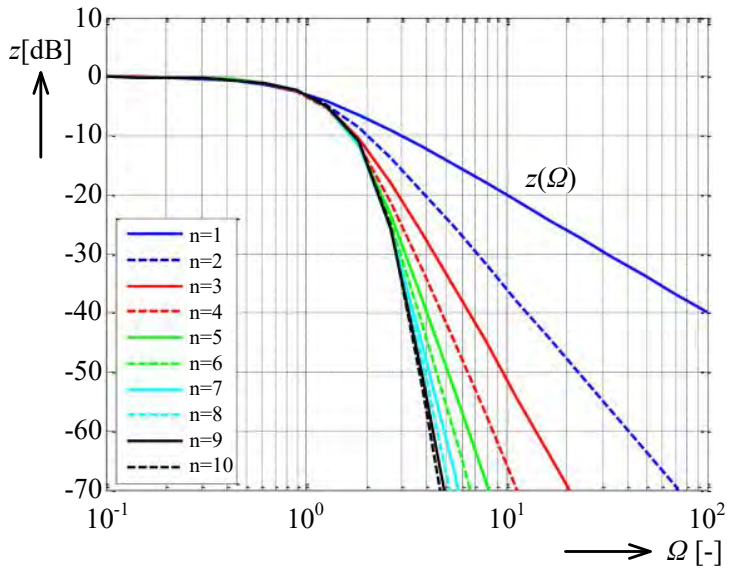

Obr. 7.16: Modulové charakteristiky dolní propusti aproximované dle Bessela

\section{Aproximace přenosové funkce dle Čebyševa}

Filtr s přenosovou funkcí aproximovanou dle Čebyševa je charakteristický tím, že pro velmi nízké kmitočty $f<<f_{\mathrm{m}}$ je přenos $K_{0}$ konstantní. V okamžiku, kdy se kmitočet filtrovaného signálu blíži k meznímu kmitočtu $f<f_{\mathrm{m}}$, resp. $\Omega<1$, má modulová charakteristika zvlněný charakter. Maximální hodnota zvlnění je dána parametry filtru a je možné ji tak nastavit na požadovanou úroveň. Platí, že zmenšování povoleného zvlnění modulové charakteristiky vede na zmenšení rychlosti přechodu modulové charakteristiky do nepropustného pásma. Přesto v př́ipadě Čebyševovy aproximace je rychlost přechodu do nepropustného pásma nejvyšší v porovnání s aproximací dle Butterwortha či Bessela. 
Odvození koeficientů $a_{i}$ a $b_{i}$ pro požadovanou hodnotu zvlnění přenosové charakteristiky $\Delta z$ je dosti náročné a proto je zde neuvádíme. Hodnoty koeficientů přenosové funkce dolní propusti aproximované dle Čebyševa jsou pro zvlnění $\Delta z$ o hodnotách $0,5 \mathrm{~dB}, 1 \mathrm{~dB}, 2 \mathrm{~dB}$ a 3 dB uvedeny v Tab. 7.7 a Tab. 7.8. Současně jsou uvedeny i odpovídající parametry dílčích filtrů, tj. mezní kmitočty dílčích filtrů vztažené k meznímu kmitočtu $f_{\mathrm{m}}$ celého filtru, $\mathrm{tj} . f_{\mathrm{m} i} / f_{\mathrm{m}}$ a činitele jakosti $Q_{i}$.

Tab. 7.7: Koeficienty $a_{i}$ a $b_{i}$ přenosové funkce dolní propusti aproximované dle Čebyševa se zvlněním $0,5 \mathrm{~dB}$ a $1 \mathrm{~dB}$

\begin{tabular}{|c|c|c|c|c|c|}
\hline \multicolumn{6}{|c|}{ zvlnění 0,5 dB } \\
\hline$n$ & $i$ & $a_{i}$ & $b_{i}$ & $f_{\mathrm{m} i} / f_{\mathrm{m}}$ & $Q_{i}$ \\
\hline 1 & 1 & 1,0000 & 0,0000 & 1,000 & - \\
\hline 2 & 1 & 1,3614 & 1,3827 & 1,000 & 0,86 \\
\hline \multirow{2}{*}{3} & 1 & 1,8636 & 0,0000 & 0,537 & _ \\
\hline & 2 & 0,6402 & 1,1931 & 1,335 & 1,71 \\
\hline \multirow{2}{*}{4} & 1 & 2,6282 & 3,4341 & 0,538 & 0,71 \\
\hline & 2 & 0,3648 & 1,1509 & 1,419 & 2,94 \\
\hline \multirow{3}{*}{5} & 1 & 2,9235 & 0,0000 & 0,342 & - \\
\hline & 2 & 1,3025 & 2,3534 & 0,881 & 1,18 \\
\hline & 3 & 0,2290 & 1,0833 & 1,480 & 4,54 \\
\hline \multirow{3}{*}{6} & 1 & 3,8645 & 6,9797 & 0,366 & 0,68 \\
\hline & 2 & 0,7528 & 1,8573 & 1,078 & 1,81 \\
\hline & 3 & 0,1589 & 1,0711 & 1,495 & 6,51 \\
\hline \multirow{4}{*}{7} & 1 & 4,0211 & 0,0000 & 0,249 & - \\
\hline & 2 & 1,8729 & 4,1795 & 0,645 & 1,09 \\
\hline & 3 & 0,4861 & 1,5676 & 1,208 & 2,58 \\
\hline & 4 & 0,1156 & 1,0443 & 1,517 & 8,84 \\
\hline \multirow{4}{*}{8} & 1 & 5,1117 & 11,961 & 0,276 & 0,68 \\
\hline & 2 & 1,0639 & 2,9365 & 0,844 & 1,61 \\
\hline & 3 & 0,3439 & 1,4206 & 1,284 & 3,47 \\
\hline & 4 & 0,0885 & 1,0407 & 1,521 & 11,5 \\
\hline \multirow{5}{*}{9} & 1 & 5,1318 & 0,0000 & 0,195 & - \\
\hline & 2 & 2,4283 & 6,6307 & 0,506 & 1,06 \\
\hline & 3 & 0,6839 & 2,2908 & 0,989 & 2,21 \\
\hline & 4 & 0,2559 & 1,3133 & 1,344 & 4,48 \\
\hline & 5 & 0,0695 & 1,0272 & 1,532 & 14,6 \\
\hline \multirow{5}{*}{10} & 1 & 6,3648 & 18,369 & 0,222 & 0,67 \\
\hline & 2 & 1,3582 & 4,3453 & 0,689 & 1,53 \\
\hline & 3 & 0,4822 & 1,9440 & 1,091 & 2,89 \\
\hline & 4 & 0,1994 & 1,2520 & 1,381 & 5,61 \\
\hline & 5 & 0,0563 & 1,0263 & 1,533 & 18,0 \\
\hline
\end{tabular}

\begin{tabular}{|c|c|c|c|c|c|}
\hline \multicolumn{6}{|c|}{ zvlnění 1 dB } \\
\hline$n$ & $i$ & $a_{i}$ & $b_{i}$ & $f_{\mathrm{m} i} / f_{\mathrm{m}}$ & $Q_{i}$ \\
\hline 1 & 1 & 1,0000 & 0,0000 & 1,000 & - \\
\hline 2 & 1 & 1,3022 & 1,5515 & 1,000 & 0,96 \\
\hline \multirow{2}{*}{3} & 1 & 2,2156 & 0,0000 & 0,451 & - \\
\hline & 2 & 0,5442 & 1,2057 & 1,353 & 2,02 \\
\hline \multirow{2}{*}{4} & 1 & 2,5904 & 4,1301 & 0,540 & 0,78 \\
\hline & 2 & 0,3039 & 1,1697 & 1,417 & 3,56 \\
\hline \multirow{3}{*}{5} & 1 & 3,5711 & 0,0000 & 0,280 & - \\
\hline & 2 & 1,1280 & 2,4896 & 0,894 & 1,40 \\
\hline & 3 & 0,1872 & 1,0814 & 1,486 & 5,56 \\
\hline \multirow{3}{*}{6} & 1 & 3,8437 & 8,5529 & 0,366 & 0,76 \\
\hline & 2 & 0,6292 & 1,9124 & 1,082 & 2,20 \\
\hline & 3 & 0,1296 & 1,0766 & 1,493 & 8,00 \\
\hline \multirow{4}{*}{7} & 1 & 4,9520 & 0,0000 & 0,202 & - \\
\hline & 2 & 1,6338 & 4,4899 & 0,655 & 1,30 \\
\hline & 3 & 0,3987 & 1,5834 & 1,213 & 3,16 \\
\hline & 4 & 0,0937 & 1,0423 & 1,520 & 10,9 \\
\hline \multirow{4}{*}{8} & 1 & 5,1019 & 14,761 & 0,276 & 0,75 \\
\hline & 2 & 0,8916 & 3,0426 & 0,849 & 1,96 \\
\hline & 3 & 0,2806 & 1,4334 & 1,285 & 4,27 \\
\hline & 4 & 0,0717 & 1,0432 & 1,520 & 14,2 \\
\hline \multirow{5}{*}{9} & 1 & 6,3415 & 0,0000 & 0,158 & - \\
\hline & 2 & 2,1252 & 7,1711 & 0,514 & 1,26 \\
\hline & 3 & 0,5624 & 2,3278 & 0,994 & 2,71 \\
\hline & 4 & 0,2076 & 1,3166 & 1,346 & 5,53 \\
\hline & 5 & 0,0562 & 1,0258 & 1,533 & 18,0 \\
\hline \multirow{5}{*}{10} & 1 & 6,3634 & 22,747 & 0,221 & 0,75 \\
\hline & 2 & 1,1399 & 4,5167 & 0,694 & 1,86 \\
\hline & 3 & 0,3939 & 1,9665 & 1,093 & 3,56 \\
\hline & 4 & 0,1616 & 1,2569 & 1,381 & 6,94 \\
\hline & 5 & 0,0455 & 1,0277 & 1,532 & 22,3 \\
\hline
\end{tabular}


Tab. 7.8: Koeficienty $a_{i}$ a $b_{i}$ přenosové funkce dolní propusti aproximované dle Čebyševa se zvlněním $2 \mathrm{~dB}$ a $3 \mathrm{~dB}$

\begin{tabular}{|c|c|c|c|c|c|}
\hline \multicolumn{6}{|c|}{ zvlnění 2 dB } \\
\hline$n$ & $i$ & $a_{i}$ & $b_{i}$ & $f_{\mathrm{m} i} / f_{\mathrm{m}}$ & $Q_{i}$ \\
\hline 1 & 1 & 1,0000 & 0,0000 & 1,000 & - \\
\hline 2 & 1 & 1,1813 & 1,7775 & 1,000 & 1,13 \\
\hline \multirow{2}{*}{3} & 1 & 2,7994 & 0,0000 & 0,357 & - \\
\hline & 2 & 0,4300 & 1,2036 & 1,378 & 2,55 \\
\hline \multirow{2}{*}{4} & 1 & 2,4025 & 4,9862 & 0,550 & 0,93 \\
\hline & 2 & 0,2374 & 1,1896 & 1,413 & 4,59 \\
\hline \multirow{3}{*}{5} & 1 & 4,6345 & 0,0000 & 0,216 & - \\
\hline & 2 & 0,9090 & 2,6036 & 0,908 & 1,78 \\
\hline & 3 & 0,1434 & 1,0750 & 1,493 & 7,23 \\
\hline \multirow{3}{*}{6} & 1 & 3,5880 & 10,465 & 0,373 & 0,90 \\
\hline & 2 & 0,4925 & 1,9622 & 1,085 & 2,84 \\
\hline & 3 & 0,0995 & 1,0826 & 1,491 & 10,5 \\
\hline \multirow{4}{*}{7} & 1 & 6,4760 & 0,0000 & 0,154 & - \\
\hline & 2 & 1,3258 & 4,7649 & 0,665 & 1,65 \\
\hline & 3 & 0,3067 & 1,5927 & 1,218 & 4,12 \\
\hline & 4 & 0,0714 & 1,0384 & 1,523 & 14,3 \\
\hline \multirow{4}{*}{8} & 1 & 4,7743 & 18,151 & 0,282 & 0,89 \\
\hline & 2 & 0,6991 & 3,1353 & 0,853 & 2,53 \\
\hline & 3 & 0,2153 & 1,4449 & 1,285 & 5,58 \\
\hline & 4 & 0,0547 & 1,0461 & 1,518 & 18,7 \\
\hline \multirow{5}{*}{9} & 1 & 8,3198 & 0,0000 & 0,120 & - \\
\hline & 2 & 1,7299 & 7,6580 & 0,522 & 1,60 \\
\hline & 3 & 0,4337 & 2,3549 & 0,998 & 3,54 \\
\hline & 4 & 0,1583 & 1,3174 & 1,349 & 7,25 \\
\hline & 5 & 0,0427 & 1,0232 & 1,536 & 23,7 \\
\hline \multirow{5}{*}{10} & 1 & 5,9618 & 28,038 & 0,226 & 0,89 \\
\hline & 2 & 0,8947 & 4,6644 & 0,697 & 2,41 \\
\hline & 3 & 0,3023 & 1,9858 & 1,094 & 4,66 \\
\hline & 4 & 0,1233 & 1,2614 & 1,380 & 9,11 \\
\hline & 5 & 0,0347 & 1,0294 & 1,531 & 29,3 \\
\hline
\end{tabular}

\begin{tabular}{|c|c|c|c|c|c|}
\hline \multicolumn{6}{|c|}{ zvlnění 3 dB } \\
\hline$n$ & $i$ & $a_{i}$ & $b_{i}$ & $f_{\mathrm{m} i} / f_{\mathrm{m}}$ & $Q_{i}$ \\
\hline 1 & 1 & 1,0000 & 0,0000 & 1,000 & - \\
\hline 2 & 1 & 1,0650 & 1,9305 & 1,000 & 1,30 \\
\hline \multirow{2}{*}{3} & 1 & 3,3496 & 0,0000 & 0,299 & - \\
\hline & 2 & 0,3559 & 1,1923 & 1,396 & 3,07 \\
\hline \multirow{2}{*}{4} & 1 & 2,1853 & 5,5339 & 0,557 & 1,08 \\
\hline & 2 & 0,1964 & 1,2009 & 1,410 & 5,58 \\
\hline \multirow{3}{*}{5} & 1 & 5,6334 & 0,0000 & 0,178 & - \\
\hline & 2 & 0,7620 & 2,6530 & 0,917 & 2,14 \\
\hline & 3 & 0,1172 & 1,0686 & 1,500 & 8,82 \\
\hline \multirow{3}{*}{6} & 1 & 3,2721 & 11,677 & 0,379 & 1,04 \\
\hline & 2 & 0,4077 & 1,9873 & 1,086 & 3,46 \\
\hline & 3 & 0,0815 & 1,0861 & 1,489 & 12,8 \\
\hline \multirow{4}{*}{7} & 1 & 7,9064 & 0,0000 & 0,126 & - \\
\hline & 2 & 1,1159 & 4,8963 & 0,670 & 1,98 \\
\hline & 3 & 0,2515 & 1,5944 & 1,222 & 5,02 \\
\hline & 4 & 0,0582 & 1,0348 & 1,523 & 17,5 \\
\hline \multirow{4}{*}{8} & 1 & 4,3583 & 20,295 & 0,286 & 1,03 \\
\hline & 2 & 0,5791 & 3,1808 & 0,855 & 3,08 \\
\hline & 3 & 0,1765 & 1,4507 & 1,285 & 6,83 \\
\hline & 4 & 0,0448 & 1,0478 & 1,517 & 22,9 \\
\hline \multirow{5}{*}{9} & 1 & 10,176 & 0,0000 & 0,098 & - \\
\hline & 2 & 1,4585 & 7,8971 & 0,526 & 1,93 \\
\hline & 3 & 0,3561 & 2,3651 & 1,001 & 4,32 \\
\hline & 4 & 0,1294 & 1,3165 & 1,351 & 8,87 \\
\hline & 5 & 0,0348 & 1,0210 & 1,537 & 29,0 \\
\hline \multirow{5}{*}{10} & 1 & 5,4449 & 31,379 & 0,230 & 1,03 \\
\hline & 2 & 0,7414 & 4,7363 & 0,699 & 2,94 \\
\hline & 3 & 0,2479 & 1,9952 & 1,094 & 5,70 \\
\hline & 4 & 0,1008 & 1,2638 & 1,380 & 11,2 \\
\hline & 5 & 0,0283 & 1,0304 & 1,530 & 35,9 \\
\hline
\end{tabular}

Průběhy modulové charakteristiky se zvlněním v propustném pásmu $\Delta z=2 \mathrm{~dB}$ jsou uvedeny na Obr. 7.17 a Obr. 7.18. Pro přehlednost jsou na Obr. 7.20a, Obr. 7.20b uvedeny jen modulové charakteristiky filtrů lichého řádu, kdy na Obr. 7.17b je uveden detail modulové charakteristiky v pásmu propustnosti. Podobně na Obr. $7.18 \mathrm{a}, \mathrm{b}$ jsou uvedeny jen moduly přenosové charakteristiky dolní propusti sudého řádu. Na Obr. $7.18 \mathrm{~b}$ je pak opět detail průběhu modulové charakteristiky v propustném pásmu. 
Na Obr. 7.19 jsou pak pro porovnání uvedeny modulové charakteristiky dolní propusti 4. řádu aproximované dle Čebyševa pro různé velikosti zvlnění. Je vidět, že pro nižší hodnoty zvlnění v propustném pásmu je také rychlost změny modulu z propustného do nepropustného pásma menší. Pro porovnání je v Obr. 7.19 uvedena také modulová charakteristika aproximovaná dle Butterwortha, kdy je vidět, že i pro nejnižší uvažovanou hodnotu zvlnění (tj. $\Delta z=0,5 \mathrm{~dB}) \mathrm{u}$ Čebyševovy aproximace je rychlost přechodu modulové charakteristiky do nepropustné části stále vyšší než je tomu u Butterworthovy aproximace. Pro zvlnění $\Delta z=0 \mathrm{~dB}$ Čebyševova aproximace přejde $\mathrm{v}$ aproximaci dle Butterwortha.
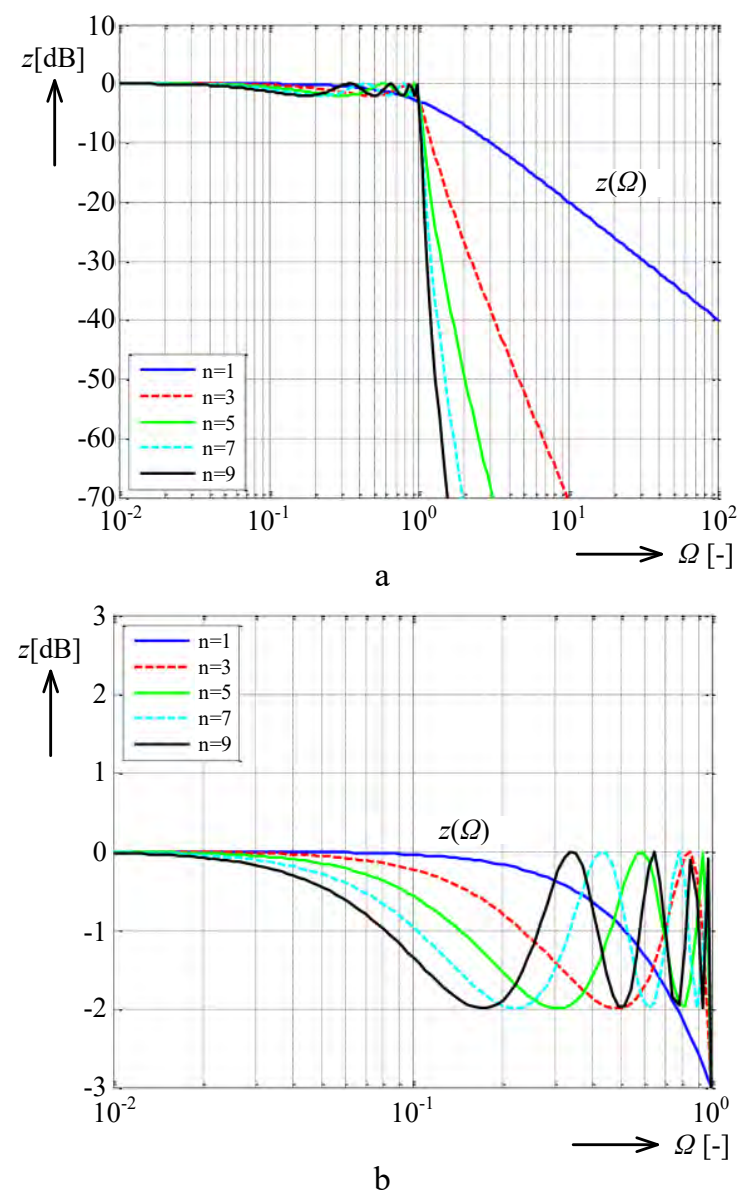

Obr. 7.17: a) Modulové charakteristiky dolní propusti aproximované dle Čebyševa se zvlněním $\Delta z=2 \mathrm{~dB}$ pro filtry lichého řádu, b) detail zvlnění 

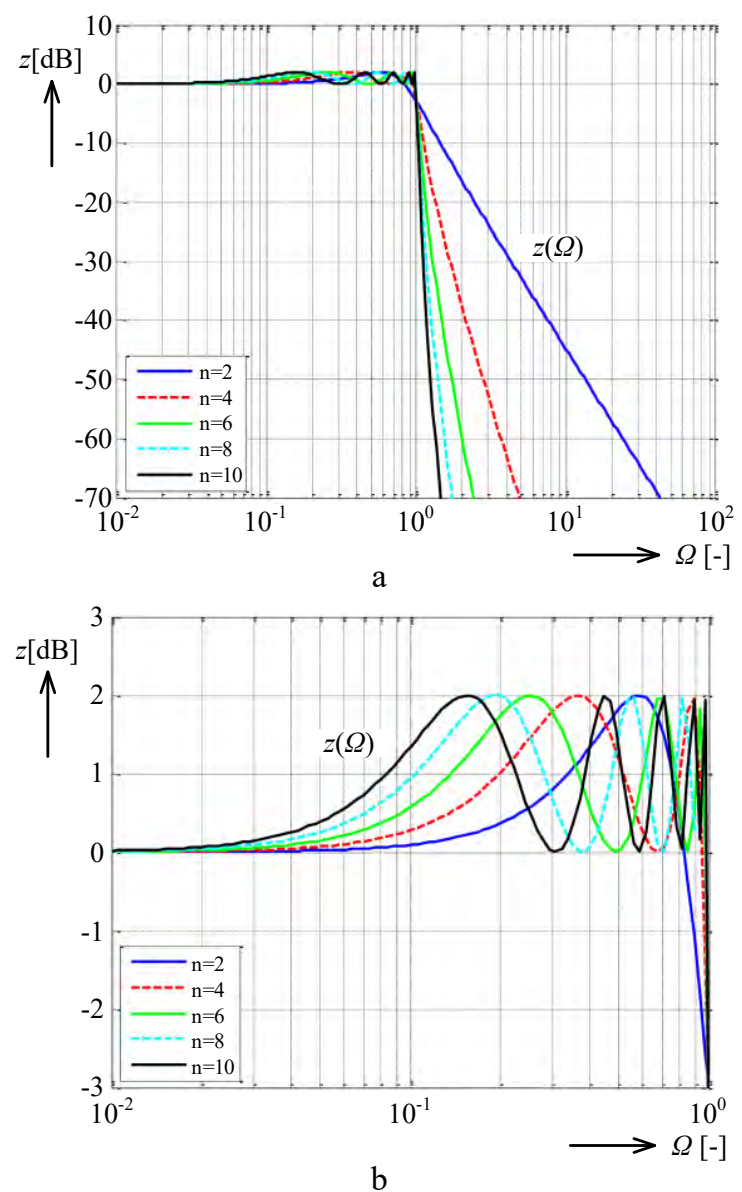

Obr. 7.18: a) Modulové charakteristiky dolní propusti aproximované dle Čebyševa se zvlněním $\Delta z=2 \mathrm{~dB}$ pro filtry sudého řádu, b) detail zvlnění

Z Obr. 7.20 je pak vidět vliv velikosti zvlněn v pásmu propustnosti na skupinové zpoždění, které se s rostoucí hodnotou zvlnění také výrazně mění a zásadně ovlivňuje odezvu filtru na jednotkový skok.

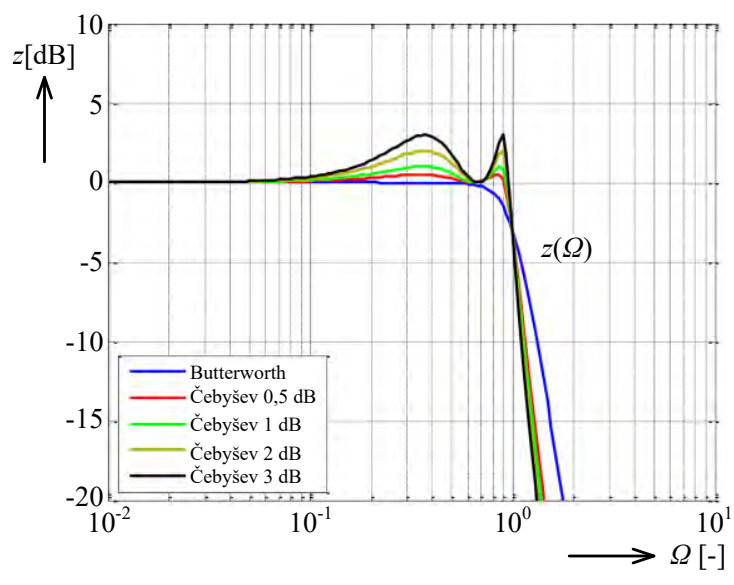

Obr. 7.19: Charakteristiky DP 4. řádu aproximované dle Čebyševa pro různé zvlnění

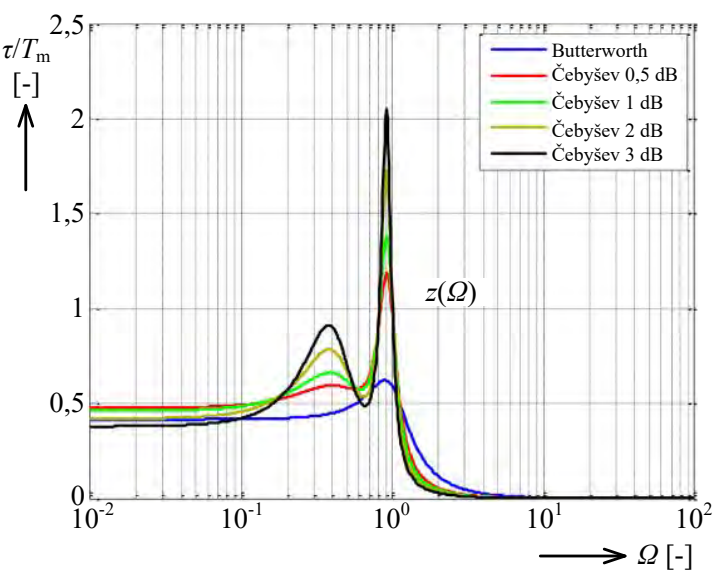

Obr. 7.20: Skupinové zpoždění DP 4. řádu aproximované dle Čebyševa 


\section{Další typy aproximací přenosové funkce}

$\mathrm{V}$ př́padě nutnosti lze přechod z propustného do nepropustného pásma udělat ještě strmější, kdy ale přenosová funkce vykazuje omezený a zvlněný průběh v oblasti kmitočtů nad mezním kmitočtem filtru. Pro návrh takových filtrů je vhodné využít tzv. Cauerovu aproximaci. Aproximace je charakteristická zvlněním pak v propustném (podobně jako je tomu u Čebyševovy aproximace) tak i nepropustném pásmu. Takto navržené filtry jsou pak označovány jako Cauerovy či také eliptické.

Mezi další typy aproximací patří např. inverzní Čebyševova aproximace, která má plochou modulovou charakteristiku v propustném pásmu a zvlněnou v pásmu nepropustném. Tato aproximace vykazuje lepší fázové vlastnosti a přechodnou charakteristiku, která je blízká filtrům navrženým dle Butterworthovy aproximace, ovšem za cenu vyšší složitosti realizace.

Další aproximací, se kterou je možné se setkat, je tzv. Gaussova aproximace, která je definována s ohledem na ideální průběh časové odezvy, podobně jako je tomu u Besselovy aproximace. Modulová přenosová charakteristika má tvar Gaussovy křivky a argumentová charakteristika je zcela lineární. Dále lze zmínit tzv. Legendrovu aproximaci, kdy modulová charakteristika dle této aproximace klesá strměji než v př́ípadě Butterworthovy aproximace za cenu ne zcela hladkého průběhu v propustném pásmu. Dalšími aproximacemi jsou pak tranzitivní Besselova-Butterworthova aproximace, či Kasteleinova aproximace. Koeficienty přenosových funkcí pro některé další typy aproximací lze nalézt v literatuře.

\subsubsection{Aktivní dolní propusti}

\section{Dolní propusti 1. řádu}

Neinvertující dolní propust 1. ̌̌ádu naznačená na Obr. 7.21 a tvoří pasivní dolní propust RC z Obr. 7.10a, za kterou je zařazen neinvertující zesilovač, který jednak odděluje pasivní filtr od zátěže a jednak realizuje potřebné zesílení pro ss. signály. Ze vztahu (7-40) je zřejmé, že přenosová funkce dolní propusti 1. ř́a může být obecně zapsána ve tvaru

$$
K(\bar{s})=\frac{K_{0}}{1+a_{1} \bar{s}} .
$$

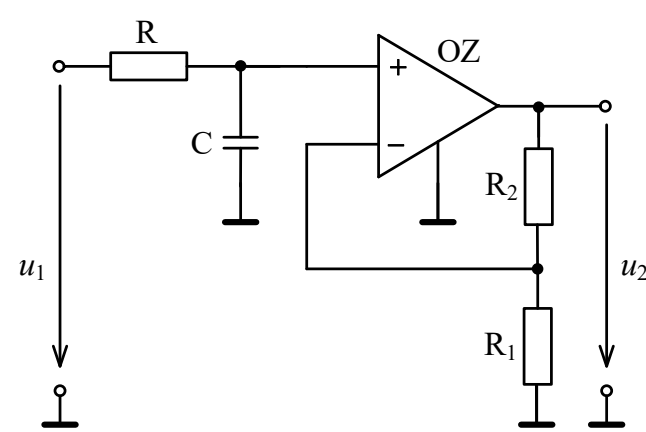

a

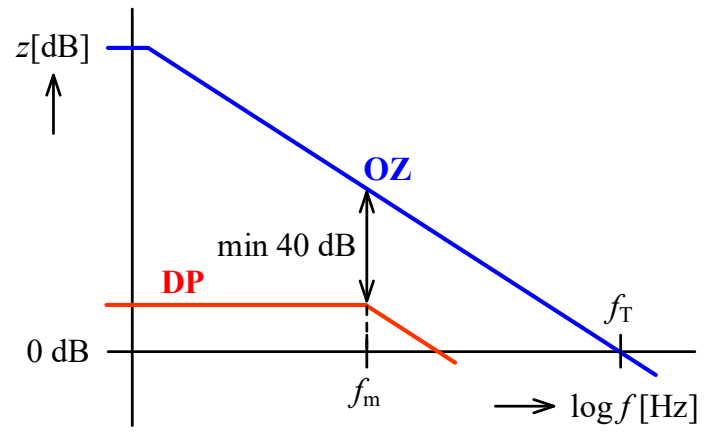

$\mathrm{b}$

Obr. 7.21: a) Dolní propust 1. řádu využívající pasivní článek $\mathrm{RC}$, b) požadavky na kmitočtovou charakteristiku operačního zesilovače

Z tabulek koeficientů aproximačních funkcí Tab. 1.5 až Tab. 7.8 je vidět, že koeficienty filtrů 1. řádu $(n=1)$ jsou u všech typů shodné a hodnota koeficientu $a_{1}$ je vždy rovna jedné. Poznámka: při realizaci filtrů vyšších řádů kaskádním řazením dílčích filtrů se vyskytují dílčí filtry 1. řádu, u kterých $a_{1} \neq 1$, to znamená, že tyto články filtru mají mezní kmitočet odlišný od mezního kmitočtu celého filtru tak, že $f_{\mathrm{m} 1}=f_{\mathrm{m}} / a_{1}$. 
Přenosové vlastnosti dolní propusti 1. řádu podle Obr. 7.21 tedy budou popsány vztahem

$$
K(\bar{s})=\frac{K_{0}}{1+\bar{s}},
$$

přičemž komplexní proměnná $\bar{s}$ je zde normována podle mezního kmitočtu dolní propusti $\omega_{\mathrm{m}}=1 / R C$, resp. $f_{\mathrm{m}}=1 / 2 \pi R C$. Pro ss. signály (kdy C vykazuje velkou impedanci) je přenos filtru $K_{0}=1+R_{2} / R_{1}$.

Při návrhu postupujeme tak, že zvolíme kapacitu $C$ kapacitoru a pak podle požadavku na mezní kmitočet určíme $R=1 / 2 \pi f_{\mathrm{m}} C$. Podle požadavku na přenos $K_{0} \mathrm{v}$ pásmu propustnosti pak určíme odpory zpětnovazebních rezistorů OZ. Zvolíme-li např. odpor $R_{2}$, bude $R_{1}=R_{2} /\left(K_{0}-1\right)$. Pokud se týká volby vlastního operačního zesilovače, je zapotřebí, aby použitý zesilovač byl dostatečně širokopásmový a neomezil vlastnosti dolní propusti (viz Obr. 7.21b).

Invertujicí dolní propust 1. řádu někdy také označovaná jako ztrátový integrátor je nakreslena na Obr. 7.22. Využívá obecného principu aktivního filtru s jednoduchou smyčkou zpětné vazby naznačeného na Obr. 7.6. Abychom přenosovou funkci získali v normovaném tvaru, budeme pracovat s normovanou komplexní proměnnou $\bar{s}=\bar{p} / \omega_{\mathrm{m}}$, resp. $\bar{p}=\bar{s} \omega_{\mathrm{m}}$.

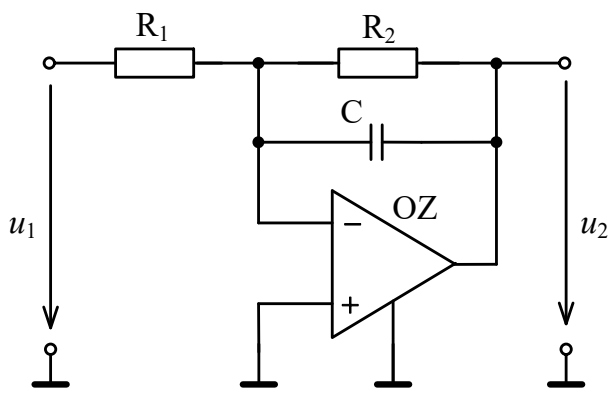

Obr. 7.22: Invertující dolní propust 1. řádu

Protože podle Tab. 7.1 jsou přenosové vodivosti použitých dvojbranů $\bar{y}_{21 \mathrm{~A}}=-1 / R_{1}$ a $\bar{y}_{12 \mathrm{~B}}=-1 / R_{2}-C \bar{p}=-1 / R_{2}-\omega_{\mathrm{m}} C \bar{s}$, bude

$$
K(\bar{s})=-\frac{\bar{y}_{21 \mathrm{~A}}}{\bar{y}_{12 \mathrm{~B}}}=-\frac{1 / R_{1}}{1 / R_{2}+\omega_{\mathrm{m}} C \bar{s}}=-\frac{R_{2} / R_{1}}{1+\omega_{\mathrm{m}} R_{2} C \bar{s}} .
$$

Z porovnání s rov. (7-55) je zřejmé, že daným obvodem můžeme realizovat přenos pro ss signály pouze záporný, $K_{0}=-R_{2} / R_{1}$ a dále, že musí být splněna podmínka $\omega_{\mathrm{m}} R_{2} C=1$. Proto při zvolené kapacitě $C$ kapacitoru bude $R_{2}=1 / 2 \pi f_{\mathrm{m}} C$ a $R_{1}=-R_{2} / K_{0}$.

\section{Dolní propusti druhého ř́ádu}

Aktivni dolní propust 2. ř́du s rozvětvenou smyčkou zpětné vazby je naznačena na Obr. 7.23. Jde o aktivní filtr, jehož uspořádání bylo obecně neznačeno na Obr. 7.7. V daném př́ípadě admitance $\bar{Y}_{1}=1 / R_{1}, \bar{Y}_{2}=1 / R_{2}, \bar{Y}_{3}=\bar{p} C_{1}, \bar{Y}_{4}=1 / R_{3}, \bar{Y}_{5}=\bar{p} C_{2}$ a přenos můžeme podle rov.(7-11) určit ve tvaru 


$$
\begin{gathered}
K(\bar{p})=-\frac{1 / R_{1} R_{3}}{\frac{1}{R_{2} R_{3}}+\bar{p} C_{2}\left(\frac{1}{R_{1}}+\frac{1}{R_{2}}+\bar{p} C_{1}+\frac{1}{R_{3}}\right)}= \\
=-\frac{R_{2} / R_{1}}{1+C_{2} R_{2} R_{3}\left(\frac{1}{R_{1}}+\frac{1}{R_{2}}+\frac{1}{R_{3}}\right) \bar{p}+C_{1} C_{2} R_{2} R_{3} \bar{p}^{2}} .
\end{gathered}
$$

Abychom mohli použít pro návrh koeficienty přenosové funkce pro požadovanou aproximaci, normujeme komplexní proměnnou $\bar{p}$ vzhledem k meznímu kmitočtu $\omega_{\mathrm{m}}, \mathrm{tj} . \bar{s}=\bar{p} / \omega_{\mathrm{m}}$, resp. provedeme substituci $\bar{p}=\omega_{\mathrm{m}} \bar{s}$. Potom normovaná přenosová funkce

$$
K(\bar{s})=-\frac{R_{2} / R_{1}}{1+\omega_{\mathrm{m}} C_{2} R_{2} R_{3}\left(\frac{1}{R_{1}}+\frac{1}{R_{2}}+\frac{1}{R_{3}}\right) \bar{s}+\omega_{\mathrm{m}}^{2} C_{1} C_{2} R_{2} R_{3} \bar{s}^{2}} .
$$

Porovnáme-li koeficienty této přenosové funkce s koeficienty vztahu (7-49), dostáváme

$$
K_{0}=-R_{2} / R_{1}, \quad a_{1}=\omega_{\mathrm{m}} C_{2} R_{2} R_{3}\left(\frac{1}{R_{1}}+\frac{1}{R_{2}}+\frac{1}{R_{3}}\right), \quad b_{1}=\omega_{\mathrm{m}}^{2} C_{1} C_{2} R_{2} R_{3} .
$$

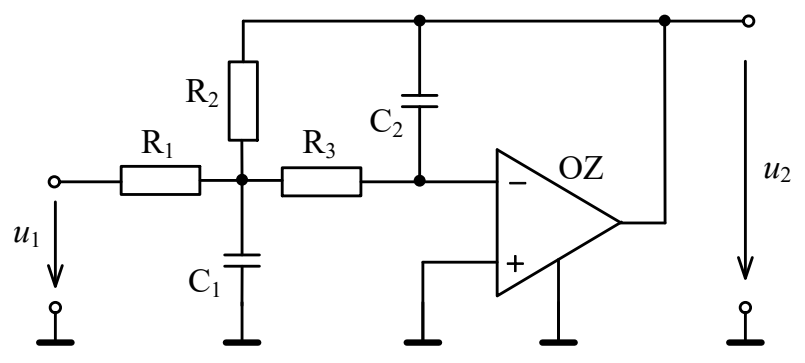

Obr. 7.23: Aktivní dolní propust 2. řádu s rozvětvenou smyčkou zpětné vazby

Při návrhu filtru můžeme zvolit např. odpory $R_{1}$ a $R_{3}$ a vyčíslit podle uvedených vztahů hodnoty $R_{2}, C_{1}$ a $C_{2}$. Aby však reálný filtr měl požadovaný průběh modulové charakteristiky, musí být použité prvky vybrány s dostatečnou přesností. Pokud se týká rezistorů, pak žádný problém nevzniká, protože jejich hodnoty (pro řadu E96 popř. E192) jsou dodávány s jednoprocentní chybou popř. i menší. Poněkud horší je to s přesností kapacit kapacitorů. Tolerance jejich nominální hodnoty může být jak známo $5 \%$ až $10 \%$. Proto je lépe při návrhu obvodu volit kapacity kapacitorů (popř. zjistit přesně kapacitu kapacitorů měřením) a k nim vypočítat požadované odpory rezistorů. $Z$ těchto důvodu raději volíme $C_{1}$ a $C_{2}$ a rovnice (7-59) řešíme z hlediska odporů. Řešení rezistoru $R_{2} \mathrm{z}$ rov. (7-59) vede na kvadratickou rovnici

$$
\omega_{\mathrm{m}} C_{2} R_{2}^{2}-a_{1} R_{2}+b_{1}\left(1-K_{0}\right) / \omega_{\mathrm{m}} C_{1}=0
$$

Kořeny této kvadratické rovnice typu $a x^{2}+b x+c=0$ řešíme jak je obvyklé podle vztahu

$$
x_{1,2}=\frac{-b \pm \sqrt{b^{2}-4 a c}}{2 a} \text {. }
$$


Protože nepotřebujeme dvě variantní řešení, volíme v rov. (7-61) v čitateli znaménko plus

$$
R_{2}=\frac{a_{1} C_{1}+\sqrt{a_{1}^{2} C_{1}^{2}-4 C_{1} C_{2} b_{1}\left(1-K_{0}\right)}}{2 \omega_{\mathrm{m}} C_{1} C_{2}}=\frac{a_{1} C_{1}+\sqrt{a_{1}^{2} C_{1}^{2}-4 C_{1} C_{2} b_{1}\left(1-K_{0}\right)}}{4 \pi f_{\mathrm{m}} C_{1} C_{2}}
$$

Z rovnic (7-59) pro $R_{1}$ a $R_{3}$ vyplývá

$$
R_{1}=-R_{2} / K_{0} \quad, \quad R_{3}=b_{1} / 4 \pi^{2} f_{\mathrm{m}}^{2} C_{1} C_{2} R_{2} .
$$

Aby odpor rezistoru $R_{2}$ byl reálný, musí být číslo pod odmocninou v rov. (7-62) kladné. Tato podmínka bude splněna když

$$
\frac{C_{1}}{C_{2}} \geq \frac{4 b_{1}\left(1-K_{0}\right)}{a_{1}^{2}}
$$

Při splňování podmínky se nedoporučuje vybírat poměr $C_{1} / C_{2}$ př́liš větší než je člen na pravé straně rovnice. Parametry filtru pak jen málo závisí na přesnosti výběru hodnot jeho obvodových prvků, a proto se uvedený obvod použivá pro realizaci filtrů s vysokou přesností.

Návrh filtru se provádí tak, že zvolíme podle nároků na průběh modulu přenosové funkce vhodnou aproximaci (viz kap.7.3.2) a z př́slušné tabulky (Tab. 1.5 až Tab. 7.8) stanovíme hodnoty koeficientů dílčího filtru $a_{i}, b_{i}$ pro požadovaný řád filtru $n$. Při dodržení podmínky (7-64) zvolíme kapacitu kapacitorů $C_{1}, C_{2}$ a podle rovnic (7-62) a (7-63) určíme odpory rezistorů.

Dolní propust 2. řádu s jednoduchou smyčkou zpětné vazby můžeme realizovat tak, že ve zpětnovazební síti obecného uspořádání (viz Obr. 7.6) použijeme dvojbrany RC uvedené v Tab. 7.1 pod pořadovými čísly 5 a 7 . Výsledné uspořádání je naznačeno na Obr. 7.24. Pro daný obvod zapíšeme rovnici (7-11), do které dosadíme přenosové vodivosti příslušných dvojbranů

$$
K(\bar{p})=-\frac{\bar{y}_{21 \mathrm{~A}}}{\bar{y}_{12 \mathrm{~B}}}=-\frac{-\frac{1}{R_{1}+R_{2}+C_{1} R_{1} R_{2} \bar{p}}}{-\frac{1+C_{2}\left(R_{3}+R_{4}\right) \bar{p}+C_{2} C_{3} R_{3} R_{4} \bar{p}^{2}}{R_{3}+R_{4}+C_{3} R_{3} R_{4} \bar{p}}} .
$$

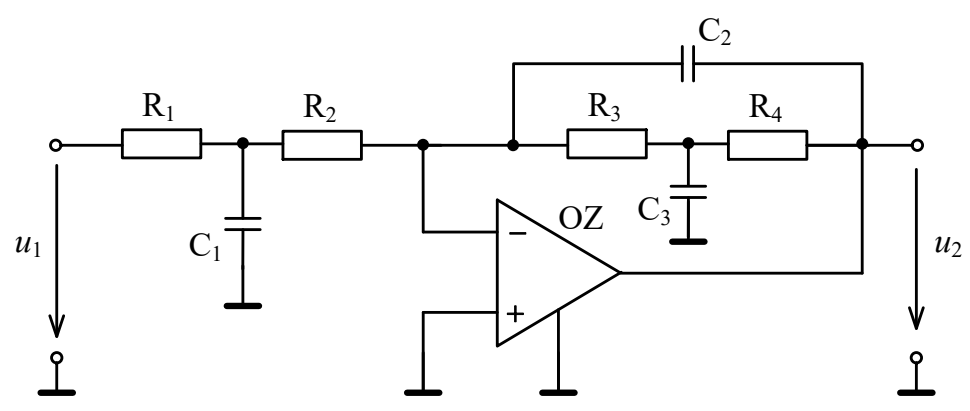

Obr. 7.24: Aktivní dolní propust 2. řádu s jednoduchou smyčkou zpětné vazby 
Odtud po úpravách

$$
\begin{aligned}
& K(\bar{p})=-\frac{R_{3}+R_{4}+C_{3} R_{3} R_{4} \bar{p}}{R_{1}+R_{2}+C_{1} R_{1} R_{2} \bar{p}} \frac{1}{1+C_{2}\left(R_{3}+R_{4}\right) \bar{p}+C_{2} C_{3} R_{3} R_{4} \bar{p}^{2}}= \\
& =-\frac{R_{3}+R_{4}}{R_{1}+R_{2}} \frac{1+\frac{C_{3} R_{3} R_{4}}{R_{3}+R_{4}} \bar{p}}{1+\frac{C_{1} R_{1} R_{2}}{R_{1}+R_{2}} \bar{p}} \frac{1}{1+C_{2}\left(R_{3}+R_{4}\right) \bar{p}+C_{2} C_{3} R_{3} R_{4} \bar{p}^{2}} .
\end{aligned}
$$

Je zřejmé, že pokud splníme podmínku

$$
\frac{C_{1} R_{1} R_{2}}{R_{1}+R_{2}}=\frac{C_{3} R_{3} R_{4}}{R_{3}+R_{4}}
$$

bude přenos filtru

$$
K(\bar{p})=\frac{-\frac{R_{3}+R_{4}}{R_{1}+R_{2}}}{1+C_{2}\left(R_{3}+R_{4}\right) \bar{p}+C_{2} C_{3} R_{3} R_{4} \bar{p}^{2}},
$$

resp. po substituci $\bar{p}=\bar{s} \omega_{\mathrm{m}}$

$$
K(\bar{s})=\frac{-\frac{R_{3}+R_{4}}{R_{1}+R_{2}}}{1+\omega_{\mathrm{m}} C_{2}\left(R_{3}+R_{4}\right) \bar{s}+\omega_{\mathrm{m}}^{2} C_{2} C_{3} R_{3} R_{4} \bar{s}^{2}}
$$

Porovnáním se vztahem (7-49) získáme

$$
a_{1}=\omega_{\mathrm{m}} C_{2}\left(R_{3}+R_{4}\right), \quad b_{1}=\omega_{\mathrm{m}}^{2} C_{2} C_{3} R_{3} R_{4}, \quad K_{0}=-\left(R_{3}+R_{4}\right) /\left(R_{1}+R_{2}\right)
$$

Obvykle se volí $R_{1}=R_{2}=R, R_{3}=R_{4}=R_{0}$ a pak při dodržení podmínky $C_{1} R=C_{3} R_{0}$ platí

$$
a_{1}=2 \omega_{\mathrm{m}} R_{0} C_{2}, \quad b_{1}=\omega_{\mathrm{m}}^{2} C_{2} C_{3} R_{0}^{2}, \quad K_{0}=-R_{0} / R .
$$

Dolní propust 2. řádu se zesilovačem s konečným zesílením. Zavedeme-li do prvního článku dvoučlánkové pasivní dolní propusti RC zesílené výstupní napětí, dostaneme aktivní dolní propust naznačenou na Obr. 7.25, která podle tvůrců bývá označována jako zapojení Sallen-Key. Neinvertující zesilovač s OZ má nastaveno zesílení $A_{\mathrm{U}}=1+R_{4} / R_{3}$. Určíme-li admitance jednotlivých prvků $\bar{Y}_{1}=1 / R_{1}, \bar{Y}_{2}=\bar{p} C_{1}, \bar{Y}_{3}=0, \bar{Y}_{4}=1 / R_{2}, \bar{Y}_{5}=\bar{p} C_{2}$, můžeme pomocí vztahu (7-13) určit přenosovou funkci

$$
\begin{aligned}
& K(\bar{p})=\frac{A_{\mathrm{U}} / R_{1} R_{2}}{\frac{1}{R_{2}}\left(\frac{1}{R_{1}}+\left(1-A_{\mathrm{U}}\right) \bar{p} C_{1}\right)+\bar{p} C_{2}\left(\frac{1}{R_{1}}+\bar{p} C_{1}+\frac{1}{R_{2}}\right)}= \\
& =\frac{A_{\mathrm{U}}}{1+\left(R_{1} C_{1}\left(1-A_{\mathrm{U}}\right)+\left(R_{1}+R_{2}\right) C_{2}\right) \bar{p}+R_{1} R_{2} C_{1} C_{2} \bar{p}^{2}} .
\end{aligned}
$$




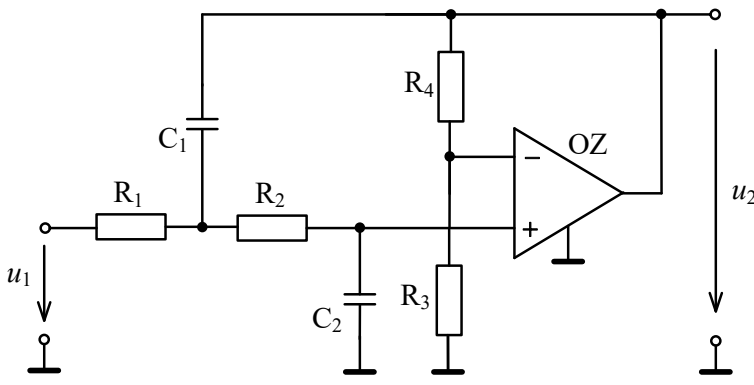

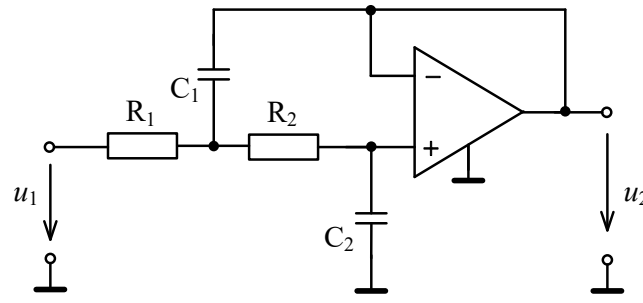

Obr. 7.25: Aktivní dolní propust 2. řádu Sallen-Key: a) se zesilovačem s konečným zesílením,

b) s jednotkovým zesilovačem

Zavedeme-li normovanou proměnnou $\bar{s}=\bar{p} / \omega_{\mathrm{m}}$, bude přenos

$$
K(\bar{s})=\frac{A_{\mathrm{U}}}{1+\omega_{\mathrm{m}}\left(R_{1} C_{1}\left(1-A_{\mathrm{U}}\right)+\left(R_{1}+R_{2}\right) C_{2}\right) \bar{s}+\omega_{\mathrm{m}}^{2} R_{1} R_{2} C_{1} C_{2} \bar{s}^{2}} .
$$

Návrh filtru na Obr. 7.25a je možno zjednodušit, položíme-li $R_{1}=R_{2}=R$ a $C_{1}=C_{2}=C$. Přenosová funkce bude mít za těchto podmínek tvar

$$
K(\bar{s})=\frac{A_{\mathrm{U}}}{1+\omega_{\mathrm{m}}\left(3-A_{\mathrm{U}}\right) R C \bar{s}+\omega_{\mathrm{m}}^{2} R^{2} C^{2} \bar{s}^{2}}
$$

a tedy koeficienty $a_{1}=\omega_{\mathrm{m}}\left(3-A_{\mathrm{U}}\right) R C$ a $b_{1}=\omega_{\mathrm{m}}^{2} R^{2} C^{2}$. Odtud dostaneme $R=\sqrt{b_{1}} / \omega_{\mathrm{m}} C=\sqrt{b_{1}} / 2 \pi f_{\mathrm{m}} C \quad$ a $\quad K_{0}=A_{\mathrm{U}}=3-a_{1} / \sqrt{b_{1}}=3-1 / Q \quad$ (viz rov. (7-38)). Z posledního vztahu je zřejmé, že při změně zesílení $A_{U}$ se změní pouze činitel jakosti $Q$ filtru, ale mezní kmitočet se nezmění. Je však také zřejmé, že při realizaci filtru se pro různé typy aproximací bude měnit hodnota přenosu $K_{0}=A_{\mathrm{U}}$. Zesílení $A_{\mathrm{U}}$ pak určuje typ aproximace přenosové funkce filtru. $\mathrm{Z}$ tabulek koeficientů $a_{i}$ a $b_{i}$ můžeme určit požadované zesílení pro různé aproximace: 1) dle Bessela $A_{\mathrm{U}}=1,27 ; 2$ ) dle Butterwortha $A_{\mathrm{U}}=1,59 ; 3$ ) dle Čebyševa a) pro zvlnění $0,5 \mathrm{~dB} A_{\mathrm{U}}=1,84, \mathrm{~b}$ ) pro zvlnění $1 \mathrm{~dB} A_{\mathrm{U}}=1,96$, c) pro zvlnění $2 \mathrm{~dB} A_{\mathrm{U}}=2,11, \mathrm{~d}$ ) pro zvlnění $3 \mathrm{~dB} A_{\mathrm{U}}=2,23$. V této souvislosti je zapotřebí poznamenat, že požadované zesílení musí být při realizaci Čebyševova filtru se zvlněním $3 \mathrm{~dB}$ obzvláště přesně nastaveno, protože při $A_{\mathrm{U}}=3$ je odvod již nestabilní a generuje kmity o kmitočtu $f_{0}=1 / 2 \pi R C$. To je podstatný nedostatek probíraného řešení dolní propusti. Výhodné na druhé straně však je, že pouhou změnou zesílení $A_{\mathrm{U}}$ můžeme realizovat filtry různého typu. Použijeme-li pro souhlasnou změnu odporů rezistorů $\mathrm{R}_{1}$ a $\mathrm{R}_{2}$ spřažené potenciometry, můžeme velmi snadno měnit pásmo propustnosti filtru.

Často se však setkáme s tím, že se zapojení na Obr. 7.25a zjednoduší použitím zesilovače $\mathrm{s}$ jednotkovým zesílením $A_{\mathrm{U}}=1$, jako je tomu na Obr. 7.25b. Potom

$$
K(\bar{s})=\frac{1}{1+\omega_{\mathrm{m}}\left(R_{1}+R_{2}\right) C_{2} \bar{s}+\omega_{\mathrm{m}}^{2} R_{1} R_{2} C_{1} C_{2} \bar{s}^{2}} .
$$

Porovnáme-li tuto rovnici s rov. (7-49) bude pro koeficienty přenosové funkce platit

$$
a_{1}=\omega_{\mathrm{m}}\left(R_{1}+R_{2}\right) C_{2}, \quad b_{1}=\omega_{\mathrm{m}}^{2} R_{1} R_{2} C_{1} C_{2} .
$$

Zvolíme-li $C_{1}$ a $C_{2}$, vede řešení těchto dvou rovnic na řešení kořenů kvadratické rovnice 


$$
\omega_{\mathrm{m}}^{2} C_{1} C_{2} R_{1}^{2}-\omega_{\mathrm{m}} a_{1} C_{1} R_{1}+b_{1}=0
$$

Protože nepotřebujeme dvě řešení, volíme ve vztahu (7-61) pro výpočet kořenů kladné znaménko a tedy

$$
R_{1}=\frac{a_{1} C_{1}+\sqrt{a_{1}^{2} C_{1}^{2}-4 b_{1} C_{1} C_{2}}}{2 \omega_{\mathrm{m}} C_{1} C_{2}}, \quad R_{2}=\frac{b_{1}}{\omega_{\mathrm{m}}^{2} R_{1} C_{1} C_{2}} .
$$

Aby hodnota $R_{2}$ byla reálná, je nutno splnit podmínku $a_{1}^{2} C_{1}^{2}-4 b_{1} C_{1} C_{2} \geq 0, \mathrm{tj} . C_{1} / C_{2} \geq 4 b_{1} / a_{1}^{2}$ . Podobně jako v předchozím př́ípadě se nedoporučuje vybírat poměr $C_{1} / C_{2}$ př́lišs větší než je hodnota $4 b_{1} / a_{1}^{2}$, protože se zvyšuje citlivost obvodu na tolerance obvodových prvků.

Dolní propust 2. řádu se třemi zesilovači je uspořádána podle Obr. 7.9 , přičemž využíváme výstup $\mathrm{OZ}_{3}$. Pro $R_{3}=R_{4}=R_{5}=R_{6}=R$ a $C_{1}=C_{2}=C$ bude mít prenosová funkce (7-16) pro normovanou komplexní proměnnou $\bar{s}=\bar{p} / \omega_{\mathrm{m}}$ tvar

$$
K(\bar{s})=\frac{1}{1+\omega_{\mathrm{m}} R_{2} C \bar{s}+\omega_{\mathrm{m}}^{2} R_{1} R_{2} C^{2} \bar{s}^{2}}
$$

a tedy

$$
K_{0}=1, \quad a_{1}=\omega_{\mathrm{m}} R_{2} C, \quad b_{1}=\omega_{\mathrm{m}}^{2} R_{1} R_{2} C^{2} .
$$

Při návrhu zvolíme nejdříve kapacity $C_{1}=C_{2}=C$, odpory $R_{3}=R_{4}=R_{5}=R_{6}=R$ a pak stanovíme zbývající veličiny podle vztahů

$$
R_{1}=b_{1} / a_{1} \omega_{\mathrm{m}} C, \quad R_{2}=a_{1} / \omega_{\mathrm{m}} C .
$$

Tato architektura filtru je velmi výhodná pro malou citlivost na tolerance použitých pasivních prvků. Filtr je nabízen integrovaný, kdy z vnějšku se připojují pouze rezistory $R_{1} a R_{2}$.

\section{Dolní propusti vyšších řádů}

Kaskádní realizace dolní propusti. Jestliže modulová charakteristika filtru nepřechází do nepropustného pásma dostatečně ostře, je zapotřebí použít filtr vyššího řádu. Za tímto účelem se do kaskády zapojují dílčí filltry, které jsou 1. nebo 2. řádu. Výslednou přenosovou funkci pak získáme vynásobením dílčích přenosových funkcí. Je však zapotřebí vždy mít na zřeteli, že kaskádní řazení, např. dvou filtrů 2. řádu s přenosovou funkcí aproximovanou dle Butterwortha osazených shodnými hodnotami pasivních prvků, nevede k získání filtru 4. řádu s aproximací dle Butterwortha. Výsledný filtr bude mít jiný kmitočet lomu a jinou modulovou charakteristiku. Proto je nutno volit koeficienty jednotlivých článků tak, aby výsledné vynásobení jejich přenosových funkcí odpovídalo požadovanému typu aproximace. Tyto skutečnosti respektují tabulky koeficientů přenosových funkcí pro jednotlivé aproximace (Tab. 1.5 až Tab. 7.8), kdy pro každý rrád filtru jsou uvedeny př́slušné koeficienty dílčích filtrů.

Jako př́iklad uvedeme postup návrhu dolní propusti 4. řádu s přenosovou charakteristikou aproximovanou dle Bessela, jestliže je požadováno $K_{0}=1, f_{\mathrm{m}}=100 \mathrm{~Hz}$. Filtr můžeme např. realizovat kaskádním řazením dvou dolních propustí 2. řádu podle Obr. 7.25b. 


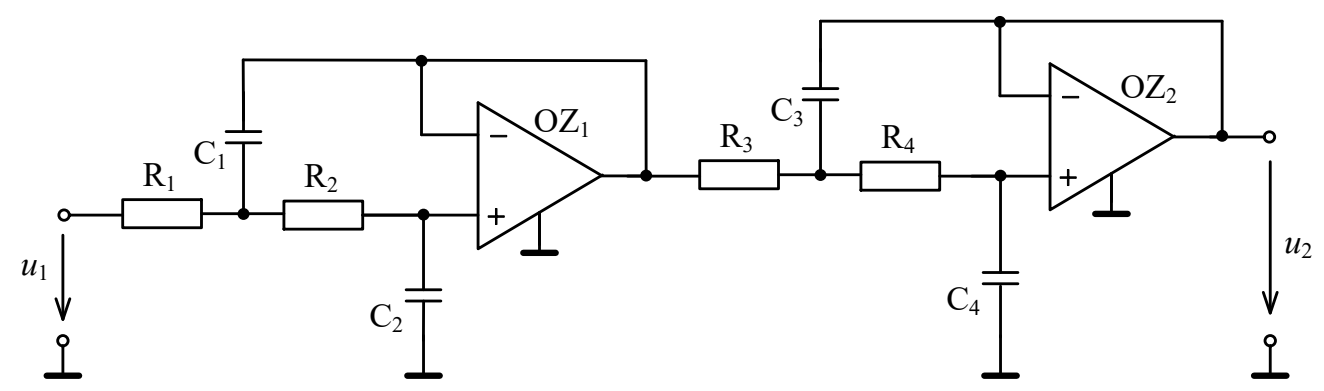

Obr. 7.26: Dolní propust 4. rádu

Celkové uspořádání filtru pro $K_{0}=1$ je nakresleno na Obr. 7.26. Z Tab. 7.6 pro Besselovu aproximaci určíme koeficienty pro 1 . článek filtru $a_{1}=1,3397, b_{1}=0,4889$ a koeficienty pro 2 . článek filtru $a_{2}=0,7743, b_{2}=0,3890$.

První článek filtru jsme již řešili pro př́ípad zapojení na Obr. 7.25b. Zvolíme $C_{1}$ a z nerovnosti $C_{1} / C_{2} \geq 4 b_{1} / a_{1}^{2}$ (viz podrobné doporučení k návrhu filtru na Obr. 7.25b) určíme požadavek na volbu hodnoty $C_{2}$. Odpory rezistorů $R_{1}$ a $R_{2}$ určíme podle stejných vztahů (2-78), kdy $\omega_{\mathrm{m}}=2 \pi f_{\mathrm{m}}$. Je třeba však upozornit, že mezní kmitočet tohoto dílčího filtru $f_{\mathrm{m} 1}$ pak není totožný s mezním kmitočtem celého filtru. Jak je vidět také $\mathrm{z}$ tab. $1.6 f_{\mathrm{m} 1} / f_{\mathrm{m}}=0,978$ tzn. $\mathrm{v}$ daném př́ípadě bude mít 1 . článek filtru pokles zisku o $3 \mathrm{~dB}$ vůči propustnému pásmu, při kmitočtu $f_{\mathrm{m} 1}=97,8 \mathrm{~Hz}$. Činitel jakosti tohoto dílčího filtru bude $Q_{1}=0,52$ (viz také Tab. 7.6).

Druhý článek filtru řešíme podobně, ale s koeficienty přenosové funkce $a_{2}, b_{2}$. Zvolíme $C_{3}$ a pak $C_{4}$ podle podmínky $C_{3} / C_{4} \geq 4 b_{2} / a_{2}^{2}$. S přihlédnutím ke vztahům (2-78) určíme obdobně i $R_{3}$ a $R_{4}$, tj.

$$
R_{3}=\frac{a_{2} C_{3}+\sqrt{a_{2}^{2} C_{3}^{2}-4 b_{2} C_{3} C_{4}}}{4 \pi f_{\mathrm{m}} C_{3} C_{4}}, \quad R_{4}=\frac{b_{2}}{4 \pi^{2} f_{\mathrm{m}}^{2} \omega_{\mathrm{m}}^{2} R_{3} C_{3} C_{4}} .
$$

Pro mezní kmitočet tohoto 2. článku filtru pak podle Tab. 7.6 platí $f_{\mathrm{m} 2} / f_{\mathrm{m}}=1,797$ a tedy v uvažovaném př́ípadě $f_{\mathrm{m} 2}=179,7 \mathrm{~Hz}$. Činitel jakosti v tomto př́padě $Q_{2}=0,81$.

Kaskádní spojení těchto dvou článků bude mít mezní kmitočet $f_{\mathrm{m}}=100 \mathrm{~Hz}$ a požadovaný průběh modulové charakteristiky dle Bessela. Třebaže jsou tedy z pohledu topologie obvodového řešení oba dílčí články identické, musí nutně obsahovat jiné hodnoty pasivních prvků.

Pro větší názornost výše uvedené skutečnosti je na Obr. 7.27 uvedena modulová charakteristika dolní propusti 10. řádu aproximovaná dle Čebyševa se zvlněním $3 \mathrm{~dB}$. Takový filtr je možné realizovat 5 bloky dolních propustí 2. řádu, kdy koeficienty $a_{i}$ a $b_{i}$ jednotlivých dílčích filtrů lze nalézt pro zvlnění $3 \mathrm{~dB}$ v Tab. 7.8 a to pro řád filtru $n=10$. Na Obr. 7.27 jsou pro představu čárkovaně znázorněny modulové charakteristiky jednotlivých dílčích filtrů, kdy až jejich kaskádní spojení vytvoří požadovanou kmitočtovou odezvu filtru (nakreslena červeně plnou čárou).

Při návrhu dílčích filtrů je zapotřebí dosazovat požadovaný mezní kmitočet $f_{\mathrm{m}}$ celého filtru, protože při určování koeficienti̊ $a_{i}, b_{i}$ bylo k této skutečnosti již přihlíženo. Dílčí filtry, jak je např. zř́jmé i z Obr. 7.27, budou mít mezní kmitočty $f_{\mathrm{m} i}$ různé od mezního kmitočtu $f_{\mathrm{m}}$. Mezní kmitočty dílčích filtrů (jako pomůcku při oživování filtru) lze určit na základě znalosti poměrů $f_{\mathrm{m} i} / f_{\mathrm{m}}$, které jsou též uvedeny v Tab. 1.5 až Tab. 7.8. 


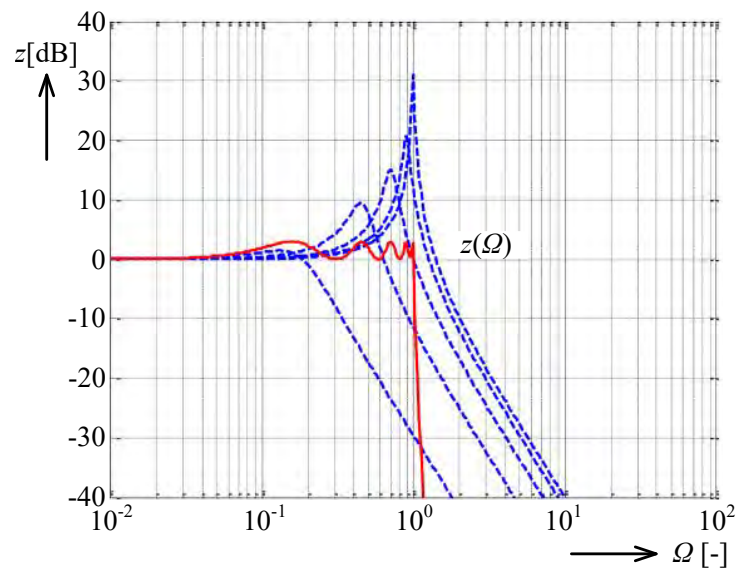

Obr. 7.27: Modulové charakteristiky dílčích filtrů 2. řádu a výsledná modulová charakteristika dolní propusti 10. řádu aproximovaná dle Čebyševa se zvlněním $3 \mathrm{~dB}$

Principiálně nezáleží na tom, v jakém pořadí budou za sebou následovat dílčí filtry při realizaci výsledného filtru. Výsledná přenosová charakteristika bude vždy stejná. Existují však různá praktická doporučení v jakém sledu spojovat dílčí filtry. Tak např̀. z hlediska ochrany filtru proti přebuzení je výhodné řadit filtry za sebou podle rostoucího mezního kmitočtu a filtr s nejmenším mezním kmitočtem umístit na vstupu. Nedodržení předepsaného pořadí by mohlo způsobit přebuzení zesilovače vstupní sekce v oblasti překmitu její modulové charakteristiky. Př́ičina je v tom, že filtry s vyšším mezním kmitočtem obvykle mají vysoký činitel jakosti a proto jejich modulová charakteristika vykazuje v blízkosti mezního kmitočtu značný překmit. Tuto skutečnost můžeme ilustrovat na modulových charakteristikách pěti článků navrhovaného filtru s přenosovou funkcí aproximovanou dle Čebyševa, nakreslených na Obr. 7.27.

Jiný pohled na pořadí dílčích filtrů je spojen s požadavkem na minimální úroveň šumu na výstupu. $\mathrm{V}$ tom př́padě musí být sled filtrů právě opačný, protože zařazení filtru s nejnižším kmitočtem na konci kaskády způsobí zeslabení šumů všech předchozích článků kaskády.

\subsection{Horní propusti}

\subsubsection{Pasivní horní propusti}

Pasivní horní propust RC 1. ̌rádu. Zapojení pasivní horní propusti 1. rádu je uvedeno na Obr. 7.28a. Podobně, jako při analýze dolní propusti 1. řádu, lze přenos zapojení určit jako poměr komplexních napětí

$$
K(\bar{p})=\frac{U_{2}(\bar{p})}{U_{1}(\bar{p})}=\frac{\bar{Z}_{\mathrm{R}}}{\bar{Z}_{\mathrm{R}}+\bar{Z}_{\mathrm{C}}}=\frac{R}{R+1 / \bar{p} C}=\frac{1}{1+1 / \bar{p} R C} .
$$

Mezní kmitočet definovaný jako pokles modulu přenosové charakteristiky o $3 \mathrm{~dB}$ vůči hodnotě modulu přenosu na vysokých kmitočtech je shodný s mezním kmitočtem dolní propusti 1. řádu (7-25), tj. $\omega_{\mathrm{m}}=1 / R C$. Využitím normované komplexní proměnné $\bar{s}=\bar{p} / \omega_{\mathrm{m}}$ , přechází přenosová funkce (2-83) do tvaru

$$
K(\bar{s})=\frac{1}{1+1 / \bar{s}}
$$

Jestliže přejdeme na normovaný úhlový kmitočet $\bar{s}=\mathrm{j} \omega / \omega_{\mathrm{m}}=\mathrm{j} \Omega$, bude přenosová funkce, popř. její modul a argument (fáze) určeny vztahy 


$$
\bar{K}(\Omega)=\frac{1}{1+1 / \mathrm{j} \Omega}, \quad K(\Omega)=\frac{1}{\sqrt{1+1 / \Omega^{2}}}, \quad \varphi(\Omega)=\operatorname{arctg} \frac{1}{\Omega} .
$$

$\mathrm{Na}$ Obr. 7.28b,c je uveden Bodeův diagram horní propusti 1. řádu, tj. závislost zisku $z(\Omega)=20 \log K(\Omega)$ a argumentu $\varphi(\Omega)$ na normovaném kmitočtu $\Omega$.

Porovnáním přenosové funkce horní propusti 1. řádu (2-84) a přenosové funkce dolní propusti 1. řádu (7-28) je vidět, že přenosovou funkci horní propusti získáme z dolní propusti jednoduchou transformací $\bar{s} \rightarrow 1 / \bar{s}$. Tato transformace je patrná i z logaritmického vyjádření modulové charakteristiky, kdy $\mathrm{z}$ dolní propusti (Obr. 7.10b) lze získat modulovou charakteristiku horní propusti (Obr. 7.28b) jejím zrcadlením kolem mezního kmitočtu $\omega_{\mathrm{m}}$, resp. $\Omega=1$, čemuž odpovídá transformace $\Omega \rightarrow 1 / \Omega\left(\right.$ resp. $\bar{s} \rightarrow 1 / \bar{s}$ ). Formálně pak i přenos $K_{0}$ $\mathrm{v}$ pásmu propustnosti dolní propusti přechází na přenos $K_{\infty} \mathrm{V}$ pásmu propustnosti horní propusti. V praxi se však pro označení přenosu v pásmu propustnosti horní propusti, resp. i v pásmu propustnosti ostatních typů kmitočtových filtr, využívá označení $K_{0}$.

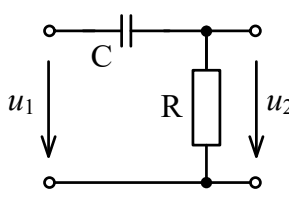

a
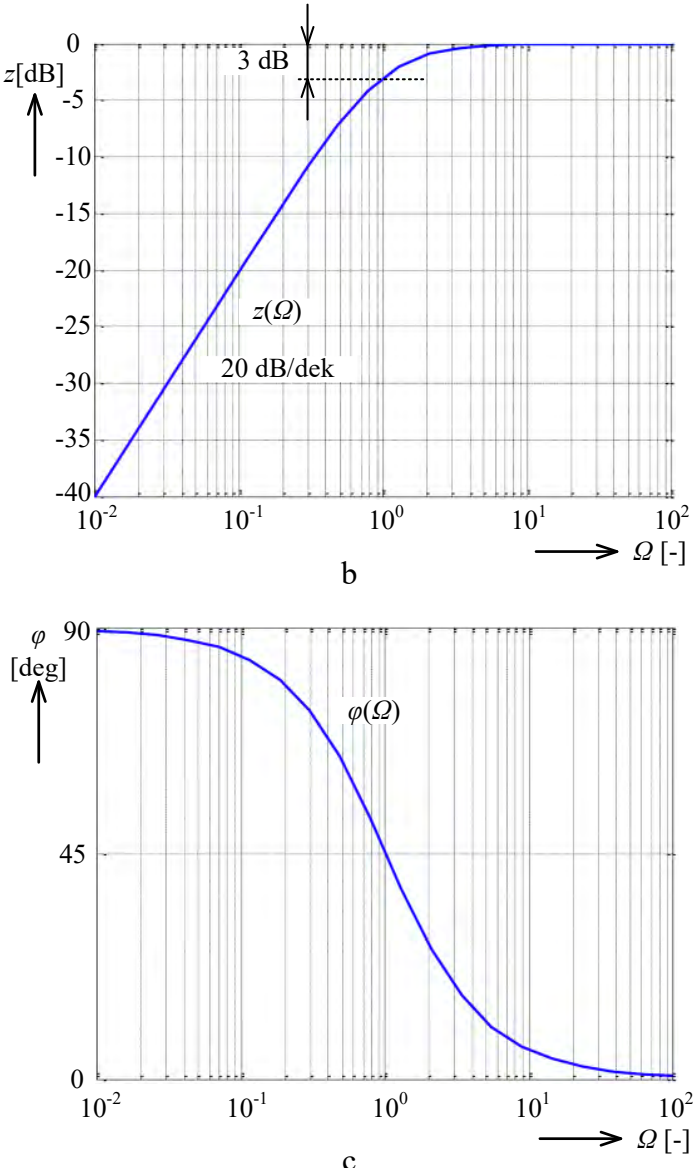

Obr. 7.28: a) Pasivní horní propust RC 1. řádu a jeho b) modulová a c) argumentová charakteristika 


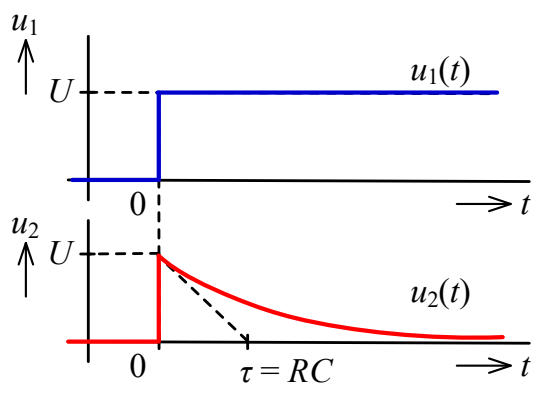

a

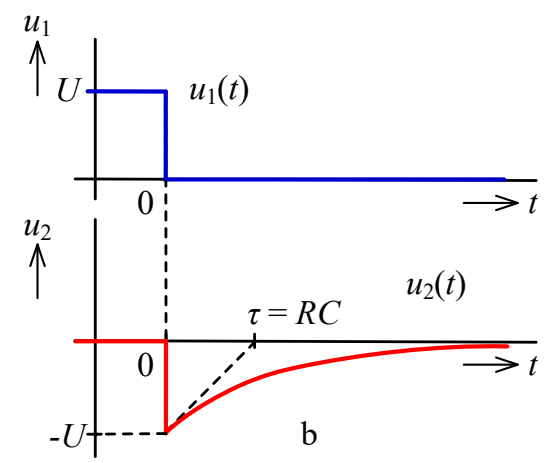

Obr. 7.29: Odezva horní propusti na jednotkový skok (přechodová charakteristika)

Přivedeme-li na vstup horní propusti RC 1 . rádu jednotkový skok napětí z nuly na hodnotu $U$, dojde k okamžitému nabití kapacitoru $\mathrm{C}$, který se bude následně exponenciálně vybíjet s časovou konstantou $\tau=R C$ podle vztahu $u_{2}(t)=U \mathrm{e}^{-t / R C}$ (Obr. 7.29a). Jestliže se vstupní napětí skokově změní z napětí $U$ na nulu, změní se výstupní napětí skokově na $-U$ (viz Obr. 7.29b). Zde je potřeba zdůraznit, že i když je napětí $U$ kladné, má výstupní napětí zápornou hodnotu. Následně se kapacitor $\mathrm{C}$ bude opět exponenciálně vybíjet na nulu. Dobu ustálení výstupního napětí pro požadovanou přesnost lze opět odhadnout z Tab. 7.4.

Jestliže bude na vstup přivedeno stř́davé napětí o kmitočtu $f<<f_{\mathrm{m}}$ bude stř́ídavé výstupní napětí malé ve srovnání se vstupním napětím a horní propust pracuje v této kmitočtové oblasti jako pasivní derivační článek

$$
u_{2}(t)=R C \frac{\mathrm{d} u_{1}(t)}{\mathrm{d} t}
$$

Tímto způsobem dochází na nízkých kmitočtech k derivaci vstupního signálu.

Pasivní horní propust RLC 2. řádu. Př́íklad realizace pasivní horní propusti RLC 2. řádu je uveden na Obr. 7.30a. Přenosová funkce tohoto filtru je dána vztahem

$$
K(\bar{p})=\frac{\bar{Z}_{\mathrm{L}}}{\bar{Z}_{\mathrm{C}}+\bar{Z}_{\mathrm{R}}+\bar{Z}_{\mathrm{L}}}=\frac{\bar{p} L}{\frac{1}{\bar{p} C}+R+\bar{p} L}=\frac{1}{1+\frac{R}{L} \frac{1}{\bar{p}}+\frac{1}{L C} \frac{1}{\bar{p}^{2}}}
$$

resp. pro normovanou komplexní proměnnou $\bar{s}=\bar{p} / \omega_{\mathrm{m}}$.

$$
K(\bar{s})=\frac{1}{1+\frac{R}{L \omega_{\mathrm{m}}} \frac{1}{\bar{s}}+\frac{1}{L C \omega_{\mathrm{m}}^{2}} \frac{1}{\bar{s}^{2}}} .
$$

Obecně lze tedy přenosovou funkci horní propusti 2. řádu zapsat ve tvaru

$$
K(\bar{s})=\frac{1}{1+a_{1} / \bar{s}+b_{1} / \bar{s}^{2}},
$$

kde $a_{1}=R / L \omega_{\mathrm{m}}$ a $b_{1}=1 / L C \omega_{\mathrm{m}}^{2}$. Je tedy zřejmé, že popsaná transformace zrcadlení $\bar{s} \rightarrow 1 / \bar{s}$ platí i pro horní propusti druhého řádu. Modulová a argumentová charakteristika RLC horní propusti je uvedena na Obr. $7.30 \mathrm{~b}, \mathrm{c}$. 

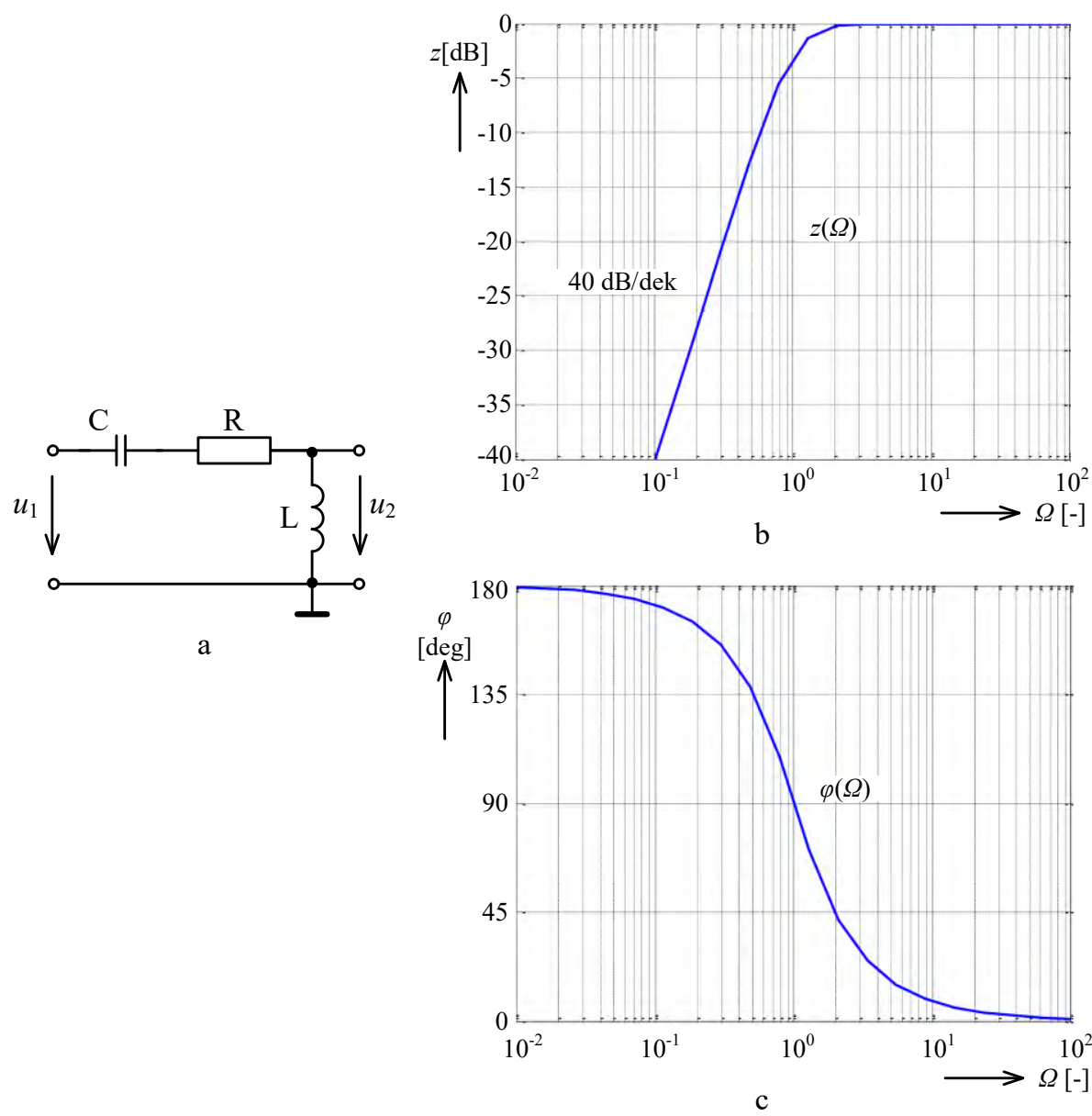

Obr. 7.30: a) Pasivní horní propust 2. řádu a její b) modulová a c) argumentová charakteristika filtru typu horní propust 2. rádu $(Q=0,707)$

\subsubsection{Transformace dolní propusti na horní propust}

Z porovnání přenosové funkce horní propusti 2. řádu (7-89) a přenosové funkce dolní propusti (7-36) je vidět, že přenosovou funkci horní propusti můžeme získat z přenosové funkce dolní propusti transformací $\bar{s} \rightarrow 1 / \bar{s}$, [3]. Tento postup se dá zobecnit i pro propusti vyšších řádů. Je to patrné i $\mathrm{z}$ logaritmického vyjádření přenosové funkce, kdy $\mathrm{z}$ modulové charakteristiky dolní propusti můžeme získat charakteristiku horní propusti transformací typu zrcadlení kolem mezního kmitočtu, resp. kolem $\Omega=1$ (viz Obr. 7.31). Tomu odpovídá transformace $\Omega \rightarrow 1 / \Omega$, resp. $\bar{s} \rightarrow 1 / \bar{s}$, přičemž mezní kmitočet zůstává beze změny a $K_{0}$ nyní značí přenos na vysokých kmitočtech.

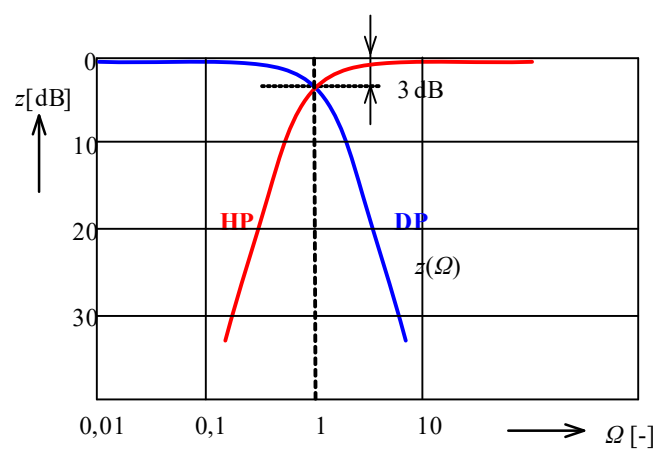

Obr. 7.31: Získání přenosové charakteristiky horní propusti z dolní propusti transformací typu zrcadlení $\Omega \rightarrow 1 / \Omega(\operatorname{resp} . \bar{s} \rightarrow 1 / \bar{s})$ 
Přenosovou funkci horní propusti $n$-tého řádu realizovanou kaskádně řazenými dílčími horními propustmi 2. řádu lze tedy získat uvedenou transformací z přenosové funkce dolní propusti $n$-tého řádu (viz rov. (7-41)) ve tvaru

$$
K(\bar{s})=\frac{K_{0}}{\prod_{i=1}^{I}\left(1+a_{i} / \bar{s}+b_{i} / \bar{s}^{2}\right)} .
$$

Pokud se tedy jedná o průběh modulové charakteristiky, lze analogicky použít tytéž aproximační postupy jako $\mathrm{v}$ př́ípadě dolní propusti. Koeficienty $a_{i}$ a $b_{i}$ pro různé typy aproximací dolních propustí uvedené v Tab. 1.5 až Tab. 7.8 proto platí i pro príípad horních propustí.

Zcela odlišné vlastnosti však vykazují průběhy odezvy horních propustí na jednotkový skok. Přechodové charakteristiky mají principiálně jiný tvar (viz Obr. 7.32) a přechodová charakteristika filtru s kritickým tlumením dokonce vykazuje zákmity při ustalování nové hodnoty.

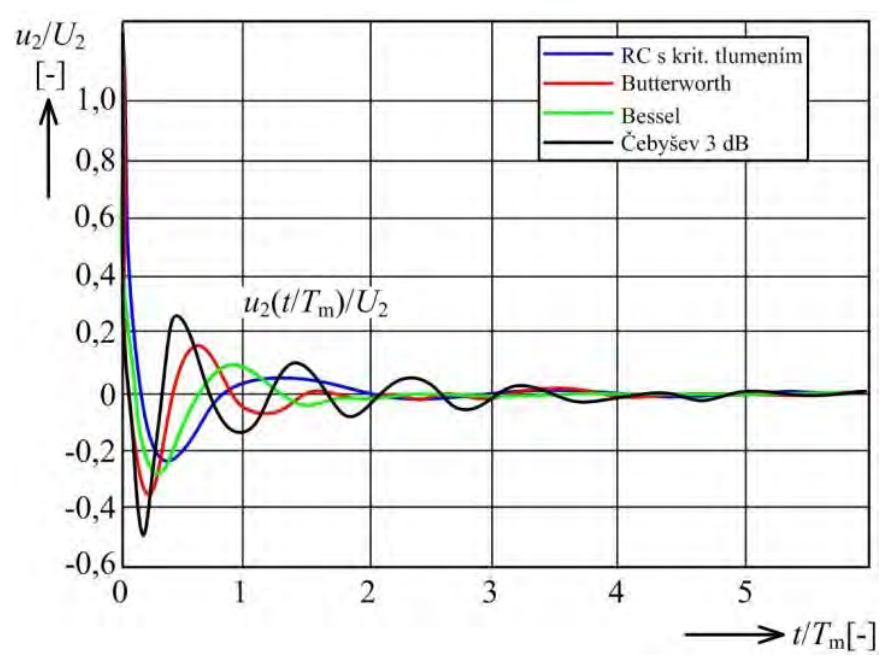

Obr. 7.32: Přechodové charakteristiky horních propustí 4. řádu

\subsubsection{Aktivní horní propusti}

\section{Horní propusti 1. ̌rádu}

Neinvertující horní propust 1. řádu sestává z pasivní horní propusti RC 1. řádu, za kterou je zařazen neinvertující zesilovač (viz Obr. 7.33a) který oddělí pasivní filtr od zátěže a dodá patřičné zesílení. Pasivní horní propust 1. řádu má podle rov. (2-84) přenos $K(\bar{s})=1 /(1+1 / \bar{s})$, přičemž pro náš př́ipad podle Obr. 7.33 bude $\omega_{\mathrm{m}}=2 \pi f_{\mathrm{m}}=1 / C R$. Přenosové vlastnosti filtru jsou pro vysoké kmitočty dány přenosem neinvertujícího zesilovače $K_{0}=A_{\mathrm{U}}=1+R_{2} / R_{1}$. Výsledná přenosová funkce má proto tvar

$$
K(\bar{s})=\frac{1+R_{2} / R_{1}}{1+1 / \bar{s}} .
$$




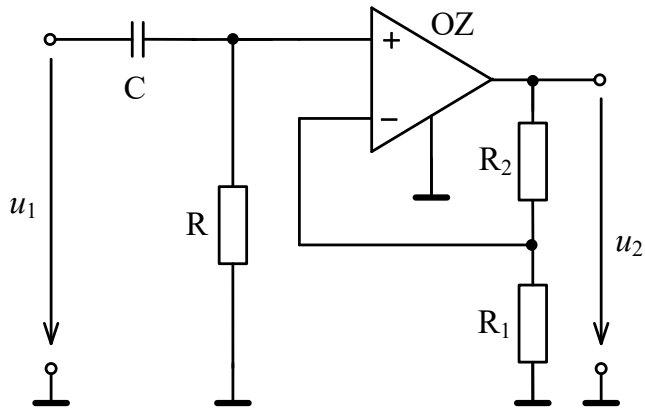

a

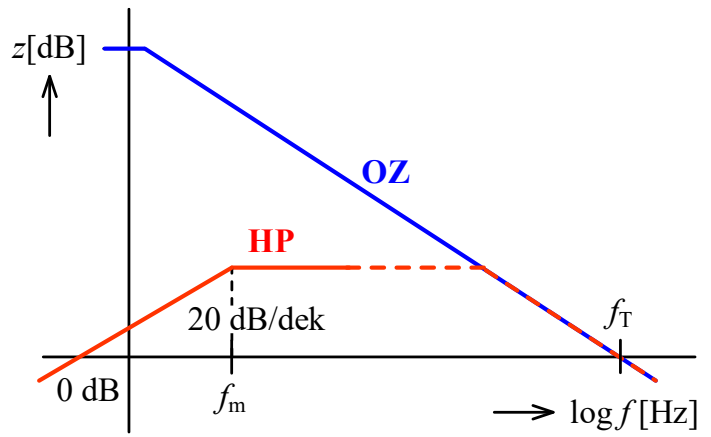

b

Obr. 7.33: a) Horní propust 1. řádu sestavená z pasivní horní propusti a zesilovače, b) požadavky na kmitočtovou charakteristiku operačního zesilovače

Zvolíme-li kapacitu $C$ kapacitoru, bude $R=1 / 2 \pi f_{\mathrm{m}} C$ a dále při zvoleném $R_{2}$ bude $R_{1}=R_{2} /\left(K_{0}-1\right)$. Výběr operačního zesilovače musí respektovat šiřku zpracovávaného kmitočtového pásma signálu, protože jeho omezené kmitočtové chování může vlastnosti horní propusti znehodnotit (viz Obr. 7.33b).

Invertujici horní propust 1. řádu (viz Obr. 7.34) je v podstatě shodná s invertujícím stř́ídavým zesilovačem s oddělovacím kapacitorem.

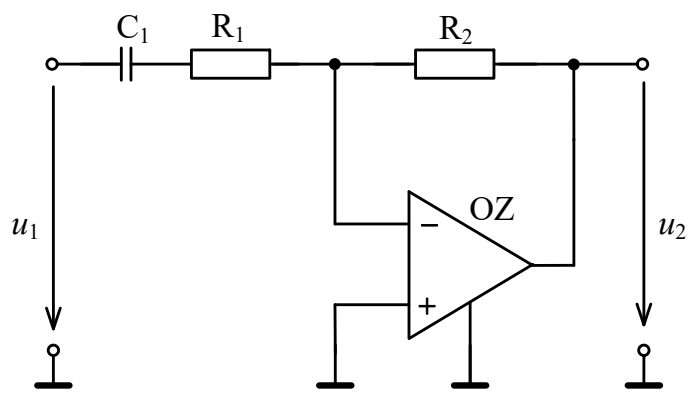

Obr. 7.34: Horní propust 1. rádu

Zapojení filtru využívá obecného principu z Obr. 7.6, a proto přenos určíme snadno pomocí přenosových vodivostí článků z Tab. $7.1 \bar{y}_{21 \mathrm{~A}}=-C_{1} \bar{p} /\left(1+C_{1} R_{1} \bar{p}\right), \bar{y}_{12 \mathrm{~B}}=-1 / R_{2}$. Přenosová funkce horní propusti 1. řádu

$$
K(\bar{p})=-\frac{\bar{y}_{21 \mathrm{~A}}}{\bar{y}_{12 \mathrm{~B}}}=-\frac{R_{2} / R_{1}}{1+\frac{1}{R_{1} C_{1}} \frac{1}{\bar{p}}}, \text { resp. } \quad K(\bar{s})=-\frac{R_{2} / R_{1}}{1+\frac{1}{\omega_{\mathrm{m}} R_{1} C_{1}} \frac{1}{\bar{s}}}
$$

Srovnáme-li koeficienty této přenosové funkce s koeficienty obecné rov. (2-90) pro $i=1$, bude $\quad a_{1}=1 / \omega_{\mathrm{m}} R_{1} C_{1}, b_{1}=0, K_{0}=-R_{2} / R_{1}$. Zvolíme-li $C_{1}$, bude $R_{1}=1 / 2 \pi f_{\mathrm{m}} a_{1} C_{1} \quad$ a $R_{2}=-R_{1} K_{0}$ pro požadovaný (záporný) přenos $K_{0}$. Jak je zřejmé z tabulek koeficientů Tab. 1.5 až Tab. 7.8 bude $a_{1}=1$ pro všechny typy aproximací a proto $R_{1}=1 / 2 \pi f_{\mathrm{m}} C_{1}$.

Poznamenejme, že i zde (stejně jako u jiných horních propustí) výraz pro přenosovou funkci platí pouze v rozmezí kmitočtů, ve kterých je přenos operačního zesilovače bez zpětné vazby větší než přenos filtru (viz Obr. 7.33b). Tato podmínka se pro vysoké kmitočty splňuje 
obtížně, protože modulová charakteristika operačního zesilovače klesá obvykle rychlostí -20 $\mathrm{dB} /$ dek a u obyčejného zesilovače je při kmitočtu $10 \mathrm{kHz}$ zesílení bez zpětné vazby jen kolem 100. Při požadavcích na větší šířku pásma je nutno použít pak tzv. širokopásmové operační zesilovače.

\section{Horní propusti 2. řádu}

Horní propust 2. řádu s rozvětvenou smyčkou zpětné vazby je uspořádána podle Obr. 7.35. $\mathrm{Na}$ základě srovnání s obecným zapojením na Obr. 7.7 můžeme zjistit, že $\bar{Y}_{1}=\bar{p} C_{1}, \bar{Y}_{2}=\bar{p} C_{2}, \bar{Y}_{3}=1 / R_{1}, \bar{Y}_{4}=\bar{p} C_{3}, \bar{Y}_{5}=1 / R_{2}$. Podle rov. (7-12) můžeme psát

$$
\begin{gathered}
K(\bar{p})=-\frac{C_{1} C_{3} \bar{p}^{2}}{C_{2} C_{3} \bar{p}^{2}+\frac{1}{R_{2}}\left(\bar{p} C_{1}+\bar{p} C_{2}+\frac{1}{R_{1}}+\bar{p} C_{3}\right)}= \\
=-\frac{C_{1} / C_{2}}{1+\frac{C_{1}+C_{2}+C_{3}}{R_{2} C_{2} C_{3}} \frac{1}{\bar{p}}+\frac{1}{R_{1} R_{2} C_{2} C_{3}} \frac{1}{\bar{p}^{2}}},
\end{gathered}
$$

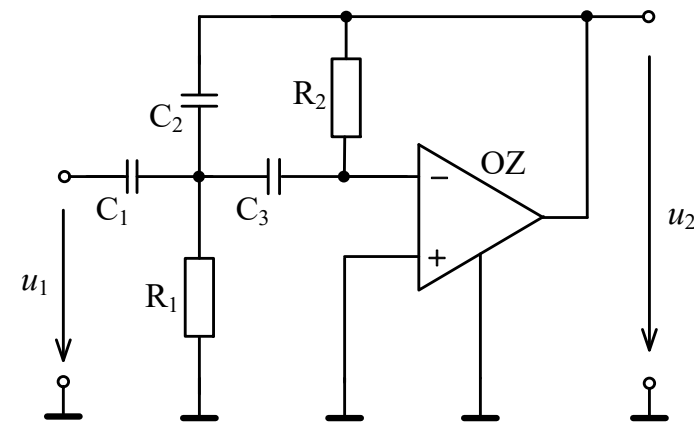

Obr. 7.35: Aktivní horní propust 2. řádu s rozvětvenou smyčkou zpětné vazby

resp. zavedeme-li normovanou komplexní proměnnou $\bar{s}$, bude $\bar{p}=\omega_{\mathrm{m}} \bar{s}$ a přenos

$$
K(\bar{s})=-\frac{C_{1} / C_{2}}{1+\frac{C_{1}+C_{2}+C_{3}}{\omega_{\mathrm{m}} R_{2} C_{2} C_{3}} \frac{1}{\bar{s}}+\frac{1}{\omega_{\mathrm{m}}^{2} R_{1} R_{2} C_{2} C_{3}} \frac{1}{\bar{s}^{2}}}=\frac{K_{0}}{1+a_{1} \frac{1}{\bar{s}}+b_{1} \frac{1}{\bar{s}^{2}}} .
$$

Z porovnání s obecnou přenosovou funkcí (2-90) pro $i=1$ vyplývá, že $K_{0}=-C_{1} / C_{2}, a_{1}=\left(C_{1}+C_{2}+C_{3}\right) / \omega_{\mathrm{m}} R_{2} C_{2} C_{3}, b_{1}=1 / \omega_{\mathrm{m}}^{2} R_{1} R_{2} C_{2} C_{3} . \quad$ Obvykle se volí $C_{1}=C_{2}=C_{3}=C$ a pak $R_{2}=3 / 2 \pi f_{\mathrm{m}} C a_{1}, R_{1}=1 / 4 \pi^{2} f_{\mathrm{m}}^{2} C^{2} R_{2} b_{1}$. Je zřejmé, že potom přenos v propustném pásmu bude $K_{0}=-1$. Koeficienty $a_{1}, b_{1}$ se zvolí podle požadované aproximace podle tabulek Tab. 1.5 až Tab. 7.8.

Aktivní horní propust 2. řádu se zesilovačem s konečným zesílením. Zavedeme-li do prvního článku pasivní horní propusti $\mathrm{C}_{1} \mathrm{R}_{1} \mathrm{C}_{2} \mathrm{R}_{2}$ zesílené výstupní napětí (viz Obr. 7.36), dostaneme aktivní horní propust 2. řádu. Přenosovou funkci určíme podle rov. (7-13) ve tvaru

$$
K(\bar{p})=\frac{A_{\mathrm{U}}}{1+\frac{R_{2} C_{2}\left(1-A_{\mathrm{U}}\right)+\left(C_{1}+C_{2}\right) R_{1}}{R_{1} R_{2} C_{1} C_{2}} \frac{1}{\bar{p}}+\frac{1}{R_{1} R_{2} C_{1} C_{2}} \frac{1}{\bar{p}^{2}}} .
$$




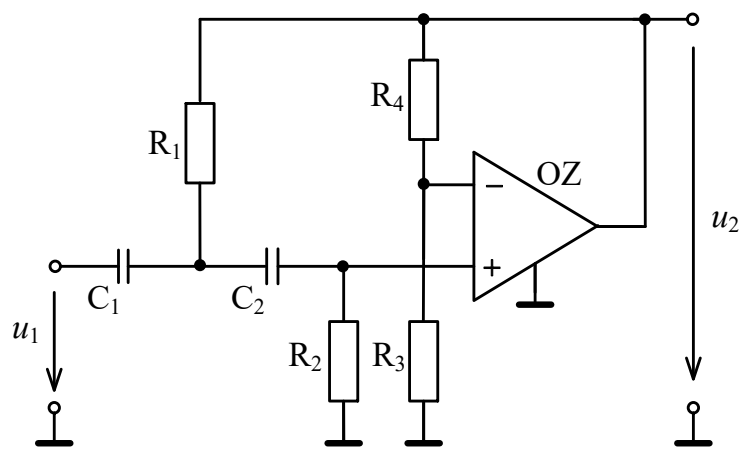

Obr. 7.36: Aktivní horní propust s neinvertujícím zesilovačem s konečným zesílením

Aby realizace obvodu byla co nejjednodušší, volí se obvykle $A_{\mathrm{U}}=1, \mathrm{tj} . R_{3}=\infty, R_{4}=0$ a $C_{1}=C_{2}=C$. Potom, pokud současně zavedeme $\bar{p}=\omega_{\mathrm{m}} \bar{S}$

$$
K(\bar{s})=\frac{1}{1+\frac{2}{\omega_{\mathrm{m}} R_{2} C} \frac{1}{\bar{s}}+\frac{1}{\omega_{\mathrm{m}}^{2} R_{1} R_{2} C^{2}} \frac{1}{\bar{s}^{2}}}=\frac{K_{0}}{1+a_{1} \frac{1}{\bar{s}}+b_{1} \frac{1}{\bar{s}^{2}}} .
$$

Odtud $\quad K_{0}=1, a_{1}=2 / \omega_{\mathrm{m}} R_{2} C, b_{1}=1 / \omega_{\mathrm{m}}^{2} R_{1} R_{2} C^{2}$. Zvolíme-li $\quad C_{1}=C_{2}=C, \quad$ bude $R_{1}=a_{1} / 4 \pi f_{\mathrm{m}} C b_{1}$ a $R_{2}=1 / \pi f_{\mathrm{m}} C a_{1}$.

Horní propust 2. řádu se třemi zesilovači lze realizovat obvodem uvedeným na Obr. 7.9, využijeme-li výstup zesilovače $\mathrm{OZ}_{1}$. Zvolíme-li $C_{1}=C_{2}=C$ a $R_{3}=R_{4}=R_{5}=R_{6}=R$, bude mít přenos (7-14) pro komplexní normovanou proměnnou $\bar{s}=\bar{p} / \omega_{\mathrm{m}}$ tvar

$$
K(\bar{s})=\frac{1}{1+\frac{1}{\omega_{\mathrm{m}} R_{1} C} \frac{1}{\bar{s}}+\frac{1}{\omega_{\mathrm{m}}^{2} R_{1} R_{2} C^{2}} \frac{1}{\bar{s}^{2}}}=\frac{K_{0}}{1+a_{1} \frac{1}{\bar{s}}+b_{1} \frac{1}{\bar{s}^{2}}} .
$$

Z porovnání sobecnou přenosovou funkcí je zřejmé, že $K_{0}=1, a_{1}=1 / \omega_{\mathrm{m}} R_{1} C, b_{1}=1$ $/ \omega_{\mathrm{m}}^{2} R_{1} R_{2} C^{2}$. Odtud pak $R_{1}=1 / 2 \pi f_{\mathrm{m}} C a_{1}, R_{2}=a_{1} / 2 \pi f_{\mathrm{m}} C b_{1}$.

\subsection{Pásmové propusti}

\subsubsection{Základní vlastnosti pásmových propustí}

Spojíme-li kaskádně za sebou horní a dolní propust 1.řádu získáme pásmovou propust. Pásmová propust je proto definována až přenosovou funkcí druhého řádu a dále pak pro vyšší řády vždy přenosovou funkcí sudého řádu, tj. 2, 4, 6 atd.

Pásmové propusti se většinou charakterizují parametry kmitavého okruhu, tj. činitelem přenosu $K_{\mathrm{r}}$ na rezonančním (středním) kmitočtu $f_{0}$ a činitelem jakosti $Q$. Přenos pásmové propusti při rezonanci budeme $\mathrm{v}$ dalším značit $K_{0}$. Obvykle se pro návrh užívá normovaný tvar přenosové funkce, kdy normovaná komplexní proměnná $\overline{\mathrm{s}}$ je vztažena vzhledem k rezonančnímu kmitočtu $\omega_{0}=2 \pi f_{0}, \mathrm{tj} . \bar{s}=\bar{p} / \omega_{0}$. Př́enosová funkce pásmové propusti 2 . rádu pak bude ve tvaru

$$
K(\bar{s})=\frac{\left(K_{0} / Q\right) \bar{s}}{1+(1 / Q) \bar{s}+\bar{s}^{2}}
$$


Tento způsob vyjádření umožňuje stanovit základní parametry pásmové propusti přímo z přenosové funkce. Substitucí $\bar{s}=\mathrm{j} \Omega$, kde normovaný úhlový kmitočet $\Omega=\omega / \omega_{0}=f / f_{0}$, lze pak stanovit modulovou a argumentovou charakteristiku filtru

$$
K(\Omega)=\frac{K_{0} \Omega / Q}{\sqrt{\left(1-\Omega^{2}\right)^{2}+(\Omega / Q)^{2}}}, \quad \varphi(\Omega)=\arctan \frac{Q\left(1-\Omega^{2}\right)}{\Omega} .
$$

Př́klad průběhu modulové charakteristiky $z(\Omega)=20 \log \left(K(\Omega) / K_{0}\right)$ pásmových propustí s činitelem jakosti $Q=1, Q=10$ a $Q=20$ je uveden na Obr. 7.37. Je zřejmé, že u pásmových propustí 2 . rádu je průběh modulové charakteristiky tím ostřejší, čím vyšší je činitel jakosti $Q$. Modulová charakteristika filtru na nízkých i vysokých kmitočtech klesá se sklonem $\pm 20 \mathrm{~dB} /$ dek. Na rezonančním kmitočtu má přenos reálnou hodnotu a fázové natočení je na tomto kmitočtu nulové. Činitel jakosti pásmové propusti určíme podle analogie s kmitavým okruhem jako poměr rezonančního kmitočtu $\mathrm{k}$ šířce kmitočtového pásma $B, \mathrm{tj}$.

$$
Q=\frac{f_{0}}{B}=\frac{f_{0}}{f_{\mathrm{h}}-f_{\mathrm{d}}}=\frac{1}{\Omega_{\mathrm{h}}-\Omega_{\mathrm{d}}}=\frac{1}{\Delta \Omega},
$$

kde $f_{\mathrm{d}}$ značí dolní a $f_{\mathrm{h}}$ horní kmitočet, kdy dojde k poklesu modulu přenosové funkce pásmové propusti o $3 \mathrm{~dB}$, resp. $\Omega_{\mathrm{d}}=f_{\mathrm{d}} / f_{0}$ značí dolní a $\Omega_{\mathrm{n}}=f_{\mathrm{n}} / f_{0}$ horní normovaný úhlový kmitočet pro pokles o $3 \mathrm{~dB}$ a $\Delta \Omega$ značí normovanou šiřku pásma $\Delta \Omega=\Omega_{\mathrm{h}}-\Omega_{\mathrm{d}}$. Protože kmitočty $\Omega_{\mathrm{d}}$ a $\Omega_{\mathrm{h}}$ jsou zrcadlově rozloženy kolem osy $\Omega=1$, platí pro ně $\Omega_{\mathrm{d}}=1 / \Omega_{\mathrm{n}}$. Horní a dolní mezní kmitočet pásmové propusti můžeme určit řešením rovnic $\Omega_{\mathrm{d}}=1 / \Omega_{\mathrm{h}}$ a $\Delta \Omega=\Omega_{\mathrm{h}}-\Omega_{\mathrm{d}}$. Odtud normovaný dolní mezní kmitočet

$$
\Omega_{\mathrm{d}}=\frac{-\Delta \Omega+\sqrt{(\Delta \Omega)^{2}+4}}{2}
$$

a normovaný horní mezní kmitočet

$$
\Omega_{\mathrm{h}}=\frac{\Delta \Omega+\sqrt{(\Delta \Omega)^{2}+4}}{2} .
$$

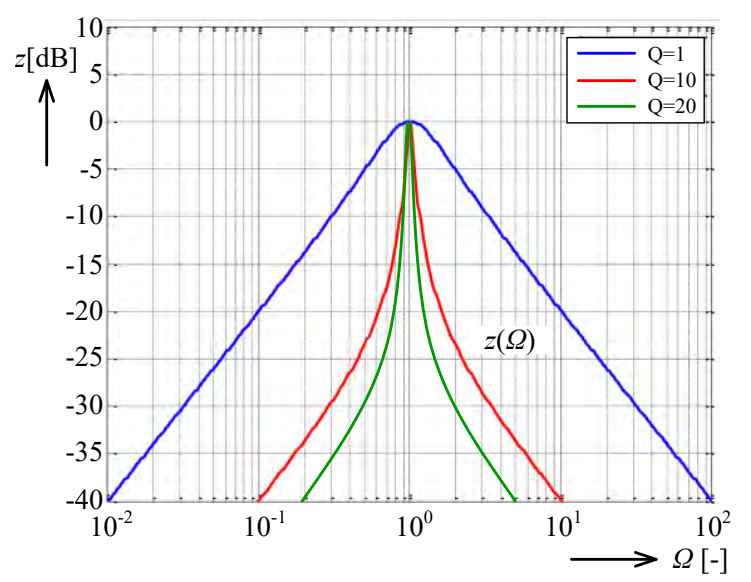

Obr. 7.37: Modulové charakteristiky pásmových propustí 2. řádu 
U pásmových propustí 2. řádu je průběh modulové charakteristik tím ostř̌ejší, čím vyšší je jejich činitel jakosti. Existují však př́ípady, kdy v okolí středního kmitočtu požadujeme pokud možno plochý průběh charakteristiky s ostrým poklesem za pásmem propustnosti. Takovouto úlohu lze řešit kaskádním řazením dolní a horní propusti s přenosovou funkcí aproximovanou některým z dříve uvedených způsobů. Kromě šiřky pásma $\Delta \Omega$ určené mezními kmitočty dolní a horní propusti je tedy možno zadat i požadovaný průběh modulové charakteristiky. Na Obr. 7.38 jsou uvedeny modulové charakteristiky pásmových propustí 4. řádu získané kaskádním řazením dolní a horní propusti 2 . řádu aproximovaných dle Butterwortha a dle Čebyševa se zvlněním $\Delta z=2 \mathrm{~dB}$. Pro srovnání je v obrázku čárkovaně naznačena modulová charakteristika pásmové propusti 2 . řádu realizovaná kaskádním řazením dolní a horní propusti 1. ř́ádu, [15], [16].

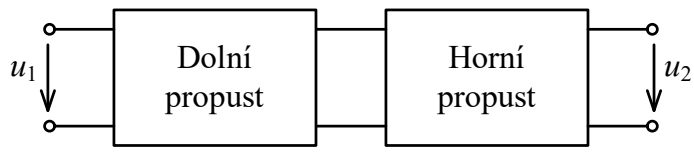

a

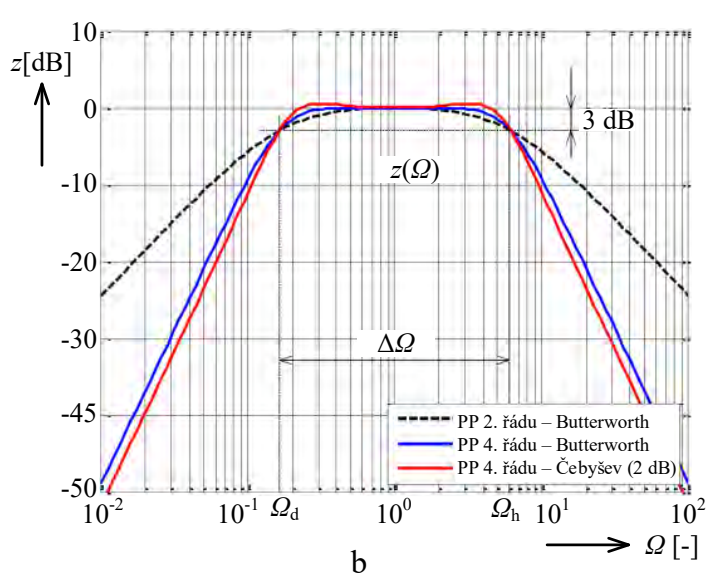

b

Obr. 7.38: a) Realizace pásmové propusti kaskádním řazením dolní a horní propusti, b) modulové charakteristiky pásmové propusti 4. řádu aproximované dle Butterwortha a Čebyševa se zvlněním $2 \mathrm{~dB}$ (čárkovaně naznačena pásmová propust 2. ̌rádu) 


\subsubsection{Pasivní pásmové propusti}

\section{Pasivní pásmová propust RC 2.ॅ̌́ádu}

Jedna z možných realizací pásmové propusti, která vznikla kaskádním spojením pasivní horní a dolní propusti, je uvedena na Obr. 7.32a. Zapojení se obvykle uvádí pod označením Wienův článek. Nejvyšší činitel jakosti dosahuje propust při shodných kapacitách obou kapacitorů a při shodných odporech obou rezistorů.
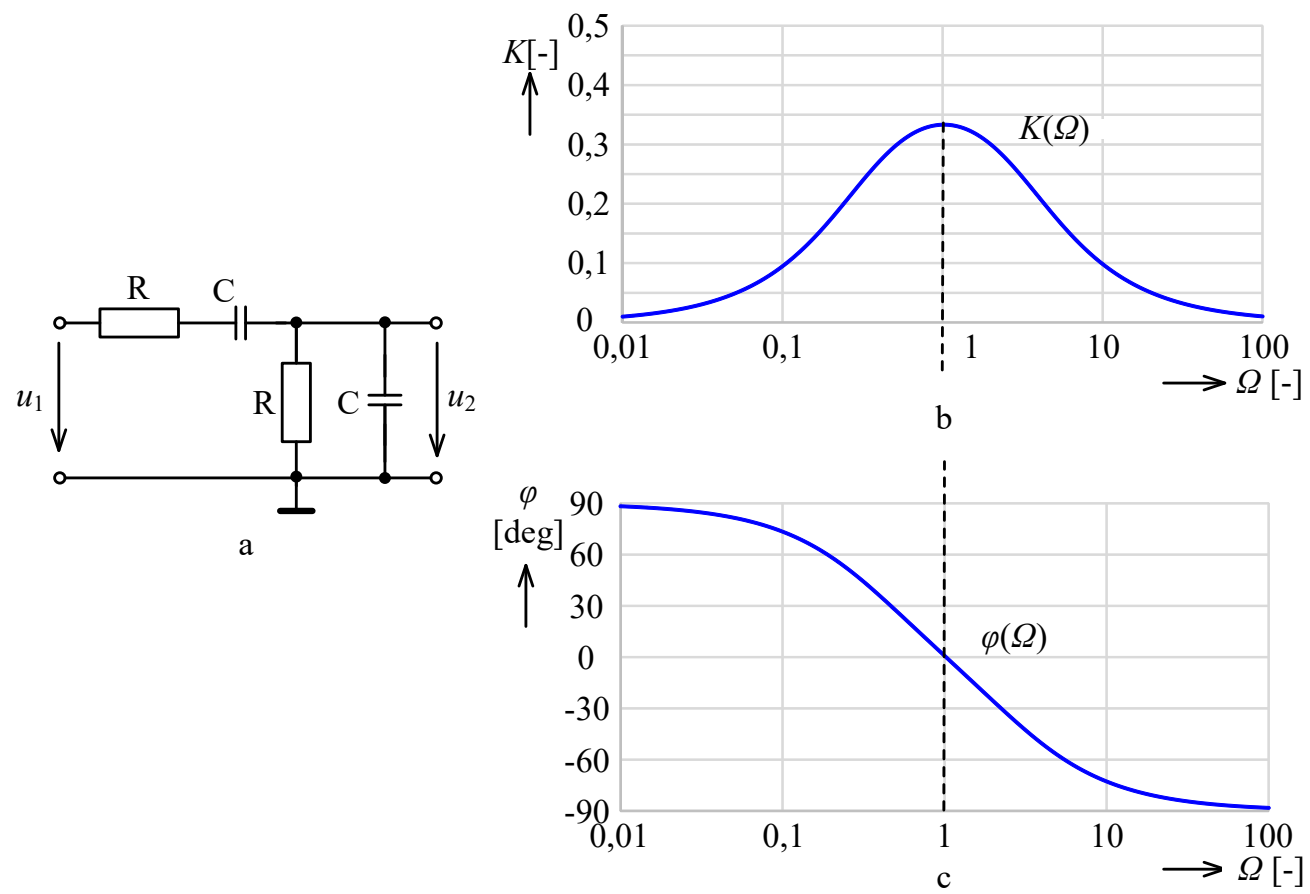

Obr. 7.39: a) Pasivní pásmová propust RC (Wienův článek) a jeho b) modulová a c) fázová charakteristika

Přenosová funkce takovéhoto kmitočtově závislého nezatíženého impedančního děliče

$$
\bar{K}(\bar{p})=\frac{\bar{Z}_{\mathrm{R}} \| \bar{Z}_{\mathrm{C}}}{\bar{Z}_{\mathrm{R}}+\bar{Z}_{\mathrm{C}}+\bar{Z}_{\mathrm{R}} \| \bar{Z}_{\mathrm{C}}}=\frac{\frac{1}{\overline{\bar{Y}}_{\mathrm{R}}+\bar{Y}_{\mathrm{C}}}}{\bar{Z}_{\mathrm{R}}+\bar{Z}_{\mathrm{C}}+\frac{1}{\bar{Y}_{\mathrm{R}}+\bar{Y}_{\mathrm{C}}}},
$$

kde $\bar{Z}_{\mathrm{R}}=1 / \bar{Y}_{\mathrm{R}}=R$ a $\bar{Z}_{\mathrm{C}}=1 / \bar{Y}_{\mathrm{C}}=1 / \bar{p} C$ a tedy

$$
K(\bar{p})=\frac{\frac{1}{(1 / R)+\bar{p} C}}{R+\frac{1}{\bar{p} C}+\frac{1}{(1 / R)+\bar{p} C}}=\frac{\bar{p} R C}{(1+\bar{p} R C)^{2}+\bar{p} R C}
$$

Pokud přenosovou funkci normujeme vzhledem k rezonančnímu kmitočtu $\omega_{0}=1 / R C$, tj. zavedeme normovanou komplexní proměnnou $\bar{s}=\bar{p} / \omega_{0}$, resp. provedeme substituci $\bar{p}=\omega_{0} \bar{s}=\bar{s} / R C$, dostaneme přenosovou funkci ve tvaru 


$$
K(\bar{s})=\frac{\bar{s}}{(1+\bar{s})^{2}+\bar{s}} .
$$

Pokud chceme vyjádřit závislost přenosové funkce na normovaném úhlovém kmitočtu, provedeme substituci $\bar{s}=\mathrm{j} \Omega$ a pak

$$
\bar{K}(\Omega)=\frac{\mathrm{j} \Omega}{(1+\mathrm{j} \Omega)^{2}+\mathrm{j} \Omega}=\frac{1}{3+\mathrm{j}\left(\frac{1}{\Omega}-\Omega\right)} .
$$

Odtud určíme modulovou charakteristiku

$$
K(\Omega)=\frac{1}{\sqrt{9+\left(\frac{1}{\Omega}-\Omega\right)^{2}}},
$$

a fázovou charakteristiku

$$
\varphi(\Omega)=\operatorname{arctg} \frac{1-\Omega^{2}}{3 \Omega} .
$$

Výstupní napětí je maximální př̀ $\Omega=1$, resp. při kmitočtu $f_{0}=\omega_{0} / 2 \pi=1 / 2 \pi R C$, kdy bude přenos $K_{0}=1 / 3$ a fázové natočení je nulové (viz Obr.1.39b, c). Selektivní vlastnosti pásmové propusti, jak bylo již řečeno, se definují činitelem jakosti $Q=f_{0} / B$, kde $B$ je kmitočtové pásmo, na jehož okrajích poklesne modul přenosové funkce na hodnotu $K_{0} / \sqrt{2}$ vůči hodnotě při rezonančním kmitočtu resp. zisk poklesne o $3 \mathrm{~dB}$. V prrípadě, že odpory rezistorů a kapacity kapacitorů jsou shodné, pak hodnota činitele jakosti je pouze $Q=1 / 3$, což ale zároveň představuje i maximální dosažitelnou hodnotu parametru této pásmové propusti.

\section{Pasivní pásmové propusti RLC 2.řádu}

Lepších vlastností lze dosáhnout použitím RLC prvků. V prvém případě (Obr.1.40a) je pásmová propust realizována s využitím sériového rezonančního obvodu LC. Přenosová funkce je dána vztahem

$$
K(\bar{p})=\frac{\bar{Z}_{\mathrm{R}}}{\bar{Z}_{\mathrm{L}}+\bar{Z}_{\mathrm{C}}+\bar{Z}_{\mathrm{R}}}=\frac{R C \bar{p}}{1+R C \bar{p}+L C \bar{p}^{2}} .
$$

Rezonanční kmitočet $\omega_{0}$ je dán Thomsonovým vztahem $\omega_{0}=1 / \sqrt{L C}$ a činitel jakosti $Q=\sqrt{L / C} / R$. 


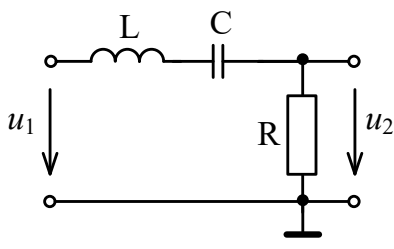

a

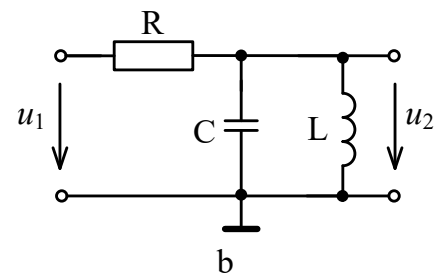

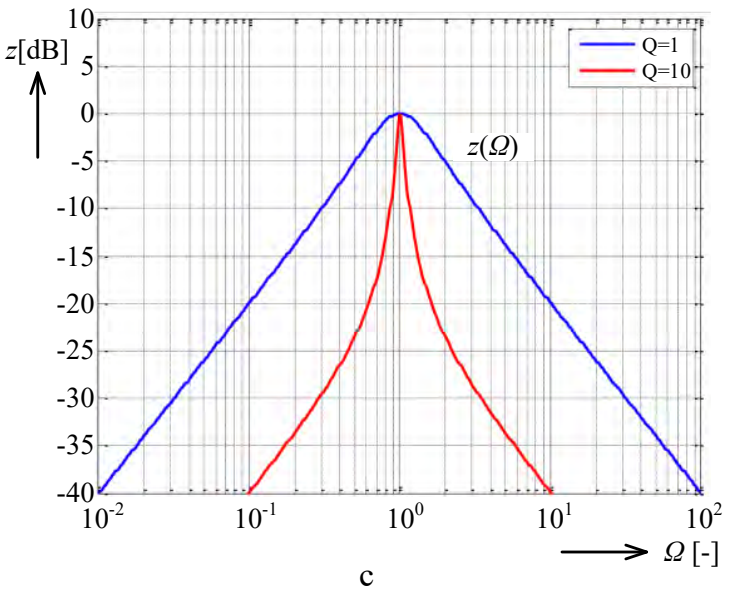

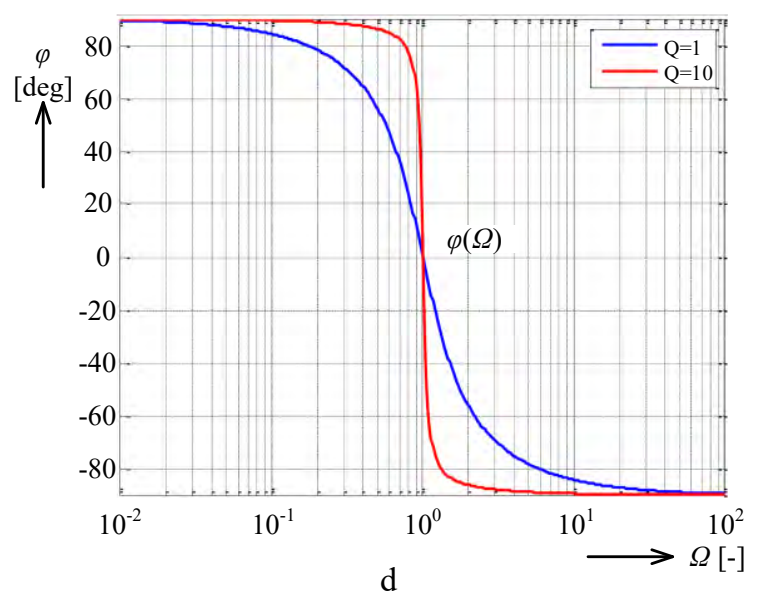

Obr. 7.40: Pasivní RLC pásmová propust 2. řádu: a) se sériovým rezonančním obvodem, b) s paralelním rezonančním obvodem a jejich c) modulová a d) argumentová charakteristika $(Q=1, Q=10)$

V druhém případě (Obr. 7.40: Obr. 7.40b) pásmová propust využívá paralelního rezonančního obvodu LC a její přenos

$$
K(\bar{p})=\frac{\bar{Z}_{\mathrm{C}} \| \bar{Z}_{\mathrm{L}}}{\bar{Z}_{\mathrm{R}}+\bar{Z}_{\mathrm{C}} \| \bar{Z}_{\mathrm{L}}}=\frac{R C \bar{p}}{1+(L / R) \bar{p}+L C \bar{p}^{2}},
$$

Rezonanční kmitočet je i v tomto případě $\omega_{0}=1 / \sqrt{L C}$ a činitel jakosti $Q=R \sqrt{C / L}$.

Při návrhu pásmové propusti dostačuje definovat rezonanční kmitočet $\omega_{0}\left(\operatorname{resp} . f_{0}\right) \mathrm{a}$ požadovaný činitel jakosti $Q$. Př́́klad průběhů modulové a argumentové charakteristiky pásmové propusti 2.ř́a pro činitel jakosti $\mathrm{Q}=1$ a $\mathrm{Q}=10$ je uveden na Obr. 7.41c,d.

\subsubsection{Aktivní pásmové propusti}

Pásmová propust se složitou zápornou zpětnou vazbou je uspořádána podle Obr.1.41a. Přenosovou funkci určíme podle rov. (7-12) platící pro obecný obvod na Obr. 7.7. Protože $\bar{Y}_{1}=1 / R_{1}, \bar{Y}_{2}=\bar{p} C_{1}, \bar{Y}_{3}=1 / R_{2}, \bar{Y}_{4}=\bar{p} C_{2}, \bar{Y}_{5}=1 / R_{3}$, bude 


$$
\begin{gathered}
\bar{K}(\bar{p})=-\frac{\frac{\bar{p} C_{2}}{R_{1}}}{\bar{p}^{2} C_{1} C_{2}+\frac{1}{R_{3}}\left(\frac{1}{R_{1}}+\bar{p} C_{1}+\frac{1}{R_{2}}+\bar{p} C_{2}\right)}= \\
=\frac{-\frac{R_{2} R_{3} C_{2}}{R_{1}+R_{2}} \bar{p}}{1+\frac{R_{1} R_{2}\left(C_{1}+C_{2}\right)}{R_{1}+R_{2}} \bar{p}+\frac{R_{1} R_{2} R_{3} C_{1} C_{2}}{R_{1}+R_{2}} \bar{p}^{2}} .
\end{gathered}
$$

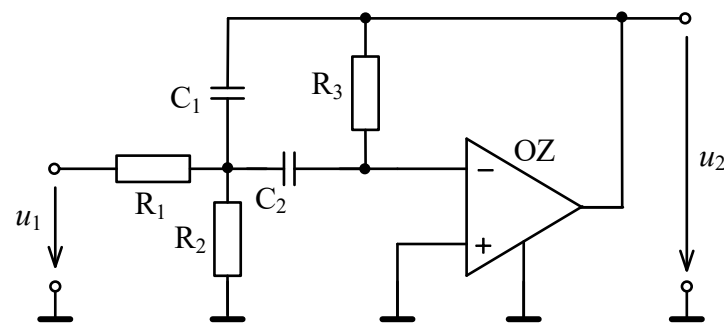

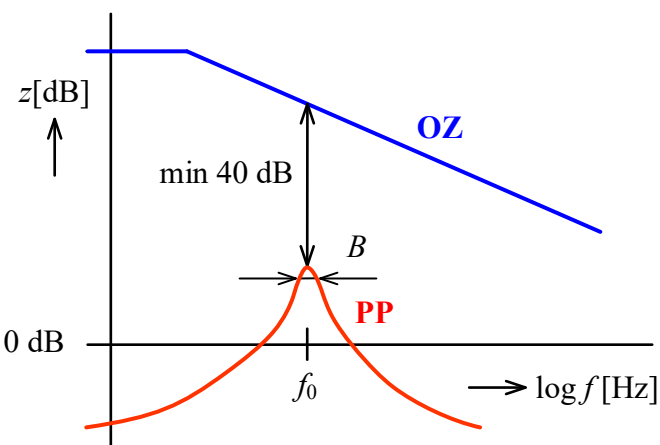

Obr. 7.41: a) Pásmová propust se složitou zápornou zpětnou vazbou, b) požadavky na kmitočtovou charakteristiku operačního zesilovače

Zavedeme-li normovanou komplexní proměnnou nyní normovanou vzhledem k rezonančnímu kmitočtu $\omega_{0}=2 \pi f_{0}, \mathrm{tj} . \bar{s}=\bar{p} / \omega_{0}$ a zvolíme-li $C_{1}=C_{2}=C$, dostaneme

$$
K(\bar{s})=\frac{-\frac{R_{2} R_{3} C}{R_{1}+R_{2}} \omega_{0} \bar{s}}{1+\frac{2 R_{1} R_{2} C}{R_{1}+R_{2}} \omega_{0} \bar{s}+\frac{R_{1} R_{2} R_{3} C^{2}}{R_{1}+R_{2}} \omega_{0}^{2} \bar{s}^{2}}=\frac{\left(K_{0} / Q\right) \bar{s}}{1+(1 / Q) \bar{s}+\bar{s}^{2}} .
$$

Srovnáme-li výsledek s obecnou přenosovou funkcí pásmové propusti, vidíme, že člen před $\bar{s}^{2}$ musí být roven jedné. $Z$ této podmínky můžeme stanovit rezonanční kmitočet

$$
\omega_{0}=2 \pi f_{0}=\frac{1}{C} \sqrt{\frac{R_{1}+R_{2}}{R_{1} R_{2} R_{3}}} .
$$

Dále je zřejmé, že

$$
1 / Q=2 \frac{R_{1} R_{2}}{R_{1}+R_{2}} \omega_{0} C=2 \sqrt{\frac{R_{1} R_{2}}{R_{3}\left(R_{1}+R_{2}\right)}}
$$

a tedy

$$
Q=\frac{1}{2} \sqrt{\frac{R_{3}\left(R_{1}+R_{2}\right)}{R_{1} R_{2}}}=\frac{1}{2} R_{3} \sqrt{\frac{R_{1}+R_{2}}{R_{1} R_{2} R_{3}}}=\frac{1}{2} \omega_{0} R_{3} C=\pi f_{0} R_{3} C
$$


a také, že $K_{0}=-R_{3} / 2 R_{1}$. Je vidět, že rezonanční kmitočet, činitel jakosti a činitel přenosu při rezonanci se mohou volit libovolně, nezávisle na sobě.

Vztah pro šířku pásma můžeme stanovit z rov. (7-100), tj. $B=f_{0} / Q$, kdy po dosazení z rov. (7-115) dostaneme $B=1 / \pi R_{3} C$. Protože veličina $B$ nezávisí na $R_{1}$ a $R_{2}$ a dále, protože $K_{0}$ nezávisí na $R_{2}$, je možno rezonanční kmitočet $f_{0}$ měnit změnou odporu rezistoru $R_{2}$, aniž se změní šířka propustného pásma $B$ či prrenos při rezonanci $K_{0}$.

Při návrhu postupujeme tak, že zvolíme $C_{1}=C_{2}=C$ a pro požadovanou šířku pásma $B=$ $f_{0} / Q$ vyčíslíme $R_{3}=1 / \pi B C=Q / \pi f_{0} C$. Dále určíme $R_{1}=-R_{3} / 2 K_{0}$ pro zvolený (záporný) přenos $K_{0}$. Z rov. (7-113) pak vyčíslíme odpor $R_{2}=R_{1} /\left(4 \pi^{2} f_{0}^{2} C R_{1} R_{3}-1\right)$.

Probíraná pásmová propust má tu výhodu, že nemá sklon k oscilacím na rezonančním kmitočtu při ne zcela přesně vybraných hodnotách jednotlivých prvků. Samozřejmě se předpokládá, že operační zesilovač má provedenu standardní korekci kmitočtové charakteristiky, jinak mohou vzniknout vysokofrekvenční kmity. Další samožrejmostí pak je, že operační zesilovač má dostatečnou rezervu zesílení při rezonančním kmitočtu (viz Obr.1.41b), jinak dojde ke zkreslení kmitočtové charakteristiky filtru.

Zapojení propusti na Obr.1.41a bude funkční i pro $R_{2}=\infty$. V tom př́ípadě $Q=\sqrt{R_{3} / R_{1}} / 2$ a $K_{0}=-2 Q^{2}$. Obvod však v tomto př́ípadě klade zvýšené nároky na výběr operačního zesilovače, protože ten při rezonančním kmitočtu $f_{0}$, musí mít zesílení s rezervou větší než $2 Q^{2}$. Např. pro $Q=100$, musí mít operační zesilovač při kmitočtu $f_{0}$ zesílení větší než 20000 .

Pásmová propust se zesilovačem s konečným zesílením. Příklad využití slabé kladné zpětné vazby pro řešení pásmové propusti ilustruje zapojení na Obr.1.41. Principiálně se jedná o zapojení obecného filtru z Obr. 7.8 a můžeme tedy pro stanovení přenosu využít rov. (7-13). Zesílení neinvertujícího zesilovače je dáno děličem zařazeným do záporné zpětné vazby $\mathrm{OZ}, \mathrm{tj}$. $A_{\mathrm{U}}=1+R_{5} / R_{4}$. Aby se řešení zjednodušilo, je možno předpokládat $R_{1}=R_{2}=R, R_{3}=2 R$, $C_{1}=C_{2}=C$ a tedy admitance $\mathrm{z}$ rov. (7-13) budou $\bar{Y}_{1}=\bar{Y}_{2}=1 / R, \bar{Y}_{3}=\bar{Y}_{4}=p C, \bar{Y}_{5}=1 / 2 R$. Pak přenosová funkce

$$
K(\bar{p})=\frac{A_{\mathrm{U}} R C \bar{p}}{1+\left(3-A_{\mathrm{U}}\right) R C \bar{p}+R^{2} C^{2} \bar{p}^{2}}
$$

a po zavedení komplexní proměnné $\bar{s}=\bar{p} / \omega_{0}$ bude přenos pásmové propusti

$$
K(\bar{s})=\frac{A_{\mathrm{U}} R C \omega_{0} \bar{s}}{1+\left(3-A_{\mathrm{U}}\right) R C \omega_{0} \bar{s}+R^{2} C^{2} \omega_{0}^{2} \bar{s}^{2}}=\frac{\left(K_{0} / Q\right) \bar{s}}{1+(1 / Q) \bar{s}+\bar{s}^{2}} .
$$

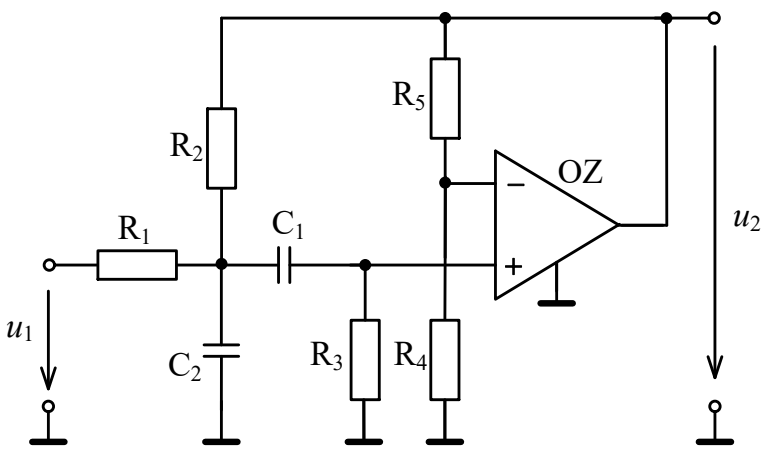

Obr. 7.42: Aktivní pásmová propust se zesilovačem s konečným zesílením 
Ze srovnání s obecným vztahem pro přenosovou funkci pásmové propusti můžeme stanovit parametry filtru. Protože člen před $\bar{s}^{2}$ se musí rovnat jedné, bude $\omega_{0}=1 / R C$, resp. rezonanční kmitočet $f_{0}=1 / 2 \pi R C$. Dále pro filtr platí $Q=1 /\left(3-A_{\mathrm{U}}\right)$ a $K_{0}=A_{\mathrm{U}} /\left(3-A_{\mathrm{U}}\right)$.

Je zřejmé, že nevýhodou filtru je vzájemná závislost veličin $K_{0}$ a $Q$. Částečnou výhodou je, že změnou zesílení $A_{\mathrm{U}}$ lze měnit činitel jakosti, aniž dojde ke změně rezonančního kmitočtu, protože ten na $A_{\mathrm{U}}$ nezávisí. Přri návrhu je dále zapotřebí počítat s tím, že pro $A_{\mathrm{U}}=3$ je činitel přenosu nekonečně velký a obvod se rozkmitá. Čím více se $A_{\mathrm{U}}$ blíží k hodnotě 3 , tím pečlivěji musí být nastavena jeho hodnota.

Pásmová propust se třemi zesilovači je uvedena na Obr. 7.9, přičemž se v tomto případě využije výstup $\mathrm{OZ}_{2}$. Obvykle se volí $R_{3}=R_{4}=R_{5}=R_{6}=R$ a $C_{1}=C_{2}=C$ a pak rov. (7-15) bude mít pro komplexní proměnnou $\bar{s}=\bar{p} / \omega_{0}$ tvar

$$
K(\bar{s})=\frac{-R_{2} C \omega_{0} \bar{s}}{1+R_{2} C \omega_{0} \bar{s}+R_{1} R_{2} C^{2} \omega_{0}^{2} \bar{s}^{2}}=\frac{\left(K_{0} / Q\right) \bar{s}}{1+(1 / Q) \bar{s}+\bar{s}^{2}} .
$$

Porovnáním s obecnou přenosovou funkcí pro pásmovou propust pak dostaneme $\omega_{0}=2 \pi f_{0}=1 / C \sqrt{R_{1} R_{2}}, Q=1 / R_{2} C \omega_{0}, K_{0}=-1$. Rezonanční kmitočet $f_{0}$ lze dostavit pomocí odporu $R_{1}$, aniž se změní činitel jakosti $Q$, nebo přenos při rezonanci $K_{0}$.

Další zapojení pásmových propustí lze např. dohledat v lit. [13], [14], [17].

\subsection{Pásmové zádrže}

\subsubsection{Základní vlastnosti pásmových zádrží}

Další ze základních filtračních funkcí je pásmová zádrž. Podobně jako pásmová propust je definována až přenosovou funkcí 2. řádu, a dále pak pro vyšší řády přenosovou funkcí sudého řádu. Praktické využití pásmové zádrže spočívá v odfiltrování rušivé složky $\mathrm{v}$ užitečném signálu, kdy obecně na rezonančním kmitočtu filtru je jeho přenos nulový a pro nízké a vysoké kmitočty má konstantní hodnotu $K_{0}$. Stejně jako tomu je u pásmových propustí, tak i u pásmových zádrží lze hovořit o míře jejich selektivity, kdy se zavádí termín činitel jakosti potlačení signálu $Q=f_{0} / B$, kde $B$ definuje kmitočtové pásmo zadržení, na jehož okrajích poklesne modul přenosové funkce na hodnotu $K_{0} / \sqrt{2}$, resp. zisk poklesne o $3 \mathrm{~dB}$. Stejně jako u pásmové propusti pak také platí, že čím větší je činitel jakosti, tím strměji se mění modul přenosu přri přechodu $\mathrm{z}$ propustného do nepropustného pásma.

Pokud zavedeme normování komplexní proměnné vzhledem ke kmitočtu potlačení $\omega_{0}=2 \pi f_{0}$, tzn. $\bar{s}=\bar{p} / \omega_{0}$, bude přenosová funkce pásmové zádrže

$$
K(\bar{s})=\frac{K_{0}\left(1+\bar{s}^{2}\right)}{1+/ Q+\bar{s}^{2}}
$$

Odtud po dosazení za $\bar{s}=\mathrm{j} \Omega$ snadno vyčíslíme vztahy pro modulovou a argumentovou charakteristiku filtru

$$
K(\Omega)=\frac{K_{0}\left(1-\Omega^{2}\right)}{\sqrt{1+\left(\frac{1}{Q^{2}}-2\right) \Omega^{2}+\Omega^{4}}}, \quad \varphi(\Omega)=\operatorname{arctg} \frac{\Omega}{Q\left(\Omega^{2}-1\right)} .
$$


Průběh modulové kmitočtové charakteristiky $z(\Omega)=20 \log \left(K(\Omega) / K_{0}\right)$ je pro $Q=1, Q=3$ a $Q=10$ uveden na Obr. 7.43.

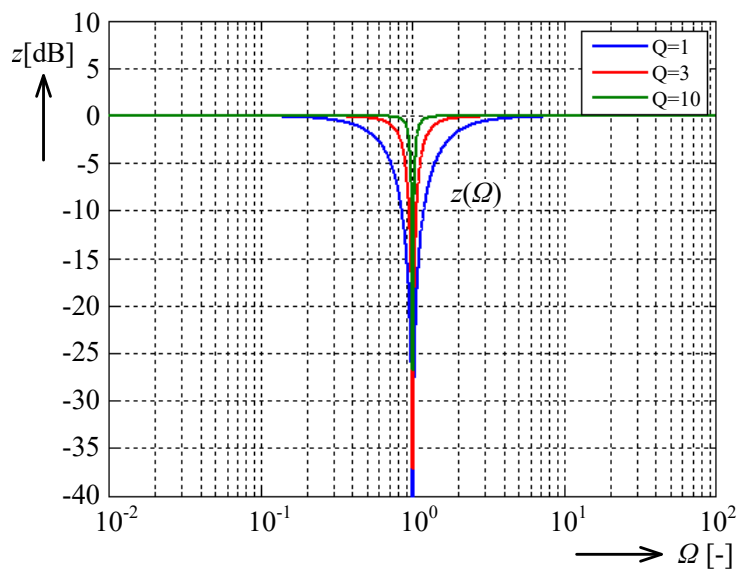

Obr. 7.43: Modulové charakteristiky pásmových zádrží 2. řádu

\subsubsection{Pasivní pásmové zádrže}

\section{Pasivní pásmové zádrže RC 2.řádu}

Dva př́klady pasivní zádrže RC 2. řádu jsou uvedeny na Obr. 7.44a, b. Budou-li odpory rezistorů a kapacity kapacitorů shodné, bude přenosová funkce v obou př́ípadech
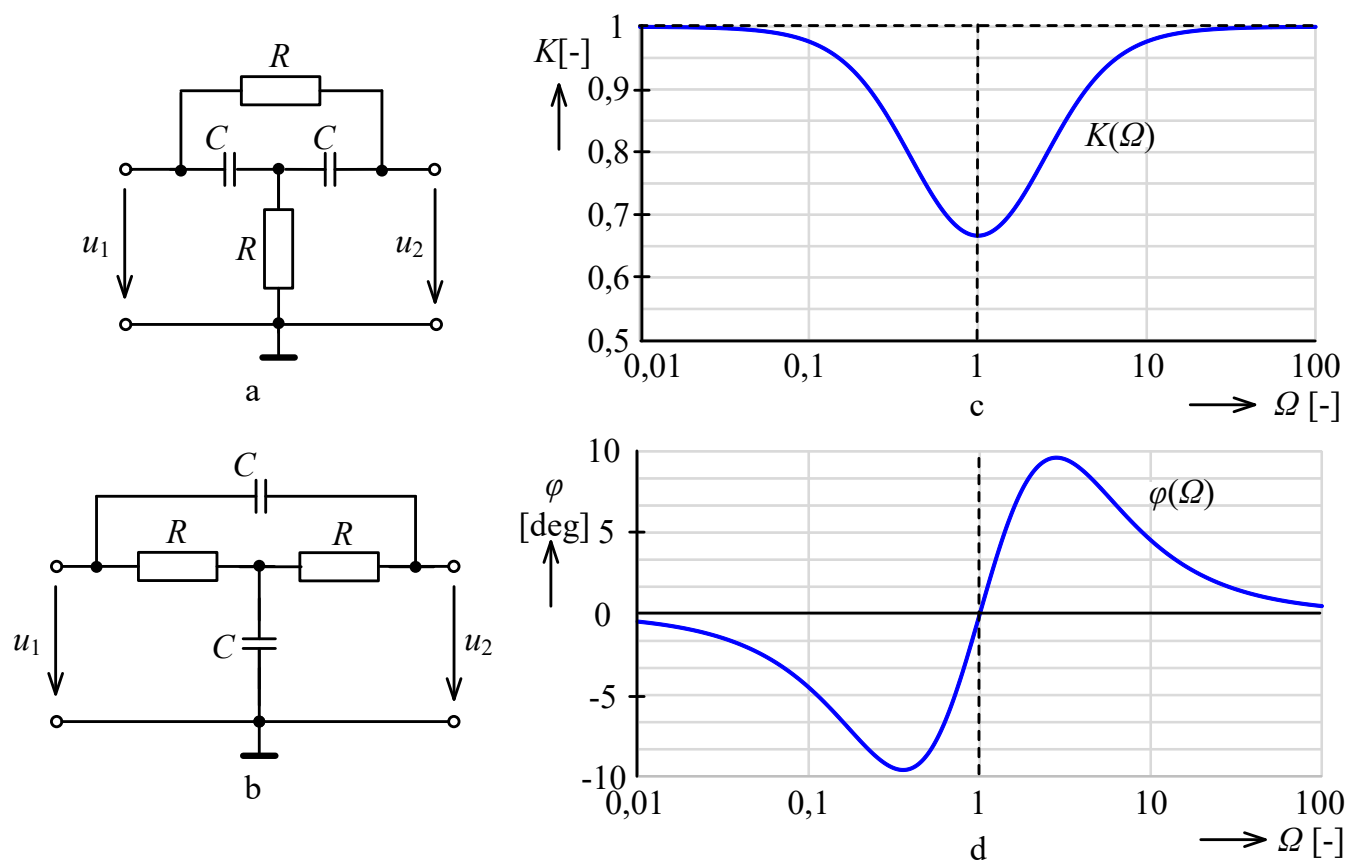

Obr. 7.44: a), b) Pasivní pásmové zádrže RC 2. řádu a jejich c) modulová a d) fázová charakteristika

$$
K(\bar{p})=\frac{\bar{p}^{2} R^{2} C^{2}+2 \bar{p} R C+1}{\bar{p}^{2} R^{2} C^{2}+3 \bar{p} R C+1} .
$$


Pro obě varianty také bude shodný kmitočet potlačení $\omega_{0}=1 / R C$ i činitel jakosti potlačení $Q$ $=1 / 3$, což je maximální hodnota činitele potlačení, kterou lze těmito zapojeními dosáhnout. Výstupní napětí je minimální při $\Omega=1$, resp. při kmitočtu $f_{0}=\omega_{0} / 2 \pi=1 / 2 \pi R C$ a na nízkých a na vysokých kmitočtech se bude přenos blížit jedné $K_{0}=1$. Průběh modulové a fázové charakteristiky je nakreslen na Obr. 7.44c,d.

Pasivni pásmové zádrže RLC 2.ř́ádu

Lepší potlačení signálu vokolí kmitočtu $f_{0}$ lze samozřejmě dosáhnout pasivními pásmovými zádržemi RLC uvedenými na Obr. 7.45a,b.

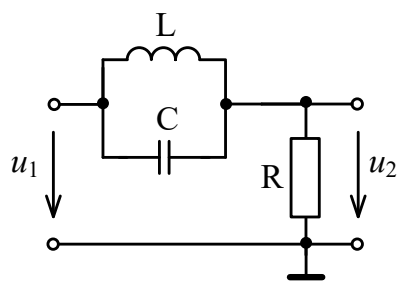

a

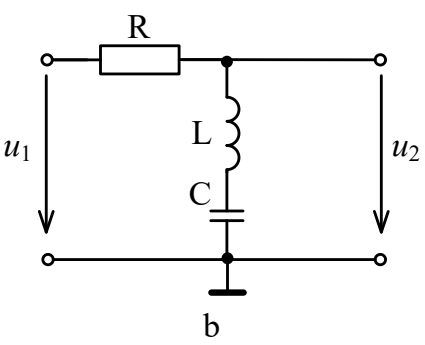

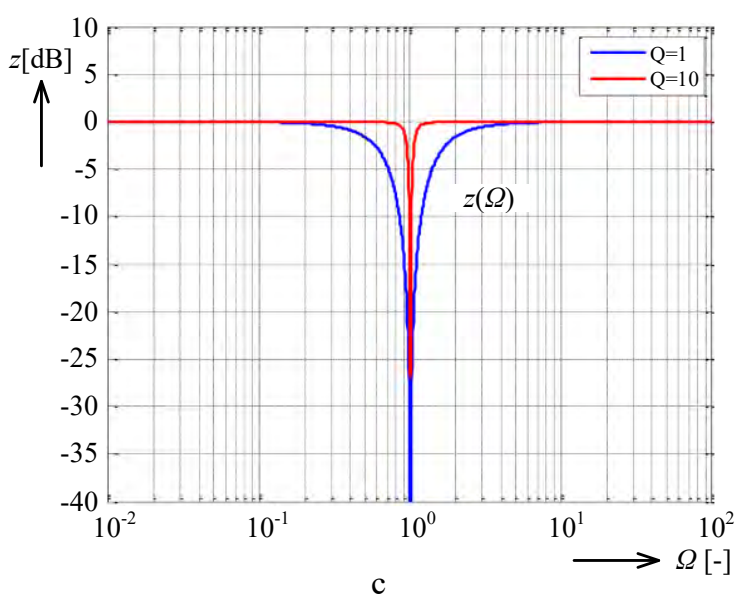

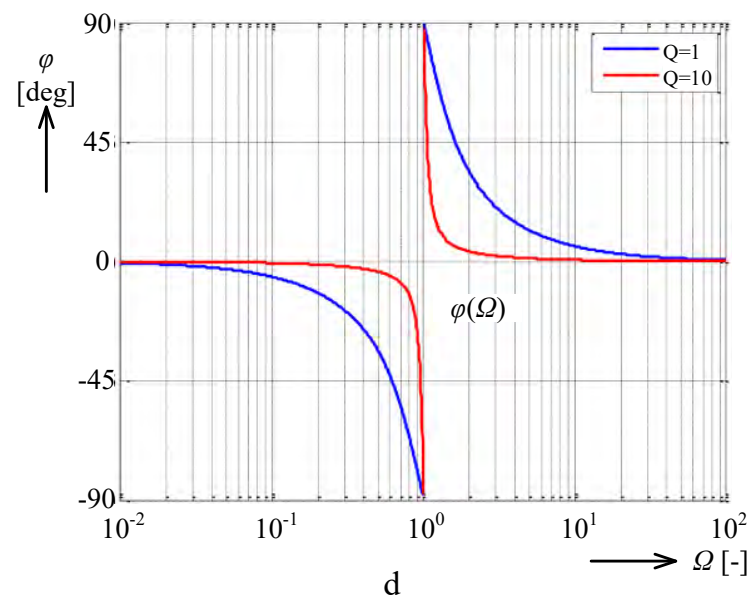

Obr. 7.45: a), b) Pásmové zádrže RLC 2. řádu a jejich c) modulová a d) argumentová charakteristika

$$
(Q=1, Q=10)
$$

Zapojení zádrže z Obr. 7.45a využívá ve své struktuře paralelní rezonanční obvod, zapojení z Obr. 7.45b pak sériový rezonanční obvod. V případě zapojení z Obr. 7.45a lze napět'ovou přenosovou funkci vyjádřit ve tvaru

$$
K(\bar{p})=\frac{\bar{Z}_{\mathrm{R}}}{\bar{Z}_{\mathrm{L}} \| \bar{Z}_{\mathrm{C}}+\bar{Z}_{\mathrm{R}}}=\frac{\bar{p}^{2} L C+1}{\bar{p}^{2} L C+\bar{p} L / R+1}
$$

a u zapojení z Obr. 7.45: b je přenosová funkce určena výrazem

$$
K(\bar{p})=\frac{\bar{Z}_{\mathrm{L}}+\bar{Z}_{\mathrm{C}}}{\bar{Z}_{\mathrm{R}}+\bar{Z}_{\mathrm{L}}+\bar{Z}_{\mathrm{C}}}=\frac{\bar{p}^{2} L C+1}{\bar{p}^{2} L C+p C R+1} .
$$


V př́ípadě zapojení z Obr. 7.45 se tedy jedná již o pásmové zádrže v pravém slova smyslu, kdy činitel jakosti může teoreticky nabývat libovolných hodnot a přenos filtru je na kmitočtu $f_{0}$ nulový.

Průběhy modulové a argumentové charakteristiky pásmových zádrží dle Obr. $7.45 \mathrm{a}, \mathrm{b}$ jsou pro hodnotu činitele jakosti $Q=1$ a $Q=10$ uvedeny na Obr. 7.45c,d.

\subsubsection{Aktivní pásmové zádrže}

Pásmová zádrž se zesilovačem s konečným zesílením. Je známo, že pasivní dvojitý článek T pracuje jako pásmová zádrž s činitelem jakosti potlačení signálu $Q=0,25$. Jakost pasivní zádrže lze zvýšit, jestliže do dvojitého článku zavedeme z jeho výstupu slabou kladnou zpětnou vazbu. Možné zapojení takovéto zádrže 2. řádu je naznačeno na Obr. 7.46. Aby se návrh zádrže zjednodušil, předpokládá se obvykle, že $C_{1}=C_{2}=C, C_{3}=2 C, R_{1}=R_{2}=R, R_{3}=R / 2$.

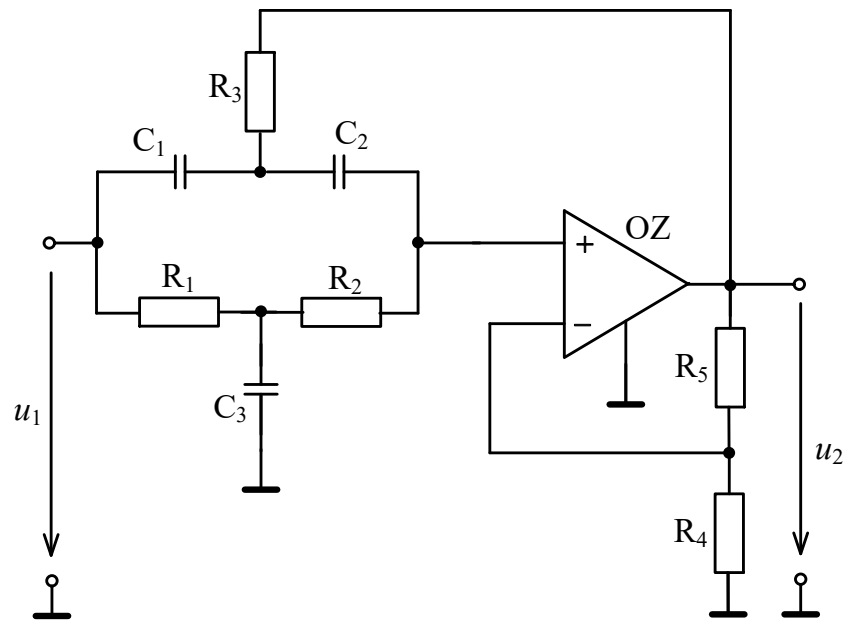

Obr. 7.46: Aktivní pásmová zádrž s dvojitým článkem T se zavedenou kladnou zpětnou vazbou

Pro signály o nízkém a o vysokém kmitočtu je přenos pasivní pásmové zádrže jednotkový, kdy signály o nízkých kmitočtech jsou přenášeny přes rezistory $R_{1}$ a $R_{2}$, signály o vysokých kmitočtech pak přes kapacitory $C_{1}$ a $C_{2}$. Největší útlum má pasivní článek při kmitočtu $\omega_{0}=1 / R C$ resp. při $f_{0}=1 / 2 \pi R C$. Prostřednictvím slabé kladné zpětné vazby, zaváděné přes rezistor $\mathrm{R}_{3}$, se zvyšuje činitel jakosti potlačení signálu $Q$. Odtlumení obvodu prŕliš silnou kladnou zpětnou vazbou však může při velkých hodnotách vést k nestabilitě obvodu popř. přímo $\mathrm{k}$ jeho rozkmitání.

Přenosovou funkci aktivní pásmové zádrže lze určit ve tvaru

$$
K(\bar{s})=\frac{A_{\mathrm{U}}\left(1+\bar{s}^{2}\right)}{1+2\left(2-A_{\mathrm{U}}\right) \bar{s}+\bar{s}^{2}}=\frac{K_{0}\left(1+\bar{s}^{2}\right)}{1+\bar{s} / Q+\bar{s}^{2}} .
$$

Z porovnání s obecnou přenosovou funkcí pásmové zádrže určíme parametry filtru

$$
K_{0}=A_{\mathrm{U}}, \quad Q=\frac{1}{2\left(2-A_{\mathrm{U}}\right)} .
$$

Nevýhodou je závislost přenosu na nízkých a vysokých kmitočtech $K_{0}$ na hodnotě činitele potlačení $Q$.

Při návrhu postupujeme tak, že zvolíme $C_{1}=C_{2}=C, C_{3}=2 C$ a určíme $R=1 / 2 \pi f_{0} C$, potom volíme $R_{1}=R_{2}=R, R_{3}=R / 2$. Výsledné zesílení určíme pro požadované $Q$ snadno 
$A_{\mathrm{U}}=2-1 / 2 Q$. Zvolíme-li $R_{4}$, bude $R_{5}=\left(A_{\mathrm{U}}-1\right) R_{4}$. Výslednému zesílení resp. volbě $Q$ musíme věnovat velkou péči, protože již pro $A_{\mathrm{U}}=2$ je obvod nestabilní a rozkmitá se. Přenos na nízkých a vysokých kmitočtech $K_{0}=A_{\mathrm{U}}$. V literatuře se často setkáme s př́ípadem, že $A_{\mathrm{U}}=1\left(\mathrm{tj} . R_{5}=0, R_{4}=\infty\right)$ a činitel potlačení je potom jen $Q=0,5$.

Pásmová zádrž s vícenásobnou zpětnou vazbou. Jiné řešení pásmové zádrže 2. řádu vychází ze zapojení aktivní pásmové propusti 2. řádu uvedené na Obr. 7.41, kde pro požadovaný tvar čitatele přenosové funkce je přes dělič $\mathrm{R}_{3}$ a $\mathrm{R}_{4}$ přivedena část vstupního signálu na neinvertující vstup OZ.

Přenosová funkce pásmové zádrže je pak dána vztahem

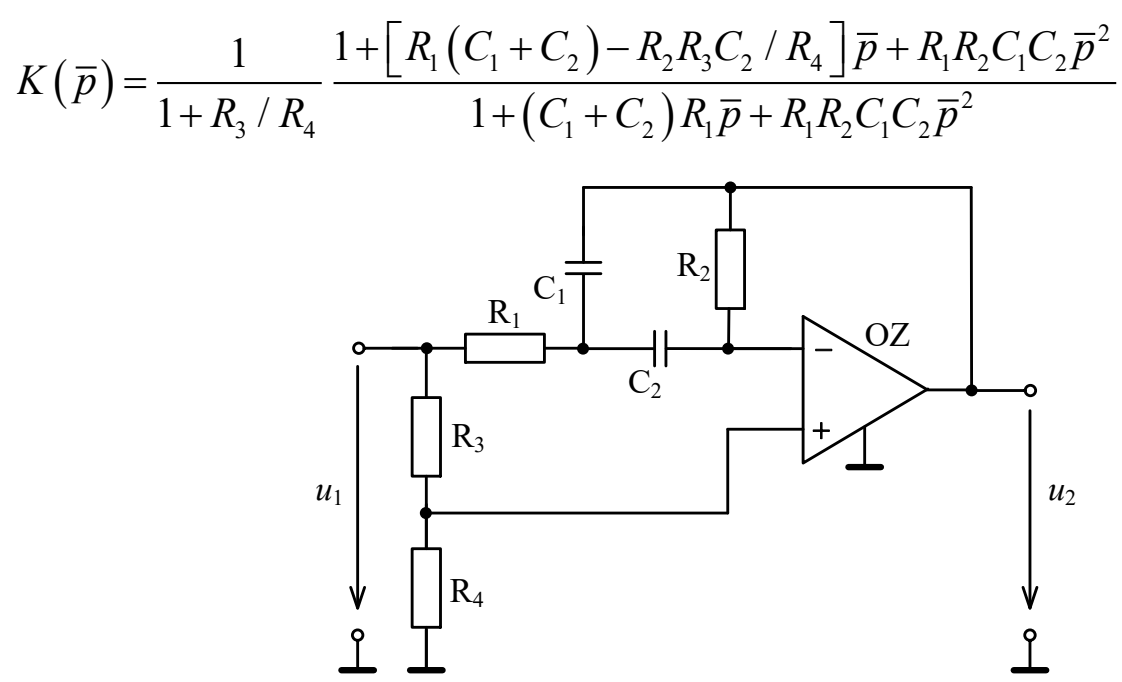

Obr. 7.47: Aktivní pásmová zádrž s vícenásobnou zpětnou vazbou

Aby obvod pracoval jako pásmová zádrž, musí být v čitateli člen před komplexní proměnnou $\bar{p}$ nulový, tj. $R_{1}\left(C_{1}+C_{2}\right)-R_{2} R_{3} C_{2} / R_{4}=0$. Zvolíme-li $C_{1}=C_{2}=C$, podmínka se zjednoduší na požadavek $R_{3} / R_{4}=2 R_{1} / R_{2}$. Potom rov. (7-126) bude mít tvar

$$
K(\bar{p})=\frac{1}{1+2 R_{1} / R_{2}} \frac{1+R_{1} R_{2} C^{2} \bar{p}^{2}}{1+2 R_{1} C \bar{p}+R_{1} R_{2} C^{2} \bar{p}^{2}},
$$

resp. pro $\bar{s}=\bar{p} / \omega_{0}$

$$
K(\bar{s})=\frac{1}{1+2 R_{1} / R_{2}} \frac{1+R_{1} R_{2} C^{2} \omega_{0}^{2} \bar{s}^{2}}{1+2 R_{1} C \omega_{0} \bar{s}+R_{1} R_{2} C^{2} \omega_{0}^{2} \bar{s}^{2}}=\frac{K_{0}\left(1+\bar{s}^{2}\right)}{1+\bar{s} / Q+\bar{s}^{2}} .
$$

Z porovnání s obecnou přenosovou funkcí zádrže vyplývá, že člen ve jmenovateli před $\bar{s}^{2}$ se musí rovnat jedné a odtud $\omega_{0}=\sqrt{1 / R_{1} R_{2}} / C$.

Potom

$$
K(\bar{s})=\frac{1}{1+2 R_{1} / R_{2}} \frac{1+\bar{s}^{2}}{1+2 \sqrt{R_{1} / R_{2}} \bar{s}+\bar{s}^{2}}=\frac{K_{0}\left(1+\bar{s}^{2}\right)}{1+\bar{s} / Q+\bar{s}^{2}} .
$$

Odtud je zřejmé, že $K_{0}=1 /\left(1+2 R_{1} / R_{2}\right)$ a $Q=\sqrt{R_{2} / R_{1}} / 2$. 
Určitou nevýhodou zapojení je skutečnost, že přenos $K_{0}$ závisí na hodnotě činitele jakosti potlačení $Q$. Při návrhu postupujeme tak, že zvolíme $C_{1}=C_{2}=C, R_{1}=R_{3}=R$ a pro požadovaný činitel potlačení $Q$ určíme hodnotu $R_{2}=4 R Q^{2}$ a $R_{4}=2 R Q^{2}=R_{2} / 2$.

\subsection{Fázovací články}

\subsubsection{Přenosová funkce fázovacího článku}

U filtrů, které jsme doposud uvažovali, závisí modul i argument přenosové funkce na kmitočtu. Existují však i filtry, jejichž modul přenosové funkce je konstantní, ale argument přenosové funkce závisí na kmitočtu. Takovéto obvody se nazývají fázovací články. Používají se zejména ke korekci fáze a k časovému zpoždění signálů.

Přenosová funkce fázovacího článku se vyznačuje tím, že v čitateli a jmenovateli jsou komplexně sdružené polynomy. Fázovací článek 1.řádu bude mít v čitateli přenosové funkce polynom 1.ř́adu, který bude komplexně sdružený polynomu 1. řádu ve jmenovateli

$$
K(\bar{s})=\frac{1-a_{1} \bar{s}}{1+a_{1} \bar{s}},
$$

resp. po dosazení za $\bar{s}=\mathrm{j} \Omega$

$$
K(\mathrm{j} \Omega)=\frac{1-\mathrm{j} a_{1} \Omega}{1+\mathrm{j} a_{1} \Omega}=\frac{\sqrt{1+a_{1}^{2} \Omega^{2}} \cdot \mathrm{e}^{-\alpha(\Omega)}}{\sqrt{1+a_{1}^{2} \Omega^{2}} \cdot \mathrm{e}^{\alpha(\Omega)}}=1 \cdot \mathrm{e}^{-2 \alpha(\Omega)}=\mathrm{e}^{\varphi(\Omega)},
$$

kde

$$
\varphi(\Omega)=-2 \alpha(\Omega)=-2 \operatorname{arctg} a_{1} \Omega .
$$

Modul přenosu takovéhoto filtru bude tedy jednotkový a jen jeho fázová charakteristika se bude měnit v závislosti na kmitočtu. $Z$ tohoto důvodu se fázovací článek také někdy označuje jako všepropustný filtr (all pass filter).

Obdobně přenosová funkce fázovacího článku 2.ř́a má v čitateli polynom 2.ŕádu, který je komplexně sdružený s polynomem 2.ŕádu ve jmenovateli.

$$
K(\bar{s})=\frac{1-a_{1} \bar{s}+b_{1} \bar{s}^{2}}{1+a_{1} \bar{s}+b_{1} \bar{s}^{2}},
$$

resp.

$$
K(\mathrm{j} \Omega)=\frac{\sqrt{\left(1-b_{1} \Omega^{2}\right)^{2}+a_{1}^{2} \Omega^{2}} \cdot \mathrm{e}^{-\alpha(\Omega)}}{\sqrt{\left(1-b_{1} \Omega^{2}\right)^{2}+a_{1}^{2} \Omega^{2}} \cdot \mathrm{e}^{\alpha(\Omega)}}=1 \cdot \mathrm{e}^{-2 \alpha(\Omega)}=\mathrm{e}^{\varphi(\Omega)},
$$

kde

$$
\varphi(\Omega)=-2 \alpha(\Omega)=-2 \operatorname{arctg} \frac{a_{1} \Omega}{1-b_{1} \Omega^{2}} .
$$

Skupinové zpoždění vyjadřuje dobu, o kterou je signál zpožděn při průchodu fázovacím článkem $\tau(\omega)=-\mathrm{d} \varphi(\omega) / \mathrm{d} \omega$. Pro zjednodušení návrhu zavedeme skupinové zpoždění normované podle převrácené hodnoty mezního kmitočtu $T_{\mathrm{m}}=1 / f_{\mathrm{m}}$ 


$$
T_{\mathrm{z}}(\omega)=\frac{\tau(\omega)}{T_{\mathrm{m}}}=f_{\mathrm{m}} \tau(\omega)=\frac{\omega_{\mathrm{m}}}{2 \pi} \tau(\omega)=-\frac{\omega_{\mathrm{m}}}{2 \pi} \frac{\mathrm{d} \varphi(\omega)}{\mathrm{d} \omega}
$$

Přejdeme-li formálně na normovanou proměnnou $\Omega=\omega / \omega_{\mathrm{m}}$ bude

$$
T_{\mathrm{z}}(\Omega)=-\frac{1}{2 \pi} \frac{\mathrm{d} \varphi\left(\omega / \omega_{\mathrm{m}}\right)}{\mathrm{d} \omega / \omega_{\mathrm{m}}}=-\frac{1}{2 \pi} \frac{\mathrm{d} \varphi(\Omega)}{\mathrm{d} \Omega}
$$

Zde na rozdíl od předchozích př́ípadů $\omega_{\mathrm{m}}=2 \pi f_{\mathrm{m}}$ značí kmitočet, př́i kterém skupinové zpoždění na vysokých kmitočtech poklesne na hodnotu $1 / \sqrt{2}$ vůči hodnotě na nízkých kmitočtech. Využijeme-li poznatků z matematiky o derivaci funkcí, bude pro př́ípad fázovacího článku 2. řádu pro normované skupinové zpoždění platit

$$
T_{\mathrm{z}}(\Omega)=\frac{1}{\pi} \frac{a_{1}\left(1+b_{1} \Omega^{2}\right)}{1+\left(a_{1}^{2}-2 b_{1}\right) \Omega^{2}+b_{1}^{2} \Omega^{4}} .
$$

Rovnici (7-135) pro fázové natočení i rov. (7-138) pro normované skupinové zpoždění můžeme zobecnit pro fázovací článek $n$-tého řádu realizovaný kaskádním řazením $I$ fázovacích článků 2. řádu popř. 1.řádu

$$
\begin{gathered}
\varphi(\Omega)=-2 \sum_{i=1}^{I} \operatorname{arctg} \frac{a_{i} \Omega}{1-b_{i} \Omega^{2}} \\
T_{\mathrm{z}}(\Omega)=\frac{1}{\pi} \sum_{i=1}^{I} \frac{a_{i}\left(1+b_{i} \Omega^{2}\right)}{1+\left(a_{i}^{2}-2 b_{i}\right) \Omega^{2}+b_{i}^{2} \Omega^{4}} .
\end{gathered}
$$

Obzvláště zajímavé je použití těchto filtrů $\mathrm{k}$ časovému zpoždění signálů, kdy požadujeme, aby při průchodu signálu nedošlo k jeho zkreslení, tzn., modul přenosové funkce musí být konstantní. Tato podmínka je při použití fázovacích článků splněna. Druhá podmínka spočívá v tom, že skupinové zpoždění článku musí být konstantní pro celé kmitočtové spektrum zpožd'ovaného signálu. Filtr, který vyhovuje této druhé podmínce, jsme již probírali při aproximaci přenosové funkce dle Bessela. Proto by ke splnění této podmínky dostačovalo dosadit do vztahu (7-133) koeficienty přenosové funkce aproximované dle Bessela. Bylo by však nutno transformovat modulovou charakteristiku, protože mezní kmitočet $\omega_{\mathrm{m}}$ dolní propusti ztrácí u fázovacího článku smysl. Proto byly koeficienty $a_{i}$ a $b_{i}$ přepočítány tak, aby při $\Omega=1$ skupinové zpoždění vykazovalo pokles $1 / \sqrt{2}$ vůči své hodnotě při nízkých kmitočtech. Přepočtené koeficienty pro fázovací články prvního až desátého řádu jsou uvedeny v Tab. 7.9, [3]. 
Tab. 7.9: Koeficienty $a_{i}$ a $b_{i}$ pro návrh fázovacích článků

\begin{tabular}{|c|c|c|c|c|c|c|}
\hline$n$ & $i$ & $a_{i}$ & $b_{i}$ & $f_{i} / f_{\mathrm{m}}$ & $Q_{i}$ & $T_{\mathrm{z}}(0)$ \\
\hline 1 & 1 & 0,6436 & 0,0000 & 1,554 & - & 0,2049 \\
\hline 2 & 1 & 1,6278 & 0,8832 & 1,064 & 0,58 & 0,5181 \\
\hline \multirow{2}{*}{3} & 1 & 1,1415 & 0,0000 & 0,876 & & \\
\hline & 2 & 1,5092 & 1,0877 & 0,959 & 0,69 & 0,8437 \\
\hline \multirow{2}{*}{4} & 1 & 2,3370 & 1,4878 & 0,820 & 0,52 & \\
\hline & 2 & 1,3506 & 1,1837 & 0,919 & 0,81 & 1,1738 \\
\hline \multirow{3}{*}{5} & 1 & 1,2974 & 0,0000 & 0,771 & - & \\
\hline & 2 & 2,2224 & 1,5685 & 0,798 & 0,56 & \\
\hline & 3 & 1,2116 & 1,2330 & 0,901 & 0,92 & 1,5060 \\
\hline \multirow{3}{*}{6} & 1 & 2,6117 & 1,7763 & 0,750 & 0,51 & \\
\hline & 2 & 2,0706 & 1,6015 & 0,790 & 0,61 & \\
\hline & 3 & 1,0967 & 1,2596 & 0,891 & 1,92 & 1,8395 \\
\hline \multirow{4}{*}{7} & 1 & 1,3735 & 0,0000 & 0,750 & - & \\
\hline & 2 & 2,5320 & 1,8169 & 0,790 & 0,53 & \\
\hline & 3 & 1,9211 & 1,6116 & 0,891 & 1,66 & \\
\hline & 4 & 1,0023 & 1,2743 & 0,886 & 1,13 & 2,1737 \\
\hline \multirow{4}{*}{8} & 1 & 2,7541 & 1,9420 & 0,718 & 0,51 & \\
\hline & 2 & 2,4174 & 1,8300 & 0,739 & 0,56 & \\
\hline & 3 & 1,7850 & 1,6101 & 0,788 & 0,71 & \\
\hline & 4 & 0,9239 & 1,2822 & 0,883 & 1,23 & 2,5084 \\
\hline \multirow{5}{*}{9} & 1 & 1,4186 & 0,0000 & 0,705 & - & \\
\hline & 2 & 2,6979 & 1,9659 & 0,713 & 0,52 & \\
\hline & 3 & 2,2940 & 1,8282 & 0,740 & 0,59 & \\
\hline & 4 & 1,6644 & 1,6027 & 0,790 & 0,76 & \\
\hline & 5 & 0,8579 & 1,2862 & 0,882 & 1,32 & 2,8434 \\
\hline \multirow{5}{*}{10} & 1 & 2,8406 & 2,0490 & 0,699 & 0,50 & \\
\hline & 2 & 2,6120 & 1,9714 & 0,712 & 0,54 & \\
\hline & 3 & 2,1733 & 1,8184 & 0,742 & 0,62 & \\
\hline & 4 & 1,5583 & 1,5923 & 0,792 & 0,81 & \\
\hline & 5 & 0,8018 & 1,2877 & 0,881 & 1,42 & 3,1786 \\
\hline
\end{tabular}

Jak již bylo uvedeno, od fázovacího článku se předpokládá konstantní skupinové zpoždění pro celé kmitočtové spektrum zpožd'ovaného signálu. Výpočet normovaného skupinového zpoždění $T_{z}(\Omega)$ dle (7-140) lze značně zjednodušit, protože postačuje určit pouze jeho hodnotu pro nulový kmitočet $(\Omega=0)$

$$
T_{\mathrm{z}}(0)=f_{\mathrm{m}} \tau(0)=\frac{1}{\pi} \sum_{i=1}^{I} a_{i} .
$$

Hodnoty normovaného skupinového zpoždění fázovacích článků $n$-tého řádu je tedy možné určit pouze z koeficientů $a_{i}$, které jsou uvedeny v Tab. 7.9. V Tab. 7.9 jsou kromě koeficienti̊ $a_{i}$ a $b_{i}$ a normovaného skupinového zpoždění $T_{z}(0)$ uvedeny i hodnoty poměrů 
kmitočtů $f_{i} / f_{\mathrm{m}}$, kde $f_{i}$ odpovídá kmitočtu při kterém natočení fáze dílčího filtru je $-90^{\circ} \mathrm{v}$ případě dílčího fázovacího článku 1 . řádu, resp. $-180^{\circ}$ pro fázovací článek 2 . řádu. Znát hodnotu kmitočtu $f_{i}$ je výhodné především $\mathrm{v}$ př́ípadě praktické realizace, nebot' daný kmitočet lze změřit mnohem snadněji než mezní kmitočet skupinového zpoždění $f_{\mathrm{m}}$.

Na Obr. 7.48 jsou uvedeny normované kmitočtové charakteristiky skupinového zpoždění fázovacích článků 1 . až 10. řádu.

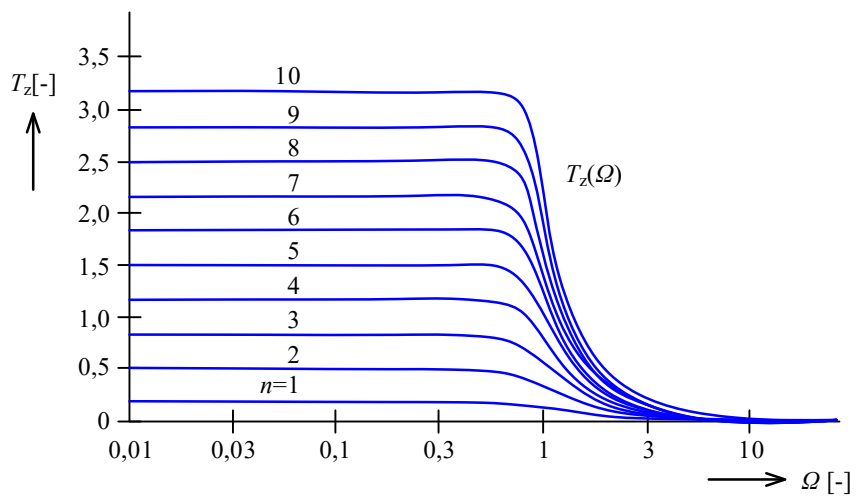

Obr. 7.48: Skupinové zpoždění fázovacích článků 1. až 10. řádu v závislosti na kmitočtu

Princip návrhu fázovacího článku ukážeme na př́kladu. Předpokládejme, že máme realizovat zpoždění vstupního signálu s kmitočtovým spektrem od 0 do $1 \mathrm{kHz}$ o čas $\tau(0)=2 \mathrm{~ms}$. Aby bylo časové zpoždění všech spektrálních složek signálu konstantní, musí být mezní kmitočet fázovacího článku vyšší nebo roven $1 \mathrm{kHz}$. Protože $T_{\mathrm{z}}(\Omega)=\tau(\Omega) / T_{\mathrm{m}}=f_{\mathrm{m}} \tau(\Omega)$, musí platit že $T_{\mathrm{z}}(0) \geq 1 \mathrm{kHz} \cdot 2 \mathrm{~ms}=2,0$. Z Tab. 7.9 je vidět, že pro uvedený případ je nutné použít fázovací článek 7. řádu, pro který $T_{z}(0)=2,1737$. Mezní kmitočet $f_{\mathrm{m}}$, při kterém skupinové zpoždění poklesne na $1 / \sqrt{2}$ vůči hodnotě $T_{\mathrm{z}}(0)$, tedy bude $f_{\mathrm{m}}=T_{\mathrm{z}}(0) / \tau(0)=2,1737 / 2 \mathrm{~ms}=1,087 \mathrm{kHz}$.

\subsubsection{Aktivní fázovací články}

Fázovací článek prvního řádu naznačený na Obr. 7.48a vykazuje pro nízké kmitočty (kdy kapacitor $\mathrm{C}$ vykazuje téměř nekonečnou impedanci) přenos +1 a pro vysoké kmitočty (kdy kapacitor $\mathrm{C}$ vykazuje téměř nulovou impedanci) přenos -1 , přičemž předpokládáme $R_{1}=R_{2}=$ $R_{0}$. Argument přenosové funkce se proto mění v závislosti na kmitočtu od 0 do $-180^{\circ}$. Obvod bude pracovat jako fázovací článek, jestliže i při středních kmitočtech je modul činitele přenosu roven jedné.

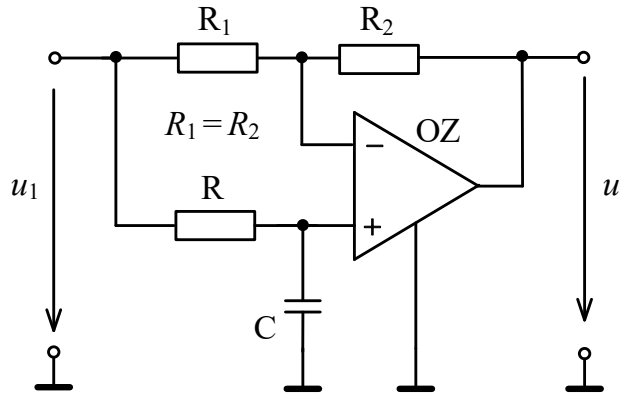

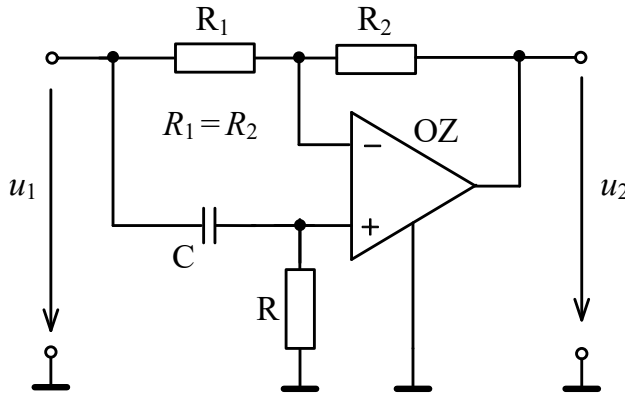

$\mathrm{b}$

Obr. 7.49: Fázovací články 1. řádu 
Přenosovou funkci článku z Obr. 7.49a lze stanovit ve tvaru

$$
K(\bar{p})=\frac{1-\bar{p} R C}{1+\bar{p} R C}, \text { resp. } \quad K(\mathrm{j} \omega)=\frac{1-\mathrm{j} \omega R C}{1+\mathrm{j} \omega R C} .
$$

Podobně jako v př́padě přenosové funkce (7-130) můžeme stanovit odtud modulovou charakteristiku $K(\omega)=1$ a fázovou charakteristiku

$$
\varphi(\omega)=-2 \operatorname{arctg} \omega R C .
$$

Skupinové zpoždění potom

$$
\tau(\omega)=-\frac{\mathrm{d} \varphi(\omega)}{\mathrm{d} \omega}=\frac{2 R C}{1+\omega^{2} R^{2} C^{2}} .
$$

Na nízkých kmitočtech bude hodnota skupinového zpoždění $\tau(0)=2 R C$.

Zavedeme-li normované přenosové funkce vzhledem ke kmitočtu $\omega_{\mathrm{m}}=2 \pi f_{\mathrm{m}}$, kdy skupinové zpoždění fázovacího článku poklesne na $1 / \sqrt{2}$ vůči hodnotě na nízkých kmitočtech, tzn. Zavedeme substituci $\bar{s}=\omega_{\mathrm{m}} \bar{p}$ bude

$$
K(\bar{s})=\frac{1-\omega_{\mathrm{m}} R C \bar{s}}{1+\omega_{\mathrm{m}} R C \bar{s}}
$$

Ze srovnání s obecnou přenosovu funkcí (viz rov.(1-131)) je zřejmé, že $a_{1}=\omega_{\mathrm{m}} R C$. Normované skupinové zpoždění fázovacího článku 1.řádu je pak na nízkých kmitočtech podle rov. (1-142) dáno vztahem

$$
T_{\mathrm{z}}(0)=\frac{a_{1}}{\pi}=\frac{\omega_{\mathrm{m}} R C}{\pi}=2 f_{\mathrm{m}} R C .
$$

Fázovací článek prvního řádu, jehož schéma je naznačeno na Obr. 7.49a, může být tedy $\mathrm{s}$ úspěchem použit jako širokopásmový posouvač fáze. Měníme-li odpor $R$, je možno nastavit požadovanou velikost posunutí fáze v rozmezí od 0 do $-180^{\circ}$, resp. nastavit skupinové zpoždění, přičemž amplituda výstupního signálu zůstává beze změny.

Fázovací článek na Obr. $7.49 \mathrm{~b}$ vykazuje pro nízké kmitočty (kdy kapacitor vykazuje téměř nekonečnou impedanci) přenos -1 , přičemž předpokládáme $R_{1}=R_{2}=R_{0}$. Pro vysoké kmitočty (kdy kapacitor $\mathrm{C}$ vykazuje téměř nulovou impedanci) bude přenos +1 . Obvod tedy natáčí fázi signálu od $-180^{\circ}$ (na nízkých kmitočtech) do $0^{\circ}$ (na vysokých kmitočtech), prričemž amplituda výstupního signálu se nezmění. Skupinové zpoždění lze i zde dostavit změnou odporu $R$.

Fázovací článek 2. rádu. Příklad řešení aktivního fázovacího článku 2. řádu je nakreslen na Obr. 7.50. Bude-li pro zjednodušení řešení pro pasivní prvky platit $C_{1}=C_{2}=C, R_{4}=R_{5}=$ $R, R_{3}=R R_{2} / 4 R_{1}$ bude přenos článku

$$
K(\bar{p})=-\frac{1-2 R_{1} C \bar{p}+R_{1} R_{2} C^{2} \bar{p}^{2}}{1+2 R_{1} C \bar{p}+R_{1} R_{2} C^{2} \bar{p}^{2}} .
$$




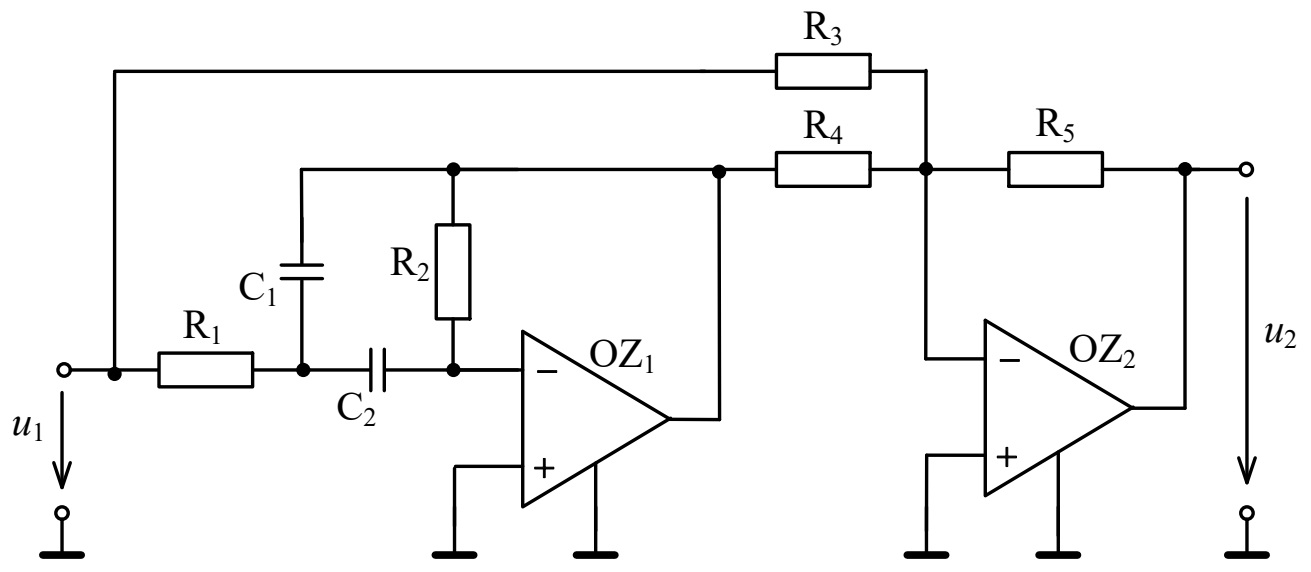

Obr. 7.50: Aktivní fázovací článek 2. řádu realizovaný pomocí pásmové propusti a sumačního zesilovače

Zavedeme-li normovanou komplexní proměnnou $\bar{s}=\bar{p} / \omega_{\mathrm{m}}$, kde $\omega_{\mathrm{m}}$ je kmitočet, při kterém skupinové zpoždění článku poklesne na hodnotu $1 / \sqrt{2}$ vǔči hodnotě na nízkých kmitočtech, bude

$$
K(\bar{s})=-\frac{1-2 R_{1} C \omega_{\mathrm{m}} \bar{s}+R_{1} R_{2} C^{2} \omega_{\mathrm{m}}^{2} \bar{s}^{2}}{1+2 R_{1} C \omega_{\mathrm{m}} \bar{s}+R_{1} R_{2} C^{2} \omega_{\mathrm{m}}^{2} \bar{s}^{2}}=-\frac{1-a_{1} \bar{s}+b_{1} \bar{s}^{2}}{1+a_{1} \bar{s}+b_{1} \bar{s}^{2}}
$$

Z porovnání vyplývá $a_{1}=2 R_{1} C \omega_{\mathrm{m}}$ resp. $R_{1}=a_{1} / 2 \omega_{\mathrm{m}} C=a_{1} / 4 \pi f_{\mathrm{m}} C$ a dále $b_{1}=R_{1} R_{2} C^{2} \omega_{\mathrm{m}}^{2}$, resp. $R_{2}=2 b_{1} / a_{1} \omega_{\mathrm{m}} C=b_{1} / \pi f_{\mathrm{m}} a_{1} C$. Je také zřejmé, že díky zápornému znaménku v rov. (7-147) bude základní fázové natočení na nízkých kmitočtech $-180^{\circ}$ a se zvyšujícím se kmitočtem se bude toto fázové natočení zvyšovat podle vztahu (7-135), tj. výsledné natočení fáze bude

$$
\varphi(\Omega)=-180^{\circ}-2 \operatorname{arctg} \frac{a_{1} \Omega}{1-b_{1} \Omega^{2}}
$$

Poznámka:

Problematika filtrů je záměrně omezena na základní uspořádání pasivních RC a RLC filtrů a na zapojení aktivních filttrů RC s operačními zesilovači. Použité aproximace jsou taktéž omezeny na tři základní aproximace a to dle Bessela, Butterwortka a Čebyševa. V běžné praxi se v drtivé většině aplikací vystačí s těmito poznatky. Další podrobnosti lze dohledat v publikacích [1] až [38]. 


\section{Použitá literatura}

[1] TIETZE, U.; SCHENK Ch.; GAMM, E. Electronic circuits: handbook for design and application. 2nd ed. New York: Springer-Verlag Berlin Heidelberg, 2008. ISBN 978-3540-00429-5.

[2] TIETZE, U.; SCHENK, Ch. Electronic circuits: design and applications. Berlin: Springer-Verlag, 1991. ISBN 354050608x.

[3] TIETZE, U.; SCHENK, Ch. Halbleiter-Schaltungstechnik. 5. Aufl. Berlin: Springer, 1980. ISBN 3540098488.

[4] TIETZE, U.; SCHENK, Ch. Halbleiter-Schaltungstechnik. 2., neu bearb. und wesentlich erw. Aufl. New York: Springer-Verlag, 1971. ISBN 3540052852.

[5] HUELSMAN, L. P. Active and passive analog filter design: an introduction. New York: McGraw-Hill, c1993. ISBN 0070308608.

[6] Kendall, L. Analog filters. Boston: Kluwer Academic Publishers, 1996. ISBN 0412638401.

[7] KULARATNA, N. Electronic circuit design: from concept to implementation. Boca Raton, FL: CRC Press, c2008. ISBN 9780849376177.

[8] HÁJEK, K.; SEDLÁČEK, J. Kmitočtové filtry. Praha: BEN - technická literatura, 2002. ISBN 8073000237.

[9] GRAEME, J. G. Designing with operational amplifiers: applications alternatives. New York: McGraw-Hill, c1977. ISBN 007023891x.

[10] GRAEME, J. G. Applications of operational amplifiers: third-generation techniques. New York: McGraw-Hill, [1973]. ISBN 0070238901.

[11] GRAEME, J. G.; TOBEY, G. E.; HUELSMAN, L. P. Operational amplifiers: Design and Applications. New York: McGraw-Hill,1971. ISBN 070649170.

[12] HUIJSING, J. H. Operational amplifiers: theory and design. Boston, MA: Kluwer Academic Publishers, c2001. ISBN 0792372840.

[13] STOUT, D.; KAUFAMN, M. Handbook of amplifier circuit design. New York: McGraw-Hill Book Company, 1976. ISBN 007061797x.

[14] CLAYTON, G. B. Operational amplifiers. London: Butterworths, 1971. ISBN 0408702028.

[15] DOSTÁL, J. Operational amplifiers. New York: distribution for the USA, Elsevier/North-Holland, 1981. ISBN 0444417133.

[16] DOSTÁL, J. Operační zesilovače. Praha: BEN - technická literatura, 2005. ISBN 8073000490.

[17] DOSTÁL, J. Analogové a hybridní počítače. Praha: SNTL - Nakladatelství technické literatury, 1971.

[18] DOSTÁL, J. Operační zesilovače. Praha: SNTL - Nakladatelství technické literatury, 1981.

[19] VEDRAL, J.; FISCHER, J. Elektronické obvody pro měřicí techniku. Praha: Vydavatelství ČVUT, 1999. ISBN 8001019500.

[20] NEUMANN, P.; UHLÍŘ, J. Elektronické obvody a funkční bloky 1. Praha: Vydavatelství ČVUT, 1999. ISBN 8001019810.

[21] NEUMANN, P.; UHLÍŘ, J. Elektronické obvody a funkční bloky 2. Praha: Vydavatelství ČVUT, 2001. ISBN 800102394x. 
[22] VRBA, K. Analogová technika. Brno: Vysoké učení technické v Brně, 2012. s. 1202. ISBN: 978-80-214-4458-4.

[23] VRBA, K. Analogová technika - numerická cvičení. Brno: Vysoké učení technické v Brně, 2013. s. 1-82. ISBN: 978-80-214-4727-1.

[24] DOSTÁL, T.; FILKA, M.; SKLENÁŘ, J.; VRBA, K.; VRBA, R. Diplomní semináře telekomunikace. Brno: Vysoké učení technické, 1989.

[25] PUNČOCHÁŘ, J. Operační zesilovače v elektronice. 2. vyd. Praha: BEN - technická literatura, 1996. ISBN 8090198430.

[26] JOHNS, D.; KENNETH, W. M. Analog integrated circuit design. New York: John Wiley, c1997. ISBN 0471144487.

[27] CHEN, W. K. The circuits and filters handbook. 2nd ed. Boca Raton, FL: CRC Press, c2003. ISBN 0849309123.

[28] FRANCO, S. Design with operational amplifiers and analog integrated circuits. 3rd ed. New York: McGraw-Hill, c2002. ISBN 0072320842.

[29] HERPY, M.; BERKA, J.C. Aktive RC-Filter: Ein Lehrbuch, aktive Filterschaltungen zu entwerfen. München: Franzis, 1984. ISBN 377237011x.

[30] RAUT, R.; SWAMI, M. N. Modern analog filter analysis and design: a practical approach. Weinheim: Wiley-VCH, 2010. ISBN 9783527407668.

[31] TOBOLA, P.; VRBA, K. Nekaskádní syntéza aktivní dolní propusti. Slaboproudý obzor, 50, 1989.

[32] TOBOLA, P.; VRBA, K. Návrh aktivní dolní propusti pro měřicí účely. Sdělovací technika, 37, 1989.

[33] VRBA, K. Vstupní obvody číslicových spektrálních analyzátorů a měřičů činitele přenosu. Brno: VUT, 1991. Knižnice odborných a vědeckých spisů Vysokého učení technického v Brně. ISBN 8021404922.

[34] VRBA, K.; VRBA, R. Antialiasing Lowpass Filter with a Transimpedance Opamp for ECG Signal Processing. In Biosignal 1994. Brno: 1994. p. 150 ( p.)

[35] VRBA, K.; VRBA, R. Low-Noise Bandpass Filter for ECG Analyzer. In International conference Biosignal. Brno: 1992. p. 89 ( p.)

[36] VRBA K., VRBA R. Syntetic circuit elements of higher order in a low-noise highpass filter design. In SYS 1994. Lyon: 1994. p. 303 ( p.)

[37] VRBA, K.; VRBA, R. DC precision LP filter employing transimpedance operational amplifier. In SYS 1995. Brno: 1995. p. 64 ( p.)

[38] HERPY, M. Analoge integrierte Schaltungen: (ein Lehrbuch Schaltungen mit Operationsverstärken und analogen Multiplizierern zu entwerfen). 2. Aufl. Budapest: Akadémiai Kiadó, 1979. ISBN 9630518317. 


\section{Nelineární obvody}

V technické praxi se užívá řada analogových obvodů, které se vyznačují nelineární závislostí mezi vstupním a výstupním signálem. V nejjednodušších případech jde o pasivní nelineární obvody, které se používají pro omezení či limitaci vstupního nebo výstupního signálu analogových obvodů, ale i obecně pro tvarování signálu.

Zařazení nelineárních prvků do zpětné vazby operačního zesilovače poskytuje další možnosti zpracování analogových signálů. Umožňuje totiž modelovat téměř libovolné funkční vztahy mezi výstupním a vstupním signálem. Často jsou však vyžadovány určité matematické operace, např. $y=x^{n}, y=\sin x, y=\ln x, y=\mathrm{e}^{x}$. Zvlášt' poslední dvě matematické operace mají velký význam, protože pomocí logaritmického a exponenciálního převodu můžeme snadno provádět analogové operace jako násobení, dělení, umocňování nebo odmocňování.

Aby měl zesilovač s nelineární zpětnou vazbou požadovanou závislost mezi vstupním a výstupním napětím, musí být ve zpětnovazební síti použity nelineární prvky, jejichž ampérvoltová př́ípadně voltampérová prrevodní charakteristika odpovídá s požadovanou přesností charakteristice definované na základě teoretického řešení problému. V mnoha př́ípadech vyhoví těmto potřebám ,pprírodní“ nelineární charakteristiky elektronických prvků. Pro naše účely se omezíme na neřízené nelineární rezistory charakterizovatelné algebraickým vztahem mezi napětím $u$ a proudem $i$, tedy bud' ampérvoltovou charakteristikou $i=\mathrm{f}(u)$ nebo voltampérovou charakteristikou $u=\mathrm{g}(i)$. V obecném prŕpadě jsou tyto charakteristiky nelineární a umožňují ve spojení s operačním zesilovačem snadnou realizaci např̀. logaritmických a exponenciálních funkčních měničů.

Samostatnou kategorii nelineárních obvodů pak představují obvody označované jako „operační usměrňovač“ či „,zesilovač absolutní hodnoty“ nebo také jako ,ideální dioda“. Tyto obvody jsou obvykle v publikacích klasifikovány jako obvody s nelineární zpětnou vazbou. Ve skutečnosti patří fyzikální podstatou své činnosti do samostatné tř́ídy obvodů s lineární zpětnou vazbou, avšak s nelineárním rozdělováním výstupního signálu operačního zesilovače podle polarity tohoto signálu. Toto řešení umožňuje konstrukci velmi přesných jednocestných a dvoucestných usměrňovačů nebo špičkových usměrňovačů určených pro vyhodnocení maxima či minima signálu a jeho zapamatování.

\subsection{Základní poznatky}

Jakýkoliv signál se při průchodu nelineárním přenosovým článkem deformuje. Jako tvarovače označujeme ty nelineární obvody, které předepsaným způsobem deformují, či přesněji řečeno tvarují analogový signál. Převážnou většinu tvarovačů tvoří obvody sestavené pouze $\mathrm{z}$ rezistorů, diod či referenčních diod a zdrojů ss napětí anebo proudu. Jednu typickou třídu jednoduchých tvarovačů signálu tvoří obvody, které omezí resp. okrojí signál na určité úrovni. Takové obvody označujeme jako omezovače či někdy okrajovače signálu.

Horní omezovač, má převodní charakteristiku $u_{2}\left(u_{1}\right)$ ve tvaru lomené přímky podle Obr. 8.1a), omezí horní část signálu $u_{1}(t)$, tj. nahradí všechna napětí $u_{1}(t)>U_{\mathrm{H}}$ napětím $U_{\mathrm{H}}$. Opačně pracuje dolni omezovač, s charakteristikou $u_{2}\left(u_{1}\right)$ uvedenou na Obr. $8.1 \mathrm{~b}$ ). Ten omezí ze signálu $u_{1}(t)$ jeho dolní část s úrovní okrojení $U_{\mathrm{D}}$. Nejčastěji se používá oboustranný 
omezovač, který má dvakrát lomenou charakteristiku $u_{2}\left(u_{1}\right)$ podle Obr. 8.1c) s horní úrovní omezení $U_{\mathrm{H}}$ a dolní úrovní omezení $U_{\mathrm{D}}$.
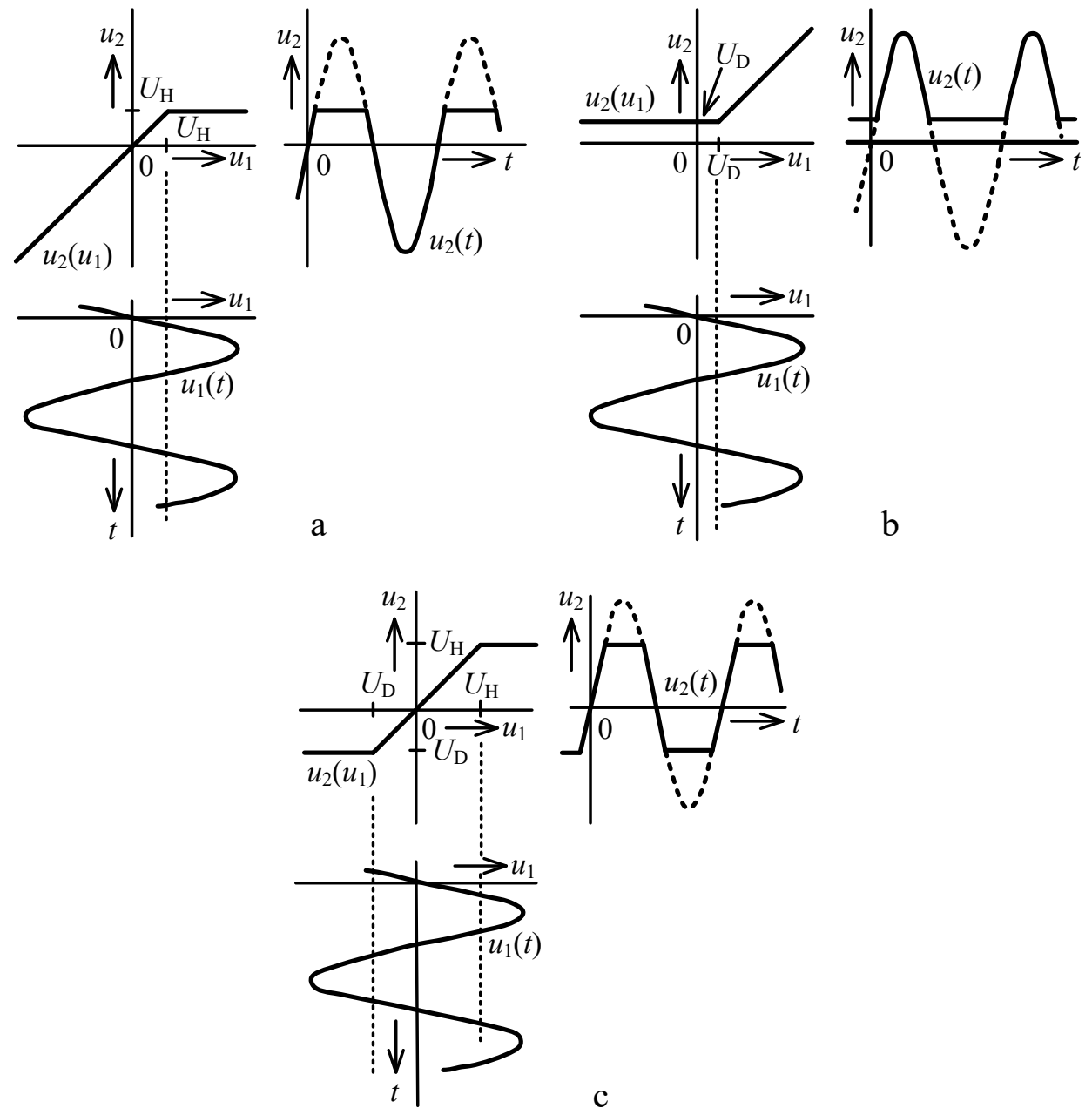

Obr. 8.1: Převodní charakteristiky a tvarování signálu v omezovačích (okrajovačích):

a) horní, b) dolní, c) oboustranný

b)

Aproximace funkcí. V řadě př́padů jednoduché obvody $\mathrm{k}$ vyřešení nelineární úlohy nestačí a musíme sáhnout ke kombinacím takových prvků. Požadovaná funkční závislost se nahrazuje jednodušší funkcí, která se v uvažovaném intervalu liší od funkce původní o povolenou chybu a při tom se snadno modeluje dostupnými technickými prostředky. Takový způsob náhrady dané funkční závislosti jednodušší funkcí se nazývá aproximace funkce. $\mathrm{V}$ analogových funkčních měničích aproximujeme požadovanou funkci nejčastěji lomenou čarou, složenou z konečného počtu prímkových, tj. lineárních úseků. Počet úseků určuje přesnost aproximace, ale i složitost funkčního měniče.

Z hlediska aproximace i z hlediska technické realizace je důležité rozlišovat funkci konvexní (vypuklou), konkávní (vydutou) a funkci s inflexním bodem (s bodem zvratu). Jednotlivé druhy křivek jsou pro názornost zobrazeny na Obr. 8.2. Typ funkční závislosti určuje druhá derivace funkce $\mathrm{f}^{\prime}$ “ $(x)$. Funkce, které nemají v uvažovaném oboru inflexní bod, jsou označovány jako monotónní. 

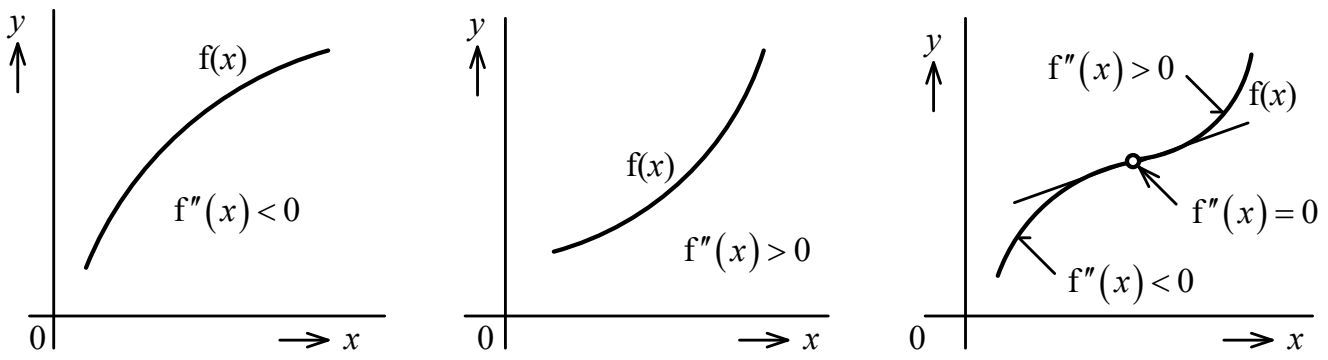

Obr. 8.2: Typy funkcí: a) funkce konkávní (vydutá), b) funkce konvexní (vypuklá), c) funkce s inflexním bodem

Při úsekové lineární aproximaci se nahrazuje spojitá funkce $y=\mathrm{f}(x)$, lomenou čarou $y=\varphi(x)$, složenou z přímkových úseků se strmostí $S_{k}=\operatorname{tg} \alpha_{\mathrm{k}}$, které mohou být bud' tečnou, tětivou nebo sečnou křivky, zobrazující danou funkční závislost $y=\mathrm{f}(x)$. Při aproximaci pomocí tečen a sečen (viz Obr. 8.3a,c) leží body lomu lomené čáry mimo křivku funkce $\mathrm{f}(x)$, při aproximaci pomocí tětiv (viz Obr. 8.3b) leží body lomu na křivce funkce $\mathrm{f}(x)$. Chyba aproximace $\mathrm{v}$ kterémkoliv bodě je definována jako rozdíl mezi hodnotou aproximační funkce $\varphi(x)$ a zadané funkce $\mathrm{f}(x), \mathrm{tj} . \delta(x)=\varphi(x)-\mathrm{f}(x)$. Při aproximaci pomocí tečen a tětiv tak, jak je to naznačeno na Obr. 8.3a,b, má chyba aproximace mezi dvěma inflexními body stále stejný smysl. Z obrázku je zřejmé, že při aproximaci vyduté křivky čarou po úsecích lineární je chyba aproximace vždy kladná, při aproximaci vypuklé křivky pak záporná. Její maximální velikost v k-tém úseku popř. v k-tém bodě lomu je $\delta_{k}$. Při aproximaci požadované funkční závislosti obvykle předepisujeme, že chyba aproximace nesmí přestoupit určitou hodnotu $\varepsilon$ (obvykle stanovenou $\mathrm{v}$ poměru k některé význačné hodnotě aproximované funkce, např. její maximální hodnotě). $Z$ toho pak vyplývá podmínka, že musí být splněno $\left|\delta_{k}\right| \leq \varepsilon$ pro každé $k$. Abychom tuto podmínku mohli splnit, musíme složit aproximační funkci z dostatečně velkého počtu $k$ lineárních úseků. Obecně platí (je to zřejmé již z pouhého názoru), že chyba $\varepsilon$ je tím menší, čím větší je počet úseků $k$. Abychom mohli dosáhnout při aproximace co nejmenší chyby $\varepsilon$, snažíme se účelným rozložením bodů lomu aproximační funkce dosáhnout toho, aby maximální chyba aproximace $\left|\delta_{k}\right|$ byla ve všech úsecích pokud možno stejně velká. 

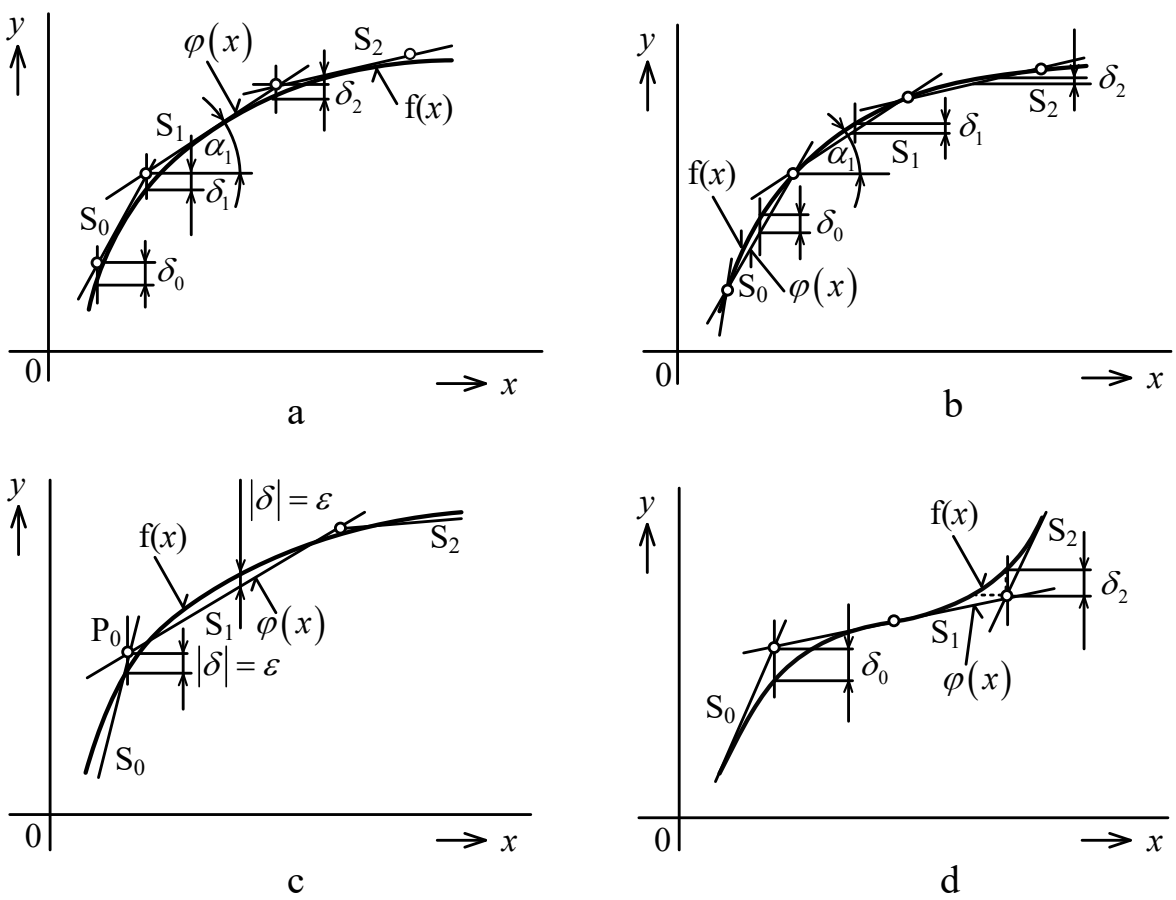

Obr. 8.3: Lineární aproximace funkce: a) pomocí tečen, b) pomocí tětiv, c) pomocí sečen se souměrně rozloženou chybou, d) pomocí tečny v inflexním bodě

Teoreticky se dá dokázat, že chybu aproximace lze zmenšit na polovinu, vedeme-li aproximační úseky jako sečny křivky $\mathrm{f}(x)$ tak, aby se maximální chyba $\delta$ souměrně rozdělila do obou polarit tak, aby platilo $\delta= \pm \varepsilon$. Při aproximaci pomocí sečen se souměrně rozloženou chybou leží body lomu mimo křivku $\mathrm{f}(x)$, a to podle typu funkce bud' na ní nebo pod ní (viz Obr. 8.3c,d). Při aproximaci složitých funkcí je možné základní způsoby lineární aproximace vhodně kombinovat.

\subsection{Pasivní nelineární obvody}

\subsubsection{Pasivní horní diodové omezovače}

Paralelni horni diodový omezovač je zapojen podle Obr. 8.4a. Protože zdroj vstupního napětí, dioda $\mathrm{i}$ neznázorněná zátěž $\mathrm{R}_{\mathrm{z}}$ připojená $\mathrm{k}$ výstupním svorkám jsou paralelně, je zapojení omezovače označováno jako paralelní. Pro zjednodušení uvažujeme, že použitá dioda je ideální spínač a spíná při nulovém napětí na diodě $\left(U_{\mathrm{P}}=0\right)$. Dioda je zavřená, je-li $u_{1}<U_{\mathrm{H}}$. Za předpokladu $i_{2} \approx 0$ (obvod pracuje jako nezatížený resp. př́́padná zátěž $R_{\mathrm{Z}}>>R$ ) nevznikne $\mathrm{v}$ tom př́padě na rezistoru $\mathrm{R}$ žádný úbytek napětí, a proto $u_{2}=u_{1}$ a tedy strmost $S=\operatorname{tg} \alpha$ převodní charakteristiky $S=1$. Jestliže $u_{1}>U_{\mathrm{H}}$, dioda napájená proudem přes rezistor $\mathrm{R}$ se otevře a v př́ípadě, že uvažujeme ideální diodu, dostaneme na výstupu napětí $U_{\mathrm{H}}$. Ve skutečnosti se dioda otevře, až bude vstupní napětí $u_{1}>U_{\mathrm{H}}+U_{\mathrm{P}}$, kde $U_{\mathrm{P}}$ značí prahové napětí diody. 

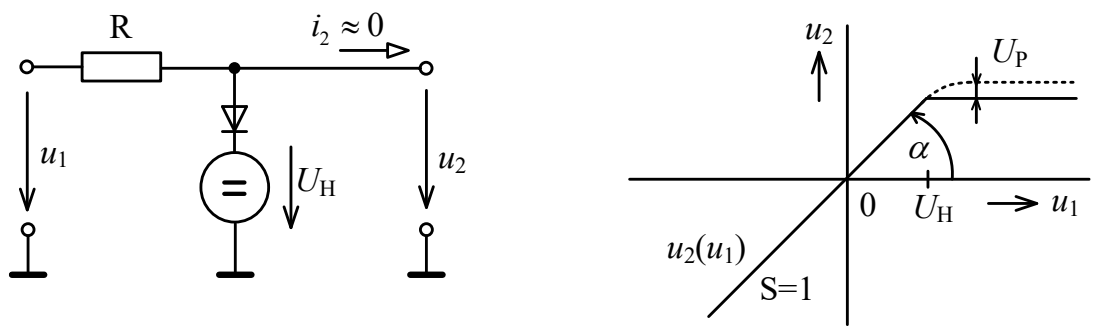

$\mathrm{a}$
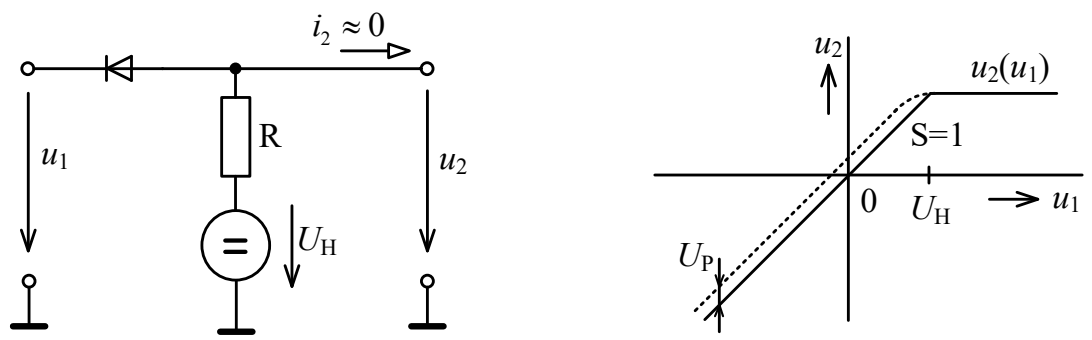

b

Obr. 8.4: Pasivní horní omezovač a jeho charakteristiky: a) paralelní, b) sériový

Skutečná charakteristika tohoto omezovače, uvedená na Obr. 8.4a čárkovaně, se bude odlišovat od ideální charakteristiky především v oblasti její vodorovné části. Při aplikacích je nutné s touto odchylkou počítat (u křemíkových diod je napětí $U_{P}$ až kolem $0,65 \mathrm{~V}$ ) a popř́padě vzít v úvahu i závislost napětí diody na teplotě.

Zapojení sériového horního diodového omezovače (zdroj vstupního napětí, dioda a zátěž jsou $\mathrm{v}$ sérii) je uvedeno na Obr. 8.4b. Je-li $u_{1}>U_{\mathrm{H}}$, bude dioda uzavřena, a protože předpokládáme $i_{2}=0$, objeví se na výstupu napětí $u_{2}=U_{\mathrm{H}}$. Jestliže $u_{1}<U_{\mathrm{H}}$, dioda se otevře a na výstupu dostaneme napětí $u_{2}=u_{1}$, resp. započteme-li prahové napětí diody $u_{2}=u_{1}+U_{\mathrm{P}}$. Charakteristika $u_{2}\left(u_{1}\right)$ má tvar podle Obr. $8.4 \mathrm{~b}$, kde plnou čarou je vyznačena charakteristika při uvažování ideální diody a čárkovanou čarou skutečný průběh.
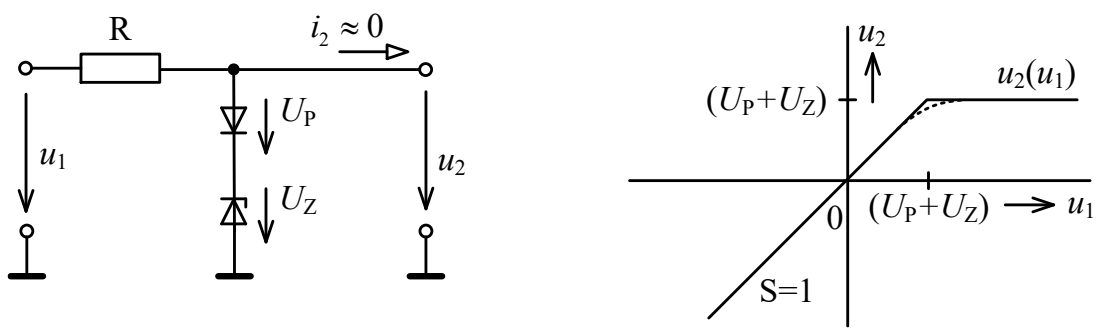

Obr. 8.5: Paralelní horní omezovač s referenční diodou

Horni omezovač lze také jednoduše realizovat s referenčni diodou. Př́klad řešení paralelního omezovače s referenční diodou je uveden na Obr. 8.5. Úroveň omezení je v tomto př́padě dána součtem prahového napětí diody $U_{\mathrm{P}}$ a napětí na referenční diodě $U_{Z}$. Rozptyl napětí $U_{z}$ je však značný a proto úroveň omezení není tak přesná jako v předchozích dvou př́padech.

\subsubsection{Pasivní dolní diodové omezovače}

Pouhou záměnou polarity diod u zapojení na Obr. 8.4 dostaneme dvě varianty dolního diodového omezovače, jejichž schémata a převodní charakteristiky jsou uvedena na Obr. 8.6. 

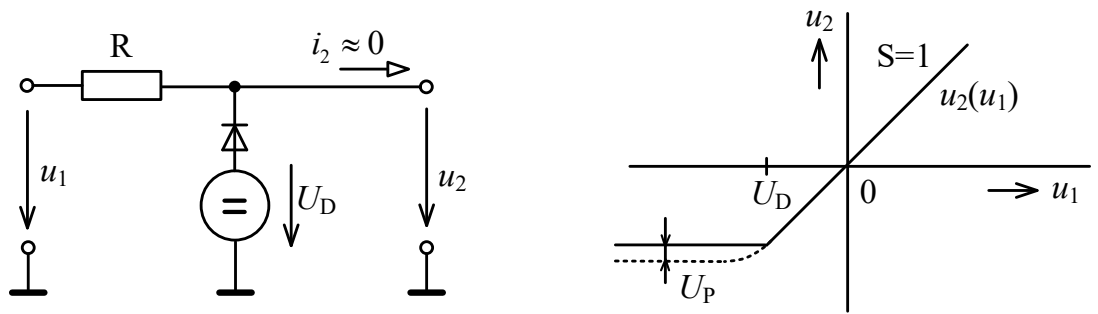

a
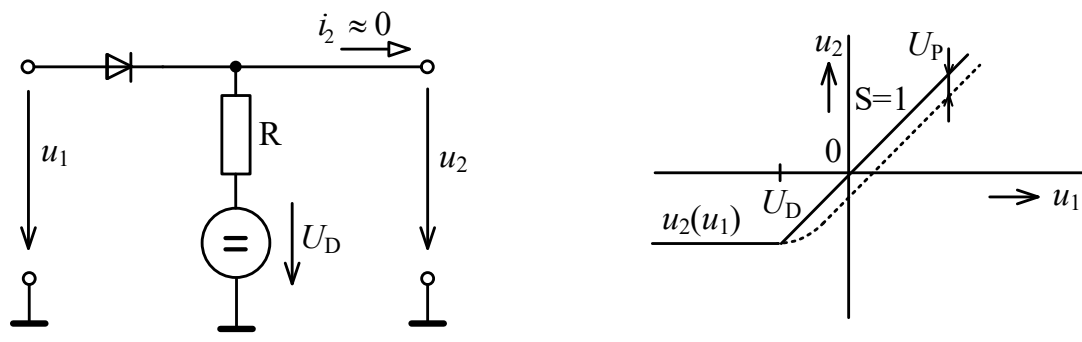

b

Obr. 8.6: Pasivní dolní diodový omezovač a jeho charakteristiky: a) paralelní, b) sériový

Činnost obvodů je odolná a proto ji blíže nerozebíráme. Podobně přepólováním polarity diody a i polarity referenční diody na Obr. 8.6 dostaneme jednoduchý dolní omezovač $\mathrm{s}$ referenční diodou. Schéma a př́slušná převodní charakteristika jsou uvedeny na Obr. 8.7.
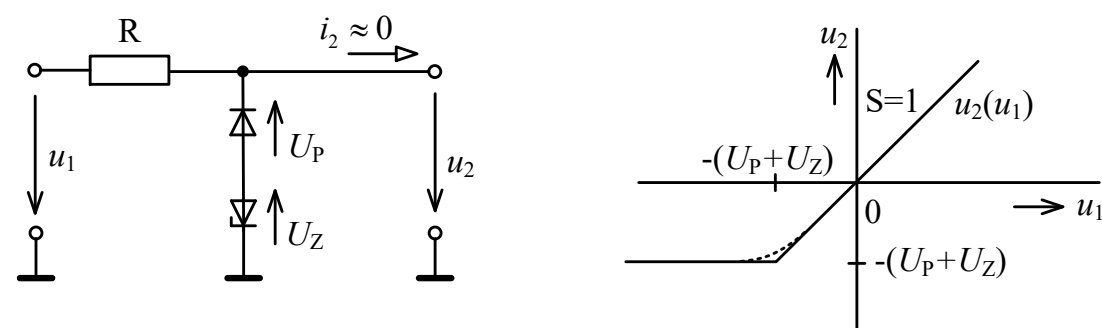

Obr. 8.7: Paralelní dolní omezovač s referenční diodou

\subsubsection{Pasivní oboustranné diodové omezovače}

Spojíme-li paralelně horní a dolní omezovač podle Obr. 8.4a a Obr. 8.6a a nahradíme-li paralelní kombinaci rezistorů jediným rezistorem dostaneme oboustranný diodový omezovač, uspořádaný podle Obr. 8.8a. Má-li obvod správně pracovat, musí být $U_{\mathrm{H}}>U_{\mathrm{D}}$. Při návrhu musíme respektovat úbytky napětí na diodách $\mathrm{D}_{1}$ a $\mathrm{D}_{2}$ tak, jak je to čárkovaně naznačeno v převodní charakteristice na Obr. 8.8a. 

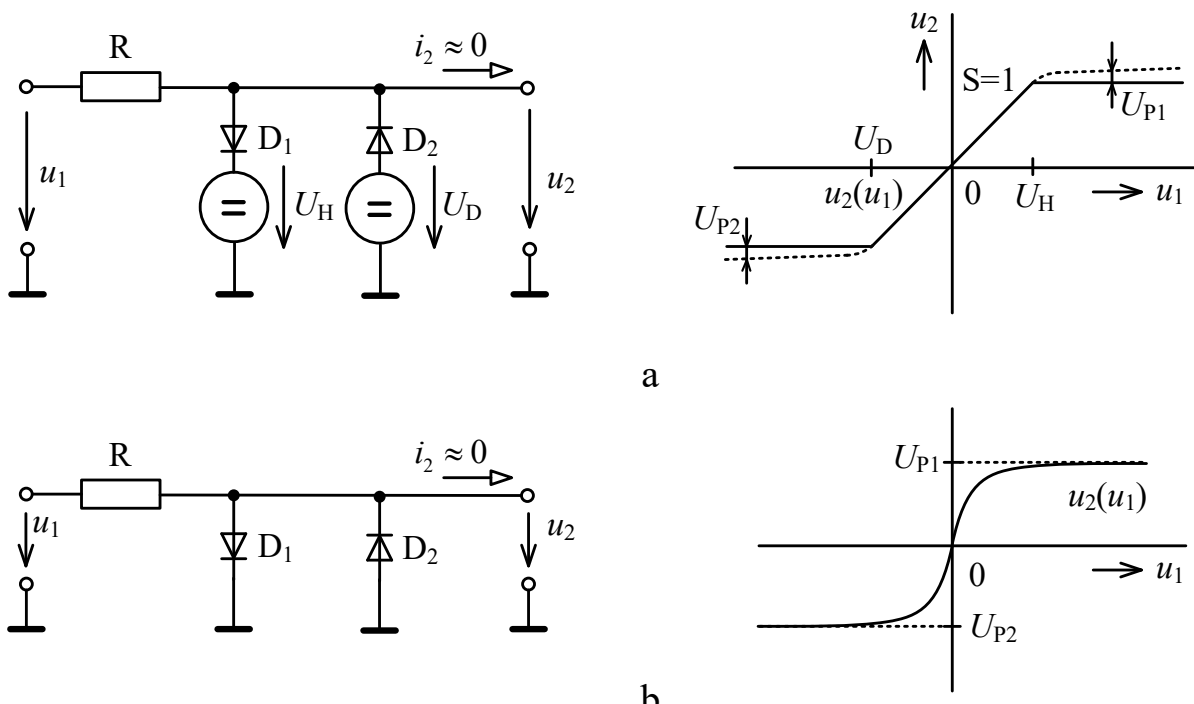

b

Obr. 8.8: Pasivní oboustranný diodový omezovač (a) a jeho nejjednodušší aplikace (b)

S tímto uspořádáním oboustranného omezovače se můžeme setkat v úplně nejjednodušší aplikaci např. pro omezení povoleného diferenčního vstupního napětí operačního zesilovače (viz Obr. 8.8b). Omezení napětí je v tomto př́ípadě přibližně na $\pm 0,6 \mathrm{~V}$.

Pro omezení výstupního napětí se často užívají oboustranné omezovače s referenčními diodami. Obvody na Obr. 8.9a,b v podstatě představují kombinaci jednostranných omezovačů z Obr. 8.5 a Obr. 8.7. Pro úplnost jen poznamenejme, že v př́padě zapojení omezovače na Obr. 8.9a je při horním omezení dioda $D_{1}$ otevřena v propustném směru a dioda $D_{2} v$ závěrném směru. Při dolním omezení je tomu opačně.
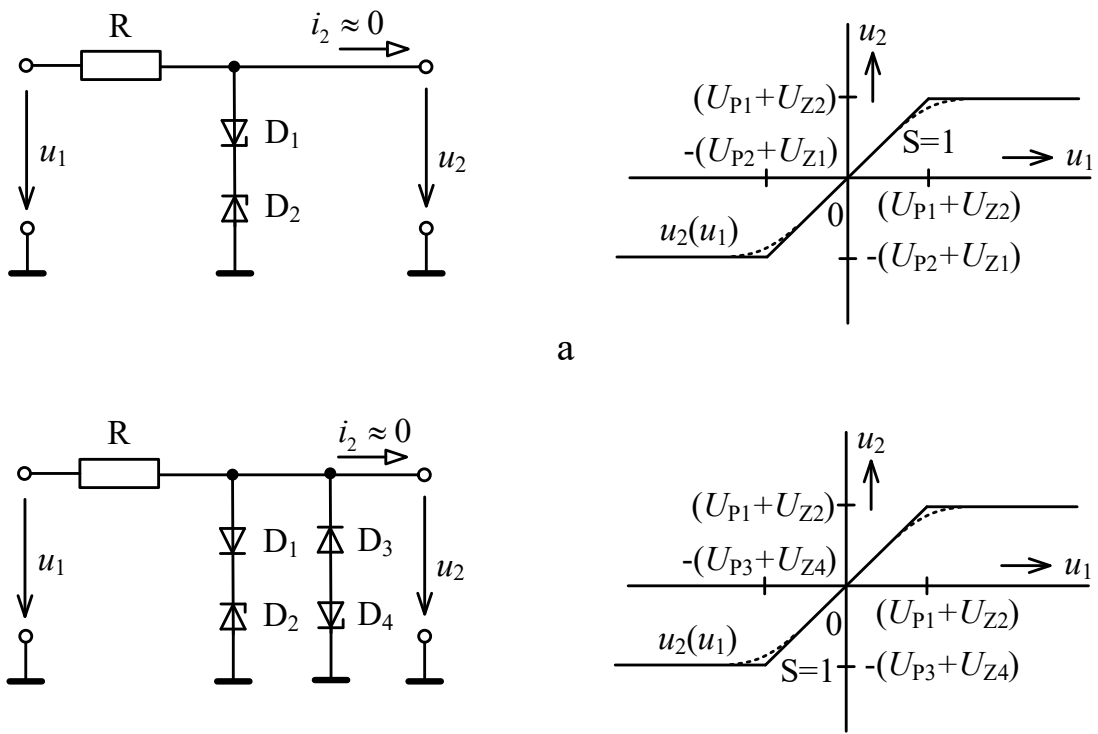

b

Obr. 8.9: Oboustranné omezovače s referenčními diodami 


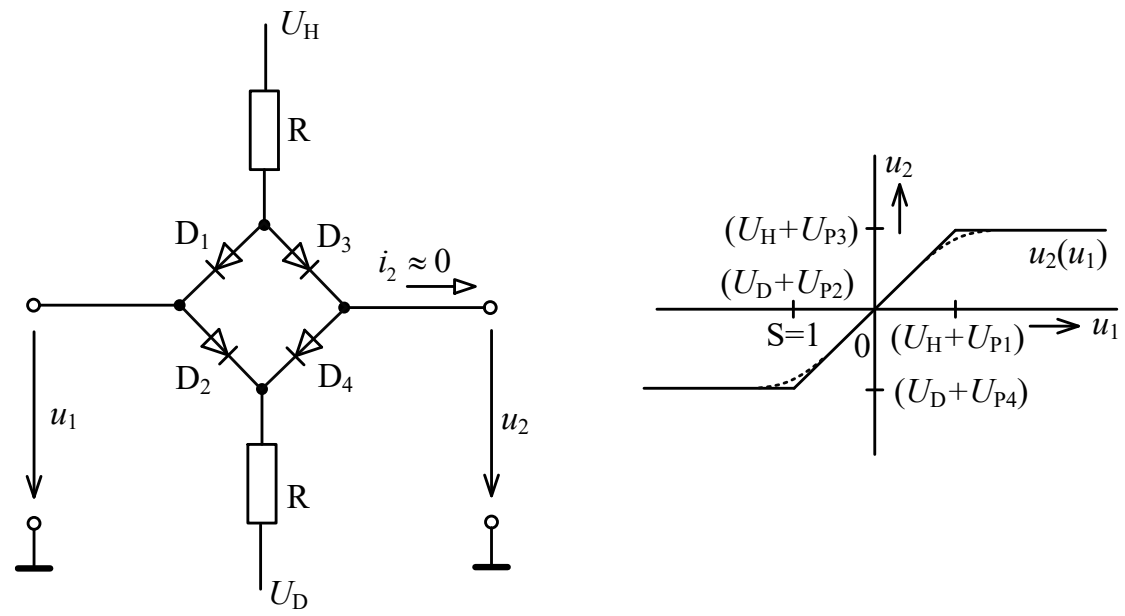

Obr. 8.10: Oboustranný diodový můstkový zesilovač

Výhodou zapojení můstkového oboustranného diodového omezovače na Obr. 8.10 je skutečnost, že teplotní závislosti diod se velmi dobře navzájem kompenzují. V oblasti, kdy nedochází k omezení vstupního signálu jsou totiž všechny čtyři diody otevřeny proudem, který protéká z napětí $U_{\mathrm{H}} \mathrm{k}$ napětí $U_{\mathrm{D}}<U_{\mathrm{H}}$. Teplotní změny napětí na diodách $\mathrm{D}_{1}$ a $\mathrm{D}_{3}$, resp. $\mathrm{D}_{2} \mathrm{a}$ $\mathrm{D}_{4}$ jsou proto $\mathrm{v}$ této oblasti vzájemně vykompenzovány. Jestliže napětí $u_{1}$ bude vyšší než napětí $\left(U_{\mathrm{H}}+U_{\mathrm{P} 1}\right)$, dioda $\mathrm{D}_{1}$ se uzavře. Diody $\mathrm{D}_{3}$ a $\mathrm{D}_{4}$ jsou však stále otevřeny a na výstupu bude napětí $\left(U_{\mathrm{H}}+U_{\mathrm{P} 3}\right)$. Obdobně je tomu pro vstupní napětí menší než je napětí $\left(U_{\mathrm{D}}+U_{\mathrm{P} 2}\right)$, kdy se zavře dioda $\mathrm{D}_{2}$ a na výstupu bude napětí $\left(U_{\mathrm{D}}+U_{\mathrm{P} 4}\right)$.

\subsubsection{Pasivní diodové funkční měniče}

Pro složitější tvarování signálu se použivají nelineární obvody složené z rezistorů, diod a zdrojů stejnosměrného napětí. Jako př́iklad si uvedeme tvarování trojúhelníkových kmitů na harmonický signál. Základní uspořádání pasivního diodového měniče je uvedeno na Obr. 8.11. Obvod pracuje na principu aproximace po úsecích lineární. V podstatě jde o rezistorový dělič,

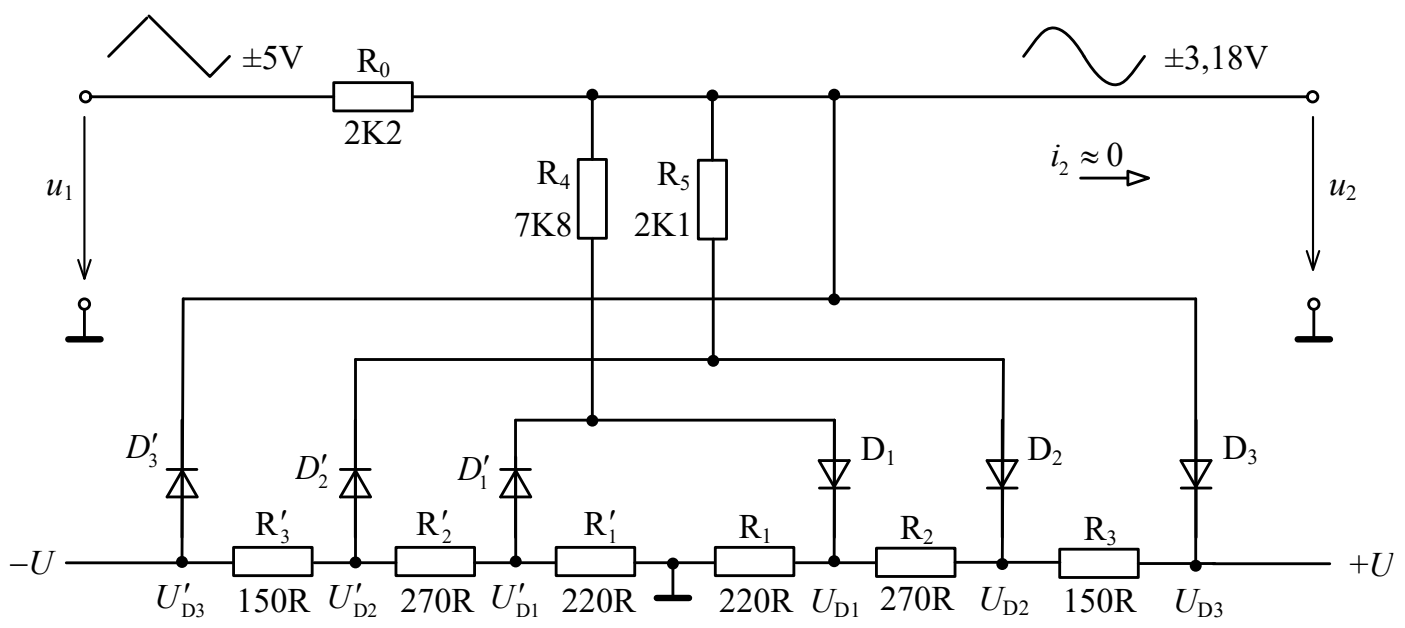

Obr. 8.11: Základní uspořádání pasivního diodového funkčního měniče 
jehož dělicí poměr se zmenšuje $z$ hodnoty jedna až na nulu. Rezistorový dělič $\mathrm{R}_{1}, \mathrm{R}_{2}, \mathrm{R}_{3}$ resp. $\mathrm{R}_{1}^{\prime}, \mathrm{R}_{2}^{\prime}, \mathrm{R}_{3}^{\prime}$ vytváří předpětí pro diody $\mathrm{D}_{1}, \mathrm{D}_{2}, \mathrm{D}_{3}$ resp. $\mathrm{D}_{1}^{\prime}, \mathrm{D}_{2}^{\prime}, \mathrm{D}_{3}^{\prime}$ a určuje body lomu převodní charakteristiky. $\mathrm{V}$ dalším budeme předpokládat, že prahové napětí $U_{\mathrm{P}}$ všech diod jsou shodné. Pro malá vstupní napětí $u_{1} \geq 0$ jsou všechny diody $\mathrm{D}_{1}, \mathrm{D}_{2}, \mathrm{D}_{3}$ zavřeny a $u_{2} \approx u_{1}$. Při vyšším vstupním napětí se sepne dioda $\mathrm{D}_{1}$ a v cestě signálu je zařazen dělič $R_{0}, R_{4}$ a proto $u_{2} \approx$ $u_{1} R_{4} /\left(R_{0}+R_{4}\right)$. Následně se sepne dioda $\mathrm{D}_{2} \mathrm{a} u_{2} \approx R_{4} \| R_{5} /\left(R_{0}+R_{4} \| R_{5}\right)$. Naposled sepne $\mathrm{D}_{3}$ a $u_{2}$ se omezí na hodnotu $U_{\mathrm{D} 3}+U_{\mathrm{P}}=U+U_{\mathrm{P}}$.

Měnič trojúhelníkových kmitů na harmonické kmity realizuje vztah

$$
u_{2}=U_{2} \sin \alpha=U_{2} \sin \left(\frac{u_{1}}{U_{1}} \frac{\pi}{2}\right)
$$

v rozmezí změn vstupního napětí $-U_{1} \leq u_{1} \leq U_{1}$, kde $U_{1}$ značí maximální hodnotu trojúhelníkových kmitů. Protože malé hodnoty argumentu sinové funkce platí $\sin \alpha \approx \alpha$, můžeme pro malé hodnoty vstupního napětí měniče psát

$$
u_{2} \approx U_{2} \frac{u_{1}}{U_{1}} \frac{\pi}{2} .
$$

Z tohoto důvodu je vhodné zvolit amplitudu požadovaných harmonických kmitů $U_{2}$ tak, aby v okolí nuly platilo $u_{2}=u_{1}$ a proto

$$
U_{2}=\frac{2}{\pi} U_{1}
$$

Při návrhu budeme předpokládat, že obvod pracuje jako nezatížený $\left(i_{2} \approx 0\right)$, resp. zátěž bude oddělena od vlastního měniče neinvertujícím zesilovačem s OZ, který vykazuje vysoký vstupní odpor. Odpor zátěže pak není nutno při návrhu uvažovat. Dále budeme předpokládat, že všechny diody jsou shodné a otevírají se při prahovém napětí $U_{\mathrm{P}}$. Aby se návrh zjednodušil, budeme uvažovat, že rezistorové děliče $\mathrm{R}_{1}$ až $\mathrm{R}_{3}$, resp. $\mathrm{R}_{1}^{\prime}$ a $\mathrm{R}_{3}^{\prime}$ představují „tvrdé“ zdroje napětí, tzn., že jejich výstupní odpor je zanedbatelný vzhledem k odporu rezistorů $\mathrm{R}_{4}$ a $\mathrm{R}_{5}$.

Při malých hodnotách vstupního napětí jsou diody $\mathrm{D}_{1}$ až $\mathrm{D}_{3}$ i diody $\mathrm{D}_{1}^{\prime}$ až $\mathrm{D}_{3}^{\prime}$ zavřeny a výstupní napětí je v tomto př́padě rovno vstupnímu $u_{2} \approx u_{1}$. Strmost převodní charakteristiky tedy bude

$$
S_{0} \approx 1 .
$$

Jakmile vstupní napětí dosáhne napětí $U_{11}=U_{\mathrm{D} 1}+U_{\mathrm{P}}$ otevře se dioda $\mathrm{D}_{1}$. Nyní bude výstupní napětí $u_{2}$ narůstat pomaleji, protože rezistory $\mathrm{R}_{0}$ a $\mathrm{R}_{4}$ tvoří dělič napětí a strmost tohoto nárůstu bude dána jeho dělicím poměrem

$$
S_{1} \approx \frac{R_{4}}{R_{0}+R_{4}} .
$$

Když vstupní napětí bude větší než napětí $U_{12}=U_{\mathrm{D} 2}+U_{\mathrm{P}}$ připojí se k děliči další rezistor $\mathrm{R}_{5} \mathrm{a}$ strmost bude ještě menší 


$$
S_{2} \approx \frac{R_{4} \| R_{5}}{R_{0}+R_{4} \| R_{5}} .
$$

Konečně dioda $\mathrm{D}_{3}$ slouží $\mathrm{k}$ aproximaci sinusové funkce $\mathrm{v}$ maximu. Když vstupní napětí dosáhne hodnoty $U_{13}=U_{\mathrm{D} 3}+U_{\mathrm{P}}$ otevře se i tato dioda a strmost převodní charakteristiky bude

$$
S_{3} \approx 0 \text {. }
$$

Na výstupu měniče bude přitom napětí

$$
U_{2}=U_{\mathrm{D} 3}+U_{\mathrm{P}}=U+U_{\mathrm{P}} .
$$
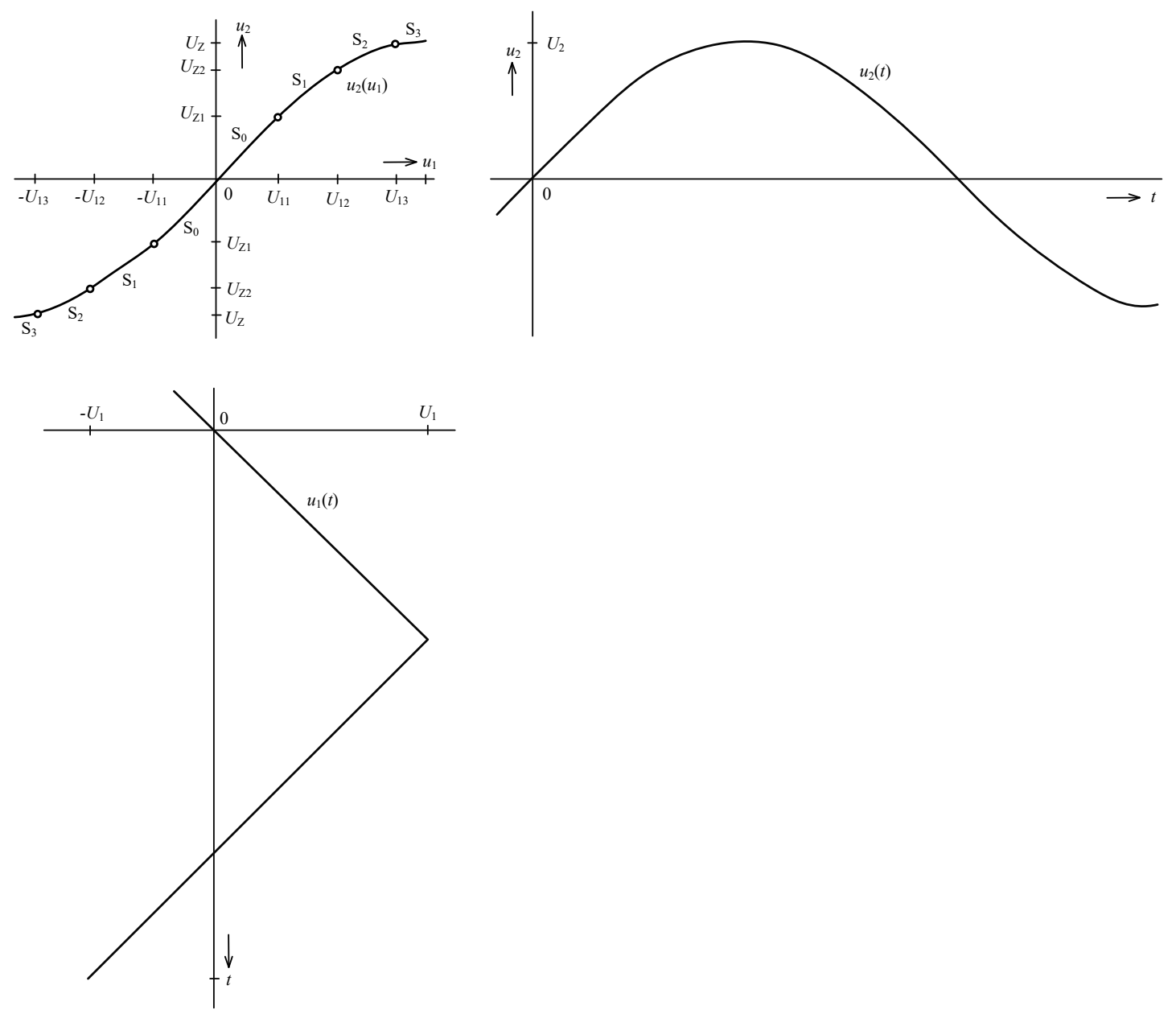

Obr. 8.12: Převodní charakteristika diodového měniče $\mathrm{z}$ obr. 8.13 a časové průběhy vstupního a výstupního signálu

Další diody $\mathrm{D}_{1}^{\prime}$ až $\mathrm{D}_{3}^{\prime}$ a rezistory $\mathrm{R}_{1}^{\prime}$ až $\mathrm{R}_{3}^{\prime}$ jsou určeny pro analogickou aproximaci charakteristiky v oblasti záporných vstupních napětí. Výsledná převodní charakteristika $u_{2}\left(u_{1}\right)$ společně s časovými průběhy vstupního a výstupního napětí tvarovače je uvedena na Obr. 8.12.

Pro vlastní návrh obvodu je zapotřebí zadat body lomu aproximující lomené čáry. Bylo by možné použít některou z aproximačních metod naznačených na Obr. 8.3. Protože nás však obvykle zajímá koeficient harmonického zkreslení výstupního signálu, použijeme poněkud jiný postup návrhu. Je možno dokázat [3], že ve spektru výstupního signálu bude chybět prvních $n$ lichých vyšších hramonických složek, jestliže $k$-tý lom výsledného harmonického signálu při 
celkovém počtu $N=2 n$ bodů lomu převodní charakteristiky (v našem př́padě $N=6$ ) nastane při úhlu $\alpha_{k}= \pm k \pi /(2 n+1)$. Podle rov.(8-1) je $\alpha_{k}=\pi U_{1 k} / 2 U_{1}$ a tedy body lomu musí nastat při vstupním napětí

$$
U_{1 k}= \pm \frac{2 k}{2 n+1} U_{1}, \quad 0<k \leq n .
$$

V důsledku symetrie aproximující funkce budou ve spektru výstupního signálu chybět také všechny sudé harmonické složky. Teoreticky lze odvodit, že činitel harmonického zkreslení nepřevyšuje $1,8 \%$ pro $N=6$ bodů lomu a $0,8 \%$ pro $N=12$. Ve skutečnosti bude výsledná převodní charakteristika funkčního měniče vyhlazena skutečným průběhem ampérvoltových charakteristik diod a skutečné zkreslení bude (při správném seřízení obvodu) ještě menší. Pro $N=6$ bodů lomu lze dosáhnout činitel harmonického zkreslení menší než $1 \%$ a pro $N=12$ bodů menší než $0,3 \%$.

Výstupní napětí odpovídající bodům lomu určíme dosazením rov.(8-9) do rov.(8-2) a s přihlédnutím ke vztahu (8-3) dostaneme

$$
U_{2 k}= \pm \frac{2 U_{1}}{\pi} \sin \left(\frac{k \pi}{2 n+1}\right), \quad 0<k \leq n .
$$

Strmost jednotlivých úseků lomené čáry bude obecně

$$
S_{k}=\frac{U_{2 k}-U_{2(k-1)}}{U_{1 k}-U_{1(k-1)}}=\frac{2 n+1}{\pi}\left(\sin \frac{k \pi}{2 n+1}-\sin \frac{(k-1) \pi}{2 n+1}\right) .
$$

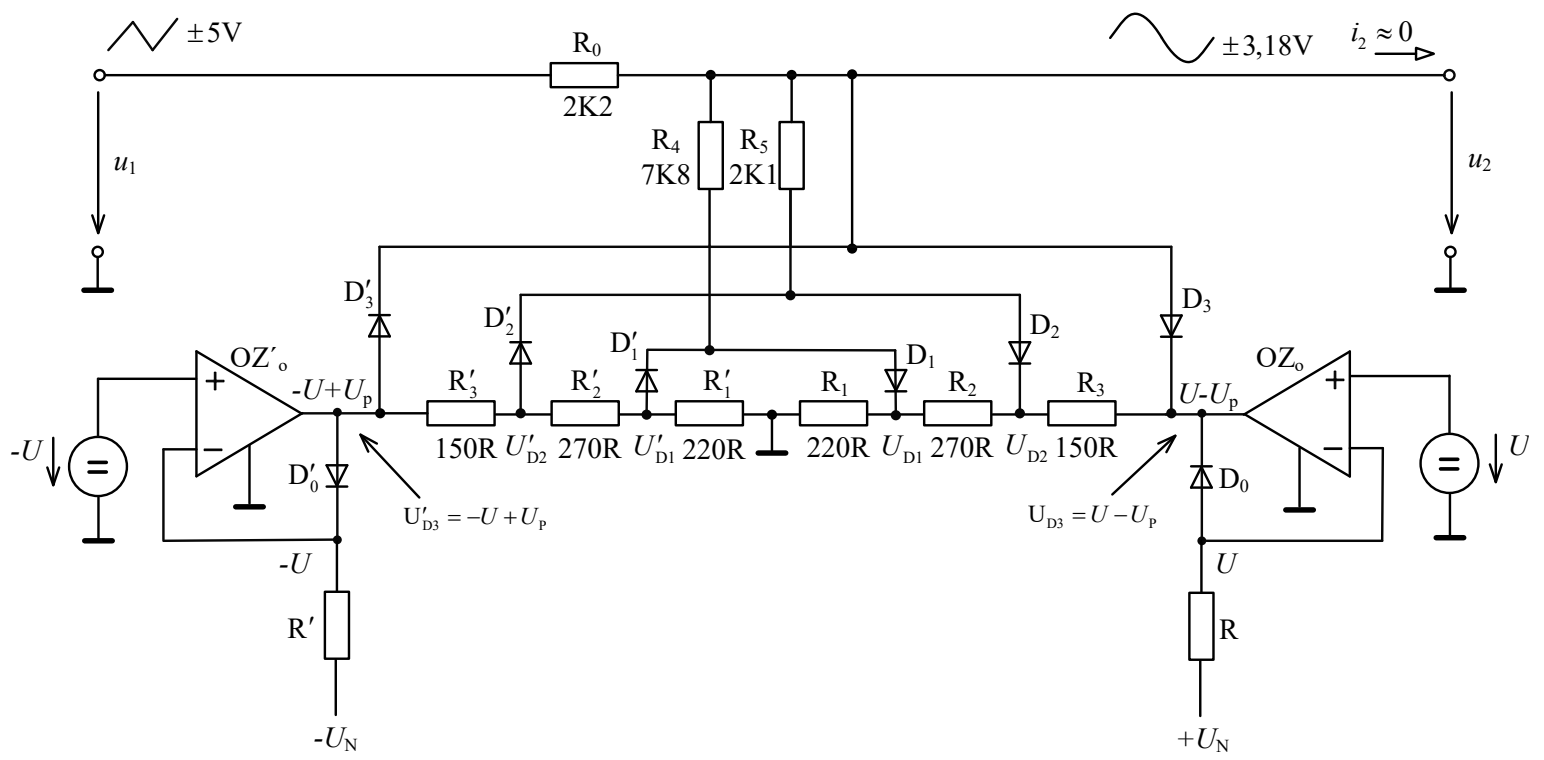

Obr. 8.13: Diodový měnič trojúhelníkových kmitů na harmonický signál s teplotní kompenzací

Protože prahová napětí použitých diod jsou značně teplotně závislá jsou referenční zdroje obvykle realizovány jako teplotně závislé s opačným teplotním koeficientem (viz. Obr. 8.13). Výstupní napětí referenčního zdroje s $\mathrm{OZ}_{0}$ bude $U_{\mathrm{D} 3}=U-U_{\mathrm{P}}$. Pokud budou sepnuty diody $\mathrm{D}_{1}$, $\mathrm{D}_{2}, \mathrm{D}_{3}$, bude výstupní napětí měniče omezeno na hodnotu $U_{2}=U_{\mathrm{D} 3}+U_{\mathrm{P}}=U-U_{\mathrm{P}}+U_{\mathrm{P}}=U$. Zdroje referenčního napětí s $\mathrm{OZ}_{0}$ musí mít tedy na vstupu napětí 


$$
U=\frac{2}{\pi} U_{1}
$$

\subsection{Obvody s nelineární zpětnou vazbou}

\subsubsection{Nelineární zpětná vazba}

Použijeme-li $\mathrm{k}$ vytvoření zpětnovazební sítě operačního zesilovače místo lineárních rezistorů (s konstantním odporem) rezistorů nelineárních, budou i přenosové charakteristiky takových zesilovačů nelineární. Uvažujme nejprve, že neřízený nelineární rezistor $\mathrm{s}$ ampérvoltovou charakteristikou $i=\mathrm{f}(u)$ je použit ve vstupní větvi zpětnovazební sítě (Obr. 8.14a). Při obvyklém zjednodušení $\left(u_{\mathrm{i}} \approx 0, i_{\mathrm{i}} \approx 0\right)$ budou $\mathrm{v}$ obvodu platit vztahy $u \approx u_{1}, i_{1} \equiv i=\mathrm{f}\left(u_{1}\right), i_{2} \approx-u_{2} / R, i_{1} \approx i_{2}$. Výstupní napětí bude tedy mít velikost

$$
u_{2} \approx-R \mathrm{f}\left(u_{1}\right) .
$$

Je vidět, že přenosová charakteristika $u_{2}\left(u_{1}\right)$ bude geometricky podobná AV charakteristice použitého nelineárního rezistoru.

V obvodu naznačeném na Obr. $8.14 \mathrm{~b}$ je pozice lineárního a nelineárního rezistoru ve zpětnovazební síti zaměněna. Pro usnadnění zápisu použijeme $\mathrm{v}$ tomto př́ípadě voltampérové charakteristiky $u=\mathrm{g}(i)$, jež je inverzní $\mathrm{k}$ ampérvoltové charakteristice $i=\mathrm{f}(u)$ daného nelineárního rezistoru. V obvodu na Obr. $8.14 \mathrm{~b}$ platí vztahy $i \equiv i_{2}, u_{2} \approx-u=-g\left(i_{2}\right), i_{2} \approx i_{1}, i_{1} \approx-u_{1} / R$. Potom pro výstupní napětí dostáváme

$$
u_{2} \approx-\mathrm{g}\left(i_{1}\right) \approx-\mathrm{g}\left(\frac{u_{1}}{R}\right) .
$$

$\mathrm{V}$ tomto př́padě tedy přenosová charakteristika $u_{2}\left(u_{1}\right)$ bude geometricky podobná voltampérové charakteristice nelineárního rezistoru.

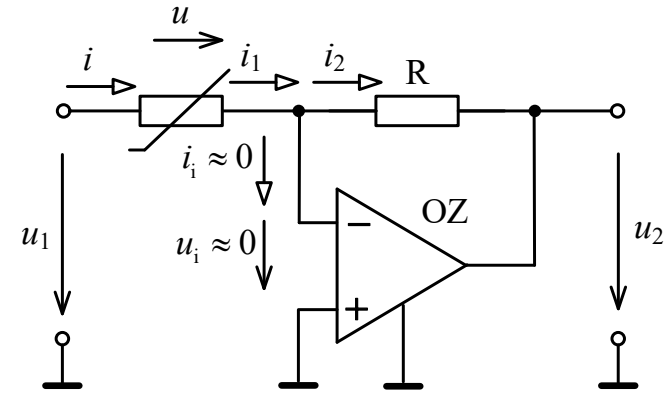

a

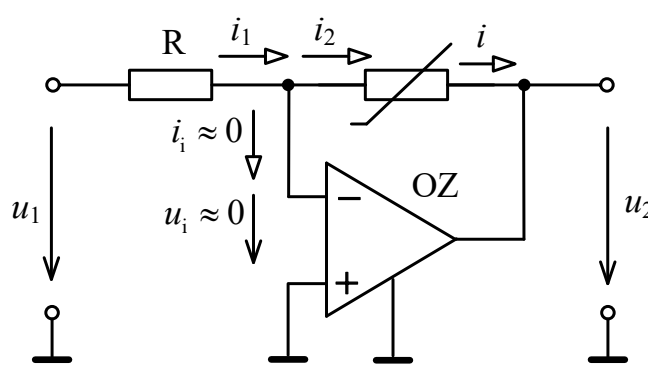

b

Obr. 8.14: Invertující zesilovač a nelineární rezistory ve zpětnovazební síti

Z předchozího odvození vyplývá, že invertující zesilovač s nelineární zpětnou vazbou má tuto důležitou vlastnost: zaměníme-li u zpětnovazebního zesilovače s přenosovou charakteristikou $u_{2}=\mathrm{f}\left(u_{1}\right)$ navzájem oba prvky zpětnovazební sítě, dostaneme zesilovač s přenosovou charakteristikou $u_{2}=\mathrm{g}\left(u_{1}\right)$, která je k charakteristice $\mathrm{f}\left(u_{1}\right)$ inverzní. Tato 
vlastnost umožňuje pouhou záměnou prvků ve vstupní a zpětné větvi zpětnovazební sítě invertujícího zesilovače modelovat např. funkce $x^{2} \mathrm{a} \sqrt{x}, \ln x$ a $\mathrm{e}^{x}, \sin x$ a $\arcsin x$ aj.

\subsubsection{Horní diodové omezovače}

Pasivní diodové omezovače se vyznačují značnou závislostí na odporu zátěže. Praktickými obvody se ve většině případů stávají až ve spojení s operačním zesilovačem, který navíc umožňuje zpracovávaný signál současně zesílit.
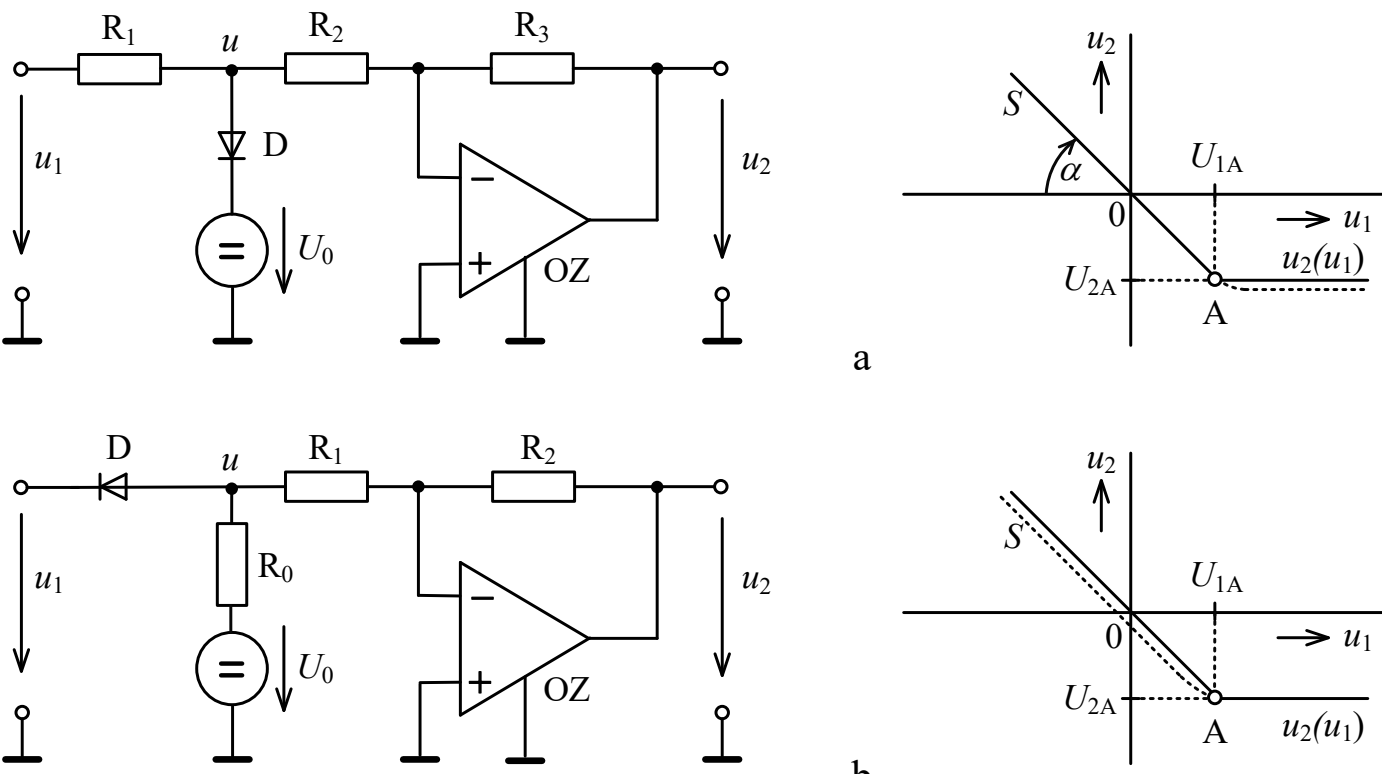

Obr. 8.15: Invertující horní omezovač a jeho charakteristiky: a) paralelní, b) sériový

Jestliže uspořádáme do kaskády paralelní horní diodový omezovač a invertující zesilovač, dostaneme invertujicí paralelní horní omezovač (Obr. 8.4a). Přri vysvětlování činnosti budeme uvažovat pro zjednodušení ideální diodu, která se otevírá při $u_{\mathrm{D}}=0$. V př́ípadě, že bude dioda zavřena zapojení se bude chovat jako invertující zesilovač

$$
u_{2} \approx-\frac{R_{3}}{R_{1}+R_{2}} u_{1} \text {. }
$$

a strmost $S=\operatorname{tg} \alpha$ převodní charakteristiky bude v tomto př́ípadě dána vztahem

$$
S \approx-\frac{R_{3}}{R_{1}+R_{2}}
$$

Rozhodné pro otevření diody bude napětí mezi rezistory $\mathrm{R}_{1} \mathrm{a} \mathrm{R}_{2}$

$$
u \approx \frac{R_{2}}{R_{1}+R_{2}} u_{1} \text {. }
$$

Dioda se otevře v okamžiku, kdy napětí $u$ bude větší než $U_{0}$. To nastane v prŕípadě, že vstupní napětí dosáhne hodnoty 


$$
u_{1}>U_{1 \mathrm{~A}}=\frac{R_{1}+R_{2}}{R_{2}} U_{0} .
$$

Jakmile se dioda otevře, bude na výstupu konstantní napětí

$$
u_{2}=U_{2 \mathrm{~A}} \approx-\frac{R_{3}}{R_{2}} U_{0} .
$$

Průběh převodní charakteristiky je uveden na Obr. 8.15a, kde je také vyznačen čárkovaně skutečný průběh při uvažování reálných vlastností diody.

Spojíme-li do kaskády sériový horní diodový omezovač s invertujícím zapojením operačního zesilovače dostaneme invertující sériový horni omezovač (viz Obr. 8.15b). Bude-li dioda otevřena, bude na výstupu napětí

$$
u_{2} \approx-\frac{R_{2}}{R_{1}} u_{1}=S u_{1} \text {. }
$$

Rozhodné pro zavření diody bude napětí

$$
u \approx \frac{R_{1}}{R_{0}+R_{1}} U_{0}
$$

Dioda se zavře, pokud vstupní napětí bude větší než toto napětí, tzn.

$$
u_{1}>U_{1 \mathrm{~A}} \approx \frac{R_{1}}{R_{0}+R_{1}} U_{0} .
$$

Jakmile se dioda zavře, bude na výstupu konstantní napětí

$$
u_{2}=U_{2 \mathrm{~A}} \approx-\frac{R_{2}}{R_{0}+R_{1}} U_{0} \text {. }
$$

Př́iklad zapojení invertujícího horního omezovače s referenční diodou je uveden na Obr. 8.16. Obvod lze použít spíše na nízkých kmitočtech, protože doba sepnutí referenční diody je podstatně delší než u rychlé spínací diody. Úroveň omezení je dána napětím referenční diody $U_{\mathrm{Z}}$ a prahovým napětím $U_{\mathrm{P}}$. Diody se musí volit tak, aby odpor sepnuté diody byl daleko menší než odpor zpětnovazebního rezistoru $R_{2}$ a naopak odpor rozpojené diody musí být daleko větší než $R_{2}$.
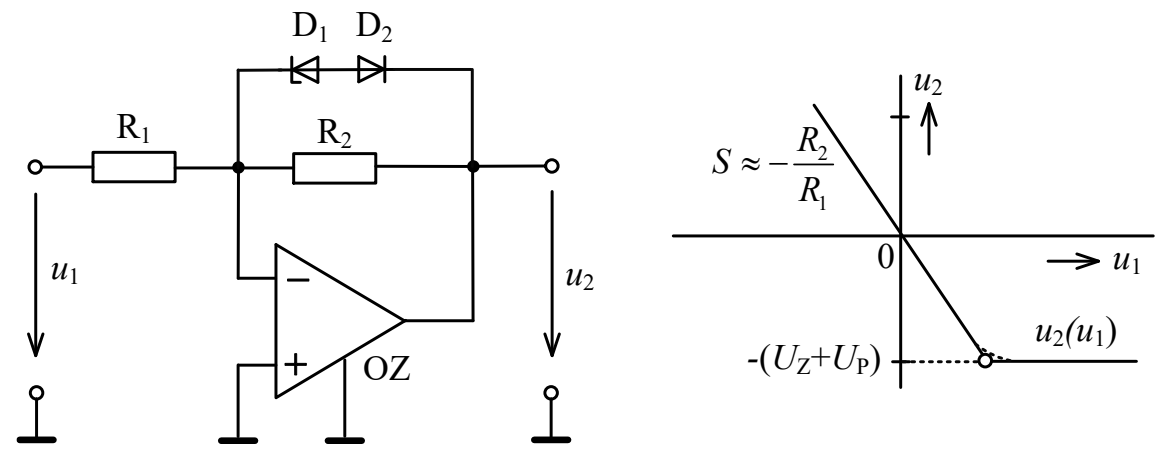

Obr. 8.16: Jednostranný omezovač s referenční diodou

Referenční diody se vybírají tak, aby měly ostrý lom ampérvoltové charakteristiky v závěrném směru, protože pak i převodní charakteristika okrajovače se blíží funkci po úsecích lineární. 


\subsubsection{Dolní diodové omezovače}

Jestliže uspořádáme do kaskády paralelní diodový omezovač a invertující zesilovač, dostaneme invertujicí paralelní omezovač (viz Obr. 8.17a). Obvod se chová jako invertující zesilovač se strmostí převodní charakteristiky $S \approx-R_{3} /\left(R_{1}+R_{2}\right) \quad$ v oblasti $u_{1}>U_{1 \mathrm{~A}} \approx U_{0}\left(R_{1}+R_{2}\right) / R_{2}$, tj. v oblasti, kde je dioda $\mathrm{D}$ zahrazena. Je-li $u_{1}<U_{1 \mathrm{~A}}$ dioda $\mathrm{D}$ se otevře a na výstupu se objeví konstantní napětí $u_{2} \approx U_{2 \mathrm{~A}} \approx-U_{0} R_{3} / R_{2}$.
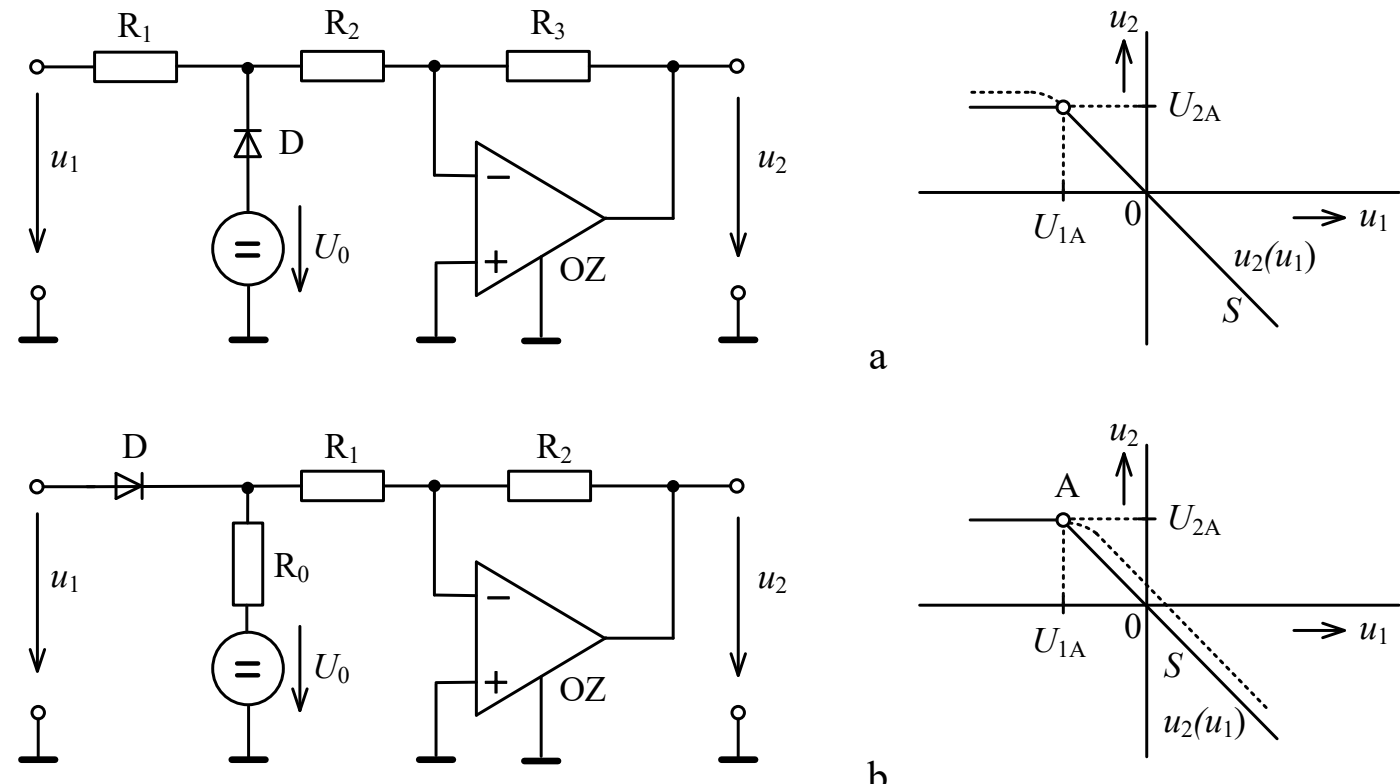

$\mathrm{b}$

Obr. 8.17: Invertující dolní omezovač: a) paralelní, b) sériový

Zapojení sériového invertujícího dolního okrajovače je naznačeno na Obr. 8.17b. Při vstupním napětí $u_{1}<U_{1 \mathrm{~A}}=U_{0} R_{1} /\left(R_{0}+R_{1}\right)$ je dioda $\mathrm{D}$ zahrazena. Výstupní napětí je proto $\mathrm{v}$ této oblasti konstantní $u_{2}=U_{2 \mathrm{~A}} \approx-U_{0} R_{2} /\left(R_{0}+R_{1}\right)$. V oblasti, kdy bude dioda otevřena, $\mathrm{tj}$. pro $u_{1}>U_{1 \mathrm{~A}}$, se obvod chová jako invertující zesilovač a převodní charakteristika má strmost $S \approx-R_{2} / R_{1}$.

Podobně jako je zapojen jednostranný invertující horní omezovač s referenční diodou na Obr. 8.16 můžeme získat dolní omezovač, když obě diody přepólujeme.

\subsubsection{Oboustranné diodové omezovače}

Invertujici oboustranný diodový omezovač (Obr. 8.18), sestrojený na bázi paralelního diodového omezovače, se vyznačují tím, že v oblasti $u_{1} \in\left\langle U_{1 \mathrm{~B}}, U_{1 \mathrm{~A}}\right\rangle$ jsou diody $\mathrm{D}_{1}$ a $\mathrm{D}_{2}$ zahrazeny (předpokladem proto je $U_{01}>U_{02}$ ) a obvod proto pracuje jako invertující zesilovač se strmostí převodní charakteristiky $S \approx-R_{3} /\left(R_{1}+R_{2}\right)$. Pokud $u_{1}>U_{1 \mathrm{~A}} \approx U_{01}\left(R_{1}+R_{2}\right) / R_{2}$, otevře se dioda $\mathrm{D}_{1}$ a na výstupu dostaneme přibližně konstantní napětí $u_{2} \approx U_{2 \mathrm{~A}} \approx-U_{01} R_{3} / R_{2}$. Jestliže $u_{1}<U_{1 \mathrm{~B}} \approx U_{02}\left(R_{1}+R_{2}\right) / R_{2}$, otevře se dioda $\mathrm{D}_{2} \quad \mathrm{a} \quad \mathrm{v}$ důsledku toho bude $u_{2} \approx U_{2 \mathrm{~B}} \approx-U_{02} R_{3} / R_{2}$. Tučně vytažená charakteristika v Obr. 8.18 platí pro idealizovaný okrajovač s ideálními diodami, čárkovaně je vyznačena deformace, způsobená reálnými vlastnostmi diod $\mathrm{D}_{1}$ a $\mathrm{D}_{2}$. 

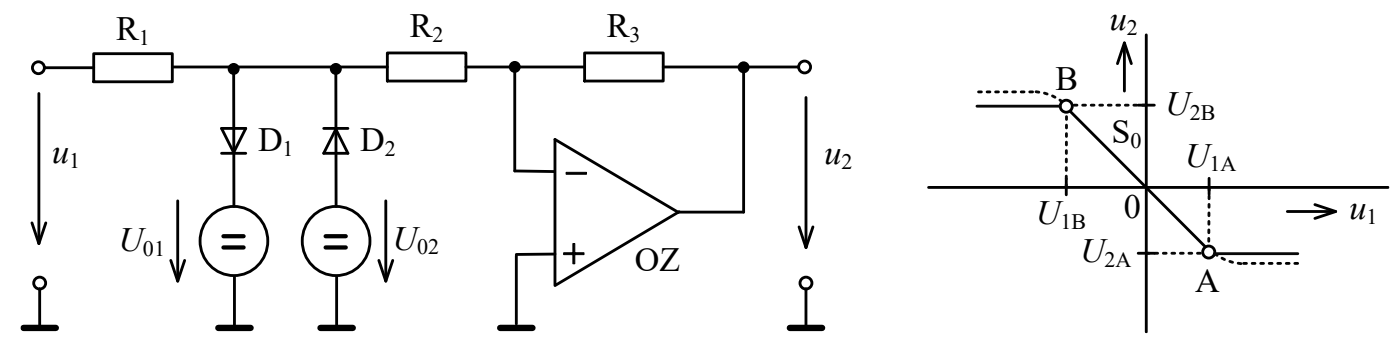

Obr. 8.18: Oboustranný diodový omezovač

Zpětnovazební oboustranný diodovýomezovač je nakreslen na Obr. 8.19. Určíme nejprve napětí $u$, jehož hodnota rozhoduje o zapnutí diody $\mathrm{D}_{1}$. K určení využijeme pomocné zapojení uvedené na Obr. 8.19b. Výstupní napětí pomocného obvodu určíme např. metodou superpozice

$$
u=\frac{R_{4}}{R_{3}+R_{4}} U_{01}+\frac{R_{3}}{R_{3}+R_{4}} u_{2} .
$$
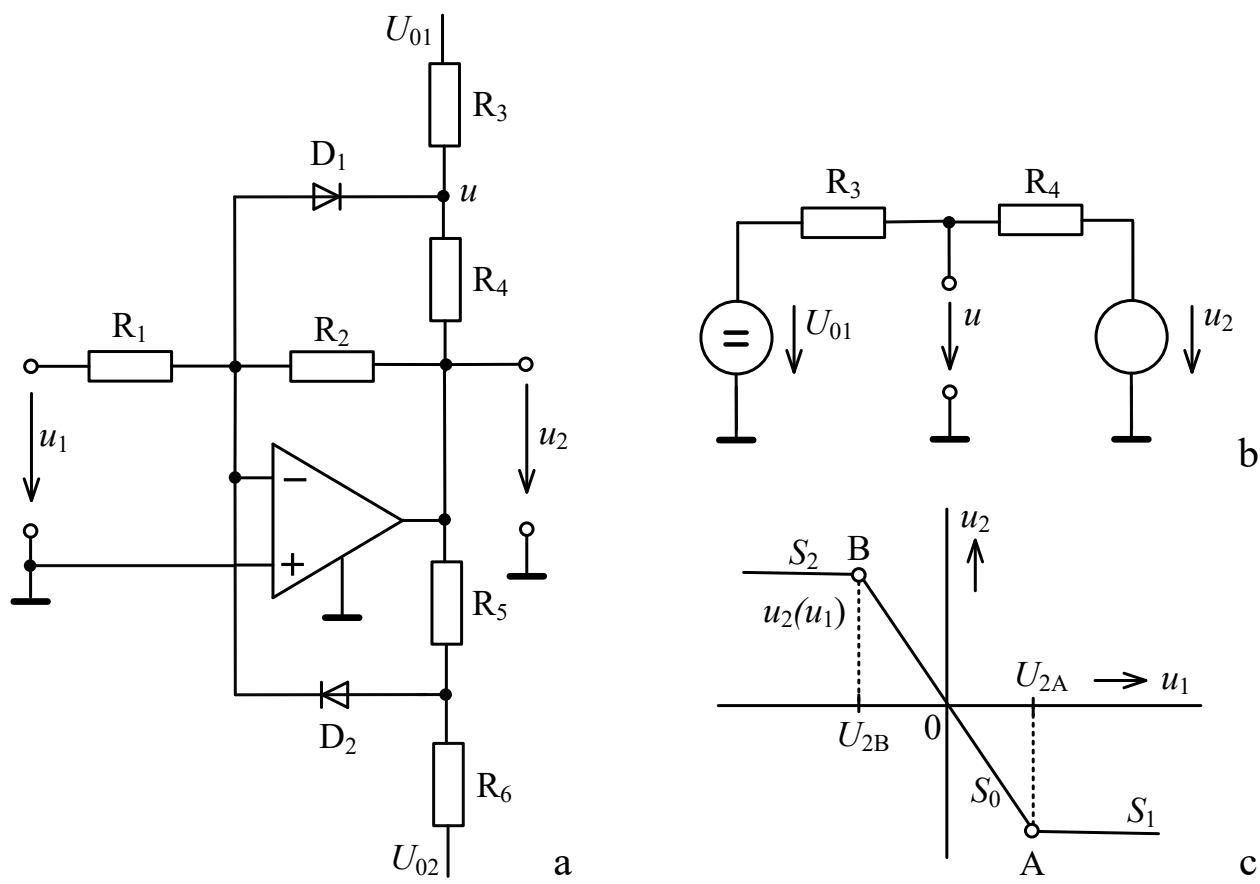

Obr. 8.19: Zpětnovazební oboustranný omezovač s diodami (a), obvod určující otevření diody $\mathrm{D}_{1}$ (b), převodní charakteristika (c)

Uvažujeme-li ideální diody, $\mathrm{D}_{1}$ se otevře př̀i $u \leq 0$ (resp. při uvažování reálné diody při $\left.u \leq-U_{\mathrm{P} 1}\right)$ a tedy podle předchozí rovnice nastane při uvažování ideální diody lom převodní charakteristiky po dosažení výstupního napětí

$$
u_{2}=U_{2 \mathrm{~A}} \approx-\frac{R_{4}}{R_{3}} U_{01} .
$$

Podobně se určí i druhý bod lomu

$$
U_{2 \mathrm{~B}} \approx-\frac{R_{5}}{R_{6}} U_{02}
$$


Odtud je také zřejmé, že musí platit $U_{01}>U_{02}$. Strmost převodní charakteristiky v oblasti, v níž jsou obě diody vypnuty bude

$$
S_{0} \approx-\frac{R_{2}}{R_{1}}
$$

Jestliže bude $\mathrm{D}_{1}$ zapnuta, bude mít převodní charakteristika strmost

$$
S_{1} \approx-\frac{R_{2} \| R_{4}}{R_{1}} .
$$

a podobně pro sepnutou diodu $\mathrm{D}_{2}$ bude

$$
S_{2} \approx-\frac{R_{2} \| R_{5}}{R_{1}} .
$$

Aby obvod pracoval jako omezovač, musíme volit $R_{4}<<R_{2}$ resp. $R_{5}<<R_{2}$ tak, aby strmosti $S_{1}$ a $S_{2}$ byly daleko menší než strmost $S_{0}$.

Omezovače s referenčními diodami se neužívají obvykle jako přesná zařízení pro tvarování signálu, ale slouží především jako obvody pro ochranu operačního zesilovače před překročením jeho dovolených napětí. U některých operačních zesilovačů by totiž překročení povolených pracovních podmínek mohlo vést $\mathrm{k}$ vyřazení operačního zesilovače $\mathrm{z}$ funkce ještě několik sekund po odstranění rušivého vlivu.

Na Obr. 8.20 jsou uvedeny př́klady dvou standardních napětových omezovačů s referenčními diodami určené pro méně náročné aplikace. Obvody lze použít spíše na nižších kmitočtech z důvodu větších parazitních kapacit referenčních diod. Úroveň okrojení je v obou případech dána referenčním napětím jedné diody $U_{Z}$ a prahovým napětím druhé referenční diody UP. Diody se musí volit tak, aby jejich zbytkový proud v závěrném směru (než dojde k jejich otevření) prŕliš neovlivnil pracovní oblast zesilovače a dále, aby diody vykazovaly dostatečně ostrý přechod při otevření do závěrné oblasti. V prrípadě invertujícho zesilovače (Obr. 8.20a) je v pracovní oblasti, kdy ani jedna z diod není sepnuta, strmost převodní charakteristiky $S \approx-R_{2} / R_{1}$. Dosáhne-li výstupní napětí hodnoty $\left(U_{\mathrm{Z} 1}+U_{\mathrm{P} 2}\right)$, bude referenční dioda $\mathrm{D}_{1}$ provozována $\mathrm{v}$ závěrné oblasti a $\mathrm{D}_{2} \mathrm{v}$ propustné oblasti a výstupní napětí se omezí na hodnotu $u_{2} \approx U_{\mathrm{Z} 1}+U_{\mathrm{P} 2}$. Obdobně je tomu i pro opačnou polaritu výstupního napětí. 


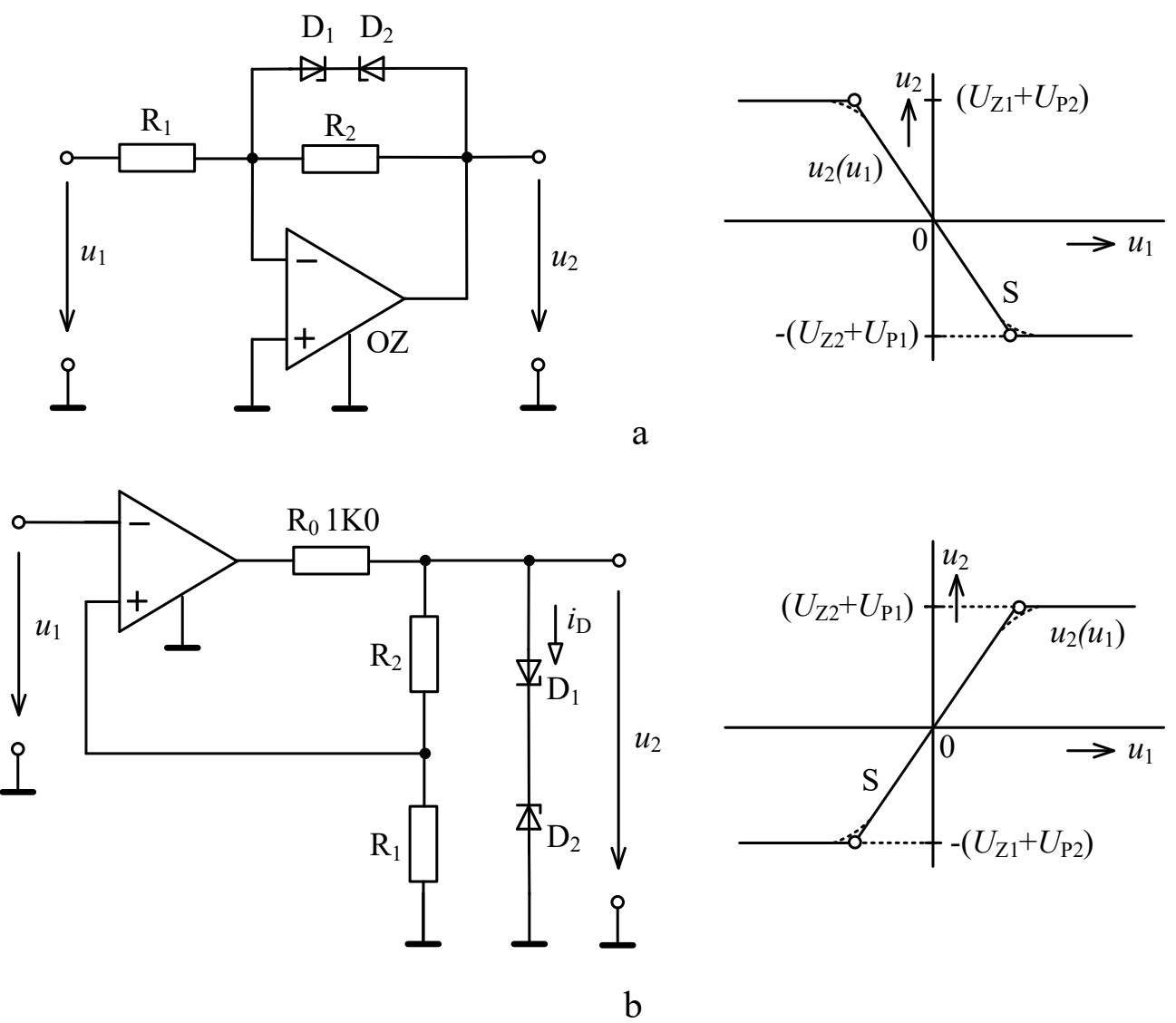

Obr. 8.20: Omezovač výstupního napětí a) invertujícího zesilovače, b) neinvertujícího zesilovače

U neinvertujícího zapojení (Obr. 8.21b) nelze referenční diody zapojit paralelně se zpětnovazebním rezistorem $\mathrm{R}_{2}$ jako $\mathrm{v}$ předchozím př́ípadě, protože $\mathrm{v}$ oblasti okrojení by byla strmost převodní charakteristiky vždy rovna jedné. Proto jsou referenční diody zapojeny na výstupu zesilovače. Pro návrh platí obdobné úvahy jako v předchozím. Aby nedocházelo k přetížení výstupu operačního zesilovače nadměrným proudem tekoucím diodami $\mathrm{D}_{1} \mathrm{a}_{2} \mathrm{D}_{2}$ v oblasti okrojení výstupního signálu, je do série s těmito diodami a zpětnovazebním rezistorovým zeslabovačem $\mathrm{R}_{1}, \mathrm{R}_{2}$ zapojen předřazený rezistor $\mathrm{R}_{0}$, který určuje proud referenčními diodami při jejich otevření. Jak víme z předchozího, tento odpor vlastnosti zapojení př́liš neovlivní, protože je potlačen zápornou zpětnou vazbou.

U obou zapojení uvedených na Obr. 8.20 můžeme k omezení vstupního napětí zesilovače alternativně použít uspořádání oboustranného omezovače s referenčními diodami z Obr. 8.9b.

Jak bylo již řečeno, je důvodem menší přesnosti uspořádání omezovače na Obr. 8.20a zbytkový závěrný proud, který teče referenční diodou před tím, než se dioda dostane do průrazu. Tento proud je až o řád větší, než je závěrný proud běžnou křemíkovou diodou. Na Obr. 8.22a je uveden oboustranný okrajovač, který do jisté míry tento jev potlačuje. Zlepšení je docíleno rozdělením závěrného proudu diodami $\mathrm{D}_{3}$ a $\mathrm{D}_{4}$ proudovým děličem sestaveným $\mathrm{z}$ rezistoru $\mathrm{R}_{3}$ o odporu $1 \mathrm{k} \Omega$ a antiparalelně zapojenými diodami $\mathrm{D}_{1} \mathrm{a}_{2}$, které mají počáteční diferenční odpor $r_{\mathrm{D}} \approx 10 \mathrm{M} \Omega$ (viz Obr. 8.22b). Proud se rozdělí v poměru $\mathrm{R}_{3} / r_{\mathrm{D}}$ a tedy do sčítacího bodu OZ poteče jen zanedbatelný chybový proud řádově 10 až 100 nA. Pokud výstupní napětí dosáhne hodnoty $\left(U_{\mathrm{P} 1}+U_{\mathrm{Z} 3}+U_{\mathrm{P} 4}\right)$ budou diody $\mathrm{D}_{1}$ a $\mathrm{D}_{4}$ pólovány v propustném směru a dioda $\mathrm{D}_{3} \mathrm{v}$ závěrném směru a výstupní napětí se omezí na tuto hodnotu. Obdobně bude obvod pracovat i pro opačnou polaritu výstupního napětí, kdy se výstupní napětí omezí na hodnotu $\left(U_{\mathrm{P} 2}+U_{\mathrm{P} 3}+U_{\mathrm{Z} 4}\right)$. 
Zapojení oboustranného omezovače pro přesné měřicí účely je uvedeno na Obr. 8.22. Zapojení se používá např. pro ochranu vstupních zesilovačů u číslicových voltmetrů. Závěrný proud referenční diody $\mathrm{D}_{5}$ je nahrazen závěrným proudem křemíkové diody $\mathrm{D}_{3}$, který je v podstatně menší. Docílíme toho tak, že referenční diodu dostaneme na okraj oblasti průrazu pomocí proudu tekoucího rezistorem $\mathrm{R}_{4}$.

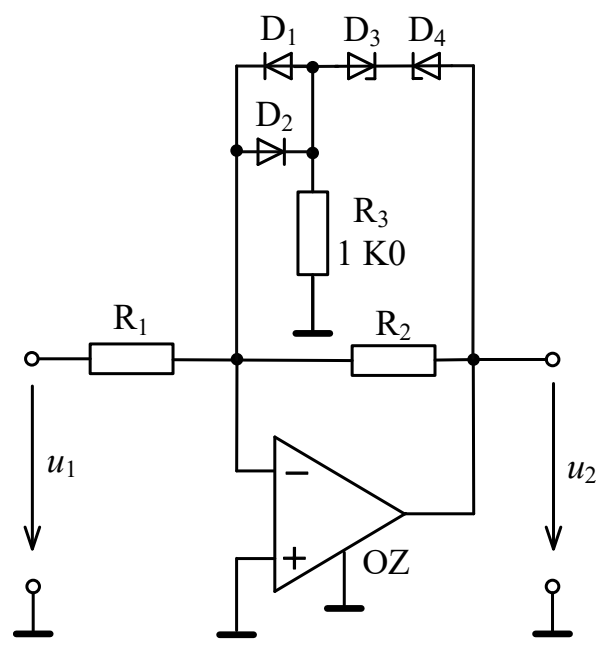

a
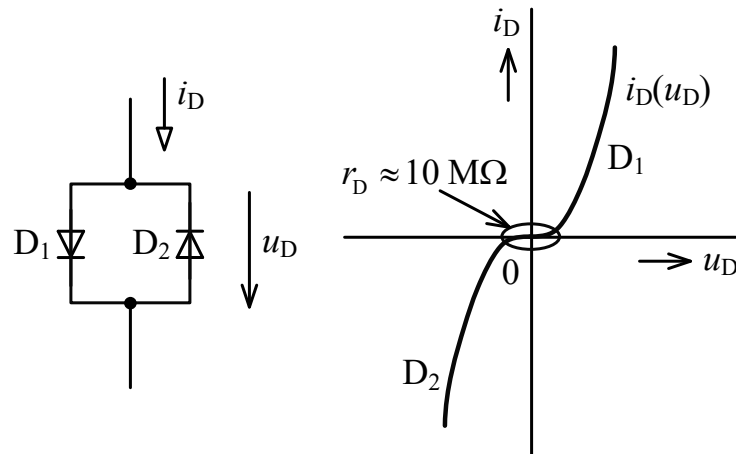

b

Obr. 8.21: a) Přesný omezovač pro ochranu operačního zesilovače před překročením napětových schopností zesilovače, b) ampérvoltová charakteristika antiparalelně spojených diod

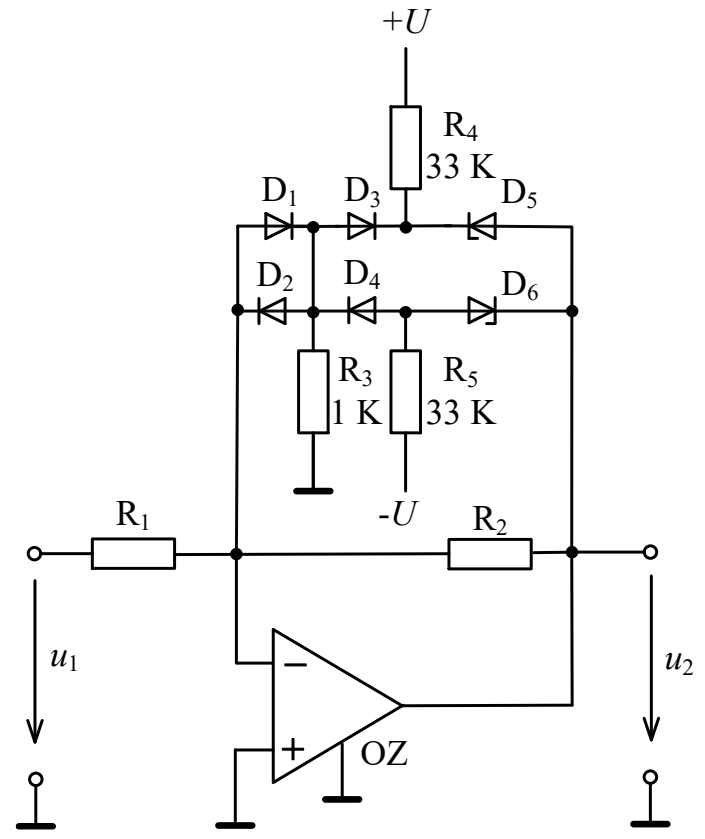

Obr. 8.22: Oboustranný omezovač pro přesné měřicí účely

Referenční diodou $\mathrm{D}_{5}$ přitom poteče poměrně velký závěrný proud (asi $0,5 \mathrm{~mA}$ ), ale dioda $\mathrm{D}_{3}$ bude namáhána $\mathrm{V}$ závěrném směru a poteče jí proud jen řádově $10 \mathrm{nA}$. Tento proud je dále ještě zmenšen proudovým děličem sestávajícím $\mathrm{z}$ rezistoru $\mathrm{R}_{3}$ a počátečního diferenčního vnitřního odporu $r_{\mathrm{D}}$ antiparalelně zapojených diod $\mathrm{D}_{1}$ a $\mathrm{D}_{2}$ stejně, jako tomu bylo u zapojení na Obr. 8.21. V tomto uspořádání poteče do sčítacího bodu jen nepatrný chybový proud kolem $1 \mathrm{pA}$. Jakmile ovšem výstupní napětí dosáhne hodnoty $-\left(U_{\mathrm{P} 1}+U_{\mathrm{P} 3}+U_{\mathrm{Z} 5}\right)$ diody $\mathrm{D}_{1}$ a $\mathrm{D}_{3}$ se otevřou a dioda 
D5 bude provozována v závěrném směru. Obdobně je tomu i pro opačnou polaritu výstupního napětí, kdy jsou v činnosti diody $\mathrm{D}_{2}, \mathrm{D}_{4}, \mathrm{D}_{6}$ a omezení nastane při $\left(U_{\mathrm{P} 2}+U_{\mathrm{P} 4}+U_{\mathrm{Z} 6}\right)$.

\subsubsection{Diodové funkční měniče}

Pod pojmem diodové funkční měniče rozumíme obvody, které pro modelování nelineárních charakteristik využívají lineární rezistory, diody a zdroje konstantního napětí zapojené do zpětné vazby operačního zesilovače. Zapojují se do vstupního nebo zpětnovazební větve operační zpětné vazby anebo do obou větví. Největší význam mají diodové funkční měniče pro modelování funkcí lineárně aproximovaných lomenou čárou, které v podstatě pracují jako sériové nebo paralelní omezovače.

Diodový funkční měnič ve vstupní větvi zesilovače využívá uspořádání tvarovacího obvodu naznačené na Obr. 8.23. Jestliže budeme uvažovat, že referenční zdroj napětí $U<0$ a $u_{1} \geq 0$, budou se jednotlivé diody při zvyšování vstupního napětí postupně spínat a tvarovat tak průběh převodní charakteristiky požadovaným způsobem. Budeme-li nejprve předpokládat, že vstupní napětí $u_{1}$ je tak malé, že všechny diody jsou zavřeny, bude strmost převodní charakteristiky $\mathrm{v}$ okolí počátku určena pouze rezistory $\mathrm{R}_{1}$ a $\mathrm{R}_{2}$
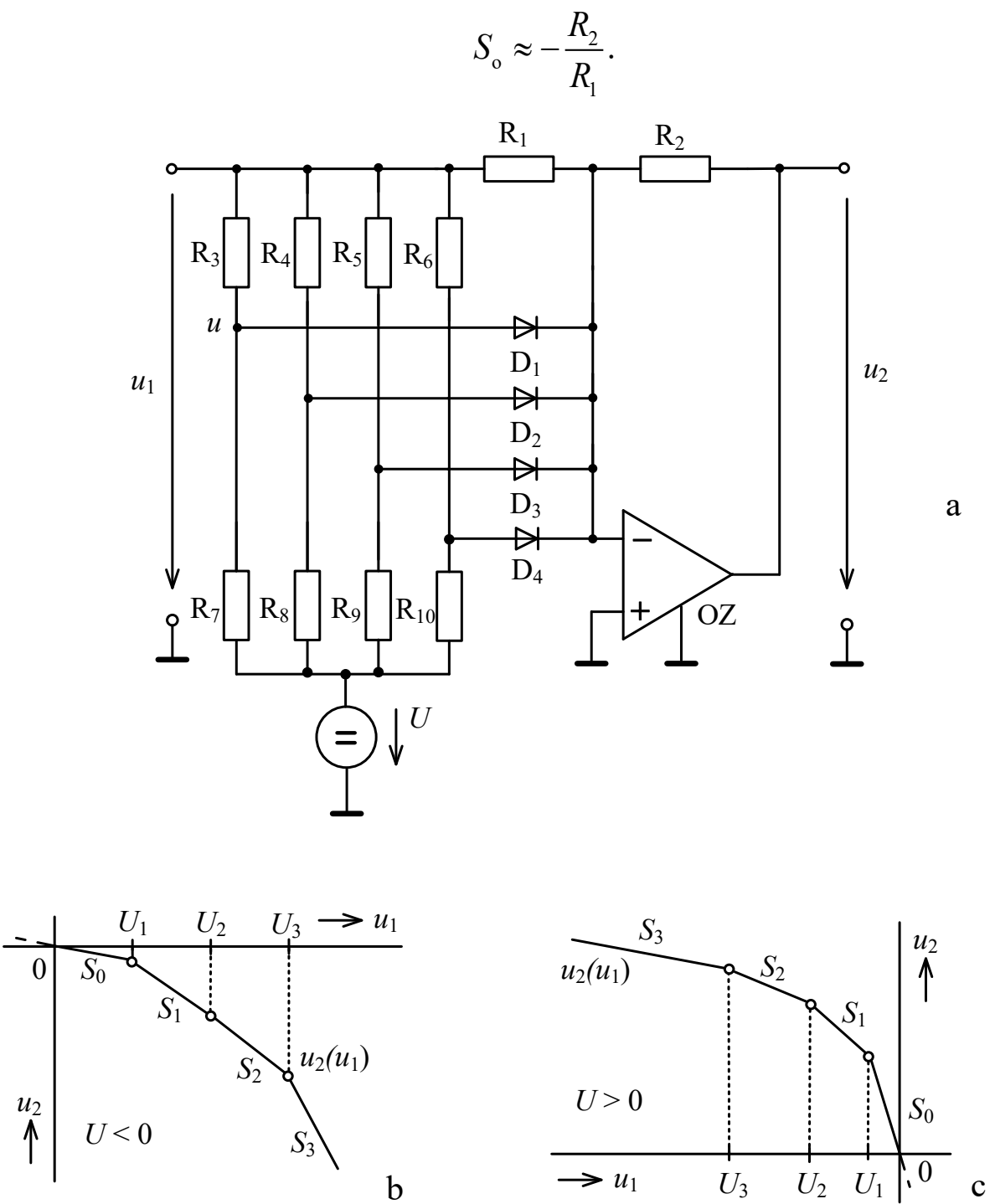

Obr. 8.23: a) Diodový funkční měnič s řadou okrajovačů ve vstupní větvi, b) průběh převodní charakteristiky při $U<0, u_{1} \geq 0$, c) průběh převodní charakteristiky při $U>0, u_{1} \leq 0$ 
Při zvyšujícím se vstupním napětí se diody postupně spínají (viz Obr. 8.23b) a strmosti převodní charakteristiky se zvětšují

$$
S_{1} \approx-\frac{R_{2}}{R_{1} \| R_{3}}, S_{2} \approx-\frac{R_{2}}{R_{1}\left\|R_{3}\right\| R_{4}}, S_{3} \approx-\frac{R_{2}}{R_{1}\left\|R_{3}\right\| R_{4} \| R_{5}}, S_{4} \approx-\frac{R_{2}}{R_{1}\left\|R_{3}\right\| R_{4}\left\|R_{5}\right\| R_{6}} .
$$

První bod lomu charakteristiky určuje dioda $\mathrm{D}_{1}$, o jejímž sepnutí rozhoduje hodnota napětí

$$
u=\frac{R_{7}}{R_{3}+R_{7}} u_{1}+\frac{R_{3}}{R_{3}+R_{7}} U .
$$

Uvažujeme-li, že dioda $\mathrm{D}_{1}$ je ideální a operační zesilovač si udržuje na invertujícím vstupu „virtuální" nulu, dioda $\mathrm{D}_{1}$ se otevře při u $\geq 0$ a tedy, podle rov.(8-31) nastane první lom převodní charakteristiky při dosažení napětí

$$
u_{1}=U_{1} \approx-\frac{R_{3}}{R_{7}} U
$$

Obdobně určíme i další body lomu

$$
U_{2} \approx-\frac{R_{4}}{R_{8}} U, U_{3} \approx-\frac{R_{5}}{R_{9}} U, U_{4} \approx-\frac{R_{6}}{R_{10}} .
$$

Při vlastním návrhu je zapotřebí zvažovat reálné diody a jejích vlastnosti zahrnout do výpočetních vztahů, zejména prahové napětí $U_{\mathrm{P}}$ nebo i odpor diody v sepnutém stavu.

Zaměníme-li u téhož funkčního měniče (Obr. 8.23a) polaritu referenčního zdroje, tj. $U>$ 0 a budeme uvažovat $u_{1} \leq 0$, budou nejprve všechny diody sepnuty a při snižování vstupního napětí se budou diody postupně odpojovat. Proto převodník charakteristika bude mít v okolí počátku největší strmost a při velkém záporném vstupním napětí pak strmost nejmenší (viz Obr. $8.23 \mathrm{c})$.

Přepólováním diod ve funkčním měniči podle Obr. 8.23a získáme měnič, u kterého se při $U>$ 0 a $u_{1} \leq 0$ bude strmost převodní charakteristiky s klesajícím $u_{1}$ zvětšovat a naopak při $U_{1}<0$ a $u_{1} \geq 0$ se bude strmost $\mathrm{s}$ rostoucím $u_{1}$ zmenšovat.

Poznámka: Dosud uvedené varianty diodových funkčních měničů dovolovaly tvarování charakteristik bud' ve čtvrtém nebo druhém kvadrantu. Můžeme je však spolu kombinovat v jednom obvodu tak, že výsledná charakteristika bude probíhat jak ve čtvrtém, tak i ve druhém kvadrantu. Přitom musíme pochopitelně používat dva zdroje stejnosměrného referenčního napětí z nichž jeden dává kladné a druhý záporné napětí.

Diodový funkčni měnič ve zpětnovazebni větvi zesilovače využívá tvarovací obvod na Obr. 8.23a. Funkční měnič při $U<0$ pracuje takto: Pokud je vstupní napětí $u_{1} \leq 0$ tak malé, že výstupní napětí operačního zesilovače $u_{2} \leq U_{1}$, jsou všechny diody zavřeny a přenosové vlastnosti jsou dány odpory rezistorů $\mathrm{R}_{1}$ a $\mathrm{R}_{2}$, tzn. strmost převodní charakteristiky $\mathrm{v}$ této oblasti bude

$$
S_{\mathrm{o}} \approx-\frac{R_{2}}{R_{1}}
$$


Zvětšujeme-li postupně vstupní napětí do záporných hodnot (a tím zvětšujeme výstupní napětí do kladných hodnot), budou se diody postupně spínat a strmost charakteristiky se bude zmenšovat (viz Obr. 8.34b)

$$
S_{1} \approx-\frac{R_{2} \| R_{3}}{R_{1}}, S_{2} \approx-\frac{R_{2}\left\|R_{3}\right\| R_{4}}{R_{1}}, S_{3} \approx-\frac{R_{2}\left\|R_{3}\right\| R_{4} \| R_{5}}{R_{1}}, S_{4} \approx-\frac{R_{2}\left\|R_{3}\right\| R_{4}\left\|R_{5}\right\| R_{6}}{R_{1}} .
$$

Pro sepnutí diody $\mathrm{D}_{1}$ bude rozhodná hodnota napětí na rezistorovém děliči $\mathrm{R}_{3}, \mathrm{R}_{7}$

$$
u=\frac{R_{7}}{R_{3}+R_{7}} u_{2}+\frac{R_{3}}{R_{3}+R_{7}} U
$$
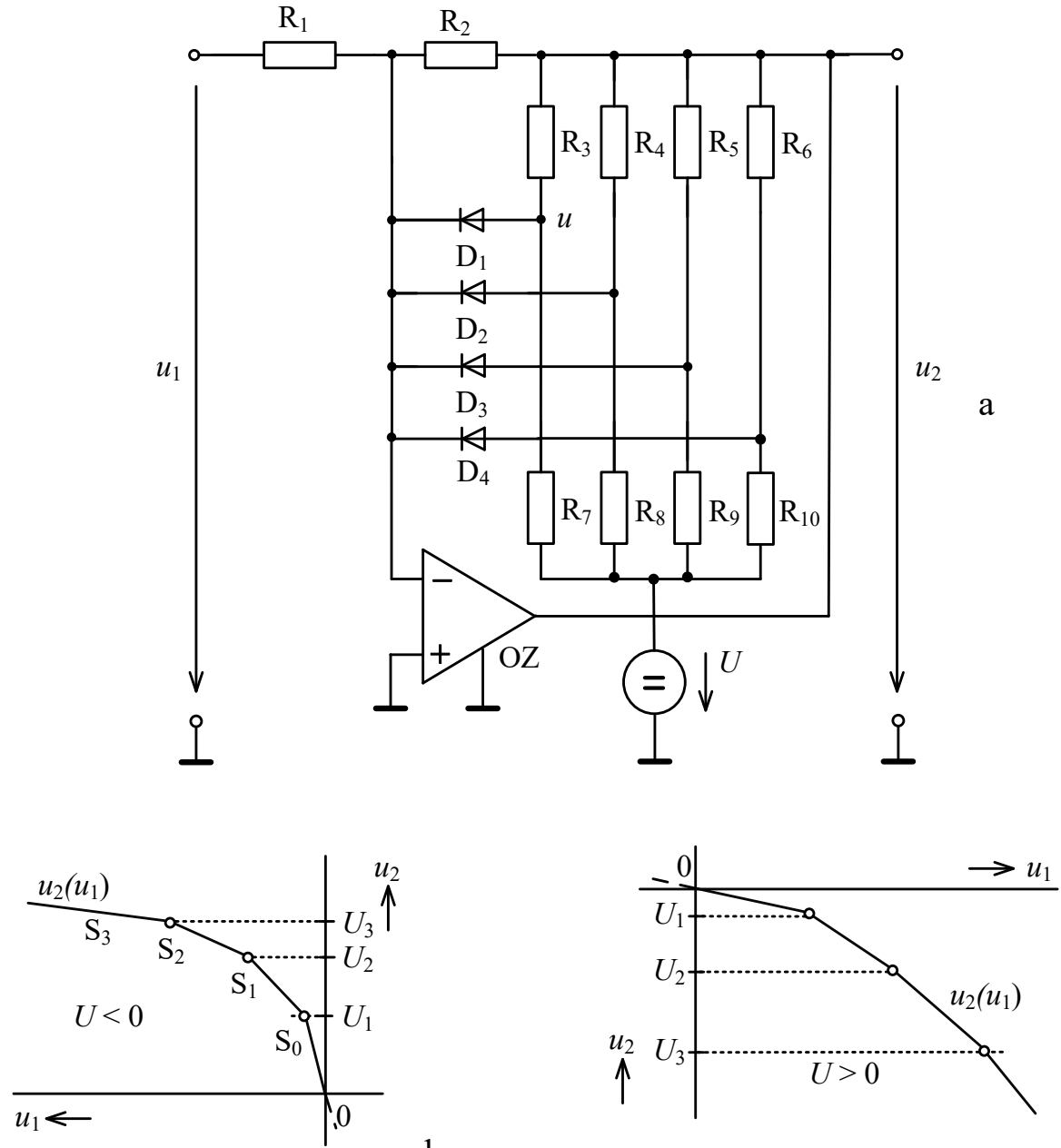

b

$\mathrm{c}$

Obr. 8.24: a) Diodový funkční měnič s řadou okrajovačů ve zpětné větvi, b) průběh převodní charakteristiky při $\left.U<0, u_{1} \leq 0, \mathrm{c}\right)$ průběh převodní charakteristiky při $U>0, u_{1} \geq 0$

$\mathrm{K}$ sepnutí ideální diody $\mathrm{D}_{1}$ dojde $\mathrm{v}$ okamžiku, kdy bude $u \geq 0$, tzn. kdy výstupní napětí dosáhne napětí

$$
u_{2}=U_{1} \approx-\frac{R_{3}}{R_{7}} U
$$

Stejným postupem určíme i další body lomu

$$
U_{2}=-\frac{R_{4}}{R_{8}} U, U_{3}=-\frac{R_{5}}{R_{9}} U, U_{4}=-\frac{R_{6}}{R_{10}} U .
$$


Při konkrétním návrhu pak musíme brát $\mathrm{v}$ úvahu prahové napětí diody $U_{\mathrm{P}}$, př́ípadně i odpor diody v sepnutém stavu.

Změníme-li polaritu referenčního napětí, tj. U > 0 a budeme-li funkční měnič provozovat při $u_{1} \geq 0$, budou při malých vstupních napětích všechny diody sepnuty, a proto strmost převodní charakteristiky bude malá. Se zvětšováním vstupního napětí se budou diody po řadě odpojovat a strmost převodní charakteristiky postupně poroste (viz Obr. 8.24c). Přepólováním diod získáme alternativní zapojení.

Diodový funkční měnič ve zpětnovazebni síti zesilovače má nelineární rezistor tvořený lineárními rezistory, diodami a referenčními zdroji zapojen jak do vstupní tak i do zpětnovazební větve operačního zesilovače (Obr. 8.25a). Takovýto tvarovací obvod je schopen modelovat funkce nemonotónní, tj. funkce s klesající i rostoucí strmostí $S$ (viz Obr. 8.25b).
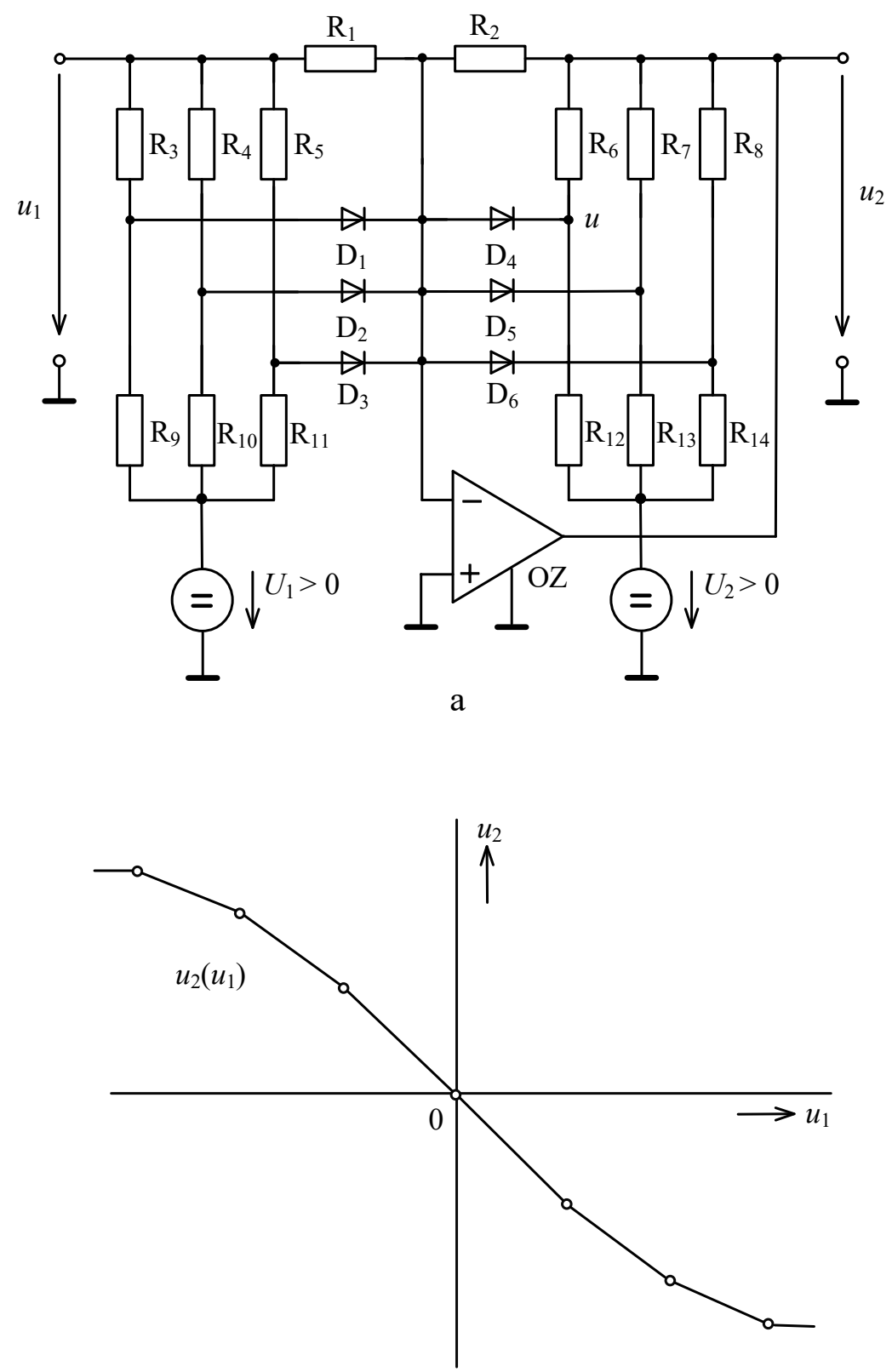

b

Obr. 8.25: a) Diodový funkční měnič pro modelování nemonotónní funkce 
Jak již bylo řečeno všechny rovnice odvozené pro návrh diodových funkčních měničů platí pro ideální diody, tj. pro diody s ostrým a jednoznačně určeným přechodem $z$ vodivého stavu do nevodivého stavu. I při uvažování odporu diody v propustném stavu a prahového napětí $U_{\mathrm{P}}$, které alespoň částečně charakterizují reálné vlastnosti diody, je teoretický návrh do jisté míry přibližný. Proto se doporučuje vypočtené hodnoty upravit podle skutečně naměřených výsledků. Pro nejpřesnější aplikace se někdy vychází přímo z voltampérové charakteristiky diody a řešení měniče se provádí grafickými popř. počítačovými metodami. To, že se dioda vyznačuje spojitým přechodem $z$ vodivého do nevodivého stavu, tedy více či méně velkým zaoblením voltampérové charakteristiky, není na závadu, protože automaticky „vyhlazuje“ ostré přechody mezi jednotlivými úseky lomené čáry aproximující danou funkci.

Diodové funkční měniče jsou značně teplotně závislé. Měniče, které mají při referenčním napětí $U=10 \mathrm{~V}$ zaručovat $\mathrm{v}$ teplotním rozsahu $\pm 10^{\circ} \mathrm{C}$ přsesnost podstatně lepší než $1 \%$, musí být teplotně kompenzovány. Teplotní kompenzace se nejjednodušeji provádí tak, že se referenční napětí, z něhož jsou odvozena předpětí jednotlivých diodových okrajovačů funkčního měniče, učiní závislé na teplotě. Dosáhne se toho např. tím, že do série se zdrojem referenčního napětí se zapojí jedna nebo i několik kompenzačních diod, pracujících v propustném směru stejně jako je to realizováno u zapojení pasivního měniče na Obr. 8.13 (diody $\mathrm{OZ}_{0} \mathrm{~s} D_{0}$ a $\mathrm{OZ}_{0}^{\prime} \mathrm{s} D_{0}^{\prime}$ ).

\subsubsection{Logaritmické a exponenciální převodníky}

Dosud uvedené lineární obvody nám umožňují realizovat celou řadu matematických operací jako je násobení konstantou, rozdíl či součet, umožňují signál integrovat či derivovat, ale neumějí signály navzájem násobit či dělit. Z matematiky je ale známo, že násobení je možno převést na součet logaritmů nebo dělení na rozdíl logaritmů. Předpokládejme obecně, že máme realizovat součin dvou signálů $x$ a $y$ a tento součin podělit signálem $z$ tj.

$$
w=\frac{x y}{z} .
$$

Jestliže obě strany rovnice logaritmujeme dostáváme

$$
\ln w=\ln x+\ln y-\ln z .
$$

Výsledek pak získáme odlogaritmováním obou stran rovnice

$$
w=e^{(\ln x+\ln y-\ln z)},
$$

popř. se někdy používá zápis

$$
w=\exp ^{(\ln x+\ln y-\ln z)} .
$$

Z těchto úvah vyplývá, že pokud máme realizovat součin či podíl dvou signálů, můžeme jej pomocí logaritmických měničů převést na jejich součet či rozdíl a konečný výsledek pak získat pomocí exponenciálního měniče.

Ke konstrukci logaritmických či exponenciálních převodníků je možno využít „přírodních“ charakteristik některých nelineárních prvků jako jsou polovodičové diody a tranzistory. Současně se využívá myšlenka, že pokud nelineární prvek umístěný ve zpětnovazební větvi operačního zesilovače realizuje logaritmickou funkci, pak takovýto prvek umístěný ve vstupní větvi operačního zesilovače bude realizovat exponenciální funkci, která je k funkci logaritmické inversní. 
Logaritmický prevodník s diodou je zapojen podle Obr. 8.26 pro proud tekoucí diodou platí v širokém rozmezí proudů (několik dekád) vztah

$$
i_{\mathrm{D}}=I_{0} e^{u_{\mathrm{D}} / m U_{\mathrm{T}}}-1,
$$

kde $I_{0}$ je nasycený teoreticky odvozený proud tekoucí diodou v závěrném směru, $U_{\mathrm{T}}$ je teplotní napětí a $m$ korekční činitel závislý na typu diody $(1>\mathrm{m}<2)$. Graficky je průběh ampérvoltové charakteristiky diody vynesen v semilogaritmickém měřítku na Obr. 8.25c. Při pokojové teplotě $296 \mathrm{~K}$ má činitel $U_{\mathrm{T}}=k T / q$ ( $q$ je velikost elektrického náboje $1,6 \cdot 10^{-19} \mathrm{C}$, k je Boltzmannova konstanta $1,38 \cdot 10^{-23} \mathrm{~J} / \mathrm{K}$ a $T$ je teplota $\mathrm{v}$ Kelvinech) přibližně hodnotu $25,5 \mathrm{mV}$. Pro napětí $u_{\mathrm{D}}>0,1 \mathrm{~V}$ převládá $\mathrm{v}$ rovnici (8-42) exponenciální člen a budeme-li předpokládat $m=1$, můžeme psát

$$
i_{\mathrm{D}} \approx I_{0} e^{u_{\mathrm{D}} / U_{\mathrm{T}}}, \operatorname{pro} u_{\mathrm{D}}>0,1 \mathrm{~V}
$$

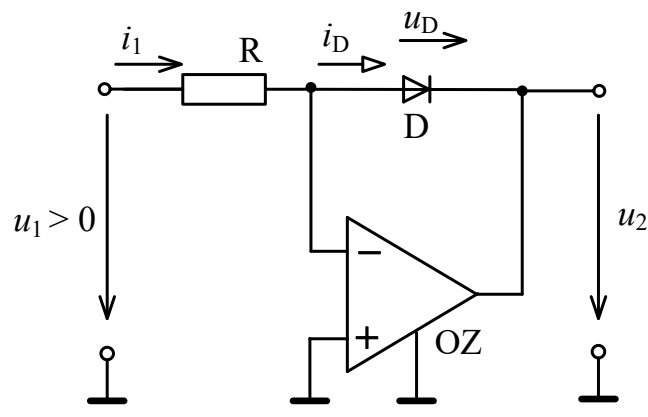

a
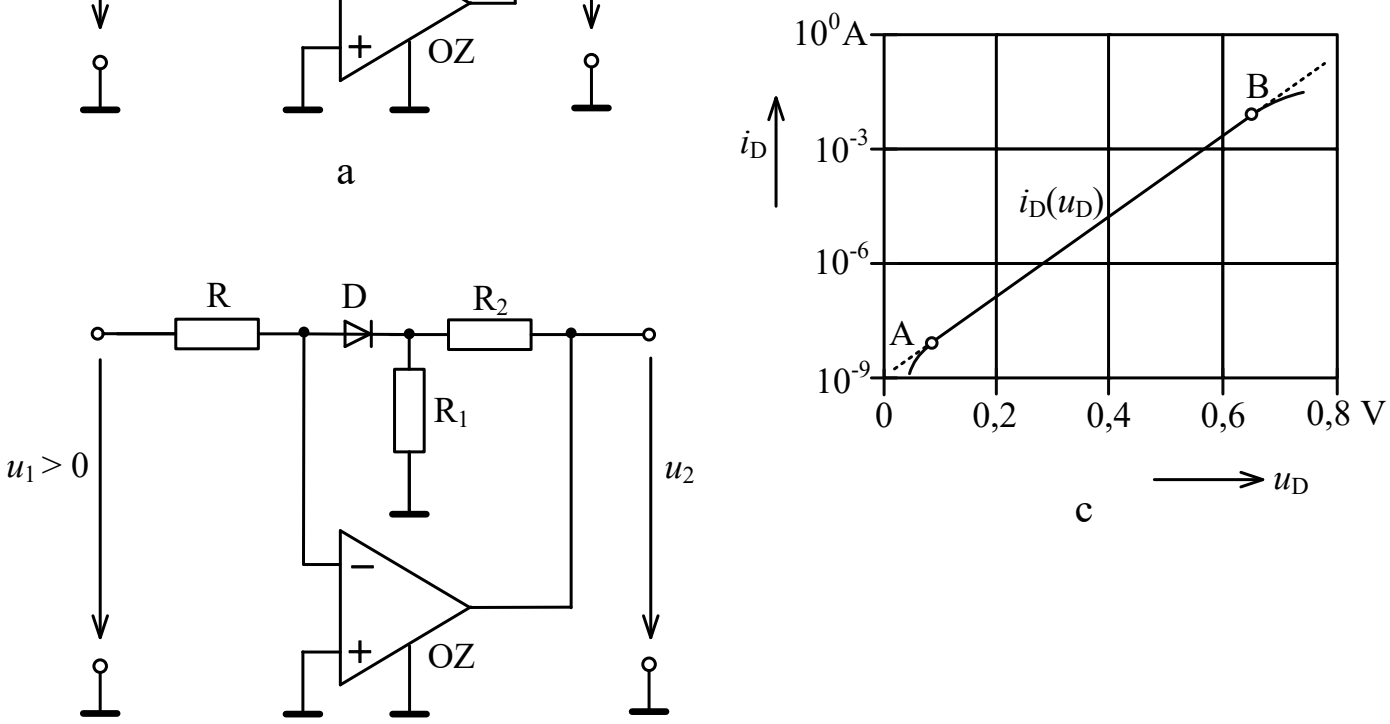

$\mathrm{b}$

Obr. 8.26: a) Logaritmický převodník s diodou, b) zvýšení výstupního napětí, c) ampérvoltová charakteristika diody v semilogaritmickém měřítku

Takováto exponenciální závislost představuje v semilogaritmickém zobrazení přímku tak, jak je to vidět na Obr. 8.26c) mezi body A-B. Logaritmujeme-li obě strany předchozí rovnice, můžeme stanovit vztah pro napětí na diodě

$$
u_{\mathrm{D}} \approx U_{\mathrm{T}} \ln \frac{i_{\mathrm{D}}}{I_{0}} .
$$

Protože v logaritmickém převodníku na Obr. 8.26a) platí $i_{\mathrm{D}} \approx i_{1} \approx u_{1} / R$ a $u_{\mathrm{D}} \approx-u_{2}$, snadno stanovíme výraz popisující chování logaritmického převodníku 


$$
u_{2} \approx-U_{\mathrm{T}} \ln \frac{u_{1}}{R I_{0}} .
$$

Výstupní napětí obvodu na Obr. 8.26a) se změní o cca $60 \mathrm{mV}$ při změně vstupního napětí o jednu dekádu a maximální výstupní napětí takovéhoto logaritmického převodníku bude kolem 0,6 V. Obvykle je však požadováno vyšší napětí převodníku, např. změna výstupního napětí o $1 \mathrm{~V}$ při změně vstupního napětí o jednu dekádu. Pak je možno použít upravené zapojení uvedené na Obr. 8.26b). Bude-li rezistorový dělič $\mathrm{R}_{1}, \mathrm{R}_{2}$ dostatečně „tvrdý“, je možno zanedbat zatěžovací proud děliče a pak

$$
u_{2} \approx-\frac{R_{1}+R_{2}}{R_{1}} U_{\mathrm{T}} \ln \frac{u_{1}}{R I_{0}} .
$$

Zapojení logaritmického převodníku s diodou má však řadu nevýhod. Jednak vztah (8-42) popisující chování diody platí pouze v relativně malém rozmezí proudů tekoucích diodou (korekční činitel $m$ závisí na protékajícím proudu) a jednak je vztah značně závislý na teplotě. Napětí $U_{\mathrm{T}} \mathrm{v}$ rov.(8-44) je lineárně závislé na teplotě a má kladný teplotní koeficient $0,33 \% / \mathrm{K}$. Tuto teplotní závislost můžeme částečně kompenzovat v obvodě podle Obr. 8.26b) nahrazením rezistoru $R_{1}$ teplotně závislým prvkem se stejným teplotním činitelem. Významnější a zřetelně nelineární teplotní závislost však vykazuje proud $I_{0}$, který se přibližně zdvojnásobí při zvýšení teploty o $10 \mathrm{~K}$. To omezuje přesný logaritmický převod obvykle jen na 2 dekády budicího signálu.

Exponenciální převodník sdiodou. Zaměníme-li lineární a nelineární prvek v logaritmickém převodníku, dostaneme převodník s exponenciální převodní charakteristikou. $\mathrm{Na}$ Obr. 8.27 je uveden př́ílad zapojení jednoduchého převodníku s exponenciální charakteristikou, která využívá polovodičovou diodu.

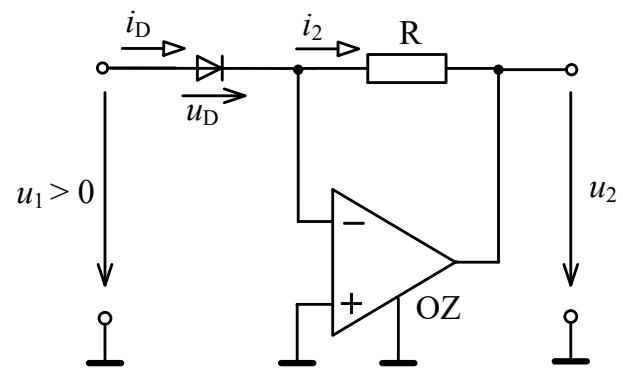

Obr. 8.27: Jednoduchý exponenciální převodník s diodou

Obdobnými postupy jako u logaritmického převodníku můžeme pro zapojení nakreslené na Obr. 8.27 odvodit jeho výstupní napětí. $\mathrm{V}$ tomto př́ípadě $u_{1} \approx u_{\mathrm{D}} \mathrm{a} i_{\mathrm{D}} \approx i_{2} \approx-u_{2} / R \mathrm{a}$ po dosazení do rov.(8-44) bude

$$
u_{1} \approx U_{\mathrm{T}} \ln \frac{-u_{2}}{R I_{0}}
$$

resp.

$$
\frac{u_{1}}{U_{\mathrm{T}}} \approx \ln \frac{-u_{2}}{R I_{0}}
$$

Z této rovnice již snadno po odlogaritmování obou stran rovnice vyčíslíme výstupní napětí

$$
u_{2} \approx-R I_{0} \mathrm{e}^{u_{1} / U_{\mathrm{T}}}
$$


Obdobně jako logaritmický převodník s diodou je toto uspořádání vhodné pouze pro 2 dekády budoucího signálu.

Logaritmický prevodník s tranzistorem. Pro přesný logaritmický převod je vhodnější používat bipolární tranzistory $\mathrm{v}$ zapojení uvedeném na Obr. 8.28a. Jestliže připojíme bázi tranzistoru T na nulový potenciál, je kolektorový proud dán rovnicí (př́i $u_{\mathrm{CB}} \approx \mathrm{OV}$ )

$$
i_{\mathrm{C}} \approx \alpha I_{\mathrm{ES}} \mathrm{e}^{u_{\mathrm{BE}} / m U_{\mathrm{T}}}-1
$$

ve které $\alpha \equiv h_{21 \mathrm{~B}}$ značí proudový zesilovací činitel v zapojení se společnou bází, $I_{\mathrm{ES}}$ zpětný emitorový saturační proud a $m$ korekční činitel závislý na typu tranzistoru $(1<m<4)$. Graficky je tato závislost $\mathrm{v}$ semilogaritmickém měřítku vynesena na Obr. 8.28b. Je známo, že závislost parametrů $\alpha$ a $m$ na proudu se vzájemně kompenzuje [9]. Proto můžeme psát

$$
i_{\mathrm{C}} \approx \gamma I_{\mathrm{ES}} \mathrm{e}^{u_{\mathrm{BE}} / m U_{\mathrm{T}}}-1 \text {. }
$$

Koeficient $\gamma$ závisí jen nepatrně na protékajícím proudu a jeho hodnota je přibližně rovna jedné. Pro hodnoty $u_{\mathrm{BE}}>0,1 \mathrm{~V}$ převládá $\mathrm{v}$ rovnici exponenciální člen a proto

$$
i_{\mathrm{C}} \approx I_{\mathrm{ES}} \mathrm{e}^{u_{\mathrm{BE}} / U_{\mathrm{T}}} \text {. }
$$

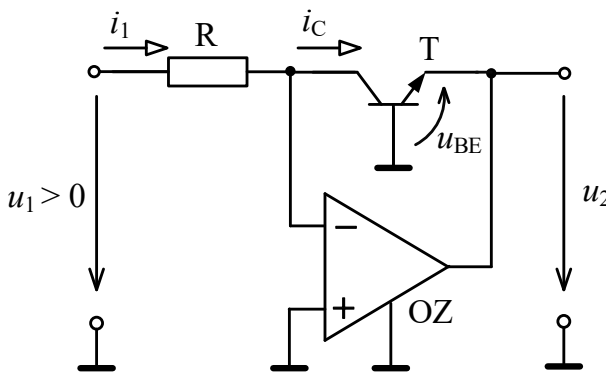

$\mathrm{a}$

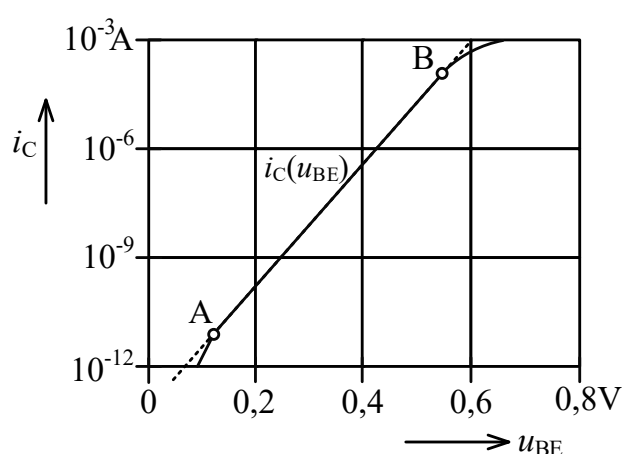

$\mathrm{c}$

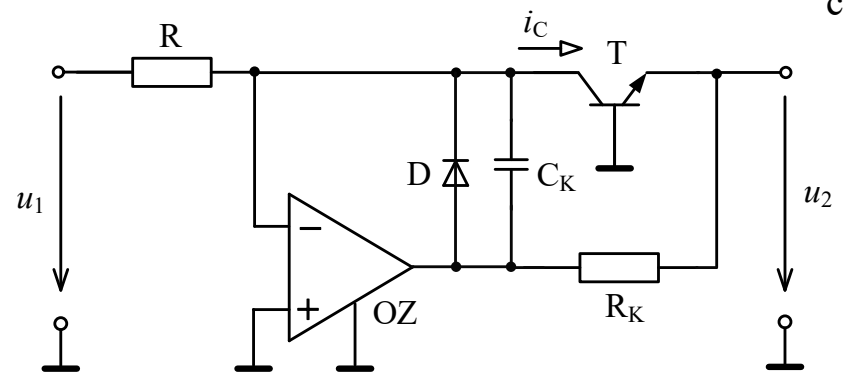

b

Obr. 8.28: a) Logaritmický převodník s tranzistorem, b) závislost mezi kolektorovým proudem a napětím na přechodu BE tranzistoru, c) zajištění stability logaritmického převodníku

Protože $i_{\mathrm{C}} \approx i_{1} \approx u_{1} / R$ a $u_{\mathrm{BE}} \approx-u_{2}$, můžeme na základě znalosti vztahu (8-52) pro výstupní napětí psát

$$
u_{2} \approx-U_{\mathrm{T}} \ln \frac{u_{1}}{I_{\mathrm{ES}} R}
$$


V logaritmických převodnících se uživají křemíkové difusní tranzistory planárního typu, pro které se uvádí logaritmující schopnost v rozsahu 9 dekád. Pokud není ale provedena teplotní kompenzace, je rozsah převodníku s tranzistorem omezen na 6 dekád.

Přestože princip logaritmického převodníku je velmi jednoduchý, skutečné zapojení je s ohledem na zajištění stability zpětnovazební smyčky a na nutnou kompenzaci teplotních vlivů mnohem složitější. Problém stability logaritmického převodníku je složitý v důsledku přídavného zesílení vloženého tranzistoru nelineárního charakteru zpětné vazby a její kmitočtové závislosti. Tranzistor T totiž zesílení obvodu zpětné vazby zapojení zvyšuje o jeho vlastní napětové zesílení a obvod je nachýlený ke kmitání. Napět’ové zesílení tranzistorového stupně může být jednoduše redukováno zapojením rezistoru $\mathrm{R}_{\mathrm{K}}$ mezi emitor a výstup $\mathrm{OZ}$ (Obr. $8.28 \mathrm{c})$. Tím se omezí napětové zesílení tranzistoru na hodnotu $R / R_{\mathrm{K}}$. Při volbě hodnoty rezistoru $\mathrm{R}_{\mathrm{K}}$ vycházíme $\mathrm{z}$ požadavku, aby na výstupu $\mathrm{OZ}$ nebylo při maximálním proudu tekoucím za provozu tranzistorem $\mathrm{T}$ překročeno povolené maximální výstupní napětí. Rychlá zpětná vazba pomocí kapacitoru $C_{K}$ pak zajištuje celkovou stabilitu obvodu. Dioda $\mathrm{D}$ chrání převodník před saturací $\mathrm{OZ} v$ př́padě, kdyby na vstup zapojení bylo přivedeno záporné vstupní napětí.

Hlavní nedostatek uvedeného logaritmického převodníku je však ve velké teplotní nestabilitě jeho parametrů. Je to způsobeno tím, že $U_{\mathrm{T}}$ a $I_{\mathrm{ES}}$ značně závisí na teplotě. Při zvýšení teploty v rozmezí 20 až $50^{\circ} \mathrm{C}$ se napětí $U_{\mathrm{T}}$ zvýší asi 1,1 krát, přičemž zpětný emitorový saturační proud se změní desetkrát. Vliv teplotních změn zpětného emitorového saturačního proudu $I_{\mathrm{ES}}$ můžeme změnit pomocí diferenčního zapojení tranzistorů (viz Obr. 8.29). Předpokládejme, že vlastnosti tranzistorů budou shodné. Pak podle rov.(8-52) platí

$$
i_{\mathrm{C} 1} \approx I_{\mathrm{ES}} \mathrm{e}^{u_{\mathrm{BE} 1} / U_{\mathrm{T}}}, i_{\mathrm{C} 2} \approx I_{\mathrm{ES}} \mathrm{e}^{u_{\mathrm{BE} 2} / U_{\mathrm{T}}} .
$$

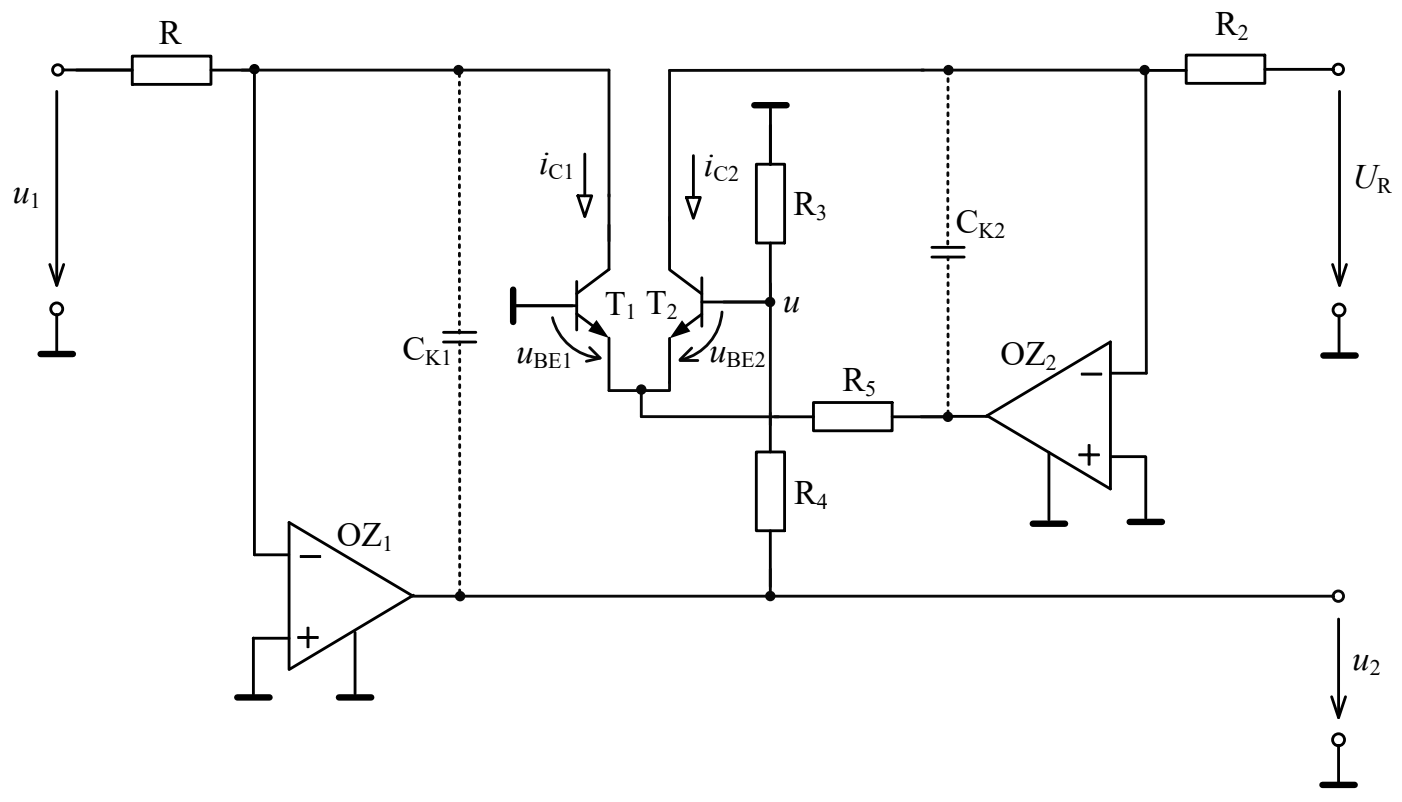

Obr. 8.29: Teplotně kompenzovaný logaritmický převodník

Pro vzájemný poměr kolektorových proudů pak můžeme psát

$$
\frac{i_{\mathrm{C} 2}}{i_{\mathrm{C} 1}} \approx \frac{I_{\mathrm{ES}} \mathrm{e}^{u_{\mathrm{BE} 2} / U_{\mathrm{T}}}}{I_{\mathrm{ES}} \mathrm{e}^{u_{\mathrm{BE} 1} / U_{\mathrm{T}}}}=\mathrm{e}^{\left(u_{\mathrm{BE} 2}-u_{\mathrm{BE} 1}\right) / U_{\mathrm{T}}} .
$$

Označíme-li $u \approx u_{\mathrm{EB} 2}-u_{\mathrm{EB} 1}$, můžeme psát 


$$
\frac{i_{\mathrm{C} 2}}{i_{\mathrm{C} 1}} \approx \mathrm{e}^{u / U_{\mathrm{T}}}
$$

Logaritmování obou stran rovnice a po malé úpravě dostaneme

$$
u \approx U_{\mathrm{T}} \ln \frac{i_{\mathrm{c} 2}}{i_{\mathrm{c} 1}} .
$$

Za předpokladu, že zesilovače se budou blížit ideálním a zanedbáváme-li bázový proud tranzistoru $\mathrm{T}_{2}$, v obvodu také platí

$$
i_{\mathrm{C} 1} \approx \frac{u_{1}}{R_{1}}, i_{\mathrm{C} 2} \approx \frac{U_{\mathrm{R}}}{R_{2}}, u \approx \frac{R_{3}}{R_{3}+R_{4}} u_{2} .
$$

Po dosazení těchto vztahů do rov.(8-55) a za předpokladu, že $R_{1}=R_{2}$ dostaneme

$$
u_{2} \approx \frac{R_{3}+R_{4}}{R_{3}} U_{\mathrm{T}} \ln \frac{U_{\mathrm{R}}}{u_{1}}=-\frac{R_{3}+R_{4}}{R_{3}} U_{\mathrm{T}} \ln \frac{u_{1}}{U_{\mathrm{R}}} .
$$

Poznamenejme, že zpětný emitorový proud $I_{\mathrm{ES}}$ se díky diferenčnímu uspořádání tranzistorů ve vztahu pro výstupní napětí vůbec neuplatní. Přitom musí být zajištěno, že oba tranzistory jsou umístěny na jednom čipu a je tedy předpoklad, že jejich vlastnosti jsou shodné i při změně okolní teploty. Odpor rezistoru $R_{5}$ také vztah pro výstupní napětí neovlivní. Odpor tohoto rezistoru se vybere tak, aby úbytek napětí na něm byl menší, než je povolené výstupní napětí zesilovače $\mathrm{OZ}_{2}$. Jestliže je na závadu ještě teplotní závislost teplotního napětí $U_{\mathrm{T}}$, lze ji zmenšit pomocí odporu rezistoru $\mathrm{R}_{3}$, který má mít kladný teplotní součinitel $0,33 \% /{ }^{\circ} \mathrm{C}$. Kmitočtová korekce obou zesilovačů je realizována stejně jako u zapojení na Obr. 8.28c pomocí kapacitorů $\mathrm{C}_{\mathrm{K} 1}$ a $\mathrm{C}_{\mathrm{K} 2}$.

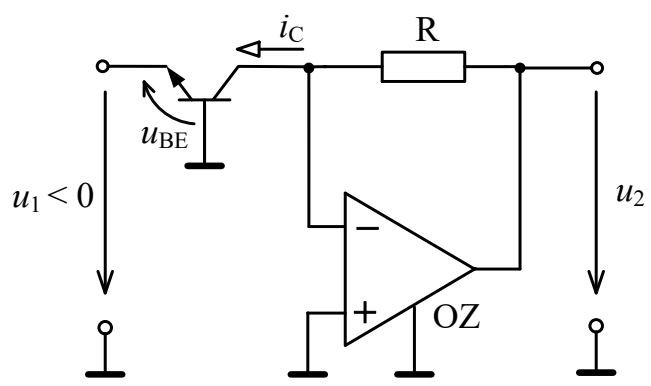

Obr. 8.30: Zapojení jednoduchého exponenciálního převodníku

Exponenciální prevodník s tranzistorem je uveden na Obr. 8.30. Jestliže na vstup přivedeme záporné napětí, poteče tranzistorem ve shodě s rov.(8-52) proud

$$
i_{\mathrm{C}} \approx I_{\mathrm{ES}} \mathrm{e}^{u_{\mathrm{BE}} / U_{\mathrm{T}}}=I_{\mathrm{ES}} \mathrm{e}^{-u_{1} / U_{\mathrm{T}}} \text { pro } u_{1}<-0,1 \mathrm{~V}
$$

a výstupní napětí pak

$$
u_{2} \approx i_{\mathrm{C}} R \approx I_{\mathrm{ES}} \mathrm{e}^{-u_{1} / U_{\mathrm{T}}}
$$

Obdobně jako v př́padě logaritmického převodníku na Obr. 8.29 můžeme teplotní vlastnosti exponenciálního převodníku zlepšit diferenčním uspořádáním tranzistorů tak, jak je to naznačeno na Obr. 8.31. Pokud budeme předpokládat shodné vlastnosti tranzistorů, zůstávají rov.(8-54) v platnosti a pro poměr proudů platí 


$$
\frac{i_{\mathrm{C} 2}}{i_{\mathrm{C} 1}} \approx \mathrm{e}^{\left(u_{\mathrm{BE} 2}-u_{\mathrm{BE} 1}\right) / U_{\mathrm{T}}}=e^{u / U_{\mathrm{T}}} .
$$

Pro zapojení na Obr. 8.31 platí také rovnice

$$
i_{\mathrm{C} 1} \approx \frac{U_{\mathrm{R}}}{R_{1}}, i_{\mathrm{C} 2} \approx \frac{u_{2}}{R_{2}}, u \approx \frac{R_{3}}{R_{3}+R_{4}} u_{1} .
$$

Bude-li $R_{1}=R_{2}$, pak po dosazení těchto rovnic do vztahu (8-62) dostaneme pro výstupní napětí exponenciálního převodníku

$$
u_{2} \approx U_{\mathrm{R}} \mathrm{e}^{u_{1} R_{3} /\left(R_{3}+R_{4}\right) U_{\mathrm{T}}}
$$

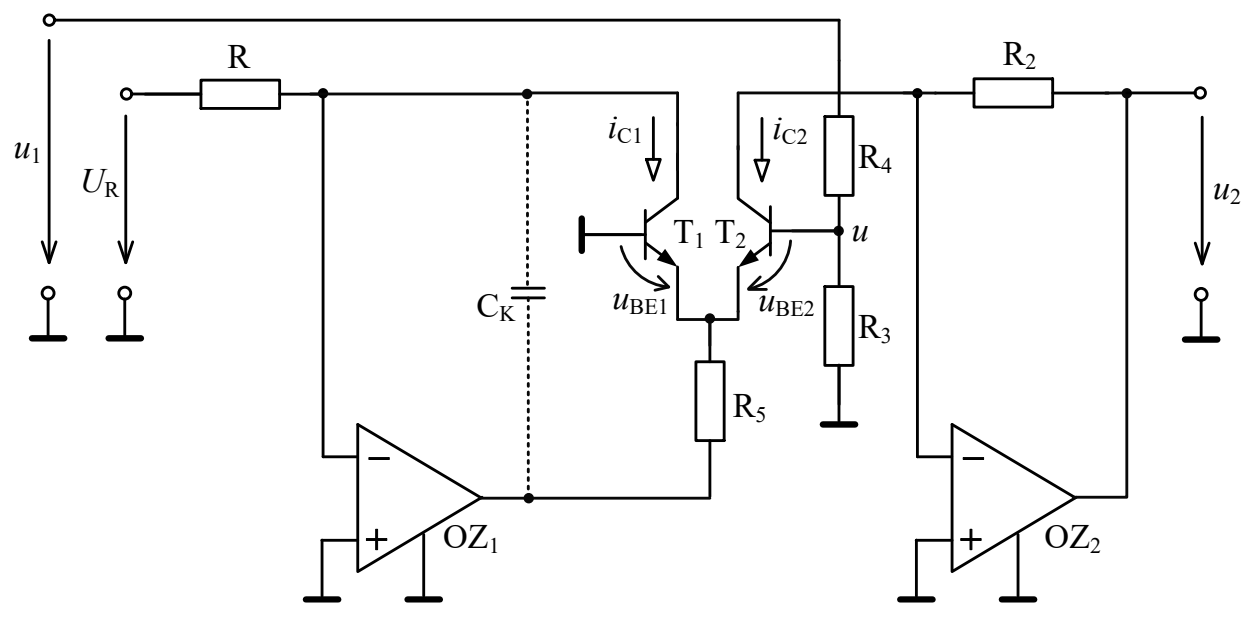

Obr. 8.31: Teplotně kompenzovaný exponenciální převodník

Vidíme, že pokud budou tranzistory na stejném čipu, tak se teplotní závislost proudu $I_{\mathrm{ES}}$ neprojeví. Odpor rezistoru $\mathrm{R}_{5}$ nemá na výstupní napětí vliv, jen je zapotřebí zajistit, aby na něm nevznikl větší úbytek napětí, než je povolené výstupní napětí zesilovače $\mathrm{OZ}_{1}$.

Analogová násobička/dělička s logaritmickým a exponenciálním převodníkem, která realizuje rov.(8-38) převedením na součet či rozdíl logaritmů podle rov. (8-40) je uvedena na Obr. 8.32. Zapojení využívá tři logaritmické převodníky a jeden převodník exponenciální. Na výstupech logaritmických převodníků s $\mathrm{OZ}_{2} \mathrm{a} \mathrm{OZ}_{4}$ bude napětí

$$
u_{1} \approx-U_{\mathrm{T}} \ln \frac{u_{\mathrm{Y}}}{I_{\mathrm{ES}} R}, u_{2} \approx-U_{\mathrm{T}} \ln \frac{u_{\mathrm{Z}}}{I_{\mathrm{ES}} R}
$$

Pro kolektorové proudy tranzistorů $\mathrm{T}_{1}$ a $\mathrm{T}_{2}$ platí rovnice (8-54) a pro jejich poměr i zde platí rov.(8-55), tj.

$$
\frac{i_{\mathrm{C} 2}}{i_{\mathrm{C} 1}} \approx \mathrm{e}^{\left(u_{\mathrm{BE} 2}-u_{\mathrm{BE} 1}\right) / U_{\mathrm{T}}} .
$$

Nyní však $u_{\mathrm{BE} 2}-u_{\mathrm{BE} 1}=u_{2}-u_{1}$ a tedy 


$$
\frac{i_{\mathrm{c} 2}}{i_{\mathrm{c} 1}} \approx \mathrm{e}^{\left(u_{2}-u_{1}\right) / U_{\mathrm{T}}}
$$

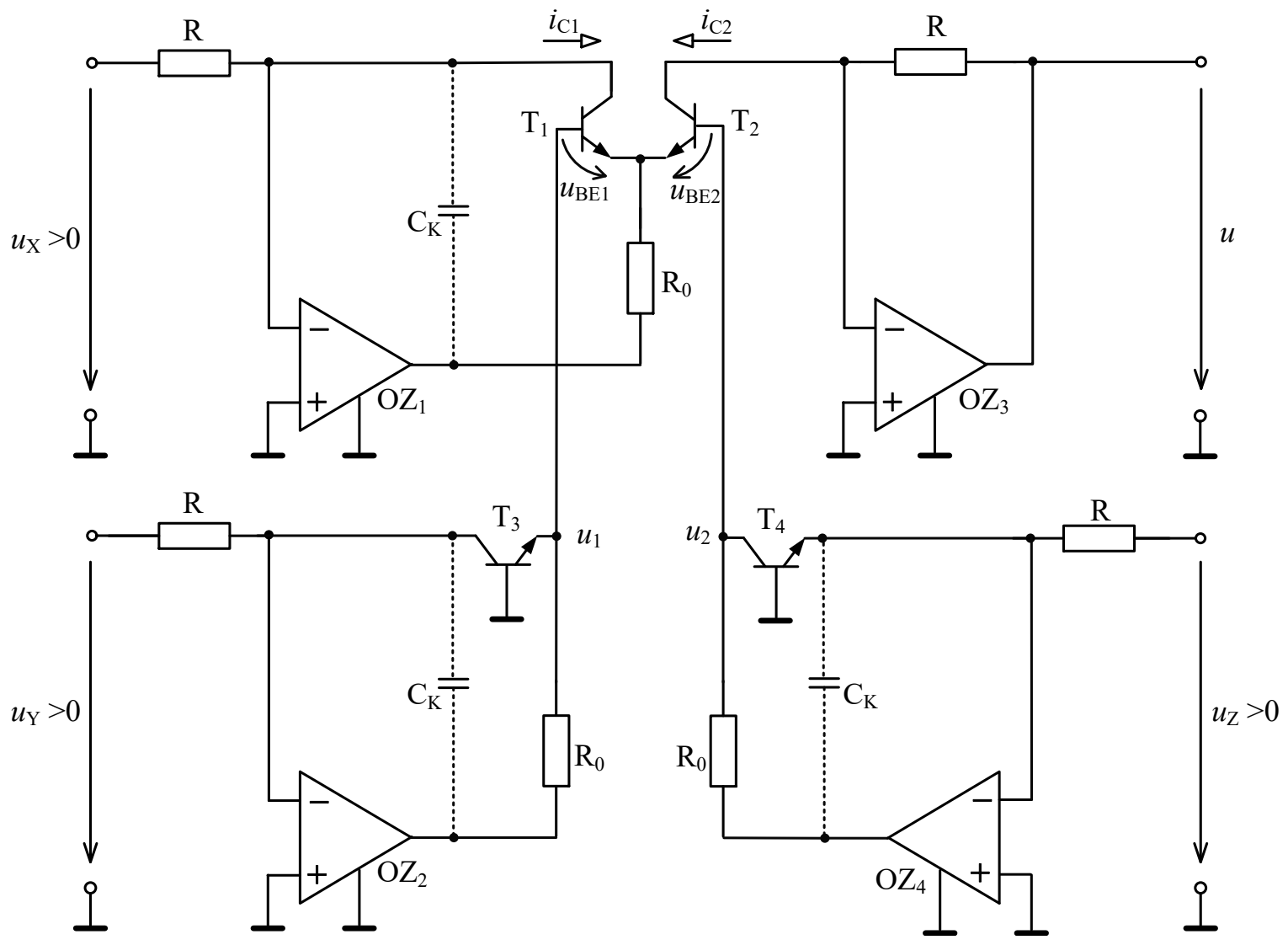

Obr. 8.32: Analogová násobička/dělička

Protože $i_{\mathrm{C} 1} \approx u_{\mathrm{X}} / R, i_{\mathrm{C} 2} \approx u / R$ a napětí $u_{1}$ a $u_{2}$ jsou dány vztahy (8-65), můžeme z rov. (8-67) vyčíslit

$$
\frac{u}{u_{\mathrm{X}}} \approx \mathrm{e}^{-\ln \frac{u_{\mathrm{Z}}}{I_{\mathrm{ES}} R}+\ln \frac{u_{\mathrm{Y}}}{I_{\mathrm{ES}} R}}
$$

a tedy

$$
u \approx u_{\mathrm{x}} \mathrm{e}^{\ln \frac{u_{\mathrm{Y}}}{u_{\mathrm{Z}}}}=\frac{u_{\mathrm{X}} u_{\mathrm{Y}}}{u_{\mathrm{Z}}} .
$$

Je zřejmé, že pokud všechny čtyři tranzistory budou na stejném čipu a budou mít stejné vlastnosti, tak se teplotní změny proudu $I_{\mathrm{ES}}$, ale ani změny teplotního napětí $U_{\mathrm{T}}$ neuplatní. Poznamenejme ještě, že všechna vstupní napětí musí být kladná a nesmí být rovna nule. Uspořádání analogové násobičky/děličky s logaritmickým a exponenciálním převodníkem je na tolik výhodné, že jej většina výrobců analogových obvodů vyrábí v integrované podobě.

\subsection{Operační usměrňovače}

Klasická řešení jednocestných či dvoucestných diodových usměrňovačů jsou zatížena velkou chybou způsobenou tím, že pro otevření křemíkových diod je zapotřebí napětí větší než 
asi 0,6 V. Zvýšení přesnosti až o několik řádů umožňuje propojení diod s operačním zesilovačem. Obvody jsou známy pod názvy „operační usměrňovač“, „zesilovač absolutní hodnoty“, či „ideální dioda“. Tyto obvody jsou obvykle v publikacích kvalifikovány jako obvody s nelineární zpětnou vazbou. Ve skutečnosti patří fyzikální podstatou své činnosti do samostatné třídy obvodů s lineární zpětnou vazbou, avšak s nelineárním rozdělováním výstupního signálu operačního zesilovače podle polarity, kdy pro každou polaritu je nutno vést samostatnou zpětnovazební cestu.

Jednocestný operační usměrňovač je zapojen podle Obr. 8.33a. K rozdělení zpětnovazebních cest podle polarity slouží diody $\mathrm{D}_{1}$ a $\mathrm{D}_{2}$. Činnost obvodu je možno stručně charakterizovat takto: Přivedeme-li na vstup napětí $u_{1}$ kladné polarity (napřr. kladnou půlvlnu harmonického střídavého napětí), objeví se na výstupu invertujícího operačního zesilovače záporné napětí, které otevře diodu $\mathrm{D}_{2}$ a usměrňovač se pak chová jako invertující zesilovač s výstupním napětím $u_{2} \approx-u_{1} R_{2} / R_{1}$. Dioda $\mathrm{D}_{1}$ je $\mathrm{v}$ tomto případě uzavřena. Jestliže prrivedeme na vstup napětí $u_{1}<0$ (např. zápornou půlvlnu stř́idavého napětí), dostaneme na výstupu operačního zesilovače kladné napětí, které otevře diodu $\mathrm{D}_{1}$, čímž vznikne stoprocentní záporná vazba a na invertujícím vstupu OZ bude jako obvykle nulové napětí. Dioda $\mathrm{D}_{2}$ je zavřena a na výstupu usměrňovače proto bude nulové napětí $u_{2} \approx 0$. Celkovou činnost usměrňovače můžeme zapsat rovnicí

$$
u_{2} \approx\left\{\begin{array}{ccc}
-\frac{R_{2}}{R_{1}} u_{1} & \text { pro } & u_{1}>0, \\
0 & \text { pro } & u_{1} \leq 0 .
\end{array}\right.
$$

Na Obr. 8.33b) je uvedena úprava zapojení, která klade nižší nároky na kvalitu operačního zesilovače, protože při kladném i záporném vstupním napětí je ve zpětné vazbě zapojen vždy rezistor. Zapojení podle Obr. 8.33a) může totiž způsobit nežádoucí zákmity operačního zesilovače při změně polarity vstupního napětí. Obvod uvedený na Obr. 8.33b) umožňuje získat současně kladné i záporné půlvlny vstupního napětí. Analyticky je obvod popsán rovnicemi

$$
\begin{aligned}
& u_{2} \approx\left\{\begin{array}{ccc}
-\frac{R_{2}}{R_{1}} u_{1} & \text { pro } & u_{1}>0, \\
0 & \text { pro } & u_{1} \leq 0 .
\end{array}\right. \\
& u_{3} \approx\left\{\begin{array}{ccc}
0 & \text { pro } & u_{1} \geq 0, \\
-\frac{R_{3}}{R_{1}} & \text { pro } & u_{1}<0 .
\end{array}\right.
\end{aligned}
$$

Usměrnění se vyznačuje velkou přesností, protože diody jsou řazeny v tzv. přímé větvi zpětnovazební smyčky a velké zesílení předřazeného operačního zesilovače způsobí, že již malé napětí na jeho invertujícím vstupu způsobí otevření jedné či zavření druhé diody. Detail převodní charakteristiky operačního je pro oblast velmi malých napětí uveden na Obr. 8.34a). Pro vyšší napětí se skutečná převodní charakteristika blíží k ideálnímu průběhu podle Obr. 8.33a) Hlavním omezujícím činitelem na vyšších kmitočtech a také při velmi malém napětí jsou tzv. zotavovací procesy v diodách, které vznikají při rychlém přechodu diody z propustné do závěrné oblasti a naopak. Největší vliv má závěrná zotavovací doba diody. Dioda, která byla před tím otevřena, má obě vrstvy polovodiče tvořící usměrňující přechod PN plné volných minoritních nosičů náboje. Pro tyto menšinové nosiče je i při obrácení proudu přechod po krátkou dobu, označovanou jako závěrná zotavovací doba diody $t_{\mathrm{rr}}$, stále průchodný. Teprve po 
odčerpání nahromaděných nosičů (odvedením do okolních obvodů a rekombinací) získá přechod blokovací schopnost.
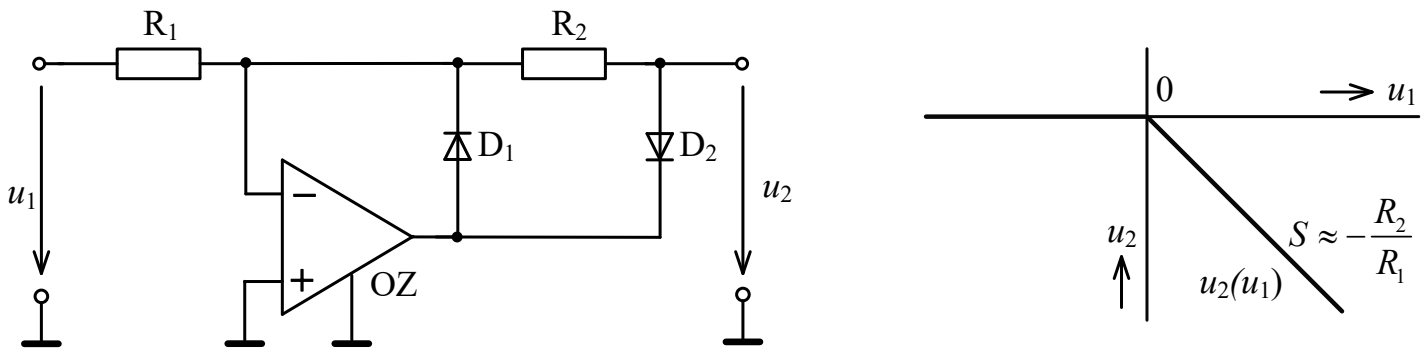

a
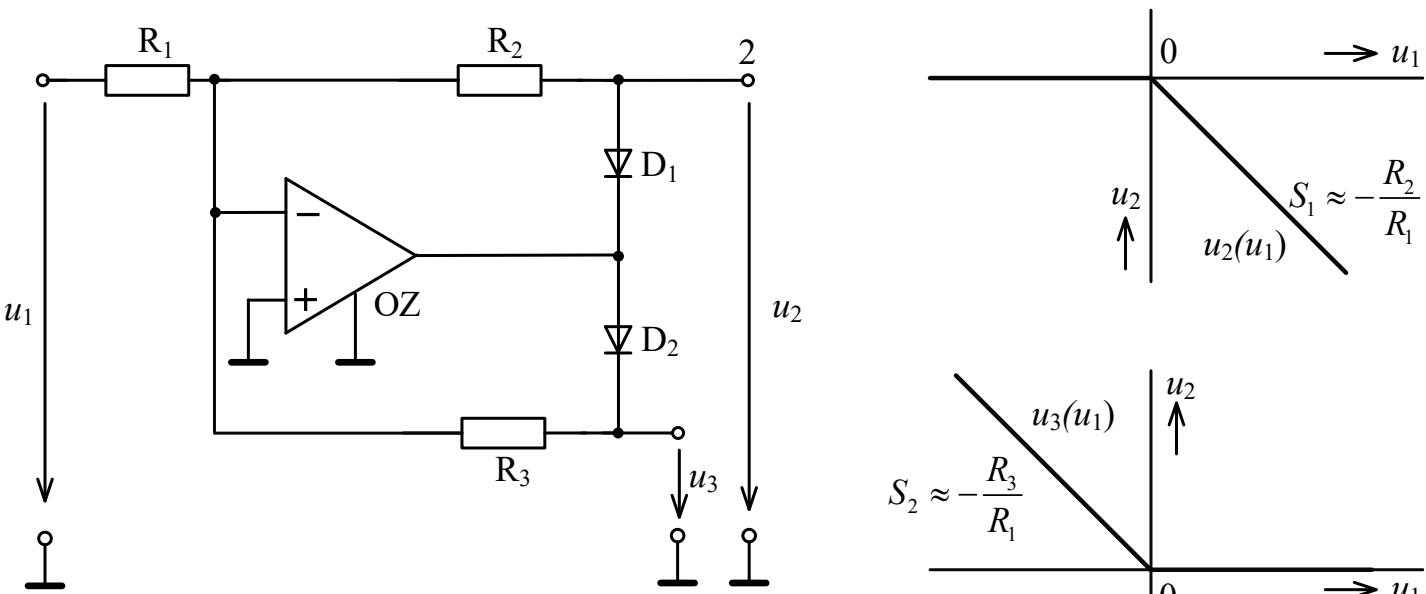

$\mathrm{b}$

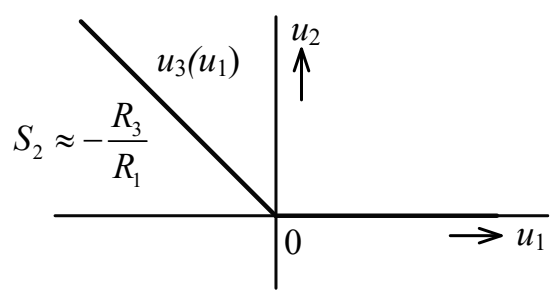

Obr. 8.33: Zapojení jednocestných operačních usměrňovačů a jejich převodní charakteristiky
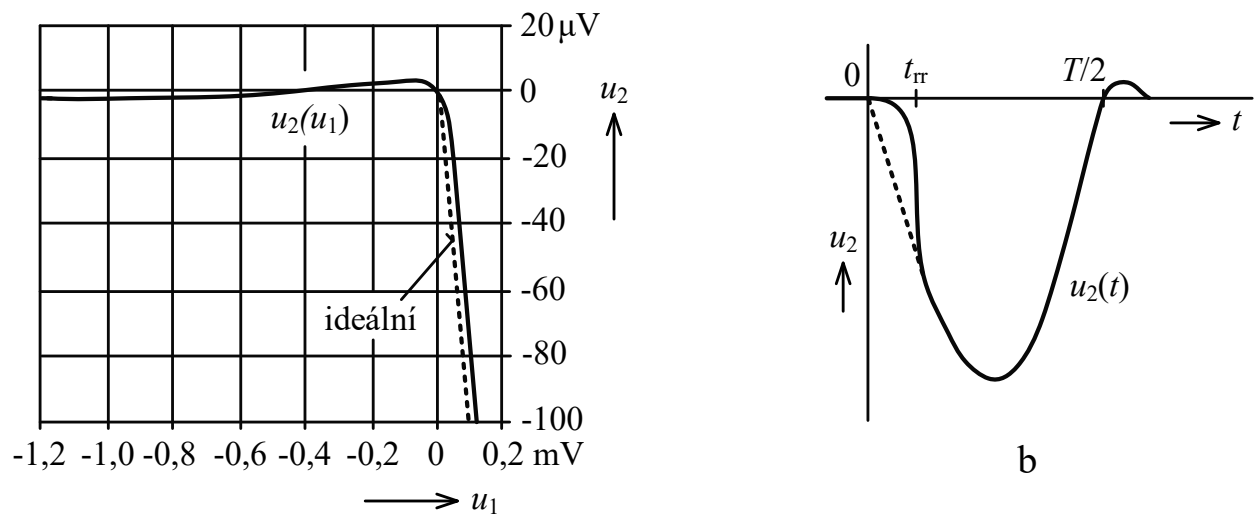

a

Obr. 8.34: a) Detail převodní charakteristiky operačního usměrňovače v okolí nuly (rozdílná měřítka na osách), b) vliv závěrné zotavovací doby diod na operační zesilovač

Předpokládejme, že operační usměrňovač uvedený na Obr. 8.33a) a bude usměrňovat harmonický signál. Bude-li v operačním usměrňovači nejprve otevřena dioda $\mathrm{D}_{1}$ a $\mathrm{D}_{2}$ zavřena, pak po změně polarity vstupního signálu se sice dioda $\mathrm{D}_{2}$ otevře, ale dioda $\mathrm{D}_{1}$ zůstane po dobu závěrné zotavovací doby stále otevřena a na výstupu usměrňovače bude stále nulové napětí. 
Teprve až dioda $\mathrm{D}_{1}$ získá po odčerpání menšinových nosičů blokovací schopnost, naroste výstupní napětí velice rychle na hodnotu, která odpovídá statické převodní charakteristice usměrňovače (viz časový průběh Obr. 8.34b). Závěrná zotavovací dioda $\mathrm{D}_{2}$ má na průběh výstupního napětí pouze malý vliv. Projevuje se jako malý překmit napětí na konci pưlvlny usměrněného napětí.

Díky zpětné vazbě v operačním usměrňovači je provozní režim diod dosti neobvyklý. Okolnost, že při malých vstupních napětích tekou zpětnovazební sítí operačního zesilovače pouze malé proudy způsobuje, že k odvedení menšinových nosičů náboje je potřeba delší doba, která je při extrémně malých vstupních napětích dána především jen vlastní rekombinací minoritních nosičů. $Z$ tohoto důvodu nelze ani pro orientační stanovení vlastností usměrňovače pro malá vstupní napětí použít katalogových údajů o závěrné zotavovací době diod. Ty jsou totiž získány měřením v testovacích obvodech, které umožňují intenzivní odvádění minoritních nosičů. Z uvedených důvodů se doporučuje používat rychlé spínací diody. Samozřejmě nejlepších parametrů se dosahuje se Schottkyho diodami.

Dvoucestné operační usměrňovače. Ze základního jednocestného operačního usměrňovače lze odvodit několik složitějších obvodů, které jsou charakterizovány převodní charakteristikou $u_{2}=k\left|u_{1}\right|$, kde $k$ značí absolutní přenos usměrňovače. Pro tyto obvody se vžil název dvoucestný operační usměrňovač, nebo se také někdy hovoří o zesilovači absolutní hodnoty. Doplníme-li jednocestný operační usměrňovač z Obr. 8.33 a invertujícím sčítacím zesilovačem dostaneme dvoucestný operační zesilovač (viz Obr. 8.35). Přri $u_{1}>0$ bude dioda $\mathrm{D}_{1}$ zavřena, dioda $\mathrm{D}_{2}$ otevřena a na výstupu jednocestného usměrňovače $\mathrm{s} \mathrm{OZ}_{1}$ bude napětí $u \approx-u_{1} R_{2} / R_{1}$. Na výstupu sčítacího zesilovače s $\mathrm{OZ}_{2}$ pak bude

$$
u_{2} \approx-\frac{R_{5}}{R_{4}} u-\frac{R_{5}}{R_{3}} u_{1} \approx\left(\frac{R_{2}}{R_{1}} \frac{R_{5}}{R_{4}}-\frac{R_{5}}{R_{3}}\right) u_{1} \quad \text { pro } u_{1}>0 .
$$
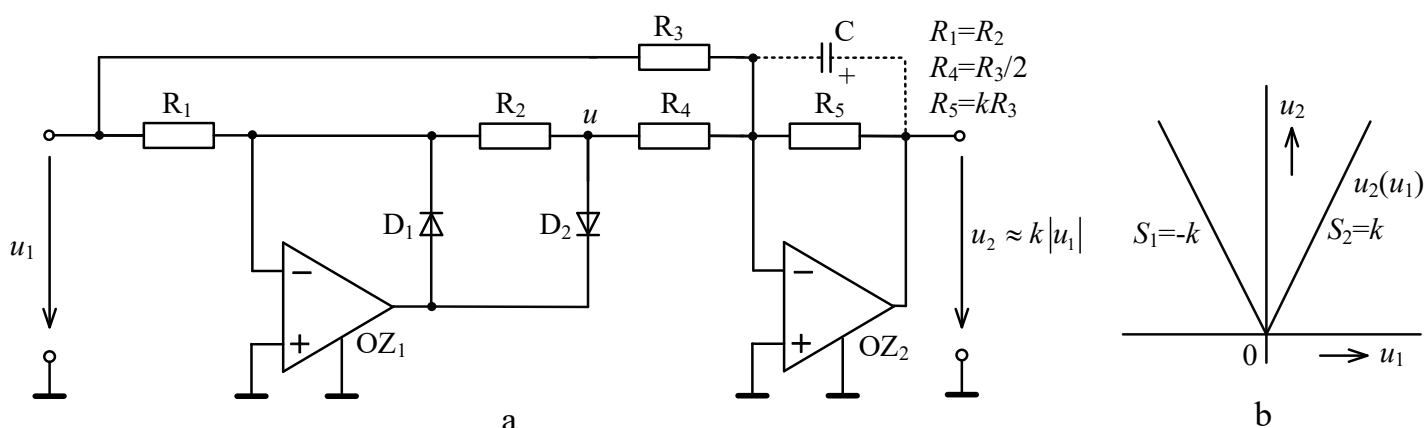

Obr. 8.35: Dvoucestný operační usměrňovač se sčítacím zesilovačem a jeho převodní charakteristika

Pro napětí $u_{1} \leq 0$ bude otevřena dioda $\mathrm{D}_{1}, \mathrm{D}_{2}$ bude zavřena a na výstupu jednocestného usměrňovače bude $u \approx 0$. Na výstupu dvoucestného usměrňovače pak

$$
u_{2} \approx-\frac{R_{5}}{R_{3}} u_{1} \quad \text { pro } u_{1}<0
$$

Aby usměrňovač pracoval jako zesilovač absolutní hodnoty $u_{2}=k\left|u_{1}\right|$ musí v prvním případě pro $u_{1}>0$ (viz rov.(8-73)) platit, že přenos je $k$ je kladný, kdežto pro druhý př́pad pro $u_{1} \leq 0$ (viz rov.(8-74)) pak musí být přenos záporný. Zvolíme-li $R_{1}=R_{2}, R_{4}=R_{3} / 2$ a $R_{2}=k R_{3}$, budou obě podmínky splněny. 
Při použití filtračního kapacitoru $\mathrm{C}$ zapojeného do zpětné vazby $\mathrm{OZ}_{2}$ můžeme získat stejnosměrné napětí, jehož velikost je úměrná střední hodnotě dvoucestně usměrněného napětí. Sčítací obvod se v tomto př́ípadě totiž chová současně jako aktivní filtr. Při usměrňování harmonického signálu lze pro kapacitu kapacitoru filtračního stanovit nerovnost

$$
C \geq \frac{1}{4 \pi f R_{5}} \sqrt{\frac{4}{9 p^{2}}-1},
$$

přičemž $f$ značí kmitočet harmonického signálu a $p$ poměr amplitudy druhé harmonické složky k velikosti stejnosměrné složky dvoucestně usměrněného signálu $\left(p<<1\right.$, např. $\left.p=10^{-3} \triangleq 0,1 \%\right)$.

Jiné uspořádání dvoucestného operačního zesilovače vznikne spojením jednocestného operačního usměrňovače z Obr. 8.33b) s rozdílovým zesilovačem (viz Obr. 8.36). Při $u_{1}>0$ se otevře dioda $\mathrm{D}_{1}$, dioda $\mathrm{D}_{2}$ bude zavřena a zapojení se chová jako dva invertující zesilovače v kaskádě, protože neinvertující vstup $\mathrm{OZ}_{2}$ je v tom př́padě připojen na nulový potenciál, který si na svém invertujícím vstupu udržuje $\mathrm{OZ}_{1}$

$$
u_{2} \approx \frac{R_{2}}{R_{1}} \frac{R_{5}}{R_{4}} u_{1}=k u_{1} \text { pro } u_{1}>0 .
$$

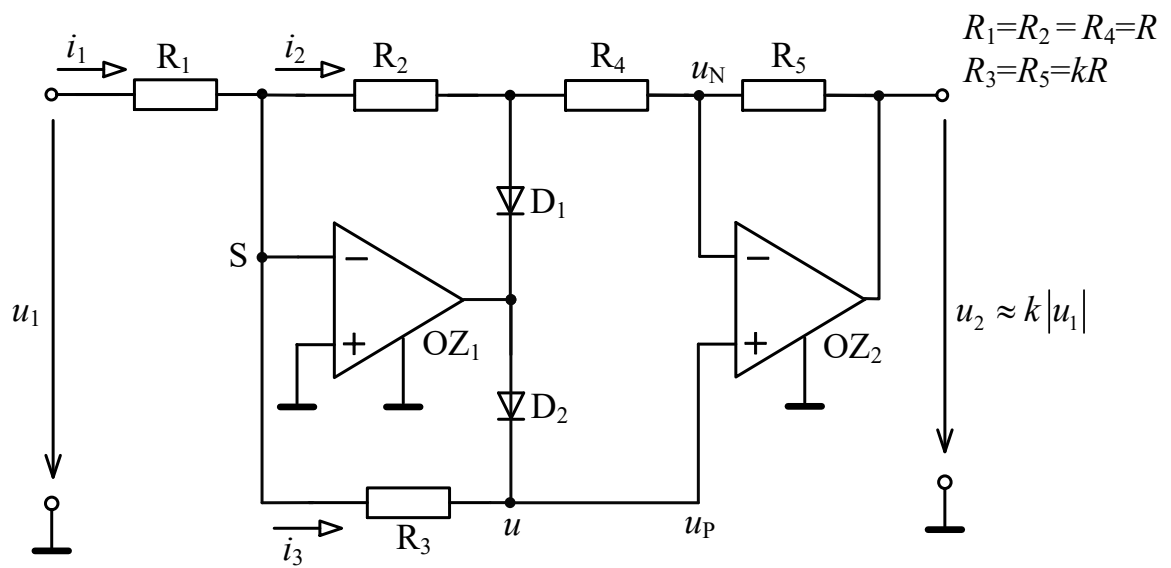

Obr. 8.36: Dvoucestný operační usměrňovač s rozdílovým zesilovačem

Pro záporné vstupní napětí bude $\mathrm{D}_{1}$ rozpojena a $\mathrm{D}_{2}$ sepnuta a $\mathrm{v}$ tomto př́ípadě ke sčítacímu bodu $\mathrm{S}$ zesilovače $\mathrm{OZ}_{1}$ jdou dvě vstupní větve, jedna přes rezistor $\mathrm{R}_{1}$ a druhá $\mathrm{z}$ výstupu $\mathrm{OZ}_{2}$ přes sériovou kombinaci rezistorů $\mathrm{R}_{2}, \mathrm{R}_{4}$ a $\mathrm{R}_{5}$. Na výstupu jednocestného operačního usměrňovače, který se v tomto př́ípadě chová jako invertující sčítací zesilovač, bude napětí

$$
u \approx-\frac{R_{3}}{R_{1}} u_{1}-\frac{R_{3}}{R_{2}+R_{4}+R_{5}} u_{2} .
$$

Protože $\mathrm{OZ}_{1}$ si invertující vstup udržuje na virtuální nule, bude $\mathrm{OZ}_{2}$ zapojen jako neinvertující zesilovač a jeho výstupní napětí

$$
u_{2} \approx\left(1+\frac{R_{5}}{R_{2}+R_{4}}\right) u .
$$

Po dosazení z rov.(8-77) pak můžeme vyčíslit výstupní napětí 


$$
u_{2} \approx-\frac{R_{3}}{R_{1}} \frac{R_{2}+R_{4}+R_{5}}{R_{2}+R_{3}+R_{4}} u_{1}=-k u_{1} \text { pro } u_{1} \leq 0 .
$$

Zvolíme-li $R_{1}=R_{2}=R_{4}=R, R_{3}=R_{5}=k R$, bude $u_{2}=k\left|u_{1}\right|$. Filtrační kapacitor nelze u toho zapojení použít. Pokud chceme získat stejnosměrnou složku dvoucestně usměrněného napětí, musíme za usměrňovač zařadit dolní propust.

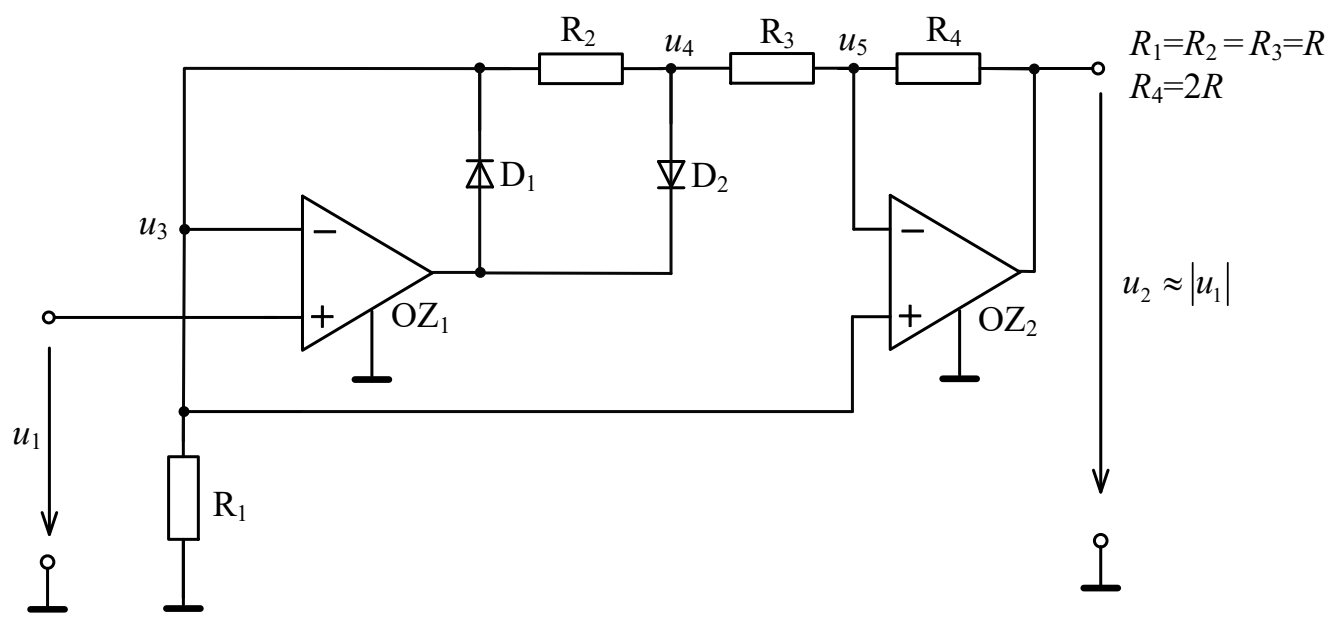

Obr. 8.37: Dvoucestný operační usměrňovač s velkým vstupním odporem a s jednotkovým přenosem

Dvoucestné operační usměrňovače s velkým vstupním odporem. U těchto usměrňovačů využíváme pro získání vysokého vstupního odporu vlastností neinvertujícího zapojení operačního zesilovače. Na Obr. 8.37 je nakresleno jedno takové zapojení usměrňovače. Zapojení umožňuje navrhnout usměrňovač pouze s jednotkovým přenosem. Je-li vstupní napětí kladné, bude dioda $\mathrm{D}_{1}$ otevřena a dioda $\mathrm{D}_{2}$ zavřena. Zesilovač $\mathrm{OZ}_{1}$ je zapojen jako neinvertující zesilovač s jednotkovým přenosem a tedy $u_{3} \approx u_{1}$. V důsledku činnosti $\mathrm{OZ}_{2}$ bude napětí $u_{5}$ stejné jako napětí přivedené na jeho neinvertující vstup, tj. $u_{5} \approx u_{3} \approx u_{1}$ a pak

$$
u_{2} \approx u_{1} \text { pro } u_{1}>0 \text {. }
$$

Při $u_{1} \leq 0$ bude dioda $\mathrm{D}_{1}$ rozpojena, $\mathrm{D}_{2}$ sepnuta a $\mathrm{OZ}_{1}$ pracuje jako neinvertující zesilovač a na jeho výstupu bude napětí $u_{4} \approx\left(1+R_{2} / R_{1}\right) u_{1}$. Zesilovač $\mathrm{OZ}_{2}$ pracuje nyní jako rozdílový zesilovač

$$
u_{2} \approx\left(1+\frac{R_{4}}{R_{3}}\right) u_{3}-\frac{R_{4}}{R_{3}} u_{4} .
$$

Po dosazení za $u_{3} \approx u_{1}$ a za $u_{4}$ bude pro výstupní napětí platit

$$
u_{2} \approx\left(1-\frac{R_{2}}{R_{1}} \frac{R_{4}}{R_{3}}\right) u_{1}=-k u_{1} \quad \text { pro } u_{1} \leq 0 .
$$

Srovnáme-li rov.(8-80) a rov.(8-82) je zřejmé, že musí platit $k=1$. To bude splněno, zvolímeli $R_{1}=R_{2}=R_{3}=R, R_{4}=2 R$. Pak je činnost usměrňovače popsána vztahem $u_{2} \approx\left|u_{1}\right|$. 


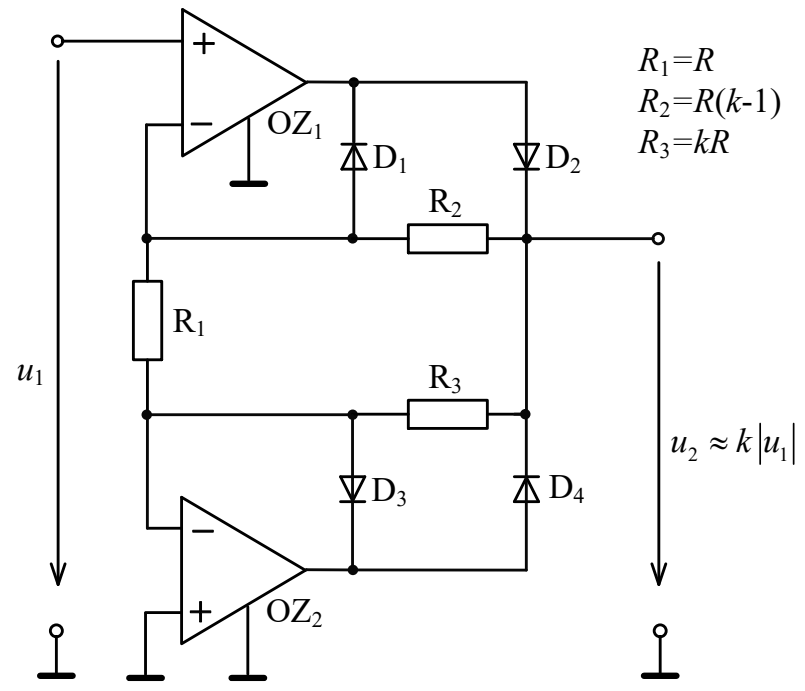

Obr. 8.38: Dvoucestný usměrňovač s velkým vstupním odporem $(k>1)$

Další zapojení dvoucestného operačního usměrňovače s velkým vstupním odporem je naznačeno na Obr. 8.38. Dá se použít pro přenos $k>1$. Přivedeme-li na vstupní svorky usměrňovače kladné napětí, otevřou se diody $\mathrm{D}_{2}$ a $\mathrm{D}_{3}$; diody $\mathrm{D}_{1}$ a $\mathrm{D}_{4}$ zůstanou zavřeny. Zesilovač $\mathrm{OZ}_{1}$ je pak zapojen jako neinvertující, protože resistor $\mathrm{R}_{1}$ je přes zpětnou vazbu $\mathrm{OZ}_{2}$ prakticky připojen na potenciál země, který si na svém invertujícím vstupu udržuje zesilovač $\mathrm{OZ}_{2}$. Výstupní napětí pak

$$
u_{2} \approx\left(1+\frac{R_{2}}{R_{1}}\right) u_{1}=k u_{1}, \quad \text { pro } u_{1}>0 .
$$

Rezistor $R_{3}$ přenosové vlastnosti nyní neurčuje, protože $v$ daném případě je zapojen pouze jako zátěž neinvertujícího zesilovače $\mathrm{s} \mathrm{OZ}_{1}$. Přri opačné polaritě vstupního napětí, tj. $u_{1} \leq 0$ budou otevřeny diody $\mathrm{D}_{1}$ a $\mathrm{D}_{4}$, zatímco diody $\mathrm{D}_{2}$ a $\mathrm{D}_{3}$ budou zavřeny. Invertujícímu zesilovači s $\mathrm{OZ}_{2}$ je předřazen neinvertující zesilovač $\mathrm{OZ}_{1} \mathrm{~s}$ jednotkovým přenosem, a tedy

$$
u_{2} \approx-\frac{R_{3}}{R_{1}} u_{1}=-k u_{1}, \quad \text { pro } u_{1} \leq 0 .
$$

Poznamenejme, že rezistor $\mathrm{R}_{2}$ pro tento prrípad přenosové vlastnosti neovlivní, protože je nyní pouze zátěží invertujícího zesilovače s $\mathrm{OZ}_{2}$. Usměrňovač uvedený na Obr. 8.38 můžeme, pokud zvolíme $R_{1}=R, R_{2}=(k-1) R$, a $R_{3}=k R$, tedy popsat rovnicí $u_{2} \approx k\left|u_{1}\right|,(k>1)$.

Špičkové usměrňovače. V analogové technice jsme často postaveni před problém určit a zachovat maximální hodnotu časově proměnného napětí. Obvod splňující tyto požadavky musí určit okamžik maxima (špičky) či minima signálu, změřit jeho hodnotu a zapamatovat si tuto hodnotu po dobu potřebnou pro zpracování v dalších obvodech. Zapojení takovéhoto obvodu je uvedeno na Obr. 8.39. Jedná se v podstatě o invertující zapojení zesilovače $\mathrm{OZ}_{1}$ doplněného diodami pro rozdělování signálu podle polarity. Pamětový kapacitor $\mathrm{C}_{1}$ slouží $\mathrm{k}$ zapamatování maximálního napětí. Aby bylo možno stanovit nulové počáteční podmínky před zahájením měření, popř. po jeho ukončení je kapacitor přemostěn mechanickým nebo elektrickým spínačem. Aby se pamět'ový kapacitor $\mathrm{C}_{1}$ nevybíjel proudem do zátěže či proudem rezistorem $\mathrm{R}_{2}$, je použit oddělovací zesilovač $\mathrm{s}$ jednotkovým přenosem $\mathrm{s} \mathrm{OZ}_{2}$. Pamětový kapacitor $\mathrm{C}_{1}$ musí mít malý vlastní svod a operační zesilovač $\mathrm{OZ}_{2}$ by měl mít na vstupu tranzistory řízené polem. 


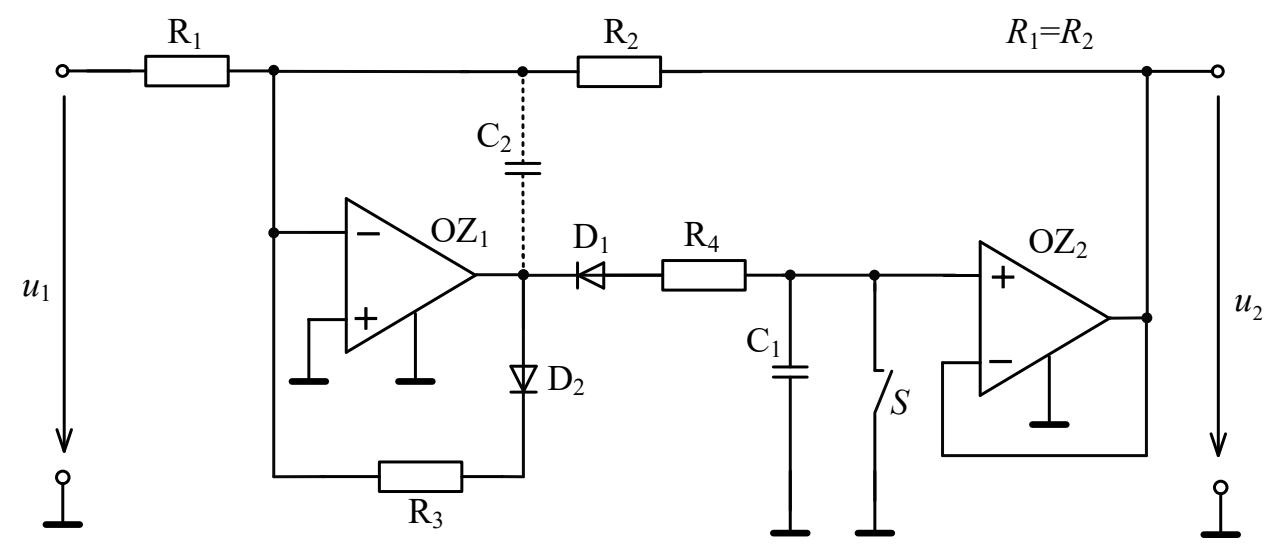

a

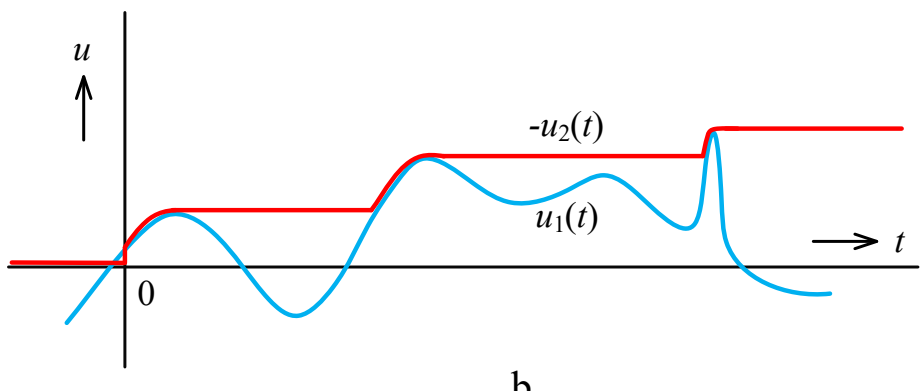

b

Obr. 8.39: a) Invertující špičkový usměrňovač, b) průběhy vstupního a výstupního napětí

Předpokládejme, že pamět'ový kapacitor $C_{1}$ bude před zahájením činnosti obvodu vybit pomocí spínače $\mathrm{S}$. Přivedeme-li na vstup rostoucí kladné napětí, bude na výstupu $\mathrm{OZ}_{1}$ záporné napětí, dioda $D_{1}$ se sepne a dioda $D_{2}$ bude rozpojena. Kapacitor $C_{1}$ se bude nabíjet přes omezovací rezistor $\mathrm{R}_{4}$ na záporné napětí (zapojení invertuje) rovné co do velikosti vstupnímu napětí. Dosáhne-li vstupní napětí maxima a začne zase klesat, přepnou se obě diody a na kapacitoru $\mathrm{C}_{1}$ zůstane ,zapamatována“ hodnota maxima vstupního signálu. Dioda $\mathrm{D}_{1}$ se při dalším provozu otvírá ( $\mathrm{D}_{2}$ zavírá) jen tehdy, dosáhne-li vstupní napětí větší hodnoty, než je poslední zapamatovaná hodnota maxima (viz průběhy na Obr. 8.39b). Kapacitor se v tom případě nabije na novou hodnotu. Přepólováním diod dostaneme špičkový usměrňovač, který reaguje na minimum vstupního napětí. Jelikož při sledování signálu pracuje operační zesilovač $\mathrm{OZ}_{1}$ do kapacitní zátěže, je nutné věnovat pozornost průběhu kmitočtové charakteristiky celého zesilovače se zpětnou vazbou a upravit tuto charakteristiku tak, aby se vyloučil nestabilní stav, avšak aby přechodová charakteristika měla přitom minimální překmity. K tomu účelu v obvodu slouží korekční kapacitor $\mathrm{C}_{2}$. 


\section{Použitá literatura}

[1] GRAME, J. G. Designing with Operational Amplifiers - Applications Alternatives. New York, McGraw-Hill Book Company, 1977

[2] TIETZE, U.; SCHENK, CH.; GAMM, E. Electronic Circuits. Hand book for Design and Applications. 2nd edition, Springer - Verlag, Berlin 2008. ISBN 978-3-540-00429-5

[3] TIETZE, U.; SCHENK, CH. Electronic Circuits. Design and Applications. Springer Verlag, Berlin 1991. ISBN 3-540-50608-X

[4] DOSTÁL, J. Operační zesilovače. BEN, Praha 2005

[5] DOSTÁL, J. Operational Amplifiers. Elsevier, Amsterdam 1981

[6] ROBERGE, J. K. Operational Amplifiers. J. Wiley, New Your, London, Sydney, Toronto 1975

[7] KOUŘIL, F.; VRBA, K. Teorie nelineárních a parametrických obvodů. SNTL, Praha 1981,

[8] KABEŠ, K. Funkční měniče a násobičky. SNTL, Praha 1973

[9] GRAEME, J. G.; TOBEY, G. E. HUELSMAN, L. P. Operational Amplifiers. Design ad Applications. Mc GRAW-HILL, New York, 1971. ISBN 07-064917-0

[10] PETERSON, W. L. Multiplication and Logarithmic Conversion by Operational Amplifier Transistor Circuit. Rewiew of Scientific Instruments 34 (1963), p. 1311-1316

[11] VRBA, K.; VRBA, K. jun. Technika analogových obvodů a systémů. Skriptum, 4. vydání. Ediční středisko VUT Brno,1989

[12] VRBA, K.; VRBA, K. jun. Technika analogových obvodů a systémů - sbírka př́kladů. Skriptum, 3. vydání. Ediční středisko VUT Brno,1989

[13] CLAYTON, G.B. Operational Amplifier. London, Butterworth Co 1971

[14] HUIJSING, J.H. Operational Amplifiers - Theory and Desing. Kluwer Academic Publishers, Boston 2001

[15] VRBA K.; Ŕíčný V. Studie operačního usměrňovače. In Knižnice odborných a vědeckých spisů VUT v Brně, svazek B-29. 1973. s. 67

[16] VRBA K. Operační usměrňovač. Sdělovací technika, 1973, č. 1, s. 19

[17] VRBA K. Jednocestný operační usměrňovač se zesilovači ve třídě B. Slaboproudý obzor, 1979, č. 2, s. 93

[18] VRBA K. Vliv závěrné zotavovací doby diod na činnost usměrňovače s operačním zesilovačem. Slaboproudý obzor, 1979, č. 1, s. 39

[19] VRBA K. Zapojení jednocestného operačního usměrňovače. Patent č. 186139

[20] VRBA K. Zapojení dvoucestného operačního usměrňovače s velkým vstupním odporem. Patent č. 178611,

[21] VRBA K. Zesilovač absolutní hodnoty. Sdělovací technika, 1975, č. 8, s. 307

[22] VRBA K. Dvoucestné operační usměrňovače. Sdělovací technika, 1975, č. 8, s. 307

[23] VRBA K. Nelineární operační zesilovač a jeho aplikace. Slaboproudý obzor, 1980, č. 1 , s. 12

[24] VRBA K. Zapojení dvoucestného operačního usměrňovače s velkým vstupním odporem. Patent č. 178611,

[25] VRBA K. Zapojení zesilovače absolutní hodnoty s velkým vstupním odporem. Patent č. 169375

[26] VRBA K. Přesné tvarovací obvody s operačními zesilovači. In Sdělovací technika 26. 1978. s. 405

[27] VRBA K. Nelineární zpětná vazba v operačních zesilovačích. Slaboproudý obzor, 1979 , č. 10, s. 454 


\section{Obvody s elektronickými spínači}

\subsection{Analogový elektronický spínač}

Elektronické spínání či přepínání signálu se dá realizovat jednoduše pomocí elektromechanických spínačů (relé). Mezi jejich výhody patří téměř nulový odpor v sepnutém stavu a téměř nekonečný odpor $v$ rozpojeném stavu. Jejich nevýhodou jsou větší rozměry (miniaturní relé v pouzdru DIL obsahují jen dva dvoupolohové přepínače), kratší živostnost a relativně dlouhá doba potřebná k jejich sepnutí. Obvykle je také nutno elektromechanický přepínač doplnit budicími obvody, aby bylo možné realizovat jejich ovládání logickými úrovněmi. Proto byly navrženy způsoby, jak pro přepínání či spínání signálu použít elektronické spínače. Obvykle jsou tyto analogové spínače již uzpůsobeny pro přímé ovládání z logických obvodů. Při použití těchto prvků se zvýší rychlost spínání či přepínání a spolehlivost obvodu.

Typické uspořádání analogového spínače v technologii CMOS je uvedeno na Obr. 9.1a. Pro získání většího rozsahu spínaného napětí jsou použity dva paralelně spojené komplementární tranzistory řízené polem. Analogové elektronické spínače se vyznačují řadou nectností, které se snažíme obvykle potlačit vhodným propojením takového spínače či přepínače s operačním zesilovačem. Zejména jde o odpor sepnutého spínače roN, který se pohybuje v rozmezí 25 až $400 \Omega$ podle typu tranzistoru, dále závislost tohoto odporu na přiloženém napětí, která může způsobit parazitní modulaci signálu a konečně značná teplotní závislost tohoto odporu (viz Obr. 9.1c). V náročnějších př́padech pak musíme vzít i v úvahu, že sepnutý tranzistor je zdrojem hned několika druhů šumu (praskavý šum, $1 / f$ blikavý šum, tepelný šum, výstřelový šum).

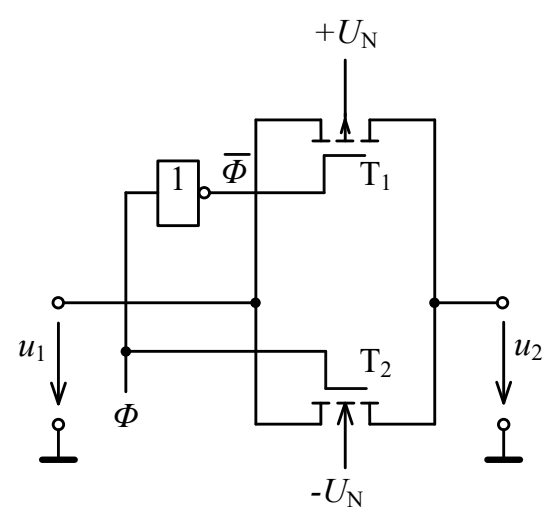

a

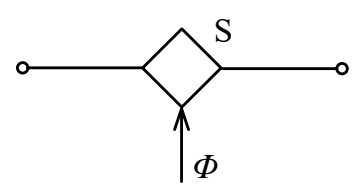

$\mathrm{b}$

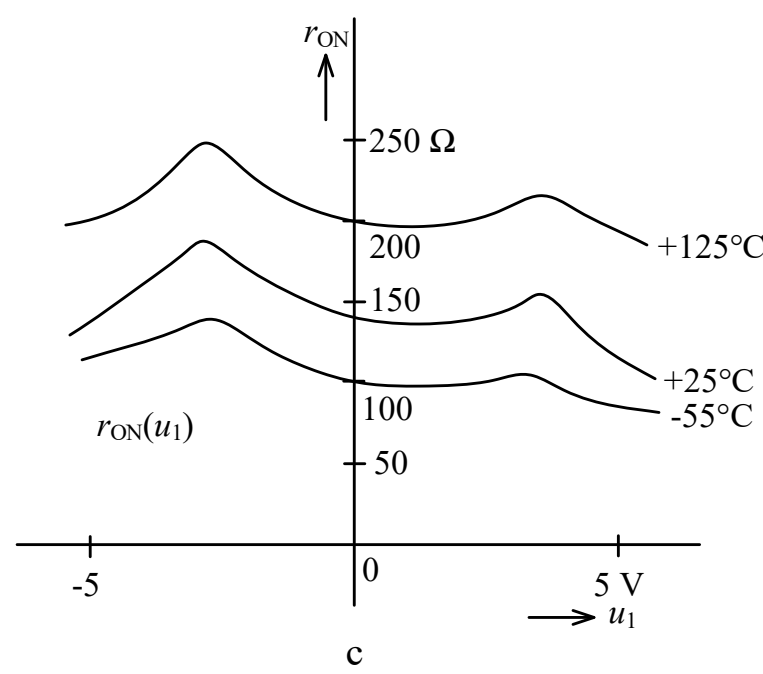

Obr. 9.1 a) Zapojení analogového spínače CMOS, b) schématická značka, c) závislost odporu spínače v sepnutém stavu na přiloženém napětí a na teplotě 


\subsection{Analogové multiplexery}

V řadě aplikací je zapotřebí přepínat několik signálů do jednoho bodu. K tomuto účelu se užívá elektronický přepínač, tzv. analogový multiplexer. Analogové multiplexery se vyrábějí obvykle CMOS technologií nebo technologií Bi-FET. Multiplexer mimo vlastních analogových spínačů obsahuje převodníky napětových úrovní a dekodér, který převede binární údaj o sepnutí požadovaného kanálu na údaj „1 z $N^{*}$ (viz Obr. 9.2a). Řídicím signálem $\Phi_{n}$ lze sepnout pouze jeden spínač $\mathrm{S}_{n}$. Obvod obvykle umožňuje pomocí řídicích signálů všechny spínače také rozpojit. Protože jde o součástku obousměrnou, lze ji použít bez jakýchkoliv úprav i jako demultiplexer. $Z$ tohoto důvodu budeme pro označení součástky ve schématech užívat zkratku AMUX a pouze $v$ textu se rozliší, zda je součástka použita jako multiplexer nebo demultiplexer.

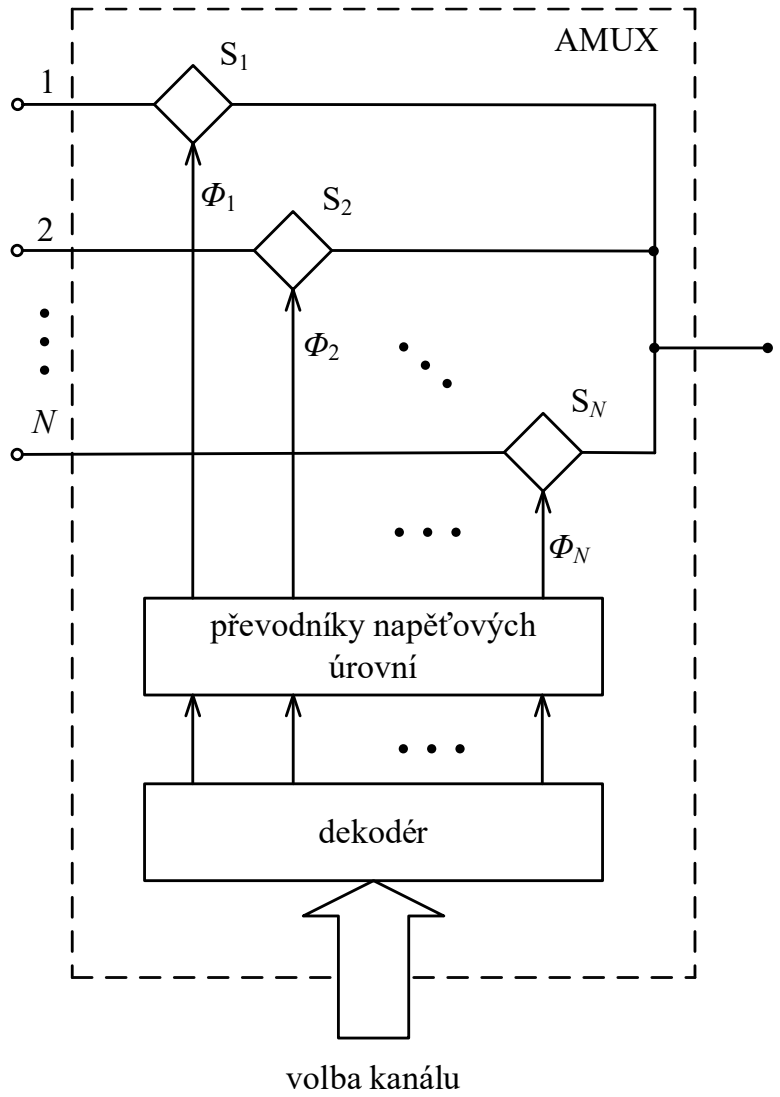

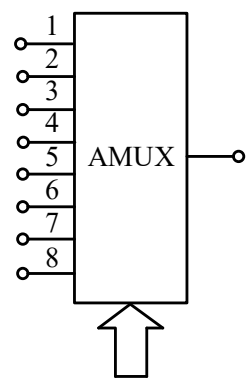

volba kanálu

b

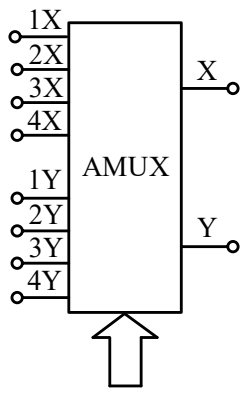

volba kanálu

c

Obr. 9.2 a) Vnitřní řešení analogového multiplexeru, b) osmikanálový multiplexer, c) diferenční čtyřkanálový multiplexer

Nejčastěji jsou k dispozici integrované osmikanálové multiplexery (viz Obr. 9.2b). Vyrábějí se také tzv. diferenční analogové multiplexery zapojené podle Obr. 9.2c. Oba systémy se v diferenčním AMUX spínají synchronně, tzn. současně je sepnut spínač $\mathrm{S}_{\mathrm{X} n}$ a $\mathrm{S}_{\mathrm{Y} n}$. Pomocí řídicích signálů lze opět všechny spínače rozpojit.

Nevýhodou přímého použití multiplexeru pro přepínání signálu je, stejně jako u analogového spínače, nenulový a značně proměnný odpor sepnutého kanálu, který se vstupním odporem následujícího obvodu tvoří nelineární dělič a to může vést ke zkreslení přepínaného signálu. Proto se v přesnějších aplikací využivá spojení s operačním zesilovačem, který nežádoucí vlastnosti potlačí a obvykle umožní zpracovávaný signál současně zesílit. 
Invertující zapojení operačního zesilovače je základem invertujícího zapojení multiplexeru uvedeného na Obr. 9.3a, [25]. Jestliže např. sepneme 2.kanál, bude výstupní napětí

$$
u_{2} \approx-\frac{R_{22}}{R_{12}} u_{12} \text {. }
$$

Ostatní vstupní napětí, která jsou vždy přes př́íslušnou sériovou kombinaci rezistorů přivedena k výstupu obvodu, nemají na činnost zapojení vliv, protože výstup představuje „tvrdý“ zdroj napětí. Volbou poměru $R_{2 n} / R_{1 n}$ je možno pro každou signálovou cestu nastavit individuální zesílení. Díky invertujícímu uspořádání se zde neuplatní vliv souhlasného napětí operačního zesilovače.

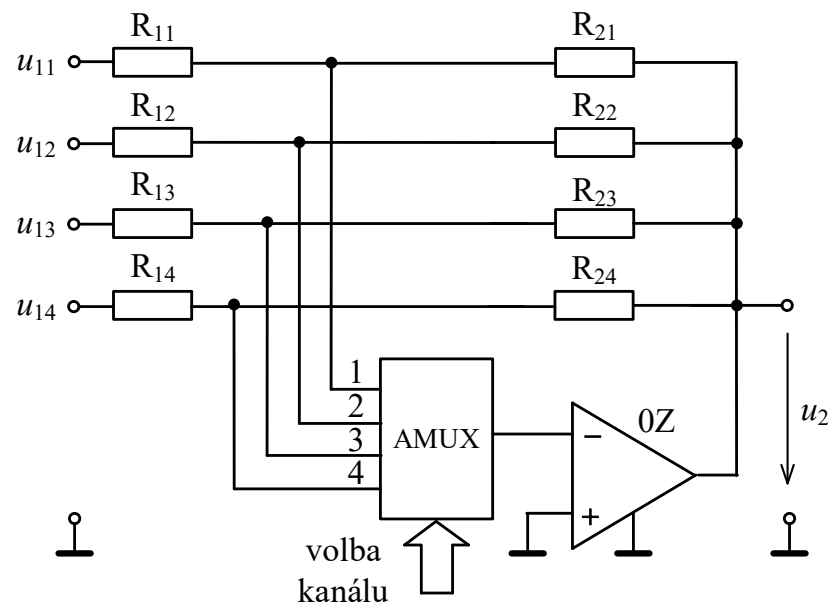

a

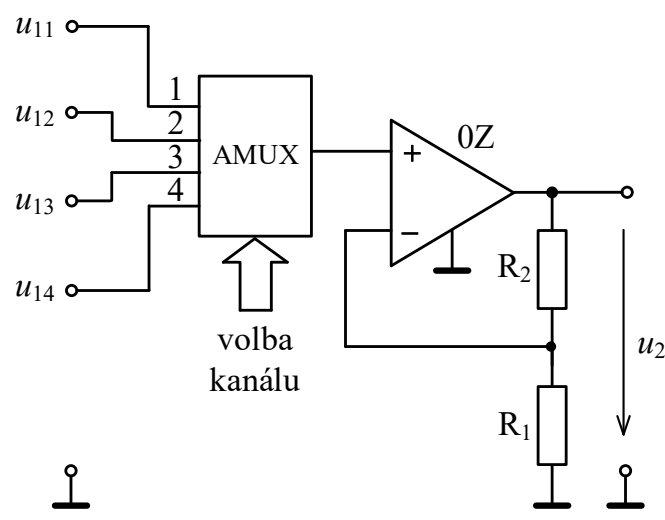

b

Obr. 9.3 a) Invertující analogový multiplexer, b) neinvertující analogový multiplexer

Díky tomu, že AMUX je zařazen do přímé větve zpětnovazební smyčky započte se odpor sepnutého kanálu do vstupního odporu operačního zesilovače a ten je jak je známo, potlačen velkým zesílením OZ a užitou zápornou zpětnou vazbou na zanedbatelnou míru. Na druhou stranu zařazení AMUX na citlivý vstup OZ může vést ke zhoršení šumových vlastností obvodu. Zhoršení šumových poměrů způsobuje totiž samotný multiplexer. Zapnutý kanál analogového multiplexeru je zdrojem hned čtyř druhů šumu. Je to praskavý šum, b1ikavý (1/f) šum, tepelný šum a výstř̌elový šum. Protože je multiplexer zařazen v přímé větvi zpětnovazební smyčky před operačním zesilovačem, je tento šum operačním zesilovačem zesilován.

Nejčastěji užívané zapojení analogového multiplexeru je schematicky nakresleno na Obr. 9.3b, [4]. Využívá se vysokého vstupního odporu neinvertujícího zapojení operačního zesilovače. Nenulový odpor zapnutého kanálu popř. jeho změny s teplotou se uplatní díky vysokému vstupnímu odporu neinvertujícího zesilovače jen nepatrně. Výstupní napětí neinvertujícího analogového multiplexeru bude mít např. při zapnutém 2. kanálu velikost

$$
u_{2}=\left(1+\frac{R_{2}}{R_{1}}\right) u_{12},
$$

Zesílení je pro každou přenosovou cestu stejné. Může se zde ale, stejně jako u každého neinvertujícího zapojení, uplatnit vliv souhlasného napětí OZ. 


\subsection{Analogové demultiplexery}

Analogové demultiplexery slouží k přepínání jednoho signálu do více kanálů (Obr. 9.4a) anebo diferenční analogové multiplexery k synchronnímu přepínání dvou signálů do více kanálů (Obr. 9.4b).

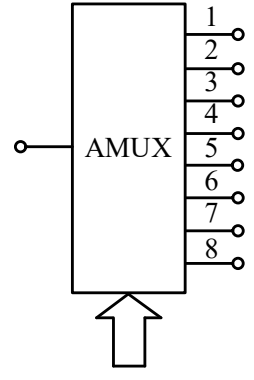

volba kanálu

a

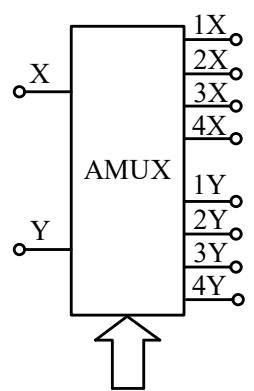

volba kanálu

$\mathrm{b}$

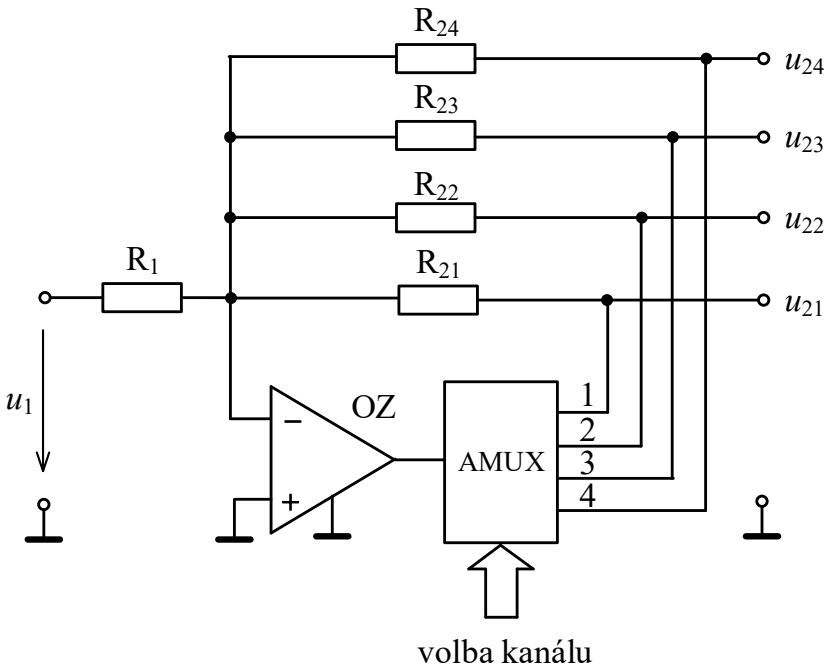

c

Obr. 9.4 a) Analogový demultiplexer, b) diferenční analogový demultiplexer, c) invertující analogový demultiplexer

Nenulový a značně proměnný odpor sepnutého kanálu potlačuje invertující uspořádání přesného analogového demultiplexeru s jedním operačním zesilovačem, které je naznačeno na Obr. 9.4c, [8]. K operačnímu zesilovači, doplněnému na výstupu analogovým demultiplexerem pro přepínání výstupního signálu, je připojena zpětnovazební odporová sít obdobně jako u invertujícího zesilovače s operačním zesilovačem, avšak s tím rozdílem, že pro každou novou výstupní svorku je vedena samostatná zpětnovazební cesta. V podstatě jde o zapojení s paralelní napětovou zápornou zpětnou vazbou stejně jako v príípadě invertujícího zapojení OZ.

Činnost analogového demultiplexeru uspořádaného podle Obr. 9.4c si nejprve stručně odvodíme za předpokladu, že operační zesilovač i použité spínače mají vlastnosti blížící se ideálním. Zapojení využívá principu invertujícího zapojení operačního zesilovače a např. pro zapnutý druhý kanál AMUX platí jednoduše

$$
u_{22}=-\frac{R_{22}}{R_{1}} u_{1} \text {. }
$$

$\mathrm{Na}$ všech ostatních výstupech bude přitom nulové napětí, protože tyto výstupy jsou přes př́íslušné zpětnovazební rezistory připojeny na sčítací bod, neboli tzv. "virtuální zem" operačního zesilovače. Volbou odporu rezistoru $R_{2 n}$ je možno nastavit pro každý výstup demultiplexeru individuální zesílení. Výstupní odpor každého z výstupů závisí na tom, zda výstup je či není v činném režimu. Z hlediska výstupu v činném režimu se zapojení chová jako tvrdý zdroj napětí a výstupní odpor je téměř nulový. Všechny ostatní výstupy vykazují výstupní odpor o velikosti prakticky rovné odporu příslušného odpojeného zpětnovazebního rezistoru.

Přesunutí demultiplexeru AMUX za výstup operačního zesilovače se ukazuje jako velmi prríhodné. Zapnutý kanál AMUX je zařazen do přímé větve zpětnovazební smyčky operačního zesilovače a díky záporné zpětné vazbě je výrazně potlačen nenulový odpor a př́padné nelinearity či teplotní závislosti odporu zapnutého kanálu ron. Výstupní odpor demultiplexeru na výstupu, který je právě aktivní, se díky tomu sníží pod $1 \Omega$. Takovýto výstup se pak chová jako „tvrdý“ zdroj napětí, který je odolný vůči průniku rušivých signálů přes parazitní kapacity. 
Další výhodou pak je, že šumy zapnutého kanálu již nejsou zesilovány operačním zesilovačem a ke zvýšení šumových poměrů přispívají jen minimálně.

\subsection{Zesilovače s elektronicky přepínaným zesílením}

Elektronické přepínání zesílení zesilovače se dá samozřejmě realizovat přepínáním zpětnovazební sítě pomocí elektromechanických přepínačů (relé). Protože odpor takovéhoto $\mathrm{v}$ podstatě mechanického přepínače $\mathrm{v}$ sepnutém stavu je menší než $1 \mathrm{~m} \Omega$, můžeme jej zařadit přímo do zpětnovazební větve zesilovače. Jak bylo již řečeno, nevýhodou jsou větší rozměry relé, relativně dlouhá doba k jejich sepnutí a zejména jejich kratší živostnost. Pokud bychom na místě mechanického přepínače použili pro přepínání zpětnovazební sítě operačního zesilovače analogový multiplexer, bude na závadu nenulový odpor zapnutého kanálu. Odpor zapnutého kanálu může způsobit chybu zesílení a navíc i parazitní modulaci signálu, protože odpor zapnutého kanálu se mění v závislosti na přiloženém napětí (viz. Obr. 9.1b).

Zapojíme-li však analogový multiplexer do přímé větve zpětnovazební smyčky, tzn. mimo vlastní zpětnovazební sít zesilovače, bude vliv nenulového odporu zapnutého kanálu zcela potlačen.

\subsubsection{Invertující zesilovače s přepínatelným zesílením}

U zesilovače podle Obr. 9.5 je sepnutím kanálu multiplexeru připojována k invertujícímu vstupu operačního zesilovače vybraná rezistorová zpětnovazební sít', [1], [2], [12]. Protože výstup operačního zesilovače představuje tvrdý zdroj napětí, nemá nevyužitá sít rezistorů vliv na činnost zesilovače a proto např. při sepnutém 2. kanálu AMUX bude na výstupu napětí

$$
u_{2}=-\frac{R_{22}}{R_{12}} u_{1} \text {. }
$$

Protože je multiplexer zařazen do př́mé (zesilovací) větve zpětnovazební smyčky, odpor zapnutého kanálu se téměř neuplatní. Zařazení multiplexeru na vstupu operačního zesilovače může zhoršit šumové vlastnosti výsledného zapojení stjně jako v př́padě zapojení na Obr. 9.3a. Tranzistory řízené polem, kterými jsou realizovány jednotlivé kanály AMUX, jsou totiž zdrojem celé řady šumů (blikavý, praskavý, ...). Při diskrétní realizaci pak může vlastnosti zhoršit nevhodně navržená sít' (dlouhých) př́ívodů k AMUX, resp. k invertujícímu vstupu OZ. Určitou nevýhodou může být velký počet použitých rezistorů. To však na druhou stranu ale umožňuje každé zesílení individuálně dostavit.

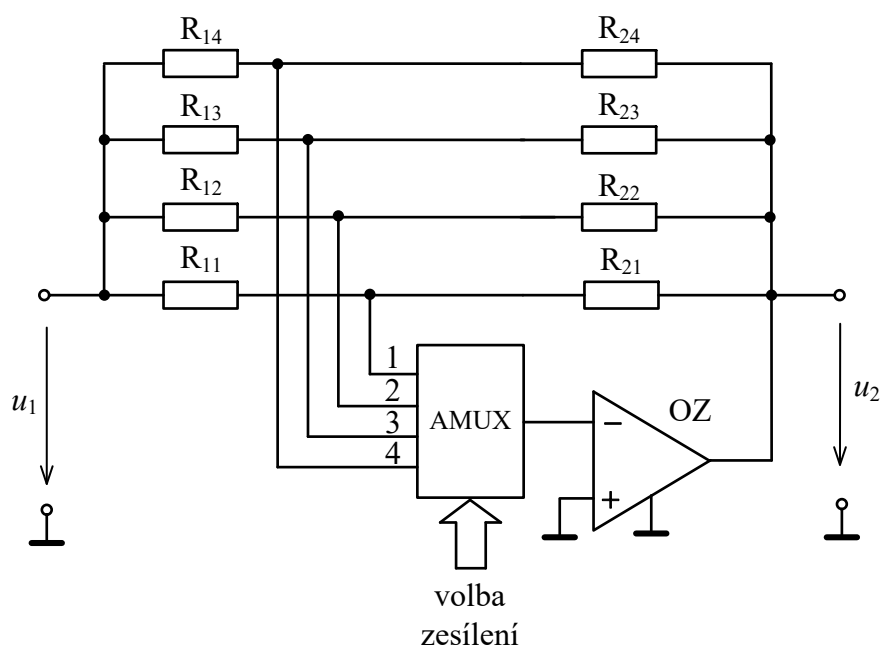

Obr. 9.5 Invertující zapojení zesilovače s multiplexerem předřazeným invertujícímu vstupu operačního zesilovače 
Jiný způsob zavedení paralelní napět’ové záporné zpětné vazby $\mathrm{k}$ operačnímu zesilovači $\mathrm{s}$ multiplexerem předřazeným invertujícímu vstupu je uveden na Obr. 9.6 [2], [3]. Zesilovač se např́klad při zapnutém druhém kanálu multiplexeru chová jako invertující zesilovač a na výstupu bude napětí

$$
u_{2} \approx-\frac{R_{0}+R_{3}+R_{4}}{R_{1}+R_{2}} u_{1}
$$

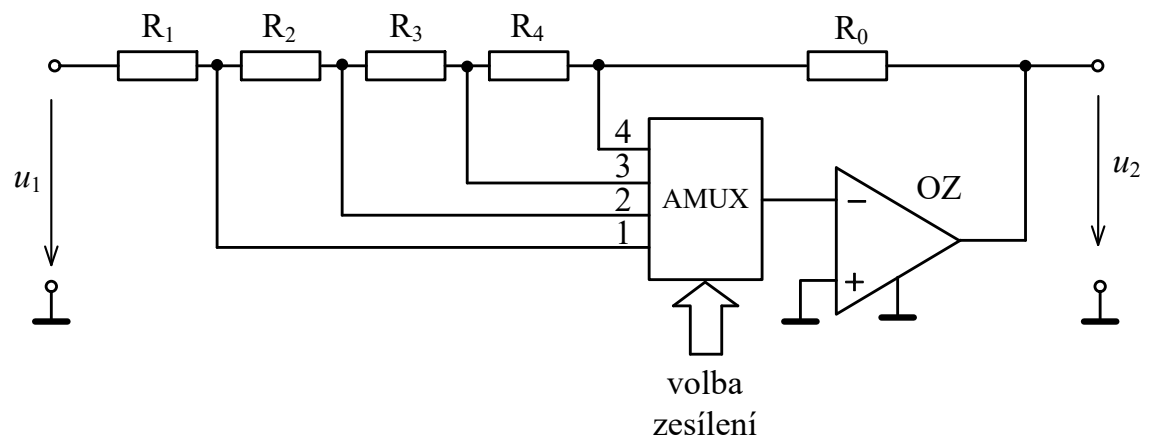

Obr. 9.6: Invertující zapojení zesilovače s elektronicky přepínanou zpětnou vazbou

Určitou nevýhodou tohoto uspořádání je skutečnost, že se při přepínání zesílené mění vstupní odpor obvodu. Např. pro sepnutý 2 . kanál bude vstupní odpor $R_{\mathrm{vst}} \approx R_{1}+R_{2}$. Výhodou je ve srovnání se zapojením zesilovače na Obr. 9.5, menší počet rezistorů. Na druhou stranu přenos obvodu určují vždy všechny rezistory a proto dostavení zesílení je obtížnější.

\subsubsection{Neinvertující zesilovače s přepínatelným zesílením}

Sériový způsob zavedení záporné zpětné vazby k operačnímu zesilovači doplněnému na invertujícím vstupu analogovým multiplexerem je použit v zapojení nakresleném schématicky na Obr. 9.7, [2]. Odpor zapnutého kanálu se zde také neuplatní, protože multiplexer je opět

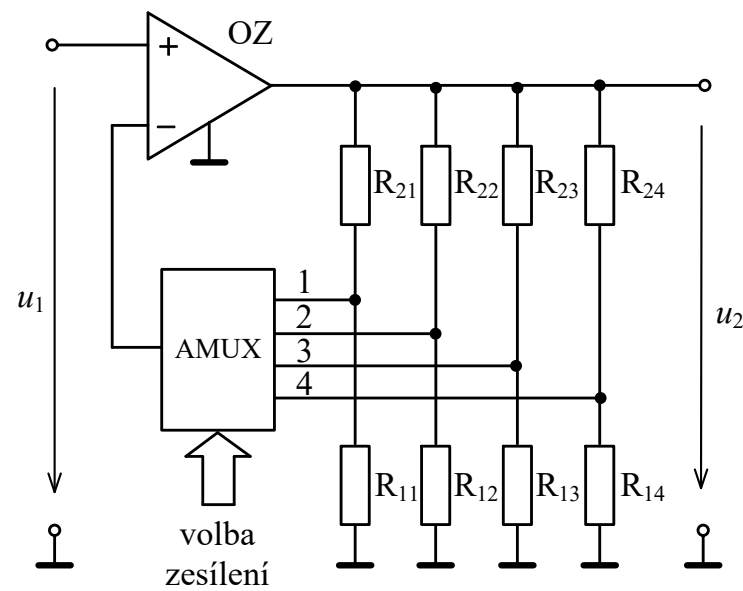

Obr. 9.7: Neinvertující zapojení zesilovače s multiplexerem předřazeným invertujícímu vstupu operačního zesilovače

zařazen do př́mé větve zpětnovazební smyčky. Obvod pracuje při např. zvoleném 2. kanálu multiplexeru zcela obdobně jako neinvertující zesilovač s operačním zesilovačem, a proto jeho výstupní napětí má hodnotu 


$$
u_{2} \approx\left(1+\frac{R_{22}}{R_{12}}\right) u_{1} .
$$

Ostatní nevyužité sériové kombinace zpětnovazebních rezistorů jsou jako rezistorové zátěže připojeny k výstupu zesilovače a mají proto na zesílení obvodu jen nepatrný vliv. Stejně jako neinvertující zesilovač s operačním zesilovačem se obvod uvedený na Obr. 9.7 vyznačuje značně velkým vstupním odporem. Bohužel má také stejnou nevýhodu jako neinvertující zesilovač - uplatňuje se u něj vliv souhlasného napětí.

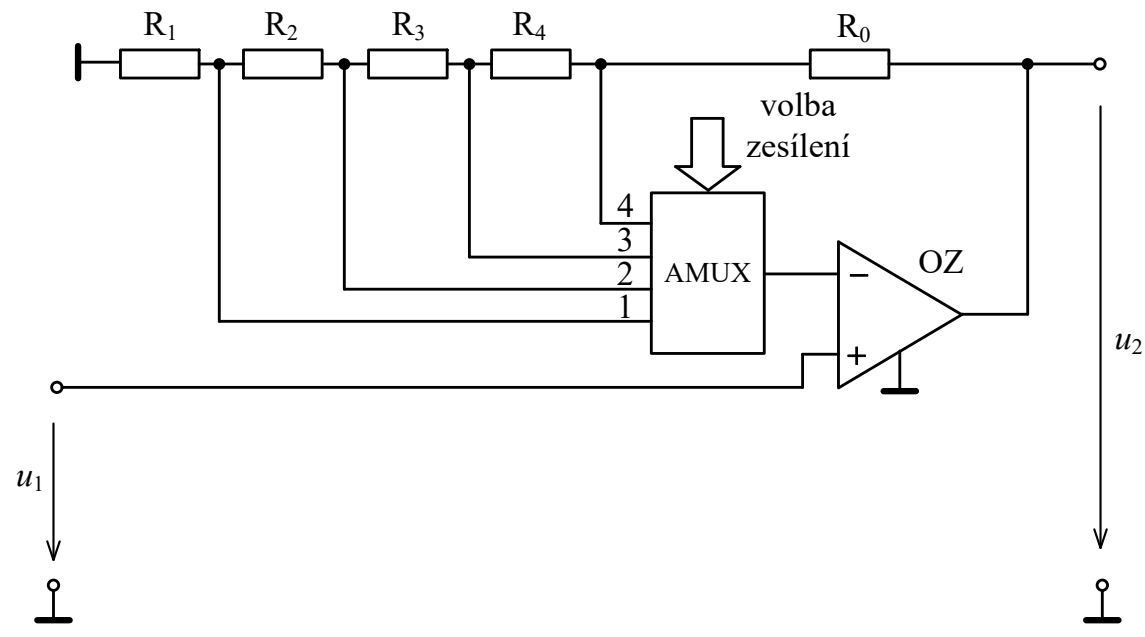

Obr. 9.8: Zapojení neinvertujícího zesilovače s elektronicky přepínanou zpětnou vazbou

Jiný způsob přepínání zpětnovazební sítě využívá neinvertující zesilovač nakreslený na Obr. 9.8, [2], [4]. V tomto př́padě jde také o sériový způsob zavedení zpětnovazebního signálu k operačnímu zesilovači a obvod bude vykazovat výstupní napětí např́klad při sepnutém druhém kanálu obdobně jako neinvertující zapojení operačního zesilovače

$$
u_{2}=\left(1+\frac{R_{0}+R_{3}+R_{4}}{R_{1}+R_{2}}\right) u_{1} .
$$

Na Obr. 9.9 je nakresleno zapojení přepínatelného zesilovače, u kterého je analogový multiplexer připojen $\mathrm{k}$ neinvertující vstupní svorce operačního zesilovače. Jde vlastně o neinvertující zesilovač s konstantním zesílením, jehož vstup je prostřednictvím multiplexeru připojován na odbočky rezistorového zeslabovače. Multiplexer zde není již zařazen do přímé větve zpětnovazební smyčky. Nežádoucí reálné vlastnosti zapnutého kanálu multiplexeru jsou 


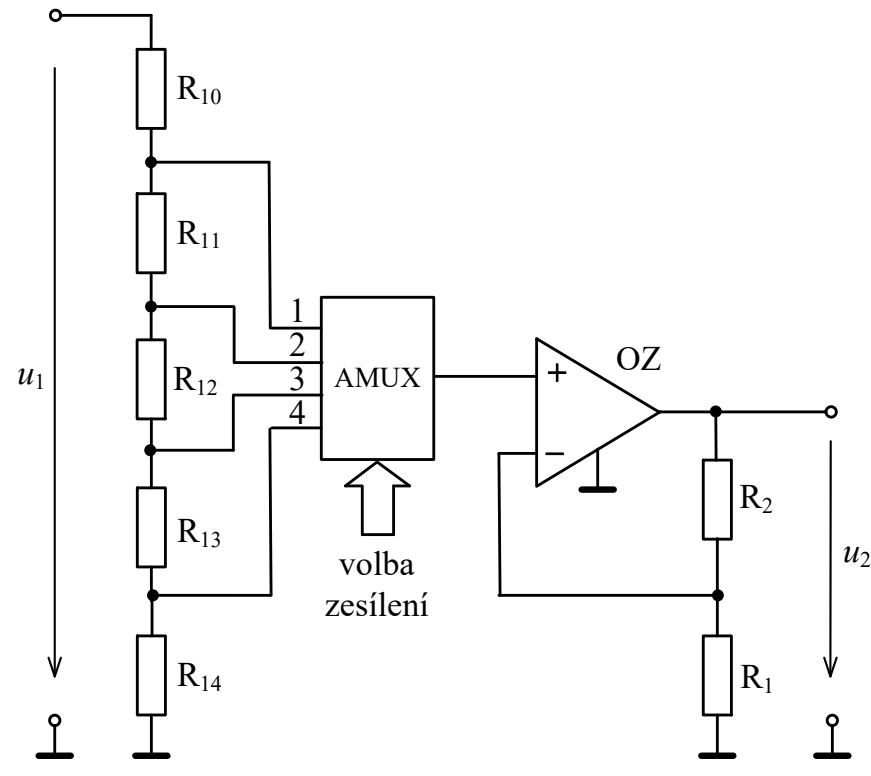

Obr. 9.9: Neinvertující zesilovač s předřazeným děličem

však i zde částečně potlačeny. To proto, že vstupní odpor neinvertujícího zesilovače je díky záporné sériové zpětné vazbě značně velký (podle typu operačního zesilovače až $10^{13} \Omega$ ) a tvoří s nenulovým odporem zapnutého kanálu AMUX dělič s dělicím poměrem blížíím se na zlomky promile jedné. Proto nenulový odpor zapnutého kanálu a jeho změny v závislosti na protékajícím proudu, resp. na teplotě nemají na celkovou činnost obvodu velký vliv. V podstatě jde o odporový dělič, za který je zařazen neinvertující zesilovač. V prrípadě, že bude naprríklad zapnut druhý kanál, můžeme pro výstupní napětí psát

$$
u_{2}=\frac{R_{12}+R_{13}+R_{14}}{R_{10}+R_{11}+R_{12}+R_{13}+R_{14}}\left(\frac{R_{2}}{R_{1}}+1\right) u_{1} .
$$

Výhodné u tohoto uspořádání je, že se zpětnovazební sít' operačního zesilovače nepřepíná a proto se kmitočtové vlastnosti celého uspořádání při přepínání zesílení nemění. Přitom samozřejmě předpokládáme, že rezistorový zeslabovač je kmitočtově korigován tak, aby se neuplatnily parazitní kapacity rezistorů. Na závadu ovšem je okolnost, že vstupní signál je nejprve zeslaben a pak znovu zesilován. Tím se zhoršují šumové poměry v obvodu. Na druhé straně ovšem šum sepnutého kanálu či šum vnesený do př́vodů k AMUX není nyní zesilován celým zesílením OZ bez zpětné vazby, ale pouze $\left(1+R_{2} / R_{1}\right)$.

\subsubsection{Zesilovače s přepínatelným zesílením pro náročnější aplikace}

Zesilovače uvedené v předchozích kapitolách mají několik nevýhod, které je předurčují spíše pro méně náročné aplikace. Především vykazují zvýšenou úroveň šumu, protože multiplexer je předřazen operačnímu zesilovači a šum sepnutého kanálu AMUX je zesilován. Další nevýhodou je skutečnost, že při přepínání zpětnovazební sítě jediného operačního zesilovače dochází k velkým změnám použitelného kmitočtového pásma.

Zesilovač s přepínatelným zesílením, jehož zapojení je nakresleno na Obr. 9.10 (lit. [13], [14]), využívá kaskádního spojení invertujícího analogového demultiplexeru z Obr. 9.4c a 


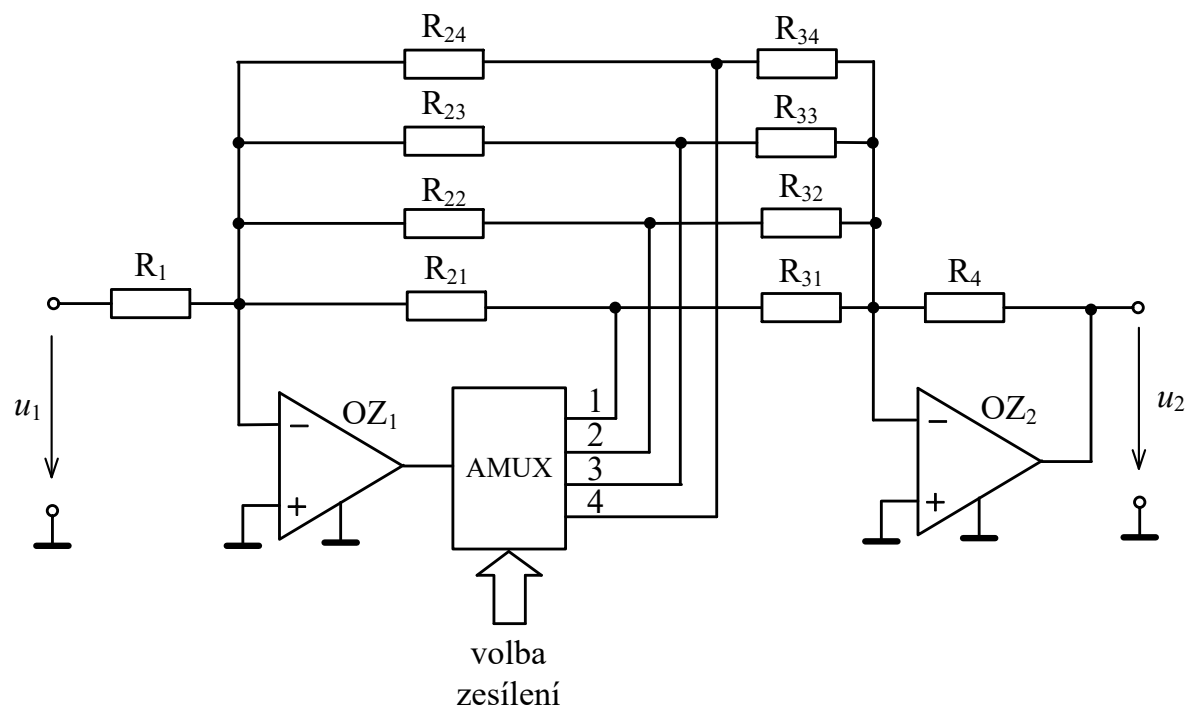

Obr. 9.10: Zapojení zesilovače s přepínatelným zesílením

(invertujícího) sčítacího zesilovače. V př́ípadě, že sepneme druhý kanál AMUX, budou za sebou v kaskádě zapojeny dva invertující zesilovače a tedy

$$
u_{2}=\frac{R_{22}}{R_{1}} \frac{R_{4}}{R_{32}} u_{1} \text {. }
$$

Ostatní sériové kombinace odporů $R_{24}+R_{34}, R_{23}+R_{33}$ a $R_{21}+R_{31}$ nemají v tomto př́ípadě na zesílení obvodu žádný vliv, protože jsou na obou koncích připojeny $\mathrm{k}$ invertujícím vstupům $\mathrm{OZ}$, které oba OZ udržují v důsledku činnosti svých zpětných vazeb na „virtuální“ nule.

Je zřejmé, že zesílení může být nastaveno pro $n$-tý př́pad poměrem odporů $R_{2 n} / R_{3 n}$. Zesílení je vhodné rovnoměrně rozdělit mezi oba zesilovače tak, aby každý stupeň realizoval zesílení $\sqrt{k_{n}}$, kde $k_{n}$ ke zesílení celého zesilovače. Jak je obecně známo, docílí se tímto způsobem rozšíření kmitočtového pásma (pro velká zesílení až o1 dekádu).

Je tedy zřejmé, že zapojení se dvěma operačními zesilovači je výhodné hned z několika důvodů. Nežádoucí reálné vlastnosti multiplexeru jako je nenulový odpor sepnutého kanálu a jeho změny $v$ závislosti na teplotě či na přiloženém napětí jsou potlačeny díky tomu, že multiplexer je zařazen v zesilovací větvi zpětnovazební smyčky. Protože multiplexer je zařazen až za operační zesilovač, nedojde ke zhoršení šumových poměrů v obvodu. Délka př́ívodů $\mathrm{k}$ multiplexeru není kritická, protože aktivní výstup se chová jako „tvrdý“ zdroj napětí. Zapojení vykazuje větší šířku pásma než zesilovač realizovaný s jediným operačním zesilovačem. Protože oba operační zesilovače pracují na principu invertujícího zesilovače, neuplatní se ani vliv tzv. souhlasného napětí. Zapojením lze realizovat i zesílení menší než jedna, tzn. může pracovat i jako zeslabovač. Nevýhodou je relativně malý vstupní odpor celého zesilovače $R_{\mathrm{vst}}$ $\approx R_{1}$.

Odlišný způsob uspořádání zpětnovazební sítě operačního zesilovače $\mathrm{s}$ analogovým multiplexerem na výstupu OZ je uveden na Obr. 9.11, [17], [18]. Je však zřejmé, že i zde zůstaly zachovány veškeré výhody, které jsou charakteristické pro zapojení analogového demultiplexeru do př́mé větve zpětnovazební smyčky, a to za operační zesilovač. 


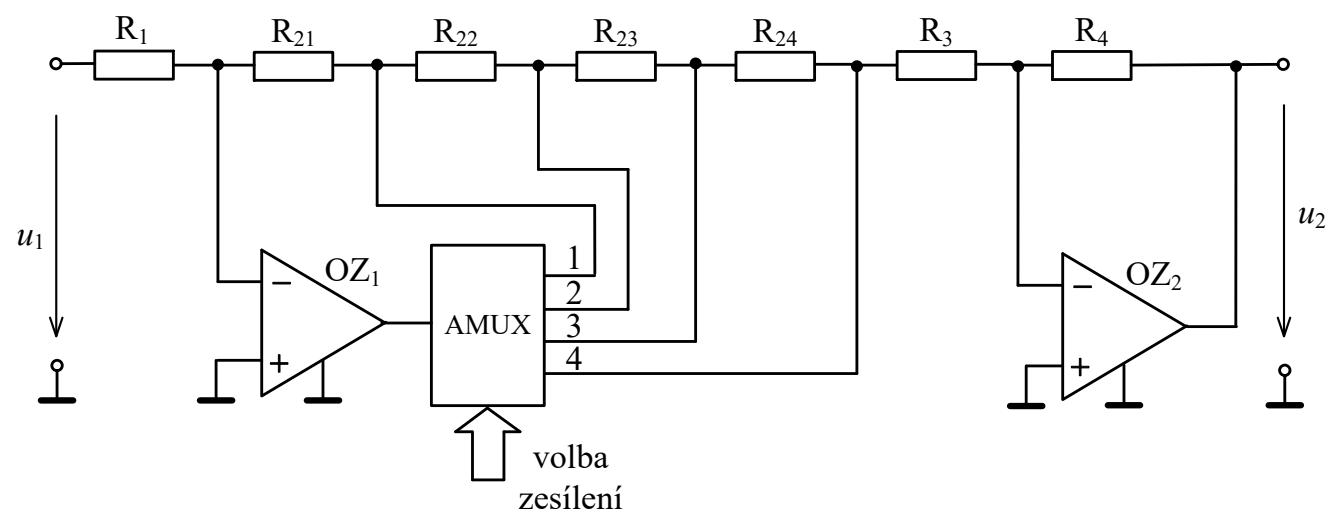

Obr. 9.11: Zesilovač s přepínatelným zesílením s malým vstupním odporem a s AMUX na výstupu OZ

Oba operační zesilovače pracují jako invertující zesilovače s paralelní napět’ovou zápornou zpětnou vazbou. V závislosti na přepnutí demultiplexeru je část rezistorů zapojena do zpětné větve prvního operačního zesilovače a zbylá část do vstupní větve druhého operačního zesilovače. Výstupní napětí celého takto uspořádaného obvodu bude pak mít např. pro sepnutý druhý kanál AMUX hodnotu

$$
u_{2}=\frac{R_{21}+R_{22}}{R_{1}} \frac{R_{4}}{R_{3}+R_{23}+R_{24}} u_{1} .
$$

Nevýhodou je poněkud nízký vstupní odpor zapojení $R_{\mathrm{vst}} \approx R_{1}$.

Velký vstupní odpor vykazuje zapojení přepínatelného zesilovače uvedené na Obr. 9.12, [10], [15], [16].

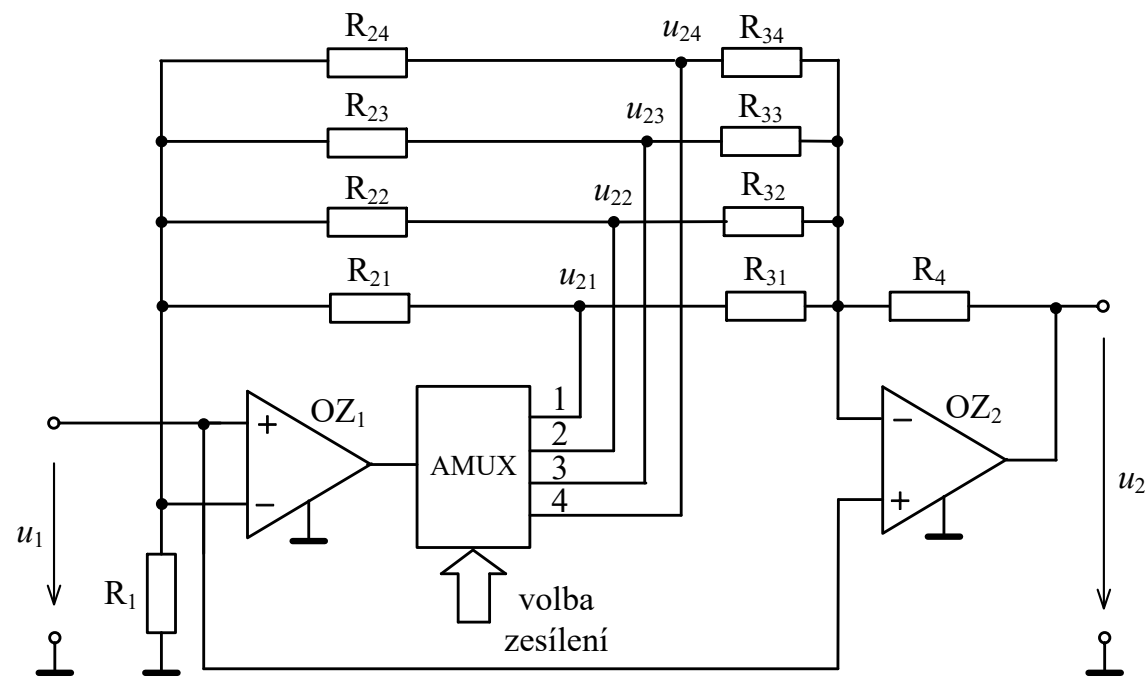

Obr. 9.12: Zapojení zesilovače s velkým vstupním odporem a s AMUX na výstupu OZ

Činnost objasníme při sepnutém 2. kanálu AMUX, kdy $\mathrm{OZ}_{1}$ se chová stejně jako neinverjící zesilovač a na jeho výstupu bude napětí

$$
u_{22}=\left(1+\frac{R_{22}}{R_{1}}\right) u_{1} .
$$

Za něj je v kaskádě zapojen rozdílový zesilovač s $\mathrm{OZ}_{2}$, který má na jednom vstupu napětí $\mathrm{u}_{22} \mathrm{a}$ na druhém $\mathrm{u}_{1}$ a tedy na jeho výstupu bude napětí 


$$
u_{2} \approx-\frac{R_{4}}{R_{32}} u_{22}+\left(1+\frac{R_{4}}{R_{32}}\right) u_{1} \approx-\left(\frac{R_{4}}{R_{32}} \frac{R_{22}}{R_{1}}-1\right) u_{1} .
$$

Ostatní rezistory nemají na přenos zesilovače nyní vliv, protože sériové kombinace $R_{2 n}+R_{3 n}(n \neq 2)$ jsou oběma konci připojeny na napětí $u_{1}$, které si na svých invertujících vstupech nastaví $\mathrm{OZ}_{1}$ i $\mathrm{OZ}_{2}$.

Velký vstupní odpor má také zesilovač zapojený podle Obr. 9.13, [19], [20]. Je to dáno tím,

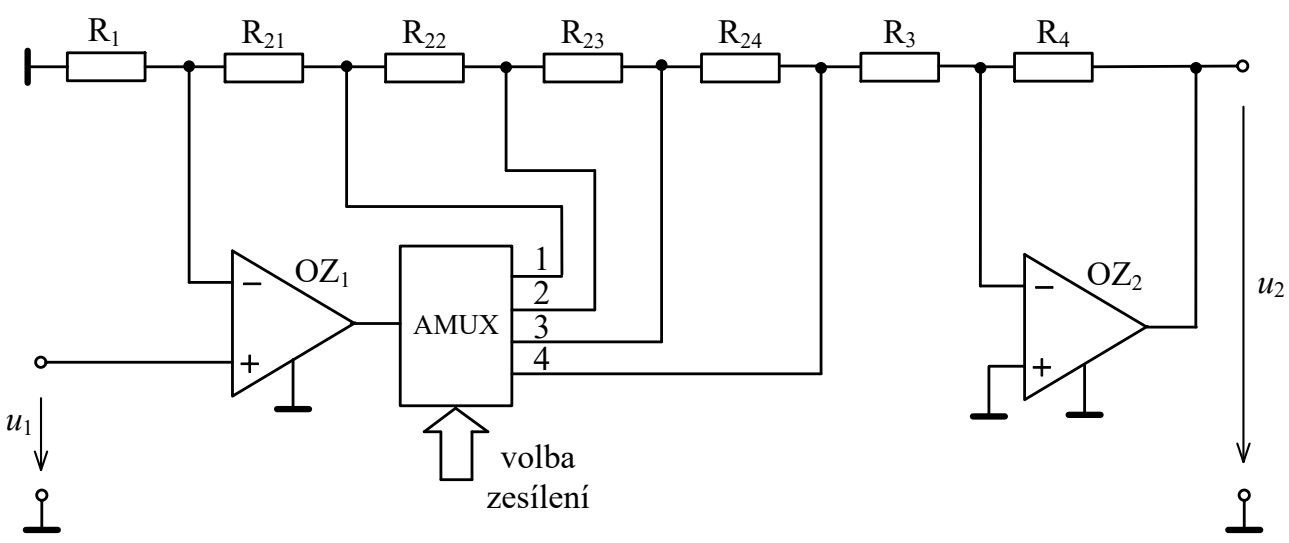

Obr. 9.13: Zapojení zesilovače s přepínatelným zesílením s vysokým vstupním odporem a s AMUX na výstupu $\mathrm{OZ}$

že první operační zesilovač pracuje v neinvertujícím uspořádání, tj. se sériovou napět'ovou zápornou zpětnou vazbou. Bude-li př́kladně sepnut druhý kanál AMUX bude mít výstupní napětí velikost

$$
u_{2} \approx-\left(1+\frac{R_{21}+R_{22}}{R_{1}}\right) \frac{R_{4}}{R_{3}+R_{23}+R_{24}} u_{1} .
$$

Srovnáme-li navzájem konfigurace zesilovačů uvedené v této kapitole je zřejmé, že nejmenší počet obvodových prvků obsahují zapojení zesilovačů z Obr. 9.11 a Obr. 9.13. Na druhé straně je u těchto zapojení nevýhodné, že zesílení je určeno současně odporem všech rezistorů a změna či dostavení jednoho způsobí změnu nastavení zesílení v ostatních polohách analogového multiplexeru. Z tohoto pohledu jsou lepší zapojení z Obr. 9.10 a z Obr. 9.12, protože zpětnovazební rezistory lze doplnit potenciometrickými trimry a zesílení je možno pro každou polohu AMUX nezávisle nastavit.

\subsection{Elektronické stř́́dače}

Z technické literatury je známa řada obvodů, které se vyznačují tím, že v závislosti na rí́dicím signálu mění polaritu přenosu, tj. $u_{2}= \pm k u_{1}$ (zde $k$ nyní značí modul přenosu obvodu, $\left.k=\left|u_{2} / u_{1}\right|\right)$. Obvody založené na tomto principu jsou podle účelu uváděny pod nejrůznějšími názvy jako např. stř́dač, rozsekávač (chopper), parametrický usměrňovač, synchronní detektor či synchronní usměrňovač, vyvážený parametrický amplitudový modulátor, synchronní demodulátor apod. Obvodové řešení těchto zařízení může být však shodné. Odlišují se jen tím, jaké jsou vlastnosti vstupního a rrídicího signálu a které spektrální složky výstupního signálu využíváme. V dalším bude používán pro uvedenou třídu obvodů pouze název střídač. 


\subsubsection{Jednoduché elektronické střídače}

Je známo několik jednoduchých zapojení střídačů s operačním zesilovačem. Obecným znakem těchto střídačů je přepínání zpětnovazební odporové sít operačního zesilovače tak, že obvod pracuje bud' jako neinvertující zesilovač, nebo po přepojení zpětnovazební sítě jako zesilovač invertující. Přepojování zpětnovazební sítě operačního zesilovače se provádí elektronickým přepínačem či spínačem. U většiny zapojení s jedním $\mathrm{OZ}$ se však v plné míře uplatňují nežádoucí reálné vlastnosti elektronických spínačů či přepínačů a to především jejich odpor v zapnutém stavu a nelineární závislost tohoto odporu na okolní teplotě a na protékajícím proudu. To proto, že spínače jsou přímo součástí zpětnovazební sítě operačního zesilovače.

Strrídač uspořádaný podle Obr. 9.14 a nemá analogový přepínač zapojen přímo do zpětnovazební sítě OZ a proto se jeho odpor v sepnutém stavu neuplatní [2], [27]. Bude-li přepínač $\mathrm{v}$ poloze 1 bude obvod pracovat jako neinvertující zesilovač $\mathrm{s}$ jednotkovým přenosem, tj. $u_{2} \approx \approx u_{1}$. Přepneme-li řidicím signálem $\Phi$ přepínač do polohy 2 , bude zapojení pracovat jako invertující zesilovač a na výstupu bude $u_{2} \approx-u_{1} R_{2} / R_{1}$. Aby obvod pracoval jako stř́idač, musí platit $R_{2}=R_{1}$. Potom pro výstupní napětí bude platit $u_{2} \approx \pm u_{1}$. Odpor sepnutého přepínače se díky vysokému vstupnímu odporu neinvertujícího vstupu neuplatní. $Z$ tohoto důvodu je pro přesné účely vhodné použít operační zesilovač osazený na vstupu tranzistory řízenými polem, poněvadž v tomto př́padě se reálné vlastnosti elektronického přepínače uplatní zanedbatelně málo.

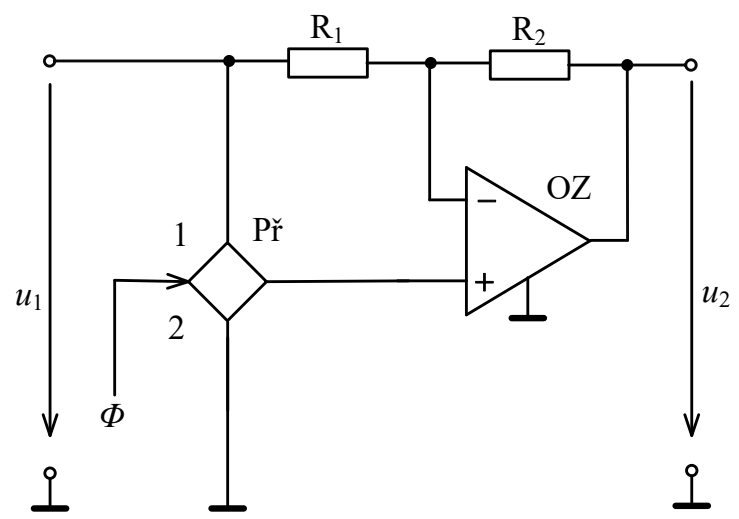

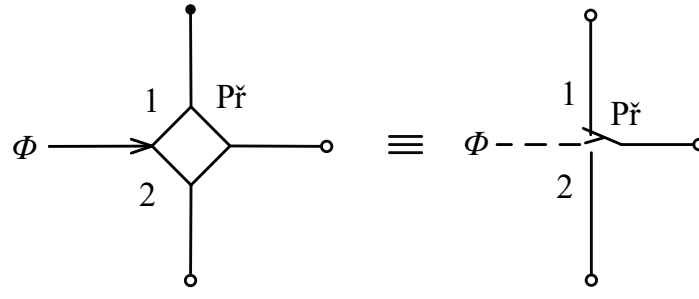

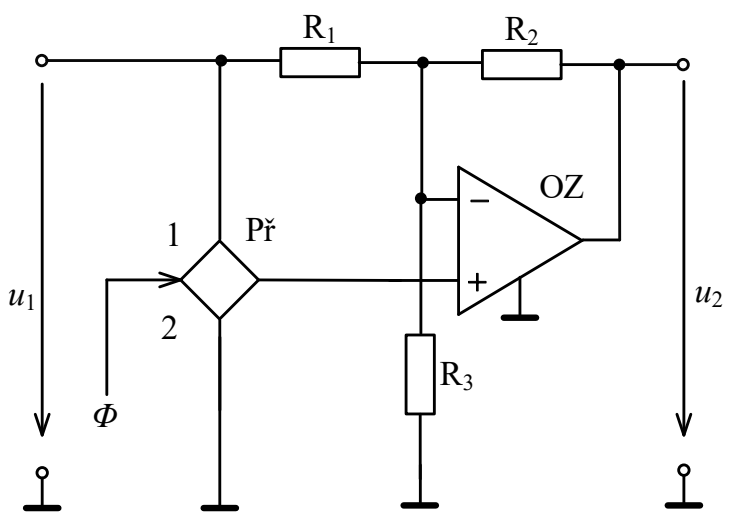

b

Obr. 9.14: Jednoduché elektronické střídače: a) s jednotkovým přenosem, b) s přenosem $k>1$

Pokud chceme zpracovávaný signál současně zesílit, můžeme použít zapojení stř̌́dače na Obr. $9.14 \mathrm{~b}$. V tomto př́ípadě bude pro výstupní napětí platit

$$
u_{2} \approx\left\{\begin{array}{cc}
\left(\frac{R_{2}}{R_{3}}+1\right) u_{1} & \text { Pŕ v poloze } 1, \\
-\frac{R_{2}}{R_{1}} u_{1} & \text { Př v poloze } 2 .
\end{array}\right.
$$


Zvolíme-li $R_{1}=R / k, R_{2}=R$ a $R_{3}=R /(k-1)$ bude činnost střídače popsána jednoduše vztahem $u_{2} \approx \pm k u_{1}$.

Nevýhodou jednoduchých střídačů je okolnost, že v závislosti na přepnutí přepínače se uplatňuje rozdílně vliv souhlasného napětí. Další nevýhodou těchto střídačů je jejich proměnný a pro některé aplikace př́liš nízký vstupní odpor, který se mění v závislosti na tom, zda je obvod přepnut na kladný nebo záporný přenos.

\subsubsection{Přesné elektronické stř́ídače}

Přesné elektronické střídače využívají výhodných vlastností invertujícího analogového demultiplexeru z Obr. 9.4c.

První zapojení stř́idače (Obr. 9.15) představuje spojení demultiplexeru s $\mathrm{OZ}_{1}$ a sčítacího zesilovače $\mathrm{s} \mathrm{OZ}_{2}$, [28], [29]. Přepneme-li př́epínač do polohy 1 , bude $\mathrm{OZ}_{2}$ zapojen jako invertující sčítací zesilovač, který má na jednom vstupu ještě předřazen invertující zesilovač $\mathrm{s}$ $\mathrm{OZ}_{1}$ a rezistory $\mathrm{R}_{1}$ a $\mathrm{R}_{2}$. $\mathrm{V}$ př́ípadě, že přepínač bude $\mathrm{v}$ poloze 2 , bude sériová kombinace rezistorů $\mathrm{R}_{2}+\mathrm{R}_{4}$ připojena na obou koncích na nulová napětí, které si oba zesilovače udržují na invertujících vstupech a tedy tyto rezistory nebudou mít na činnost obvodu vliv. Obvod se bude chovat jako invertující zesilovač s $\mathrm{OZ}_{2}$ a s rezistory $\mathrm{R}_{3}$ a $\mathrm{R}_{5}$.

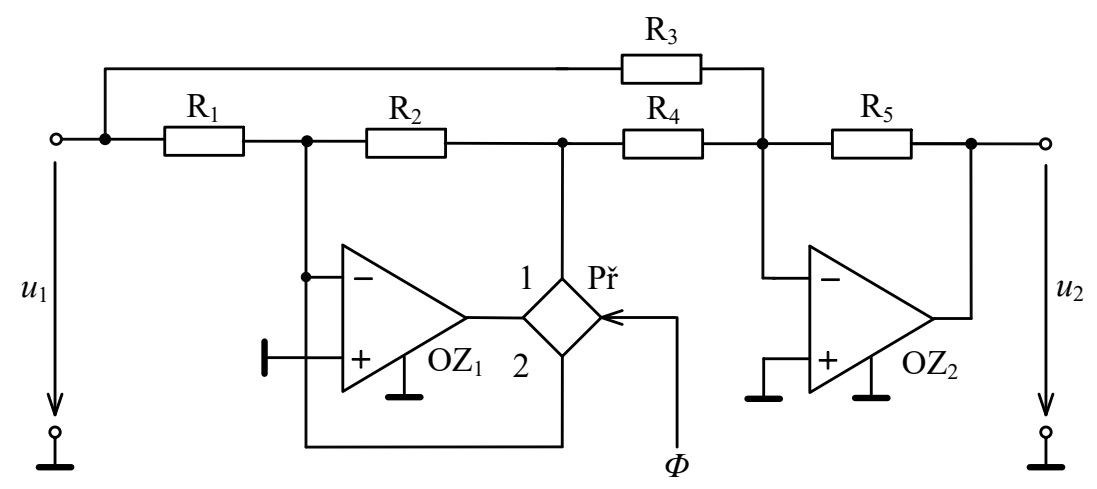

Obr. 9.15: Přesný elektronický stř́idač se sčítacím zesilovačem

Celkově je činnost střídače popsána rovnicí

$$
u_{2} \approx\left\{\begin{array}{cc}
\left(\frac{R_{2} R_{5}}{R_{1} R_{4}}-\frac{R_{5}}{R_{3}}\right) u_{1} & \text { Př v poloze } 1, \\
-\frac{R_{5}}{R_{3}} u_{1} & \text { Př v poloze } 2 .
\end{array}\right.
$$

Zvolíme-li $R_{1}=R_{2}, R_{4}=R_{3} / 2$ a $R_{5}=k R_{3}$, bude zapojení pracovat jako střídač $u_{2} \approx \pm k u_{1}$.

Jiné uspořádání přesného stř́dače je uvedeno na Obr. 9.16, [30]. Analogový demultiplexer $\mathrm{s} \mathrm{OZ}_{1}$ je využit ve funkci přesného (invertujícího) analogového přepínače, za který je připojen rozdílový zesilovač s $\mathrm{OZ}_{2}$. Při zapnutí přepínače do polohy 1 se stř́idač chová jednoduše jako dva invertující zesilovače zapojené v kaskádě. V poloze 2 přepínače je 


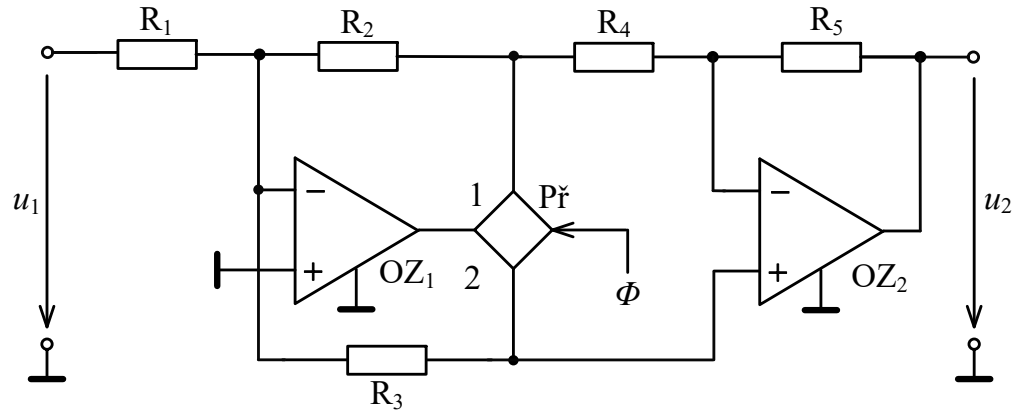

Obr. 9.16: Přesný elektronický střídač s rozdílovým zesilovačem

situace poněkud složitější. $\mathrm{V}$ tomto prípadě totiž $\mathrm{k}$ invertujícímu vstupu $\mathrm{OZ}_{1}$ směrují dvě zpětnovazební cesty. Jedna $\mathrm{z}$ výstupu $\mathrm{OZ}_{1}$ přes přepínač zapnutý do polohy 2 a resistor $\mathrm{R}_{3}$, druhá z výstupu $\mathrm{OZ}_{2}$ přes rezistory $\mathrm{R}_{5}, \mathrm{R}_{4}, \mathrm{R}_{2}$.

Pro výstupní napětí střídače můžeme psát

$$
u_{2} \approx\left\{\begin{array}{cc}
\frac{R_{2} R_{5}}{R_{1} R_{4}} u_{1} & \text { Př v poloze } 1, \\
-\frac{R_{3}\left(R_{2}+R_{4}+R_{5}\right)}{R_{1}\left(R_{2}+R_{3}+R_{4}\right)} u_{1} & \text { Př v poloze } 2 .
\end{array}\right.
$$

Pro $R_{1}=R_{2}=R_{4}=R, R_{3}=R_{5}=k R$ bude $u_{2} \approx \pm k u_{1}$.

Zapojení stř́idače uvedené na Obr. 9.17 [31] představuje paralelní spojení invertujícího a neinvertujícího zapojení operačního zesilovače s analogovým přepínačem na výstupu.

Jsou-li oba přepínače Př $_{1}$ a Přr $\check{r}_{2}$ v poloze 1 , je výstupní napětí dáno pouze výstupním napětím invertujícího zapojení s operační zesilovačem $\mathrm{OZ}_{2}$. Rezistor $\mathrm{R}_{2}$ je sice připojen jedním koncem na napětí přibližně rovné vstupnímu, které si na svém invertujícím vstupu udržuje operační zesilovač $\mathrm{OZ}_{1}$, ale proud tím vyvolaný se uplatní jen v zanedbatelné míre, protože obvod s $\mathrm{OZ}_{2}$, se chová při přepnutí Př́2 do polohy 1 jako velice tvrdý zdroj napětí. Po přepnutí obou přepínačů do polohy 2 je výstupní napětí dáno jen výstupním napětím neinvertujího

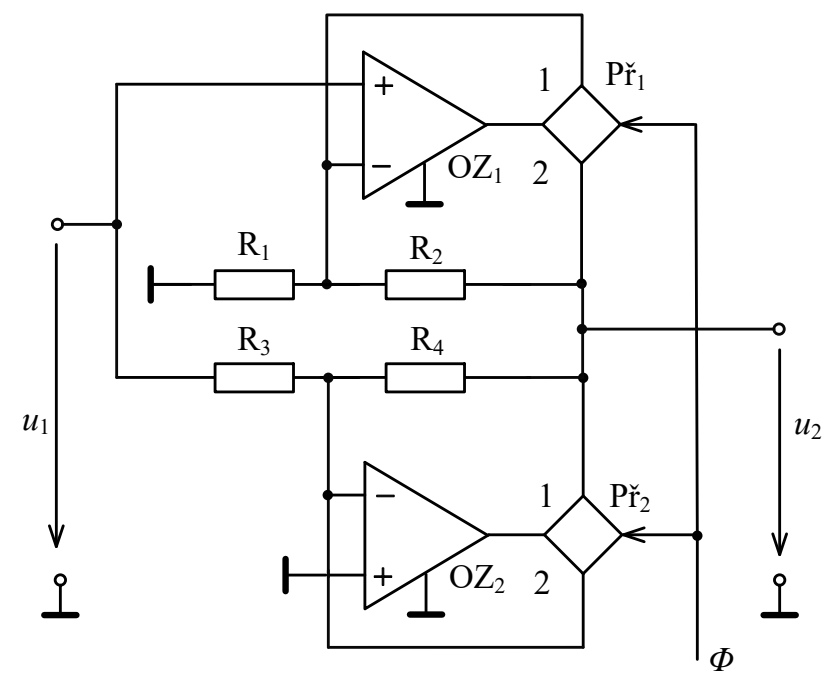

Obr. 9.17: Jiné zapojení přesného elektronického střídače 
zapojení s operačním zesilovačem $\mathrm{OZ}_{1}$. Rezistor $\mathrm{R}_{4}$ je nyní pouze zátěží neinvertujícího zesilovače s $\mathrm{OZ}_{1}$. Proto

$$
u_{2} \approx\left\{\begin{array}{cc}
-\frac{R_{4}}{R_{3}} u_{1} & \mathrm{P}_{1}, \check{\mathrm{P}}_{2} \text { v poloze } 1, \\
\left(1+\frac{R_{2}}{R_{1}}\right) u_{1} & \mathrm{P}_{1}, \check{\mathrm{P}}_{2} \text { v poloze } 2 .
\end{array}\right.
$$

Určitou nevýhodou může být větší počet užitých elektronických přepínačů. Obvykle však není tato okolnost na závadu, protože při použití integrovaných přepínačů je $\mathrm{v}$ jednom pouzdře několik přepínačů. Střídač je vhodné provozovat s modulem přenosu $k=1$, protože přesnost pak v rozhodující míře závisí na poměru odporů rezistorů $R_{3}$ a $R_{4}$. $V$ tom prípadě se totiž volí $R_{1}=\infty, R_{3}=R_{4}, R_{2} \neq 0$ (odpor rezistoru $\mathrm{R}_{2}$ sice nyní přenosové vlastnosti neurčuje, ale je nutno ho volit tak, aby $\mathrm{OZ}_{2}$ nebyl prétížen). Pokud zvolíme $R_{2}=(k-1) R_{1}, R_{4}=k R_{3}$ bude střídač popsán vztahem $u_{2} \approx \pm k u_{1}$.

\subsubsection{Stř́ídače s velkým vstupním odporem}

U všech dosud uvedených střídačů může být v některých případech na závadu relativně malý vstupní odpor a u některých pak navíc závislost vstupního odporu na přepnutí přepínačů. $\mathrm{Z}$ tohoto důvodu by $\mathrm{v}$ některých aplikacích bylo nutno před stř́idač předřadit ještě oddělovací neinvertující zesilovač s dalším OZ. Bude-li mít ale střídač vysoký vstupní odpor, můžeme oddělovací zesilovač vypustit.

Jedno takové zapojení střídače s vysokým vstupním odporem je uvedeno na Obr. 9.18 [32]. Zapojení umožňuje navrhnout stř́dač pouze s jednotkovým přenosem.

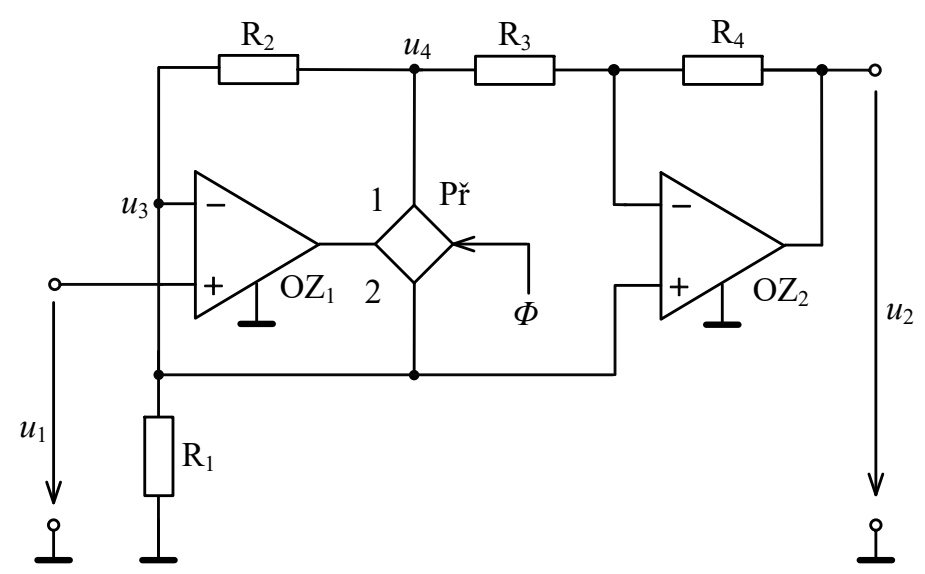

Obr. 9.18: Střídač s velkým vstupním odporem a s jednotkovým přenosem

Bude-li přepínač přepnut do polohy 1 , bude $\mathrm{OZ}_{1}$ zapojen jako neinvertující a na jeho výstupu bude napětí $u_{4} \approx\left(1+R_{2} / R_{1}\right) u_{1}$. Na invertujícím vstupu si $\mathrm{OZ}_{1}$ bude přitom udržovat napětí $u_{3} \approx u_{1}$. Zesilovač $\mathrm{OZ}_{2}$ je zapojen jako rozdílový zesilovač a tedy

$$
u_{2} \approx\left(1+\frac{R_{4}}{R_{3}}\right) u_{3}-\frac{R_{4}}{R_{3}} u_{4}
$$

a po dosazení za $u_{3}$ a $u_{4}$ bude 


$$
u_{2} \approx\left(1-\frac{R_{2} R_{4}}{R_{1} R_{3}}\right) u_{1} .
$$

Přepneme-li přepínač do polohy 2 , je $\mathrm{OZ}_{1}$ zapojen jako neinvertující zesilovač s jednotkovým přenosem a tedy $u_{3} \approx u_{1}$. Zesilovač $\mathrm{OZ}_{2}$ je i zde zapojen jako rozdílový, ale jeho vstupní napětí a přenos jsou nyní jiné

$$
u_{2} \approx\left(1+\frac{R_{4}}{R_{2}+R_{3}}\right) u_{3}-\frac{R_{4}}{R_{2}+R_{3}} u_{3}=u_{3} \approx u_{1} .
$$

Odtud je zřejmé, že stř́idač může mít pouze jednotkový přenos. To bude splněno, když $R_{1}=R_{2}=R_{3}=R, R_{4}=2 R$ a celková činnost obvodu bude popsána jednoduše vztahem $u_{2} \approx \pm u_{1}$

Z hlediska potřebného počtu přesných rezistorů je velmi výhodné řešení střídače s vysokým vstupním odporem podle Obr. 9.19 [33]. Činnost stř́idače je jednoduchá. Jsou-li oba přepínače $\mathrm{v}$ poloze 1 , pracuje první operační zesilovač $\mathrm{OZ}_{1}$ jako oddělovací zesilovač $\mathrm{s}$ jednotkovým přenosem, za který je zapojen invertující zesilovač $\mathrm{s} \mathrm{OZ}_{2}$. Odpor rezistoru $\mathrm{R}_{2}$ přenosové vlastnosti nyní neovlivňuje, protože je zapojen jako zátěž zesilovače s $\mathrm{OZ}_{2}$. Budouli přepínače přepnuty do polohy 2 , chová se obvod jak neinvertující zesilovač, protože dolní konec rezistoru $R_{1}$ je připojen prakticky na nulový potenciál, který se v důsledku zpětné vazby přes zapnutý přepínač Př $\check{r}_{2}$ udržuje na invertující vstupní svorce operačního zesilovače OZ. Přenos $v$ tomto př́padě neovlivňuje odpor rezistoru $\mathrm{R}_{3}$, protože ten je pro tento prrípad zapojen jako zátěž zesilovače s $\mathrm{OZ}_{1}$. Celkově je strrídač popsán rovnicí

$$
u_{2} \approx\left\{\begin{array}{cc}
-\frac{R_{3}}{R_{1}} u_{1} & \mathrm{P}_{1}, \check{\mathrm{P}}_{2} \text { v poloze } 1, \\
\left(1+\frac{R_{2}}{R_{1}}\right) u_{1} & \mathrm{P}_{1}, \check{\mathrm{P}}_{2} \text { v poloze } 2 .
\end{array}\right.
$$

Doporučená volba hodnot rezistorů pro $k>1$ je $R_{1}=R, R_{2}=(k-1) R, R_{3}=k R$ a pak $u_{2} \approx \pm k u_{1}$.

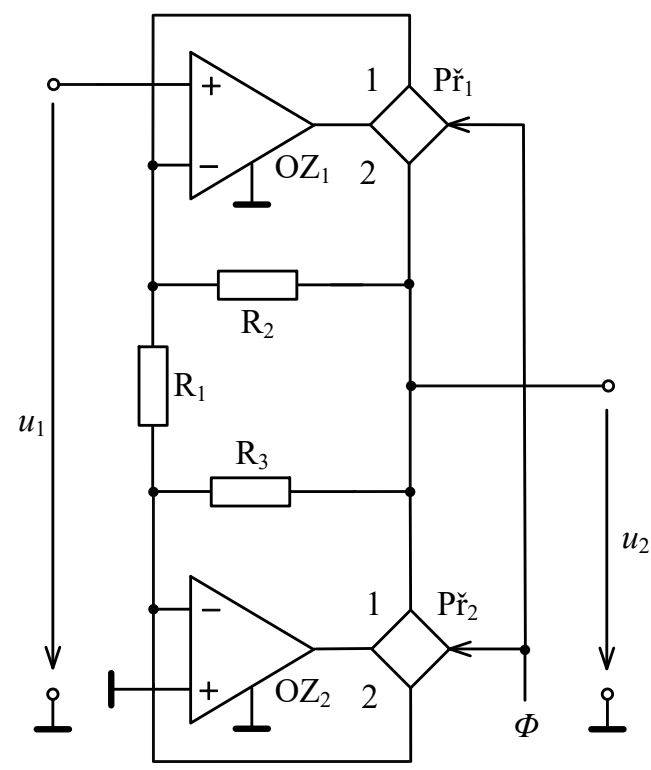

Obr. 9.19: Přesný elektronický stř́idač s vysokým vstupním odporem a s přenosem $k>1$ 


\subsection{Vzorkovače/sledovače s pamětí}

\subsubsection{Princip vzorkovače/sledovače s pamětí}

Při digitalizaci analogového signálu je nutno provést vzorkování signálu, ale často také zapamatování tohoto vzorku po určitou dobu, protože převedení do digitálního tvaru jistou dobu trvá. Pro správnou činnost A/D převodníku je proto často nutné, aby se vstupní napětí během převodu A/D neměnilo. $K$ definovanému odběru a uchování vzorku z časově proměnného analogového signálu se používají vzorkovače s pamětí $(\mathrm{S} / \mathrm{H}$ amplifier $=$ sample and hold amplifier) nebo sledovače s pamětí $(\mathrm{T} / \mathrm{H}$ amplifier $=$ track and hold amplifier). Obvody se vzájemně liší pouze tím, po jakou dobu se analogový signál vzorkuje.

Základní princip vzorkovacího obvodu je naznačen na Obr. 9.20a, [34], [35]. Vlastní vzorkovací obvod tvoří elektronický spínač $\mathrm{S}$ (např. tranzistor řízený polem) s pamětovým kapacitorem $C_{\mathrm{P}}$. Zesilovač $\mathrm{Z}_{1} \mathrm{~s}$ jednotkovým prenosem pouze odděluje zdroj budicího signálu od vlastního vzorkovacího obvodu, protože při sepnutí elektronického spínače $\mathrm{S}$ teče do pamětového kapacitoru velký nabíjecí proud a tento proud musí být schopen zesilovač $Z_{1}$ dodat. Zesilovač $Z_{2}$ s velkým vstupním odporem odděluje pamět'ový kapacitor $C_{P}$ od zátěže (představovanou vstupním odporem následujícího převodníku $\mathrm{A} / \mathrm{D}$ ), protože by docházelo $\mathrm{v}$ době pamatování $\mathrm{k}$ nežádoucímu vybíjení pamětového kapacitoru.

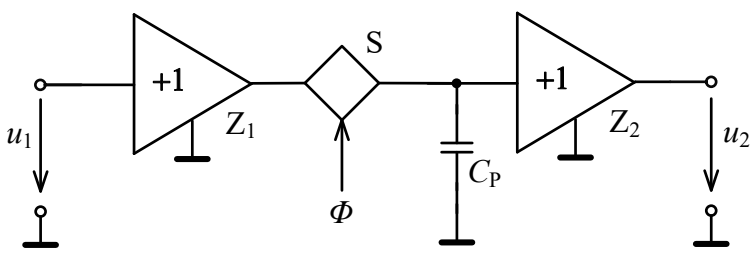

a

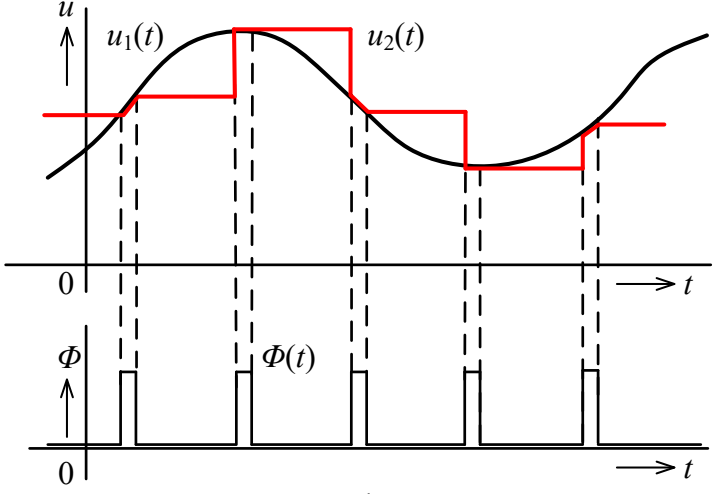

b

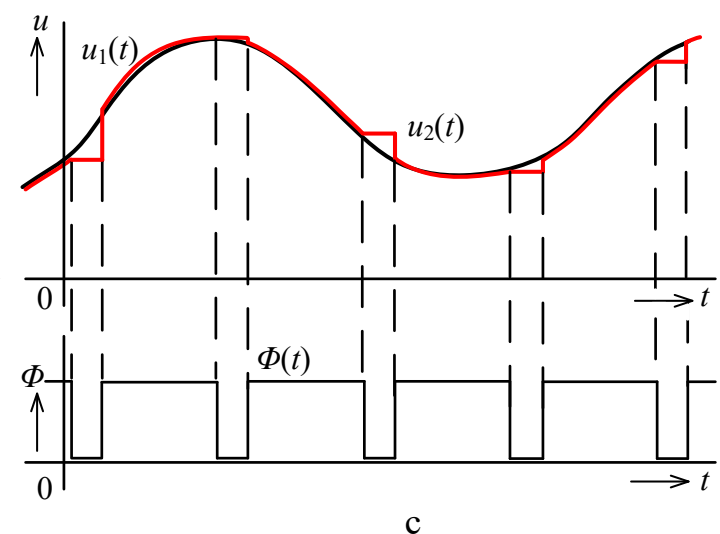

C

Obr. 9.20: a) Princip vzorkovače/sledovače s pamětí, b) režim S/H, c) režim T/H

Ideální vzorkovač s pamětí by měl vzorkovat analogový vstupní signál tak, že doba na odebrání vlastního vzorku by měla být co nejkratší (viz Obr. 9.20b). Přitom se požaduje, aby i během této krátké doby vzorkování odpovídal vzorek okamžité hodnotě vzorkovaného signálu. V režimu pamatování by pak měl být zapamatovaný vzorek signálu na výstupu vzorkovače $\mathrm{k}$ dispozici beze změny alespoň po dobu, kterou potřebuje následující převodník $\mathrm{A} / \mathrm{D}$ pro př̀evod analogového signálu do číslicového tvaru.

Režim sledovače se užívá při vzorkování velmi pomalých změn zpracovávaného signálu. Sledovač s pamětí v podstatě trvale sleduje měřený signál a poslední hodnotu si pamatuje pouze po dobu, kterou následující převodník A/D potřebuje pro převod do digitálního tvaru (viz Obr. 9.20c). 
S výjimkou speciálních vzorkovačů s dobou odběru vzorku kratší než časová konstanta nabíjecího obvodu pamět'ového kapacitoru nemá praktický význam odlišovat vzorkovač s pamětí $(\mathrm{S} / \mathrm{H})$ od sledovače s pamětí $(\mathrm{T} / \mathrm{H})$. Fyzikálně realizovatelný vzorkovač $\mathrm{k}$ tomu, aby sejmul vzorek, musí na krátkou dobu vždy přejít do sledovacího provozu. Teprve po ukončení přechodného děje nabíjení pamět'ového kapacitoru se může vrátit zpět do provozu pamětového (doprovázeného dalším přechodným dějem). Z hlediska těchto přechodných dějů není podstatný rozdíl mezi vzorkovačem a sledovačem. Jediný rozdíl je v organizaci povelových signálů, které u vzorkovače zkracují sledování na nejmenší možnou míru a v tom, že u vzorkovačů se klade větší důraz na zkrácení doby upnutí vzorku k analogovému signálu (viz Obr. 9.20b). Konstrukčně jsou ale oba obvody provedeny téměř nebo úplně stejně.

Uved'me ještě, že vlastní obvod může být proveden v různých variantách. Především nemusí pracovat jako „klasický“ sledovač napětí s jednotkovým přenosem, ale jeho zesílení ve sledovacím provozu může být různé od jedné, obvod může i invertovat. Integrované vzorkovače či sledovače pro všeobecné použití mají většinou možnost připojení vnějšího pamětového kapacitoru.

Výběru pamětového kapacitoru je nutno vždy věnovat velkou pozornost. Použité dielektrikum (keramika, nebo izolační fólie z polystyrenu či polyetylenu aj) není ideální izolací a reálné vlastnosti kapacitoru ještě zhoršuje materiál vnějšího pláště (termoplast, ochranný tmel, izolační lak apod). Izolační či svodový odpor pamětového kapacitoru by měl být $10^{11}$ až $10^{12}$ $\Omega$. U některých kapacitorů pak navíc další ztráty způsobuje trvalý průchod tzv. zbytkového stejnosměrného proudu. Z tohoto důvodu jsou jako pamětový prvek zcela nevhodné elektrolytické kondenzátory. Velkou pozornost je nutno také věnovat dielektrické absorbci pamět'ového kapacitoru. Nabije-li se kapacitor na určité napětí, část náboje se váže s dielektrikem a nelze ho odstranit krátkodobým vybitím. Nevhodný výběr kapacitoru s velkou dielektrickou absorbcí může způsobit velkou chybu zapamatovaného napětí o desítky nebo dokonce stovky $\mathrm{mV}$. Jako materiál dielektrika se proto doporučuje volit polystyrén nebo polypropylen, které vykazují součinitel dielektrické absorbce lepší než $0,02 \%$. Špatné dielektrické vlastnosti mají kapacitory s keramickým dielektrikem. Bohužel dielektrická absorbce se liší typ od typu a některé série kondenzátorů s polystyrenovým či polypropylenovým dielektrikem mohou vykazovat velkou dielektrickou absorbci. Proto se vyplatí investovat 30 až 50 \% ceny navíc a pro vzorkovače koupit kapacitory se zaručenou malou dielektricku absorbcí.

\subsubsection{Vzorkovače/sledovače s pamětí bez zpětné vazby}

Jednoduché uspořádání vzorkovače s pamětí je uvedeno na Obr. 9.21. Operační zesilovače zapojené jako sledovače napětí (zesilovače s jednotkovým přenosem a vysokým vstupním odporem) slouží k oddělení vstupu a výstupu vlastního vzorkovacího obvodu. Tato architektura zapojení se označuje jako vzorkovač s pamětí bez zpětné vazby, protože spínač není zařazen do zpětnovazební smyčky. Výhodou je velká rychlost vzorkování, nevýhodou pak horší přesnost, protože stejnosměrné chyby obou zesilovačů se sčítají. Vynikajících dynamických vlastností se dosahuje volbou rychlých součástek: velmi rychlé impulsové zesilovače, rychlý převodník napětových úrovní z logických úrovní pro ovládání vlastního spínače, realizace spínače diodovým můstkem se Schottkyho diodami, volbou malé kapacity pamět'ového kapacitoru (např. 4 až 5 pF) a značným proudovým dimenzováním výstupu $\mathrm{OZ}_{1}$. 


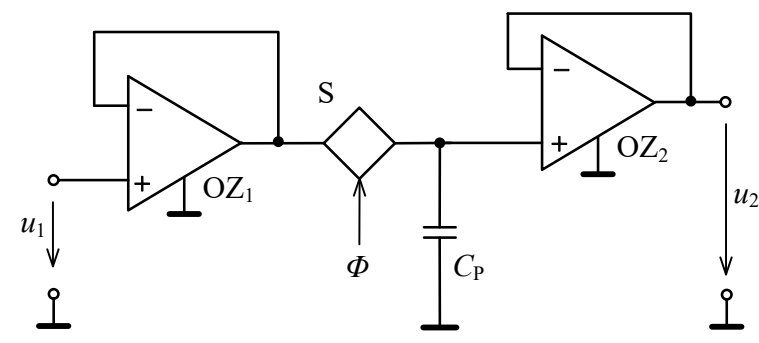

Obr. 9.21: Vzorkovač/sledovač s pamětí bez zpětné vazby

V režimu pamatování se může u zapojení vzorkovače na Obr. 9.21 uplatnit vliv vstupního klidového proudu zesilovače $\mathrm{OZ}_{2}$, který je sice malý, ale způsobuje neustálou změnu zapamatovaného napětí $\mathrm{v}$ čase. Vliv vstupního klidového proudu můžeme minimalizovat úpravou zapojení uvedenou na Obr. 9.22. Oba spínače se spínají synchronně. V režimu vzorkování se kapacitor $C_{P}$ nabije a současně se kapacitor $C_{K}$ vybije. V režimu pamatování jsou pak oba kapacitory vybíjeny vstupními klidovými proudy operačního zesilovače $I_{+}$a $I_{-}$ tekoucími do neinvertujícího a invertujícího vstupu $\mathrm{OZ}_{2}$. Vliv vstupních klidových proudů bude eliminován když

$$
C_{\mathrm{K}}=C_{\mathrm{P}} \frac{I_{-}}{I_{+}}
$$

Zvolíme-li $C_{\mathrm{K}}=C_{\mathrm{P}}$, bude se na vybíjení pamět'ového kapacitoru $C_{\mathrm{P}}$ podílet pouze vstupní proudová nesymetrie zesilovače $\mathrm{OZ}_{2}$. Zapojení je vhodné pro středně rychlé aplikace (s dobou vzorkování kolem $1 \mu \mathrm{s})$. Díky této úpravě se dosahuje vynikající doby pamatování (řádově $1 \mathrm{~s}$ ).

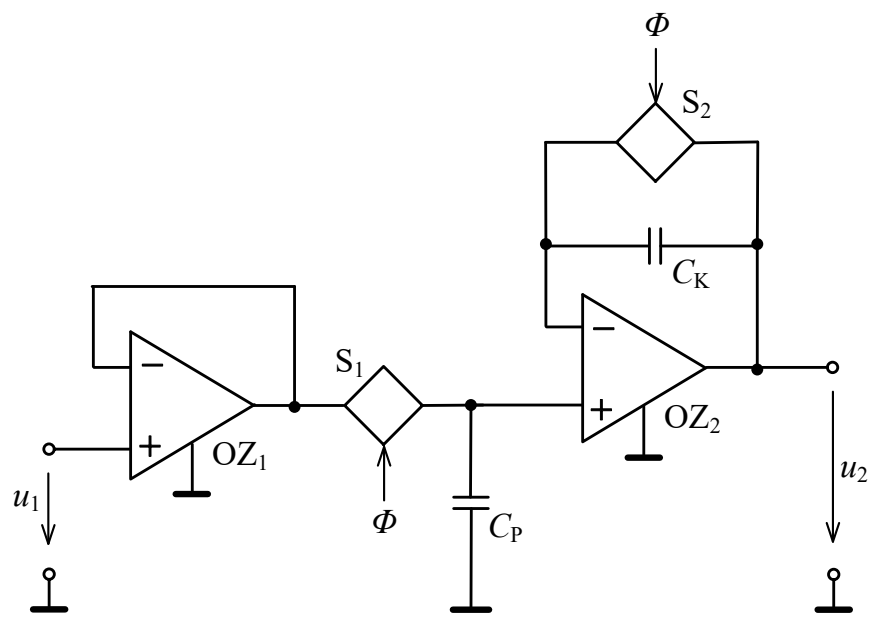

Obr. 9.22: Vzorkovač/sledovač s pamětí bez zpětné vazby s kompenzací vstupních klidových proudů

\subsubsection{Vzorkovače/sledovače s pamětí se zpětnou vazbou}

Pro aplikace vyžadující vyšší přesnost můžeme využít zpětnovazební zapojení vzorkovače s pamětí (viz Obr. 9.23a). Zpětná vazba zvyšuje přsesnost obvodu v režimu vzorkování ve srovnání se vzorkovači bez zpětné vazby. Nevýhodou je prodloužení doby vzorkování vlivem delšího ustalování zpětnovazební smyčky. Velké zesílení $\mathrm{OZ}_{1} \mathrm{v}$ režimu vzorkování způsobuje, že pamět'ový kapacitor $C_{P}$ se v první fázi nabíjí z daleko většího napětí, než tomu bylo v případě zapojení na Obr. 9.21 a to po dobu, dokud napětí na diferenčních vstupech $\mathrm{OZ}_{1}$ nebude shodné. Stejnosměrné chyby zesilovač $\mathrm{OZ}_{2}$ jsou díky zpětné vazbě 
eliminovány a proto stačí napět'ovou nesymetrii nulovat v režimu vzorkování jen u zesilovače $\mathrm{OZ}_{1}$.
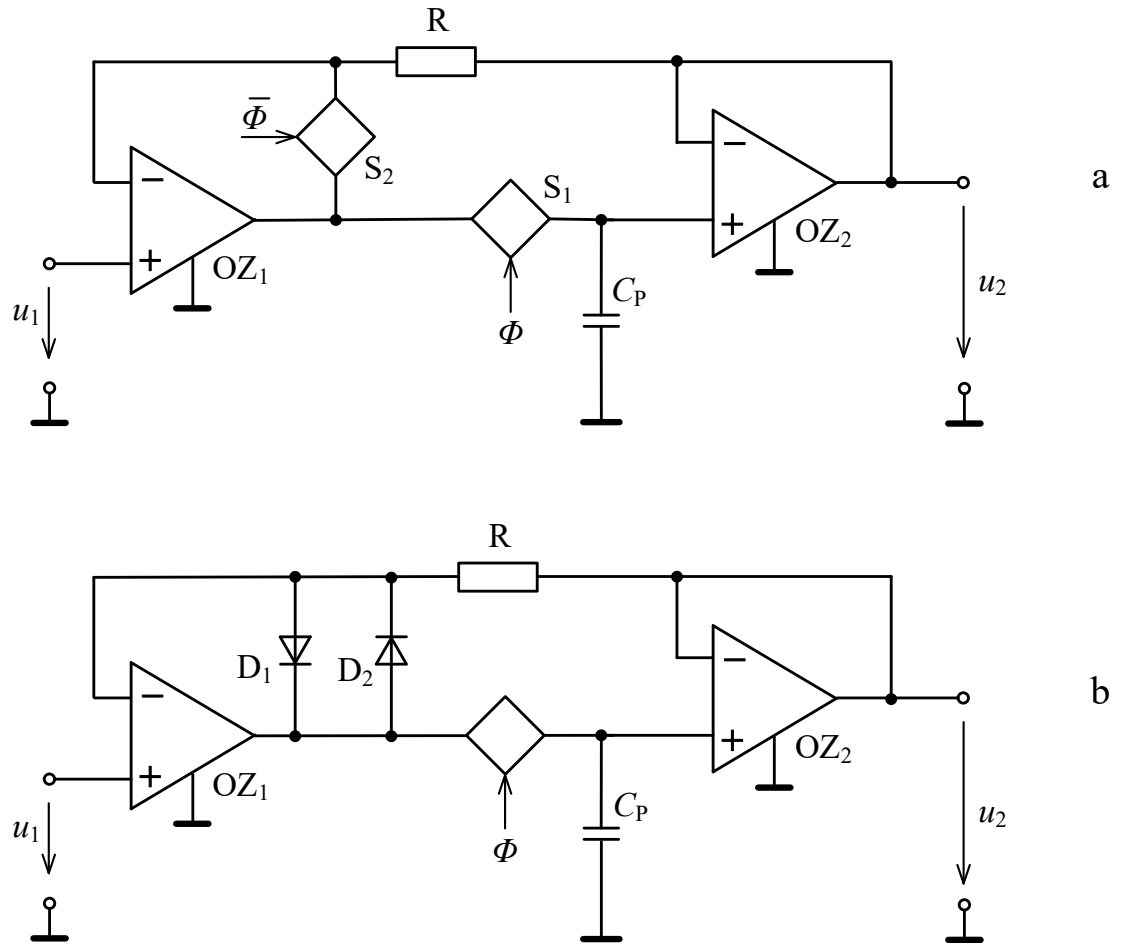

Obr. 9.23: a) Zpětnovazební zapojení vzorkovače s pamětí, b) zamezení saturace antiparalelně zapojenou dvojicí diod

Aby nedošlo v době pamatování ( $\mathrm{S}_{1}$ rozpojen) $\mathrm{k}$ rozpojení zpětnovazební smyčky a $\mathrm{k}$ saturaci výstupního napětí $\mathrm{OZ}_{1}$, je vzorkovač doplněn o protitaktně spínaný spínač $\mathrm{S}_{2}$. Doba zotavení operačního zesilovače ze saturace by byla totiž řádově delší, než jsou obvyklé požadavky na dobu vzorkování. Stejně dobře saturaci zesilovače $\mathrm{OZ}_{1}$ zabrání dvojice antiparalelně zapojených diod u zapojení vzorkovače na Obr. 9.23b. Diody $\mathrm{D}_{1}$ a $\mathrm{D}_{2}$ omezují v režimu pamatování (S rozpojen) výstupní napětí zesilovače $\mathrm{OZ}_{1}$ na $\pm 0,6 \mathrm{~V}$. Toto řešení se např. využívá u nejrozširreneněšího integrovaného vzorkovače na světě typové řady 198/298/398.

Přesnost zpětnovazebního vzorkovače s pamětí z Obr. 9.23a můžeme zlepšit kompenzací vstupních klidových proudů zesilovače $\mathrm{OZ}_{2}$ tak, jak je to uvedeno na Obr. 9.24. I v tomto prrípadě volíme $C_{\mathrm{K}}=C_{\mathrm{P}}$, protože pak se na vybíjení pamět'ového kapacitoru bude podílet jen vstupní proudová nesymetrie operačního zesilovače $\mathrm{OZ}_{2}$. Protitaktně spínaný spínač S3 zabraňuje saturaci zesilovače $\mathrm{OZ}_{1}$ v režimu pamatování, kdy je zpětnovazební smyčka rozpojena. 


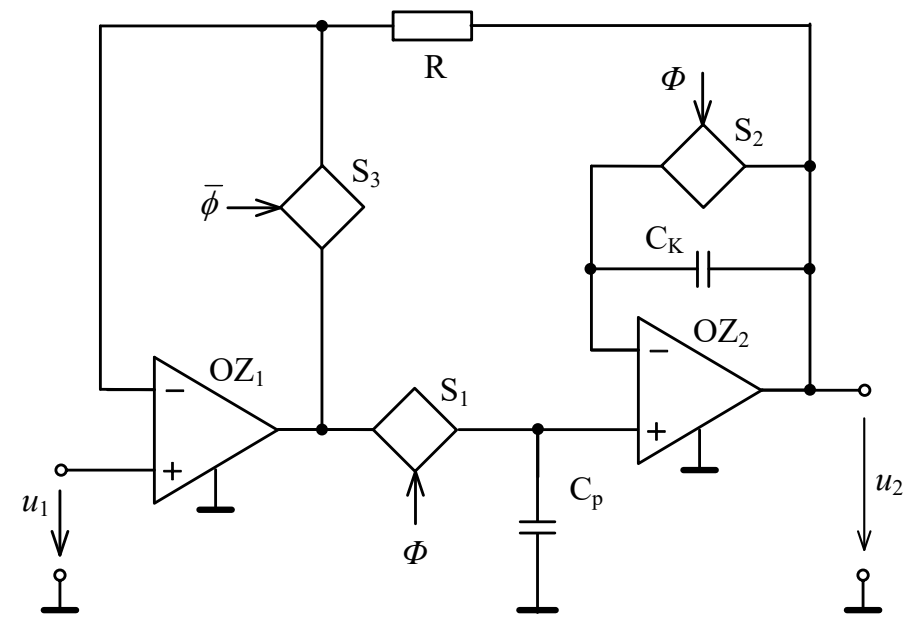

Obr. 9.24: Zpětnovazební vzorkovač s pamětí s kompenzací vstupních klidových proudů

Přesunutí pamět'ového kapacitoru do zpětné vazby integrátoru (viz Obr. 9.25a) snižuje nároky na analogový spínač, protože ten se nyní spíná k nulovému napětí, které se vytvoří virtuálně na invertujícím vstupu OZ. Jde o klasické zpětnovazební řešení a je používáno u řady integrovaných vzorkovačů. V režimu vzorkování se spínač sepne a pamět’ový kapacitor se nabíjí podle exponenciální funkce s časovou konstantou $\tau=\left(R_{2}+r_{\mathrm{ON}}\right) C_{\mathrm{P}}$, kde $r_{\mathrm{ON}} \mathrm{značí} \mathrm{odpor}$ sepnutého elektronického spínače $\mathrm{S}$. Po určité době (např. pro přesnost $0,01 \%$ za dobu $T_{\mathrm{V}} \geq 9$ $\left(R_{2}+r_{\mathrm{ON}}\right) C_{\mathrm{P}}$ se výstupní napětí ustálí na hodně $u_{2} \approx-u_{1} R_{2} / R_{1}$. Aby se požadovaná doba na vzorkování co nejvíce zkrátila, je nutné volit odpor $R_{2}$ co nejmenší. To všem naráží na omezené proudové schopnosti operačního zesilovače.

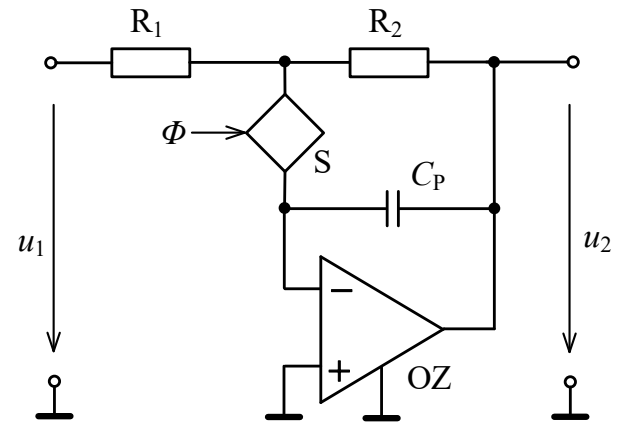

a

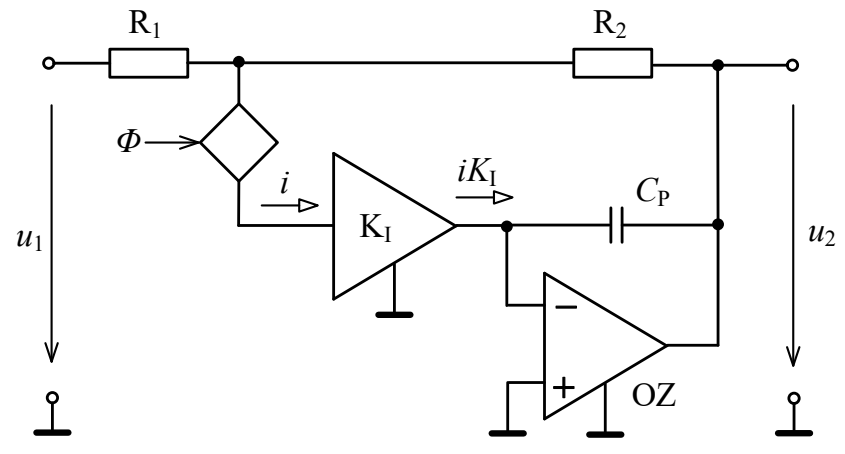

$\mathrm{b}$

Obr. 9.25: Invertující zapojení vzorkovače s pamětí s integrátorem: a) základní řešení, b) s urychleným nabíjením

Řešení zkracující nabíjení pamětového kapacitoru je uvedeno na Obr. 9.25b. Za analogový spínač je doplněn zesilovač proudu s proudovým přenosem $K_{\mathrm{I}}$. Nabíjecí proud pamětového kapacitoru v režimu vzorkování bude nyní $K_{\mathrm{I}}$-krát větší a doba nabíjení kapacitoru na požadovanou přesnost se $K_{\mathrm{I}}$-krát zkrátí. Pozn.: velikost proudového přenosu $K_{\mathrm{I}}$ je omezena tím, že maximální hodnota nabíjecího proudu kapacitoru $C_{\mathrm{P}}$ nemůže být větší než maximální výstupní proud operačního zesilovače OZ. 


\section{Použitá literatura}

[1] GRAME, J. G. Designing with Operational Amplifiers - Applications Alternatives. New York, McGraw-Hill Book Company, 1977

[2] VRBA, K. Zpětnovazební zapojení operačního zesilovače s elektronickým přepínačem na vstupu. Slaboproudý obzor 42 (1981), č. 6, s. 276-281

[3] VRBA, K. Zapojení elektronického invertujícího zesilovače s přepínatelným zesílením. Patent č. 207991

[4] BOWERS, D. Analogue multiplexers: their technology and operation. Electronic engineering 50 (1978), č. 612, s. 23-29

[5] VRBA, K. Programovatelný zesilovač. Sdělovací technika 38, 1990, č. 2, s. 52

[6] BURR-BROWN. Integrated Circuits Data Book. Schiphol (Holland)

[7] VRBA, K. Zapojení zesilovače s přepínatelným zesílením s možností přepínání polarity zesílení. Patent č. 214346

[8] VRBA, K. Zapojení analogového demultiplexeru. Patent č. 207202

[9] VRBA, K. Zapojení analogového demultiplexeru s velkým vstupním odporem. Patent č. 211519

[10] VRBA, K. Zesilovače s elektronicky přepínaným zesílením. Slaboproudý obzor 41, 1980, č. 9, s. 457-459.

[11] HARRIS SEMINOCONDUCTOR. Linear Integrated Circuits. Data Book

[12] CONNELlY, J. A. ed. Analog Integrated Circuits - Devices, Circuits, Systems, and Applications. New York, John Wiley and Sons 1983

[13] VRBA, K. Zapojení elektronického zesilovače s ř́zeným zesílením. Patent č. 207897

[14] VRBA, K. Několik aplikací přesného analogového rozdělovače. Slaboproudý obzor 41, 1980, č. 7, s. 357-359

[15] VRBA, K. Zapojení elektronického analogového zesilovače s velkým vstupním odporem. Patent č. 207986

[16] VRBA, K. Zapojení elektronického zesilovače s velkým vstupním odporem, zejména pro dálkové přepínání velikosti zesílení. Patent č. 207985

[17] VRBA, K. Zapojení elektronického invertujícího zesilovače s řiditelným zesílením. Patent č. 206689

[18] VRBA, K.; PESLAR, V. Invertující zesilovač s elektronicky přepínanou zpětnou vazbou. Slaboproudý obzor 42 (1981), č. 1, s. 42-43

[19] VRBA, K. Zapojení elektronického zesilovače s řiditelným zesílením. Patent č. 206690

[20] VRBA, K. Neinvertující zesilovač s elektroniky přepínanou zpětnou vazbou. Elektrotechnický časopis 32 (1981), č. 3, s. 243-246

[21] VRBA, K. Zapojení rozdílového obvodu s přepínatelným zesílením. Patent č. 216057

[22] VRBA, K. Zapojení rozdílového zesilovače s přepínatelným zesílením. Patent č. 220461

[23] DOSTÁL, J. Aplikace analogově-číslicových obvodů. In: Sborník ČSVTS k.p. Tesla Rožnov, 1986

[24] VRBA, K.; BARTUŠEK, K. Programovatelný měřicí zesilovač. Patent č. 274852

[25] VRBA, K. Zapojení analogového multiplexeru. Patent č. 207276

[26] VRBA, K. Zapojení rozdílového analogového multiplexeru. Patent č. 233353

[27] NATIONAL SEMICONDUCTOR: Linear Integrated Circuits. Santa Clara, National Semiconductor Corporation, 1986

[28] VRBAK, K. Přesné elektronické střídače. Elektrotechnický časopis 32 (1981), č. 2, s. $102-131$

[29] VRBA, K. Zapojení elektronického stř́idače. Patent č. 207974

[30] VRBA, K. Zapojení synchronního usměrňovače. Patent č. 207900

[31] VRBA, K. Zapojení přesného elektronického střídače. Patent č. 207979 
[32] VRBA, K. Zapojení elektronického synchronního usměrňovače s velkým vstupním odporem. Patent č. 205832

[33] VRBA, K. Zapojení vyváženého modulátoru s velkým vstupním odporem. Patent č.202934

[34] ANALOG DEVICES MT-090. Sample and Hold Amplifiers. Analog Devices Tutorial, 2009.

[35] TEXAS INSTRUMENTS. Application Note 775 Specifications and Architectures of Sample and Hold Amplifiers Texas Instruments, 2011. 


\section{Napájecí zdroje}

V této kapitole se budeme zabývat pouze tzv. spojitými napájecími zdroji. Nespojité, tzv. spínané či impulsní napájecí zdroje jsou již mimo rámec toho textu. Spojité napájecí zdroje vykazují sice nižší účinnost a mají větší rozměry, ale jejich výhodou je menší zvlnění a nižší šum výstupního napětí. Co je ovšem nejdůležitější, spínané zdroje pracují obvykle s kmitočty $20 \mathrm{kHz}$ až $200 \mathrm{kHz}$ a pro tyto jehlové impulsy parazitní kapacity ( 5 až $10 \mathrm{pF}$ ) představují jen malou reaktanci a úzké jehlové impulsy snadno proniknou z napájecích zdrojů prímo do analogových signálových cest. Spojité napájecí zdroje mají zvlnění, které vzniká při dvoucestném usměrnění, na základním kmitočtu jen $100 \mathrm{~Hz}$ a pro tyto kmitočty parazitní kapacity představují velkou reaktanci a zvlnění napájecích zdrojů do analogových signálových cest $\mathrm{v}$ tomto př́padě nepronikne.

Základní uspořádání klasického spojitého napájecího zdroje je uvedeno na Obr. 10.1. Transformátor sníží sítové napětí $230 \mathrm{~V}_{\sim}$ na potřebnou úroveň, pak dochází k usměrnění stř́idavého napětí a k jeho vyhlazení střádacím (filtračním) kapacitorem. Pro dobré vyhlazení usměrněného napětí je nutno použít velkou kapacitu stř́ádacího kapacitoru a proto se obvykle užije elektrolytický kondenzátor. Kapacitu střádacího kapacitoru však nelze volit nekonečně velkou. Abychom zmenšili kolísání napětí a vliv zátěže na toto kolísání, zařazuje se stabilizátor napětí. Pro dobrou stabilizaci se doporučuje, aby úbytek napětí na stabilizátoru nebyl menší než $3 \mathrm{~V}$ a proto $U_{\mathrm{Z}}=U_{\mathrm{S}}+3 \mathrm{~V}$. Samotný stabilizátor př́liš velký proud neodebírá a proto $I_{\mathrm{Z}}=I_{\mathrm{S}}$. Filtrační kapacitor bude proto zatížen ekvivalentní zátěží $R_{\mathrm{Z}}=U_{\mathrm{Z}} / I_{\mathrm{Z}} \approx\left(U_{\mathrm{S}}+3 \mathrm{~V}\right) / I_{\mathrm{S}}$.

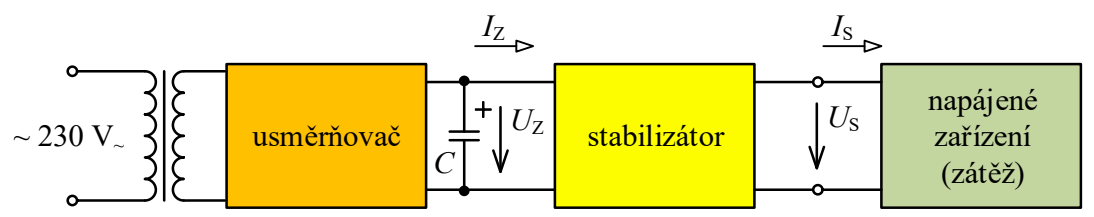

Obr. 10.1: Základní uspořádání klasického spojitého napájecího zdroje napětí

\subsection{Výkonové usměrňovače}

\subsubsection{Jednocestný usměrňovač}

Nejjednodušší způsob přeměny stř́davého napětí na stejnosměrné je založen na doplňování náboje kapacitoru přes diodu (viz Obr. 10.2). Zátěž $R_{Z}$ je dána napětím $U_{Z}$ proudem $I_{Z}$, který takovýto napájecí zdroj má dodat napájenému zařízení. Jestliže takovýto obvod pracuje naprázdno $\left(R_{\mathrm{Z}} \rightarrow \infty\right)$, pak se tzv. stř́dací filtrační kapacitor $C$ nabije prakticky na hodnotu amplitudy tohoto napětí $U_{\text {zo }} \approx \sqrt{2} U_{20 \text { ef }}$, kde $U_{20 \text { ef }}$ značí efektivní hodnotu napětí sekundární vinutí naprázdno. Největší závěrné napětí na diodě bude v okamžiku, kdy naptí na sekundárním vinutí dosáhne hodnoty $-\sqrt{2} U_{20 \text { ef }}$. Proto se dioda musí dimenzovat na závěrné napětí větší než $2 \sqrt{2} U_{20 \text { ef }}$. Jestliže je po celou dobu, kdy dioda nevede proud, př́ipojena zátěž, vybíjí se kapacitor $\mathrm{C}$ exponencionálně přes odporovou zátěž $R_{\mathrm{Z}}$. Jestliže napětí na sekundárním vinutí 
transformátoru bude větší o hodnotu prahového napětí diody $U_{\mathrm{P}}$ než výstupní napětí na kapacitoru, dioda $\mathrm{D}_{1}$ se otevře a kapacitor se začne dobíjet. Zde poznamenejme, že usměrňovací diody určené pro větší proudy mají obvykle prahové napětí vyšší $U_{\mathrm{P}} \approx 1 \mathrm{~V}$. Hodnota napětí na jaké se nabije kapacitor závisí na vnitřním odporu transformátoru $R_{\text {tr }}$. Časový průběh výstupního napětí i proudu usměrňovací diodou je uveden na Obr. 10.2b. Kmitočet zvlnění usměrněného napětí je shodný se sít'ovým kmitočtem. Pomocí průběhů uvedených na obr.10.2c můžeme orientačně určit kapacitu střádacího kapacitoru $C$, přičemž odpor zátěže je dán napájeným zařízením, tzn. $R_{\mathrm{Z}}=U_{\mathrm{Z}} / I_{\mathrm{Z}}$.

Vzhledem tomu, že u jednocestného usměrňovače je velký nepoměr mezi dobou nabíjení a dobou vybíjení kapacitoru, snižuje se hodnota výstupního napětí takového obvodu znatelně již při malém zatížení. Z uvedeného důvodu se tento obvod v sít'ových zdrojích používá jen málokdy (význam má však v impulsně regulovaných zdrojích, kde se usměrňuje signál o vysokém kmitočtu a tato nevýhoda nevadí).

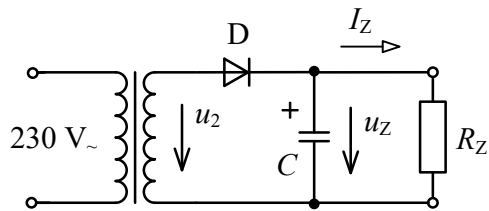

$\mathrm{a}$
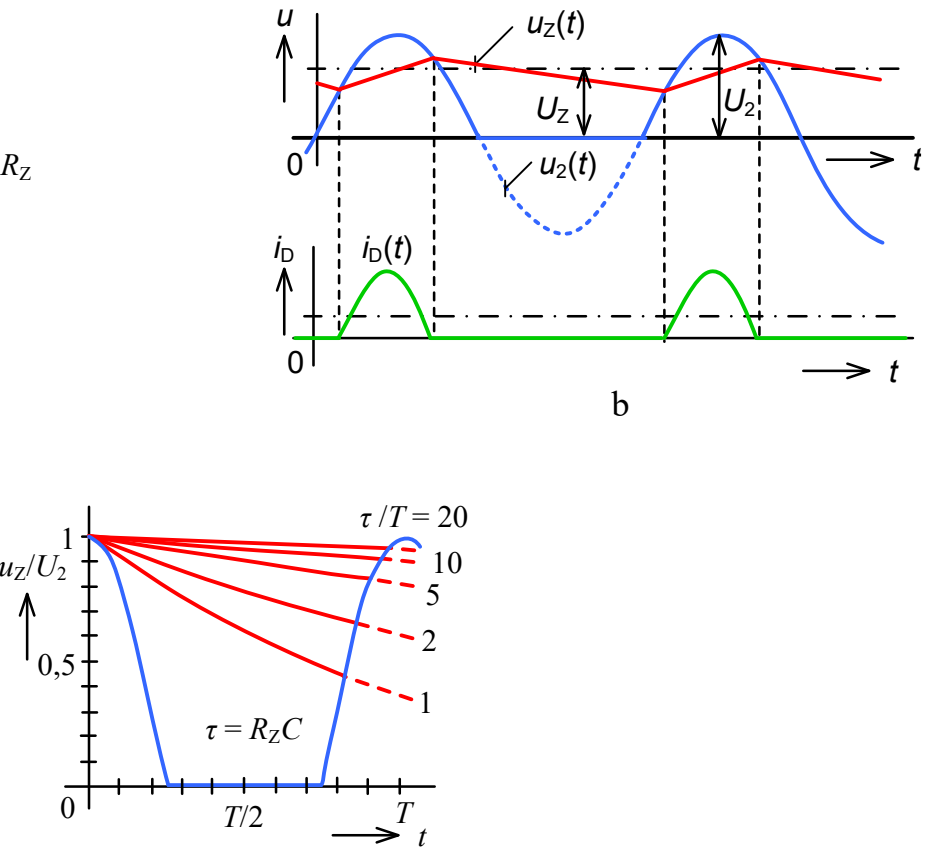

$\mathrm{c}$

Obr. 10.2: a) Jednocestný usměrňovač se stř́dacím kapacitorem, b) průběhy napětí a proudu v obvodu, c) určení kapacity stř́dacího kapacitoru

\subsubsection{Dvoucestné usměrňovače}

Poměr mezi dobou nabíjení a vybíjení kapacitoru může být značně zlepšen, jestliže se náboj kapacitoru doplňuje jak při kladné, tak i při záporné půlvlně stř́ídavého napětí. Dvoucestné usměrnění se používá většinou ve dvou typech usměrňovačů: v dvoucestném můstkovém usměrňovači (Obr. 10.3a) a v dvoucestném usměrňovači využívajícím střední odbočku transformátoru (Obr. 10.3b). Z jednoduché úvahy vyplývá, že v prvém případě dostačuje dimenzovat diody na závěrné napětí $\sqrt{2} U_{\text {eff }}$, kdežto v druhém případě na $2 \sqrt{2} U_{2 \text { ef }}$. Hlavní nevýhodou usměrňovače z Obr. $10.3 \mathrm{~b}$ je však dvojnásobné vinutí transformátoru. Tuto nevýhodu nevyváží ani poloviční počet diod. Nejčastěji se proto užívá můstkový dvoucestný usměrňovač (Obr. 10.3a), který je podle svého objevitele nazýván Graetzův). Usměrňovač 
podle Obr. 10.3b se využívá pro napájení symetrických napájecích zdrojů, kdy se ušetř́i čtyři diody. Kmitočet zvlnění usměrněného napětí je v tomto prŕípadě dvakrát vyšší než je kmitočet sít’ového kmitočtu (viz Obr. 10.2c). Kapacitor se bude dobíjet v př́padě, že napětí na sekundárním vinutí transformátoru bude větší o hodnotu $2 U_{\mathrm{P}}$ protože budou otevřeny současně dvě diody.

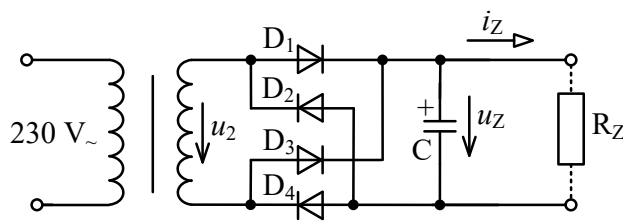

a

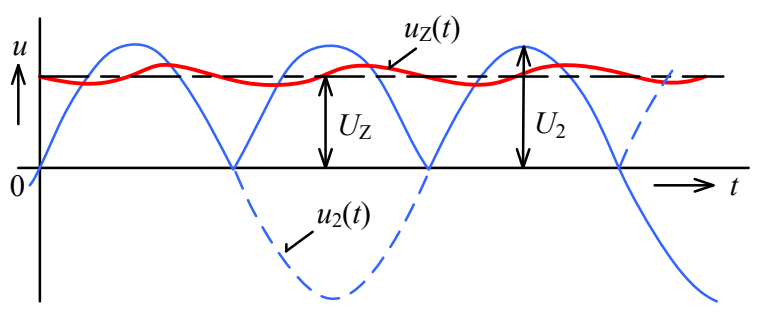

C

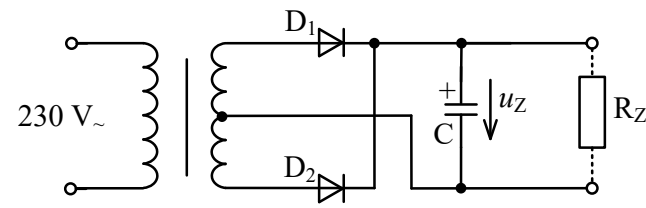

$\mathrm{b}$

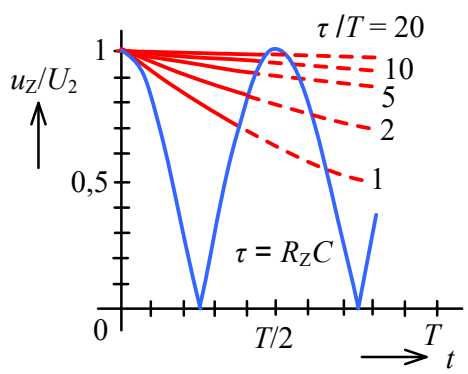

d

Obr. 10.3: a) Dvoucestný můstkový usměrňovač, b) dvoucestný usměrňovač využívající stř̌ední odbočku transformátoru, c) časové průběhy, d) k určení střádacího kapacitoru

Kapacitu střádacího kapacitoru $C$ můžeme orientačně určit pomocí průběhů naznačených na Obr. 10.3d. Neméně důležité než kapacita vyhlazovacího kapacitoru je i jeho provozní napětí, které musí být vždy větší, než je špičkové sekundární napětí transformátoru, tzn. $\sqrt{2} U_{2 \text { ef }}$ . Bezpečné jmenovité napětí kapacitoru by mělo být voleno přiměřeně větší, a to alespoň $\sqrt{2} U_{20 \text { ef }}$, protože této hodnoty může napětí na kapacitoru dosáhnout při odpojení zátěže.

Pokud máme realizovat symetrický napájecí zdroj (např. pro napájení operačních zesilovačů) je výhodné použít dvojitý dvoucestný usměrňovač zapojený podle Obr. 10.4. Transformátor se symetrickým výstupem (sekundární vinutí se střední odbočkou) dodává dvě stejná vstupní střídavá napětí v opačné fázi stejně jako v prř́padě usměrňovače na Obr. 10.2b. Opačně pólované diody $\left(\mathrm{D}_{3}\right.$ a $\left.\mathrm{D}_{4}\right)$ pak vytvoří na symetrickém výstupu opačně pólované výstupní napětí.

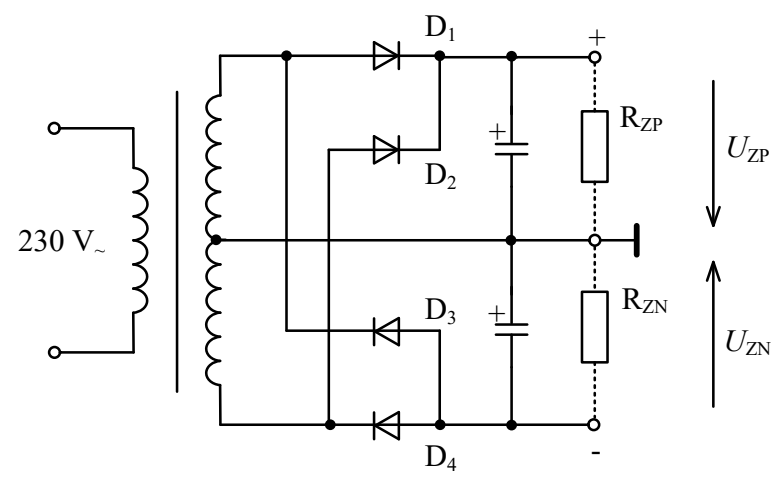

Obr. 10.4: Symetrický napájecí zdroj 
Takto realizované zdroje by však měly pro běžné použití několik nevýhod, především tu, že se jejich výstupní napětí bude měnit se změnou odporu zátěže i se změnou vstupního (sít’ového) napětí. Aby bylo výstupní napětí konstantní, je zapotřebí napájecí zdroj doplnit stabilizátorem napětí.

\subsection{Stabilizátory napětí}

Výstupní napětí usměrňovače se střádacím (filtračním) kapacitorem obvykle vykazuje zvlnění až několik voltů, protože kapacitu filtračních kondenzátorů nemůžeme volit nekonečně velkou. Kromě toho, výstupní napětí takovéhoto zdroje značně závisí na kolísání napětí v sít’ovém rozvodu a na změně zátěže. Abychom zmenšili vliv uvedených faktorů, zařazuje se obvykle za napájecí zdroj stabilizátor stejnosměrného napětí (Obr. 10.5a). Jeho úkolem je přenést ss složku napětí na výstup stabilizátoru zmenšenou pouze o malý konstantní úbytek napětí mezi vstupem a výstupem. Přenos změn vstupního napětí na výstup stabilizátoru však musí být nepatrný, ideálně nulový.

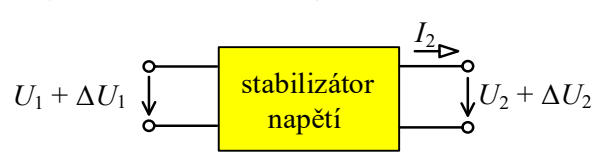

a

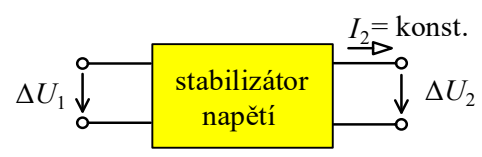

b

Obr. 10.5: Stabilizátor napětí a jeho model pro střídavé změny

Vlastnosti stabilizátoru při konstantním proudu do zátěže $\left(I_{2}=\right.$ konst.) definuje činitel potlačení zvlnění (viz Obr. 10.5b)

$$
P_{\mathrm{S}}=\frac{\Delta U_{2}}{\Delta U_{1}}
$$

Často se činitel potlačení zvlnění uvádí v procentech

$$
P_{\mathrm{S} \%}=\frac{\Delta U_{2}}{\Delta U_{1}} \cdot 100 \%
$$

nebo v decibelech

$$
P_{\mathrm{SdB}}=20 \log \frac{\Delta U_{2}}{\Delta U_{1}}
$$

Také se někdy používá činitel stabilizace

$$
S_{\mathrm{S}}=\frac{1}{P_{\mathrm{S}}}=\frac{\Delta U_{1}}{\Delta U_{2}}
$$

Kvalitní stabilizátory ss napětí mívají činitel potlačení zvlnění $0,1 \%$ až $0,01 \%$, tj. 60 až $80 \mathrm{~dB}$, resp. činitel stabilizace 1000 až 10000.

\subsubsection{Jednoduché stabilizátory napětí}

Pro napájení drobnějších zařízení a při nepř́liš velkých požadavcích na stabilitu výstupního napětí lze použít ke stabilizaci napětí jednoduchý stabilizátor s tranzistorem naznačený na Obr. 10.6a. V podstatě jde o emitorový sledovač, jehož báze je připojena ke zdroji referenčního napětí, odvozeného pomocí referenční diody a rezistoru $\mathrm{R}$ z nestabilizovaného vstupního napětí $u_{1}$. Jde o nejjednodušší tzv. sériový stabilizátor napětí protože regulační prvek 
(tranzistor T) a zátěž jsou zapojeny v sérii. V důsledku záporné zpětné vazby se výstupní napětí emitorového sledovače ustálí na hodnotě

$$
U_{\mathrm{P}}=u_{\mathrm{ZD}}-u_{\mathrm{BE}} \approx U_{\mathrm{Z}}-u_{\mathrm{BE}} .
$$
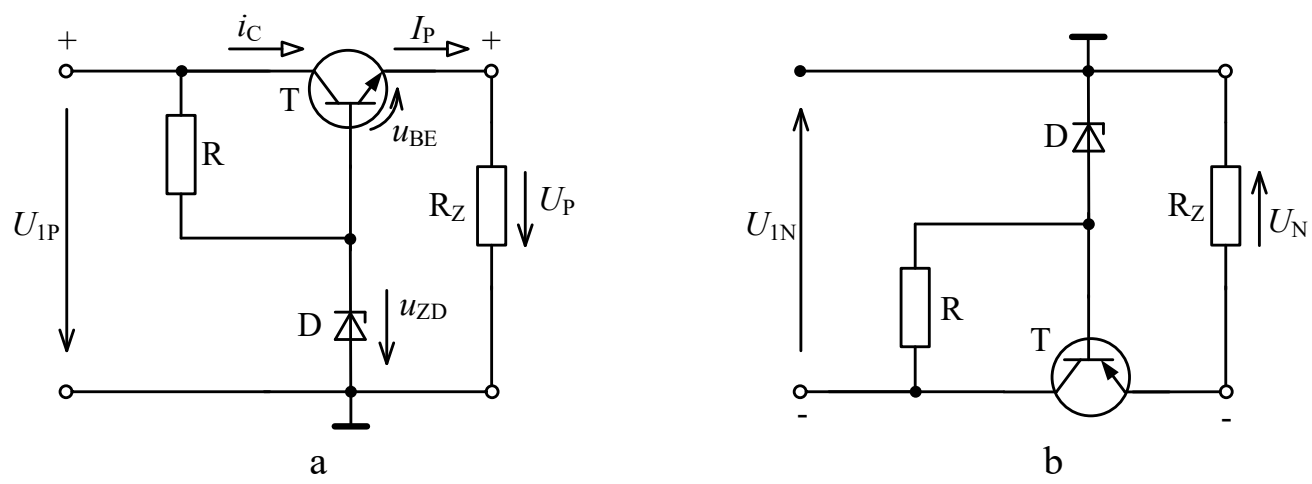

Obr. 10.6: Jednoduchý stabilizátor s tranzistorem

Zvlnění vstupního napětí je na výstupu vyhlazeno díky malému diferenciálnímu vstupnímu odporu $r_{\mathrm{ZD}}$ referenční diody, protože

$$
\Delta U_{\mathrm{P}} \approx \Delta u_{\mathrm{ZD}}=\frac{r_{\mathrm{ZD}}}{R+r_{\mathrm{ZD}}} \Delta U_{1 \mathrm{P}} \approx \frac{r_{\mathrm{ZD}}}{R} \Delta U_{1 \mathrm{P}}
$$

Činitel stabilizace

$$
S_{\mathrm{P}}=\frac{\Delta U_{1 \mathrm{P}}}{\Delta U_{\mathrm{P}}} \approx \frac{R}{r_{\mathrm{ZD}}}
$$

Změna výstupního napětí $\mathrm{v}$ závislosti na proudu tekoucím do zátěže je určena výstupním odporem stabilizátoru

$$
r_{\mathrm{S}} \approx-\frac{\Delta U_{\mathrm{P}}}{\Delta I_{\mathrm{P}}} \approx-\frac{\Delta\left(U_{\mathrm{Z}}-u_{\mathrm{BE}}\right)}{\Delta i_{\mathrm{C}}} \approx \frac{\Delta u_{\mathrm{BE}}}{\Delta i_{\mathrm{C}}}=\frac{1}{S} \approx \frac{1}{40 i_{\mathrm{C}}} \approx \frac{1}{40 I_{\mathrm{P}}},
$$

přičemž zde $S$ značí strmost tranzistoru $S \approx 40 i_{\mathrm{c}}$. Předpokládáme-li proud do zátěže $I_{\mathrm{P}} \approx 100$ mA bude výstupní odpor takovéhoto zdroje řádově $0,3 \Omega$.

Výhoda obvodu je zřejmá: proud do zátěže je regulován pouze malým proudem tekoucím do báze tranzistoru a tedy odpor rezistoru $R$ je dimenzován pouze na nastavení vhodného proudu referenční diody. Uspořádání obvodu pro získání záporného napětí s komplementárním tranzistorem je naznačeno na Obr. 10.6b. U jednoduchého stabilizátoru s tranzistorem lze dosáhnout činitel stabilizace v rozmezí 10 až 100.

\subsubsection{Stabilizátory se zesilovačem regulační odchylky}

Účinnější stabilizátory jsou vlastně regulátory napětí nebo proudu se zesilovačem odchylky a zdrojem referenčního napětí, který je obvykle realizován referenční diodou, často teplotně kompenzovanou. Blokové zapojení sériového stabilizátoru, kdy regulační prvek a zátěž jsou zapojeny v sérii, je naznačeno na Obr. 10.7a. Referenční napětí se v porovnávacím obvodu srovnává s částí výstupního napětí. Rozdíl (tzv. chybové napětí) se dále zesiluje v zesilovači regulační odchylky a přivádí na regulační prvek (výkonový bipolární či unipolární tranzistor), který udržuje výstupní napětí na konstantní hodnotě. Klasické zapojení sériového stabilizátoru využívá regulační tranzistor zapojený principiálně jako emitorový sledovač (viz 
Obr. 10.7b). Podle provedení stabilizátoru může činitel stabilizace dosahovat hodnot až kolem několika tisíc. Sériové uspořádání regulátoru je nejpoužívanější.

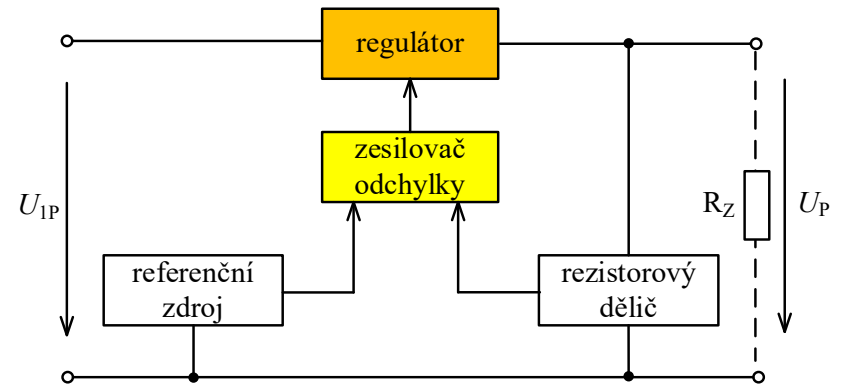

$\mathrm{a}$

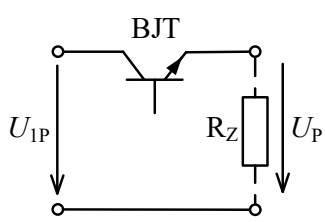

b

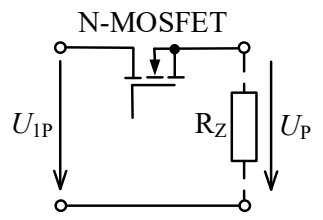

Obr. 10.7: Sériový stabilizátor napětí: a) blokové schéma, b) regulační prvek zapojený jako emitorový sledovač

Zapojení stabilizátoru využívající zesilovač regulační odchylky se prakticky neliší od zapojení stejnosměrných zdrojů s operačním zesilovačem, uvedených v kapitole o stejnosměrných referenčních zdrojích napětí. Proudové schopnosti těchto zdrojů jsou však nedostačující. $Z$ tohoto důvodu je zapotřebí doplnit obvod výkonovým tranzistorem, zařazeným do př́mé větve zpětnovazební smyčky operačního zesilovače. K tomuto účelu je možno principiálně použít emitorový sledovač $\mathrm{s}$ bipolárním tranzistorem, nebo $\mathrm{s}$ tranzistorem MOSFET (viz Obr. 10.7b), popř. při větších proudech do zátěže se použije Darlingtonovo uspořádání tranzistorů nebo výkonový MOSFET.

Na Obr. 10.8 jsou uvedeny dvě nejčastější obvodové realizace sériového stabilizátoru napětí. Stabilizátor využívá operační zesilovač zapojený v neinvertujícím uspořádání, tzn. se zápornou napět'ovou zpětnou vazbou, jehož proudové schopnosti jsou posíleny emitorovým sledovačem s tranzistorem T. Výstupní napětí stabilizátoru proto můžeme určit shodně jako u neinvertujícího zesilovače

$$
U_{\mathrm{P}} \approx\left(1+\frac{R_{2}}{R_{1}}\right) U_{\mathrm{Z}} .
$$

Operační zesilovač není napájen jako obvykle symetrickými napětími vůči zemi, ale kladným napětím jedné polarity. To klade omezení na povolený rozsah vstupních i výstupních napětí, které mohou být pouze kladné polarity. Pro stabilizátor napájecího zdroje nemá toto

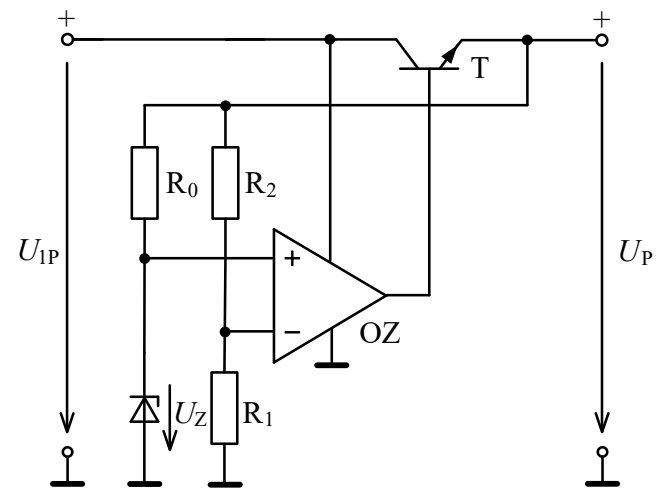

a

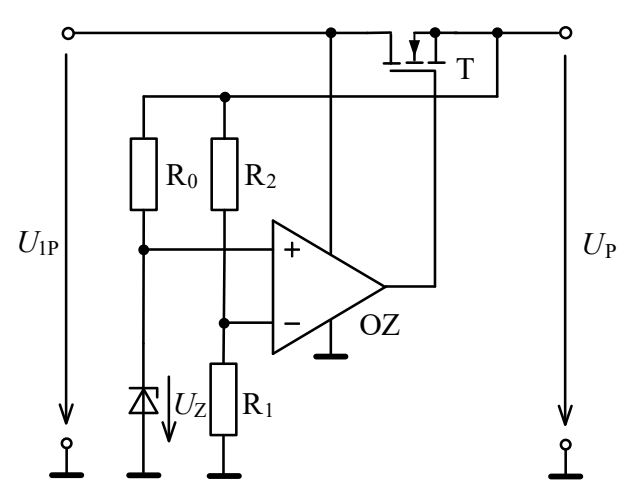

b

Obr. 10.8: Př́iklady klasického řešení sériového stabilizátoru napětí 
omezení řádný význam, protože pro stabilizaci záporného napětí lze obvod duálně uspořádat s komplementárním tranzistorem. Velmi výhodné je, že výstupní napětí nezávisí na velikosti napětí $u_{\mathrm{BE}}$ regulačního tranzistoru jako tomu bylo u zapojení na Obr. 10.6. Další výhodou tohoto uspořádání je, že je možné zdvojnásobit kladné napájecí napětí operačního zesilovače, aniž dojde $\mathrm{k}$ překročení povolené hodnoty výstupního napětí operačního zesilovače. Tímto způsobem lze standardní operační zesilovače provozovat ve stabilizátorech s výstupním napětím až $30 \mathrm{~V}$. V této souvislosti ještě poznamenejme, že operační zesilovač v uspořádání podle Obr. $10.8 \mathrm{~b}$ je napájen př́mo z nestabilizovaného zdroje $U_{1 \mathrm{P}}$. Zvlnění tohoto napětí však nemá na stabilitu výstupního napětí prakticky vliv, protože průnik napájecího napětí do výstupního napětí je u operačního zesilovače v př́padě spojitého napájecího zdroje zanedbatelně malý.

Určitou nevýhodou konvenčního řešení stabilizátoru s regulačním tranzistorem zapojeným jako emitorový sledovač je okolnost, že vyžaduje rozdíl mezi vstupním a výstupním napětím minimálně $1 \mathrm{~V}$, častěji je však požadován rozdíl mezi vstupem a výstupem 2,5 až $4 \mathrm{~V}$. Jinak stabilizátor není schopen potlačit zvlnění vstupního napětí. Proto tento typ stabilizátorů není př́íhodný pro zařízení napájená z baterií. Na druhou stranu je zapojení schopné dodat díky malému výstupnímu odporu emitorového sledovače do zátěže velký proud. Výhodou také je, že stabilizátor je stabilní i při velké kapacitní zátěži.
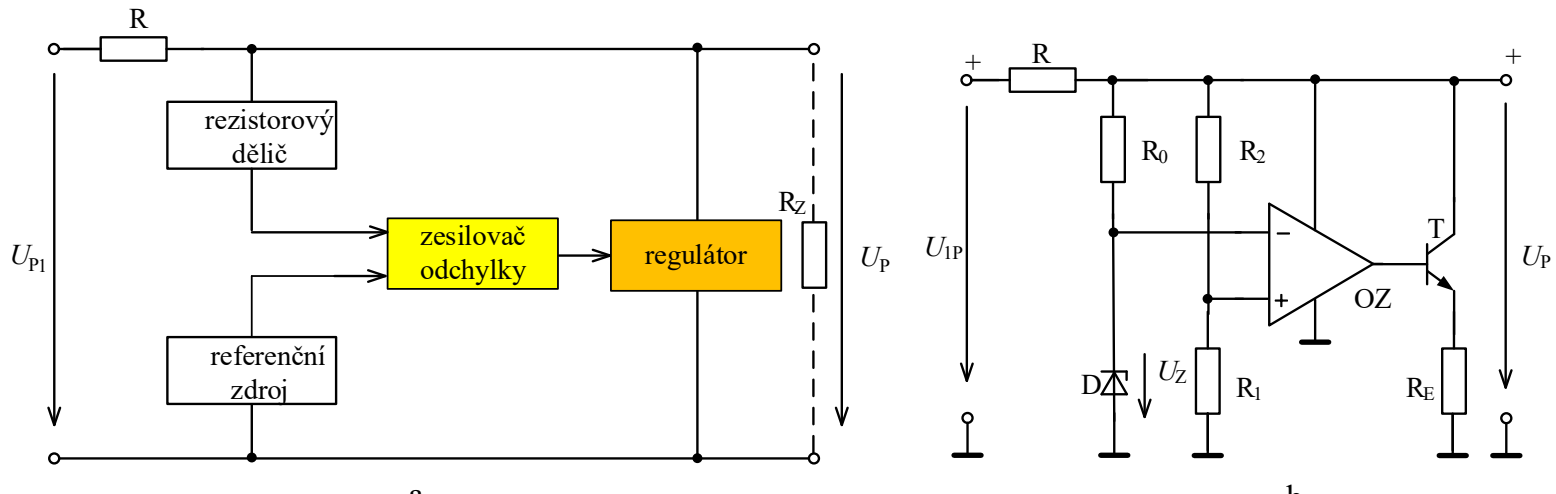

a

b

Obr. 10.9: Paralelní stabilizátor napětí: a) blokové uspořádání, b) př́iklad realizace

Jestliže regulační prvek zapojíme paralelně k výstupu tj. paralelně se zátěží $\mathrm{R}_{\mathrm{Z}}$, dostaneme paralelní stabilizátor. Blokové uspořádání je nakresleno na Obr. 10.9a. Tranzistor $\mathrm{T}$ je v zapojení se společným emitorem a tedy na jeho kolektoru bude signál posunut o $180^{\circ}$. Aby byla zachována záporná zpětná vazba, jsou vstupní svorky operačního zesilovače zaměněny. Př́iklad řešení je uveden na Obr. 10.9b. Na výstupu stabilizátoru se bude udržovat napětí

$$
U_{\mathrm{P}} \approx\left(1+\frac{R_{2}}{R_{1}}\right) U_{\mathrm{Z}} .
$$

Účinnost tohoto zapojení stabilizátoru je poměrně malá, protože podstatná část výkonu se ztrácí na sériovém rezistoru $\mathrm{R}$. $\mathrm{Z}$ těchto důvodů se tento typ stabilizace napětí př́íliš nepoužívá.

Elektronická pojistka. Stabilizátory mají obvykle zabudovánu elektronickou pojistku pro omezení výstupního proudu. Jako nejlepší způsob se jeví sledovat skutečnou velikost výstupního proudu stabilizátoru. K tomuto účelu slouží v obvodu uvedeném na Obr. 10.9a rezistor $R_{3}$ a tranzistor $T_{2}$. Jestliže napětí na rezistoru $R_{3}$ způsobené př́liš velkým proudem do zátěže převýší napětí asi $0,6 \mathrm{~V}$, otevře se tranzistor $\mathrm{T}_{2}$ a zabrání dalšímu zvyšování proudu do 


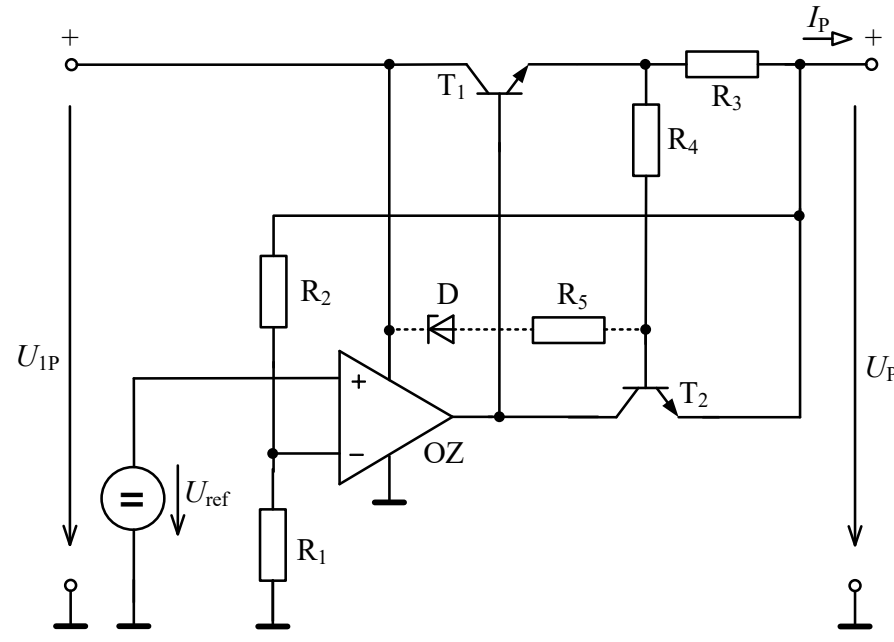

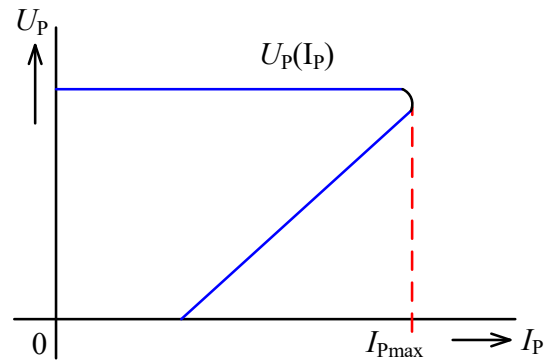

b

Obr. 10.10: a) Stabilizátor s elektronickou pojistkou, b) výstupní charakteristika stabilizátoru s proudovou ochranou

báze tranzistoru $\mathrm{T}_{1}$. Rezistor $\mathrm{R}_{4}$ slouží k ochraně tranzistoru $\mathrm{T}_{2}$ před velkým proudem do báze tranzistoru při jeho sepnutí. Vlastní činnost elektronické pojistky neovlivní, protože pokud tranzistor není sepnut, teče do jeho báze jen malý proud, který na rezistoru vyvolá zanedbatelný úbytek napětí.

Hodnota výstupního proudu stabilizátoru bude ohraničena úrovní

$$
I_{\mathrm{P} \max } \approx u_{\mathrm{BE} 2} / R_{3} \approx 0,6 \mathrm{~V} / R_{3} .
$$

Přitom ztrátový výkon regulačního tranzistoru $\mathrm{T}_{1}$ má hodnotu

$$
P=I_{\mathrm{P} \max }\left(U_{1 \mathrm{P}}-U_{\mathrm{P}}\right) \text {. }
$$

V př́padě zkratu na výstupu stabilizátoru může ztrátový výkon značně překročit povolenou výkonovou ztrátu tranzistoru $\mathrm{T}_{1}$, protože výstupní napětí stabilizátoru je v takovém případě nulové. Abychom snížili ztrátový výkon regulačního tranzistoru při zkratu na výstupu, je možno současně se snižováním výstupního napětí stabilizátoru zmenšovat úroveň omezení výstupního proudu. Přri takovémto omezení výstupního proudu musí výstupní charakteristika stabilizátoru mít průběh naznačený na Obr. 10.9b.

V případě značného zvětšení vstupního napětí nebo zmenšení výstupního napětí stabilizátoru dojde $\mathrm{k}$ rychlému nárůstu ztrátového výkonu regulačního tranzistoru. Je to způsobeno tím, že odpovídajícím způsobem vzroste napětí $U_{1 \mathrm{P}}-U_{\mathrm{P}}$ určující v rov. (10-12) velikost ztrátového výkonu. Ochrana regulačního tranzistoru před přehřátím se $\mathrm{v}$ tom případě realizuje tak, že se úroveň ohraničení výstupního proudu $I_{\mathrm{Pmax}}$ učiní závislá na rozdílu napětí $U_{1 \mathrm{P}}-U_{\mathrm{P}}$. V Obr. 10.9 a $\mathrm{k}$ tomuto účelu slouží rezistor $\mathrm{R}_{5}$ a referenční dioda $\mathrm{D}$.

Jestliže je rozdíl napětí $U_{1 \mathrm{P}}-U_{\mathrm{P}}$ menší než napětí referenční diody $U_{\mathrm{Z}}$, neteče přes rezistor $\mathrm{R}_{5}$ proud. $\mathrm{V}$ tom př́padě zůstane úroveň ohraničení výstupního proudu rovna hodnotě $0,6 \mathrm{~V} / \mathrm{R}_{3}$. Převýší-li rozdíl napětí hodnotu $U_{Z}$, pak se v důsledku činnosti děliče napětí sestávajícího $z$ rezistorů $R_{4}, R_{5}$ objeví na přechodu báze - emitor tranzistoru $T_{2}$ kladné napětí. Tranzistor $T_{2}$ se pak bude otevírat již při menším úbytku napětí na rezistoru $\mathrm{R}_{3}$, resp. při menším proudu než je $I_{\text {Pmax }}$ (viz Obr. 10.9b). 
Některé integrované obvody, zejména číslicové obvody, jsou náchylné ke zničení velkým napájecím napětím, které je obvykle způsobeno naindukováním přepětových špiček napětí do napájecího rozvodu. Proto se někdy stabilizátory doplňují elektronickou pojistkou proti přepětí na výstupu. Nejčastěji se využije vestavěné proudové pojistky, která se uvede do činnosti pomocí tyristoru připojeného paralelně k výstupu stabilizátoru. Př́́klad řešení je uveden na Obr. 10.11. Obvodem $\mathrm{s}$ rezistorem $\mathrm{R}_{2}$ a referenční diodou $\mathrm{D}$ při normálním provozu neteče proud, tranzistor T i tyristor Ty jsou zavřeny. Dojde-li však k nežádoucím zvýšení výstupního napětí stabilizátoru, poteče rezistorem $\mathrm{R}_{2}$ proud, tranzistor $\mathrm{T}$ se otevře a způsobí sepnutí tyristoru $\mathrm{Ty}$, což vyvolá zapnutí proudové pojistky ve stabilizátoru. Tyristor nemusí být dimenzován na velkou výkonovou ztrátu, protože velký zkratový proud jím poteče po velmi krátký okamžik jen těsně po jeho sepnutí a pak se proud tyristorem zmenší (viz Obr. 10.9b).

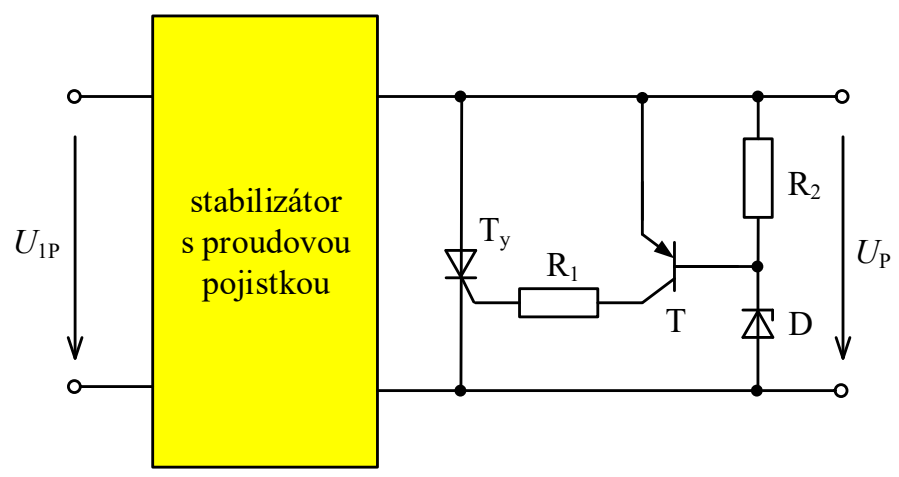

Obr. 10.11: Stabilizátor s ochranou proti přepětí na výstupu

\subsubsection{Integrované stabilizátory napětí}

Integrované stabilizátory většinou využívají sériový způsob stabilizace napětí (Obr. 10.7). Bud' jde o jednoúčelové stabilizátory s pevně nastaveným výstupním napětím např̀. třísvorkové stabilizátory typové série 7800, nebo o tzv. universální stabilizátory, jejichž výstupní napětí lze nastavit jednoduše pomocí vnějších prvků jako např. čtyřsvorkové stabilizátory typové série $78 \mathrm{G}$, nebo třísvorkové série 317. Pro záporná napájecí napětí jsou pak k dispozici komplementární varianty typové série 7900 s pevně nastaveným napětím, nebo universální stabilizátory typové série 79G nebo série 337.

Napětové stabilizátory s pevně nastaveným výstupním napětím. Požadavky na zesilovač regulační odchylky nejsou přiliš velké a proto zpravidla vyhoví jednoduché zapojení diferenčního zesilovače $\mathrm{s} \mathrm{T}_{1}$ a $\mathrm{T}_{2}$, jak je naznačeno na Obr. 10.12a. Pro získání opěrného referenčního napětí může být použito různých způsobů diskutovaných dřive. Bud' se použije teplotně kompenzovaná referenční dioda, nebo, jak je tomu v př́padě třísvorkového stabilizátoru typové řady 7800 , se využije princip šířky zakázaného pásma v polovodiči. Pro zjednodušení je teplotně kompenzovaný zdroj $U_{\mathrm{R}} \approx 5 \mathrm{~V}$ vyznačen $\mathrm{v}$ Obr. 10.12a jen schématicky. Zjednodušeně je vyznačeno i Darlingtonovo zapojení regulačního tranzistoru $\mathrm{T}_{4}$ (viz Obr. 10.12b).

Díky záporné zpětné vazbě realizované děličem $R_{1}$ a $R_{2}$ se výstupní napětí bude udržovat na hodnotě

$$
U_{\mathrm{P}} \approx U_{\mathrm{R}}\left(1+\frac{R_{2}}{R_{1}}\right) .
$$



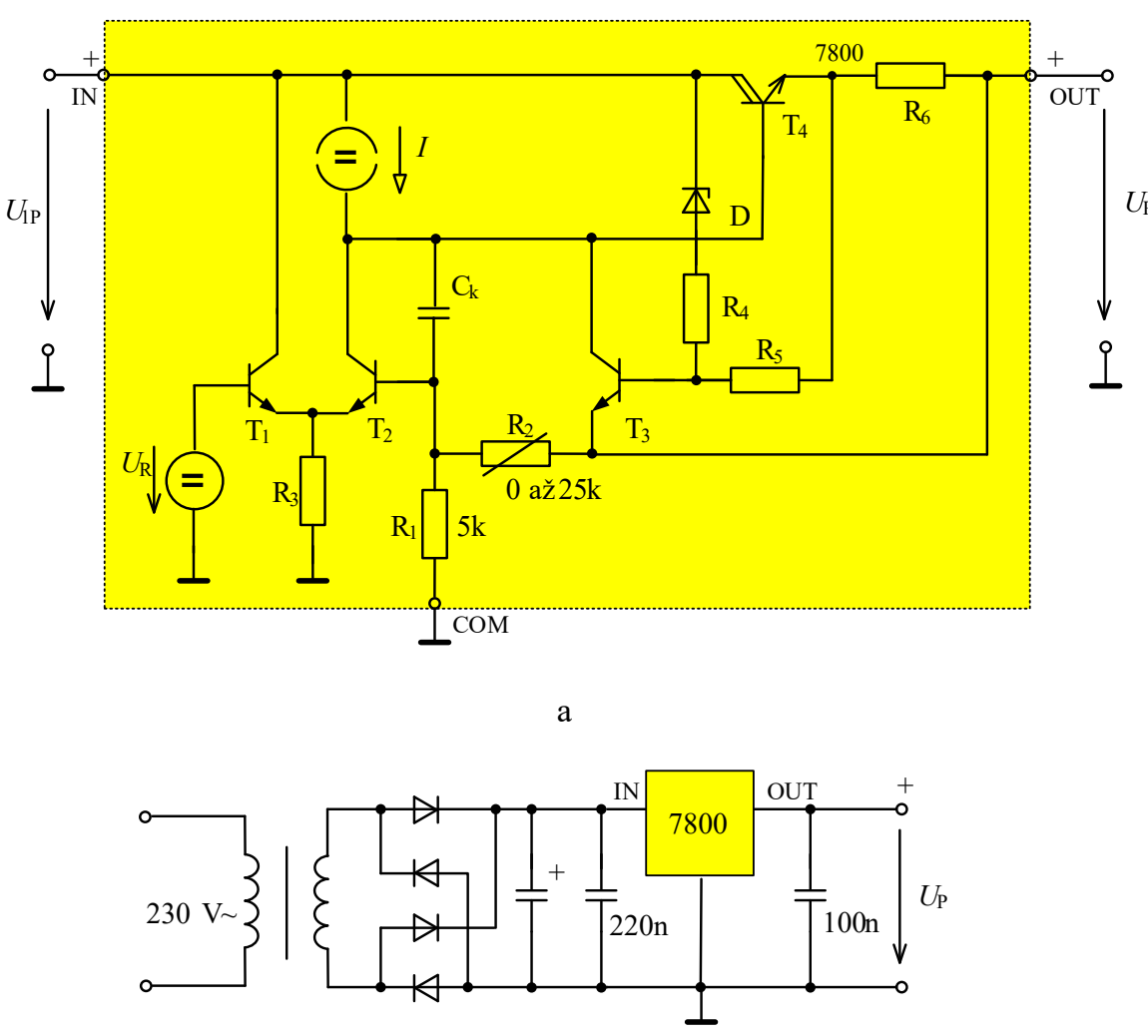

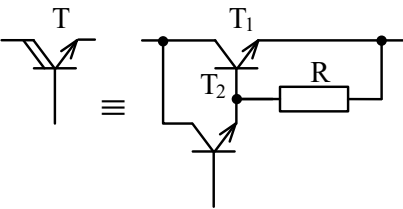

b

Obr. 10.12: a) Principiální řešení třísvorkového stabilizátoru s pevně nastaveným výstupním napětím typové série 7800, b) Darlingtonovo zapojení regulačního tranzistoru, c) základní aplikace

Tranzistor $\mathrm{T}_{3}$ společně $\mathrm{s}$ rezistorem $\mathrm{R}_{6}$ tvoří elektronickou pojistku pro omezení výstupního proudu. Referenční dioda $\mathrm{D}$ a rezistor $\mathrm{R}_{4}$ omezí v př́padě potřeby napětí mezi kolektorem a emitorem $\mathrm{T}_{4}$ tak, aby nedošlo $\mathrm{k}$ jeho přehřátí a $\mathrm{k}$ tzv. druhému průrazu tranzistoru, který by vedl $\mathrm{k}$ jeho zničení. Rezistor $\mathrm{R}_{1}$ má odpor $5 \mathrm{k} \Omega$ a odpor rezistoru $\mathrm{R}_{2}$ se nastaví při výrobě podle požadovaného výstupního napětí. Stabilizátory jsou dodávány pro několik standardně nastavených napětí: $5,8,10,12,15,18$ a $24 \mathrm{~V}$.

Základní uspořádání napájecího zdroje s jednoúčelovým stabilizátorem série 7800 je naznačeno na Obr. 10.12c. Aby se zabránilo rozkmitání stabilizátoru vlivem impedancí dlouhých př́vodů doporučují výrobci přemostit vstup stabilizátoru hned u pouzdra keramickým kapacitorem s kapacitou kolem $220 \mathrm{nF}$. Keramický kapacitor $100 \mathrm{nF}$ připojený k výstupu stabilizátoru zlepšuje jeho dynamické vlastnosti při skokové změně proudu do zátěže.

Stabilizátory typové řady 7800 (resp. 7900) se vyrábějí v několika modifikacích pro různé proudové odběry. S tím je také spojen způsob zapouzdření do plastového či výkonového pouzdra.

Chceme-li realizovat stabilizovaný zdroj s odběrem vyšším než cca $1 \mathrm{~A}$, je nutno stabilizátor doplnit výkonovým tranzistorem podle Obr. 10.13a. Úbytek napětí na rezistoru $\mathrm{R}_{1}$ určuje stav, kdy tranzistor $\mathrm{T}_{1}$ začíná vést a tím přemost'uje vlastní regulátor. $\mathrm{V}$ daném př́padě to bude přibližně při proudu $220 \mathrm{~mA}$, kdy na rezistoru $\mathrm{R}_{1}$ vznikne úbytek $0,66 \mathrm{~V}$. 


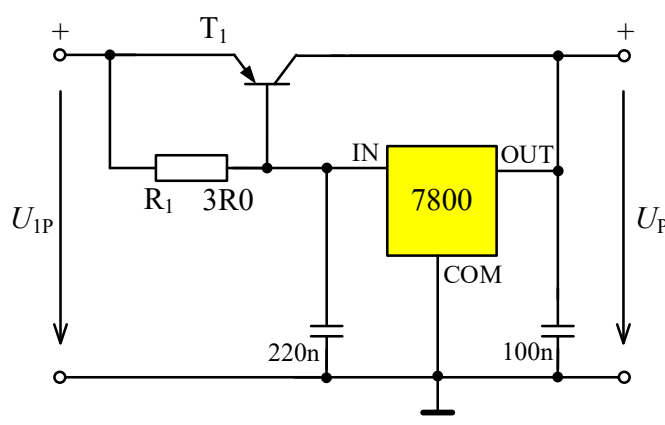

a

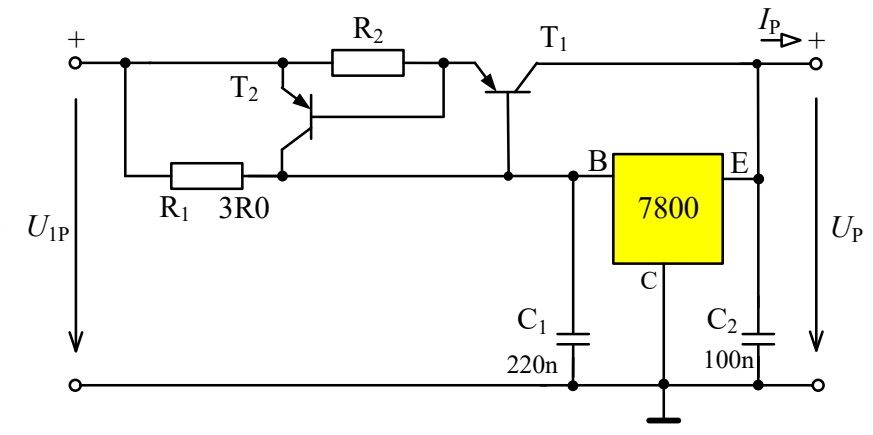

b

Obr. 10.13: Zapojení stabilizátoru pro vyšší odběry

Tento zdroj se může proti zkratu chránit tím, že se připojí rezistor $\mathrm{R}_{2}$ vně integrovaného obvodu jako zkratové čidlo a tranzistor $\mathrm{T}_{2}$ podle Obr. $10.13 \mathrm{~b}$. $\mathrm{V}$ tomto obvodu musí být schopen tranzistor $\mathrm{T}_{2}$ dodávat zkratový proud stabilizátoru, nebot' uzavře-li se tranzistor $\mathrm{T}_{1}$, vstupuje regulátor do svého zkratového režimu. Odpor rezistoru $\mathrm{R}_{2}$ určuje maximální proudový odběr stabilizátoru $I_{\mathrm{P} \max } \approx u_{\mathrm{BE} 2} / R_{2} \approx 0,6 / R_{2}$.

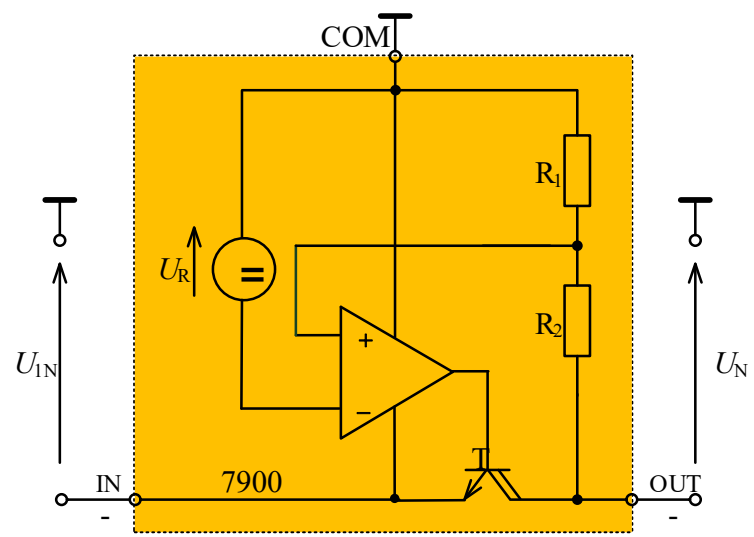

Obr. 10.14: Zjednodušené zapojení stabilizátoru záporného napětí série 7900

Pro záporná napájecí napětí existuje obdobná komplementární typová řada 7900. Nejde však o př́rmou komplementární variantu stabilizátoru série 7800. Principiální uspořádání takovéhoto stabilizátoru je naznačeno na Obr. 10.14. Výkonový tranzistor T v Darlingtonově uspořádání pracuje nyní v zapojení se společným emitorem. Aby zůstala zachována záporná zpětná vazba jsou vstupní svorky operačního zesilovače zaměněny. Výkonový tranzistor NPN je použit z důvodu snadnější realizace při výrobě integrovaného obvodu. Výstupní napětí stabilizátoru bude podobně jako $\mathrm{v}$ předchozím dáno vztahem

$$
U_{\mathrm{N}} \approx U_{\mathrm{R}}\left(1+\frac{R_{2}}{R_{1}}\right) .
$$

$\mathrm{V}$ tomto případě je vnitřní referenční napětí záporné $\left(U_{\mathrm{R}} \approx-2,23 \mathrm{~V}\right)$.

Základní uspořádání záporného stabilizovaného napájecího zdroje s obvodem 7900 je naznačeno na Obr. 10.15a. Pro získání souměrného zdroje stabilizovaného napájecího napětí se použijí oba typy tř́svorkových stabilizátorů (viz Obr. 10.15b). Toto zapojení je určeno pro méně náročné účely, protože záporné výstupní napětí nesleduje kladné napájecí napětí tak, jak tomu je u symetrických stabilizátorů sledovacího typu (viz dále). Pro běžné účely je však zcela dostačující. 

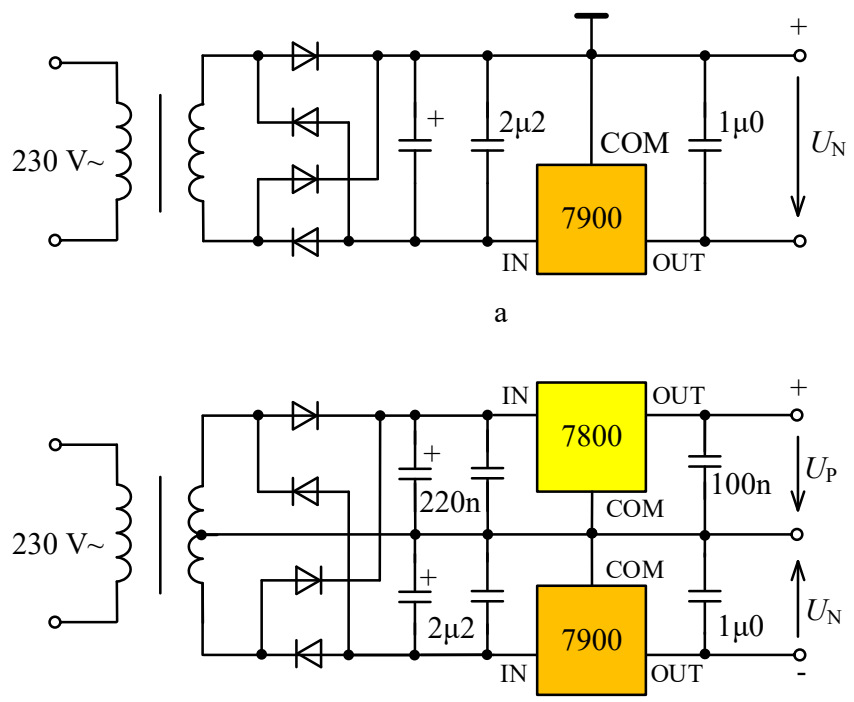

$\mathrm{b}$

Obr. 10.15: a) Základní zapojení stabilizovaného zdroje se tř́svorkovým stabilizátorem typové série 7900,

b) zapojení pro získání souměrného napájecího napětí

Napětové stabilizátory s nastavitelným výstupním napětím. Individuální hodnoty stabilizovaného napětí umožňují nastavitelné typy stabilizátorů, jejímž představitelem je typová rada $78 \mathrm{G}$ (viz Obr. 10.16). Vnější rezistory $\mathrm{R}_{1}$ a $\mathrm{R}_{2}$ určují výstupní napětí stabilizátoru. Referenční napětí $U_{R}$ má u tohoto typu hodnotu $5 \mathrm{~V}$. Výstupní napětí je dáno rov. (10-9) stejně jako pro př́pad stabilizátoru s pevně nastaveným výstupním napětím na Obr. 10.12a.

Nastavitelný čtyřsvorkový stabilizátor záporného napětí typové řady $79 \mathrm{G}$ je zapojen stejně jako stabilizátor na Obr. 10.14 , jen rezistory $\mathrm{R}_{1}$ a $\mathrm{R}_{2}$ se připojují z vnějšku. Vnitřní referenční napětí $U_{\mathrm{R}} \approx-2,23 \mathrm{~V}$, rovnice (10-14) zůstává v platnosti.

Jiné vnitřní uspořádání mají nastavitelné tř́svorkové stabilizátory typové řady 317 (viz Obr. 10.17a) určené pro získání velmi nízkých stabilizovaných napětí. V tomto prŕípadě zdroj referenčního napětí není připojen na zem, ale na společný bod děliče $R_{1}, R_{2}$. Činnost stabilizátoru je poněkud odlišná než v předchozích př́ípadech, protože zesilovač pracuje nyní ze $100 \%$ zápornou zpětnou vazbou a má jednotkový přenos. Obvod zesilovače nastavuje na rezistoru $\mathrm{R}_{2}$ referenční napětí $U_{\mathrm{R}}$.

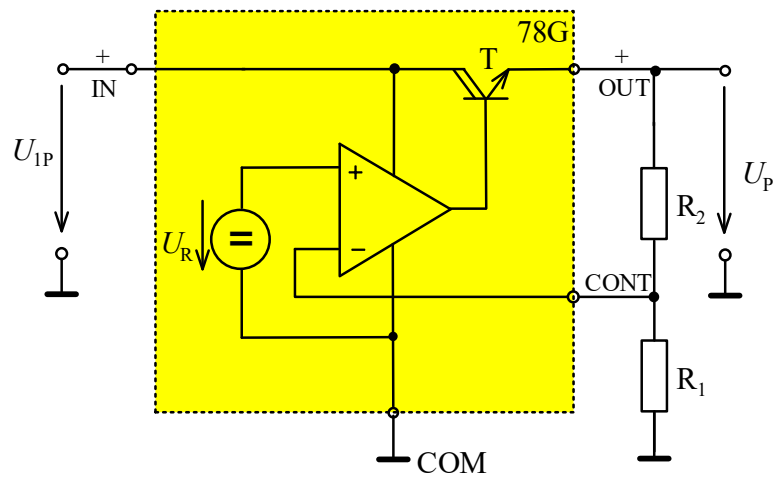

Obr. 10.16: Nastavitelný čtyřsvorkový stabilizátor typové řady $78 \mathrm{G}\left(U_{\mathrm{R}}=5 \mathrm{~V}\right)$ 

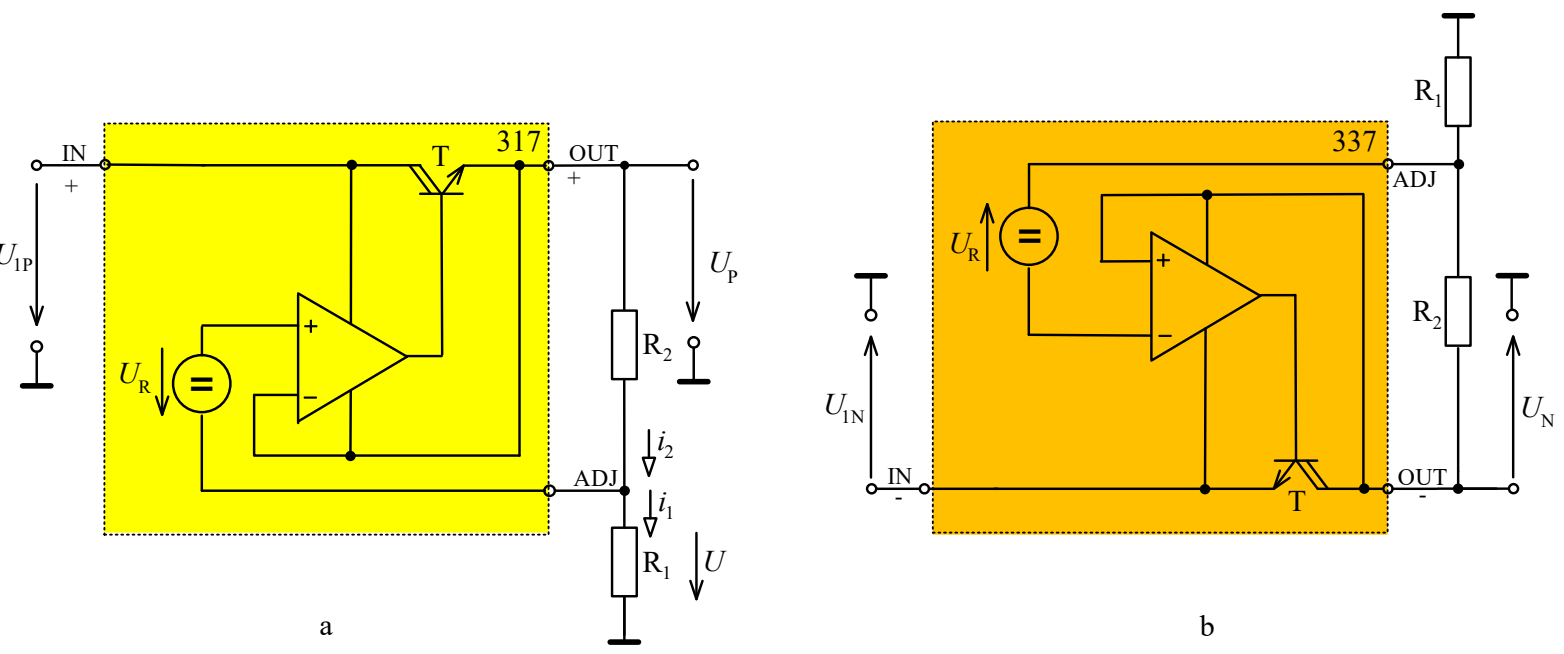

Obr. 10.17: Nastavitelné třísvorkové stabilizátory pro: a) kladné napětí typové řady $317\left(U_{\mathrm{R}}=1,25 \mathrm{~V}\right)$,

b) záporné napětí typové řady $337\left(U_{\mathrm{R}}=-1,25 \mathrm{~V}\right)$

Výstupní napětí stabilizátoru podle Obr. 10.17a bude mít pak velikost

$$
U_{\mathrm{P}} \approx U_{\mathrm{R}}+U=U_{\mathrm{R}}+i_{1} R_{1} \approx U_{\mathrm{R}}+i_{2} R_{1}=U_{\mathrm{R}}+\frac{U_{\mathrm{R}}}{R_{2}} R_{1}=U_{\mathrm{R}}\left(1+\frac{R_{1}}{R_{2}}\right) .
$$

Referenční zdroj má nastaveno napětí $U_{\mathrm{R}} \approx 1,25 \mathrm{~V}$.

Nastavitelný trŕsvorkový stabilizátor záporného napětí typové řady 337 není ale př́ímou komplementární variantou stabilizátoru řady 317. Důvodem je opět snažší realizace NPN tranzistorů. Principiální uspořádání tohoto typu stabilizátoru je uvedeno na Obr. 10.17b. Výkonový tranzistor $T_{1} v$ Darlingtonově zapojení s tranzistorem $T_{2}$ pracuje v zapojení se společným emitorem, které jak známo posune fázi výstupního signálu na kolektoru o $180^{\circ}$. Aby zůstala zachována záporná zpětná vazba, jsou vstupní svorky operačního zesilovače zaměněny. Princip činnosti je však zachován jako v předchozím př́ípadě. Zesilovač na rezistoru $\mathrm{R}_{2}$ udržuje napětí $U_{\mathrm{R}}$ a proto na výstupu stabilizátoru bude napětí

$$
U_{\mathrm{N}} \approx U_{\mathrm{R}}\left(1+\frac{R_{1}}{R_{2}}\right)
$$

Nyní je ovšem referenční napětí $U_{\mathrm{R}} \approx-1,25 \mathrm{~V}$.

\subsubsection{Symetrické stabilizátory sledovacího typu}

Stabilizovaný zdroj symetrického napětí uvedený na Obr. 10.15 b se vyznačuje evidentní nevýhodou, protože zapojení není sledovacího typu. Oba stabilizátory jsou zcela nezávislé a kolísání jejich výstupních napětí je tedy také nezávislé. Avšak v řadě případů, zejména pro napájení operačních zesilovačů, je výhodné, aby rozdíl absolutní hodnoty obou napětí byl nulový. To se dá docílit např. tím, že jedno z napětí sleduje absolutní hodnotu druhého napětí. 

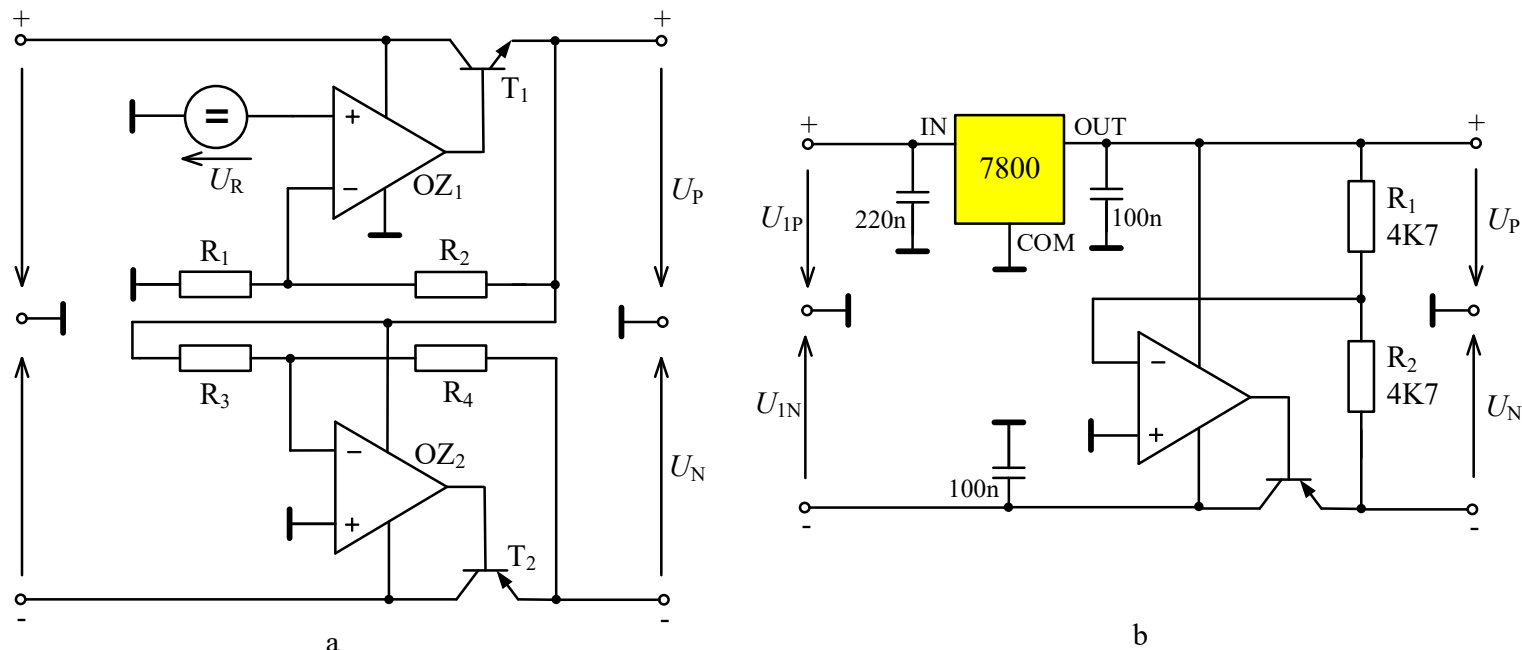

Obr. 10.18: Symetrický stabilizátor sledovacího typu: a) základní princip, b) řešení s tř́svorkovým stabilizátorem

Tento požadavek se dá splnit uspořádáním symetrického stabilizátoru sledovacího typu podle Obr. 10.18a. Kladné výstupní napětí $U_{\mathrm{P}}$ je stabilizováno stejným zpơsobem jako na Obr. 10.7b. Výstupní stabilizované napětí $U_{\mathrm{P}}$ se použije jako referenční napětí pro odvození záporného napětí $U_{\mathrm{N}}$. Protože operační zesilovač $\mathrm{OZ}_{2}$ je zapojen jako invertující, dostaneme při $R_{3}=R_{4}$ jednoduše $U_{\mathrm{N}}=-U_{\mathrm{P}}$.

Jiné uspořádání symetrického stabilizátoru sledovacího typu, které využívá jako základ třísvorkový stabilizátor typové řady 7800 je naznačeno na Obr. 10.18b. Bude-li splněno $R_{1}=$ $R_{2}$, bude záporné výstupní napětí $U_{\mathrm{N}}$ sledovat s opačnou polaritou kladné výstupní napětí $U_{\mathrm{P}}$.

Symetrický stabilizátor sledovacího typu lze také sestavit s využitím nastavitelných čtyřsvorkových stabilizátorů 78G a 79G. Díky tomu, že zpětnovazební sít' je vnější, lze oba typy

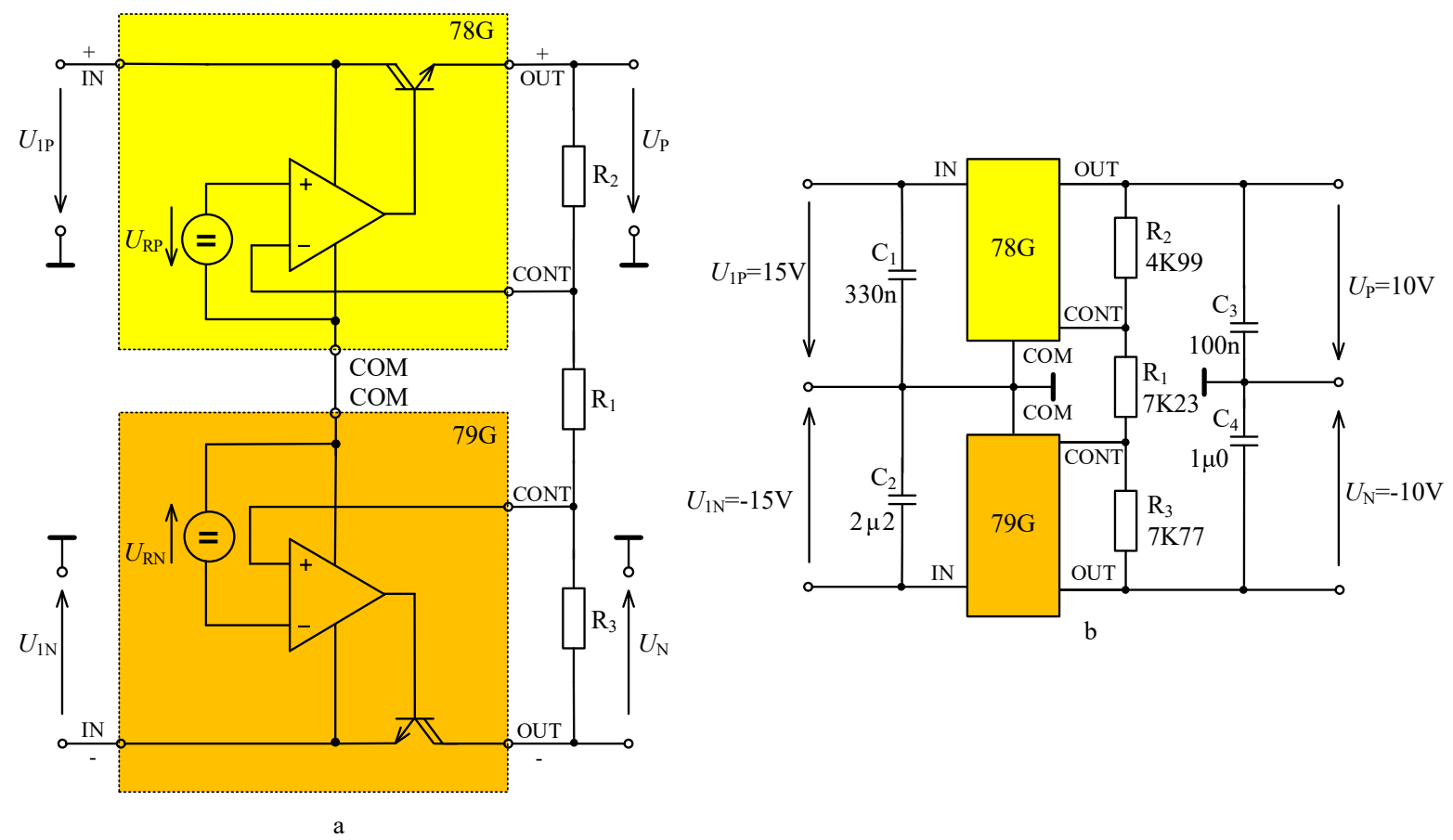

Obr. 10.19: Symetrický stabilizátor sledovacího typu s nastavitelnými čtyřsvorkovými stabilizátory 78G a 79G:

a) principiální uspořádání, b) symetrický zdroj $\pm 10 \mathrm{~V}$ 
navzájem provázat (viz Obr. 10.19a). Zapojení se pak chová obdobně jako diferenční zesilovač $\mathrm{s}$ diferenčním výstupem a napětí $U_{\mathrm{N}} \mathrm{v}$ absolutní hodnotě sleduje napětí $U_{\mathrm{P}}$. Obvod vyřešíme jednoduše s využitím metody superpozice. Předpokládejme nejprve, že $U_{\mathrm{RN}}=0$, potom

$$
U_{\mathrm{P}} \approx\left(1+\frac{R_{1}}{R_{2}}\right) U_{\mathrm{RP}}, U_{\mathrm{N}} \approx-\frac{R_{3}}{R_{1}} U_{\mathrm{RP}} .
$$

Pro $U_{\mathrm{RP}}=0$ bude obdobně platit

$$
U_{\mathrm{N}} \approx\left(1+\frac{R_{3}}{R_{1}}\right) U_{\mathrm{RN}}, U_{\mathrm{P}} \approx-\frac{R_{2}}{R_{1}} U_{\mathrm{RN}} .
$$

Dílčí výsledky metody superpozice nyní sečteme a pro obě výstupní napětí dostáváme

$$
\begin{aligned}
& U_{\mathrm{P}}=U_{\mathrm{RP}}+\frac{R_{2}}{R_{1}}\left(U_{\mathrm{RP}}-U_{\mathrm{RN}}\right), \\
& U_{\mathrm{N}}=U_{\mathrm{RN}}+\frac{R_{3}}{R_{1}}\left(U_{\mathrm{RN}}-U_{\mathrm{RP}}\right) .
\end{aligned}
$$

Poznamenejme ještě, že referenční napětí mají různá napětí $U_{\mathrm{RP}}=5 \mathrm{~V}$ a $U_{\mathrm{R}_{\mathrm{N}}}=-2,23 \mathrm{~V}$.

Př́klad konkrétního řešení zdroje $\pm 10 \mathrm{~V}$ je uveden na Obr. $10.19 \mathrm{~b}$. Kapacity kapacitorů $\mathrm{C}_{1}$ až $\mathrm{C}_{4}$ jsou zvoleny podle doporučení výrobce.

\subsubsection{Stabilizátory s malým úbytkem napětí}

Stabilizátory s malým úbytkem napětí mezi vstupem a výstupem označované jako stabilizátory trrídy LDO (Low Drop-Out regulator) pracují na stejném principu jako klasický sériový stabilizátor napětí. Regulační prvek je však zapojen jako tranzistor se společným emitorem (viz Obr. 10.20a). To proto, že mezi vstupním a výstupním napětím nyní pro dobrou stabilizaci stačí úbytek 0,1 až $0,3 \mathrm{~V}$. Pokud tento úbytek srovnáme s konvenčním zapojením regulačního prvku jako emitorového sledovače, tak ten potřebuje rozdíl napětí minimálně $1 \mathrm{~V}$, obvykle však více než 2,5 V.

Dva př́klady zapojení stabilizátorů LDO s malým úbytkem napětí mezi vstupem a výstupem jsou uvedeny na Obr. 10.20b, c. Protože tranzistor v zapojení se společným emitorem invertuje na výstup napětí z báze tranzistoru, je pro zachování záporné zpětné vazby u operačního zesilovače zaměněn invertující a neinvertující vstup. Stabilizátory třídy LDO jsou k dispozici s pevně nastaveným výstupním napětím, nebo se jejich napětí nastavuje pomocí vnějšího děliče. Pevně nastavená napětí bývají v typické řadě $1,25 \mathrm{~V} ; 1,5 \mathrm{~V} ; 1,8 \mathrm{~V} ; 2,5 \mathrm{~V} ; 3 \mathrm{~V}$; 3,3 V; $5 \mathrm{~V}$.

Malý úbytek napětí je velkou výhodou u bateriových zařízení, protože baterie se může vybít na daleko nižší napětí, než stabilizátor přestane správně fungovat. Např. při napájení obvodů s napětím 3,3 V může napětí baterie klesnout až na 3,5 V. To v př́ípadě klasického řešení stabilizátoru s emitorovým sledovačem není možné.

Určitou nevýhodou stabilizátorů třídy LDO je, že malý úbytek napětí platí pouze pro relativně malé proudy do zátěže. V závislosti na proudu do zátěže úbytek totiž narůstá a proto 

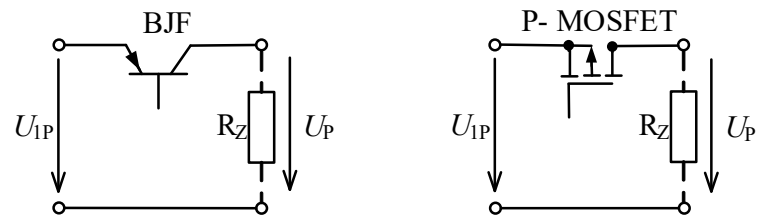

a
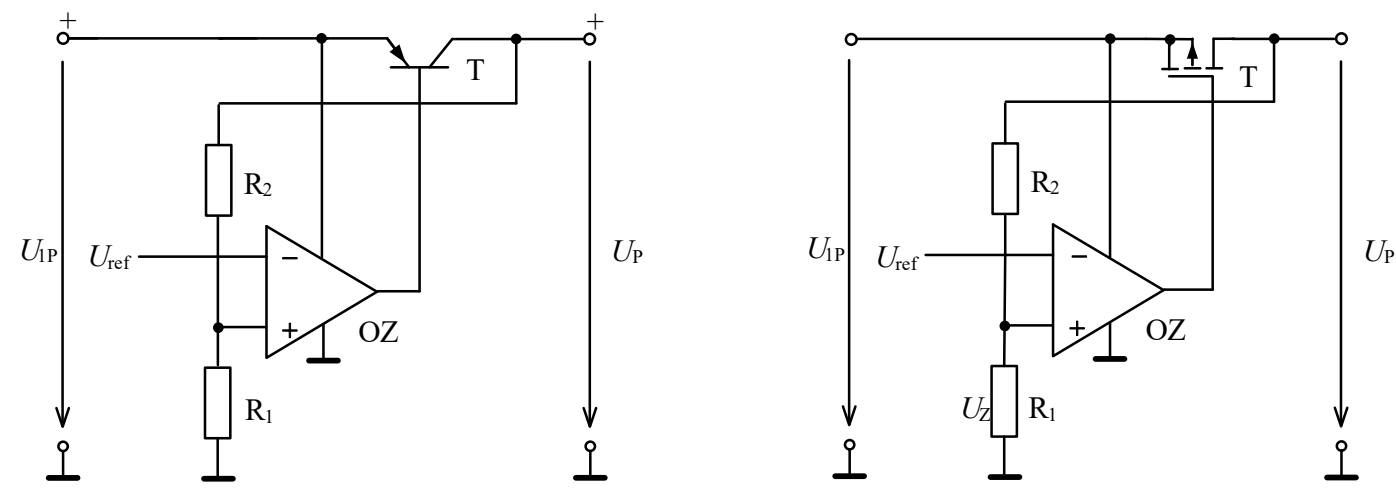

b

c

Obr. 10.20: a) Regulační prvek zapojený jako tranzistor se společným emitorem, b)c) př́klady zapojení stabilizátorů LDO s malým úbytkem napětí mezi vstupem a výstupem

tuto vlastnost vykazují většinou jen LDO stabilizátory pro proudy maximálně do 0,5 až $0,8 \mathrm{~A}$, kdy je úbytek mezi vstupem a výstupem menší než $1 \mathrm{~V}$.

Další nevýhodou stabilizátorů třídy LDO je jejich náchylnost k rozkmitání, protože př́liš velký nebo př́liš malý ekvivalentní sériový odpor ESR kondenzátoru připojeného k výstupu stabilizátoru může vést k oscilacím (viz Obr. 10.20). Proto je nutno vždy dodržet doporučení výrobce. Někteří přímo doporučují typ blokovacího kondenzátoru (např. elektrolytický nebo tantalový) anebo pro doporučenou kapacitu definují rozmezí ekvivalentního sériového odporu $E S R$ pro požadovaný rozsah proudu do zátěže (např. $E S R=0,1$ až $10 \Omega$ pro $I_{\mathrm{OUT}}$ $=0 \mathrm{až} 500 \mathrm{~mA})$.
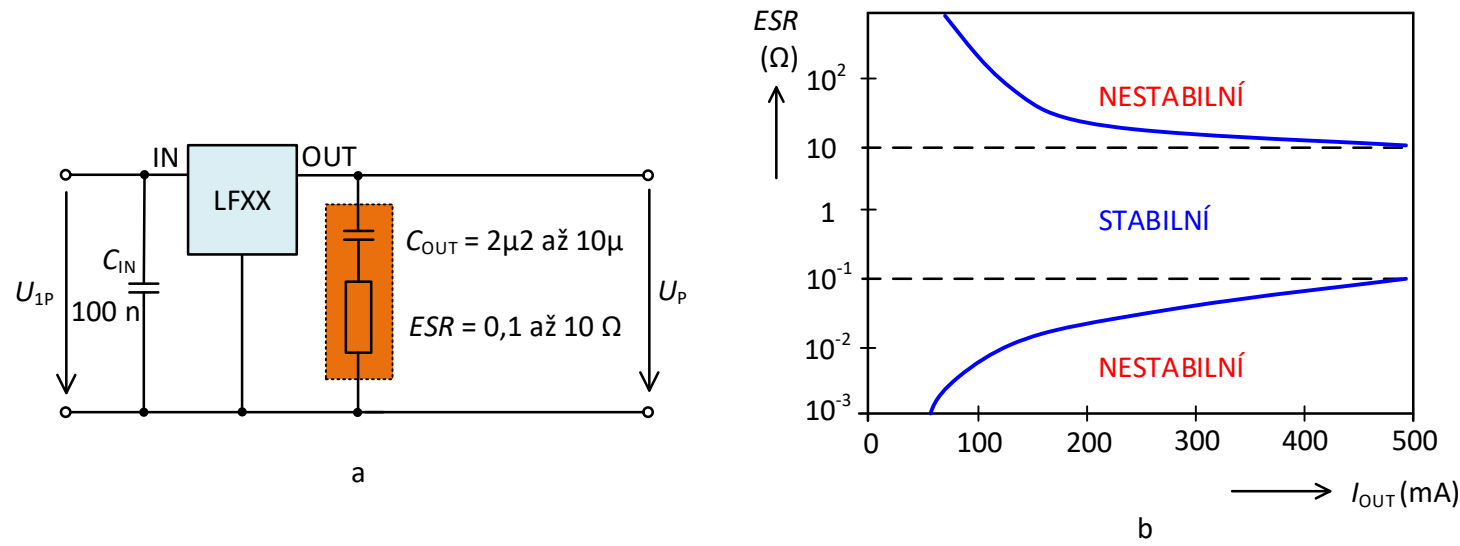

Obr. 10.21: a) Př́klad zapojení blokovacích kondenzátorů u stabilizátoru třídy LDO, b) ke kmitočtové stabilitě stabilizátorů třídy LDO 


\subsubsection{Jiné druhy stabilizovaných zdrojů}

Dosud probírané stabilizátory napětí patří do kategorie stabilizátorů se spojitou regulací. Vyznačují se poměrně malou účinností (cca 25 až $40 \%$ ), ale mají řadu výhod pokud se týká ostatních dosahovaných parametrů. Jejich použití je proto omezeno jen pro menší výkony.

Specifika zdrojů pro číslicovou a výkonovou techniku vyplývají z požadavků značně odlišných od potřeb analogové a měřicí techniky. Typická je potřeba relativně nízkého napětí při velkém výkonu (ř́dově desítky $\mathrm{W}$ až $\mathrm{kW}$ ). Z této skutečnosti pak vyplývá důraz na velkou účinnost, kterou nelze dosáhnout spojitou regulací klasických stabilizátorů. Naopak přednosti spojitě regulovaných stabilizátorů, tj. jinak velmi dobré výstupní parametry nejsou v číslicové či výkonové technice tolik důležité. Požadavek vysoké účinnosti se zajišt'uje jiným principem, tzv. impulsní regulací. Zvětšení účinnosti je zpravidla provázeno podstatným zlepšením objemového ukazatele, obojí však za cenu zhoršení řady výstupních parametrů: zvlnění, doba přechodného jevu při změně zátěže, stupeň impulsního rušení. Obvodově je tento typ stabilizátorů oproti předchozímu složitější a potřeba speciálních součástek ztěžuje možnou integraci. Konstrukce impulsně regulovaných napájecích zdrojů značně překračuje rámec této publikace a proto odkazujeme zájemce na odbornou literaturu zaměřenou na principy a konstrukci impulsně regulovaných napájecích zdrojů.

\section{Použitá literatura}

[1] TIETZE, U.; SCHENK, CH.; GAMM, E. Electronic Circuits. Hand book for Design and Applications. 2nd edition, Springer - Verlag, Berlin 2008. ISBN 978-3-54000429-5

[2] TIETZE, U.; SCHENK, CH. Electronic Circuits. Design and Applications. Springer Verlag, Berlin 1991. ISBN 3-540-50608-X

[3] DOSTÁL, J. Operační zesilovače. BEN, Praha 2005

[4] DOSTÁL, J. Operational Amplifiers. Elsevier, Amsterdam 1981

[5] ROBERGE, J. K. Operational Amplifiers. J. Wiley, New Your, London, Sydney, Toronto 1975

[6] KOUŘIL, F.; VRBA, K. Teorie nelineárních a parametrických obvodů. SNTL, Praha 1981

[7] GRAEME, J. G.; TOBEY, G. E. HUELSMAN, L. P. Operational Amplifiers. Design ad Applications. Mc GRAW-HILL, New York, 1971. ISBN 07-064917-0

[8] VRBA, K.; VRBA, K. jun. Technika analogových obvodů a systémů. Skriptum, 4. vydání. Ediční středisko VUT Brno,1989

[9] VRBA, K.; VRBA, K. jun. Technika analogových obvodů a systémů - sbírka př́íkladů. Skriptum, 3. vydání. Ediční středisko VUT Brno,1989

[10] CLAYTON, G.B. Operational Amplifier. London, Butterworth Co 1971

[11] ELLIOTT, R. Low Dropout (LDO) Regulators - A short primer on these sometimes difficult devices. Elliott Sound Products, 2017. https://sound-au.com/articles/ldoregulators.htm

[12] DENG, Q. A LDO Primer-Part I: A Review on Pass Element. Analog and Interface Products Division Microchip Technology Inc., 2019

[13] PATOUX, J. Ask The Applications Engineer 37: Low-Dropout Regulators. Analog Dialogue, 2019 


\section{Komparátory}

Napět'ový komparátor je obvod, který slouží pro porovnání dvou napětí. Má stejně jako operační zesilovač dvě vstupní svorky (invertující a neinvertující) a jednu výstupní svorku. Pokud napětí přivedené na jednu vstupní svorku bude větší nebo menší než napětí přivedené na druhou vstupní svorku, pak výstup komparátoru změní skokově svůj stav.

\subsection{Základní vlastnosti komparátorů}

Jako komparátor se dá použít libovolný diferenční zesilovač, vykazující na převodní charakteristice horní a dolní oblast nasycení výstupního napětí. Princip je patrný z Obr. 11.1. Jako komparátoru je použito operačního zesilovače $(\mathrm{OZ}) \mathrm{s}$ diferenčním vstupem. Jeho převodní charakteristika $u_{2}\left(u_{\mathrm{i}}\right)$ je také nakreslena na Obr. 11.1. Je vidět, že je-li vstupní napětí $u_{1}$ menší než srovnávací napětí $U_{\mathrm{s}}$, je $u_{\mathrm{i}}=u_{1}-U_{\mathrm{s}}<0$ a na výstupu je proto kladné saturační napětí $u_{2}=$ $U_{2 \mathrm{p}}$. V př́ípadě $u_{1}>U_{\mathrm{s}}$ je $u_{\mathrm{i}}>0$ a na výstupu dostáváme záporné saturační napětí $u_{2}=U_{2 \mathrm{n}}$. Přechod z $U_{2 \mathrm{p}}$ na $U_{2 \mathrm{n}}$ je velmi strmý, jak lze poznat $\mathrm{z}$ orientačních měřítek na osách přenosové charakteristiky. Operační zesilovač se však př́mo jako komparátor nedoporučuje používat, protože pokud se jeho výstup dostane do saturace, nastane navíc jev zvaný upnutí výstupu na napájecí napětí („latch up“), který značně prodlouží dobu překlopení do opačné saturace. Pokud se použije jako komparátor operační zesilovač, musí se jeho výstup ošetřit např. omezovačem se Zenerovými diodami.
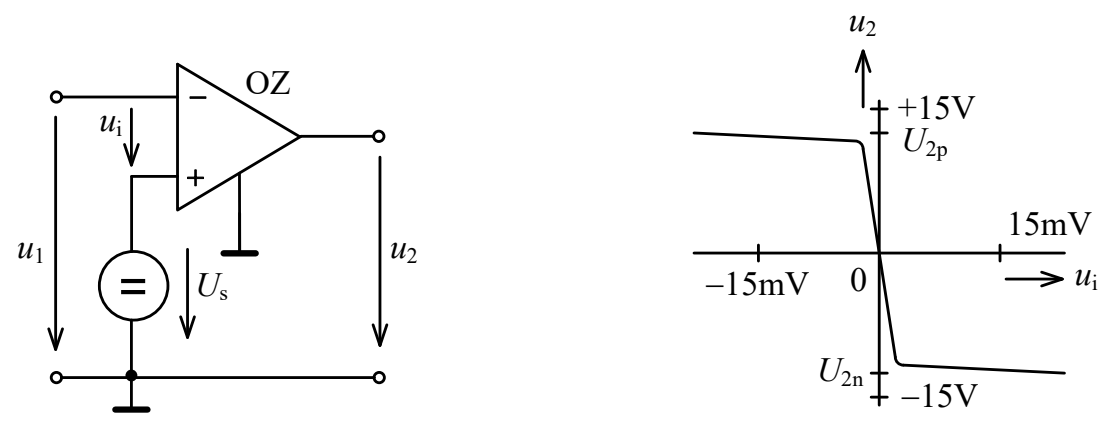

Obr. 11.1: Komparátor s diferenčním operačním zesilovačem a jeho převodní charakteristika

Diferenční zesilovače používané v komparátorech mají obvykle malé zesílení (cca 1000), ale vyznačují se vysokou rychlostí přeběhu. Koncová část komparátoru však má podobnou strukturu jako digitální obvody a je koncipována tak, aby se komparátor dostal při změně vstupních napětí velmi rychle ze své saturace. Rozdíly mezi operačním zesilovačem $(\mathrm{OZ})$ a komparátorem lze shrnout do těchto bodů:

- Vstupní obvody komparátorů jsou sice analogové, podobně jako u diferenčních operačních zesilovačů, ale výstupy komparátorů jsou digitální (je na nich úroveň H či L). Výstupní napětové úrovně komparátorů jsou většinou uzpůsobeny tak, aby je bylo možné přímo propojit s logickými obvody CMOS, TTL, LVDS apod. To u operačních zesilovačů neplatí.

- OZ jsou uzpůsobeny k provozu se silnou zápornou zpětnou vazbou, bez ní jsou velmi náchylné ke kmitání. Naopak komparátory jsou určeny k provozu bez záporné zpětné vazby.

- Diferenční vstup OZ předpokládá, že je na něm rozdíl napětí blízký nule. Naopak vstupy komparátoru snesou i velké rozdíly vstupního napětí. 
- Když se výstup OZ dostane do saturace, jen těžko a pomalu se z ní dostává ven. Komparátory tímto netrpí, jejich výstup je k takovému provozu př́mo konstruován, výstup se chová stejně jako výstup logického obvodu.

Klasické řešení komparátoru má symetrické napájení a společnou zem analogové a číslicové části (Obr. 11.2a). Mohou mít přímý i inverzní výstup jako např. komparátor s diferenčním výstupem na Obr. 11.2b. Podobně jako A/D převodníky, mají některé komparátory samostatné napájecí př́vody pro vstupní (analogovou) část a výstupní (digitální) část. Rychlé překlápění výstupu komparátoru generuje rušení, které se nesmí šírit do analogového napájecího rozvodu. Díky samostatným napájecím prrívodům též mohou být použita různá napájecí napětí, což v praxi nastává velmi často. Typický př́pad je, že analogová část je napájena symetrickým napětím $\pm 15 \mathrm{~V}$ a výstupní část je napájena $\mathrm{z}+3,3 \mathrm{~V}$ pro logické obvody, jak ukazuje Obr. $11.2 \mathrm{c}$.

Symetrické napájení komparátoru má opodstatnění pouze v měřicí a audio technice. Pro běžnou spotřební elektroniku se vyrábí obrovské množství komparátorů, kterým dostačuje nesymetrické analogové napájení jako na Obr. $11.2 b$ a někdy mají nesymetricky napájené komparátory i dva vývody pro zem, jeden pro analogovou (AGND) a druhý pro digitální (DGND) tak, jak je znázorněno na Obr. 11.2d. Účelem je opět zamezit průniku rušení z digitální části do analogových obvodů.

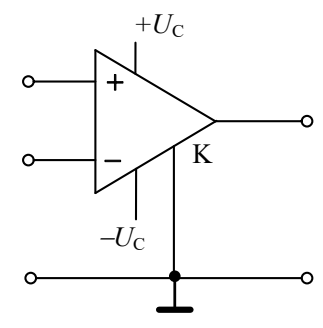

a

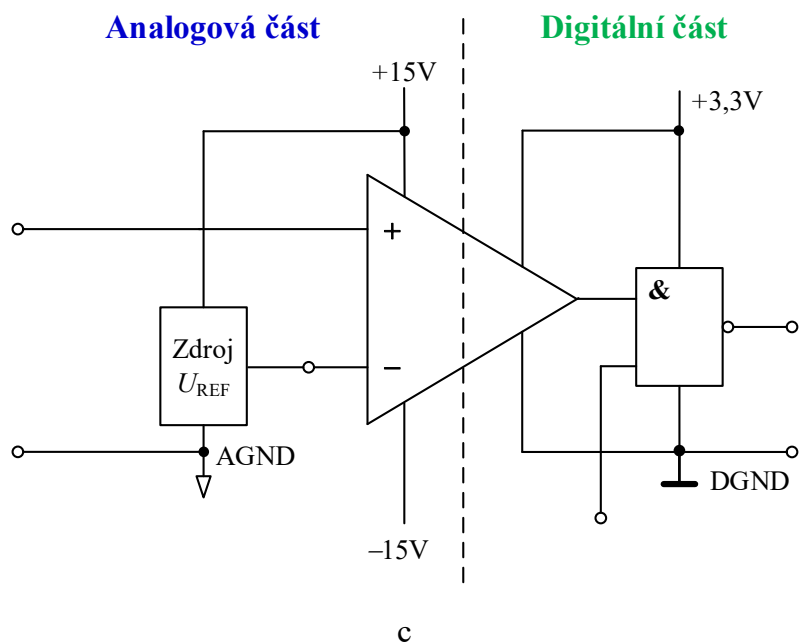

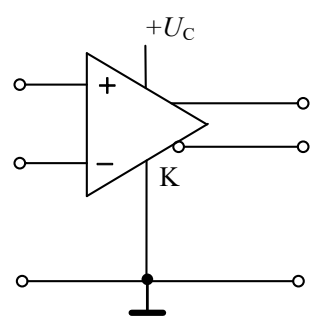

b

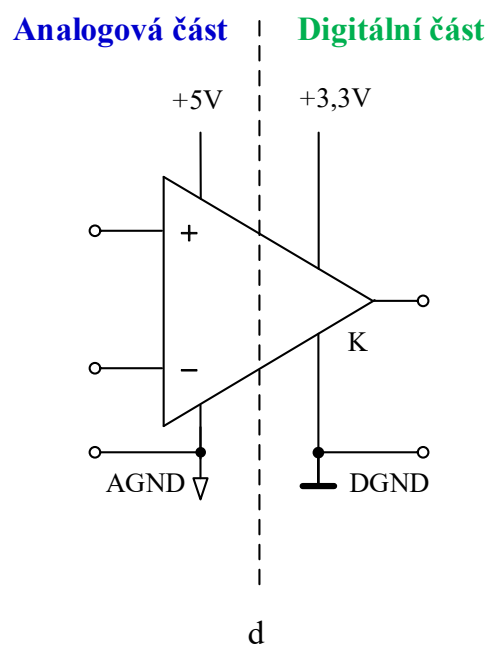

d

Obr. 11.2: Typická zapojení komparátorů

\subsection{Parametry komparátorů}

Některé parametry komparátorů mají stejný význam jako u OZ, např. vstupní napětová a proudová nesymetrie (input offset voltage/current) či citlivost na souhlasné napětí (common 
mode rejection ratio, CMMR). Komparátory jsou však určeny k jinému účelu než OZ a proto při jejich výběru je nutné sledovat zcela jiné parametry:

- Vstupní napět’ový rozsah (input voltage range) je u některých komparátorů omezený. Omezení přitom může být celá řada, záleží na konstrukci vstupního zesilovače. Např́íklad komparátor napájený $\mathrm{z} \pm 15 \mathrm{~V}$ může být schopen zpracovat vstupní napětí $U_{\mathrm{P}}$ či $U_{\mathrm{N}}$ pouze $\mathrm{v}$ rozsahu $\pm 5 \mathrm{~V}$ proti zemi (viz Obr. 11.3a). Pokud napětí na některém vstupu tento rozsah překročí, komparátor se dostane do hluboké saturace, ze které se dostává jen pomalu. Jiné komparátory zase snesou vstupní napětí v celém rozsahu napájení, ale jejich vzájemný rozdíl $U_{\mathrm{P}}-U_{\mathrm{N}}$ nesmí překročit např. $7,5 \mathrm{~V}$. Na druhou stranu však existují i komparátory, které na vstupu snesou celý rozsah napájecího napětí (rail-to-rail input).

- Doba zpoždění tPD (propagation delay) je nejdůležitější údaj, od kterého se odvíjí i cena komparátoru. Jeho interní obvody nejsou nekonečně rychlé, vždy nějakou dobu trvá, než výstup zareaguje na změnu vstupního napětí. $\mathrm{Na}$ Obr. $11.3 \mathrm{~b}$ je pro ilustraci uvedena časová odezva komparátoru z při přechodu vstupního napětí $u_{\text {i }}$ přes nulu (ze záporných do kladných hodnot). Společně se jmenovitou dobou zpoždění $t_{\mathrm{PD}}$ je vždy udáván i rozdíl napětí na vstupu (overdrive voltage), který je nutný pro její dosažení (na Obr. 11.3b je označen jako $U_{\mathrm{ov}}$ ). Pokud je tento rozdíl menší, je i reakce komparátoru pomalejší. Na tuto skutečnost je tedy také nutné dávat při výběru komparátoru pozor. Dnes jsou běžně dostupné komparátory, které mají $t_{\mathrm{PD}}$ kratší než 0,2 ns.

- Rychlost přeběhu výstupu (slew rate) je obvykle udávána dobou náběžné hrany (rise time) $t_{\mathrm{R}}$ viz Obr. $11.3 \mathrm{~b}$ resp. dobou sestupné hrany (fall time) $t_{\mathrm{F}}$. Zde záleží na konstrukci budiče výstupu, nicméně informace o době náběžné či sestupné hrany je obvykle podobná době zpoždění $t_{\mathrm{PD}}$ (pomalý komparátor nepotřebuje rychlý výstup a naopak). Kapacitní zátěž na výstupu strmost hran zhoršuje (doba trvání hran se prodlužuje), což je nutné při aplikacích zohlednit.

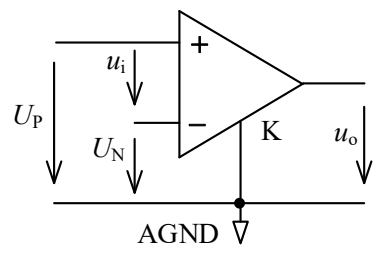

a

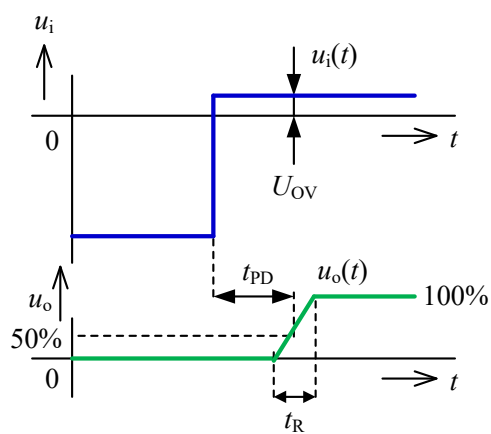

b

Obr. 11.3: K významným parametrům komparátorů

- Maximální výstupní proud (output current capability) úzce souvisí s výše zmíněnými kapacitními zátěžemi na výstupu - čím větší proud je výstup schopen dodat, tím rychleji dokáže kapacity nabít a tedy dosáhnout strmějších hran. K dispozici jsou i komparátory speciálně konstruované pro buzení velkých kapacitních zátěží.

- Vnitřní hysterezní obvody (internal hysteresis) - téměř všechny vysokorychlostní komparátory mají hysterezi (viz dále) realizovanou přímo na čipu. U některých typů je nastavena napevno, zpravidla okolo 10 až $20 \mathrm{mV}$ (fixed hysteresis). U jiných typů je nastavitelná z vnějšku (adjustable hysteresis), typicky v rozsahu 0 až $200 \mathrm{mV}$.

- Synchronizační/aktivační vstup (latch enable) - protože komparátory jsou ve své podstatě jednobitovými $\mathrm{A} / \mathrm{D}$ převodníky, je často $\mathrm{v}$ praxi nutné jejich překlápění 
synchronizovat s hodinovým signálem z nadřazeného digitálního systému. Některé typy k tomu mají př́mo na čipu synchronizační obvody a samostatný digitální vstup.

- Vstup pro řízení spotřeby (shutdown input) - některé komparátory mají vstup, kterým lze komparátor vypnout a tím radikálně snížit jeho spotřebu. To se typicky používá v zařízeních napájených z baterií.

Mezi další významné vlastnosti komparátorů lze zařadit i konstrukci výstupu (output stage type). Výstup komparátoru je obvykle digitální, takže i jeho konstrukce a napět'ové úrovně se mohou lišit podle logických obvodů, pro které je určen. Dnes jsou vyráběny komparátory se třemi druhy výstupů:

Dvojčinný výstup (push-pull output) se používá pro připojení k běžným logickým obvodům CMOS, TTL apod. (viz Obr. 11.4a). Je to klasický logický výstup, kdy v úrovni H teče proud z výstupní svorky a v úrovni L teče proud naopak do výstupní svorky.

Výstup s otevřeným kolektorem (open collector/drain output) umožňuje připojit zátěž $R_{L}$ napájenou z vnějšího napětí $U_{\mathrm{EXT}}$ (viz Obr. $11.4 \mathrm{~b}$ ). V tomto případě může proud téci pouze

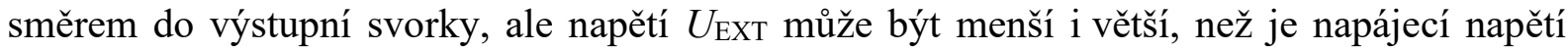

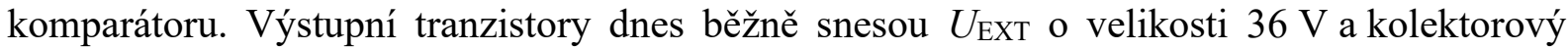
proud $20 \mathrm{~mA}$, takže jimi lze přímo spínat i poměrně velké zátěže (LED, relé, optotriaky apod). Výstupy s otevřeným kolektorem je také možné zapojovat paralelně jako na Obr. 11.4c, takže jednu zátěž lze ovládat z více komparátorů současně (zapojení plní logickou funkci OR).

- Diferenční výstup (differential output) či komplementární výstupy (complementary outputs) se užívají u všech vysokorychlostních komparátorů $\left(t_{\mathrm{PD}}<10 \mathrm{~ns}\right)$. Takové komparátory jsou vždy určeny pro konkrétní standard vysokorychlostních logických obvodů a nelze je použít nikde jinde. Dnes jsou nejčastěji k dispozici výstupy pro standardy LVDS (Low-Voltage Differential Signalling), ECL (Emitter-Coupled Logic), PECL (Positive Emitter-Coupled Logic) a CML (Current-Mode Logic). Všechny diferenční výstupy musejí být připojeny na vedení o definované vlnové impedanci (např. u LVDS je to $100 \Omega$ ) a vedení musí být na konci předepsaným způsobem zakončeno. Komparátory též musejí být napájeny napětím, které je pro daný logický standard předepsáno. Na Obr. 11.5 je př́klad zapojení komparátoru s LVDS diferenčním výstupem.

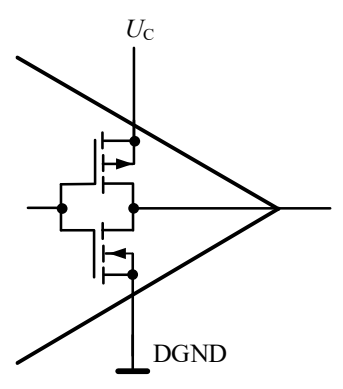

a

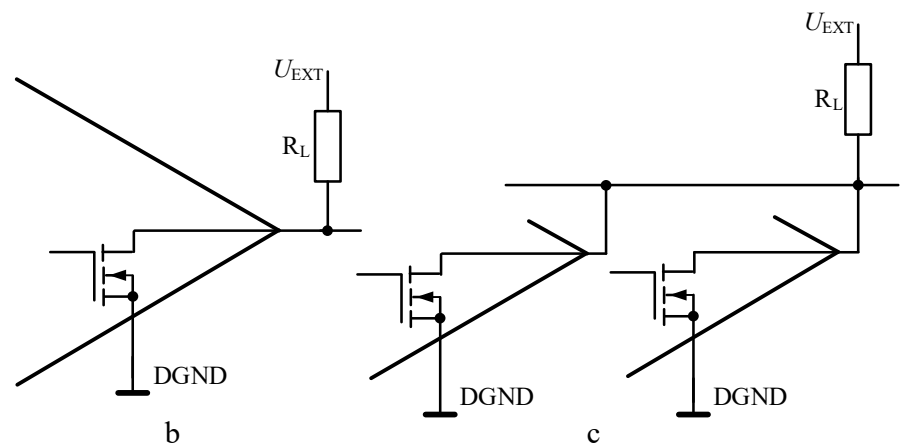

b
Obr. 11.4: Dvojčinný výstup a otevřený kolektor 


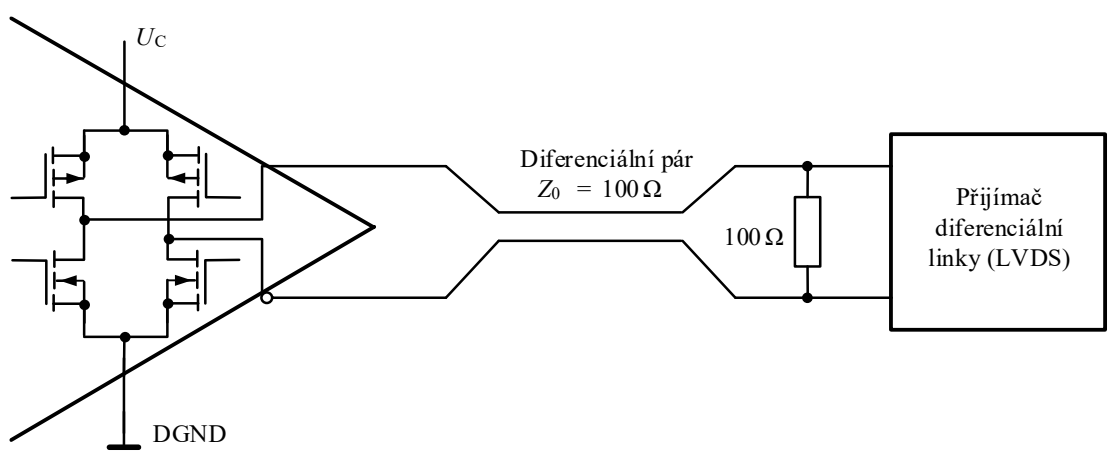

Obr. 11.5: Př́́klad zapojení diferenčního výstupu komparátoru

\subsection{Okénkové komparátory}

V praxi je často nutné zjistit, jestli sledované napětí nevybočuje ze zadaných mezí. $\mathrm{K}$ tomu lze použít tzv. okénkový komparátor (window comparator), který je možné vytvořit vhodným zapojením dvou „obyčejných“ komparátorů. Jeden z nejčastějších př́íkladů zapojení je na Obr. 11.6a. Rezistorový dělič zapojený mezi napájení $U_{\mathrm{C}}$ a zem vytváří dvě referenční napětí pro komparátory. Na Obr. 11.6a jsou rezistory shodné, takže referenční napětí jsou $U_{\mathrm{C}} / 3$ a $2 U_{\mathrm{C}} / 3$. Pokud je vstupní napětí $u_{1}$ větši než $2 U_{\mathrm{C}} / 3$, zareaguje horní komparátor $\mathrm{K}_{1}$ a na jeho výstupu se objeví úroveň $\mathrm{H}$. Naopak, pokud je vstupní napětí menší než $U_{\mathrm{C}} / 3$, zareaguje dolní komparátor $\mathrm{K}_{2}$. Jinými slovy, na výstupech obou komparátorů je úroveň $\mathrm{L}$ pouze pokud se vstupní napětí pohybuje mezi $U_{\mathrm{C}} / 3$ a $2 U_{\mathrm{C}} / 3$. Pro praktické aplikace je zapotřebí výstupy komparátorů sloučit, což se provádí logickou funkcí OR - na Obr. 11.6a je k tomu použito logické hradlo. Výstupní napětí $u_{2}$ celého okénkového komparátoru je pak znázorněno na Obr. $11.6 \mathrm{~b}$.

Protože rezistorový dělič pro vytvoření komparačních hladin je př́mo napojen na napájecí zdroj, doporučuje se zablokovat vstup komparátoru $\mathrm{K}_{1}$ kondenzátorem $\mathrm{C}_{\mathrm{B}}$, jak je naznačeno na Obr. 11.6a. Jestliže to přesnost úlohy vyžaduje, je možné horní rezistor děliče odpojit a invertující vstup komparátoru $\mathrm{K}_{1}$ připojit přímo na vnější zdroj referenčního napětí se stabilitou lepší než má napájecí napětí $U_{\mathrm{C}}$. Blokovací kondenzátor je v takovém př́ípadě zbytečný. 

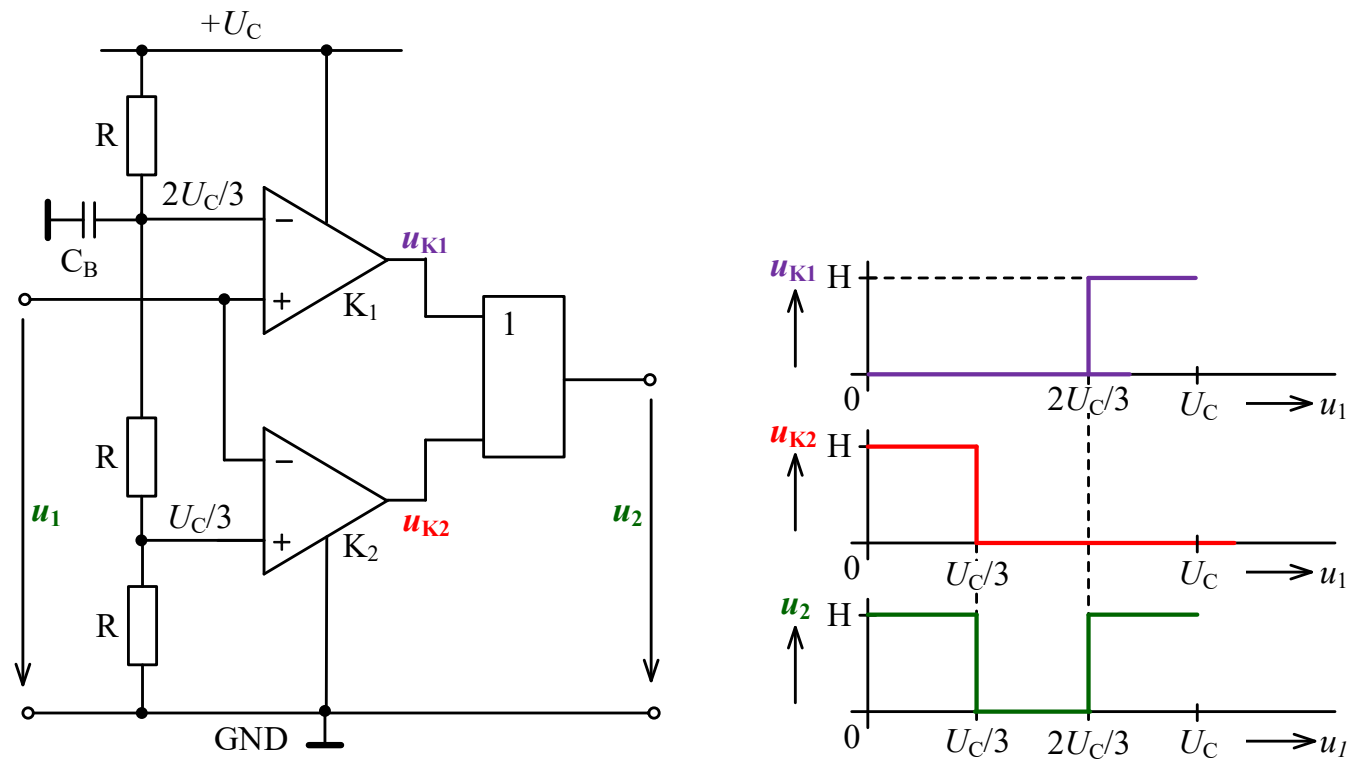

Obr. 11.6: Okénkový komparátor

\subsection{Komparátory s hysterezí}

Komparátor s hysterezí je takový komparátor, který reaguje dvěma opačnými skokovými změnami na dvě různé úrovně. Toho u diferenčního komparátoru dosáhneme zavedením kmitočtově nezávislé kladné zpětné vazby. Zapojení je patrné z Obr. 11.7 a z literatury je známo jako invertující Schmittův klopný obvod, resp. jako invertující komparátor s hysterezí. Na neinvertující vstup operačního zesilovače působí napětí $u_{\mathrm{s}}=u_{2} R_{1} /\left(R_{1}+R_{2}\right)=p u_{2}$. Výstupní napětí komparátoru $u_{2}$ nabývá pouze dvou úrovní a to kladné saturační napětí $U_{2 \mathrm{p}}$ nebo záporné saturační napětí $U_{2 n}$. Podle toho, zda je na výstupu kladné nebo záporné saturační napětí, přivádíme na neinvertující vstup bud' kladné srovnávací napětí $U_{\mathrm{sp}}=p U_{2 \mathrm{p}}$ nebo záporné srovnávací napětí $U_{\mathrm{sn}}=p U_{2 \mathrm{n}}$. Napětí $U_{2 \mathrm{p}}$ je na výstupu operačního zesilovače jen tehdy, je-li $u_{\mathrm{i}}$ $<0$, tj. pokud $u_{1}<U_{\text {sp. }}$. Bude-li se napětí $u_{1}$ blížit srovnávacímu napětí $U_{\mathrm{sp}}$, dostane se zesilovač $\mathrm{z}$ oblasti nasycení na klesající část přenosové charakteristiky $u_{2}\left(u_{\mathrm{i}}\right)$ znázorněné na Obr. 11.1. Záporná změna výstupního napětí $u_{2}$ má okamžitě za následek i zápornou změnu srovnávacího napětí $u_{\mathrm{s}}$. V důsledku toho dojde ke kladné změně napětí $u_{\mathrm{i}}=u_{1}-u_{\mathrm{s}}$; ta vyvolá další zápornou změnu $u_{2}$ a celý proces lavinovitě pokračuje, až se výstupní napětí ustálí na záporné saturační hodnotě $U_{2 n}$ (viz též převodní charakteristiku na Obr. 11.7 - pozor však na to, že na rozdíl od Obr. 11.1 jsou v tomto př́padě měřítka na obou osách stejná). Srovnávací napětí se přitom automaticky přestaví na hodnotu $U_{\mathrm{sn}}$, protože je odvozeno od výstupního napětí komparátoru. V tomto stavu obvod setrvá, pokud bude $u_{\mathrm{i}}<0$, tedy bude-li $u_{1}>U_{\text {sn. }}$. Jestliže se napětí $u_{1}$ zmenší

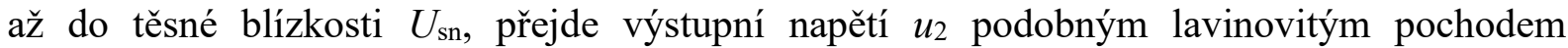
podporovaným kladnou zpětnou vazbou skokově z hodnoty $U_{2 n}$ na $U_{2 p}$. Současně s tím se

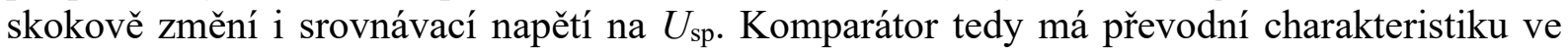
tvaru hysterezní smyčky a reaguje podle předpokladu skokovými změnami na dvě napětí $U_{\text {sp }}$ a $U_{\text {sn. }}$ Pokud by to bylo potřeba, je možné celou hysterezní smyčku posouvat podél osy $u_{1}$, např̀. tak, že do série $s$ rezistorem $\mathrm{R}_{1}$ přidáme zdroj stejnosměrného napětí. 

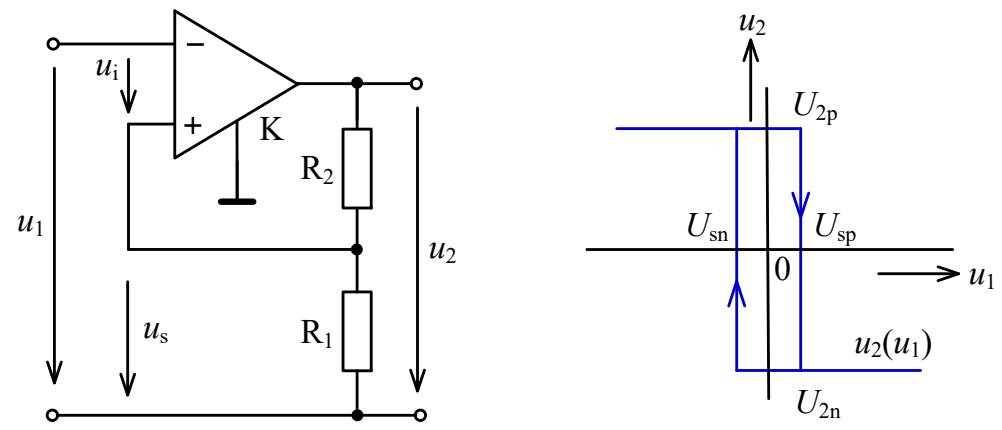

Obr. 11.7: Invertující komparátor s hysterezí - invertující Schmittův klopný obvod

Zapojení neinvertujícího komparátoru s hysterezí (neinvertující Schmittův klopný obvod) je naznačeno na Obr. 11.8, kde je také uvedena odpovídající převodní charakteristika. Jestliže na vstupu bude velké kladné vstupní napětí $u_{1}$, bude na výstupu komparátoru napětí $u_{2}=U_{2 p}$. Budeme-li vstupní napětí snižovat, výstupní napětí komparátoru $u_{2}$ se nebude měnit až do té doby, kdy napětí na neinvertujícím vstupu bude nulové. Tato situace nastane při $u_{1}=U_{\mathrm{sp}}=-$ $\left(R_{1} / R_{2}\right) U_{2 p}$. Poté se výstupní napětí prudce změní a výstupní napětí se ustálí na záporné nasycené hodnotě $U_{2 n}$. Tento stav trvá tak dlouho, dokud vstupní napětí nedosáhne hodnoty $u_{1}=U_{\mathrm{sn}}=-\left(R_{1} / R_{2}\right) U_{2 \mathrm{n}}$.
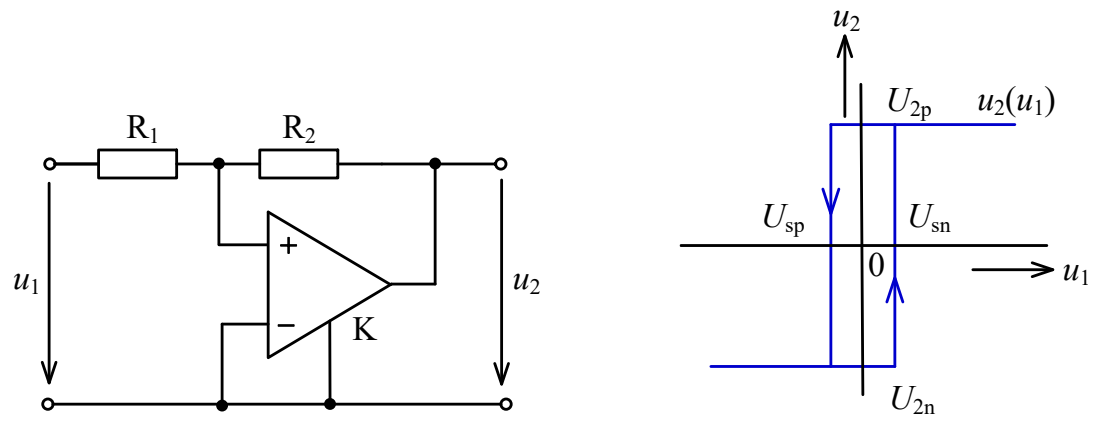

Obr. 11.8: Neinvertující komparátor s hysterezí - neinvertující Schmittův klopný obvod

Protože komparační napětí $U_{\mathrm{sp}}$, resp. $U_{\mathrm{sn}}$ je odvozeno od výstupního napětí v saturaci $U_{2 \mathrm{p}}$, resp. $U_{2 \mathrm{n}}$, není přesně definováno ani není stabilní a navíc může nastat jev upnutí výstupu OZ na napájecí napětí. Proto se často $\mathrm{k}$ výstupu komparátoru realizovaného diferenčním operačním zesilovačem připojuje omezovač, tvořený obvykle dvěma referenčními diodami.

V případech, kdy je zapotřebí zabezpečit vysokou přesnost komparačních úrovní je možno použít uspořádání se dvěma komparátory podle Obr. 11.9. Zapojení využívá základního principu z Obr. 11.1. Rozdíl je pouze $\mathrm{v}$ tom, že komparátory $\mathrm{K}_{1}$ a $\mathrm{K}_{2}$ mají dvojčinný výstup, tzn., že výstupní napětí komparátorů je uzpůsobeno logickým úrovním. Pro vytvoření hystereze je použit klopný obvod RS s hradly NAND. Jestliže bude vstupní napětí $u_{1}$ větší než horní komparační úroveň $U_{\mathrm{s} 2}>U_{\mathrm{s} 1}$, bude na výstupu komparátoru $\mathrm{K}_{1}$ úroveň $\mathrm{L}$, na výstupu $\mathrm{K}_{2}$ bude úroveň $\mathrm{H}$ a tedy na výstupu klopného obvodu RS bude úroveň $\mathrm{H}$. Překlopení obvodu RS na úroveň $\mathrm{L}$ nastane $\mathrm{v}$ okamžiku, kdy na výstupu komparátoru $\mathrm{K}_{1}$ bude úroveň $\mathrm{H}$ a naopak na výstupu $\mathrm{K}_{2}$ bude úroveň $\mathrm{L}$, tj. v okamžiku kdy $u_{1}<U_{\mathrm{s} 1}$. Další podrobnosti jsou zřejmé z průběhů uvedených na Obr. 11.9. 

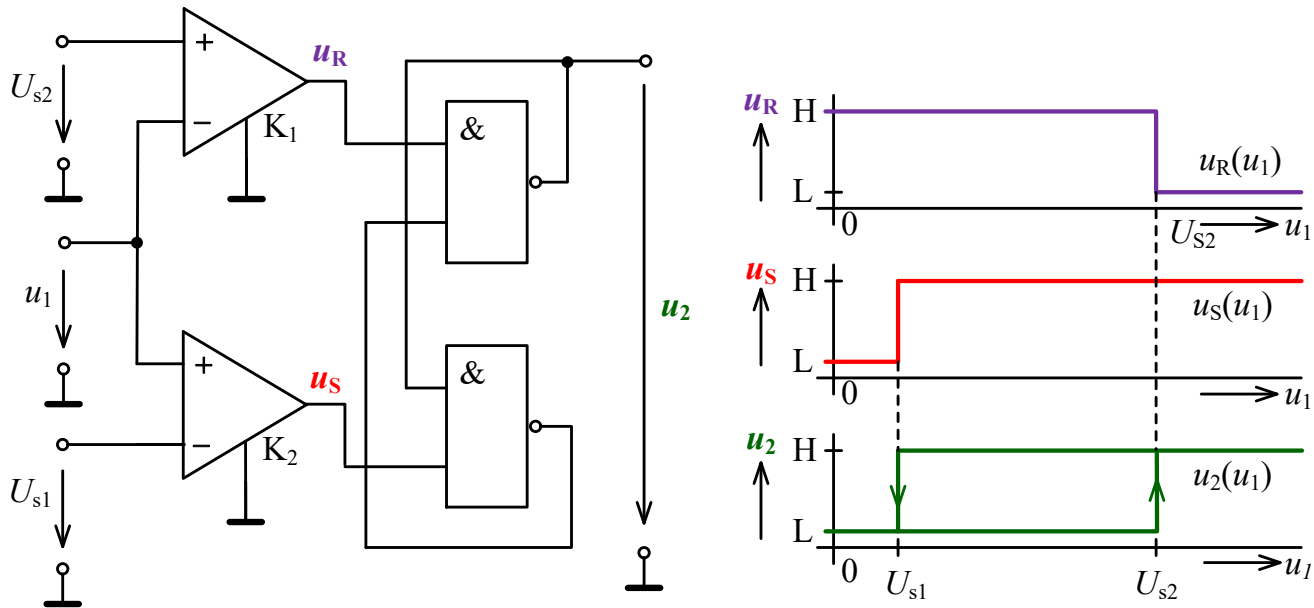

Obr. 11.9: Přesný komparátor s hysterezí 


\section{Použitá literatura}

[1] GRAME, J. G. Designing with Operational Amplifiers - Applications Alternatives. New York, McGraw-Hill Book Company, 1977

[2] CONNELLY, J. A. ed. Analog Integrated Circuits - Devices, Circuits, Systems, and Applications. New York, John Wiley and Sons 1983

[3] TIETZE, U.; SCHENK, CH.; GAMM, E. Electronic Circuits. Hand book for Design and Applications. 2nd edition, Springer - Verlag, Berlin 2008. ISBN 978-3-54000429-5

[4] TIETZE, U.; SCHENK, CH. Electronic Circuits. Design and Applications. Springer Verlag, Berlin 1991. ISBN 3-540-50608-X

[5] DOSTÁL, J. Operační zesilovače. BEN, Praha 2005

[6] DOSTÁL, J. Operational Amplifiers. Elsevier, Amsterdam 1981

[7] ROBERGE, J. K. Operational Amplifiers. J. Wiley, New Your, London, Sydney, Toronto 1975

[8] KOUŘIL, F.; VRBA, K. Teorie nelineárních a parametrických obvodů. SNTL, Praha 1981,

[9] VRBA, K.; VRBA, K. jun. Technika analogových obvodů a systémů. Skriptum, 4. vydání. Ediční středisko VUT Brno,1989

[10] VRBA, K.; VRBA, K. jun. Technika analogových obvodů a systémů - sbírka prríkladů. Skriptum, 3. vydání. Ediční středisko VUT Brno,1989

[11] CLAYTON, G.B. Operational Amplifier. London, Butterworth Co 1971

[12] HUIJSING, J.H. Operational Amplifiers - Theory and Desing. Kluwer Academic 


\section{Generátory}

Generátor je elektrický obvod vyrábějící periodické netlumené elektrické kmity bez jakéhokoli vnějšího periodického buzení. Jde o autonomní obvod, představující z energetického hlediska měnič stejnosměrného napětí na napětí střídavé.

Podle tvaru časového průběhu vyráběných kmitů (napětí či proudu) tř́ííme generátory do dvou základních skupin: a) generátory harmonických kmitů, zvané zpravidla oscilátory; b) generátory tvarových kmitů, tj. např. pilovitých, trojúhelníkových, pravoúhlých kmitů nebo pulsů. Protože pomocí funkčního měniče lze z trojúhelníkových kmitů snadno získat harmonický signál, bývají generátory tvarových kmitů označovány jako funkční generátory. Pokud generátory vyrábějí pouze pravoúhlé kmity, jsou označovány jako multivibrátory.

Periodické kmity vznikají v obvodech obsahujících jeden nebo více akumulačních prvků, sloužících jako zásobníky energie. Aby mohly v takovém obvodu vzniknout netlumené kmity, musíme do něj přivádět elektrickou energii $\mathrm{v}$ takových dávkách a $\mathrm{v}$ takových časových okamžicích, aby se kmity trvale udržovaly. Proto musí být mezi zdroj elektrické energie a obvod s akumulačními prvky zařazen prvek, který automaticky řídí přivádění elektrické energie v potřebném taktu do obvodu, v němž dochází ke kmitavé výměně energie. Dodávka energie musí samozřejmě krýt i výkon dodávaný připojené zátěži.

\subsection{Generátory harmonických kmitů - oscilátory}

Činnost oscilátoru vysvětlíme na základě blokového schématu uvedeného na Obr. 12.1. Oscilátor sestává ze zesilovače s přenosem $\bar{A}_{U}(\omega)=\bar{U}_{2} / \bar{U}_{1}$ a ze zpětnovazebního článku (např. kmitavý okruh), jehož přenos $\bar{K}_{U}(\omega)=\bar{U}_{3} / \bar{U}_{2}$. Celkový přenos řetězce pak

$$
\bar{U}_{3} / \bar{U}_{1}=\bar{A}_{U}(\omega) \bar{K}_{U}(\omega) .
$$

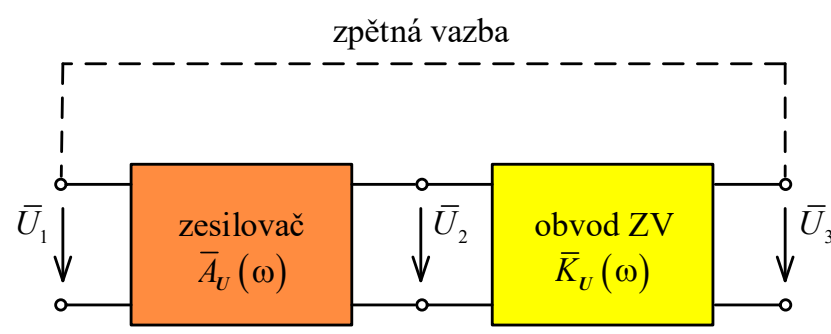

Obr. 12.1: Blokové schéma oscilátoru

Přitom předpokládáme, že soustava je selektivní tak, že při kmitočtu generovaných kmitů $\omega_{0}$ je výstupní napětí harmonické. Jedině za tohoto předpokladu můžeme použít komplexní symbolické vyjádření veličin v obvodu. Dále je třeba předpokládat, že přenos zesilovače závisí na amplitudě vstupního napětí $U_{1}$ tak, že při zvětšování vstupního napětí se přenos zesilovače zmenšuje. Za tohoto předpokladu vzniknou v oscilátoru kmity s konstantní amplitudou. Základní podmínkou pro vznik kmitů při zavedení zpětné vazby je v uvažovaném případě rovnost

$$
\bar{U}_{1}=\bar{U}_{3}=\bar{U}_{1} \bar{A}_{U}(\omega) \bar{K}_{U}(\omega)
$$


V obvodu tedy vzniknou harmonické kmity o takovém kmitočtu $\omega_{1}$, při kterém je splněna podmínka

$$
\bar{A}_{U}\left(\omega_{0}\right) \bar{K}_{U}\left(\omega_{0}\right)=1
$$

Vyjádříme-li komplexní veličiny v exponenciálním tvaru $\bar{A}_{U}=A_{U} e^{\mathrm{j} \varphi_{A}} \mathrm{a} \quad \bar{K}_{U}=K_{U} e^{\mathrm{j} \varphi_{K}}$, můžeme vyslovit dvě podmínky, a to

$$
\begin{gathered}
A_{U}\left(\omega_{0}\right) K_{U}\left(\omega_{0}\right)=1 ; \\
\varphi_{A}\left(\omega_{0}\right)+\varphi_{K}\left(\omega_{0}\right)=n 2 \pi, \quad(n=0, \pm 1, \ldots) .
\end{gathered}
$$

První z nich je tzv. modulová podmínka, která říká, že celkový přenos zpětnovazební smyčky v oscilátoru generujícího kmity musí být vždy roven jedné. Druhá rovnice (12-5) je tzv. argumentová resp. fázová podmínka, z níž vyplývá, že celkové fázové posunutí ve smyčce zpětné vazby musí být při kmitočtu $\omega_{0}$ nulové, resp. musí být celým násobkem $2 \pi$. Posouvá-li tedy zesilovač fázi o $\pi$ (invertující zesilovač), musí zpětnovazební článek posunout fázi bud' o $\pi$ nebo $\mathrm{o}-\pi$. V oscilátoru tedy musí být zavedena kladná zpětná vazba a zesilovač musí pokrýt ztráty v obvodu zpětné vazby.

\subsubsection{LC oscilátory}

Jako př́íklad tohoto oscilátoru LC rozebereme zapojení uvedené na Obr. 12.2. Operační zesilovač je zapojen jako neinvertující a zesiluje vstupní napětí $u_{1} A_{\mathrm{U}}$-krát $\left(A_{U}=1+R_{2} / R_{1}\right)$. Přitom předpokládáme, že zesilovač zpracovává takové kmitočty, kdy se ještě neuplatní jeho omezené kmitočtové chování. Protože výstupní odpor neinvertujícího zesilovače je velmi malý, je kmitavý okruh LC v obvodu zpětné vazby připojen k operačnímu zesilovači přes rezistor R. Pro určení parametrů obvodu zpětné vazby aplikujeme na uzel označený X první Kirchhoffův zákon $i_{\mathrm{R}}-i_{\mathrm{C}}-i_{\mathrm{L}}=0, \mathrm{tj}$.

$$
\frac{u_{2}-u_{1}}{R}-C \frac{\mathrm{d} u_{1}}{\mathrm{~d} t}-\frac{1}{L} \int u_{1} \mathrm{~d} t=0
$$

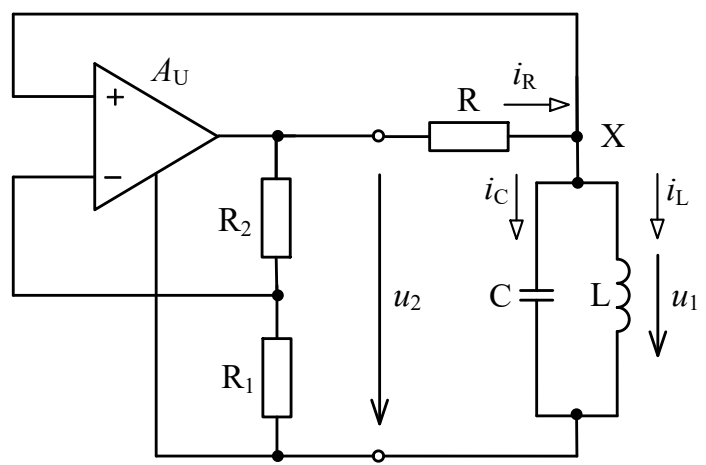

Obr. 12.2: Zapojení oscilátoru LC

Protože $u_{2}=A_{U} u_{1}$, můžeme po úpravě psát 


$$
\frac{\mathrm{d}^{2} u_{1}}{\mathrm{~d} t^{2}}+\frac{1-A_{U}}{R C} \frac{\mathrm{d} u_{1}}{\mathrm{~d} t}+\frac{1}{L C} u_{1}=0
$$

Tato diferenciální rovnice popisuje kmity vznikající v obvodu. Pro zkrácení zápisu zavedeme činitel tlumení

$$
\alpha=\frac{1-A_{U}}{2 R C}
$$

a rezonanční kmitočet kmitavého okruhu LC

$$
\omega_{0}=\sqrt{\frac{1}{L C}} .
$$

Pak diferenciální rovnice bude mít tvar

$$
\frac{\mathrm{d}^{2} u_{1}}{\mathrm{~d} t^{2}}+2 \alpha \frac{\mathrm{d} u_{1}}{\mathrm{~d} t}+\omega_{0}^{2} u_{1}=0
$$

Tato rovnice jak známo z matematiky má řešení

$$
u_{1}(t)=U_{1} e^{-\alpha t} \sin \omega_{V} t
$$

kde $\omega_{V}=\sqrt{\omega_{0}^{2}-\alpha^{2}}$ je vlastní kmitočet volných kmitů v rezonančním okruhu.

Podle toho zda je činitel tlumení $\alpha$ kladný, záporný nebo nulový, mají vlastní kmity ve zpětnovazebním okruhu trojí možný charakter. Při $\alpha<0$ (tj. $\left.A_{\mathrm{U}}>1\right)$ budou kmity narůstat podle exponenciály, při $\alpha>0\left(\mathrm{tj} . A_{\mathrm{U}}<1\right)$ půjde o tlumené kmity doznívající podle exponenciály a konečně při $\alpha=0\left(\mathrm{tj} . A_{\mathrm{U}}=1\right)$ půjde o netlumené kmity s konstantní amplitudou a s kmitočtem $\omega_{V} \equiv \omega_{0}$.

Modulovou podmínku (12-4) můžeme nyní rozebrat podrobněji. Při $A_{U}=1$ vznikají harmonické kmity s konstantní amplitudou a s kmitočtem $\omega_{V}=\omega_{0}=1 / \sqrt{L C}$. Při velmi slabé kladné zpětné vazbě se amplituda kmitů výstupního napětí zmenšuje, při velmi silné roste. Samovolné nasazení kmitů po připojení oscilátoru k napájení je možné pouze při splnění podmínky $A_{\mathrm{U}}>1$. Amplituda napětí bude narůstat do té doby, pokud se zesilovač nepřetíží, tzn., dokud se výstup zesilovače nedostane do saturace. Bude-li se zesilovač dostávat do saturace, bude se jeho zesílení $A_{\mathrm{U}}$ zmenšovat, až bude rovno jedné. Tvar výstupních kmitů však nebude již harmonický. Jestliže požadujeme harmonické výstupní napětí, je zapotřebí provést řízení přenosu zesilovače $A_{\mathrm{U}}$ tak, aby modulová podmínka byla splněna dřív, než se operační zesilovač dostane do saturace. Při vysokých kmitočtech je však snadné realizovat kmitavý okruh s vysokým činitelem jakosti. Z tohoto důvodu napětí na kmitavém okruhu zůstane prakticky vzato harmonické, i když zesilovač pracuje až do nasycení. Proto se u vf oscilátorů neužívá žádná speciální metoda řízení přenosu zesilovače a výstupní napětí se snímá př́imo na kmitavém okruhu (uzel X).

Oscilátory LC se neuživají ke generování nf kmitů, protože by byly zapotřebí velké hodnoty indukčnosti a kapacity. Protože vf oscilátory LC ve většině případů využívají jako zesilovače tranzistory, nebudeme se tímto typem oscilátoru zde podrobněji zabývat. 


\subsubsection{Oscilátory RC}

Oscilátory RC pracují v principu stejně jako oscilátory LC. Jejich základní uspořádání plně odpovídá blokovému schématu uvedenému na Obr. 12.1 a pro ustálené kmity v nich platí opět modulová a argumentová podmínka (12-4) a (12-5). Hlavní odlišnost je v tom, že zpětnovazební obvod neobsahuje kmitavý okruh, ale je tvořen dvojbranem RC s kmitočtově závislým činitelem přenosu (viz Obr. 12.3). Zpětnovazební přenosový článek může mít charakter horní, dolní i pásmové propusti, anebo i pásmové zádrže. Charakteristiky těchto dvojbranů RC nevykazují typické rezonanční průběhy článků s kmitavými okruhy LC, nýbrž jsou poměrně ploché. Činitelem určujícím kmitočet oscilátoru RC je v tomto př́padě fázové posunutí ve smyčce zpětné vazby, které musí při kmitočtu $\omega_{0}$ generovaných kmitů vyhovovat argumentové podmínce (12-5). Podle toho, zda se při stavbě oscilátoru použije invertujícího či neinvertujícího zesilovače, musí zpětnovazební článek RC při kmitočtu $\omega_{0}$ posouvat fázi bud' $\mathrm{o} \pm \pi$ anebo 0 (popr. $\pm 2 \pi$ ).

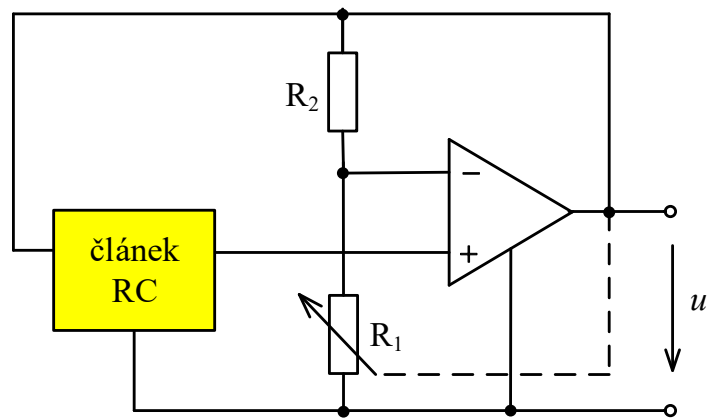

Obr. 12.3: Oscilátor RC

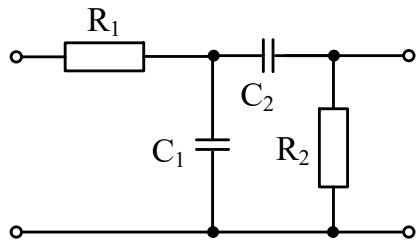

a

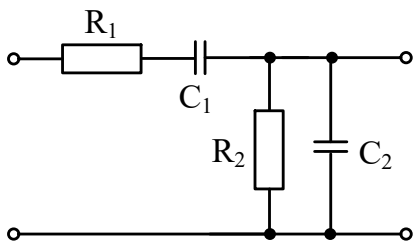

b

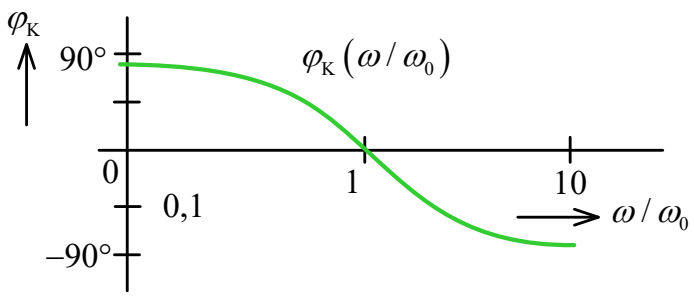

c

Obr. 12.4: a) b) Příklady zpětnovazebních RC článků, c) jejich argumentová (fázová) charakteristika

Dva příklady zpětnovazebních článků RC jsou uvedeny na Obr. 12.4. Zpětnovazební článek podle Obr. 12.4a má dvě sekce, dolní propust $\mathrm{R}_{1} \mathrm{C}_{1}$ a horní propust $\mathrm{R}_{2} \mathrm{C}_{2}$. Pro $C_{1}=C_{2}=C, R_{1}=R_{2}=R$ se jejich fázová posunutí při kmitočtu $\omega_{0}=1 / C R$ právě kompenzují. Při kmitočtu $\omega_{0}$ je přenos $K_{U}\left(\omega_{0}\right)=1 / 3$ a je tedy třeba, aby v oscilátoru s tímto článkem byl použit neinvertující zesilovač se zesílením $A_{U}=3$. Další zpětnovazební dvojbran (Obr. 12.4b) 
využívá přenosových vlastností Wienova článku. Jestliže $C_{1}=C_{2}=C$ a $R_{1}=R_{2}=R$, je také činitel přenosu $K_{U}\left(\omega_{0}\right)=1 / 3$ a důsledek je obdobný. Průběh argumentové (fázové) charakteristiky těchto článků (viz Obr. 12.4c) splňuje argumentovou podmínku oscilací, protože fázové natočení je při kmitočtu $\omega_{0}$ právě nulové.

Mají-li oscilátory s články RC generovat harmonické kmity bez zkreslení, snažíme se, aby se v nich co nejméně uplatnila nelinearita zesilovače, která je zdrojem vzniku vyšších harmonických složek. Tento požadavek je ovšem v rozporu s požadavkem udržení konstantní amplitudy kmitů, které se u oscilátorů LC ustalovaly právě díky nelinearitě zesilovače. Proto se u oscilátorů RC použivá k omezení amplitudy kmitů zvláštní napět'ově závislé záporné zpětné vazby kdy rezistor $\mathrm{R}_{1}$ je lineárně rízen $\mathrm{v}$ závislosti na amplitudě výstupních kmitů, jak je to uvedeno na Obr. 12.3. Do invertujícího vstupu se zavádí přes rezistorový dělič R1, R2 takový díl výstupního napětí, aby zesílení z neinvertujícího vstupu na výstup se právě rovnalo požadované hodnotě $A_{\mathrm{U}}$ (napřs. $A_{\mathrm{U}}=3$ pro RC články podle Obr. 12.4). V děliči je odpor rezistoru $\mathrm{R}_{1}$ závislý na amplitudě generovaných kmitů (resp. na amplitudě procházejícího harmonického proudu). Jestliže amplituda výstupního napětí poroste, pak požadujeme, aby se záporná zpětná vazba zvětšila, tj. aby se dělicí poměr zeslabovače $\mathrm{R}_{1}, \mathrm{R}_{2}$ zmenšil. To bude splněno tehdy, jestliže se odpor $R_{1}$ při zvětšení amplitudy výstupního napětí zvětší (např̀. tranzistor řízený elektrickým polem, jehož odpor řídíme usměrněným výstupním napětím zesilovače tak, aby se jeho odpor při vzrůstu amplitudy výstupního napětí oscilátoru zvětšoval).

Na Obr. 12.5 je nakreslen př́klad zapojení oscilátoru RC s Wienovým článkem. Protože Wienův článek společně s rezistory $\mathrm{R}_{2}$ a $\mathrm{R}_{1}^{\prime}$ tvoří můstek, bývá zapojení často také označováno jako oscilátor s Wien - Robinsonovým můstkem. V prvním přiblížení budeme uvažovat, že místo sériové kombinace rezistoru $\mathrm{R}_{1}$ a tranzistoru ř́zeného polem $\mathrm{T}$, je $\mathrm{v}$ obvodu zapojen pouze rezistor o odporu $R_{1}^{\prime}$. Jak vyplynulo z předchozího, musí mít zesilovač při použití Wienova článku zesílení $A_{\mathrm{U}}=3$ a tedy $R_{2}=R$ a $R_{1}^{\prime}=R / 2$.

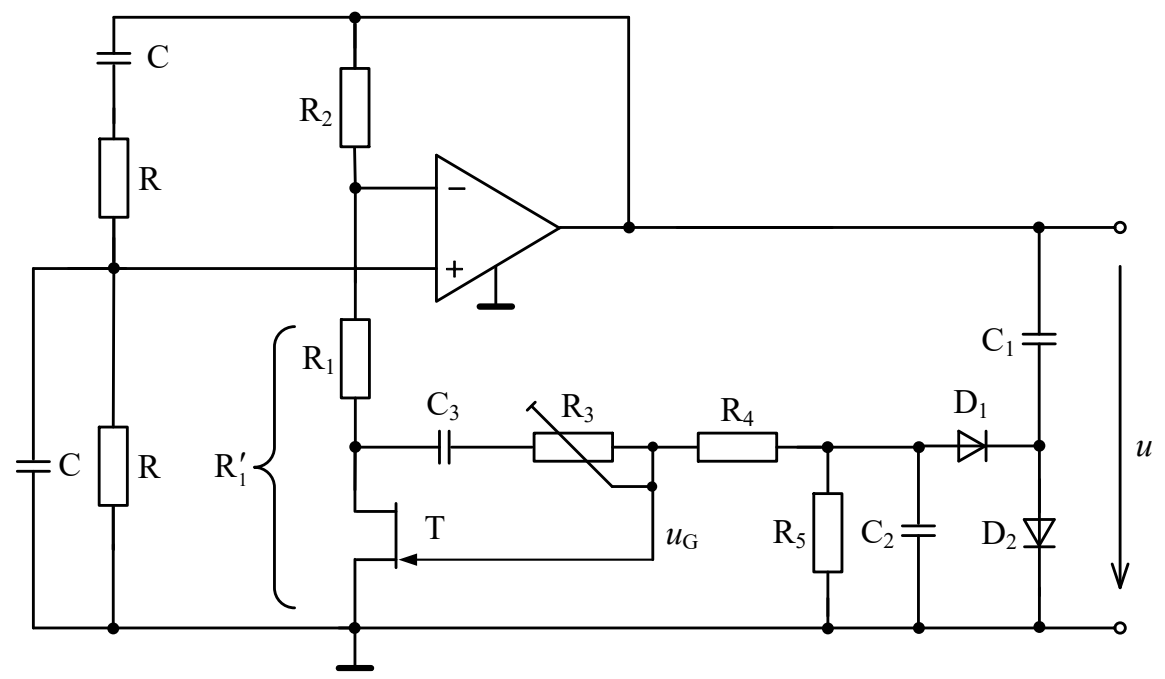

Obr. 12.5: Př́klad zapojení RC oscilátoru s Wienovým článkem (s Wien - Robinsonovým můstkem)

V praxi však není možné předpokládat, že odpory $R_{1}^{\prime}$ a $R_{2}$ budou vybrány tak přesně, aby byla splněna podmínka $A_{\mathrm{U}}=3$. Bude-li zesílení jen o něco menší, pak se oscilátor vůbec nerozkmitá. Bude-li zesílení naopak o něco větší, bude amplituda výstupních kmitů narůstat, až dojde k saturaci výstupu operačního zesilovače. Jak bylo již řečeno dřive, je nutno odpory rezistorů automaticky regulovat $\mathrm{v}$ závislosti na amplitudě výstupního signálu. Proto je ve schématu na Obr. 12.5 v sérii s rezistorem R1 zapojen tranzistor T řízený elektrickým polem, 
který složí jako lineární řízený rezistor ( $k$ linearizaci slouží $\mathrm{R}_{3}$ a $\mathrm{R}_{4}$ ). Protože tranzistor $\mathrm{T}$ při úplném sepnutí vykazuje konečný odpor $R_{\mathrm{DSsep}}$, musí být odpor rezistoru $R_{1}$ vybrán tak, aby byl menší než $R / 2-R_{\mathrm{DSsep}}$, jinak by se oscilátor nerozkmital.

Jestliže nyní zapneme napájecí zdroje, pak ihned po zapnutí bude napětí na řídicí elektrodě tranzistoru $u_{\mathrm{G}}=0$ a tedy $R_{\mathrm{DS}}=R_{\mathrm{DSsep}}$. Zesílení $A_{\mathrm{U}}$ je $\mathrm{v}$ tomto př́padě dostatečně velké, aby v obvodu vznikly oscilace a amplituda kmitů bude narůstat. Výstupní napětí oscilátoru se usměrňuje zdvojovačem napětí s diodami $\mathrm{D}_{1}, \mathrm{D}_{2}$, stř́dacími kapacitory $\mathrm{C}_{1}, \mathrm{C}_{2}$ a vybíjecím rezistorem $R_{5}$. Rezistor $R_{5}$ vybíjí kapacitor $C_{2}$ tak, aby zpětná vazba dostatečně rychle řídila amplitudu výstupních kmitů. Amplituda výstupního signálu bude narůstat do okamžiku, kdy bude splněna rovnost $R_{\mathrm{DS}}+R_{1}=R / 2$.

Koeficient nelineárního zkreslení výstupního napětí oscilátoru značně závisí na linearitě AV charakteristik tranzistoru rrízeného polem. $K$ linearizaci jsou proto použity rezistory $R_{3}, R_{4}$ doplněné oddělovacím kapacitorem $\mathrm{C}_{3}$, které tvoří obvod záporné zpětné vazby. Obvykle se volí $R_{3} \approx R_{4}$; bude-li navíc možno odpor rezistoru $\mathrm{R}_{3}$ měnit, lze koeficient nelineárního zkreslení dostavit na minimum. Prakticky dosažitelná hodnota činitele nelineárního zkreslení je $0,1 \%$.

\subsection{Funkční generátory}

Doposud jsme studovali vlastnosti a zapojení oscilátorů, vyrábějících kmity přibližně harmonické. Avšak v technické praxi se používá také periodických kmitů, které se svým průběhem od harmonických kmitů podstatně liší. Vyznačují se zpravidla více či méně strmými skoky nebo prudkými změnami strmosti průběhu. Takové kmity označujeme jako kmity relaxační. Typickými představiteli relaxačních kmitů jsou trojúhelníkové kmity, pravoúhlé kmity, pilovité kmity a pravoúhlý puls (periodický sled pravoúhlých impulsů). Tyto průběhy jsou nakresleny na Obr. 12.6. Většinou generátory umožňují generovat více druhů kmitů současně, a proto bývají označovány jako funkční generátory. Zatímco oscilátory vyrábějící harmonické kmity, představují vždy soustavu nejméně druhého řádu (se dvěma akumulačními prvky, tj. kapacitory nebo induktory), vystačíme při generování relaxačních kmitů mnohdy i se soustavou prvního řádu s jediným akumulačním prvkem. Ovšem mechanismus periodické činnosti generátorů neharmonických kmitů je jiný než u oscilátorů. Protože se ve funkčních generátorech používá jako akumulačních prvků téměř výhradně kapacitorů, budou na ně orientovány i všechny následující úvahy. Je ovšem nutné podotknout, že nejsou žádné zásadní námitky proti duální analogii těchto generátorů, $v$ nichž by byly jako akumulační prvky použity induktory.
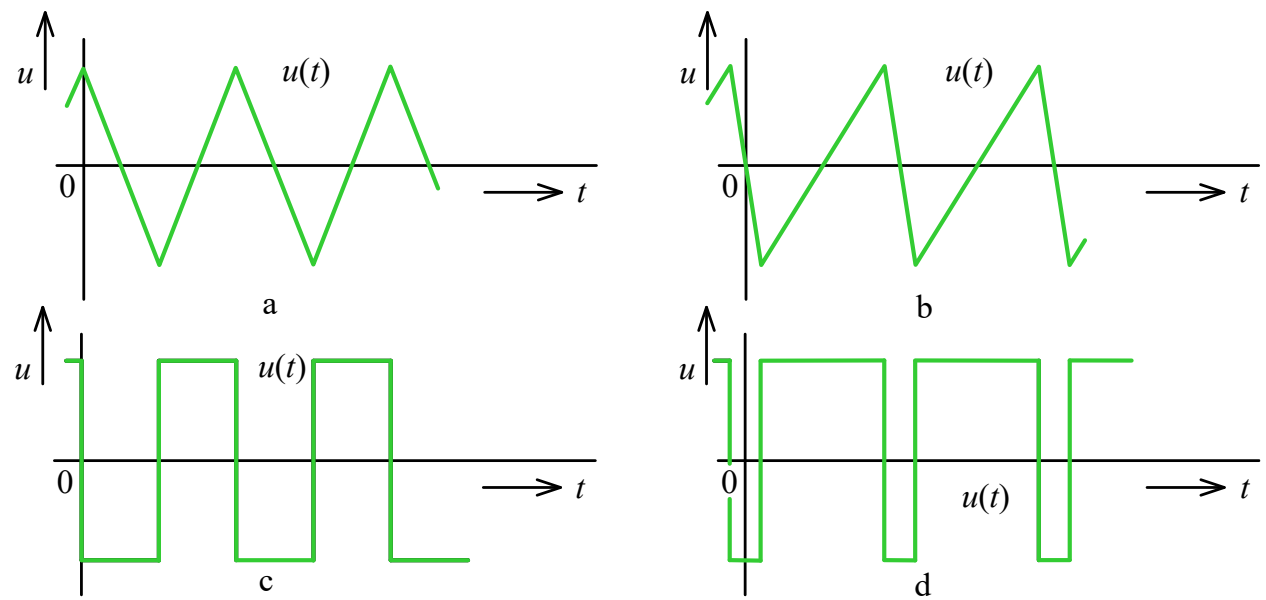

Obr. 12.6: Relaxační kmity: a) trojúhelníkové, b) pilovité, c) pravoúhlé se střídou 1:1, d) pulsní 
Činnost funkčního generátoru s kapacitorem je možné si vysvětlit na základě elementární představy podle Obr. 12.7a. Při činnosti generátoru se periodicky stř́iají intervaly nabíjení kapacitoru $\mathrm{C}$ kladným proudem $i_{\mathrm{C}}(t)=I_{1}$ a záporným proudem $i_{\mathrm{C}}(t)=-I_{2}$. Přepnutí z jednoho zdroje na druhý obstarává elektronický přepínač $\mathrm{P}$, jehož činnost je řízena úrovněmi napětí $u_{1}(\mathrm{t})$ na kapacitoru $\mathrm{C}$. Je-li přepínač $\mathrm{P}$ v poloze 1 , teče do kapacitoru $\mathrm{C}$ kladný proud $i_{\mathrm{C}}(t)=I_{1}$ a napětí na něm roste lineárně s časem

$$
u_{1}(t)=U_{\mathrm{sn}}+\frac{1}{C} \int_{0}^{t} i_{\mathrm{C}}(t) \mathrm{d} t=U_{\mathrm{sn}}+\frac{I_{1}}{C} t
$$

kde $U_{\text {sn }}$ je počáteční napětí na kapacitoru (např. jeho dolní úroveň). Napětí $u_{1}(t)$ působí na vstup komparátoru s hysterezí K. Jeho úkolem je, aby při dosažení určité horní úrovně napětí na kapacitoru (označme ji $U_{\mathrm{sp}}$ ) přešlo jeho výstupní napětí $u_{2}(t)$ z jedné konstantní hodnoty, např. $U_{2 \mathrm{n}}$ na jinou, např. $U_{2 \mathrm{p}}$ (viz Obr. $12.7 \mathrm{~b}$ ). Tato skoková změna napětí $u_{2}(t)$ vyvolá přepnutí přepínače $\mathrm{P}$ do polohy 2 . Doba $T_{1}$ potřebná k tomu, aby se kapacitor $C$ nabil z napětí $U_{\mathrm{sn}}$ na $U_{\mathrm{sp}}$ je podle rovnice $(12-12) T_{1}=\left(U_{\mathrm{sp}}-U_{\mathrm{sn}}\right) C / I_{1}$.

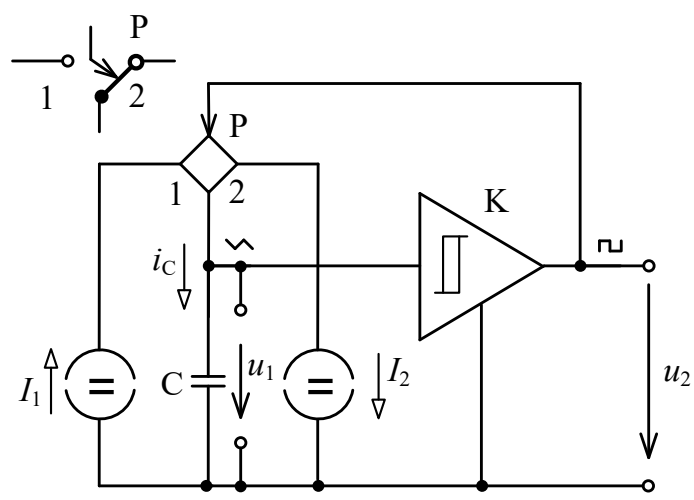

a

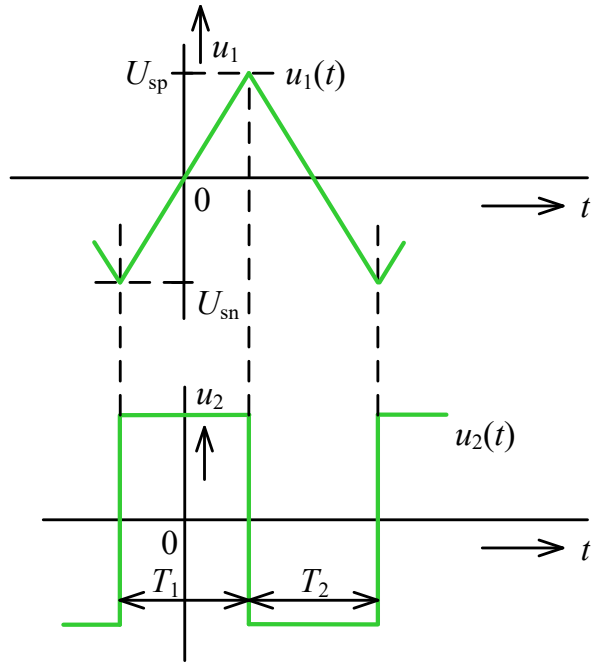

b

Obr. 12.7: Obecné schéma funkčního generátoru s kapacitorem a průběhy napětí

Následuje druhá fáze děje. Kapacitor $\mathrm{C}$ je nyní nabíjen záporným proudem $i_{\mathrm{C}}(t)=-I_{2}$. Jeho náboj se zmenšuje a napětí

$$
u_{1}(t)=U_{\mathrm{sp}}+\frac{1}{C} \int_{0}^{t} i_{\mathrm{C}}(t) \mathrm{d} t=U_{\mathrm{sp}}-\frac{I_{2}}{C} t
$$

s časem lineárně klesá, a to popřípadě až do záporných hodnot. Dosáhne-li napětí $u_{1}(t)$ dolní úrovně $U_{\mathrm{sn}}$, reaguje opět komparátor $\mathrm{K}$, a to tak, že jeho výstupní napětí přejde z úrovně $U_{2 \mathrm{p}}$ opět na původní úroveň $U_{2 \mathrm{n}}$. Přepínač $\mathrm{P}$ se $\mathrm{v}$ důsledku toho přepne do polohy 1 a celý děj se opakuje. Protože doba vybíjení kapacitoru $\mathrm{C}$ z napětí $U_{\text {sp }}$ na $U_{\text {sn }}$ je $T_{2}=\left(U_{\text {sp }}-U_{\text {sn }}\right) C / I_{2}$, můžeme odvodit, že celý děj se periodicky opakuje s periodou 


$$
T=T_{1}+T_{2}=\left(U_{\text {sp }}-U_{\text {sn }}\right)\left(\frac{1}{I_{1}}+\frac{1}{I_{2}}\right) C .
$$

Je zřejmé, že při rovnosti obou proudů, $I_{1}=I_{2}$, dostaneme trojúhelníkové napětí $u_{1}(t)$ $\mathrm{s}$ průběhem podle Obr. 12.6a a spolu s ním pravoúhlé napětí $u_{2}(t)$, jehož průběh odpovídá Obr. 12.6c. Jestliže $I_{2}>I_{1}$, bude generátor vyrábět pilovité napětí $u_{1}(t)$ znázorněné na Obr. $12.6 \mathrm{~b}$ a kromě toho ještě pravoúhlý puls $u_{2}(t)$ podle Obr. $12.6 \mathrm{~d}$.

Kapacitor může být také zapojen ve zpětné vazbě $\mathrm{OZ} \mathrm{tak,} \mathrm{jako} \mathrm{je} \mathrm{tomu} \mathrm{u} \mathrm{integrátoru.}$ Funkční generátory s integrátorem se používají nejčastěji ke generování velmi pomalých kmitů, řádově od $0,0001 \mathrm{~Hz}$ až $100 \mathrm{~Hz}$. Jednoduchý funkční generátor lze realizovat pomocí integrátoru a neinvertujícího komparátoru s hysterezí tak, jak je to naznačeno na Obr. 12.8. Invertující integrátor integruje výstupní napětí komparátoru $U_{2}$. Jestliže lineárně klesající výstupní napětí integrátoru dosáhne dolní úrovně komparačního napětí, výstupní napětí komparátoru skokově změní svoji polaritu a výstupní napětí na výstupu integrátoru bude lineárně narůstat. Napětí roste tak dlouho, dokud nedosáhne horní srovnávací úrovně komparátoru. Kmitočet tvarových kmitů lze v širokém rozmezí měnit vhodnou volbou integrační konstanty RC. Rozkmit napětí trojúhelníkových kmitů závisí pouze na nastavených komparačních úrovních.

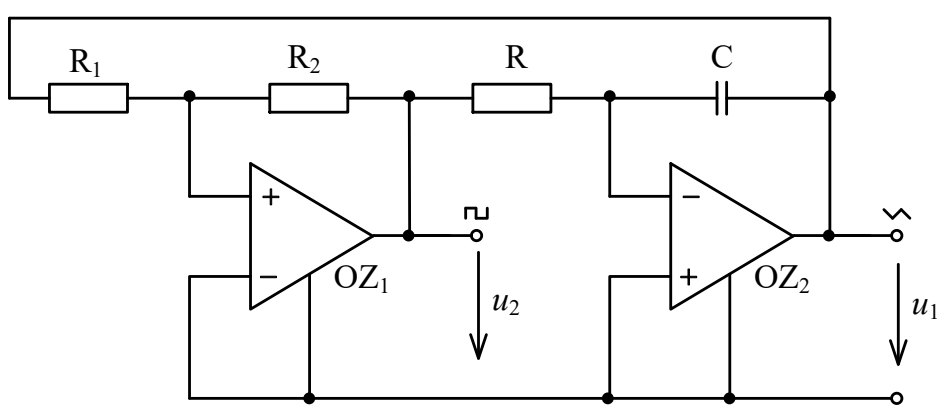

a

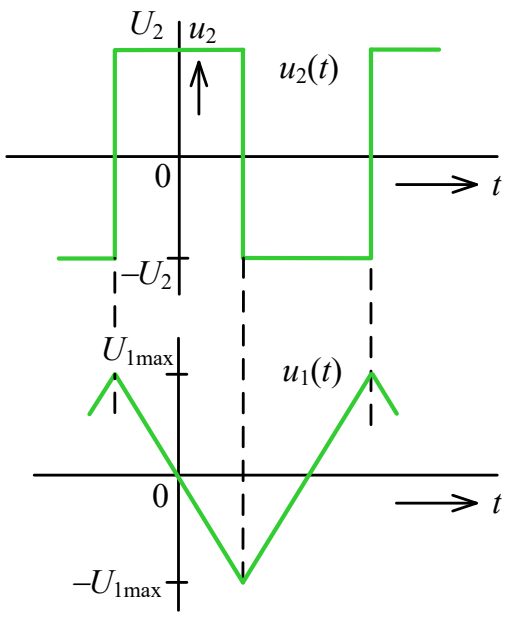

b

Obr. 12.8: Jednoduchý generátor trojúhelníkových a pravoúhlých kmitů s integrátorem

Jestliže bude $U_{2 \mathrm{p}}=\left|U_{2 \mathrm{n}}\right|=U_{2}$, bude maximální hodnota výstupního napětí integrátoru a tedy i maximální hodnota trojúhelníkových kmitů

$$
U_{1 \max }=U_{2} R_{1} / R_{2} \text {. }
$$

Je vidět, že maximální hodnota trojúhelníkových kmitů závisí pouze na vlastnostech komparátoru. Doba periody kmitů je dána dvojnásobkem doby, která je zapotřebí, aby se výstupní napětí integrátoru změnilo od $-U_{1 \max }$ do $U_{1 \max }$. Proto 


$$
T=4 R C R_{1} / R_{2} \text {, resp. } f=1 / T=R_{2} / 4 R_{1} R C .
$$

Kmitočet kmitů tedy nezávisí na hodnotě saturačního napětí komparátoru $U_{2}$. Na výstupu operačního zesilovače $\mathrm{OZ}_{1}$ jsou k dispozici pravoúhlé kmity s maximální hodnotou $U_{2}$. Zapojení se vyznačuje malou stabilitou maximálního výstupního napětí $U_{1 \max }$ trojúhelníkových kmitů. Je to způsobeno tím, že komparační úrovně jsou odvozeny ze saturačního napětí $\mathrm{OZ}_{1}$. Klademe-li na tento typ funkčního generátoru vyšší nároky, musíme použít kvalitnější komparátor s hysterezí, který má přesně definované a stabilní výstupní napětí při saturaci.

Př́klad zapojení generátoru splňujícího př́ísnější požadavky je uveden na Obr. 12.9. Principiálně je zapojení i činnost zcela shodná jako v případě generátoru na Obr. 12.8. Neinvertující komparátor s hysterezí je preciznější a je zde tvořen zesilovači $O_{1}$ a $O Z_{2}$. Zesilovač $\mathrm{OZ}_{1}$ pracuje s př́mým zesílením, ale jeho výstupní napětí je omezeno diodovým omezovačem na cca $\pm 0,7 \mathrm{~V}$. Zesilovač $\mathrm{OZ}_{2}$ pracuje také s plným zesílením, ale ve zpětné vazbě má zařazen přesný diodový omezovač, a proto na výstupu $\mathrm{OZ}_{2}$ bude napětí $U_{2 \mathrm{n}}$, resp. $U_{2 \mathrm{p}}$ při saturaci přesně definováno. Kladná zpětná vazba tvořená rezistory $\mathrm{R}_{1}, \mathrm{R}_{2}$ definuje úrovně překlápění a určuje tak maximální hodnotu trojúhelníkových kmitů (viz rov. (12-15)). Pomocí potenciometru $\mathrm{P}\left(R_{\mathrm{P}}<<R\right)$ lze lineárně měnit kmitočet generátoru v poměru $1: 10$ podle vztahu

$$
f=1 / T=\beta R_{2} / 4 R_{1} R C,
$$

kde $\beta$ značí dělicí poměr potenciometru. Větší přeladitelnosti se dosáhne přepínáním časové konstanty integrátoru RC. Pokud chceme, aby funkční generátor generoval současně harmonický signál, doplní se diodovým funkčním měničem, který vytvaruje trojúhelníkové kmity na harmonický signál.

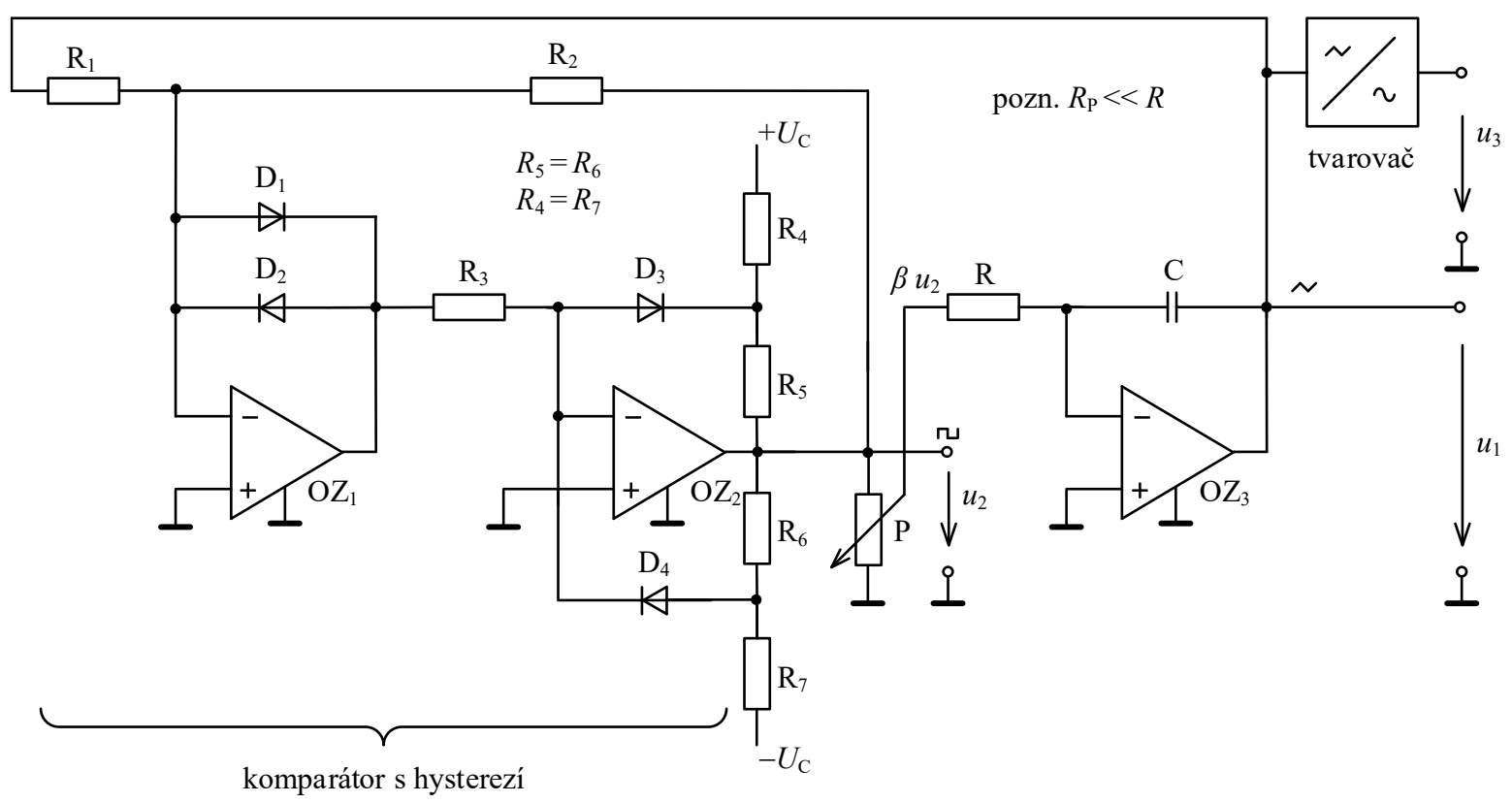

Obr. 12.9: Přesný funkční generátor s integrátorem 
Funkční generátory s přepínanými zdroji proudu se užívají obvykle pro generování kmitů v kmitočtovém rozsahu $1 \mathrm{~Hz}$ až $20 \mathrm{MHz}$. Zjednodušené schéma generátoru trojúhelníkových a pravoúhlých kmitů je uvedeno na Obr. 12.10. Operační zesilovač $\mathrm{OZ}_{1}$ je zapojen jako invertující komparátor s hysterezí. Jeho výstupní napětí je upraveno na předepsanou velikost omezovačem sestávajícím $\mathrm{z}$ rezistoru $\mathrm{R}_{3}$ a dvojice referenčních diod $\mathrm{D}_{3}$ a $\mathrm{D}_{4}$, které jsou vybrány se stejným napětím $\mathrm{v}$ závěrném směru.

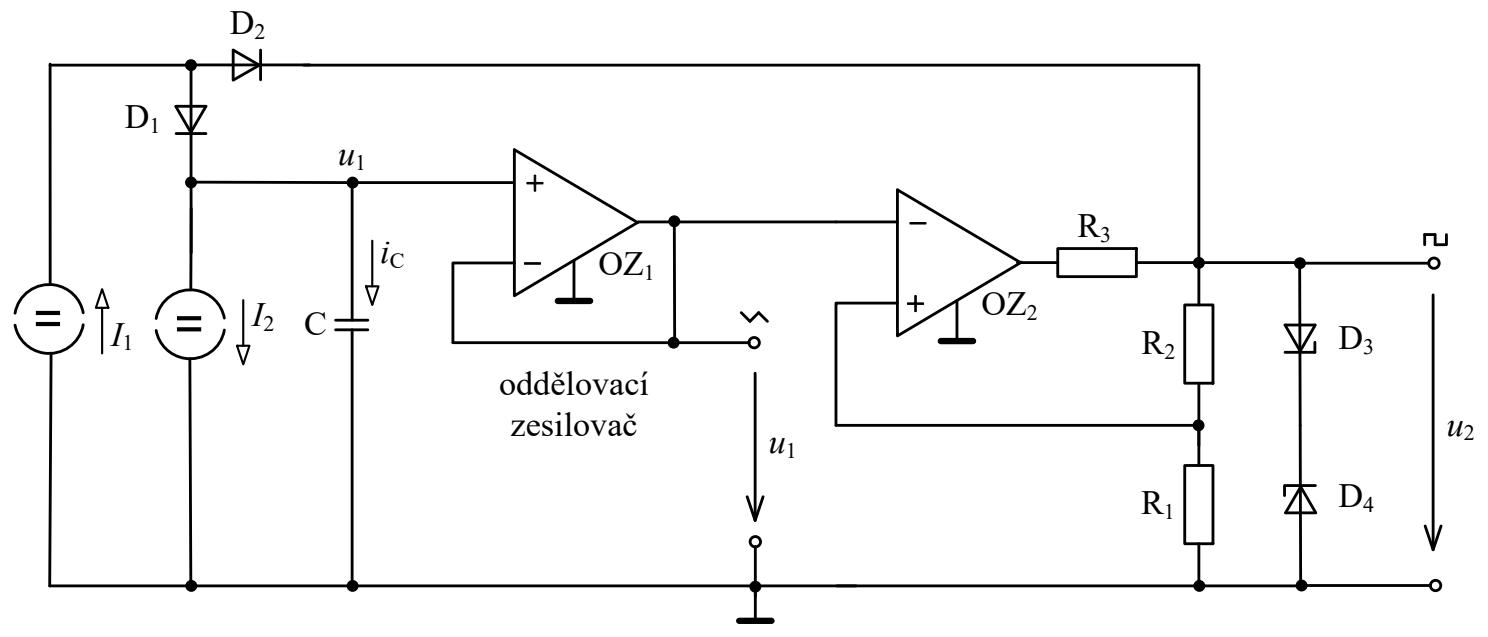

Obr. 12.10: Principiální uspořádání funkčního generátoru s přepínatelnými zdroji proudu

V komparátoru je zavedena děličem $\mathrm{R}_{1}, \mathrm{R}_{2}$ kladná zpětná vazba, $\mathrm{s}$ níž má invertující komparátor požadovanou hysterezní přenosovou charakteristiku. V obvodu jsou dva zdroje konstantního proudu. Jsou dimenzovány tak, že $I_{1}>I_{2}$. Zatímco zdroj proudu $I_{2}$ je připojen ke kapacitoru $\mathrm{C}$ trvale a neustále jej lineárně vybíjí, je zdroj proudu $I_{1}$ připojován periodicky elektronickým přepínačem s diodami $\mathrm{D}_{1}$ a $\mathrm{D}_{2}$. Je-li na výstupu komparátoru kladné nasycené napětí $U_{2 \mathrm{p}}>u_{1}$, je dioda $\mathrm{D}_{2}$ zavřena a diodou $\mathrm{D}_{1}$ prochází proud $I_{1}$. Kapacitoru $\mathrm{C}$ je tedy dodáván proud $i_{\mathrm{C}}=I_{1}-I_{2}>0$. Napětí $u_{1}$ na kapacitoru lineárně roste a jakmile dosáhne horní komparační úrovně $U_{\mathrm{sp}}=U_{2 \mathrm{p}} R_{1} /\left(R_{1}+R_{2}\right)$, změní se výstupní napětí komparátoru skokem na záporné nasycené napětí $U_{2 n}$. To má za následek, že se dioda $\mathrm{D}_{2}$ otevře a veškerý proud $I_{2}$ teče přes ni do výstupu komparátoru ( $k d e$ se přidá $\mathrm{k}$ proudu procházejícímu diodami $\mathrm{D}_{3} \mathrm{a}_{4}$ ). Dioda $\mathrm{D}_{1}$ se v důsledku toho uzavře a kapacitor $\mathrm{C}$ je vybíjen konstantním proudem $i_{\mathrm{C}}=-I_{2}$. Napětí $u_{1}$ lineárně s časem klesá, až při dosažení dolní úrovně $U_{\mathrm{sn}}=U_{2 \mathrm{n}} R_{1} /\left(R_{1}+R_{2}\right)$ se výstupní napětí skokem vrátí na hodnotu $U_{2 \mathrm{p}}$ a celý cyklus se může opakovat. Má-li se z generátoru odebírat napětí $u_{1}$, nesmí se ovlivnit nabíjecí a vybíjecí pochod. Proto je nutné použít oddělovacího zesilovače s $\mathrm{OZ}_{2}$, který zabezpečí bezproudový odběr tohoto napětí z kapacitoru $\mathrm{C}$.

Tvar generovaných periodických kmitů bude ovlivněn poměrem proudů $I_{1}$ a $I_{2}$. Je-li $I_{1}=2 I_{2}$, vznikají souměrné trojúhelníkové kmity $u_{1}(t)$. Bude-li proud $I_{1}<2 I_{2}$, bude nabíjecí proud kapacitoru menší než vybíjecí proud a vzniknou pilovité kmity $u_{1}(t)$ nakloněné doprava. Naopak při $I_{1}>2 I_{2}$ vzniknou pilovité kmity nakloněné doleva. Samozřejmě jsou současně s trojúhelníkovými, popř. pilovitými kmity $u_{1}(t)$ generovány i odpovídající pravoúhlé kmity $u_{2}(t)$.

Protože doba nabíjení kapacitoru $T_{1}=C\left(U_{\mathrm{sp}}-U_{\mathrm{sn}}\right) /\left(I_{1}-I_{2}\right)$ a doba jeho vybíjení $T_{2}=C\left(U_{\mathrm{sp}}\right.$ - $\left.U_{\text {sn }}\right) / I_{2}$, je perioda vznikajících kmitů

$$
T=\left(U_{s p}-U_{s n}\right)\left(\frac{1}{I_{1}-I_{2}}+\frac{1}{I_{2}}\right) C .
$$


Zapojení generátoru podle Obr. 12.11 využivá k přepínání zdrojů konstantního proudu diodového můstku $\mathrm{D}_{1}$ až $\mathrm{D}_{4}$. Předpokládejme, že je sepnuta dioda $\mathrm{D}_{1}$ a $\mathrm{D}_{2}$ je zahrazena a kapacitor $\mathrm{C}$ se nabíjí proudem $i_{\mathrm{C}}=I_{1}$. Jakmile napětí na kapacitoru dosáhne horní komparační úrovně $U_{\mathrm{sp}}$, změní se výstupní napětí komparátoru skokem na $U_{2 \mathrm{n}}$. Dioda $\mathrm{D}_{1}$ se sepne a $\mathrm{D}_{2} \mathrm{se}$ rozpojí a proto zdroj proudu $I_{1}$ je od kapacitoru $C$ odpojen a proud jím dodávaný teče do výstupu komparátoru. Současně se však zahradí dioda $\mathrm{D}_{3}$ a kapacitor $\mathrm{C}$ je přes sepnutou diodu $\mathrm{D}_{4}$ vybíjen konstantním proudem $i_{\mathrm{C}}=-I_{2}$. Napětí na kapacitoru lineárně klesá, až dosáhne dolní komparační úrovně $U_{\mathrm{sn}}$ komparátoru. Komparátor se překlopí a na jeho výstupu bude napětí $U_{2 p}$. Přritom se diody $\mathrm{D}_{1}$ a $\mathrm{D}_{4}$ opět zahradí. Proud $I_{2}$ poteče přes sepnutou diodu $\mathrm{D}_{3} \mathrm{k}$ výstupu komparátoru a kapacitor $\mathrm{C}$ bude přes sepnutou diodu $\mathrm{D}_{2}$ nabíjen proudem $i_{\mathrm{C}}=I_{1}$. Perioda vznikajících kmitů je dána rov. (12-14). Omezovač sestávající z rezistoru $\mathrm{R}_{3}$ a diod $\mathrm{D}_{5}$ až $\mathrm{D}_{8}$ slouží k úpravě výstupního napětí komparátoru na předepsanou hodnotu $\left(U_{2 \mathrm{p}}, U_{2 \mathrm{n}}\right)$. Diody $\mathrm{D}_{5}$ a $\mathrm{D}_{6}$ nutno vybrat na stejné napětí jako diody $\mathrm{D}_{7}$ a $\mathrm{D}_{8}$.

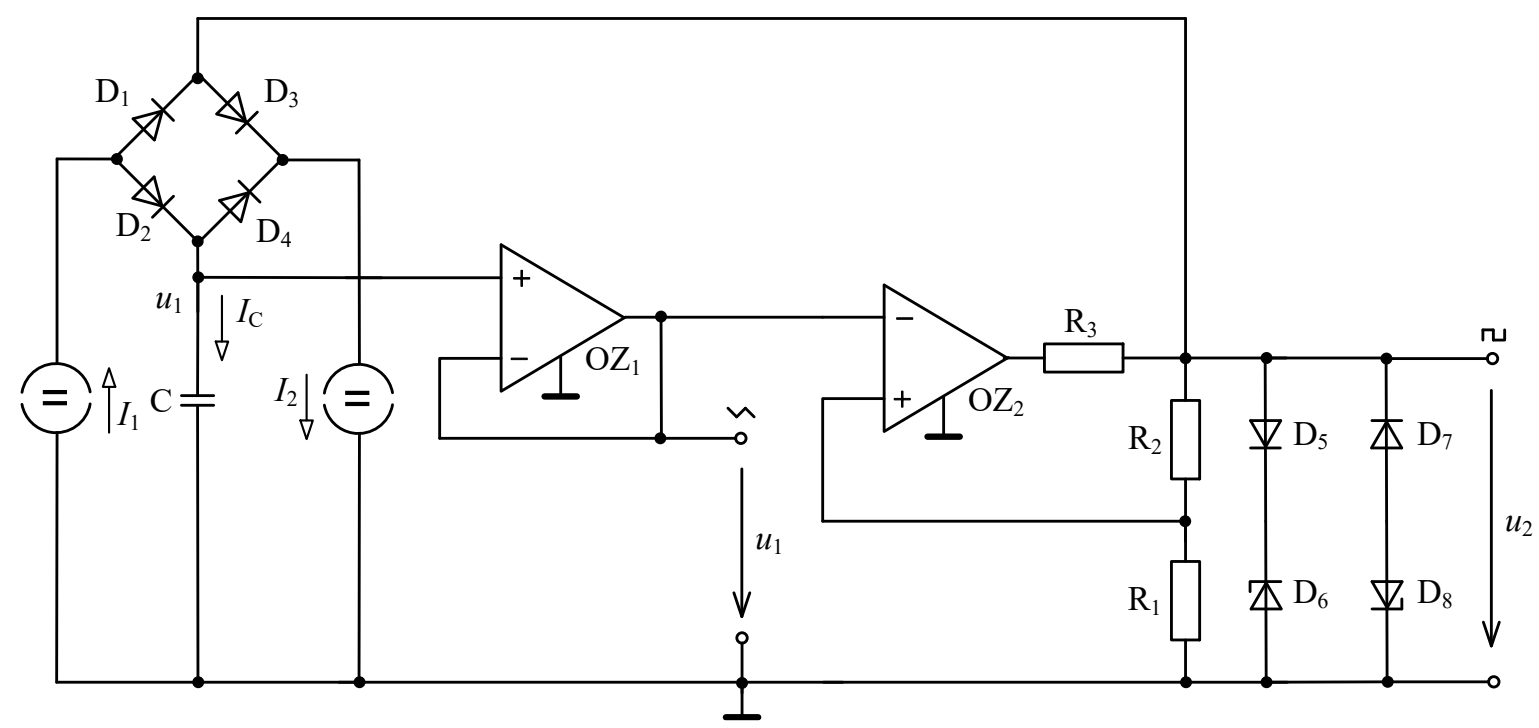

Obr. 12.11: Zjednodušené schéma funkčního generátoru se dvěma přepínanými zdroji proudu

Tento princip je podrobněji rozpracován u zapojení funkčního generátoru na Obr. 12.12. Komplementární zdroje proudu jsou tvořeny tranzistory $\mathrm{T}_{2}$ a $\mathrm{T}_{3}$. Rízení velikosti nabíjecího, resp. vybíjecího proudu (a tedy i řízení kmitočtu generovaných kmitů) umožňuje operační zesilovač $\mathrm{OZ}_{1} \mathrm{~s}$ tranzistorem $\mathrm{T}_{1}$. Označíme-li $\alpha \in\langle 0,1\rangle$ úhel natočení potenciometru $\mathrm{P}$, bude na neinvertující vstup $\mathrm{OZ}_{1}$ přivedeno napětí $u=(1-\alpha) U_{\mathrm{C}}$. 


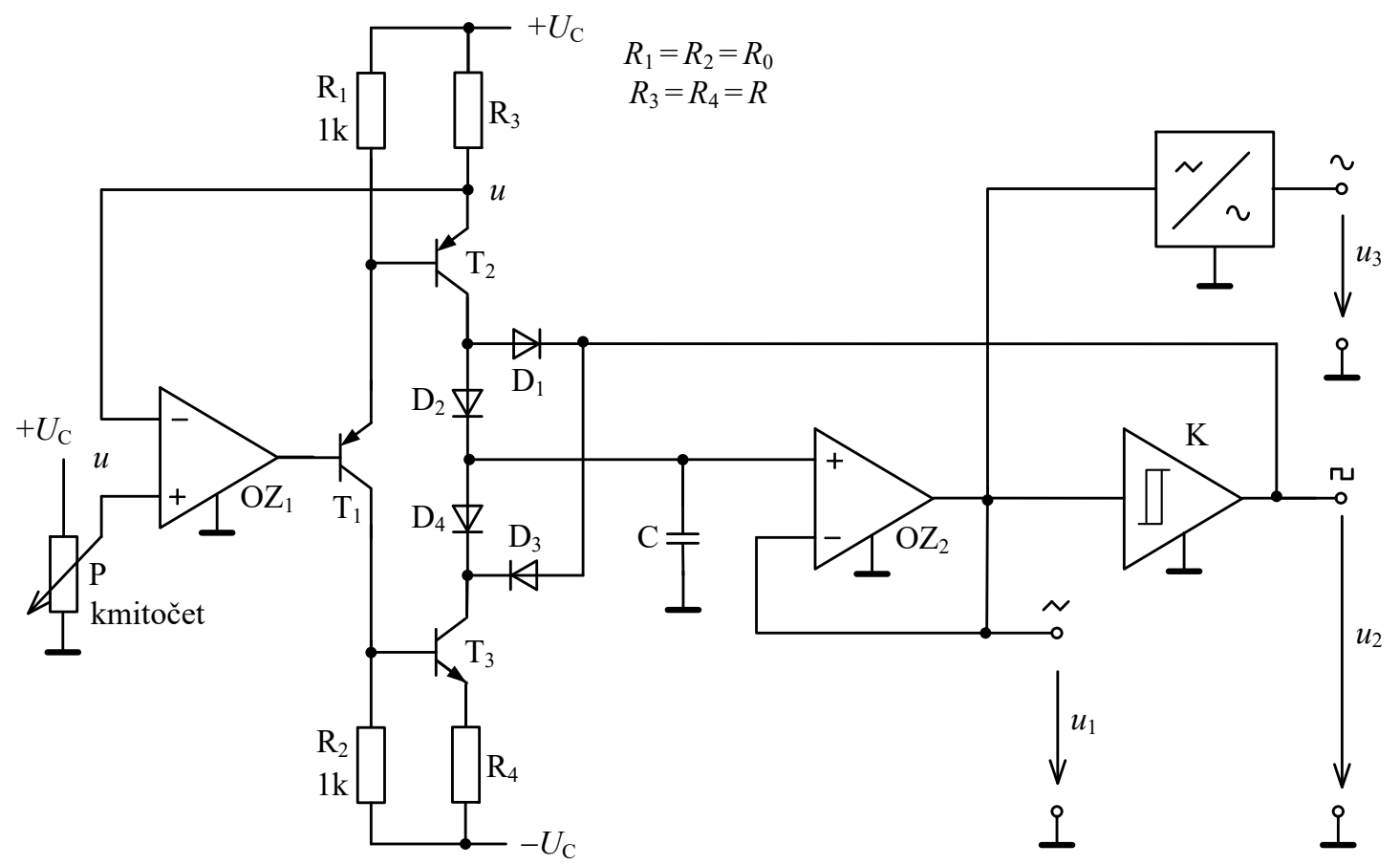

Obr. 12.12: Příklad zapojení funkčního generátoru se dvěma přepínanými zdroji proudu

$\mathrm{Na}$ invertujícím vstupu $\mathrm{OZ}_{1}$ se díky zpětné vazbě nastaví napětí stejné a zdroj proudu $\mathrm{s}$ tranzistorem $\mathrm{T}_{2}$ dodává proud

$$
I_{1}=i_{K 2} \approx i_{\mathrm{E} 2}=\frac{U_{C}-u}{R_{3}} \approx \frac{U_{C}-(1-\alpha) U_{C}}{R_{3}}=\alpha U_{C} / R_{3} .
$$

Díky tomu, že kolektorový a emitorový proud $\mathrm{T}_{3}$ jsou si přibližně rovny $i_{\mathrm{E} 1} \approx i_{\mathrm{K} 1}$ a $R_{1}=R_{2}$ , bude řídicí napětí tranzistoru $\mathrm{T}_{3}$ shodné jako pro $\mathrm{T}_{2}$ a komplementární zdroj proudu $\mathrm{s}$ tranzistorem $\mathrm{T}_{3}$ odebírá proud $I_{2}=i_{\mathrm{K} 3} \approx i_{\mathrm{E} 3}=\alpha U_{\mathrm{C}} / R_{4}$. Stř́davé připojování proudu $I_{1}$ či $I_{2} \mathrm{ke}$ kapacitoru obstarává diodový přepínač $\mathrm{D}_{1}$ až $\mathrm{D}_{4}$, jehož činnost je řízena $\mathrm{z}$ výstupu komparátoru $\mathrm{K}$. Za předpokladu $I_{1}=I_{2}\left(\mathrm{tj} . R_{3}=R_{4}=R\right)$ bude pro kmitočet generovaných kmitů podle rov. (12-14) platit

$$
f=1 / T=\alpha U_{C} / 2\left(U_{\mathrm{sp}}-U_{\mathrm{sn}}\right) R C .
$$

Potenciometrem P se generátor přelad’uje obvykle pouze v rozmezí jedné dekády. Větší rozsah přeladění musí být doprovázen změnou kapacity kapacitoru $\mathrm{C}$.

Aby nedocházelo $\mathrm{k}$ nežádoucímu vybíjení kapacitoru $\mathrm{C}$ vstupním klidovým proudem komparátoru, je vlastnímu komparátoru $\mathrm{K}$ předřazen operační zesilovač $\mathrm{OZ}_{2}$ v neinvertujícím uspořádání $\mathrm{s}$ jednotkovým přenosem. Vlastní komparátor $\mathrm{K}$ je stejné koncepce jako předchozím prrípadě (Obr. 12.11). Harmonický signál se vytváří z trojúhelníkových kmitů diodovým funkčním měničem. 


\subsection{Multivibrátory}

Multivibrátory tvoří jednu trrídu relaxačních generátorů. Jestliže hlavním produktem generátoru mají být pravoúhlé kmity a na linearitě trojúhelníkových kmitů nezáleží, můžeme výše uvedená zapojení funkčních generátorů značně zjednodušit. Multivibrátor uvedený na Obr. 12.13a je tvořen invertujícím komparátorem s hysterezí, který sleduje nabíjení kapacitoru C. Kapacitor je nabíjen přes rezistor $\mathrm{R}$ z výstupního napětí komparátoru $U_{2 \mathrm{p}}=U_{2}$. Jakmile napětí na kapacitoru dosáhne komparační úrovně $U_{\text {sp }}$, dojde k překlopení komparátoru, na jeho výstupu bude napětí $U_{2 \mathrm{n}}=-U_{2}$ a kapacitor je nyní přes rezistor $\mathrm{R}$ vybíjen. Dosáhne-li napětí na komparátoru dolní úrovně $U_{\mathrm{sn}}$, dojde opět k překlopení komparátoru a proces se opakuje (viz Obr. 12.13b).

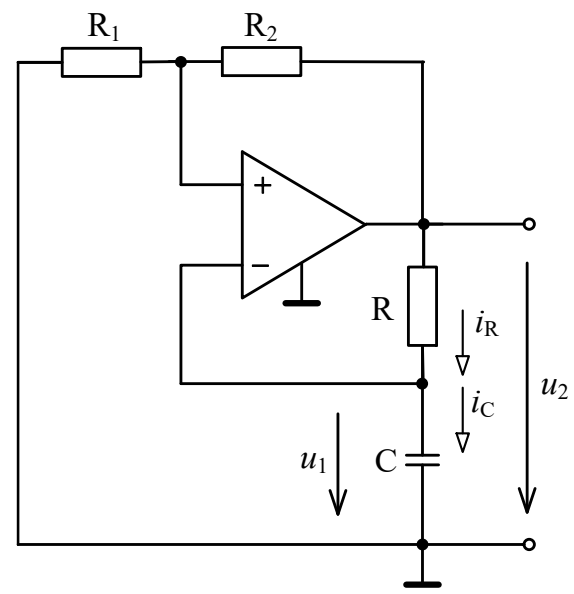

a

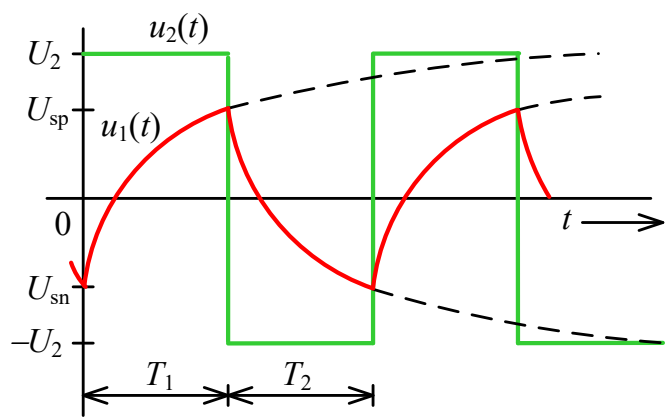

$\mathrm{b}$

Obr. 12.13: a) Multivibrátor s operačním zesilovačem, b) časové průběhy v multivibrátoru

Komparační úrovně pro $U_{2 \mathrm{p}}=-U_{2 \mathrm{n}}=U_{2}$ mají velikost

$$
U_{\mathrm{sn}}=-p U_{2} ; U_{\mathrm{sp}}=p U_{2}
$$

kde $p=R_{1} /\left(R_{1}+R_{2}\right)$ značí dělicí poměr $\mathrm{R}_{1}$ a $\mathrm{R}_{2}$. Protože $i_{\mathrm{C}}=C \mathrm{~d} u_{1} / \mathrm{d} t$ a $i_{\mathrm{R}}=\left(U_{2}-u_{1}\right) / R$, můžeme $\mathrm{z}$ rovnosti $i_{\mathrm{C}} \approx i_{\mathrm{R}}$ psát

$$
\frac{\mathrm{d} u_{1}}{\mathrm{~d} t}-\frac{u_{1}}{R C}-\frac{u_{2}}{R C} \approx 0
$$

Řešení této diferenciální rovnice má při počátečních podmínkách $u_{1}(0)=U_{\mathrm{sn}}=-p U_{2}$ tvar

$$
u_{1}(t)=U_{2}\left[1-(1+p) e^{-t / R C}\right]
$$

Napětí na kapacitoru dosáhne tedy komparační úrovně $U_{\mathrm{sp}}=p U_{2}$ za dobu 


$$
T_{1}=R C \ln \frac{1+p}{1-p}=R C \ln \left[1+\left(2 R_{1} / R_{2}\right)\right]
$$

Doba periody výstupních pravoúhlých kmitů multivibrátoru

$$
T=2 T_{1}=2 R C \ln \left[1+\left(2 R_{1} / R_{2}\right)\right] \text {. }
$$

Při $R_{1}=R_{2}$ bude

$$
T \approx 2,2 R C \text {, resp. } f=1 / T=1 / 2,2 R C \text {. }
$$

V př́ípadě multivibrátoru na Obr. 12.13 jsou komparační úrovně odvozeny ze saturačních úrovní komparátoru, a proto tento multivibrátor vykazuje nižší stabilitu kmitočtu generovaných kmitů. Vyšší stabilitu kmitočtu výstupního napětí lze docílit odvozením komparačních úrovní pomocí děliče a užitím dvou komparátorů tak, jako je to např. použito v časovači typového označení 555 (Obr. 12.14a). Pokud použijeme zabudovaný rezistorový dělič $R_{3}=R_{4}=R_{5}=R$, budou mít komparační úrovně hodnotu $U_{\mathrm{C}} / 3$ a $2 U_{\mathrm{C}} / 3$. Předpokládejme, že tranzistor $\mathrm{T}$ není sepnut a kapacitor $\mathrm{C}$ se exponenciálně nabíjí s časovou konstantou $\left(R_{1}+R_{2}\right) C$. Dosáhne-li napětí na kapacitoru horní komparační úrovně $2 U_{\mathrm{C}} / 3$, bude na výstupu komparátoru $K_{1}$ úroveň $\mathrm{L}$, na výstupu $\mathrm{K}_{2}$ bude úroveň $\mathrm{H}$. Výstupní napětí klopného obvodu RS (vývod č. 3) bude mít úroveň $\mathrm{L}$, na rezistor $\mathrm{R}_{6}$ bude $\mathrm{z}$ druhého výstupu klopného obvodu $\mathrm{RS}$ přivedena úroveň $\mathrm{H}$ a tranzistor $\mathrm{T}$ se sepne. Kapacitor $\mathrm{C}$ se nyní bude vybíjet přes rezistor $\mathrm{R}_{2} \mathrm{~s}$ časovou konstantou $R_{2} C$ tak dlouho, dokud napětí na něm nedosáhne dolní komparační úrovně $U_{\mathrm{C}} / 3$ (viz průběhy na Obr. 12.14b). Tento děj bude probíhat po dobu

$$
T_{2}=R_{2} C \ln 2 \approx 0,693 R_{2} C \text {. }
$$
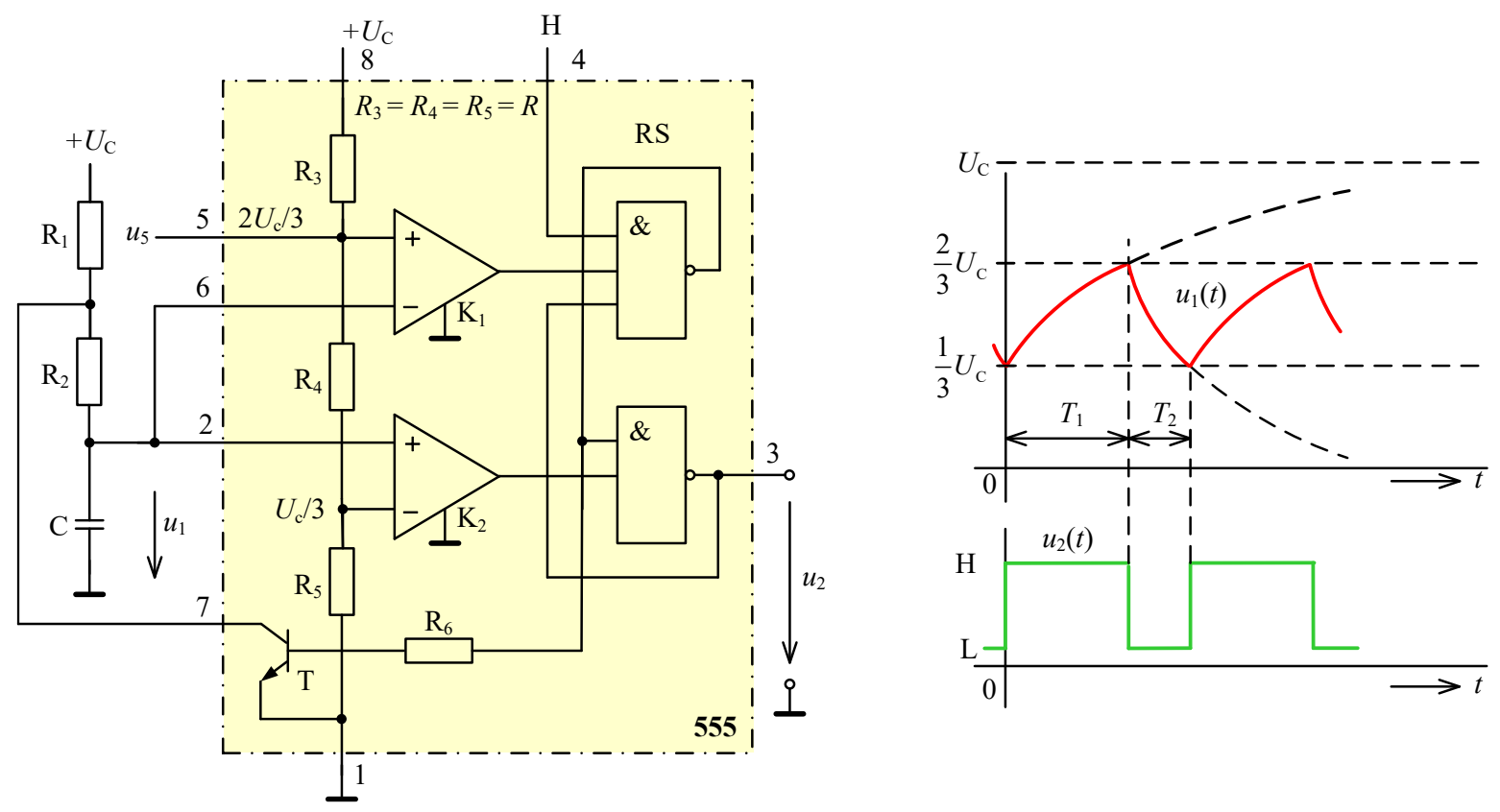
Obr. 12.14: a) Multivibrátor s časovačem 555, b) časové průběhy multivibrátoru

Po dosažení dolní komparační úrovně $U_{\mathrm{C}} / 3$ se na výstupu komparátoru $\mathrm{K}_{2}$ objeví úroveň $\mathrm{L}$, na výstupu $\mathrm{K}_{1}$ bude úroveň $\mathrm{H}$ a dojde $\mathrm{k}$ překlopení obvodu $\mathrm{RS}$ tak, že na výstupu tohoto klopného obvodu (vývod č. 3) bude úroveň $H$. Tranzistor $T$ je zahrazen (na rezistor $R_{6}$ je nyní prrivedena úroveň $L$ ) a kapacitor $C$ je opět nabíjen přes sériovou kombinaci rezistorů $R_{1}, R_{2}$. Napětí na kapacitoru dosáhne horní komparační úrovně za dobu

$$
T_{1}=\left(R_{1}+R_{2}\right) C \ln 2
$$

Kmitočet výstupního signálu generátoru

$$
f=\frac{1}{T_{1}+T_{2}} \approx \frac{1,44}{\left(R_{1}+2 R_{2}\right) C}
$$

Přivedeme-li na vývod č. 4 časovače 555 úroveň L, generování kmitů se zastaví. Komparační úrovně lze ještě zpřesnit, využíváme-li i vývod č. 5 integrovaného obvodu. Pokud se k vývodu č. 5 připojí vnější referenční zdroj $U_{\mathrm{R}}$, budou mít komparační úrovně hodnotu $U_{\mathrm{R}}$ a $U_{\mathrm{R}} / 2$. 


\section{Použitá literatura}

[1] GRAME, J. G. Designing with Operational Amplifiers - Applications Alternatives. New York, McGraw-Hill Book Company, 1977

[2] CONNELLY, J. A. ed. Analog Integrated Circuits - Devices, Circuits, Systems, and Applications. New York, John Wiley and Sons 1983

[3] TIETZE, U.; SCHENK, CH.; GAMM, E. Electronic Circuits. Hand book for Design and Applications. 2nd edition, Springer - Verlag, Berlin 2008. ISBN 978-3-54000429-5

[4] TIETZE, U.; SCHENK, CH. Electronic Circuits. Design and Applications. Springer Verlag, Berlin 1991. ISBN 3-540-50608-X

[5] DOSTÁL, J. Operační zesilovače. BEN, Praha 2005

[6] DOSTÁL, J. Operational Amplifiers. Elsevier, Amsterdam 1981

[7] ROBERGE, J. K. Operational Amplifiers. J. Wiley, New Your, London, Sydney, Toronto 1975

[8] KOUŘIL, F.; VRBA, K. Teorie nelineárních a parametrických obvodů. SNTL, Praha 1981,

[9] VRBA, K.; VRBA, K. jun. Technika analogových obvodů a systémů. Skriptum, 4. vydání. Ediční středisko VUT Brno,1989

[10] VRBA, K.; VRBA, K. jun. Technika analogových obvodů a systémů - sbírka prríkladů. Skriptum, 3. vydání. Ediční středisko VUT Brno,1989

[11] CLAYTON, G.B. Operational Amplifier. London, Butterworth Co 1971

[12] HUIJSING, J.H. Operational Amplifiers - Theory and Desing. Kluwer Academic 


\section{Aplikační pravidla pro analogové integrované obvody}

\subsection{Aplikační pravidla pro operační zesilovače}

\subsubsection{Základní doporučení}

Charakter zpětnovazební sítě. Charakter zpětnovazební sítě musíme vždy dát do relace $\mathrm{s}$ přenosovou charakteristikou operačního zesilovače, nebot' zanedbání těchto souvislostí vede téměř vždy $\mathrm{k}$ nestabilitě obvodu a tedy $\mathrm{k}$ jeho rozkmitání. Uvedeme si jednoduché kriterium použitelné k orientačnímu určení stability obvodu. Uvažujme elementární obvod uspořádaný podle Obr. 13.1a, kde v operační síti zesilovače jsou zapojeny dva jednobrany $Z_{1}$ a $Z_{2}$, charakterizované impedancemi $\bar{Z}_{1}$ a $\bar{Z}_{2}$. Určíme tzv. zpětnovazební poměr (nebo také někdy činitel zpětné vazby) při rozpojené zpětnovazební smyčce $\bar{\beta}$. V podstatě jde o to určit, jaká část výstupního napětí $\bar{U}_{2}$ se při zkratované vstupní svorce a rozpojené zpětnovazební smyčce dostane na invertující vstup $\mathrm{OZ}$ přes impedanční dělič $Z_{1}$ a $Z_{2}$ (viz Obr. 13.1b)

$$
\bar{\beta}=\frac{\bar{U}_{\mathrm{i}}}{\bar{U}_{2}}=\frac{\bar{Z}_{1}}{\bar{Z}_{1}+\bar{Z}_{2}}
$$

V semilogaritmickém měřítku vyneseme do grafu na Obr. 13.1c závislost

$$
z_{\beta}(f)=20 \log |1 / \bar{\beta}| .
$$

Do téhož grafu vyneseme závislost zisku zesilovače (bez zpětné vazby) na kmitočtu

$$
z(f)=20 \log A(f) .
$$

I když tato charakteristika není běžně udávána, lze ji u operačních zesilovačů se standardním poklesem přenosové charakteristiky $20 \mathrm{~dB} / \mathrm{dek}$ určit pomocí asymptot ze znalosti stejnosměrného zesílení a tranzitního kmitočtu $f_{\mathrm{T}}$.

Obvod bude zcela stabilní, pokud bude rychlost přibližování charakteristiky $z_{\beta}(f)$ a $z(f)$ před jejich průsečíkem rovna nebo menší než $20 \mathrm{~dB} /$ dek. Ještě lze povolit přibližování charakteristik $30 \mathrm{~dB} /$ dek. Při rychlosti přibližování $40 \mathrm{~dB} /$ dek je fázová bezpečnost $0^{\circ}$ a obvod se zcela jistě rozkmitá. Předpokládáme-li průběh převráceného zpětnovazebního poměru na kmitočtu $z_{\beta}(f)$ podle Obr. 13.1c, bude obvod při použití běžného operačního zesilovače stabilní, ale při použití širokopásmového operačního zesilovače s podstatně vyšším tranzitním kmitočtem již obvod stabilní nebude, protože rychlost přibližování charakteristik $z_{\beta}(f)$ a $z^{\prime}(f)$ nyní bude $40 \mathrm{~dB} /$ dek. 

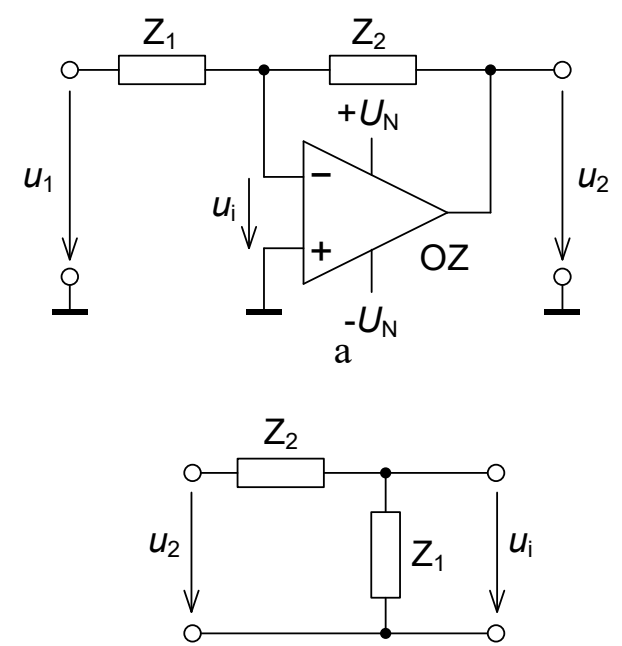

b

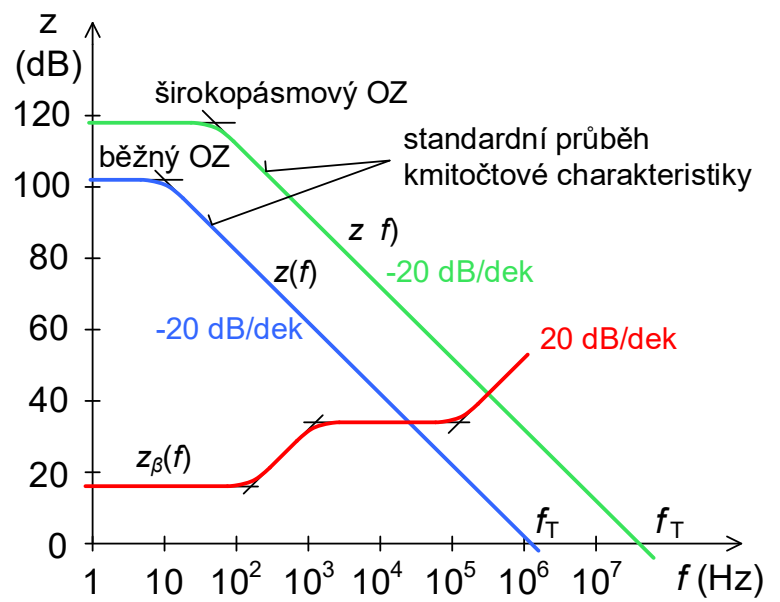

c

Obr. 13.1: a) Operační zesilovač s kmitočtově závislou zpětnou vazbou, b) k určení zpětnovazebního poměru, c) grafický způsob posouzení kmitočtové stability obvodu

$\mathrm{K}$ obdobné situaci může dojít i u zesilovače s čistě rezistorovou operační sítí, pokud operační zesilovač vykazuje na vysokých kmitočtech tzv. rychlý pokles kmitočtové charakteristiky. Tento př́pad je pro názornost uveden na Obr. 13.2a, kde je zapojení invertujícího zesilovače se zesílením $A_{\mathrm{U}}=-2$. Stanovíme-li zpětnovazební poměr $\beta=R_{1} /\left(R_{1}+R_{2}\right)$ a zakreslíme-li závislost $z_{\beta}(f)=20 \log \left(1+R_{2} / R_{1}\right)$ do grafu na Obr. 13.2c je nám okamžitě jasné, proč výrobce udává pro tento typ zesilovače $\left|A_{U}\right| \geq 5$. Rychlost přibližování charakteristik je totiž pro menší zesílení větší než $20 \mathrm{~dB} / \mathrm{dek}$ a OZ bude na mezi stability, nebo se rozkmitá.

I když by se při prvním zběžném pohledu zdálo, že použití integračního kapacitoru ve zpětné vazbě integrátoru (viz Obr. 13.2b) musí vést ke zlepšení stability obvodu, není tomu tak vždy. Zpětnovazební poměr je $\mathrm{v}$ tomto př́ípadě komplexní $\bar{\beta}^{\prime}=R_{0} /\left(R_{0}+1 / j \omega C_{1}\right)$, charakteristika $z_{\beta}^{\prime}(f)$ má jeden lom při kmitočtu $1 / 2 \pi R_{0} C_{1}$ a na vysokých kmitočtech se $\mathrm{k}$ charakteristice $z(f)$ operačního zesilovače s rychlým poklesem kmitočtové charakteristiky přibližuje rychlostí $40 \mathrm{~dB} /$ dek (Obr. 13.2). Je zřejmé, že použití operačního zesilovače s rychlým poklesem přenosové charakteristiky pro konstrukci integrátoru nebude obecně vhodné. Vždy je proto nutné $\mathrm{v}$ př́ípadě integrátoru použít operační zesilovač se standardním průběhem přenosové charakteristiky. 

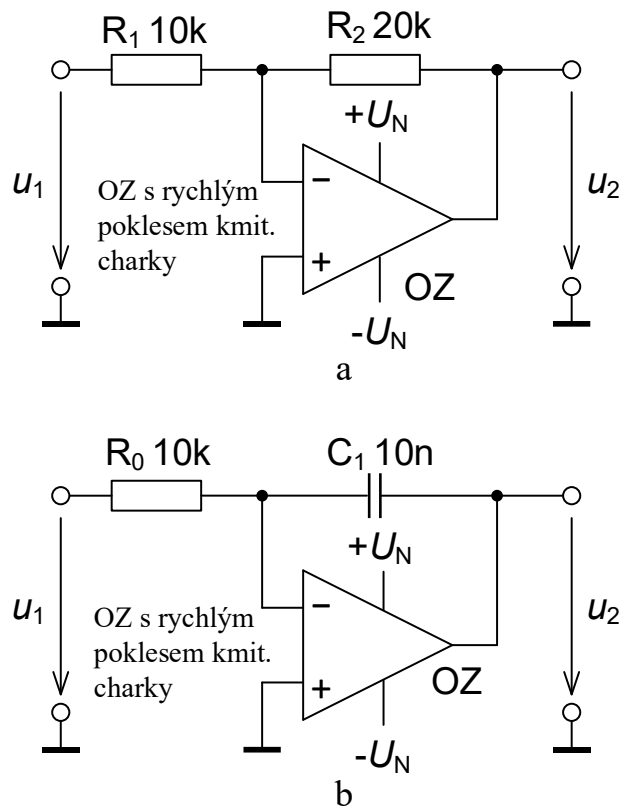

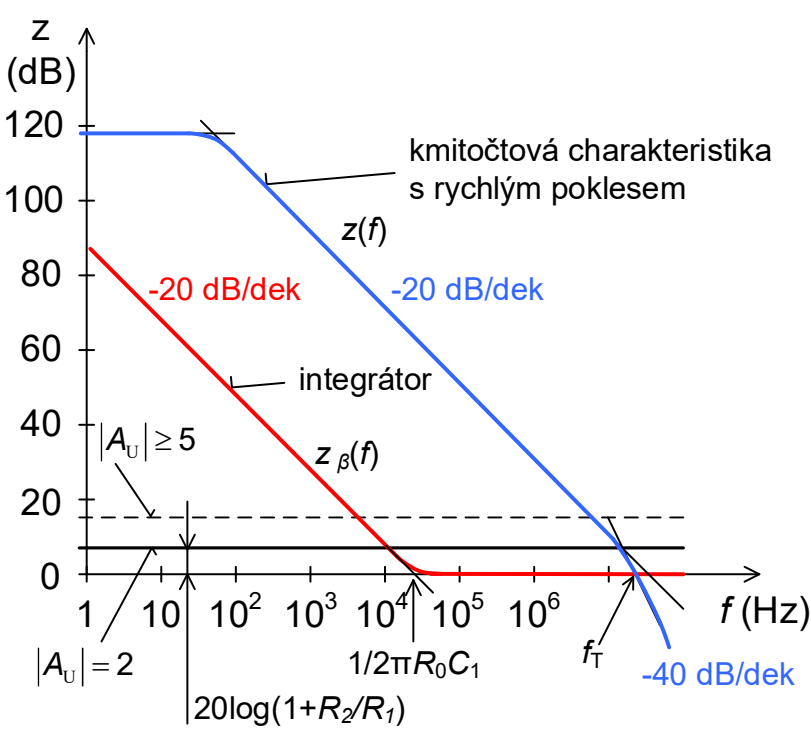

c

Obr. 13.2: K určení kmitočtové stability a) invertujícího zesilovače, b) integrátoru, c) grafické řešení

Bohužel i v případech, kdy by obvod měl být stabilní, může se bud' rozkmitávat, popř. může dojít k odtlumení obvodu, což způsobuje velký překmit při skokové změně vstupního napětí a dlouhé doznívání tlumených kmitů přechodného děje. Je to obvykle způsobeno některou parazitní veličinou, kterou jsme při prvním rozboru stability neuvažovali. K rozkmitání zesilovače, zapojeného v dané operační síti, může např. přispět rozptylová kapacita sčítacího bodu (invertující vstup OZ) zesilovače, zapojeného podle Obr. 13.3. Rozptylová kapacita, zahrnující kapacitu přívodních vodičů, diferenční vstupní kapacitu $C_{\mathrm{i}}$ a souhlasnou vstupní kapacitu $C_{\mathrm{cm}}^{-}$operačního zesilovače, je pro názornost $\mathrm{v}$ zapojení modelována kapacitorem $C_{p}$ o kapacitě asi $50 \mathrm{pF}$. Nebude-li ve zpětné vazbě zařazen korekční kapacitor $C_{k}$ bude zpětnovazební činitel

$$
\beta=\frac{R_{1}}{R_{1}+R_{2}} \frac{1}{1+j \omega C_{\mathrm{p}}\left(R_{1} \| R_{2}\right)}
$$

a může dojít k rozkmitání obvodu, protože se kmitočtové charakteristiky přibližují rychlostí 40 $\mathrm{dB} /$ dek (viz červený průběh $z_{\beta}(f)$ v Obr. 13.3b). Přidaný korekční kapacitor $\mathrm{C}_{\mathrm{k}}$ upravuje zpětnovazební poměr do tvaru

$$
\beta=\frac{R_{1}}{R_{1}+R_{2}} \frac{1+\mathrm{j} \omega C_{\mathrm{k}} R_{2}}{1+\mathrm{j} \omega\left(C_{\mathrm{p}}+C_{\mathrm{k}}\right)\left(R_{1} \| R_{2}\right)}
$$

a charakteristika $z_{\beta}^{\prime}(f)=20 \log \left|1 / \beta^{\prime}\right|$ má již vzhledem $\mathrm{k}$ charakteristice $z(f)$ operačního zesilovače př́iznivý průběh (modrý průběh na Obr. 13.3b). Optimální hodnota kapacity korekčního kapacitoru se určí obvykle experimentálně při buzení obvodu pravoúhlými kmity (viz Obr. 13.3c). Zpravidla se ukáže, že tato optimální hodnota je menší než hodnota $C_{\mathrm{k}}=C_{\mathrm{p}} R_{1} / R_{2}$, která př́sluší zcela vykompenzovanému zpětnovazebnímu děliči. 

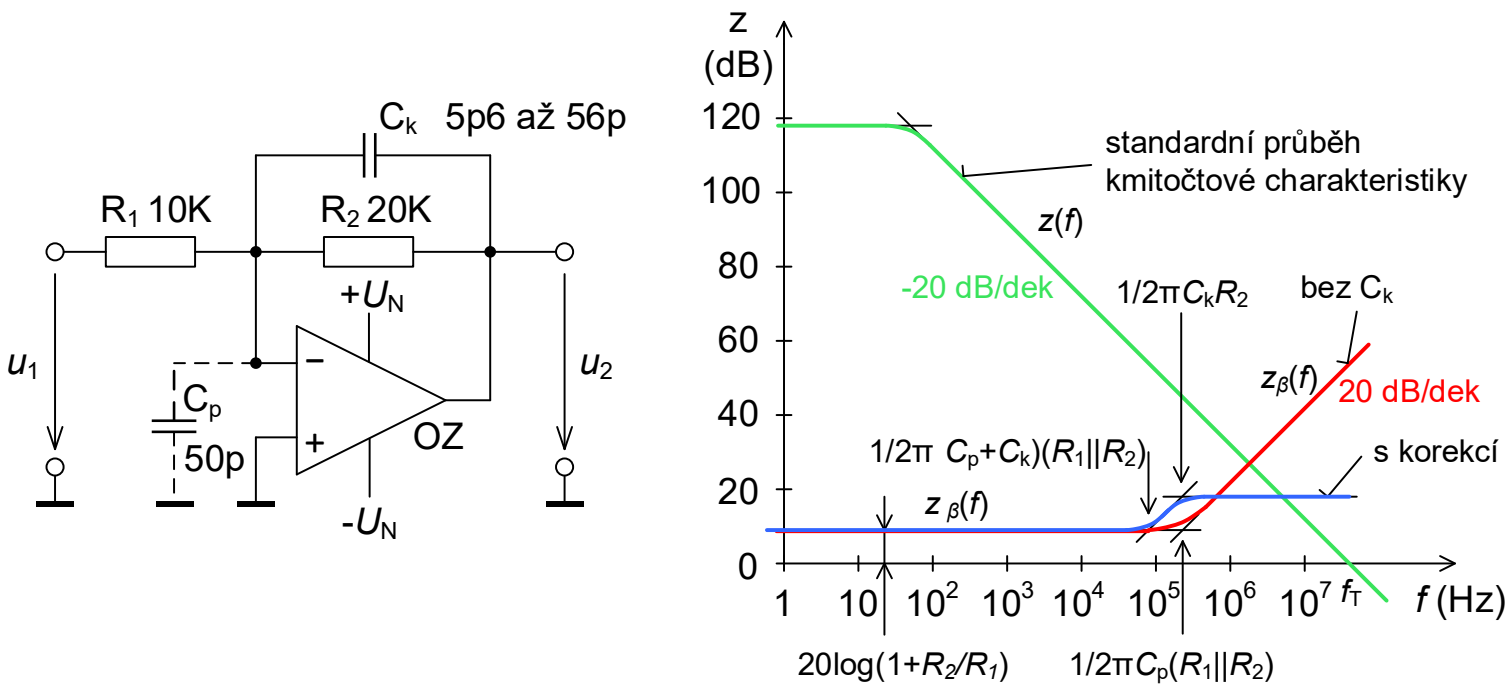

a

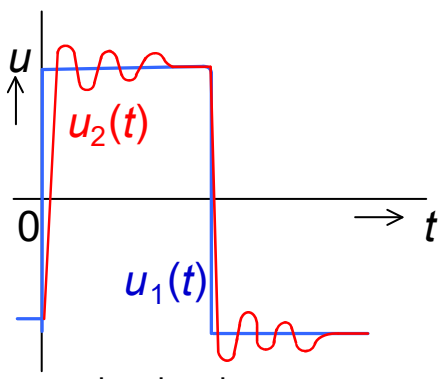

bez korekce

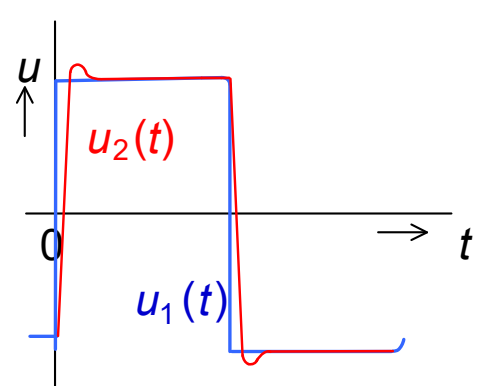

optimální korekce

$\mathrm{c}$ $\mathrm{b}$

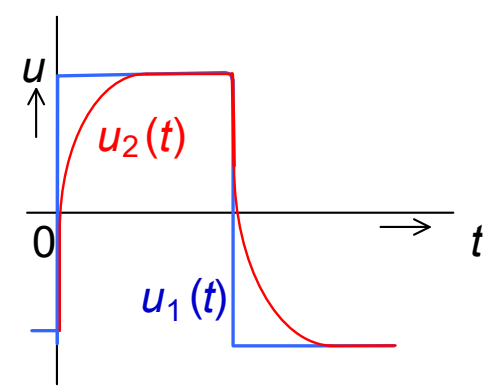

překorigováno

Obr. 13.3: Korekční kapacitor s malou kapacitou zapojený ve zpětné vazbě zlepší kmitočtovou stabilitu obvodu

Použití malého zpětnovazebního kapacitoru má i další příznivé účinky: zkrátí se doba ustálení, zmenší se šumová šiř́ka pásma a odstraní se rezonanční zvětšení šumu. Jeho důležitost ani není možné docenit. I když se podaří zmenšit rozptylovou kapacitu spojů sčítacího bodu, zůstane neodstranitelná vstupní kapacita operačního zesilovače $C_{\mathrm{i}}+C_{\mathrm{cm}}^{-}$, která stejně korekci vyžaduje. Zakreslení zpětnovazebního kapacitoru do schématu navržené operační sítě by mělo být samozřejmé, a to dokonce i tehdy, když se funkční vzorek obejde bez něho. Spíše jeho vynechání by mělo být podloženo úvahou a ověřením. Máme-li pochyby o vhodné hodnotě, předepíšeme $C_{\mathrm{k}}=15 \mathrm{pF}$. Cena levného keramického kapacitoru se vrátí v ušetřených hodinách, které bychom později strávili nad kmitajícím nebo šumícím vzorkem.

Jen v jednom př́padě nesmí být zpětnovazební korekční kapacitor zapojen: při použiti operačního zesilovače s rychlým poklesem kmitočtové charakteristiky v operační síti s velkým zesílením. Stabilita takové operační sítě předpokládá definované zeslabení ve zpětné vazbě, které by zpětnovazební kapacitor svoji malou reaktancí na vysokých kmitočtech zrušil. Zpětnovazební korekční kapacitor je samozřejmě zbytečný u napět’ového sledovače s přímým spojením výstupu a invertujícího vstupu operačního zesilovače.

Korekce kmitočtové charakteristiky. Většina operačních zesilovačů má interně korigovánu kmitočtovou charakteristiku tak, že na vysokých kmitočtech klesá rychlostí 20 $\mathrm{dB} /$ dek a její lom na $40 \mathrm{~dB} / \mathrm{dek}$ je až pod osou $0 \mathrm{~dB}$. V nabídce výrobců však stále existuje řada 
operačních zesilovačů s tzv. rychlým poklesem kmitočtové charakteristiky, u kterých je možno podle nastaveného zpětnovazebního zesílení připojit vnější korekční kapacitor. Při použití operačního zesilovače $\mathrm{s}$ rychlým poklesem přenosové charakteristiky je nutno správně korigovat kmitočtovou charakteristiku celého zesilovače, aby se předešlo možnosti rozkmitání obvodu na vysokých kmitočtech. Korekční prvky - kapacitor (viz příklad na Obr. 13.4a), někdy také sériová kombinace $\mathrm{RC}$ - se připojí $\mathrm{k}$ prŕslušným vývodům zesilovače pokud možno krátkými spoji. Doporučenou kapacitu korekčního kapacitoru udává výrobce vždy pro určité zesílení nastavené zpětnovazební síti tak, aby rychlost přibližování charakteristiky $\mathrm{z}_{\beta}(f)$ a korigované kmitočtové charakteristiky operačního zesilovače byla $20 \mathrm{~dB} / \mathrm{dek}$. Ve většině př́padů je korekce kmitočtové charakteristiky provedena interně a nemusíme se tímto problémem zabývat. $\mathrm{V}$ tom př́padě výrobce uvádí, že $\mathrm{OZ}$ je stabilní i pro jednotkové zesílení.
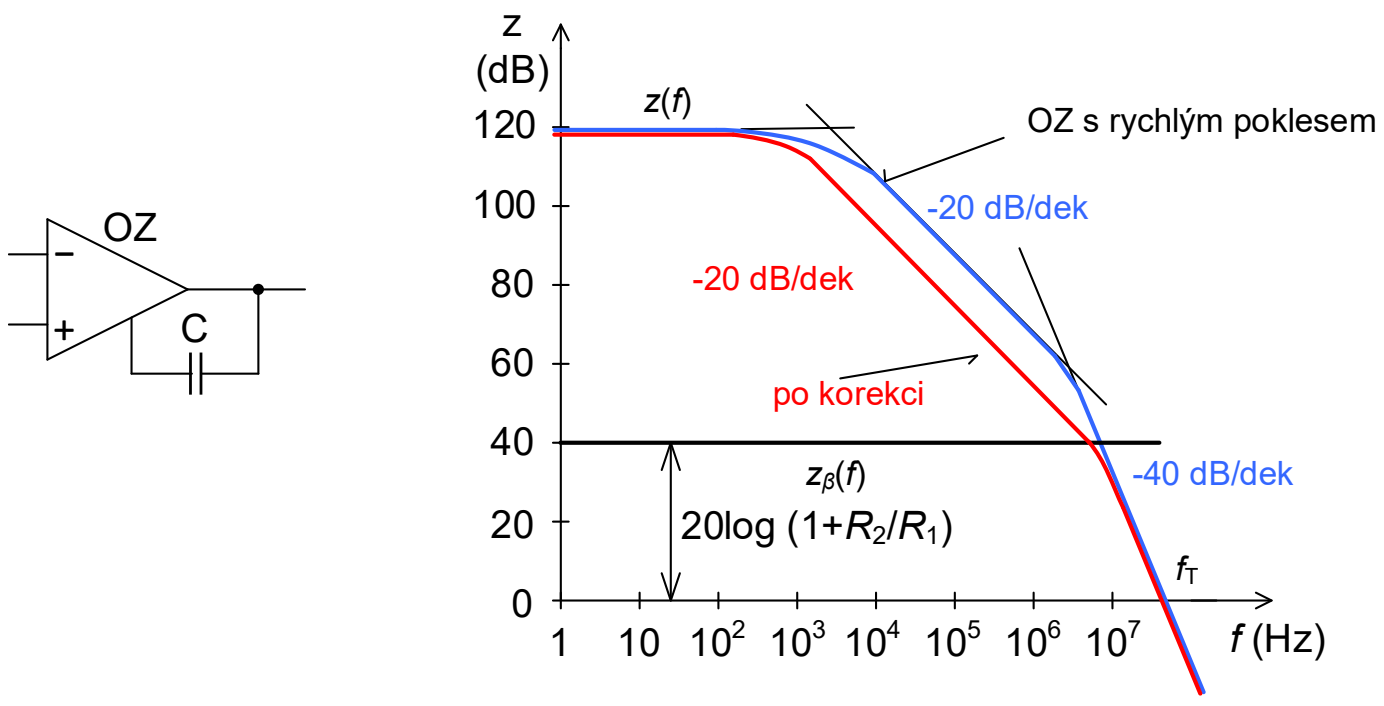

a

b

Obr. 13.4: Připojení vnějšího kapacitoru pro korekci kmitočtové charakteristiky OZ s rychlým poklesem kmitočtové charakteristiky, b) průběh kmitočtové charakteristiky před korekcí a po korekci

Charakter zdroje signálu. Volba zapojení operačního zesilovače (invertující či neinvertující zapojení) může být podstatně ovlivněna tím, zda je signál dodáván $\mathrm{z}$ tvrdých zdrojů (zdroj napětí s malým vnitřním odporem), popř. tím, jakou velikost (amplitudu) má zpracovávaný signál. Není-li vyžadováno zpracování stejnosměrné složky, je možno navíc vložit do cesty signálu oddělovací kapacitor; tím se současně dosáhne potlačení zbytkových napětí, jako např. napětové asymetrie (ofset) nebo ujíždění napět'ové nesymetrie (drift).

Charakter zátěže. Zátěží jsou dány nároky na výstupní napětí a proud. Nesmí se zapomínat na to, že část výstupního proudu teče do připojené zpětnovazební sítě. V př́padě, že parametry operačního zesilovače nestačí k pokrytí požadavků na napětí či proud dodávaný zátěží, je nutno použít napět’ový anebo proudový posilovač (booster). Velmi př́íhodně se dá ke zvýšení proudových schopností operačního zesilovače použít integrovaný posilovač nebo $\mathrm{v}$ náročných př́ípadech použít posilovač z diskrétních výkonových tranzistorů, který je schopen dodat do zátěže daleko větší proud. Zpoždění signálu, které posilovač ve smyčce zpětné vazby způsobí, má však stejné důsledky jako kapacitní zátěž.

Kapacitní zátěž má mnohdy nežádoucí vliv na kmitočtovou charakteristiku a v důsledku toho na stabilitu zesilovače. Taková kapacitní zátěž se proto připojuje k výstupu operačního zesilovače přes rezistor s odporem několika desítek ohmů (viz Obr. 13.5a). Vlastní korekci však provádí kapacitor $C_{k}$ o malé kapacitě zapojený mezi výstup operačního zesilovače a jeho 
invertující vstup. Zpětnovazební informace se nyní dostává na vstup operačního zesilovače dvěma cestami, stejnosměrnou a střídavou. Hlavní stejnosměrná smyčka uzavřená přes rezistor $\mathrm{R}_{2}$ reguluje výstupní napětí $\mathrm{v}$ místě spotřeby, tj. na zátěži, ale při rychlých změnách podává informaci zpožděnou a sama vede k rozkmitání. Tomu zabrání střídavá smyčka uzavřená přes korekční kapacitor $\mathrm{C}_{\mathrm{k}}$, který snímá fázově nezkreslené napětí na výstupu operačního zesilovače a přivádí je krátkou cestou na vstup. Vzhledem $\mathrm{k}$ malé reaktanci kapacitoru $\mathrm{C}_{\mathrm{k}}$ na vysokých kmitočtech převáží tato nezkreslená informace nad chybnou informací, kterou zprostředkuje rezistor $\mathrm{R}_{2}$. Obecné vztahy pro volbu korekčních prvků $\mathrm{R}_{0}$ a $\mathrm{C}_{\mathrm{k}}$ neuvádíme. Hodnoty uvedené v Obr. 13.5a jsou typické a jejich zpřesnění pro konkrétní úlohu se provede nejlépe experimentálně. Sledujeme prritom osciloskopem výstupní signál obvodu při buzení pravoúhlými kmity a prvky vybereme tak, aby při skokových změnách nevznikaly na výstupním signálu zákmity, které jsou průvodním znakem odtlumené operační sítě (viz Obr. 13.3c).

Obr. $13.5 b$ ukazuje použití popsané korekce u napětového sledovače. Přidaný rezistor $\mathrm{R}_{1}$ izoluje zatěžovací kapacitor $\mathrm{C}_{z}$ od invertujícího vstupu, modře kreslený rezistor $\mathrm{R}_{2}$ popř́padě slouží ke kompenzaci vstupního klidového proudu při použití bipolárního operačního zesilovače. Při použití unipolárního zesilovače jsou vstupní klidové proudy za normální teploty zanedbatelné a použitý kompenzační rezistor $\mathrm{R}_{2}$ by byl př́iliš drahý a šumící.

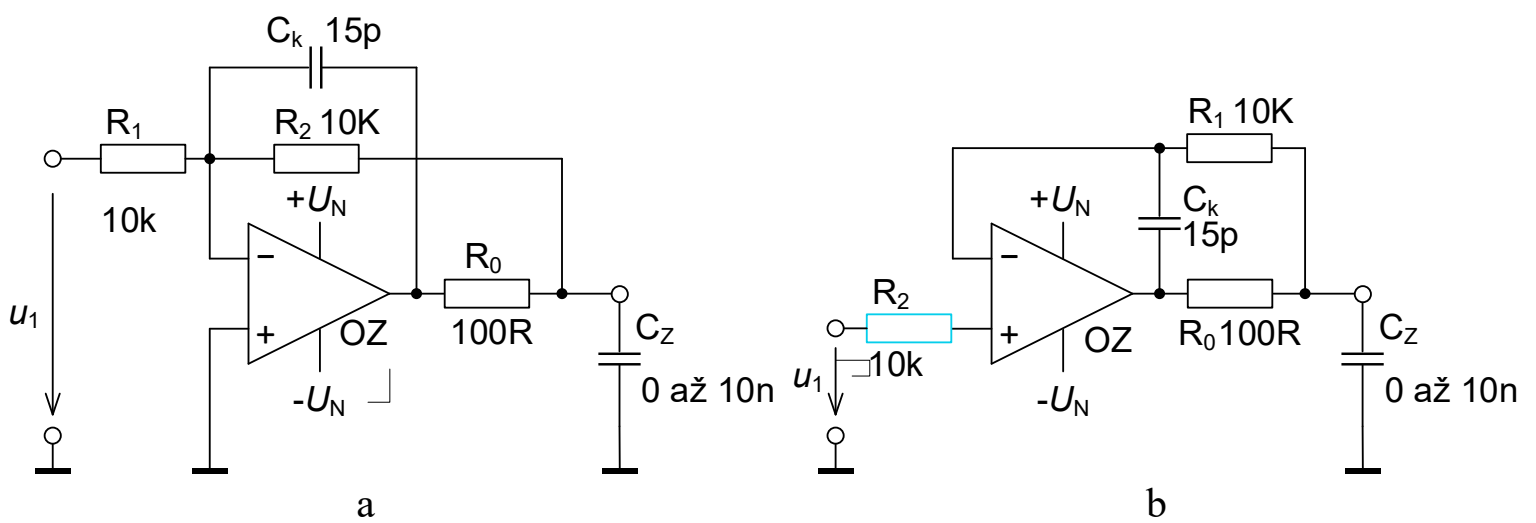

Obr. 13.5: Izolace kapacitní zátěže: a) invertujícího zesilovače, b) napětového sledovače

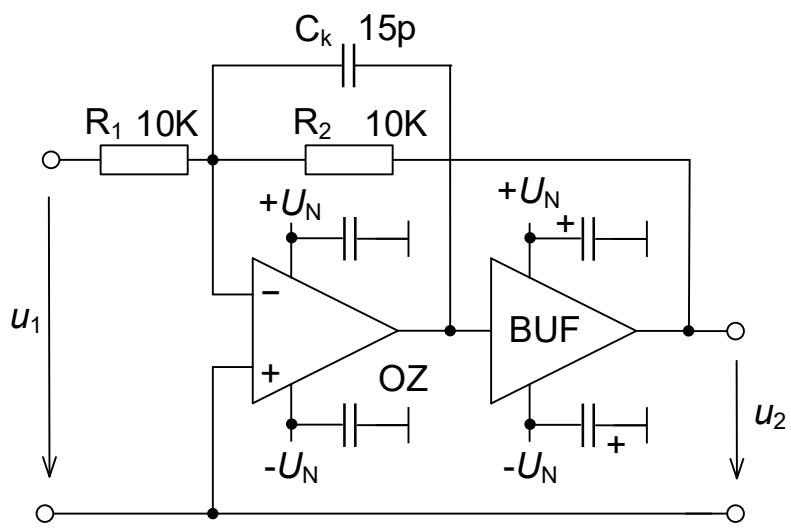

Obr. 13.6: Zajištění stability zesilovače s proudovým posilovačem

Podstata popsané korekce, jak bylo již řečeno, se dá použít i v jiných situacích, např. při použití posilovače připojeného za výstup operačního zesilovače, kdy se na vložený posilovač nahlíží jako na zpožd’ovací článek, který se na vyšších kmitočtech překlene rychlou 
zpětnovazební smyčkou přes korekční kapacitor, podobně jako při izolaci kapacitní zátěže (viz Obr. 13.6).

\subsubsection{Další konstrukční doporučení}

Okolní podmínky. Operační zesilovač je nutno zvolit tak, aby byl schopen spolehlivě pracovat bez jakéhokoliv nastavování $\mathrm{v}$ daném rozmezí teplot a s danými napájecími napětími, a to po celou predpokládanou dobu provozu.

Činnost obvodů s operačními zesilovači je taktéž ovlivňována rušením z okolních zdrojů, které se projevuje jako tzv. interferenční šum či rušení. Interferenční rušení, pozorované na výstupu operační sítě, může být způsobeno elektrostatickou indukcí (kapacitní vazbou), elektromagnetickou indukcí (indukční vazbou), jiskřením kontaktů, zvlněním či jehlovými impulsy v napájecích zdrojích. V náročných případech je pak nutno uvažovat ještě interferenční rušení způsobené mechanickým chvěním, fluktuací svodových proudů, fluktuací termoelektrických napětí, ionizujícím zářením a fotoelektrickými proudy. Za citlivá místa, kterými interferenční rušení vniká do operační sítě lze označit signálový zdroj, vstupní přívody, vstup operační sítě, vstupy operačního zesilovače, nulovací, korekční a napájecí vývody operačního zesilovače, zpětnovazební součástky a vodiče, plocha uzavřených smyček operační sítě a zemní rozvod. Nepostradatelným nástrojem pro identifikaci původu rušení je citlivý osciloskop.

Kapacitní vazba ze střídavého sít'ového rozvodu je nejčastější prŕíčina brumu operační sítě. Na osciloskopu se pozná snadno podle periody $20 \mathrm{~ms}$. Kapacitní vazbou proniká do operační sítě také rušení blízkým rozhlasovým vysílačem. Jeho odlišení od autooscilací operační sítě je někdy obtížné. Napomáhají tomu dva příznaky:

- Amplituda vf kmitů se zvětšuje s přiblížením ruky beze změny kmitočtu. Doporučujeme tento postup ověření: levá ruka se uzemní dotknutím na kostru nebo zem, čímž se odstraní kapacitní sít'ový brum a pohyblivá pravá ruka funguje jako anténa s měnitelnou vazbou.

- V některých prŕípadech je při pozorování na osciloskopu zřejmá i amplitudová modulace signálu.

Ochrana je v obou případech snadná. Uzavřeme citlivý zesilovač do stínicí krabice (třeba tenké hliníkové), použijeme stíněné signálové přívody a elektrostaticky odstíníme sítové transformátory a v krajním př́ípadě použijeme napájení z baterií. Snad neškodí připomenout, že veškeré elektrostatické stínění musí být vždy uzemněno.

Indukční vazba bývá způsobena rozptylovým tokem sítového transformátoru a je druhým nejčastějším zdrojem rušení. Potlačení rozptylového toku je všeobecně obtížnější a nákladnější. Doporučuje se zmenšit plochy smyček jiným rozvržením plošného spoje, přemístit nastavovací prvky z panelu př́mo na desku a nastavovat je např. číslicově, navzájem zkroutit dlouhé př́vodní vodiče, oddálit vodiče od citlivé části, pootočit o $90^{\circ}$ nebo magneticky odstínit sít'ový transformátor.

Jiskření rozpínaných kontaktů je provázeno emisí série elektromagnetických vln $\mathrm{s}$ kmitočtem řádově $100 \mathrm{MHz}$, které proniknou nekontrolované všude. Částečně pomáhá zmenšení rozměrů operační sítě. Úplně pomáhá likvidace jiskřícího kontaktu, jeho nasazení polovodičovým spínačem, nebo přenesení citlivého obvodu jinam. Podobně, ale pravidelně se projevují také radiolokační impulsy blízkých radiolokátorů. 
V přesných metrologických aplikacích musíme uvažovat i další vlivy. Mechanické chvění se projevuje mnoha způsoby, a to mikrofoničností, přerušováním uvolněného pájeného spoje, piezoelektrickými projevy (generování náboje ohybem koaxiálního kabelu) a triboelektřinou (generování náboje třením kabelu), nebo indukcí způsobenou zemským magnetickým polem. Pomáhá oddálení zdroje chvění (motoru, větráku apod.), použití nízkošumových koaxiálních kabelů (grafitový povlak polyetylénového dielektrika pod stínicím pláštěm) a tuhá konstrukce s vysokým vlastním kmitočtem rezonance, popř. spojená s použitím mechanických tlumicích prvků.

Znečištěný nebo zvlhlý povrch plošného spoje s ekvivalentním svodovým odporem $10 \mathrm{G} \Omega$ mezi napájecím rozvodem a vstupem operačního zesilovače vyvolá vstupní svodový proud 1,5 nA, který přesahuje 50-násobně nad vlastním vstupním klidovým proudem operačního zesilovače s tranzistory řízeným polem na vstupu. Dielektrická absorpce laminátu, nasáklého zbytky chemikálií z mokrých technologických procesů, vyvolá neočekávané časové konstanty, které zcela (např. o 3 dekadické řády) znehodnotí dynamické chování operační sítě v časové oblasti. Nepř́ijemná pak také je fluktuující složka těchto svodových proudů. Ochrana proti těmto jevům zahrnuje očištění a vysušení svodových cest, použití zemního nebo aktivního ekviponenciálního stínění, použití teflonových opěrných bodů a teflonem izolovaných vodičů, přenesení kritických signálových cest mimo laminát a popř. použití kvalitního laminátu na bázi teflonu nebo použití hydrokarbon/keramického laminátu spojené s chemickým ošetřením DPS po ukončení technologických procesů.

Ionizující záření, nejčastěji tvrdé kosmické částice $\alpha$ (rychlá héliová jádra), ruší elektrometrické aplikace. Prolétlá částice zanechává stopu ionizovaného vzduchu. Zasáhne-li vzniklý prostorový náboj vstup zesilovače, projeví se náhodným krátkým impulsem - jehlou na pamětovém osciloskopu. Pomoc je dvojího druhu: 1) při měření objektů ve vakuu se do vakua vloží i zesilovač, 2) v ostatních méně výlučných př́ípadech se kolem vstupní části zesilovače vytvoří elektrostatické aktivní stíněni (guard) ve tvaru těsné mosazné nebo hliníkové krytky nasunuté přes elektrometrický rezistor a přes související vstup operačního zesilovače. Krytka absorbuje přitékající prostorový náboj a redukuje ionizační objem přístroje na vnitřní objem krytky. Nedostatkem je zvětšená parazitní kapacita rezistoru.

Fotoelektrické proudy vznikají v operačním zesilovači (částečně průsvitné nekvalitní pouzdro) nebo i v signálovém zdroji. Mění se s denním svitem, s pohybem osob, s rozsvícením. Potlačí se optickým zastíněním. Běžně se ale tento problém nevyskytuje.

Konstrukční doporučení pro návrh DPS. Náchylnost operačního zesilovače k rozkmitání a k zesilování nežádoucích rušivých signálů se dá potlačit tak, že umístíme „sčítací bod“ zpětnovazební sítě co nejblíže invertujícímu vstupu zesilovače. Rozhodující rezistory zpětnovazební sítě musí být připojeny k vývodu invertujícího vstupu zesilovače co nejkratším spojem. Ostatní spoje (např. připojení zpětnovazebního rezistoru k výstupu operačního zesilovače, nebo připojení vstupního rezistoru ke zdroji zesilovaného signálu) mohou již být delší. V nutných př́ípadech použijeme stínění. Realizace sčítacího bodu na co nejmenší ploše a co nejblíže vstupu zesilovače zabraňuje vnikání nežádoucích rušivých signálů z okolí do zpracovávaného signálu. Umožňuje tedy také snížit parazitní kapacity sčítacího bodu a omezit svodové proudy, které by mohly způsobit chybu výstupního napětí zesilovače. Uvedená doporučení jsou zřejmá z příkladu zapojení rozdílového obvodu s operačním zesilovačem na Obr. 13.7a. Všechny přívody k invertujícímu vstupu OZ musí být úplně co nejkratší (Obr. 13.7b), protože rušení či šum je zesilován celým zesílením operačního zesilovače. Přívody k neinvertujícímu vstupu již tak kritické nejsou, protože rušení či šum jsou zesilovány pouze zesílením $A_{\mathrm{U}}=1+R_{2} / R_{1}$. Pokud však dělič $\mathrm{R}_{3}, \mathrm{R}_{4}$ není dostatečně „tvrdý“ zdroj napětí a jeho výstupní odpor $R_{3} \| R_{4}>1 \mathrm{k} \Omega$, pak se doporučuje rezistory $\mathrm{R}_{3}$ a $\mathrm{R}_{4}$ připojit také blízko $\mathrm{OZ}$. 
Aby se zabránilo nežádoucím vazbám, které mohou vést až $\mathrm{k}$ rozkmitání obvodu $\mathrm{s}$ operačním zesilovačem, je nutno mezi prrívody napájecích napětí a společný vodič (zem) připojit bezindukční keramické kapacitory s kapacitou $10 \mathrm{nF}$ až $220 \mathrm{nF}$ a to u každého zesilovače. Tyto kapacitory, které představují zkrat pro vysokofrekvenční proudové složky, musí být umístěny těsně u operačního zesilovače tak, aby takto vytvořené spojení mezi společným vodičem a příslušnými vývody operačního zesilovače bylo co nejkratší. Př́ivody napájecích napětí musí mít dostatečně velký prưřez, aby měly pokud možno malý odpor a (což je snad ještě důležitější) malou indukčnost.

Velká pozornost se při konstrukci zařízení s operačními zesilovači musí věnovat zemním spojům. Jak jsme podrobně ukázali v jiné kapitole, odděluje se tzv. signálová zem od výkonové země a zejména pak tyto analogové země nesmí být společné se zemí pro číslicové obvody. Spojení všech zemí se pak provede v zařízení jen v jednom vhodně zvoleném bodě.
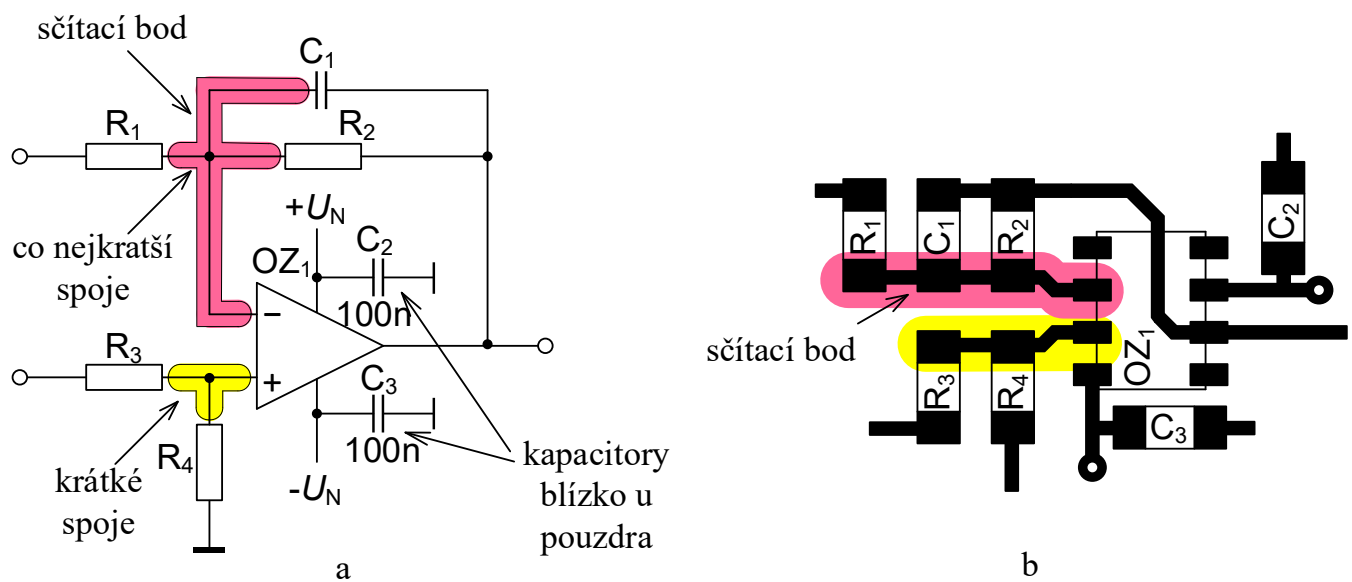

Obr. 13.7: Konstrukční doporučení při aplikaci operačního zesilovače

Nulování napětové nesymetrie. Většina moderních operačních zesilovačů má již z výroby nastavenu tak malou napět'ovou nesymetrii (offset), že přidání prvků pro jejich vynulování by bylo zbytečně drahé. Nulování napětové nesymetrie provádí výrobce před zapouzdřením laserovým trimováním, nastavením převodníku D/A aj. Napět'ová nesymetrie je pak jen desítky až stovky $\mu \mathrm{V}$. Navíc u složitějších zařízení se chyby způsobené napět'ovou nesymetrií kompenzují softwarově.

Existuje však stále ještě velká nabídka operačních zesilovačů, kdy jsou od výrobce připraveny svorky pro připojení potenciometrického trimru pro vynulování napět'ové nesymetrie. Tyto svorky jsou dalšími vstupními svorkami zesilovače. Jejich ss napětí je obvykle posunuto proti nulové úrovni a impedance je většinou menší než na „pravých“ vstupech. Citlivost na signál, přivedený na tyto svorky, může však být značná. Řada operačních zesilovačů má asi dvakrát větší zesíleni z nulovacího než z „pravého“ vstupu.

Povšimněme si v této souvislosti části zapojení nulovacího vstupu uvedeného na Obr. 13.8a. Bude-li běžec potenciometru $P$ přibližně uprostřed dráhy tak, aby můstek $R_{P 1}, R_{P 2} a R_{A}$, $\mathrm{R}_{\mathrm{B}}$ byl vyvážen, má napětí $\Delta U$ na vstupech $\mathrm{A}, \mathrm{B}$ stejnou velikost; působí tedy jako soufázový signál bez rozdílové složky. Jeho vliv na zesilovač je v tomto př́ipadě zanedbatelný.

Jiné poměry nastanou, vyvážíme-li potenciometrem $P$ napětovou nesymetrii zesilovače. Běžec již nebude uprostřed. Odpor potenciometrického trimru $R_{P}$ je obvykle $10 \mathrm{k} \Omega$. Pro představu předpokládejme, že vynulování napětové nesymetrie odpovídá $R_{P 1}=3 \mathrm{k} \Omega$ a $R_{P 2}=7$ $\mathrm{k} \Omega$. Rezistory $\mathrm{R}_{\mathrm{A}}$ a $\mathrm{R}_{\mathrm{B}}$ mají odpor $1 \mathrm{k} \Omega$. $\mathrm{V}$ tomto př́padě již můstek $\mathrm{R}_{\mathrm{P} 1}, \mathrm{R}_{\mathrm{P} 2}$ a $\mathrm{R}_{\mathrm{A}}, \mathrm{R}_{\mathrm{B}}$ není vyvážen a $\mathrm{v}$ úhloprríčce $\mathrm{A}-\mathrm{B}$ bude napětí $\Delta U / 8$. Vzhledem $\mathrm{k}$ dvojnásobnému zesílení $\mathrm{z}$ 
nulovacích svorek se projeví signál $\Delta U / 4$ mezi vstupními svorkami. Velikost $\Delta U$ je určena především velikostí odběru zesilovače ze záporného napájecího zdroje. Koncový stupeň zesilovače pracuje ve třídě B. To znamená, že odebírá proud ze záporného zdroje pouze při záporné půlvlně výstupního napětí. Výsledkem tedy je nelineární zkreslení výstupního signálu, jehož prríčinu bychom bez pochopení předchozích souvislostí obtížně hledali.

$\mathrm{Na}$ Obr. $13.8 \mathrm{~b}$ je uvedeno správné připojení běžce potenciometru $\mathrm{P}$ pro nulování napětové nesymetrie (ofsetu). Běžec je připojen prímo na napájecí svorku zesilovače tak, aby byla potlačena uvedená nežádoucí závislost. Jednootáčkový potenciometrický trimr je použitelný pro nulování napětové nesymetrie přibližně pro zpětnovazební zesílení $\left|A_{\mathrm{U}}\right| \leq 5$. Pro zesílení větší je nutno použít potenciometrický trimr víceotáčkový.

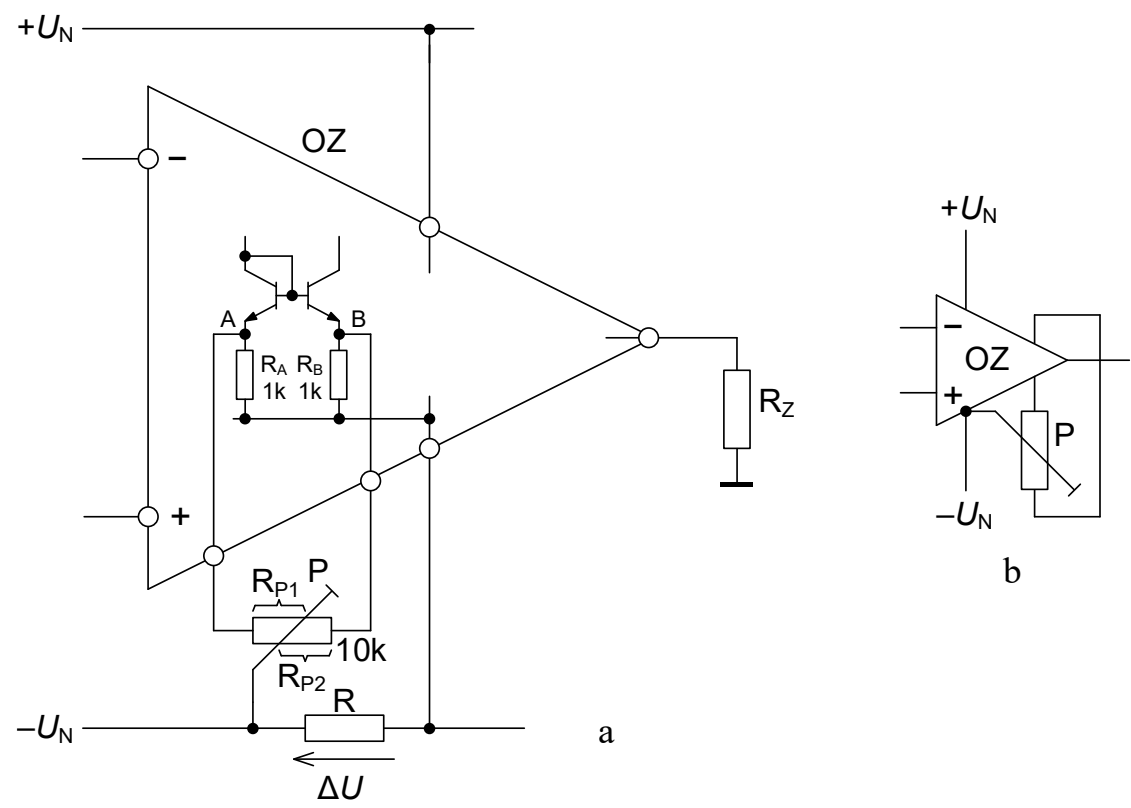

Obr. 13.8: a) K vysvětlení nesprávného způsobu připojení potenciometrického trimru ke svorkám pro nulování napět'ové nesymetrie, b) správné připojení běžce potenciometru pro nulování napět'ové nesymetrie

\subsubsection{Požadavky na napájecí zdroje}

Volba napájecích zdrojů. Volba typu napájecích zdrojů, tj. zda použít klasické napájecí zdroje se spojitou regulací, založené obvykle na dvoucestně usměrném napětí o sítovém kmitočtu $50 \mathrm{~Hz}$, či impulsně regulované zdroje, vždy záleží na konkrétní aplikaci. Pro běžné účely vystačíme $\mathrm{s}$ impulsně regulovanými zdroji, ale musíme počítat $\mathrm{s}$ tím, že úroveň impulsního rušení bude $\mathrm{v}$ signálové cestě vyšší a že bude nutno věnovat zvýšenou péči filtraci impulsního rušení v napájecích rozvodech.

Klasické napájecí zdroje se spojitou regulací dosahují menšího zvlnění stabilizovaného napětí, přičemž při jednocestném usměrnění sítového napětí má zvlnění kmitočet $50 \mathrm{~Hz}$ anebo při dvoucestném usměrnění $100 \mathrm{~Hz}$. Tato skutečnost představuje velkou výhodu při napájení operačního zesilovače, protože pomalé změny je operační zesilovač schopen potlačit. Zvlnění se do signálové cesty operačního zesilovače dostává zejména přes napájecí prŕvody a to především přes parazitní kapacity mezi kolektorem a emitorem koncových tranzistorů (viz Obr. 13.9). Pro nízké kmitočty $50 \mathrm{~Hz}$ či $100 \mathrm{~Hz}$ představují tyto parazitní kapacity velkou impedanci a zvlnění napájecích zdrojů do výstupu OZ nepronikne. Nevýhodou klasických zdrojů je jejich nižší účinnost (40 \%) a větší rozměry (sítový transformátor). 


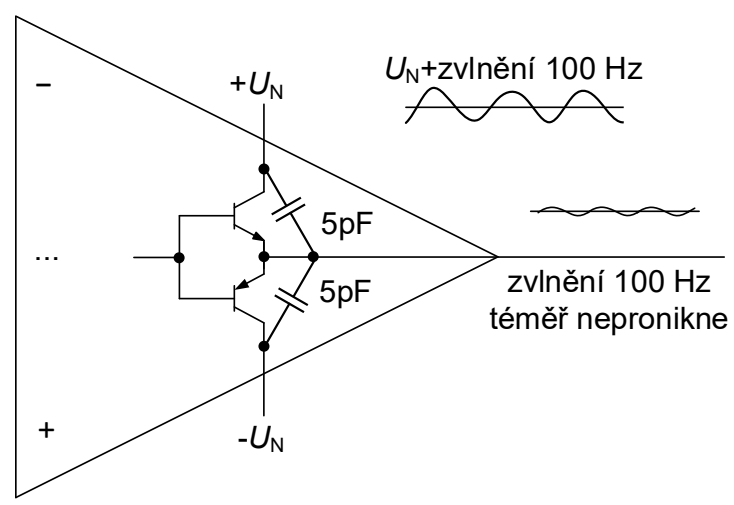

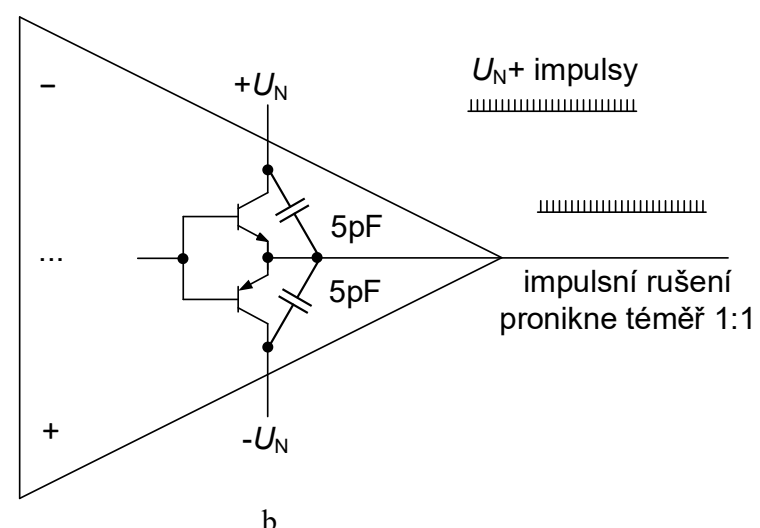

$\mathrm{b}$

Obr. 13.9: a) Vliv zvlnění klasického napájecího zdroje na operační zesilovač, b) pronikání impulsního rušení z impulsně regulovaného zdroje do výstupu operačního zesilovače

Výhodou spínaných či impulsně regulovaných zdrojů je jejich vysoká účinnost a malé rozměry. Jejich nevýhodou je delší doba přechodného děje při změně zátěže a vysoký stupeň impulsního rušení, protože impulsní zdroje pracují na kmitočtech $20 \mathrm{kHz}$ až $200 \mathrm{kHz}$. Pro jehlové impulsy vznikající při pulsní regulaci, představují parazitní kapacity koncových tranzistorů operačního zesilovače jen malou impedanci a impulsy proniknou snadno do signálových cest (viz Obr. 13.9b).

Pokud bude zařízení obsahovat citlivé vstupní zesilovače, zpracovávat audiosignály, nebo generovat přesné měřicí signály nízkých úrovní (pod $100 \mathrm{mV}$ ), vyplatí se vždy tuto část zařízení napájet z klasických napájecích zdrojů se spojitou regulací. Samozřejmě výkonovou část zařízení, kdy již nedochází k velkému napět'ovému zesílení je již možné napájet $\mathrm{z}$ impulsně regulovaných zdrojů.

Symetrické napájecí zdroje. Operační zesilovač je prioritně určen pro symetrické napájení $\pm U_{\mathrm{N}}$. Zem není v operačním zesilovači vyjádřena a stejnosměrně ji představuje střed mezi symetrickým napájecím napětím, tj. O V. Nesymetrie napájecích zdrojů může tedy ovlivnit ss složku zpracovaného signálu. Při volbě velikosti napájecího napětí je třeba počítat s tím, že rozkmit výstupního napětí $\mathrm{OZ}$ bude o něco menší než $\pm U_{\mathrm{N}}$. U klasického řešení $\mathrm{OZ}$ musíme počítat s tím, že rozkmit výstupního napětí bude asi $\pm\left(U_{\mathrm{N}}-2 \mathrm{~V}\right)$. Operační zesilovače, u kterých se dá dosáhnout téměř rozkmitu $\pm U_{\mathrm{N}}$ jsou označovány jako operační zesilovače s plným rozkmitem (rail-to-rail).

Pro běžné aplikace vystačíme se symetrickým zdrojem sestaveným ze stabilizátoru typové řady 7800 pro kladné napájecí napětí a ze stabilizátoru 7900 pro záporné napájecí napětí (viz Obr. 13.10). Aby se zabránilo rozkmitání stabilizátorů vlivem impedancí př́vodů doporučují výrobci přemostit vstup a výstup stabilizátorů hned u pouzdra keramickými kapacitory s kapacitou kolem $100 \mathrm{nF}$. Oba typy stabilizátorů jsou dodávány pro několik standardně nastavených kladných či záporných napětí: 5, 8, 10, 12, 15 a 24 V. Stabilizátory typové řady 7800 (resp.7900) se vyrábějí v několika modifikacích pro různé proudové odběry. 


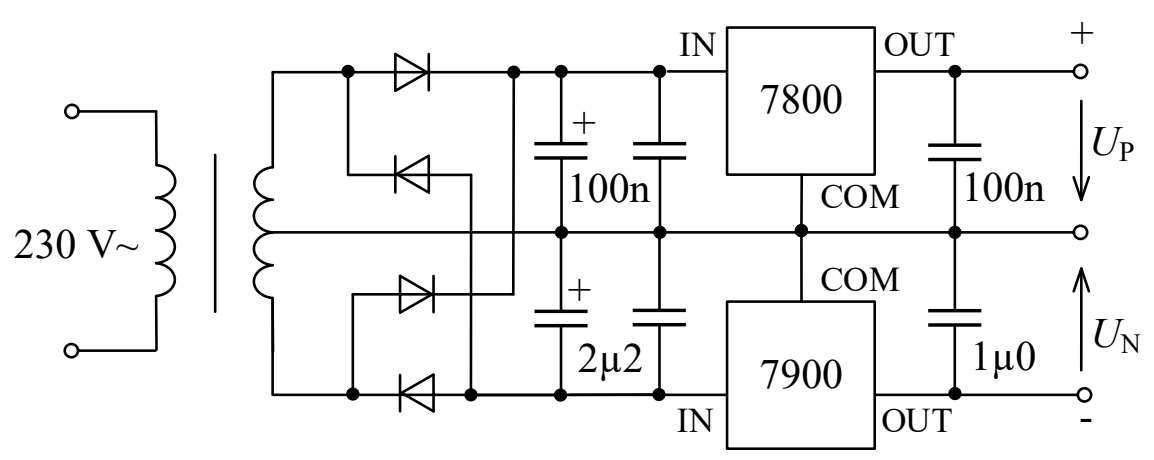

Obr. 13.10: Zapojení třísvorkových stabilizátorů jako symetrický napájecí zdroj

S tím je také spojen způsob zapouzdření do plastového či výkonového pouzdra. Pro získání velmi nízkých stabilizovaných napětí je pak možno použít třísvorkové stabilizátory typové řady 317 resp. 337. Uvedené zapojení se dvěma samostatnými tř́svorkovými stabilizátory je určeno pro méně náročné účely, protože záporné výstupní napětí nesleduje kladné napájecí napětí tak, jak tomu je u symetrických stabilizátorů sledovacího typu (viz dále). Oba stabilizátory jsou zde zcela nezávislé a kolísání jejich výstupních napětí je tedy také nezávislé. Tato nesymetric a kolísání kladného a záporného napětí se přenáší na výstup napájených operačních zesilovačů a přidává se ke stejnosměrné složce zpracovávaného signálu.

V řadě př́ípadů, např. pro napájení obvodů pro měřicí účely, nebo u zesilovačů s velkým ss zesílením je výhodné, aby rozdíl absolutní hodnoty obou napětí byl nulový. To se dá docílit např. tím, že jedno z napětí sleduje absolutní hodnotu druhého napětí. Tento požadavek se dá např. splnit uspořádáním symetrického stabilizátoru sledovacího typu podle Obr. 13.11. Pro získání kladného stabilizovaného napětí $U_{\mathrm{P}}$ je použit tř́svorkový stabilizátor typové řady 7800 stejně jako v př́padě zapojení na Obr. 13.10. Výstupní napětí $U_{\mathrm{P}}$ se použije jako referenční napětí pro odvození záporného napětí $U_{\mathrm{N}}$. Protože operační zesilovač $\mathrm{OZ}_{2}$ je zapojen jako invertující, dostaneme při $R_{1}=R_{2}$ jednoduše $U_{\mathrm{N}}=-U_{\mathrm{P}}$. Tranzistor slouží pro posílení výstupního proudu operačního zesilovače.

Symetrický stabilizátor sledovacího typu lze také sestavit s využitím nastavitelných čtyřsvorkových stabilizátorů $78 \mathrm{G}$ a 79G. Díky tomu, že jejich zpětnovazební sít' je vnější, lze oba typy navzájem provázat (Obr. 13.11b). Zapojení se pak chová obdobně jako diferenční zesilovač s diferenčním výstupem a napětí $U_{\mathrm{N}} \mathrm{v}$ absolutní hodnotě sleduje napětí $U_{\mathrm{P}}$. Obvody $78 \mathrm{G}$ a $79 \mathrm{G}$ mají různá vnitřní referenční napětí $U_{\mathrm{RP}}=5 \mathrm{~V}$ a $U_{\mathrm{RN}}=-2,23 \mathrm{~V}$ a proto rezistory $\mathrm{R}_{2}$ a $\mathrm{R}_{3}$ nemají shodné odpory. Obecně pro výstupní napětí symetrického stabilizátoru na Obr. 13.11 b platí

$$
\begin{aligned}
& U_{\mathrm{P}}=U_{\mathrm{RP}}+\frac{R_{2}}{R_{1}}\left(U_{\mathrm{RP}}-U_{\mathrm{RN}}\right), \\
& U_{\mathrm{N}}=U_{\mathrm{RN}}+\frac{R_{3}}{R_{1}}\left(U_{\mathrm{RN}}-U_{\mathrm{RP}}\right) .
\end{aligned}
$$




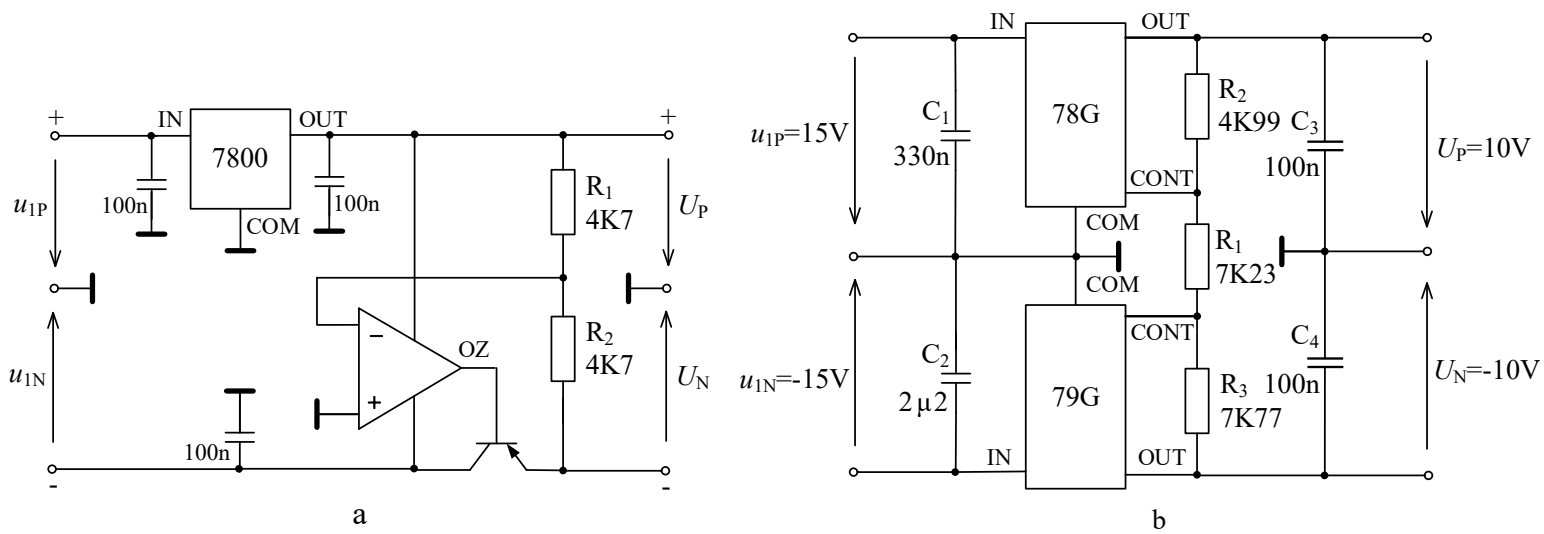

Obr. 13.11: Symetrické stabilizátory sledovacího typu

Impedance napájecích zdrojů. Napájecí zdroje musí mít malé výstupní impedance. Nejsou-li totiž výstupní impedance obou napájecích zdrojů proti zemi malé v celém kmitočtovém rozsahu operačního zesilovače, mohou vzniknout potíže s vlastnostmi zesilovače. Nejde však jen o výstupní impedance samotných napájecích zdrojů, ale do těchto impedancí musíme zahrnout i celý napájecí rozvod až k vlastní součástce, který může při špatném provedení impedanci zdrojů zhoršit.

$\mathrm{Na}$ Obr. 13.12a je naznačeno zjednodušené zapojení klasického řešení operačního zesilovače, přičemž uvažujeme, že napájecí zdroj záporného napětí a přívodní vodiče vykazují impedanci $\bar{Z}$. Diferenční vstupní napětí se převádí na jednočinný signál vǔči zápornému napájecímu zdroji ve vstupní části zesilovače, skládajícího se $\mathrm{z}$ diferenčního stupně $\mathrm{T}_{1}, \mathrm{~T}_{2} \mathrm{a}$ proudového zrcadla $T_{3}, T_{4}$. Další zesilovač $T_{5}$ je zapojen společně s korekčním kapacitorem $C_{K}$ jako jednoduchý integrátor. Tento integrátor má dvě vstupní svorky. Invertující, tvořená ř́dicí elektrodou tranzistoru $\mathrm{T}_{5}$, je připojena na proudové zrcadlo, neinvertující, emitor tranzistoru $\mathrm{T}_{5}$, je připojena přímo na sběrnici záporného napájecího napětí. Změní-li se napětí záporného zdroje (např. skokem vlivem úbytku na vnitřním odporu zdroje způsobené odběrem jiného obvodu), zesilovač integrátoru přenáší tuto změnu ze své neinvertující vstupní svorky na výstup. Protože však celý zesilovač používáme ve zpětnovazebním zapojení, projeví se tato změna jako chybový signál, který je vlivem zpětné vazby potlačen. To však platí pro dostatečně pomalé změny napětí záporného napájecího zdroje. Rychlé změny, vyvolané např̀. vlivem spínání výkonových obvodů připojených $\mathrm{k}$ tomuto rozvodu napětí, nebo jehlové impulsy $\mathrm{z}$ impulsně regulovaného napájecího zdroje, které nestačí zesilovač vlivem omezené rychlosti přeběhu zpracovat, plně pronikají na výstup. 


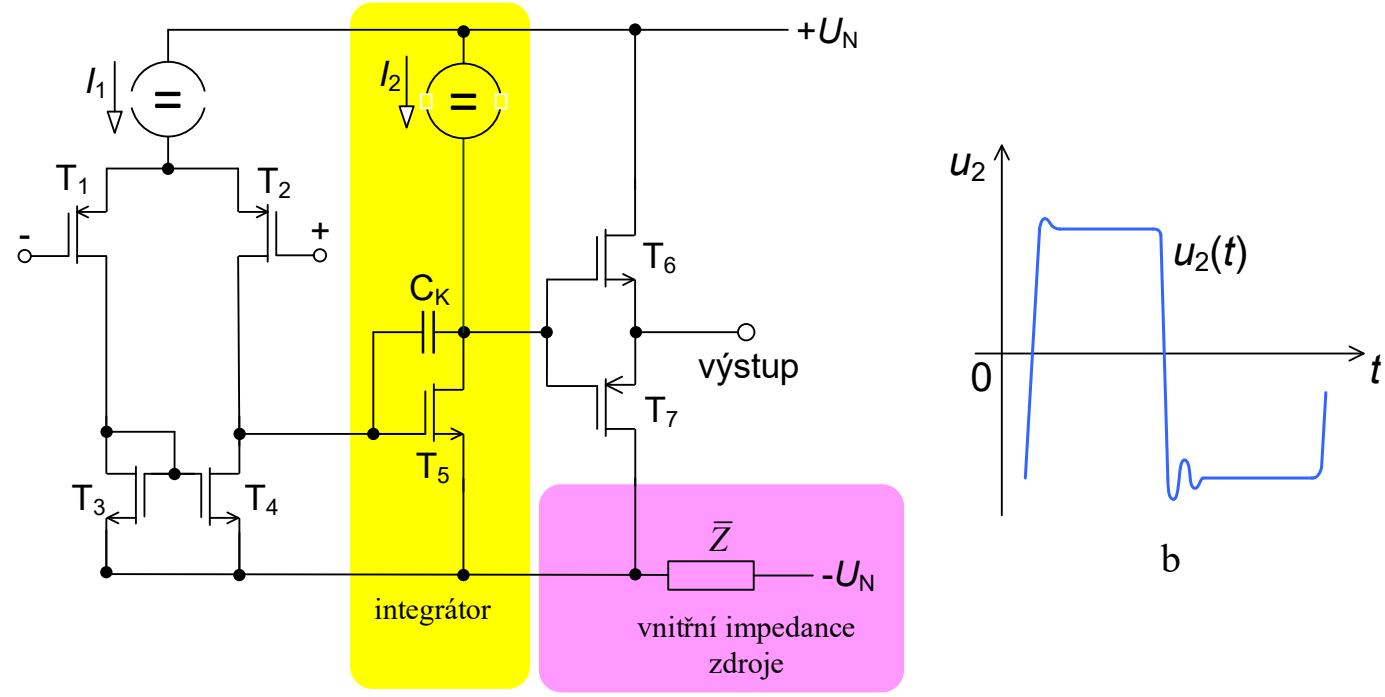

a

Obr. 13.12: a) Zjednodušené zapojení operačního zesilovače, b) důsledek asymetrie impedancí v přechodové charakteristice zesilovače

Potlačení vlivu změny kladného napájecího napětí se zmenšuje se zvyšujícím se kmitočtem, ale vliv malých změn tohoto napětí je podstatně menší než u záporného napájecího napětí. Tím je způsobena asymetrie v přechodové charakteristice zesilovače. Impuls kladné polarity na výstupu zesilovače vyvolá proudový impuls z kladného napájecího zdroje. $\mathrm{V}$ důsledku dobrého potlačení vlivu kladného napájecího zdroje je tvar impulsu určen vlastnostmi zesilovače a zdroj má malý vliv na tvar výstupního impulsu. Naopak, impuls záporné polarity na výstupu zesilovače vyvolá impuls proudu ze záporného napájecího zdroje. Tento impuls vyvolá na vnitřní impedanci záporného napájecího zdroje zákmit, který se přenese na výstup zesilovače (viz Obr. 13.12b). Jestliže kladný výstupní impuls ukázal přechodové vlastnosti zesilovače, záporný výstupní impuls ukazuje nejen přechodové vlastnosti OZ, ale současně je zkreslen nenulovou vnitřní impedancí a vlivem poruch na napájecích svorkách záporného zdroje. Vlivem vnitřní impedance záporného napájecího zdroje je tedy přechodová charakteristika pro impulsy kladné a záporné polarity různá.

Blokováni napájecích přvivodi̊. Pro blokování napájecích přívodů OZ při napájení z klasických napájecích zdrojů obvykle dostačuje zablokovat každý napájecí př́ivod vůči zemnímu vodiči keramickým kapacitorem 100 nF až $220 \mathrm{nF}$ (viz Obr. 13.13a). Aby přes napájecí přívody $\mathrm{OZ}$ nepronikalo rušení ostatních obvodů připojených ke stejným napájecím zdrojům, je důležitý konkrétní způsob připojení těchto blokovacích kapacitorů na DPS. 

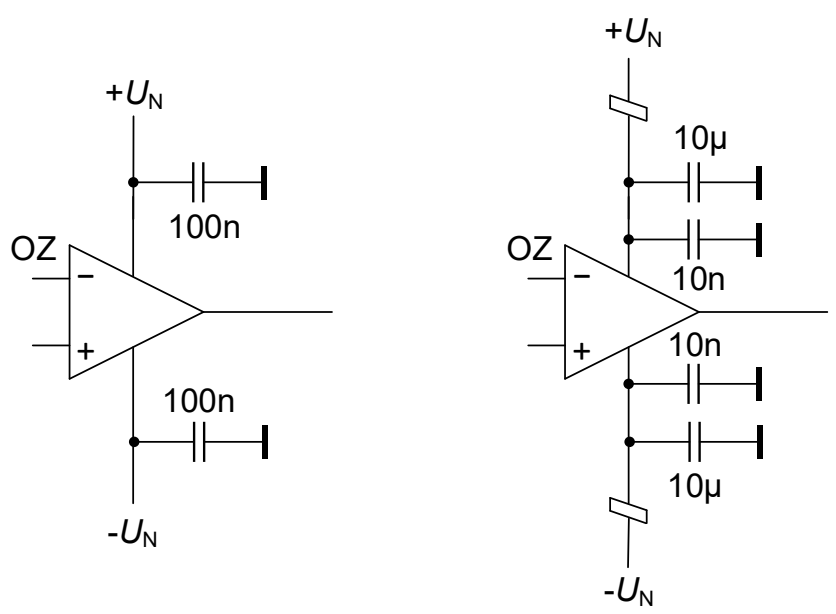

Obr. 13.13: a) Blokování napájení při použití klasických zdrojů, b) zařazení filtru LC při napájení z impulsně regulovaných zdrojů

Jak se impulsní rušení ze strany záporného napájecího zdroje může projevit na vstupní svorce zesilovače, závisí na tom, které zdroje rušení obsahuje smyčka uzavřená přes vodivý výstupní tranzistor zesilovače, zátěž a blokovací kapacitor. Způsob blokování uvedený na Obr. 13.14a nebude účinný. Ve smyčce A-B-C-D-E je rušivý signál $\mathrm{z}$ vodiče $\mathrm{C}-\mathrm{B}$ společného $\mathrm{s}$ jinými obvody přenášen př́mo na zápornou napájecí svorku $\mathrm{D}$ a přes parazitní kapacity tranzistoru se dostane na výstup zesilovače. V zapojení podle Obr. 13.14b je smyčka A-B-C pro vf složky proudu zátěže uzavřena nejkratším možným způsobem a kapacitor $\mathrm{C}_{\mathrm{b}}$ potlačuje vliv rušení z obvodů záporného zdroje. Vyplývá z toho poznatek, že blokovací kapacitor by měl být připojen co nejblíže k napájecímu vývodu OZ. To, co bylo uvedeno pro operační zesilovače pro záporný vývod zdroje, platí většinou i pro zdroj kladného napájecího napětí. Proto způsobu připojení blokovacích kapacitorů musíme věnovat patřičnou pozornost $\mathrm{v}$ obou napájecích př́ivodech.

Zvlnění, jehlové impulsy šum a kolísání napětí napájecích zdrojů proniká do signálové cesty nejen přes napájecí svorky operačního zesilovače, ale i přes nulovací obvody a také př́mo, jestliže z napájení je odvozena reference pro ss posunutí převodní charakteristiky obvodu. Zvlnění se pozná u klasicky řešeného zdroje jako brum s kmitočtem obvykle $100 \mathrm{~Hz}$. Vliv kolísání nekvalitně stabilizovaného klasického zdroje se ověří záměrnou zkusmou záměnou napájecích zdrojů nebo napájením z akumulátorových baterií. Dobrý klasický napájecí zdroj nebručí a nešumí víc než $1 \mathrm{mV}$ a nekolísá o víc než $10 \mathrm{mV}$.

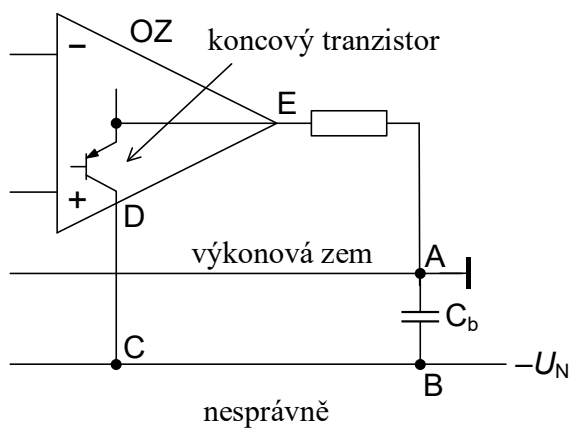

a

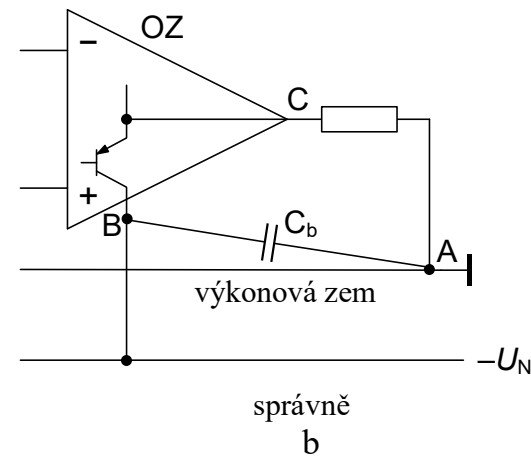

b

Obr. 13.14: a) Zapojení blokovacího kapacitoru do nevhodného místa není účinné, b) správné zapojení blokovacího kapacitoru 
Blokování napájení při použití impulsně regulovaných zdrojů. V případě použití impulsně řízených zdrojů pro napájení operačních zesilovačů je vhodné zařadit do napájecích prrívodů dolní propusti LC (Obr. 13.14b). Filtr LC je realizován feritovou perlou (Ferrite Bead) a kapacitorem $1 \mu \mathrm{F}$, který je pro zlepšení vf vlastností doplněn kapacitorem $10 \mathrm{nF}$. Obvykle toto opatření dostačuje realizovat jednou hned za konektorem desky plošného spoje a operační zesilovače pak blokovat běžným způsobem jen kapacitory $100 \mathrm{nF}$. Pro zablokování celé desky se pak společně s feritovou perlou použije napřr. kapapacitor $10 \mu \mathrm{F}$ a paralelně s ním $10 \mathrm{nF}$.

Blokováni napájení při neuzemněné zátěži. Složitější př́ípad neuzemněné zátěže je naznačen na Obr. 13.15. Zátěží zesilovače $\mathrm{OZ}_{1}$, je neuzemněný rezistor $R_{2}$ připojený $\mathrm{k}$ tzv. „virtuální nule“ $\mathrm{OZ}_{2}$. Proudu přes tranzistor $\mathrm{T}_{1}$ ze záporného zdroje odpovídá proud přes tranzistor $\mathrm{T}_{2} \mathrm{z}$ kladného zdroje. Kapacitor $\mathrm{C}_{\mathrm{b}}$ uzavírá nejkratší cestu mezi oběma zesilovači. Pokud by zesilovače byly napájeny z impulsně regulovaných zdrojů, bylo by nutné do napájecích př́vodů vložit feritové perly tak, jako v př́padě na Obr. $13.14 \mathrm{~b}$ a kapacitor $C_{\mathrm{b}}$ realizovat paralelní kombinací kapacitorů s kapacitou $1 \mu \mathrm{F}$ a $10 \mathrm{nF}$. Ve většině případů se však vystačí s blokováním obou napájecích přívodů proti zemi a problémy s neuzemněnou zátěží se řeši až pokud vzniknou.

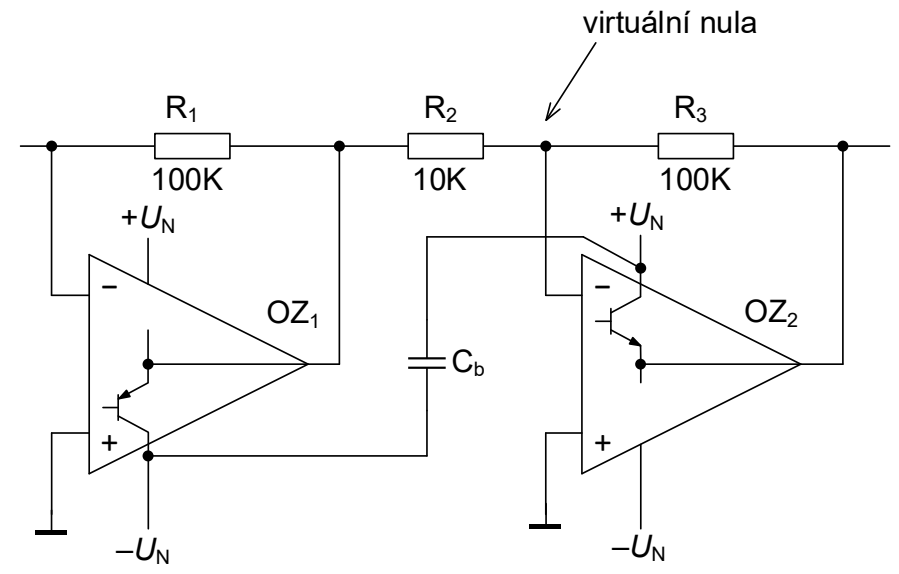

Obr. 13.15: Zapojení blokovacího kapacitoru Cb pro neuzemněnou zátěž R2

Dalši doporučení $k$ napájecím zdrojům. Odpory přívodů $\mathrm{k}$ napájecím zdrojům $\mathrm{u}$ složitějšího systému (napřr. milivoltmetru nebo stereofonního zesilovače apod.) mohou být, jak už bylo řečeno zdrojem nežádoucích vazeb. Obtíže jsou způsobeny tím, že výstupní proud zesilovače musí vždy protékat smyčkou, uzavřenou přes napájecí zdroj. Proud vyvolává úbytky napětí na vodičích napájecího vedení, které jsou superponovány na napájecí napětí a mohou se přenášet do nežádoucích míst zapojení. Abychom se zbavili těchto obtíží, snažíme se zmenšit možnost výskytu nežádoucí vazby některým z následujících opatření:

1. citlivé vstupní stupně napájíme ze samostatných zdrojů nebo stabilizátorů,

2. každý zesilovač napájíme po samostatném vedení od napájecího zdroje, nebo dokonce

3. každý zesilovač napájíme ze samostatného zdroje,

4. v kritických př́ípadech volíme bateriové napájení nebo napájení z akumulátorů.

Volba vhodného opatření závisí na složitosti a citlivosti zařízení. Ve velkých a náročných př́strojích se nemá šetřit na napájecích zdrojích, jejich provedení a stabilizaci, má-li být plně využito dosažitelných vlastností. Stále více se používají integrované zesilovače, které jsou svým principem širokopásmové. Jejich vlastnosti jsou definovány při napájení ze zdrojů $\mathrm{s}$ malým vnitřním odporem. Běžné stabilizátory napětí mají pro kmitočty vyšší než $100 \mathrm{kHz}$ 
výstupní impedanci indukčního charakteru, která se proti impedanci na nižších kmitočtech zvětšuje. Je to způsobeno zmenšením zisku v elektronické části stabilizátoru, který již nestačí udržet malý výstupní odpor zdroje a induktivním charakterem reaktance elektrolytických kondenzátorů na vyšších kmitočtech. Také přívody od zdroje delší než $10 \mathrm{~cm}$ se mohou projevit u širokopásmových zesilovačů svým induktivním charakterem. Proto znovu upozorňujeme na nutnost použít keramické blokovací kapacitory u každého zesilovače, a to co nejblíže $\mathrm{k}$ pouzdru.

Nesymetrické napájení operačních zesilovačů. Operační zesilovač má obvykle invertující a neinvertující vstupní svorku a výstup, čtvrtou signálovou svorku představuje společný vodič, který je obvykle spojen s nulovým potenciálem, tj. se zemí. Tato signálová svorka je při symetrickém napájení (Dual-Supply Operation) operačního zesilovače pomyslná (Obr. 13.16a). Stejnosměrně představuje střed mezi symetrickým napájecím napětím, tj. $0 \mathrm{~V}$. Při symetrickém napájení nečiní obvykle aplikace operačního zesilovače problémy, všechna napětí jsou vztažena k nulovému potenciálu (k zemi).
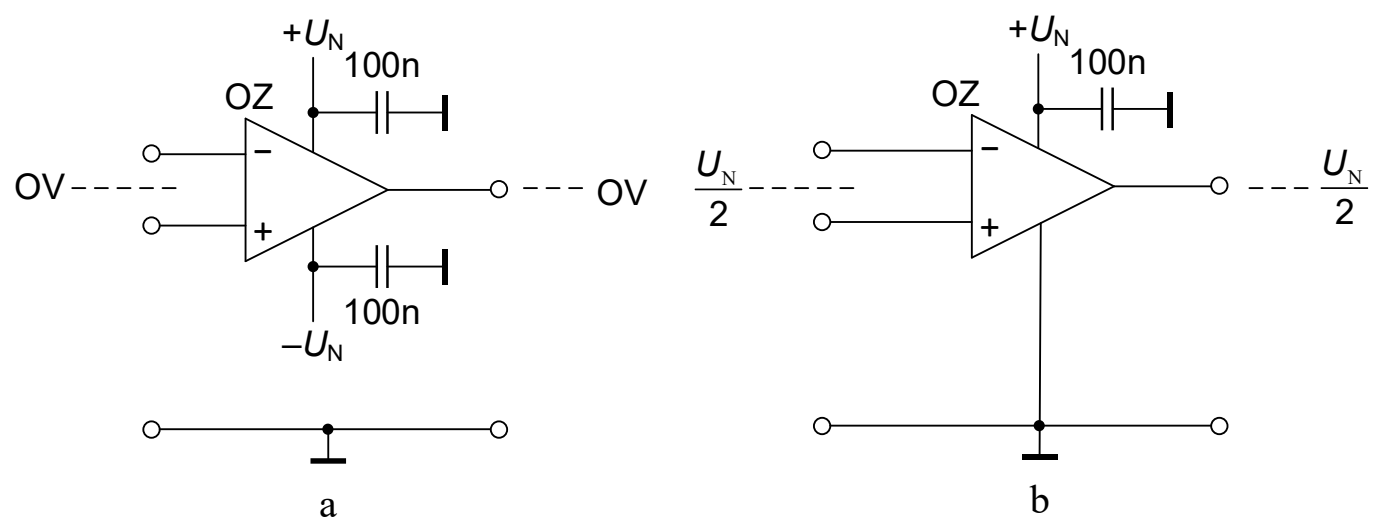

Obr. 13.16: a) Symetricky napájený operační zesilovač, b) operační zesilovač napájen z jednoho zdroje

V př́padě nesymetrického napájení z jednoho zdroje (Single-Supply Operation) musíme počítat s tím, že vstupní i výstupní signál bude stejnosměrně posunut o $U_{\mathrm{N}} / 2$ (viz Obr. 13.16b). Rozkmit výstupního napětí nyní bude o něco menší a to v rozmezí $0 \mathrm{~V}$ až $U_{\mathrm{N}}$. Při napájení $\mathrm{OZ}$ z jednoho napájecího zdroje tedy musíme zpracovávaný signál ss posunout vytvořením „plovoucí země“ na potenciálu $U_{\mathrm{N}} / 2$, nebo v prŕípadě zpracování stř́ídavých signálů (např̀. audiosignálů) provést stejnosměrné oddělení vstupního i výstupního signálu. I přses tyto nevýhody se $\mathrm{OZ}$ napájejí často jen z jednoho napájecího zdroje, protože to umožňuje jeho aplikace $\mathrm{v}$ bateriově napájených zařízeních, nebo $\mathrm{v}$ př́ídavných kartách do počítačů, kdy je $\mathrm{k}$ dispozici obvykle jen napájecí napětí jedné polarity $(+12 \mathrm{~V},+5 \mathrm{~V}$, nebo dokonce jen $+3,3 \mathrm{~V})$. Obr. 13.17 a ukazuje, jak se dá konvenční OZ, který je navržen pro symetrické napájení, napájet z jednoho napájecího zdroje $U_{\mathrm{N}}$. „Plovoucí zem“ je zde vytvořena referenční diodou, která by měla mít vybráno Zenerovo napětí přibližně $U_{\mathrm{N}} / 2$. Referenční dioda má nastaven pracovní bod pomocí rezistoru $\mathrm{R}_{0}$. 


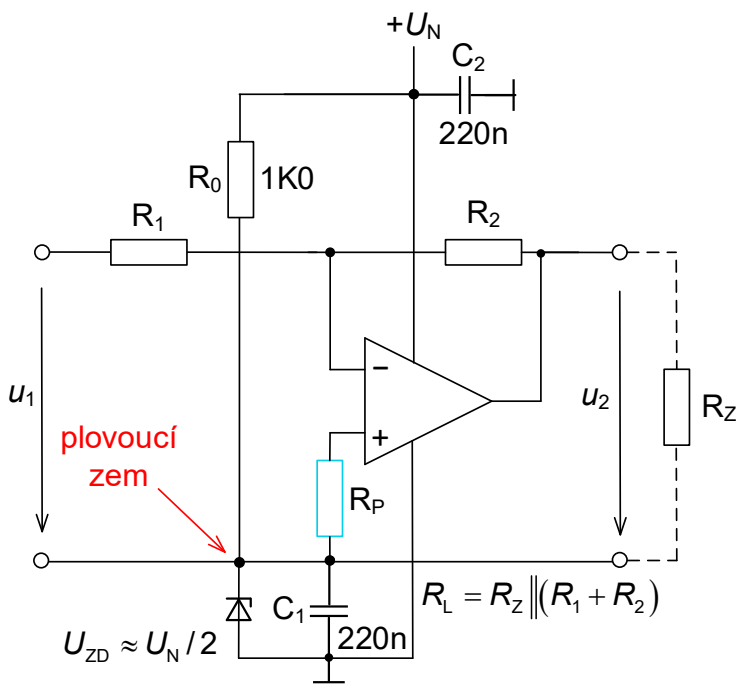

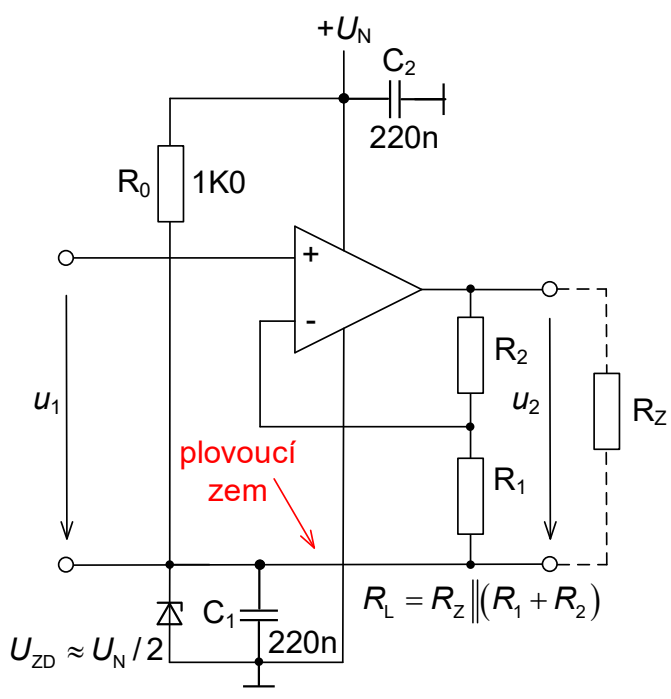

b

Obr. 13.17: Použití konvenčního OZ se symetrickým napájením při napájení z jednoho zdroje: a) invertující zesilovač, b) neinvertující zesilovač

Odpor rezistoru $R_{\mathrm{p}} \approx R_{1} \| R_{2}$ (ve schématu vyznačen modře) slouží ke kompenzaci vstupního klidového proudu. $\mathrm{V}$ prrípadě unipolárního $\mathrm{OZ}$ se volí $\mathrm{R}_{\mathrm{p}}=0 \Omega$. Vzhledem $\mathrm{k}$ tomu, že vstupní i výstupní svorka jsou vztaženy ke stejné „plovoucí zemi“, která je na potenciálu $U_{\text {ZD }}$, není přesnost a stabilita Zenerova napětí kritická. Na vstupu i výstupu nyní mohou být vzhledem k ,plovoucí zemi“ bipolární signály. Provoz je podobný provozu se symetrickým napájením. Proud zátěží $R_{\mathrm{L}}=R_{\mathrm{Z}} \|\left(R_{1}+R_{2}\right)$ však teče do „plovoucí země“, kde se bude přidávat $\mathrm{k}$ proudu referenční diodou (záporný zatěžovací proud se bude odečítat od proudu nastavujícího pracovní bod referenční diody). Referenční dioda a proud nastavující její pracovní bod musí být proto zvolen tak, aby referenční dioda byla provozována $\mathrm{v}$ závěrném směru při všech způsobech zatížení OZ.

Neinvertující zesilovač napájený z jednoho napájecího zdroje je uveden na Obr. 13.17b. Opět uvažujeme použití konvenčního OZ, navrženého pro symetrické napájení. V tomto prrípadě bude výstup zatížen stejně jako v předchozím, tj. $R_{\mathrm{L}}=R_{\mathrm{Z}} \|\left(R_{1}+R_{2}\right)$ a proud touto zátěží se bude přidávat $\mathrm{k}$ proudu referenční diodou.

Někdy se v jednoduché aplikaci pro odvození napětí „plovoucí země“ použije odporový dělič (viz Obr. 13.18a). Jeho výstupní impedance a tedy i výstupní impedance takového pomocného zdroje je $R_{\mathrm{A}} \| R_{\mathrm{B}}$. 


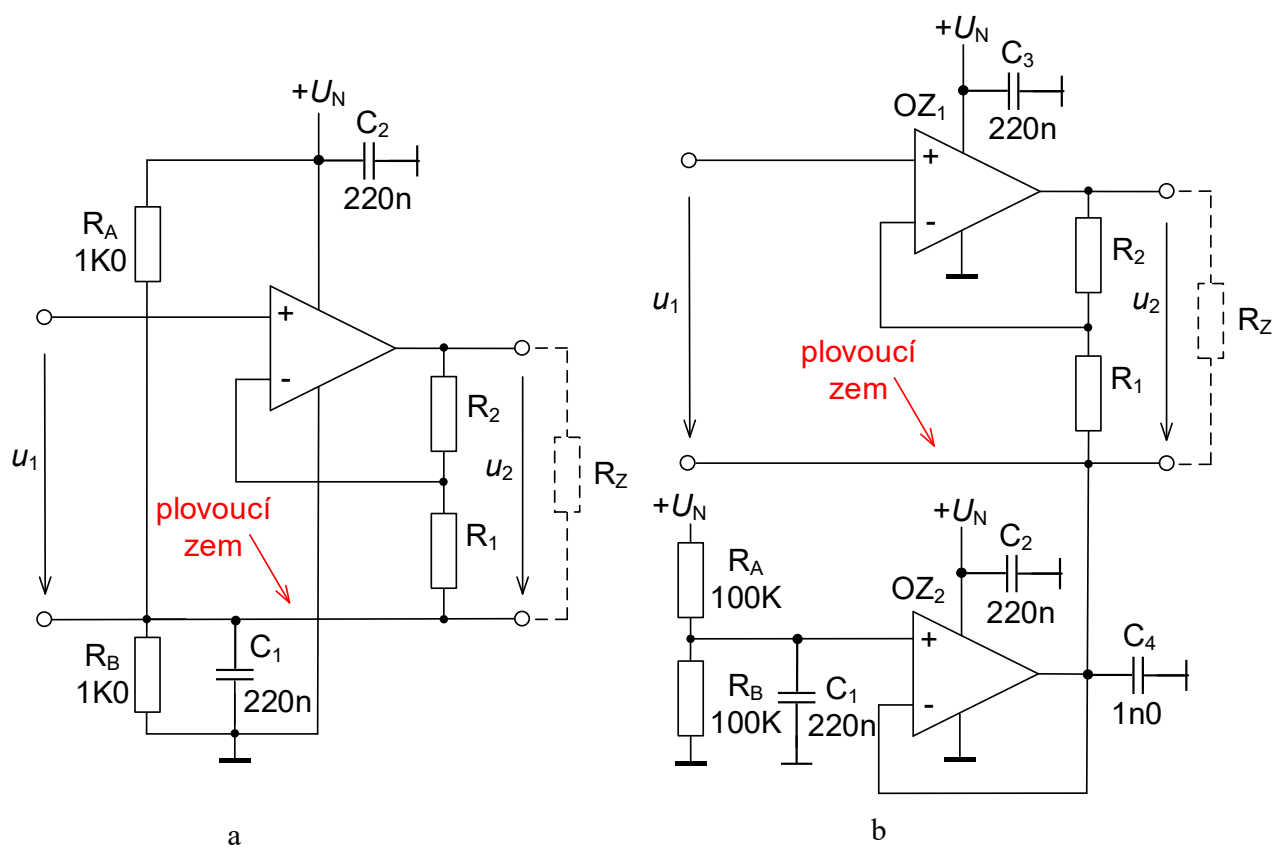

Obr. 13.18: Vytvoření „plovoucí země“ a) pomocí děliče, b) pomocí děliče a oddělovacího zesilovače

I přesto, že výstupní odpor děliče $R_{\mathrm{A}}, R_{\mathrm{B}}$ je zapojen v sérii s rezistorem $R_{1}$, je zesílení obvodu stále určeno jen odpory rezistorů $R_{1}$ a $R_{2}$. Vzhledem k tomu, že vstupní i výstupní napětí jsou vztaženy $\mathrm{k}$,plovoucí zemi“ nemá tato impedance vliv na zesílení obvodu. Proud zátěží $R_{\mathrm{L}}=R_{\mathrm{Z}} \|\left(R_{1}+R_{2}\right)$ teče výstupním odporem děliče $\mathrm{R}_{\mathrm{A}} \| \mathrm{R}_{\mathrm{B}}$ a může způsobit posunutí napětí „plovoucí země“. Protože je zapotřebí, aby dělič $R_{\mathrm{A}}, R_{\mathrm{B}}$ byl dostatečně „tvrdý“ zdroj napětí, je nutno jeho odpory volit malé. To však klade zvýšené nároky na napájecí zdroj.

Zvláště náročné aplikace mohou vyžadovat velmi malý proudový odběr z napájecího zdroje, přičemž vnitřní odpor posuvného zdroje má být malý. Jeden způsob je naznačen na Obr. 13.18b. Vstupní napětí oddělovacího zesilovače OZ2 s jednotkovým přenosem může být vytvořeno různými způsoby uvedenými dříve. Zde je použit dělič $R_{\mathrm{A}}, R_{\mathrm{B}}$. Oddělovací zesilovač se $100 \%$ zápornou zpětnou vazbou vytváří velmi kvalitní „plovoucí zem“, protože výstupní impedance takovéhoto zdroje je pro ss signály menší než $1 \Omega$. Kmitočtová charakteristika a výstupní impedance OZ bez zpětné vazby určují výstupní impedanci oddělovacího zesilovače na vysokých kmitočtech. Přemostěním výstupu oddělovacího zesilovače kapacitorem $C_{4}$ můžeme výstupní impedanci na vysokých kmitočtech ještě snížit, ale jeho impedance nesmí překročit povolenou kapacitní zátěž $\mathrm{OZ}$, protože by mohlo dojít k rozkmitání oddělovacího zesilovače.

Napájení operačního zesilovače z baterie umožňuje vytvořit plovoucí zem rozdělením napájecího napětí $\mathrm{U}_{\mathrm{N}}$ pomocí děliče $R_{\mathrm{A}}, R_{\mathrm{B}}$ na polovinu (viz Obr. 13.19). Kapacitor $\mathrm{C}_{1}$ slouží $\mathrm{k}$ potlačení šumu rezistorového děliče. Zesilovač $\mathrm{s} \mathrm{OZ}_{1}$ má jednotkový přenos a pouze slouží k oddělení děliče $R_{\mathrm{A}}, R_{\mathrm{B}}$. Oddělovací zesilovač s $\mathrm{OZ}_{1}$ i neinvertující zesilovač s $\mathrm{OZ}_{2}$ je pak napájen symetrickým napětím. Pokud se použije nízkovoltová baterie, např. $3,0 \mathrm{~V}$ je použití operačních zesilovačů umožňujících pracovat s plným rozkmitem výstupního napětí (,,rail-torail“) nezbytné. 


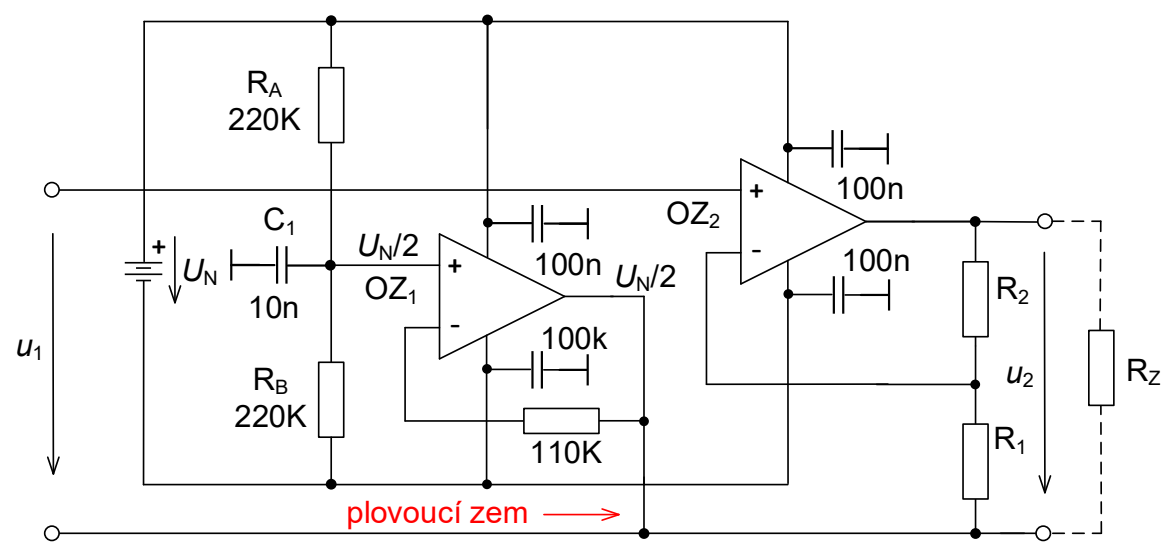

Obr. 13.19: Užití operačního zesilovače pro vytvoření plovoucí země neinvertujícího zesilovače napájeného $\mathrm{z}$ baterie

Při zpracování střídavých signálů lze užít i jiné způsoby využití OZ napájeného z jednoho zdroje. Základní princip je schematicky naznačen na Obr. 13.20. Na vstup zesilovače je přivedeno ss napětí $U_{\mathrm{N}} / 2$, které je odvozeno z napájecího napětí $U_{\mathrm{N}}$. To může vést ke zhoršení šumových poměrů, protože impulsní rušení z impulsně regulovaného zdroje, nebo zvlnění klasického zdroje se podělí děličem s odpory $R_{\mathrm{A}}=R_{\mathrm{B}}$ na polovinu, tzn. že rušení či zvlnění zdroje bude potlačeno pouze o $6 \mathrm{~dB}$.

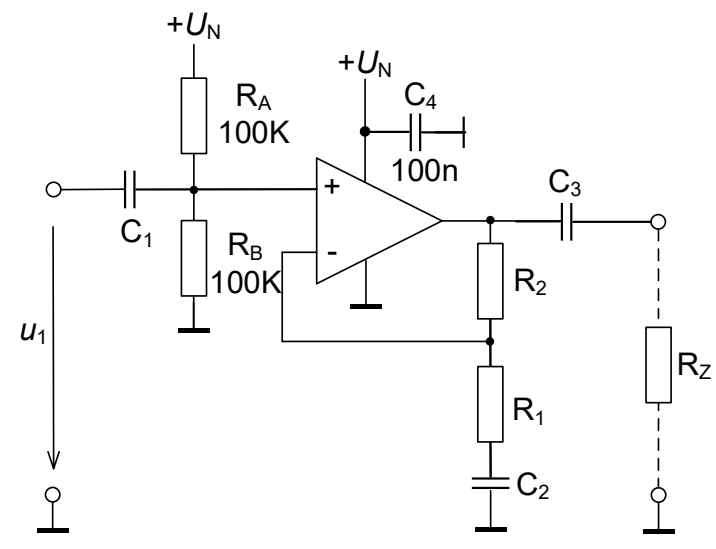

$$
\begin{aligned}
& f_{\mathrm{m} 1}=\frac{1}{2 \pi\left(R_{\mathrm{A}} \| R_{\mathrm{B}}\right) C_{1}} \\
& f_{\mathrm{m} 2}=\frac{1}{2 \pi R_{1} C_{2}} \\
& f_{\mathrm{m} 3}=\frac{1}{2 \pi R_{\mathrm{Z}} C_{3}} \\
& \text { strídavé zesílení : } \\
& A_{\mathrm{U}}=1+R_{2} / R_{1} \\
& \text { pro } X_{\mathrm{C} 2}<<R_{1}
\end{aligned}
$$

Obr. 13.20: Základní princip nastavení předpětí na vstupu OZ může vést ke zhoršení šumových poměrů nesymetricky napájeného střídavého zesilovače

Řešení tohoto problému nabízí modifikace zapojení Obr. 13.21. Výstup děliče $R_{\mathrm{A}}, R_{\mathrm{B}}$ je nyní pro stř́idavé signály přemostěn kapacitorem $C_{4}$. Ten se při použití klasického napájecího zdroje volí elektrolytický tak, aby platilo $f_{\mathrm{m} 1}<f_{\mathrm{m} 2} / 10$. V př́ípadě impulsně regulovaného zdroje se na pozici kapacitoru $C_{4}$ použijí tři paralelně zapojené SMD kapacitory např. $10 \mu \mathrm{F}, 1$ $\mu \mathrm{F}$ a $1 \mathrm{nF}$. 


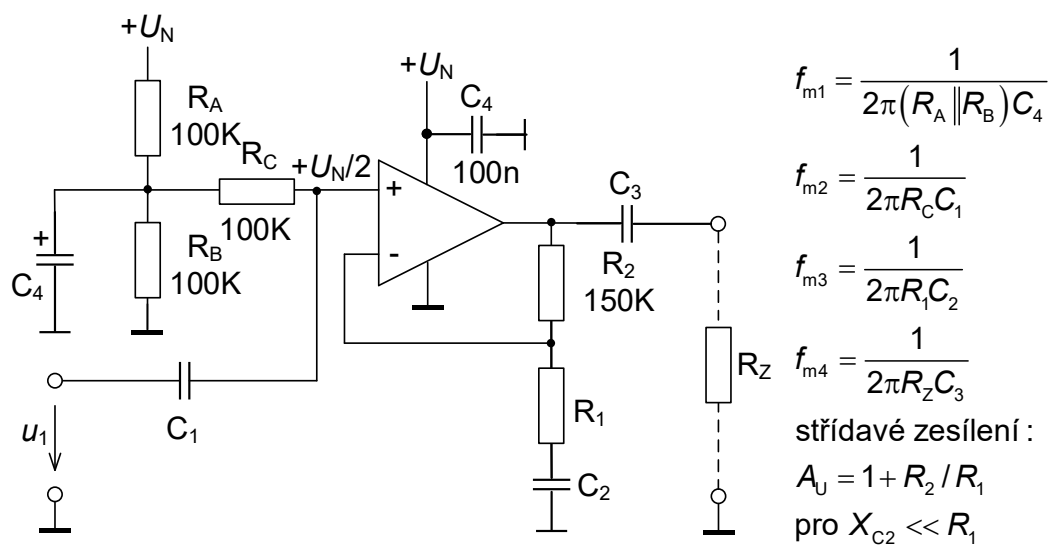

Obr. 13.21: Střídavý neinvertující zesilovač s OZ napájeným jediným napájecím napětím

Povšimněme si, že zesílení pro ss signály je jednotkové (kapacitor $C_{2}$ má pro ss signály vysokou impedanci) a OZ má pro ss signály ve zpětné vazbě pouze rezistor $R_{2}$. Dále musíme vzít v úvahu, že výstupní odpor děliče $R_{\mathrm{A}}, R_{\mathrm{B}}$ společně s odporem rezistoru $R_{\mathrm{C}}$ zapojeným před neinvertujícím vstupem $\mathrm{OZ}$ je značný $R_{\mathrm{A}} \| R_{\mathrm{B}}+R_{\mathrm{C}}$. Pokud nebudou odpory v invertujícím a neinvertujícím vstupu přibližně shodné, mohou vstupní klidové odpory OZ vyvolat ss posunutí jeho výstupního napětí. To však potřebujeme udržet přibližně na hodnotě $U_{\mathrm{N}} / 2$, protože jinak může dojít k omezení rozkmitu výstupního napětí. $\mathrm{Z}$ tohoto důvodu se volí $R_{2}=R_{\mathrm{A}} \| R_{\mathrm{B}}+R_{\mathrm{C}}$.

Při napájení z jednoho zdroje $12 \mathrm{~V}$ představují odpory děliče $100 \mathrm{k} \Omega$ rozumný kompromis mezi proudovým odběrem z napájecího zdroje a chybou vyvolanou vstupním klidovým proudem. Při napájení $+5 \mathrm{~V}$ je možné odpory děliče zvolit $42 \mathrm{k} \Omega$. V př́ípadě napájení ze zdroje 3,3V je nezbytné použít OZ s plným rozkmitem výstupního napětí („rail-to-rail“) a odpory děliče lze snížit na $27 \mathrm{k} \Omega$.

Samozřejmě problémům se vstupními klidovými proudy se můžeme vyhnout použitím unipolárního zesilovače. Chceme-li však zařízení provozovat v širokém teplotním rozsahu je vyrovnání odporů v invertujícím a neinvertujícím vstupu $\mathrm{OZ}$ př́hodné i pro tento prrípad.

Invertující uspořádání střídavého zesilovače s OZ napájeným z jednoho zdroje je uvedeno na Obr. 13.22. V tomto př́padě bude vliv vstupních klidových proudů eliminován při $R_{2}=R_{\mathrm{A}} \| R_{\mathrm{B}}$. Aby se potlačil průnik rušivých signálů z napájecího zdroje je dělič $R_{\mathrm{A}}, R_{\mathrm{B}}$ zablokován kapacitorem $\mathrm{C}_{2}$ a pro dolní propust tvořenou výstupním odporem děliče $R_{\mathrm{A}} \| R_{\mathrm{B}} \mathrm{a}$ kapacitou $C_{2}$ musí platit $f_{\mathrm{m} 1}<f_{\mathrm{m} 2} / 10$.

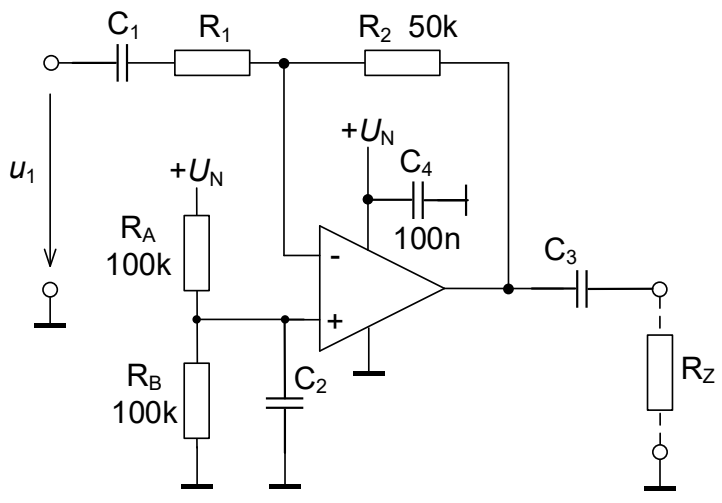

$$
\begin{aligned}
& f_{\mathrm{m} 1}=\frac{1}{2 \pi\left(R_{\mathrm{A}} \| R_{\mathrm{B}}\right) C_{2}} \\
& f_{\mathrm{m} 2}=\frac{1}{2 \pi R_{1} C_{1}} \\
& f_{\mathrm{m} 3}=\frac{1}{2 \pi R_{\mathrm{z}} C_{3}} \\
& \text { stř́idavé zesílení : } \\
& A_{\mathrm{U}}=-R_{2} / R_{1} \\
& \text { pro } X_{\mathrm{C} 1}<<R_{1}
\end{aligned}
$$

Obr. 13.22: Stř́idavý invertující zesilovač s OZ napájený jediným napájecím napětím 


\subsection{Aplikační pravidla pro vzorkovače a sledovače s pamětí}

\subsubsection{Výběr pamět'ového kapacitoru}

Integrované vzorkovače či sledovače pro všeobecné použití mají většinou možnost připojení vnějšího pamětového kapacitoru. Pokud ke vzorkovači či sledovači s pamětí připojujeme vnější pamět'ový kapacitor, musíme při jeho výběru věnovat velkou pozornost jeho vlastnostem. Použité dielektrikum (keramika, nebo izolační fólie z polystyrenu či polyetylenu aj.) není ideální izolací a reálné vlastnosti kapacitoru ještě zhoršuje materiál vnějšího pláště (termoplast, ochranný tmel, izolační lak apod.). Tyto ztráty se modelují v náhradním zapojení kapacitoru jako izolační nebo svodový odpor $\mathrm{R}_{\mathrm{i}}$ připojený paralelně ke kapacitoru $\mathrm{C}$. Izolační odpor pamět'ového kapacitoru by měl být $10^{11}$ až $10^{12} \Omega$. U některých kapacitorů pak navíc další ztráty způsobuje trvalý průchod tzv. zbytkového stejnosměrného proudu. Z tohoto důvodu jsou jako pamět’ový prvek zcela nevhodné elektrolytické kondenzátory.

Velkou pozornost je nutno také věnovat dielektrické absorbci pamět'ového kapacitoru. Jak bylo již uvedeno dř́ve, nabije-li se kapacitor na určité napětí, část náboje se váže $\mathrm{s}$ dielektrikem a nelze ho při vzorkování následující hodnoty úplně odstranit. Nevhodný výběr kapacitoru s velkou dielektrickou absorbcí může způsobit velkou chybu zapamatovaného napětí ŕádově $\mathrm{mV}$. Jako materiál dielektrika se doporučuje volit polystyrén nebo polypropylen, které vykazují součinitel dielektrické absorbce lepší než 0,02\%. Špatné dielektrické vlastnosti mají kapacitory s keramickým dielektrikem. Bohužel dielektrická absorbce se liší kus od kusu a některé série kondenzátorů s polystyrenovým či polypropylenovým dielektrikem mohou vykazovat velkou dielektrickou absorbci. Proto se vyplatí investovat 30 až 50 \% ceny navíc a pro vzorkovače koupit kapacitory se zaručenou malou dielektricku absorbcí.

\subsubsection{Doporučení pro návrh plošného spoje}

Velká pozornost se musí také věnovat návrhu plošného spoje vzorkovače či sledovače s pamětí, protože u těchto obvodů je na závadu pronikání svodových proudů po znečištěném povrchu plošného spoje do citlivé svorky pamět'ového kapacitoru. Nosným prostředím těchto svodových proudů je elektrolytická kaše na povrchu plošného spoje vzniklá z prachu, ze zbytků pájedel, poutanou vlhkostí či vlhkostí ze zkondenzovaných par. Svodové proudy mohou být minimalizovány promyšleným použitím vodivého izolačního prstence, který obklopuje citlivý uzel a je na stejném potenciálu jako tento uzel. Vzhledem k tomu, že mezi nimi pak není žádný rozdíl potenciálů, nemůže mezi nimi téci žádný svodový proud. Poznamenejme ještě, že svodové proudy tekoucí po povrchu plošného spoje jsou daleko větší než vnitřní objemové proudy tekoucí izolačním materiálem a proto se doporučuje izolační prstence provést na obou stranách plošného spoje a $v$ prŕípadě vícevrstvého plošného spoje i ve všech vnitřních vrstvách.

Připojení prstence na vhodný potenciál musí být velmi dobře promyšleno a je zapotřebí znát alespoň zjednodušené vnitřní zapojení integrovaného vzorkovače. Např. ve zpětnovazebním zapojení na Obr. 13.23 se citlivý uzel pamětového kapacitoru $C_{\mathrm{p}}$ nachází na stejném potenciálu, jaký je na výstupu napětového sledovače s OZ2. Aby byl tento uzel chráněn proti svodovým proudům tekoucím po povrchu desky plošného spoje, je nutno prstenec připojit na výstup napět'ového sledovače s OZ2, který představuje „tvrdý“ zdroj napětí (s malým vnitřním odporem) a je tedy schopen svodové proudy absorbovat. 


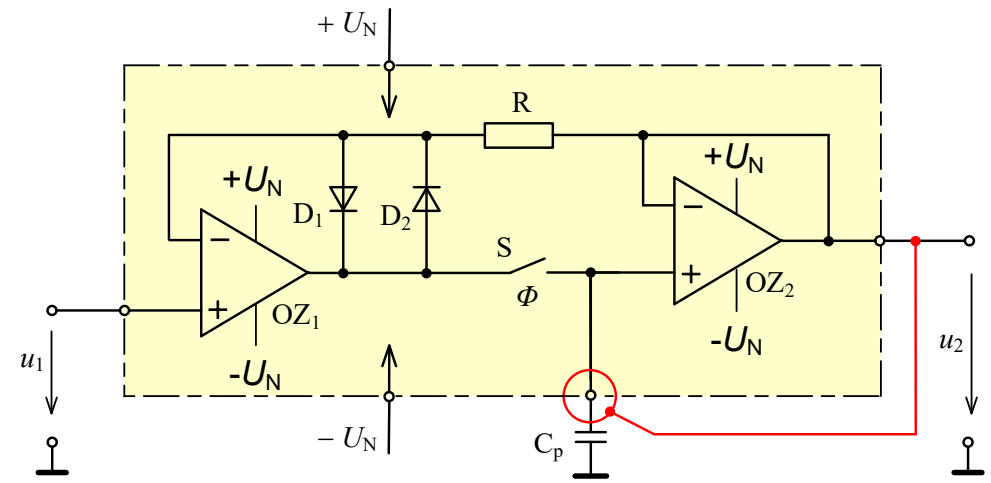

Obr. 13.23: Aktivní izolace pamět’ového kapacitoru na desce plošného spoje

Jiná situace je v prŕípadě vzorkovače s integrátorem (viz Obr. 13.24), protože citlivý uzel pamět'ového kapacitoru je nyní na nulovém potenciálu, který se udržuje na invertující vstupní svorce $\mathrm{OZ}_{2}$ (tzv. „virtuální nula“). V tomto př́ípadě se ochranný prstenec připojí na nulový potenciál.

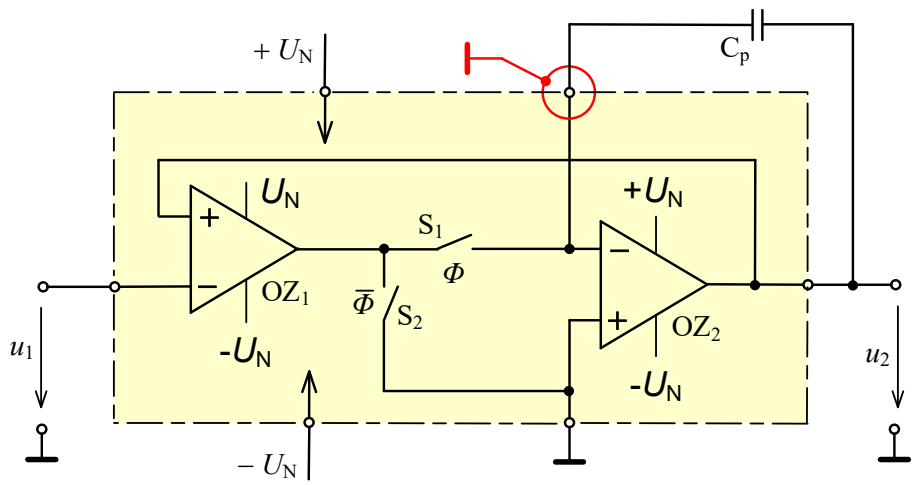

Obr. 13.24: Izolace pamět'ového kapacitoru uzemněným prstencem

\subsection{Aplikační pravidla pro komparátory}

\subsubsection{Základní zásady}

Při použití komparátorů je nutné vyloučit parazitní vazby mezi vstupem a výstupem komparátoru, jinak dojde k jeho samovolnému rozkmitání. Situaci vysvětluje Obr. 13.25a, na kterém je mezi výstupem a invertujícím vstupem parazitní kapacita $C_{\mathrm{PAR}}$ o kapacitě pouhého $1 \mathrm{pF}$. Při každém překlopení komparátoru se na jeho výstupu objeví velmi ostrá hrana $-\mathrm{u}$ moderních komparátorů mají běžně strmost (rychlost přeběhu) $\Delta u / \Delta t=100 \mathrm{~V} / \mu \mathrm{s}$ i více. Snadným výpočtem zjistíte, že po dobu trvání hrany bude parazitní kapacitou procházet proud

$$
i_{\mathrm{PAR}}=C_{\mathrm{PAR}} \frac{\Delta u}{\Delta t}=1 \cdot 10^{-12} \cdot \frac{100}{1 \cdot 10^{-6}}=100 \mu \mathrm{A} .
$$

Tento proud na vstupní impedanci zdroje signálu $R_{\mathrm{i}}=100 \Omega$ vyvolá špičkový úbytek napětí okolo $10 \mathrm{mV}$, který se přičte $\mathrm{k}$ užitečnému signálu. Taková změna však dokáže spolehlivě komparátor překlopit zpět a celý proces se může opakovat - komparátor začne kmitat na vysoké frekvenci. Poznamenejme, že u klasického komparátoru (tj. s dvojčinným výstupem) je ke vzniku tohoto jevu náchylný právě invertující vstup. Existují však i komparátory s obrácenou 
logikou výstupu, u kterých je pak naopak náchylnější neinvertující vstup. Nicméně v obou př́ípadech je pronikání špiček do vstupního signálu nežádoucí, takže je snahou $\mathrm{C}_{\mathrm{PAR}}$ minimalizovat. Výrobci komparátorů o tomto problému pochopitelně vědí a záměrně vstupy a výstupy umist'ují na opačné strany pouzdra IO. To je vidět i na Obr. 13.25b, ve kterém parazitní kapacita $C_{P A R}$ vznikla nesprávným vedením spojů - takové uspořádání by zaručeně vedlo ke kmitání. Naopak na Obr. 13.25c je správné provedení, kdy jsou vstupní a výstupní spoje vedeny co nejdále od sebe. Pro další potlačení vzájemných vazeb jsou pod IO vedeny zemní plochy, které slouží jako stínění.

Z podobného důvodu se doporučuje vstupní prrívody komparátoru po celé délce chránit zemními plochami proti pronikání takovýchto špiček ze všech sousedících vodičů, které přenášejí digitální signály. Aby se omezila úroveň pronikajících špiček přes zbylé parazitní kapacity, doporučuje se vstupy komparátoru budit z „tvrdých“ zdrojů napětí, tj. ze zdrojů $\mathrm{s}$ výstupním odporem menším než $1 \mathrm{k} \Omega$.

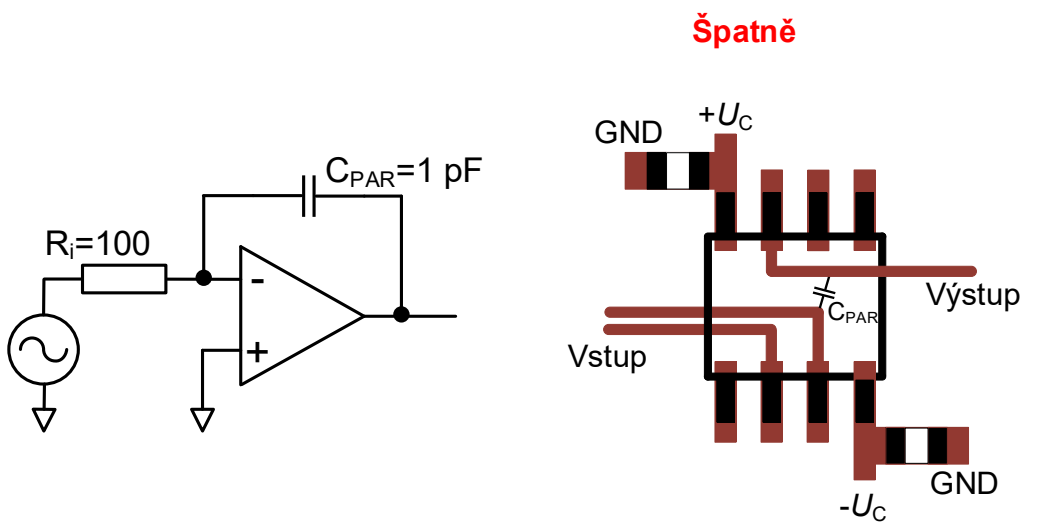

a

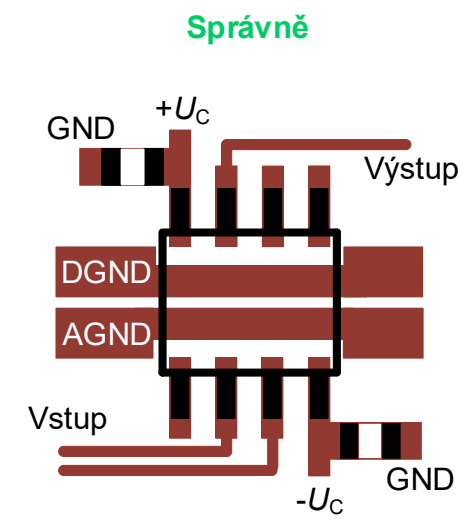

c

Obr. 13.25: Vedení spojů komparátoru

Rychlé komparátory využívají pro rychlé překlopení vydatnějších zdrojů proudu pro nabíjení parazitních kapacitorů uvnitř integrovaného obvodu. To způsobuje špičkové odběry proudu z napájecích zdrojů. Napájecí rozvody proto musí být masivní a musí být velmi kvalitně zablokovány. Výběr blokovacích kondenzátorů se odvíjí od rychlosti komparátoru pro potlačení ostřejších proudových špiček jsou zapotřebí i kondenzátory na vyšší pracovní kmitočty. Dnes se k tomuto účelu téměř výhradně používají keramické kondenzátory. Pro vysokorychlostní komparátor je možné použít například paralelní kombinaci tří kondenzátorů: $10 \mu \mathrm{F}$ a $100 \mathrm{nF}$ z materiálu X7R a $1 \mathrm{nF}$ z materiálu NP0. Každý z nich je nejúčinnější v jiném kmitočtovém pásmu a navzájem se doplňují. Přitom platí, že čím menší (SMD) pouzdro se použije, tím lepši jsou frekvenční vlastnosti kondenzátoru. Kondenzátor $1 \mathrm{nF}$ musí být co nejblíže pouzdra a ostatní dva v jeho těsné blízkosti. Kondenzátory musí být umístěny a propojeny tak, aby byla co nejkratší proudová smyčka do země. Doporučené zapojení blokovacích kapacitorů včetně řešení plošného spoje je uvedeno na Obr. 13.26a. Země jsou rozděleny na signálovou analogovou AGND, číslicovou DGND a na výkonovou GND. Země se vzájemně propojí až v centrálním zemnicím uzlu celého zařízení. V případě, že vstupní analogová část je napájena ze symetrického zdroje a výstupní digitální část $\mathrm{z}$ nesymetrického napájecího zdroje, dostačuje takto kvalitně blokovat pouze výstupní část obvodu komparátoru (viz Obr. 13.26b). Protože každý komparátor má jiné parametry a rozmístění vývodů na pouzdru, je vhodné se při výběru blokovacích kondenzátorů a jejich umíst'ování rrídit doporučením výrobce. 

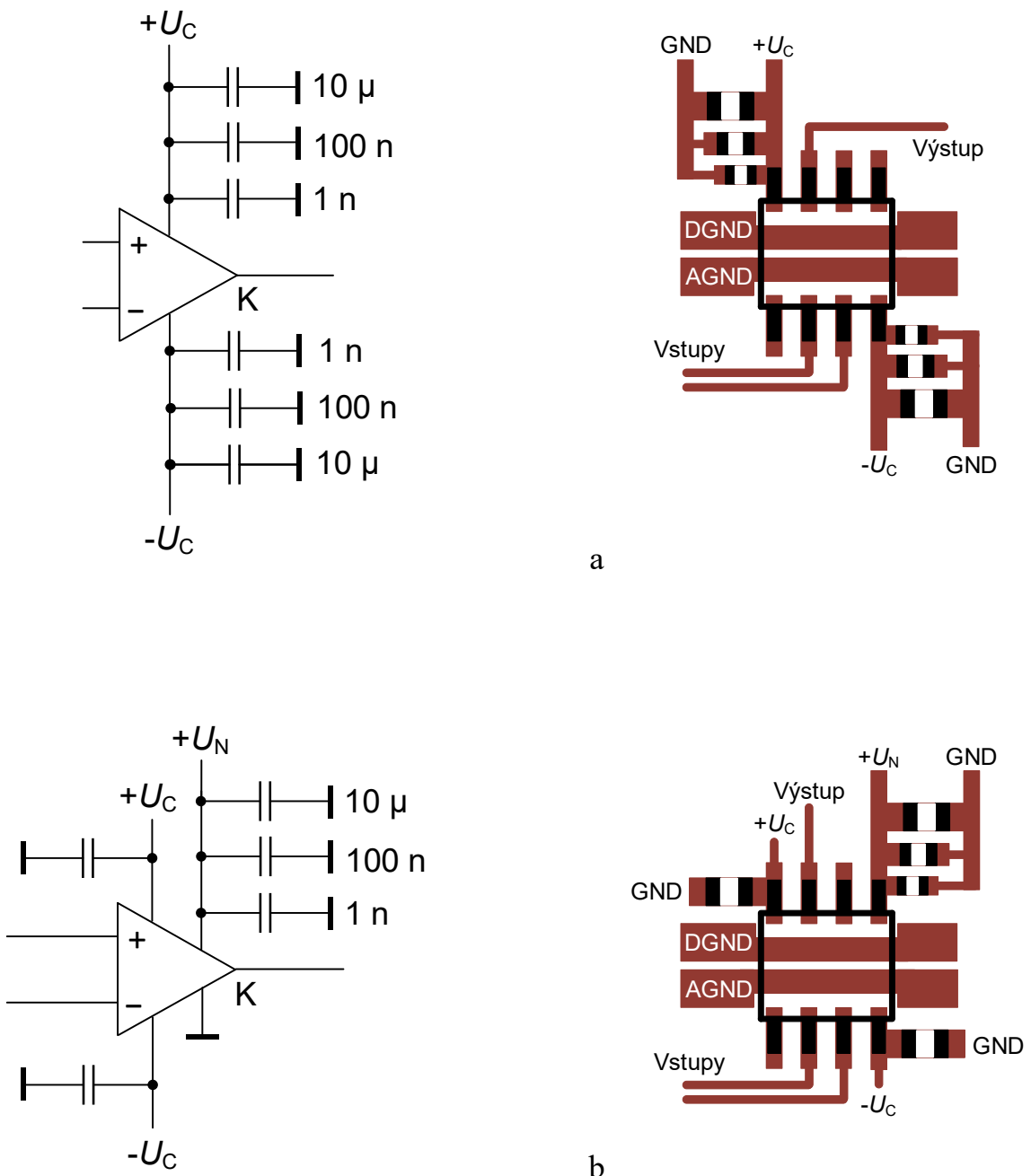

b

Obr. 13.26: Blokování napájecích přívodů rychlých komparátorů: a) při napájení vstupní i výstupní části ze symetrických zdrojů, b) při napájení vstupní části ze symetrických zdrojů a výstupní části z nesymetrického zdroje

\subsubsection{Shrnutí zásad při aplikaci komparátorů}

Při použití komparátorů je tedy nutné dodržovat následující zásady:

1. Nikdy nepoužívejte zbytečně rychlé komparátory - jsou náchylnější ke kmitání, jejich spotřeba je vždy vyšší a jejich použití je náročnější.

2. Vstupní a výstupní spoje musejí být vedeny na DPS co nejdále od sebe, viz Obr. 13.25c.

3. U komparátorů s drátovými vývody nesmí být použity patice, protože výrazně zvyšují parazitní kapacity mezi vývody.

4. V př́padě potřeby je vhodné zavést hysterezi nebo použít komparátor s interní hysterezí.

5. Komparátory při překlápění vyvolávají proudové špičky v zemním rozvodu. V př́padě komparátorů s oddělenými zeměmi (AGND, DGND) se proudové špičky vyskytují zejména v digitální části komparátoru. Rozvod zemí by proto měl být masivní, u rychlých komparátorů se obvykle doporučuje použít souvislé plochy mědi. Ty by měly vést i mezi vstupy a výstupem, jak ukazuje Obr. 13.25c. U velmi rychlých komparátorů je doporučeno použít čtyřvrstvý plošný spoj, kdy v první vnitřní vrstvě je souvislá zemní plocha a v druhé vnitřní vrstvě je masivní rozvod napájení. Ovšem pozor, takové plochy současně zvyšují 
kapacity signálových spojů proti zemi, což může degradovat rychlost překlopení komparátoru.

6. Stejné proudové špičky se objevují i v napájecích přívodech. Jak bylo zmíněno výše, u velmi rychlých komparátorů musí být jejich napájecí rozvod masivní, aby měl nízkou impedanci. Obvykle jsou opět požadovány souvislé plochy ve vnitřních vrstvách DPS.

7. Napájecí vstupy komparátorů proto musí být velmi kvalitně blokovány v blízkosti pouzdra komparátoru. Pro blokování napájení se uživají kapacitory určené pro vyšší pracovní kmitočty a napájení rychlých komparátorů se nejlépe zablokuje třemi paralelně zapojenými kapacitory $10 \mu \mathrm{F}, 100 \mathrm{nF}$ a vf kapacitoru $1 \mathrm{nF}$.

8. Oba vstupy by měly být buzeny ze zdrojů o podobné impedanci. Pro jejich vyrovnání je možné do vstupu sériově zapojit rezistory.

\subsection{Aplikační doporučení pro časovače}

Do kategorie časovačů se řadí generátory periodicky se pakujících pravoúhlých kmitů, tzv. multivibrátory a dále obvody, které generují jednorázové impulsy po přesně definovanou dobu, tzv. nonostabilní klopné obvody. Ve většině prŕípadů jsou založeny na nabíjení resp. vybíjení kapacitoru, kdy napětí na kapacitoru je porovnáváno s referenčním napětím pomocí komparátoru či komparátorů. Výstupní napětí časovačů má většinou logické úrovně a proto bývají často zařazovány do kategorie číslicových obvodů. Ve skutečnosti tomu tak není a při aplikaci časovačů se musí pracovat obezřetně. Úskalí při aplikacích si vysvětlíme na příkladu časovače na Obr. 13.27 zapojeného jako multivibrátor.

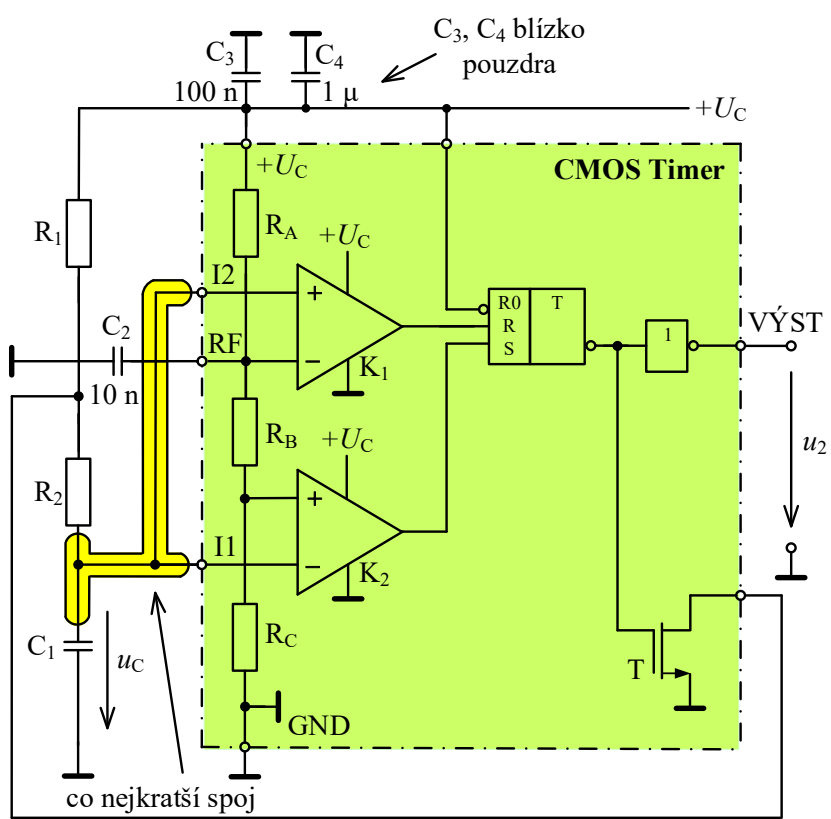

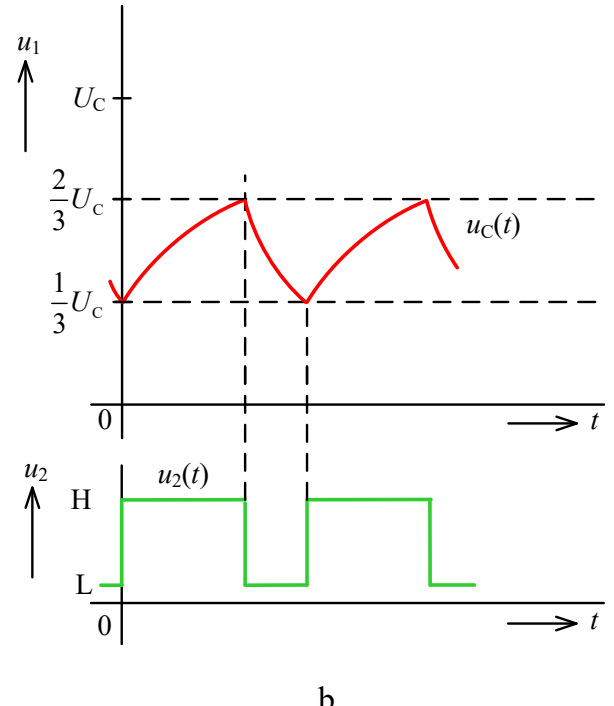

$\mathrm{b}$

Obr. 13.27: Časovač zapojený jako multivibrátor

Na Obr. 13.27 je záměrně rozkresleno zjednodušené vnitřní zapojení integrovaného časovače, aby bylo zcela zřejmé, které vstupy obvodu jsou citlivé na pronikání rušivých signálů. Př́vodní vodiče k oběma komparátorům musí být velice krátké. Kromě toho může snadno dojít k průniku rušivých napětí na kapacitor $C_{1}$, a to parazitní kapacitní vazbou z okolních vodičů vykazující prudké změny úrovní signálu (např. číslicové signály). Může tak nastat strhávání 
kmitočtu multivibrátoru. Proto od tohoto uzlu odkloníme i ve vnitřních vrstvách desky plošného spoje zejména ty vodiče, kterými jdou signály vyznačující se velkými skokovými změnami. V kritických případech můžeme tento bod chránit elektrostatickou bariérou spojenou se zemí, popř. na horní straně desky ponechat pod pouzdrem komparátoru souvislou zemní vrstvu plošného spoje. Napájecí vývod je zapotřebí zablokovat opět co nejblíže pouzdra elektrolytickým či vícevrstvým kondenzátorem $1 \mu \mathrm{F}$ a $\mathrm{k}$ němu paralelně připojit keramický vf kapacitor $100 \mathrm{nF}$. Protože vnitřní dělič sestávající ze tří rezistorů se shodnými odpory je napájen prrímo z napájecího rozvodu, doporučuje se vstup RF zablokovat keramickým kapacitorem 10 nF. V prŕípadě, že chceme docílit větší přesnosti, je možné na svorku RF připojit vnější zdroj referenčního napětí se stabilitou lepší než má napájecí zdroj. Pak je ovšem kapacitor $C_{2}$ zbytečný.

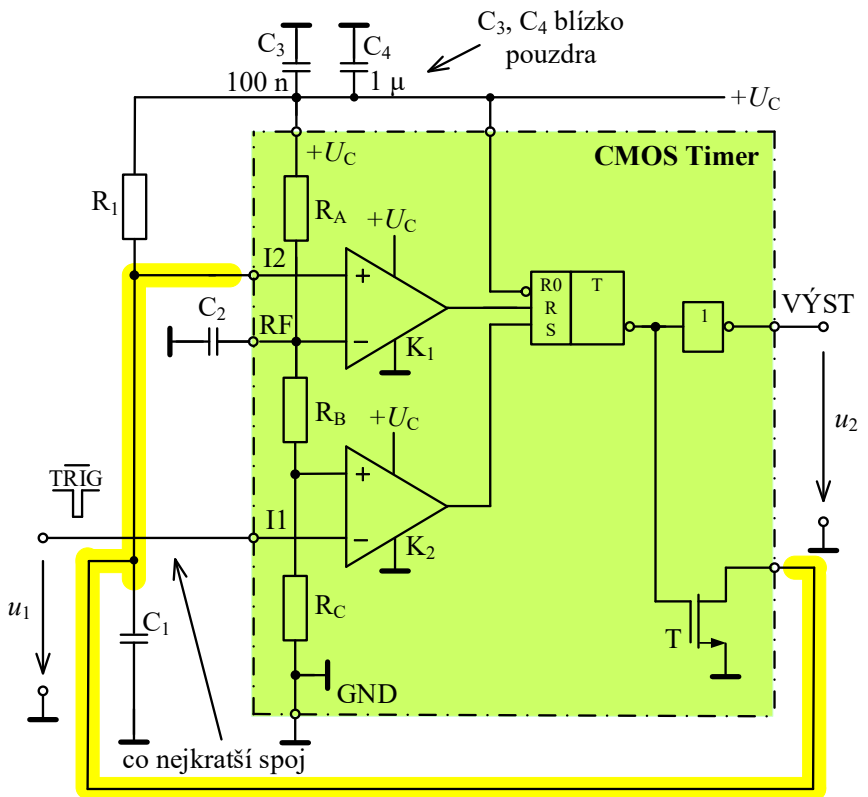

a

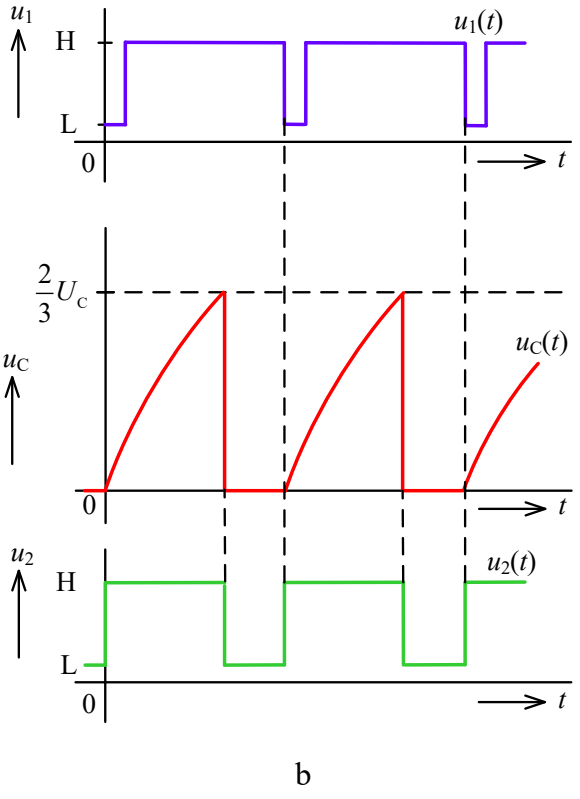

Obr. 13.28: Časovač zapojený jako monostabilní klopný obvod

Ještě větši péči při návrhu plošného spoje vyžaduje zapojení monostabilního klopného obvodu s časovačem na Obr. 13.28. Zde navíc musí být i krátký spoj vedený z kapacitoru $C_{1}$ na vývod spínacího tranzistoru T. I v tomto př́ípadě se kapacitor $C_{1}$ chová jako tzv. „měkký zdroj napětí“ a veškeré rušivé signály, které se dostanou do tohoto uzlu mohou způsobit zkrácení či prodloužení časového intervalu generovaného impulsu. Doporučené řešení plošného spoje pro tento monostabilní klopný obvod je uvedeno na Obr. 13.29.

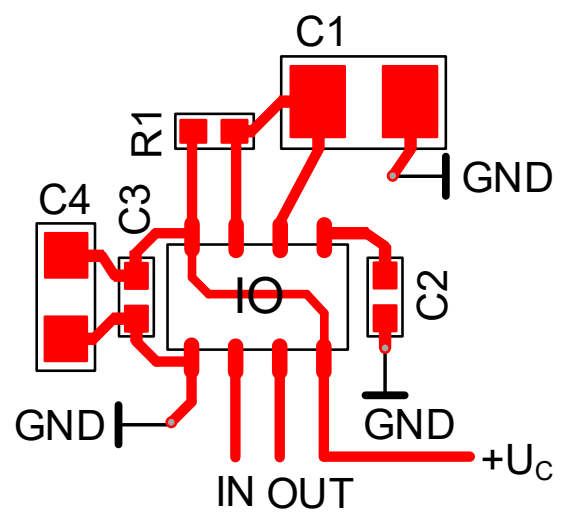

Obr. 13.29: Doporučený plošný spoj pro zapojení monostabilního klopného obvodu s časovačem 
Jiný typ jednoúčelového monostabilního klopného obvodu uvedený na Obr. 13.30 je všemi výrobci jednoznačně zařazen do kategorie logických obvodů. Z principiálního zapojení je však zřejmé, že má svoji analogovou část, která je citlivá na vnější vlivy.
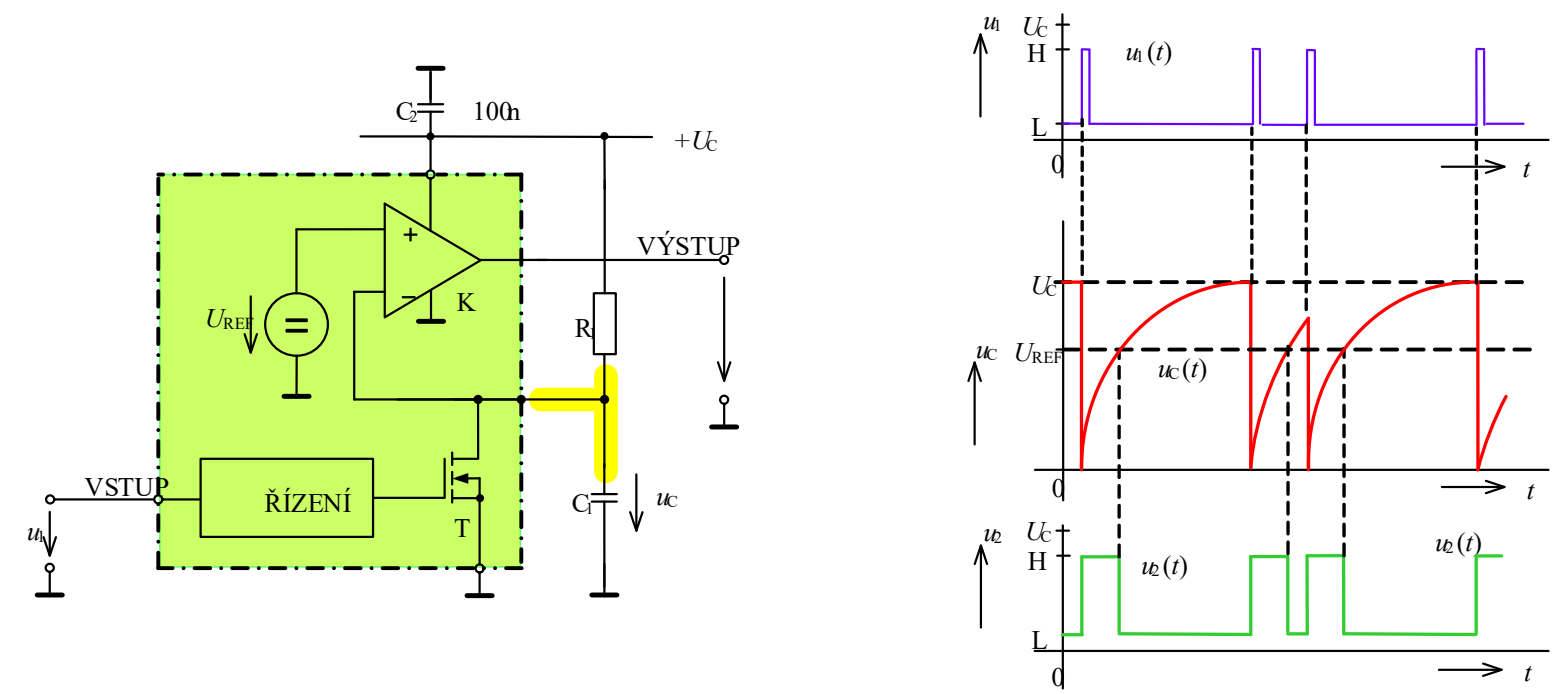

Obr. 13.30: Monostabilní klopný obvod

V klidu je tranzistor T rozpojen a kapacitor je nabit na napětí $U_{\mathrm{C}}$. Jestliže je na vstup časovače přiveden časovací impuls, řídicí obvod na okamžik sepne tranzistor T a kapacitor $C_{1}$ se rychle vybije a pak se začne nabíjet s časovou konstantou $R_{1} C_{1}$ na napájecí napětí. Výstupní napětí komparátoru má v této době hodnotu H. Jakmile napětí na kapacitoru dosáhne hodnoty interně nastaveného referenčního napětí $U_{\mathrm{REF}}$, dojde k překlopení komparátoru a na jeho výstupu bude $\mathrm{L}$.

Je zřejmé, že kritickým uzlem je zde vstup komparátoru připojený $\mathrm{k} R_{1}$ a $C_{1}$. Kolem tohoto uzlu se nedoporučuje vést žádné logické signály, protože průnik rušení do tohoto obvodu může způsobit zkrácení či prodloužení výstupních impulsů monostabilního obvodu. Tento uzel má být co nejmenší a v kritických př́ípadech se doporučuje pod integrovaným obvodem a $\mathrm{v}$ jeho okolí rozvést zemnicí plochy.

Většina multivibrátorů či monostabilních klopných obvodů pracuje na stejném principu založeném na nabíjení kapacitoru v RC obvodu. Vzhledem k tomu, že se používají externí rezistory a kapacitory, bude přesnost těchto obvodů určena zejména výrobními a tepelnými tolerancemi těchto obvodových prvků. Rezistory do RC článku vybíráme přesné a stabilní $\mathrm{s}$ nízkým teplotním koeficientem lepším než $\pm 15 \mathrm{ppm} /{ }^{\circ} \mathrm{C}$. Kapacitory volíme taktéž přesné a stabilní třídy 1, nejlépe s nulovým teplotním součinitelem (COG/NPO aj.). Kapacitor by měl vykazovat malou dielektrickou absorbci lepší než $0,2 \%$. 


\section{Použitá literatura}

[1] GRAME, J. G. Designing with Operational Amplifiers - Applications Alternatives. New York, McGraw-Hill Book Company, 1977

[2] CONNELLY, J. A. ed. Analog Integrated Circuits - Devices, Circuits, Systems, and Applications. New York, John Wiley and Sons 1983

[3] TIETZE, U.; SCHENK, CH.; GAMM, E. Electronic Circuits. Hand book for Design and Applications. 2nd edition, Springer - Verlag, Berlin 2008. ISBN 978-3-54000429-5

[4] TIETZE, U.; SCHENK, CH. Electronic Circuits. Design and Applications. Springer Verlag, Berlin 1991. ISBN 3-540-50608-X

[5] DOSTÁL, J. Operační zesilovače. BEN, Praha 2005

[6] DOSTÁL, J. Operational Amplifiers. Elsevier, Amsterdam 1981

[7] ROBERGE, J. K. Operational Amplifiers. J. Wiley, New Your, London, Sydney, Toronto 1975

[8] VRBA, K.; VRBA, K. jun. Technika analogových obvodů a systémů. Skriptum, 4. vydání. Ediční středisko VUT Brno,1989

[9] VRBA, K.; VRBA, K. jun. Technika analogových obvodů a systémů - sbírka př́kladů. Skriptum, 3. vydání. Ediční středisko VUT Brno,1989

[10] CLAYTON, G.B. Operational Amplifier. London, Butterworth Co 1971

[11] HUIJSING, J.H. Operational Amplifiers - Theory and Desing. Kluwer Academic 


\section{Počítačová analýza analogových obvodů}

\section{1 Úvod do počítačové analýzy analogových obvodů}

Ověřování činnosti elektronických obvodů lze provést dvěma způsoby. Bud' experimentálně, kdy vzorek je postaven z diskrétních součástek a za pomoci měřicí techniky je činnost zkoumána, nebo lze použít vhodný simulační nástroj - zpravidla počítačový program. Obě metody mají samozřejmě své výhody a nevýhody. Pro počítačovou analýzu se spíše hodí výraz simulace a v dnešní době slouží k prvotnímu ověření činnosti a chování zkoumaného obvodu. Tyto programy jsou založeny na některé známé numerické metodě řešení obvodů. Činnost simulačních programů vyžaduje použití vhodných modelů prvků. Tak, jako jsou metoda řešení obvodů zpravidla dána, je tvorba vhodných modelů pro simulační programy již podstatně složitější, a to především u aktivních prvků. Renomovaní výrobci aktivních součástek dnes běžně poskytují počítačový model daného prvku. Za takový standard jsou považovány modely pro simulátor SPICE (,Simulation Program with Integrated Circuit Emphasis“ - jedná se o program používaný při návrhu integrovaných obvodů, ke kontrole integrity obvodů a $\mathrm{k}$ predikci chování obvodů.). Tyto modely jsou použitelné i pro řadu jiných simulačních programů, včetně programu Micro-Cap (MC).

Existují i další simulační programy, které většinou jsou jistým „klonem“ výše zmíněných programů. Mají zpravidla stejné výpočetní jádro a liší se zejména schématickým editorem, definicí součástek a modelů, případně odlišným způsobem ovládání, zobrazením výstupních průběhů či kompatibilitou s ostatními programy nebo jsou součástí jiných systémů, zpravidla pro návrh plošných spojů. Jsou to např́iklad programy TINA, Multisim, Eagle a jiné.

Z předchozího tedy jednoznačně vyplývá, že kvalita simulace je dána jednak použitou numerickou metodou, přičemž nejvíce používanou je modifikovaná metoda uzlových napětí a dále použitými modely součástek. Co se týče používaných numerických metod, zde zpravidla problém nenastává. Podstatně horší situace, jak již bylo řečeno, je u modelů vlastních prvků. Je nutno zdůraznit, že neexistuje univerzální model. Použitý model výrazně ovlivňuje dosažené výsledky. To je zapotřebí mít na paměti. Při každé simulaci je proto nutné zvolit vhodný model a seznámit se s jeho strukturou. Může se snadno stát, že sledovaný jev daný model neumožňuje vůbec modelovat a výsledky jsou pak zavádějící, aniž si to uvědomíme. V některých speciálních př́padech je nutné si vhodný model vytvořit. Tvorba modelů je samostatná a poměrně složitá technická disciplína. Pro základní simulace obvodů většinou vystačíme se standardními modely, které jsou implementovány $\mathrm{v}$ jednotlivých programech. Jak již bylo zmíněno výše, všeobecně dostupné modely prvků SPICE pokryjí prakticky všechny základní potřeby požadovaných simulací. Je ovšem nutné dobře porozumět jednotlivým parametrům, které model popisují, a to u některých modelů elektronických součástek může vyžadovat poměrně hluboké znalosti.

Výše uvedené obvodové simulátory SPICE a Micro-Cap a jsou jistým standardem v oblasti počítačové simulace. Zkušenosti ukazují, že pro začátečníky je program Micro-Cap vhodnější. Ovládání je více intuitivní a nevyžaduje významnou znalost různých nastavení, respektive i při základním nastavení lze snadno ověřit funkci řady obvodů nejen analogových, ale i číslicových či smíšených. K dispozici je řada ukázkových př́kladů či makroobvodů, které jsou součástí běžné instalace programu. Proto je tento program často využíván pro počítačovou analýzu analogových obvodů a dále proto budou uvedeny ukázkové simulace v programu 
Micro-Cap. Poslední dostupnou verzí je verze 12 (z roku 2020), která je použita pro dále uvedené ukázky řešení obvodů. Základní způsob ovládání je zachován ve všech předchozích verzích a dá se očekávat, že tomu tak bude i ve verzích následujících.

SPICE je spíše profesionálnější nástroj s celou řadou možností a nastavení, proto je pro použivání poněkud složitější a méně znalým trvá delší dobu, než jsou schopni získat jistou orientaci v programu. Firmami je SPICE podporován a výrobci elektronických součástek poskytují SPICE modely vyráběných typů součástek a tyto modely jsou pak považovány za standardy modelů pro počítačovou simulaci.

Program SNAP je méně známý nástroj pro semisymbolickou analýzu obvod. Jeho výhodou je možnost zadání prvků pomocí obecných parametrů a výstupem je pak funkce popsaná opět obecnými parametry. Umí také realizovat numerickou analýzu, nebo i kombinovanou analýzu, kdy některé prvky jsou zadány obecně a některé numericky.

\subsubsection{Základní vlastnosti simulačního nástroje Micro-Cap}

Micro-Cap je produktem firmy Spectrum Software (http://www.spectrum-soft.com) a je charakterizován jako počítačový obvodový simulátor s integrovaným schematickým editorem, s lehce pochopitelným nastavením parametrů simulace a dobře propracovanou a jednoduše nastavitelnou grafickou prezentací výsledků. Software Micro-Cap je určen především pro operační systém Windows, lze jej však provozovat v systémech Linux pomocí emulátoru Wine. Program Micro-Cap verze 12 je volně dostupný v plné verzi. Předchozí verze vyžadovaly hardwarový klíč a volně dostupná byla tzv. „školní“ (verze edu), která obsahovala knihovnu s omezeným počtem elektronických prvků a omezeným počtem uzlů ve schématu.

Program na základě obvodového schématu sestaví matematický popis obvodu (soustavu rovnic), jejichž řešení je provedeno pomocí numerických metod. Jádro programu pracuje na principu modifikované metody uzlových napětí a vytváří zkrácenou pseudoadmitanční matici. Z toho vyplývají i některé vlastnosti programu. Pro simulaci se používají jak vlastní modely či upravené modely Micro-Cap, př́padně modely SPICE nebo makromodely. Správnost výsledků simulace závisí na výchozích podmínkách, nastavení parametrů simulace, výpočtu pracovního bodu apod. Tyto parametry lze variantně nastavovat, ale i v základním nastavení simulátor poskytuje dobré výsledky pro většinu standardních obvodů.

Tato kapitola neslouží jako manuál programu. Uvedené informace jsou účelově zaměřené na rychlou orientaci při použití simulátoru při řešení vzorových prríkladů. Prríklady ukazují základní analýzy obvodů s operačními zesilovači, model operačního zesilovače a základní nastavení parametrů analýz a výsledků analýz.

Program Micro-Cap poskytuje řadu analýz, mezi základní analýzy patří zejména:

- Analýza v časové oblasti (Transient analysis). Přechodová analýza zobrazuje chování obvodu v časové oblasti, a to $\mathrm{v}$ závislosti na počátečních podmínkách nebo na časově závislých zdrojích připojených do obvodu. Tato analýza představuje „klasický“ osciloskop.

- Kmitočtová analýza (AC analysis). Kmitočtová analýza zahrnuje simulaci obvodu buzeného signálem o malé amplitudě. Dostupné jsou tyto charakteristiky: modulová a fázová charakteristika v lineárním a logaritmickém měřítku, skupinové zpoždění, průběh vstupní impedance, vstupní admitance, výstupní impedance, výstupní admitance, vstupní a výstupní šum v lineárním a logaritmickém měřítku, Nyquistovy diagramy. Všechny výstupy, kromě šumu, jsou komplexní a vyjadřují se modulem a fází v závislosti na kmitočtu. Jestliže obvod 
obsahuje nelineární prvky, systém vypočte pracovní bod a linearizuje obvod v okolí výsledných stejnosměrných napětí.

- Stejnosměrná analýza (DC analysis). Stejnosměrná analýza nabízí buzení obvodu pro různé průběhy až pro dva proměnné zdroje, přenosové funkce, vliv ofsetů, klidových proudů, napětí, zahrnuje krokování vstupního zdroje napětí nebo proudu a měření výsledného výstupního napětí nebo proudu.

- Fourierova spektrální analýza. Fourierova analýza vyhodnocuje průběhy vytvořené v časové (tranzient) analýze. Výstupem je soubor $N$ datových bodů. Předpokládá se, že každá hodnota představuje hodnotu průběhu (obvykle napětí nebo proudu) $\mathrm{v}$ každém časovém okamžiku.

- Statistická analýza - Monte Carlo. Použíá se ke statistickému testování parametrů obvodu. Pro každý jednotlivý výpočet jsou vygenerovány nové parametry, které odpovídají určitému typu rozdělení a nacházejí se v zadaném tolerančním pásmu daného prvku.

Prvky analyzovaného obvodu - schéma obvodu se skládá z pasivních prvků (rezistory, kapacitory, induktory, diody, přenosové články, transformátory včetně nelineárního magnetického jádra) a z aktivních prvků (bipolární tranzistory, MOSFETy, JFETy, MESFETy, operační zesilovače). Dále jsou k dispozici časově závislé zdroje (sinusové zdroje, pulsní zdroje, zdroje konstantního napětí nebo proudu, zdroje definované uživatelem ve formě vztahu nebo souboru dat), lineární Laplaceovské zdroje (algebraicky a tabelárně definované přenosové zdroje s komplexním kmitočtem), nelineární funkční zdroje $f(u, i, t)$ (algebraicky a tabelárně definované zdroje), makra (reprezentující modely kompletních obvodů, obsahující elementární prvky) a spínače (ř́zené napětím, proudem nebo časem).

Integrovaný schématický editor - schématický editor umožňuje vytvářet vícestránková obvodová schémata. Při kreslení schémat jsou k dispozici obvyklé nástroje, jako je změna měřítka zobrazení, vkládání objektů, výběr částí schémat, otáčení prvků, zrcadlení či využití funkcí „clipboardu“ - kopírování obsahu bloku do pomocné paměti. Pro tvorbu vlastních schematických značek je v programu Micro-Cap zabudovaný schématický editor, který umožňuje vytvářet a upravovat značky prvků. Obsahuje množinu značek, které mohou být modifikovány tak, aby vyhovovaly uživateli nebo mohou být přidávány značky nové. K tomu slouží moduly - Shape editor - editace a tvorba nových schématických značek, Component editor - propojení schématické značky a vlastního matematického modelu at' již v interní nebo externí knihovně, Package editor - tvorba knihovny pouzder součástek, vytvoření netlistu simulovaného obvodu pro další programy (např. pro návrh plošných spojü).

Kompatibilita - Micro-Cap umožňuje pracovat se standardními textovými formáty pro SPICE. Je možné načíst či uložit schémata ve SPICE formátu a používat pro simulace modely SPICE.

Digitální simulátor - Micro-Cap poskytuje simulace číslicových obvodů i tzv. smíšených obvodů (mixed-mode simulatio), umožňující simulovat obvody na analogové a logické úrovni současně.

Návrh aktivních a pasivních filtrů - program poskytuje prostředky pro návrh dolních propustí, horních propustí, pásmových propustí, pásmových zádrží nebo zpožd’ovacích článků s různými typy aproximací dle Čebyševa, Butterwortha, Bessela. 


\subsubsection{Instalace programu Micro-Cap 12}

Program Micro-Cap verze 12 lze zdarma stáhnout na adrese: http://www.spectrumsoft.com/download/download.shtm. Po načtení stránky ve webovém prohlížeči zvolíme stažení patřičného souboru, Full CD jak je naznačeno na Obr. 14.1.

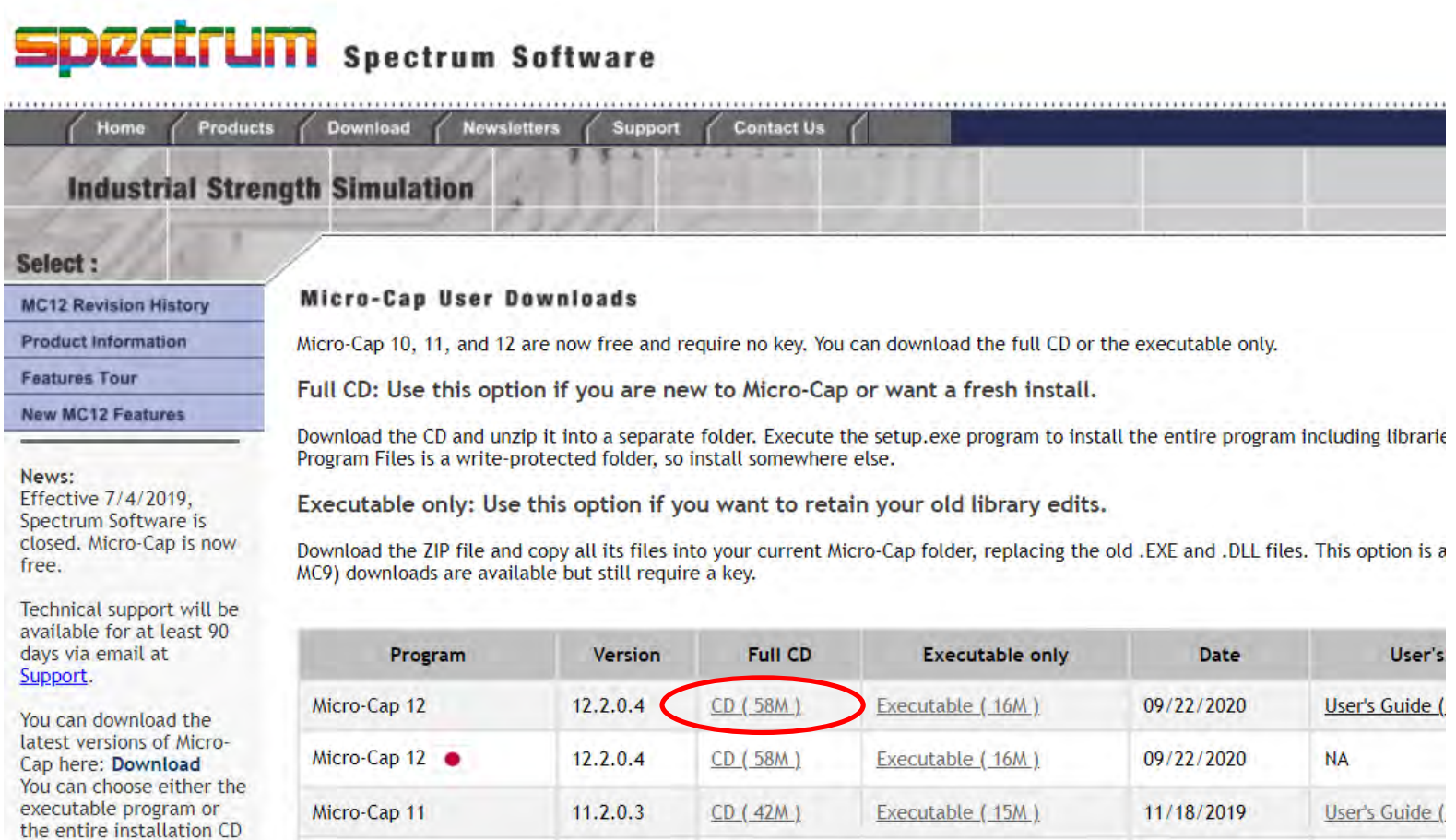

Obr. 14.1: WWW stránky Micro-Cap Spectrum Software.

Program lze spustit př́mo $\mathrm{z}$ extrahované složky kliknutím na mc12.exe nebo mc12_64.exe dle požadované verze, (není třeba instalovat).

Druhou možností je instalace pomocí setup.exe. Jedná se o standardní instalaci obvyklou v systému Windows a př̀i vhodně zvolené instalaci se na ploše monitoru objeví ikona na spuštění programu. 


\subsubsection{Základní okno Micro-Cap}

Po nainstalování a následném spuštění programu se zároveň otevře nový prázdný soubor schématu zapojení obvodu s názvem circuit1.cir. V základním okně schématického editoru na Obr. 14.2. je uveden základní popis jednotlivých ikon, které se používají při zadávání nového schématu. Zobrazení jednotlivých ikon je závislé na nastavení programu, ale ve většině případů bude horní lišta vypadat, jak je uvedeno. Ostatní ikony v uživatelském nastavení jsou všeobecně známé z prostředí Windows.

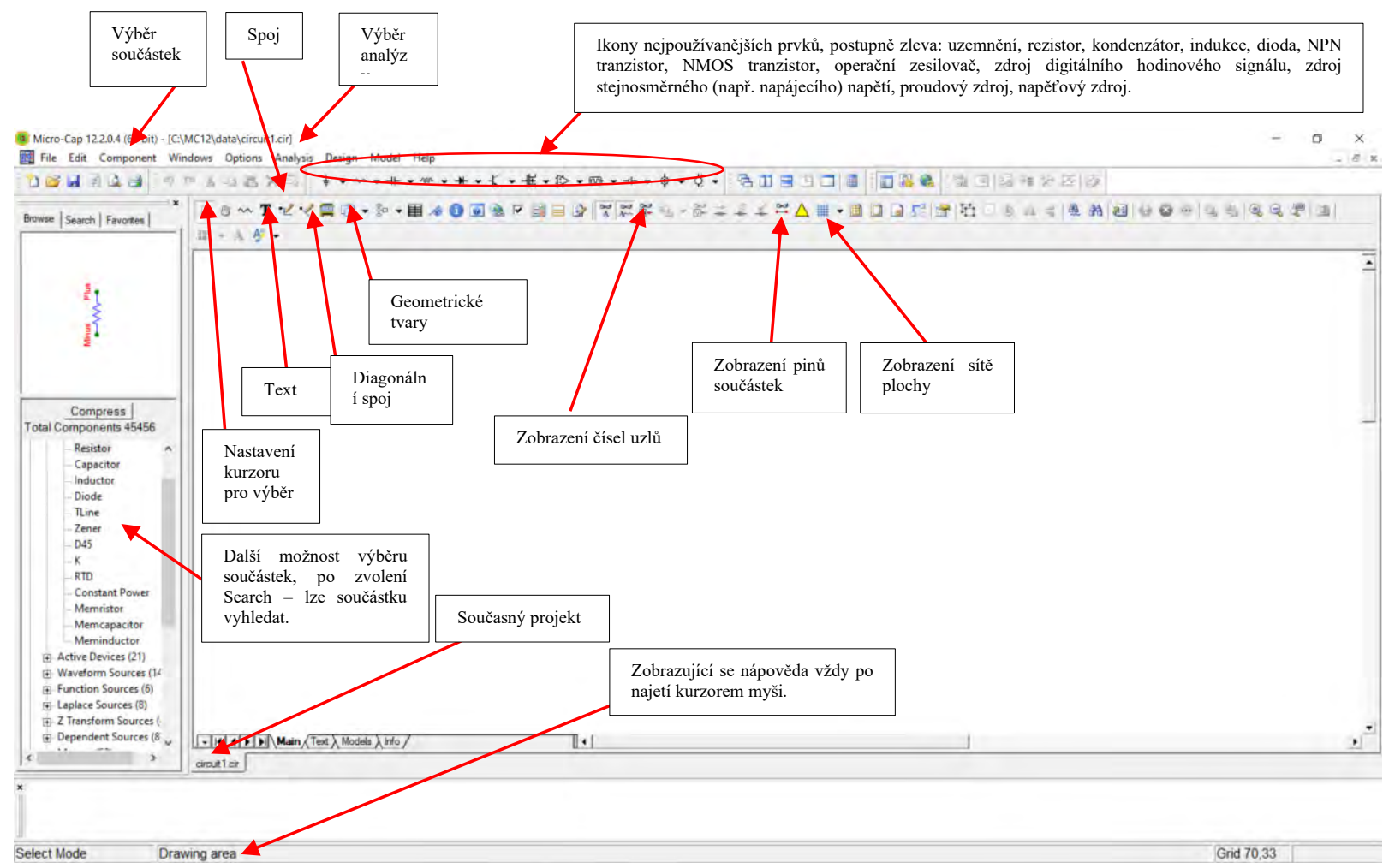

Obr. 14.2: Význam hlavních ikon schematického editoru.

Některé často používané položky menu jsou dostupné také pomocí tlačítek (ikon) v panelech nástrojů. Z menu File jsou to např. položky New, Open a Save. Při pohybech v položkách menu se zobrazuje kontextová nápověda ve stavovém pruhu okna programu (Status Bar - u spodního okraje okna). Micro-Cap poskytuje tuto kontextovou nápovědu $\mathrm{k}$ většině činností při najetí kurzoru na příslušný objekt (položku menu, ikonu, součástku v zapojení, položku při nastavování parametrů simulace a vlastností součástek, nastavení grafického výstupu programu apod.). Tato vlastnost je velmi užitečná zvláště při zadávání parametrů modelu součástky a při nastavování grafického výstupu simulací, kdy kontextová nápověda obsahuje také syntaxi vkládaného parametru. Při umístění kurzoru myši nad tlačítka v pruzích nástrojů se navíc zobrazí také „bublinová“ nápověda.

V další položce menu, položce Edit (úpravy) najdeme známé „editační př́íkazy“ pro práci s textem, součástkami ve schématickém editoru apod. Tedy zejména položky $\boldsymbol{C u t}$ (vyjmout), Copy (kopírovat) a Paste (vložit), prrípadně také Undo (zpět) a Redo (opakovat). Položka Windows (okna) umožňuje kromě jiného uspořádat různá dílčí podokna $\mathrm{v}$ okně 
programu (Cascade, Tile Vertical, Tile Horizontal). Například je takto možné vhodně uspořádat podokna schématu a výsledků simulace, aby byla vidět obě současně. Položka Options (volby) zahrnuje nastavení mnoha různých parametrů programu. Několik prvních položek nastavuje, které lišty, panely nástrojů a další ovládací prvky budou zobrazeny (zvolené lišty či panely jsou označeny zatržením):

- Main Tool Bar - hlavní lišta nástrojů se zobrazuje standardně.

- Default Main Tool Bar - obnovení výchozího nastavení a rozvržení tlačítek hlavní lišty nástrojů.

- Status Bar - stavový pruh na spodním okraji okna (kontextová nápověda) se taktéž zobrazuje standardně.

- Panel - postranní panel s nabídkou obvodových prvků (součástek), pohodlná alternativa k výběru součástek $\mathrm{z}$ menu Component nebo $\mathrm{z}$ palet součástek (Options $\rightarrow$ Component Palletes).

\subsubsection{Schematický editor}

Kreslení schématu můžeme zahájit poté, co máme otevřený nový prázdný soubor (.cir) pomocí prŕkazu File $\rightarrow$ New... nebo automaticky po spuštění programu. Nejprve vybíráme součástky ze seznamu a umist'ujeme je kliknutím na plochu editoru schémat. Součástky dále propojujeme pomocí vodičů, zadáváme popisný text, kreslíme grafické objekty a podobně. Editor schématu pracuje v několika módech, které se nastavují pomocí menu Options $\rightarrow$ Mode. Pro základní kreslení schématu jsou důležité následující módy:

- Select Mode - umožňuje označit (vybrat) prvek schématu (součástku, vodič apod.) či jejich skupinu a poté je přesouvat, mazat je, kopírovat atd. Prvek zvolíme jednoduchým kliknutím na jeho grafický symbol. Držíme-li klávesu <Shift> lze označit najednou více prvků. Skupinu prvků lze také vybrat označením obdélníkové oblasti (stisknout levé tlačítko myši a držet, táhnutím myší označit oblast, tlačítko uvolnit). Označené prvky jsou zvýrazněny barevným podkladem. Označené prvky lze „uchopit“ myší a přesunout je na jiné místo, smazat klávesou $<$ Del $>$, zkopírovat a vložit pomocí $<\mathrm{Ctrl}+\mathrm{C}>$ a $<\mathrm{Ctrl}+\mathrm{V}>$, př́padně vyjmout pomocí $<\mathrm{Ctrl}+\mathrm{X}>$. Př́ḱkazy pro manipulaci s označenými objekty jsou též dostupné z menu Edit. Často potřebnou funkcí je duplikace již existující součástky, kterou provedeme nejsnáze následovně: stiskneme a držíme klávesu $<$ Ctrl $>$ a pomocí myši „uchopíme“ a „táhneme“ zvolenou součástku (nebo celou označenou skupinu součástek) na jiné místo a následně součástku ,pustíme“ a teprve poté uvolníme klávesu $<\mathrm{Ctrl}>$. „Tažená“ součástka zůstane na původním místě a na místě, kde jsme „pustili““ se objeví její duplikát.

Standardně se při přesunu na jiné místo daný prvek nebo skupina „utrhne“ od vodičů v místech spojení. Pokud chceme spojení vodiči zachovat, je nutno zapnout volbu Rubberbanding. To je možné bud' přes menu: Options $\rightarrow$ Preferences $\rightarrow$ Options $\rightarrow$ Circuit a pak zvolit Rubberbanding, či použít klávesové zkratky $<\mathrm{Ctrl}+\mathrm{Shift}+\mathrm{R}>$.

- Component Mode - vkládání součástek na plochu editoru. Součástky jsou rozděleny do několika logicky členěných skupin (knihoven) a podskupin. Součástku vybereme některým z následujících způsobů: 
- z horní lišty (Main Tool Bar), kde jsou vybrané nejčastěji užívané součástky,

- z menu pod položkou Component, kde jsou rovněž vybrané nejčastější součástky,

- z menu pod položkou Component, poté vybereme skupinu, podskupinu a nakonec př́íslušnou součástku (prvek),

- z postranního panelu, který je nutno mít zobrazen (viz menu Options $\rightarrow$ Panel ),

- z menu přes položku Options $\rightarrow$ Component Palletes $\rightarrow$.

Součástku umístíme na plochu jednoduchým kliknutím, po němž se otevře okno s nastavením parametrů součástky, kde je možné a někdy i nutné nastavit alespoň některé základní parametry a potvrdit tlačítkem $\boldsymbol{O K}$. Okno parametrů prvku kdykoliv znovu zobrazíme dvojklikem na jeho značku. Chceme-li součástku při umístění otočit do jiné polohy (s krokem $90^{\circ}$ ) stiskneme a podržíme levé tlačítko myši a opakovaným stiskem pravého tlačítka natočíme součástku do žádané polohy a poté uvolníme levé tlačítko. Je třeba upozornit, že např. u operačního zesilovač se po otočení o $360^{\circ}$ prohodí svorky neinvertujícího a invertujícího vstupu a také kladná a záporná svorka napájení. Další otočení o $360^{\circ}$ vrátí součástku do původního stavu. Stejným postupem můžeme takto natočit každou již umístěnou součástku. Mezi Select Mode a Component Mode lze rychle přepínat pomocí mezerníku na klávesnici.

- Text Mode - vkládání textu, textových popisků.

- Wire Mode - kreslení pravoúhle vedených vodičů pomocí myši, vodiče lze kreslit po částech, automaticky se napojují. Standardně se jako zvýrazněné uzly vykreslují pouze místa spojení tř́i a více vodičů. Je možné zobrazit všechna místa napojení vodičů a můžeme tak odhalit např. místa nechtěného propojení křížících se vodičů. Zobrazení všech bodů napojení aktivujeme bud'to z menu Options $\rightarrow$ View $\rightarrow$ Pin Connections nebo alternativně tlačítkem ve schématickém editoru dle Obr. 14.2. Označování, přesouvání, mazání a kopírování vodičů lze provést podle poznámek k módu Select Mode.

- Diagonal Wire Mode - kreslení úhlopříčně vedených vodičů pomocí myši.

\subsubsection{Základní obvodové prvky a jejich parametry}

Obvodové prvky jsou rozděleny do pěti základních kategorií:

- Analog Primitives - základní analogové (ideální) obvodové prvky a obecné modely některých skutečných analogových součástek, např. polovodičových (dioda, tranzistor, tyristor aj.).

- Analog Library - rozsáhlé knihovny modelů skutečných analogových součástek (výběr podle skutečného typového označení). V některých starších verzích Micro-Cap nemusí být některé modely dostupné ( $\mathrm{v}$ menu označeno šedým písmem, $\mathrm{v}$ postranním panelu poznámkou ,(Professional version only)“.

- Digital Primitives - základní číslicové či logické prvky, převážně různé typy hradel a generátory logických signálů.

- Digital Library - rozsáhlé knihovny modelů skutečných digitálních součástek (výběr podle skutečného typového označení).

- Animation - animované prvky, které se pro větší názornost při simulaci hýbou, svítí a točí (voltmetr, ampérmetr, spínač, přepínač, LED dioda, motor apod.). 
Některé základní prvky mají též své rychlé tlačítko v panelu nástrojů. Příklady takových prvků jsou:

Analog Primitives $\rightarrow$ Passive Components (pasivní prvky) $\rightarrow$

- Resistor - ideální rezistor, zadává se u něj hodnota odporu v ohmech (položka s názvem RESISTANCE, číselná hodnota se zadává do políčka „Value“).

Poznámka: Micro-Cap zobrazuje „, americkou“ značku rezistoru (,,cik-cak“ čára) namisto „evropské“ (obdélník). Přenastaveni lze provést z menu Windows $\rightarrow$ Component Editor..., nabídka Resistor a přnastavit v poli Shape Name položku „,Resistor" na „Resistor_Euro“.

- Capacitor - ideální kapacitor, zadává se u něj hodnota kapacity ve faradech (položka s názvem CAPACITANCE, číselná hodnota se zadává do políčka „Value“).

- Inductor - ideální induktor, zadává se u něj hodnota indukčnosti v jednotkách henry (položka s názvem INDUCTANCE, číselná hodnota se zadává do políčka „Value“).

Číselné hodnoty je možné v Micro-Capu zadávat několika zpo̊soby. Např. odpor 1 kiloohm je možno zapsat jako 1000 nebo 1 e3 (exponenciální vyjádření $10^{3}$ ) nebo $\mathbf{1 k}$. Fyzikální jednotka (např. ohm, volt apod.) je určena podle zadávaného parametru, proto se nezapisuje ani nezobrazuje. Předpony v zápisu, jak je zobrazuje Micro-Cap (zápis tučně), mají následující význam: $\mathbf{f}=$ femto $=10^{-15}, \mathbf{p}=$ piko $=10^{-12}, \mathbf{n}=$ nano $=10^{-9}, \mathbf{u}=$ mikro $=10^{-6}, \mathbf{m}$ $=$ mili $=10^{-3}, \mathbf{K}=$ kilo $=10^{3}, \mathbf{M E G}=$ mega $=10^{6}, \mathbf{G}=$ giga $=10^{9}, \mathbf{T}=$ tera $=10^{12}$. Micro-Cap nerozlišuje velká a malá písmena. Pozor na záměnu předpon mili a mega. V Micro-Capu $\mathbf{m}$ či M znamená mili, avšak MEG či meg znamená mega.

Nastavení budicích zdrojů signálu.

Analog Primitives $\rightarrow$ Waveform Sources (nezávislé zdroje signálů) $\rightarrow$

- Battery - baterie, ideální zdroj konstantního stejnosměrného napětí. Jeho napětí se nastaví v položce s názvem VALUE na požadovanou hodnotu ve voltech v políčku „Value“. Využívá se pro analýzu DC nebo Transient a také pro napájení součástek např. OZ.

- ISource - ideální zdroj konstantního stejnosměrného proudu, jehož hodnota se nastaví v položce VALUE na požadovanou hodnotu v ampérech v políčku „Value“.

- Voltage Source - univerzální ideální zdroj napětí o definovaném časovém průběhu. Podle volby záložky v okně parametrů můžeme zdroj definovat nap̌r. jako stejnosměrný, pulzní, harmonický apod. Zvlášt' se nastavuje chování pro různé druhy analýz. Parametr pro stejnosměrnou DC analýzu je označen DC, parametry pro stř́idavou AC analýzu jsou označeny AC, další parametry slouží pro časovou Transient analýzu atd.

Analog Primitives - Connectors - Ground - zem, společná svorka, referenční uzel s napětím $0 \mathrm{~V}$. Velmi důležitý prvek, který v obvodu musí být alespoň jednou použit, jinak nelze spustit analýzu (oznámení: „Nodes x, y, ... have no DC path to ground“).

Analog Primitives -Special Purpose - S (V-Switch) - spínač řízený napětím (např̀. pro analýzu přechodných jevů, spínaných zdrojů ap.). - Switch - spínač řízený napětím, proudem nebo časem (použití viz $\boldsymbol{S}(\boldsymbol{V}$-Switch)). 
Animation (animované prvky) - animované prvky jsou užitečné zejména pro „dynamické“ analýzy (Dynamic DC a Dynamic $\boldsymbol{A C}$ ), kdy jejich stav interaktivně reaguje na změny provedené v obvodu.

Animated Meter - animovaný analogový či digitální voltmetr nebo ampérmetr.

\subsubsection{Základní typy analýz obvodů}

Jak již bylo zmíněno výše, Micro-Cap, podobně jako většina dalších simulačních programů, nabízí řadu dostupných analýz. V následujících prŕíkladech se zaměříme na tři základní typy analýz, které jsou nejčastěji využívané při simulacích elektronických obvodů. Jedná se zejména o analýzu v časové oblasti, kmitočtovou charakteristiku obvodu a stejnosměrnou charakteristiku, resp. převodní charakteristiku. Zopakujme zde základní vlastnosti těchto analýz:

- Transient - analýza v časové oblasti (nazývána také časová či transientní analýza nebo analýza přechodových dějů). Jejím výsledkem jsou časové průběhy zvolených obvodových veličin (např. napětí, proudů apod.) v daném časovém intervalu. Odpovídá laboratornímu měření pomocí osciloskopu.

- $A C$ - analýza obvodů v harmonickém ustáleném stavu neboli analýza v kmitočtové oblasti (označována také jako stř́́davá nebo AC analýza). Výstupem jsou zde kmitočtové charakteristiky veličin analyzovaného obvodu, např. závislost velikosti přenosu na kmitočtu, tj. modul a fáze přenosové funkce. Odpovídá laboratornímu měření pomocí obvodového analyzátoru.

- $\boldsymbol{D C}$ - analýza obvodů ve stacionárním ustáleném stavu nebo také stejnosměrná či DC analýza. Umožňuje zjištění statických voltampérových nebo voltvoltových převodních charakteristik obvodů, tedy výpočet různých stejnosměrných charakteristik v závislosti na proměnné hodnotě některé stejnosměrné budicí veličiny. Typicky tak může být výstupem DC analýzy grafické znázornění voltampérové charakteristiky diody nebo např. výstupních charakteristik tranzistoru.

Vybraná analýza se spouští z menu Analysis. Poté se objeví okno s titulkem ,„[název analýzy] Limits" s nastavením parametrů analýzy a formátu grafického výstupu (zobrazované veličiny, počty grafů, měřítka aj.). Nastavení parametrů mohu být velmi rozmanitá od několika parametrů pro analýzu $\boldsymbol{D C}$ až po detailní definování požadovaných časových či kmitočtových průběhů u analýz Transient nebo $\boldsymbol{A C}$. Většinou jsou všechny parametry analýzy přednastaveny, $\mathrm{v}$ príípadě potřeby je upravíme na požadované hodnoty a můžeme $\mathrm{v}$ okně Limits potvrdit tlačítkem „Run“, čímž analýzu spustíme. Po jejím proběhnutí dojde k modifikaci hlavního menu programu. Položka Analysis je nahrazena položkou s názvem dané analýzy (Transient, $\boldsymbol{A C}, \boldsymbol{D C}$, př́ípadně dalších), dále jsou položky Design a Model nahrazeny položkami Scope a Monte Carlo, případně jinými pro další varianty analýz. K obnovení původní podoby hlavního menu dojde až po opuštění módu analýzy. Pro většinu analýz zůstane okno Limits po spuštění analýzy otevřené, ale minimalizuje se na lištu Windows. Pokud po proběhnutí analýzy chceme změnit její parametry a spustit ji znovu, okno Limits obnovíme z lišty, provedeme potřebné změny a analýzu opětovně spustíme tlačítkem ,Run“. Okno Limits lze vyvolat i z menu dané analýzy pomocí položky Limits. V módu analýzy jsou u analýz Transient, $\boldsymbol{A C}$ a $\boldsymbol{D C}$ aktivní 
dvě okna, a to okno s výsledky analýzy a okno se zapojením obvodu. Standardně jsou okna umístěna přes sebe a přepínat se mezi nimi je možné pomocí „listü“ u spodního okraje oken. Pokud v okně zapojení změníme v módu analýzy zapojení nebo parametr některého prvku či třeba přepneme přepínač, analýza se automaticky spustí znovu a výsledky se aktualizují podle provedených změn.

Mód analýzy ukončíme z položky menu příslušné analýzy pomocí $\rightarrow$ Exit Analysis, prrípadně zavřením okna s výsledky analýzy. Rozsáhlejší změny v obvodu se doporučuje provádět mimo mód analýzy. Každá změna v obvodu v módu analýzy vyvolá nový běh výpočtu, a to může být $v$ některých príípadech značně časově náročné. Při aktivním módu analýzy není možné změny provedené $\mathrm{v}$ obvodu ukládat do souboru.

\subsection{Př́́klady simulací}

V následujících příkladech se zaměříme především na simulaci obvodů s operačními zesilovači $(\mathrm{OZ})$. Proto je zapotřebí především znát, jaký model operačního zesilovače je programem využíván. Znalost modelu je nutná proto, abychom dokázali posoudit, jaké jevy je možné modelovat a co zkoumat nelze, protože to použitý model prostě neumožňuje. Než začneme simulovat funkci obvodů s operačními zesilovači, popíšeme jaké modely operačních zesilovačů jsou v programu používány a jakými parametry je př́slušný model operačního zesilovače popsán.

Model operačního zesilovače $\mathrm{v}$ programu Micro-Cap je modifikace lineárního modelu. Program umožňuje nastavit tři úrovně složitosti modelu. Tak je vhodnou volbou úrovně možné neuvažovat některé vlastnosti, které v dané situaci nejsou podstatné. Jednotlivé úrovně představují následující modely:

LEVEL 1 Operační zesilovač je modelován jako nesetrvačný zdroj proudu ř́zený napětím s uvažováním konečného výstupního odporu a konečného zesílení operačního zesilovače bez zpětné vazby. Tato úroveň je vhodná pro rychlou idealizovanou analýzu, sloužící k ověření správnosti principu obvodového řešení.

LEVEL 2 Tř́stupňový model obsahuje dva lomové kmitočty na modulové kmitočtové charakteristice operačního zesilovač a konečnou rychlost přeběhu. Model je vhodný pro běžnou analýzu zejména $\mathrm{v}$ kmitočtové oblasti. Představuje kompromis mezi složitostí a přesností modelu. Při výpočtu rozšiřuje obvodovou sít' o dva vnitřní uzly.

LEVEL 3 Rozšířený Boylův model, blížící se svou dokonalostí subobvodům SPICE. Je charakterizován celkem 23 parametry - viz dále. Model této úrovně již není lineární.

Model LEVEL 1 je uveden na Obr. 14.3. Jak je vidět, jedná se jednoduchý ideální lineární model, který je zpravidla používán při jednoduchých výpočtech. Neobsahuje žádné prvky pro modelování kmitočtových závislostí operačního zesilovače. 


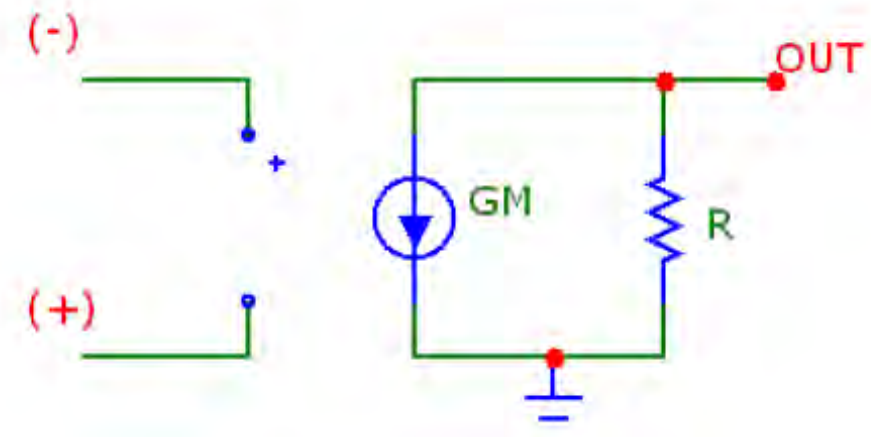

Obr. 14.3: Model operačního zesilovače úrovně LEVEL1 v Micro-Cap. [2]

Vztahy pro úroveň Level 1:

$\mathrm{R}=$ ROUTAC+ROUTDC,

$\mathrm{GM}=\mathrm{A} / \mathrm{R}$,

kde

ROUTAC je hodnota výstupního odporu OZ pro stř́idavé signály,

ROUTDC je hodnota výstupního odporu OZ pro stejnosměrné signály,

A je zesílení operačního zesilovače bez zpětné vazby,

GM je strmost,

$\mathrm{R}$ je hodnota výstupního odporu daná součtem odporů pro střídavé a stejnosměrné signály, $\mathrm{v}$ tomto př́padě jeho hodnota odpovídá hodnotě uváděné v katalogovém listu operačního zesilovače.

Značení odpovídá jednotlivým parametrům tak, jak jsou označeny při zadávání hodnot $\mathrm{v}$ př́íslušném okně programu Micro-Cap. Souhrnný popis parametrů bude uveden v závěru této části.

Pro ověřování vlastností obvodů s operačními zesilovači, kdy je již požadována zejména kmitočtová závislost zesílení $A(f)$ samotného operačního zesilovače, je určen model LEVEL 2, který je uveden na Obr. 14.4.
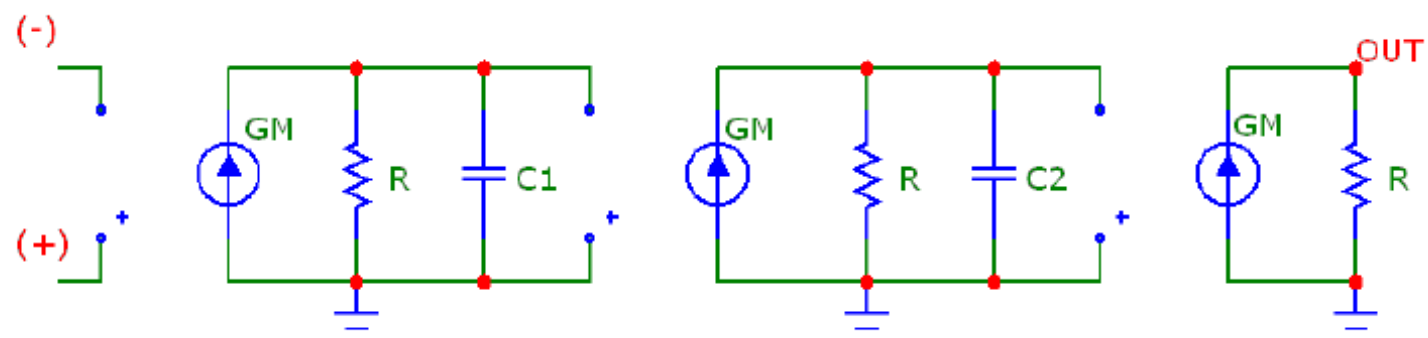

Obr. 14.4: Model operačního zesilovače úrovně LEVEL2 v Micro-Cap. [2]

Vztahy pro úroveň Level 2:

$\mathrm{R}=\mathrm{ROUTAC}+\mathrm{ROUTDC}$

$\mathrm{GM}=\mathrm{A}^{1 / 3} / \mathrm{R}$

F1 $=$ GBW/A $\quad$ (první pól, první lomový kmitočet)

F2 = GBW/tan(90-PM) (druhý pól, druhý lomový kmitočet) 


$$
\begin{aligned}
& \mathrm{C} 1=1 /(2 \cdot \pi \cdot \mathrm{F} 1 \cdot \mathrm{R}) \\
& \mathrm{C} 2=1 /(2 \cdot \pi \cdot \mathrm{F} 2 \cdot \mathrm{R})
\end{aligned}
$$

Model operačního zesilovače LEVEL 3 s tranzistory typu NPN je uveden na Obr. 14.5. Jedná se o nelineární Boylův model. Jeho využití je především při zkoumání detailních jevů při aplikaci operačního zesilovače. Je však nutné dobře porozumět funkci modelu. Tento model nejlépe charakterizuje vnitřní strukturu běžných operačních zesilovačů. Bližší popis vnitřní funkce lze nalézt v [1], [2].

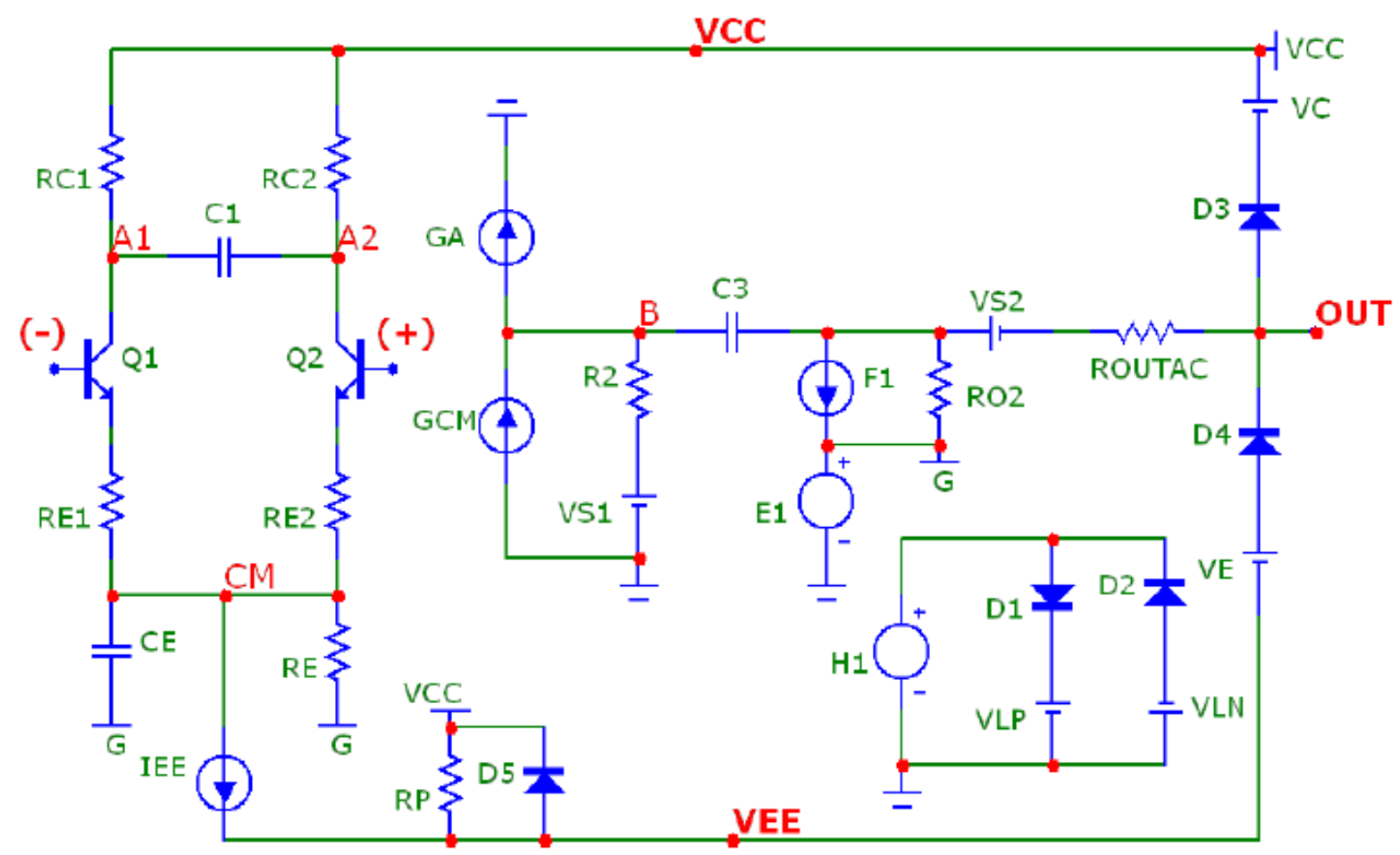

Obr. 14.5: Model operačního zesilovače úrovně LEVEL3 NPN v Micro-Cap. [2]

Dále jsou v simulátoru volitelné modely s PNP či JFET vstupními tranzistory. Typ tranzistorů se volí v tabulce parametrů modelu příslušného operačního zesilovače. Definiční vztahy této úrovně jsou již rozsáhlejší a není účelné je zde uvádět. Bližší popis modelu a platné vztahy lze nalézt v lit. [1], [2].

Popis a význam parametrů, kterými je operační zesilovač definován v programu MicroCap a jejich použití v jednotlivých modelech uvádí následující tabulka: 
Tab. 14.1: Popis a význam parametrů operačního zesilovače v programu Micro-Cap

\begin{tabular}{|c|c|c|c|c|}
\hline Name & Parameter & Units & Default & Level \\
\hline LEVEL & $\begin{array}{l}\text { Model Level } \\
\text { úroveň modelu }(1,2,3)\end{array}$ & & 1 & \\
\hline TYPE & $\begin{array}{l}1=\mathrm{NPN}, 2=\mathrm{PNP}, 3=\mathrm{JFET} \\
\text { typ vstupnich tranzistoru }\end{array}$ & & 1 & 3 \\
\hline $\mathrm{C}$ & $\begin{array}{l}\text { Compensation Capacitor } \\
\text { kompenzačni kapacita }\end{array}$ & $\mathrm{F}$ & $30 \mathrm{e}-12$ & 3 \\
\hline A & $\begin{array}{l}\text { DC open loop gain } \\
\text { stejnosmérné zesíleni otevřené smyčky }\end{array}$ & & $2 \mathrm{e} 5$ & all \\
\hline ROUTAC & $\begin{array}{l}\text { AC output resistence } \\
\text { stř́davý výstupní odpor }\end{array}$ & $\Omega$ & 75 & all \\
\hline ROUTDC & $\begin{array}{l}\text { DC output resistence } \\
\text { stejnosmérný výstupní odpor }\end{array}$ & $\Omega$ & 125 & all \\
\hline VOFF & $\begin{array}{l}\text { Input offset voltage } \\
\text { vstupní napětová nesymetrie }\end{array}$ & $\mathrm{V}$ & .001 & 3 \\
\hline IOFF & $\begin{array}{l}\text { Input offset cureent } \\
\text { vstupni proudová nesymetrie }\end{array}$ & A & $1 \mathrm{E}-9$ & 3 \\
\hline SRP & $\begin{array}{l}\text { Maximum positive slew rate } \\
\text { max. pozitivni rychlost přeběhu }\end{array}$ & $\mathrm{V} / \mathrm{s}$ & $5 \mathrm{e} 5$ & 2,3 \\
\hline SRN & $\begin{array}{l}\text { Maximum negative slew rate } \\
\text { max. negativni rychlost přeběhu }\end{array}$ & $\mathrm{V} / \mathrm{s}$ & $5 \mathrm{e} 5$ & 2,3 \\
\hline IBIAS & $\begin{array}{l}\text { Input bias current } \\
\text { vstupní klidový proud }\end{array}$ & A & $1 \mathrm{e}-7$ & 3 \\
\hline VCC & $\begin{array}{l}\text { Positive power supply } \\
\text { kladné napájecí napétí }\end{array}$ & $\mathrm{V}$ & 15 & 3 \\
\hline VEE & $\begin{array}{l}\text { Negative power supply } \\
\text { záporné napájecí napétí }\end{array}$ & V & -15 & 3 \\
\hline VPS & $\begin{array}{l}\text { Maximum positive voltage swing } \\
\text { max. kladný rozkmit výstupního napětí }\end{array}$ & $\mathrm{V}$ & 13 & 3 \\
\hline VNS & $\begin{array}{l}\text { Maximum negative voltage swing } \\
\text { max. záporný rozkmit výstupního napětí }\end{array}$ & V & -13 & 3 \\
\hline CMRR & $\begin{array}{l}\text { Common-mode rejection ratio } \\
\text { činitel potlačeni souhlasného napětí }\end{array}$ & & $1 \mathrm{e} 5$ & 3 \\
\hline GBW & $\begin{array}{l}\text { Unity gain bandwidth } \\
\text { tranzitni kmitočet }\end{array}$ & $\mathrm{Hz}$ & $1 \mathrm{e} 6$ & 2,3 \\
\hline PM & $\begin{array}{l}\text { Phase margin } \\
\text { fázová bezpečnost }\end{array}$ & $\circ$ & 60 & 2,3 \\
\hline $\mathrm{PD}$ & $\begin{array}{l}\text { Quiescent power dissipation } \\
\text { rozptylovaný výkon }\end{array}$ & $\mathrm{W}$ & 0,025 & 3 \\
\hline IOSC & $\begin{array}{l}\text { Output saturation current } \\
\text { výstupni proud nakrátko }\end{array}$ & A & 0,02 & 3 \\
\hline T_MEASURED & $\begin{array}{l}\text { Measured temperature } \\
\text { teplota při které byly parametry změřeny }\end{array}$ & ${ }^{\circ} \mathrm{C}$ & undefined & 3 \\
\hline T_ABS & $\begin{array}{l}\text { Absolute temperature } \\
\text { „absolutni" teplota }\end{array}$ & ${ }^{\circ} \mathrm{C}$ & undefined & 3 \\
\hline T_REL_GLOBAL & $\begin{array}{l}\text { Relative to current temperature } \\
\text { relativní teplota vztažená } k \text { teplotě nastavené } \\
\text { globálně príkazem. TEMP= }\end{array}$ & ${ }^{\circ} \mathrm{C}$ & undefined & 3 \\
\hline T_REL_LOCAL & $\begin{array}{l}\text { Relative to } \mathrm{AKO} \text { model temperature } \\
\text { relativni teplota vztažená } k, \text {,absolutni" teplotě }\end{array}$ & ${ }^{\circ} \mathrm{C}$ & undefined & 3 \\
\hline
\end{tabular}


Parametry VCC a VEE jsou jmenovité hodnoty napájecího napětí, při kterých jsou pro úroveň LEVEL3 specifikovány hodnoty napětí VPS a VNS, tj. hodnoty kladného a záporného saturačního napětí. Hodnoty napájecích napětí je možné změnit, jejich velikost ovlivňují pouze ztrátový výkon a výstupní saturační napětí.

Modely úrovně 2 a 3 používají jako vstupní parametr Gain Bandwidth (GBW, šířka pásma operačního zesilovače při jednotkovém zesílení). Model operačního zesilovače respektuje hodnotu PM (fázová rezerva, resp. fázová bezpečnost) kdy zisk je $-3 \mathrm{~dB}$ při tranzitním kmitočtu $f_{\mathrm{T}}=$ GBW. Průsečík asymptoty křivky zisku (tečna ke křivce zisku za prvním lomovým kmitočtem, zpravidla s poklesem zisku $20 \mathrm{~dB} /$ dek) a hodnoty kmitočtu $f_{\mathrm{T}}=$ GBW je při zisku $0 \mathrm{~dB}$, tedy kdy protíná osu kmitočtu. Parametr GBW nelze měnit libovolně, je respektováno zesílení $A_{0}$ samotného operačního zesilovače bez zpětné vazby na nulovém kmitočtu, viz tabulka výše. Při zadaném tranzitním kmitočtu a zesílení $A_{0}$ se první lomový kmitočet dopočítá dle známého přibližného vztahu. Fázová bezpečnost $\mathrm{PM}=$ Fázový úhel + $180^{\circ}$.

Většinu hodnot těchto parametrů pro zadání modelu lze získat v katalogu součástek. V knihovně Micro-Cap se standardně nacházejí modely běžných operačních zesilovačů, př́ípadně lze použít SPICE modely dodávané výrobci.

\section{PŘÍKLAD_1}

Základní vlastnosti operačního zesilovače, operační zesilovač bez zpětné vazby, model úrovně LEVEL2, ověření parametrů modelu pomocí simulace.

Prozkoumejme kmitočtovou charakteristiku samotného operačního zesilovače. Uvažujme všeobecně známý běžný operační zesilovač typu LM741. Analyzovaný obvod vytvořený v editoru Micro-Cap je uveden na Obr. 14.6. Upozorněme, že Micro-Cap nesmí obsahovat plovoucí vstupní svorky. Je proto zapotřebí mít na vstupu zapojen vhodný zdroj napětí (zpravidla časově závislý). Pokud tomu tak není, může nastat problém se sestavením výpočetní matice a může se objevit chybové hlášení ve smyslu, že neexistuje stejnosměrná cesta ke společnému uzlu. Bližšśi informace k této problematice viz lit. [2].

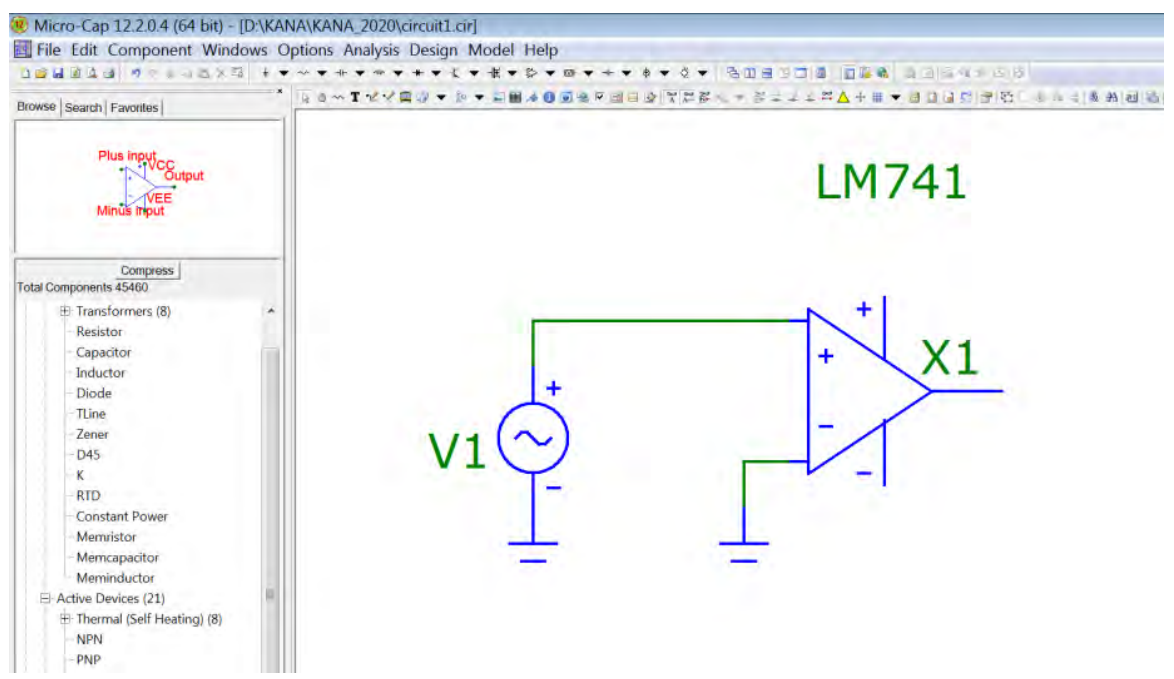

Obr. 14.6: Operační zesilovač v editoru Micro-Cap pro kmitočtovou analýzu. 
Postup při kreslení schématu je naznačen na následujícím Obr. 14.7. Zde je třeba zmínit několik poznámek k volbám v programu, které zpočátku mohou být poněkud nejasné.

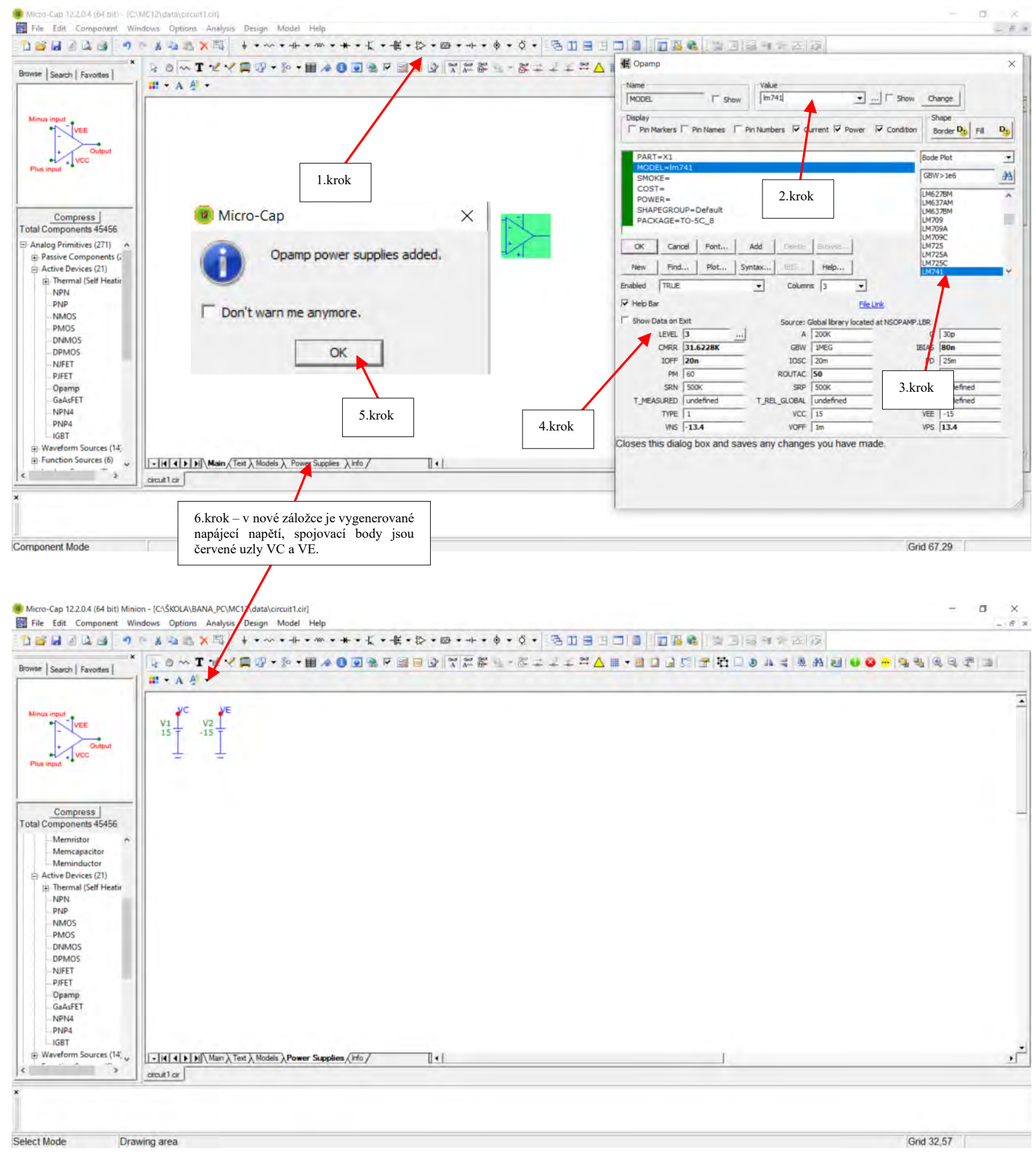

Obr. 14.7: Postup při výběru OZ a zobrazení Power Supplies.

Schematický editor umožňuje automaticky vkládat napájecí zdroje operačního zesilovače (automatické vkládání lze vypnout v nastavení programu) a jejich př́ípojné body jsou označeny VC a VE. Tyto zdroje jsou nutné při simulaci, kdy využíváme model operačního zesilovače LEVEL3. Proto, když je nastavena tato úroveň je zároveň nabídnuta možnost automaticky tyto zdroje vložit. Pokud je zvolena úroveň modelu LEVEL1 a LEVEL2, není možnost vložení napájecích zdrojů nabídnuta, protože tyto úrovně modelů nepracují s hodnotou napájecích napětí a tyto zdroje nejsou využívány. Pokud tedy zvolíme úrovně 1 a 2 , zapojení je 
plně funkční a při změně na úroveň 3 jsou pak napájecí zdroje vloženy a již ve schématu zůstanou i při zpětné volbě na nižší úroveň modelu. Napájecí zdroje jsou umístěny na zvláštním listu „Power Supplies“, viz Obr. 14.7.

Zdroj napětí V1 ve schématu byl již zmíněn dříve. Pokud zkoumáme kmitočtové vlastnosti, je tedy vcelku logické, zvolíme-li zdroj harmonického napětí (v reálných podmínkách by to nejspíš byl nějaký vhodný generátor). Tento zdroj je v knihovně prvků Analog Primitives $\rightarrow$ Waveform Sources $\rightarrow$ Sine Source. Je celkem nepodstatné, jaký konkrétní zdroj z této knihovny vybereme.

V našem př́kladu pracujeme s modelem úrovně LEVEL2. Přednastavené hodnoty parametrů LM741 v knihovně prvků programu Micro-Cap využívané pro tuto úroveň jsou tyto (parametry prvku jsou dostupné dvojklikem na daný prvek):

$\begin{array}{rll}\text { LEVEL } & : & 2 \\ \text { A } & : & 200 \mathrm{~K} \\ \text { ROUTAC } & : & 50 \\ \text { ROUTDC } & : & 75 \\ \text { SRP } & : & 500 \mathrm{~K} \\ \text { SRN } & : & 500 \mathrm{~K} \\ \text { GBW } & : & 1 \mathrm{E} 6 \\ \text { PM } & : & 60\end{array}$

Z výpisu je patrné, že zvolený model (LEVEL2, kmitočtově závislé zesílení) má zesílení $A=200 \cdot 10^{3}$ na nulovém kmitočtu (odpovídá obvyklému značení $A_{0}$ ), výstupní odpor $R_{0}=125 \Omega$ (dáno součtem výstupních odporů pro ss a st signály), rychlost přeběhu $S_{\mathrm{R}}=500 \cdot 10^{3} \mathrm{~V} / \mathrm{s}$ v obou směrech, šiřka pásma $G B W=1 \mathrm{MHz}$, fázová bezpečnost $P M=60^{\circ}$. Provedeme analýzu v kmitočtové oblasti a zobrazíme kmitočtovou a fázovou charakteristiku operačního zesilovače bez zpětné vazby.

Po volbě položky <Analysis $>$ a typu analýzy <AC....> nastavíme hodnoty parametrů vymezující průběh analýzy. Velikost zadávaných hodnot je třeba volit smysluplně s ohledem na sledovaný jev. Je tedy nutné si uvědomit, co sleduji a jaký výsledek zhruba očekávám. Je vhodné vykreslovat průběh zisku a fáze do samostatných grafů. Ze zadaných hodnot v modelu operačního zesilovače víme, že tranzitní kmitočet je cca $1 \mathrm{MHz}$. Nemá tedy smysl sledovat průběh charakteristik na kmitočtu vyšším než $(10$ až 100$) \cdot f_{\mathrm{T}}$. Na kmitočtu vyšším než $f_{\mathrm{T}}$ operační zesilovač již nezesiluje a není v této oblasti ani využíván. Kmitočtové pásmo se zadává na dvou místech - jednak jako rozsah výpočtu a jednak pro měř́tko osy x na grafu. Dále se zadává rozsah osy y a specifikace pro zobrazování proměnné y. Zde si opět uvědomíme nastavené zesílení na kmitočtu menším než $f_{0}$ (první lomový kmitočet), to je $\mathrm{v}$ našem případě $z_{0}=20 \cdot \log (200000) \cong 106 \mathrm{~dB}$ a dále fakt, že zisk na tranzitním kmitočtu $z\left(f_{\mathrm{T}}\right)=0 \mathrm{~dB}$. Abychom mohli dobře odečíst druhý lomový kmitočet, zvolíme rozsah poněkud větší. Podobným způsobem postupujeme i při volbě rozsahu fázové charakteristiky.

V menu AC analýzy ponecháme „Frequency range“ nastavené na Log (logaritmické měřítko) a změníme pouze rozsah simulace 1E7, 1 (zapisuje se fmax, fmin). Dále je třeba nastavit význam os $x$ a $y$. Na ose $x$ je kmitočet $\mathbf{F}$, na ose $y$ pak modul kmitočtové charakteristiky (první průběh) v decibelech a chceme-li zobrazit napětí na výstupu (uzlu) - zapíšeme dB(v(3)). 
Obdobně zvolíme osu y pro fázovou charakteristiku (druhý průběh) - zapíšeme ph(v(3)). Př́́klad nastavení rozsahů i ostatních parametrů v tabulce AC analýza je uveden na Obr. 14.8.

Poznamenejme, že při zatržení políčka „Auto Scale Ranges“ jsou při každém spuštěném výpočtu ,Run “nastavena automatická měřítka všech os zobrazených grafů. Obdobná nastavení lze nastavit prímo i v položkách „X Range“ a „Y Range“, kde lze zadat bud' přímo požadované rozsahy (jak je uvedeno na Obr. 14.8) nebo klíčová slova „Auto“, „AutoAlways“, vztažené k jednotlivým osám zobrazovaných grafů.

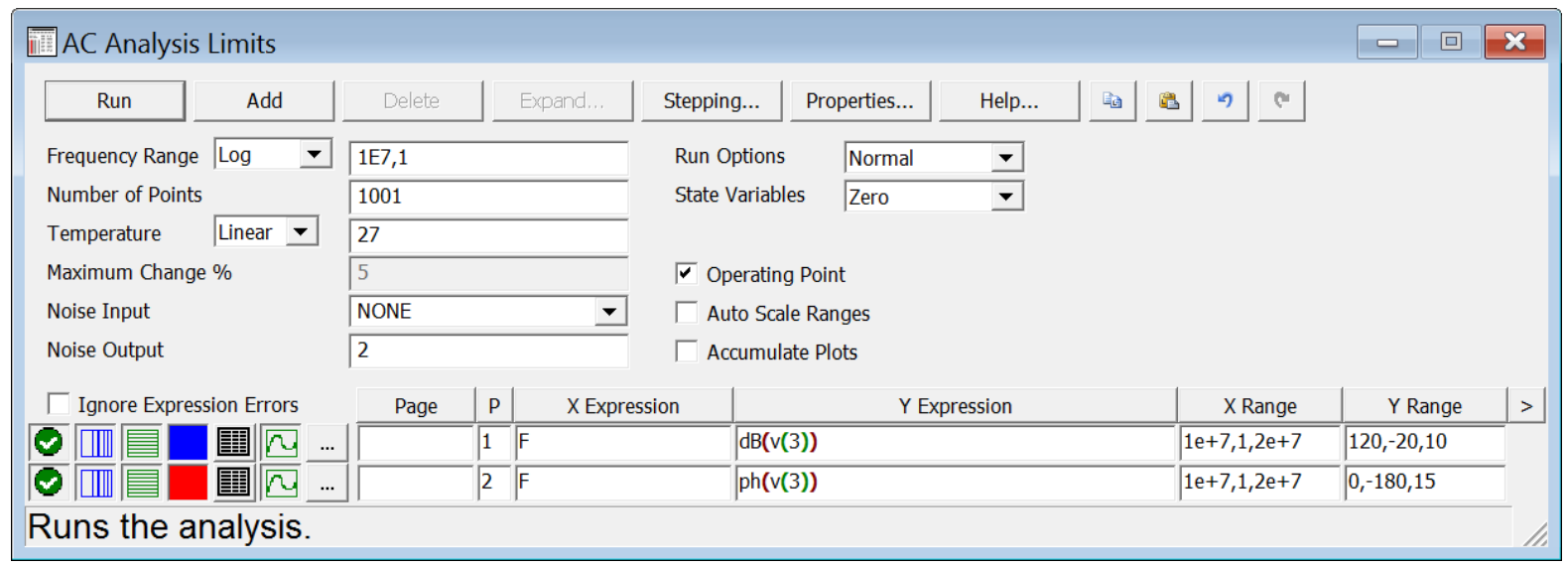

Obr. 14.8: Příklad nastavení parametrů pro kmitočtovou analýzu.

Vykreslená modulová a fázová kmitočtová charakteristika je uvedena na Obr. 14.9. Všimněme si, že $f_{0}=5 \mathrm{~Hz}$ a $f_{\mathrm{T}} \approx 0,9 \mathrm{MHz}$. Modulová charakteristika klesá za prvním lomovým kmitočtem rychlostí $20 \mathrm{~dB} /$ dek a odpovídá to standardnímu průběhu kmitočtové charakteristiky.

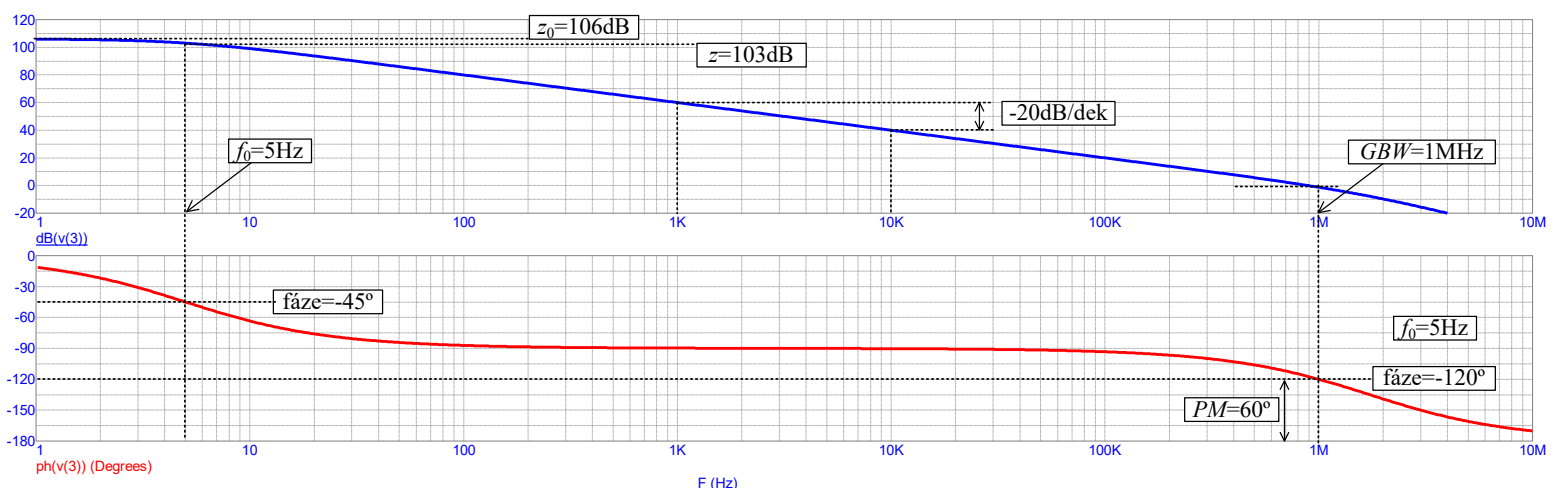

Obr. 14.9: Kmitočtová charakteristika operačního zesilovače bez zpětné vazby (modul a fáze).

Z Obr. 14.9 rovněž můžeme ověřit přibližný vztah mezi $A_{0}, f_{0}$ a $f_{\mathrm{T}}$, kdy modulovou charakteristiku nahrazujeme přímkou, což je možné $\mathrm{v}$ prrípadě, když $f_{0}<<f_{\mathrm{T}}$. Tranzitní kmitočet $f_{\mathrm{T}}=G B W$ lze potom určit z diagramu nebo jej vypočítat z přibližného vztahu

$$
f_{\mathrm{T}} \approx A_{0} \cdot f_{0} \text {, tedy } \quad f_{\mathrm{T}} \approx 200 \cdot 10^{3} \cdot 5=1 \mathrm{MHz} . .
$$


Průběhy uvedené na Obr. 14.9 zřetelně ukazují význam nastavených parametrů modelu operačního zesilovače úrovně LEVEL2, konkrétně kmitočtově závislé zesílení $A$, šiřřu pásma $G B W$, fázovou bezpečnost $P M$.

Prokažme nyní pomocí simulace i ostatní výše zmíněné parametry modelu operačního zesilovače. Důležitým parametrem operačního zesilovače je rychlost přeběhu $S_{\mathrm{R}}$. Ta je definována jako maximální rychlost změny výstupního napětí za jednotku času. Bývá zpravidla vyjadřována ve $\mathrm{V} / \mu \mathrm{s}$. $\mathrm{V}$ parametrech modelu je hodnota rychlosti přeběhu zadávána ve $\mathrm{V} / \mathrm{s}$ a je rozlišena rychlost přeběhu při rostoucím výstupním napětí a (SRP) a při klesajícím výstupním napětí (SRN). Zpravidla obě hodnoty jsou v modelech operačních zesilovačů shodné. U modelu operačního zesilovače LEVEL2 není uvažována úroveň hodnoty kladné a záporné saturace, tedy výstupní napětí může růst nade všechny meze.

Při simulaci ukazující rychlost přeběhu operačního zesilovače tedy provedeme analýzu v časové oblasti (Transient) a zdrojem vstupního napětí bude vhodně nadefinovaný pulsní zdroj.

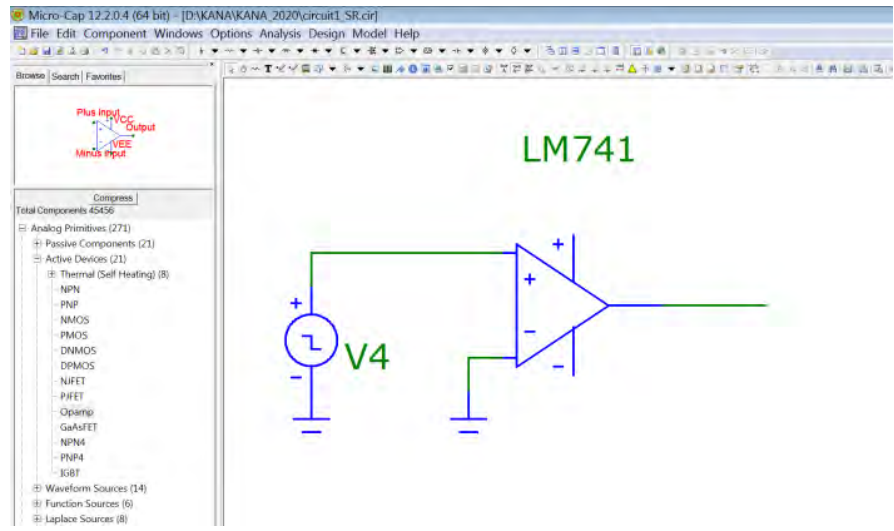

Obr. 14.10: Operační zesilovač v editoru pro analýzu v časové oblasti.

V určitém čase na vstupu operačního zesilovače dojde ke skoku napětí a výstupní napětí operačního zesilovače začne růst či klesat, a to takovou rychlostí, jak je nastavena rychlost přeběhu v parametrech modelu operačního zesilovače. Zapojení operačního zesilovač pro ukázku a potvrzení nastavené rychlosti přeběhu je uvedeno na Obr. 14.10. Po volbě analýzy „Transient" nastavíme vhodně parametry analýzy a spustíme analýzu. Výsledný průběh v časové oblasti je uveden na Obr. 14.11.

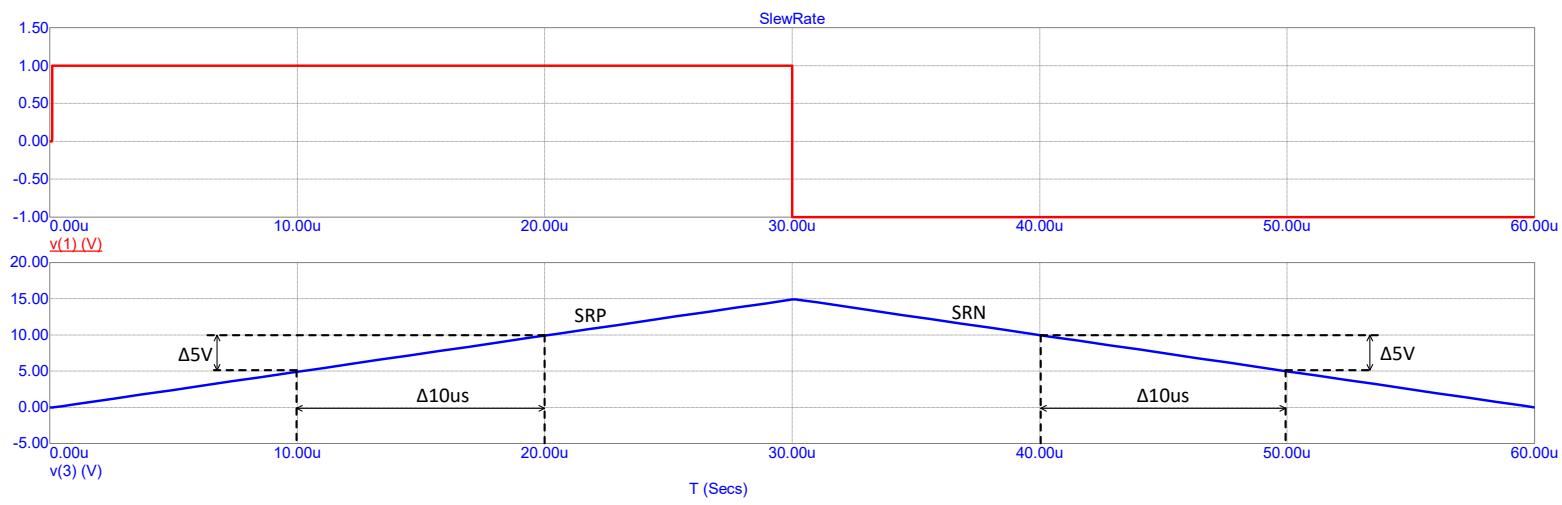

Obr. 14.11: Průběhy napětí pro určení rychlosti přeběhu. 
V horním grafu na Obr. 14.11 je uveden průběh vstupního napětí operačního zesilovače a ve spodním pak průběh výstupního napětí. V uvedeném př́ípadě je v modelu nastavena stejná hodnota rychlosti přeběhu pro rostoucí i klesající výstupní napětí. Z grafického průběhu můžeme nyní odečíst tedy odečtem z průběhu

$$
\mathrm{SRP}=\mathrm{SRN}=\frac{5 \mathrm{~V}}{10 \mu \mathrm{s}}=0,5 \mathrm{~V} / \mu \mathrm{s}=500 \cdot 10^{3} \mathrm{~V} / \mathrm{s}
$$

Toto odpovídá nastavené hodnotě SRP a SRN uvedené výše.

Pro dokreslení možností nastavení rozdílných rychlostí přeběhu pro kladný a záporný směr výstupního napětí je tato situace ukázána na Obr. 14.12.

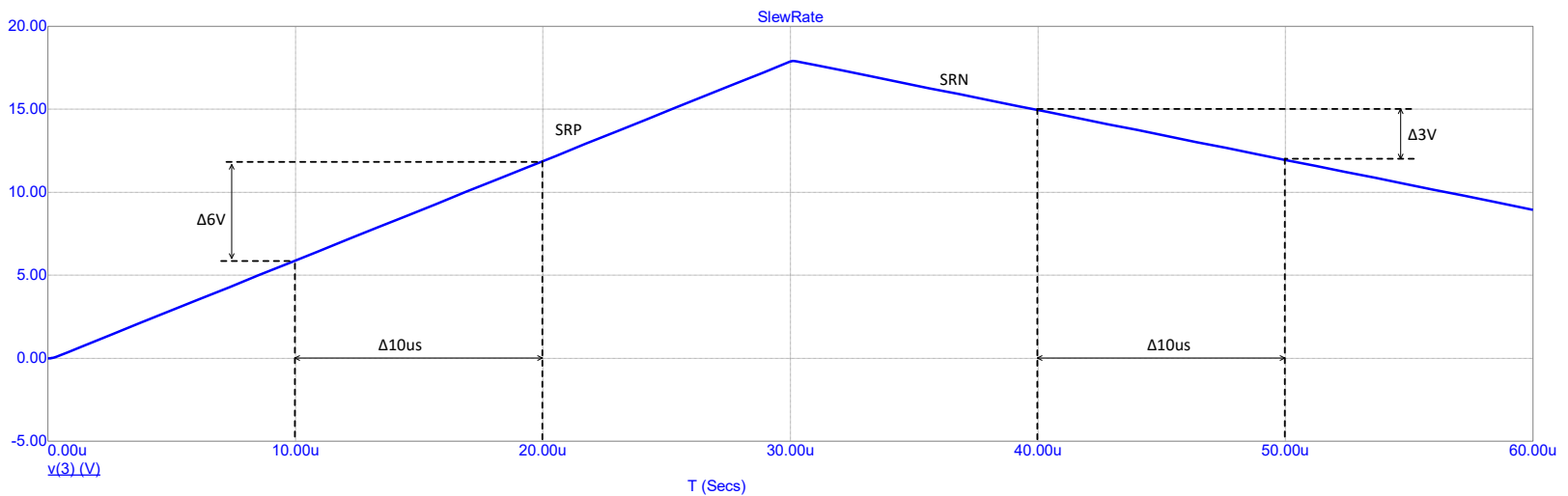

Obr. 14.12: Průběh výstupního napětí pro odlišné hodnoty SRP a SRN.

V tomto případě opět můžeme z grafu odečíst hodnoty pro

$$
\begin{aligned}
& \mathrm{SRP}=\frac{6 \mathrm{~V}}{10 \mu \mathrm{s}}=0,6 \mathrm{~V} / \mu \mathrm{s}=600 \cdot 10^{3} \mathrm{~V} / \mathrm{s}, \\
& \mathrm{SRN}=\frac{3 \mathrm{~V}}{10 \mu \mathrm{s}}=0,3 \mathrm{~V} / \mu \mathrm{s}=300 \cdot 10^{3} \mathrm{~V} / \mathrm{s},
\end{aligned}
$$

tedy simulací jsme potvrdili rozdílně nastavené parametry rychlosti přeběhu operačního zesilovače v jeho modelu.

Poslední ukázka simulace parametrů operačního zesilovače je zaměřena na výstupní odpor. Toto ověření je nutno brát spíše jako ukázku možností počítačové simulace a náměty pro další samostatnou práci se simulačním programem, získání základních dovedností a především uvědomění si důležitosti znalosti modelů prvků, v našem př́ípadě modelu operačního zesilovače.

Podívejme se opět na model operačního zesilovače úrovně LEVEL1 a LEVEL2 (viz Obr. 14.3, Obr. 14.4), vidíme, že výstupní část modelu je tvořena zdrojem proudu řízeného napětím, který je definován parametrem $g_{\mathrm{m}}$ (v modelu je značen $\left.\mathrm{GM}\right)$, tedy transkonduktancí neboli strmostí. Tato situace s ř́zenými zdroji je zobrazena na Obr. 14.13a. 


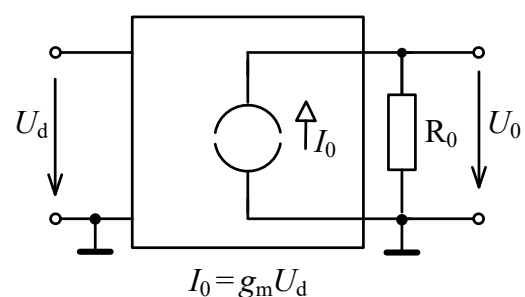

a)

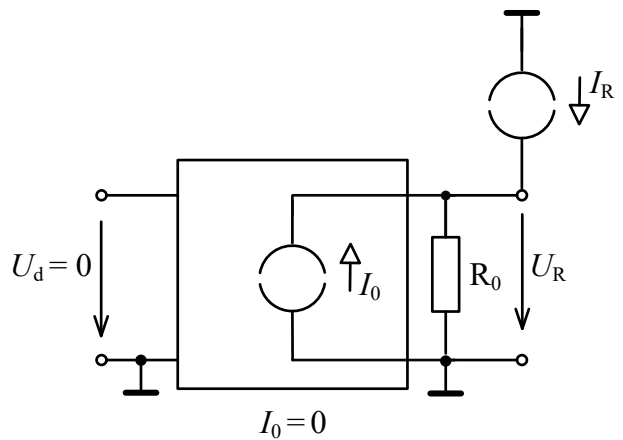

b)

Obr. 14.13: a) Zdroj proudu řízený napětím jako model OZ, b) obvodové řešení vhodné pro demonstraci hodnoty výstupního odporu OZ.

Ze schématu je zřejmé, že velikost výstupního proudu $I_{0}$ řízeného zdroje je závislá na vstupním diferenční napětí $U_{\mathrm{d}}$ a tento proud protékající výstupním rezistorem $\mathrm{R}_{0}$ na něm vytvoří úbytek napětí $U_{0}$, které tvoří výstupní napětí operačního zesilovače. Pokud není výstup operačního zesilovač zatížen, celý proud $I_{0}$ protéká rezistorem $\mathrm{R}_{0}$. S uvažováním vztahu pro zesílení $A$ modelu OZ lze pro výstupní napětí $U_{0}$ určit

$$
U_{0}=R_{0} \cdot I_{0}=R_{0} \cdot g_{m} \cdot U_{\mathrm{d}}=R_{0} \cdot \frac{A}{R_{0}} \cdot U_{\mathrm{d}}=A \cdot U_{\mathrm{d}}
$$

To je logický výsledek, který byl již uveden v kapitole základního popisu operačního zesilovač. Toto odvození nám poslouží k úvaze, jak demonstrovat a určit velikost výstupního odporu operačního zesilovače vhodnou simulací. Základní úvaha je uvedena na Obr. 14.13b. Vstupní diferenční napětí $U_{\mathrm{d}}$ nastavíme nulové, potom i výstupní proud $I_{0}$ řízeného zdroje bude nulový a rovněž výstupní napětí $U_{0}$ bude nulové. Vzhledem k charakteru modelu OZ, jako řízeného zdroje, můžeme na výstup operačního zesilovače připojit definovaný zdroj proudu $I_{R}$, kdy tento proud bude jako jediný protékat rezistorem $R_{0}$ a vytvoří na něm úbytek napětí $U_{\mathrm{R}}$. $\mathrm{Z}$ úbytku napětí a proudu snadno určíme výstupní odpor. Vztah pro výpočet může být př́ímo zadán jako parametr výstupní analýzy, jak bude ukázáno níže. Konkrétní obvod pro tuto simulaci je uveden na Obr. 14.14. Pro použitý operační zesilovač LM741 je v modelu nastaveno ROUTAC $=50$, ROUTDC $=75(\Omega)$ a výstupní odpor je dán součtem obou složek, tedy $R_{0}=$ $125 \Omega$. Externí zdroj proudu pro jednoduchý výpočet nastavíme $I_{\mathrm{R}}=1 \mathrm{~mA}$. Připomeňme, že modely úrovně LEVEL1 a LEVEL2 nemají žádná omezení výstupního napětí a proudu a nijak nereflektují na v praxi nereálná nastavení a hodnotu proudu, tedy z pohledu ,jednoduchosti“, můžeme nastavit třeba $1 \mathrm{~A}$. Je ovšem vhodné se i při počítačové simulaci přidržet hodnot, které odpovídají reálnému stavu. 


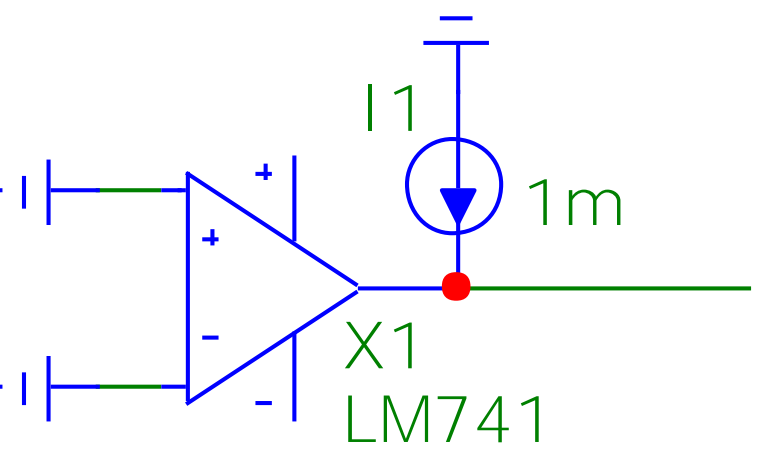

Obr. 14.14: Zapojení pro ověření velikosti výstupního odporu OZ.

Zobrazení či ověření nastavené velikosti výstupního odporu je velmi jednoduché. Jako první možnost simulace je využití analýzy ,Dynamic DC“. Tato položka ve volbě „Analysis“ není simulací v pravém slova smyslu, ve schématu jsou přímo ukázány hodnoty napětí $\mathrm{v}$ jednotlivých uzlech a prípadně proudy $\mathrm{v}$ jednotlivých větvích. Ke zvolení DC analýzy lze využívat přímo ikony v horní liště. Výsledná uzlová napětí a proudy ve větvích, v našem př́ípadě se jedná pouze o jednu větev se známým proudovým zdrojem, jsou uvedena na Obr. 14.15 .

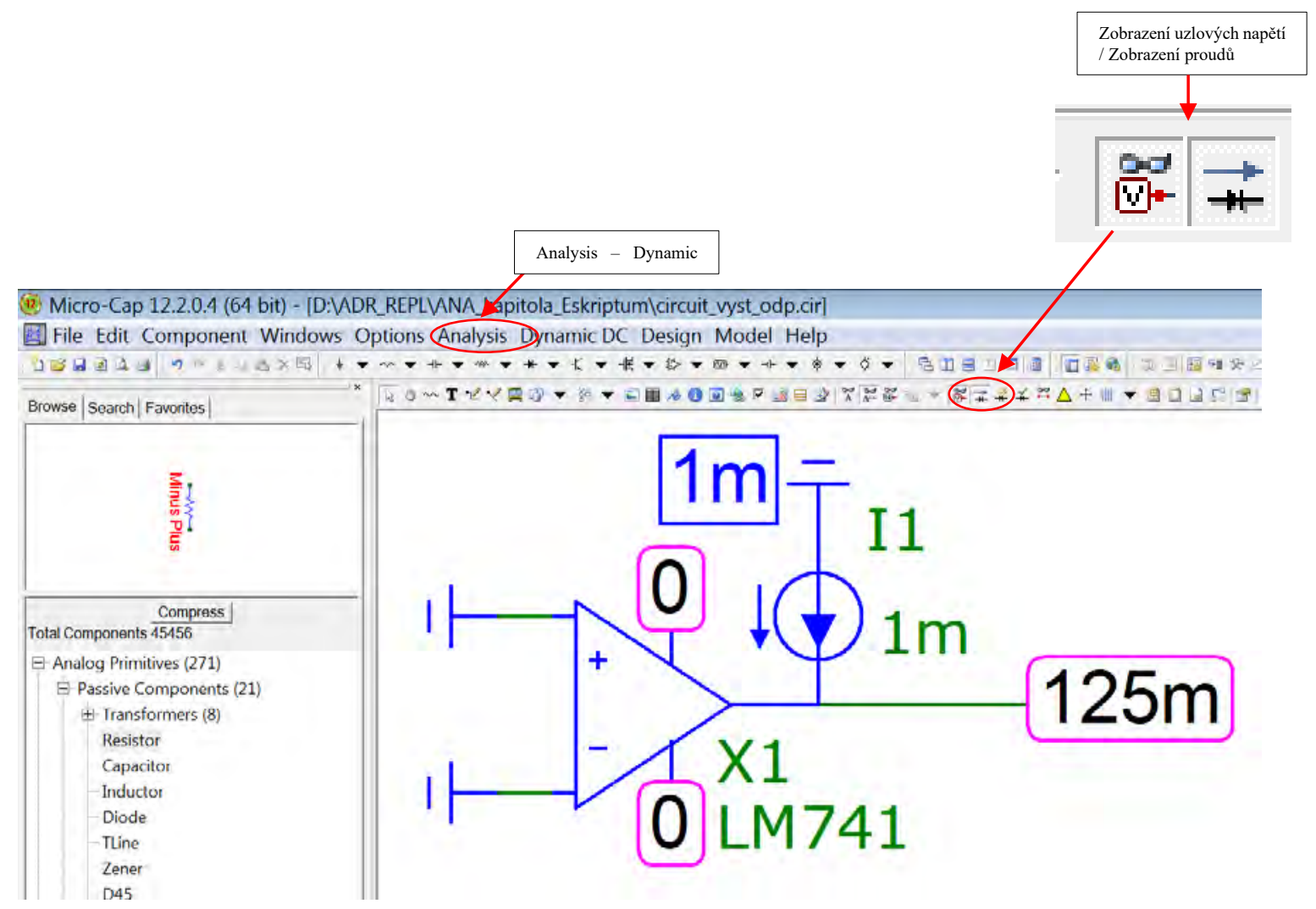

Obr. 14.15: Dynamic DC analýza, zobrazení uzlových napětí, proudů ve větvích. 
Z Obr. 14.15 je tedy patrné, že na výstupu operačního zesilovače je napětí $U_{\mathrm{R}}=125 \mathrm{mV}$ a vnitřní výstupní odpor $R_{0}=U_{\mathrm{R}} / I_{\mathrm{R}}=125 \mathrm{mV} / 1 \mathrm{~mA}=125 \Omega$. Tato hodnota odpovídá nastavené hodnotě v modelu, viz výše.

Obdobně můžeme využít i analýzu „DC Analysis“, kdy je zvolený zdroj napětí nebo proudu rozmítán ve zvoleném rozsahu a jsou zobrazena uzlová napětí nebo proudy ve větvích. V našem př́ípadě bude rozmítán zdroj proudu $\mathrm{I} 1$, a to $\mathrm{v}$ rozsahu $0 \ldots . .1 \mathrm{~mA}$. Výstupní odpor operačního zesilovače je lineární prvek, takže výstupem bude prŕímka. Nastavení tohoto typu analýzy je uvedeno na Obr. 14.16.

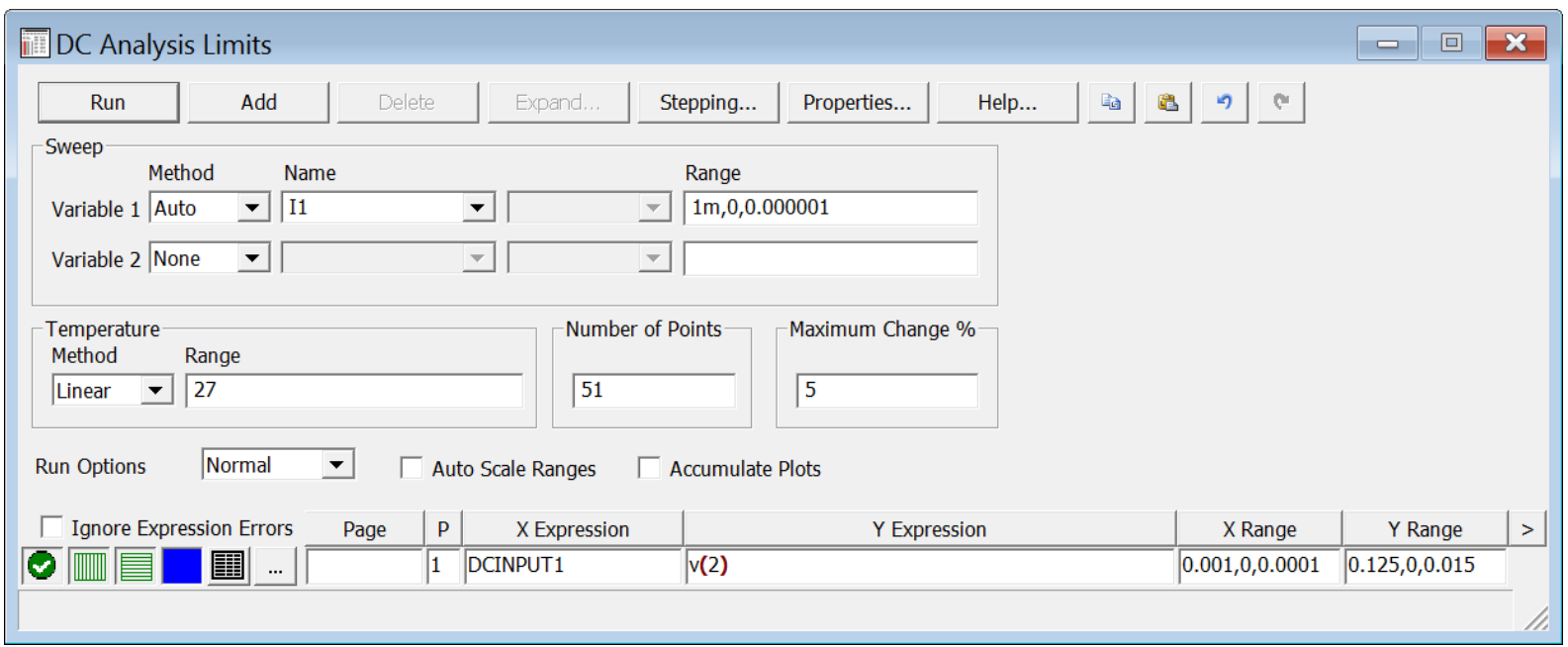

Obr. 14.16: Nastavení parametrů pro DC analýzu.

V tabulce nastavení jsou podstatné následující položky:

Name ... volba zdroje, který bude rozmítán,

Range ... nastavení rozsahu rozmítání ve tvaru <horni mez, dolní mez, krok>, při volbě kroku je potřeba být opatrný, pokud je velký, nemusí být zachycen průběh dostatečně přesně a výsledek může být zavádějící, pokud je velmi malý, může výpočet trvat velmi dlouho, respektive je vypsáno upozornění, že počet počítaných bodů je př́liš vysoký,

X Expression ... klíčové označení zdroje, který je rozmítán,

Y Expression ... napětí ve specifikovaném uzlu, výstup operačního zesilovače.

Po spuštění analýzy je zobrazen průběh uvedený na Obr. 14.17. Z něho je patrné, že na ose $x$ je proud proudového zdroje I1 a na ose $y$ je výstupní napětí operačního zesilovače, tedy jak už bylo uvedeno výše, je to napětí $U_{\mathrm{R}}$ na výstupním odporu $R_{0}$.

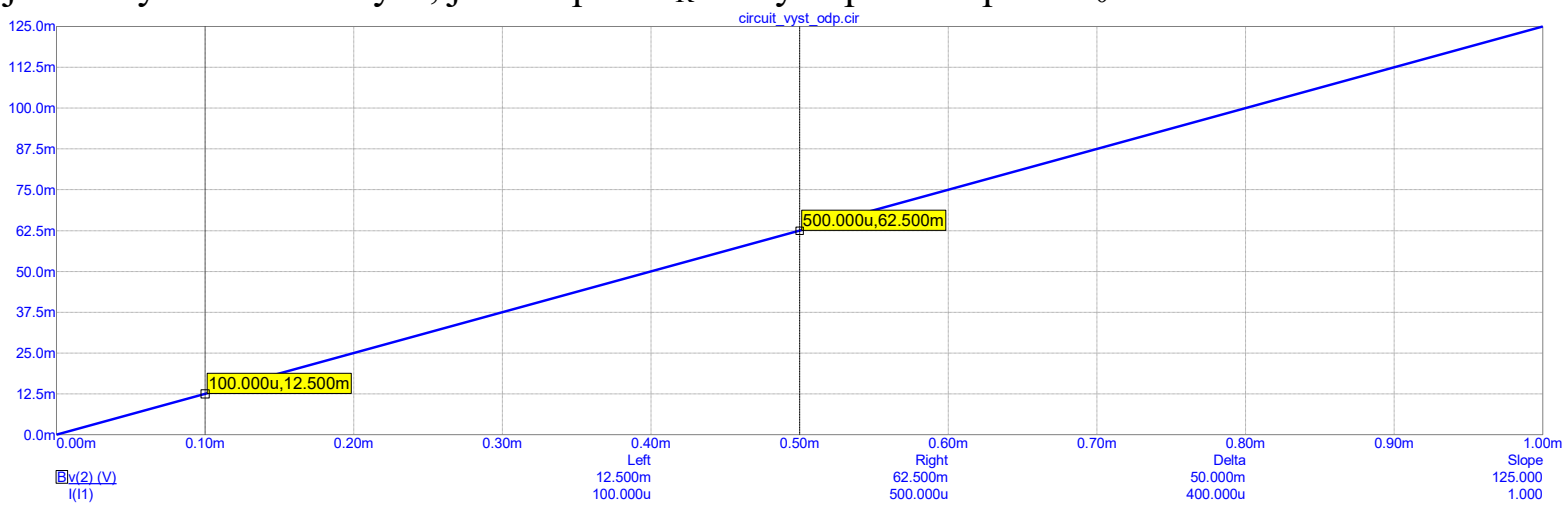

Obr. 14.17: DC analýza. 
V jakémkoli bodě odečteme hodnotu $I_{\mathrm{R}}$ a $U_{\mathrm{R}}$ (výstupní napětí $\mathrm{OZ}$ ) a obdobně jako výše vypočteme z Ohmova zákona velikost $R_{0}=U_{\mathrm{R}} / I_{\mathrm{R}}=12,5 \mathrm{mV} / 0,1 \mathrm{~mA}=125 \Omega$. Z matematického hlediska je hledaná hodnota odporu směrnice zobrazené přímky, hodnota této směrnice je př́mo uvedena pod grafem vpravo dole jako 'Slope', což je přímo hledaná hodnota odporu.

$\mathrm{Na}$ závěr ukažme simulaci, kdy bude přímo zobrazena hodnota výstupního odporu operačního zesilovače. Využijeme opět DC analýzu a do výrazu Y Expression, viz Obr. 14.16, zapíšeme př́mo výpočtový výraz, tedy napětí na výstupu OZ lomeno proud, který dodává zdroj I1 - v(2)/i(I1). Po spuštění analýzy dostaneme př́mo ,průběh“ výstupního odporu, a to je samozřejmě konstantní hodnota $125 \Omega$ (viz Obr. 14.18), odpovídající zadání v popisu modelu.

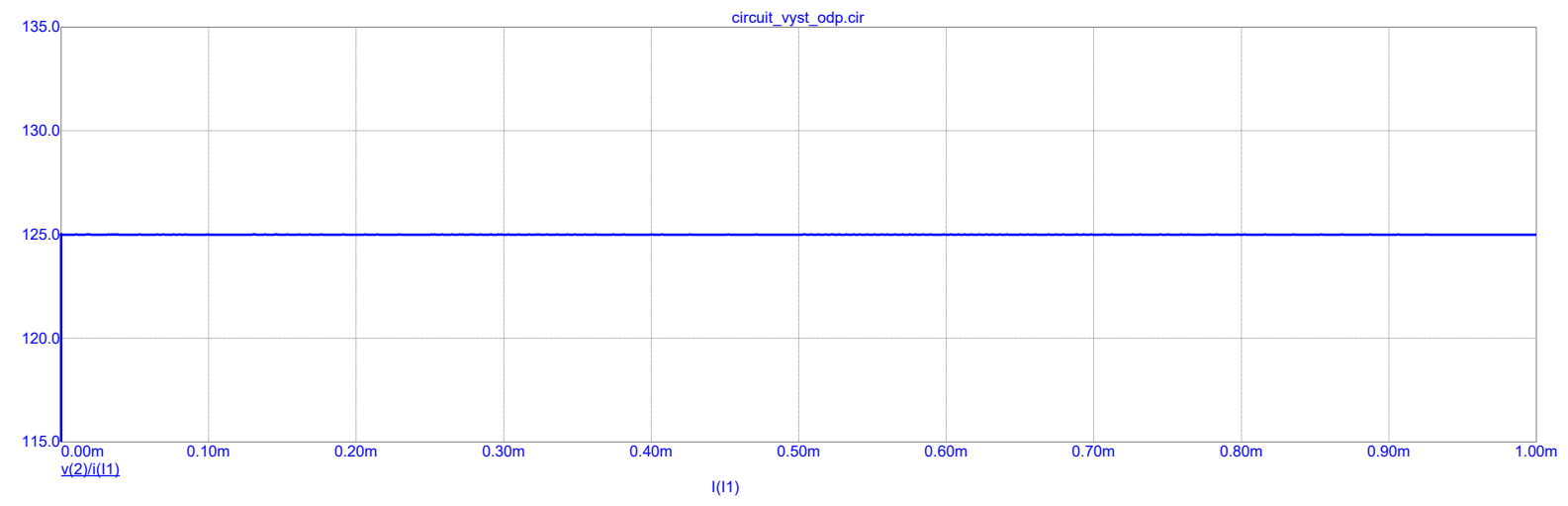

Obr. 14.18: DC analýza - výstupní odpor.

\section{PŘÍKLAD_2}

Základní zapojení s operačním zesilovačem - invertující zesilovač, zesílení, kmitočtová charakteristika, šířka pásma, vstupní odpor, simulace $v$ časové oblasti, výkonový kmitočet.

Realizujme invertující zesilovač s $\mathrm{OZ}$ se zesílením $A_{\mathrm{u}}=-10$. Zapojení je uvedeno na Obr. 14.19. Hodnoty odporů zvolme $R_{1}=10 \mathrm{k} \Omega$ a $R_{2}=100 \mathrm{k} \Omega$. Napětové zesílení tedy bude $A_{\mathrm{u}}=-R_{2} / R_{1}=-100 \cdot 10^{3} / 10 \cdot 10^{3}=-10$ a zisk $z=20 \cdot \log 10=20 \mathrm{~dB}$. Znaménko minus značí, že zesilovač obrací fázi o $180^{\circ}$. Použijme opět OZ typu LM741. Vlastní schéma v editoru MicroCap je uvedeno na Obr. 14.20a, úroveň modelu OZ nastavme na LEVEL2 a toto nastavení je využito ve všech dále uvedených simulacích, pokud nebude uvedeno jinak. Jak již bylo zmíněno výše, pro ověření vlastností a funkce obvodu je nejlépe začínat s jednoduššími modely. V prvé řadě zobrazíme kmitočtovou charakteristiku, zjistíme šírku pásma - mezní kmitočet $f_{0}$, ověříme zesílení, určíme tranzitní kmitočet. $\mathrm{K}$ tomu využijeme ,AC Analysis“, nastavení mezí analýzy je uvedeno na Obr. 14.20b.

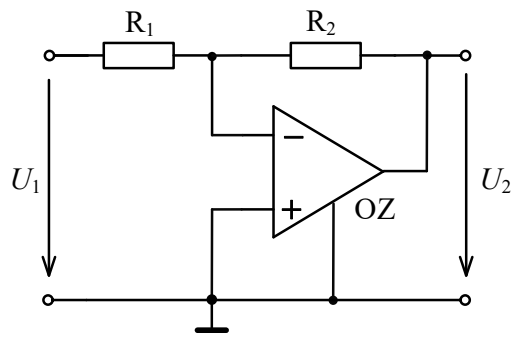

Obr. 14.19: Invertující zesilovač 


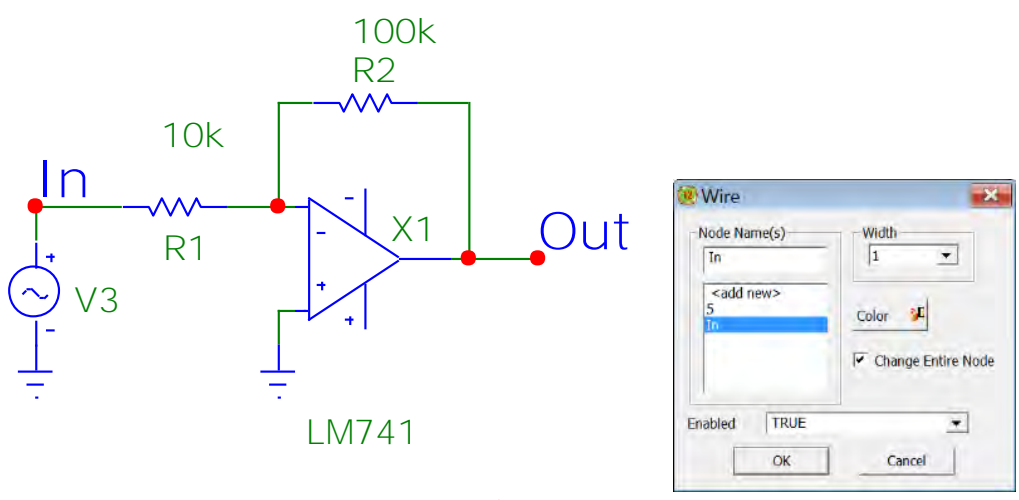

a)

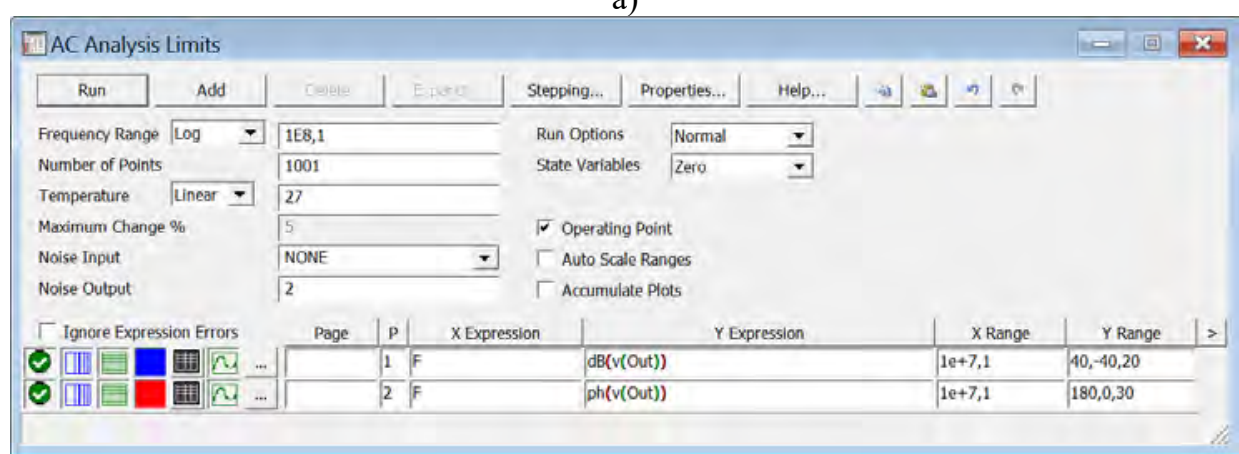

b)

Obr. 14.20: a) Invertující zesilovač ve schematickém editoru, b) nastavení mezí analýzy.

Na Obr. 14.20a si všimněme označení vstupního (In) a výstupního (Out) uzlu. Uzly jsou automaticky číslovány tak, jak jsou součástky přidávány do schématu. Čísla uzlů lze zobrazit zakliknutím prŕslušné ikony a čísla uzlů lze pak užívat při nastavení analýz. Pro větší přehlednost lze vybrané uzly pojmenovat. Toto provedeme kliknutím na vybraný vodič nebo uzel a zobrazí se okno uvedené na Obr. 14.20a vpravo, do okénka vepíšeme název vodiče/uzlu, který pak můžeme používat v nastavení analýz, jak pak uvedeno na Obr. $14.20 \mathrm{~b}$ v položce $\mathbf{Y}$ Expression. Vstupní zdroj V3 harmonického signálu je „Sine Source“ z knihovny prvků Waveform Sources. Tento zdroj logicky odpovídá použité simulaci a z nabídky můžeme vybrat kterýkoli z dostupných. Jeho nastavení není v této chvíli podstatné.

Výsledný průběh kmitočtové charakteristiky je uveden na Obr. 14.21. Z průběhu je vidět soulad s nastaveným zesílením, zisk je $20 \mathrm{~dB}$ a zesilovač obrací fázi. První lomový kmitočet se posunul na hodnotu cca $96 \mathrm{kHz}$ a tranzitní kmitočet $f_{\mathrm{T}} \approx 1 \mathrm{MHz}$, kmitočet $G B W=f_{\mathrm{T}}$ a fázová bezpečnost $P M$ jsou v souladu s kmitočtovou charakteristikou OZ bez zpětné vazby. Kurzory na odečet hodnot lze zvolit na horní liště, jak je naznačeno v horní části na Obr. 14.21.

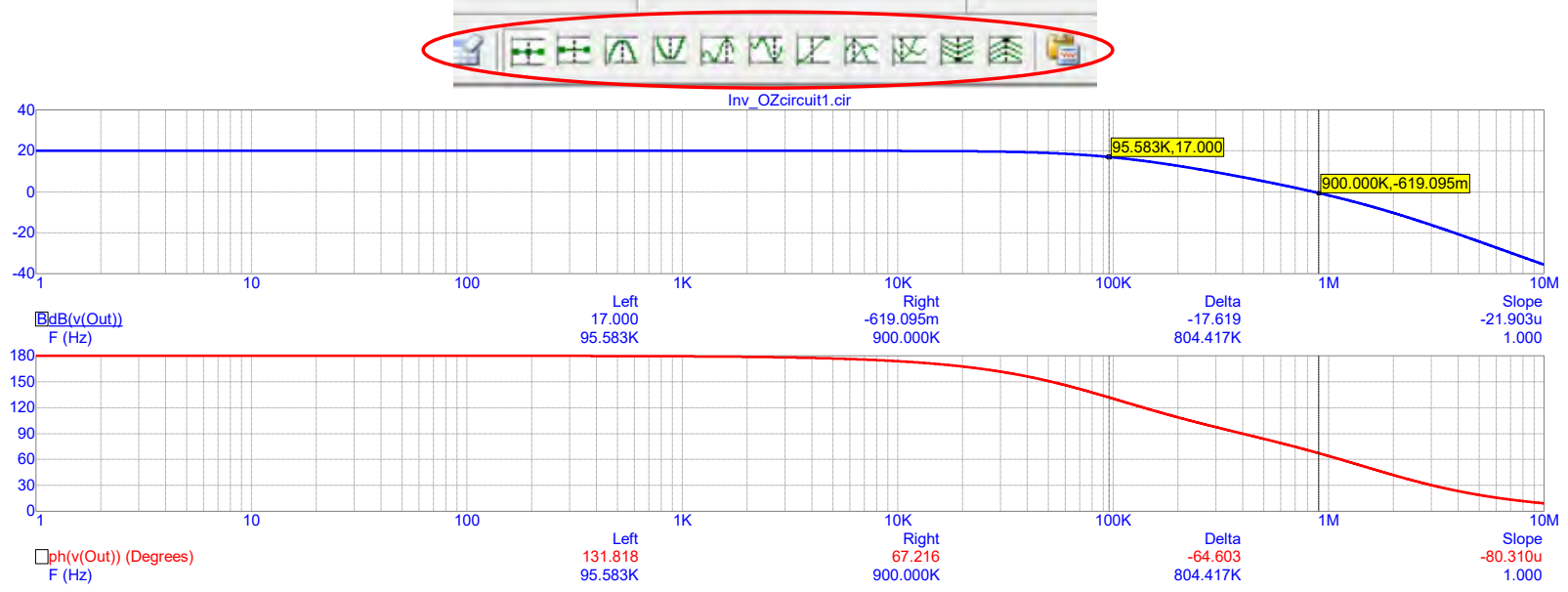

Obr. 14.21: Kmitočtová charakteristika invertujícího zesilovače s OZ, odečítací kurzory. 
V kapitole „Invertující a neinvertující zesilovač” bylo ukázáno, že pro invertující zesilovač s OZ je charakteristická konečná hodnota vstupního odporu. Jak již bylo zmíněno, u invertujícího zesilovače je uzel $\mathrm{S}$ na nulovém potenciálu, vstupní diferenční napětí $u_{\mathrm{i}} \approx 0$, a vstupní proud $i_{1}$ je určen pouze vstupním napětím $u_{1}$ a odporem rezistoru $\mathrm{R}_{1}$ a tedy vstupní odpor invertujícího zesilovače $R_{\mathrm{vst}} \approx R_{1}$. Toto je platné, pokud se vlastnosti operačního zesilovače blíží ideálnímu OZ. V simulaci je uvažován model úrovně LEVEL2, kde vstupní diferenční odpor není v modelů uvažován a je tedy nekonečně velký.Tuto situaci nyní budeme analyzovat v programu Micro-Cap. Postup bude obdobný jako v předchozím příkladě 1.

V rámci prověření činnosti proved'me DC analýzu vstupního odporu invertujícího zesilovače dle dřive zmíněného postupu, tzn., že i nastavení bude obdobné jako dříve, viz závěr př́kladu

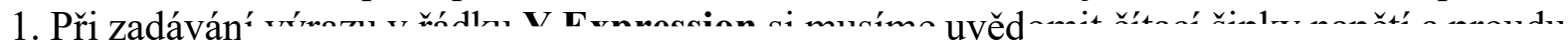
Význam směr zem.

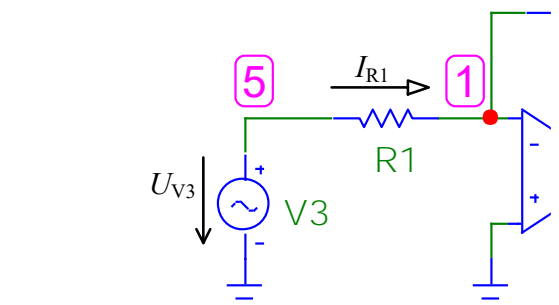

$\mathrm{v}(5) / \mathrm{i}(5,1) ; \mathrm{v}(5,0) /-\mathrm{i}(1,5) ; \mathrm{v}(\mathrm{VB}) / 71(\mathrm{R} 1)$ ipon

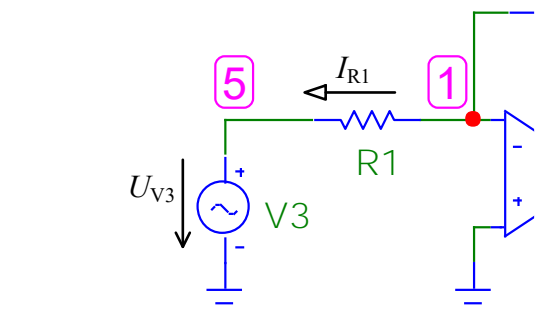

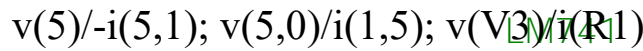

Obr. 14.22: Zápis napětí a proudů a význam čítacích šipek.

Z uvedených př́ikladů jsou patrné způsoby zápisu tak, aby hodnota vstupního odporu byla zobrazena správně. Výsledný průběh je ukázán na Obr. 14.23.

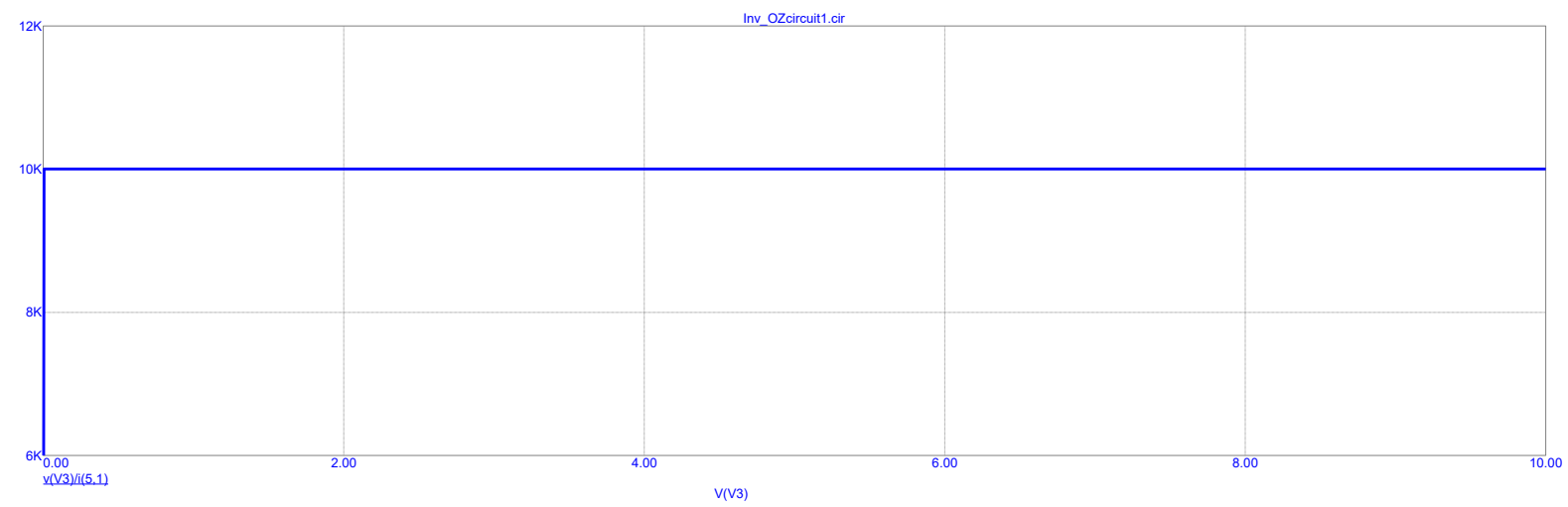

Obr. 14.23: Zobrazení vstupního odporu invertujícího zesilovače.

Z průběhu je patrné, že vstupní odpor invertujícícho zesilovače odpovídá hodnotě odporu $R_{1}$ tak, jak bylo předpokládáno a uvedeno výše. Tento průběh ovšem nic neř́ká o př́ípadné kmitočtové závislosti vstupního odporu.

Podívejme se opět na průběh kmitočtové charakteristiky na Obr. 14.21. Z průběhu je vidět, že šiřka pásma uvedeného zesilovače je cca $96 \mathrm{kHz}$ a fáze je na tomto kmitočtu cca $130^{\circ}$. Zesilovač tedy již není zcela invertující (otočení fáze $180^{\circ}$ ) a tedy již ne zcela platí předpoklad 
pro vstupní odpor. Je ovšem nutné si uvědomit, že využitelná pracovní šiřrka pásma je do prvního lomového kmitočtu a tedy zesilovač nebude za tímto kmitočtem využíván, nebot' to postrádá smysl. Zobrazme průběh vstupního odporu invertujícího zesilovače v kmitočtové oblasti a zobrazme rovněž průběh modulu a fáze výstupního napětí. Rozsah simulace má význam do cca kmitočtu $1 \mathrm{MHz}$. Výsledné průběhy jsou uvedeny na Obr. 14.24.

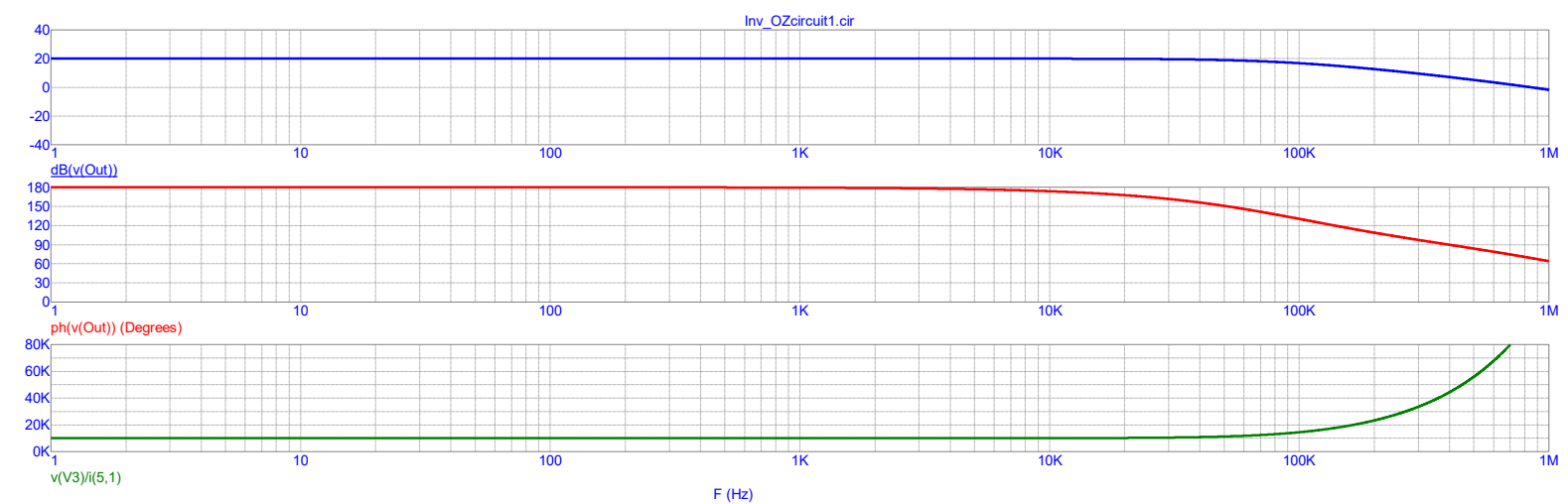

Obr. 14.24: Zobrazení vstupního odporu invertujícího zesilovače v kmitočtové oblasti.

Z průběhu je patrné, že vstupní odpor ve využitelném kmitočtovém pásmu odpovídá předpokladům a je roven odporu $R_{1}$. Za lomovým kmitočtem se již začíná uplatňovat pokles zesílení a změna fáze. Tento vliv snadno ověřime změnou odpovídajících parametrů v modelu operačního zesilovače nebo zvolíme model OZ úrovně LEVEL1. Průběhy s touto úrovní zde není třeba uvádět, všechny grafy z Obr. 14.24 budou vodorovné přímky na př́slušných hodnotách $v$ celém kmitočtovém rozsahu.

Zobrazme nyní analýzu v časové oblasti, kdy vstupním signálem bude zdroj harmonického signálu o určitém kmitočtu. Z předchozích ukázek již máme na vstupu zdroj V3 a na Obr. 14.25 je uvedeno nastavení jednotlivých parametrů zdroje. V našem prŕípadě je zvolen zdroj “GENERAL". Podstatné parametry jsou A (amplituda), F (kmitočet), dále pak pro úplnost DC (stejnosměrná složka) - v našem př́ípadě musí být nulová, RS (vnitřní odpor zdroje).

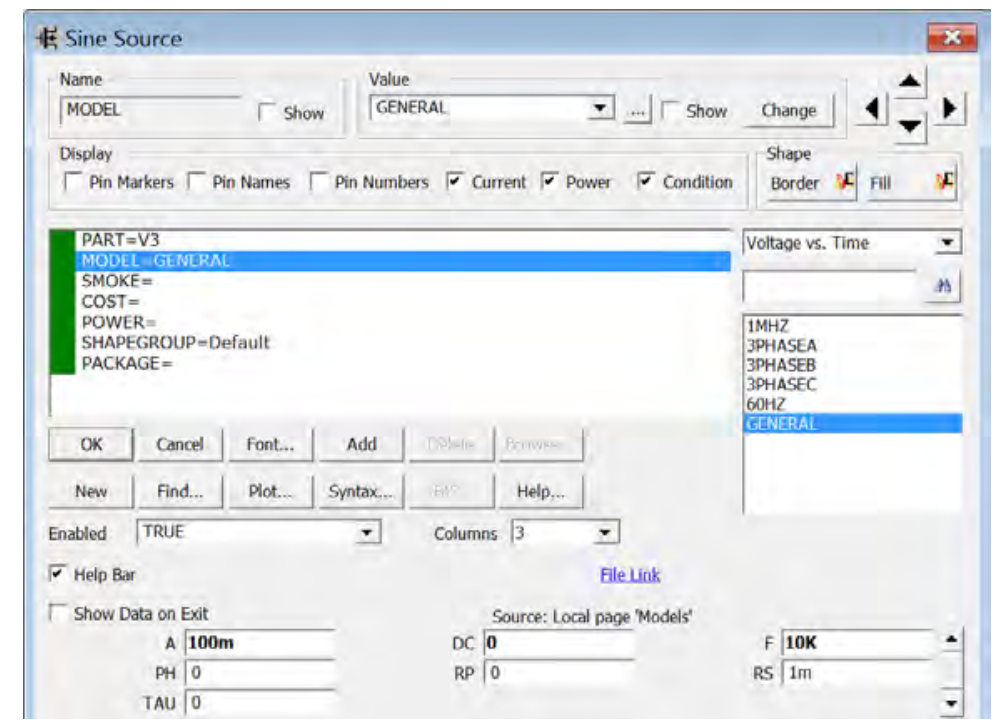

Obr. 14.25: Nastavení parametrů zdroje "Sine Source". 
Spustíme analýzu „Tranzient" a vhodně nastavíme parametry analýzy a měřítka os. Zde jenom zmíníme parametr 'Maximum Time Step', kdy při velké hodnotě kroku nemusí být zobrazený průběh dostatečně přesný, při malém kroku může výpočet trvat neúměrně dlouho nebo bude zastaven pro velký počet výpočtových bodů.

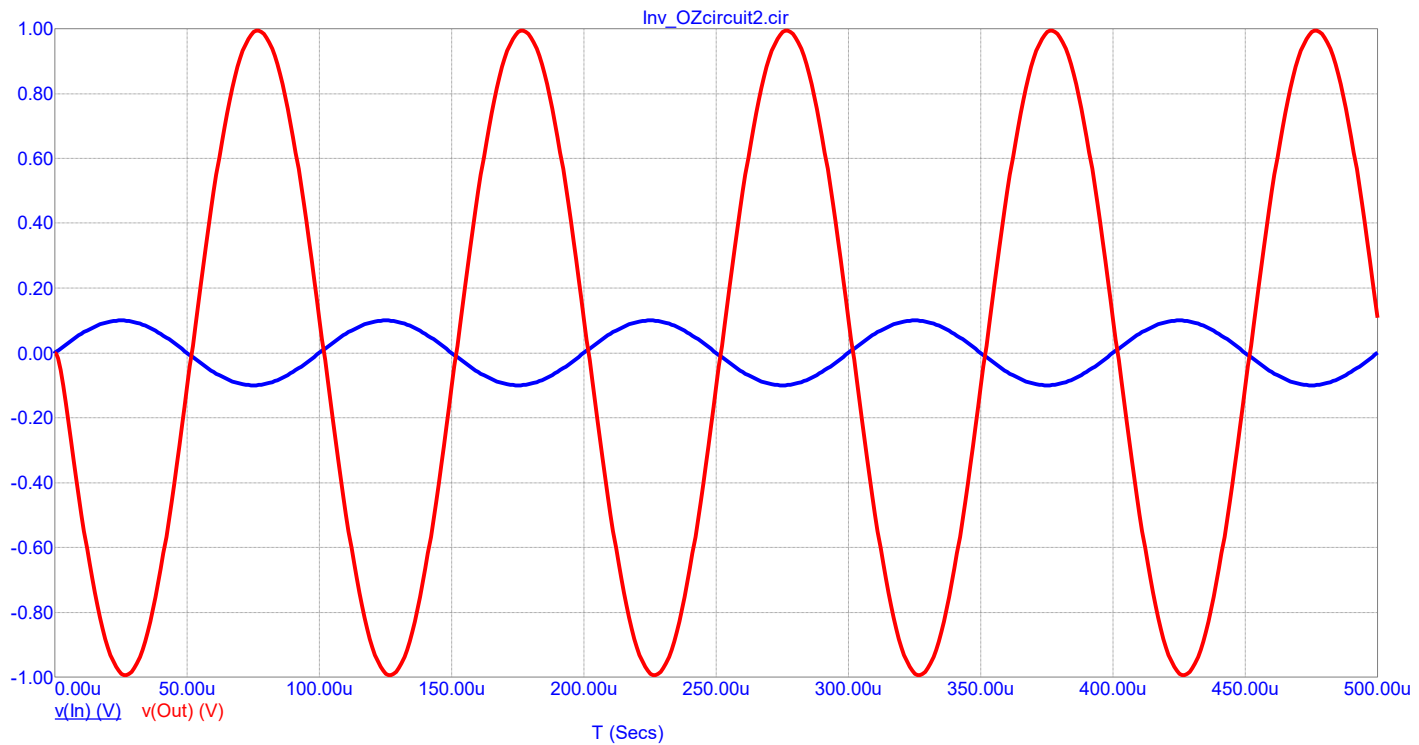

Obr. 14.26: Výsledné průběhy časové analýzy.

Výsledný graf je uveden na Obr. 14.26, kde jsou uvedeny dva průběhy. Modrý průběh je vstupní signál s amplitudou $100 \mathrm{mV}$, červený průběh je fázově posunut o $180^{\circ}$ (invertující zesilovač) a jeho amplituda je $1 \mathrm{~V}$, tedy výstupní signál je 10 krát zesílen. Kmitočet signálu je $10 \mathrm{kHz}$, tedy cca $10 \mathrm{x}$ nižší kmitočet, než je mezní kmitočet tohoto zesilovače, $f_{0} \approx 96 \mathrm{kHz}$, tedy kmitočet zesilovaného signálu se nachází v pracovní oblasti zesilovače.

Pokud budeme zvyšovat kmitočet signálu, bude se amplituda výstupního signálu snižovat dle modulu kmitočtové charakteristiky. Zaměřme se nyní na zesílení resp. amplitudu výstupního signálu. Ta je ve výše uvedeném případě výrazně nižší, než je jmenovité výstupní napětí $U_{0 \max }$ operačního zesilovače.

V kapitole „Parametry operačních zesilovačů“ je popsán parametr „,Mezní výkonový kmitočet". Ten je dán konečnou rychlostí změny výstupního napětí, která způsobuje zkreslení harmonického signálu, přestože jeho kmitočet je v propustném pásmu zesilovače. Při zesilování harmonického signálu nízkých kmitočtů můžeme plně využívat dovoleného rozkmitu výstupního napětí a pracovat s amplitudou $U_{\text {omax }} 13$ až $14 \mathrm{~V}$ (v modelu operačního zesilovače je to hodnota VPS, VNS a uplatňuje se pouze v úrovni modelu LEVEL3). Při zvyšování kmitočtu vstupního signálu je třeba, aby výstupní harmonický signál neměl absolutní strmost větší než je strmost $S_{\mathrm{R}}$. Jak je v odkazu uvedeno, pokud bude $S_{\mathrm{R}} \geq 2 \pi f U_{0}$, rychlost přeběhu neovlivní průběh výstupního napětí, v opačném prŕípadě nastane situace uvedená na Obr. 14.27 (převzato z uvedené kapitoly pro lepší přehlednost). 


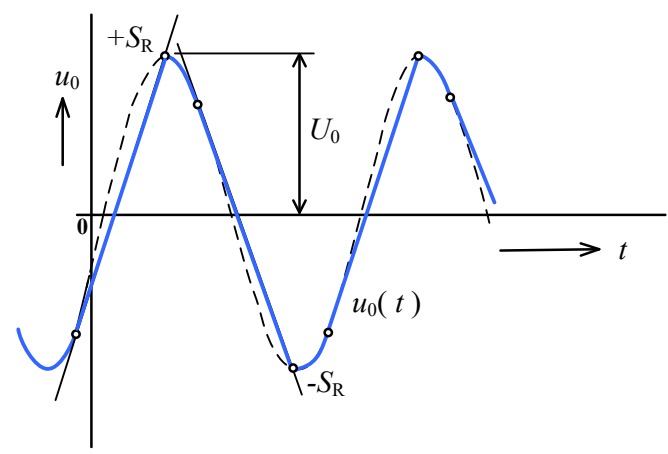

Obr. 14.27: Vliv konečné rychlosti přeběhu na výstupní signál.

Kmitočet, do kterého můžeme pracovat s maximálním výstupním napětím $U_{0 \max }$ je dán vztahem

$$
f_{\mathrm{P}}=\frac{S_{\mathrm{R}}}{2 \pi U_{\mathrm{omax}}},
$$

který je v katalogu součástek uváděn jako výkonový kmitočet $f_{\mathrm{P}}$. Při kmitočtu vyšším než $f_{\mathrm{P}}$ je nutné snížit amplitudu výstupního harmonického napětí tak, aby průběh nebyl zkreslen.

Tento jev nyní budeme simulovat s invertujícím zesilovačem. Připomeňme, že pracujeme s modelem operačního zesilovače LEVEL2, u kterého se neuplatňuje nastavené saturační napětí, tedy velikost výstupního napětí bude dána velikostí vstupního napětí a zesílením. Toto ovšem není při simulaci na závadu, sledujeme určitý jev, který nebude ovlivněn jevem jiným, nesledovaným. Víme, že zesílení invertujícího zesilovač je 10 a ponechme výstupní napětí $\mathrm{s}$ reálným předpokladem rozkmitu výstupního napětí $\pm 15 \mathrm{~V}$, tedy velikost vstupního napětí zdroje V3 (viz Obr. 14.20a)) nastavíme na 1,5 V.

$\mathrm{V}$ modelu LM741 je nastavena rychlost přeběhu $\mathrm{SRP}=\mathrm{SRN}=500 \cdot 10^{3} \mathrm{~V} / \mathrm{s}$. Podle předchozí rovnice je $f_{\mathrm{P}} \approx 5300 \mathrm{~Hz}$ a tedy kmitočet vstupního signálu musí být větší než $f_{\mathrm{P}}$, aby uvedený jev nastal. Zvolme kmitočet vstupního signálu $7 \mathrm{kHz}$, aby zkreslení průběhu bylo dostatečně zřetelné. Spustíme analýzu „Tranzient“ a vhodně nastavíme parametry analýzy a osy grafu. Výsledný průběh je uveden na Obr. 14.28, červený průběh A.

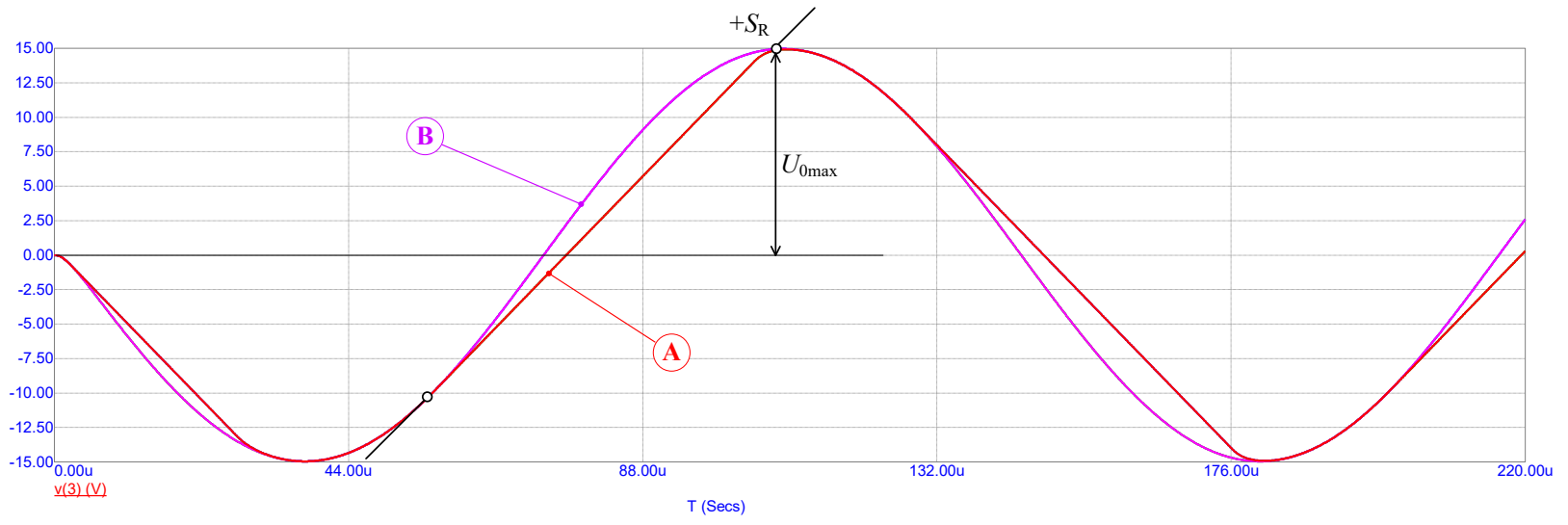

Obr. 14.28: Simulace vlivu konečné rychlosti přeběhu na výstupní signál. 
Z průběhu je zcela zřejmé, že výstupní signál je zkreslen. Pro porovnání je ve stejném grafu zobrazen nezkreslený signál, fialový průběh $\mathrm{B}$, u kterého je nastavena vyšší rychlost přeběhu. Odečtěme z průběhů, jaké jsou rychlosti přeběhu, viz Obr. 14.29.

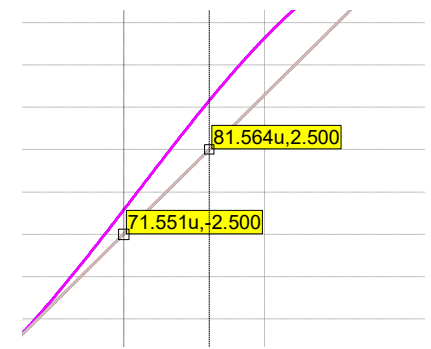

Průběh A

$$
S_{\mathrm{A}}=\frac{2,5 \mathrm{~V}-(-2,5 \mathrm{~V})}{81,564 \mu \mathrm{s}-71,551 \mu \mathrm{s}}=499 \cdot 10^{3} \mathrm{~V} / \mathrm{s}
$$

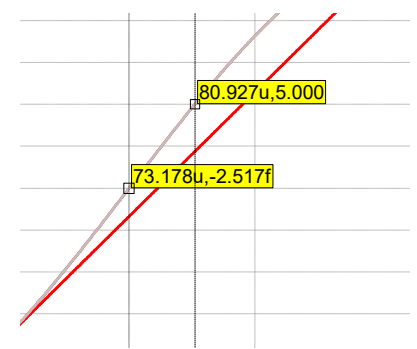

Průběh B

$$
S_{\mathrm{B}}=\frac{5 \mathrm{~V}-0 \mathrm{~V}}{80,927 \mu \mathrm{s}-73,178 \mu \mathrm{s}}=645 \cdot 10^{3} \mathrm{~V} / \mathrm{s}
$$

Obr. 14.29: Určení rychlosti přeběhu pro průběh A a B.

Je zřejmé, že u průběhu A je vypočtená rychlost přeběhu dána nastavením v modelu operačního zesilovače. Průběh B ukazuje, že rychlost přeběhu potřebná pro nezkreslený průběh je $645 \cdot 10^{3} \mathrm{~V} / \mathrm{s}$, a to je podstatně vyšší hodnota než máme $\mathrm{k}$ dispozici. Je tedy nutné snížit amplitudu výstupního signálu nebo použít jiný typ operačního zesilovače. 


\section{PŘÍKLAD_3}

Integrátor s OZ, časově závislý zdroj napětí, základní funkce integrátoru, analýza v časové oblasti, rychlý integrátor, rychlostní chyba, dopředný přenos.

Základní zapojení integrátoru s operačním zesilovačem je uvedeno na Obr. 14.30. Činnost integrátoru je pči nulové počáteční podmínce popsána vztahem

$$
u_{2}(t)=-\frac{1}{R C} \int u_{1}(t) \mathrm{d} t .
$$

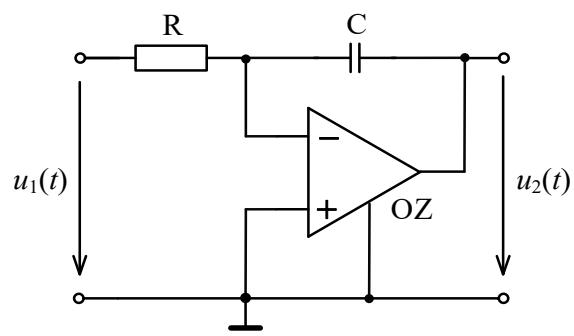

Obr. 14.30: Integrátor s operačním zesilovačem

Součin $R C=\tau$ je časová konstanta integrátoru, $t$ je doba integrace. Uvažujeme-li, že vstupní napětí je konstantní, $u_{1}=U_{1}$, pak

$$
u_{2}(t)=-\frac{U_{1}}{\tau} \cdot t
$$

Tento vztah využijeme pro orientační stanovení v určitém čase při zadávání mezí v časové analýze. $Z$ matematického hlediska se jedná o rovnici př́mky, kde směrnice této prímky je $k=$ $-U_{1} / \tau$.

Při vlastní analýze integrátoru využijeme časově závislý zdroj napětí, který je v knihovně prvků Analog Primitives - Waveform Sources - Pulse Source. K definici zdrojů se dostaneme obdobným způsobem jako u operačního zesilovače. Při definici těchto zdrojů se zadávají tyto parametry:

VZERO : nulová úroveň [V]

VONE : jednotková úroveň $[\mathrm{V}]$

P1 : časový okamžik vzniku náběžné hrany [s]

P2 : časový okamžik dosažení jednotkové úrovně [s]

P3 : c časový okamžik vzniku sestupné hrany [s]

P4 : $\quad$ časový okamžik dosažení nulové úrovně [s]

P5 : perioda kmitů [s]

Průběh napětí definovaný těmito parametry nejlépe dokumentuje Obr. 14.31. Všechny zadávané časové okamžiky P1 až P4 jsou vztaženy k počátku $(t=0)$. 


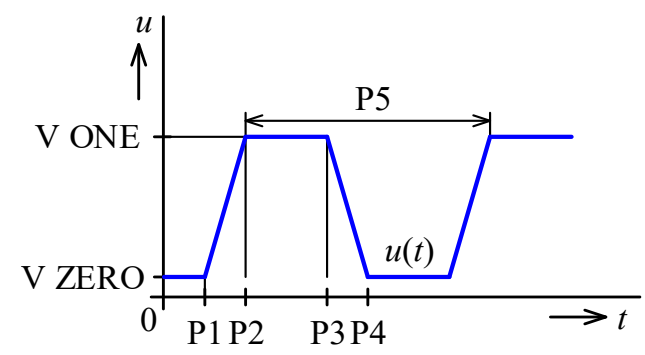

Obr. 14.31: Význam parametrů v časově závislém zdroji.

Vhodnou volbou hodnot parametrů P1-P5 lze vytvořit rozmanité průběhy napětí. Dále jsou uvedeny př́iklady nastavení parametrů zdroje napětí, které ukazují, jak získat typické průběhy.

Tab. 14.2: Příklady nastavení parametrů zdroje napětí

\begin{tabular}{|l|l|}
\hline \multicolumn{2}{|l|}{ Skok napětí } \\
\hline Sled pravoúhlých impulsů s nulovou dobou trvání čela a týlu \\
\hline
\end{tabular}

Při simulaci základní činnosti integrátoru použijeme model operačního zesilovače LF155 (LEVEL2), u něhož nastavíme výstupní odpor $R_{0}$ na hodnotu $2 \Omega$. Jak již bylo uvedeno, model operačního zesilovače v Micro-Cap obsahuje jak střídavý, tak i stejnosměrný výstupní odpor. V modelu OZ jsou tyto odpory zapojeny ve výstupním obvodu do série, (ROUTAC + ROUTDC $=R_{0}$, nastavíme oba odpory shodně na $1 \Omega$ ). Malý výstupní odpor nastavujeme z důvodu potlačení tzv. dopředného přenosu. Tento jev reálného operačního zesilovače bude osvětlen dále. Je-li časová konstanta dostatečně velká, není vliv dopředného přenosu významný, ale v této simulaci jde především o ověření funkce integrátoru. Zvolme tedy $R=50 \mathrm{k} \Omega$ a $C=2000 \mathrm{nF}$, tzn. $\tau=R C=50 \cdot 10^{3} \cdot 2000 \cdot 10^{-9}=100 \mathrm{~ms}$.

Dále nastavíme parametry zdroje vstupního napětí. V první fázi zvolíme skok napětí, kdy se v určitém okamžiku na vstupu integrátoru objeví konstantní napětí, (předpokládejme, že $\mathrm{v}$ čase před napět'ovým skokem je $U_{1}=0$ !). Parametry zdroje např. mohou být $\mathrm{P} 1=1 \mathrm{~m}, \mathrm{P} 2=1 \mathrm{~m}$, $\mathrm{P} 3=50 \mathrm{~m}, \mathrm{P} 4=50 \mathrm{~m}, \mathrm{P} 5=1, \mathrm{VONE}=5, \mathrm{VZERO}=0$. To znamená, že v čase $1 \mathrm{~ms}$ se vstupní napětí integrátoru změní z $0 \mathrm{~V}$ na $5 \mathrm{~V}$ a integrátor začne integrovat. Dle předchozích úvah každou 1 ms klesne výstupní napětí (invertující integrátor, záporná směrnice přímky, viz výše) o $50 \mathrm{mV}$, $k=-U_{1} / \tau=-5 \mathrm{~V} / 100 \mathrm{~ms}=-50 \mathrm{~V} / \mathrm{s}=-50 \mathrm{mV} / \mathrm{ms}$.

Spustíme analýzu „Tranzient" a vhodně nastavíme parametry analýzy a měřítka os. Průběhy vstupního a výstupního napětí integrátoru jsou uvedeny na Obr. 14.32. 


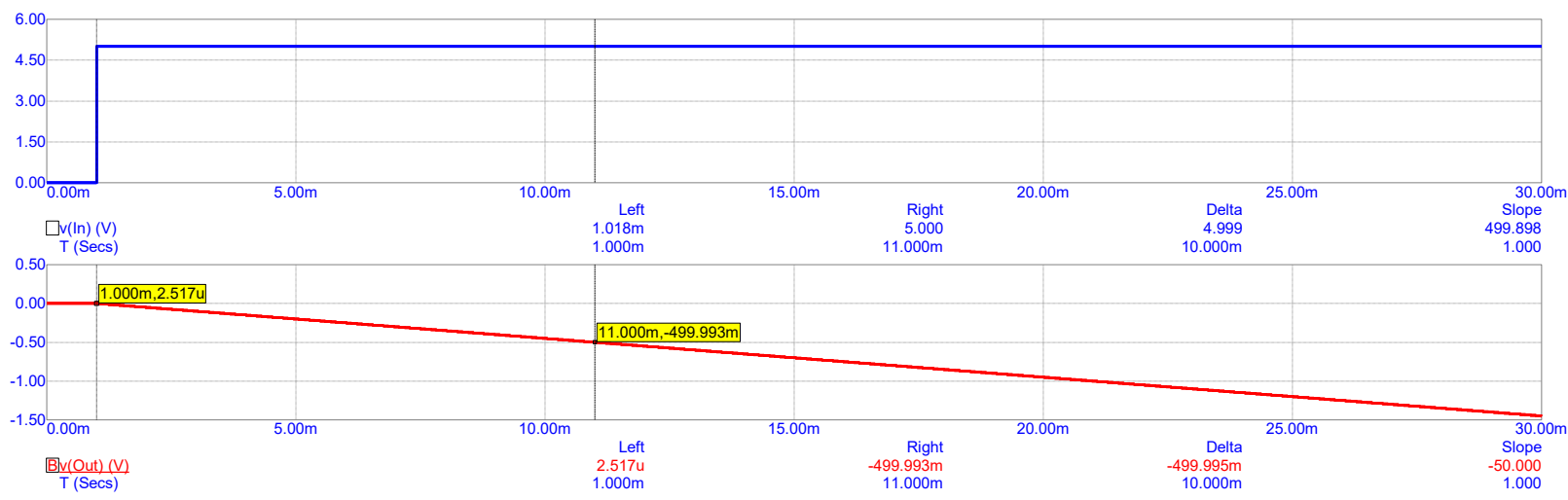

Obr. 14.32: Časové průběhy vstupního a výstupního napětí integrátoru.

$\mathrm{Z}$ průběhů je vidět, že v čase $1 \mathrm{~ms}$ se na vstupu integrátoru objeví skok napětí $5 \mathrm{~V}$ a integrátor integruje. Po $10 \mathrm{~ms}$ je na výstupu dosaženo napětí $-500 \mathrm{mV}$ Tato hodnota odpovídá vypočteným předpokladům, viz výše. Strmost klesání lze odečíst také vpravo dole, ,Slope“, kde je hodnota -50.000 , která je vypočtena $\mathrm{z}$ rozdílu hodnot umístěných kurzorů.

Změňme nyní hodnoty $R$ a $C$ na $R=2,5 \mathrm{k} \Omega, C=2 \mathrm{nF}$, tzn. $\tau=R C=2,5 \cdot 10^{3} \cdot 2 \cdot 10^{-9}=5 \mu \mathrm{s}$. Pokud je časová konstanta dostatečně malá, jedná se o tzv. „rychlý“ integrátor, u něhož lze pozorovat některé jevy, způsobené reálnými vlastnostmi operačního zesilovače. S ideálním OZ by směrnice přímky byla $k=-U_{1} / \tau=-5 \mathrm{~V} / 5 \mu \mathrm{s}=-1 \cdot 10^{6} \mathrm{~V} / \mathrm{s}$. To znamená, že pokud se nemá uplatnit omezení dané rychlostí přeběhu, musí být v modelu tato hodnota vyšší. Operační zesilovač LF155 toto splňuje, jak můžeme ověřit, je $\mathrm{SRP}=\mathrm{SRN}=7 \cdot 10^{6} \mathrm{~V} / \mathrm{s}$. Dále u tohoto operačního zesilovače je zesílení $A=200 \cdot 10^{3}$ a šiřča pásma $G B W=2,5 \mathrm{MHz}$. Právě omezená šířka pásma $\mathrm{OZ}$ má značný vliv na průběh výstupního napětí v okamžiku změny vstupního napětí, napět'ového skoku. Parametr GBW je v modelu úrovně LEVEL2 uvažován, a proto se jeho vliv projeví, jak je patrné z časové analýzy na Obr. 14.33.

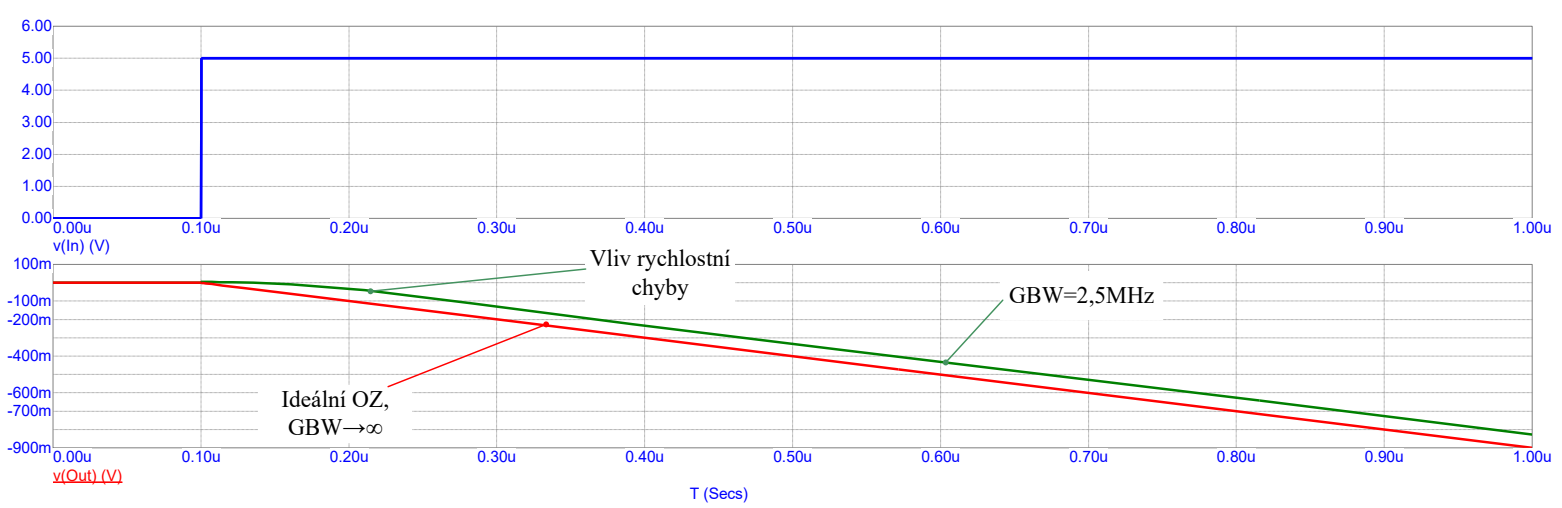

Obr. 14.33: Rychlostní chyba integrátoru vlivem omezené šířky pásma.

Zelený průběh ukazuje jev, kdy výstup reaguje s jistým zpožděním. Jedná se o tzv. „,rychlostní chybu“ a nastává u tzv. rychlých integrátorů, a to i v př́padech, kdy je rychlost přeběhu operačního zesilovače dostatečná. Vzniká v největší míře vlivem konečné šířky pásma. Druhý červený průběh je pro případ ideálního operačního zesilovače, kdy šířka pásma není omezena a odpovídá ideálnímu průběhu. Oba průběhy jsou prakticky rovnoběžné, minimálně ve využívaném časovém rozsahu. Uvedená chyba snižuje přesnost integrace a je třeba ji mít na paměti zejména $\mathrm{v}$ zapojeních, kde může způsobit systematickou chybu, např. v integračních analogově číslicových převodnících. 
Dalším jevem, který se u rychlých integrátorů vyskytuje, je tzv. „dopředný přenos“. Jedná se o neinvertující skok napětí na výstupu integrátoru v okamžiku skokové změny vstupního napětí, typicky tedy při změně směru integrace. Na Obr. 14.34 je uvedeno náhradní schéma integrátoru a naznačena situace vokamžiku skokové změny napětí na vstupu integrátoru, kdy pro skokovou změnu kapacitor vykazuje nulovou impedanci (zkrat).

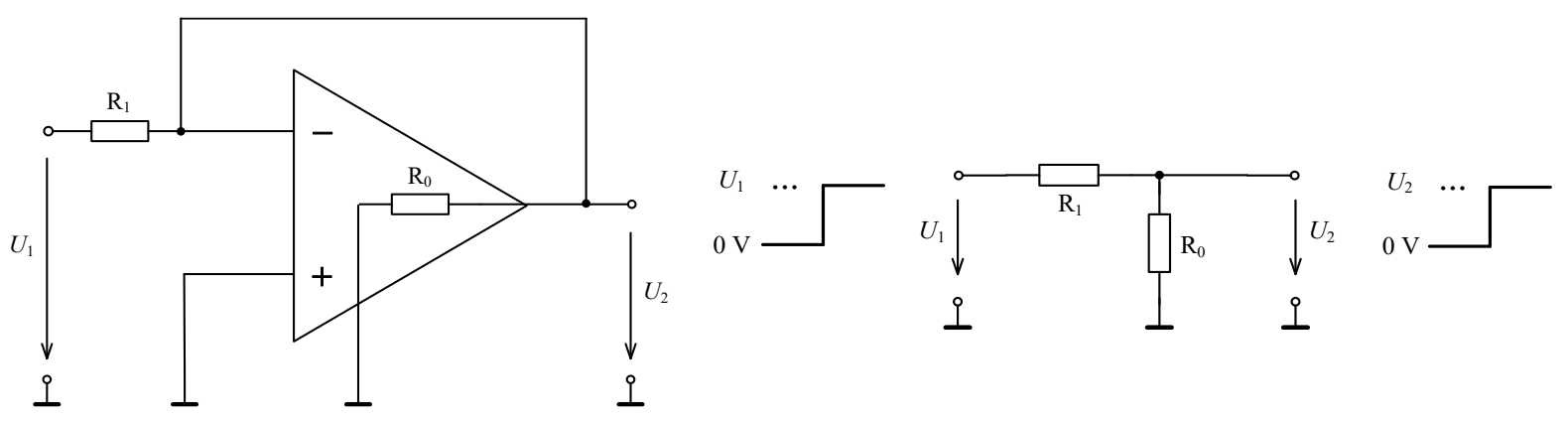

Obr. 14.34: Náhradní schéma integrátoru pro dopředný přenos.

$$
U_{2}=\frac{R_{0}}{R_{1}+R_{0}} \cdot U_{1}
$$

Je zřejmé, že v okamžiku skokové změny se skokově změní proud tekoucí rezistorem $\mathrm{R}$, který následně teče přes kapacitor $\mathrm{C}$, který se $\mathrm{v}$ dané chvíli chová jako zkrat a proud dále protéká rezistorem $\mathrm{R}_{0}$, který představuje výstupní odpor operačního zesilovače. Je tedy evidentní, že kombinace rezistorů $\mathrm{R}$ a $\mathrm{R}_{0}$ představuje $\mathrm{v}$ tomto okamžiku rezistorový dělič a výstupní napětí integrátoru je $\mathrm{v}$ daný okamžik kladný skok napětí o velikosti dané dělicím poměrem odporů rezistorů $\mathrm{R}$ a $\mathrm{R}_{0}$. $\mathrm{V}$ našem případě, pokud je $U_{1}=5 \mathrm{~V}$, pak na výstupu integrátoru bude špička napětí

Následně začne integrátor integrovat, kdy se ovšem projeví vliv rychlostní chyby, popsaný výše. Abychom v simulaci rychlostní chyby eliminovali vliv výstupního odporu, byl proto u předchozí simulace výstupní odpor $R_{0}$ nastaven na hodnotu $2 \Omega$, a proto byl výstupní kladný skok napětí velmi malý, $R>>R_{0}$. Nyní v modelu operačního zesilovač LF155 nastavme výstupní odpor $R_{0}$ na hodnotu $250 \Omega$, ROUTAC $=100 \Omega$ a ROUTDC $=150 \Omega$. Při těchto hodnotách bude neinvertovaný skok napětí $U_{2}$ na výstupu integrátoru roven

$$
U_{2}=\frac{R_{0}}{R+R_{0}} \cdot U_{1}=\frac{250 \Omega}{2,5 \cdot 10^{3} \Omega+250 \Omega} \cdot 5 \mathrm{~V}=455 \mathrm{mV} .
$$

Reálně je výstupní odpor podstatně menší, zde jsme jeho odpor poněkud zvýšili, aby skok napětí byl na průběhu dostatečně zřetelný. Výsledný simulovaný průběh („Tranzient" analýza) je uveden na Obr. 14.35. Zelený průběh je zatížen dopředným přenosem, červený průběh je pro ideální operační zesilovač. Dopředný přenos má vliv na přesnost integrace a v zapojeních se projevuje přepínacími špičkami. U zapojení, která jsou na mezi stability, pak dochází k nežádoucím zákmitům. 

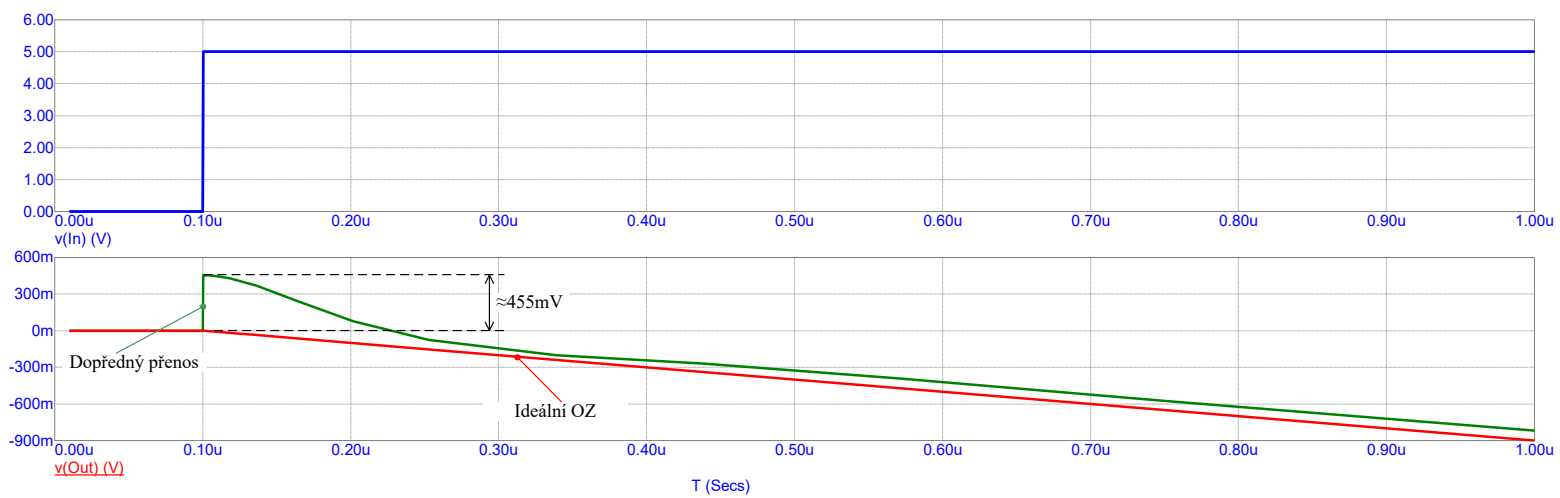

Obr. 14.35: Dopředný přenos rychlého integrátoru.

Horší stabilitu operačního zesilovače můžeme v našem př́ipadě simulovat změnou parametru PM (fázová bezpečnost) v modelu operačního zesilovače. Standardně je nastavena hodnota $P M=60^{\circ}$, viz výše. Pokud změníme tuto hodnotu na podstatně menší hodnotu, bude mít zapojení horší stabilitu a na výstupu se v okamžicích změny směru integrace objeví zákmity. Nastavme tedy parametr $P M=8^{\circ}$, ostatní parametry - úroveň modelu (LEVEL2) a nastavený výstupní odpor ponecháme. Vstupní průběh napětí upravíme na sled impulzů s periodou $10 \mu$ s. Výsledný průběh je uveden na Obr. 14.36, kde je uvedený souhrn průběhů napětí integrátoru pro různá nastavení. Na Obr. 14.36a je vstupní průběh napětí, amplituda je $5 \mathrm{~V}$ a každých $5 \mu$ s dochází k přepnutí směru integrace výstupního napětí. Průběh b) je ideální průběh s ideálním operačním zesilovačem, neuplatňuje se ani rychlostní chyba ani dopředný přenos. Na Obr. 14.36c je průběh zatížený rychlostní chybou a dopředným přenosem a konečně na Obr. 14.36d je ukázán výstupní průběh s nižší úrovní stability, která byla nastavena pomocí horší hodnoty fázové bezpečnosti v modelu operačního zesilovače. Průběh uvedený na Obr. $14.36 \mathrm{~d}$ se nejvíce přibližuje situaci s reálným běžným operačním zesilovačem.

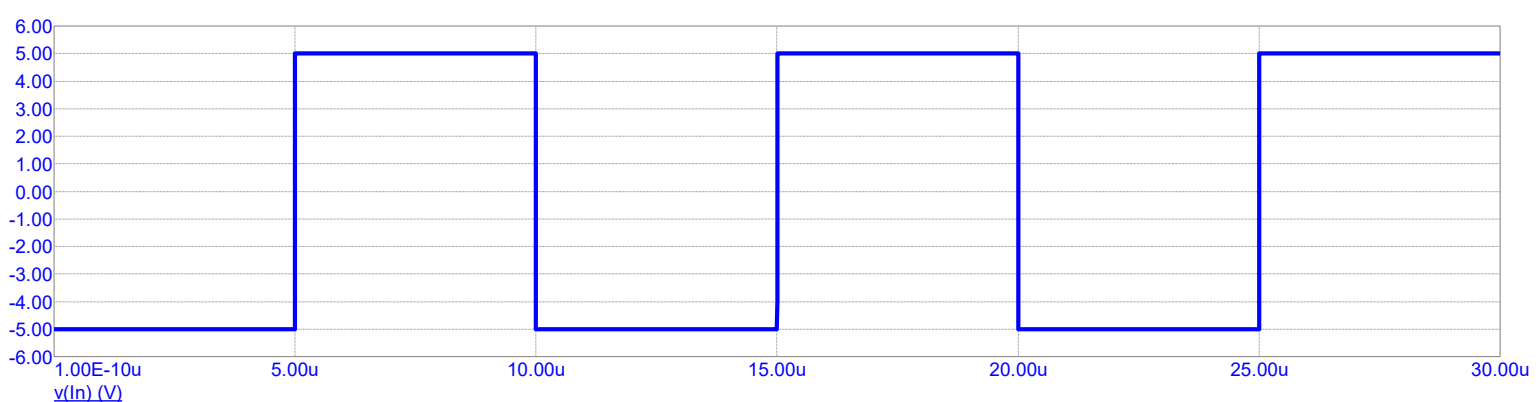

a)

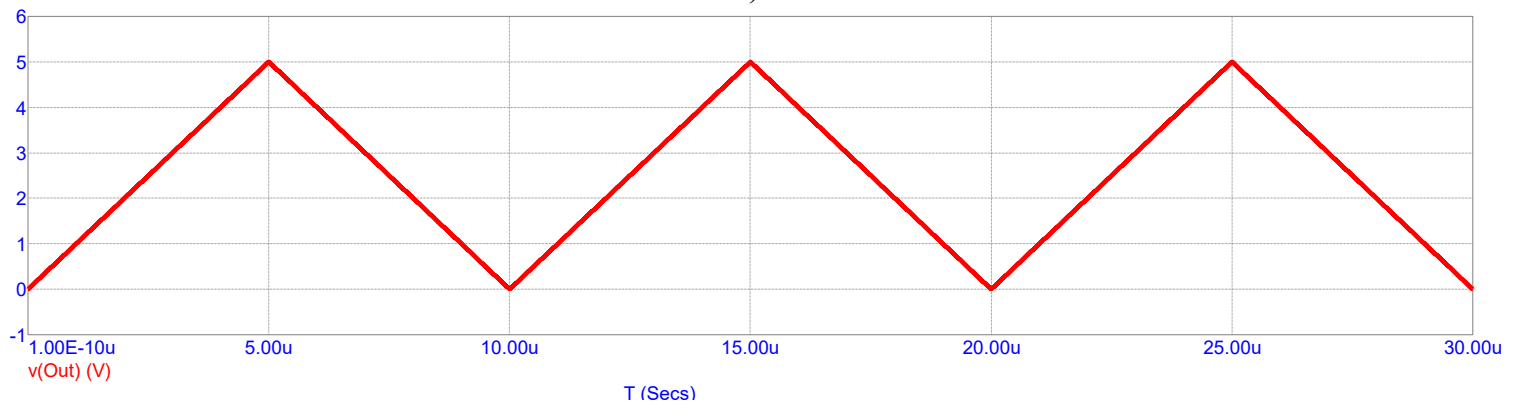

b) 


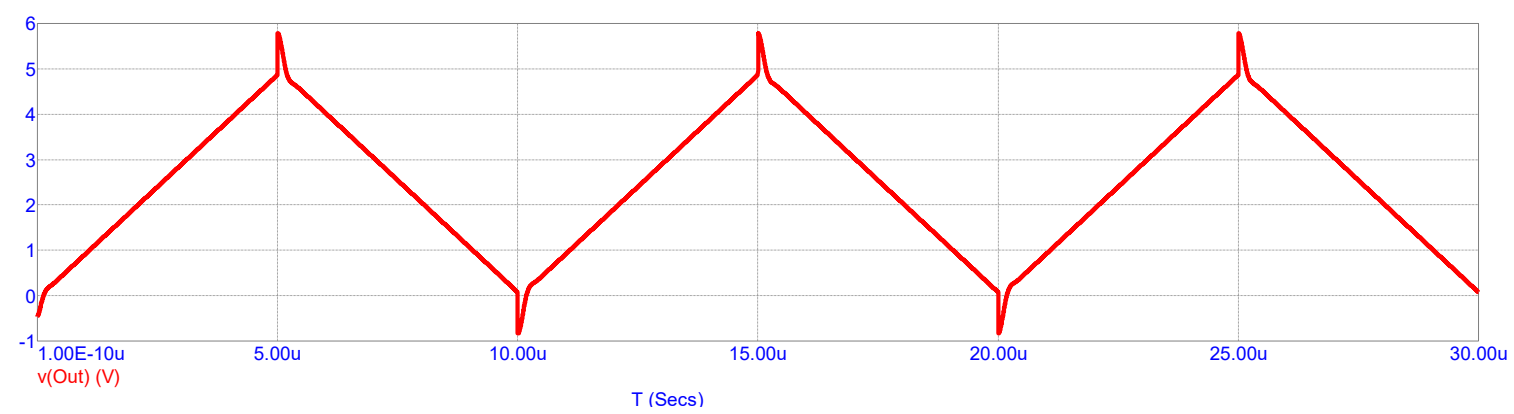

c)

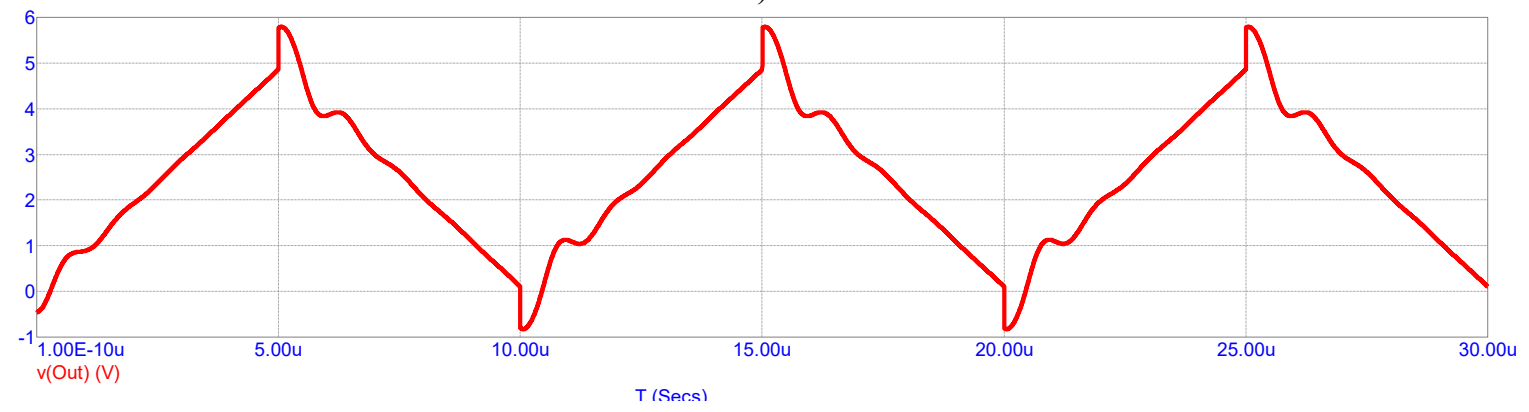

d)

Obr. 14.36: Vstupní a výstupní napětí rychlého integrátoru, a) vstupní pulzní signál, b) výstupní signál integrátoru s ideálním operačním zesilovačem, c) výstupní signál ovlivněný rychlostní chybou a dopředným přenosem, d) vliv rychlostní chyby, dopředného přenosu a snížené stability OZ.

\section{P̌̌ÍKLAD_4}

Filtr s operačními zesilovači, kmitočtová charakteristika, krokování, SPICE model integrovaného obvodu, toleranční analýza.

Uvažujme filtr 2. řádu, který je uveden na Obr. 14.37. Struktura tohoto filtru je nazývána KHN filtr podle autorů Kerwin-Huelsman-Newcomb. Pro toto zapojení je typická nízká citlivost parametrů filtru na změny hodnot součástek. Výstupy prvních tríi operačních zesilovačů realizují filtry typu horní propust, pásmová propust a dolní propust. Čtvrtý operační zesilovač je zapojen jako sčítací obvod, který ve vhodném poměru sečte výstup horní a dolní propusti a výstup sčítacího zesilovače se chová jako pásmová zádrž (notch filter) Bližší informace jsou nad rámec tohoto textu, dále se zaměříme jen na základní vztahy, které mají vztah k počítačové simulaci. 


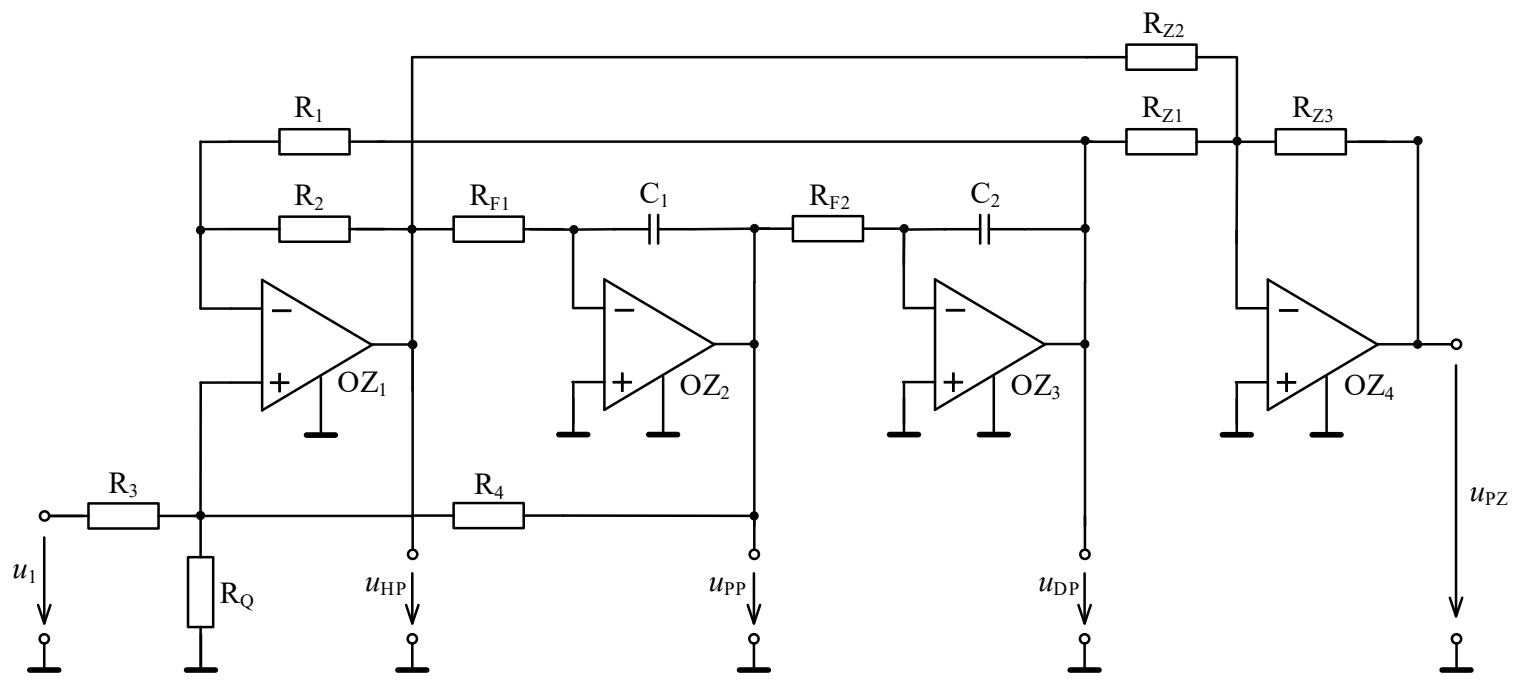

Obr. 14.37: Filtr KHN, pásmová zádrž (notch filter).

Uvedený filtr díky sčítacímu obvodu s operačním zesilovačem realizuje notách filtr (pásmovou zádrž) s kmitočtem zadržení $f_{0}$, kdy na tomto kmitočtu dojde ke skokové změně fáze mezi signály z horní a dolní propusti a signál je na tomto kmitočtu potlačen. Nastavme

$$
R_{1}=R_{2}=R_{3}=R_{4}=R=50 \mathrm{k} \Omega \quad, C_{1}=C_{2}=C=1000 \mathrm{pF} \quad \text { a } \quad R_{\mathrm{F} 1}=R_{\mathrm{F} 2}=R_{\mathrm{F}} .
$$

Potom pro kmitočet potlačení platí

$$
f_{0}=\frac{1}{R_{\mathrm{F}} C 2 \pi} .
$$

Zvolme $f_{0}=50 \mathrm{~Hz}$ (např. je potřeba potlačit kmitočet energetické silové sítě) a dále zvolme činitel jakosti potlačení $Q=5$ a dopočítáme odpory

$$
\begin{aligned}
& R_{\mathrm{F}}=\frac{1}{f_{0} C 2 \pi}=\frac{1}{50 \cdot 1000 \cdot 10^{-12} \cdot 2 \pi}=3,18 \mathrm{M} \Omega, \\
& R_{\mathrm{Q}}=\frac{R / 2}{Q-1}=\frac{25 \mathrm{k} \Omega}{Q-1}=\frac{25 \mathrm{k} \Omega}{5-1}=6,25 \mathrm{k} \Omega .
\end{aligned}
$$

Zisk filtru v propustném pásmu je ovlivněn činitelem jakosti potlačení $Q$ a naopak. Předpokládáme, že zisk v propustné části, tedy pro $f<<f_{0}$ a $f>>f_{0}$ je $0 \mathrm{~dB}$, pak pro poměr odporů $R_{\mathrm{Z} 1}, R_{\mathrm{Z} 2}, R_{\mathrm{Z} 3}$ platí vztah

$$
Q=\frac{R_{\mathrm{Z} 3}}{R_{\mathrm{Z} 1}}=\frac{R_{\mathrm{Z3}}}{R_{\mathrm{Z} 2}}
$$

Zvolme $R_{\mathrm{Z} 1}=R_{\mathrm{Z} 2}=2 \mathrm{k} \Omega$, potom bude $R_{\mathrm{Z} 3}=10 \mathrm{k} \Omega$. Pro úplnost poznamenejme, že šířka pásma zadržení $B$ je dána poměrem

$$
B=\frac{f_{0}}{Q}=\frac{50}{5}=10 \mathrm{~Hz},
$$

tzn. kmitočtové pásmo zadržení pro pokles o $3 \mathrm{~dB}$ na modulové charakteristice. 
Je vidět, že oba hlavní parametry filtru, rezonanční kmitočet $f_{0}$ a činitel jakosti $Q$, mohou být nezávisle nastaveny vhodnou volbou hodnot odporů $R_{\mathrm{F} 1}, R_{\mathrm{F} 2}$ a $R_{\mathrm{Q}}$.

Obvodové zapojení pásmové zádrže v editoru Micro-Cap je uvedeno na Obr. 14.38. Jak

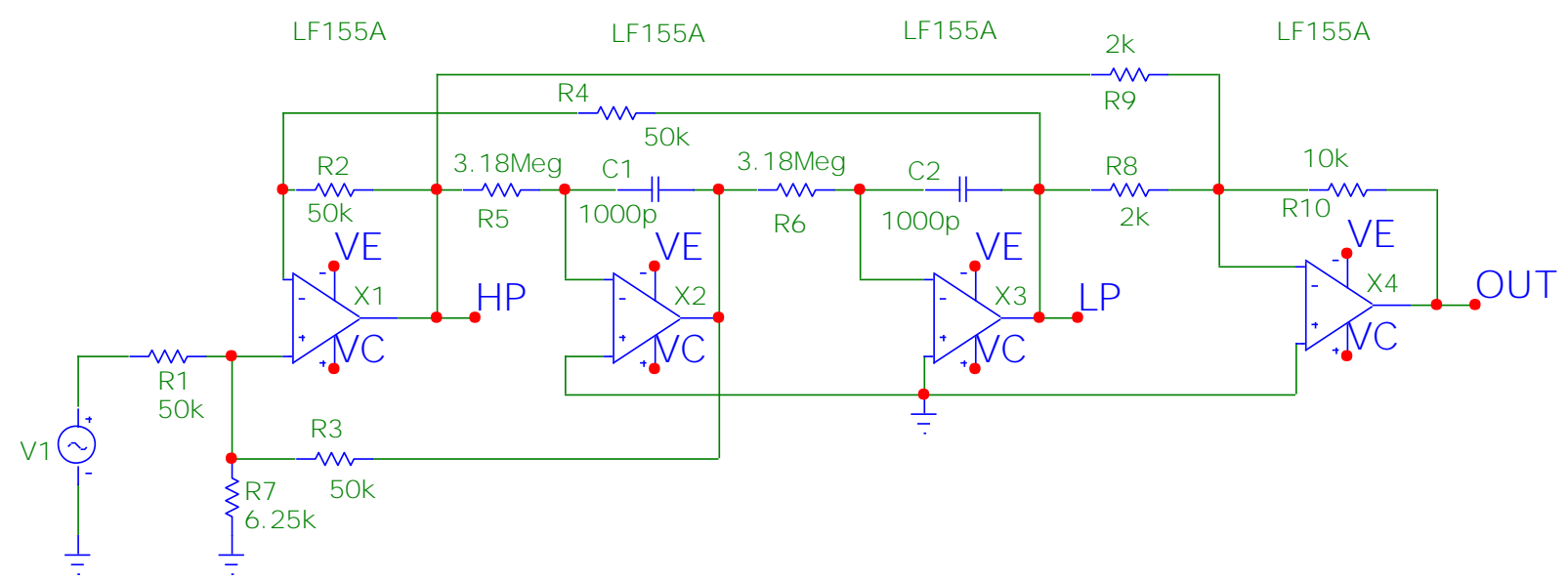

Obr. 14.38: Pásmová zádrž v editoru Micro-Cap.

Jak již bylo uvedeno dříve, pro prvotní ověření činnosti obvodu pracujeme většinou s jednoduššími modely, proto je nastavena úroveň LEVEL2 modelu operačního zesilovače LF155A. Modulová a fázová kmitočtová charakteristika tohoto notch filtru je uvedena na Obr. 14.39 , kde jsou rovněž zvýrazněny parametry filtru.

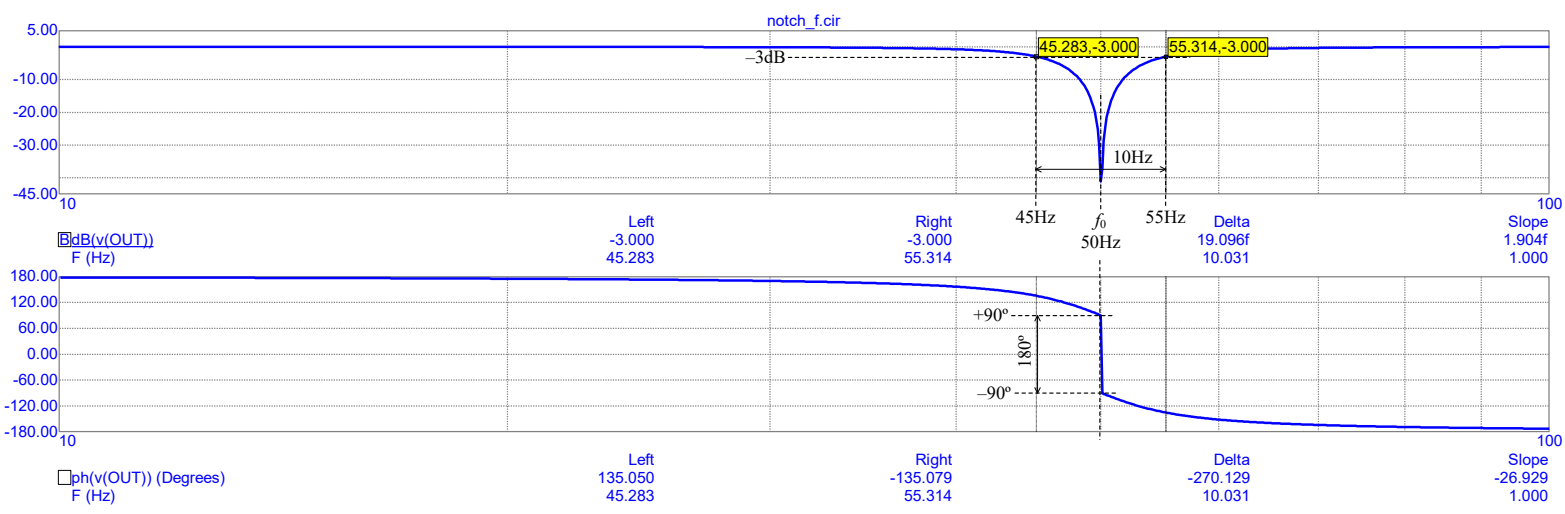

Obr. 14.39: Kmitočtová charakteristika pásmové zádrže.

Z průběhů je patrné, že na rezonančním kmitočtu dochází ke skokové změně fáze o $180^{\circ}$. Z výše uvedeného popisu je také zřejmé, že ve sčítacím zesilovači se sčítají signály z horní a dolní propusti, které jsou brány z výstupu prvního a třetího operačního zesilovače. Výstupy těchto dílčích filtrů jsou ve schématu na Obr. 14.37, popř. na Obr. 14.38 označeny High-pass a Low-pass, resp. HP a LP Zobrazme si nyní kmitočtové charakteristiky všech tří diskutovaných filtrů, přičemž výsledek je uveden na Obr. 14.40. 


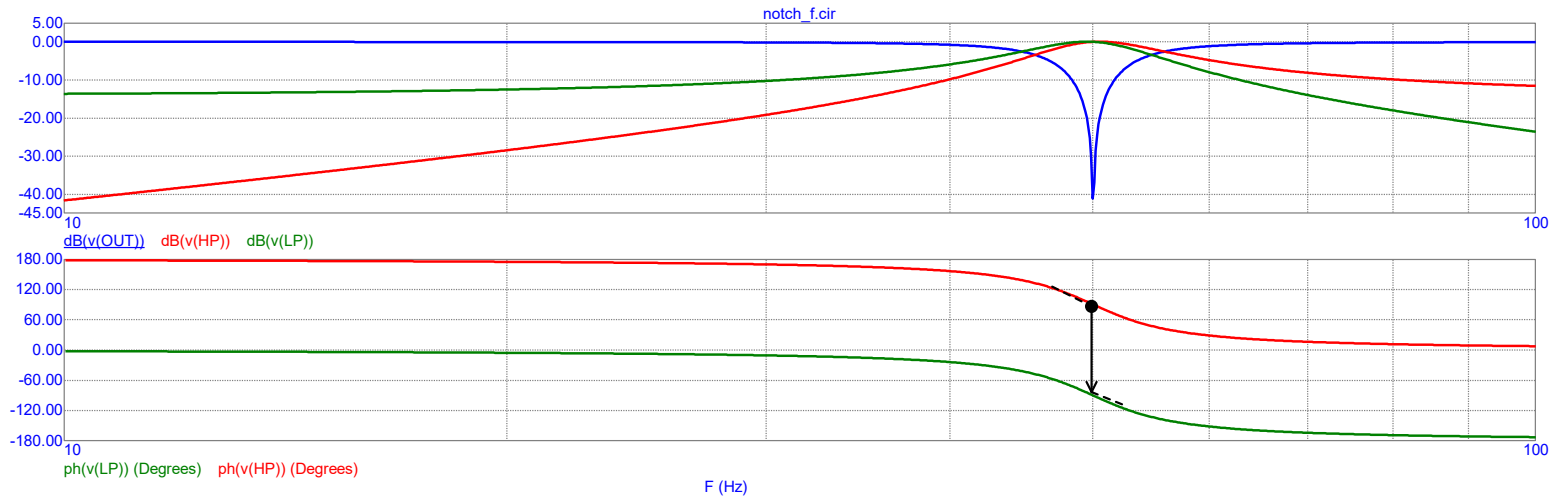

Obr. 14.40: Kmitočtová charakteristika horní a dolní propusti KHN filtru a pásmové zádrže.

V grafu je pro srovnání uveden modrý průběh modulu pásmové zádrže. Červený průběh je modul a fáze horní propusti a zelený průběh je dolní propust. Mezní kmitočty horní a dolní propusti jsou opět při $-3 \mathrm{~dB}$, tedy v místech na modrém průběhu, kde jsme vymezili šířku pásma pásmové zádrže. U fázového průběhu sledujme, jak se mění fáze filtru notch. Do rezonančního kmitočtu fáze sleduje průběh fáze horní propusti, na rezonančním kmitočtu dojde ke skoku fáze a další průběh sleduje fázi dolní propusti, to je naznačeno černou šipkou. Tento průběh dokládá tvrzení uvedené výše.

Podívejme se nyní na přechodovou charakteristiku, což je odezva filtru na jednotkový skok. Jedná se tedy o simulaci v časové oblasti a na vstupu je zdroj napětí, kde je pro určitý čas nastavena změna z „nulové“ úrovně na ,jednotkovou“ úroveň, jak již bylo ukázáno v předchozím př́kladě. Na Obr. 14.41 je uvedeno jen vstupní zdroj a nastavení jednotkového skoku na vstupním pulsním zdroji.

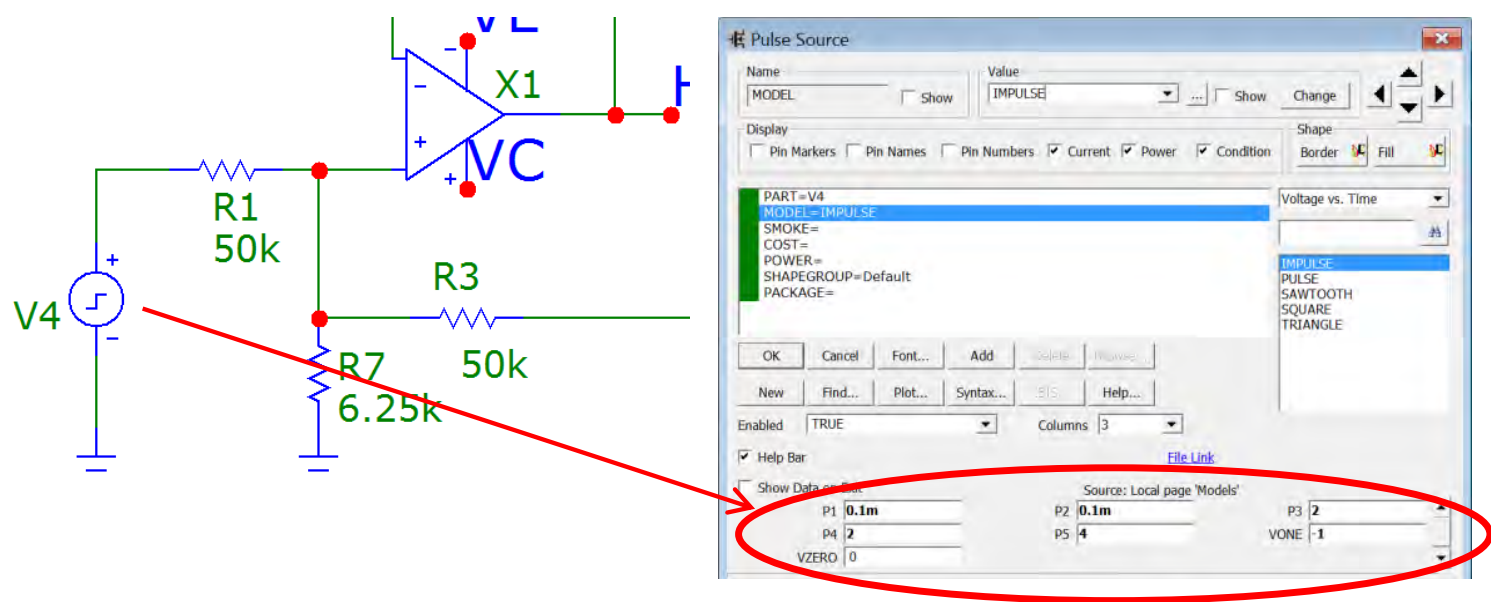

Obr. 14.41: Nastavení zdroje pro simulaci odezvy na jednotkový skok.

Časová odezva na vstupní skok napětí (1 V) je uvedena na Obr. 14.42. Je vidět, že v okamžiku skoku se na výstupu objeví zákmity, které se ustálí po cca 100 ms, jedná se o stabilní obvod. 


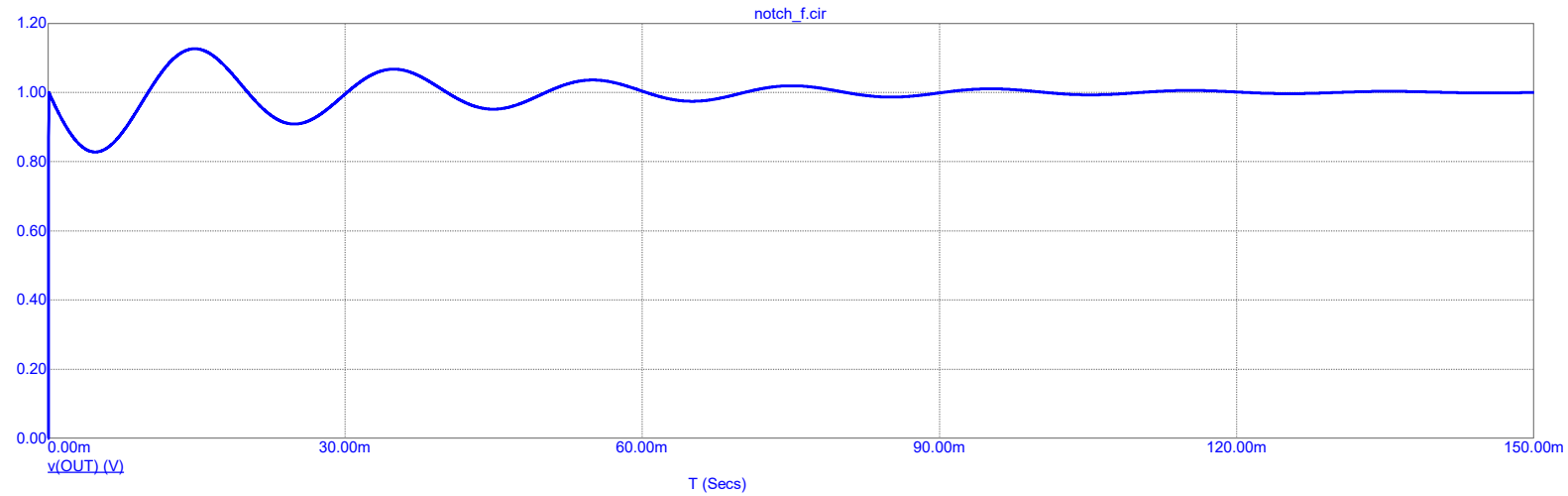

Obr. 14.42: Průběh výstupního napětí filtru jako odezva na jednotkový skok.

Prověříme ještě filtrační schopnosti pásmové zádrže v časové oblasti. Uvažujme, že na vstupu filtru bude signál, který je složen ze dvou harmonických signálů, první, tzv. užitečný, $\mathrm{s}$ kmitočtem $100 \mathrm{~Hz}$ a amplitudou $1 \mathrm{~V}$ a druhý, nežádoucí, o kmitočtu $50 \mathrm{~Hz}$ s amplitudou $0,5 \mathrm{~V}$, který může představovat naindukované napětí silnoproudé sítě. Zapojení těchto zdrojů a jejich nastavení pro simulaci je patrné z Obr. 14.43. Z nastavení je také patrný nastavený fázový posun u zdroje V1 daný parametrem $\mathrm{PH}$, který se zadává v radiánech.

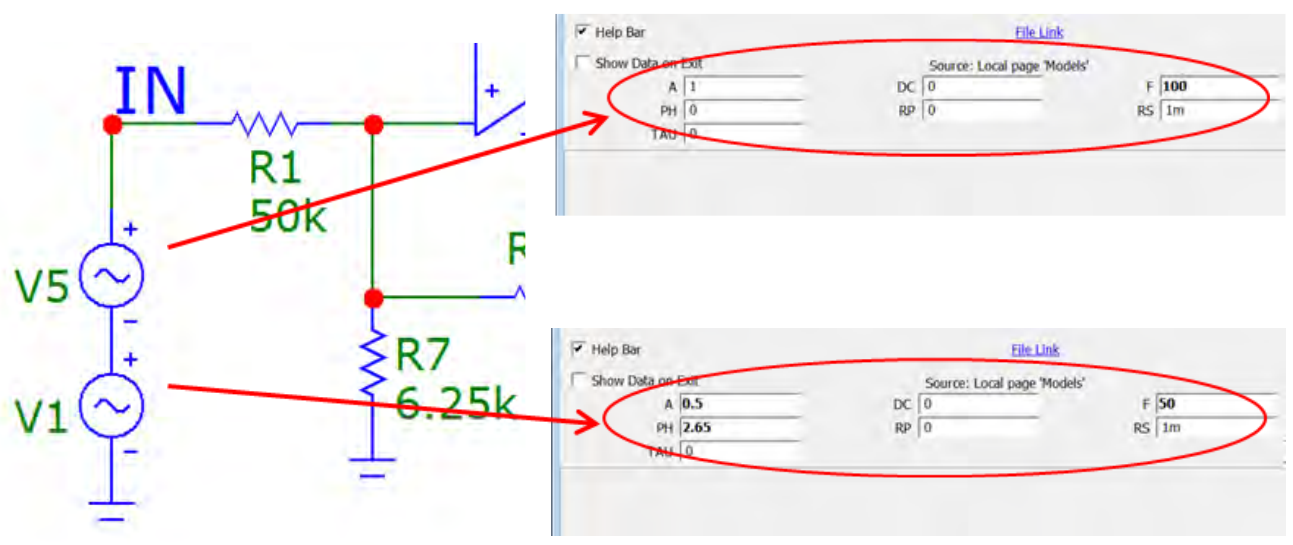

Obr. 14.43: Nastavení zdrojů pro simulaci filtrace nežádoucího signálu v časové oblasti.

Výsledné průběhy jsou uvedeny na Obr. 14.44, kde v horní části je vstupní signál, která obsahuje dvě kmitočtové složky $50 \mathrm{~Hz}$ a $100 \mathrm{~Hz}$. Na spodním průběhu zjištěného na výstupu filtru je zrretelně patrné, že došlo k potlačení složky o kmitočtu $50 \mathrm{~Hz}$ a na výstupu je čistý harmonický signál s kmitočtem $100 \mathrm{~Hz}$.

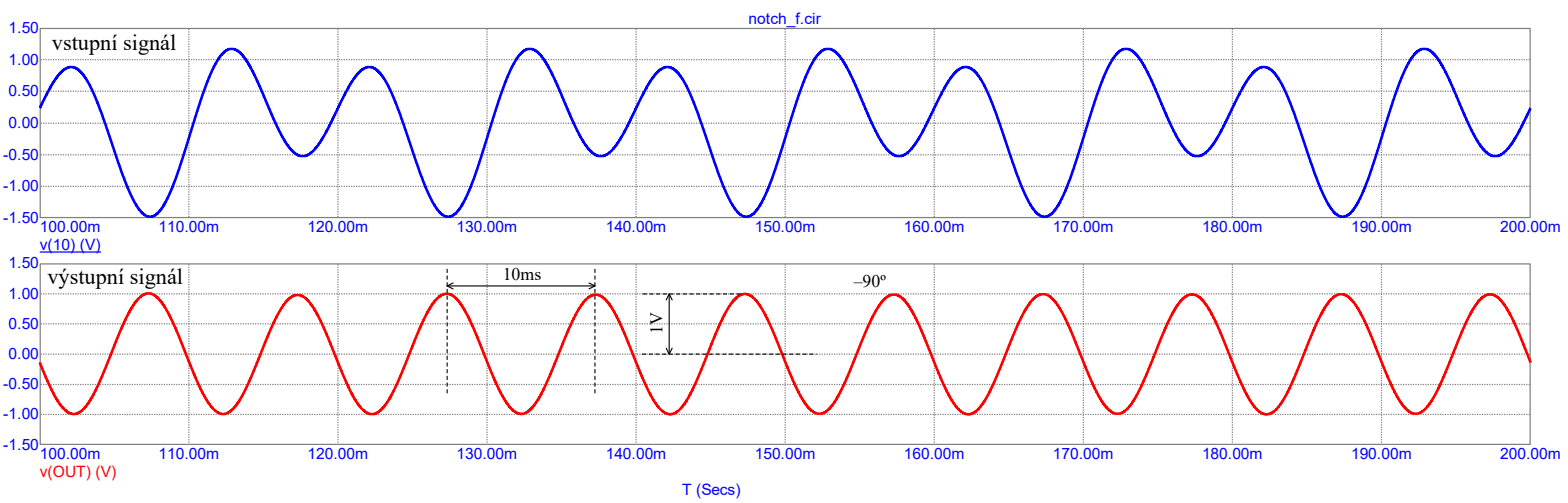

Obr. 14.44: Průběh vstupního a výstupního napětí filtru a filtrace nežádoucí $50 \mathrm{~Hz}$ složky. 
V dřívějších příkladech s operačními zesilovači jsme ukázali možnosti výpočtu či zobrazení vstupního a výstupního odporu simulovaného obvodu. Nyní ukážeme jinou možnost jak tyto údaje zjistit a zároveň zobrazit i přenos zapojení. V položce <Analysis> zvolíme položku <Transfer Function>. Zobrazí se okno uvedené na Obr. 14.45 vlevo, kde zadáme výstup obvodu („,Output Expression“), název vstupního zdroje a zvolíme, zda požadujeme zobrazení výsledku na ploše schématu, jak je ukázáno na obrázku vpravo. Po stisku tlačítka < Calculate $>$ je vypočtena hodnota přenosu v propustném pásmu, „Transfer Function“. Znaménko minus značí otočení fáze o $180^{\circ}$. Dále je vypočtena hodnota vstupní impedance a výstupní impedance. Vstupní odpor filtru je vypočten 55.555,6 $\Omega$ a výstupní odpor je $6,9 \mathrm{~m} \Omega$.

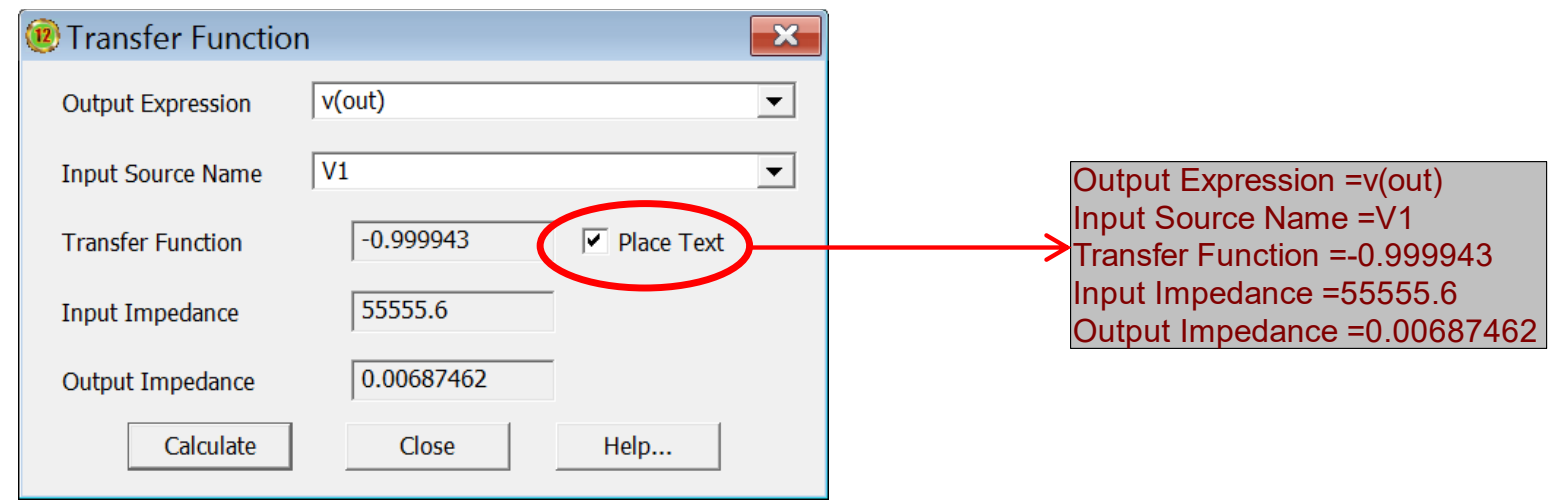

Obr. 14.45: Nastavení a výpočet analýzy „Transfer Function“.

V poslední části tohoto příkladu se zaměříme na využití SPICE modelů elektronických součástek, které poskytují samotní výrobci. Pro realizaci pásmové zádrže použijeme integrovaný obvod s typovým označením UAF42, který vyrábí řada výrobců, např. Texas Instruments, Burr-Brown a jiní. Na Obr. 14.46 je uvedeno vnitřní zapojení tohoto obvodu. Doplněním několika externích součástek pak získáme požadovaný filtr.

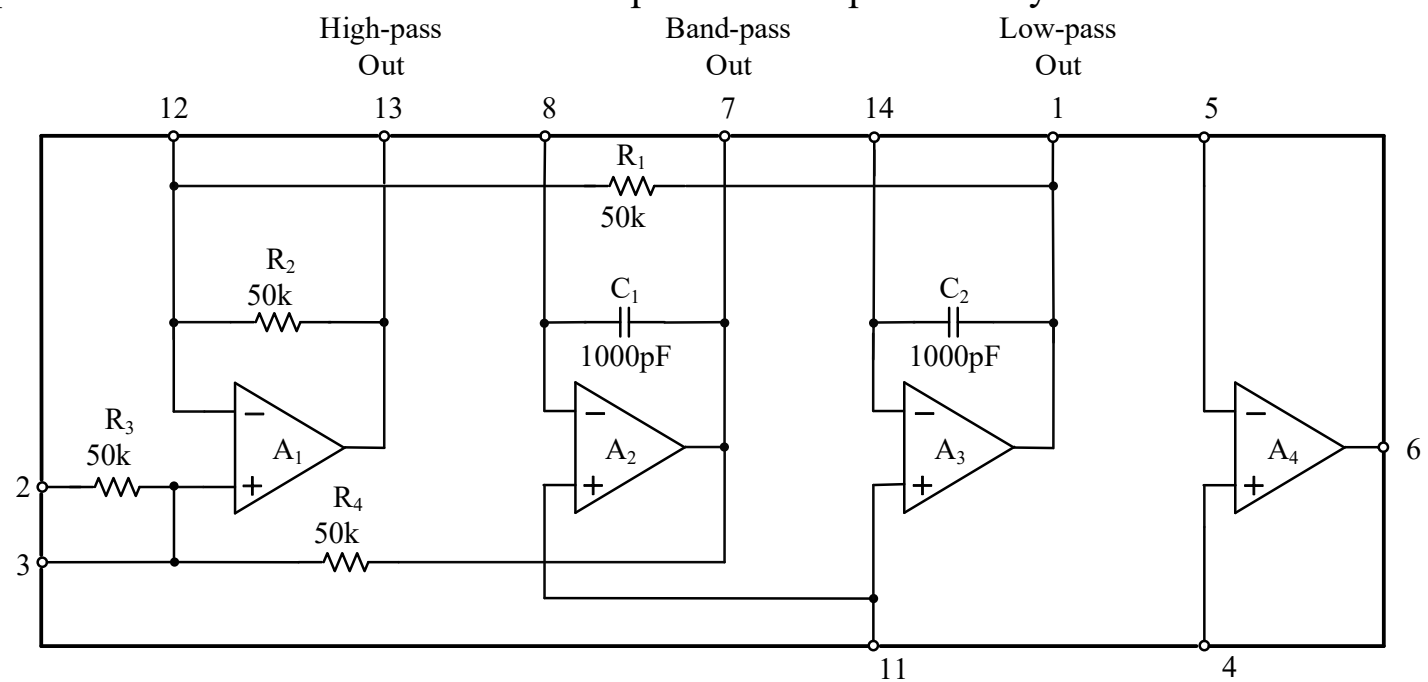

Obr. 14.46: Vnitřní zapojení integrovaného obvodu UAF42.

Na webových stránkách výrobců je možné nalézt nejen dokumentaci k obvodu, ale většinou i soubor s modelem obvodu ve formátu SPICE. Načtení SPICE modelu do knihovny 
Micro-Cap lze provést několika způsoby, ale konkrétní postup není předmětem tohoto textu, blíže viz [2].

V posledních verzích programu Micro-Cap je obvod UAF42 již standardně k dispozici v knihovně prvků. Pokud použijeme model ze stránek výrobce, bude soubor mít zpravidla název daný jménem prvku s prŕíponou .LIB, tedy v našem př́ípadě UAF42.LIB. Obsahem tohoto souboru je SPICE popis modelovaného prvku a zapojení vývodů „univerzálního“ vícevývodového pouzdra. Uved'me jen ukázku (Obr. 14.47) tohoto souboru popisující obvod UAF42. Úvodní část textového souboru CONNECTIONS popisuje přiřazení jednotlivých pinů v obvodu, další část je popis zapojení jednotlivých operačních zesilovačů (X1 až X4) $\mathrm{k}$ jednotlivým vnitřním uzlům obvodu a poslední část je popis pasivních součástek, jejich zapojení mezi vnitřní uzly obvodu a hodnoty. Rezistor R4 je rozdělen na dva paralelně spojené rezistory R4A a R4B. Obdobný popis nalezneme i prímo v programu Micro-Cap, při prvotní volbě součástky nebo kliknutím na umístěnou součástku, kdy se otevře popis součástky. V další části souboru (zde již není uveden) se nachází popis modelu použitých operačních zesilovačů, jednotlivé součástky, hodnoty jejich parametrů apod. Popis SPICE parametrů operačních zesilovačů je nad rámec tohoto textu.

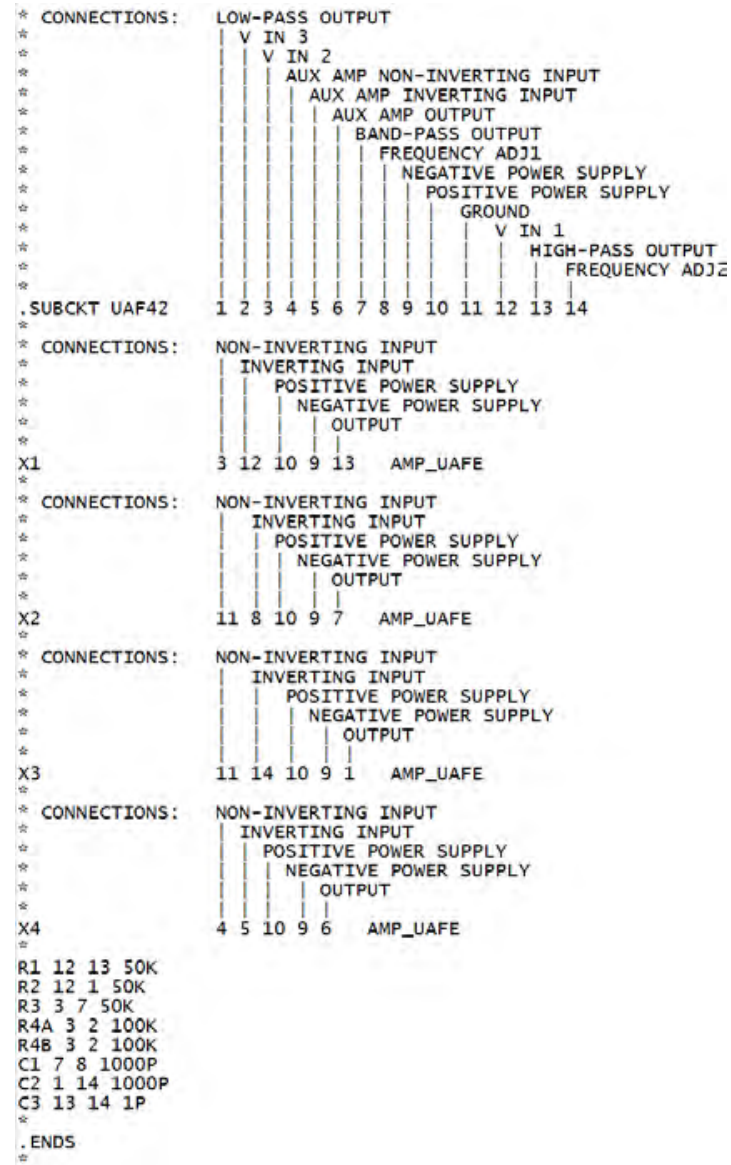

Obr. 14.47: Ukázka popisu SPICE modelu obvodu UAF42. [3]

Použijme nyní tento obvod k realizaci stejného filtru, tj. pásmové zádrže, který jsme popisovali výše. Zapojení pásmové zádrže ve schématickém editoru Micro-Cap je uvedeno na Obr. 14.48. 


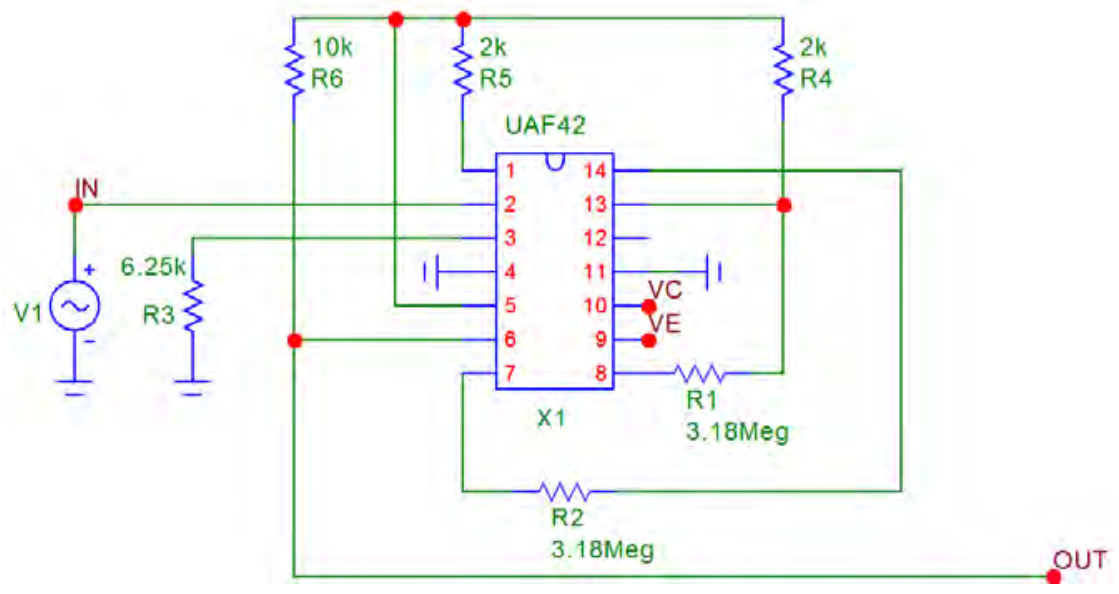

Obr. 14.48: Pásmová zádrž s obvodem UAF42, SPICE model.

Je vidět, že k realizaci pásmové zádrže postačuje šest externích součástek, přičemž rezistory $R_{1}$ a $R_{2}\left(R_{\mathrm{F}}=R_{1}=R_{2}\right)$ a $\mathrm{R}_{3}$ mají vliv na rezonanční kmitočet $f_{0}$ rezistor $R_{3}\left(R_{\mathrm{Q}}=R_{3}\right)$ určuje činitel jakosti potlačení $Q$, jak již bylo uvedeno dř́ve. Všechny simulace provedené výše lze provést i zde se stejným výsledkem. Vztah pro výpočet odporu $R_{\mathrm{Q}}=R_{3}$ při požadované hodnotě $Q$ můžeme upravit a vyjádřit závislost $Q$ na odporu $R_{\mathrm{Q}}$

$$
Q=\frac{R / 2}{R_{\mathrm{Q}}}+1=\frac{25 \mathrm{k} \Omega}{R_{\mathrm{Q}}}+1,
$$

kdy odpor $R_{\mathrm{Q}}$ zadáváme $\mathrm{v} \mathrm{k} \Omega$ a dále známe vztah pro šířku pásma (viz dříve) kam můžeme dosadit vztah pro činitel jakosti

$$
B=\frac{f_{0}}{Q}=\frac{f_{0}}{\frac{25 \mathrm{k} \Omega}{R_{\mathrm{Q}}}+1}=f_{0} \cdot \frac{R_{\mathrm{Q}}}{25 \mathrm{k} \Omega+R_{\mathrm{Q}}},
$$

přičemž $R_{\mathrm{Q}}$ zadáváme i zde $\mathrm{v} \mathrm{k} \Omega$. Proved'me simulaci, jak se bude měnit šířka pásma $B$ v závislosti na změně odporu $R_{\mathrm{Q}}=R_{3}$. Uvažujme tři hodnoty odporu $R_{3}=2,77 \mathrm{k} \Omega ; 6,25 \mathrm{k} \Omega$; $9,73 \mathrm{k} \Omega$. Tomu odpovídá šířka pásma dle výše uvedeného vztahu $B=5 \mathrm{~Hz} ; 10 \mathrm{~Hz} ; 13,37 \mathrm{~Hz}$, resp. činitel jakosti potlačení $Q=10 ; 5 ; 3,57$. K zobrazení průběhů využijeme možnost tzv. „Krokování“ v programu Micro-Cap. Potřebujeme měnit hodnotu odporu $R_{3}$ ve schématu filtru, a to v rozsahu od $2,77 \mathrm{k} \Omega$ do $9,73 \mathrm{k} \Omega \mathrm{s}$ krokem $3,48 \mathrm{k} \Omega$. Po spuštění analýzy v kmitočtové oblasti zvolíme v tabulce nastavení analýzy položku „Stepping...“ a v okně nastavíme parametry krokování dle Obr. 14.49.

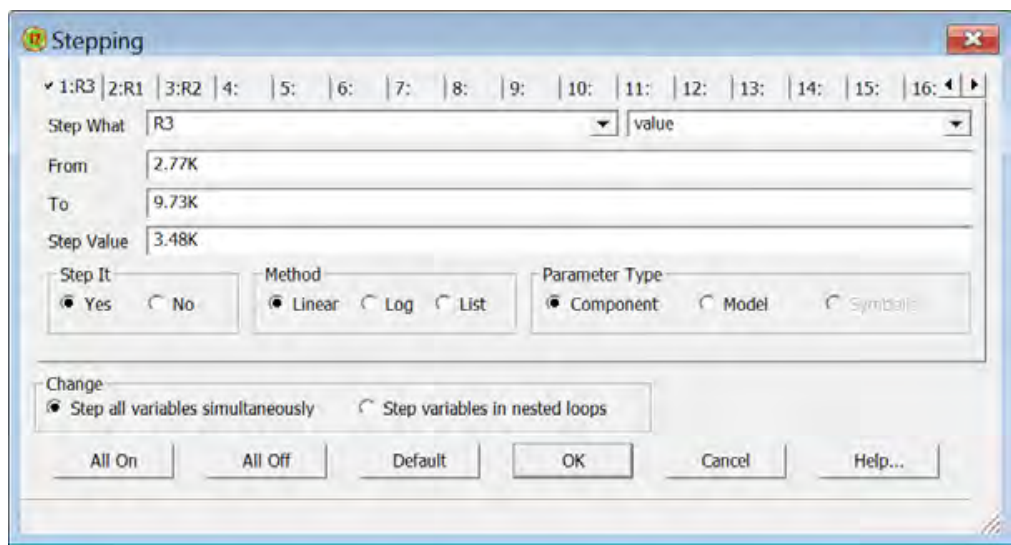

Obr. 14.49: Nastavení parametrů krokování odporu R3. 
Aktivace krokování je dána položkou „Step It“ a následně po spuštění analýzy je vypočteno a zobrazeno tolik průběhů, kolik odpovídá nastavenému rozsahu a kroku změny. V našem případě jsou to tři průběhy, které jsou zobrazeny na Obr. 14.50. Všechny výše vypočtené parametry jsou $\mathrm{z}$ uvedených průběhů zřejmé.

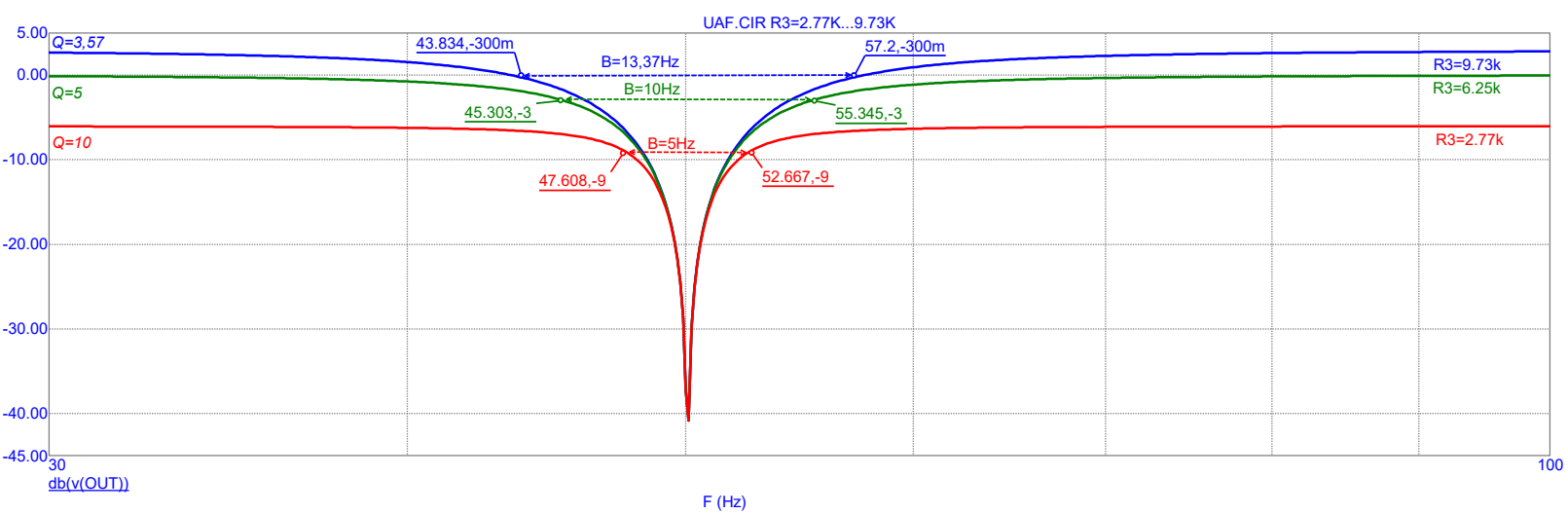

Obr. 14.50: Kmitočtová charakteristika filtru při změně činitele jakosti potlačení pomocí odporu R3.

Z průběhů je také patrné, že se mění zisk v propustném pásmu. To je dáno výše uvedeným vztahem, kdy činitel jakosti je závislý na poměru zpětnovazebního odporu a přímého odporu ve sčítacím zesilovači (čtvrtý operační zesilovač) a pokud změníme $Q$, musíme změnit i poměr odporů $R_{\mathrm{Z} 3}$ ku $R_{\mathrm{Z} 2}$ resp. $R_{\mathrm{Z} 1}$, (ve schématu Micro-Cap se jedná o odpory $R_{6}, R_{5}, R_{4}$ ). Pokud např́klad uvažujeme $Q=10$, viz Obr. 14.51 červený průběh, je šířka pásma $B=5 \mathrm{~Hz}$ a zisk v propustném pásmu $-6 \mathrm{~dB}$ a poměr $R_{6} / R_{5}=R_{6} / R_{4}=5\left(R_{6}=10 \mathrm{k} \Omega, R_{4}=R_{5}=2 \mathrm{k} \Omega\right)$, což neodpovídá nově uvažované hodnotě činitele jakosti, který je nyní 10 . Je proto nutné změnit poměr odporů tak, aby byl v souladu s hodnotou činitele jakosti. Stačí změnit hodnotu odporu $R_{6}=20 \mathrm{k} \Omega$ pak $R_{6} / R_{5}=R_{6} / R_{4}=10$. Pro porovnání obou průběhů, pro hodnoty odporů $10 \mathrm{k} \Omega$ a $20 \mathrm{k} \Omega$ opět můžeme využít volbu krokování odporu $R_{6}$. Postup je obdobný jako výše a výsledné průběhy jsou uvedeny na Obr. 14.51, kde je patrné, že zisk je v propustném pásmu 0 $\mathrm{dB}$ při hodnotě $R_{6}=20 \mathrm{k} \Omega$.

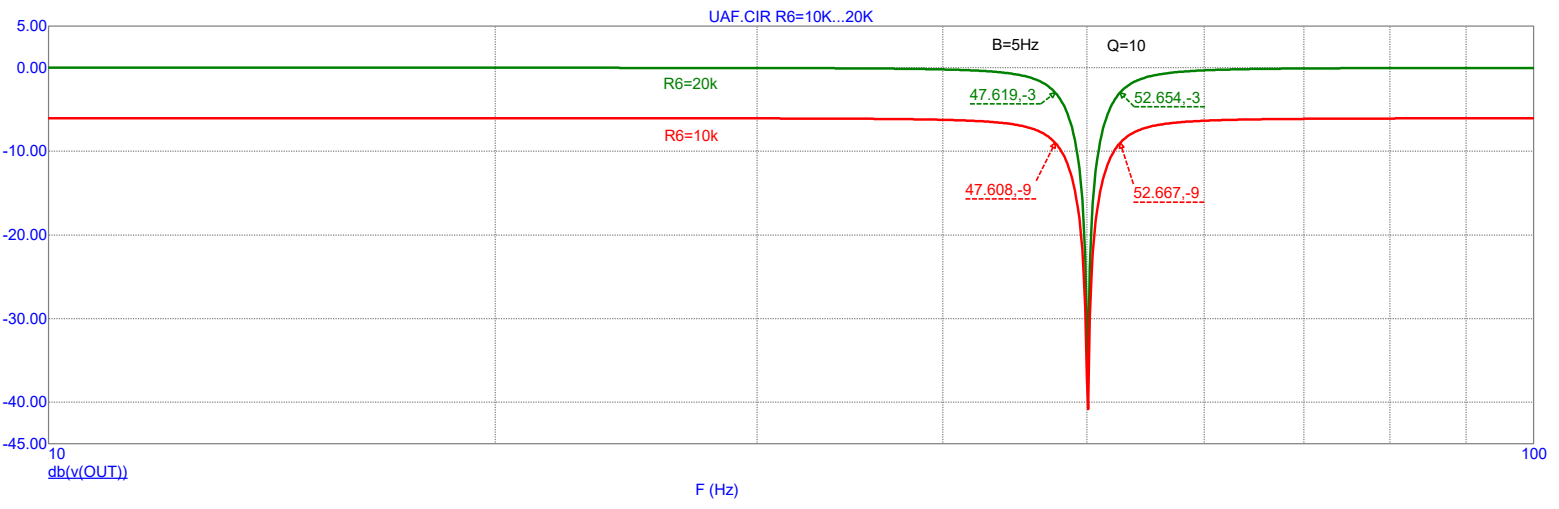

Obr. 14.51: Kmitočtová charakteristika filtru při změně odporu R6.

Z výpočtových vztahů je patrné, že na rezonanční kmitočet mají vliv hodnoty odporů $R_{\mathrm{F} 1}$ a $R_{\mathrm{F} 2}$ (viz Obr. 14.37), ve schématu Micro-Cap s integrovaným obvodem UAF42 to jsou odpory 
$R_{1}$ a $R_{2}$ (viz Obr. 14.48). Změnu rezonančního kmitočtu $f_{0}$ vlivem změny odporů $R_{1}, R_{2}$ může jednoduše simulovat změnou hodnot nebo krokováním, jak bylo uvedeno výše.

V následujících simulacích se zaměříme na toleranční analýzu, tedy reálnou situaci, kdy součástky jsou vyráběny $\mathrm{v}$ řadách $\mathrm{s}$ určitou povolenou procentuální přesností. Ve výše uvedených simulacích byla hodnota odporu vždy přesně dána zadanou hodnotou $\mathrm{v}$ popisu rezistoru. To je v praxi samozřejmě naprosto nemožné. Toleranci hodnot součástek lze rovněž v programu Micro-Cap simulovat a výsledkem je toleranční pásmo, kde se sledovaný výstupní parametr filtru bude nacházet. Můžeme simulovat vliv jedné hodnoty nebo více hodnot, které zásadním způsobem ovlivňují požadované parametry. Může být uvažována celá řada vlivů změny hodnot součástek, např. výrobní tolerance, vliv teploty aj.

$\mathrm{V}$ simulaci se zaměříme na výrobní toleranci odporů rezistorů $\mathrm{R}_{1}$ a $\mathrm{R}_{2}$, kdy budeme uvažovat $10 \%$ toleranci ( $\mathrm{z}$ důvodů názornosti). Hodnotu tolerance zadáváme procentuálně a $\mathrm{k}$ definici tolerance slouží klíčové slovo ,LOT‘ a zapisuje se do vstupního boxu $<\mathrm{R}>$ modelu prvku. Formát zápisu je následující:

\section{násobitel LOT=tolerance.}

Př́klad zápisu pro rezistor: 1 lot $=10 \%$ znamená rezistor o odporu daný hodnotou VALUE $=$, hodnota' $\mathrm{s}$ násobitelem 1 a $10 \%$ tolerancí. Pro nastavení modelu rezistoru provedeme dvojklik na danou součástku. Otevře se okno, které je zobrazeno na Obr. 14.52. V otevřeném okně zvolíme položku ,MODEL=“ a v položce ,Value zapíšeme jméno nového modelu nebo model zvolíme $\mathrm{v}$ seznamu v pravé části okna. Parametry modelu jsou pak zobrazeny ve spodní části okna. Jednotlivé položky zde můžeme podle potřeby editovat.

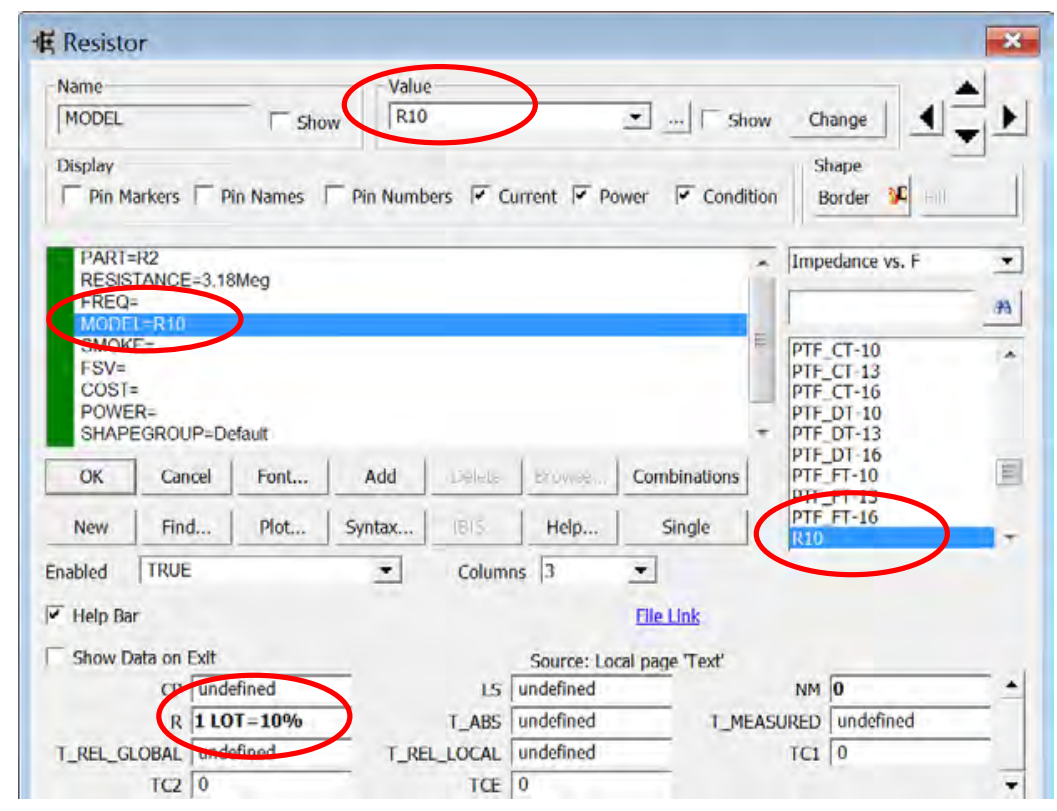

Obr. 14.52: Nastavení hodnoty tolerance $10 \%$ u rezistoru R2.

Takto nastavíme toleranci u odporů $R_{1}$ a $R_{2}$. Následně spustíme ,AC Analysis', nastavíme potřebné parametry a necháme proběhnout analýzu. V horní liště je prístupná položka $<$ Monte Carlo $>$ a volba ,Options'. V prvé řadě zvolíme, jak má být provedena volba hodnot prvků, které mají nastavenou toleranci. Lze zvolit ,Uniform‘ (rovnoměrné rozdělení), ,Gauss“ (Gaussovo normální rozdělení) a ,Worst Case“ (nejhorší mezní případ). Dále zvolíme počet „,běhư“, tedy kolikrát bude proveden výpočet. Toto je pro vlastní analýzu postačující a mohli bychom spustit analýzu. V tomto okně lze dále nastavit parametry pro zobrazení 
histogramu, takže můžeme dále položkou, Get‘ nastavit, co má být výsledkem této analýzy pro zobrazení histogramu. K tomu se otevře další okno, viz Obr. 14.53 vpravo. V našem př́padě nás zajímá, $\mathrm{v}$ jakém rozsahu se bude měnit rezonanční kmitočet $f_{0}$ pro dané tolerance hodnot $R_{1}, R_{2}$. Hledáme tedy minima průběhů na kmitočtové ose $\mathrm{x}$, takže $\mathrm{z}$ rolovacího menu ,Function“ vybereme „Valley_X“ pro ,Expression“,,db(v(OUT))“, tedy výraz, který již známe z nastavení

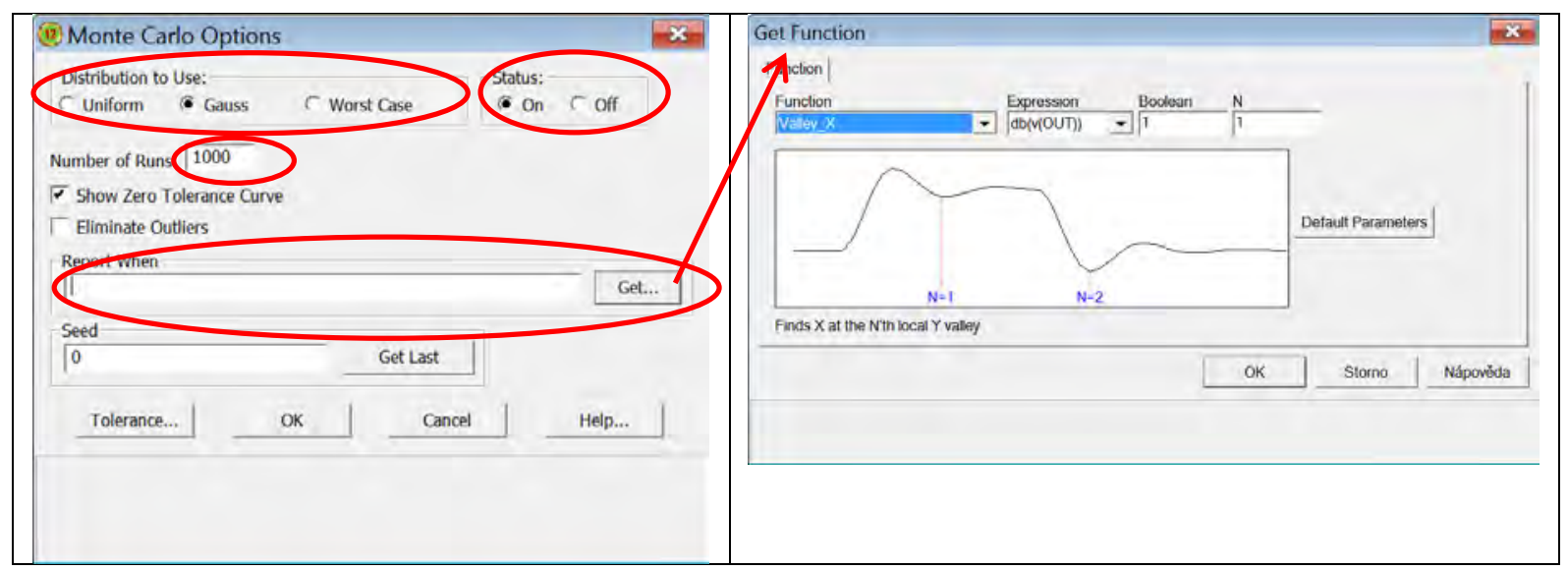

Obr. 14.53: Nastavení podmínek analýzy Monte Carlo.

analýzy. Zbylé dva parametry ponecháme, jejich význam je patrný z naznačeného průběhu. Po potvrzení a spuštění analýzy ,Run` získáme průběhy uvedené na Obr. 14.54.

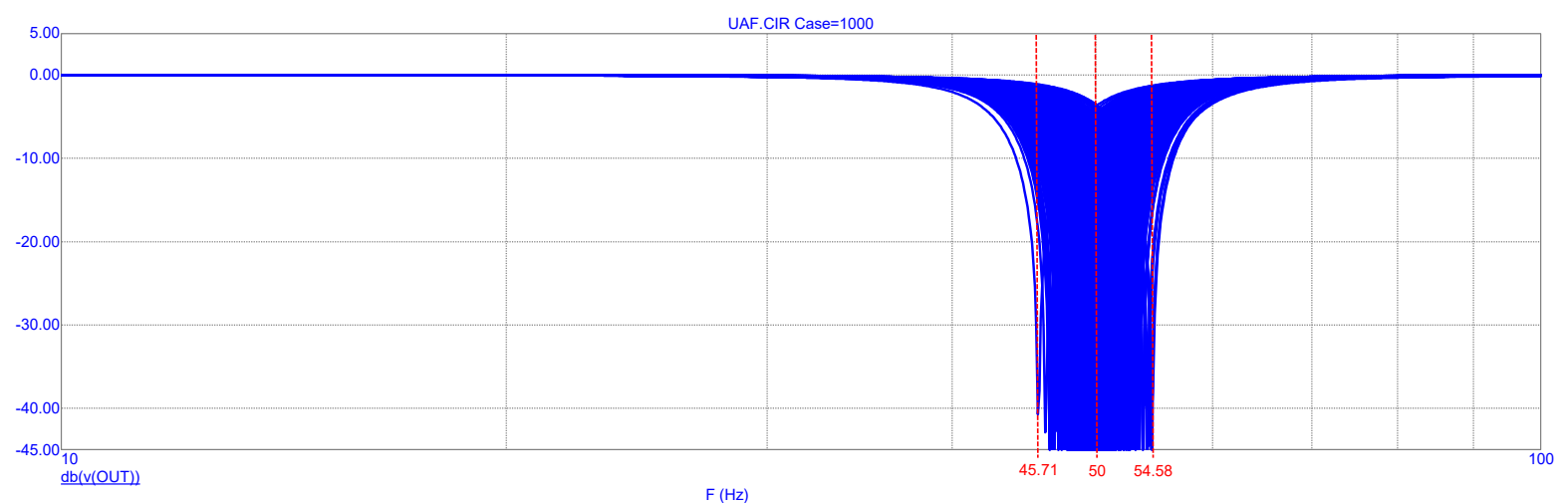

Obr. 14.54: Vymezení pásma změny f0 při $10 \%$ toleranci odporů $R_{1}, R_{2}$.

Je zřejmé, že při použití odporů s $10 \%$ tolerancí se kmitočet potlační bude pohybovat v rozmezí $45.71 \mathrm{~Hz}$ až $54.58 \mathrm{~Hz}$, tedy zhruba v pásmu $8.87 \mathrm{~Hz}$. Toto ovšem nic neříká o tom, $\mathrm{s}$ jakou četností se např́klad budou hodnoty vyskytovat $\mathrm{v} 1 \mathrm{~Hz}$ pásmech od požadované hodnoty $f_{0}$. Tuto informaci nám poskytuje histogram. Gaussovo rozdělení je v tomto př́padě poměrně logické, protože se dá nejspíš očekávat, že hodnoty odporů budou nejvíce oscilovat kolem jmenovité hodnoty. Podívejme se tedy na histogram pro tisíc průběhů. Graf histogramu vyvoláme v položce $<$ Monte Carlo $>$ volba ,Histograms“ a volbou připraveného histogramu ,Show Valley_Xdb(v(OUT) )`a zobrazí se histogram uvedený na Obr. 14.55. 


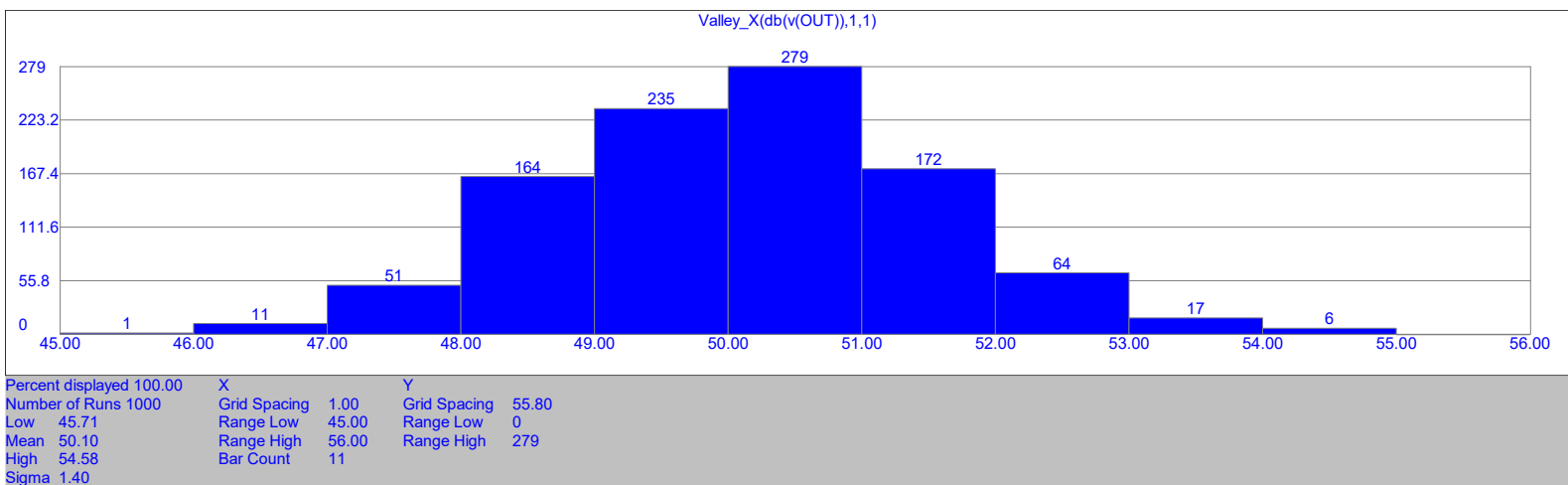

Obr. 14.55: Histogram rozložení rezonančního kmitočtu $f_{0}$, Gaussovo rozdělení při $10 \%$ toleranci odporů $R_{1}, R_{2}$.

Průběh histogramu je celkem logický, přes 50 \% př́ípadů je v rozmezí $49 \mathrm{~Hz}$ až $51 \mathrm{~Hz}$. $\mathrm{Z}$ dolní části tabulky je také možné zjistit nejnižší hodnotu $f_{0}$, to je $45.71 \mathrm{~Hz}$, střední hodnotu $50.10 \mathrm{~Hz}$ a nejvyšší hodnotu $54.54 \mathrm{~Hz}$. Poznamenejme, že při každém novém spuštění jsou z podstaty získány mírně jiné hodnoty. Další volby rozložení tolerančních hodnot a zobrazení výsledků je zcela obdobné a není účelné je zde uvádět. Jen pro doplnění je na Obr. 14.56 uveden histogram pro volbu ,Worst Case‘ již bez komentáře.

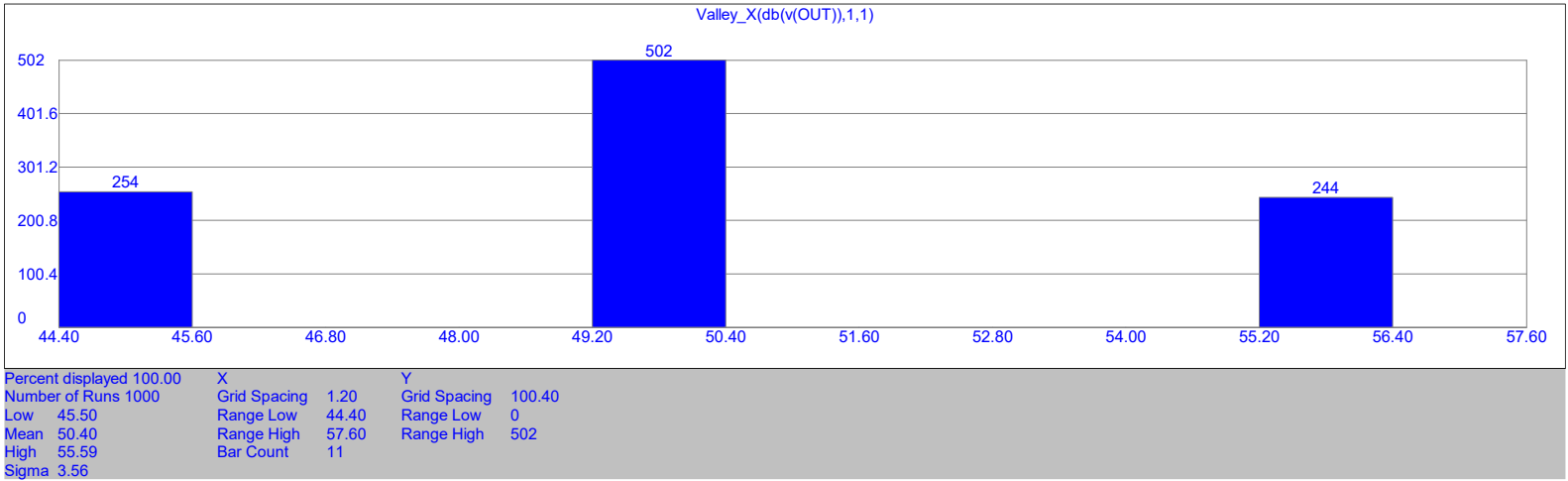

Obr. 14.56: Histogram rozložení kmitočtu potlačení $f_{0}$, Worst Case při $10 \%$ toleranci odporů $R_{1}, R_{2}$.

Pro úplnost a komplexnější náhled na funkci obvodu jsou na Obr. 14.57, Obr. 14.58, Obr. 14.59 a Obr. 14.60 uvedeny histogramy pro $10 \%$ tolerance všech externích rezistorů, tedy odpory $R_{1}, R_{2}, R_{3}, R_{4}, R_{5}, R_{6}$. Získáme tak celkový náhled na požadované tolerance použitých rezistorů. Analyzovat tolerance vnitřních odporů a kapacit není účelné, jejich výrobní tolerence, případně teplotní závislosti jsou zpravidla o několik řádů lepší, než je tomu u externích součástek. 


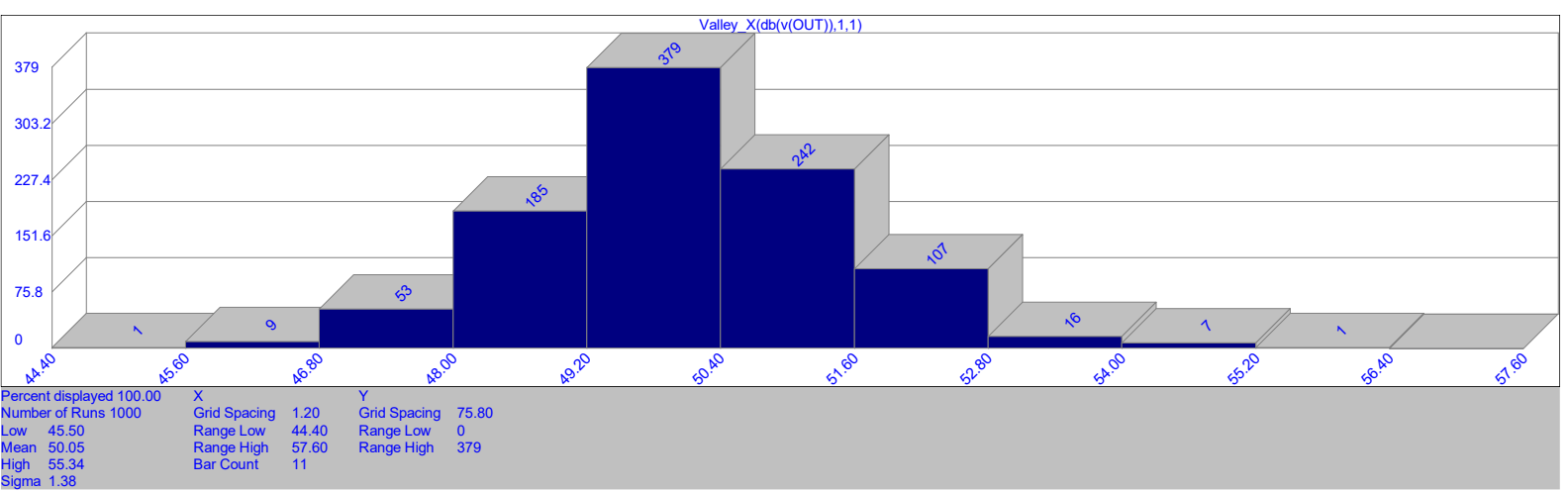

Obr. 14.57: Histogram rozložení rezonančního kmitočtu $f_{0}$, Gaussovo rozdělení při $10 \%$ toleranci externích odporů $R_{1}, R_{2}, R_{3}, R_{4}, R_{5}, R_{6}$.

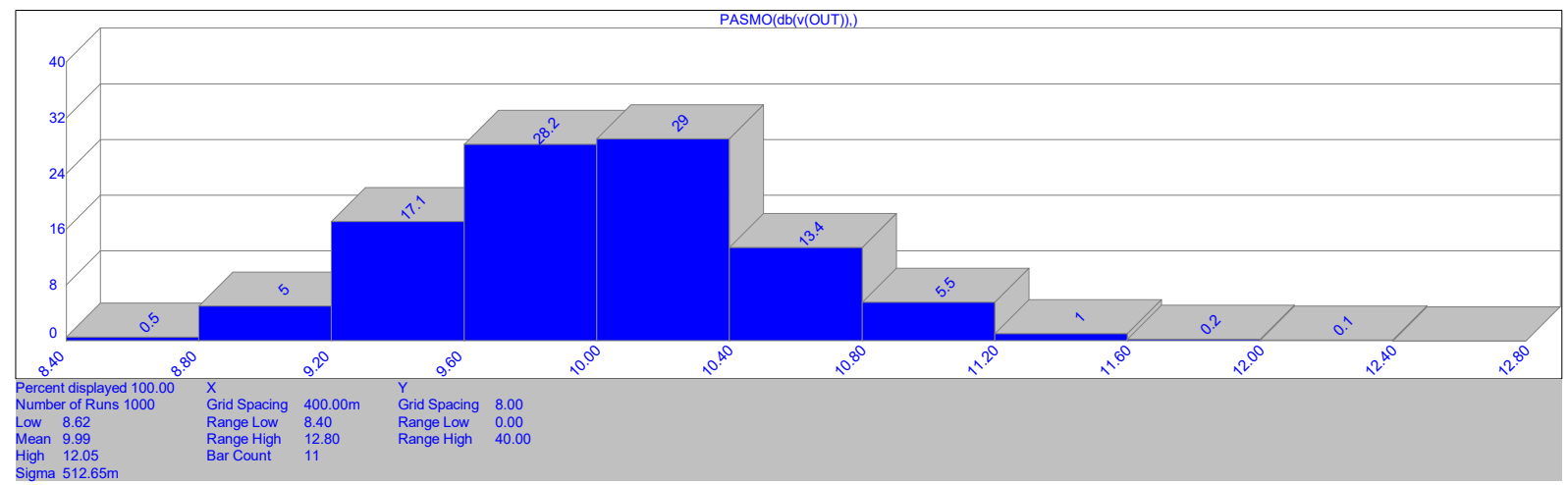

Obr. 14.58: Histogram rozložení šířky pásma $B$, Gaussovo rozdělení při $10 \%$ toleranci externích odporů $R_{1}, R_{2}$, $R_{3}, R_{4}, R_{5}, R_{6}$.

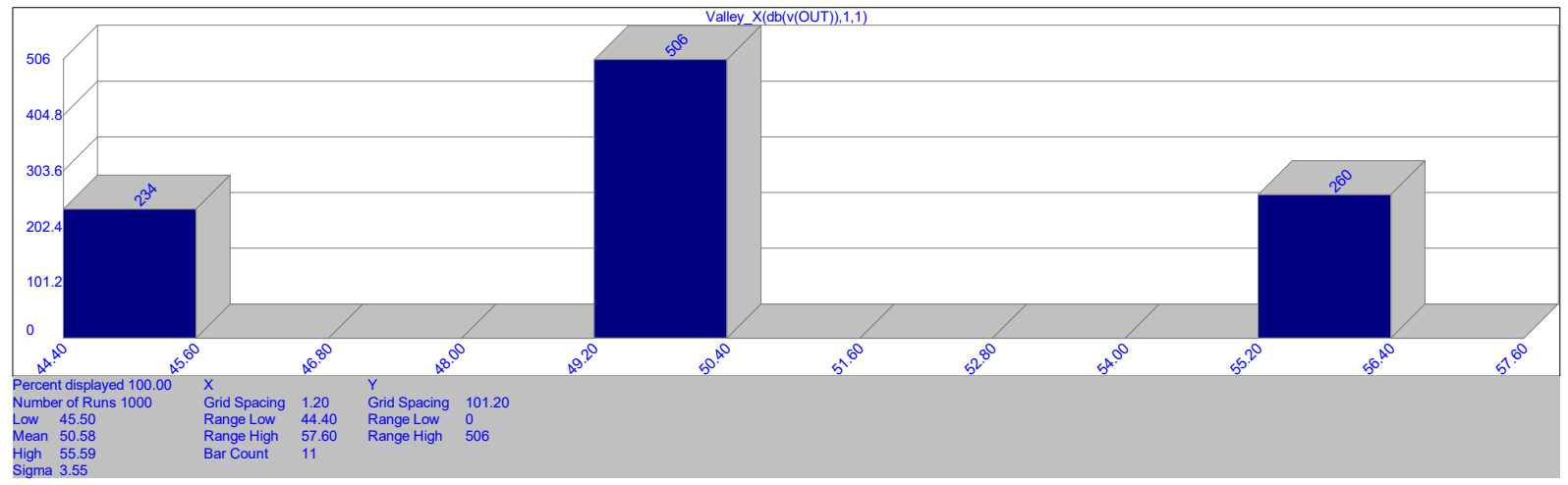

Obr. 14.59: Histogram rozložení rezonančního kmitočtu $f_{0}$, Worst Case při $10 \%$ toleranci externích odporů $R_{1}$,

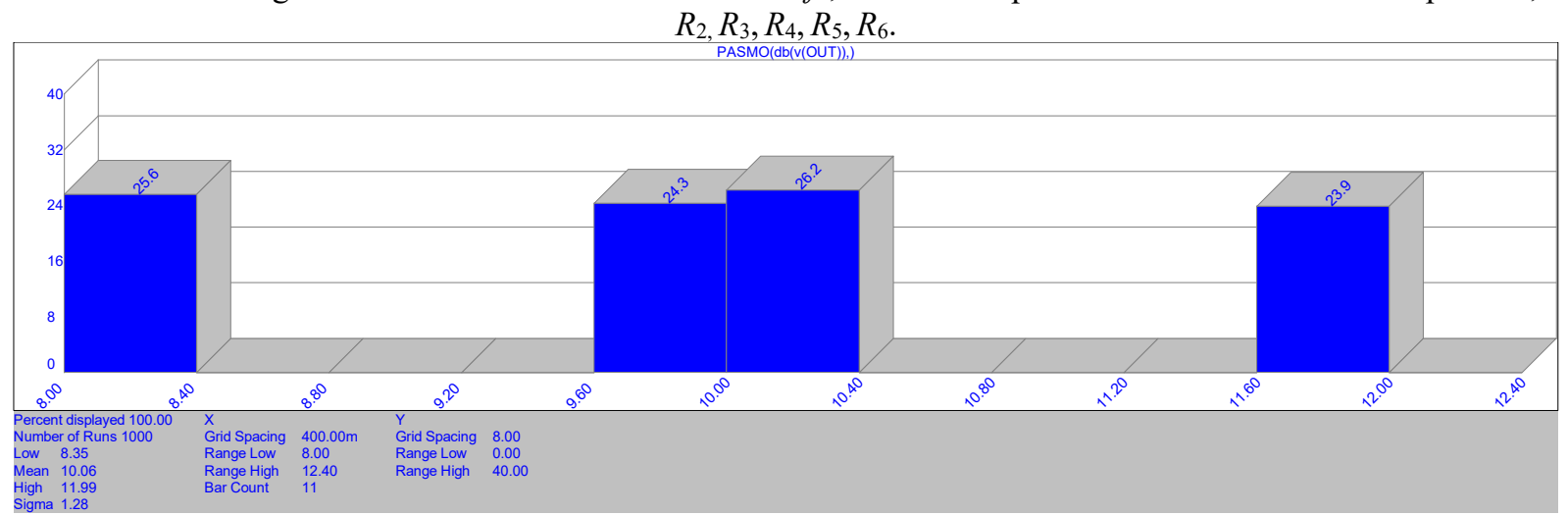

Obr. 14.60: Histogram rozložení šířky pásma $B$, Worst Case při $10 \%$ toleranci externích odporů $R_{1}, R_{2}, R_{3}, R_{4}, R_{5}$, $R_{6}$. 
Problematika simulace různých tolerancí je v programu Micro-Cap poměrně důkladně propracována, výše uvedený prríklad je jen jednoduchou ukázkou. Bližší informace k této problematice lze nalézt $\mathrm{v}$ lit. [2] a řadě př́ikladů, které jsou součástí instalace programu.

\section{PŘÍKLAD_5}

\section{Kmitočtově kompenzovaný dělič v měřicí sondě.}

Mezi základní měřicí prŕístroje analogové techniky bezpochyby patří osciloskop pro sledování průběhů signálu zejména v časové oblasti. Mezičlánkem mezi měřeným objektem a osciloskopem je osciloskopická sonda, která poměrně zásadním způsobem může ovlivnit měřené výsledky. V následujícím prríkladě budeme pomocí počítačové simulace demonstrovat, jak se projevuje nesprávné seřízení osciloskopické sondy.

Podívejme se nejdř́ve jaké obvykle máme informace o sondě a vstupních obvodech osciloskopu. $\mathrm{V}$ technickém popisu $\mathrm{k}$ osciloskopu, resp., přímo na panelu př́ístroje, získáme základní informace o vstupním odporu a kapacitě vstupů, jak je uvedeno na Obr. 14.61. Obdobně máme $\mathrm{k}$ dispozici i parametry osciloskopické sondy, pomocí které snímáme napětí v zájmových bodech obvodu. Na Obr. 14.62 je uvedena běžná osciloskopická sonda a její parametry. Z Obr. 14.62 je rovněž patrné, že sonda obsahuje nastavovací prvky pro kmitočtovou kompenzaci průběhu přenosové funkce vlastní sondy, která má zásadní vliv na získané průběhy.

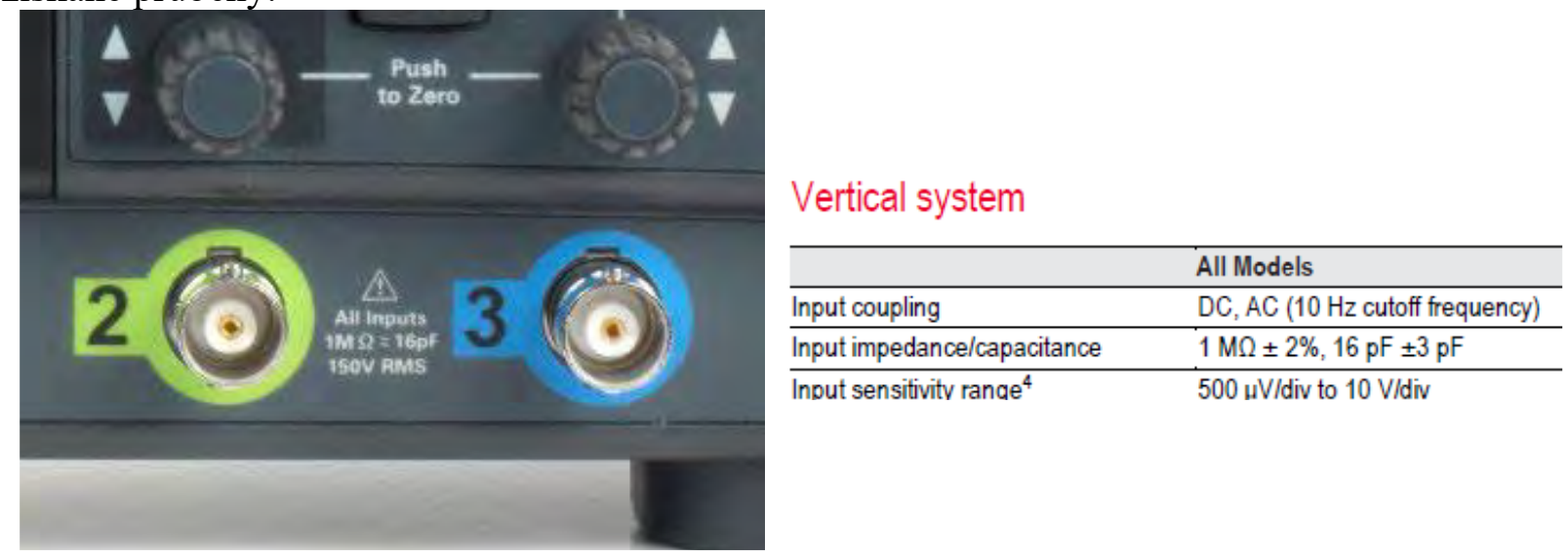

Obr. 14.61: Parametry vstupů na osciloskopu, popis z katalogu.

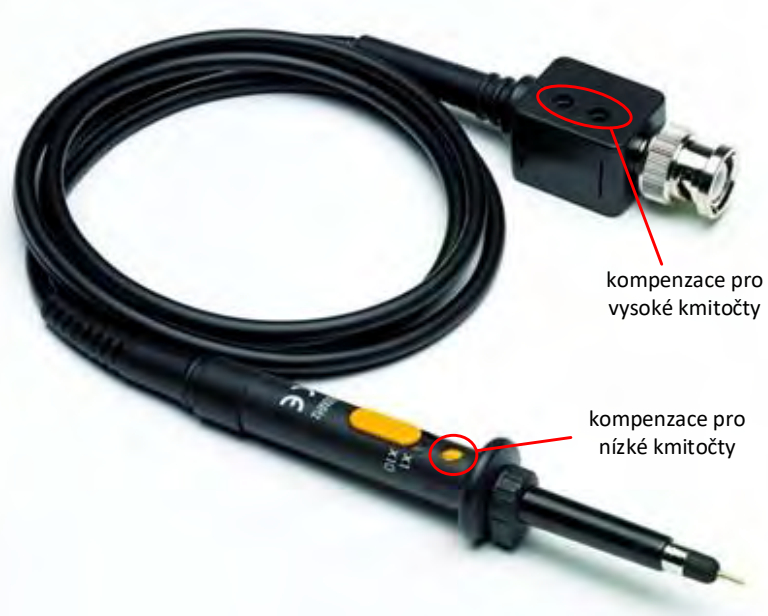

Sonda 1:1/10:1, 100MHz, 1/10M $\Omega$

Dělicí poměr:

- 1:1 kmitočtový rozsah $\mathrm{DC} \div 6 \mathrm{MHz}$, vstupní odpor $1 \mathrm{M} \Omega$, vstupní kapacita $85 \div 115 \mathrm{pF}$,

- 10:1 kmitočtový rozsah $\mathrm{DC} \div 100 \mathrm{MHz}$, vstupní odpor $10 \mathrm{M} \Omega$ vstupní kapacita $18.5 \div 22.5 \mathrm{pF}$.

Obr. 14.62: Běžná osciloskopická sonda a její parametry. 
Provedeme simulaci př́íkladu osciloskopické sondy s dělicím poměrem 10:1 a s jedním kompenzačním prvkem. I když se jedná o zjednodušený př́íklad, bude z něj patrná problematika správného nastavení sondy. Obvodová situace měřicího řetězce je ukázána na Obr. 14.63, který představuje vlastní sondu, připojenou koaxiálním kabelem na vstup osciloskopu.

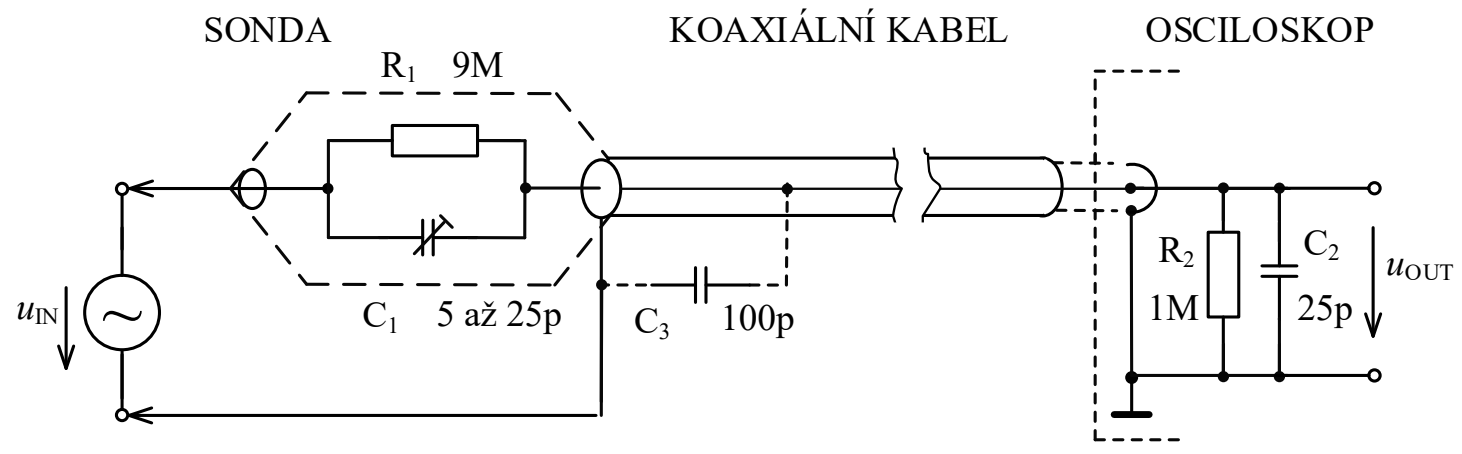

Obr. 14.63: Osciloskopická sonda v měřicím řetězci.

Rezistor $\mathrm{R}_{2}$ představuje vstupní odpor osciloskopu, v našem př́padě $R_{2}=1 \mathrm{M} \Omega, C_{2}$ je vstupní kapacita osciloskopu, volme $C_{2}=17 \mathrm{pF}, R_{1}$ je podélný odpor sondy $R_{1}=9 \mathrm{M} \Omega$. Rezistory $\mathrm{R}_{1}$ společně s $\mathrm{R}_{2}$ tvoří dělič $10: 1$ a vstupní odpor sondy $R_{\mathrm{vst}}=10 \mathrm{M} \Omega$. Jedná se o jisté zjednodušení, které ovšem není zásadní. Kapacitor $C_{1}$ je kapacitní trimr pro kmitočtovou korekci sondy. Kapacitor $\mathrm{C}_{3}$ modeluje kapacitu koaxiálního kabelu kterým je sonda připojena $\mathrm{k}$ osciloskopu. Uvažujme zjednodušeně délku kabelu asi $1 \mathrm{~m}$ a $\mathrm{z}$ katalogu výrobce kabelů můžeme uvažovat kapacitu $C_{2}=100 \mathrm{pF}$. Obvodově pak sonda představuje kmitočtově závislý rezistorový dělič, který je naznačen na Obr. 14.64.

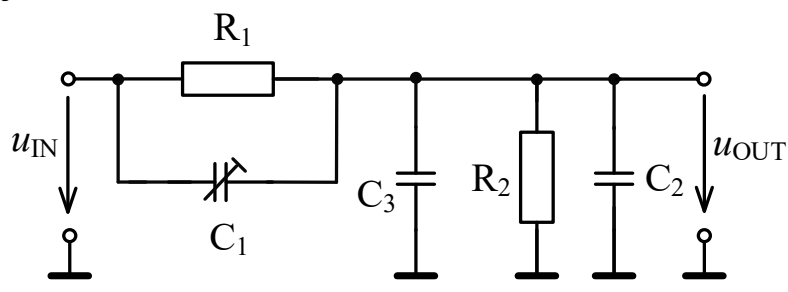

Obr. 14.64: Náhradní model osciloskopické sondy.

Protože je nutné, aby sonda v požadovaném kmitočtovém rozsahu byla kmitočtově nezávislá je nutné nastavit kapacitu $C_{1}$ tak, aby tato podmínka byla splněna. Ze známé podmínky pro kmitočtovou kompenzaci děliče můžeme určit

$$
C_{1}=\frac{R_{2}\left(C_{2}+C_{3}\right)}{R_{1}}=\frac{1 \cdot 10^{6}\left(100 \cdot 10^{-12}+17 \cdot 10^{-12}\right)}{9 \cdot 10^{6}}=13 \cdot 10^{-12}=13 \mathrm{pF} .
$$

Pro tuto hodnotu bude přenos sondy v celém kmitočtovém rozsahu nezávislý na kmitočtu. Je zřejmé, že sondu je potřeba před měřením patřičně vykompenzovat kapacitním trimrem. Nastavitelný rozsah kapacity kapacitního trimru $\mathrm{C}_{1}$ je u tohoto typu sondy 5 až $25 \mathrm{pF}$. Nyní proved'me počítačovou simulaci demonstrující tuto situaci. Zapojení obvodu v programu Micro-Cap je uvedeno na Obr. 14.65a a kmitočtová charakteristika na Obr. 14.65b. 


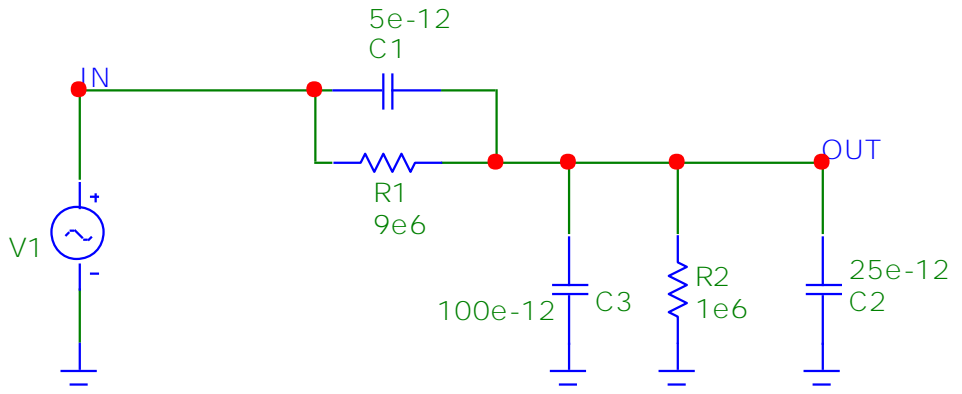

a)

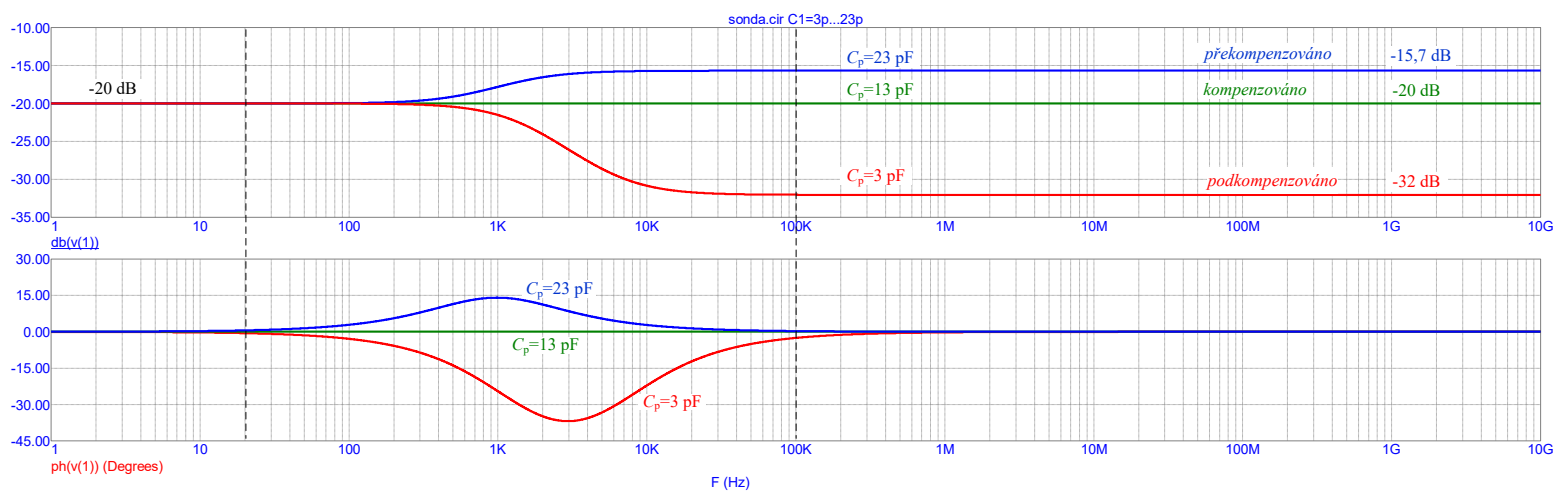

b)

Obr. 14.65: a) Schéma zapojení sondy v programu Micro-Cap, b) kmitočtová charakteristika kompenzované, překompenzované a podkompenzované sondy.

U správně kompenzované sondy (zelený průběh) je přenos v celém rozsahu kmitočtů $20 \mathrm{~dB}$, což odpovídá dělicímu poměru 10:1, fázová charakteristika je rovněž v celém rozsahu konstantní. Další průběhy představují podkompenzovanou sondu (červený průběh) a překompenzovanou sondu (modrý průběh), který je dán krajními hodnotami nastavení kapacity $C_{1}$. Z průběhů můžeme vymezit tři oblasti: do $20 \mathrm{~Hz}, 20 \mathrm{~Hz}$ až $100 \mathrm{kHz}$ a nad $100 \mathrm{kHz}$. Dále si ukážeme vlastnosti různě kompenzované sondy v těchto kmitočtových oblastech při simulaci v časové oblasti.

Zvolme jako vstupní signál pulsní průběh s kmitočtem $20 \mathrm{~Hz}$ a nastavme patřičné parametry u vstupního pulsního zdroje V1. Výsledný průběh je uveden na Obr. 14.66.

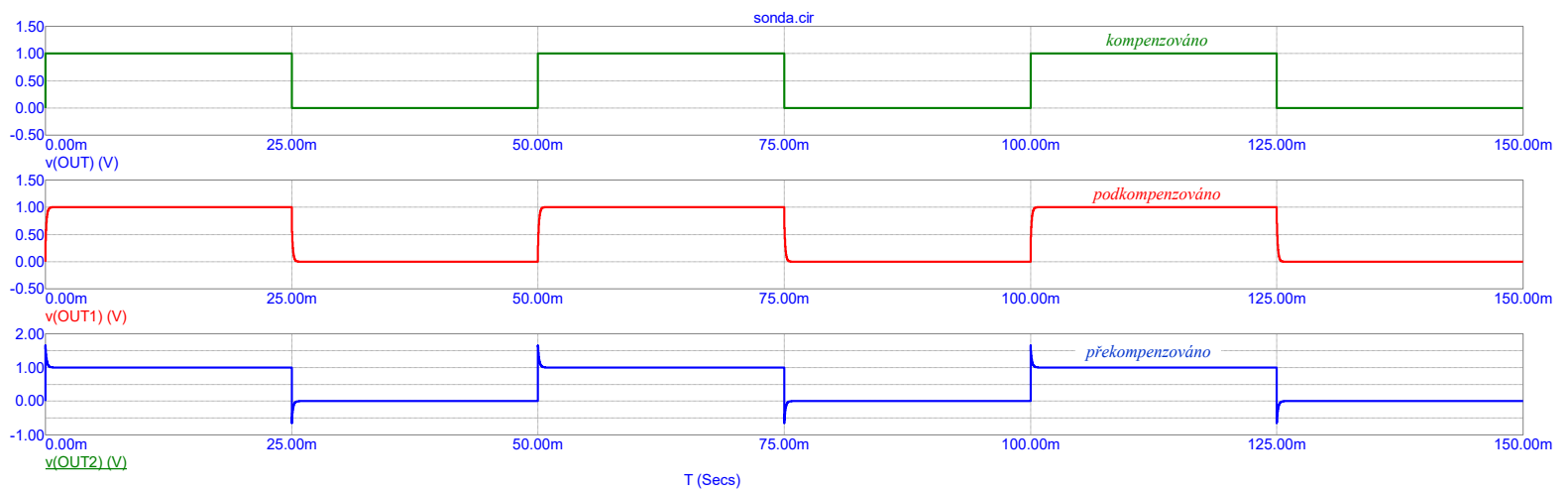

Obr. 14.66: Časové průběhy kompenzované, podkompenzované a překompenzované sondy na kmitočtu $20 \mathrm{~Hz}$. 
U překompenzované sondy jsou na průběhu patrné překmity, u podkompenzované jsou patrné zaoblené hrany. Oba tyto př́ípady jsou důsledkem špatně kompenzované sondy nikoli sledovaného průběhu. Ve všech případech je výška pulsů $1 \mathrm{~V}$, která odpovídá nastavenému útlumu 10:1, když vstupní pulsy jsou $10 \mathrm{~V}$.

Nyní zvolme kmitočet vstupních pulsů ze střední části kmitočtové oblasti. Je to oblast, kde u nevykompenzované sondy dochází nejen k fázovým změnám ale mění se i útlum sondy. Výsledné průběhy pro vstupní kmitočet $1400 \mathrm{~Hz}$ jsou uvedeny na Obr. 14.67. Je zřejmé, že časové průběhy jak pro podkompenzovanou, tak i pro překompenzovanou sondu, vůbec neodpovídají skutečnosti

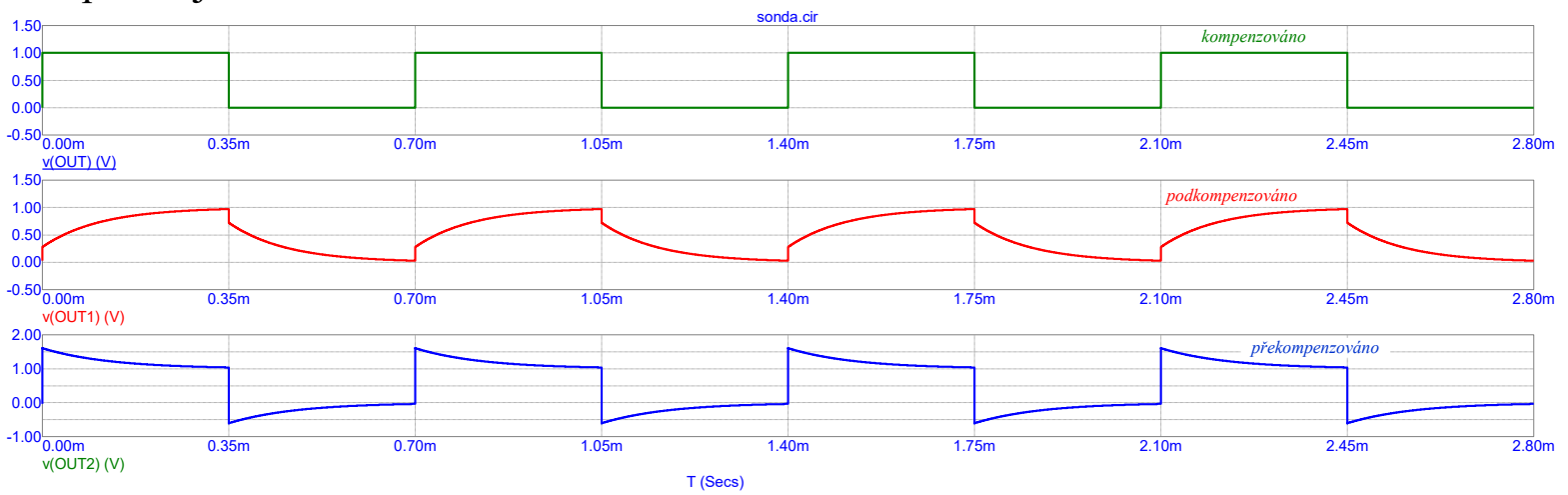

Obr. 14.67: Časové průběhy kompenzované, podkompenzované a překompenzované sondy na kmitočtu $1400 \mathrm{~Hz}$.

Na závěr zvolíme kmitočet pulsů $10 \mathrm{MHz}$, tedy z oblasti, kde fázové změny jsou opět nulové, ale útlum je rozdílný dle kompenzace. Výsledné průběhy jsou uvedeny na Obr. 14.68. Z průběhů je nyní patrné, že vlastní tvar impulsů sice odpovídá skutečnosti, nesprávná je však výška pulsů.

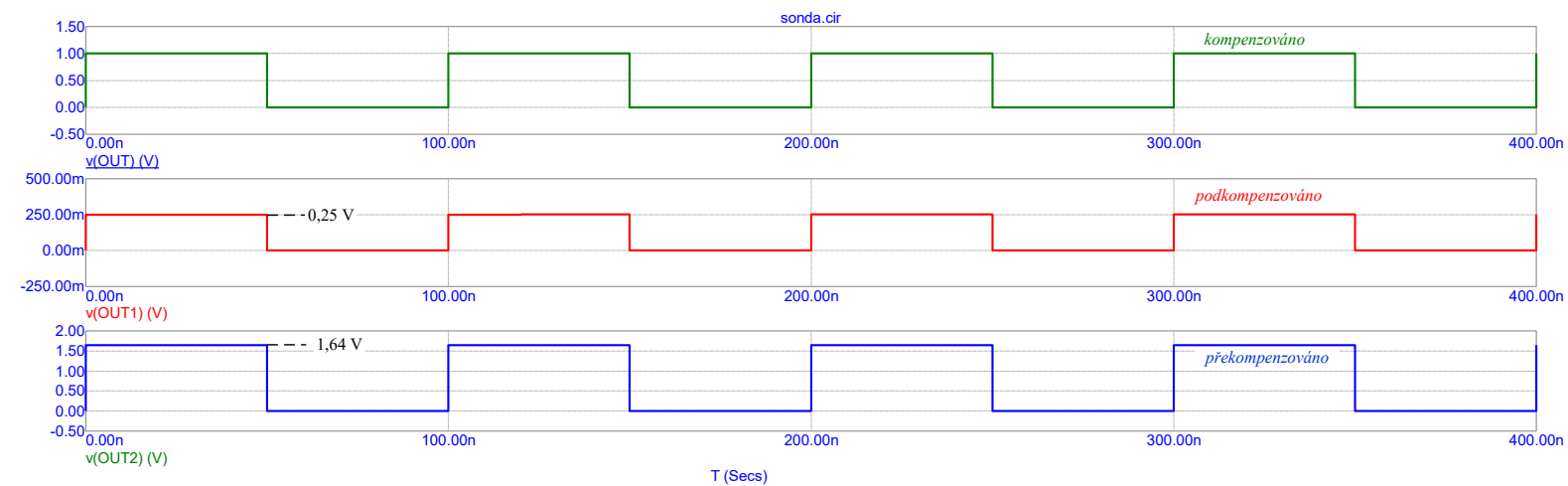

Obr. 14.68: Časové průběhy kompenzované, podkompenzované a překompenzované sondy na kmitočtu $10 \mathrm{MHz}$. 
U správně kompenzované sondy je výška výstupního signálu sondy $1 \mathrm{~V}$, což odpovídá dělicímu poměru sondy 10:1. Pokud je sonda podkompenzována je výška pulsů $0,25 \mathrm{~V}$. Pokud se opět podíváme na Obr. 14.65b je patrné, že u podkompenzované sondy je na kmitočtu 10 MHz přenos $-32 \mathrm{~dB}$, nikoli požadovaných $-20 \mathrm{~dB}$. Tedy pro uvedené výstupní napětí je útlum

$$
z=20 \cdot \log \frac{U_{\text {OUT }}}{U_{\mathrm{IN}}}=20 \cdot \log \frac{0,25}{10}=-32 \mathrm{~dB} .
$$

Obdobně u překompenzované sondy je amplituda $1,64 \mathrm{~V}$, nikoliv $1 \mathrm{~V}$. To odpovídá přenosu

$$
z=20 \cdot \log \frac{U_{\text {OUT }}}{U_{\text {IN }}}=20 \cdot \log \frac{1,64}{10}=-15,7 \mathrm{~dB} .
$$

Z uvedených simulací je patrné, že při měření osciloskopickou sondou je zapotřebísondu vždy kmitočtově vykompenzovat. Osciloskop bývá většinou vybaven generátorem pravoúhlých pulsů, pomocí kterého se kapacitní trimr nastaví tak, aby dělič v sondě nebyl překompenzován, ale ani podkompenzován.

\section{Použitá literatura}

[1] BIOLEK, Dalibor. Řešíme elektronické obvody - aneb kniha o jejich analýze. 1. vydání. Praha: BEN - technická literatura, 2004. ISBN 80-7300-125-X.

[2] Spectrum Software. Micro-Cap 12 Electronic Circuit Analysis Program Reference Manual, 11. Edition, June 2018, [online]: http://www.spectrumsoft.com/download/rm12.pdf

[3] TEXAS INSTRUMENTS: Technical documentation. Universal Active Filter UAF42.

[4] LÁNÍČEK, R. Simulační programy pro elektroniku. BEN technická literatura, 2000, $113 \mathrm{~s}$. 